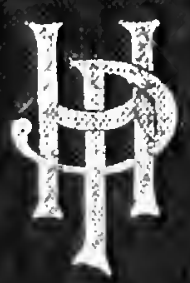


6.

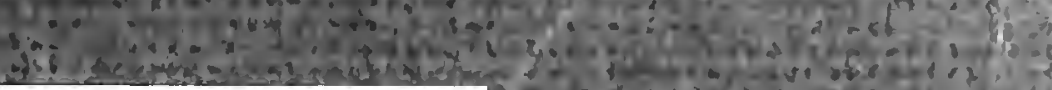

\section{|||||||||||||||| \\ 31822001129816}

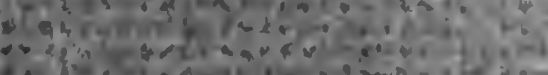

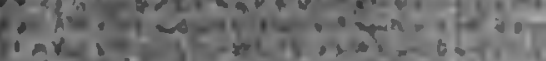

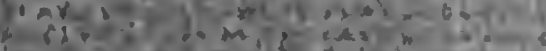

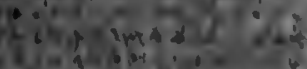

Y.

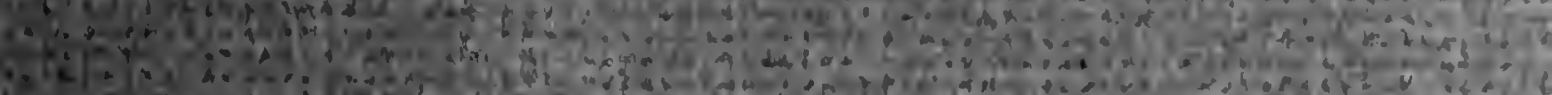

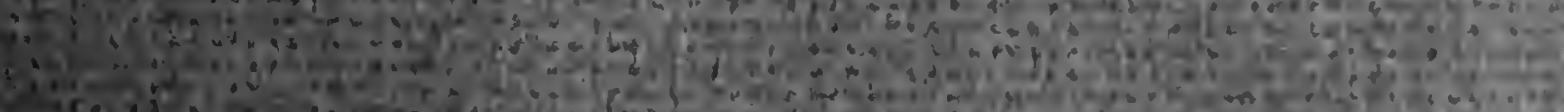
19,1 ;

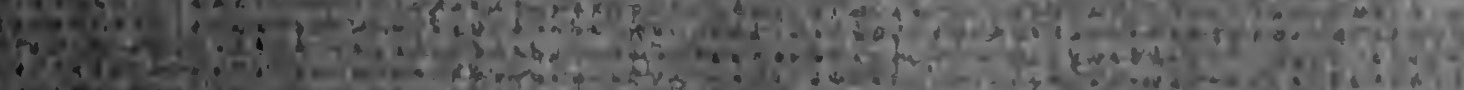

\section{Fintis :}

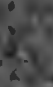

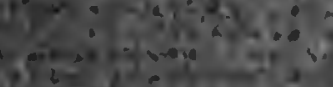

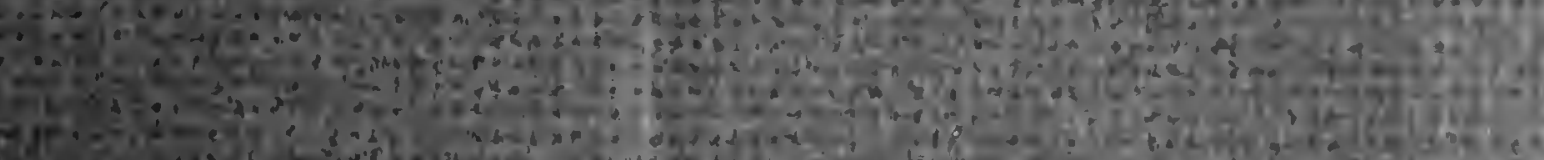
Fon

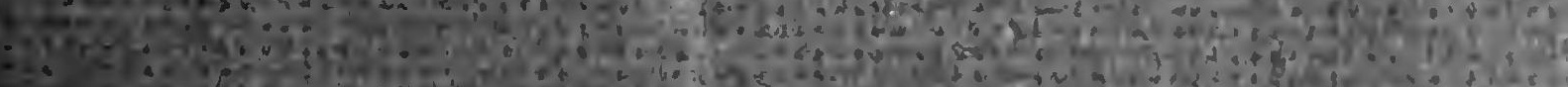

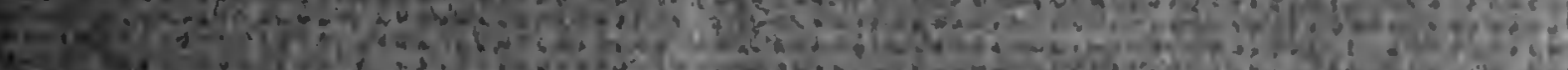

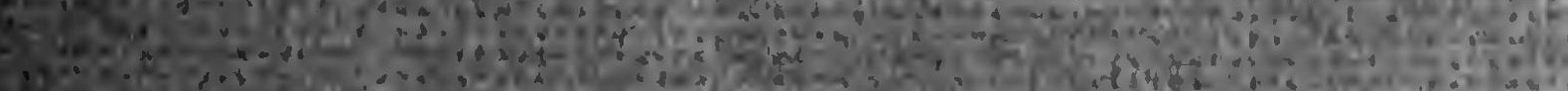

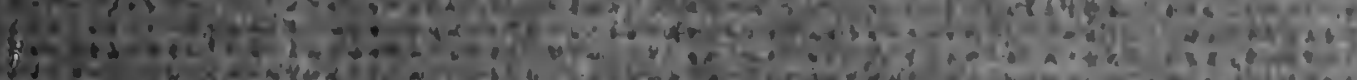

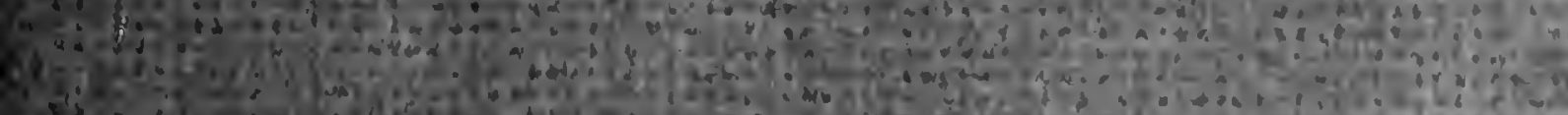

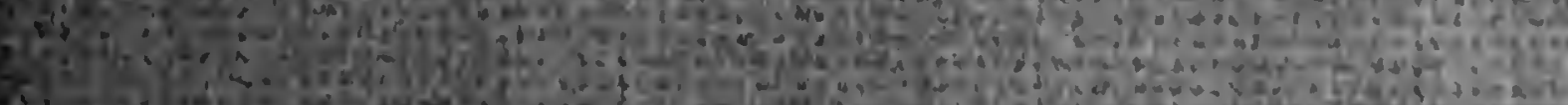
Eves

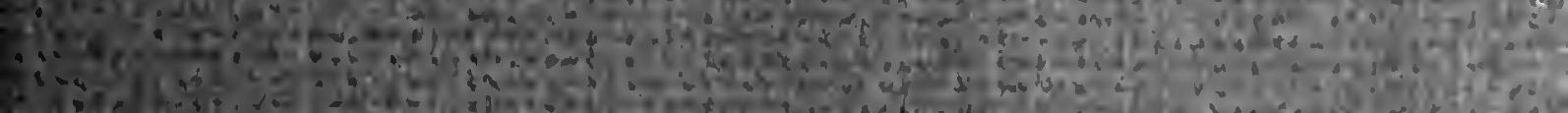
E. He

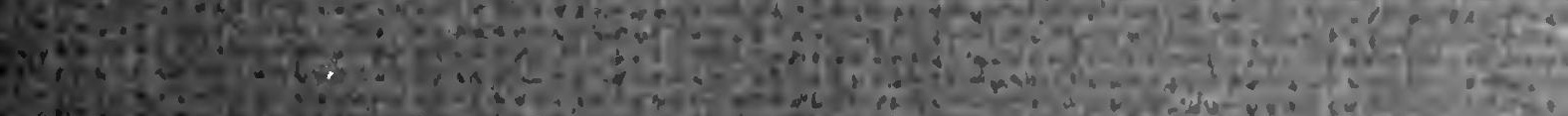
(3) W.

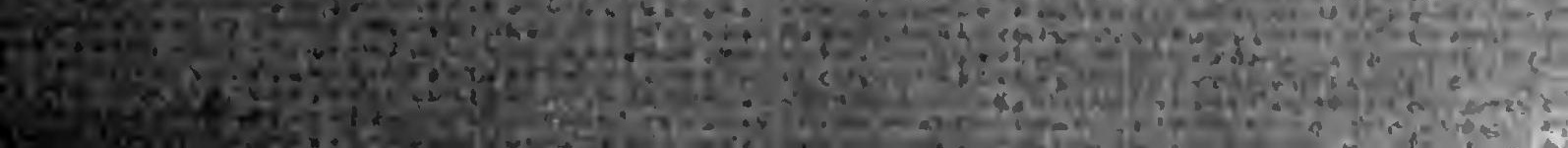



-

1 


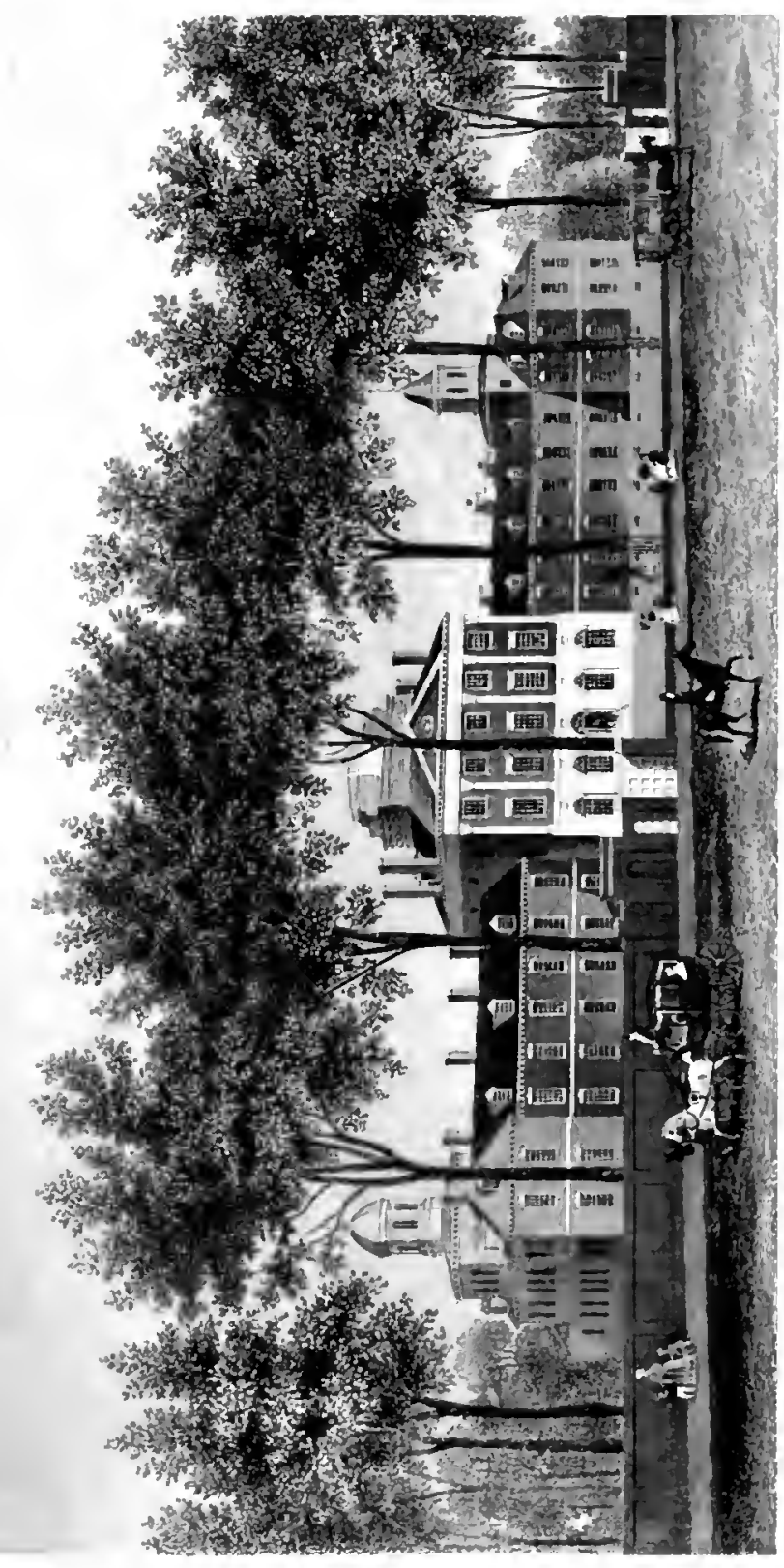




\title{
THE HISTORY
}

\author{
(1) 1115

\section{Pennsyluania Hospital}

\author{
$1751-I 895$ \\ $\overline{-}$ \\ 1.1

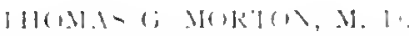

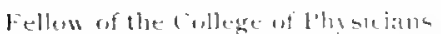

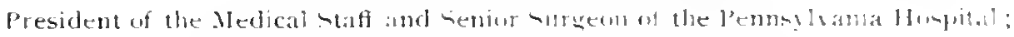

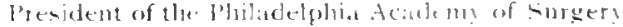

Fici.. 1.t.

$\operatorname{incin} 11.11$ i.

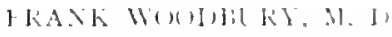

Fellow or the lollege of l'ht hicians?

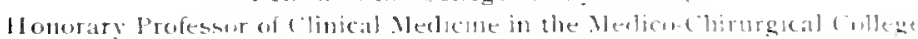
lil fic.

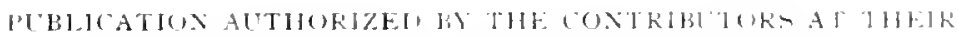

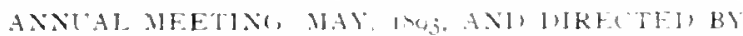

[HE BOAKI) W VAX+1, K-

1'111. 111:1.1 111

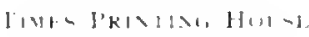

I.

THE UNIVERSITY LIBRARY

UNIVERSITY OF CALIFORIVIA, SAN DIEGO

LA JOLLA. CALIFORNIA 
finporight, tsiss.

in

Ihe (intributors to the Pennsivania Hosphtial 


\section{L.IST OF ILLLISTRATIONS.}

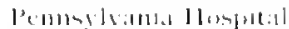

lin. 1

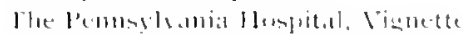

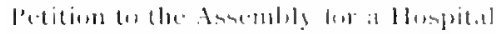

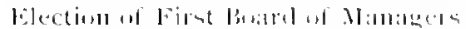

kindial letter

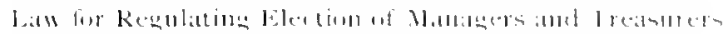

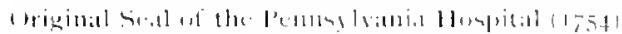

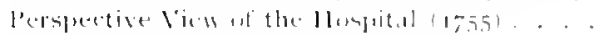

llae (')

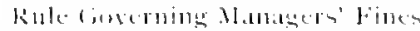

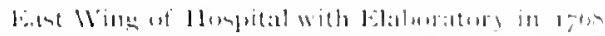

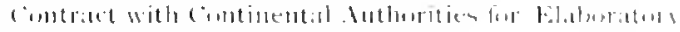

Bum ol Fines, I-5.5

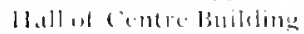

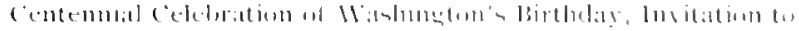

linglistionter

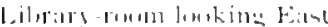

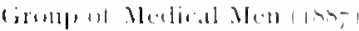

Niltater Itume

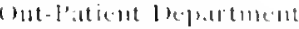

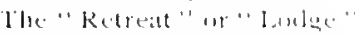

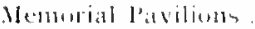

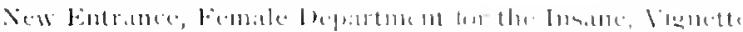

l'urtratil af Mr. l'alll busti

. . -

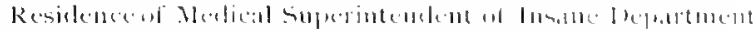

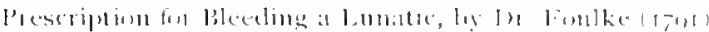

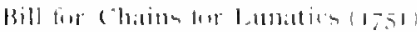

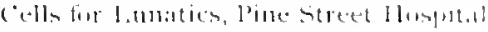

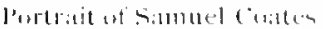

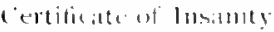

Findersement un extifialle

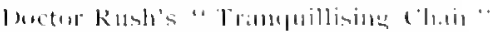

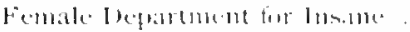

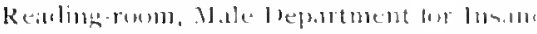

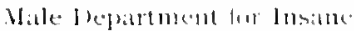

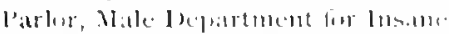

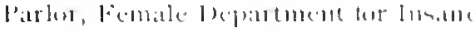

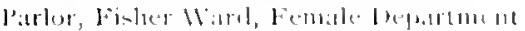

koom in Fisler Mand.

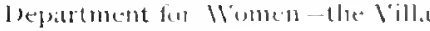

"The Villat," 


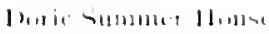

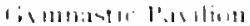

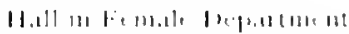

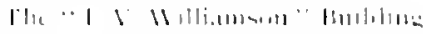

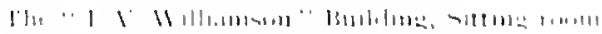

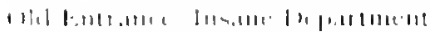

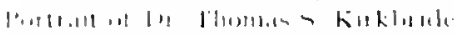

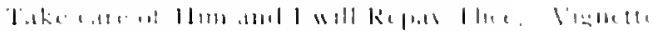

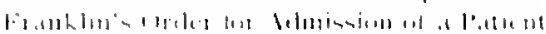

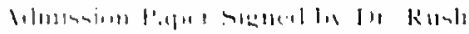

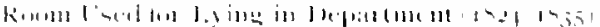

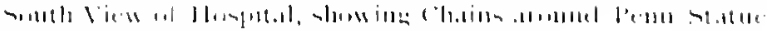

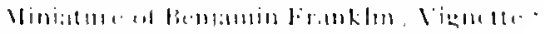

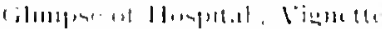

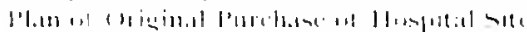

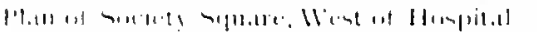

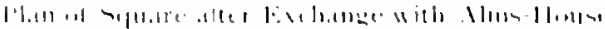

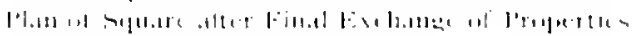

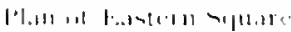

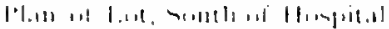

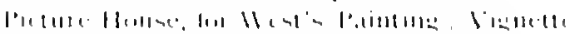

chout Healibe the sick

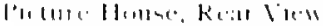

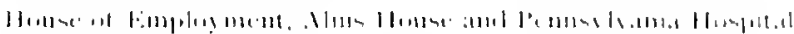

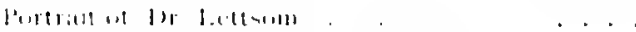

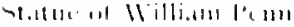

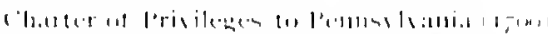

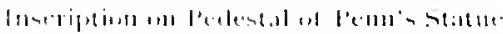

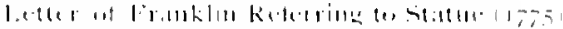

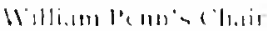

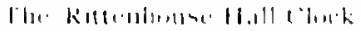

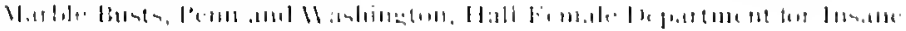

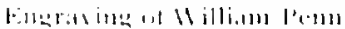

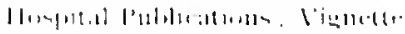

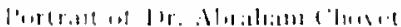

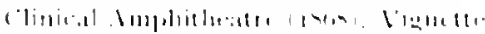

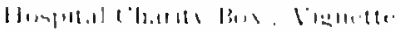

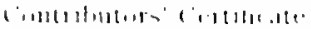

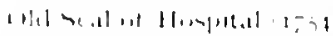

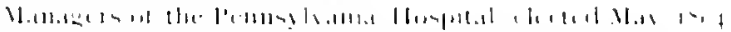

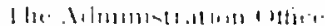

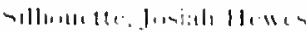

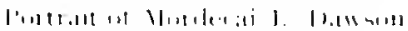

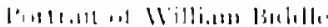

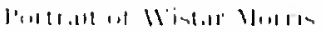

-

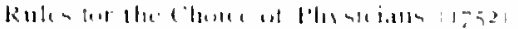

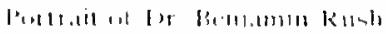

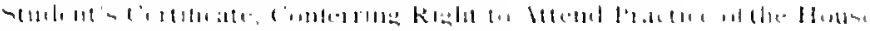

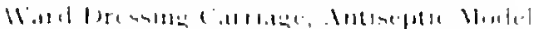

IV.arl Jiend carriage

lmelenture. 
Library tooking Sruth, Managers Meeting Ronm

Portratit of Thomals freme, M. I).

Portrait of Thomas ("arkaliderer. M. B)

Portrait of John R..lman, M. I)

Portrat of l.lend Kathars, . I. I)

lortrait of Phine:as Brold, . Y. ().

Portrait of Jolun MLrean, II. I).

Provtrait of Aclam Kulu, . .1. I)

linetrate of Themain Parke, If 11

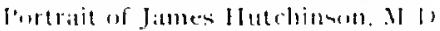

Pentrait of William Shilgeen, J1, 3. I"

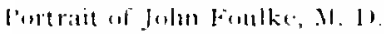

lentrait of (anpar llistar, 31. I)

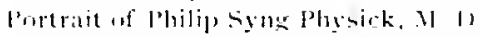

lortratit of Benjamin smith Bartin. . I I)

Pertrait of John Redluan (ONee, M. I).

fortrait of Thomats (C. James, M. I)

leartrait of folm syme leorsey, , .1. I.

lentrait of Josegh Hartshorne, .1. I)

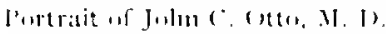

fortate of samuel lomlen, M. V.

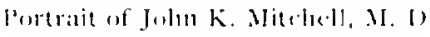

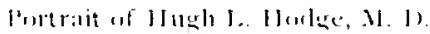

l'ortrait of treurge B. Wionel, M. I

Portritit of Jacol) Ralndolph, M. [1.

Portrait of fiecrere W. Nurris. W. 1)

Portratit of (Hatrles 1). Meigs, . M. I.

Portrait of William Jeeplet. II. I).

Portratit af Jeseph ('atrom, M. I).

l'ortrait of Joseph l'ancoraht, M. I)

lortrat of Jolun Forseth Meigs, .1. 1'

Pintrait of Edward llartsherme, M. 1).

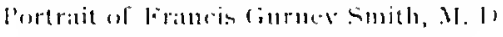

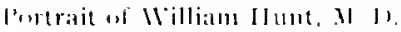

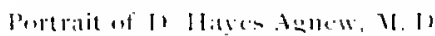

Purtrait of Jimes A. Neien, .1. II

l'ortrait of Richatol J leesis. Mt I

The Henpital Platrmatey 
TABI. OF CONTENTS.

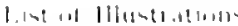

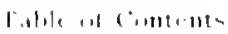

H'it.14:

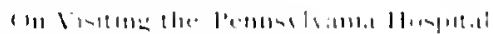

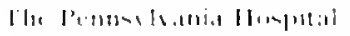

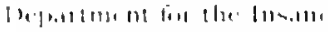

la..1110.1)t

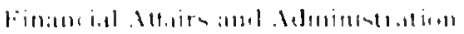

kitil listere.

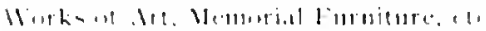

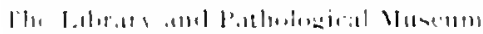

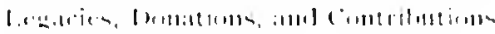

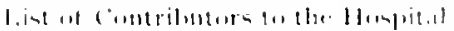

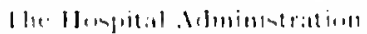

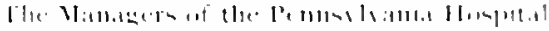

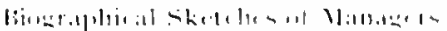

fle Merlical $-2.01 t$ 


\section{PREFACE.}

Alout ten years ago, in an al andoned "loset in the "Retreat." an nut-building of the Hospital, was found a large collection if letters, accounts, and memoranda. which were liable to be lost ur destroyed. Among them were discovered many of the early papers of the Institution. The attention of the Buard of Managers heing directed to the existence of thene perishable archives the following action was taken in reference thereto:

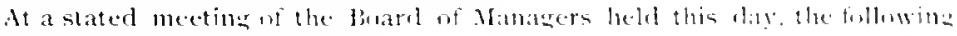
wats ardepted:

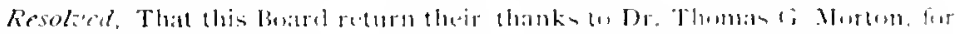

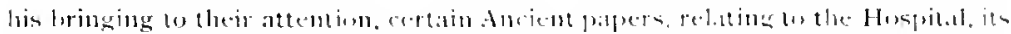

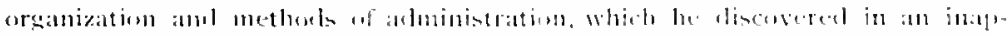

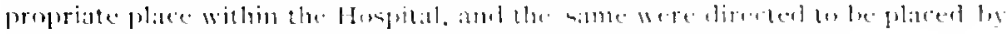

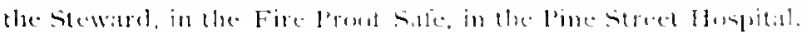

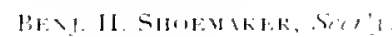

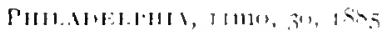

It appears that sume thirty years leefore, when alterations were m progress in the library, these old documenti had leen carried over to the Retreat, where they were subseduently overlooked and their existence forgotten. In order to preverve the valualbe historial material contained in the manucripts and to prevent their being again mislaid or lost. it was suggested, anan eminently proper frocedure to incorporate them in a publication, which shomlil be. in fact, "The History of the Pennsylvania Hospital." This was taken up for consideration at the contributore Mecting. in May, 1 sos, when it met with cordial approval. as expressed in the followin: extract from the minutes:

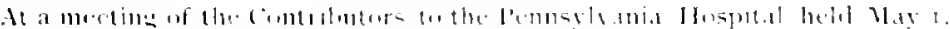

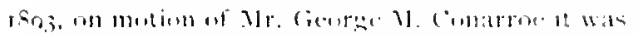

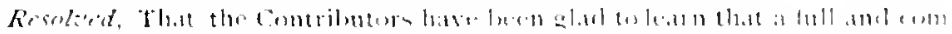

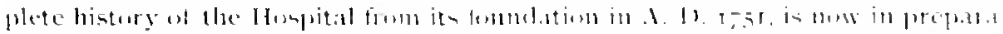

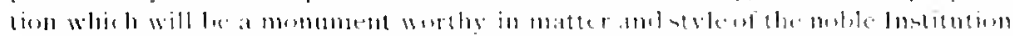

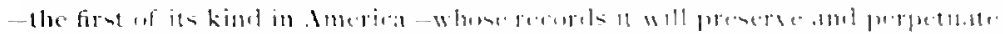

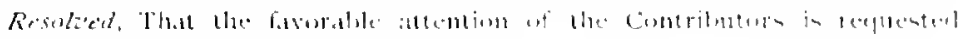

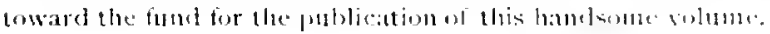


Not only was moral support offered. Int substantal contribu. tion, were siven. at that time and since. towards the expense of publishing the work. of which. arateful mentoon may lxe made in this Hare

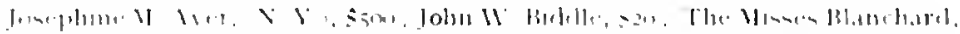

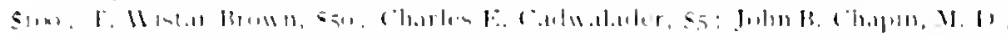

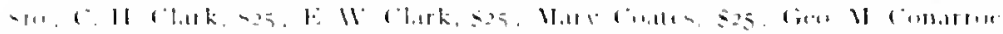

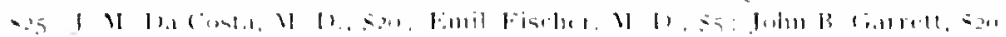

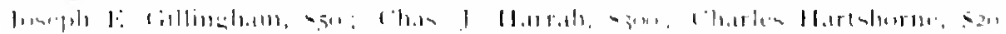

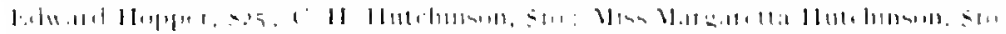

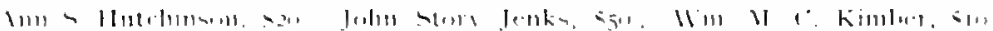

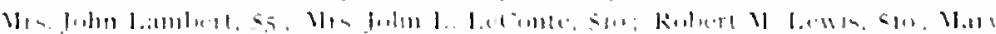

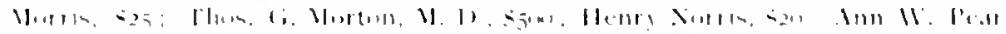

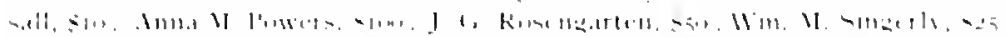

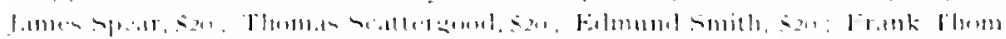

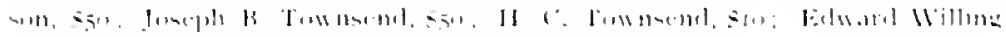

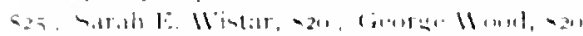

The thantis of the compilese of these records are cordially seturned also to the lioarel of Managers for the encouragement and sipport given during the pregress of the andertaking. and ackmol.

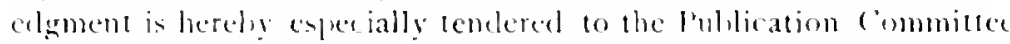

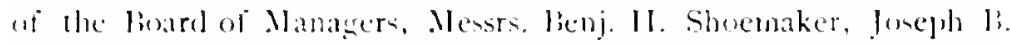
lownsend, and dexander biddle, fur active assistance and interest in the work. and alse (1) Mrs. A. I. ()urt, Jehn B. Chapin. and Henrs II. Wetherill, and to Mensrs. W. W. lest and W. A. Irmetrong l'hanks are alon returbed to Mre. (itllenge for permission to use the very artistic miniature of lianklin, wheh finds an appropriate place wer the article on Finam ial Affairs ams Adminiatration. The fol lowing letter is of smate interent in connection therewith:

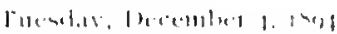

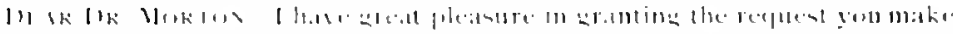

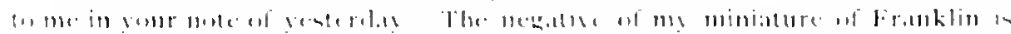

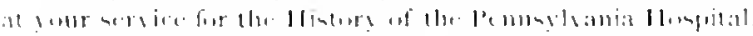

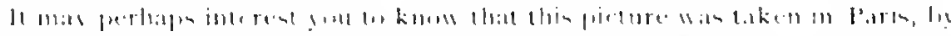

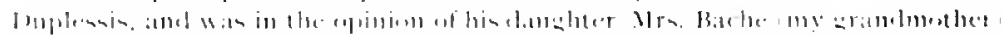

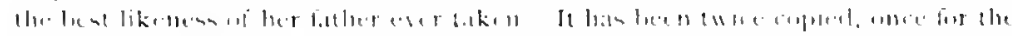

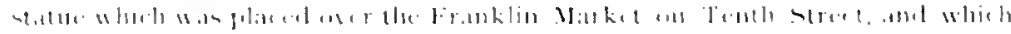

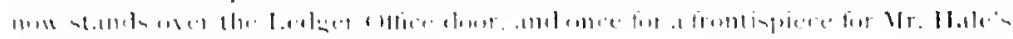
"liaklin in Frane.".

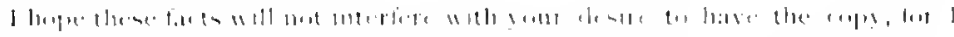

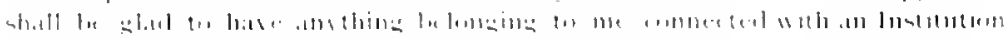

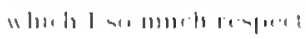

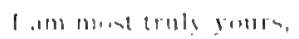

$$
\text { L. H. FiLLE, ILIL. }
$$

lin the ygus raphical excellence of this book, the Contributor we indelited to the Manazers of the times I'rinting llouse, who h.t:e leen most accommodating and courlesun. rendering the task 
of the compilers as pleasant and an light as possible. Thanks are also due to Mr. James P. Llarbeson of the Ciutekunst Company for the unusual excellence of the illustration.

While the list of Contributors to the Hospital has been mont carefully compiled from the records, it is still pussible that there may have been some errors, or omissions, and in fact, the following names have been olsersed to be incorrect, for which slight typo. graphical errors due alpology in made:

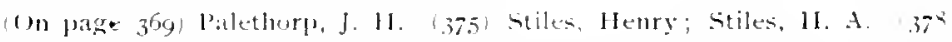

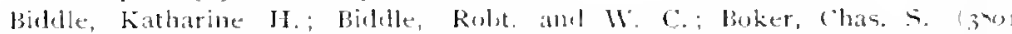
Cash, Andrew, D. : Catteli, Elijah d; ; Clighurn, James L. ; Claglasn, James II:

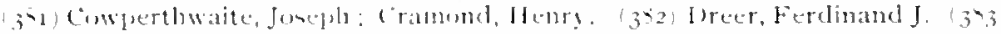

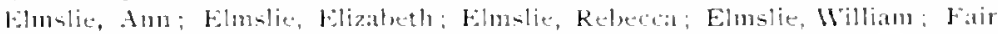

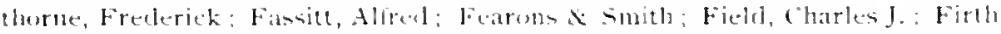

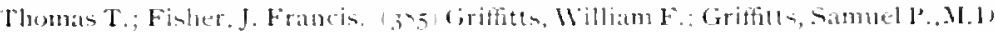

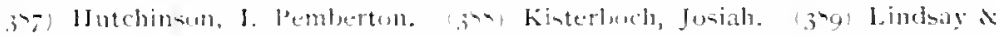

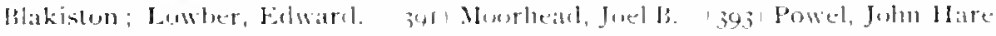

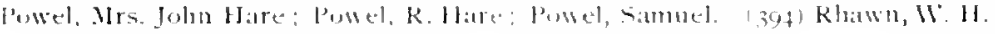

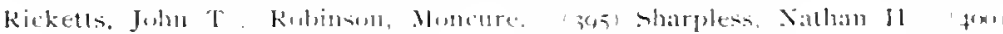
Wurts, clates s., M. W.

ln preparing this History of the l'enmiliania Hospital. from the original documents, special effort has lieen thade to jereserve the form of archaic expression and jectliar orthography, of these ancient papers, by careful comparison of the jroof with the original, even at the risk of seeming to sanction freculiarities of orthography, or of grammatical construction, which eliffer from the standards of the present day. The exertions made to olutain jortraits of the Managers and Physicians have been only measurably successful and lead w regret that this attempt to secure complete set had not been made many years ago.

Among the noteworthy features of this work is material which. hitherto, has never heen published, such at the letters from lieutenant Governor Hamilton tu the Penn: also varions letters of the Managers to the Proprieturs; letters from 1r. Fothergill of London; cor rejpondence of the Managers with (jovernors benny and Richard l'enn and also letters of Penjamin Franklin, who was the first clerk of the board of Managers. The account of the difficulties of the Hospital administration during the trying period of the Revolution and the report of the action taken by the Vlanagers on the betuest of 'puestionable value containd in l'ranklin's will, are of special intere-t. The history of the development of the Department for the Insime and of the ceremonies atlending the laying of the corner-stones of the buildings, has atso decided interest and value. The upinion uf Horace Binney, Esy., prepared b! reques of the Buard of 
Mandece on the "Phties of the coroner," and the text af the

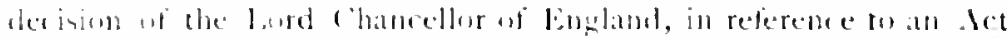

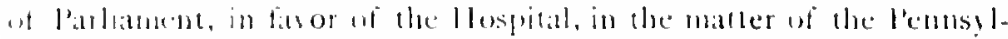

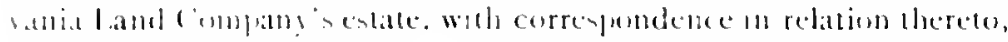

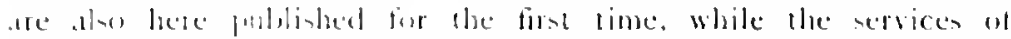

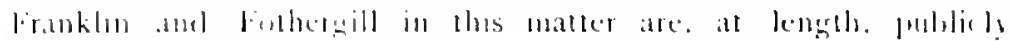

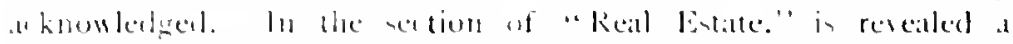
"hapter wi local history which hithertu has been inacessible amel

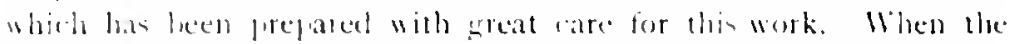

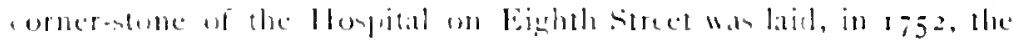

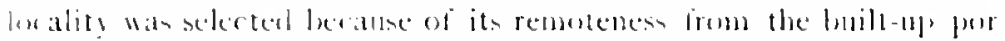

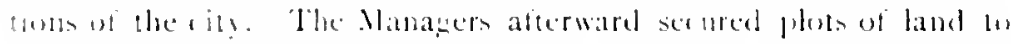

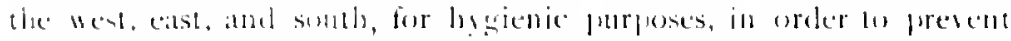

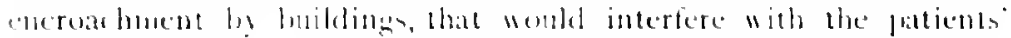

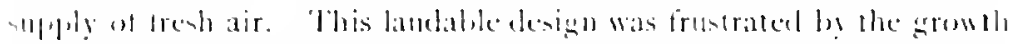

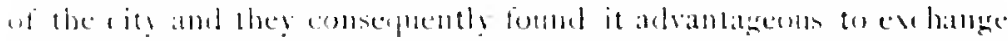

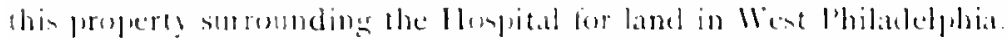
The illustation, is is beliered, add reyg materially to the valuc of thin llintors. Among them attention is especially ralled to the fine

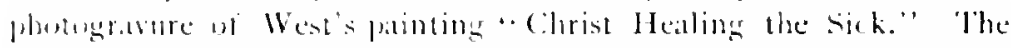
vignetee at the heads of the sectims, as indecd most of the illustra.

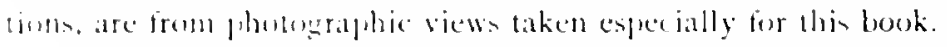

lanicl Medeter, in his speech at the " Plymomth (elebration,"

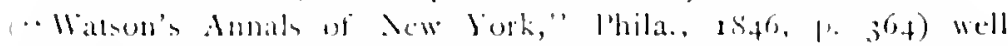

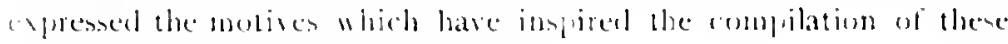

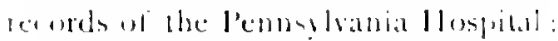

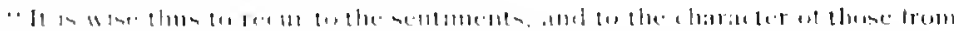

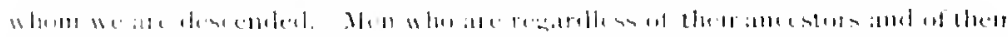

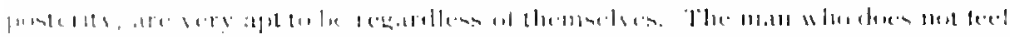

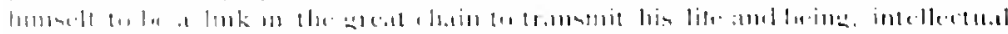

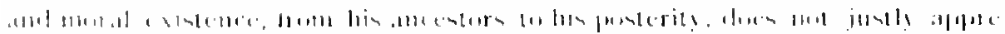

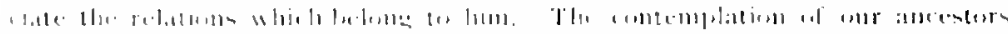

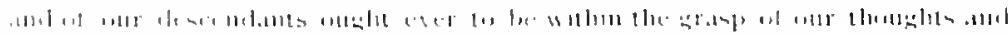

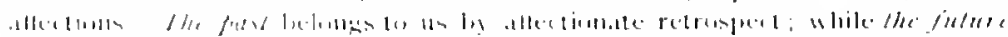

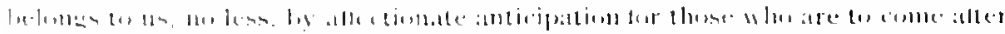

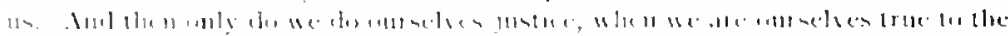

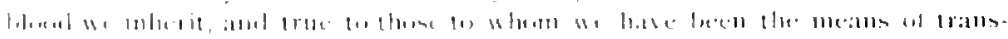

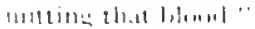




\title{
"On Visiting \\ Jbe Deminglvania bospital."
}

\author{
FrANOIS SUDTT KEY.
}

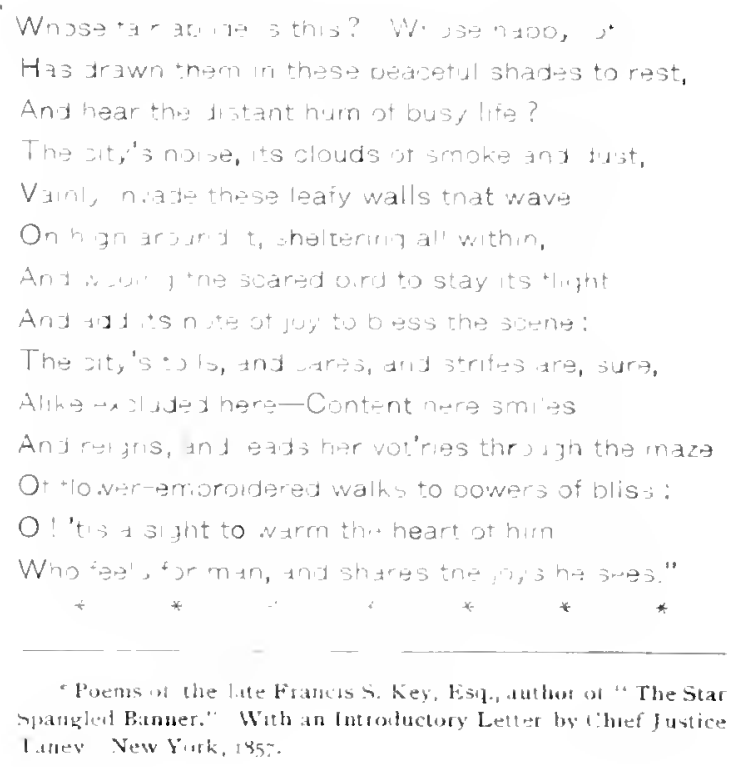

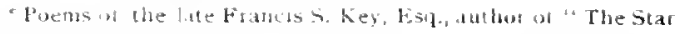
spanglest Banner." With an Introduclory Letter by chef funtice I whey New riark, 195: 
卢 


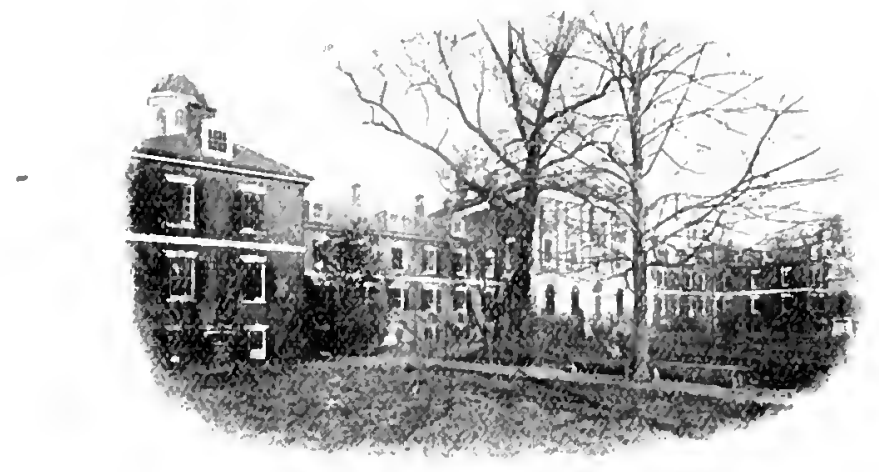

\section{THE PENNSYLVANIA HOSPITAL.}

From a petition presented, the $23 \mathrm{~d}$ of January', 1751 , to the Assembly of the Province of Pennsylvania, by "sundry Inhabitants." it appears that, prior to the founding of the Pennsylvania Hospital, no permanent, public provision had been made in this Province for the care of persons "distemper'd in Mind and depriv'd of their rational Faculties," or for the relief of sick and injured inhabitants. 'The petitioners speak of the insane as:

Some of them going at large, a Terror to their Neighbours, who are daily apprehensive of the Violences they may commit: And others are contunally wasting their substance, to the great injury of themselves and Fanilies, illdisposed Persons wickedly taking Advantage of their unhappy Condition, and drawing them into unreasonable Bargains, ete.

With reference to the indigent sick of the Province, it is set forth :

That the good laws of this Province have made many compassionate and charitable Provisions for the Relief of the Poor, yet something farther seems wanting in favour of such whose Poverty is made more miserable by the additional Weight of a grievous Discase, from which they might easily be relieved etc.

The fact that temporary accommodation had been provided for sick strangers, although nothing of this kind had heen furnished for permanent residents, was certainly a strong argument in favor of estahlishing a Hospital, and this is expressed in clear terms at the conclusion of the petition :

The kind Care our Assemblies have heretofore taken for the Relief of sick and distempercel Strangers, hy pruviding a Place for their Reception and Accommodation, leaves us no Rnom to donbt their slywing an equal tender Concern for the Inhabitants. And we hope they will be of Opinion with us, that a small Provincial Hospital, erected and put nuder proper Regulations in the Care of Persons to be appointed by this House, of oherwise, as they shall think meet, with Power to receive and apply the charitable Benefactions of good People towards enlarging and supporting the same, and some other Provisions in a Law for the Purposes abovementioned, will be a gool Work, accertable to God and to all the good People they represent.

Petition to Provincial Asstubly. 
Cite of Sick and lnsante

poor.

The pultic provision made for the sick and dintempered immi. gram alowe relerred to had, in all probability, been inspired, not so muth by tender coneern for their welfare, as by the desire to kecp the herons ont of the city, amb by thes isolating them, to prevent the intronction of contagious disease. The provicions here referred to constibuted the first atcompts to protect the inhahitants by the estallishment of purantine at the port of Ihilatelphia. Incleed. 1u, to 17.40 . whenever sick inmigrants arrived at lhiladelphia, it was the wistat wistom to place them in emply louses about the city, and in this way infertion was frepuently communicated to the neightivers.

It may be intere-ting to note some of the means and methods alopted in the Province for the care of sick and insane perer. from 16,6 to the time when the petition just referred to was presented to the Iscembly. The earliest provision for maintaining an insane paticnt is found in the records of the Cptand Court, letaware County, l'a, in $16: 0$.

Jan Cornelissest, of Amesland, Complayning to ge Court that bis son Erick is

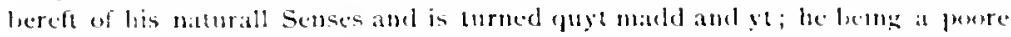

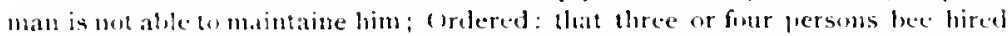
to build a little bleck house at Ameshand for to put in the said madman, and at the next court, weder will be taken yt: a stmall Lesy be latich for wo pay for the buifling of ye house and the maintaining of ge said motdmatn according (1) laws of ye tivermment.

This apjears to have been the customary method of procedure, umler the laws of the Brovince, in the case of indigent lunates, who were incarcerated at the discretion of the Court; such provision was coferced, however, only where the safety of citizens was imperilled, or, where the humatic had destructive or homicidal impmeses.

The opening of the l'ennsylrania llospital inaugurated a new eporh in the treatment of hunatics in this comtry, as it legan hy receiving them as patients suffering with mental dincase, to be subjected to such treatment as their cases required, with a view to their ultinate restoration to reason. instead of simply confining lhem as malefactors.

The project of establishing a public hospital in this city. the need of which constantly became more urgent, was considered by the Ansociation of lirienclo as carly as r 709 .

At a monthly meeting of firiends of thiladelfhia, held the $25^{\text {th }}$ of the ninth month of that year, the Records state:

Siegrs loward

Patiblolushing a llospital.

Thonses Griftith is ordered th pay Edward Shippen to the value of bight Putuls sterling when there is stock in his hands, twatsds defraying the charges uf negelidting matters in England in rebatin to the Schos Charter and one that is endeatrorel to be obtaincd fir an lhospital, according to the agreement and concurrence of the Heeting some time past, and was accordingly to send wer 
by Isaac Norris to request of Gos. Penn who was willing to grant the same; but upon advice thought it proper to have the School and Hospital in me which this meeting desires may be moved again by James Logan, who is now going over to England.

This appears to have been the first effort toward estallishing a Hospital in this community. Whether the intention was to inaugurate an institution for the exclusive use of memlers of the society of Friends or a general Hospital, is, of course, at the present time, unknown.

Ihiladelphia being a place which could only develop in its early years by immigration, it was necessary to regulate the reception of persons who came by sea. The accommodations in the ships for passengers were insufficient, and too often. long volages, poor ventilation, and improper food produced, among closely crowded passengers, scurry, malignant fevers, and diseases of a dangerous type.

In early Provincial times, a Hoyjital was usually considered as a Pest House place where lunatics and other sick persons were confined, so that and citizens generally might he protected from contagious discare, or the Lazaretto. irresponsible acts of the insane. The medical care of paupers and lunatics was not deemed of so much importance as it is now. Not that the physicians appointed by the authorities to serve the quaran. tine station were incapable or unsympathetic, but the time consumed in journeying to the Pest House was so great that only physicians of limited practice, or those who had assintants to do the rork, could accept such a position. Those who did undertake to attend the Pest House, it appears, occasionally neglected their duties. When Dr. 'Thomas Graeme presented a lill for twenty years' services at the Lazaretto, the Assembly rejected the clajm, "awing to his neglect of the service."

The Pest House on Fisher's Island was purchased by the authorities February $3,17+3$, for a quarantine station for shelter and isolation of persons arriving from sea with epidemic diseases, hut not as a refuge for the sick of the province. Even if it had possessed proper accommodations. it was too remote and inaccessible to be of any practical use to the citizens of Philadely hia. The want of a hospital located in the city soon came to be seriously felt. The Almshouse was simply a place of cunfmement. Wrlling physicians devoted much of their time to the poor, though many of these unfortunates were necessarily much neglected, owing to their homes being located in different and scatterel parts of the city and sulurbs, where they could not receive proper carc.

No one was more semsible of these difficultes than 1)r. "lhomats Bond. a prominent physician of large practice in Philadethia. Te was a man of great henevolence and occupied a position where the 


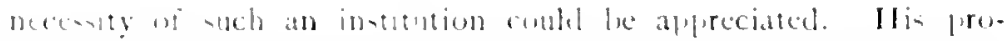

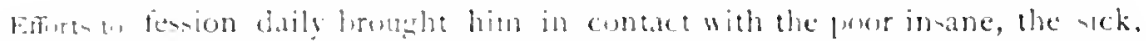

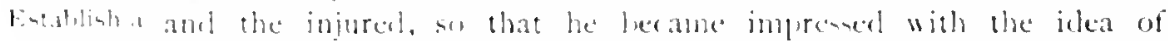
isener.t? Itispit.,1. sathering a number of thene mostunaten under one roof. where they wombl le proviled with the are. cumfort. and individual necesarice

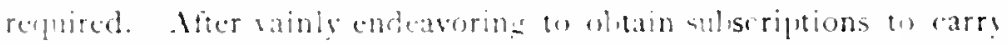

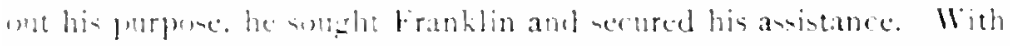
the aref of this pwertul auxiliary, of influential and withal so methex?ical in coersthing he underusti, and be their combined efforts, the frojert llas som placed on a firm basis and the sucress of the undertaking asweded.

franklin has hat a-criled to him the homor of leing the orisinatur of the l'enmithania Hospital; hut he generously sets

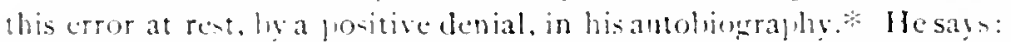

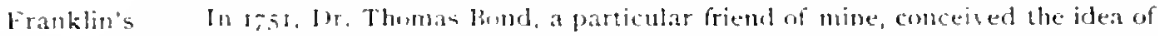
Assistance, establishung a hoppital in Philadejphia, a very heneficent descrn, which has been ascriberl to me, but was uriginally and truly his for the reception and cure of purs sick peronos, whether inhalitants of the prosince or strangers. He was

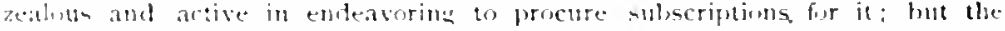
propusal beins a twrelty in America, and at first not well understend, he met with but little success.

At length he came to me with the compliment, that he found there wis mu such thing an carrying a puldic-spirited profect through without my being concerned in it. "Fur." he said, "I am often asked by those t" whon I propose subscribing. 'Have vou consulted Franklin on this husiness? And what does he think of it?" And when I tell thena 1 have mot, sulpwsing it rather ont of your

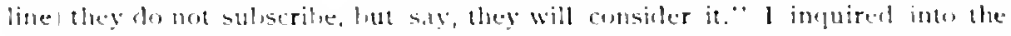
nature and probathe utility of the scheme, and receiving a very satisfactory cxplandtom. 1 mot only subscrited to it myself, but engaged heartily in the

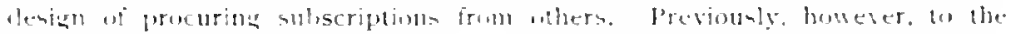

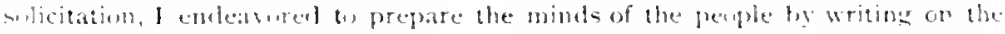

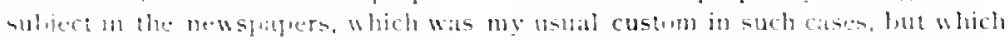
lac harlumith il

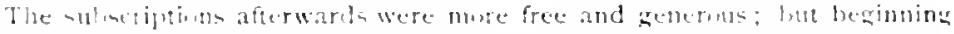

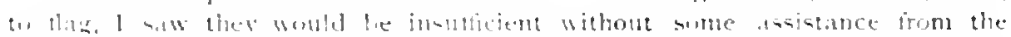

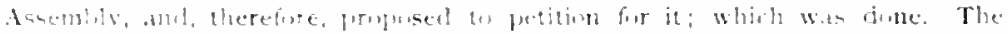

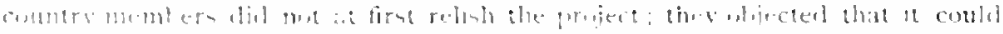

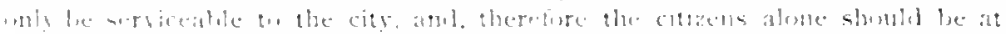

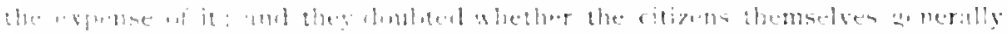

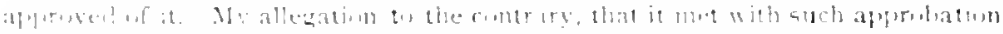

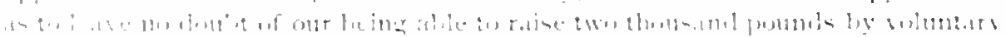

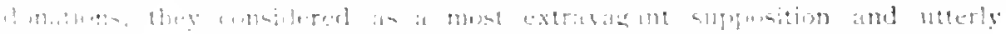
11:

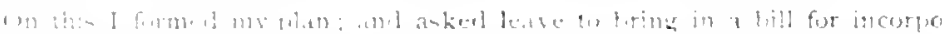

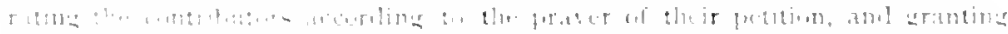

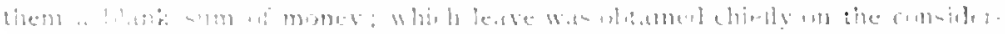

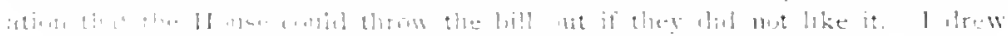


it so as to make the important clause a conditional one, viz. : "And be it enacted by the authority aforesaid, that when the said contributors shall have net and chosen their Managers and treasurer and shall have raised hy their contributions a capital stock of two thousand pounds value, the yearly interest of which is to be applied to the accommotation of the sick poor in the said hosptal, anr free of charge for diet, attendance, advice and medicines, and shall make the same appear to the satisfaction of the speaker of the Assembly for the time being; that then it shall and may be lawful for the said spetker, and he is hereby required to sign an order on the provincial treasurer, for the prament of two thousand pounds in two searly payments, to the treasurer of the said hospital, to be applied tu the founding, building and finising of the same."

This condition carried the bill through; for the members who had opposed the grant, and now conceised they might have the credit of being charitable without the expense, agreed to its passage; and then in soliciting subscriptions among the people, we urged the cunditional promise of the law as an additional motive to give, since every man's donation would be doubled; thus the cause worked both ways. The subscriptions accordingly soon exceeded the requisite sum, and we claimed and received the public gift, which enabled us to carry the design into execution. A convenient and handsome building was soon erected, the institution has by constant experience been found useful, and flourishes to this day, and I do not remember any of my political manceusres, the success of which at the time gave me more pleasure; or wherein, after thinking of it, 1 more easily excused nyself for having made some use of cunning.

After taking up the project, Franklin soon became enthusiastic and was always a zealous worker in behalf of the Hospital. He was intrepid, forcible, and logical. His appeals supported by plain statements of facts were irresistible, convincing his hearers and readers of the necessity of establishing such an institution. The fact of its support by voluntary contributions, heretofore considered impossible, he demonstrated to be no longer a matter of doulst. In his " Brief Account of the Pennsyliania Hospital," Philadelphia, 1754 , he makes the following statements:

About the end of the year 1750 , some Persons, who had frequent Opportunities of observing the distress of such distemper'd Poor as from Time to Time came to Philadelphia, for the Advice and Assistance of the Physicians and Surgeons of that City ; how difficult it was for them to procure suitable Lodgings, and other consenences proper for their respective cases, and how expensive the Providing good and careful Nurses, and other Altendants, for want thereof, many must suffer greatly. and some prohably perish, that might otherwise have heen restored to Health and Comfort, and become useful to themselves, their Families, and the Publick, for many years after; and considering moresur. that ceren the poor inhubituts of this city. tho they h.t ho:nes, yet were therein hut hally accommodated in sickness, and could not be so well and easily taken Care of in their Suparate Hatitations, as they might be in one convenient Houne, under une. Inspection, and in the hamds of skilful practitiners; and severd of the inhabi. tants of the Prusince, who unhappily hecame disordered in their Sonses, wantered

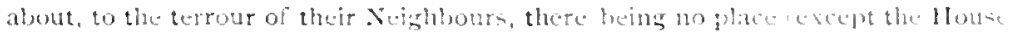
of Correction or Almshouse' in which they might he confined, and sulfiected to

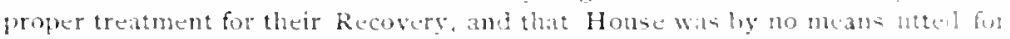
such Purpones: did charitably consult together, and confer with their Frable

\section{Franklum} Account of Founding the Hospital.
Sick and

Insane Puor withont proper Care. 
and Açuaintances, on the luest means of relieving the Distressed, under those circumbtmes; and an Infirmary, ur llespital, in the manner of several lately entalplished in Great l3ritain, being proposed, was so gencrally approved, that chere was reason to expect a considerable Subsciption from the Inbabitants of this "ity. $t$ wards the support of allo a llompital; but the expense of erecting a Bulding sutficienty large and commodious for the purpose, it wis thought would be tw havy, unles the subscription could be made general through the lrovince, anel seme arsistance eomld be olvained from the Assembly" : the following petition was thereforedrawn, and presented th the lfusce un the 231 of January; $1,50-51$

Petition

Vacle to the Assemtily.
To thi honow anle Llowse of Represenhaties of

the Pronimie of Pentustrlania,

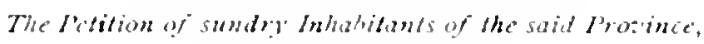

Jumbly shonelh,

TII.IT with the Numbers of People, the number of Lunaticks or Persons distempered in Wind and deprived of their rational Facuities, hath greatly encreased in this P'rovince.

That sıme of them going at large are a Terror to their Neighbours, who are daily apprehensive of the Violences they may commit And others are continually wastin: their Substance, to the great lnjury of themselves and Families, ill disposed Pernons wickedly taking Advantage of their unhappy Condition, and draw. ing them into unreamonatse Bargains, Sc.

Th:t few ur none of them are so sensible of their Condition, as to submit voluntarily to the Treatment their respective Cases require, and therefore continne in the same deplorable statc during their Lives; whereas it has been found, hy the Foxperience of many lears, that above two Thirds of the Mad Penple received istw Bethlehem Ilsipital, and there treated properly, have been perfectly cured.

Yin l'etitioners beg l.eave farther to represent, that tho' the good Laws of this Pruvince have made many compassionate and charitable provisions for the Relief of the Poor, yet something farther seems wantung in Favour of such, whose Poverty is nade more miserable by the additional Weight of a grievous Diseane, from which they might easily lee relieved, if they were not situated at too great is bistance from regular Advec and Assistance; wherehy many languish nut their Lives, tortur'd perhaps with the stone, devour'd by the Cancer, deprived of cialu he cataracts, or gradually decaying by loathsome Distendyers; who, if the bxpense in the prenent manner of Xursing and Attending them separately when they come tw Town were not so discouraging, might again, by the judicious . Lisistance of Physic and Surgery, be enabled to taste the Blessings of Health, and the mate in a few Weeks, useful Members of the Community, able to provide for themselves aml Families.

The hind 'are our Assemblies have heretofore taken for the Relief of sick an! distempered strangers, hy prosiding a Place for their Reception and Accom. molation, leaves us no kom to loul, their showing an equal tender Concern for the inhabituts. Am we helpe they will be of Opinion with 15 , that a small pro-

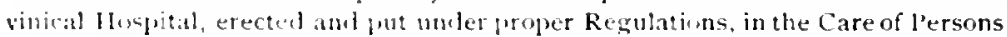
(1) be aprointed by thin lIouse, or utherwise, as they shall think meet, with puwer t) recedive and apply the charitable benefictions of good peotle toward entarging ant suppurting the sante, and hone other Provisions in a Law for the Purposes aluse mentionet, will be a grod Wirt, acceptathle to God and to all the good leople theg represent. 


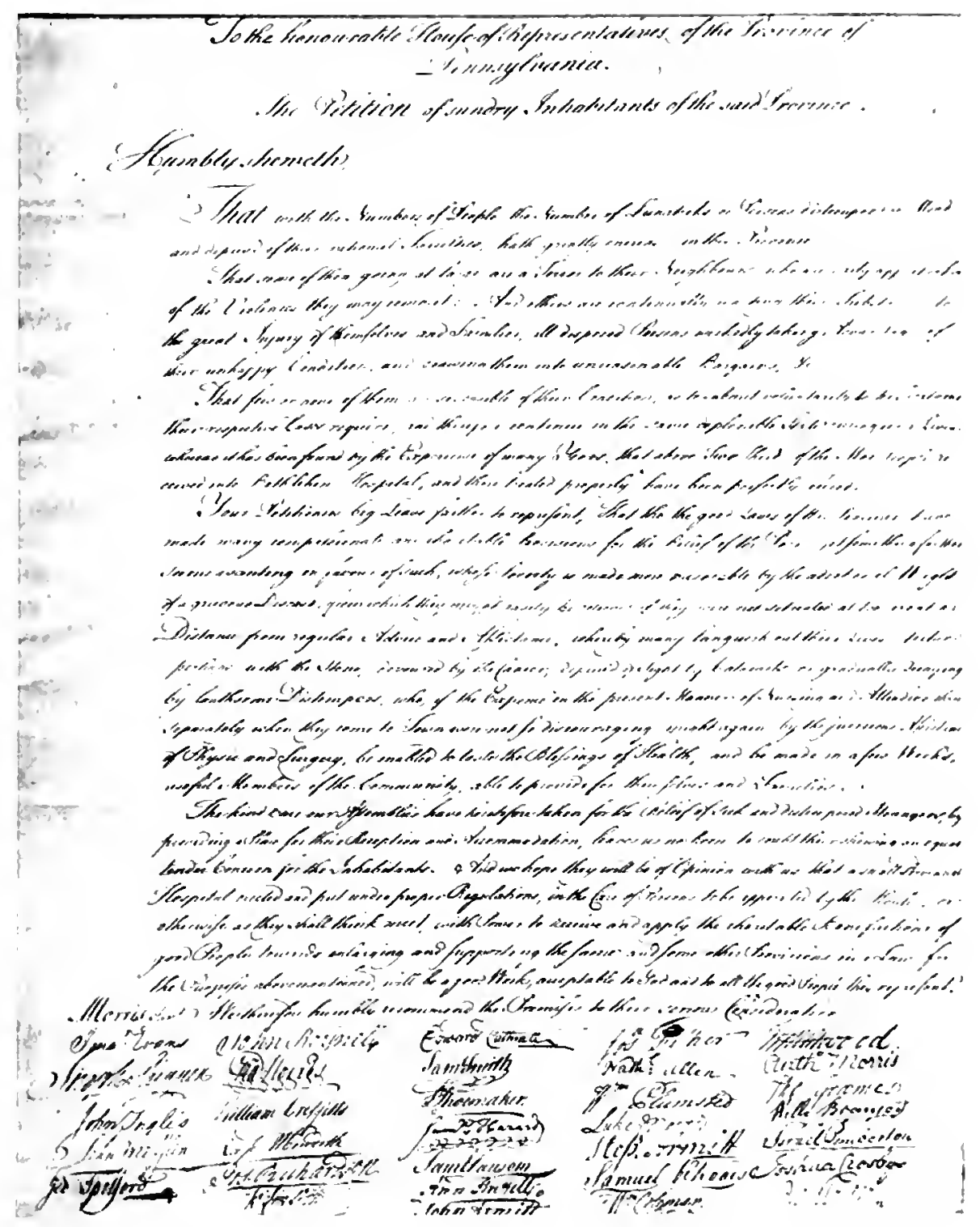



We therefore humbly reconmend the Premises to their serious consideration

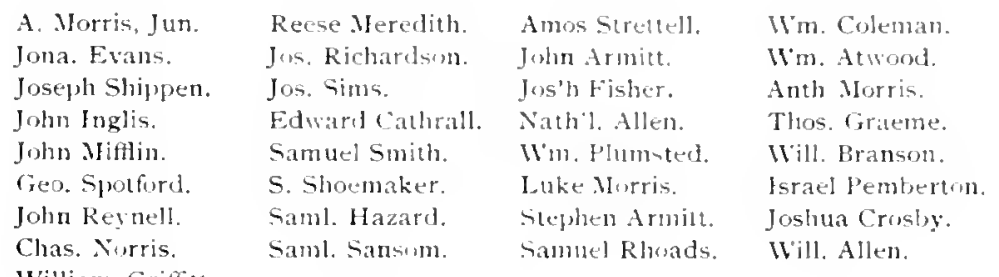

Villiam Griffits.

'l'his interesting document was in the handwriting of Franklın. Petilin though not signed ly him, prolably from the fact that he was before presented to the people as a candidate for pululic office (being soon after elected to represent the City of Philadelphia in the Provincial Assemlly). The wording of this petition is at once forcible and significant, not merely. adrocating the needs of the sick and injured, but the insane are referred to first, as if constituting the most important sulject for legislation, and in a manner truly humane and highly enlightened. The views expressed on behalf of this afflicted class were far in advance of the times, and this document remains an imperishable monument to the honor, intelligence, and philanthropy of the originators and promoters of thic charity. Referring to this, Franklin sais:

On the second reading of the Petition, January 29, r75t, the House erave l'etition raal leave to the Petitioners to bring in a Bill, which was read the First Time on the a second lime lirst of February. For some time it was douldful whether the Bill would not and favorably miscarry, many of the Members not readily conceiving the Necessity or ["sefulness considered. of the design: and apprehending moresver, thit the Expense of paying Physicitus and Surgeons, would eat up the whole of any Funl that conld be reas nably. expected to be raised: but three members of the Medical Profession, viz. : Doclors Lloyd Zachary. Thomas Bum, and Phineas Bund, senerously wfiering to attend the Hospital gratis for thee years, and the other Myections heing hy degrees got over, the Bill, on the seventh of lhe same Month, passed the floust, Nimine Conbadicent, and on the Ith of May following, it received the Governor's approval.

The following is the text of the original:

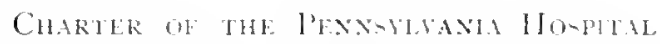

Anno Regni Georgii IJ. Regis, Mignae Brittanice, Franciae Hibernia. Vigesimo (2) uarto.

At a General Assembly of the l'rovince of l'ennsylvania. begun and holden at Philalelphia, the Fourteenth day of October, Anno Domini, $175^{\circ}$, in the twenty-fonth sear of the Reign of our Sovereign Lord George II. by the cirace of Gud, of Cireat Britain, France a Ireland, King, lefenter of the liath, etc. And from thenee com-

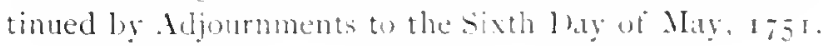


In . M"l te encenrage the establishing of an l Iospital for the Relief of the sirk l'our of this l'rovince, and for the Reception and Cure of l.matichs.

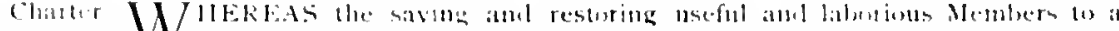

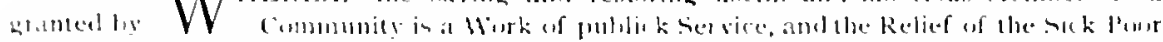

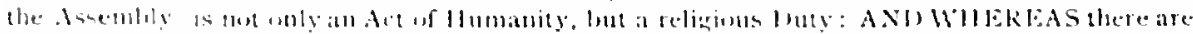

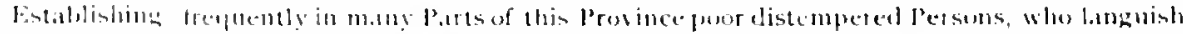

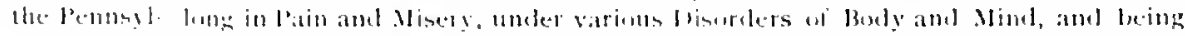

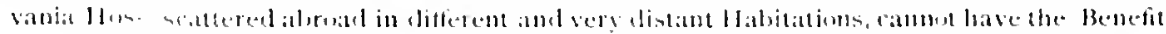

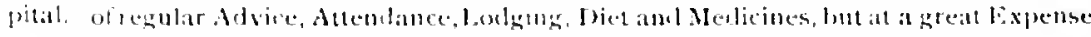

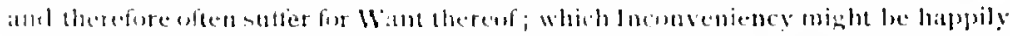

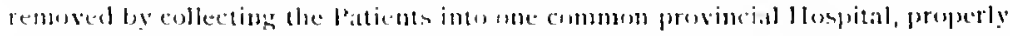
strpmsed and appointed, where they may le comfortably subsisted, and the is lloulth taken care of at a sntall Charge, and where by the Blessing of fied on the fincleavuls of skiful physicians and surgens, their biscases may be cured am romeded. ANO MHERlEAs it is represented to this Assembly, that there is a

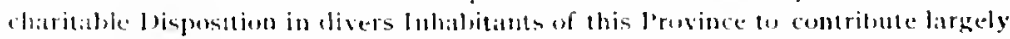

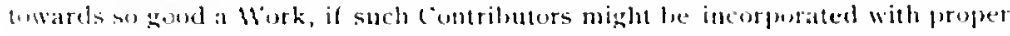
powers and l'rivileges for carrying an and compleating the same, amb stme part of

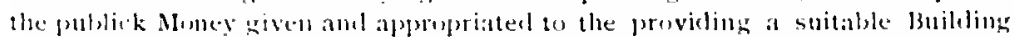
for the Purpuses aforessid.

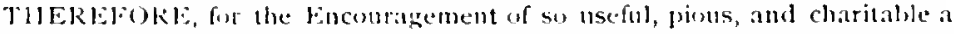

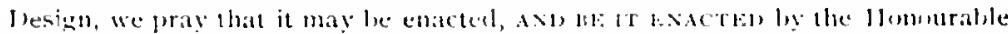

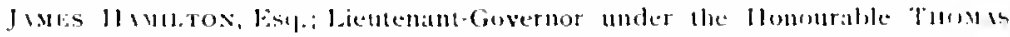

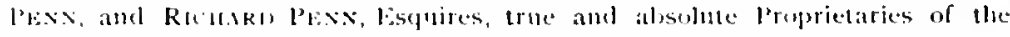

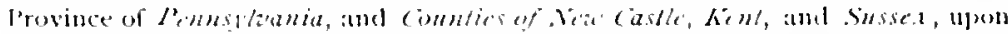

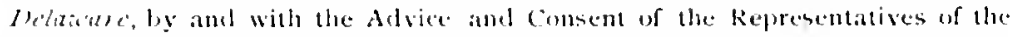
Freemen of the satd f'rovince, in General Assembly mel, and ly the Authority

Gevernment vestedincior

peration of cintrituturs

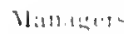
and Tilat wertine . 1 mintailly (isincent of the same, That it shall and inaly be law ful bu and for all fectons, each of whom

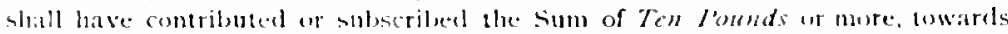
finuding and establinhing an Jlonpital, for the Reception and Reticf of loumaticks and uther diatempered and sick loor within this Prosince, or an many uf them as

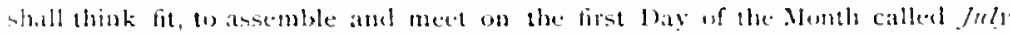
mext; and for all leesulls, whe shall thereafter contribute the like sum of rin

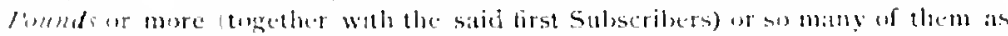

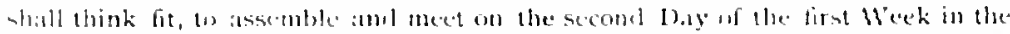

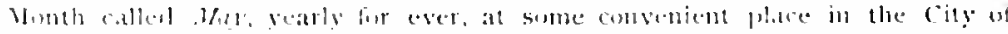

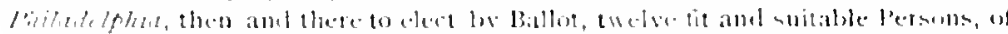

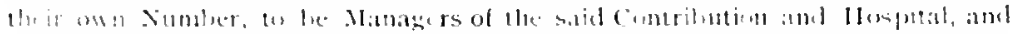

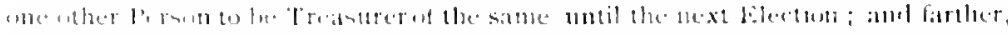

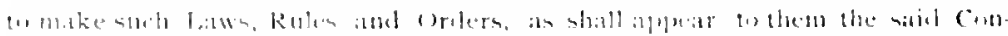

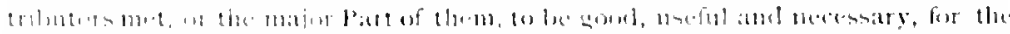

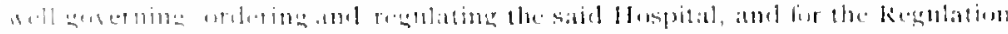

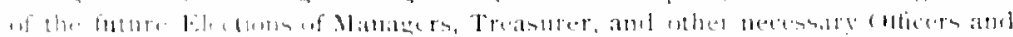

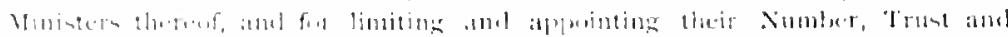

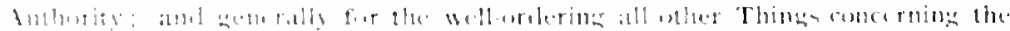

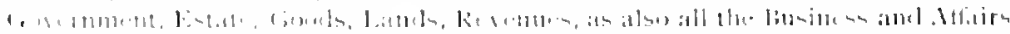

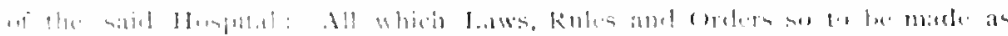

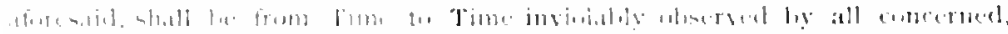

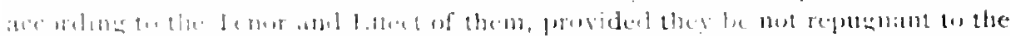

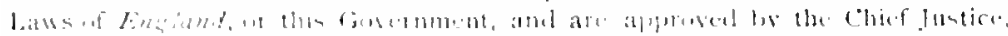

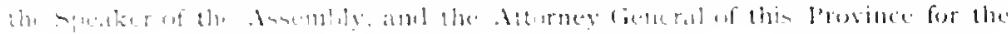


Time being, under their llands and seats. Awl the said Contributors shablue, and are herely made a Body corporate in haw, wall Intents and Purposes, and shall cimutibutur.

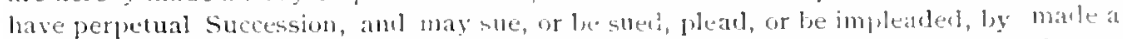

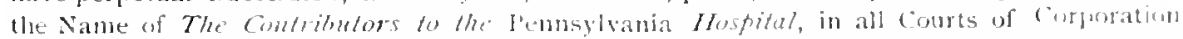
Judicature within this Province; and l,y that Nante shall and may receive and take any Lands, Tenements or Hereditaments, wh exceeding the yearly Value of one Thousund Ponnds, of the Cift, Alienation, Betuest, or Devise of ally I'erson or Persons whomsrever; and if any Gomls or Chattels whatroever; and the sain Contributors are hereby impowered to have and use one common Seat in their Affairs, and the same at their l'leasure to change and alter.

PROVIDED nevertheless, "lhat no General Meeting of the said contrilutors, nor any Persons acting under them, shall emplny any Noney, or wher Estate, expressly given or added to the capital Stuch of the saicl Hospital, in any uther Way, than by applying its annual Interest or Rent, towards the Entertainment and Care of the sick and distempered Poor, that slall be from Time to Time brought and placed therein, for the Cure of their Diseases, from any I'art of this Province, without Partiality or Preference.

AND for the further Encouragement of this beneficent Condertaking, BE IT ENACTED by the Authority aforesaid, That when the said Contributors shall have met and chosen their Managers and Treasurer as aforesaid, and shall have raised by their Contritutions, at capital stock of Tito Thousand funuds Value the yearly Interest or Rent of which is to be ajplied to the accommodating of the sick Poor in the said Hospital, free of Charge for I viet, Attendance, Advice am Medicines) and shall make the same appear to the Satisfaction of the Speaker of the Assembly for the Time being; that then it shall and mat be lawful forthe said Speaker of the Assembly, and he is hereby requised, tu sign an Orler or Orelers on the Provincial Treasurer, or Trustees of the Loan-Office, for the l'ayment of Tatn Thonsund Prunds, in two yearly Payments, to the Treasurer of the sind Iluspital, to be applied to the Founding, Building and Furnishing of the same.

AND BE IT FURTHER ENACTED, by the Authrity aforesaid, That Aecunte 4

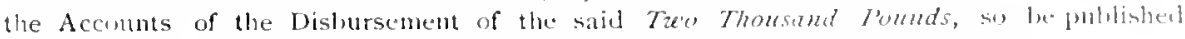
undered lyy the Speaker of the Assembly afforesaid, or any Part therew that shall he hereafter expended, as the Case may he, and of the Rents, Products ant Interents of any real or personil Estates or Sums of Money charitaby given to the ["se of the said IJospitul, together with a List of such Imonations, shall le farrly

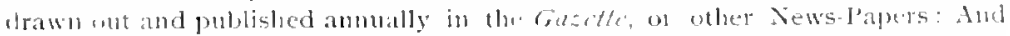
the Manazers of the said Huppital, shatl at all Times, when required, submit the

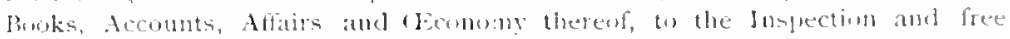
Examination of such Visitors as maty from foune to Tine be apponited lig the Assemlaly of this Province, th visit and inspect the same.

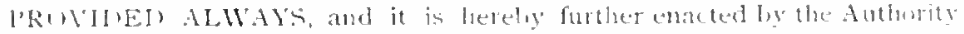
aforesial, That if at any Time herealter, there shonlal not be al comstant suces-s sind of Contributors to meet yearly and chuse Manages ats afousesald, then the

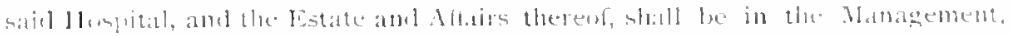

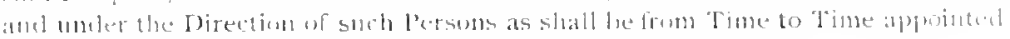

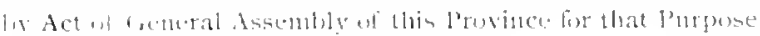

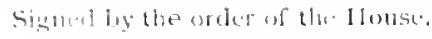

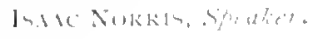

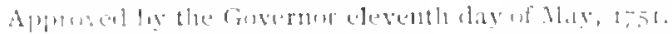

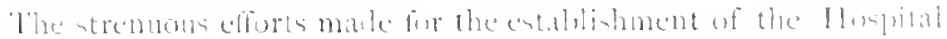

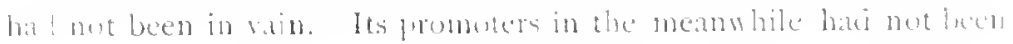

Inf faline 11,1

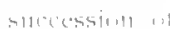
(in1:ilultill 


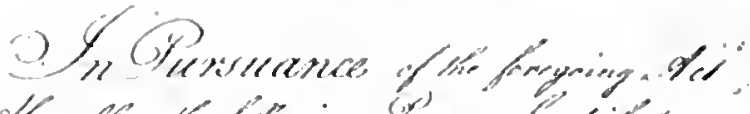

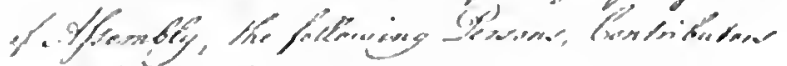

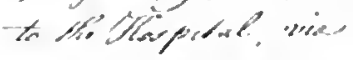

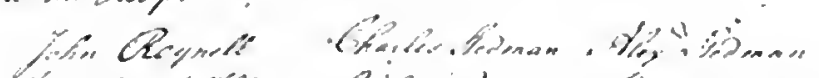

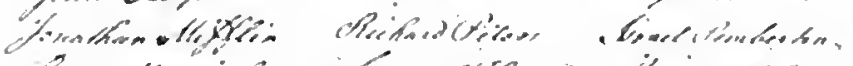

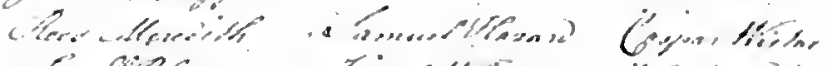

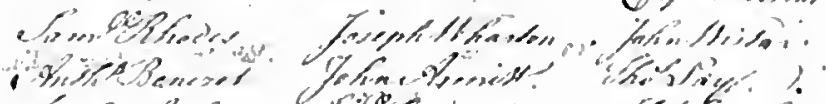

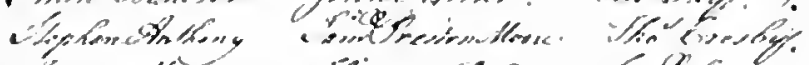

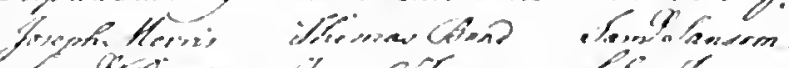

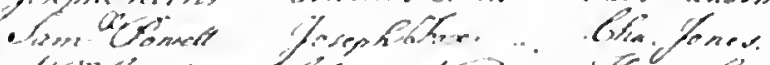

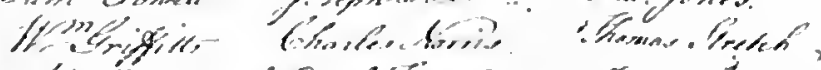

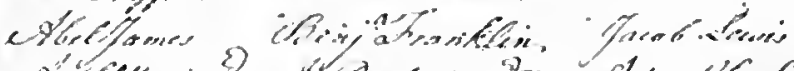

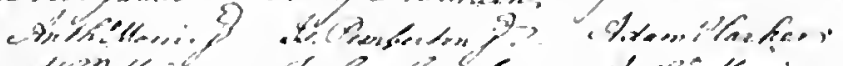

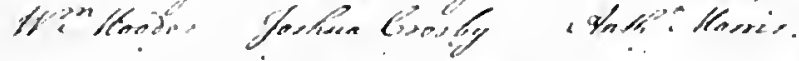

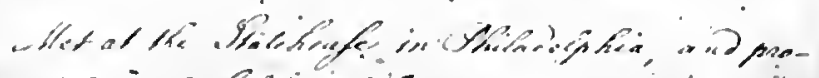

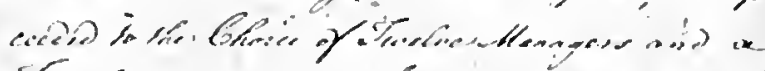

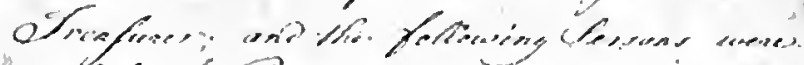

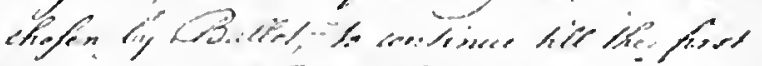

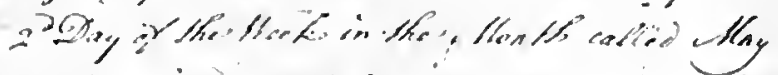

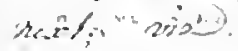

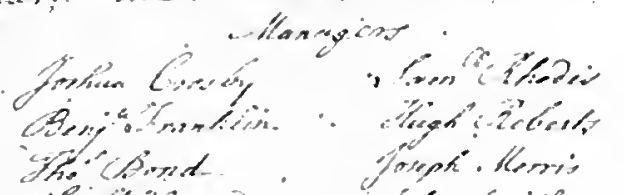

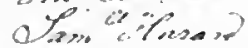

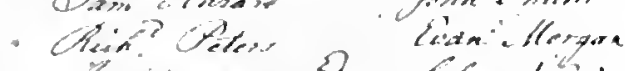

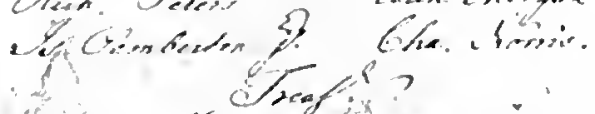
$y$ Forsons?

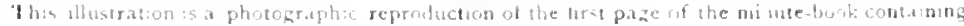

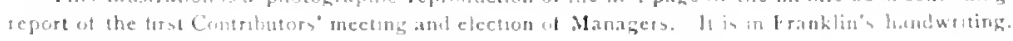


idle; a suloscription list was set on foot which in a short time amounted to over $f_{2} 275^{\circ}$, a sum much in excess of the figure recuired by the law to obtain the f, zooo from the l'rovincial Truasurer or Trustees of the loan Office.

On July $2 \mathrm{~d}$, the Managers met at the Willow l'ratt's Royal Selection Standard Tavern. After some 1)incussion on the Choice of a l'iece of a Site of Ground on which to erect the I lospital, they adjourned and went in a body to riew several places near " the "lown" 1 which were thought suitable for a location. They eventually agreed upon one particular lot belonging to Thomas and Richarel l'enn, the Proprietaries, on the South side of Mulberry (now Arch) Strect, from Ninth to Tenth Streets, and extending 360 feet in depth sonthward from Muberry Street.

The Managers agrain met on July 6th, when it was "voted minine contradicente, that Joshua Crosly be the President of this Board until the next election, and that lienjamin Franklin officiate as Clerk until another shall be apprinted."

This particular piece of ground having been selected, the Managers drafted the following adelress, and forwarded it to Thomas Hym and Sylrants bevan, their agents at London, to be by them presented to the P'roprictaries. What was done in this matter. and the answers the Manarers received, and the other documents relating to the same, it is lelieved are of sufficient interest to be here flaced on record.

The Managers before alpealing to the Prop rietaries in England, sought to enlist the interest of Lieut. Gor. Hamilon, who at that time represented the Penns. It will le seen by the following corresFavorable location found. pondence that in this they were less successful than in other dirctions. The following is a confdential letter sent ly Governor Lamilton" to Thomas Penn, in England:

$$
\text { PHIL.MDELIHIA, JUly 5, IZ5I. }
$$

Hon'd Sir: I had the honour to write You a few days agoe by Captain Styles I eetter from and as every thing remains in the same situation ats was therein mentioned, 1 have ciovernor w nothing new to add at present.

We have heard by the publick Papers of the unfortunate Accident that hefel] Sou, in your joumey to Bath, and should have treen kept in a very cruel suspence with respect to the consequence, But that Mr. Paris was so kind as to infirm me ty way of Buston, of your being ont of all danger from the Wound so that we were at the same time made acyuainted, with the Peril you had been in, $x$ won happy recovery from it. Upon which, 1 legge leave must sincerely to congratulate You, and hope you do me the Justice to belicve, that, no man more heartily rejoices at your escape from so imminent a I)isister.

1 By the Charter of wetober $25,170 \%$, the City was incorporated under the name of "l he Mayor and Commonality of the Ciry of Philadelphia." previous to this it had been called a "town."

2James Hamilton, son ol Andrew Hamilion, was appointed Lieutenant Governor of Pennsylvania in 174 . He was the first native Governor. In 1754 he resigned his commission, but in 175y. when in England, he again accepted the same office, which in zfiz. he yielded to John Penu. 


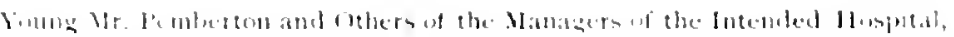

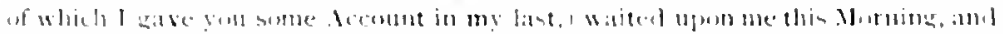

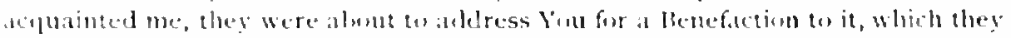

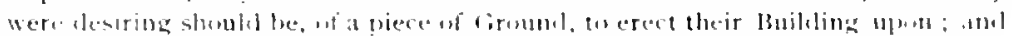

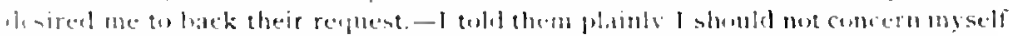

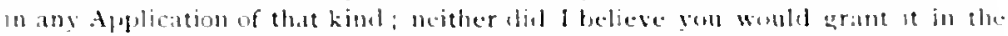
"aly they desirel. Hut that, if you chose w make them a present, it wuld he wit a

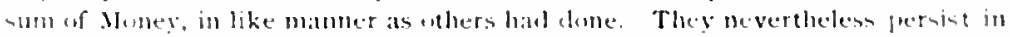
making the application, ant will put it inte the hands of some of the printipat

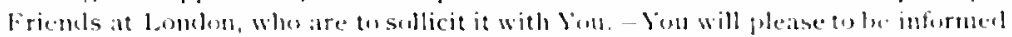

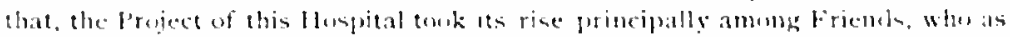
they say, are desirous of shewing the llirld, that, where, shey are not restraned

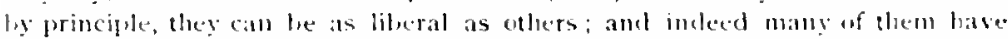

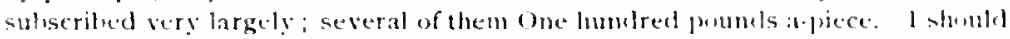
likenise Observe that, the design, is in general well thumglat of, and if righty conducted wili nudouthedly lue of service in many Resperts. 1 thought it my duty to apprise lou as early a possible of the intended Application, previous to

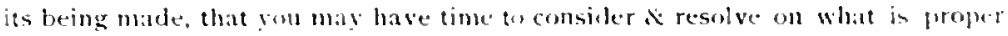

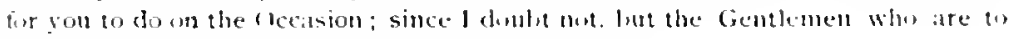
sollicit gum in their behalf. will be very importumate. lam with all pussible Regatel, Sir,

Vour Mlust (Hbliged a Most humble serv't.

He huble Thumas Menn, Ery.

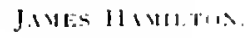

The following extract from another letter is of similar tenor:

Anotherlener tram Gins. Ilamiltom to l'ruprietors.

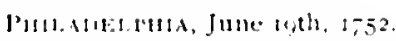

Honored Sir. - The Manigers of the llosprital, hearing from their Agents in Lundon, that 1 had received your ()rders to grant them a piece of land to build on: Mr. Crusly and Mr. Charles Sorris, in their helsalf, watited an me, and requested to know the particulars, with which I immediately arquainted them, by reading Your instructions to me upun that heat. They then asterl, whether, as their memories might not be able to retain the whole contents, I wuld favor them with a copy of the lnstrument? "which I anreed, anel ordered one on he made ont anel teliver'd to them, at the same time letting them know. I shovid expect their answer, to be sent to you by the first opportunity. - Some time after Mr. Crosby and another femtleman came to me again and acquainted me, lhat the Manavers de hat helel several Meetings on the subject, lut had mothen come tu any determination, whether they could accept "f your donation upon the proposed Terms : particularly they could not engige that the Assembly womlel repeal the Acts. But that. when they should come to a final resolution thereupon. they would direct their Agents in England to wait wh bou and acquaint bo with it. I easily perceived this was a piece of evasion tu conceal their intentions from me, but 1 let it pass withont taking any notice of it. - l think it however my lmove as they are asking so considerable a fift from lou, to make bou acquainted with my sentiments of this affair, after which, bin will be pleased to to therein, as Vin shall think right. - It is my opinion then, that these people mean nothing less, than acceptint of your Donation upon the Conditions oflered them: but are desirous to defay giving a positive answer to your progrosal till they are informed that the Act of Ascembly has received the Royal asscmt, to which, some of the Chicfs of them are apprebensive lon will put a stope and being once secure in that point, they will in the next place, by many smoth llords and Compliments to You, and encommms in bour Ancesturs. encleavour to prevail on Vin th grant 
them the Land fret from the conditiun of reversion \&e. Which is an Objection w it, a very leading man among them made to me: And when they have obtained all they have to expect from you; I am persuadled they will think a very small sinate either of the Honour or w the direction wught to be lodged with You, or with any in Authority under lou.

I would not for any consideration have said thus much, has it not been my real Opinion. But there is a pussitility of my beng mintaken, of of my having judged too uncharitably of these Crentemen; I would desire that nothing of what is above said maty transpire. so as tureach them, as it would be to do me a very great prejudice without answering any gond purpose that i know of ; and a little time will satisfy lou, whether or momy surmises are well foutuled.

As for myself, I have not contributel any thines to the Huspital, as it appears clear to me. One particular society, hy making it a point with their people to subscribe small smms, will have the entire numagentelt of it, and are desirous, by the contributions of others, to build a reputation to themselves without ever having done any thing of this kind in conjunction with people of other persuasions. That, however, shall mut be an Objection sufficient to prevent my subscribines to so useful a design, if upon further experitence, I find things are fairly and impartially conducted, and the necessitics of the province call for stlch an Establishment, which I beliere upon Tryal are found to be much less than was expected.

These letters were found in a package of old papers relating to the Hospital, which had probally lueen brought over, among other correspondence referring to this matter, by Thomas Penn, Es r., and being left here by him, were afterwards given to the llanagers as possibly being the most interested in them. It is not to be supposed that Gov. Hamilton could have ever contemplated the possibility of these letters ultimately finding their way into the archises of the Pennsylvania Hospital.

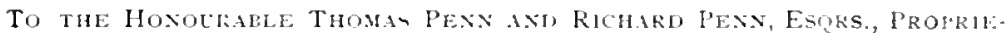
TORS of THE PROVINCE OF PExGILIANA, dC.

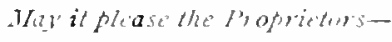

It hath been long observed, that this your Province, remarkable for the froudness of its Constitution, Laws and Government, and many other Advantages, is ret deficient of a common Hospital or Infirmary for the Relief of such Pour as are afficted with curable I iseases.

Your good People here, to supply this Defect, and out of a tender charitable Regard to their Fellow-Creatures, have voluntarily subscribed and are still subscribing large Sums towards a Stuck for the Support of such an Hospital and the General Assembly, being petitioned by a Number of the Inhabitants of all Ranks and Denominations, have passed an Act to Encourage the sante, and granted Two thrusand pounds for the Founding, Building \& Furnishing thereof.

In Pursuance of that Act, we the Sulsscriters were on the first of this Instant chosen by the Contributors to be manigers of the said Ilompital, and think it our Duty to take this tirst Opportunity of laying the Affair luefore our l'roprietors, in lumbie Confidence that ho good \& Pinus an Endertaking will nut fail of their Approbation. Hopeing withal from the accustomed Bonty of the Proprietary Family, in encouraying former Designs of Publick Ltility to the People of their Privince, the present will also receive their kind Assistunce: and 
as l'tuate lersoun raine at Stock to support the llospital and the Asseasbly build the llunse so that all concerned in the l'rovine may share in the Honour, Merit

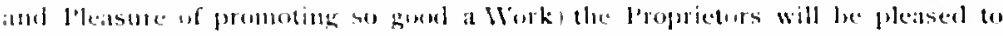

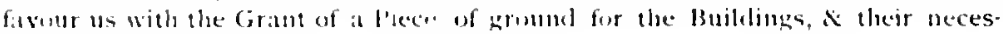
s.tr! locommulatiens.

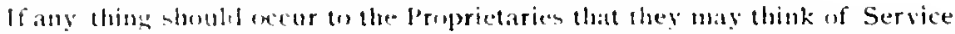
with : ospect tu the management of Rules of the lompital we shomlel be obliged to them tor their sentiments, being desirous that what falls withon our luty, may lec done to the ereatest advantage for the lublick.

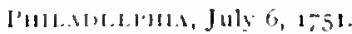

Application was also made, ly the following letter, to Meesrs. Hyan and Bevan. in Jondon. repuesting their friendhip in dediverint the preceding addrens of the danizers the the Proprietaries, informing them of the estaldishment of a Hospital in their I'rovince and also soliciting a Pece of (iround for the linildings and their necessary accommodations.

(iorespund. ence with sechiril in site int lluspial.

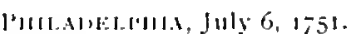

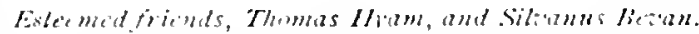

The Opjinion we have of your Beneficent l'rinciples induces us to make this

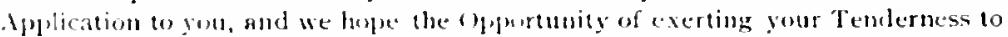
the Aftleted and destessed will he so acceptable as to renrler any Apology" unnecessary for one Freedout in requesting your Friendship in delivering atnd selliciting the adelress we herewith semd to mo l'roprietors, Thomas and Richatd Penn.

The circumstances of this l'rovine have, in a few lears past been much altercd, by the Addition if a great Number of leesons who arrive luefe from sereral pasts of Europe, matuy of whom are poor and sestle in Remote parts of lle Contuty, where suitable provision cannot be male for their Rehef frum the

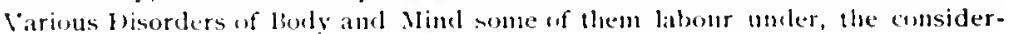
atiun of which bath latcly ratised in many of the luhabitants of this City a leenesolent Concern and engaged them to apply for the Assintance of the Legislatuc by whom a l.aw is passed and some provision made out of the l'rovincial Treastury for the erecting a lublick llospital of Infirmary under the lirection of a Corporation hy whom we have bately been Flected the mandects. But as the fublick founds are not sufficient wanswer the expense of emdowing it, a charitable subseription for that Purpuse hatl been proposed and hegun with gout Success. The Necessty atul Advantages of this Institution are so Apparent that Persons of all Ranks mite very heartily in promoting it and as Several of unt most Fininent Hhysicians and Surgeons have freely offered their Service for some years Whe have Food grounds wexpect that this lmolertaking maty be of General Service much soner than was at first expected and that our leckislature will son make a further provision for the Building which we apprebend it will be prudent to contrive and erect in such manner as to Admit of such Additions as the Future sate of the lerovince maty require. The Principal bisticulty we nuw labour under is the want of a commudions Lott of ciroundin a healthy Situation for (tho' we hase so erreat encouritgement as we have mentinned yet we camnot fatter ourselves will Specdily raining a Sum Sufficient to enable us (1) provicte for all other necessary chartes and to purchase a Suitable piece of Groumbl so near the built part of the City as the constant attendance of the Physicians and other consideratims will necessarily require. W'e therefore are under the lecessity of latying 
the State of our Case before our Proprietors, and we hope the same Hotives which have induced Others will have due Weight with them to promote this cinor Work, and that they will genernusly direct a Piece of Ground to lec allotied for this Service.

There are several Lotts in different Parts of this City very suitable but from their Situation etc, are of rreat Value for other Purposes we have therefore though: of one which is in a part of the Tewn quite unimproved and where in all Probalsility there will le the Conveniency of an Open Air for many years, it is the vacant part of the Square hetween the Ninth and Tenth Streets fom Delaware on

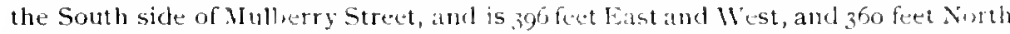
and South. The Lotts in this part of the City have mot advanced in Value for several Vears Past, and are not likely to be soon settled so that we atre in bupes If you will favor us with your Alphication for this Plece of ground you will weet with no difficulty in olstianing it.

The Interest of the Proprietors and People are so nearly connected that it seens to us Self-evident that they mutually share in whatever contributes to the Prosperity and Advantage of the Province which consideration addec to the satisfaction arising from Acts of Chatity and benevulence will we hope have 4n much Weight with them, as to render any other Argument Suyerfluns, hut as your swn prudence will suggest to you the most Effectual Method of solliciting this Adiress successfully we rely thereon so much as to think it umecessary a ald any thing more on this Occasion than that your Frtendship therein will be cxcect. ingly gratefull to Es and our Fellow citizems in general, and next wolutainum the Lott lle Ask for the most agrecable Service you can do us, is to thitain a Specdy Answer, for the promoting this Indertaking appears to us so necessary that all concerned therein are unamimous in detcrmining to prepare for the Bundang early. in the Spring of next year

We are, with much respect, your obliged, real friends.

To this the following reply was received:

L.NIOON, 18th, 1st Hhe, 1752 .

Estemed Friends. - We received yours the sixth July past, and the address which it brought was by us delivered to Thomas l'enn, Esquire, wnte which we most readily joined what interest we have with him and his brother, to grame your request of a piece of ground, whereon to build the proposed Hospital in your City; and we make no doubt but Joshtia Croshy hath inforned you of what his answer was, and also of what Thomas Hyan and Son urote him from time to time on the subject; and now we have the pleasure to acquaint you that yenterday we received a letter from him grantiong your request, a copy whereof is here under. lle are your assured friends.

$$
\text { Timus Hran, Silvares Beyax. }
$$

Gonllemen.- You may inform the directors of the llospital at Philadeiphia, that we sent orders to the Governour, the nineteentle of Decenber, ly way of New England, tu grant them a piece of ground to build the Hospital upm, thungh mot the pritce they asked, yet one of the same size, and where, if it should be necus. sary, we can grant them an, addition.

I Am, Gentlemen, your aftectimate friend,

To, Me'ssieners Silianus Be'an, and Thomas Hom.

THONAS PENX.

The Governor was pleased to favor the managers with a coly of the instructions he received upon this occasion, which, after due con- 
sideration, they made some observation upon, and sent to their agents. A copy of thene several papers here follow in their orter:

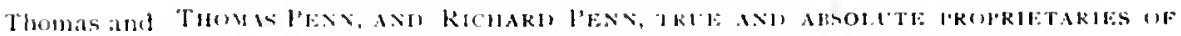
Richard

lemin, Fintrs'.

Cliatiter and trint of is piece $n$ stounel.

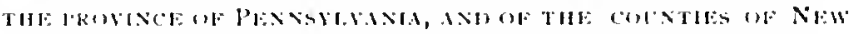

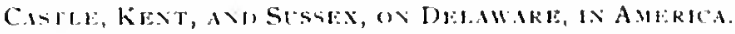

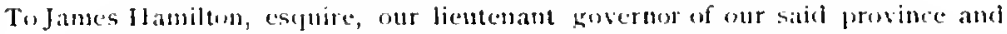
counties, and to all other persons whom these presents may concen, Hreeting.

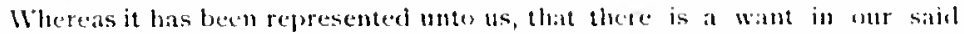
provine of a common lfospital, or hufirmary, for the relief of ancle por as are

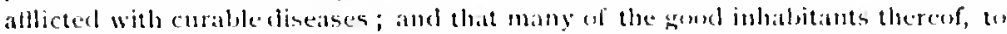
supply that lefert, and ont of a tender and chatable refiral to their follow creatures, had voluntarily subseriled, and were still subscribing, barge sums of mones, towards a stock for the support of sucl a Huspital; and that the assembly there, heing petitioned by a mumber w the inhabitants of all ranks and lemomsina-

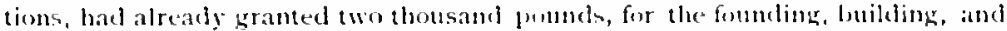
furmishing thereof: and that the persons who hat contributed towarils the stoxk thereof, or many of them. bat, ju the month of July frast, chosen certain persons to be managers of the sndintencled l lospital.

And where:s the said managers had atelresscelus, laying the said aftaid leefue us, in confidence that so good and pious an unclertaking would ont fail uf onr approbation, and heping, from the accustemed bounty of our family in encouras. ing former designs of public utility to the people of our sabid proviuce, the present would alno receive our bind assistance; and that as privite persons raised the stack to support the llosprital, and the assembly were to build the house, so that we would be pleased to favour the sajd malnagers with the gramt of a piece of ground for the buildings and necessary accommoditions for the said llosprital; and also requesting our sentiments, if anythimg should ocent to us that we might think of service with respect to the manterment or rules of the said lfuspital :

Know ye therefore, that we, having taken the premises iuto our consicleration, and approving and greatly favouring the sajd gencral scleme ancl intemion, and being desirous to aid and assist the same, as conceiving that the due execution thereot may tend to the relief of many poor and necessitus persons m our said province and to the getleral henefit and advantage of the same, have resolved to incorporate the present and future subscribers by wh grant of incorporation; and at the same time to gramt unto such corporation so incurporated, a valuable trace of land in a proper phace wathinenr good city of Nhilabelphia.

In ordel whereto, we do by these presents, give, grant, and commit unto you, our said lientenant governour. full power, commission, and authority, by onte instrument or grant of incorporation, to be issucd in our names, and to be sealed whth the great seal of our satic province, 10 incorjurate and crect into a boty poli. tick or cuporate, by such mane or title as 11 you shitl seem most apt and conven. ient, all and coery such persons, who alreaciy have subscribed and paid, or at any time hercitter shall subscribe and pay the sum of ten pounds or more, of current money of our said province, towards the founding and establishing a Hospital for the reception and relief of lmaticks, and other distempered and sick poor within our said province, such corporation to have continusuce to such contributors and their successours for cver; and to grant all usmal, common, proper and reasonable powers of a corporation umto such corgoration, and their successors; and particularly for the making of such reasomable and lawful by-laws, rules and orders, as in the said corpuration, or the major part of them, when duly assembled in such manner as shall be therein appointed, shall seem useful and necessary for 
the well ordering, regulating and governing the said Huspital; for the regulation of the future elections of manigers, treasurer or treasurers, and other necessary officers and ministers thereof; for limiting their numbers, trusts, and authorities, and the times and durations of their respective continuance in their offices, and the causes and manner of remusung any of them (if occasion should require) and generally, for the well orelering all other matters and things, any way relating to or concerming the good government, estate, linds, fents, fevenues, interest monies and goods, and all other the business and attairs of the said Huspital, and of the poor therein, and of the uffecers and ministers thereof. Ant ilso to grant, that all such by-laws, rules and orders, so to be made as afomesaid, shall be from tine to time inviolably wbserved by all concerned, according to the tenonr and effect of themi, provided they tre reasonable in themselves, not repugnant to the laws of Great Britain, or of our said province, and be first approved by us, or such of us. our leeirs or assigns, proprietaries of our said province, as shall for the time lacing be in America, and by the chief justice, and speaker of the assembly for the time being, under our and their hands and seals, in case we, or either of us, or the heirs or assigns of us, or either of us, or any of them, shall for the time heing happen to be in America; but in case we, or either of ns, nor any of the heirs or assigns of either of us, proprietaries of our said province, shall happen from time to time to be in America, then beng first approved lyg and under the hathls and seals of the governour or lieutenant govermur, the chict justice, the sluaker if the assembly, and the attorney general of onr said province for the tince heing. of by any three of them. And also to grant and appoint such persons to be present and immediate offcers of such corprotion (until a future election of new ones) as havealready been chesen and appointed by the subscribers thereto, and to grant power to the said corporation, and to their successours, to take and receive, and to hold and enjoy, for the use of the said comporation, any lands, tenements or bereditaments within our said province, not exceeding in the whole the yearly vilue of one thousand pounds at the time of such taking of the gift, grant, alienation, bequest or devist of any person or persons whatsuever; and also to take, receive, hold and enjoy, any gouds or chattels, to any value whatsoever; and to grant unto the said corporation power to use a common seal for the business of the said corporation, and the same at pleasure to alter and change; but you are in such our grant of incorporation to insert one or more express provisoes and conditions, that nogeneral meeting of the members of such conpurations, or any persons acting muder them, shill sell or convert into money, any real estate, siven or to be given to the said corporation (unless directed so to do by the donor or donors of the same nor shall employ or dispose of any principal money or uther effects, which are or shall be given or added for the purpose of increasing of the capital stock of the said corporation in any other manner than by applying the anmal rent, revenue, income, or interest of the same, twwards the entertainment and cure of the sick and distempered poor, that shall from time to time be brought and placed in or under the care of the said llospital, and the officers and ministers thereof, for the cure of their diseases, from any part of uur said province, witlumt partiality or preference. And also that fair, full, and plain accounts in writing, of all suluscriptions, benefactions, donations, and gifts of every kind to the said corforation, and of the disposal, employment and disbursements of the same, and of the rents, revenues, incomes, interest and prodnce arising therefrom, and in the disposil thereuf, and of all salaries paid to any ufficers or survants, shall constantly lie ofen in some publick part of the Hospital, for the free view and inspection, at all times in the day, of any subscriber or wntributur, and that an accont of the sume, signed ly three or more of the managers, be, frum time to time, ance

(hater from

Propritors. 


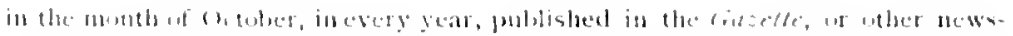

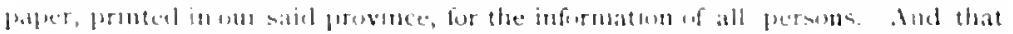

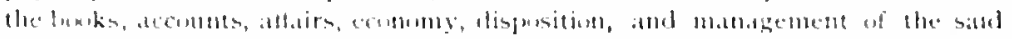

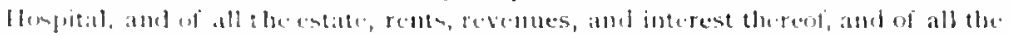

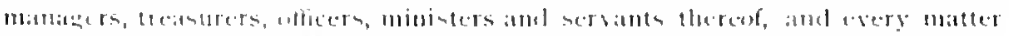

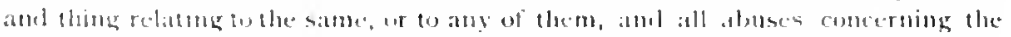

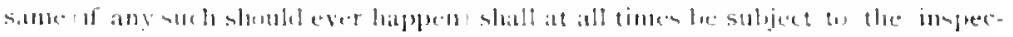

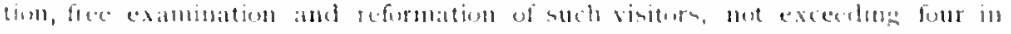

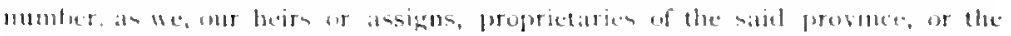

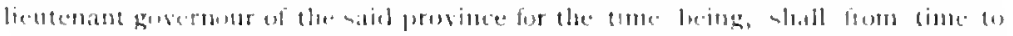

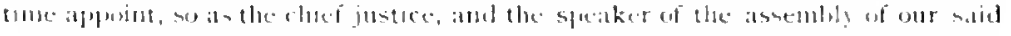
provine for the time beimg, be alwats twe af steh visions.

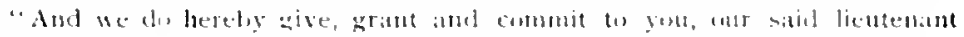

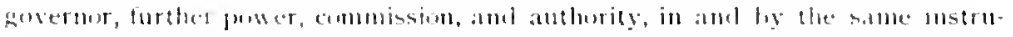

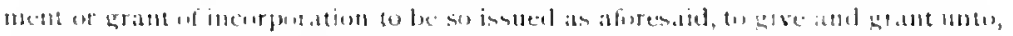

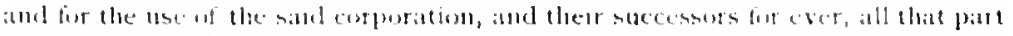

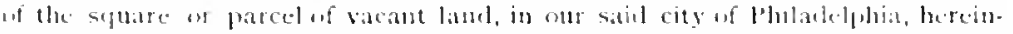

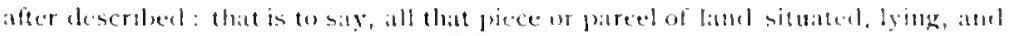
being on the nurth side al siss.lfas street, leetween sixth atul sebuth strets

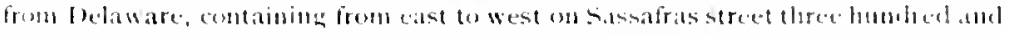

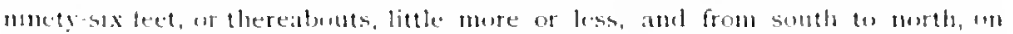

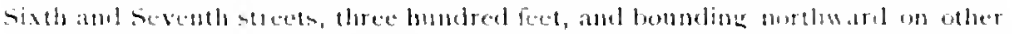

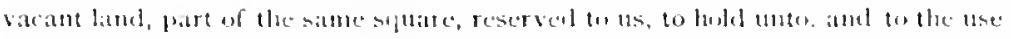

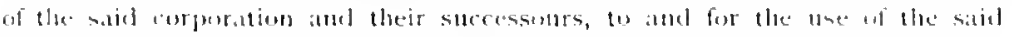

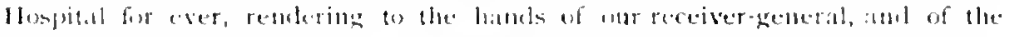

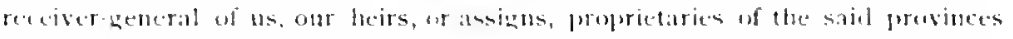

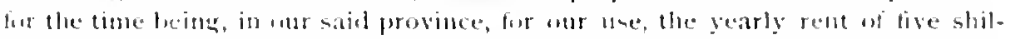

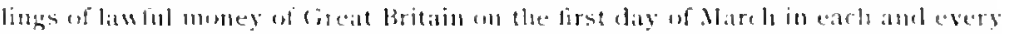
geats henceforth for aver, under a declared and express provises and comdition to

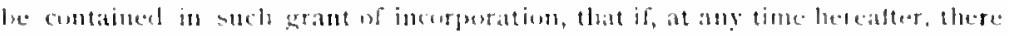
shall not he a cumstant - hecessich uf contributurs to meet gearly and clumese

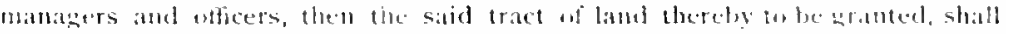

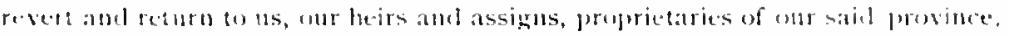

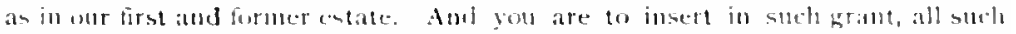

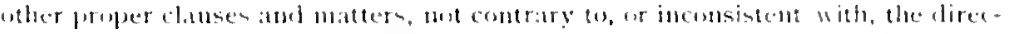

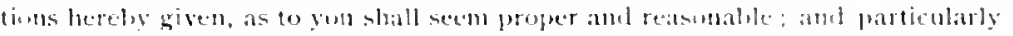

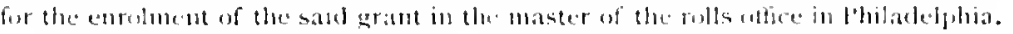

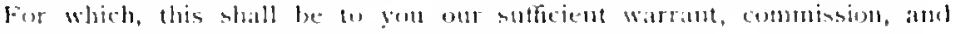
authority.

fiven muler mur hasd and seals, this twenty-cighth day of octuter, one thousatud seven humatreet amel fifty-ouke.

THeNIS PENX. T.. S.

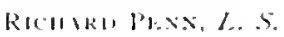

The proposed grant was respectully lut firmly declined; and the following "Remarks" mate thereon, written by Franklin, were ent with a letter to Messrs, 11 yam and lievan. July 2, 1752.

Grint

The alesign of the luspital being (in itself) so bencticent, and our honorable declined an proprietaries laving fully expressed their abprobation of it in strung terms, as ugsintable. Well a declared their kind intentions of aiding and assisting it, by granting a valuable tract of lasd, in it proper place, for a llospial ; alt therefire that setms mecessary for us to $d$, is $n$ cumvince our humourable proprietaries, that the 
methods by which they have proposed to aid and assist the Ilospital, will by no means answer these gond intentions, but are really inconsistent therewith.

We must then beg leave to remark in the first place, with reyard to the charter, that, as the act of assembly is undoulitedly the best grant of incorporation that we can possibly have, and as the representatives of the freemen of this province have generously contributed towards the design, we should fail of the respect that is justly due to them, were we to accept of any other, without sbtaining some very great and manifest advantage by it ; but that there are no such advantages in the charter proposed, is evident at first view: (1) the contrary, we should by it he confined to stricter limits than we now are, particularly with respect to the power of making by-laws, and being subjected to visitors of the proprietaries' appointment. But that clause which makes the lot and of conserquence the buildings on it revert to the proprietaries, on failure of a succession of contributors, is so weighty an objection, that were there no other, we could not entertain the least thoughts of accepting the charter; for as the sum allowed for support of the Hospital is limited, we may reasonably conclude, that in time there will ctase to be a succession of contributors, and noperson can imagine that when that hap. pens to be the case, the lot and buildings ought to become the prisate property of any man: And though the act of assembly hath marle provision in a manner which may be liable to some inconveniences, yet it can scarce fail of answering the purposes first intended. The proprietaries, tu he sure, have not attended to these consequences, or they never would have proposed any thing so inconsistent with the design they intended to promote.

As to the lot that the proprietaries designed for the Hospitial, it is so situated, and so circumstanced, that it will by no means be suitable for the purpose. It is a moist piece of ground, adjoining to the brick yards, where there are pronds of standing water, and therefore must be unhealthy, and more fit for a burying place (to which use part of it is already applied) than for any other service; besides, as it is part of a square allotted by the late hunouratite proprietary for publick uses, as the old maps of city will show, our fellow citizens would tax us with injustice to them; if we should accept of this lot by a grant from our present proprietaries, in such terms as would seem to imply our assenting to their having a right to the remainder of the square.

The ground granted to the Contributors ly the Projirietaries having been found unsuitalle, the gift of the site desired was again solicited, or, failing in this, the Proprietaries were requented to name a price, if willing to sell.

The following letter was accordingly addressed by the managers to Messrs. Hyam and beran:

$$
\text { Philueritu, 2d of th mo., } 1752 .
$$

Esteemed/liends:

We now, an helati of the contributurs to the l'ennsylumia Hospital, with much gratitude and respect, acknowlerge the benesolent dispostron you have manifested, by your industry and cate in subliciting our address to nur proprien. taries; and as we are fully convincel nothing hath been wanting on your parts. we should have been much pleased that the Lot which the proprictarico fropmed for the Hompitat, and the terms of their Grant, weresuch as we desired, or could xсcept.

Immediately after the receipt of pour letter, with the copy of that gou had from the proprietaries, sur l'resident wated on the Gosernour, who wan pleased 
(1) commmingate to ths the instruction he hat teceived; atbl as the answer given

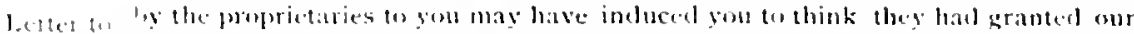

Ve:sis 11 yalm and he+vin lect Jining errant and witering to pultisise. repuest, IVt think it uecessary to send you a copy of their instructions to the sovernour; after permsil of which, and of the few remarks we have mote thereon, we hate nu doulit, you will approse of aur resolutions, not to aecejt af a 1 ote on illese terms.

Before we apreed on the adibess to the proprietaries, we surveyed the stuare (of which the lot proposed hy them is a part) and the situation appeared to ns in in every respect inconsenient and unsuitable for our jurpose. It is contiguous to the brictimakers ground, from which the city hath bech furnished with briets above forty years past, so that their large ponds being comstantly filled with stameling witer, reuclers the neighborhood undealthy, and of course al solutely improper for onr purpose, which is to restore the sick to health: and the only propuer use of thit square will be for a burial groume, to which service some part of it hath been applied ly a grant from the proprietaries: aslell the dissatusfaction which appeat'l, and still subsists among our fellow-citizens, on the proprictors claiming a right to make that grant is sogreat, that if tiere were no otter ohjections, we wouhl mut rum the rispue of increasing it.

We still think that the Isott we first mentioned is more suitable for us thatn any other su near the cits, and of so small value, and we are not entirely without hopes that the proprieters, who have so fully declared tineir approbation of our design, will still grant the samc to us: We are assured, if they regard their own interest in the alfections uf the people, or even attend to the Justice of their conentring in the promming of esery scheme calculated for the publick utility of their province. Jhey will chestully urant it to us ; And if you should entertain the same semtiments, we repluest pout to renew your sollicitations to them, ancl if you find them still unwilling to fowotur our reguest, we sluobld be pleased to kmow Whether they will sell it to 11, or lett it for ever on an anmual rent, and the price or rent they propuse for as the number of contributors still continues gralually concreasing, we shall rather enceavour fo purchase a Jott in a proper situation, than to builel the lususe in an inconvenient place, or to acept of any lont on streli term as we knew would gise a general dissatisfaction.

One of the contrilutoms hath ofler's to givea lott of gromud muchlarger than that we now ast, and in a very gunt air; lut heing about a mile ont of town, we are apprebensive it will le inconvenient to the physicians. who, as they freely give their attendance, should he subjected to as little thliendy as possible.

We have, for the present, biret a house toleratsly convenient, into which we begne to admit pationts about six months since. The number received is twenty threc, of which welse have lecen cured and dischargeel, and eleven are remaining; and as the benelith of this institution becone daily more aticnded (1), we hase not the least douht that the minds of such who are bless'd with the means, will gradualiy become the more freely dinposed to comtribute towards this powa work, and that it will soun become of general service to the people of this provinec.

The tind mammer in which vou have checrfolly engaged fo serve us, gives us reason to thint you will aprove of onr writing to you with so much freedom: we shall non therefore offer ally apology for it.

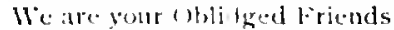

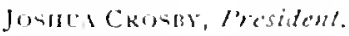

The l'mprietaries, through Messrs. Hyam and lievan, cylained the objectionable Reversion , lasse in their tharter, and disclained any wsh waphrogriate w themselves the huilding which might he erected. 
The only contingency contemplated was a restoration of the grounds, when they should cease to be used for the purposes for which granted. The proprietaries were, bowever, still of the ofjinion that their charter and the ground offered shuuld be accepted by the contributors.

TO THE MANAGERS OF THE PEXNAYHANAA HOSITTAL.

Reply of

Respected Friends,--We attended your proprietary, Thomas Penn, enquire, and presented to him your remarks on the grant of land made by him and his brother Richard to your society (dated the eighth of October, 1751), and requested instead thereof that spot which your memorial mentioned, and desired might be granted for the istended Hospital. He perused the renarks, and made objections to them, alleging that the ground which you desired was contiguous to that which they have offered, consequently no difference in the bealthiness thereof. And as to the remark aganst its reverting to the proprietaries he very readily declared notbing more was intended by the clause in the grant, than that provided the scheme for the establishment and continuance on the Hospital sbould not succeed, either for the want of the sum proposed to be raised as a fund, or through any other cause, that then the ground should revert, Ec., but as to the erections thereon, they should be at the managers disposal. We desired his answer in writing, but he refused the giving it in that manner, and added, the governour should have the necessary instructions on the atlair, unto whom you misht apply concerning it. On the whole, he came to this resolution, not to make any alteration in what was before granted, nor to let or sell the spot of ground you pitch upon; and therefore we are of upinion, ynu sbould either accept the proprietaries' ofter, with the clause relating to the reverting to them being explained, or else fix on some other fiece of around. And if there is no other objection than the small distance of a mile to the place which one of the contributors hath offered to give ycu, may not hat be more fie for a Hospital or Infirmary, than to have it in the city, where infectious diseases may he much more liable to spread. Nhat seens to us to disquiet the Proprietaries is your Questioning their Right to the Square of which the Sput whith they offer is a part and also that you esteem an Establishment from the Assembly preferable to a Charter from the Proprietaries. Vie olserve, with pleasure, the success that hath attended the beginning of the good work you are engaged in. and hope it will go forward, and be happily completed, and are, with hearty salutes, Your rual friends,

Jan'y 3t, 1753 .

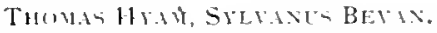

The Manager acknowledged the courtesies of Menrs. Hyan and Bevan, and regretted the failure of their repuest to the proprietaries: the accountiof the Hosplital to be sent as som as published.

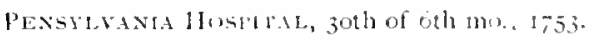

\section{Estermed filindi:}

Another lettei of Monagers.

We have lately rec'd your favour of thirty-first, first month last, with duplicate of your former letters to our President, and being sensible that you have solicited our ardiress to the proprietaries with alt the diligenete ind care we could desire or axpect, we gratefully acknowledge your friendship, anct think ourselves under the same obligations we sho d have been if your kind Endeavours had ohtained the desired Effect.

The accounts of the alfars of the Ilospital, and of its present state, will be laid before the assembly at their next mecting, and som abter publishil, withich 
we slall (frect duplicates tu be sent you ; and as you have interested yourselves in the promotion of $\mathrm{it}$, and we are cunvinc d of your goud wishes for its success, when w. can wibe you a pleasing aceunt of its adrancement, shall take the interty of emmmunicating the same, hejug, with reat resperts.

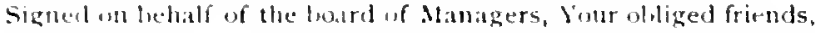

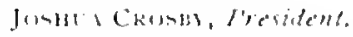

The next matter which engaged the attemtion of the manager "an the ever recurring necessity of raising further contributions. Fier which purpose copics of the "lise and P'rogress of the Ilospital"

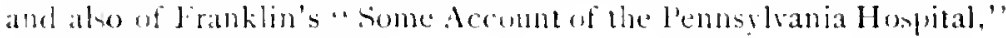
were seme to lomilon.

I.etter and

Accounts sent 10 London.

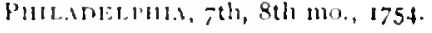

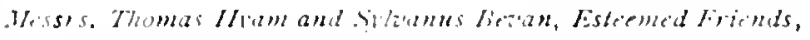

Your cheerful concurrence with us, in the foundation of the Pennsylvania lluspital, so fully assures us of the pleasure rou would take in its success and alvancement, that we determined to embrace every suitable occasion of commu. ucating the accounts of our progress; And the publick having received some benetit, and being. we hope, gradually beconce more sensible of the advantage of the institution, it was indg'd expedient, besides the general state of our accumnts, (1) publish a narrative of ont affairs from the beginning; which being now compleated. We send you a dozen of them, not doubting of your friendship in distribut ing them in such manuer as,may be of most service; and that if you find any of your friends disposed to contribute towards this good work, you will promote their duing it.

Wie salute you with Respect

The appeal of the Contributors to the Proprietaries had only resulted in the granting of a chater the provisions of which effectually precluded the pussilibity of its being accented. They offered a lot of smomel, which was entirely unsuitable on accomt of its marshy sur. romblings. and, moreoser, diel not letong to the I'roprictaries. since it hat leen previously albued and dedicated to pulbic purpones for a gate. The accepance of this particular piece of sround ly the

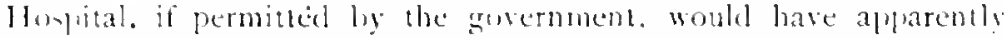
evalulined the risht of the l'roprietarien to rlispone of the remander of the around and thus alkow it to revert from publit use to private

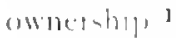

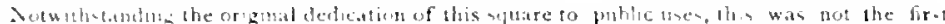

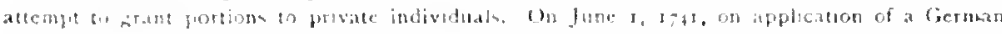

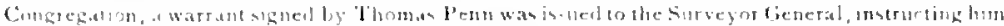

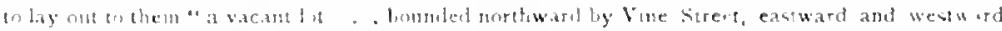

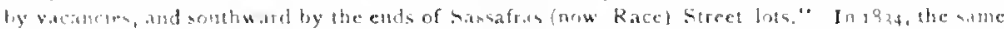

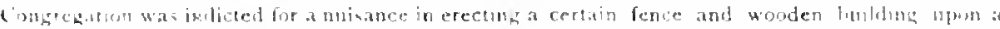

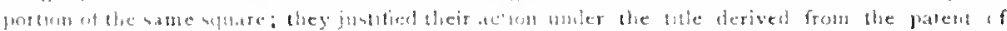

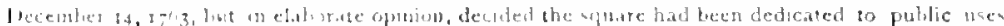

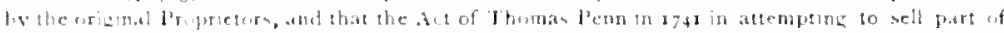

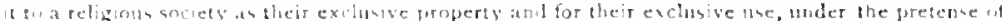

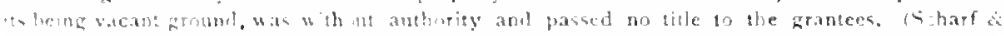

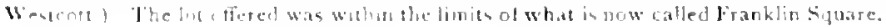


After the election of officers, laws and rules of order became necessary, and Jonhua Crosly, the l'resident, lir. Thomas Bond. Hugh Roberts, and Jenjamin linklin were aplointed a Committee to draught a set of Jaws and kules for the Managers. to be acted upon by the next Ileeting of Contributors.

The first rule adopted shows the thrift of the newly elected managers and their regard for punctuality.

Resolicd to meet hereafier on the First Fifth-day of the week in every month at five in the afternoon, and that each Manager absent at such Neetings should pay two shillings and those not coming in dne time should pay one shilling; the Fines to be disposed as the Majority slall direct

In the meantime, R. Peters. S. Hazard, and Israel I'emberton agreed to go around with the subscription papers to a number of persons who had not yet contributed and endeavor " to procure their assistance to this undertaking." livery expedient that promised a source of revenue was considered; and the Managers did not spare themselves, as the above extract shows.

The prospect of olstaining the two thousand pounds granted by the Assembly stimulated every friend of the Hospital to increaned effort to raise the amount required in order to secure such a welcome alpropriation.

On July I zth, I $75 \mathrm{I}$, the problem was discussed by the IBoard of how to olstain the two thousand pounds from the Assembly, since it was necessary in order to secure this grant that proof that an equal sum had been obtained from private sources should be produced.

The list of subscribers presented to the Assembly on August $\mathbf{I}$. failed to give sufficient evidence that the amounts reported were bona-fide. The sleaker stated that, as he would be beld individually responsible, he felt it his duty to rupuire that legal notes shoukd be in their possession to insure the prompt payment of the moners which had leen subscribed.

The President therefore annomed that the Speaker wished that Penal Xinte the sulscriptions should lie made a certainty ly taking fenal notes of unch as du not pay their money immediately to the Treaurer.

On Alugust r, it wai

Resolede, that Penal folls be printed and he execuled by such as do not immedately pay; payale on the 2 th of the month called Jume next, wibl interest from the time of sulseribing.

(I) June zoth of the same ycar, this wa changed to read:

That no interest be demandect of such an pay before the first of Ditulues next

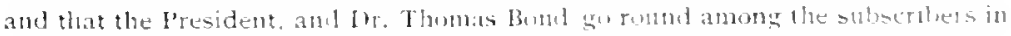
orcier to get the Bills executed. 
Qutineriptione ()) lintreal

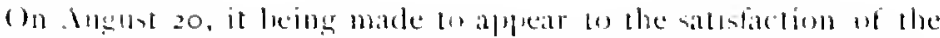

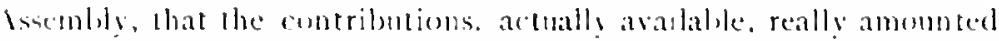

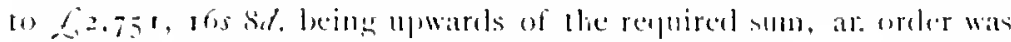
drawn on the Prustees of the loan cffiec for the jayment of 2000

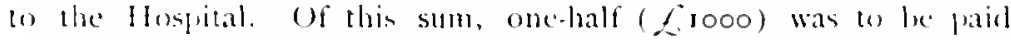
immediately, the balance to become due and payable in tonetre monthe.

Thin money was phaced by the Managers to lhe eredic of ciphal

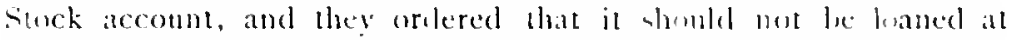
interest ly the Freasurer without suffecient real security nor in less sums than

The first real estate owned on the Hempital was donated ly Mathias Koplin, a pious, hut cecemric German. The following fuaingly expressed letter is self-explanatory:

Firs alon:1

[11] uf ke., Eistille.

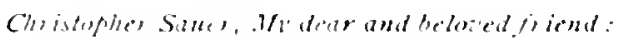

Septemliner the 2, 1751.

Where:ts I have seen out of your hewsplyper that the contributurs of the Huspital at Philadelphia are carelully concerned about it and made a beginnims t. take care of the pour sick people and observed that it has not such a foundalion nor is likely o become such a Hospital as I hive seen and bun wh in Germany, where areat sums of alms were collectert and ill used acenreting to the atlection of the manters of the llospital, governed by self-hive, entiching themselyes and fabriner their friends, so that they lived in l'lenty. Superfluity and Voluphousness, in so much that lhey could drive in carriages lake people of Rank, although they hat nothing helore nor any Income but cut uf the funds of the Ilospital (when on the contrary) the poor and needy an spite of alms being collected, suffered great want and were not taken care of aceordms to their necessity, lecause it was consumed otherwise. But (consiclering the mothe foumdation of this our llospital, 1 can't but hopes it will be lalso winely manazed hy imparti.ll hamds, therefore I thought to make a free gif, and accorlungly (I do make a gift of a small hot of hut for the use of it, situate between fiemantuwn and Philactelphia. And I do semel herety, a my betwed friend the deed of it. The managers of the Hospital may make (a deerl out of it for the lfospital of philatelphia and send it lo me, and 1 and my wife will set llabds and seals to 1t, hefore lawful witnesses, and if 1 should live some years longer in the flesh, I may not be expeeted to come to Phaladelphia every gear for the election of the twelve managers of the II spitill since that can be done without me, and l prefer to stay at home rather than ride on horseback, drive or walk.

lam lhe ohl

II IIIIAS KMU1.

P. S. - I pray you will not take it amiss that I made kmown my experience in the debalthery of alms as I have had no ill thollghts nor have any as yet.

The above leter appears in foll on bhe minuter, in cerman script. and is folloncel by the Fuglish translation.

lhe Managers duly acknowledged this donation in the following letter, the eriginal of which is in Franklin's handw riting : 

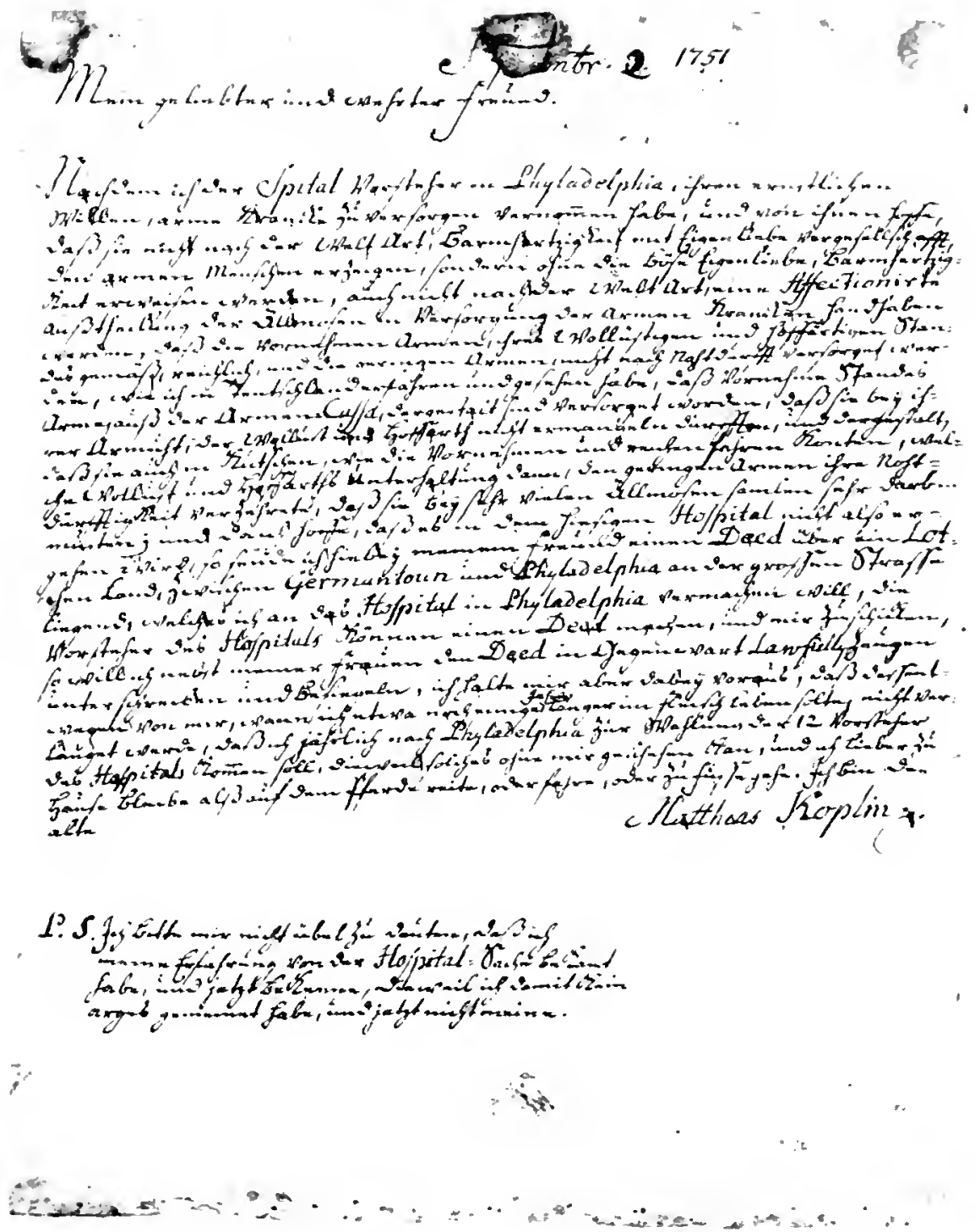

Thy Friend Christopher Saur hath communicated to the Managers of the Pennsyluania Hospital thy letter to him, expressing thy Intention of making a free Gift to the said Hospital of a valuable Lot of Ground situate between Ger. mantown \& Philadelphia; for which the Managers, in Behalf of the Poor, return thee sincere Thanks; and hope thy charitable and generous Donation, and those made by other well-dispos'd People to this Huspital, will never be misapplyed in the Manner mention'd in thy letter, as hath been usual in some Juspitals in Germany. As a Cautiun to future Nanagers against such Misapplications, they have order'd thy Letter to be copied in their Book of Ninutes or Records of their Proceedings, that it may be preserved to Posterity as a Testimony of the origimal Intention of the Founciers of this pious Institution.

The Nanagers sainte thee respectully, by

$$
\text { Thy Frienci. }
$$

$$
\text { J. Ckusbr, Presidenl. }
$$

On October 3. I 75r, fr.000 was received ly the Treasurer. The first borrowers were James l'emlerton and Israel Pemberton. Ir. who took the money merely as an accommodation and as a mean to further contribute to the Hospital's interests. They also engaged in the Board to repay any bart of it sooner than the allotted time, should it be wanted to make provision for the linilding.

At the same meeting, two hundred of the Subscription Papers werc directed to be printed and dispersed in the country to collect subscriptions, Fearing lent some charitable persons might not have had the opjortunity of secing one of the papers, the Treasurer was ordered " to Advertine in the lewsplers that such as are incliatel to subscribe may apply to him and such as have already subscribed may pily."

It being mentioned by the Treasurer, that he was willing to give security in Wne Thousand Pounds for the faithful berformance of his office, the same was agreed to, and that hereafter it slould be a rule for the future that all Treasurers give security in such sums, as the Managers should require.

The idea of preparing for lubleng early in the following spring was mentioned in the letter to Hyam and Fevan, agents of Thmmas and Richarl Penn, and it shows how desirons the Managers were to A Temporar Hospilial Considered lubile the Hospital on land ownet ly the contributors: but at that time, owing to the want of funds, this was not possible. Realixing that the money then at command was not sufficient to warrant them in beginning to build, and knowing so well the mumber in the rom. mmity of sick poor needing immediate attention, it was agreed to lesin operations in a privatc house without waiting until a lot rould be secured and the Hosjital erected. For this purpone. at a meetmes on September 5. again hela at Widow Pratt's Rogal standard

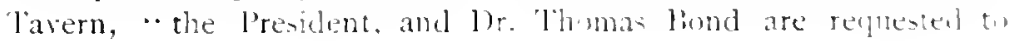

Iuntes Iront Assembly [ IIverele/

Treasurer sive securlty 


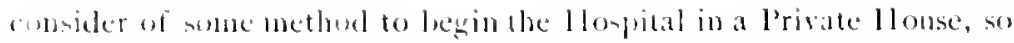
an to arcommudate a few patients in order that at least some good might le dering, in the me:m time till the Hospital is built."

in (16toler 12, $175 \mathrm{I}$. this commitlee reported:

Judie Kin sey's.M.|nsinu

Hired : :

Hovgit.1.

Physiciant

Services ar

Secued.

"That the house late of John Kinsey, Est., deceised, with gardens, pasture, table, etc. woln very sulable and could be nhatned for the purpose: whereupon it wis agreed thot the Wantgers should meet there on secomd day morning nevt. at tenseluck to view the same and consider what repars it would reguire and "hat Proprosals on make (1) the atministraturs of that estate."

Ifter meeting on the appointed day, it was agreed-

lin lake the said house and apurtchances at Forty punds per anmum and to loy ont in kepairs the sum of Twenty-Five pounds, of if less be laid wit, the

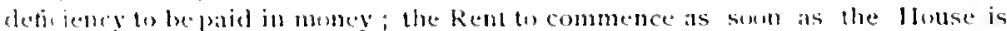
fitted; : and the Term to be Eighteen Vonths certain, and it the Managers should desire w continue bonger the Administrators agree to use their interest that it may be at the samerent.

While repatirs propressed, no lime was lost in prejarimg and pruviling everyhing which would be required for prospective patients. " lstacl l'umlerton ame l)r. Thomas liond were denired to look out for a mitalile matron to take care of the louse and of the sick that shall le placel there."

The next impertant matter was to select the lest physicians from among those that conbl le had who were willing to serve on the Ilompital saff wilhout compensation. Three had already tenclered their rervices, for we have already scen that un Octoler 23,1751 , -1 H. l.lond /achary and I)rs. Thomas bumd amel thineas liond signified their willingness: to give theje attendance fratis in taking care of the sick as lpysicims and surgeons for the first three years." The l'rendent. ly resolution. Was desired to "give them the thanks of

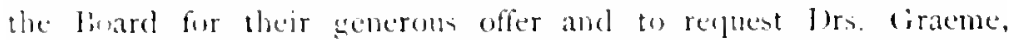
("adwalater. Noore. and Redman to alssist in comsultations on extramlinary casc's."

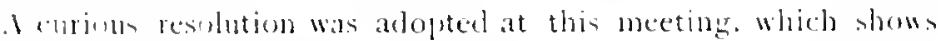

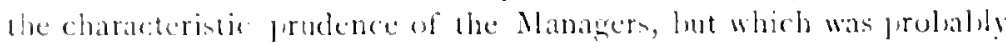
never carried into clfect:

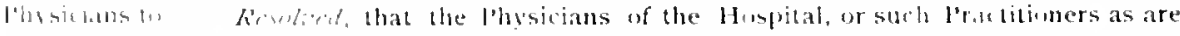

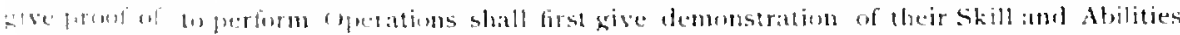

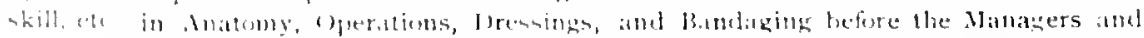

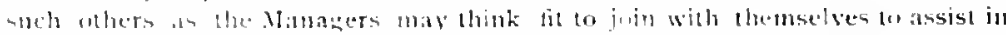

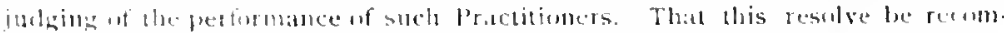

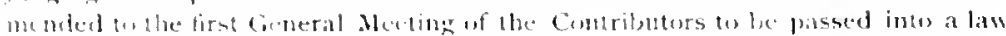

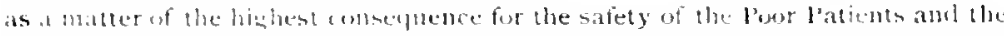
kegutaltion of the Huspital.

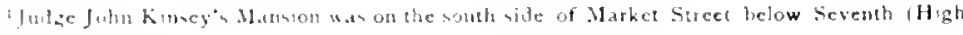

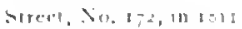


On January 2, 1752 , the Committee entrusted with the preparatom of a draft of a Law to appoint and linit the power and duty of the Managers, etc., presented the same. This was agreed to. lyy the Contributors, at a special meeting. as will be seen from the following resolution:-

The contributors, having been duig notified, assembled on the $13^{\text {th }}$, J January at the Cint Honse and adopted the following:

L.aw regula. ting Fiectum

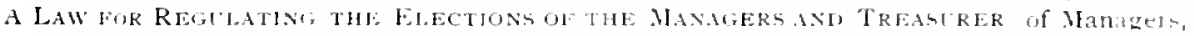

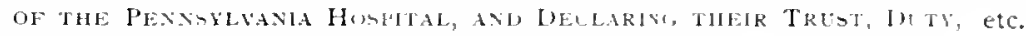

ANI AI'THORITY.

WHEREAS, by an Act of the General Ansembly of the E'rovince of Pennsyl. vania, entitled "an ACl to encourage the Establishine of an IJospital for the

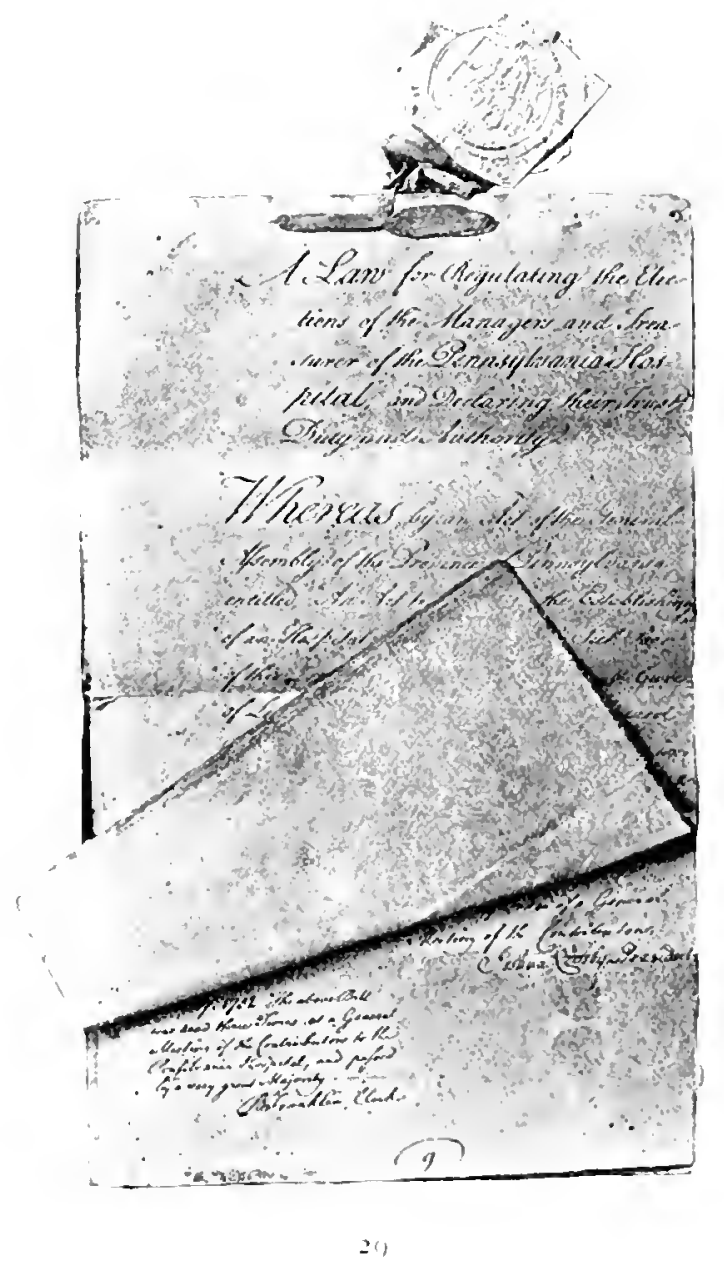


Relicf if the Sick Poor of this letosince, and for the Receptints \& Cure of lomaticks," the (imbributors to the said Ilospital are made a Hody corpurate, anel inverwered so meet, and to make such I.aws, Rules, 2 Orders, as shall

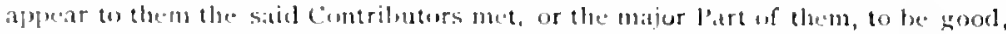
Ilsaful and necensory, for the well geverning atud regulatiog of the saiel buspritul, and for the Reguldtion of the Elections of Mandigets, at Treasturer and other mecessiry officers and Ministers thereof, and for limiting and Appenting their Number, Trust and Authority.

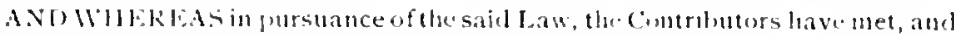
have hosed Twelse Nanagers and a Treasurer. which Treasuret hath received

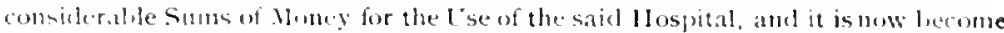
hecessary for the more urderly lisposition and Application uf the said Monies, and of such sums as may hereafter be receised, and for the more sure birection of the Managers amd Treasuret therein, to decluse and Apjoint their Trust, Authoricy and buty:

TIUREFORE IT IS ENACTEI by the Contributors to the Fennsylianis

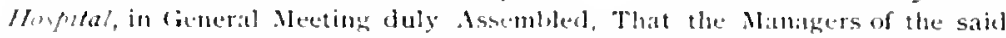
Ilospital for the time bejng, slatll have the lower uf pisposing of all Montes paid to the Treasurer for the Building, Furnishing, Support, the and Servicent the IJospital, and for the hiring and Furnishing a House or llouses for the Reception of fiutents until the sitid llospital slabl he huilt, under the Limitations and Restrietion of the lefore-mentioned Act of Assemlily. And the said Managers shall likewise hate the buser to direct the Manner and letms of Receiving and bischarging of pattents. And all Otticers and Servants befonging to the llosplital, wher than the Treastrer, shall be in the Choice, and under the birection of the Managers, who shall allow and order their respective salaries and may displace them and appoint others as often as they shall think hit. And the said Managers slinll hase the Power of calling General Beetings of the Cintributors, as often as they judpe it necessary for the Service and Advatige of the IJuspilat and shat] cause dac am publick Notice to be given of the Time, Place, and besign or Purpose uf ateh occasional Meeting. at least Ten I)ays before the sime is to be leld, and shall nominate some discreet Member to preside therein and regulate the belates thereof. And the said Mandgers shall have the kecpings, and power of Alfixing the Seal of the Corporation, which Scal shatl be made acarly agreeable. to the form or lonft herento annexed. And they shall settle the Accoumts with the Treasurer from Tinu to Time; and take Care that all Jaws, Rules and Ordess mate by the contributors and legally approved, be duly and faithfully executed: For all which, or anyother Services relatimg to the Hospital, they shall not clain, rective or retain any Fee, Gratuity or Reward whatsoever.

Axil for the more orderly Execution of their Duty and Trust, the Manazers are hereby reguired to nseet at least once a .lontl at the Hospital, or some other fit Place in the City of Philadelphia, to confer and conclude concerning the datters hereby committed tu them: And shall cause fair Minutes of their Proceedings to be kept by their clerk in a Book to be provided for that purpose. In every of which Meetings of the Managers aforesaid, Eight of their Number met shall be a L) norum, capable to consult, confer and conclude of and upon all Matters appertaining to their Jrust, according to the afosesaict Act of Assembly, and the faws of this Corporation: And whatsosver Seven of the Number so met shall so conclule, shall be deemed and tiken for and as the Resolution of the Managers for the Time, and acrordingly entered in their Hinutes. To which Minutes, and also to the Treatsurer's Accounts, all Persons concerned shall have free Recourse at all seatsmallle Times. 
AND IT IS FURTIIER ENACTED l,y the Cuntributors aforesaid, that every Treasurer hereafter chosen, shall, before he take upon himself the Exerution of his Office, enter into an Obligation with one suticient Surety, in arouble the Value that doth or probably may come to his Hands during the Continuance of his Office, as near as can be estimated by the Managers, unto the Contrilututs of the Pennsylvania Fospital, Conditioned, that he will once in Three Months, or oftener if required, render his Accounts to the Managers of the said Hospital, and well and truly account, adjust and settle with them when required, for and concerning all Monies that are or shall come into his Ilands belonging to the said Contributors, and pay the Ballance that shall appear on such settiement to be in his Hands, unto such Person, or for such Service as a Boand of hanavers for the time beins shall order \& appuint, and not otherwise; and that he will at the Expiration of his office well and truly deliver $u_{p}$ and pay the Ballance of the Monies then remaining in his llands, together with the Books of Accounts concerning the same, and other the Papers and Writings in his keeping belonging to the Contributors, unto his Successor in the said office, and that he will do \& Execute all other Things as Treasurer to the Contributoms aforesaid, according to the true Sense and Meaning of this law. And he is hereby author. ized immediately upon entering into his Ofice, to demand and receive of the Preceding Treasurer, his Heirs, Executors or Administraturs, the Cash, Books of Accounts, Writings \& other Effects belonging to the Curporation, griving hir Receipt for the same.

AND for the more regular and satisfactory Conducting of future Elections, and the Preventing of Disputes and Misunderstandings anomg the Contributors concerning the same, IT IS HEREBY FURTIIER ENACTED, That the Place and Hour of the Elections shall he appointed by the Managers of the Current Year, and notified by their Clerk at least Twenty Days lefore the Election, by printed Aclvertisement. And the sald Managers shall and are hereby required and impowered to nominate three discreet Nembers of this Corporation to inspect and judge of the said Election, and declare who are the Persons elected. and the Managers shall ciluse their Clerk to enter in their Book of Minutes the Names of the Persons elected, according to the Tickets.

ANI if any Person elected Manager shall refuse or neglect to act, or shall be absent from three successive Monthly Meetings of the Managers, in any of the first Ten months of the year for which he sliall be elected Manager; or if within the same lear or Term of his Office he shall be Confined by Sickness, or otherwise rendered incapable of executing the Office of a Manager according to the true Neaning of this Law, or shall die, the rest of the Managers as often as Occasion shall require in any of the Cases aforesaid, shall proceed in their I) uty and Office without him, or, if they think hit, they shall nominate another of the Contributors to supply his Plice as Manager, until the then next ensuing Election

AND if any l'ersm so elected Treasurer shall absent himself from his said office for the Space of Thirty Days, or shall be utherwise rendered uncapable, or neglect his Office or Duty of Treasurer; it shall and may be lawful for the Managers for the time being to displace him from the sitich office. And the Managers causing their Clerk to make a Minute for the pmrpose, containing their Reasons for Displacing him, he shall thereupon, and from thenceforth, cease to be the Treasurer aforesaid, and shall upon Notice thereof, adiust and settle with the Managers, and pay and deliver the Money, Books, Writings, Accounts, and all other Effects whatsotver in his Hands, belonging to this Corporation, to such Person or Persons as the Managers shall urder and ampunt. And in that Case, 


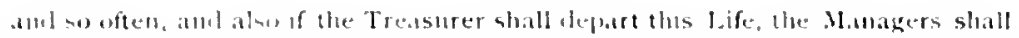

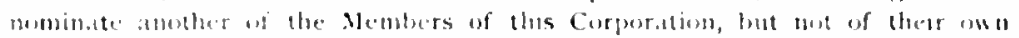

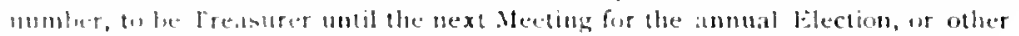

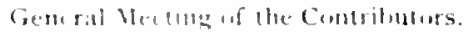

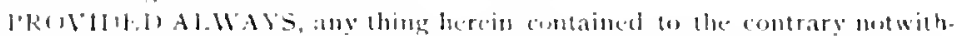

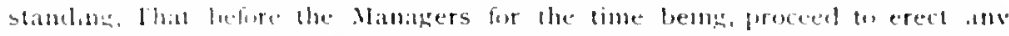
Bubling for the sainl Ituspital, a l'lan of such foropused Bubling, with an

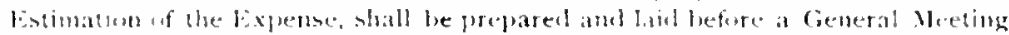

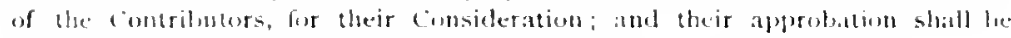

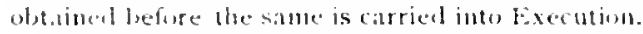

signeat lin forter of al Ceneral Neeting of the Contributors.

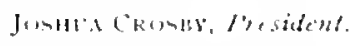

The following endorsement alpears on the alowe instrument:

Jany 17, 1,52, The above Bill was read thee Times at a General Blectiug of the Combributers to the Penusylvania Hospital, and pased hy a very great maljority.

B, FRikLIN, C , k.

Wlingruse this 1 anw.

WHet: Al,1, Chicf Iustive.

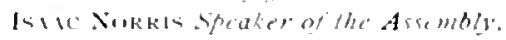

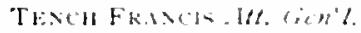

Rule's fir Mrmissinn! 1.t l'aticlls.

Temporats: Ilompitial 1) Hened

Feturary 6,1752 , the lawe and kules regulating the almissun of latiente having recested the approbation of the chicf lustice "ere also ordered to lee recorded in the minutes of the boart. (sece section entitled I'atients.)

(1) the same date, the wards being deemed sufficienty fannished, an alvertsenent was inserted in the "Gazette" stating that the 11 pepital was now ready to recerve patients.

()n feluruary io, a sfecial meeting was called to comider the applitation of patients for alusision into the ward for treatment. The combltants, lectors (iraeme, Cadwalader, Moore, and Redman. were invited to meet the Managers and attending physians of the Ilogpital to assist in (letermining the most deserving. The Oeterseers of the fenr were also prenent and offered a number of sick prour for almision. After an examination, the phssicians reported that Marearet sherlock's disorder was relievable and her rase suitalie; she was the lirst patient received and also the first one cured. Other cibes thought relievalbe were postponed to a more favorable season

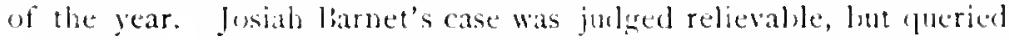
"whether within the Rules of the Hospital." Ianmah Shines, the first lunatic patient, was admitted on the poor list. Several other cases were referrel to a committee appointed to meet the attending physcians wechly. Whose duty it was to le preecnt at the Ilospital on Mondays and thurulays of every week at ten o'clock in the morning. Nice Conrtnet was engaged an a maid or nurse at the rate of then punds per annum. "she was to le considered on trial for one montly, in 
order that in cane her services were not snitable she was to be discharged, otherwise kept the year."

The first lunatic pay-patient, a woman, was admitted on March 5 . 1752 :-her son-in-law agreeing to pay Twenty l'onnds per annum, in quarterly jayments, for her hoard and care.

The fitting up of the (Market Street) Hospital, cost more than had been anticipated and necessitated a deltt of one hundred and fifty pounds, over and alove the available funds accruing from interest on capital. It was agreed that the deficit should be borrowed from the one thousand pounds given ly the Assembly, and that the same be replaced as soon as it can be spared out of the interest of the remainder of the capital stock.

August 20, r752, the second instalment of $E_{1000}$, voted by the Assemllyly, was paicl, and it was decided to loan this amount, also, at interest with real estate security.

As an example of economy, this item is worth recording: (nn November the 2d "the roof of the south side of the Hospital being much out of repair," it was agreed that "it lse covered with cedar boards, reserving the right and privilege of removing them upon giving up the house."

On September 29, 1753, James Kinsey agreed to let the house now used for the llospital and land thereunto belonging, for the term of 'Three Years at $3^{S}$ pounds, ro shillings per annum.

In the early Hospital days, after pratients had been cured and dis. charged, it appears that sometimes they returned to express their thanks; no mention of the custom is found in the later records. On November 17,1753 . a patient returned and gave thanks for the benefit he had received and offered his promissory Note for Three Pounds, Ten Shillings, as a substantial token of his gratitude, whith was duly acknowledged.

The Managers. probably at the suggestion of Franklin, realized Paticnts lo be that the inmates of the IIospital who were ahle to perform some light amployed. mannal labor, should le employed, if only to keep them ont of mischief; so they were provided with Jarge and small spinning wheels, and two pair of cards, with some wool and flax, "to employ such l'ersons as may be capable of using the same."

Thomas Bond and Benjamin Franklin, at a meeting held July 12, whial seal. I751, had heen aplointed a cimmittee to prepare a seal for the corporation. In order to secure a creclitalle work of art, franklin wrote to boston to have designs for a seal prejared. Sulsequently he submitted, for the inspection of the Managers, four different draught of the Guod Samaritan, projer for a Seal, which had leen sent lis the 
lingrover. Ifter some slight alterations made by the buard, ome was sclected amel aljuresed.

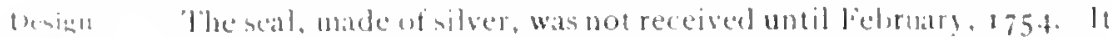

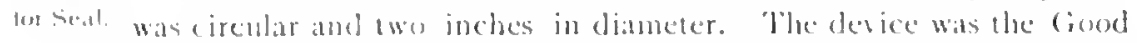
Samaritan taking varge of the sick man, and delivesing him to the

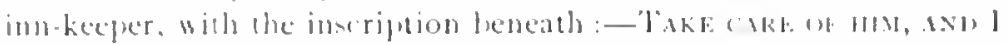

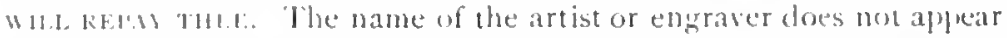
on the records of the llospital. This seal was destrosed (being worn (2011) in June. 183.3 , and the une at present in use, of exactly the sane design and proportions, but made of steed, was sumpituted. The

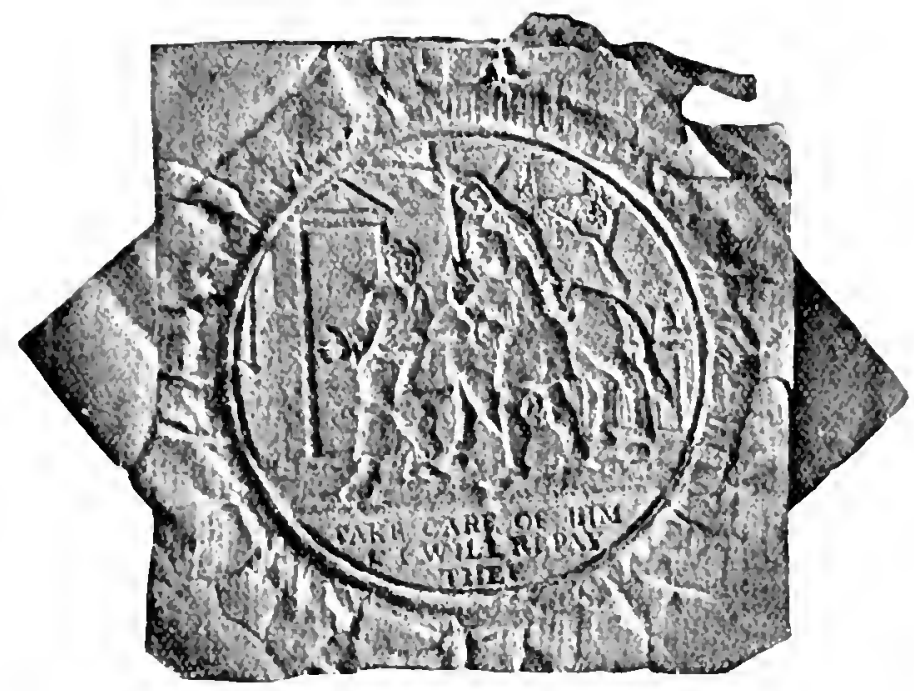

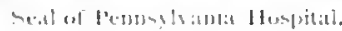

second one wan engrated ly Christian Gobreche of Mhiladelphia; a

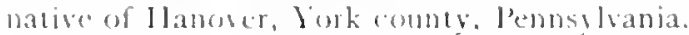

ledievine tlat bedefit would accrue from the circulation of a frief acrount of the Iloyplat, franklin was regpented to prejare such a histors.

Fr.molis

wriles:

Mislony of

th. Horit:at

On $11,1928,1754$. franklin presented his manuscript, "Some

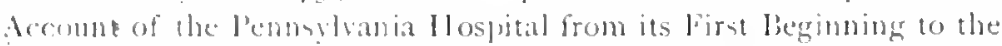
fifth Month, ralled May, I75.4." H was ordered hat the clerk, fohnsinib. get fifteen lombled coples printed, in guarto, and, on July 27. he reported that he had had the account of the IJospital printed.

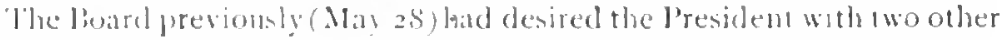
Managers 10 "wait "1pon the (iovernor, James I Iamilen, and acquaint 
him with our design of publishing the account together with a list of sulmcribers, and with our desire of having his name added to said list." The result of this interview with the Governor is briefly recorded. The gentlemen appointed to call upon the Governor reported, Ime 29, I 75.t, that they had waited 10 jon him and delivered the message of the Board to him, but without the desired success.

February 23,1754 , the accomnts were presented to the Assemlily. by Franklin. Soon afterwards, Mahlon Kirkbride with others who were appointed a committee, vicited the IIospital; they declared themselves "well satisfied and pleased with what they had seen," and reported to that effect to the Assembly.

At a meeting held August I 4, r 754, a report was made by several Managers who had been endeavoriug to raise money, showing the advantage of systematic effort. It was stated that several sulscriptions had been obtained since the last metnlng. which, with those previously received, was the result of the adoption of "A methol of soliciting sundry inhaljitants of the (ity and County for subcriptions;" it was agreed to be very careful in asking others This method provided against an unpleasant coincidence in solicitation. Many sulsscriptions were now secured which formerly might bave lseen lost; as persons were likely to he annoyed or angered lyy repreated requests for donations, especially when coming from more than one person.

Sufficient funds having at length heen accumulated to warrant the Managers taking up, the project of building a Hospital, an effort was again male to secure a sutable hot of ground, but this tume the Managers appealed to the public instead of to the l'roprietaries and with much better success. Franklin gives the following interesting account of the early efforts of the Managers to secure the mears to buy the ground for the erection "of a proper building 10 accommodate the sick and injured and the lunaticks," under their care.

In his "lirief Accomt" (page f2) applears the following:

When the Niture of this charitable Design became known to the generous Franklins Pemsylvanians, consideratile Sums were som added to the Stock, particularly by " brief the Citizens of Philadelphia, where few of the Wealthy, or those of a midding Account." Rank, fated of contributing according to their (ircumstances: Some Benetactons were alsoobtained from London, and some Parts of the Wesl Indies, which encouraged the Managers to attempt the important Task of Building: a Task the more difficult, as they were not authurized for gond Reasons! to apply any Part of the Capital suck to that Pupose; the Sum of Hones given by the Assembly mit being half sufficient, and the certain Prospect of a llar in Americal, while it was like to increase the Occasion, lessened the Exprectillin of any further Assistance from them. Nevertheless, confidung in the same lovine Providence, which had butherto biessed their pious Endeavours beynd their most sanguine IJopes, for 


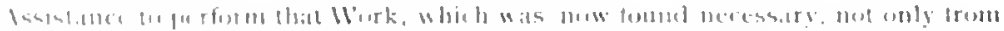

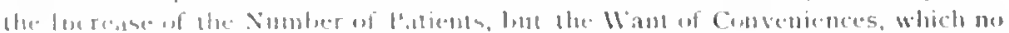

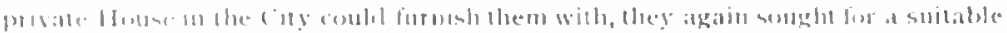

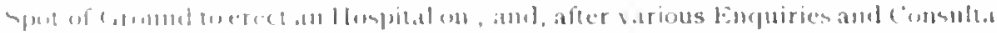

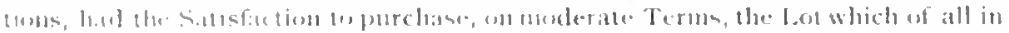

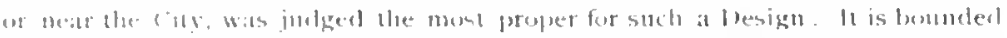

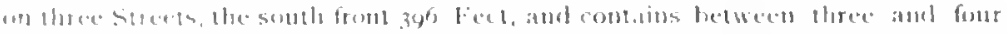

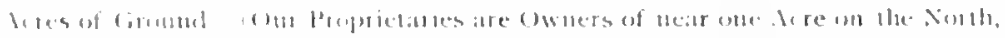

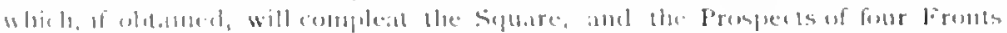

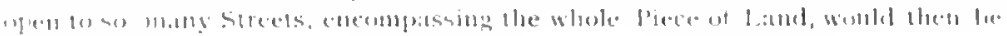
s.'(1111.

(itsminc?

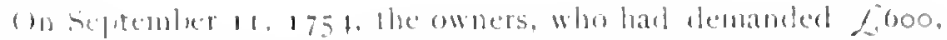

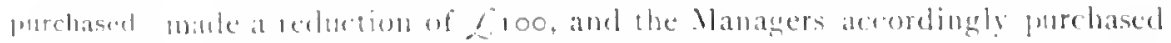

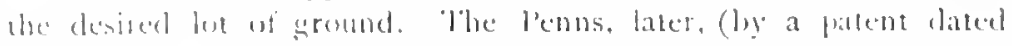

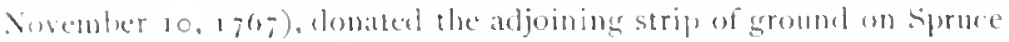

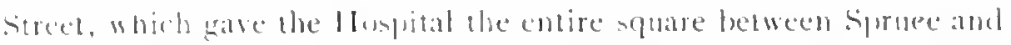

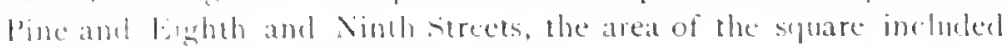
being abunt four and thece-tenths acres.

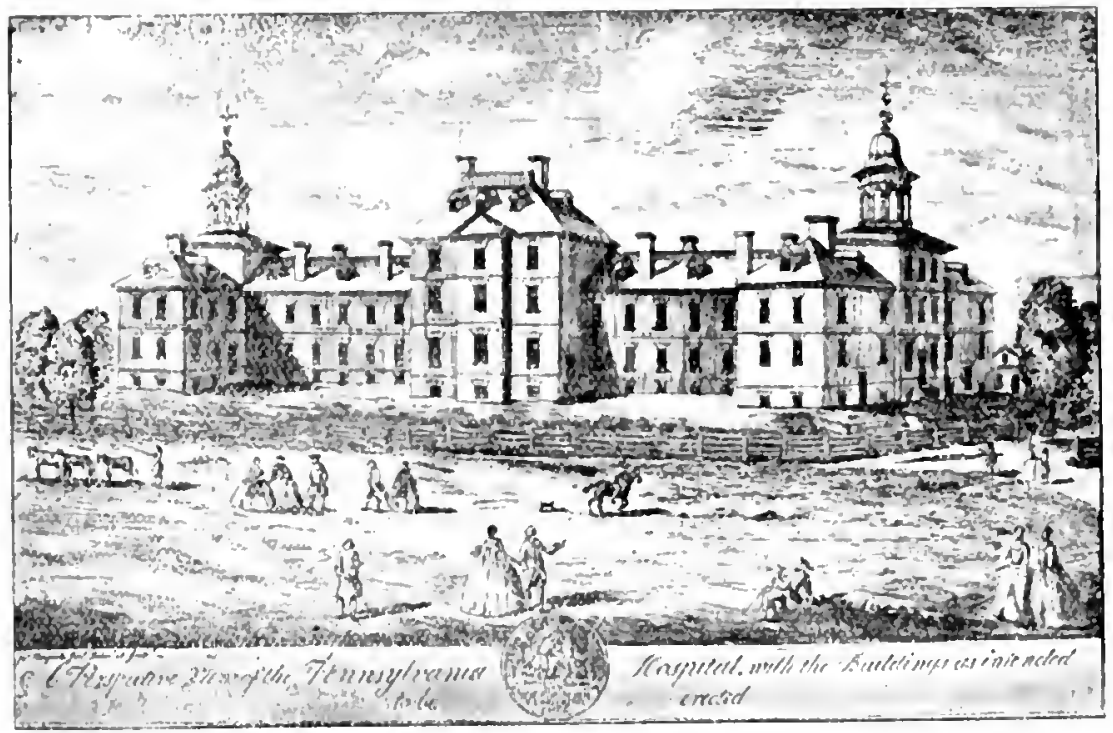

l'kin

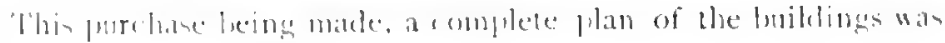

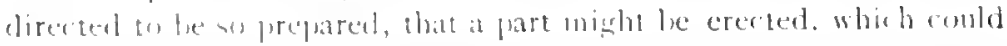

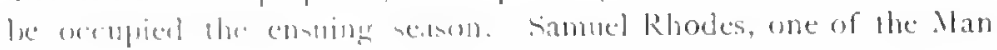

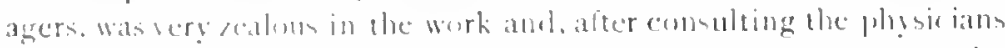
in regard (1) the ibmotion of the celts and other conveniences. he presented a design of the whele lubilduge, in such form, that one-thirel 
might first alone be erected with toleratile symmetry ; and containing, independently of the other parts, all arcommodations rerpusite and suitable for the present purposes and needs.

At the meeting held fannary 25. 1755, this flan of the entire buileling was presented and discussed, and it fair draught of the Lastem Wing and Ward, with an estimation of $\mathrm{jts}$ cost, was directed to be made, "in order that we may advertise the contributors of the design, and obtain their assent to proceed in bulding early the ensuing spring."

The Contributors were summoned to meet January 10. 1755, at the Court House, at three o'clock in the afternom, "to consider the plan of the proposed Inilding for the Hospital and an Estimation of the Expense then to be laid before them."

On Narch roth, at a meeting of the Contributors, at the Court House, a working plan of the new buiding was presented, the estimate submitted for completung one wing being abont three thousand Pounds. After due consideration, this plan and estimate were unamimously approved and the Managers "were desired to proceed in getting the said eastern part built with what expedition they conveniently can."

Manager Rhoads was appointed to supervise the work, provide materials, and make agreements with workmen, etc. A building committee was appointed to advise and assist therein, as occasion might require. The Committee carefully husbanded its resources and conscientiously adopted the most economical methods of carrying on the work, and it was also quite successful in collecting funds for the building. By soliciting contributions from all persons engaged in the work, they secured from most of those from whom material. were purchased, either a large proportion of what they furnished, or Encien Businces Managenent. is sulstantial reduction in their accomts. Their purchates were also distributed among the dealers so as 10 interest as many an posibile and in order to obtain contribution from a larger number. Sis diligent were they in their applications, that scarcely a tradesman was patronized, or even a workman employed. without his tirst pletging a donation or a discount, or inducing him to become a contributor. By systematically pursuing methodis such as these the lianagers were successfui in engaging the sympathy and support of almont the entire community for this charitable enterprise.

The approved plan of the new huilding is seen in the accom panying illustration on the precerling page.

In the complete design as exhibited, the ground flin was that of a centre structure of sixty-two fect front, its roof elevated almse 
the two lateral imilelings, (the east and west wings), and projecting leepran of yont thema nifficient distance to accommorlate a balcony intended to lfmpmal lie placed on the south front of each of the wards. The buildings frunted south, the principal entrance with a night of marble steps, leacling to a double door, heing in the centre of the administration luilding faring Pine street. The interior arrangement was briefly as follows: The ajarments for the steward, matron, ajothecary, the offices. parlor. library, (lrugshop, and a hall with a large stair-case learling to the nlper wards, and many other conveniences, were centre provided in the first floor of the three storied central luilding. In Building. the basement was a large kitchen, steward's dining-room, and matron's room. I)irectly adjoining this, on the east and west, were two wings, each of which was eighty feet front, twenty-seven feet decp. These also had three stories, lut with lower ceilings. so that they were lens high than the administration building, which was made still more conspicuous by being surmounted ly a tower for observation.

1.aterab, "Ir In the hirst itory or ground floor of each lateral wing were the

Fast and cells for lunatics. A gallery ran the whole length of eighty feet down West. Wing" the centre, for such patients as could lee trusted to walk about. There wats also a place for hathing, latrines. etc. The second story was the men's ward: it had four open fireplaces. and was also supplied with ventilators to carry off the foul air. The third story was like the second hut intended to be devited to the care of the women patients only. The upler flow or garret was intended for servants. It was alo to be utilized for cases needing isolation and was for the use of either sex.

Termun The plan also provided two terminal wings, each twenty-seven llings feet wide, and extending in length. north and south, ro fect. built at a right angle to each of the lateral wards, and connected with them. as will be seen in the plan.

In the middle of each terminal north and south wing. opposite the wards, there was a hall on each floor twenty-eight feet square (including a stair-ase). The roufs projected beyond the other wings suffie iently w cower their cornices. They also were to be raised one sory ahove the lateral wards, and were surmounted with a halustrade around the top, and a cupola. This was not intended merely as crmament. lut to afurel a secure and comenient way out in case of fire.

The whole extent of the bulleing from east to west was 2 - 6 feet. The nurth and south fronts were to be nearly alike. liy having the terminal wings run lengthwise acrons the wards. both convenience and looks were consulted, and it was hoped that " the east and we-t trunts will make an agreeable appearance." 
The olject of building the cross wings at the ends of the lateral wings was stated as follows:

Besides the additional rooms for cells, private apartments for such patients as may be improper to be received into the great wards, these wings will also affurd many conveniences for the family, as cellars, store-rooms for provisions, kitchens, laundry, lodgings for servants, etc.

The luilding usually known and herein described as the East Wing was completed at a total expense of $\$ 2.927,1.45 .3 / 4 d$.

The part of the Hospital buildings first erected was the east wing, exactly as now standing, about midway between sipruce and Pine Streets, facing Eighth Street. On the 2sth of May, 1755, the President, Joshua Crosby, attended by all the Managers, the physicians. and many contributors, hy previous appointment, marched in a loody from the Hospital on Market Street, accompanied ly a select concourse of citizens, to the grounds, where a large crowd had assembled.

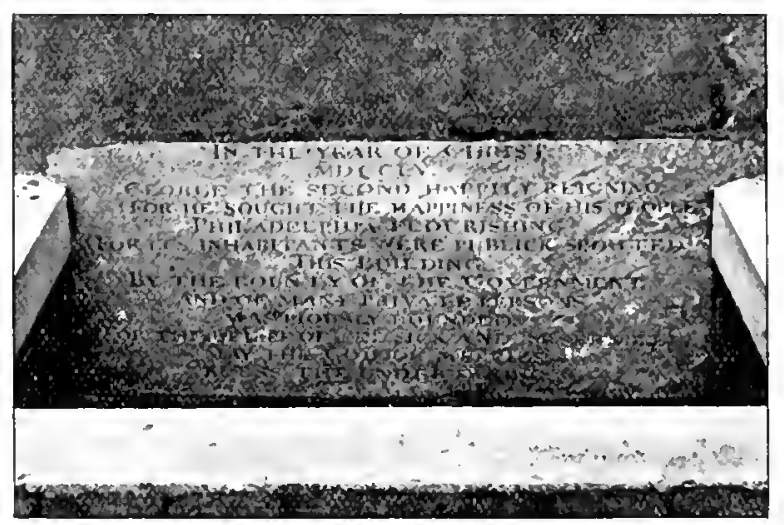

The Corner sione in 1504.

The public schouls of the city had been dismissed, and all the children of an age suitalle to recollect the fact had been invited to attend to witness the ceremony. An invitation was also sent to John Key, the first individnal born in the Colony in 1682, after the arrival of William lenn, to be present on this occasion. He accepted the invitation and assisted in the ceremonie's.

The corner-stone was a large piece of white marlle. Which was connerstone. deposited with due formality and with Masonic riter, in the sontleast corner of the foundation. It contains the following inseriftion, which had been written by Franklin:

East Wing completed. 


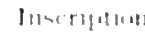
- 11 the finter $\rightarrow$ tinlt.

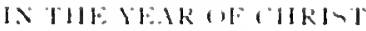

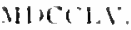

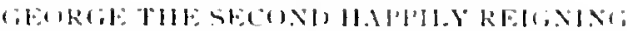

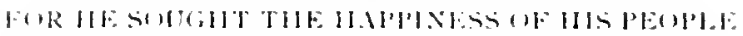

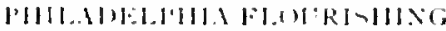

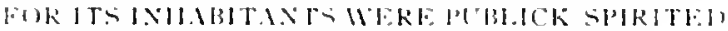

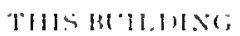

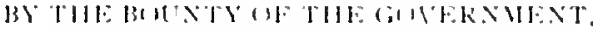

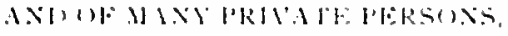

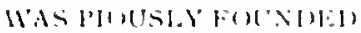

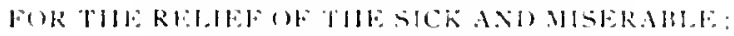

M.1 TIJ

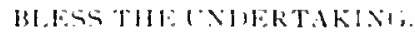

The stome han survived the bieisitulen of the weather and the abse instription is still puite legrible.

The lublding was so far complefed that the root wat raised Ortolxer 27.1755 ; and the rooms were direted to be at ance made reasle for unc.

The firet regular meeting of the llanagers to inspet the llospital was held on I lecember zith of the same year.

The Hospital, lefore the building of the East Wing wa completerl, suffercel a serious lous in the death, on June 27,1755 . of the seneralite President Joshua ('rushy. In addition to his many other benefar. tions, he left a legacy of 6 oo towards the building fund.

On June $30,175,1$ r. lranklin was unanimously elected P'resident of the Board, to suceed Mr. Croshy, and he presided at the first meeting helel in the new bulding.

Early in 175 , the building was sufficiently finished to holut the ammal meeting under its roof; accordingly, on Nhy oth. the meeting uf the contritutor was first held in the new IIospital, and sime that time the ammual meetings bave leen regularly held in the same place.

lihe: Manaser met for organiation immetiately after the contributors' mecting on May oth, when the following me was alopleal:

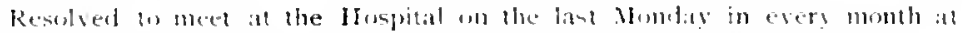

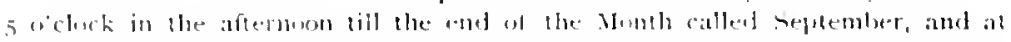

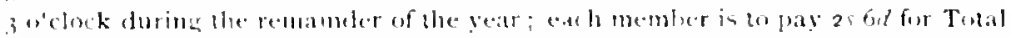

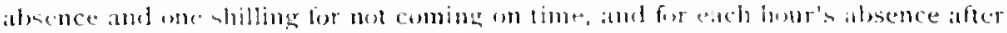

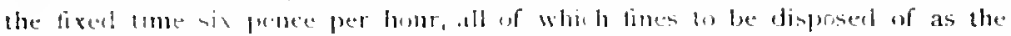

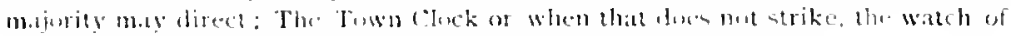

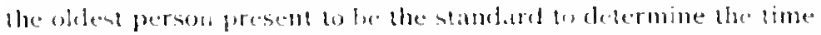

The same resolution had been in force during the year. an is seen in the extract reprodnced from the minutes, on the next pase.

In lugust, $155^{6}$, the Managers hearing of the exper ted arrival of the new lientenant Cowernor. ('ild. William Denny. concheded 
"that it may be expedient to address our new Governor on his arrival;" and it was agreed, that the I'resiclent of the Board. lienjamin

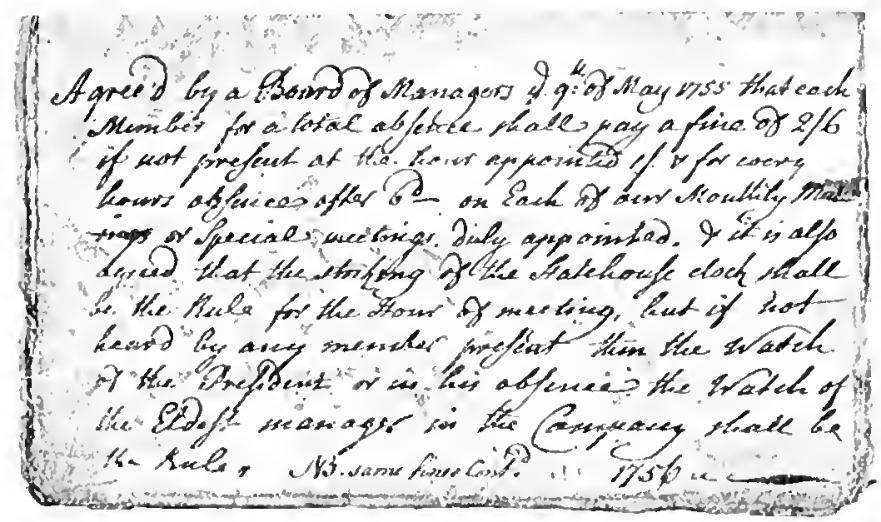

Frankin, and others, should prepare a format ardress. A record makle on the book of minules, Seplember 1, 1756. states that:

William Denny, Escl., having lately arrived from Lumden, to surceed Rubert Hunter Morris, Escl, in the Government of this Province, the llanagers and Treasurer waited upon him, on the First of Ninth Month with the following Congratulatory Address:

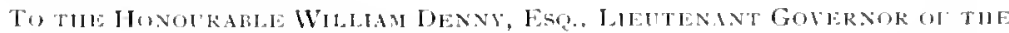

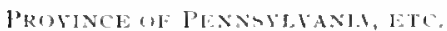

The Address of the Hanagers and Treasurer of the Lemonswania Hospital.

$$
\text { Mut it please the Gorer mor, }
$$

The Managers of the Pennsylvania Hospital beg leare to tentify the Share they tiake in the general Joy, on his Accession to the Government of this Province. Through the Favour of the Govermment, the Contributors to our llospital were incorporated by Law, and vested with the l'owers and Privileges necessary fur the well ordering as well as increasing this extensive Charity. The nontutum has ever since dlourisherl, and we have the great Satisfaction to lind, that onr Care and diligent Endeavors to relieve the Miscries, and heat the Discases of the Poor, have been blessed with much Success; and that our Power of dung goud is loy the Benefactions of well-disposed Persons daily increising. While this right I'se continues to be made of the Privileres granted us, we lupe our Comporation will

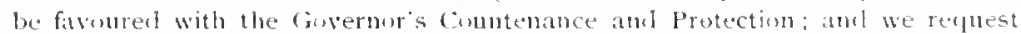
he would accopt of our sincere Wisle's for his Heatth, 1 lappliness and successful Administration.

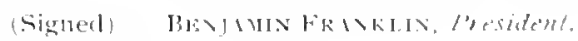

'lo which the (iswernor replied:

Ginllemen. The Satisfaction you atre pleased to expmes on my Arival, lays me under purticular obligations; and your gond llighes deserbe my bearty Thanks. 1 an glat I find so generous and humant an [nstitution as yours is, managed with so much prudence, supported by Laws and encouraged by Public and private Benefactions. It will give me a sincere l'leasure, to contribute islt the Means in my Power to carry an this Charity in the most 'xtensive Manner. 
The Hospital now being sufficiently advanced, it was conRemosil of sidered desirable to have patients moved to their new puarters as som fatiente. an practicable, although the building was still far from finished. 'lhis was the more necessary, sinee the Market Street house had by this time so outgrown its capacity that the demand for more commodious fjuarters had lecone imperative. The Managers also deeided to have the accounts of the Hospital put in proper shape for publieation and printed and circulated, in the hope of gaining new concributors. It was deemed advantageous to include in this publication an alsstract of the cares, with the names of the patients, and also the names of several contributors adeled since the last publication harl been laid before the Assembly. "This work was directed to be done by the Mombly Committee, aided by Benjamin Franklin and laniel kolercleau. Samuel Rhoads was instrueted to get in all the traclesmen's bills relating to the new IIospital, in order that the Board at its next meeting might andit them and formulate a general aceount of the cont.

(on December 17,1756 , all the patients were removed from the Temperary Hospital on Market street to the new huilding at Pine street, and the first new patient admitted into the Hospital was on the following day.

Frankliu. Altorney for

At the meeting hele . March 28,1757 , the following minute was male:

The President of the Board, Benjamin Franklin, being appointed Provincial Agent to England and is alout to sail in a short time, he is reguested after his arrival there, to use his interest in Suliciting Donations to the llospital whenever he maty have a Prospert of Success therein, and Israel Pemberton and Evan Morgall are desired to prepare a letter to Thomas Ilyam and Sylvanus levan, deniring their Friendship in Assisting our l'resident in :tny occasion he may have. of l'romoting the lnterest of the 1 fospital.

"The oligect of making this request of lianklin was evidently to mest him with official authority so that he might legally solicit subsrijnions and tramalet any other fnancial husiness which might lee presemed for comsideration: this letter to 11 yam and besan serving as credentials and as a power of attorney in any emergency requiring such efficial sanction and authorization.

When firanklin salled on his first mission to lingland, in 1757 , his irele of correypondents, both husiness and scientific, had already lecome widely extended. Among his liurupean friends and correspondents were Millian Sirahan, lort Kames, Javid llume, liaskerville the printer. Cralloway, Batram, bubourg, Bencet, Joseph l'riestly, and many uthers. This gave him a large field of acguaintance in wheh to wo:k in arlvaneing the interests of the Hosplital. 
On December 29,1760 , a letter was written to Franklin for some necessary drugs and medicines, and he was aiso asked "to join with some olhers of our fellow citizens, now in I,ondon, in soliciting contributions on behalf of the Hospital from several merchants who, we apprehend, may be induced to encourage the progress thereof."

Instructions were also written to Franklin, while in London, to procure a specimen iron bedstead such as are commonly used in the hospitals in England.

Franklin's agency and mission in England detained him for five years, but it finally came to a successful conclusion and he returned to Philadelphia November 1,1762 .

In October, I757, a Committee of the Assembly risited the Hospital and made examination into the condition of the patients, and the general state of its finances, and " they were pleased to express themselves to le well satisfied with the order and management thereof."

The following advertivement appeared in the "Pennsylvania (iazette" December 27, 1759:

$$
\begin{aligned}
& \text { For TIIE BENEFIT of the } \\
& \text { PENNSYLVANIA HOSPITAL }
\end{aligned}
$$

On Friday, the $2 x t h$, of this instant, lecember, at the Theatre on SOCIETY HIJ.L will be presented the celebrated TRACEDY' of HAWLET, PRINCE UF IJENWARK Tickets will be sold by William Wunidp, William Bradford, Thomas Gordon and Evan Morgan.

As the money originated from what was considered such an objectionable source, the matter gave rise to some discussion as to the proper course to be jursued, the Nanagers feeling in doubl as to the propriety of receiving it under the circumstances; yet unwilling to deprive the Hospital of it. The difficulty was finally haplily adjusted, the Managers escaping from their dilemma in yuite an original and ingenious manner. without sacrificing the interests of the Hospital. as the following minule will show:

The Board being informed that a sum of Money hath been lately raised for the Benefit of the Hospital, by i Stage Play acted near this City, which has been paid into the Hands of the Treasurer, the Matter being consider'd $\&$ most of the Managers being dissatisfied therewith, think it necessary that the following information should be published in the next "Pennsylvania Gazette," of Jannary totls, viz. :

"THE PENXSYLVANA HOSPITAL.

Was fonnded in the lear $775 \mathrm{I}$, by an Act of the Assembly of this Province, ly which every Person contrhuting Ten Pounds, or upwards, towards fom the said Hospital, is qualified annually tu Choose by Billot twelve Persons of their own Number to be the Managers of the said Contrilutors, $x$ one other lerson t. 
Fiphimalours - tatementils VI.111:1:21

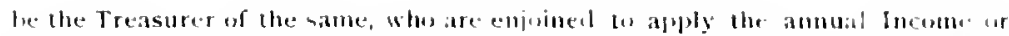
luberest of the satid contrihution lowards ble Entertainment and cure of suld siek and destempered lower, is shall, from time latime, le brought or placed in

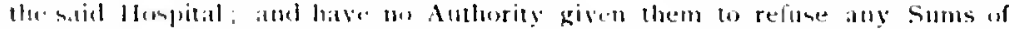

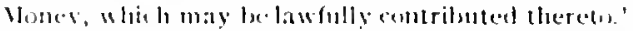

This acomte of the foumding the said limptal and of the Power of the

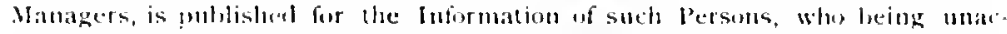

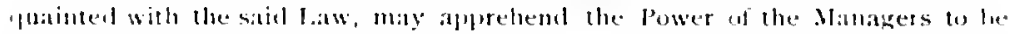
more evenowe than it is, and to satisty such that they are unt anthorized to direct the 'Preasurar to refuse the Wondy lately raised by exhibiting a Stage play near the (ity, which was done witheut the fonsent of the said Mantyers, in conce

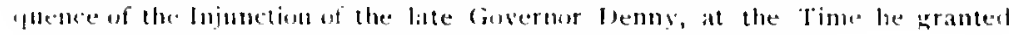

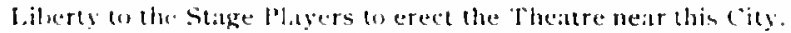

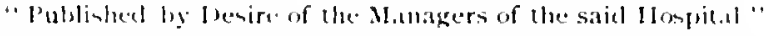

The Ilallam Theatrical comprany, of Iondon. Whith salle the fenefit, relieved the conscientious scruples of the llanagers in a delicate and gracefial manner. ly placing the amount realized at the

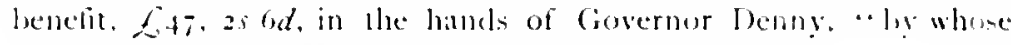
order through livan Morgan it was gaid to ge hephitil."

It is not surprising that the Managers were bath to receive money obained in this manner: since the condition of the pullie mind, al the lime, "an greatly excited against all of the kinds of public. amberments then in veshe, and especially against theatrical perform ances. Moreover. the .1 inagers, who were nearly all members of the seriety of firiends. had themselses joined with other citizens, not long ixfore. in a petition for an injunction against the erection of the theatre on society IIill.

(seremented comdition in Jispllat

. Now whthatanding the inc reased accommodations which had leen frovideal in the new luspital. it was soon found that the overerowled condition again callsed serious combarrassment. It was puite difficult lu reject many worth applicants, who were daily presenting themseles for atmision. Precantions were taken to admit only thase reppiring immediale and urgent altention, lut in spite of everything the warls were malliy erowded to their numost apratily. The Managers were aloo obliged to wive serium consiteration to the froblem an to the bert means of purste to meet the increased experme and the expected deficiency an it reconed imposilste to lessen the number of patients. They acoodingly in their emergency, decided to make another

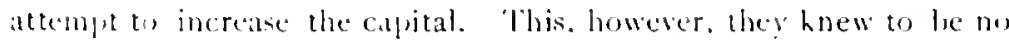
casy mater. Their predicament is clearly indicated in the minutes of the uneeting held J:11. 29, 1559 :

On consideration of the present state of the funds of the llospital, 1 is resolved that there is urgent necessity of lessening the expense, unless we con succed better than we have lately in unr endeavors wincrease the capial stork 
It was agreed to have a conference with the Treasurer and Physcians to devise some means to overcume this difficulty. This meetung was to have taken place on the twelfth of second month (lebruary), but it seems that the subject was of so grave and important a nature that it conld not le summarily settled f for on the ad of February, 1759 , it was noted:

I aving conferred on the subject matter and no definite means decided upon, the Doctors agreed to eximine and consider the mothods of providing for several hospitals in England, fc., and when prepared to lay a plan before us at a future metting

The Mlanagers in their extremity decided to make another appeal to the Assembly for aid in this emergency. An address was accordingly prepared, and a committee was appointed to present it to the Speaker. It read as follows:

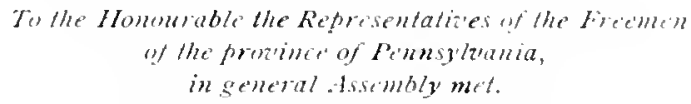

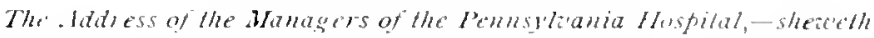

That the said Ifosyital, founded alout eight years sinee, with the approba tion, and hy the Assistance of the Assembly, hath been hitherto supported by the Contributions of privale lersons and by divine lilessing on the encleatrours of the Physicians, upwards of three hundred distressed Persolns have been cur'd of various Ilisorders of hody and Mind, under which they had languished; and many other have been consideribly relieved, and thereby restor'd to a calpaty of being servicealite to themselves and the pullick.

That the two thousand Pounds contributed by the Assembly, towards the building, leeing long since expended, we have been under the necessity of alply. ing most of the contributums obtained from private Persons the last three years towards compleating the Wirk, and of conrse are prevented fron increasing the Capital Stock; the anmual interest of which is the only fuml we have loc receiverl for the support of the institution.

That the number if patients, who from all parts of the province apply for adnittance, is lately much increased, so that upwards of olle thousind pounds is expended more than mur Capital Stock; and as the lemefits referied by our distress'd Fellow suljects are daily more known and considered, the prospect of our inceasing Fxpences exceeds any rotional expectations we can indulge, of being able to sulpurt the Honse, accorehng lo the original deagn, without sume further Assistance from the publick.

We therefonc reemmend the present state of the II spital w your serione Consideration, ind hape the same leme volent disponition wn which it was founded. will still be mamfented hy the Assombly of Pemsylvania, lo promote so landilide an Institution, shitually becoming of the mont extensibe sersice to this pant of the King's Inumionom.

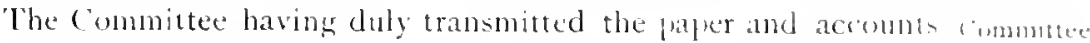
to the speaker of the Assembly reported, Aprit 30, 1759, that the enorted. had performed the service assigned and that he had promined in bring the same before the House of Ascemlily. 
The Nanigers waited for several monthe for some notie of their

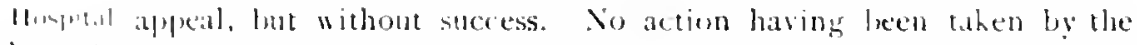
lownes Insembly it wan decided to pulitely remind this body of the pressing leetwe the necels of the hospital ly abling to the documents the accounts of the last rear past $(1758-59)$. for sulmussion.

Before the llouse of Ansembly nuw sitcing, and to not fy them that we shoufle

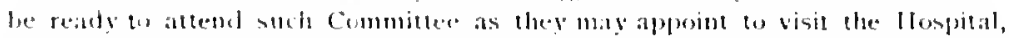
inspert the Bangement and state thereof, also to remind them of the present Secessitien to wheh we are sulject fol supporting the hostitution which we hope they will take umler Comideraten and grant that Assistance and Releef reduested in our Addess presented at their last Sitting, in creler lo promote the progress of a Work which lith been found to be of so great Benefit to the lain. tressed and Indigent.

The addrew and oller papers were finally laid before the disemlily on June $25,175 \%$.

The necels of the llospital were now very pressing, money was scarce and commanted a high rate of interest. and as yet no sign of relief apleared from the Issembly. The legishave machinery, at alt times ponderus and slow, was at that time engrossed with novel and complex political froblems; which with other matters, entirely owershadowed the appeal from the llosplital, which was accordingly temporarily set asile. Franklin's influence and prestige were sadly missed ; his experience and energy" were no longer avalable in behalf of the Ifoppital's interests in the Assembly, which he had so often wielded to great advantage-the philosopher, statesman and wise counsellor was now in london. No one seemed to possess the necensary ability or interent to press the measure 10 a successful isune. The resuirements of the llospital were urgent, every-lay wants were to be met, lills to be setuled, forrowing afforded bent temporary relief, and only involved future expense in the payment of interest charges.

In order to cmphasize the urgency of their predicament to the people and Arsembly, adopting Franklun's tactics, the Managers hat recourse to the pullic prints, as appears from the following communication in "The l'consyluania Gazette," of July $12,1759,1$ with an Alstract of Records and decombts and the following remarks:

Aprean! in sise Pulutic thrulugh the "Gitzetle."

Fipm this liew of the state of the Acounts. and hy comparing the Abstract of the caves with those formerly puldished, the Publick may ofoserse the great

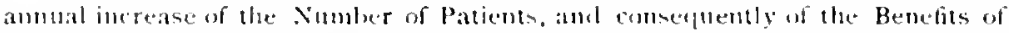
the luntutution: whith lonsideration, tegrether with that of the Adrlitional Conveniences for thes Reception and decommortation, which have been attended with comsiderable Labour, and umavidable bapence nuse undoubtedly afforel an "gual beyree of saturaction to those who are already Benefactors to this Charity :

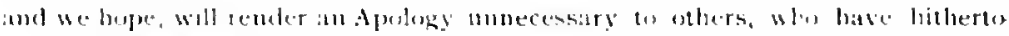

I Vule Franklin"s" Some Account," etc. 
neglected or deferred entering the List of Subscribers, for a Repetition of our Request for their Assistance in so commendable a Work ; and it being impracticat. ble to make a persinal Application to all such, especially to those who live at at Distance, it is to be hoped mo onfence will be taken, to the Prejudice of the Charity; but that all who are disposed to contribute, will pay their subscriptions for enter their intended Berbefictions) to the Treasurer. or either of the Managers, as her-tofore motified. If notwithstanding what has been frequently urged in Favour of this Institution, such who are sensible of the undeniable Advantages of an Ilospital, do yet withold their Bounty, on a Supposition of the small Benefit which their Neighbourhood is to receis from it, they will please to consider, That they can never hope to do any Service for their wwn Poor, till they lave made it more practicable to do so, by the Ascistance they lend those who are already engaged in it ; which is the only probable Heans of bringing the Charity nearer to themselves, and therefore it is much to be wished, that if they have it mot in their Power to begin this Charity at home, they would legin it in a Place where it can be well attended by Plysicians and surgeons, and where it is necesarily formed on so large a bottom, as to require more Help than can be had from thise only who are at Hand, many of whom have not more interested Reasons for their Bounty, than if they lived in a distant Country; their Notives being to promute a spirit of Goodness and Ilumanity, which may extend itself on every Side, ly administering the most effectual Relief to all deserving Objects, withour considering from whence they conse- They are encouraged to do it, by the great success which hath attended this good Work in every other Place; the moral, religious, and civil Benefits of which, being visible, certain, and lasting, do immechately tend to the Honsur of the Christian Religion, and the Happiness of Mankind.

The Contributions which have been generously made this Vear, have enabled the Managers to proceed in compleating some necessary Conveniences, which were Immediately wanted, ancl to receive and entertain a much larger Number of Patients in the House, than their Stock wenld permit before; and if the Splirit of Charity towards this lustitution contumes, with egual Wam mhereafter, it will suon become more extensively useful. To give it its proper Wenght with the Publick, let it be considered, that in a city of larcre Trade, many ponir People must be employed in carrying on a Cummerce, which subjects them to frejuent terrible Accidents. That in a country, where great xumlers of indigent Foreigners have been but lately imported, and where the common listresses of Powerty have been much incteased, by a numit savage and bluody War, there must be many Poor, Sick, and Mained. That poor Perple are maintuned by the ir Labunr, and, if they canmu labour, they canm live, withont the lielp of the more Fortunate. We all know, many Nouths are fed, many Boties cluathed, by one poor Man's Industry and Diligence; should any I listemper seize and aftlict this Person; should any sudden Hurt happen to him, which shuthl render him incapable to follow the Business of his calling, unfit him to work, disable him to labout but for a little time; or shumb his Duty to his aged and diseased Parents, or his fatherly Tenderness or an aflicted Chl, engross his Attention ancl care. How great must he the Calanity of such a Family! Inw prescing their Wants! How moving their Distresses! And how much does it bebone the Communty tw take them immediately uncler their foutdianship, and have the Causes of thers Misfortunes as speedily remedied as pussible! Fxperience sluews, this will be more effectually and frugally done in a publick Hospital, than ly any ofleer method whatever.

Can anything in this checkered World, aflord more real and hasting Satisfaction to humane Mlinds, than the Reflection of having miate sucts a sociall ['se al 
the Favours uf l'ruvidence, as renders them, in some dleasure, Instruments which open a Dow of forse and Comfort 20 such as are bowed down with peresty and Sickness: and which mat be a Means of increasing the Number of lees ple, and preserving many useful Menleers to the Publick from Ruin and bistress?

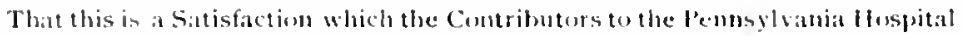
hate a just claim 2 , all mat be astured, by vising the House, examiting the Patticats, and consile ring the extrandinary Cases which are there received, and

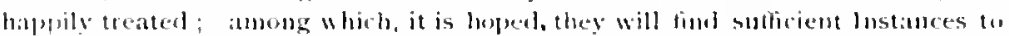
comvince them, that every lndivielual, in this and the adiacent lrosmes, are interested in the Prosperity of this chatitalle Institution: and induce them to consider, that "Riches make themselves llings, and liee awaty; but blessed is he that considereth the Weak, Sick, and seedy, the Lord will deliver hom in lime of trouble." And that it is better to give Ams, than lay up ciold.

Nolwithuanding the efforts made to advance the cause of the Ilospital Ixefore the Assembly and in the minds of the pulplic, lhe appeal remained without apparent result.

'These means fruving fruitlens, the Nanagers' hopes turned agait to the pullic, and they determined to develop their own resources, in which they were more stccessful. They issued prints or pictures of the Hospital, and also a second "small quarto" cdition, similar to the one pulplished in 1754 . It was called a "continuation of the Acount of the Pennsyliania Hospital: from the first of $.19 y, 1754$. to the fifth of May. I 76 ." This literary lank was ferformed satisfactorily ly a Committec on Publication, of which Sannel Rhoads was chairman.

The essay which was presented to the Managers and approved by them, contains the following apleal:

Fismal

The Experience of above Nine Years, has givenumdeniable Proofs of the neces. sity and lsefulness of this laudable institution; and, it is boped, the berusil of the fixtegoing Accumt, with what has been heretufore published, will afford pleatsing ketlections tw the beneficient (ontributurs, by " hose generous Assistance and bucouragenens, it has gradutly arrived to its present sutuation, capable of extemling Relicf to the Iniste'sses of many miscrable Objects, depressed by Poverty" and lisease, and the Managers hate the Satisfaction to observe its Reputation adaly to increase, by the frequent Applications for the Admission of Patients from various l'arts of this and the Neyghlouring l'rovinces, which they batter themselses they shall still be enabled to contiaue and conturge, by the future benefiations of many charitalde Persons from distant Places, ats well as those of our own Comntry, who hase yet delityed contrbuting, the allanent Circumstances of many of whom will casly atmit of their Impastiun a share of the Blessings they enjoy, for the benefit of snch, whose Indigence and Miseries claim the Attention of every compassionate lleatt.

It would be a Neglect of that Justice which is due to the physicians and surgeons of this lingpital, not to acknowlerge, that their Care and Skill, and their punctual and regulur Attendance, moler the bivine Blessing, had been a principal Mhans of arlancing his fharity to the Hourishing state in which we

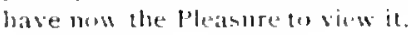


In $x_{7} 65$, Signers of the liills of Credit donated fees amounting to $\mathrm{E}_{601}, 2 s, 6 \mathrm{~d}$; this sum was afterwards increased.

The Iouse of Representitives of this Province, having for divers lears past voted considerable Sums of Money for the services of the Gusernment, which have been issued in Paper Bills of Credit, several of the Inhabitants of Philadel. phia, already Contributors, and some others, concurring in a Desire for the l'rosperity of this Hospital, voluntarily offeres to be nominated signers of the same, and generously bestowed the Wages, usually allowed for such Service, for promoting the good Purposes thereof, whereby the total Sum of One Thousand Eight Hundred Thirty Eight Pounds Seventeen Shillings and Sixpence has been adderl to the Contributions, and proved a very seasonable Assistance. ${ }^{1}$

Great hopes centered in the accounts of the work of the Honplital which were now to go forth and eloquently plead its caune. The princifral objective point was the Assembly. which had so long neglected and overlooked the important work which was donely the Hospital for the poor, lunatics, and the destitute suffering sick of the Province. The Managers again approached the Speaker, armed with their pathetic: appeal, with the request that he read it and then leave the matter with his conscience to dictate the course to pursue. Their trust, very happily, was not misplaced.

One of the Books lately published containing a Narrative of the Management of the Hospital for the last Seven J'ears including the Account of the last l'ear an Abstract of the Patients and a List of the Cuntributors having been delivered tothe Speaker and by him on Sept. $9^{\text {th, }}, 86 \mathrm{r}$, communicated to the House of Representatives, William Allen, the Chief Justice and most of the Members of the Assembly visited this Hospital and after viewing the Patients and inspecting the Institution were pleased to express theinselves much satisfied to observe the Iecency and Economy of the House and that the goot Purposes of the Charity were so carefully attended to.

The results of this visit were favorable, inasmuch as on May 17 . 762 , the Board was notified that:

The Provincial Assembly had granted the Sum of Three Thousand Pounds to the Corporation of Contributors to be applied towards paying off the Balance due to the Capital Stock and for such other Purposes as the Managers may direct.

Accordingly on June 2,1762 , an order was drawn on the Trustees of the Loan office of the Province for $E_{3} .000$, payable to the Treasurer, being the sum above mentioned, which was to be apphed by the Nanagers in replacing the several sums borrowed from the Capital Stock. It is seen that no time was lost by the Nanagers after

'A bill for reminting and contuning the currency of the bills of credit of the province and for striking a further sum, was laid before the House on February 11 th, : 754 , by twenty-seven citizens and three Members of the House, who offered to sign the said money, upon the same terms as had been previously made for this service, and their names were accordingly inserted in the bill, with the expressed intention of donating the money thus earned to the Pennsylvania Hospital, but nothing

was then oltained by this proposal for the Hospital, for thus bill falled to become a law. 
they were alpersed of the munes baving been appropriated by the Asemlly, in whtaining possession of the much needed assistance, and replacing the sims they had been forced to borrow from the Capital. The yearly acrounts, which it wanecessary to present to the Assembly, bacl in bow that the ariginal captal remained intact, otherwise the ver! existence of the llosplatal miglat be jeopardized, and its future thefulnens certainly curtaikel.

Fin (1) lanuary $25,1,62$. the Ditectors of the Philadelphia Contri. bunrance Imtionship for Insurane of hemes from loss ly fire notified the Managers that they had ascreed to sign a poliry of insurance in three parts "w the amount of 5500 on the huilding. and that a return of surver hatl heen made. This literal and considerate offer was gratefully wepted by the Managers, and the insurance, although changed on iwn ocrasions, in 1822 and 1850 , still remains in force. though in reased in amount.

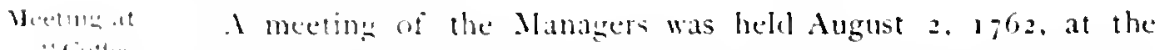
"cinle. "Confere Honde" to execute a power of attorney to James l'ilghman. to enable him to collect James Brown's legacy. These outside meetings seem to have leen beld at various places: another one is found mentionel. Nivember $\$, 1 ; 62$, as being held in the Warden's room at the Cintr House, where they were informed by lor. William Shipien, Ir. lately arrived from london. lhat several cases containing anatomical drawings, etc, sent by Dr. John Fothergill, harl reached this gort. 'This was the nucleus of the future Museum.

thiten . It a meecing held Covember $8,176_{3}$, it was agreed to address

1.. Jwan John l'enn. Eif. (one of the proprietors. and the son of Richard, Pentin, linit. l.je-11k-n,ant and uratison of William Penn), lately arrived (Octoler $3^{0}, 1^{6} 3$ ), from london, who had hately come to preside as covernor of thin Province.

The following is the text of the adolress as delivered:

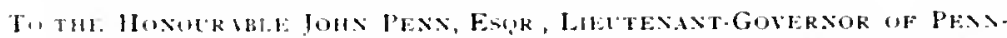

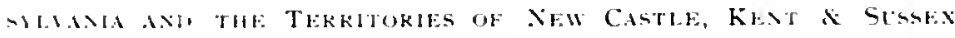

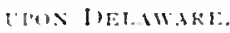

The Address of the Managers \& Treasurer of the Pennsylvania Hospitil.

$$
\text { .hat it please the Gonernor: }
$$

The Managers \& Treasurer of the Pennsylvania Hospital Chearfully enbrace this opportunily of expressing the Pleature the receive on his safe Arrival $\mathbb{E}$ Accession on the Government of this Province. This Ilospital established for relieving the Diseases $\&$ restoring the Health of the Indigent \& Miserable under Divine Providence through the Patronage of the Legislature \& the Benevolence

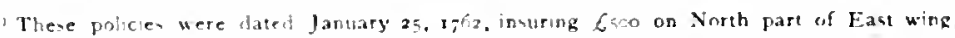

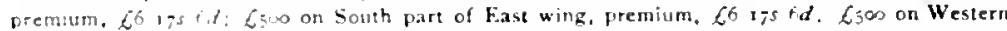

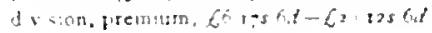


of the Inhabitants of this Prowince $x$ Invern charitable Persons in Great Britain Nanagers' \& other places from a small beginning hath sradually beconte of extensive Compliments utility and it is wh great Satisfaction we find has obtained the Approbation to rov. Penn. \& Favour of our homorable Proprietaries crnfirmed by their generous Benefactions which Merits our thankful Acknowledgment. The Harmony \& Concord with which it has been hitherto Cunclucted and the Success attending the united endeavours of the Physicians and Managers yeld the pleasing Hope it will still flourish $\&$ increase in Benefit to Mankind. The Powers \& Privileges granted by Jaw to the Curporation of Contributors being fund useful \& necessary \& having received the Cumtenance $\&$ incouragental of the fuvernor's Prede. cessors we contide that prudent and proper Exercise thereof will recommend this laudable fnstitution to his Protection \& Favour. Our sincere Wishes attend the Governor that his Administration may be Conducted to his wn Satisfaction and the Happiness of lie Province.

Philadephia, Nov, gth, $1,-63$.

On November 29 , it is recorded that:

The Treasurer $\&$ all the Managers attended at the Coffee House on the isth Inst. and from thence proceeded to the Governor's, \& after reading the Address Delivered it $\&$ received from him the following Answer:

Gintlemen: I heartily thank you for your Address it gives me a particular Pleasure to find that the Charitable $\&$ well founded Hospital in this Province has Received such (ieneral Encouragement and that by the l'rudent Care of its Physicians \& Managers it has become so very extensive a Charity and be Assured that the Duties of Humanity will ever incline ne to give ali the Countenance in my Power to so guod an Institution.

No "benefaction" followed this exchange of courtesies, until $1 ; 88$, when the name of John Penn. Ir., appears on the list of contributurs.

Gor. Penn was received by the citizens of Philadelphia with great demonstrations of respect, and many entertainments were given in his honor.

In address was prepared and sent to the proprietors acknowledging the grant of forty pounds per anmum and gift of the lot next adjoining the Hospital property on the north, of which they had been informed by the Receiver (ieneral, the year before. This decment was signed at a meeting held December 29,$1 ; 63$; and at the same time a letter was written to William Allen, then in London, refuest. ing him "to present our Address to the Proprictaries." The person to whom these letters were confided instead of going to london, it was afterwards discovered, had sailed for the West Indies, and not until August 27, I764. dicl the Managers learn of the miscarriage of their communcations: there having been sent to William Allen, who was then in Philadelphia, together with an explanatory note stating the eaure of the delay. At the last mentioned date, the package was returned, "very much defacel," which necesitated the re-copy. ing of both document?.

Iis Acknow edgment
Donation of ground from the Penns. 


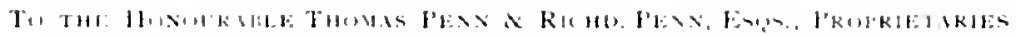

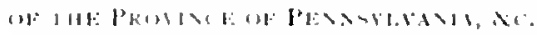

The Adress of the Mandered Treasurer of the Pennsyluania Hospital.

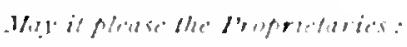

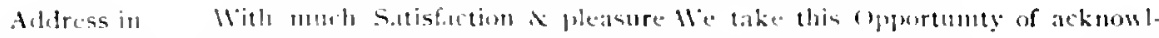

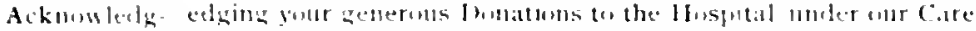

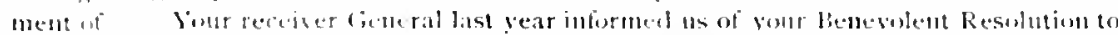

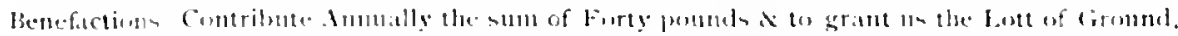
which Cempleats the sifuare on which the Ihomital is erected $x$ pursuant to your directius fle hath since paid us the sum gou orelefid fur two jears bast.

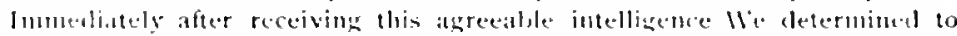

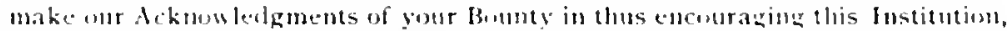
the Bunefits it which, be the blessing of bivine Providence, are become very evi.

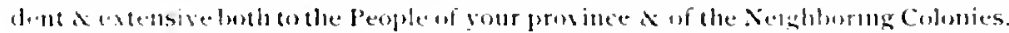

Mith the number of People in these f'rovinces, the Patients in thin Hompital

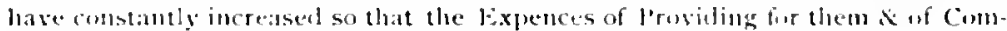
pleatiog thet part of the Buibliner which is erecterl, hase Anmually greatly

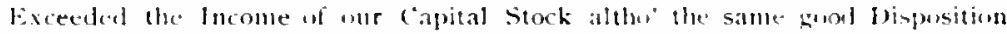
continum in the lenple of this city in particular 2 of some in onther parts uf the Provine which enalstel us to begin the Mirk, \& Considerable smms have beten learly aldeled to the Stock ly their private bunefactions. Smme generous bonations hate alsu been made from Gireat Britain \& frum some of the Adjacent Provinces and the llest ludia Islands, fet the whole being imbutitient the sum of Threte thusand pounds was lig the favour of the fiosermur \& Assembly of sour J'rowince last year Aldetl to their former Gram, part of which hath heen applied to bincharge the lefieiency of our former Funds a the Remainder to the Increase of tur fipital, which is still tou small to Answer the l'resuing Cries We hear, "f many whostand in neenl of such an lastitution.

There hove been constanty npwards of One hunlrect patients, in the House for somet tinte past at the present Circumstances of the province en ince to las. who are fcyutinted with the Numbers of distressed llijects who daily apply for lielp. that both charity a food loblicy demand the exertion of our Findeavours, to Restore thesn wo a Capacity of becoming unefull Hembers of society. This Con-

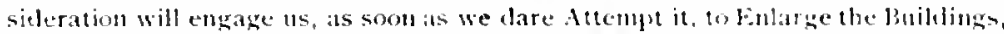
Nother Conveniences for the reception of such, $\mathrm{N}$ we shall the somer Adsenturte on the undertaking as, from the biligent Attention of the lhysians all others Concernd in the cate of this Charity and the llatmony S Concord which hath subsisted among us. We bave the pleasing prospect of the Cumbunance of that gond success, we bave hitherto bat and ons lope is Fxcited that as this lufirmary is the first, it will he the most Extensive in benefits on the King's subjects in lis Anerican bominions.

The information given us of your Intentions of sonn ordering a Patent to the granted us for the Lett, Oceasioned our deferring this ackmwledgement of your Benevolence being destous with it of lnformog lou that this patrt of your kinel purpose was (ompleated. 11 e bege yur fasourable excuse of this belay $\mathrm{d}$ assure yul we are with nucl respect and fratitude

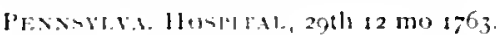

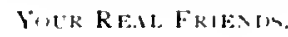

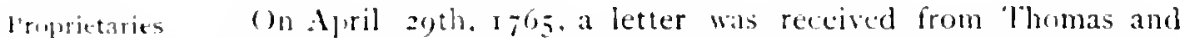
iscue littent. Richard Penn, directing that a patent should te issued ly the forernor to the Contributors for the lot lying immediately north of the society 
lot on which the Hospital was erected. The warrant for a survey from Gos: Penn, dated Sept. 12th. 1765. was read at a meeting held the 28 th of the same month. The l'atent for the lot was eventually delivered in the latter part of 1,$6 ;$, some three years after receiving notice of its having been contributed acknowledgment of which is made in the following letter:

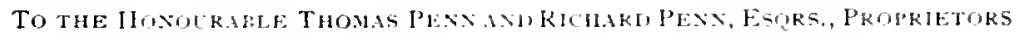

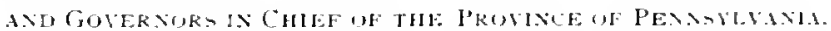

The Managers and Treasurer of the Penusylwania Hospital, with much Adaress to Proprietors Respect and Gratitude, acknowledge your Benevolence, in your genterous Donations for the Support and Advancement of the Institution under our Care.

lour annual Contribution of Forty Pounds, was in the year 1,62 , and hath ever since been, regularly paid by your Rectiver General.

The Patent was deliv'd us at our Meet'g last month for the Lot you were pleased to grant: by which the Ilospital is agreeably accommodated. and its Situation now secured from future Interruptions of the Room and Air from any part of that Square on which it is built.

The approbation of our Conduct, you have manifested by thuse raluable Donations will incite us to pursue every measure in our Power to render the Pennsylvania Hospital the Object of your continued Faror and Regard: and confiding therein, we beg leave to lay hefore you the State of the Hospital and of its Funds, in the three last amual Settements of the Accounts, and of the Returns of the number of Patients admitted and discharged. On comparing these with our small beginning, a few years since, we have just Cause. with reverent Thank. fulness, to acknowledge, that, the Divine Blessing hath been conferred on the Endeavours of those concerned in its Foundation, Establishment and Support.

The Physicians continue to attend gratis with great Care and Diligence, and besides the Service immediately afforded to the annual increasing number of Patients, there's a Prospect of contributing towards the Establishing a Hedical School for the Instruction of the linth of this and the adjacent Provinces; and thereby rendering the regular study and Practice of Physic and Surgery attainable by many whose Circumstances will not fernit them to pursue it at the great Expence of a Foreign Education.

The annual Expences of the Hospital bave hitherto exceeded the lucome of our Funds with the additional Contributions we have received: but from the Useful Foundation lately provided by the Legislature for the Employment of the Poor we hope to receive some Relief, as, by a mutual fritndly Concurrence of the Trustees of both Institutions, many of the Poor who are in want of Medicines and Assistance from the Hospital may during their Continuance under our Catre, be exercised in some Employment to Lessen the Expence; and render them alterwards more useful, both to themselves and the Public.

Whatever we can do for the advancement of these good Purposes, and in the Discharge of the Trust committed to us, for the general lnterest of your Province, and thereby manifesting our Desire of the continued Patronage of our Prupritetaries, shall be cheerfnlly attended to by us.
PEXXSTlinia Hositital.
(Signed by all the Managers.)

December 24,1767 .

On January gth, $1 ; 66$, a Committee of the Assmbly risited the Hospital, inspected the several wards and reported that they were 
pheased with the gowel order on which they found thesn and the care which is taken of the patient, and reportcd:

bet it please the sperater.

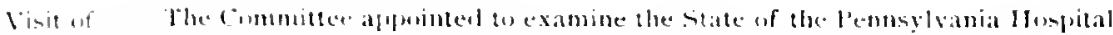

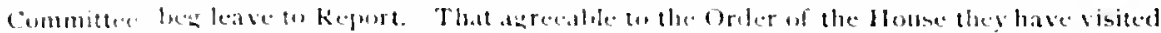

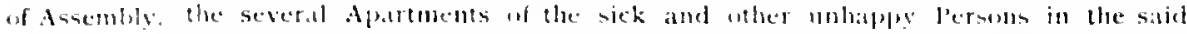

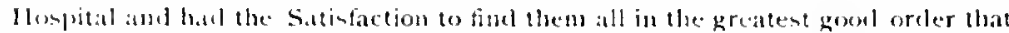
thromgh the mweared allembume and Comstant cate of the Managers the

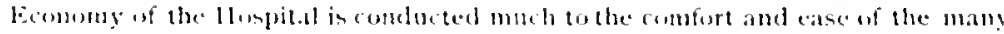

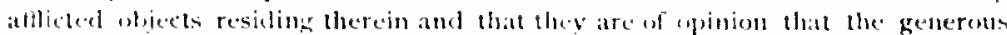
servies performed by the several ahle Phyicians who by Rolition attend the said II mpital hatre greatly contrilsuted under the Favour of Divine l'rovidence in the Relief and ofters to the perfect cure of many por Persons uho without the benclits of the ir assistance in this Charitable institution must have languish'd in kreat bistress and laain.

Precautions Wook being the only fue then in use, chimney fires were not unarainst Fire. common. The Nanagers were fully aware of this surce of danger and such a fire, which fortunately camed but litte damage, happening at this time, it is recurded, (1) $27,1,66$, that:

The situing Managers are desired to inspect the seberal fire phaces in the respertive wards and ebambers and take the necessary care that they be so secured as io prevent any risk or danger from the use of fires.

Gratuitics It was the cutom in these days, especially on sunday, for curious from Visitors. and idle jersons to walk out to the Hospilal " to see the crazy people." The crowds finally caused so much annoyance to the patients that on April $27^{\text {th }}, 1767$, orders were renewed:

That the llatch door be kept carefully sluut and that no person be admitled withoul paying the gratuity of Four Pence formerly agreed upon and that care be taken to prevent the throng of leople who are led by Curiosity to frequent the llowse on the first day of the Wete to the great disturbance of the Patients.

Commitlee 'The Committee of the Assemhly again visited the llospital in of Assembly 1767 and made the report, which is found in the minutes of Oct. 5. Visit.

In Ohedience to the Order of the House your Comnittec pray leave to report that they have visited the Pennsylvania Hospital and the several apartments therein provided for the Reception of the Sick and biseased and find then clean, wholesome, and in the best order greatly owing to the remarkable Care, Assi. dity and close attention of the Managers in the functual Discharge of the im. portant Trust in them reposed, And your commiltee are fimly pursuaded that the utmost care and Skill has been and is daily afforded for the Relief and the Recovery of the Varions Sick and loiseased there Remaining by the worthy Ihysicians of this City, who, without Reward, charitably attend this important Service.

Patent from the Pems for another lot.
In 3769 , another pratent was received from the Penns for a lot of ground on the south side of sipuce sireet, extending westward from Ninth street, sog feet, and suthwarlly 107 feet, which wan a valuable Acquisition, as will be understood by referring to the article on "Real Estate." 
At a meeting held at the "Conestoga Wagron." ()etober $2 .$. $17 \%$, the Managers decided to consratulate Kirhard Penn. Est. on liktesw in his arrival and accession to the government of the trovince. as the the rowm had his jredecessors:

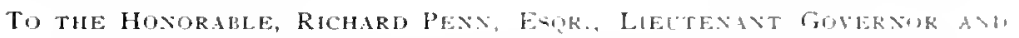

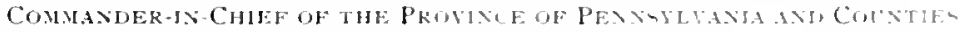

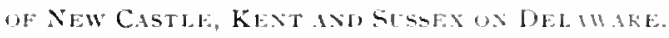

The Address of the Managers and Treasurer of the Peansylvania Itospital.

$$
\text { May it plesse the Guternor, }
$$

To accept our sincere and hearty Congrabulations on his safe return and Accession to the Government of this Province. The Blessing of Divine Providence, the Bounty of the Hon. Proprietarien, with the countenance and Aid of the Legislature of this Province and the Generous Contributions ci our Fellow Citizens and others, have rendered our Endeavurs, assisted by the benevolent Care of the Physicians of this 1laspital more extensively successfut than in the first Founding of it, we had reason to expect. A faithful discharge of the Truat committed to us in order to continue and still to extend the benefits of this Laudable Institution for the relief of the Sick and distressed poor will we hrie recommend it to the Patronage and Favor of the Governor who we confide will protecl our Corporation in those necessary and useful Powers and Privileges granted by Charter and the Laws of the Province. We wish the Governor all the Satisfaction and Pleasure which result from a Wise and Equal Administration. and from a benevolent Inclination to promote every Charitable design for the present and future Happiness of the People.

To which Governor Penn very graciously responded:

Gentlemen, I accept with pleasure your Congratulations upon my accession to the Government of this Province, and I heartily thank you for your kind wishes. I am happy to find that the Bounty of the Proprietaries has concurr'd with other favourable Circumstances to render the Charitable and benevient Institution at present under your prudent Management of such extensive litity. An Institution founded upon the first principles of Humanily, cannot but recun. mend jtself to Favor and Protection. And the Managers and Treasurer if the Pennsylvania Hospital may rest assured that the privileges which this charity derives from its Charter and the Laws of the Province shall want no stipurom which I am able to give.

On October 26. 1772, there not being a sufficient number present to hold a meeting, it was decided to meet the 28 th inst., at 6 ciclock. at the "Committee Room adjoining Friends' Meeting House in Fourth Street." Another meeting, for the purpose of preparing a letter to the correspondents in Europe, was beld at the house of Thomas Mifflin.

About this time, the Nanagers began drawing bills of exchange on their agents in London, for money which was then hecoming bue (i)tmmatce HeEl it Frienuls' NeetingIl'ISe. from the Pennsylvania Land Company's umblamed shares roted ly Parliament. On November fth, after entumerating some eleven bill drawn, amounting in the aggregate to 52.450 sterling. the Manager sal: 


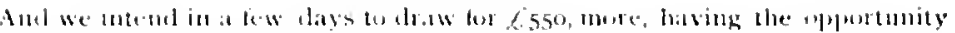

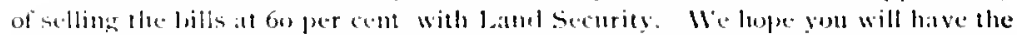

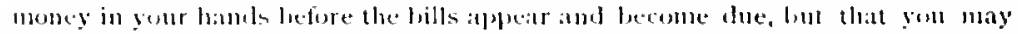

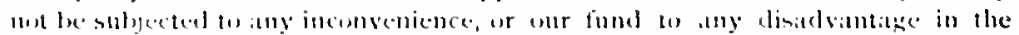

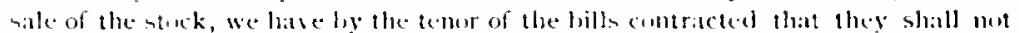
be liable to any fuather damage than the payment of our lawiul interest after they become done, umil it suts you to dinchorge them.

The 11 ospital Iin the Ris verIntionaty

I'eriod.

The l'roprictary Gowermment of lennsyliania definitely termi nated september 26, 1776 , with the final adjomrment of the l'rovinrial Ascombly, althomgle the latter had practically ceased to exist at least six monthe before this time. The authority of the king of Great liritan was puthicly and fomally cast off ly the official amnouncement of the aldoption of the leclaration of Independence which was celelerited in l'onnsylvania on luly sth. liy the sane act. the Royal Charter, and all the powers conferred hy it, as well als the former laws of the l'rovine, lecame of no effect. As these laws were for the most part ad dithed to the circumstances of the people, the new Assembly sulseguently (lanuary 2s, 1777) passed an act to revive and put them angin in force. The die reads as follows:

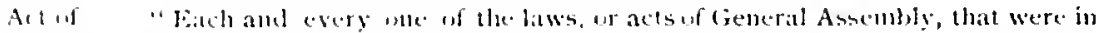

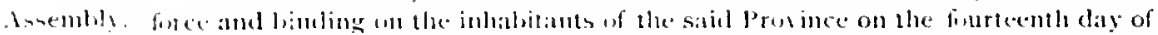
May last, shall he in force and binling on the inhatitants of this state from and

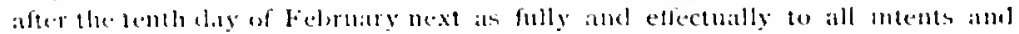

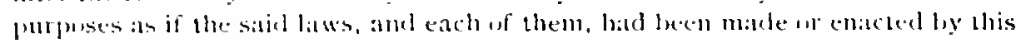
Genceal Assembly ; and all and every person and persons whomsocerer are herely.

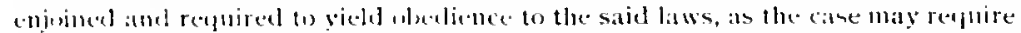

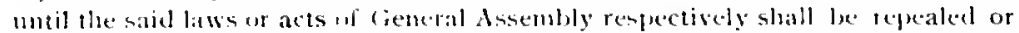
altered, ur antil they expire ly their awn lintation, and the commen law and

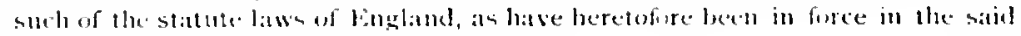
province, except as is leveafter excepted."

foring the intersening period, although the situation was leset with unusual diffenties, the Managers continued to carry on their hmonane work under the origrinal charter. The funds of the Ilespital at this period might have leen sufficient to meet its ordinary current cxpenses, lnt - " ertain contingencies and unfortunate circmmstances,"

Hospotal arising ont of the disturbances incident to the impencling war, in diffeultues. reduced at onee loth the capital of the fospital and its reventee. lobe cxpenses were also increased, so that, notwithstanding careful manasement. the imtitution became more and nore involved in debt. 'l'he Manager were comprelled to dispose of securities, and loans were returned depreciated in value, or bad in paper money which comlel nut le redecuned. I

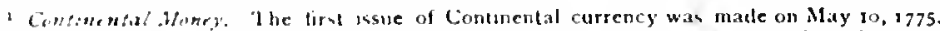

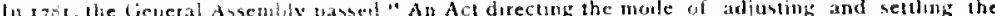

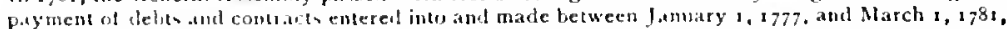

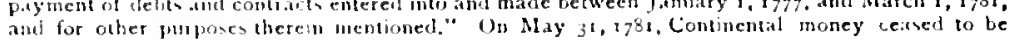
recelvable for toxes abd was no longer legal iender. 
Their distress cumminated when the British army entered l'hiladelthia, September 26, 1777. The English military authorities forcibly took possession of the Hospital, filled it with their sick and wounded soldiers and sailors, overturned the usual orderly management, and on their departure appropriated to their own use the blankets, ledding, and instruments, for which the llospital received no compensation, either at the time, or afterwards.

After the evacuation of Thiladelphia by the British, June 17, I 778 , the Managers were confronted by a serious financial problem. A law was passed compelling the acceptance in payment of delts of the Continental currency and this was taken adiantage of by some debtors of the Hospital to discharge their mortgages and other obligations in depreciated money. The Managers were willing to compromise by accepting the interest in Continental mones, but insisted that the principal or Capital Stock should not be impaired by payment in depreciated currency. However, twenty-seven of the borrowers insisted on the acceptance of the Continental paper isste, which destroyed over one-half of the Capital Stock of the institution-so depreciated had become this currency that on May + , I $-S 1$. State money was hy proclamation declared to be 175 Continental for I State, and State being only + for i in Gold, made Continental $; 00$ for $\mathrm{I}$.

The loss 1 of capital and interest hy the Hospital from April. 1774 , to April, 1784 , is partially shown in the following Exhibit:

In $177+$ the productive calital stock (money at interest), was............. . . . . . . . 607 ss $4 t$ $1117 S_{4}$ the productive capital stuck (money at

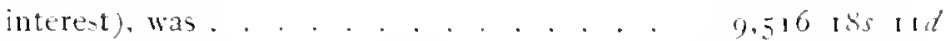

Reduction of principal or capital stock . . . . 9,oyo ys 5.6 Loss lyy receiving interest in Continental currency, 2.349 is 2 d Total loss in principal (or capital stork), and

interest by Continental money . . . . Enit+39 175 7 d

The loss Iy receiving payer money for board of patients, students' privileges, etc, is not included in the ahove calculation, but was without doubt very considerable.

During this trying period it was impossible without gold and silver to maintain the Huspital, the Managers therefore were olnliged to borrow hard money on their private credit, giving their individual

I 'The estimated loss was based on Kicharal Wells" scale of depreciation of Contunental money, called the equitable scale. 


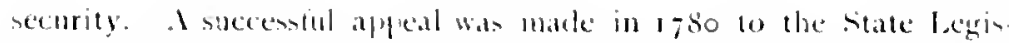

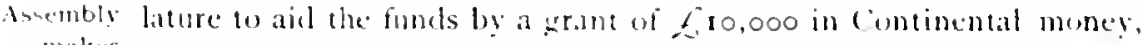

makes but so great was the depreciation that the value of the grant was

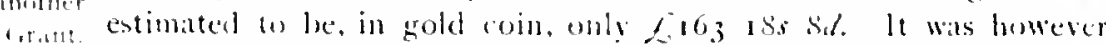
sufficient to ticke over the energency. and with the return of peace, new life and vigur was infused inter the manafenent, and once more

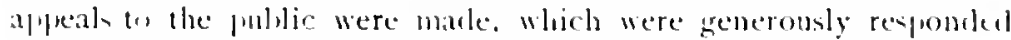
to. and the Howpital asain restored to its former state of prom perity.

A transaction illustrating the difficuly moler which the Managers

pender of beprecialled (iursency lor Vortigage

Continental and British soldiers

Managers opposed to the II:tr:

lahored, on accomint of thes depreciated condition of the currences. occurred towards the cloce of 1756 . The authorities of the college of l'hiladefphia having purchased a property, desired to have it made free from an incumbrance, if a mortgage held by the llospital, amouming to some three thowisand pounds sterting. The Manager objected strongly to receiving the proceeds in Comtinental money on account of the injustice to the trunt under their charge, by the greatly impaired value of the eurrency at that time. A special meeting was called, which was attended ly the representatives of the College, Rer. William smith and Rer. William White, the former being the l'rurost and the latter the lreasurer of this rising educational institution. The matter was linally amicalbly arranged by the Managers arcepting substitute bonds for a part of the amount and receiving the balance, amomting to over eight hundred pounds in currency.

'The first mention of the Resulutionary War, made on the records of the Hospital, accurs on becember 5, 1776 , when a large number of wounded soldiers, sent by the Committee of Safety, were atmitted. Again. on lanuary 8,$1 ; i ;$, we find that many wounded soldiers. seamen and Hessians were received, and subsequently others were admitted.

'The members of the suciety of Friends were, by their religious. principles, non-combatants. At the period just preceding the Revolutionary War, the leading liriends were not only among the wealthjest and most infuential citizens of the Province, hut they had always taken an active part in promoting all measures pertaining to the welfare of the l'rovince, as is well shown in the interest which they manifested in the l'onsulvania Hospital. When the colonies resorted to arms. however, acting in accordance with their religions principles, many Quakers refused to take up arms or actively assist, either directly or indirectly, the American cause. Their neutral attitude and consistent conservatiom gave rise to the popular belief that their personal 
influence would be exerted against the Colonies, hence, durng the excesses of party feeling the became the objects of general smplicion by the remainder of the community.

Congress, in 177\%. formally recommended that the Exerutive Council of Pemnsyliania apprehend and secure a number of the most frominent and representative members of this sect living in Ihiladelphia; and ly order of Council. in August of that year, a mumber, including several Managers of the Hospital, were arrested and without a trial were exiled to Staunton, Virginia, where they were compelled to remain for about eight months.

On Septemler 29. $17 \%$, the following appears on the Hospital record:

The present Commotions, and arbitrary Heasures of our late Rulers in Banishing four Members to Virginia, to Wit, lsrael lemberton, James Pemlerton. Thomas Wharton, and Edwarel Pemnington prevent the lleeting of a Board.

These contributors and Managers were among the most active and efficient members of the lioard.

Again upon the minutes of September 29 th it is stated that:

Part of the British Army, under the Command of Sir William Howe, arriving in the City on the 26 th of last month; on the next day a great number of sick and wounded Soldiers wi:hout previous notice given, or application to the Managers were brought into the Hospital, who crowded the Wards, inconmoding our Patients, and rendering it impracticable to pursue the former good Order of the House.

Also that :

Samuel Rhoads, Joseph Swift, and Robert Strettell Jones are appointed a committee to draw up a memorial to the Comr. in Chief, representing the present distress'd Situation of the hospital $\&$ requesting relief in the premises.

At the period of the occupancy of the Hospital by the British troops, the Managers were again confronted with the financial trouble arising from the suspension of the continental currencs, and the scarcity and high prices of provisions and other necessaries. so that they were obliged to borrow gold, or " hard money," for the support and care of the lunatics and provide medicines for the sick. On December 29,1777 , it is recorded:

In the present Situation of Affairs it being impossible to carry on the Charitable design of this Institution without gold or silver Coin, it is agreed 10 borrow the sum of one hundred Pounds in Specie upon Interest from Jacob Shoemaker.

On Nay 25, I 778 :

A Committee consisting of Samuel Rhoads, Robert Strettell Jones, lames Pemberton and Thomas Wharton, was appinted to wait upon Dr. Wurris, the Inspector General of the British Hospitils, to represent to hin the Loss in Blankets, Medicines and Hay that the lnstitution had sustained by the admission of the sick and wounded Soldiers of their Army, and the detention of the Instrul.

Managers Banished to Virginia
Soldier

paluients summarily. introdnced.

\author{
.
}




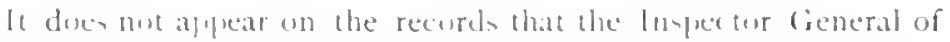
the liritide llomplats offered to matic an! restitution or elen acknowl. celecel the rlation

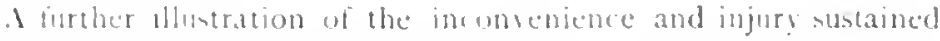
clurine the periusl of occupation is found in the message sent to the

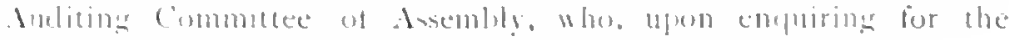

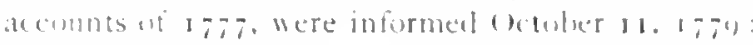

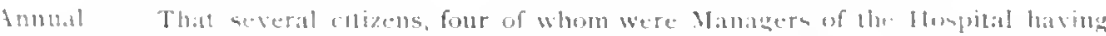

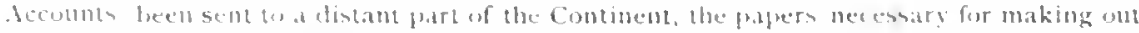

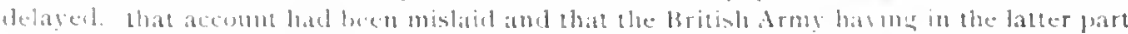

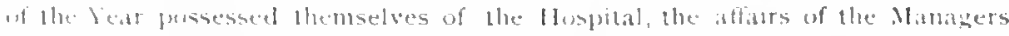

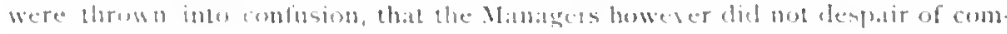

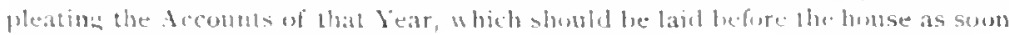
an they could be compleated.

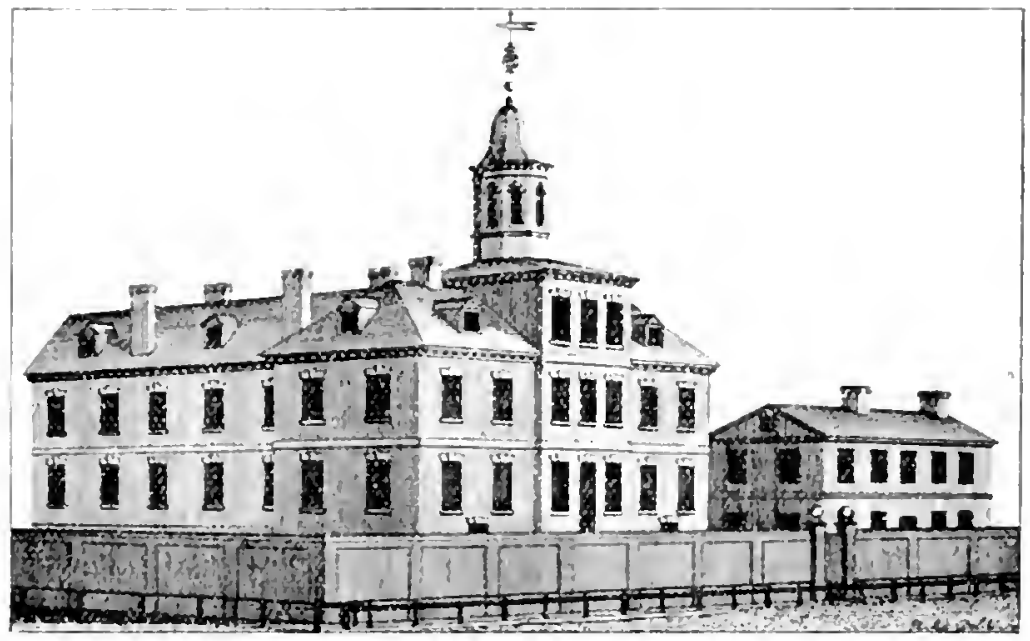

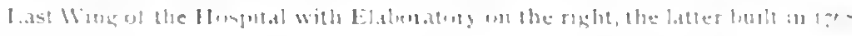

Continental Armin use of Hisepital.

(1) July 22, 1,75, an agreenent was entered into with Jonathan

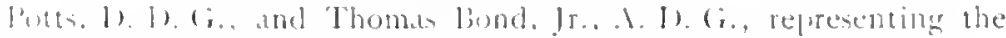
Merlical befartment of the continemtal Army. for the use by the latter of the pharmaceutical "Fialuratery" 1 of the Hopital for the

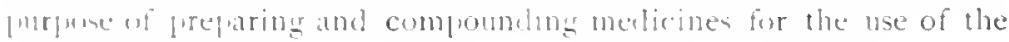
Military Ilwpitals.

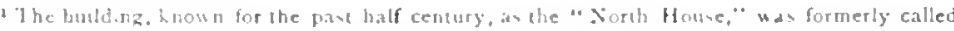

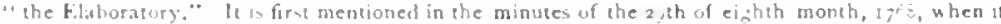
1s recurded, that" samuel hhoads, Jacob Lewis and laac tirecnleate, are appointed to purchase Hueriats \& employ Tradestren to Erect a liuilung adjoining the Kuchen Convenien for an 
On September $8, \mathbf{r} ;,-S$ :

Doctor Bond, Jr., of the Continental Hosputals applied to the board for the admission of a large number of convalescent suldiers, under the direction and management of their Ploysicians aml Surgerns, to which mode the Managers objecting, and upon a free conference, it was propused to admit from time to time such of them as having passed the usual Examination of the attending Physicians and sitting Wanagers, may be deemed profer objects; so far as they can be accommodated without prejudice to our own Patients, and they being subject to the rules and management established in the house-the Soldiers, if admitted, are to be supplied with bedding and Provisions, which are to be delivered to our Steward by their Commissaries, their Nursing Kc. to be paid for as shall bereafter be agreed upon.

The following letter received ly Samuel Rhoads wan communicated to the Board at a meeting held third month 30 , i 75 :

Sir.-I am calied upon by the Medical Director General of the C.. S. Army Hospitals to accommodate a number of convalescents who are to be removed from the general Hospital without delay.

We shall therefore be much obliged for such part of your Hospital as can be spared, for which a reasonable rent will allowed.

I am Sir, Yuurs, etc.,
Signed
i. MELCHER.

Monday, 2gth . March.

Which being considered,

Samuel Rhoads, Edward Penington, Jos. Swift and Robt. Strettell Jones were appointed to inform him, that thete is no part of this house can be convenienty spared for the purpose he requires, and that we had reason given us to expect,

Elaboratory." This structure is shown on an old print to the North of the east wing, or first part of the Hosptal, which was built in 1755-56.

Although originally intended to be but one story high, and as a "Elaboratory" to prepare the drugs for the Hospital, it was subsequently devoted to varions other uses. Lectures were delivered there, and at one ume it was used for patients, especially for sailors from U. S. Customs, and subsequently negroes were for many years treated in this building. Of late years no distinction of color, race or condition is made in assigning or treating patients in the wards.

On November $24,178_{3}, \mathrm{Dr}$. John Foulke applied for the liberty to use one of the upper room of the "Elaboratory" for tbe purpose of exhibiting Lectures on Chirurgical and Physical subjects durng the season, which was granted, and this was the only occasion where the "Elaboratory" in mentioned as being the place selected and destgnated by the lecturer.

This venerable bulding, built with the same kind of brick as the Hospital, was put to many uses besides the lectures delivered in it. It was seized and occupied as a military Laboratory by the British while in Philadelpha, and was afierwards used by Dr. Bond.

On the 25 th of the second month, 1782 , the committee for collecting the debts was aluthorized to receive from Robert Morris, E\&qr., the Financier General, a Certificate bearng Interest for Rent due from the Unuted States for the use of the Elaboratory before Robert Morris undertook the office of Financler General. There had occurred some misunderstanding with the Financier General which was eventually adjusted. On the 29 th of the ninth month, 1733 , there is an eatry of " 68155 , in Kobert Morris's Note;, for balance of Rent, to the ist of the 8th Mlonth last, for the Elaboratory," reported paid to the treasurer, by the committee. Again in 175. " Received for rent of the Elabo. ratury and tenements $L_{76}{ }^{4}+5 .^{\prime \prime}$ As late as 1790 , there was received a certificate of a debt due for rent of the Elaboratory from the United states with interest from January" 16, $1,53$.

Subsequenty, (182), the Managers directed a statr-case to be erected for the accommodal on of female colored pattents, with liberty to enclose part of the garden for a yard for their use.

The building, in $\mathbf{1} 89 \mathbf{t}$, was put in comple:e order, and has since Leen used as a general Reception room for recent accidents. The second story has been converted iuto a general Surgtcal Ward.

invalescent sidiers.

Corresponrence with Military Althorities 
when we accommolated the Ductors of the Continental Army, with our Elatoratory, that they woutd secure us against heing farther incommoted; and to use such other arguments as mity occur to them, to convince him of the incespediency and impropricty of hie request, which if he does mot decline, they are to apply to the (ictlerit, and such others in power as maty le proper to prevent the soldiers being semt these.

At a meeting of the lioard held April 1,1779 , Dr. Fond atsended and made the following proposal in writing:

Dector Thomis Bond, Jr., reculuests the M.magers of the Pennsyluania Ifosplat would receive "a number of convalescent latients from the general Hos.

Soldier pitals into theirs, as the Betlering llouse is exceding crowcled, and the prescribing

P.ticuts. Surgeons of the Nilitary llospitals has pointed their house as the must proper for their purpose; they and I)r. Bond agree that dhey shall be under the care of lit. Story as Stewart, but that a military Surgeon will preseribe to them: that I)r. Boml will le in town, and hereby angayes to do everyhling in his power to restratio the Soldiery, and prevent their commiting Damages, and belaving Irregularly, ancl the sitiel Bond further promises to do all in his power to remove them totally: from thence in six weeks - the lower Ward and garret only will suffice."

Which the Managers taking into Consideration, agree to receive such convalescents an having passed the usual examination of the antending l'hysicians and sitting Nanagers, may be dectued proper Objects, so far as they can he accom. molated in the lower llard and long (Batret, under the care of their own lohisi. cians and Surgeons, but subject to the rules and Government established in the llospital. The soldiers upm admission are to be supplied free of any expenceto the Intitution, with bedtling, provisions, Firewood and all other necessariestheir victuals to be cook (-1) bo some person appointed by Dr. Bond or his agents for lant service, in the wash house, and that a reasonable compensation be allowed for the use of the house. The Managers duly cunsidering the trust reposed in them, apprehent they cannot receive patients upon uther terms, no persons aflicted with any infections distemper, can on any accum be admitted, and they are rather incluced to acquiesce in this proposal from Dr. Bund's engaring "th dn all in his power to renove them in six wecks."

\section{June 16,1779 :}

1)r. Boncl, Jr., watited upon the Buard and returned thanks for the use of the house for the Comvalescents of the military llospitals A expressed his desire of paying for the same. The Manayers leave it to the Drs.' generosity to make such compensation for lhe benctit, as he may deen adequate.

Propesition to receive Sick Prisoners.
Dr. Bond, Ir., in a subscyuent commumication, dated fuly zz, 1781 , to the loard, proposed:

That all the British l'risoners now sick in the Gacil of this City should be admitted as pay Paticnts into the Hospital, the number he supposed to lne abme Ninety and that in future the Sick belonging to the Army, or Sick Prisoners. should at all times be admitted on the same footing: le judged the average numher to be cared for womld he from forty to sixty. He also stated that he hat com. versed with Robelt Morris, Finane fer fencral, who gave himexpectations that some Money would te abilible to enable the Managers to provide Berbling, Ec. lpon being informed by the Board that no persons afticted with maliznant or infectious disnrders could be admitted consistent with the Rules establishted in this Institution, he insisted that all the sick must be admitted or none. 


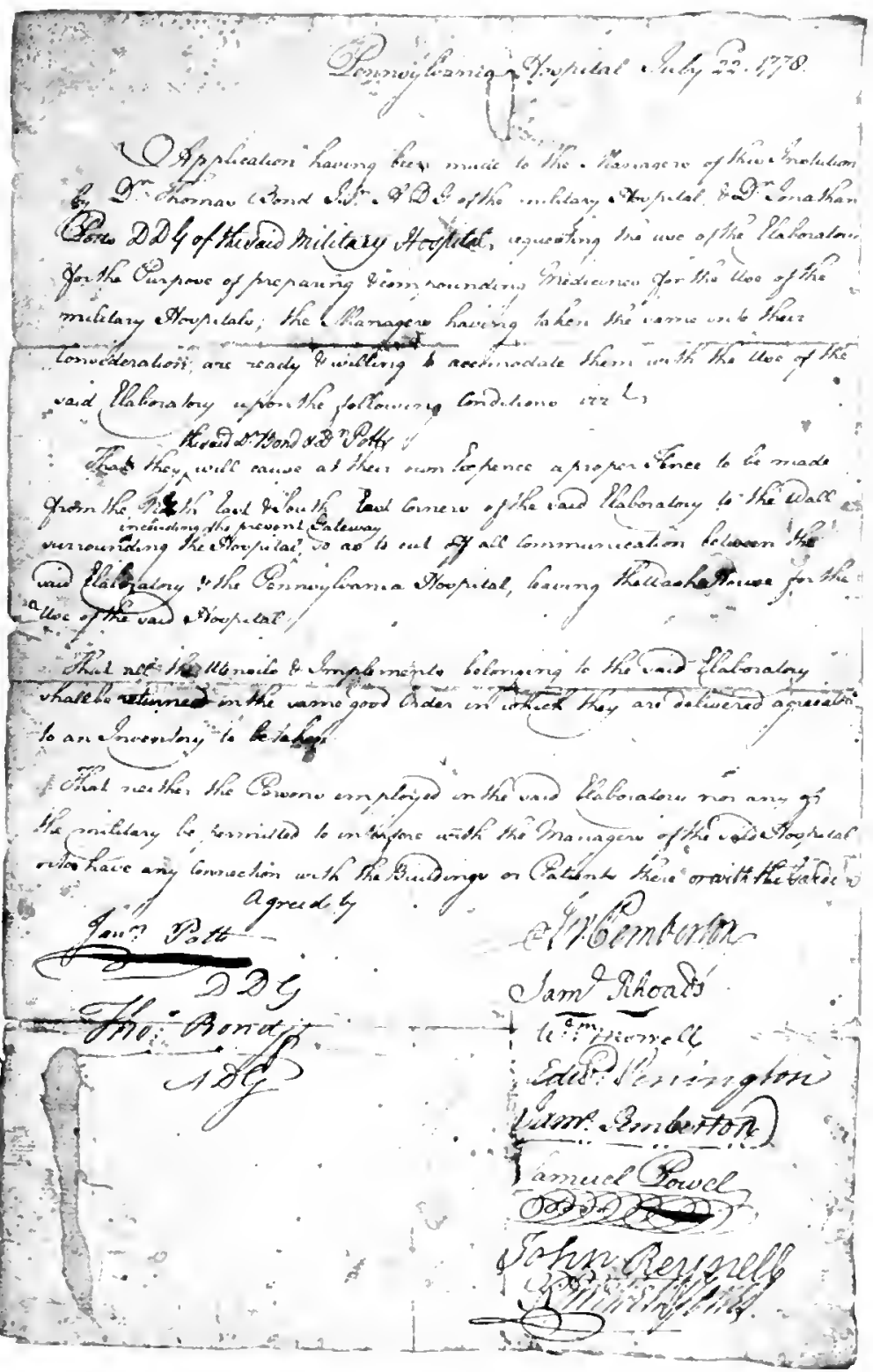

CONTRACT WITH CONTINENTAL ARMY FOR USE OF ELABORATORY. 

The Buard having maturely considered 131. Bond's proposals ate of ripinin The Proposi they are totally inadmissible heing in direct repugnance to the Rules of the linn rejected Institution.

Two letters were received fron Robert Morris, Esqr., the Financier General, Continental at a meeting heid on December 3, 1783 , relating to the above application made by soldiers [)r. Bond, Jr., for the admission of a number of Sick Continental Soldiers. A almitued Commitce at the sime meeting reporterl unm a conference they had with the Financier. Mr. Morris having acceded to the rules established in the Ifospitil, the Managers decided to receive such of the diseased Soldiers at fifteen shillings Per Weck, provided bedding \& cloathing be furnished for them and that they shall in all Instances be subject to and governed by the same Rules \& Regula tions as otler Pay Patients.

Some years later, during the war with England of $1812-15$, the Hospital was again called upon by the Military authorities for aid. The minutes of the Neeting of April 25, 1814 , refer to a letter from Solditer l'aticuts of $1 \$ 12$. Alexander Walker, Jr., A rent for British Prisoners, in which he stated that

he had pail for the Board of Wounled Prisoners Sent to the Ilospital "certain Suns which Col. Barclay Com'r. General declines to refund" was received \& read. The l'resident is requested to return an answer to the said Letter and to inform Alexander Valker that this Institution is chiefly supported by privalte Contribution \& the $[T$. States do not contribute at all to its support. That the United States having no Marine Hospital in this district send their diseased Sajors to the Pennsylvania Hospital and pay for their Board regularly as a Matter of course \& thit allhough individuals who are strangers and destitute of Monty and friencls ate frequently received maintained and relieved at the expence of the IJospital yet that in all Cases where there are private friends or Public Agents the Managers take Security from them and receive the price agreed for the support of the Patients.

On January 5, 1780, upon making up the account for 1777 , it ruspital was found that the Hospital had become indebted to a number of the anain in l her. Managers and other private citizens, for varioussums of money loaned during the term of British occulation. These sums aggregated firot izs. $3 d$. To cancel this indebtedness, the Managers were compelled. ly assigning several bonds and mortgages, to cripple the finances, which were already in a state of great depletion, on account of the depreciation of paper money and insettled condition of the currency.

On January 20, i 780 , the Assembly was memorialized for further assistance in the financial emergency. In this document the recent military experience was referred to. as follows:

Certain Contingencies and unfortunate Circumstances, in the present War concurred in reducing the Cipital, augmenting the common Expenses and invol. ing the lustitution in Debt. First - The Law's compelling the Managers to give up their Securitics for Monies lent and receiving in lieu thereof depreciated paper Currency. Secondly-The British Army, invading the City pussessing them. selves of the Hospital, occasioning the suspension of Pajel Currency within their 


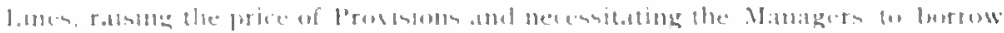

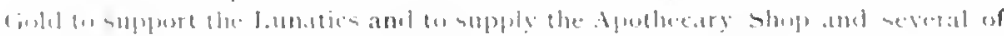

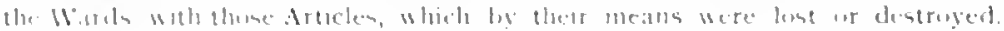

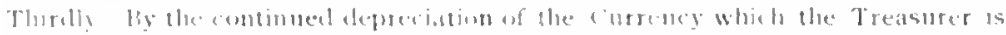

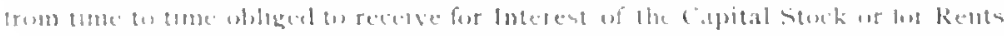

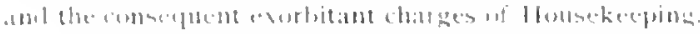

M.11.12010

loberale relative a lines w be impmed on the Manalogers for

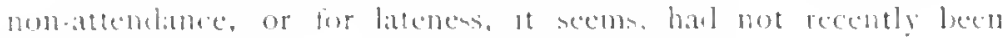

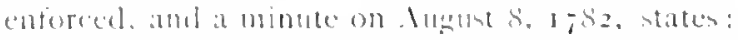

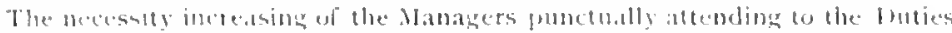
of theor appointed beetings it is chetermined that every Nember who shatl be

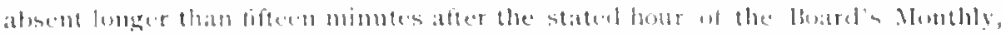

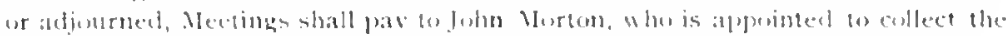

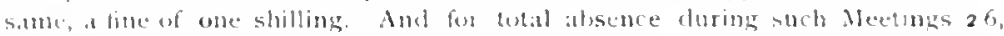
unless preventenl by sickness.

The bonk of lines was kept ly the clerk and is shown in the

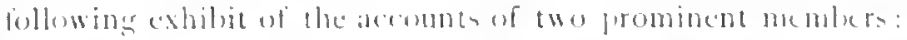

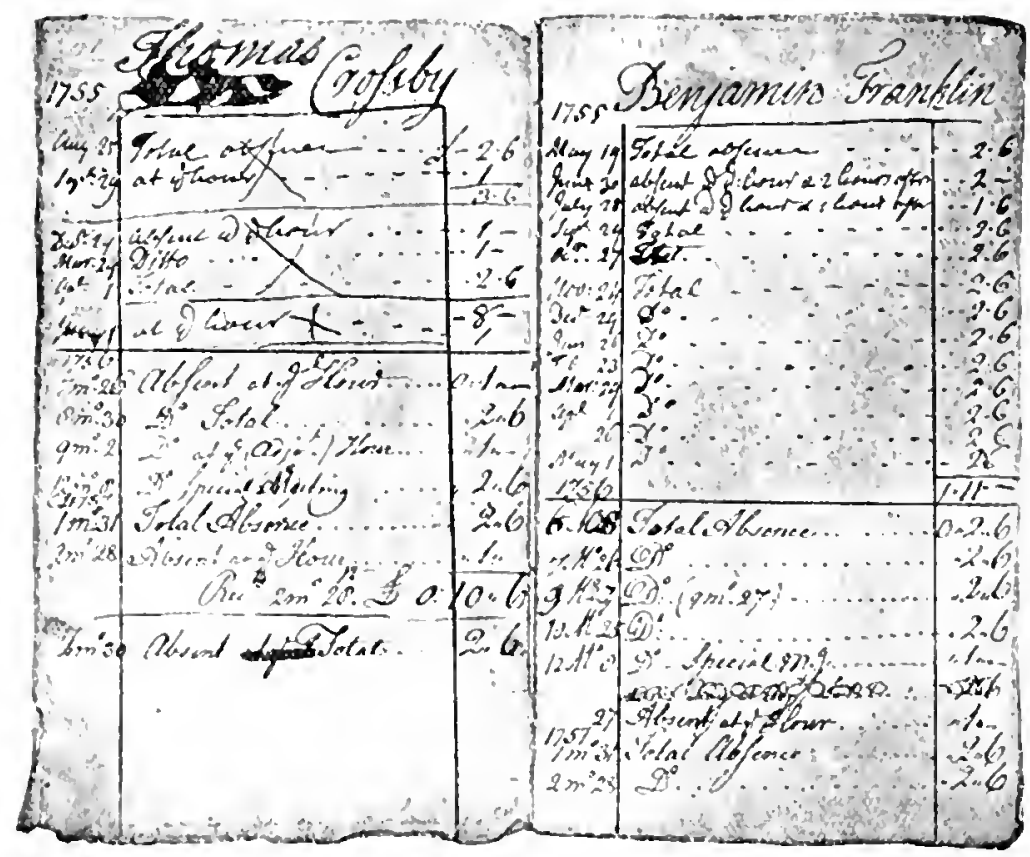

The confidence and sympathy of the Issemlily of Pennsylsania

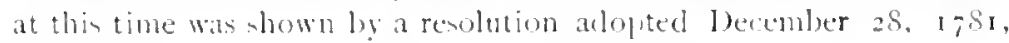
an follows:

Assumbly Liesolied, That the money arising from fines paid ly Members of the llonse approve the for not attending pursuant to aljournment. Ar., be paid th the Treasurer of the

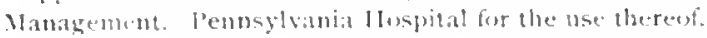


This grant of the Assembly was received by the Managers in

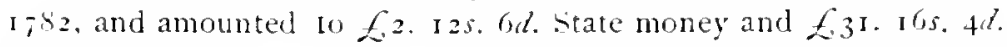
sperie, as stated in the Hospital financial report for year ending Ajril $26, i, 82$.

On March $3,1_{7} 8_{3}$, the minutes state:

Nathaniel Falconer represents, that in Compliance with the desire of the last Baard, he applied to the Comptroller's office, to know wbetber the account exhibited by the Hospital for Money due from the supreme executive Conncil was examined, and he was informed by the Comptroller that the Sum of ten thousand Pounds continental Moncy received by this Institution in the months of March, April N. May, 1780 , stood charged against the Hospital, as so much lent by the Assembly - which being contrary to what he conceived, was understoud by the Managers, it was deemed necessary to call this Meeting.

Whereupon the following action was taken:

The Buard taking the same into their serious Consideration, and finding on perusing the Nemorial presented on the 20 th of the first montb, 1750 , to the honorable house of Assembly that it prayed for a pecuniary ajd to the distressed situation of the llospital; and the said $f 10,000$ was by the Treasurer credited in his Accounts as a grant, from tbis State, not as a luan, it's judged expedient to address the Assembly thereon, requesting the honorable House will be pleased to consider it as a I)onation.

\section{I memorial was accordingly prejared and sent}

To the Fonorable the Representatives of the Freemen of the Commonwealth of Pennsylvania in General Assembly met.

The Hemorial of the Managers of the Penusylvania Hospital, Respectifully Sheweth,

That their predecessors in Office were under the necessity of applying in the Vear 5 to to your honourable llouse for such "Aids as might extricate them from their Fifficulties by discharging the Hospital debts, resturing the Capital Stock, and enabling the Managers to prosecute the laudable purposes of the Institution."

That in consequence of this application the Assembly were pleased tu direct an order to issue bearing date the 27 th of Marcb, $1,-80$, in favor of the Hospital for ten thousand Pounds continental Money, which was received and considered by the Managers as a gift, entered as such in their Books, and soon dispused of in the necessary Expenses of the House.

That your Memorialists unexpectedly, and with great concern find, that the above Sum stands recorded on your minutes as a Loan; and that they are liable to be called on for the repayment of the same.

Your Memorialists thetefore are obliged to solicit the Indugent Attention of your Honourable House on this accasion, contidently hoping you will be pleased to order the above Clain ts be relinquished. They beg leave at the same tine to unserve, that the same cause, which produced the former Memorial still exists with equal force-and that the Pennstrania llospital now stands in the greatest need of support, public as well as private.

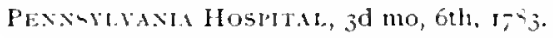

The Committee also prepared the following "brief view," for the Assembly, which proved succesful and the claim was remitted.

Grant of Assembly alleged to be a Luan.
Petition of Managers tu Assembly:
Brief Vick to $b x$ presented. 
The Members whe are so obliging an to deliser the Memuriat of the Managers

St.ifement

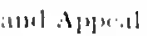
le. Assembly.
Exemptina frum Military linly of the l'entusylyania llospital to the Assembly, will please lo he informed-that

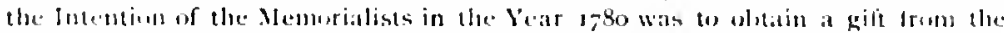

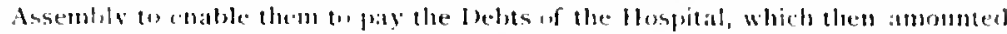

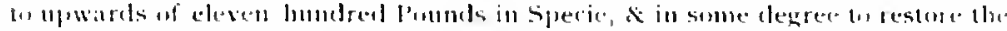

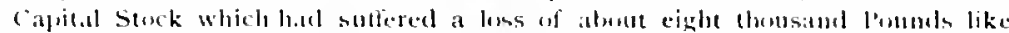

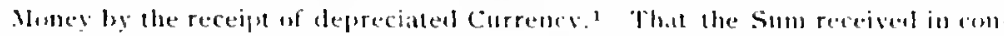
sequence of that application was Ten thonsand pounds romtinental currems which at sixtyone, for one, the Fexchange established by Government amented

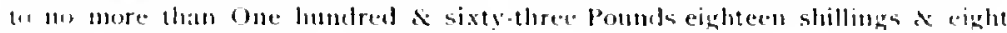
pence.

That the Managers of the Hospital remainerl strangers to th being considereyl as a les:an, until on their Steward lately exhibiting an Acemot againt

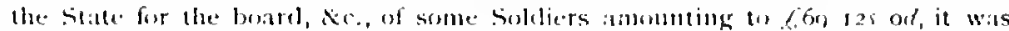

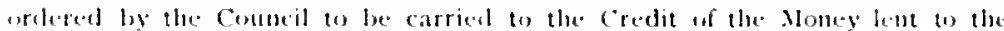
Ilospital.

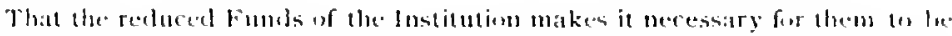

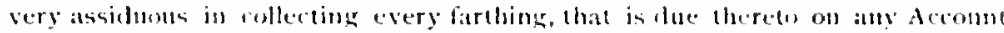
and even then what ther receive is insulficient to paty the hire of netessars atlend.uts, purchase. Woud, and provide bethling, and other conseniences, and puts it out of their lowwer to take few, lun l'ay l'atients, which is far from being within the uriginal lewe of the Pentsyluatia IJospital.

These Comsideratims, the Mathagress are perstudded will be sufficient th inchee the Assembly to comply with the present Recplest, and they llatler them. selves would produce some immediate relief if the state of the Public foinances worulcl pussibly achuit of it.

lo this was added sulserguenty this suggestion. May $6,17 x_{3}$ :

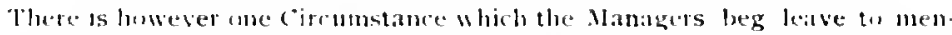
tion, and which they linge the Gentlement to whose Care the preasent Memorial in commstled will not think improper-they eosuld wish their Stewant was excuned from Militi: fines and luties as in the first place, it is out of his Power to leave his Trust for the Time that is uecessiry for the purpuse; and the cont of non-com pliance fall uhimately upon the Ilospital.

(1) Nisember 2, 1766 , the Manatgers again fetitioned the Issemby to exempl the sleward, Ipethecary and cell Keeper from Military Service. in consideration of the injury to whin h the patients would he biable when these employees would be alsent from lheir gent duties.

In accordance with this refuest these ofiders of the llosplital were exempted ly statute from military service.

Intatiment The Nemorial to the discmbly, on second monts $25,1782$. mize muney $110+01$ resuled in the appropriation of all unelaimed shares from prises tatien by the Anerican privateers and leters of marefue. by a special Act. While the amomonts ntimately received appeared larese. the enreat depreciation of Continental curency mate the domation of compara-

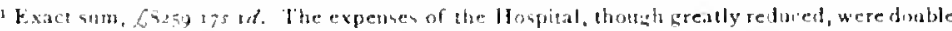

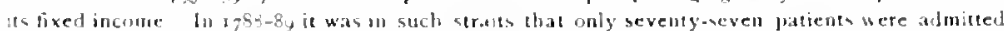
during the year, of which number only tucnty eight were tree or charity patients-the average number under treanent bent forty-ueven, mostly incurable lunatics. 
tively little value for the purpose of defraying current expenses. These unclaimed shares were those of seamen and others killed in naval engagements or lost at sea. who had no surviving relatives to claim the amounts belonging to them.

It was deemed advisable by the Isoard at a Meeting held committen March 2, I786, to appoint a Committee on Economy with powers Focolumy. not very clearly defined, but which proved to be very extensive.

While great service was undouldedly rendered by this Committee, the fact remained that, probably on account of its activity and efficiency. it became very unpopular with some of the Managers, sulsequently, who thought it too officions and unduly interfering. "This finally led to a spirited dispute in I $8 \mathbf{2}$, which proved to the the only serious disagreement recorded during the existence of the Hospital. (Page 85.)

The American l'hilosophical Society sent an invitation to the Eulogium un Hospital officials to meet with this Society at the German Lutheran Fronkhn Church on liourth above Arch Street, on March 1st, I 791, to hear an Eulogium on the late Dr. Benjamin Franklin, by the Rev. William Smith. This invitation was accepted by the Managers. Among the distinguished guests present were l'resident and Mrs. Washington, the Vice-I'resident and Mls. Adams, the Congress of the United States. the Governor, and state Legislature, and a large number of prominent citizens.

In the spring of 1798 , when the Managers were using every endeavor to increase the funds of the Hospital, a rumor lecane current in the "ity that Franklin had left a considerable legacy to the Hospital of which no public acknowledgment had ever heen made. The following letter, signed by eighteen contributors was receiven ly the Managers:

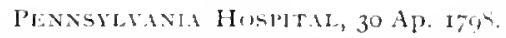

Benthens: There having leen published in the News Papers al piece intimating that the plan of the Pennsylvania I Iospital has not been approved by the Contributors; also that the late J hoctor Franklin left a considerable Legacy which has aded to the funds of the Institution of which no accomt has been given to the Public, We request you in order to remure any improper impreasions that may have been mate on the minds of the peopic to the prejudice of the Hospital in respect to the said Plan \& Legacy to publish in one of the new papers of the city, the Fixtract of loc. Franklin's Will with the Minute mate by the Nanagers on the 31 st of $5^{\text {th }}$ mo. and the 2 sth of oth mo., r,go; also the minntes of the Contributors on the said Will dated the 13 th of 7 th 1 mo, 1790 , logether with the minutes of the Conlributors made at lowir especial Meeting the Ist of the ad month, 1794, respecting, the phan of the new building, ete.

The Managers agreed to publish the extracts from the will af Doctor franklin and also the minutes as refuested in one of the payers as follows: 
Extract fromil loriuklin's

11:ill.

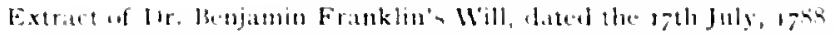

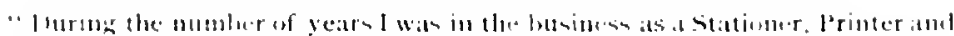

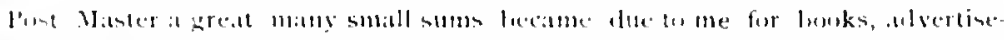

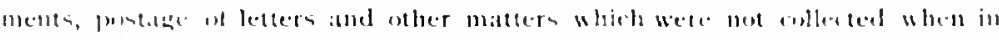

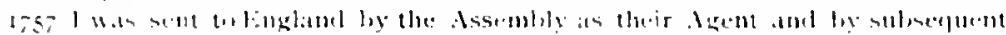

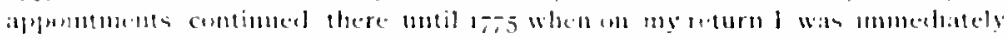

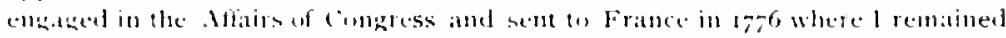

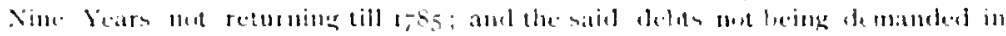

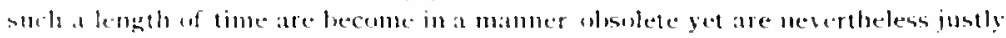

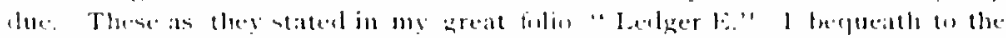

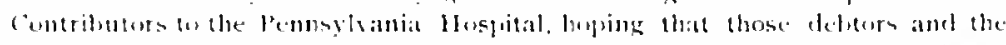

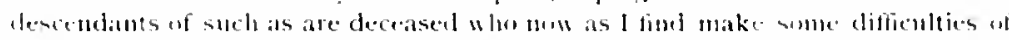

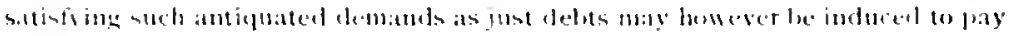
or give them as Charity to that excellemt Jnstitution. I am sensible thit much muat inevitubly be lost but I hope sumething considerable may be lecuered. It

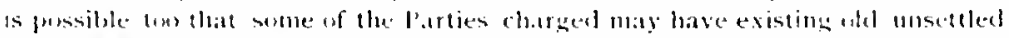
Accumts against me in which case the Manderes of the satel flespital will allow

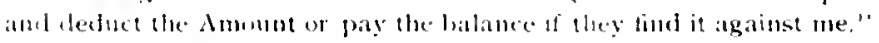

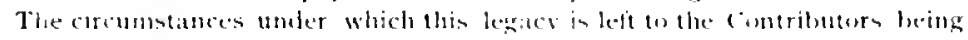

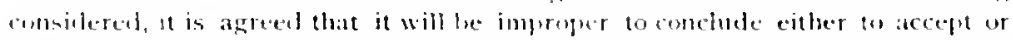

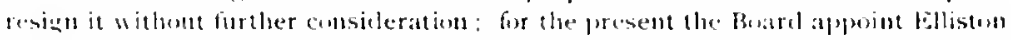

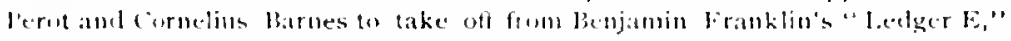

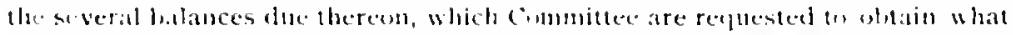
luformation they can respeeting the debts and to call a special Meteting when they atre reads tu repurt.

kegort of flic Committec appinted to examine the beciger of the late lbotor Commultee Franklin and to repurt thereon, now produced a state of several Acoumts upon astanged in Niphabetical Order on the while of which there atpuats a balatsee

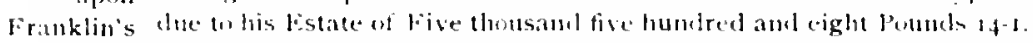

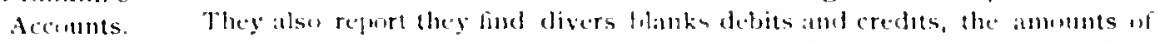
"hich they are mot able to ascertitio; the (immittee forthet repurt they called on

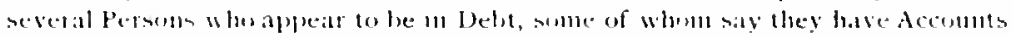
against the butor exceeding comsiderably his temands agaiust then ; othegs sity the fostites of their l'redecessors have been settled many leats since and bivision made, so that they cammest comsent to almit of any such antiquated

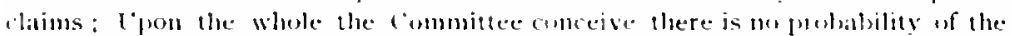
lesacy being productive because the det of limitations applies anainst all the demands on the Authuraty of this Iedger and it lecing a condition annexed to the

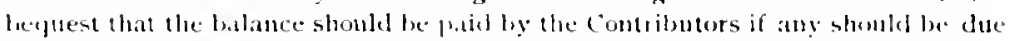
from the testator's listate, the Managerecanmet therefore accept of this gift at the rask of paying the debts of the decedent unless the Contriluturs reguite them to do it and theretore in order to knww their opinion and bo be enabled to purstes their directions, it is agreed that the cierk shall advertise a fietheral Mlectiog of the contribututs bu be heid at the Hespital on Tueselay, the I, sth uf July next at 3 o'clock in the afterneun, in order to lay before them an extract wf the llill for

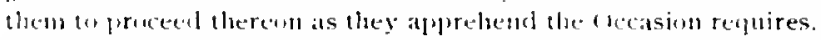

combibuters The Clerk advertised the Contributors aneet and consiler Dr. dincuss franklin's legalcy. who accordingly met, and made the following Franklin's minutes on the subject:

At a genetal Meeting if the Contributors bul seventh momth, July 13. 1790, at the IIspotal forsuant to Law puldic Notice therest being given in two of the 
News Papers of this City of Philadelphia, advertising them to meet for the Especial purpose of considering of a leegacy left to the Contributors for the l'se of the Institution hy Dr. Beniamin Franklin decessed and to determine what is proper to be done on the Occasion

An extract from the last will and Testament of Dr. Benjamin Franklyn deceased was read, which has already been inserted under the Hinutes of 5 mo. 31, т790.

The Minutes of the Managers respecting the Care were then rearl liken ise The Conthe Report of the Committee appointed by then to arjust the bilinces of the said tributors Ledger and the answers they received from a number of Persons to whom they lecline the have applied and who appear to be in debt; An alphabetical List of the delsts Conditional taken by the same Committee was also inspected and a general view of the Ledger Bequest. taken by the Contributors, from which it appears that many of the delst are small, numbers of them due from Persons unknown, and all of them from thirty: to sixty years old, which precludes every hope of recovering as nuth as will

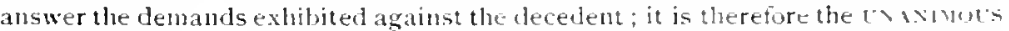

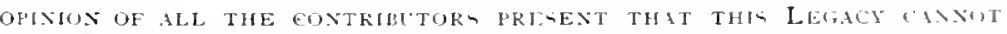
WTH SAFETY EE ACCEITEH.

Sererthereni being sratefully sensithe of the active part which Ductor Franklyn took in promoting the Institution and having experienced the benefits of his benevolent Exertions for the Interests thereof on varions occasions, they lament the Necessity they are under of declining to accept of a legncy from which the Doctor expresses a hope that something considerable might be recovered but which the Contributors bave great reason to believe will never be the Case; Lnder these 1 mpressions it is agreed that the Managers should return the Ledger to Dr. Franklyn's executors with a Copy of this Minute.

Signed in behalf and by desire of the Contributors

Hituess: Shutel Contes Cleth.

JAUES PEVHeRTM President.

On April 30 , 1792, however, the minutes state that:

A curious Bedstead is presented for the use of ye Patients, by the Executors of Dr. B. Franklin, at his request in his life time, which the Steward is to put in the long Room against ye next .lleting.

A special meeting was held, at the house of Samuel Coates, 8 mo, 24, 1793. fur the purpose of looking into a violation of the rules of the Hospital on account of patients having been admitted, said to $\mathrm{k}$ - suffering from "yellow fever."

bellow fiever Patients.

It having been learned that

Two men had lately been admitted why were infected witl at putris malignant fever, which now prevails in the city: one of whom a negron died the morning after he came in ; and the other suppused to be in the last stage of lellow Fever, for which there is great reason to fear the spreading thereof, th the danger of the other patients in the House: as well an comnunicating therewith.

Lr. Foulke, under whose authority the patients had been admitted. was requested

To visit the patients and invertigate the matter, and do everything in hipower to present the increase of this disorder in the fumily.

Heing thoroughly aroused to the impending danger from the epidenac, it was agreed that every phyician should exerciet cxera 


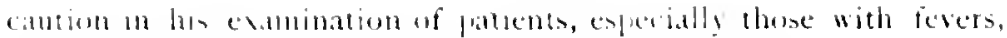
leefore almitting them wo the wards of the Itospital.

Yellon Fere Ilispit.t. in a house and property of William Hamilton which had been taken by the city physeians as a llospital wa acommoslate sellow fever patients amd other vid tim of epidemic discatse. The Manggers, therefore, were contermed in their pontion that it was not their duty wo receive such patients, for lear of spreading the disease in the more hickly seteled part of the city.

The condition of affars in l'hiladedphia at this time was appalling; the minutes of septemler 30, 1793 . state:

The Vellow Fever riging in the city with great violence, a Board of 9:alatgers cannot be expected to meet until it abates, many of them being out of town or sick, and Cormelius Barmes dead. It is agreedly the Managers present that ach of then will attent and do the duty of the sitting Mandgers, the ensuing month, if their health permits as often as they can.

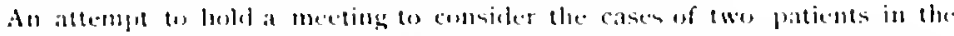

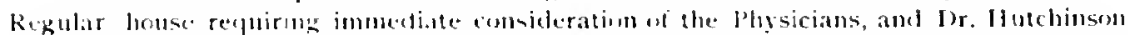

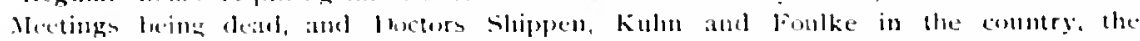
of Matwigers lors. Rush and l'ark. whu are the only two plysicians of ale houne who have suspencled. remained in the (-ity, are regmestest to gise their attendance as sen as possible, (1) bold a cinsultation thereon: in which Dr. Wistar is requested as a favour, to insist them.

There leeing no suomm, it was decided that

As husiness of importance reguires the larly attendance of the Managers, and as the bellow Fever is much abated, and the house is clear of it, that this

Spereial

Mecting callexl. Veeting he adjourned an the Gll day of the ath month, at it a'clock in the Morning, bejng ve fourth lay of the week and that the clerk notify the Managers to meet there at the time appointed.

The attending Managers borrowed one hundred and fifty pounds from the "ireanurer. for the use of the house, as it was not considered sale for the siteward to go into the town to collect money. It is recorded that Dr. Foulke

I Iath only appeared three times in the course of the month; the last time be was here he excused himseif hy saying, it was improper for him (1) attend the hospital when he was continually amongst the infected cases.

In November 25,1793 , the Managers considered it their duty to record their reasons for not mecting for three months and apparent neglect of duty:

Reasoms Iservmalignam disereler, commonly called the Vellow Fever, hath raged with assigned for not meeting arreat Violence from the early part of the sth month last, to the gth day of the at month inclusive: in llatt short perime of 99 days 11 pwards of four thousand Per sons have died in the city and liburties.

This number we compute to be nearly edual wo the one fifteenth part of all the Inbalviants including strangers. A calamity sogreat involving various other 
duties to ourselves, our families and friends hath preventerl many of the nembers of this buard, from attending the Services of the house. We have reason, however, to be thankful, that during the awful visitation, mot more that twe Perom in the fever were admitted into the hospital, who died therein, without spreading the disease. This was owing through disine blessing to the care that was taken to prevent the least Communication with infected Persons for whose Accommuda. tinn the Citizens lork and suppurted a separate Building. But the los we lament to this instiqution in particular, is the death of Cornelius Barnes, a very upright and fathful Manager; and of lor. James Hutchinson, a very able and eminent Physician who spent many of his Vouthful days as a resilent Apothecary of the house, and cheerfully devoted the last if lears of his valuable time in performing successfully the most diffecult and disagreeable duties of Surgery, by which he was mate through the blessing of Providence the Instrument of saving many lives. He was, moreover, known with other friends of this Institution, effectually to advocate its Interest with the Assembly and People on every Occasion; whereby many additional yrants and Donations were secured to the house, for all of which the Manarers and sick poor of the Institution, will hold him in grateful Remembrance. But whilst we lament the Loss of our valuahle fellow Citizens and friends, let us remember that resignation to the Sovereign will of the Almighty- Disposer of human Events, is onr indispensable duty; and heing thankful individually, for his merciful preservation of us, we proceed under a due sense of Sympathy for all the afticted and distressed to the other business of the Meeting.

In 179, , the signs of the approaching epidemic were again recogniced. Past experiences had so thoroughly terrorized the inhabitants that large numbers took the precaution to escape danger by fleeing from the city.

At the monthly meeting. August 27, 1799, yellow fever then raging in the city, there were only three Managers present, whose minds were not reassured when it was ascertained that a patient had died recently in the house of the fever.

Deeming it too dangerous to hold meetings at the Hospital, the Alanagers decided to temporarily meet and transact all business relating to the Hospital, at Middle Ferry (Market Street) on the Schnylkill, until the epidemic should have subsided. At the meeting held september 24. 1798 , at " the Ferry." there were only four Mlanagers prement, Samuel Coates, Robert Waln, Israel Pleaiants, and Robert Smith. with Mordecai Lewis. the Trea-urer. An assistant female nurse of the men's ward was reported

Sick with yeltow fever, she is supposed to have caught it by going for clothes in an infected house in the city.

Other cases of the same disease soon developing in the Hospital, medures were taken to have them removed to the City Hospital.

The following note explains the failure to meet July i 3 . I 805 :

Five of the llanagers being out of town, one wf them sick and the Appearance of a heavy Gust rising about the time of this meeting, a Buarel could nut he ohtained, wheretore adjourned to the next stated meeting.

beitll of a

II:anager and a

Physicis:t.

Yellow Fever again Epidemic.

Neetings : it Niddle Ferry The Epidemic prevents Meeting 
At this time alos anolher alarming diseare in the rommunity wats causing erave apprelensions. On septemler 3 oth, the minutes state that

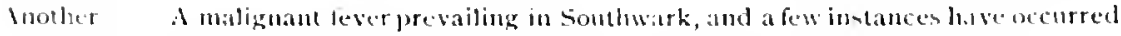
Finde-mis. in some parts of the city is supposed to have uccasioned the atsence of several memalers for which reason a Board cannot be mode.

The following contempurary notes hy samuel Crates, whe of the most active of the Managers, are sufficiently curious to he put $11 \mathrm{pm}$ record. They are taken from a diary which he hal hitually tarried with him, and in which were found many interesting olservation relative to the hoyital, some of which appear upen other pases of this history:

Juleresting

"This year $\left.(179)^{\prime}\right)$ the yellow fever mate more terrille rat age than it had ever hefore done in lhilada. in propurtion to the no. of Vidlow Faver times. people whoremained in the (ity"; it is conjectured that 23 rth at least of all the Inhobitants had abandoned it : I cautioned rery strictly the family of one lightludy, who Hed to berly for silety. not to return lefore the Committee of Health invited the ("itizens to seturn home, lut lee wals too bold. A returned, notwithetanding my earnest remonstrance againit $t$ in one or 2 days after 1 saw him, with all his bamily of 6 l'ersons thinking that a slight fromt which had only checked the fever hat stopt it : the consequence was that himself is his l'artmer in lumeness with 3 out of their four children, all died $N$ were buried in 7 or 8 l)ays-only one daushter surviving if the whole family of 6 Persons.

"I Imring the continuance of the fever my family left the (ity 8 I took up my abode in the Penns'a llospital from which l came ahmost daily to the (ity to assint the Committee of lleatth in their arduous duty: whike I was at the Hospital I had the following remarkalse Jream which was soon realized.

A Manager's "One night I lreamed the P'risoners would make a violent Reidiatic attempt to rush out of Gaol and it made me very unhaply as l felt bream. a confident assurance it would come to lass; accordingly I left the llospital immediately after Breakfast and wated on kobert Wharton. the Masor, who turned Prison keeper for the time being all account of the sickness, and told him of my dream s how molnaply I feltand that I thought he resuired more assistance than he hadl-1 mentioned that if he womld aceept my offer I wended end liancis lligginn to his aid who was Stewarl of the lloppital. A hurl formerty leen a prison kecpers a used to their whemes it knew haw to comnteract thems: if that whd mot answer his purpese if he denired it I would go to the Ciovernor a request a further ciuard to prosect 
him-he told me he was much obliged to me. Bnt it was umecessary - that they well knew he was well provided with Armi d pointing to several Musquets in the room he took up one with the bayonet fixed a presented it towards the Wall of his room sang I am ready for them, but there is no Danytr' - I told him keep a good lookout for I was confudent they would try to escape, a left him; but in parting he asked me if I would go in the yard a see the Prisoners at their work. I excused myself for that time. A said groodby, perhaps I may come another time-from the Gaol I proceeded immediately. towards my own house to enquire how matters were at home, having received a hint that some thieves had entered my next Neighbour's house in the Night, - In my way home, in less than 5 minutes as 1 believe after I left Robert \& when I had just reached Friends' Almshouse, I heard the sound of a Drum; It startled me very much for Drum was never hut then sounded in the City in the fever of $1798-1$ instantly turned round, knowing there mut be trouble in the GaolI now hurried to it. $\mathbb{E}$ found Edw'd lefore the Gaol with a box of cartridges made up, it a number of People running to it from the state house which at that time was the rendevous of the Committee of Health with all their attendants-and just hefore we got to the (iaol steps a Musquet was fired.

"On entering the house Robert Wharton accosted me thus: 'O Samuel what you said has happened already.' "

The warning which Mr. Coates gave to Robert Wharton jrepared him to arm himself and run to the rescue of a keeper named Evans, just in time, as it appeared, to save his life. It was certainly an odd coincidence that Mr. Coates should have stopped at the prison to warn his friend Wharton of the threatened outbreak, as a result of a vivid dream, and that the rising of the prisoners should have taken place almost inmediately afterward. ${ }^{1}$

1 In Scharf and Westcot's History of Ihiladelphia this incident of the epidemic is referred to more in detail.

"The fever made its appearance in the Walnut Street prison on the $13^{\text {th }}$ or sth $^{\text {th }}$ of September, and its mortality was severe. There were then three hundred persons in confinement, includug debtors. This disaster rendered it necesiary to remove as many as could be safely taken away. - Some of those who remained became desperate and on the isth made a bold attempt to escape. This was not a general movement on the part of the prisoners. Some of the convicts confined in the East wing took advantage of the visit of Dr. Dufield to seize the key and make an effort to escape. They knocked down Mr. Evans, a constable, who was acting as deputy kecper, and then called to the other convicts in the yard to aid them. Kobert wharton, then an alderman of the city. who was in another part of the jall, ran to the assistance of the keeper. When he arrived, Niller. the ringleader, had all axe raised to kill Fvans. Wharton and $G$. Gass, an assistant keeper, seeing this, both fired their muskets at the same time. One of the balls supposed to be from the musket of Gass) broke the right arm of Miller and entered his body. Vaughan, another convet, struck Evanswith a bar of iron, and retreated into his apartment. Evans pursued him, and fired at him, sending a ball into his lungs. Another convict was wounded by a bayonet in the hands of a priconer, a negro, who sided with the kepers. The majority of the convicts had nothing to do wh this attempt. li commenced and ended with its projectors. Seven prisoners brotie oul afterwards by undermining the prison walls, and escaped." Vol. I., page 4.5 
In Pholatelphis. duroug the summers of 1794. 1,95 and 1796 ,

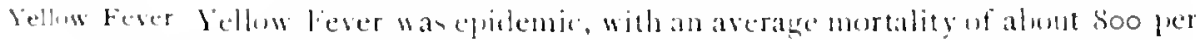
kasiges vear, In 1797 the deathe were 1, 21)2. In 170,5 no less than 3.645

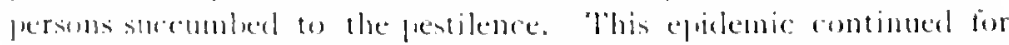

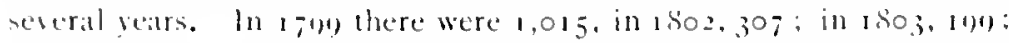
in $1 \$ 05,400$; in 1810,20 ; in 1820.93 leaths. Then followed

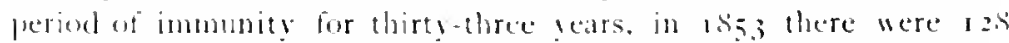

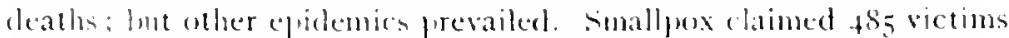
during the season of $1823^{-24}$ : 427 deaths in $1852: 755$ in 1861 : 524 in 1865 and $4 .+6+4$ in $1871-72$. Asiatic cholera carried oli 9.35 of the ritigens in 18,32 , and 1,012 in 18,4 ). Sirarlet fever made ravages

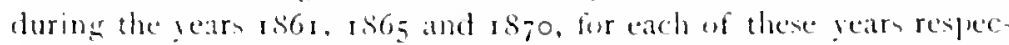
tively, the deaths mumbering: 1.190, 624. 749 and $955^{6}$. These ligures are bere referred $t w$ in order to explatu the state of panic which prevailed at times, when several of the managers and fhisidians temprarily left the cily.

The operations of the Hospital were sulsecpuenty inserrupled only once ly an epidemic, and this was of less severity than those which oecurred alout the beginning of the century.

The minutes of fuly y. 1832 , state that

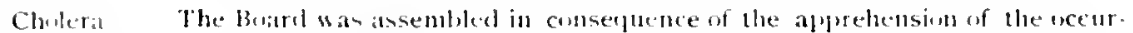
Epridemic, icnce of pestlential disease of the chatrater which has mate its appentance in

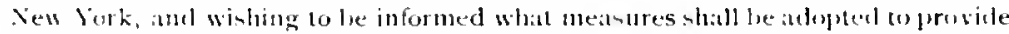

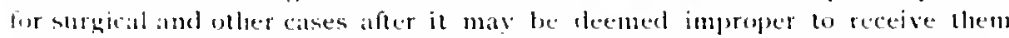
inte the apartments of the Hospital

The fear of the epidemic was not without foundation, although the general exeshes which characteried that of yellow feser did not (1) hain this year. The first case of cholerat acrurred on fuly 5 the the

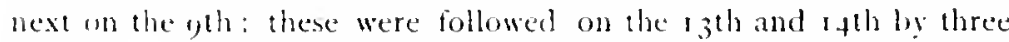
deaths. After the 1 fth the efidemic lingered. There were only thee or funr canes a day until about the zith or zsth of fuly, when the epidemire fairly set in. The cholera lasted until the fourth of Oetoler. Nogether there were wo thousand three butudred and fourteen cases repurted in the city with nine hundred and thirty-live deaths.

Necting of

The first mecting of the Contributors was held on July 1. 175

M.nagers at the State flouse on Chestnut strect, when, in pursuance of the

:outside of Act of Assembly, they organized and elected Iwelve Managers and a the Hospital. 'Treasurer. 1

The Leguslause body first occupled the State Howe in October, 1735. A toom in the State

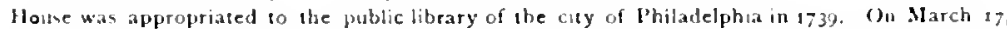
1602. the Legislature grauted permission to Charles Wilnon Peate to whe the upper story and the casternend of the lower slory of the State Howse for his Museum, which was, in February, 1821 , uncorporated Ly act of legisditure into the Philadelpha Museum Company. Originally Mr. Peaie had opened the museum it his residence, corner of Thurd and lombard sirects. 
The Royal standard livern, a famom, house, was located on Market street near Second, and was kept ly Henry Pratt. After his decedse his widow, Relecca l'ratt, succeeted to the proprietorhip and the house then lecame known as "Widow l'ratt's Standard Tavern." The first meeting of the revently elected Managers was held at this place on July 2,1351 . There were no meetings of the Mlanagers from June zoth until Septemler 5. 1751, when 1)r. Thomas Bond, the President, Joshua Cronby, and John smith, met here to consider the "beginning of the Hospital in a private house to accommodate a few patients, until the Hospital is built, also the rules for the adnission of patients." Another meeting was held here on October 27,1751 .

The election of Managers had been held at the State House or Court Howe for several years, until April I, 1756 , when the new Hospital being sufficiently completed to afford the accommodations for the purpose, the llantgers decided to hold all future meetng: there. 'This was not strictly adhered to, as meetings were appointed to be held elsewhere, at taverns and citizen' houses. On November 8. $1_{7} 62$, a meeting of the Managers and Treasurer was held in the Warden's Room at the Court-House, when "' they were informed ly Dr. Shipjen, Ir. lately arrived from London, that seven cases containing anatomical drawings, etc., sent by 1)r. John Fothergill, had reached this port." The first session of Congress in the Court House building commenced March 4, i770; and the last sension ended Ilay i 4 , isoo.

The Old London Coffee House was more generilly know'n simply as the "Coffee Ilouse." The more important public demonstrations in Philadelphia in connection with political and other events for many years occurred at this popular hostelry, which was located at the southwest corner of Front and Market streets. It had a large slued extending over the entire sidewalk to the curbstone. Watson's Annals represents the old huilding with the addition in the foreground of a grouly of negro slaves leeing sold at auction and stancling on a platform made of boards resting on two barrels. May 27,1762 , a meeting of Mlanagers held here to consicler the sale of the John Jones house, which property had been leequeathed by Jones, a cordwainer, to the llospital. Another meeting was held on Augtist 2, 1762, to execute a power of attorney to James Tilghman to enable him to collect the Christopher Brown legacy in Maryland, and still another on May 27, 1765 , when the Managers met to approse a letter to 1)r. John Fothergill. 
There was another "landen Colfee House." said to have Ixen locateel at carpenter's Mhari, on front street below lilack Horse Illes.

Davemport's lavern, or "The Bunch of Grapee," was tormeri! called the " Bull's Heanl:" it was situated on Phird below Mlullerry (now .Ireh) Strect. August 28 . 1760, the Managers "adjourned tw meet at lavenport's lavern, fo consicler the matter of employing an Apothecary and stewarl." A committee was also appointed at the Ileeting to purchase material and employ tradesmen to ereet the famous luilding afterwards known at the "Flaboratory." whic h figures comspicuonsly several times in the annals of the lloppital.

A tavern located in liank street hal for its sign a pertrat of liurns.

1 meeting was held May 1 t-15, 1770, at "Burns' Taverm" (1) discuss the prededing measures, and "the result sumnitted to the Physicians who agreed to meet together to consider the same and give us their sentiments thereon." (Ine important matter lronght ml was the excessive rates charged by the apothecaries of the town fior the irugs furnisherl to the IIoppital. All further supply was ly resu. lution agreed to be ordereal from landon, execen such an should le wanted in cases of extreme emergency.

It the same meeting the Managers and Phyicians considered "the attenclance of the situdents whe have not paid six Pistoles and their improper condet while dissecting, also the indiseriminate pur. chasing of lougs."

There were several taverns with the name of " Hecee," the one on Serond street opposite laylor's Alley was the " Golden lilece ;" here the Nanagers on April 15,$1 ; 7$, met to consicler some important matters relating to the Pennsylvania land Company.

"The Comentoga IIaggon" was locaterl on Market street aluse Fourth. It was popular with the Nilitary and Wentern men. Octoluer 29,1771 , the Mallagers met here to prepare an address to cincernor Kichard lemn, congratulating him on his arrival and accession whe (iovermment of this Province

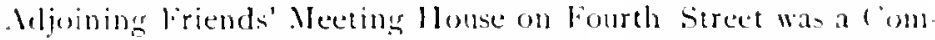

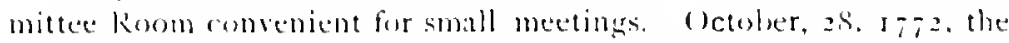
Nanazers met here "to ensider the offer of thomas Forrent of the undivided burth part of a lot, in right of his wife, to sell for S. 300 . out of which he argees to contribute 525 , aid lot being sitwated in the spluare beween serenth, Fighth, Siruce and Pine street."

Inblic taverms and Ordimaries were not the only places where the Managers of the Iennoylvania I lospital helel meetings. Several are 
recorded as having taken place also at the houses of the members of the Board and other citizens.

Among these, the most interesting is the meeting of the Nanagers and physicians at the house of Dr. Thomas Bond, Novemler 26 , i $; 66$. to hear him read his Introductory Lecture to a Course of Clinical Observations in the P'ennsylvania Iospital, which was afterwards delivered to the students at the Hespital Decemfer 3,1766 . This aplears in full in the section on Medical Lectures.

A special meeting was held at the house of Samuel Coates, on November $2 d$, i 786 , for the purpose of requesting Reynold heen to deliver a petition (asking for the exemption from militia duty of the Steward, Apothecary and cell keejer) to one of the rity members to lay before the Assembly. Another special meeting was held here Angust 28.1793 , in regard to the Yellow Ferer, and again September 7. 795 . During the epjdemic of Vellow Fever in 1798 , the Managers held meetings for the transaction of business at the Niddle Ferry, Market Street Schuylkill, until the epidemic subsided.

13. Act of Assembly of April II, I793, the sum of Twenty-six thousand six hundred and sixty six dollars and sixty-seven cents were granted the Contributors ont of the Arrears due to the Commonwealth under the loan Office Act of Feloruary 26, 1773 . The Managers were Further cirants by Assembly: directed to aplyly the money granted to erect, finish, and furnish for the accommodation of the diseased in body and mind. one buiding (the west wing) and also one other buildng (centre building), the first floor being for the accommodation of the managers, physicians, apothecary, steward, matron and other officers and servants of the house, the upper floors to be used for patients. By the same Act, unclaimed dividends of bankrupts' estates were to be paid to them ly the Commissioners of Bankrupts, the contributors to be liable therefor, when claimed. etc. (whith yielded in the end, nineteen thousand dollars for maintenance of the Hospital).

In the proceedings of Decemlier 10, 1795, is recorded the cop! of a memorial, which was sent to the Legislature, reciting the foregoing facts, and requesting an additional grant in order to complete the centre and west wing of the flospital. It concludes with this powerful appreal to the members of the Assembly:

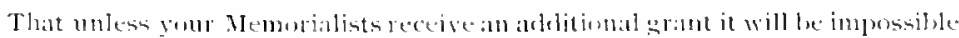

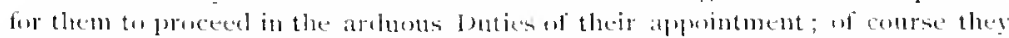

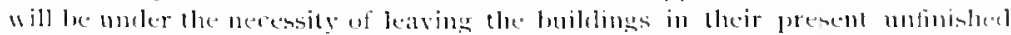

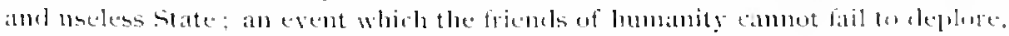

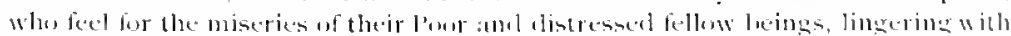

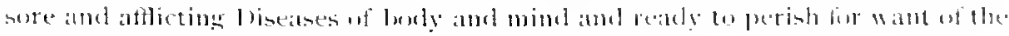
comforts which such an Institution womled atfint them. 


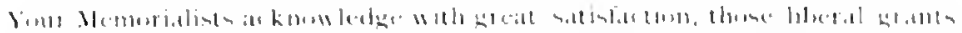

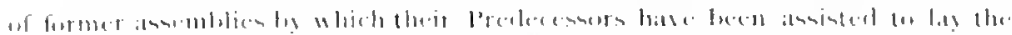

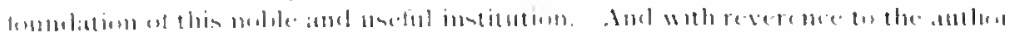

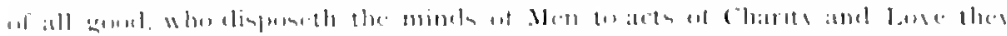

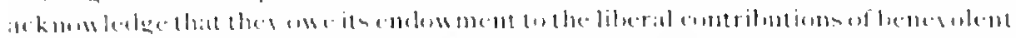

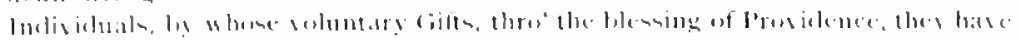

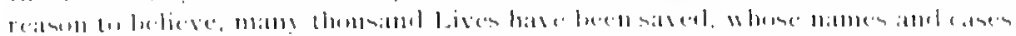

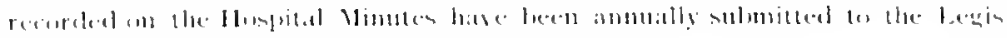

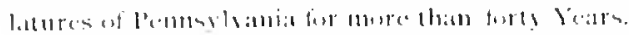

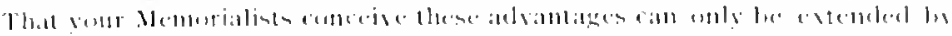

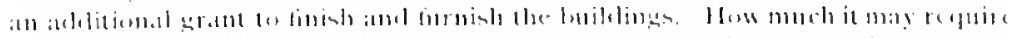

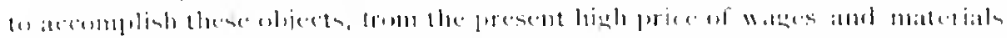

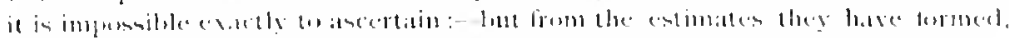

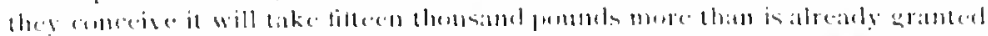

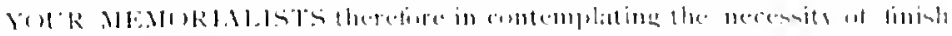

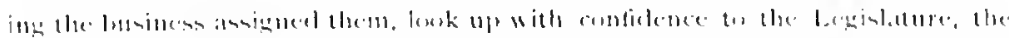

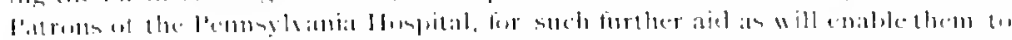

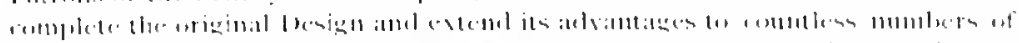

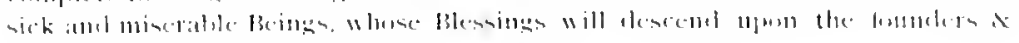

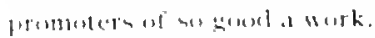

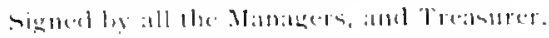

I'his appreal was not without result. for the amonncement wan

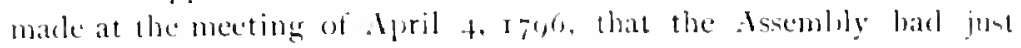
paned an . 1.t making an aclelitional grant to the Hlospital of $\$ 25.000$. Furher apleals to the legislature for aid will be relerred 4 in a subserpent set tion especially cleroted to financial aicl.

Nest IVing

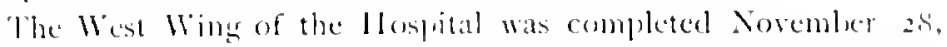

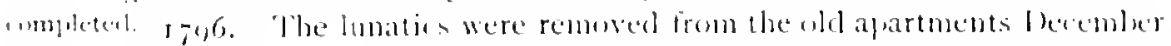

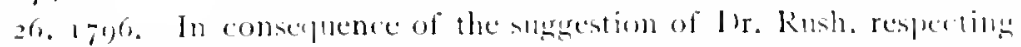
laths. awo rooms were provided, one with hot, the other with a cold and shower lath near to the centre of the West Wing. to lxe sulphled with water from a recrovir plared leneath the ceiling of the lower

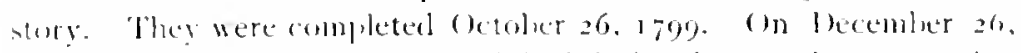
1 Sok. a warm lath machine of original design lut goond construction was prencuted by Charles Wilson leale for the use of the patients, for which the Managers returned thanks.

on May 30 . 1ioz. The cummitte were directed to creat ane conl stove, to warn the cells with coal, on the fllan suggested ly fohn lorey, and to have the experiment made how lar it will save fuel.

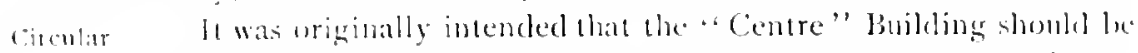

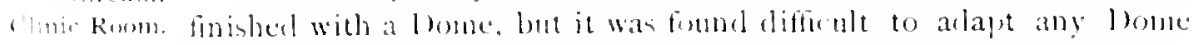
to the present style of the linnt; and the operating-room leeing apable of an and a lient from the Plation of the Roof:

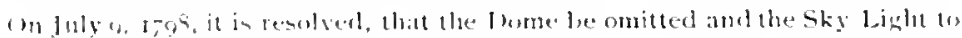

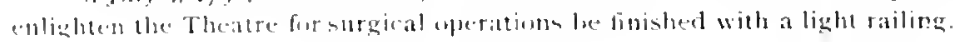


Early in ISO4, Lectures were given and Operations performed therein, which were so continued until IS68, when the new amphitheatre was finished and when the circular room was converted into a ward dining-room and an annex to the library.

The Managers having considered the advanced price of every necessary article of life, found themselves, on Nay 30,1796 , under

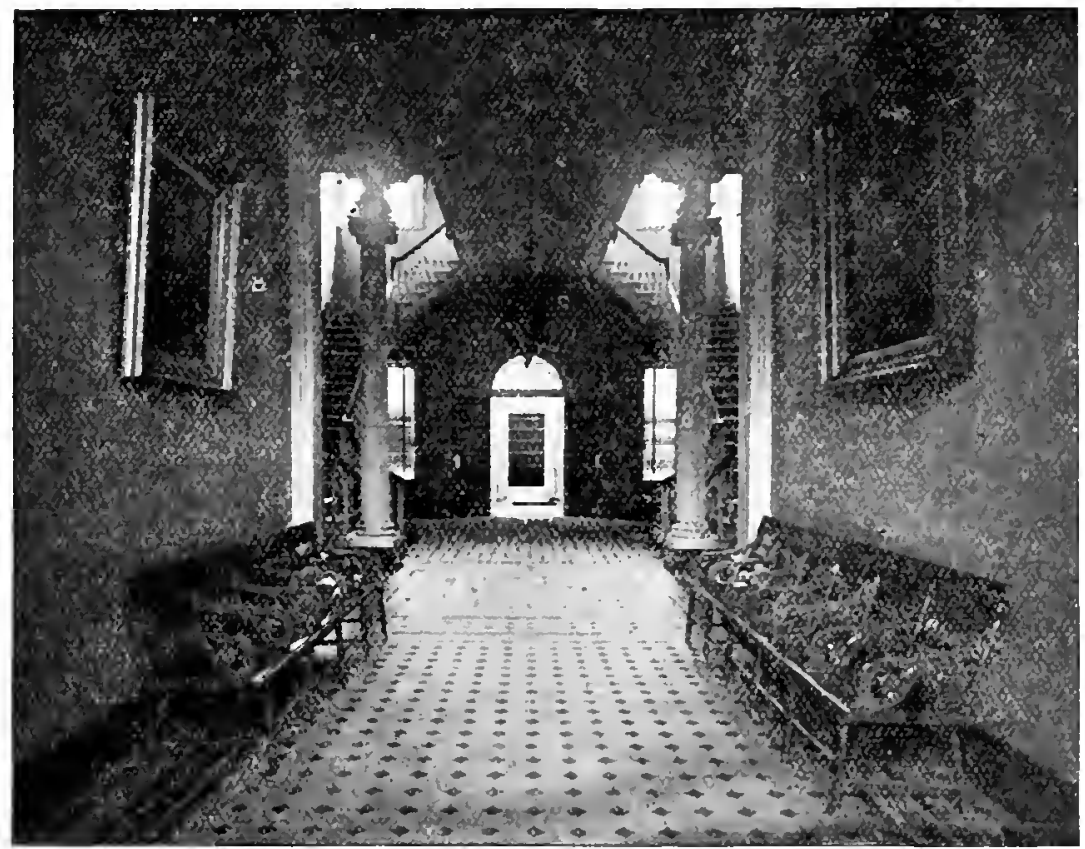

Hall of the Centre Ruilding, Jonking notth.

the necessity of increasing the Iboard of pay patients and limiting the Pay P'atients' number of admissions of the poor, in order to keep within their Buard resources. They therefore resolved:

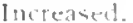

That until further order is taken in this business, not more than thirty poor shall be admitted at one time unless an accident or sone very particular case should require it.

The French Ilonjital had been established in Philadehohia sone proposal years previously, but had not been very prosperous. The Managers from French received a rommuniration, dated Iuly 2, 1796, stating that I)r. Hospit.l Colomb, the Inspertor General, was desirous of dissolving that organDeclined. ization, and proposed to transfer all the patients to the l'ennsylvana 
llowpital. On July fll, the Manager anembled at the house ot

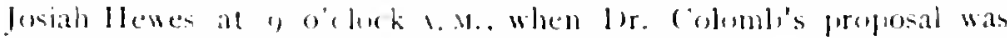
conudered and declined. This action was direeted to be conseged (1) the linelle hininter.

Rules fir (In lederuary 26, rogs, the Nanagers having olserved that

Amission

Several berntus hitd heen admitted intuthe Hene last bear, and some lated.

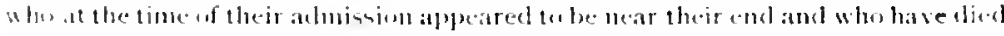
- burtiy after they were laken in, alld having alos observed that some sick berous have nen been visited previnusly to their satel atmission hy any one of the llospital

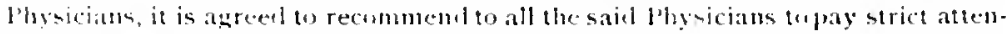
tion tu these rules of the llune which provirle that no incurable case except l.uma-

lomiciliary tirs shall le admitted, nor any ethers, without such previens Visitation and, as

Visits by the rules further require that lwh physicians bould alwass attemi on every

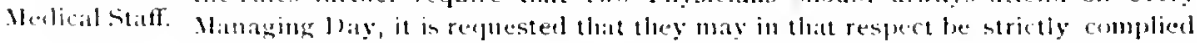

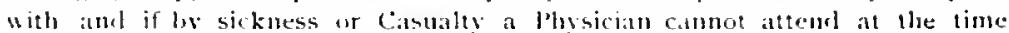
alpointed, it is recommended that he procure some on of the other blysicians of the louste th atteud for him.

At at meeting held September ist, thoo, a lexter was reacl and directed to be sent w, Benjamin llest, whe was then Presielent of the Royal Acallemy of Arts in lomion, soliciting on behalf of the Contributors at pamting, ending with the complinentary conclusion "The woths of an at tint which ornament the palace of his king cannot fail to honor him in his native land." The reqfuest was favorably chlertanted by West, who sone years later prenented the Hospital with the picture of "Christ llealing the Sick." A huilding was ereched from designs furnished in consultation with West. The picture arrived on the 13 th of Octuber, 1st. It was exhibited for several years and prosed a source of considerable revenue to the llospital, amounting to thousands of dollars.

Pupits of On Nowember 15,1802 , the following communication was sent Phymeians, ly the l'hysicians, to the board of Managers:

Wherear delays incouvenient amd sometimes dangerous te life have sometimes accured or may ocenr from the inability of the Physicins of the Pennsyl.

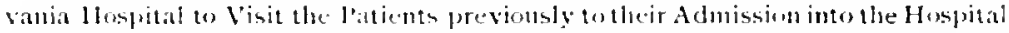
agreathly wa rule of the Managers. on . Iccontut of Numerous and prior Engage.

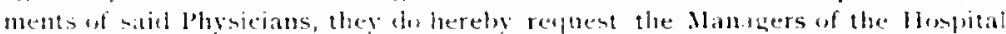

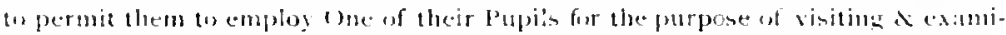

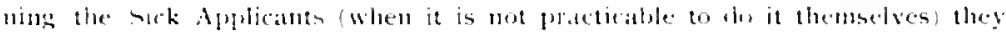

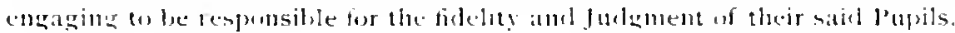

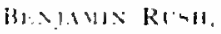

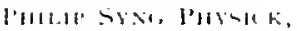

$$
\begin{aligned}
& \text { JuIN REMUIN COSH, }
\end{aligned}
$$

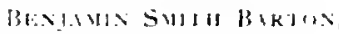

$$
\begin{aligned}
& \text { cinlek limlik, Junior. }
\end{aligned}
$$

The lollowing repig was male:

The Manarers are all of uptum that they anming dispense with any part of the present form of admissint. In this aceasm, the Buard sincerely regret that

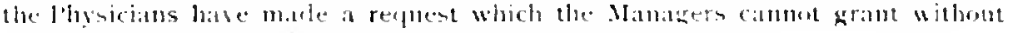
intringing 11 pon the butes they owe the institution.

See llorks of Artand Memorial Furniture. 
At a meeting held Oct. 20, 1804:

Simmel Coates prestuts to the Huspital a German Servint rirl, ated almut years old, named _________ to remain three years, which the Board accept and reduest that he will get her Indentures exerntel. He also offers —- who is now in the lonuse, for Eighty dollats, for the sane time, which the Managers agree to pay she consenting therets; He likewise wfers Froncis for Einhty dollars for three vears, which the Buarl agree to erive, Francis comsenting to Serve, and wo perform erery duty rerpired of him by the Steward but the principal object the Managers hate in view, in luying him, is ts emplny him in the spothecary Shop, to beep it in grond orter, and to go of such Errands as may be thought necessary in the Medical Deprartment.'

It was ancertained, December $2.9,1805$, that in viltue of the ten shares owned by the llompital, the nse of Schuslkill water shulat be gratis for three years, thereafter at the rate of fifty dollars per anum.

The committer on building the stalile and wash-house were instructed to bave a cistern dug to contain forty hogsheads for the purpose of washing. Schuylkill water was also to be introduced into the stable and wash-house, July 27 , Iso 7 . On May ruth, a permit was obtained for the introduction of a pipe

Frum Spruce street under the wall to the green house, the watering cummiztee having consented to grant one.

Angust 2 I, I So 7 , the Steward is directed to read in wery Ward the Rules to be olserved ly the Patients once in every Month \& to inform them particularly that

If anyone of them persist in smoking of Pipes or Segars after being cantioned by him to desist, such Patients on complaint to the Sitting Managers will lie discharged for irregular behaviour.

'The custom of leaving the city dtring the summer months which began when epidenics threatened or prevailed, sulseruently lecame the fashion. Angtist 25, iso6. there were rejurted as alsentees:

Peter Brown, on account of his sickness, Thomas Mnrris at Lomg Branch for his health, and Joseph Sannders Lewis, Treasurer, gone in Bustom. Pattison Ilartshorne and Lawrence Seckel were granted leave of alsence.

May 27, 1 son, it was agreed:

To Advertize the Poor from the City or Commy to come to the Hospital where Viccination. they will be vaccinated rratis.

On May 13, r Sir, the Managers' fines were increased to fifty Fines cents for total alsence and to twenty-five cents for leing late at any lucreased. meeting and no excuse to he admitted for total or partial abence.

1 It was the custom in the early part of lat century for ummigrants to puy for their pansage by personal service, and, under such agreement, many were sold for a term of years, by vessel owners to work out their indebtedness, and, hence, were known as " Redemplion Servants." Some of them afterwards acquired wealth and became inluential citizens. (Sec article on Redemption Servants, in "W Watson's Annals of Philadelphia," p $260_{0}$ ) 


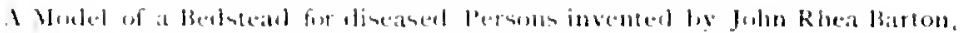

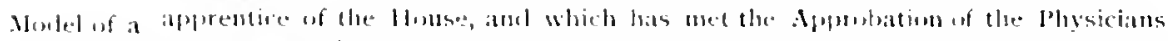

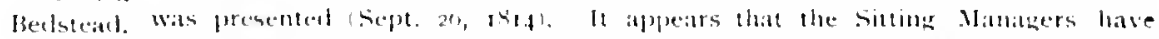

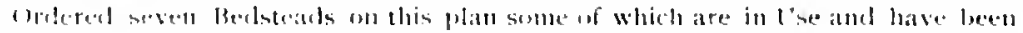
found (1) answer better than any heretufore introluced ints the Hospitial. The

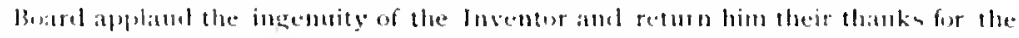
Model.

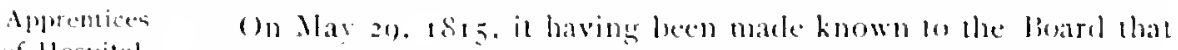
of Hospital. the Managers of the Mmmhouse hat invited the Apprentices of this llome lo attend an operation in that institution:

It in Resilved "n permit the Meclical Apprentices of the Almshouse to attemd the surgical mperations, which may hereafter le performed in the lenosyl. Ilospitiol.

The following resolution, dated Jume 26,1815 , from the Almshomse and House of Employment, was clirected, July $31,1815,40$ le fllt on the Ninutes:

Ke'soled, That the Medical students of the Penncylunia IJospital he permitted to attend the Surgical operations which mat hereafter be performed in llis Ilouse.

Apprentices November 27.1815.01 motion it was agreed:

attemel

I.ectures.

That the Apprentices of thin llonse hate the Liberty of atending the lectures of thyseians belonging to the leniversity other than these connected with the Institution and the expenses thescof be defriged ont of the general fund.

Proposed correspontence letween the 'Prustess of the University af Clanic for the leviversity of Pentusylvania l'enustlania (regarding teaching in the Hospital) and the Managers of the llospital faled to bead to any mutuil agreement.

Nisumler $22,1817$.

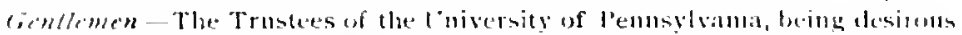
to secure to the Pupuls of the Nodical Department the ald wantages of a clinical bistablishment in which the lreatment of the varosts diseases to which the human Frame is liable mate be illustrated under the direction of ane of the l'rofessors of the conversits, hice appointed a Committe with pewer to make the arrangements recpuisite for the Accomplishment of that Object.

Persuded that your lbard will be well inclined to conperate with the Truslees in a matter so highly impurtant to the improvement and discesuination of

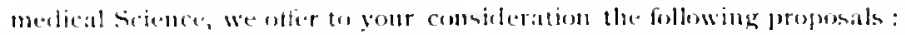

1. That the re he awn Warch of the Hospital, one of the Males the other ot Fenales, appropriated exclunively to the Clinical Teacher, each Warcl of sulticient climensions on acommmblate with conventence at least Fifteen Patiente-twis apartments are of course recpured in order that the Malks and Fenbles may be separationt

2. Besides the misceltaneous Cases in these Wands, the Mamagers will allot at certain number or portion of the maniacal and Venereal patients wo he under the Carte of the reacher.

The llospital will as usual pruvinle eompetent Nurses, one of whom wh be entilled Matron who shall exercise a controul ower the whole. The Matron and Nurses wact under the direction of the Teacher in their care of the sick subject to the regulations of the Itomplat. 
4. The Prescriptions of the Teicher twhe furnished by the Hospital.

5. The Teacher wh have the use of the Lecture Rom fir the accommodation of the Class-the necessary Fuel and Attendants to be supplied by the Hospital.

6. Each Sindent in the Clinical Estalulishnent shall pay th the Hospital the Sum of Ten dollars for every conrse of Clinical Lectures he may attend; and no Candidate shall be admitted to a begree in the thaiversity who does not produce a Certificate of having attended a Course of such Leetures and of having paid the Fee to the Institution.

7. The Clinical Teacher to be responsible for the Observance of such Rules as may be agreed upon with your Board, as w the Conduct of the Pupils.

We beg to be favor'd with an answer to these Proposals as som as may suit your convenience, and shonld a conference be deemed advisalble, we shall be ready to meet your Buard for the furtherance of the wished-for ithect

With much Respect We Remain, Gentlemen, lour Obed. Servis.,

$$
\begin{aligned}
& \text { BENTHAIX CHEW, } \\
& \text { IV. MEREUTH, } \\
& \text { NoS, CALWALWEK. }
\end{aligned}
$$

After this proposition had been discussed, it was referred to a Committee which rejorted as follows:

The Committe to whom was referred the communication from the loniversity of Pennsylvania have given to that subject all the attention \& delibertion to which, from its interesting complexion, it seemed to be so justly entitled.

The interests of medical science are so intimately interwoven not only with the original design but present economy of the lennsylvania Huppital, that your Committee would cheerfully advocate any plan, having for its object the more effectual cultivation and diffusion of that important branch of knuwledge, lut which should not, at the same time, essentially interfere with the long establisherl practice and wholesome regulitions of the Husprtal.

Deeply impressed with these considerations, your Commitiee convened your Physicins \& Surgeons, the Physicians of the Lying in Departments excepted, on whose duties it was supposed the proposals of the University conld have no mate. rial bearing-They all attended-The communication from the Trusters was placed in their luands-They have since returned it, wh their writun opinion, which for your information is herewith submitted.

Vour Committee have endeasured to discover whether in any $\mathrm{N}$ in what manur the views of the University could be rendered in accoldince with sour rules, but the have leen unsuccessful in the attempt-se reput it as blat result of their judgment, that the proposals of the Liniversity catum he catred into eftect in the Pcomsylvama IIospital.

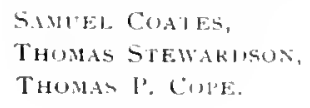

P'HILAD.3, t2th mu. 6th-1817.

The following formal oprinion was received from the Medical Staff in relition to the subject:

The Subscribers are of opinion that the proposils of the Truntees of the Cniversity canmot be acceded (1) without infringing the right of rour plychicians. All the patients of the Hospital have heretofore been atcended exclusively hy 
the physicians and Surgeons whom the dlangers have chesen-and we betieve

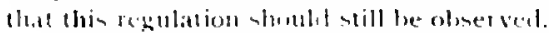

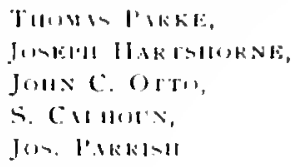

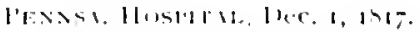

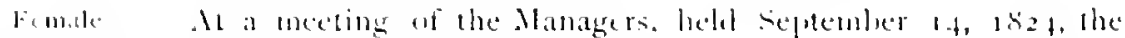
loust of following minute was mate:

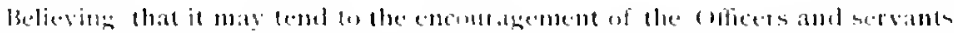

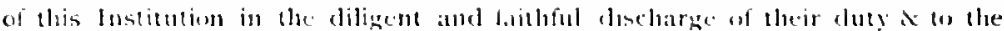
comfort and ingmosement of the patients wete we ansisted in the internal mantage-

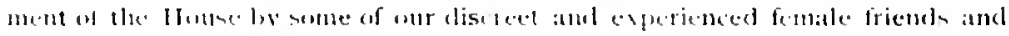

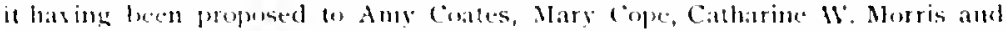

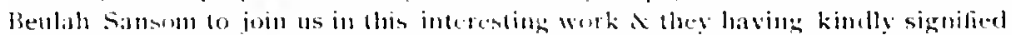

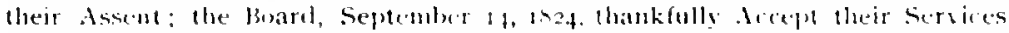
and Authorize $\alpha$ empower them either juintly or separately as they shall see lit at all times convonicht whemselves w visit and inspect the several llards 8

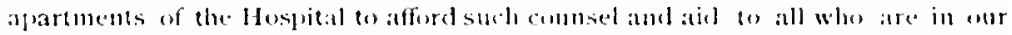

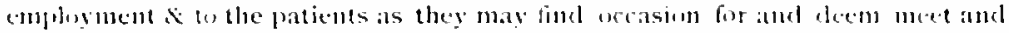
report from time (o time to the Mantigers individantly or Collectively such altetal. tions amb improvements in the internal ceommy of the llouse ats they maty juthe silutity, wetwil ar medrul.

Report from To the lantigers:

Boitrel of

Asteeably to your Minute of Aplointmeot dated 9 mo. hast, we have fre-

fiemale. Ansistituts. gently visited the Hospital, and clurimg the coutse of our attention te the Aftars of the Honsetroled in its various departments, we are encouraged en believe cur exertions altogether taseless; and it is in the pleasing hope thit similar appuintments in succession will continue to be indruntageous to the hustitution, that we are free to propose the collargement of our mumber.

pursuant to these views of the subject, we take the liberty of naming for your consideration the election of Hannth Lewis, and Mary flornor, as our cuadjutors.

As descriptive of the nature of onr engagement, and for the sake of cont. venience, we have adopted the title of "The Board of Assistant for the internal management of the Pentmylvania Jospital."

With sentiments of respert we remain your friends,

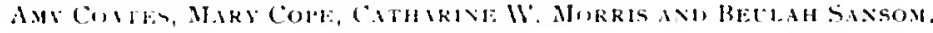
4 1111, 1., 1 sizs.

lioard of

This Buard, if mo. 3o, 1825 , being well sittisted that Considerable benedit has resulfed to the Institution from the disinterested services of flictse friends appoint llamals Lewis and M.ory llomor to le Members of the said Buard of Assistants. WWo are hereafter to be designated, "The Buald of Assintants for the Internal llsuagement of the Hospitial"

At the imnual election, held May 9,1825 , the Board of dssistants for the lntemal Manatgement of the Huipital were re-elected.

The following year, Catharine 11 . Morris, llannah lewis and Mary Cope resigned, and their places were nlled by the election of Hannah l'aul, Martha Johnson and lilizaleth Archer. 
On December $3 I, I S 27$, a communication was received from the "Board of Female Assistants," expressing their disapprobation of retaining "a certain employee in the Hospital, in any capacity whatever." The Managers, after due consideration, refused to comply with the request. The ladies theren and the Managers, by motion, declared the organization of the Board of Female lisistants abolished.

At the same meeting the Managers gave consideration to the End complaints concerning the Committee on Economy, which had been in operation since March ${ }_{7} 86$. (see page 67 ), and the following resolution was offered :

Resolzed, That so much of any rule of this Board as constitutes a Committee of Economy be and the same is hereby repealed.

It is recorded that

The votes being equally divided, the motion did not prevail. Whereupon Joseph R. Jenks, resigned his seat as Member of the Committee of Economy, "but not as Manager."

Charles Roberts then offered the following, which was adopted:

Resoled, That the Steward, with the advice of the attending Managers shall have power to employ and discharge the servants and nurses as they may judge proper and the first Rule respecting Nurses and Servants is repealed.

The object, evidently, was to abolish the Committee on Economy, which had, according to some of the Managers, overstepped the hounds of their powers in deciding questions which had come before them. The communication from the Female Assistants l,rought forward the matter, which had been smouldering for some time, to a crisis. The Committee of Economy had been invested with great powers in the control of the internal administration of the affairs. which may have engendered some want of harmony among the other members of the Board. It may be said, however, to the credit of the manasement that it appears to be the only instance of a disagreement of ans importance, which has occurred in the history of the institution.

On Feloruary 25. I 828 , the following communication was presented :

Sensible that under existing circumstances, we can render you no acceptaly]e or efficient aid, we have concluded th retire and you are therefore no bonger to consider us as Members of your Buart.

PHILADElrHIA, February 25th, 1828 .

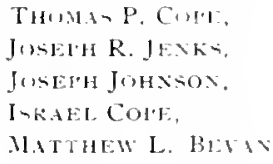

To the Mangers. 
Rolerte Vaw was repluested to act as Secretary. The Boarel lecing unahle lo transat theiness, there being no puorum :

It is agreed that Thomas Stewarhom, lhe President, with Thomas Morris,

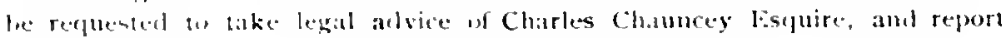
the roum.

Op)

It a mecting held March 1, Iszs, the following opinion was Charles prencented:

Chaturees.

Est.

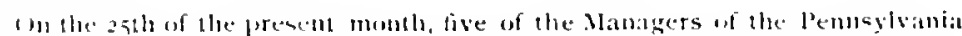
Ilempital communicated their resignation, in whing. 10 the Board and retited.

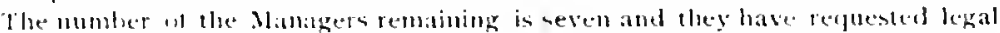

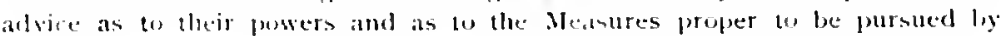
lhem.

On the while me alsice is lhat the remaning dlangugers proceed without

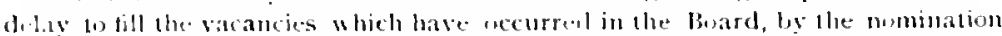

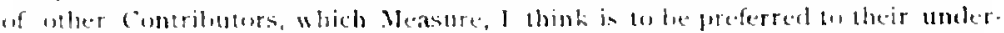

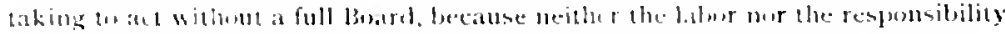

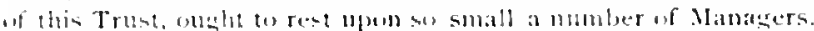

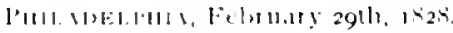

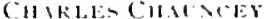

Acting in

Advice of

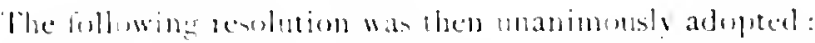

(inllilse)!

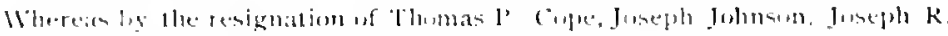

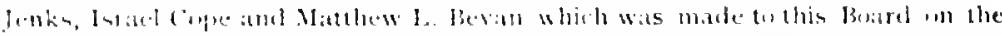

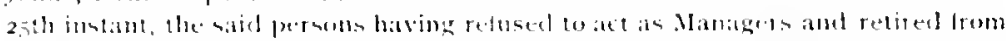

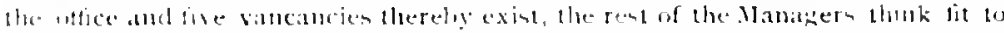

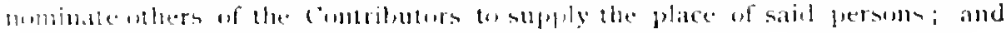

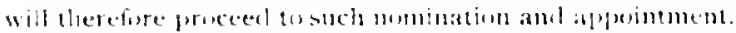

Joseph Price, Alexanter W'. Johmenn, Mordecat Lewis, John J. Smith and Patholomew llistar were appointed in the place of the persoms resigned.

(entemmial

The firs uftecial recognition and celeluration of the hirthelay

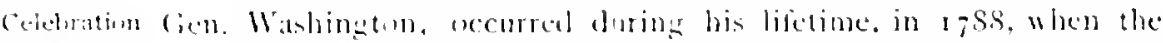

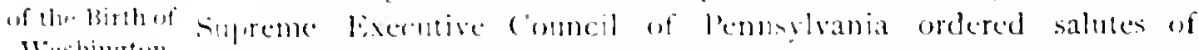
II:athingten. artillery 6 be bed in his honor. lint hiv iriends and admircrs had. freviously to this. met and informally entahlished a custom, which was so well sustained ly publir opinion that it suberpuenty received the anction of the (its authorities. Ger his death, the celeliration was distinguiber be sperial enactment of coneress. then bolding its clening sesion in thilatelphia. It was recommended ly appropriate resulutions, that the zed of fieloruars, 1800 , hould le oberved throughum the lonited states as at lay set apart for excrcises manifesting the pespular esteen for the character of Wa-hington. In Philatelphia, there was a public procession under the direction of the society of the Cincimati and aho a parade of the Nasonic Iraternity and of the Militory, and appronriate addresses were delivered.

In the war is 32 . aceurred the centemnal amniverary of Washington's hirthdes. and it wa celebratted with nperial distinction. A 
large civic parale wa a prominent part of the procedongs. In the ceremonies the Firemen's and odel fellow' uranizations appeared for the first time in pullic procesion. Every interest in the city was sought to be enlisted in this inmense display, and the freace-loving Managers of the Hospital were eren invited to participate. as will be seen in the following formal invitation which was inserted in the minutes, but the action taken by the Board upon the matter is not recorted.

CEVTEYNIAL CELEBRATIOY.

Sra, -The Committee of Arrangement, appoirted by the Citjzens of the City and County of Philadelphim beg leave to

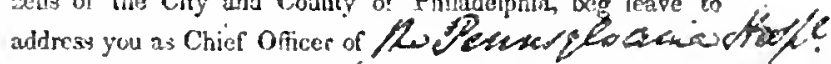

They respectully request, that upon this occasion, in the appor priate cclebration of which, the lonor of Philutelphia is ean. cerned, tho body over which you presidc, will heartily unite in foroing a part of the Civie Procession ou the 22d of February. An early Report to this Committe is peculiarly desirable.

By order and on behalf of the Committee,

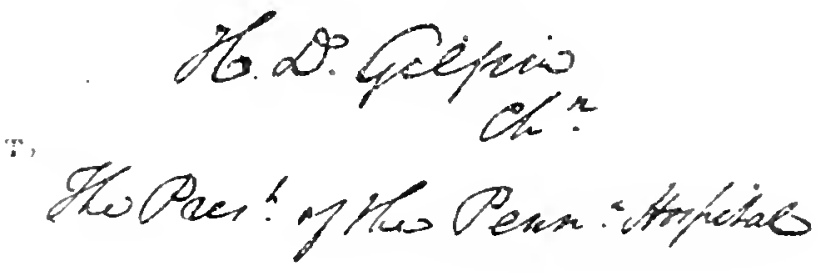

The Committee some time agn appointer an the sulijert of the Mortgare macknowledged against the Estate of the Hospital reprorted having conferred with Charles Chauncer thereon and he having prepared an essay of a memorial to the lesiclature arking relief in the Opinions of Itr Chauncey on Stale Clains. premines, it was read Febuary 25, I 833 , and appowed. as follows:

\footnotetext{
Tothe Senale and Honse of Represenhatites

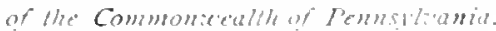

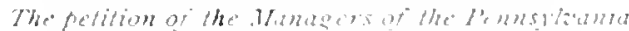

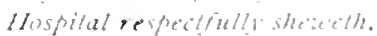

That by an Act of dsembly faraed the eleventl day of April ome thousand Petition for sesen hundred and ninely-three emitted "An Act for evemolng the benetits Relief. experienced from the institution of the l'ennsylvania lfuspital "there was aranted 


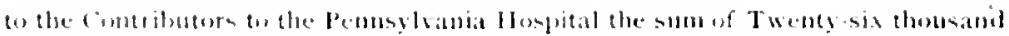
six humbled and sivfy-six tollars and sive-seven cents ont of the principat and inferest flue to the commonwealth in pursuance of an Aet passed the 26 th of Fetruary 17.;. And by the said Act it was provicled that such suffecient security

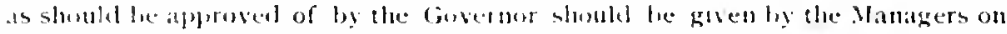
techalf of the imetitution with cumdition that the and their suceessors should une

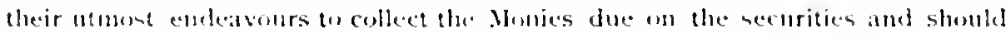

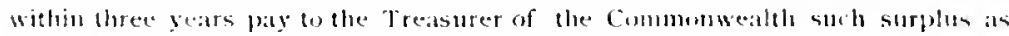
might sentain in their hands, hevond the sad sum uf twells six thousand six hundred and sixty-sic dollats and sixty-seven cents, together with interest thereon from the tince of their receiving the same.

Mortgage on That in confermity with the provisinn in said act Security was given with the the Hosprtat. approbition of the gowernor by a bortgage of the Corporate estates to Thombs

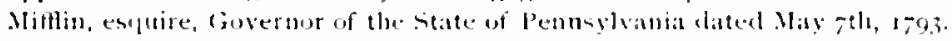

That the Mandgers entered upun the performance of their duties under the said Act of Assmlily and recosereel and received the sum su granted by the Legrislature and applied the same agreeably to the directions of the said Act; and thereafter applied to the Lewislature to be discharged from the other duties assigned to the'm by the sand Act; and on the fth day of April ane thousand enght hundred ant live an Act of Assembly entitled " A supplement to the det entitled

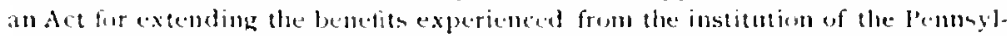
rania llospltal wats passed by which it was enacted That whenever the said Managers sbould transfer and deliser to the State. Treatsuret all the bumds, Mortgatges and securities assigned to them in pursllance of the Act before mentioned and give him all the information they posnessed, all the Trusts and duties ansigned by the said fot should cease and determine-

Satusfaction of liortgitge not Recorded.

That the said Managers did agreeally to the prosisions of satid det transfer, assign and deliver to the Stite Freasterer all the sadd lunds, mortgages and securities and give him all the information they possersed and were thas by vircue of the sadd Act disclarged from the said thusts $x$ ilutes

Thit the said Ifortgage bereinhefire mentionet of the corporate estates still remains an recurd th the inconvenience of shal fnstifution, satisfaction therenf having never hen acknowledged; is the same of right sholld have heen when the Watnagers were in confornuty with the lant mentioned fot of Assembly discharged from the duties and trusts aforesaid.

Your petitioners therefore respectully ank that authurity maty bisen by law

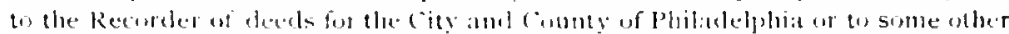

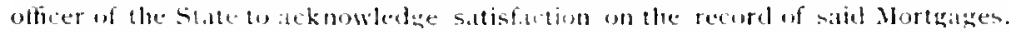

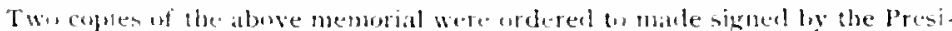

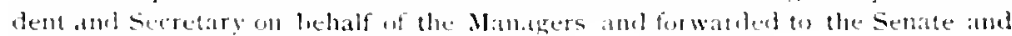
Huse of Representatives at llarrisburg.

"lhe committec appointed for the purpune reported that :

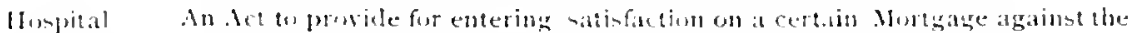

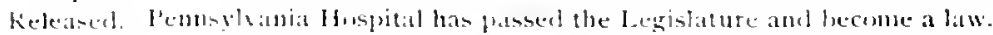

lhe following is an Findact trom this law relating to the Mortigage :

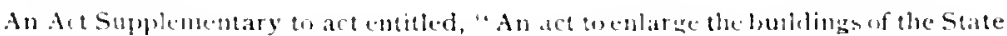
Penitentialy for the Eastern bistriet, and fir uther furpunes," passed the tweoty-eighth day of Marh, Answ bomini, ane thousand ejght bundred and thirty-une, and for wher purposes 


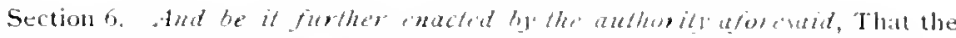
recorder of deeds for the city and commy of Philatelphia le, and is herefor antur. ized and required to acknowledge satisfaction of record of a Murtgage cecuted by the Contributors to the Pennsylvania Hospital to Thomas Mnflin, Estuine, Fovernor of the State of Pennsylvina hearing date the seventh day of May, one thousand seven hundred and ninely-three, recorded in the ofice for recordung deeds, Nc, in and for the city and comnty of philadelphia in Mortgage book Number nine, page three hundred and thirty-five, \&c.

Approsed the ninth day of Aptil. A. D. one thousand eight hundred and thirty-three.

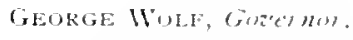

During the years from 1833 to 18 to the Nanagers performed Continued their duties regularly, the physicians were recorded as leing attentive to the patients, and the routine work of the Ilospital continured Growth of Hospritil. without special incident and without interruption. It was found, however, that the reputation of the institution was attracting to it a constantly increasing number of patients, making it necessary to provide greater accommodations, especially for the insane. Accordingly the Contributors antherized the Managers to sell some of the lots in the city, and buy ground in Went Philadelplia, and to erect thereon the lepartment for the Insane, which was opened in I 8 to. As the records of the two departments thenceforward became distinct and independent, the account of the Insane will be taken up for consider. ation later un.

On May 26, $179+$, the Building Committee proposed the erection tee Hunses. of an lce House which was approved and they were instructed w luild one of stch dimensions as they deem proper. On lecember $3^{\circ}$. $18 \mathrm{~s}$, "sioo wa praid towards building a New Ice House, offered ho

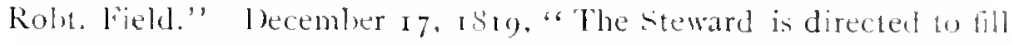
the old lae Homse, when stritalle Ice can be had, hut to omit filling the New (Ine. It is understond that ice is not to be as heretofire supplied from this lnstitution to the citirens." "The winter of 18,3 , however, was of stuch musual mildness that sery few ice houscs were filied, and the l'ennsylania Hospital again sold ice to its neighbors.

On the removal of the Insane patients to West lhiladethina, in $18+1$, the wenters wing of the buildings, and two-thirds of the grounds Extenaive Repairs. which had lecen formerly ocrupied ly them in the Hompital at bightl and l'ine strects, were at once masle analatile for the needs of the sick and injured, hut quite extensive reparn were necessary in order to adapt the building for the purpuses of a lieneral Houpital.

from the Minutes it is learned that his nork num chsaged the attention of the .Managets. 


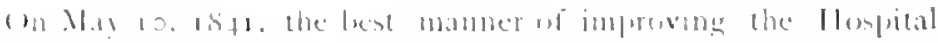

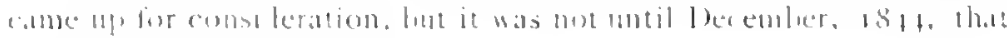
artiom w.1 l.1ken an follows:

f'latris for

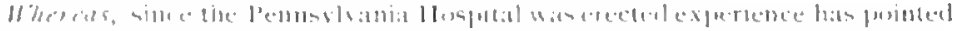
Imprusment (i)susiderent

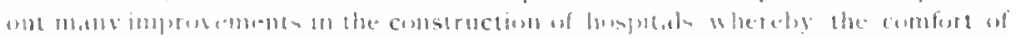

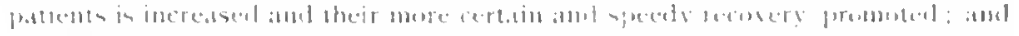

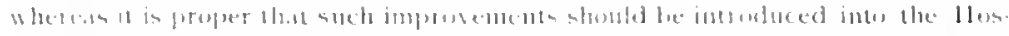

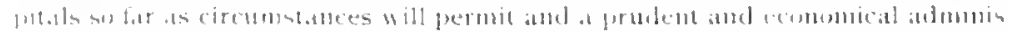

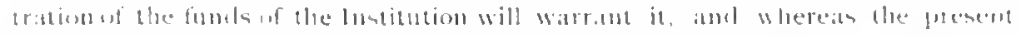

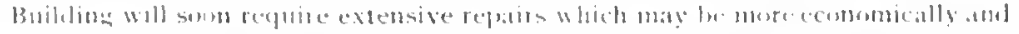

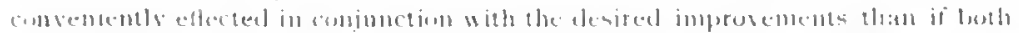

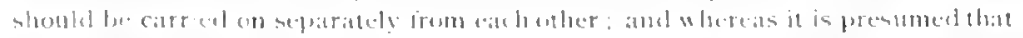

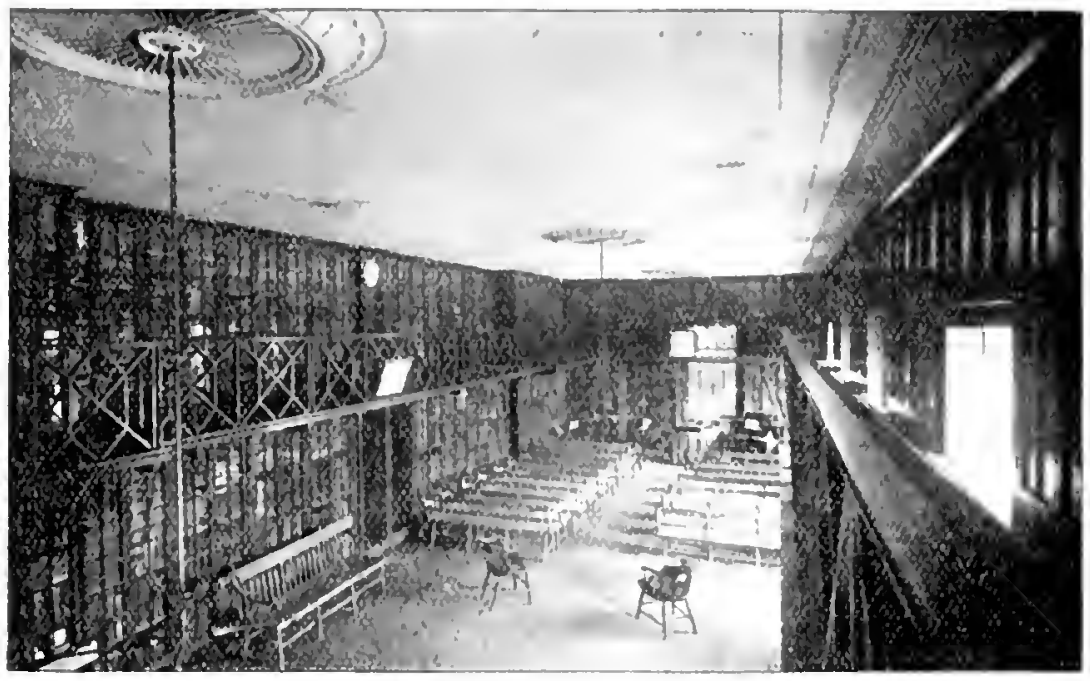

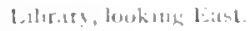

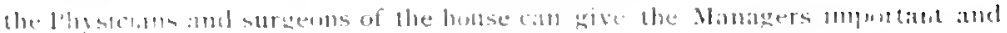

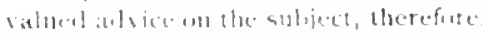

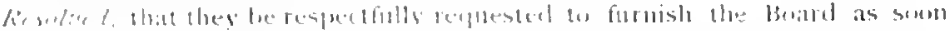

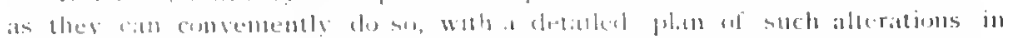

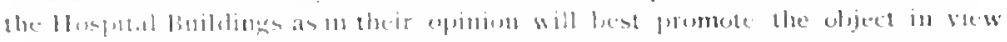
lonethes with ghe it reasoms therefore.

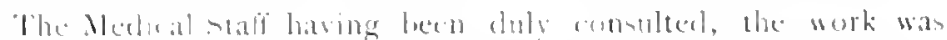

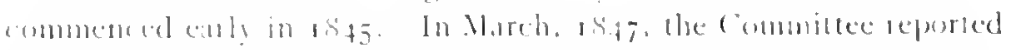
completion of improbenent, which rost $\$ 5.500$, in adelition an expense of 55.000 fur warming the homse. Juong the many changes male. the repunt stated that here ha l becon a change in losution of

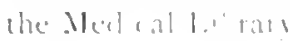


The large rom in the second story of the Centre building, finmerly uned as a female neclicil ward, has been hindsomely fitted un for the reception of the Library; the expense has been defrayed out of the "Medical fund."

With regard to the alterations, the building Committee reported:

l.ittle more than the old walls uf the transierse sections and the belfry on the Hospital Remodelled. Tower reminin to remind us of the past.

April 24,1848 , the following appears upon the minnter:

Several gentlemen having contrituted the sum of s.5n for the purpose of Tren having trees planted around the outsile of the IIompilal Square, the Treasurer is Planted instructed to take account thereof and to give to such of the donors as were not herelofore emtributors and have in this case made the lexgl contribution, certificates of Contributionship. He is also requested to pay the muty over t" the Steward of the Penusylvania Ilospital in the City, who is instructed to see to the application of the fund in company with the attending Maningers.

The exterior of the Centre Building remains to day very much as centre it was originally in 1796 , lut the interior arrangements have been Building. altered materially. On the third floor there is now one lurge ward, extending along the entire south front. In improvement was also made in the amphitheatre,

"By means of wilich there is a gain of about fifty seats, making accommo. d.timens for alout three humbet students." "In the Hall the wh wouden fhors were rephlacerl by handsome tiles."

lieloruary 25. 1850 , the Managers

fir wefed, That it is expedient that the entrance on P'ne street shall be permanently closed for the admission and dischatrge of patients within eighteen mombs from the present time.

Jannary 27,1851 , the Managers roted:

That the principal entrance to the Hospital be remosed to Eighth sirect

The building at the Eighth street entrance. Which was built for the gatckeever's londge. has a front of seventy feet on Eighth sireet. In the centre is an arched sateway, which is the principal carriage entrance to the enclosure. There are also waiting-roums for patients.

The Contrilutors, at a meeting held 113914,1855 , requested the Managers to take energetic measures to oltain such an amount of sulscriptions as would enalle them to put me a separate huilding to accommodate the male patients of the insane defarment in llest I'liladelpluia. The following contributors were alpointed to assist the Managers: Isaac Colline, Frederick l'raley. William Bettle. William Welsh," Wistar Murris, Samuel Mason. 'lhomas lasker, Horatio (.. Wool.

It the annual meeting, Nay, i 856 , the Managers state that :

It has mot been customary an repurt to the contributors the shate of the Huspital in the city, but merely l. sulmit at their ammal meetings a contensed

'I'hi, apartinemt has been used, wnce that time, also as the Maurgers' Heeting Koom. 
A1111:1

kicpurts

Intuel.

Picture

flun-e leased

to the

College of

Physicians.

I IImane

Suciely

Funds.

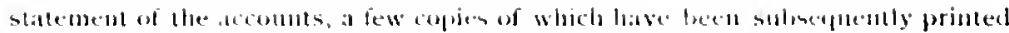

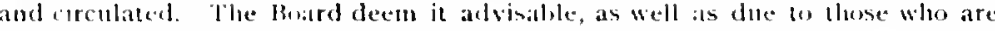
interested in this Chatrity to make them more fully acquantedi with its peenliar situitien it this time.

fircm that time to the prexent, the reporthof all the departments, compiled he the Managers and steward, have been submited to the contributors at the amnual meeting, the hirst Monday in Maty of ear h yar, and alterwards published in pamphlet form for distribution (1) the friends of the llospital. The lant anmual reports of the several departments have been durably lomul in black cloth, making a handsome volume.

1) July 26. 1854, the college of Physician of lhiladelphia leased the building on spruce sitreet for holding its meetings and library and it was so occupied until 1870 , when the collegre moved into its own commodins. lireproul builduge at the corner of Thir. teenth and locust Streets.

An unexpecterl source of assistance was found in the dissolution of the Ilumane Society of lhilarlelphia. The olject of this organization was the recovery of drowned persoms, the giving of medals for saving humbun life. also to offer aid to thone suffering from cantalties. A consideralle fund having acrumulated in the conse of years, which the society fonmi difficult to expend bor the purposes specified, the

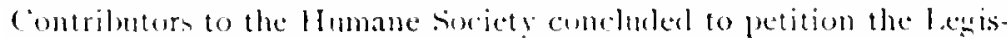
lature for the privilege of transforme its fumds, then amounting to

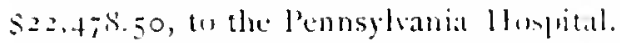

On Septemler 29,1856 , when the sulject of the transer of the fund of this society to the llospital wah sulmitted to the lionarl, the following communication was sent in reply:

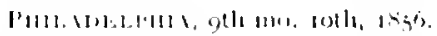

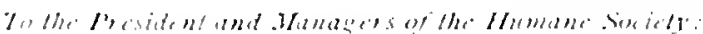

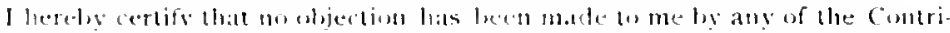

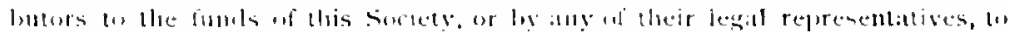

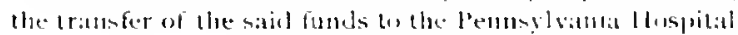

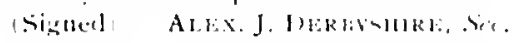

Wherenpon the following preamble amb resolutions were adpled ly the llumble suciety. and a coly transmitted to the loard of Mamiar.r.

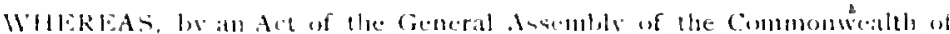

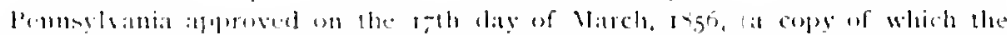

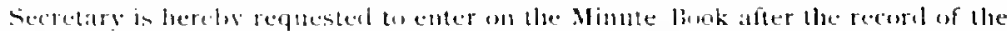

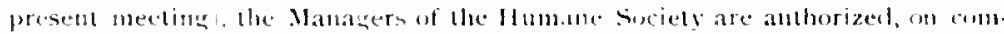

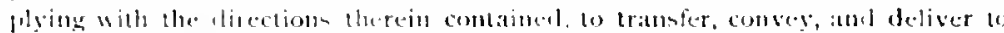

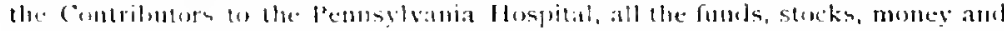

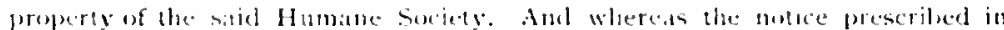


Section I of said Act has been publisherl in the "North American and lnited States Cazette" and the "Waily News," tww of the daty newsapers of the City of Philadelphia, wire a week from the igh day of Fourth Month to the luth day of Seventh Month, $15^{\circ}$. And whereas the Secretary has this day certified that no objection has been made to him hy any of the Contributors to the fumels of the llumane society or by any of their lexal representalives to the transfer of the said funds to the Pennsylunia llospital:

Now therefore be it firselied, That the President and Secretary be and they hereby are, atulwrized and instructed to transter, compey and hand over to the Contributors to the lenusylvania IImpital as soon as they conveniently can, all the funds, stocks, money and property of this Society, and recetve from the

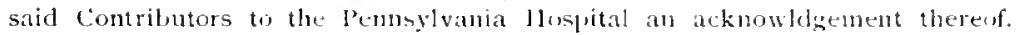
hesolede. That the Treasurer he and be hereby is, directed to surtender and pay wer to the said Contributors on the Pennsylyna Hospital, whenever the President and Secretary shall direct him so to du, all the cash, stucks, loans and wher securities belonging to this suciety that may he remaining in his hands, after the payment of the orders authorized to he drawn upon him.'

(SIGNEM H OJPLERS OF IHUMNE SOCHTY.)

The money was accordingly conveyed to the treasury of the Hospital to be used for charitalle purposes in caring for the sick and injured, and the Humane Society, whici was established in 1780 , dissolvel its ormination and passed out of existence after an honorable and useful career of seventy-six years.

On January 28, 1 856 , the following memorial to the Legistature applying for an amendment to the Charter to enable the Hospital to receive and hold contrilutions, berpuests, etc., to an increased amount the sum of which shall not exceed $\$ 50,000$ annually, was read and Limitation of Estate held by I Irspital directed to be forwarded to Harrisburg :

$$
\begin{aligned}
& \text { To the Senate and House of Representatie's } \\
& \text { of the Commonacollh of Pennsylania. }
\end{aligned}
$$

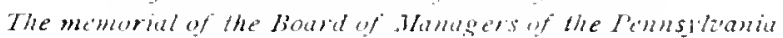

$$
\begin{aligned}
& \text { Hospithl respecthull! erpesents }
\end{aligned}
$$

That in the year 1751 a number of the hencwolent Citizeus of the CommonWealth associated together to estatsish in the City of Philadelplia a Huspital for the relief of the sick poor and insine of the Province, that a Charter was soon alter granted to "The Contributors to the lemnsylvania Hospital" and that since that period it has been dispensing its benefits, as far as its means wonld permit through every section of the State. lour memorialists would further represent that with the exception of sume assistance granted by the l'rovincial Assembly. and an early Legishature towards the erection of the original Structure, it has always depended for its support npon the contributions of the benewolent and the income from its vested funds derived from the silne source, and that from its

The following is a list of securicies received by the Pennsylvana Hospital from the Humane Society: Lehigh Coal and Navigation Co, Certificates, $\$ 6,000$; City Sixes, five Certificales, $\$ 5.500:$ Insurance Co., North America, 1 to shares: Farmers' and Mechanics' Fank, rrz shares: Philadel. pha lank, seven shares: t'hladelphid and Lancaver 'lurnpike Co., three shares; Mlortgage, (Christopher W. Wesselmann), \$t,500: Mortgage, (lesse Williams1, st, ,on; Check on Philadelphia liank, 166 . Acknowledited ly 'lreasurer John l'. lewis. 


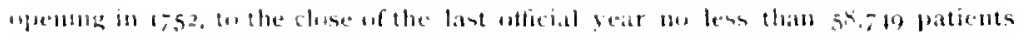

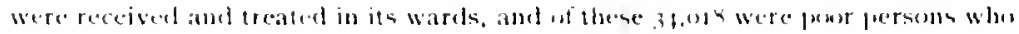

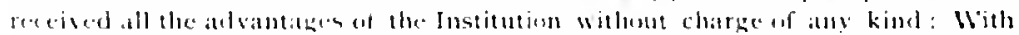

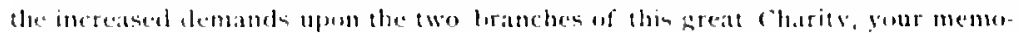

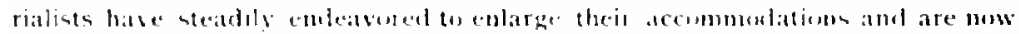

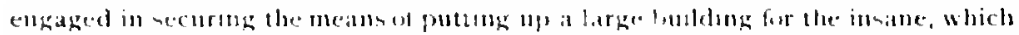

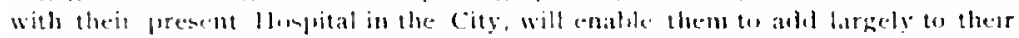

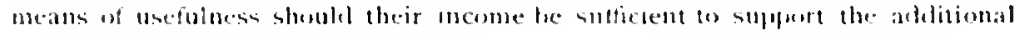
number who can the-11 le ret rived.

fine memorialints would therefore pray your lomorable buelies that "the contributor to the lenustvania Ifospital" may receive and hold any hequests or contributions made them for the purjuse at extenting the accommedations of the indigent sick and insane of Pennsyluania, and that they may lohel rested

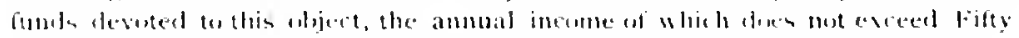
thousaud dollars.

The apleal proved rucesesful and the following was enanted:

Limiting the income of

certain

Charitable Institutions.

Wheseas, The contributurs to the Pelunsylvania buapital have cosisted ats at

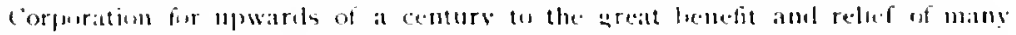

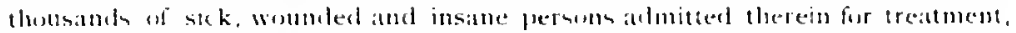

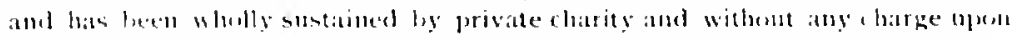

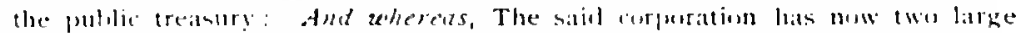

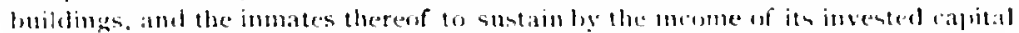

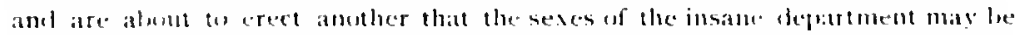

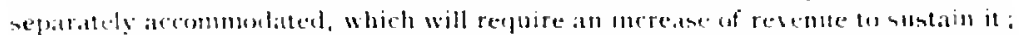

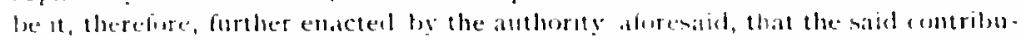

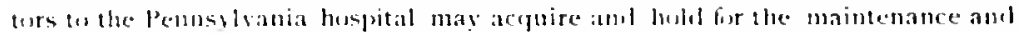
support of the several departments, and the immates fherent. pround rents, fwols and mothages, fublic and corpurate leans and stocks, tu furluce an ammal income, together whth such investments now lectel, wis excending in the whole titty themand dullats per :mmum.

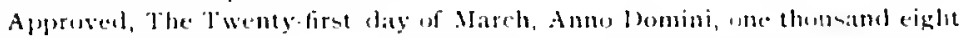
humbled and fifty six.

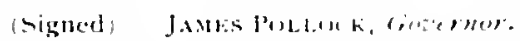

Sick and

Wiounded Suldiers and Sailors

IIounded Suldiers. "lhe Nanagers in their anmual report at a Contuilutors" Meteting helel May, 1S6, made mention of the sperial necels of the Institution. particularly unentioning the prospective demands likely to le made ly the Civil 11 ar, which had just legun and which is referred to in the following terms:

At the present time, when our country in theatened with the terrible scourge, war, it behowes as to condeavor to be prepared by every means in anr puwer, to relitse tha se whom mith huterers from the insepatrable ills which must follow in its train, and hat not one applicant should be allewed to leave our gatle while there is ruom to acconmodate, becallse the funds adeduate to redieve are wanted.

The following communication was received on Oe [oler 27 , $1 \$ 61$ :

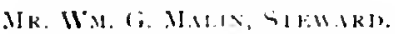

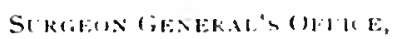

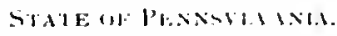

le'd" Sh, - I have been requested on luhalf of the [nited states to ask how many patients the lecmoylvania Hospital will ofler to take and the rate of board. 
I have sugrested $\$ 3$ gler week, and said I had been informed that lhe lowrd had offererl al least roo beds. Will you promplly reply as I litte promised an answer by 930 to-morrow? Of course you can obtain the desired information either to-nisht or to-morrow normong as it is an emergency and I think the acting Managers will and can promptly respond. Intil the arrangement is completed let this application be confidential. Send worl by bearer what you can do to did $m$ in the matter and ollige,

Vours respectully,

HEXRS H. SMIIII

It was found that the Ilospital could at once receive sixty pationts decommo and be prepared very fromptly to admit eighty additonal. I com- dation for mittee was alpointed to confer will surgeon General smith and to sick and vrepare at once for the reception of the Soldiers and also to offer to winded the fovernment sroumd for the arection of temuorary hosplital enfered. acrommodation.

At a sleci,l meeting held June $3,1 \$ 62,10$ consider the further accommodation of sick and wonnded soldiers, it was:

fiesulede That all the accommodations in the Institution in the Medical and Surgical wards are againoffered for the nse of the sick and wounded suleliers of our army who may he bronglut to the Ilospital.

On June 231, an agreement was made with reference to the admission of fick and Wounded Suldiers, and a contract was signed with R. H. Cuolidge, Medical Inspector IT. S. Army.

The first reception of wounded soldiers was on fuly $7_{\text {th }}$ and all were removed by Octoleer $13^{\text {the }}$, the Govermment having. in the mean. time, erected hoipitals in and aromol lhibdelphia. The whole number admitted and trealed in the Hosplital was izf. Suberpuent? many sick or wounded Soldiers am sidurs applien for treatment as individuals and were received into the wards.

In 754 , Franklin wrote that:

The kind visits and conversation of some serions persons, and the puls books whe sick that bave been left in the Hospital, recommended to the perusal of the patients, hy Visitors. have been altended with a blessing in these respects.

It would therefore seem likely that ministrations to futienls were resularly conducted, but no furber mention is made of such work for many years

[n 1764, a number of bibles. Testaments and some Sermonswere presented to the Hospital ly the Society for the l'romotion of Religions knowledge.

One of the most attentive and interested visitors to the sick was visitors. Mr. Edmund J. Yard, affectionately known as Father lard. He was born in Trenton, N. I., Jamury' 1\%, r 792, and died in Milulelphia, December 5, 18;6, aged noarly cighty-five gears. He had leen a 
Rolinills

11ink alsumbs the thatients.

regulatr workes in the wards of the llospital from his twentieth year of

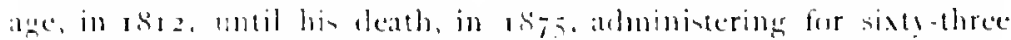

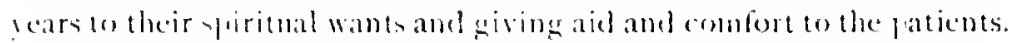

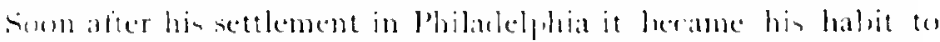

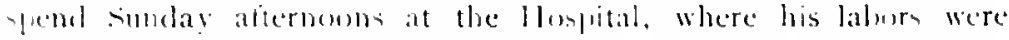

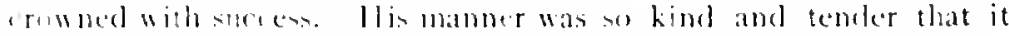

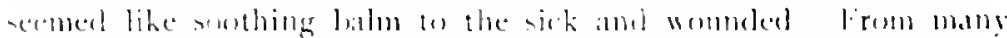
patients, after their leaving the llespital. he receded sists at his own home, and leteres, after the ir removal from the rits, afforeling rich cestimoniale to the charater of the anond wort wronght.

Mr. Howard lidwarels and Mr. lowis l. liorles have been visiturs in the ward for alout thirg sears, also laking fart in the sumbar sersices.

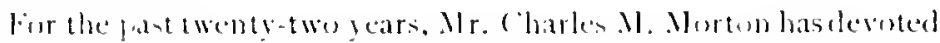

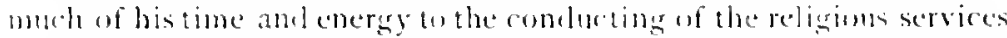
which are hedel regularly in the Library apartuent of the flospital, crers sumbar afernoon and on Wednesdar evenings. These services are mon-sectarian, such are mate as at tractive and jorofitalole as jussible. sinne of the laty vivitor conduct the mure. With the assistance of the nurses and others comnected with the lluspital. Musical and other entertamments are abs given several times during the winter,

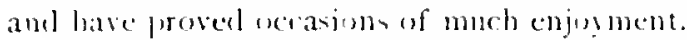

The value of these bencrolent minstrations anong the patients in the wards, which for so many years have heen so regulat and so sat is factory, have repeatrdly been acknowledged he resolutions of thanks from the lioard of Managers.

Clergumen of every denomimation are freguently in attendance and are xent for when clesired by patients.

Contrihution froml: l. Situitars inmmission.

(1) Veloruary 220 , 1869 , a welcome contribution of $s 2,000$ was rercived from the United States Sanitary (ommission Association, with the comelition that it should be applied to the relief of sick or wommeder United States Soldiers ur Sailors, or the orphan Children of such soldiers or Salors who have lost their liven in the Lnited states service. The donation was received with a veteof thanks, and the tremurer wats directed to keep the money in a separate fund, to be expended only for the mirposes specified.

It an anmual meeting of the contributors, beld May 2. I864. it was

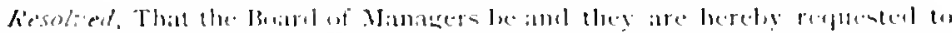

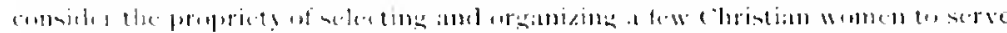

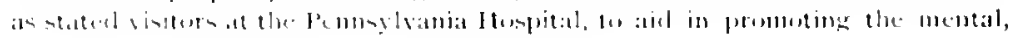




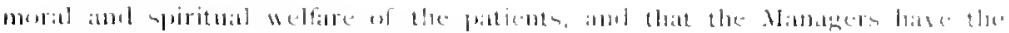

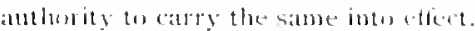

In lebruary, 1865 , the Managers recalling the valuable services onfinal of the former lioard of Visitors (see prose sf), voted to appoint a Womam committec of

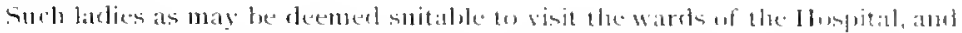
read and comperse with the patients from time to time.

'The following communication was received from the Visitors, Rumm of June 26,1866 , as their first anmual report:

Wim:III

As it is mow more than whe yeat since a company of latien were insted by

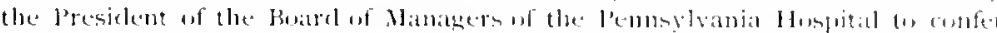

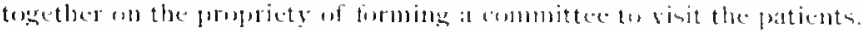

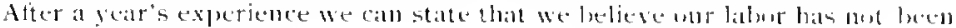
in vilin.

The plan w organization hats been a l'resilent, secretary and committen fin

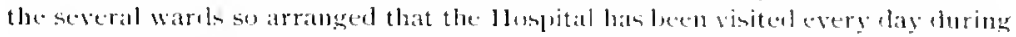
the two stumber months.

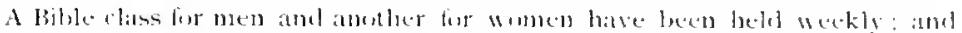

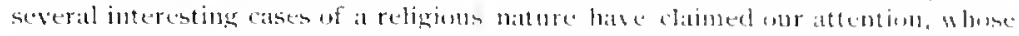

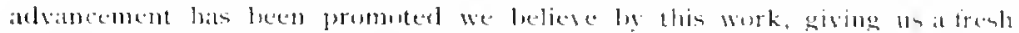
atsoldatuce of the truth: "Ny word shall nest return unte me bojel, list it hall

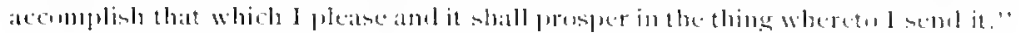

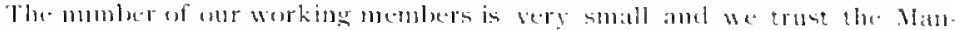

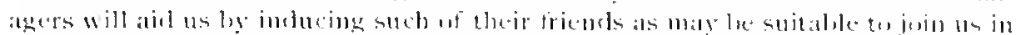
this interesting tield of labur.

'This committee has continued to visit to the present time and has been of unquestionable service in ameliorating the condition of many of those whose sufferings have compelled them to lecome Hospital inmates.

With regard to the care of firemen, the following contract with lujureal the I'biladelphia Contributionshipl was approved, Ituly 29, 186\%. Firemen.

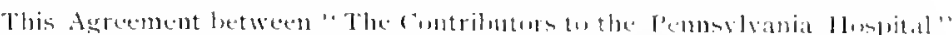

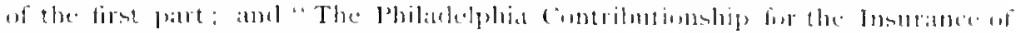

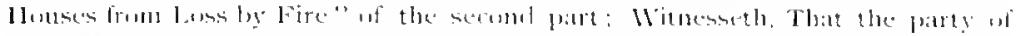

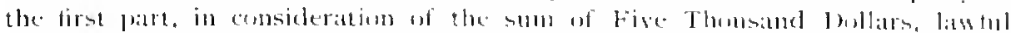

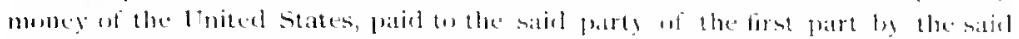

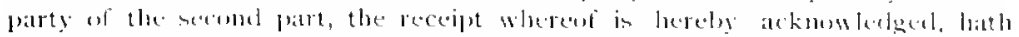

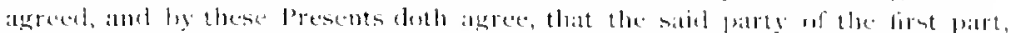

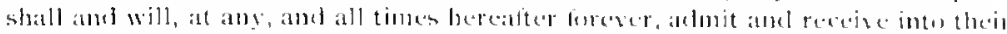

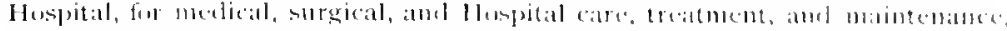

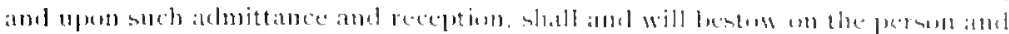

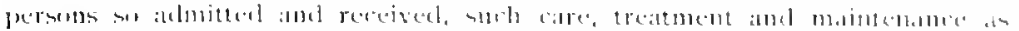

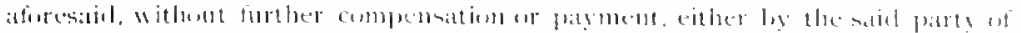

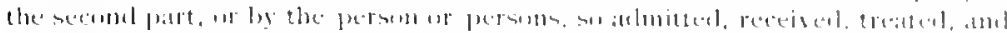

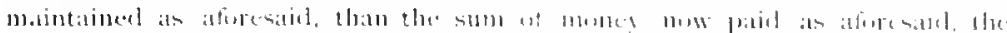

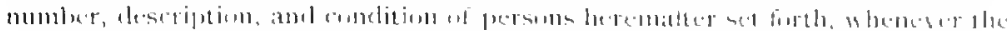

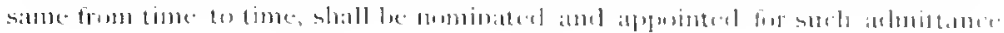

Hice Buthe Fintillisluet. 


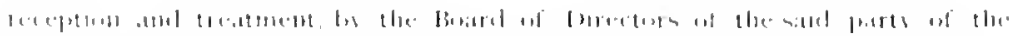

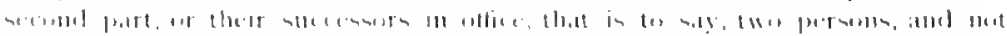

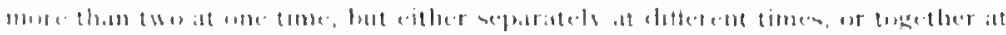

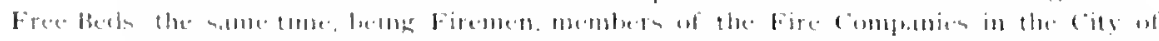

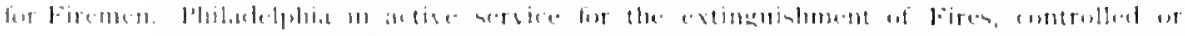

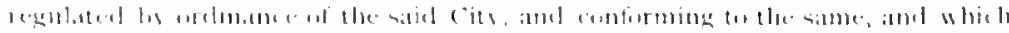

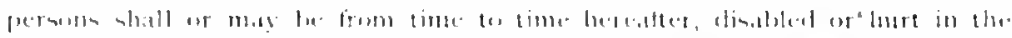

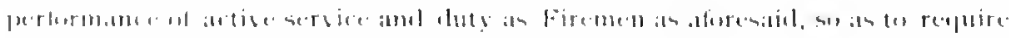

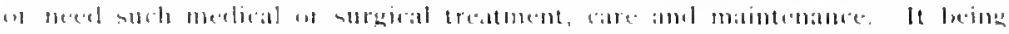

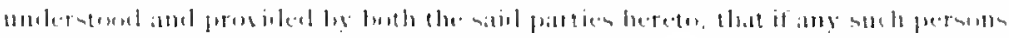

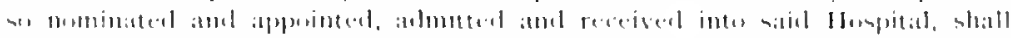

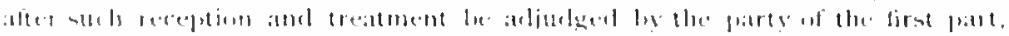

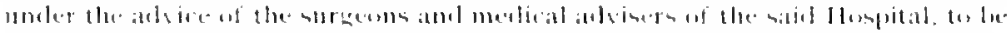

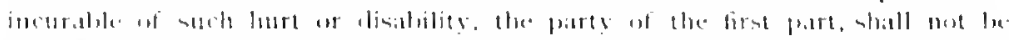

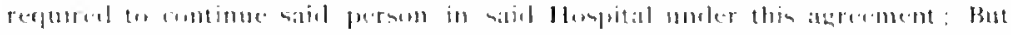

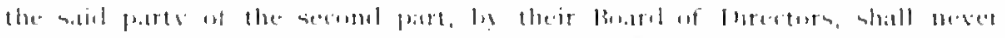

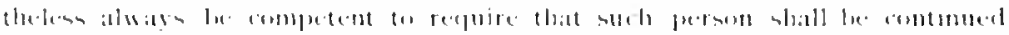

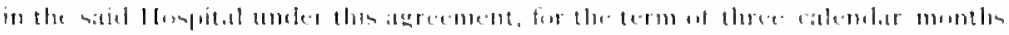

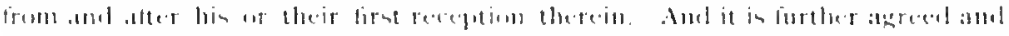

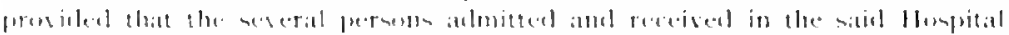

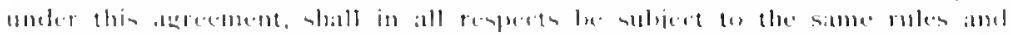

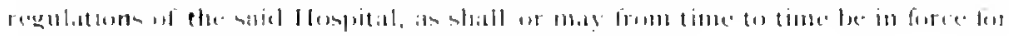

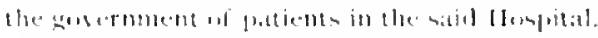

Vutu.1 In response to an application, the Mutual . Inoctation made a Amani.tinas similar algreenent:

(impitm Ti. the Honaters

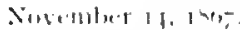

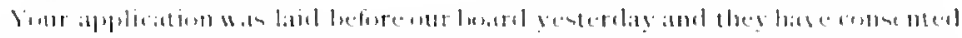

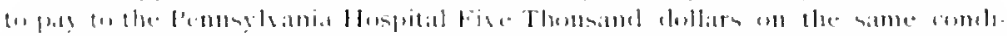

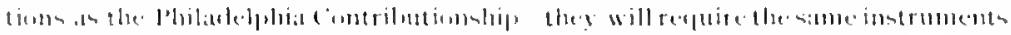

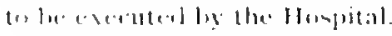

"lhis agreenent was marle and the money duly faid to the licuanturer.

Sen At a meeting beld octoler 11, 1867, a conference with the thinial Medical staff wa held in reference to the erection of the new operattiminlis the:itti. ing and lecture-room.

(1) April 27 , I 86,8 , the minutes state that:

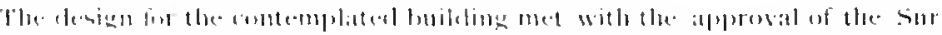

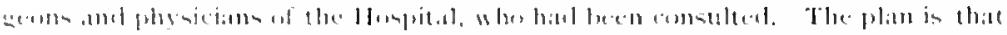

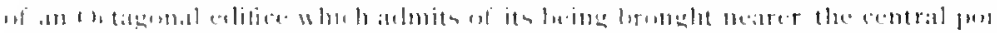
tind of the old If

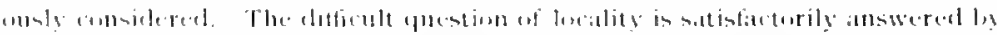

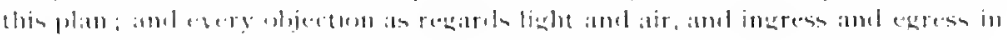

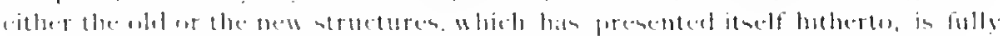

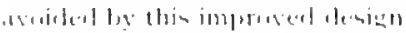

The amphitheatre was completed and formally opened January 9. 1860 , ly an aldress delivered ly Wr. John F. Meigs, of the Medical staff, to the Managers, and also to four or five humdred physirians and stulents. 


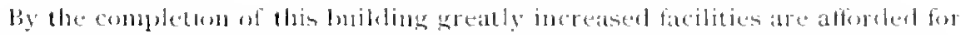

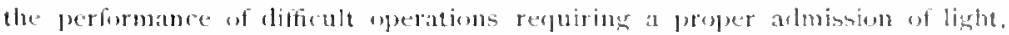
which will remedy an ineonvenience berinsly felt in the wh operating roum,

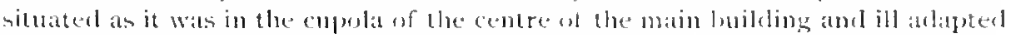
for accommodating the large number of students.

The whole cost of the building was $\$ 27,072.08$. while the subscriptions received from friends amounted to $\$ 12,7+2.82$; the balance leeing paid from the Medical Library liund.

This building has been constantly in use since 1868 , indeed up to the present time. With the completion of the New Memorial wards, a new operating and general lecture-room will be required, in addition to the three small operating rooms in the new buildings, so that the octagonal amphitheatre of $\mathbf{x} 868$ is doomed soon to be demolished.

At a meeting held March 20, 1860, at the request of the Hos- Mirminum. pital Staff, Joseph G. Richardson, M. D., was elected Microscopist to the Hospital. He was succeeded May +1885 , by Henry M. Fisher, M. D., the present incumbent. On May 5, 1890, the office was combined with others and Henry M. Fisher, M. D., was designated as l'athologist, Curator, and Microscopist.

The office of Pathological Chemist was estahlished November 28 , 1870 , at the request of the Hospital Staff, to make such chemical examinations as may be required, by the direction of the Medical officers. At the date given, Horace linney IIare, M. D., was elected the l'athological Chemist. 'This office was alolished Mlay 26, is 79. 'The Managers, having recently' decided to equip hacteriological and chemical laboratories, will probalsly, in the near future, revire the office of l'athological Chemist.

In 1 lecember, 1870 , the II istorical Society of Pennsylrania made application for the use of the licture House recently vacated by the ( illege of Plyysicians, to be used for a depository of their collection, and as a place for meetings. The Society made some additions, by luildings, which included an extension on the east and west sides. The Historical Society occupied the premises until it decided to purchase the property of the late General l'atterson at the south-west comer of Thirteenth and Locust Streets, to which it removed its harge and valuable collection in March, 1884.

The Legislature in 1871 prassed an Act to set lack the south line of Spruce Street, between Eighth and Ninth Streets: which would reguire the removal of the Hospital wall, on that street, ahout ten feet southward.

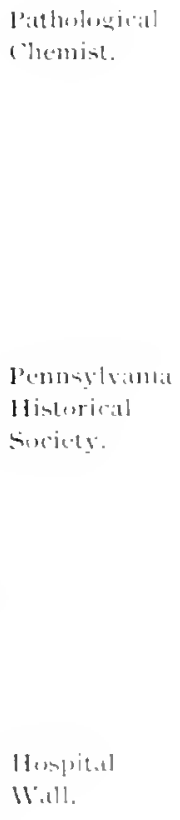

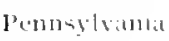
Hislerical 


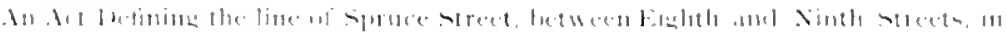

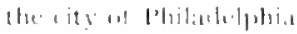

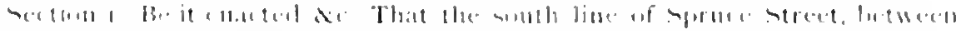

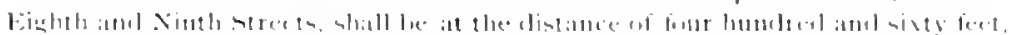

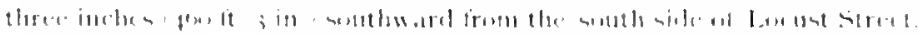

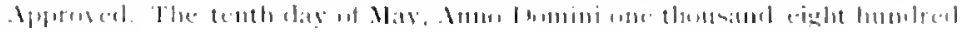
and herente ine.

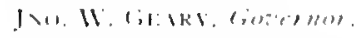

Mirlenalw

The Managers, in referene to this . Iet of May 10,1871 , to nel if sprese back the wall on sprence sireet,

itrect.

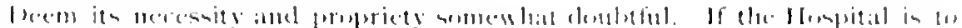

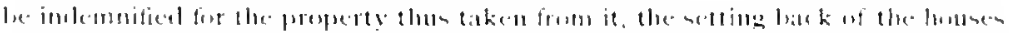

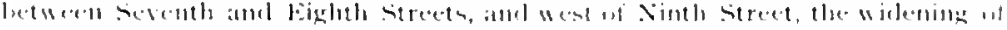

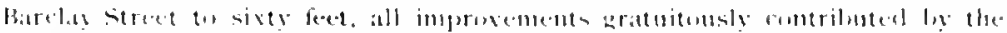

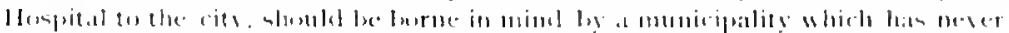

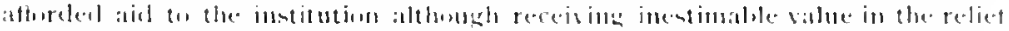

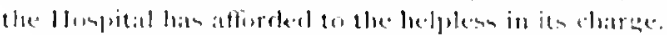

Sulsespenty, in the case of the petition an the Court of (ommon l'leas to secure the widening of fipruce streel, which was "lunered ly the Managers, the Court dismined the petition and

Ilumlamm refused the writ of mandamus applied for by the petitioners. The refined. Managers on their part petitioned the lecgislature for the rejeal of the Act anthorizing the mutilation of the Hoypital property, on the ground that it was an act to promote private interests, and not for the seneral benefit of the people. Soon afterwards the legislature granted relief by a supplementary act.

The carrying out of this ict would have necessitated the destrue. tion of many fine old trees, 1 which the managers and man! of the ritians of the neightorhood were desirous of having preserved.

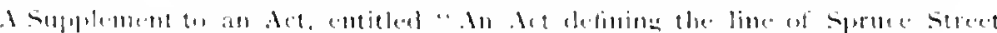

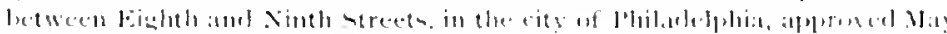

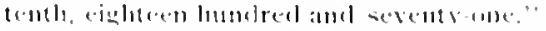

Reliei arinterl

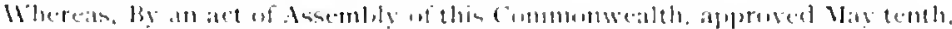

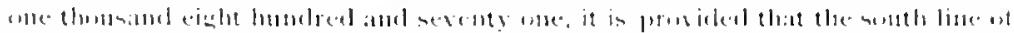

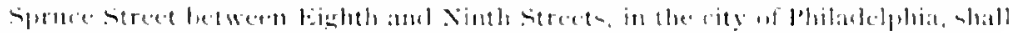

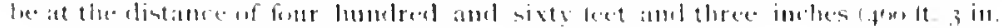

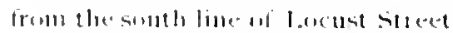

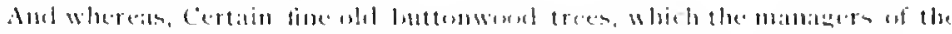

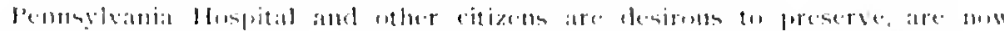

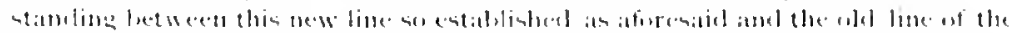
street: theretione.

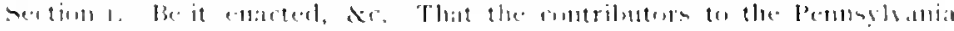

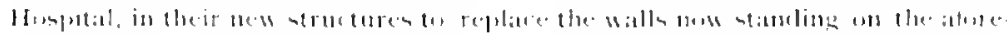

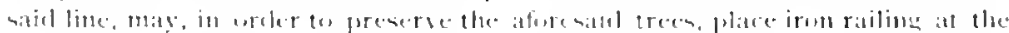

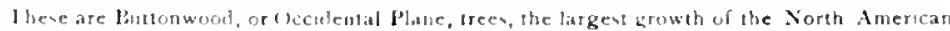
fores: llicy were plantel an the year 1756, by llugh Roberis, one of the fint Managers of the

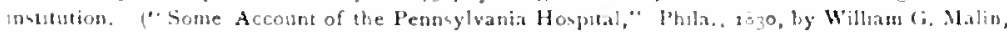
l.arat:an.1 


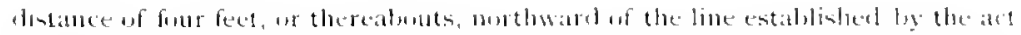

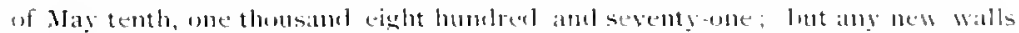
wi brick or stone bo be erected shall be wh the new line, as established by that

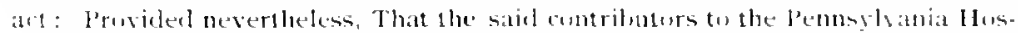

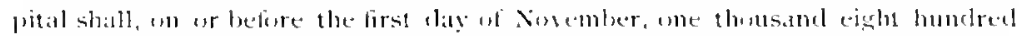

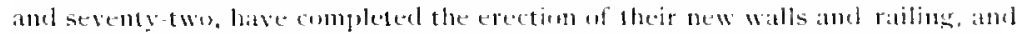

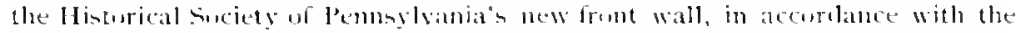

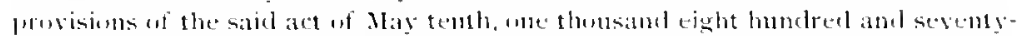
ome, and of this supplementary at: And provided further That the sidel com.

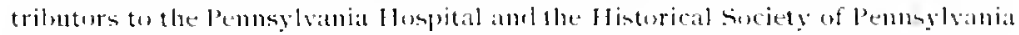

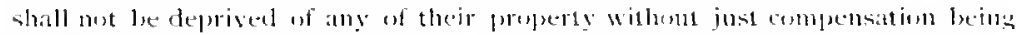
male therefirs.

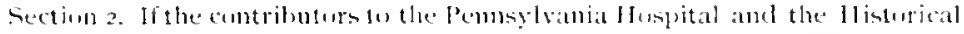

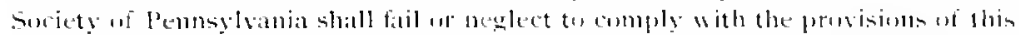
al', and the act to which this is at sopplement, by setting bate the Hospital wall

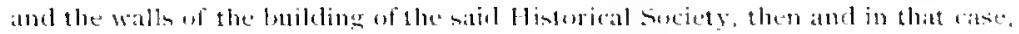

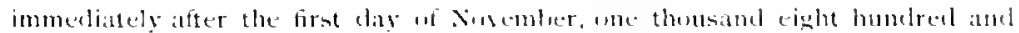

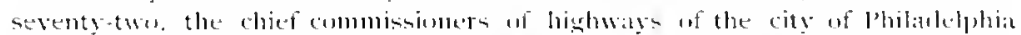

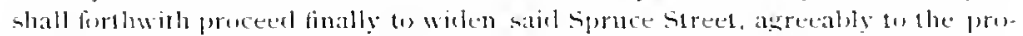
visions of the act on which this is a supplement: and the rity sulicitur of the cits"

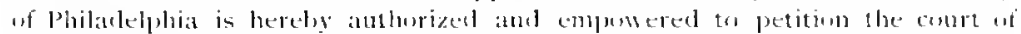
guarter sessions of the county uf Philatelphia for the appointment uf a jurg 10

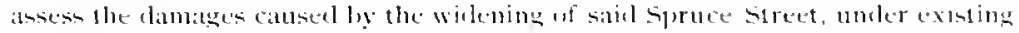
laws for the assessment of damages for the opening and widening of strets in the cily uf philadelphia.

Approved. The thirel day of April, Anmo fomini une lousame eight luumbecl ancl sevents-two.

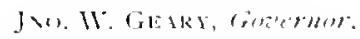

The practice of keeping notes of interesting cases and surgical kepurthen operations had been introduced very early in the history of the IJospital. Cisces The Managers passed the following resolution, ()ctober 29,1836 :

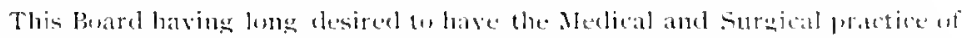

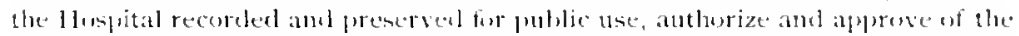
publeation of such parts or the whole of it, under the inspection atul supervision of the attending physicians atml surgens fon the time leeing wn whom whly the

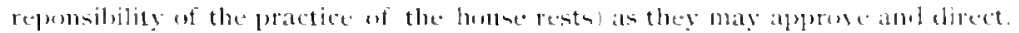

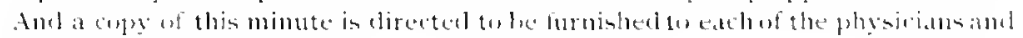
surgens of this lustilution.

However, it was not until 1833 , that a systematic method of rerording all cases by the Resident Physicians was hegun by direction of the Managers, and has since been maintained. In rsso. the Managers, at the sugrestion of two members of the medical staff, I)rs. T. (. Norton and William Hunt, issued a volume, entitled "suresery in the I'ennsylyania Itospital," which containet an epitome of the practice of the Hospital since 1756 , with an accosmt of the more interesting cases, and also some statistical tables. some years previously, in I 868 , publication of the medical and surgical reprorts of the Pennsyliania Hospital had been commenced, but they were discontinued at the termination of the second volume. 


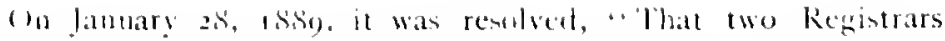

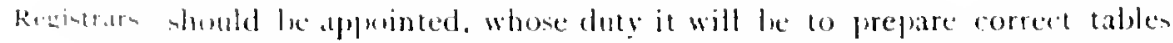
wi all cases for publication in the Ammual Report."

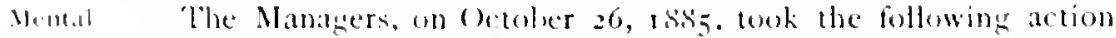

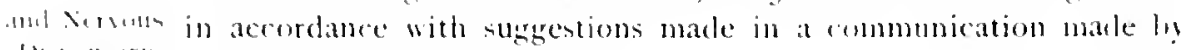

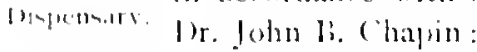

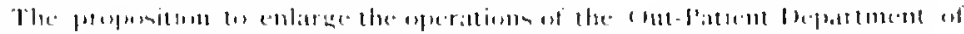

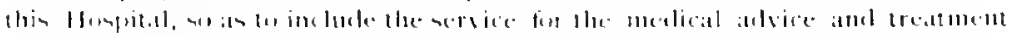

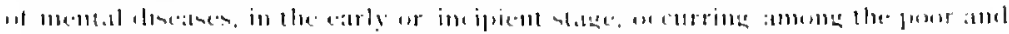

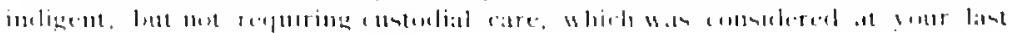

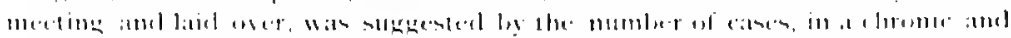

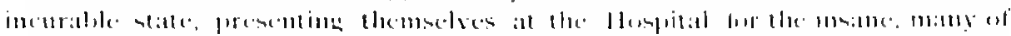

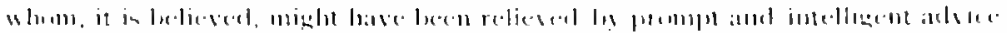

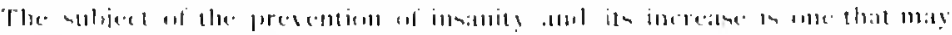

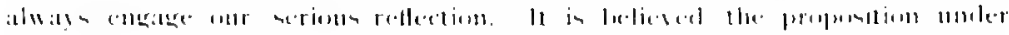

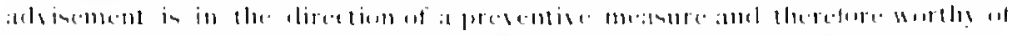

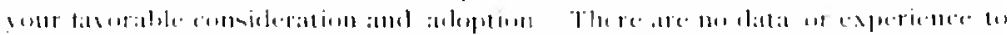

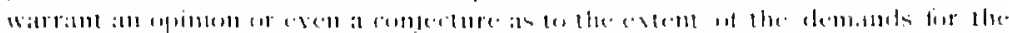

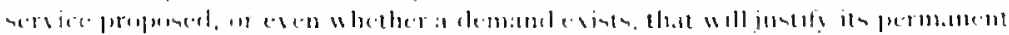

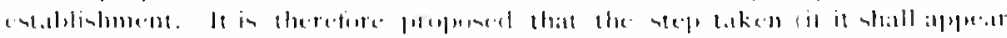

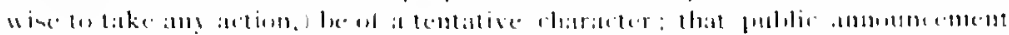

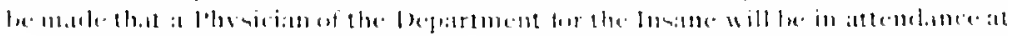

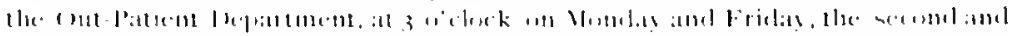

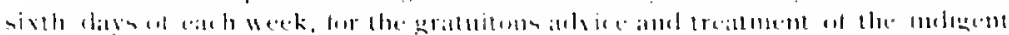

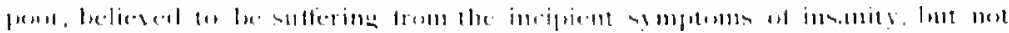

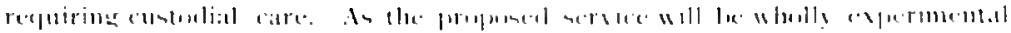

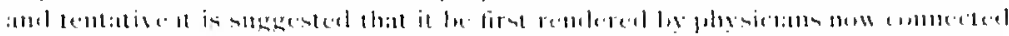

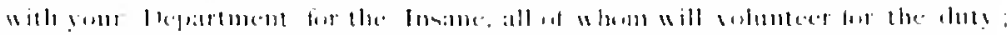

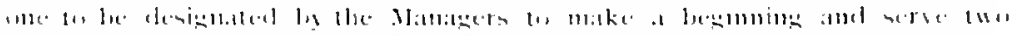

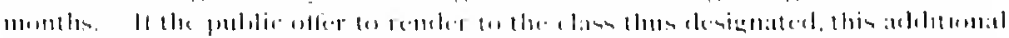

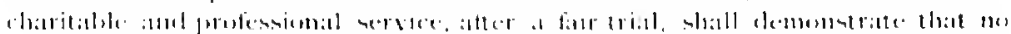

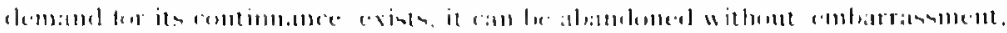

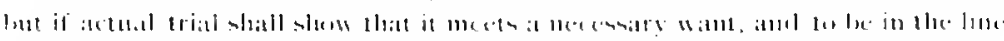

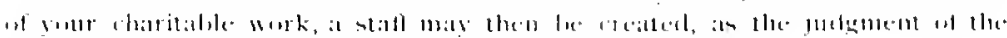

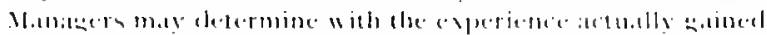

The propusent branch was establinhed and publir clinicesplobinted to be held regularly twice a weet, which are well attended. and the service has been mate permanent.

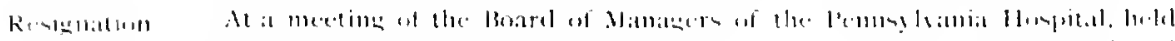

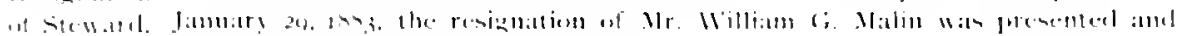

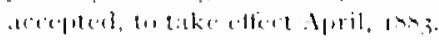

The Medical staff and Resident l'hysicians, deeming it fitting to take some fublic notice of the above action of the lioard of Mana-

implimen sers, determined to tender the venerable steward the honor of a

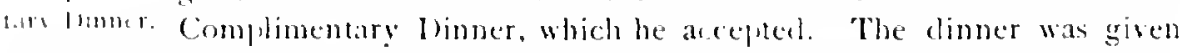

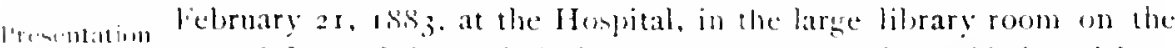

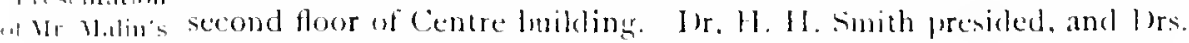
lintis. Morton and Hunt were the (ommittee on .Irrangenents. In inter- 


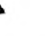




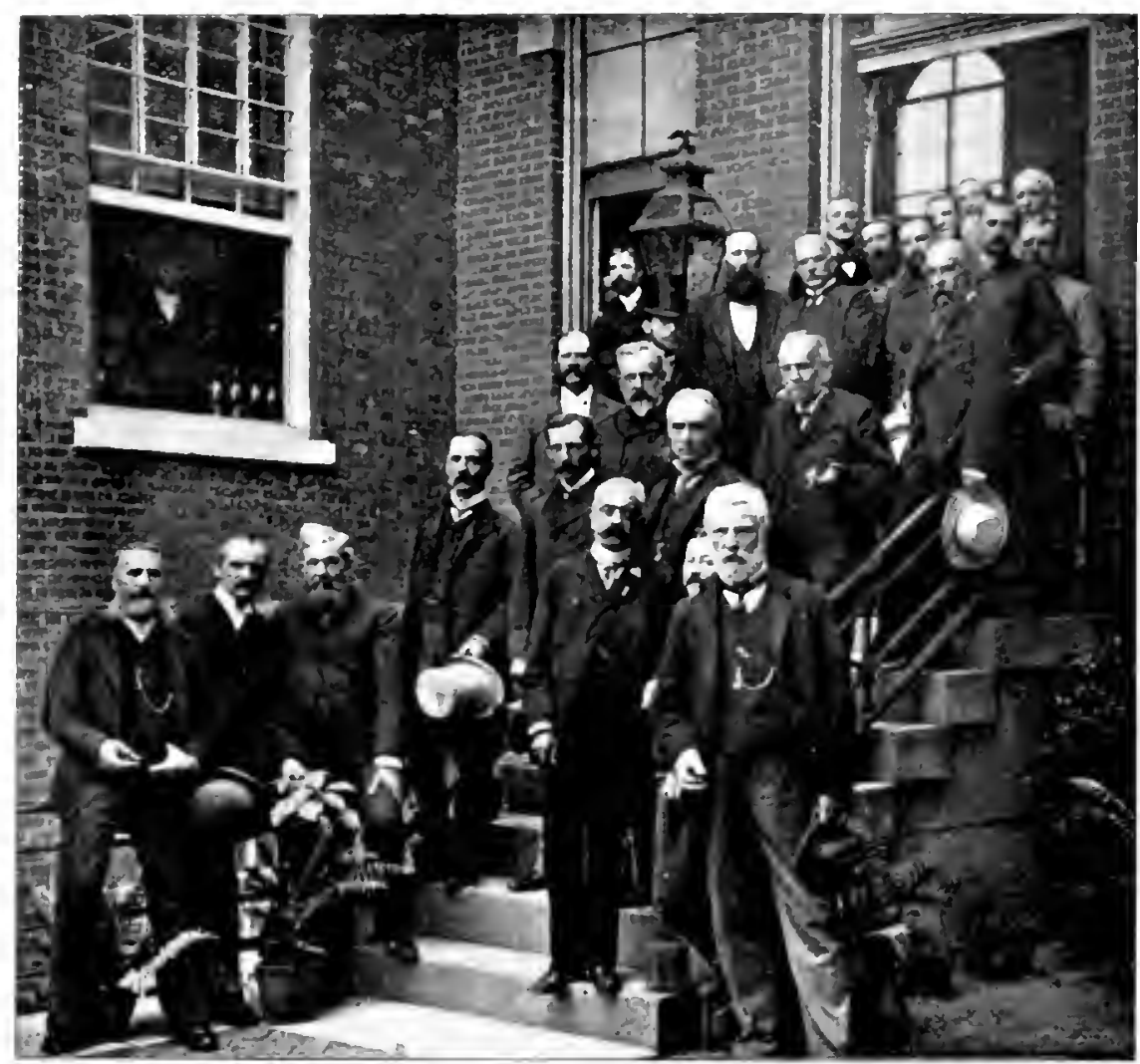

1). Molton

Ms. Beni. H. Shrenaker 1)r. Cordes Dr, f: Felding Blandford Surg, Cien"] Marston Prof. Wiliam Lloyd

1), Willaw Anderson

I)r. Josegh Recamier

I'r of. I.eon I.efort

Dr. A. 1.. rubh

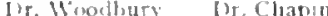


esting feature of the occasion was the gresentation of a life-size portrait in oil of Mr. Malin, by the ex-Residents ancl Medical staff to the Managers, which now adorns the wall just outside of the old steward's room.

In I 885, the "Association of Resident Physicians" was formed. the intention leing to meet each year at the Hospital; the first meeting was held in the Library of the Hospital on Thursday evening. December 17, 1885; dinner was served at $6.3^{\circ}$, after which several addresses were made; these remnions have been held on several occasions, at irregular intervals, since that time.

The Ninth International Medical Congress was held in the city Fureirn of Washington, D. C. ; the Sessions opened on Monday, September 5 , Visiturs I 887 , and a number of distinguished medical visitors from all parts of the world were in attendance upon its deliberations, during the week that it remained in session. As some of the delegates to the Congress stopped in Jhiladelhia for a few days on their way to Washington, it was thought that they might well be entertained by a visit to the Pennsylvania Hospital. Accordingly, the Buard of Managers invited them to pay a visit to the Hospital, and arrangements were made to hold an informal Reception, asking some l'hiladelphia physicians to meet them, and Dr. Thomas G. Morton, of the Hospital Staff. was appointed to hold a surgical clinic, at which some special cases might be presented.

The reception was held September ist, at three o'clork. 'The visitors were received by Messrs. Wistar Morris, Benj. H. Shoemaker, Alexander Biddle, and John 1:. Garrett, of the lioard of Nlanagers, and the memlers of the Medical Staff were also in attendance, consisting of llrs. William Hunt, Thomas G. Norton, John II. Packarel, John Ashhurst, Jr., J. M. Da Costa, James H. Ilutchinson, Morris Longstreth, and Arthur V. Meigs. Among the foreign visitors were 1)r. Jos. Recamier, of Paris; Dr. Julius Andeer, of Munich; Dr. J. S. Cirant Bey, of Egypt; Dr. Chas. 1. Phillips, of London; Deputy surgeon General J. A. Marston, England; Prof. Leon le Fort, Paris; Dr. Wm. Anderson, London, England; 1)r. Wm. Lloyd, of London ; Prof. Wm. Nurrell; [Mr. 11. l.eopuld Servais, of belgium; Dr. J. Cordes, of Ceneva; Ir. (r. Fielding Ilandford, of London, and Dr. A. L. Ciulh, of London.

A brief address of welcome was then delivered by Juhn li. Garrett, Ere, reprenenting the l,oard of Managers. after which some clinical cases of unusual interest were shown. illustrating the pratice of the house, by l.)r. Morton, and the gnests made a tour of inspection. ending with a collation in the library and a general comerarione. 
The initers departed, highly pleased with all that they had seen, which had evidently made a very favorable impression upon them.

The Niun

Trinturns

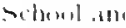

Iline.

For many years previons to 1875 . the duty of muring the sick and injured in the Honpital, ats wats generally the custom in all hospitals, was entruted to male nurses and ansistants in each of the men' warels, and female nurses and asvintants for the women's wards. These ponitions were given to trustortiny and experienced nures. althomgl they had no special training in the technical sense.

. Whout this time a commiltee appuinted to establish a "Pennsylumia lloppital Trainine sichool for Nurses," reported favorally upen al flan which was approverl and a Sistem of Rules for Nursen in Training arlopted.

Applicants for the benefits of the sichool were refurired to be cwenty-one sears of age. After al rourse of training of one vear in the warels, both Medical anel sirgioal, the candiclate having the spproval of the Mamagers. Medical staff and Matron, was presented with a certificate that she had fulfilled all the repuirements of the contre and approving her good conduet and competency in nursing.

In 1.575 . Miss frances Irwin was appointed the (hief Nurse to supervice all the wards and served three years. In 1879 the office of superintendent of Nursen was created. Miss Rachel A. Bunting was appointed, who, with a corps of women trained under her direction. las the entire charge of the mursing in the female warts. At the clene of the first year of trial, the Managern reported, " we helieve we can with propriety say that in cleanliness, neatness and exactnes, of attention to all requirements and caretiul tender attention to their surgical and medical patients, the duty ferformed is all that can lee clesired."

The Managers of the Woman's Ilospital of l'hilatel, hia being cenirous that the female nurses in training in that Institution should have the advantages of at least une year's service in the wards of the lennstrania llospital, application wats made to the Mlanagers early in $18 ; 9$ and after several conferences with a Committee from the Wimun's Hospital, this privilege was wanted.

This plan of introducing woman stuclent nurses from the pupil of the Woman's llospital was put inte operation Octoleer $27,1879$.

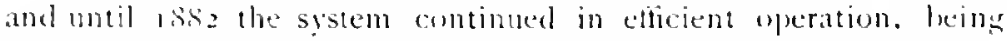
arefinly supervised for the benefit of patients, and it was foumel of great value an a practical school in nursiug.

In tisis. at the refuest of the manager of the lloman's Hospital, who felt the need of a more extended serice from the murnes in their 
own wards, the arrangement which had been in force for four years, to the mutnal advantage of both institutions, was terminated.

On May 9, I 852 , the following communication was received:

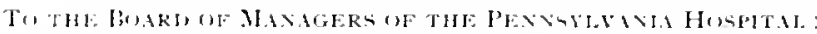

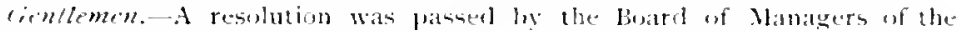

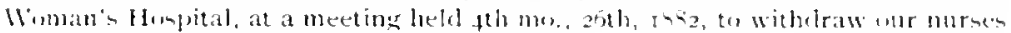
from the l'ennayluania Hospital.

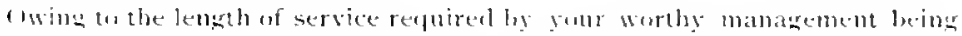

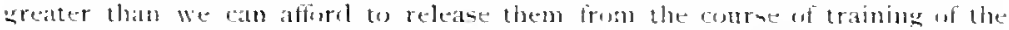

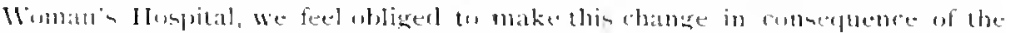

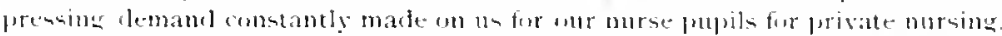

Me herely tender our sincere thanks for the kinduess and courtesy shown us during the existence of the contrart betuede us

(n) July 26, i886, it was resolved that the Picture Houne could the made, after some alterations, a suitable temporary home for the Nures, and a Committee was appointed to carry out the jlan, which was accomplished. The cost of the necessary alterations and furnish. ing. alout $\$ 4,500$, was paid by the individual nembers of the Boarl of Wanagers: this building was so occuplied until $\mathbf{s} 593$, when the new lmilding for the Nurses' Home was opened. (See page 106).

The late Charles J. Harral presented a piano, and numerom. engravings to adorn the walls.

It was also decided to provide a special reference library and, on lugust 29.1887.

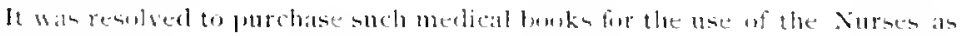
mas le reypirect.

As a result, and with the donatione from many friends. the lihrary of the Home has become a valuable aljunct to the teaching. and contains. at fresent, the modern text look, lesides many volumes upon mincellancous sulpjects, making a useful collection.

Lertures to the nurses during several months of each vear were inaugurated and systematically delivered ly members of the Medical and Surgicalstaff of the Hospital and Out-Patient Staff, in 1896 , as a voluntary aid to the instruction by the superintendent, and these have heen regularly given ince this time. Miss Marion E. Smith was appointed Head Lurse in 1896 , and in June, 1889 , resigned her position, having receivel a more remunerative apjointment at the City Almshouse in West l'hiladelphia. In accepting her resignation. the thanks of the Board were presented to her for the faithful and efficient manner in which she had performed the duties of her position during her term of service in their employ. Miss Anna A. Hinte was elected Septemler ist. Isss, who, three years later. was succeeded ly Miss Rachel I'leteher,

Tenuporary Nután Inume. [.tetilant Sinrite

II earl Xiuna. 


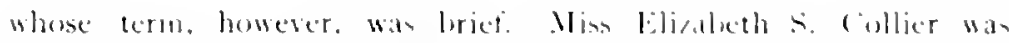
appointed to the position . Augut 28, 1 sog, and has since disc harged its arduous and reoponsible duties.

An (event occurred, in the bear 1 sion, which showed the efficiency of medical skill and nurse training in the lloppital:

(I) April 27. ISg2, the Cirand Central Theatre, on Walnut

kinisurianil

|limplit

necrents

landed.

$$
\text { crim }
$$

\section{(n)} their coming. Some were hrought in carriages, but many more were on foot. They fomnd the gater open, the kesident Phy-icians at their ponts, and the llead Nurse, with ber thirty-two nures, all on duty, and within twenty minutes afeer the fire had started everything was prepared for their reception and promple treatment.

Within forty minutes after the first paticnt from the fire was received. all hat been properly cared bor, forty-seven severe injuries were dressed in the wards. and those able to walk were on their way home, duly relieved. Neanwhile the Ambulance, with a sulply 16! elressing material, under the charge of a physician. harl gone to the ground, and wenty-two anes were dressed on the yme, sithont coming to the llospital.

Eight of the cases received into the Honptal were so ball! injured that they subsequently diecl. The Hospital staff ha rarely been so sudetenly and urgently taxed; fut it nevertheless responded so energetically and effectually a to clicit the warmest commendation of their service and the humame spirit whirh artuated them.

The corps of nurses responded likewine to the emergency and were deserving of high praise for their efficient service.

In May, ISg2, the new lubleling, known as the ". Vursen' Home." was commenced; it was finished the following vear. It is set hark twenty feet from the Siruce sitreet line, near the northwent cornet of the grounds. It extends one humbed amol four fect southwad aloug Ninth street, and thirty-seven feet ean an Siruce street. It contain forly-two bed-roums, twelle of these leing $12 \times 12$ : twenty-four rof them are $9 \times 52$, and the rematioler about $12 \times 14$ feet. There in a

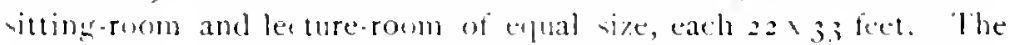

\footnotetext{
The only calamity in the history of the Hosputal at all conparable to this, hed happened thirty years previously. Un Match 29, 1862, an explosion had occurted at Tenth and Keed Streets, at the factory of Samuel Jackson, a maker of pyrolcchnics, wo at the time had a large order for the manufacure of carridges for the Governmeat. In this exploston and subsefuent fire, many perions uere killed or horrbly mutilated or burned-of thove thus injured, twenty fema'es and e'ght males uere admuted to the Hospital.
} 


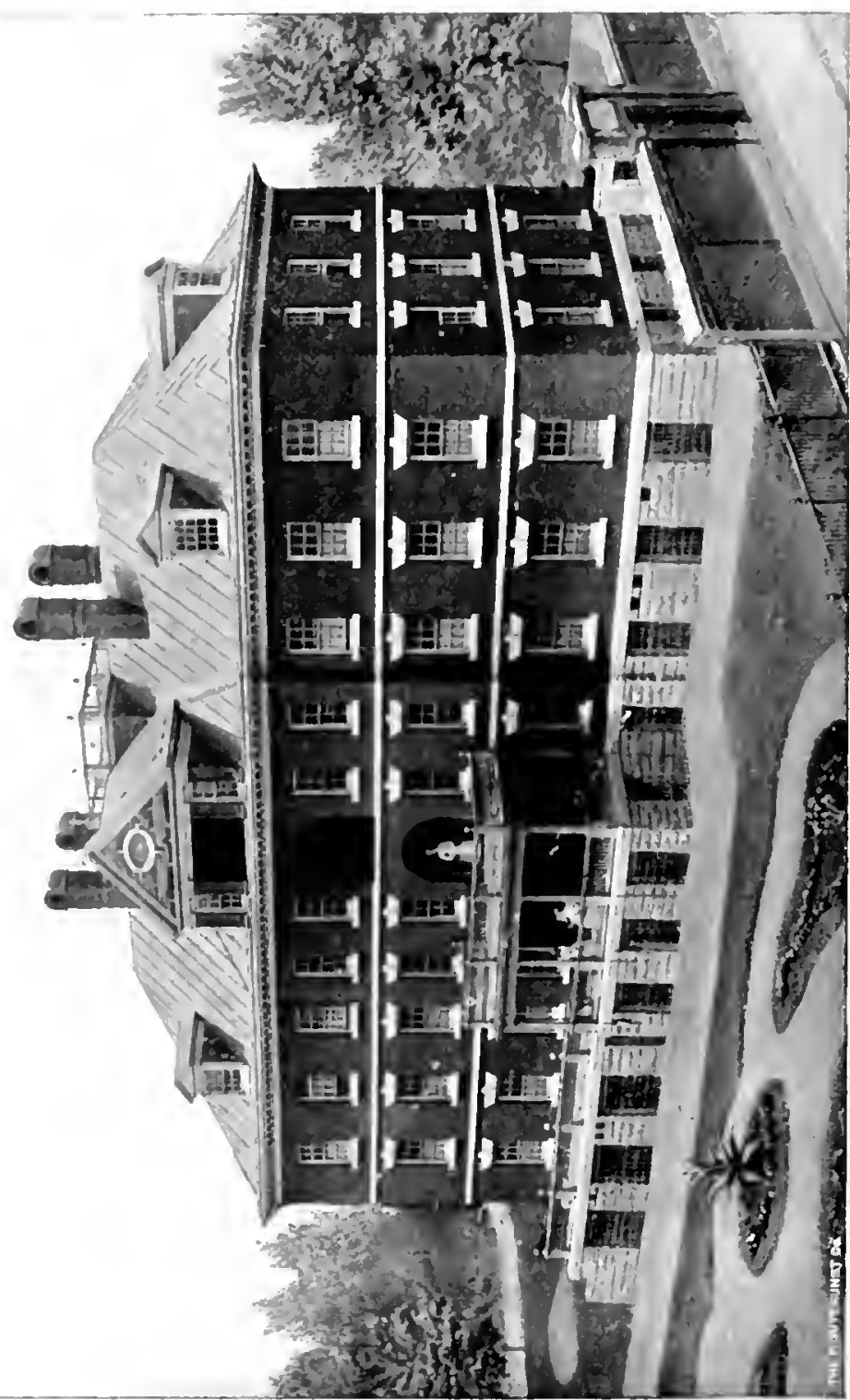

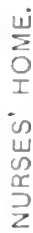


building is three stories in height, with basement and attic. The latter is reserved for unexpected occasions, or isolation in case of emergency.

The Misses Blanchard, of Jhiladelphia, in 1892 , with largeminded liberality, supplied the means for the entire cost of the building and its furmishing, by a gift of $\$ 50.000$.

A tablet of Caen stone, inserted in the hallway just at the entrance, records that,

TIIS BUILINNG IS ERECTED IN IANING MEMORY UF

WILLIAM A. BLAN(IARU ANU MARIA E. BLANCHARI)

B' TIIEIR CHIIJRE.

In May, 1893 , the first public commencement of the Training school was held, and at this time, a class decoration in the shape of a lin bearing the design of the Hospital seal was first userl. This has since been adopted as a balge and will be worn by the graduates.

There are now thirty-four female nurses, and twelve male nurses in the Training School. There have been sixty-four graduates from the Nurse Training School during the time it has been in operation.

The nurses for two years past, in addition to the regular duties in the wards, have been thoroughly taught cooking and massage, besides the systematic instruction by lectures given by the medical and surgical staff, the resident physicians and the physicians connected with the Out Department, as in former years.

'The Dispensary service of the Hospital was inangurated December 1) P'otient I3, 1752, soon after the Hospital was opened. The minutes of hormm. January 2, 1753, record that on the ahove date John small was admitted to be treated as an Ont-Patient; "a case of periodical Madness." Subsequently the records state " that several out-patients had received the advice of the physicians and the use of the medicines received from London."

Medical attendance in the early days of the Hospital was also given the indigent at their own homes, the Apprentices being respuired "to visit the poor sick in the City." Occasionally the members of the Medical staff were also called upon to perform this duty. The Hospital then leing some distance from the built-up part of the City, a horse was kejt for this service.

In $\mathrm{I} S \mathrm{SO}_{7}$ the Nedical Staff recommended the appointment of

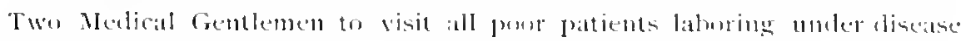
whe may apply for assintince, and that thoir preseriptions be mate up at the Hospititl.

This plan was adopted and J)r. John Syng I lorsey was placed in charge of the Northern, and 1 r. Nathaniel Chapman of the Sunthern. district of the City. 
Conder this arrangement Drs. Hartshurne, Hirgant, Hopkins, Euth Mural liestum. Calbun, Moore. and others suberguently rendered efficient (int lortent publit service.

In 1 sis, when two new dinpensaries were establisherl by the ( ity, wne in the Nurthern liberties, and the other in Soushwark, visitation of the poor at their homes and the Out-latient service of the Huppital were dincontinues. There in at present no record of the number of but-latients attended before 1797. lut from 1797 to $1818,15.258$ persm, had been charitally attended and furnished with medicine at the expense of the Ilompital.

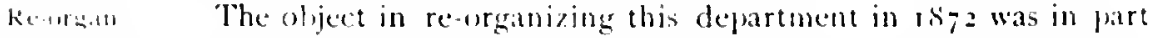
izatint) $\cdots 1 / n$.

()at [) to prevent the available means for the relief of recent accirlents from leing restricted, and this. it was ledieved, could be accomplished ly relieving the wards of such convaleseents as could be safely returned th their homen, and be an well cared for by occasionally presenting themelves at the Out-1)epartment.

form 1872 until 18 is the rooms in the Eighth Stree diate

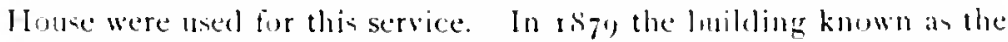
" Ketreat," " (also sometimen called "the lodge") was so eccupried, but the numlers alphying for relief increased to sub hat extent, that larger accommodations were demanded. Arcordingly. in $\mathrm{r} 892$, in lot of ground $3^{\text {sh }} \times 100$ feet was purchated an spruce street, directly opposite the llospital, upon which a inilflung was erecterl, esfecially

xin designed for the Out-latient Department, and presented to the lablane Hospital by Mr. Garrett. one of the contrilustors (sce illustration). prenemed In the rear of this building an Ambulanse Honse was built.

In regard to the plan of the new Out-lepartment, the minutes state lhat

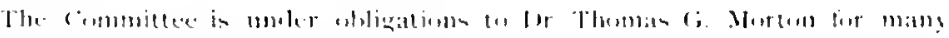

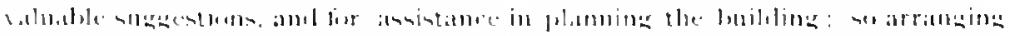

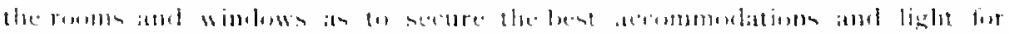

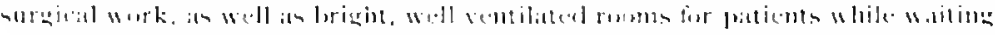

I memorial tablet records the gift of the luilding (which, with the grount, cost aluent $\$ 50.000$ ) to the (intriluturs of the Hespital, as follow:

In order to atford increased accommodation fur the insane women, and to provide rouns for exercine and anuement, the Manigers, wh the coment of the Contributom, in 1825, built atwo. sory brick utructure near the northwent corner of lhe lot, on Spruce Strect below Nin:h. On reverit] occasion the neighbors complained of the noises of the insane during their periods of recreation and at other tumes. In 1 - to the new Lulding in Weat thiladelphia wetecrected and all the insane patients were taken across the river. Subsejuently the Retreat was ued as an isolasing ward during an epidemic of cholera and for caves of other infectiou, diseases at varous times. In several necasions. while the utargal wards were being refiared or cleaned, the patents were temporarily iransferred to the Retreat. It was torn down when the new d)t-Patient llepartment was built in 1803. 



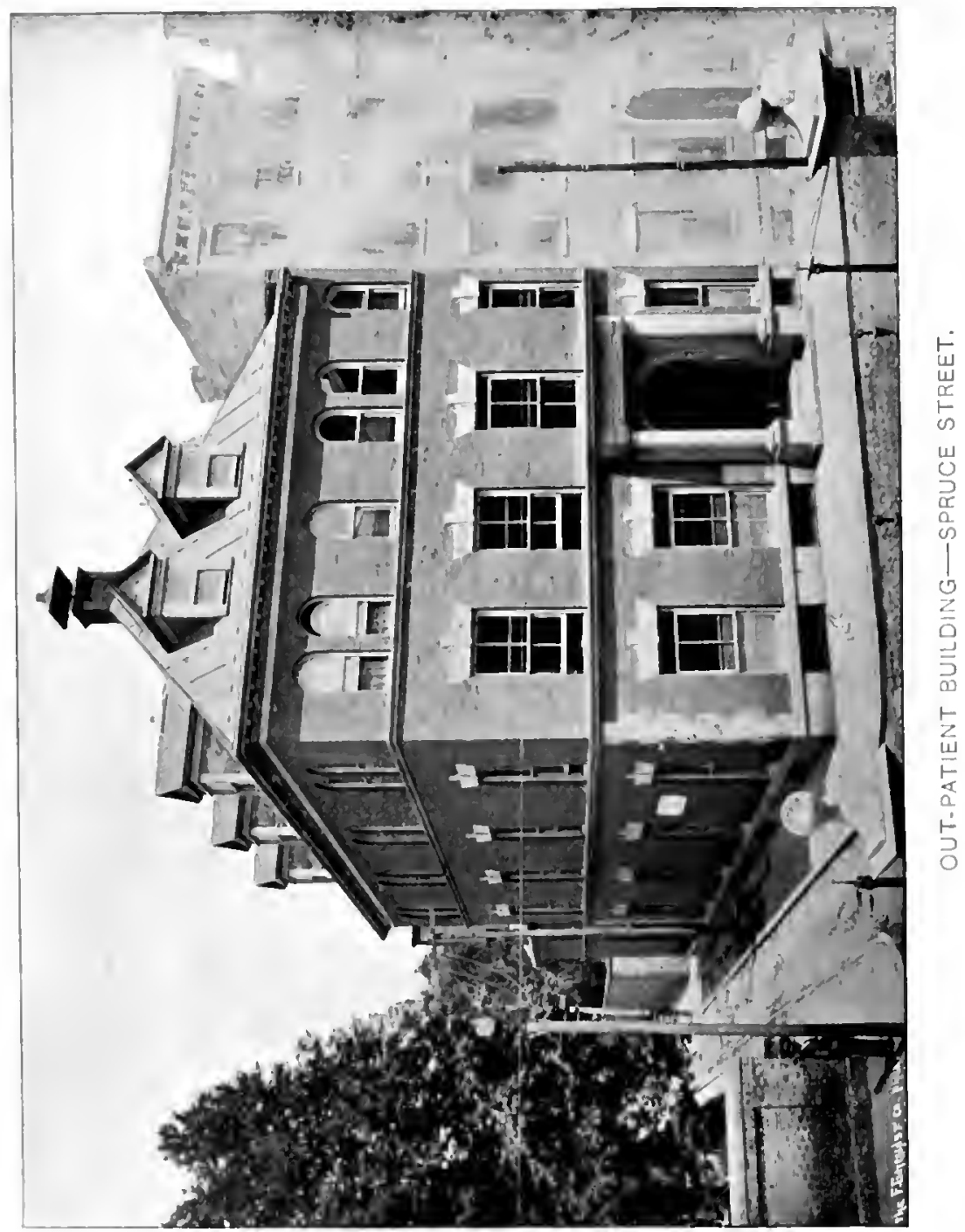




$$
1, x_{3,3}
$$

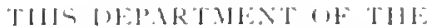

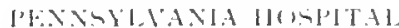

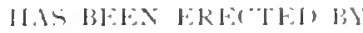

III. FVAXS LiARRETT, JR.

IX MEMUR OF HIS FATHER

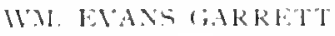

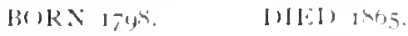

The daily clonical service for the patients who aphly at the (utPatient Department is now divided into Medical, Surgical, Mental and

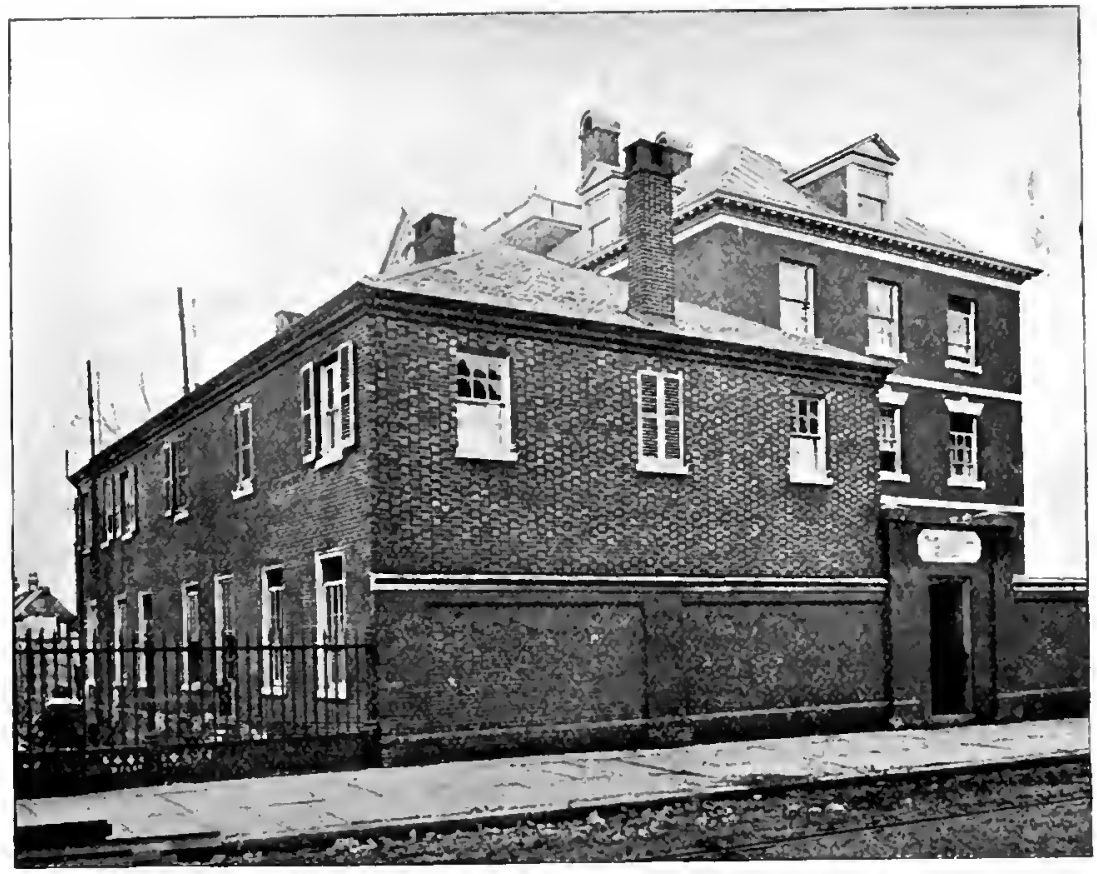

The "Retreat," or "Lodke," also used for Out-Patient Vepartment. Torn down in a has.

Nervous. Eye and Ear, Throat and Nose, and hiseases of Women and Children. The details of the service will be mentioned hereafter in considering the present administration of the Hospital, and appointments for the different departments

About 1873 , the necessity of providing in reased accommolation, in the wards, esper ially for surgical rates, was frepluently discussed by the Board, and each year the need became more urgent. The cluestion was referred, from time to time. to various committets of 
conferenu a abel wancarefully rombdered. The necessity for the crection

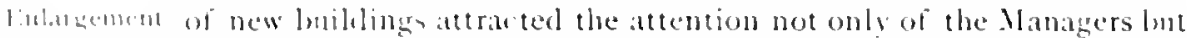
1.1 bloc HIn \{11, 11 $1+2+1\}$ ninlenl also of the medical ntaft of the llospital. Molern surgeical prosesese mixke it julprssible to continue any longer in the chl methods, and this fart leing tully recognized, this sulject was finally bronght lecore the contrilutors at the annual mecting. May 4,1891 , when the Managers reported in the following forcilste terms, the sereat needs of the llospital:

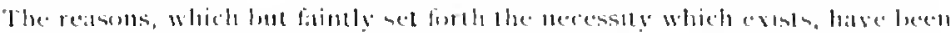

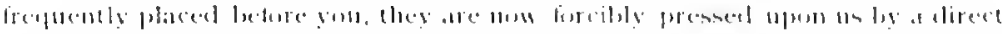

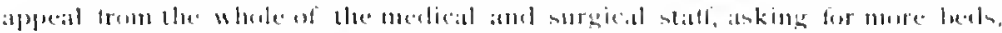

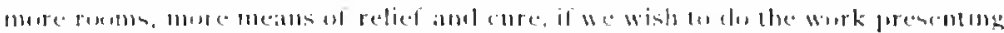

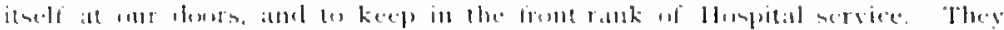

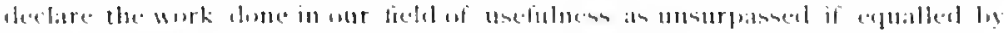

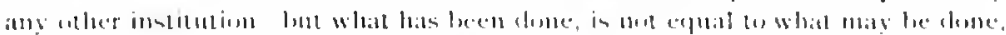

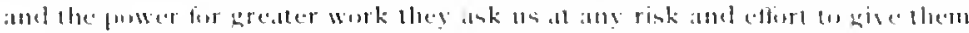

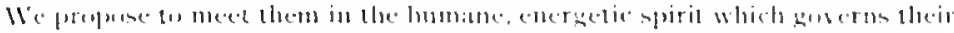

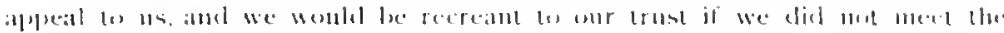

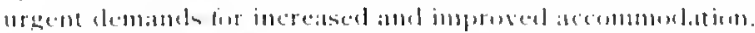

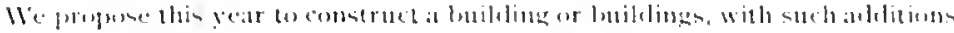

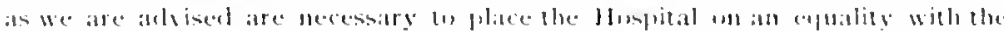

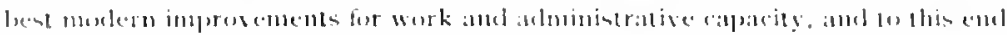

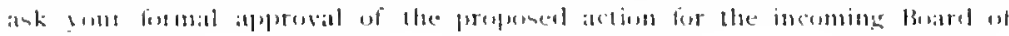

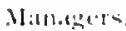

The Contributors promplly and unanimously approsed the propusition, and directed the Mlanagers to proceed with the work.

ine lihe consideration of varions plans inmediately followed, and Buildinzes after mumerous meetings and much liscussion, the Medical Staff l.. be recommended to the Managers, that Dr. Filward Cowles, of Boston, t.1 tertert whone scientific and thoroughly practical knowledge of motern hospital construction was generally recognized, should be askeal to present a plan for the new buildings. This was agreed to and 1)r. Cowles prepared a plan. which was approved, and work was commenced in Noremler. 1892 , under the supervision of Architect Adulinen Ilution, and fohn Sunderlaud as superintendent.

(1) May 1, 1893, Mr. licnjamin II. Shoemaker, l'resident of the boarl of Mamagers, leing alment on acrount of sickness, Joseph li. nee wene. Townsend, lispl. laid the corner-stone of the New Pavilions. The uration was dedivered by George W. libldle, Esro., from whose interesting and elopuent address the following extracts are mate:

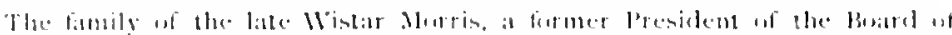

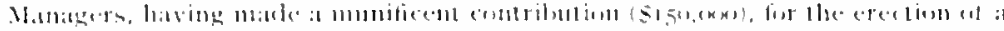

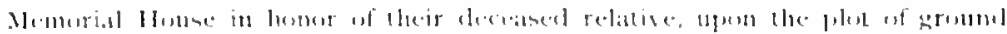

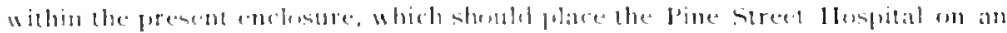

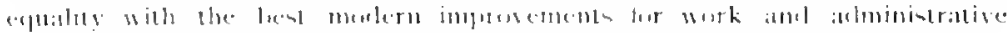

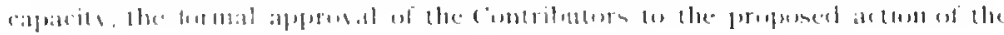





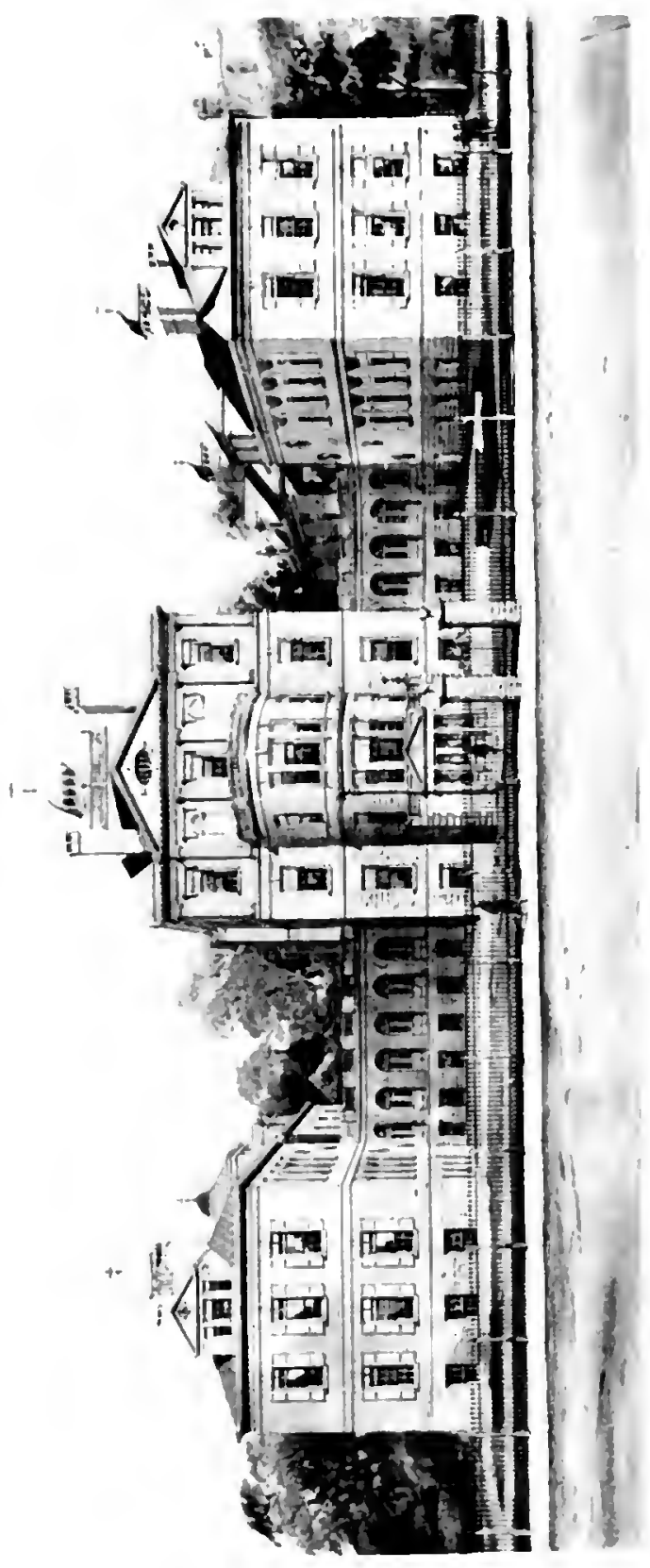




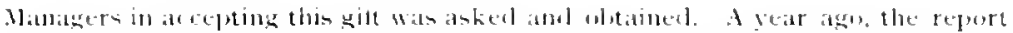
of the Mallagers to the cindributors exhibited a pretty full ontline rif the charater and style of the new constructions, their probstsle cost and the changer made necessiry for their erectim ly the removal of certain existing buildings upm the propused site. One of thest changes required the building of a new Uut-Patient Department, which is now finished, and in use, upun the morth side if spruce Street, opposite the Huspital lon. The Nurse's House, also begum in Jaubary, Isgz, and finished at the cluse of the sime year, gives afcom. modation, in single romms, for forty-two nurses, and thus provisles for the efficient working of this valuable staff of officers. Fo-duy, you are asked in particinate in the layines of the corner-stone of the Memorial huldings, which, under l'ruvidence, it is hoped will be the means of maintaining and of greatly extending the gond work of this venterable lnstitution.

The citizens of Plibatelphia scarcely need to be remiuded of the history and wotk of this fluspital, devoted to the relief of pitin and of sickness, which seems to be an much at part of their civic heritage as that wether historic bulding within the stumb of whose bell we now are, where over a century agn the beclaration of thin Country's Independence was proclamed to the nations of the world. Antelating that erent by a score of years, the stream of beneficent usefulness of the Pennsylyania flospital hats fluwed steadily and folly during all this spatce of neatrly a centurv anci a half.

But little remains to be said except to express the lupe that this ald lnstitutim, surrumbled as it an is with somany fellus workers in the same cause, may cuntinue with them to pun mut mpon the ifflicted, in sreater abundance than ever. the lenefits which it has heretofore seattered soliberally and indiscriminately. npm all ; and that the rearing of this new bulding, the corner-stune of which we are planting to-day, may fructify to the same deeds of beneficence, which hatse just leeth sis imperfectly referred to, as the origiual purpuse and desisn of this ancient finmolation.

It is in plate to say here, that the external features of the new constructions will he in perfect harmm with the existing buldings, themselyes a molel of exedlence, in the style of the architecture of the beginning w the last century. The new buthlings hate been designed in the same spirit, and will be character ized by the sime refined tiste, and whe'l finished, will be a great adurmment to this part of our city.

A great, classicial author has saicl in begrinning an acesunt of the life of a dis tineruisled relative, that it is an ancient and homrable custom in describe the artions and chatracter of the mighty dead for the instruction of thuse coming afte then: and that it has exer been permitted to sume oi then to speak. witimut artogance, of the ir wa career of departed glory, for the same purpose.

let us cluse loy stying, how much more applicalde is this language to the history of an institution. founded in benevolente and gend will to all, which fon mearly at century and a half has been daty and actively dispensing its adtatutages (1) the aftlicted in mind and body, and which is continuing, and we trust will still continue in the future, its lahurs of charity, w ith increased strength and renewed vigur, to countless generation- to come.

The new buildings face Spruce street and extend 220 feet east bestrinum and wew and $12+$ feet north and south, but, owing to the broken out - if the line, these figures exaggerate the area covered.

The utimate total capacity of these pavilions will be about 150 Henurial lisilion becls, of which eighty will he in the four large wards. ten in the 
women's special ward, twenty in the two children's wardi and the rent in the recovery and private wards.

The cust of the buildings, complete and furnished, will be about $\$ 300,000$. The havement watts are of fomeshorough granite, the superstructure lhilalelphia red brick, with granite trimmings and root of slitte.

New Imong the improvements contemplated in the near future are a Clinical new (Cinical Operating Roum and Amphitheatre, and aho isolating Amphi pavilion wards for infectious diseases. It is proposed, also. to erect a the:sere. new reception ward building for men and women, for which plams will shortly be presented, in relationship with the new operating-room and connected ly a corridor with the main buitsings. 


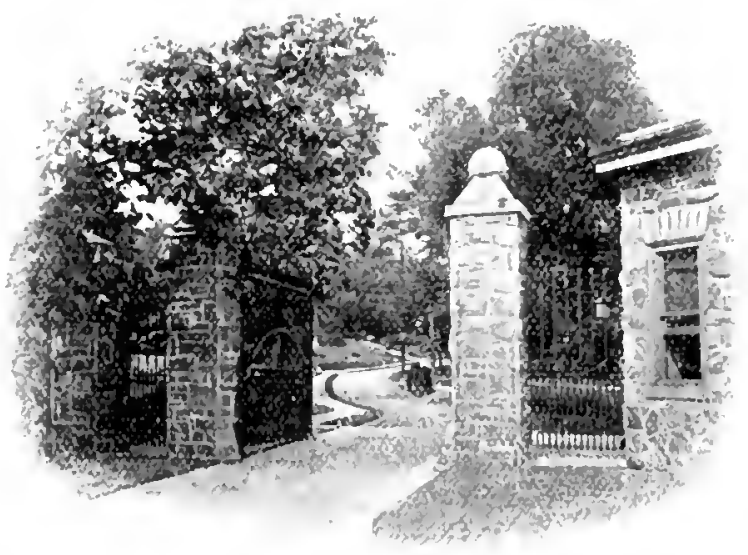

LEPARTMENTS FOR THE INSANE.

The princifal motive which had inspiren the founders of the l'ennighania Hospital as well as the main argument expresed in the petition to the Provincial Ansemlly, afterwards embodied in the Act of May Ir, 1751, was " the cure and treatment of lunaticks," in order that "they may le restored to reason and become usetul members of (:ille if the Insilne : : injuliling motive in findindiste the the community." It was principally out of consideration for those unfortunate beings, who through loss of reason had become " a terrour to their neighbours," and for whom no adenuate provision had hitherto been made, that the Ilanagers felt the necessity of pros iding immediate accommodations. They accordinaty decided to occuls. temporarily, the building known as Judge Kinser"s Mancion, for hospital purpuses. Of the two patients who were admitted on the first day after the doors were open, February r I 752 , one was a "lunatick" recommended by the Visitors of the Poor of the city.

It was very soun apparent that neither the house which they had adapted. nor indeed "any other that could be hired" at that time, had what the Nanagere were willing to consider as "any convenient aprartments" for the proper custodial care and treatment of the luna- $1-1,1 \cdot 1,1$ Inilitim:

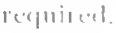
tirs. This, in their judgment, mate it obligatory ujon them, at the earliest fossilite moment, to construct a special Hospital, which should contain the desired conveniences. l'lan were accordingh drawn, and, being duly considered and approved, huilding operations. were legun in May i 755. The construction proceeded slowly. lnit steadily, until the Lant wing of the l'ine street Hospital was at length 
a far completel that gatient cenld be tranferred. This was acVew buldus complinhed un lecember 37,1756 , as already tated. The insane

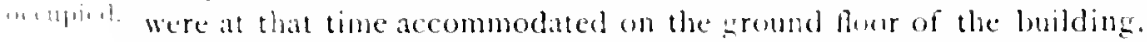
which bisd leeen especially constructed for their use. l'soler regard wats shown for exercise, hecause in addition to the extensive grounds, there wa on the first story of each warel "a gallery eighty feet in length for such of them as may be trusted w walk alout. with a flace for lathing." etc.

$1,11.114211111$

liy 1792 . the demand upron the Hospital had sery much inc reased $11 \cdot 1 \cdot 2-2.111$ and the number of lunatic had lecome su large as to call for even greater warrl accommodations. and to make it necenary, as speedily an pusulhe, to complete the Hoppital, according to the original plan, which haw feen referred th previously. ${ }^{1}$

To carry out still further the intention of the liounders, al petition,

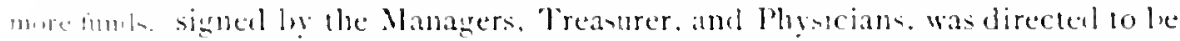
flecented to the Ancmbly, on January is. 37)2, anking for another lipropriation of some of the public funds for this purpose. The minute read a collow:

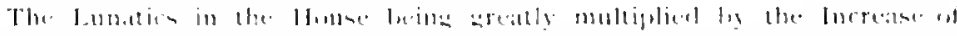

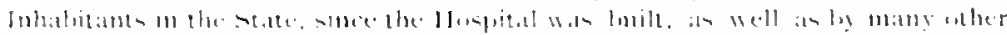

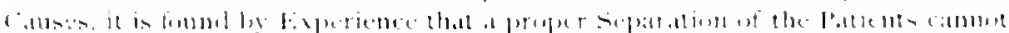

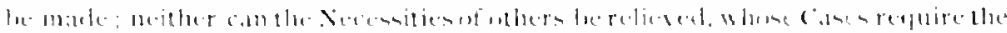
.

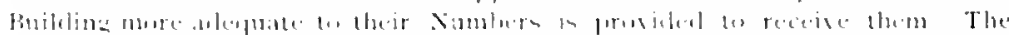

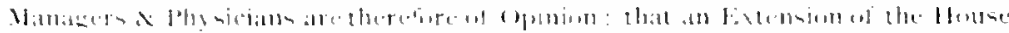

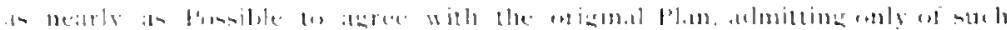

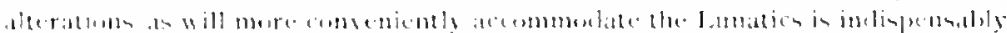

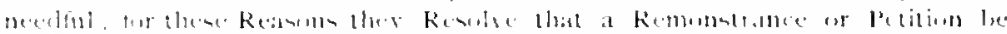

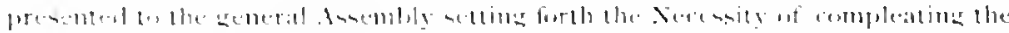

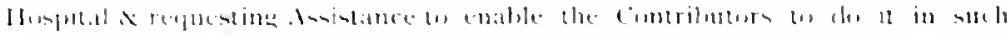

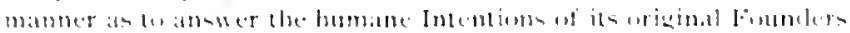

Implenta- The petition was duly sent, and was fororably received : ten wh thousand poumls and the unclaimed dividends of liankrupts' effects

flo..ne were ordered to be appropriated to the we of the llospital. ly Act of

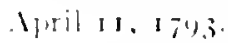

II, se:n (1) November 28,1796 . the wentern addition to the new building

Whe wa reported by the Committee an ready for the reception of gatients, (1.mplectent and it was accordingly directed to le enened for immediate use.

The on llay 9, 3\$25. it was "Resolved. That the Apartments in the

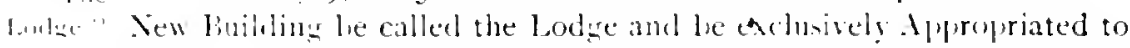
female lunatic Patients to le under the care of female Auendants mly." This hulding was also known in "the Retreat." (See illustration 1. 109.)

1 Page $j^{6}$. 
On June $3^{\circ}, 1829$, it was strongly insisted by the attending Managers that the present crowded state of the Institution and the prospect of abundance of funds made it incumbent upon the Board to take measures more effectually to separate the sexes, classify the different grådes of lunatics, and provide more ample space for their recreation.

The needs of the insane at length became so urent that action could no longer be delayed. It is recorded, January 31,1831 :

Separation

1, Sexterand

("Iasiliventiun.

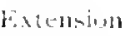

l).ented

Deceshitry.

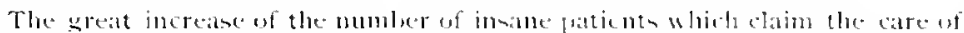

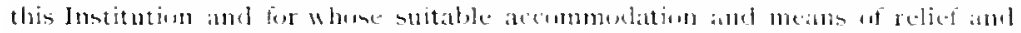

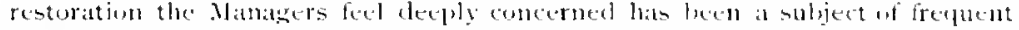

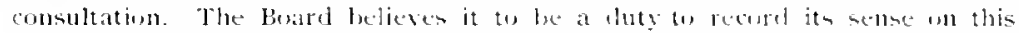

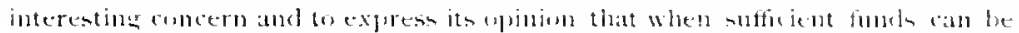

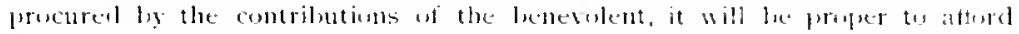

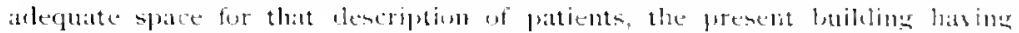
become crimded.

It a meeting of the Managers, held April the $25^{\text {th }}$, it was resolved that a copy of the foregong minute be laid hefore the Contributors at their next meeting.

At the meeting of the Contributors, held May the ad, the further association of Lunatics and sick patients under the same rour, atter due consideration, was deemed inconvenient and not conducive to their welfare, and the following appropriate resolutions were adopted:

Siaratco liniliting tis the $\ln a \mathrm{an}$

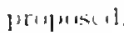

Whereals finm the great increase of lusane patents muler the care wi this Institution, that pertion of the Hospital appropriated fo the receptin tif such

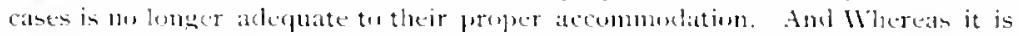
evikent that an Assemblage ul bunatics and Sick patient murke the Same Ruof

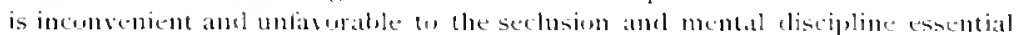
in cases of lnsinity: thereffire

Resoliet, That We cunsider it necessity to the interests of this institution and the furtherance of its lumane design that a separate Asylum le provided for our losane patients with anple space fin their proprer seclusinn, classification a empleswent.

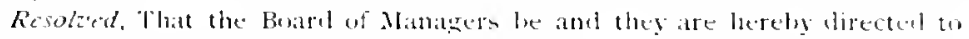
propuse at a future neeting of the Cuntributors to be called lig the Mandacts when prepared, a stutalble site for such an lsylum and the ways and means fort carrying into effect the foregoing Resolutions.

The Managers evidently did not feel able to take immedate action, for we read that, at the Contributors' Meeting, held June roth, is $\$_{35}$, Horace Binney, Es!, , submitted the following resulutions. which were adopted:

Resoled. That in the upinion of this meeting it is expediem that the Lumatic department of the Pennsylumia Hespital sheuld be temened from the (ity of

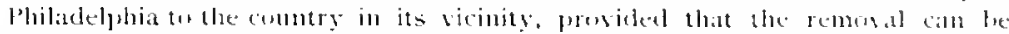
effected upon such a plan as will promete the comfint and inperese the health of the patients and axhit of the superintendence and cuntrol essential te a suod adounistration ut the institution.

$R(\cdot 11+\cdots, a)$ in l.111:attic Deprirtucint ti. the (inantry alprirased lug. Cintriliuturs 


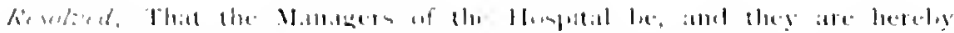

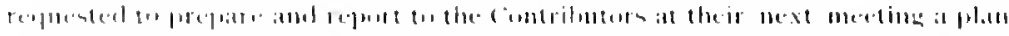

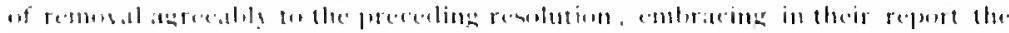

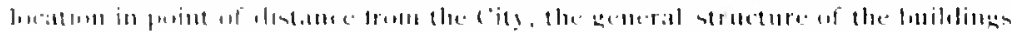

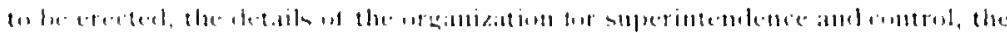

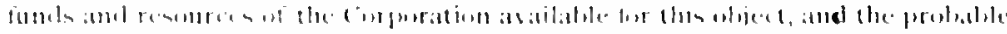

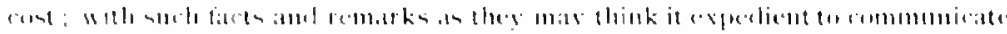

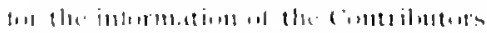

1 commitlee was alppointed by the lioard of llanager lo comsider the alweve resolution and to repont nen lenality and plans for the proposed new lonilelings.

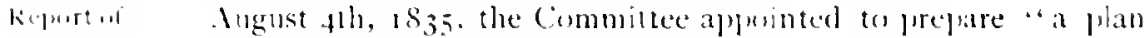

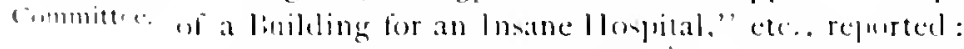

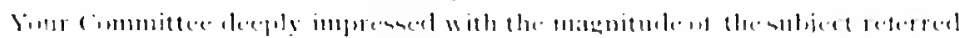

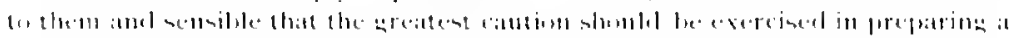

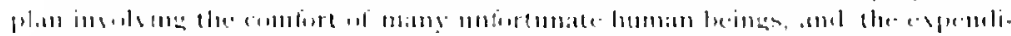

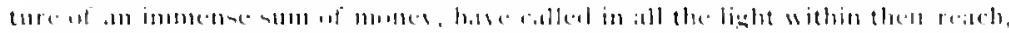

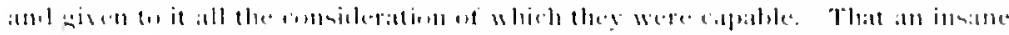

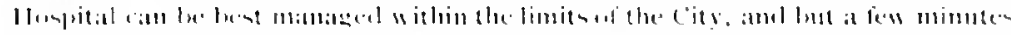

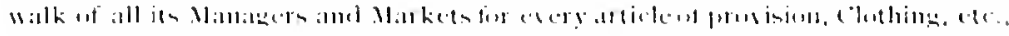

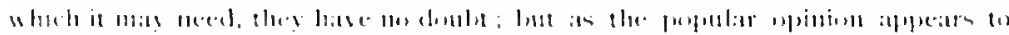

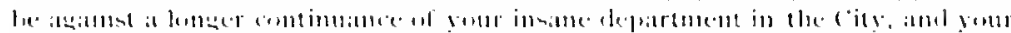

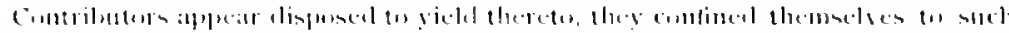

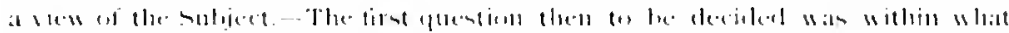

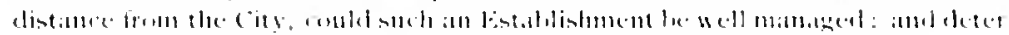

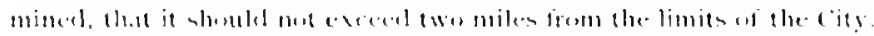

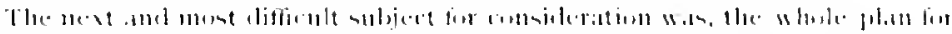

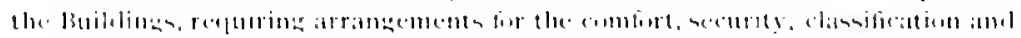

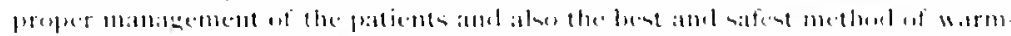

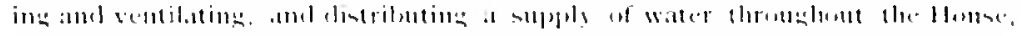

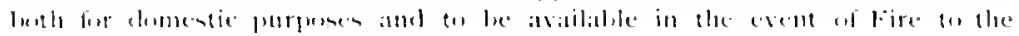
promines.

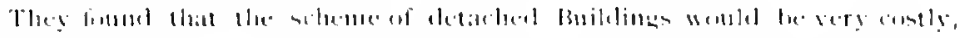

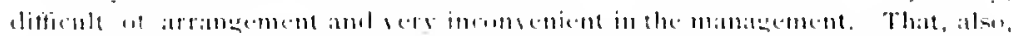

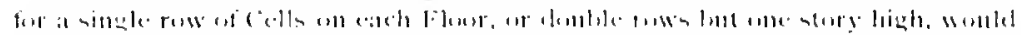

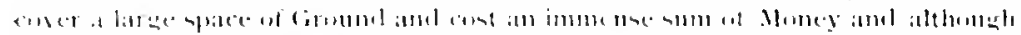

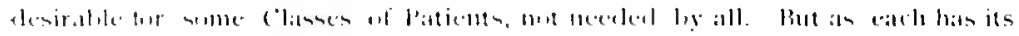

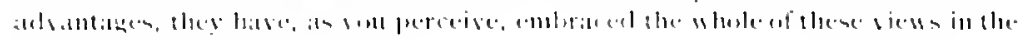

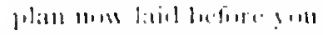

Plintion Nin Bublelines tis 111. Jinallie.

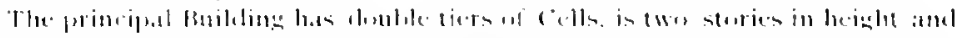

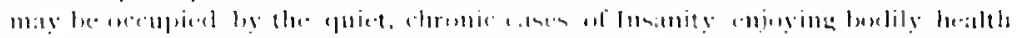

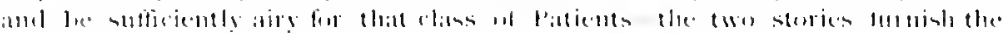

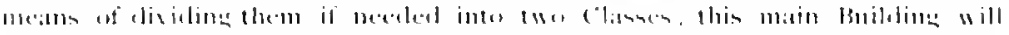

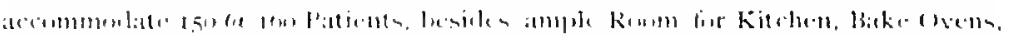

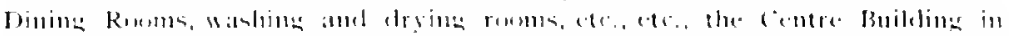

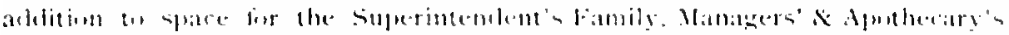

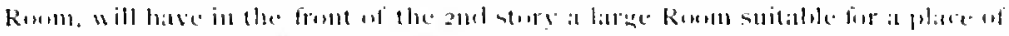

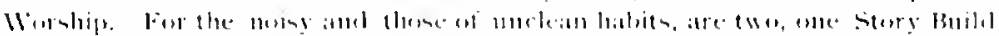

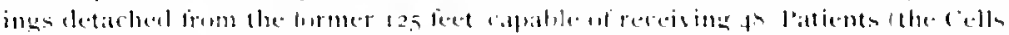

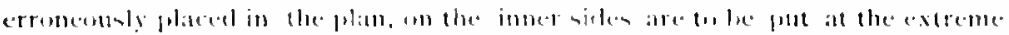

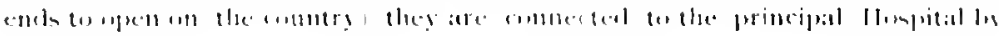




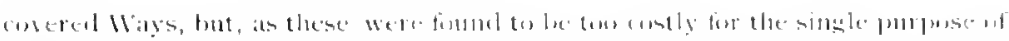

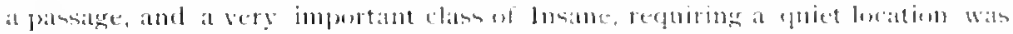

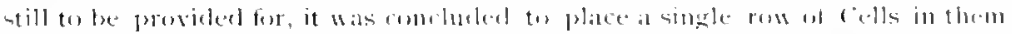
lowking out inte the country ; ancl to insure still greatter quict a passage waly an be constructed in the Basenent-these nill accommenlate thirty pattents. The abjection which has been made to whes at right angles the the man building on

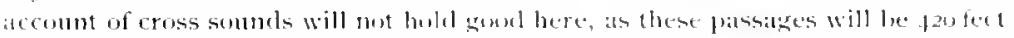
aprart ex but une Story high.

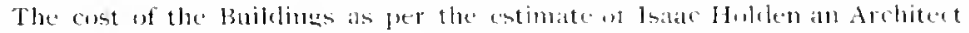
who drew the plan, and to whom your committec are intehted for a comsiderable

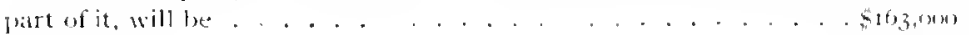

(iround . . . . . . . . . . . . 20, . 2(2n)

Wachinery and pipes for elevating and conveying water through-

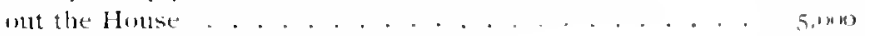

Furniture, Becls, Beclelings, Linen, etc., ete ........ 15.0 (n)

$$
521,3,116)
$$

MURIECAI LEWIS.

JuH: Patri,

JHAX J. SiITH,

DAKTHW. WISTIR, Commitfer:

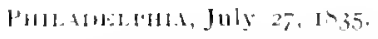

Estimaterl

(ant of

Improvere

mis'ilts.

At a special meeting of Contributors, held September the $14^{\text {th }}$, the above rejort and flan were submitted and discussed. It was theretion

Resolied That the Managers le authorized to purchase a proper site and ad acent grounds for the ereetion and accommodation of the saicl blupital.

It was also" "Fesolede. That the repurt from the Bonal lee recommitted to the Namagers, to mate further repurt therempun and suecially to report whether

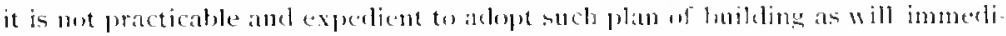
ately accommodate I 60 patients, and may from time to the be extended as the mumber of patients shall increase. Ant also to repert what are the funds as atiable for the purpose of the propesect llospital and what all remain for the city

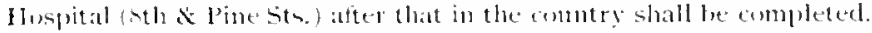

A Committee was appointed to look out for a suitable site for the new establishment, and to prepare a plan and estimate for new huildings, etc.

January $1+183^{6}$, the Committee reported:

That after taking inte sleliberate comsideration the various subjects refored to them, they proceded to seck ont at site suited to the blifect in siew. - And atter bating visted a number of Firms. some of which, the atfording lofty stuations, commanting pieturesplue vicus of the arljacent comntry were bouml an he destitute of Health, and particularly the last Autmom subject to the Fesers, of latter years se prevalent in the envirums of the (-ity- while others, tho com-

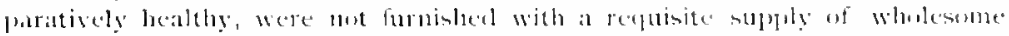

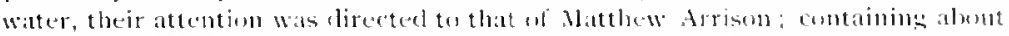

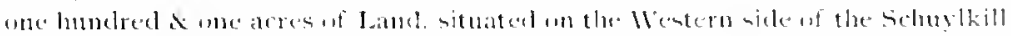

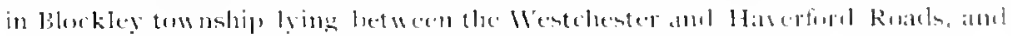

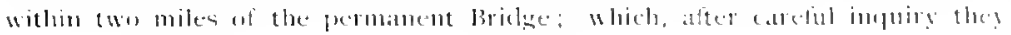

(imtribnturs authurizc

Prurbalse uf Reall Estate.
Arrisum

listittere re

(inemmenterel as a sitt. 


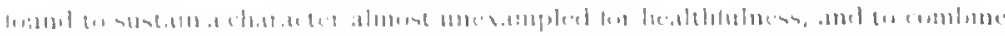

linililin:

$-10$

$\operatorname{ate}(10.1)$

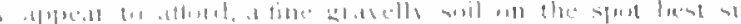

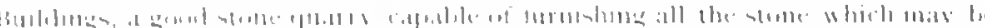

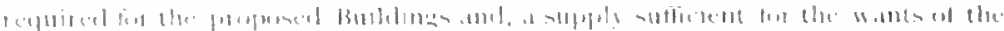

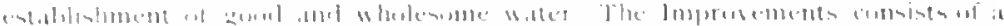

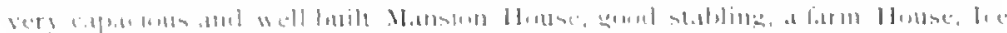
Hullue, e"li"

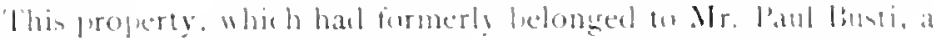

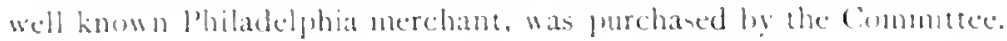

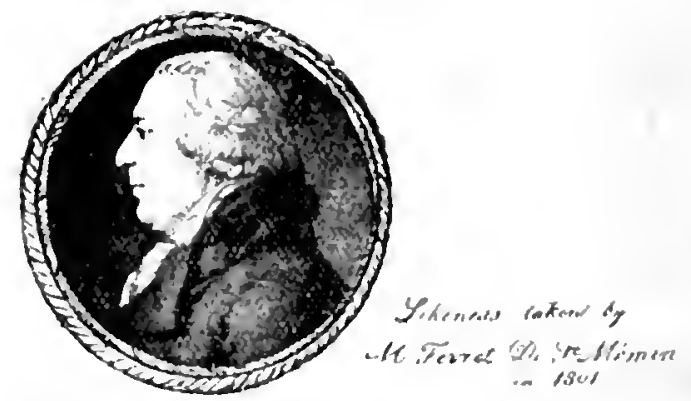

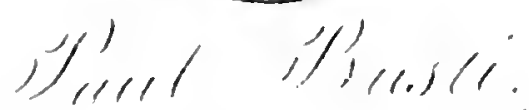

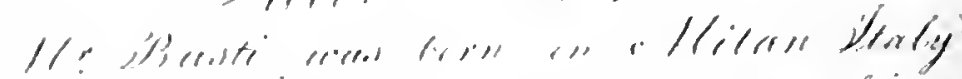

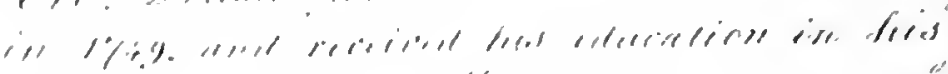

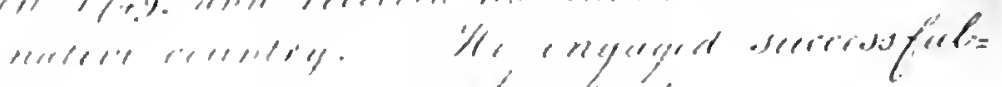

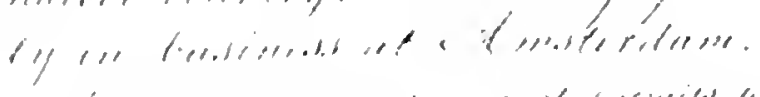

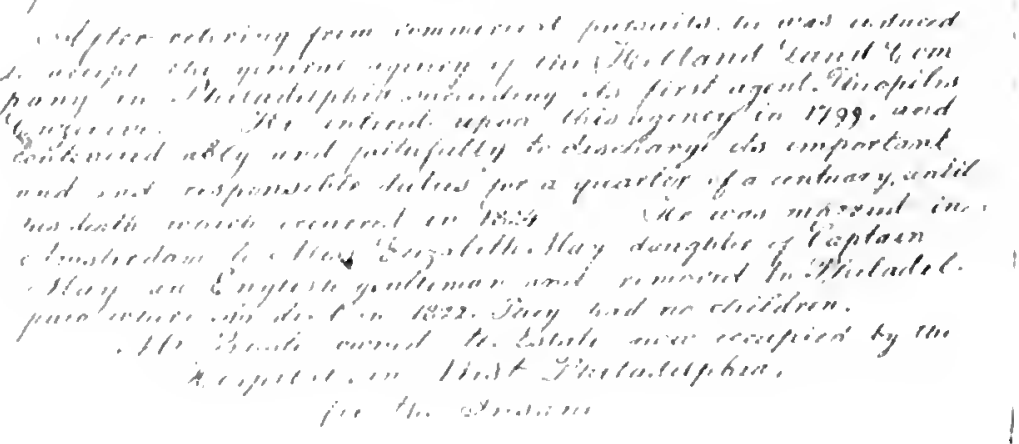




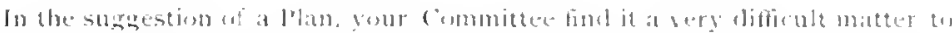

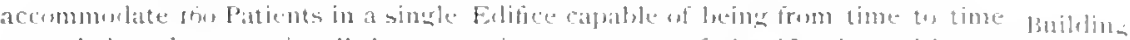

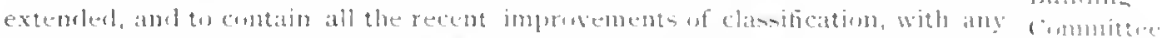

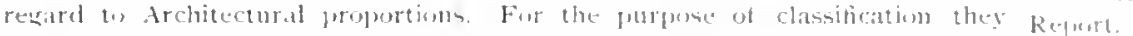

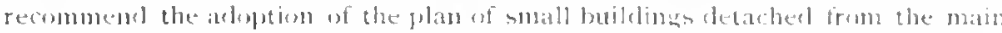
Asylum, unter which will be sufficient at the outset. A plan for whith togethel with one of the principal Asylum they nom lay before yeut

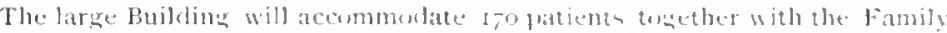

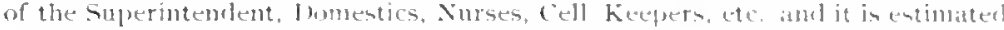

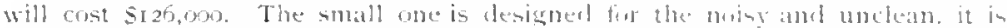
represented in the phan tout ane story higla, will furnish rum his to enty patient

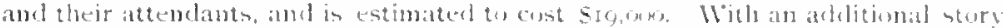

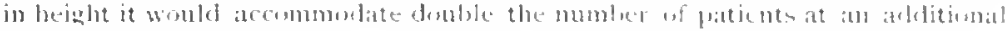
(n) ist of lont $\leqslant 4,(x)$,

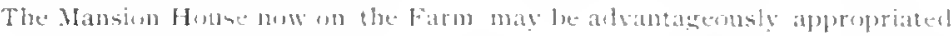

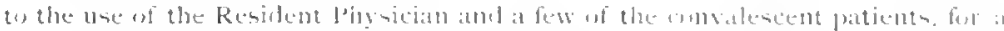

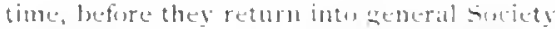

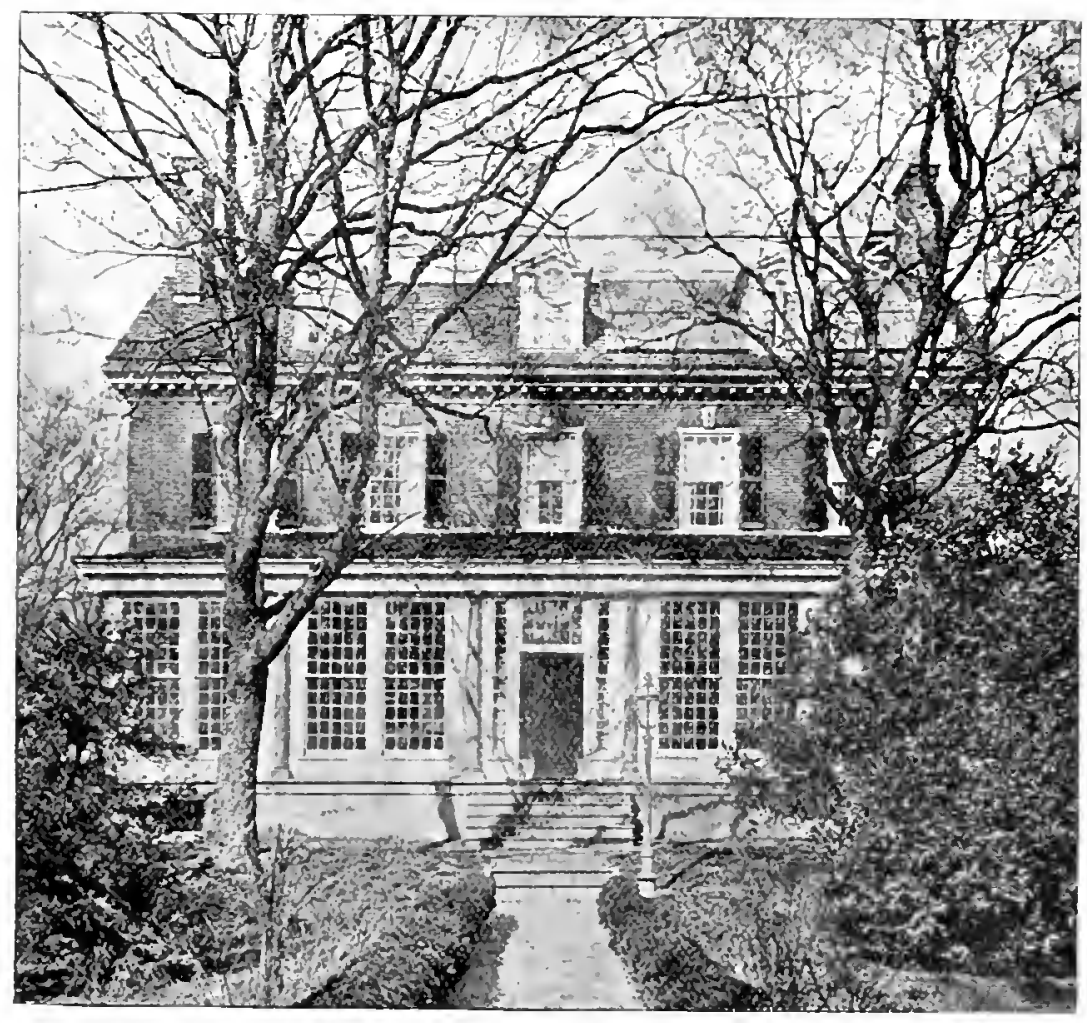

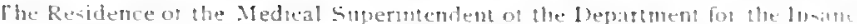

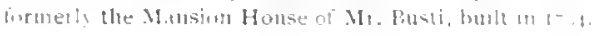




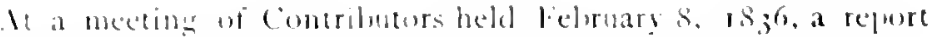

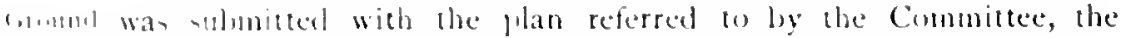

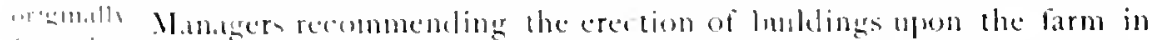
libetiley recenty purchated for this purpone of Matthew Arrison, whis h hat prevously letonged tu l'atul linsti, and which the Managers arenired at the cont of twenty-eight thomand dollars. The illustratim, containing a portrait of Mr. Busti, is a photograph from a small engraving made in sisor, now to le secu in the hall of Mr. linsti's former residence, at prexent occupied ly the .llediral superintenclent. (Illustration on preceding page).

The Contributors, at this meeting, adopted the following resolus. tion:

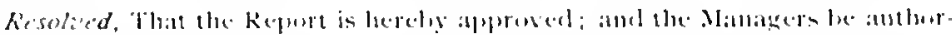

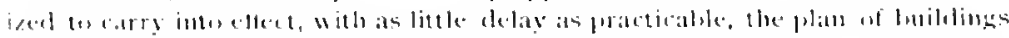

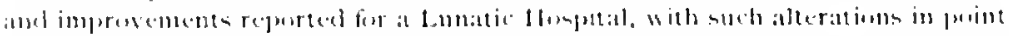

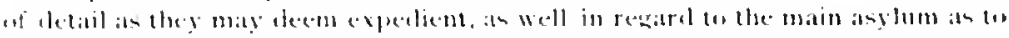

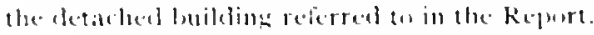

Building The following Building Committee of the Managers was appointed cummitue February the zoth, to carry the alove resolutions into effect, vis.. Mordecai lewis. Nexander W. Johnston, John J. Smith, Bartholomew Wintar, John Yanl, and William W. Fisher.

$11,111:+1$

() March the 12 th, the Committee having satistied themselves with respect to the pualifications of Inaac Holden. he was appointed Irchitect and mechanic for the construction of the new buildings under the direction of the Committee and sanction of the Board.

inimlinus linatterl.

In a minute entered April the 25 th. it is recorded:

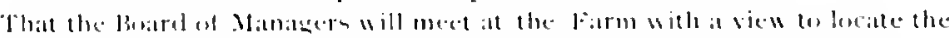

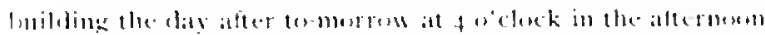

The leation baving been decided upon, the work was carried on rapidly. On gune the zast. flue Commintee met

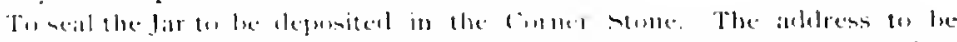

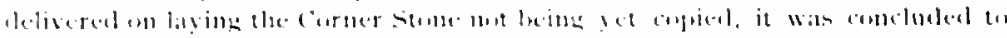

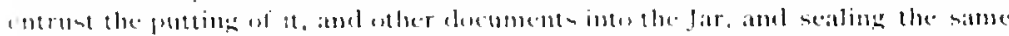

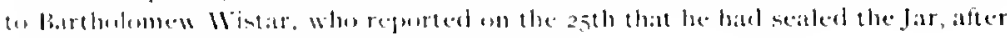

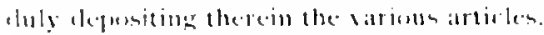

forme The Corner-stene of the bujlding was laid at 5 o'elock on the

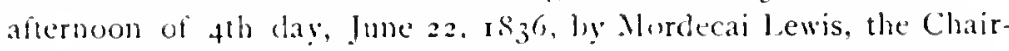
man. It is a large fiece of (iranite, fuarried on the premises, and was laid in the South bast corner of the (intre building. In a cavity made in the stone was deposited a large thass jar, or bottle, closed, containing coins of the United states currency as follows:

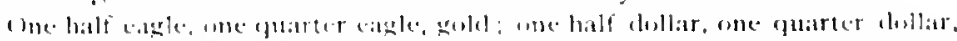

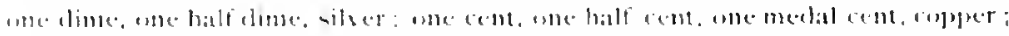

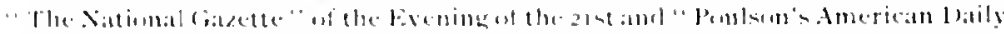

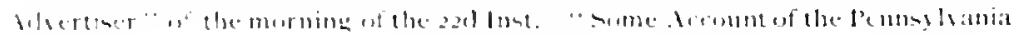




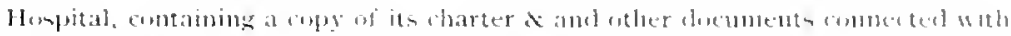

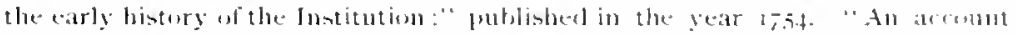
of the origin, whjects, and present state of the Pennsylyania Howpital," hy IIm.

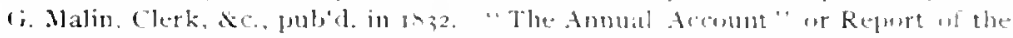

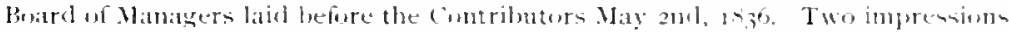
of the Corporate Seal, one the original, and the wther recently made. A sopg of l)r. Benjamin H. Cuates' oration.

With the following brief explanatory note:

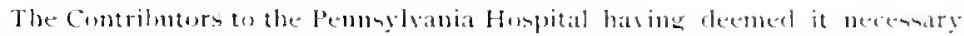
to extend the Insane department the reuf, and to ehange its loneation, by reasm of the increased ponnlation of philaclelphia, and the erection of elwelling hounes near to and on all sides of the llospital in the city:-this Corner stone of a build-

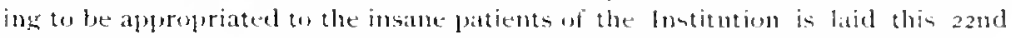
(lity of the Sixth month (June) in the gear of ons Loril bne thounand Eight hundred and thirtr-six.

Dr. Benjamin H. Coates then delivered, before a large assembly, an address, which was chiefly a sketch of the history of the Institution.

The following extracts from this Address are of special interest:

To found public institutions of an enduring chararter is acting fur the benefit of future gemerations. The labor is one of dignity ; dignified far beyond anything that occurs amid the ordinary qurmoil of daily passins and interests and lowking to the welfare of men whe are to inhabit this earth lones after earld bead that mow attents with anxious interest to the philanthopie labor shall rest beneath the cleds of the valleg. Long after the few years allotted to these vain and buntling sectes shall hate elapsed, when time and death shall have setted the pruny effersesecence of emotions that wow fret in the pursuit of fortume or of fames, shall uther men seck these sharles for the relief of wretchedness and disease. Their busoms will he distracted with the same feelings which at this mement agritate ourselves. Little will they reck of the ambitions, the hones, and the fears which

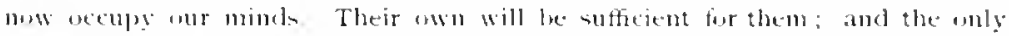
questions they will ank will relate to the titness of the means we hate employed to the ends for which they are designed, the relief and service of unfortmate luman nature. Tasks of this kind do mot belong to any age or country: the connere antiquity and punterity, and they unite remote and hostile empiren in the commum bond of usefulness and charity. We benefit ly the cares, the sturlies and the munificence of onr predecessors, and we are leond in onr turn to imitate their example. From the dass of Fabiold the Christian lady wh hounded the first lunatic asylum, to an indefinte pusterity, there is a continuous series of necessity and leneficence which knuws net the distinction of race or generattion. By far the smallest gond effected in the erection of at areat hompital in achieved during the lifetime of the founders. The great institutionn of Lomdon and Paris continue from age to ase to allevite human suffering and adminiater to human wellate while the inguiring stranger asks who were the pions individuals whose splendid munificence has endowed these huldings, or whether the " were indeed the offspring of the charity of nations. In the course uf human events rendts arise different from these originally contemplated by the founder: benefit are achieved in new and unexpected directions; and the institnt in which comtimues to fultil with nuabated scrupulousness it primitise uffece of protecting and relieving misery, acquires in addition the still greater unetuhnem of diffusing and improving the most important and valuable part w metionl sicience. 


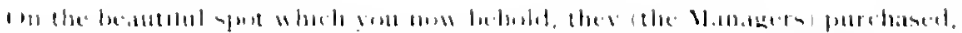

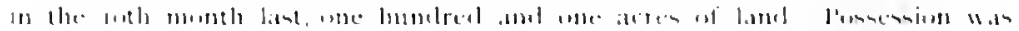

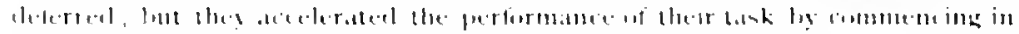

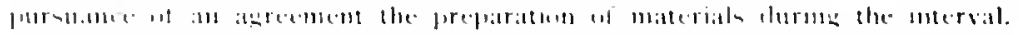

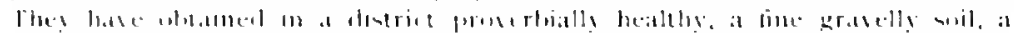

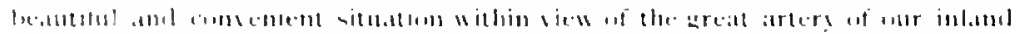

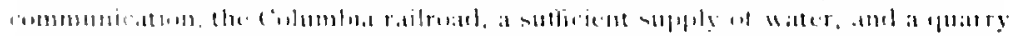

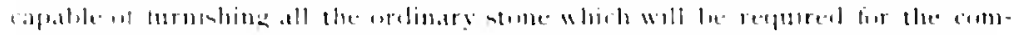

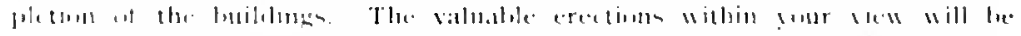

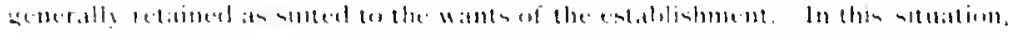

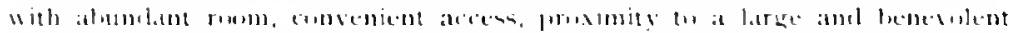

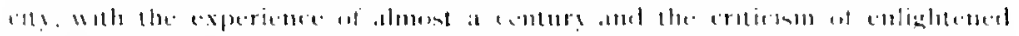

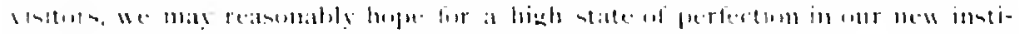

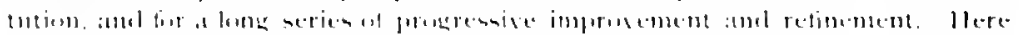

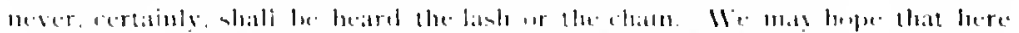

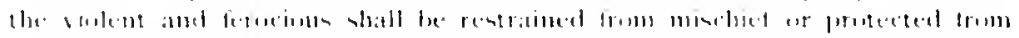

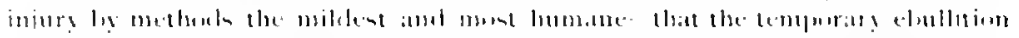

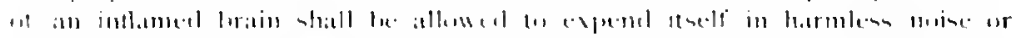

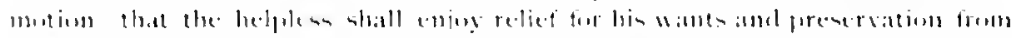

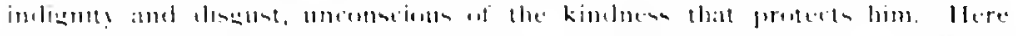

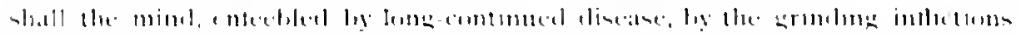

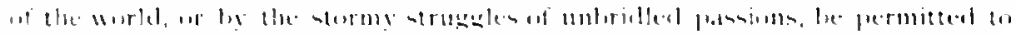

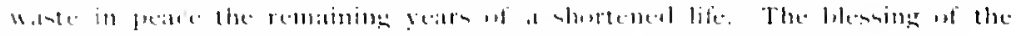

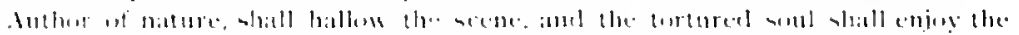

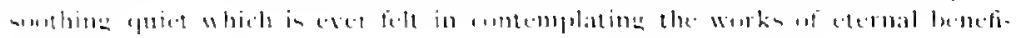
(1)

$x, 11$ limllin: "1, 110.1

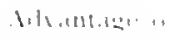

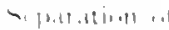

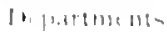

The new huikding for the Insane was finally completed, fully

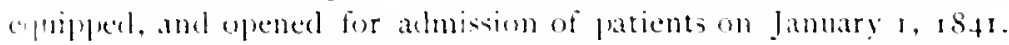
from lethuary 11. 1752. when the sick and insane were first received into the line strect Hosplat, to date aluse given, when the new department was nened, a period of eighty-nine years, 39.400 patients altogether hal been receired. 4,360 of which were insane. of the hatter, 1493 were dim harged cured. 913 were impreved, 995 were remo:el without material improvement. $2+6$ edeped (in the early days of the Hospital, the square was imperfectly encheded) and 6ro died. Of the number remaining, 93 mily were transferred to the new department fambry 1, 1s+1, keaving tels patients in the old Hospital awating the completion of a detarhed huldings.

It is noteworthy in womidering the hintory of the Hospital, that the early movements to establish it, the petitions. the appeals to the pmlice the charter and the laws, all make-pecial reference to the care of the insane. (1)e-half of the luildings at the l'ine street Hesprital ancl two-thirs of the adjacent grounch were appropriated to the imane. and when they were remover to Mest Philadelphia, they bated to the l'ine strect llospital for the sick and injured, one. balt of all the Hospital hulding and wo-thirds of the entire square of ground unon which they stand. 
Thus the transfer of the Insane to their new abode in every way tended to increase the prosperity of the Pine Street Hospital, and the resources applicable to the relief of the sick and hurt, and furnished a full equivalent for any benefit received from the common fund by the Dejartment for the Insane.

On October $3 \mathrm{I}, 18_{+2}$, the Committe appointed February 29. $18_{3} 6$, with power to erect suitable buildings for the Department for the Insane, having fulfilled their duties reported, as follows:

On causing a survey of the farm to be made, they foumd that the lines on the Haverforl Road did uot correspond with the enclosures: a part of the property lying on the opposite side of the Road, and a part of the line being considerably inside of the fencing on the South sicle corresponding with a road ditected to be laid out by order of the Court of Quarter Sessions for the Connty of Philat ditterl in 173 but which was never so laid wat. The present boction being considered the most convenient therefore before your Committee conla with propriety incur the expense of erecting an expensive wall it became necessary either tu cause the old regulation to be carried into effect or the present rad to be comfirmed. Having informed you of this difficulty they by pour direction frer minuten on

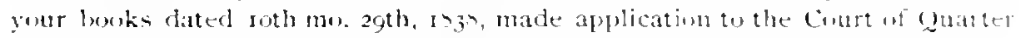
Sessions for the County which appointed a Jury and confirmed the roud at it now standis on the 25 th of the ard mo. rsia.

With the view to make straighter lines in the wall and to have cuntrol of all the springs in the neightorhod of the pump-house there was purelated from the executors of the Estate of Henry l'ratt, 9 acres and 92 pretehes of land. from Henry Comnelly $12^{2}=$ perches, beth immerliately atjoining.

The Buiddings which had been erected were an folluws: The Principal-has al fromt of $4.35 \mathrm{ft} .6 \mathrm{in}$. a hasement and two upper sturies all of stume. and it is cont -

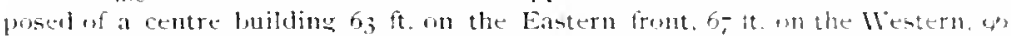

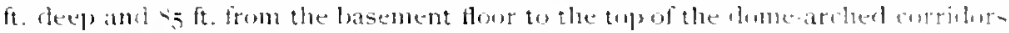

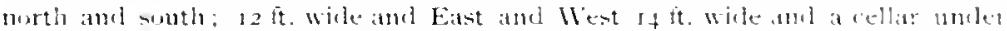

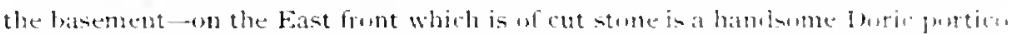
with four columus and on the West side a portico of the some atume an the numt

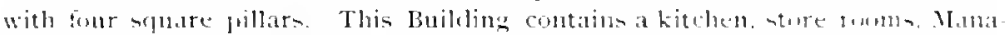

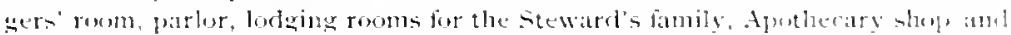

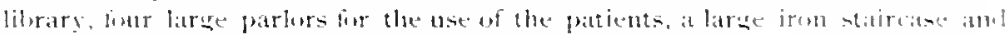
two romm in which patients may receive their friende withont expming thene in the warklow the vien of visiturs

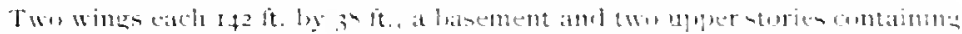

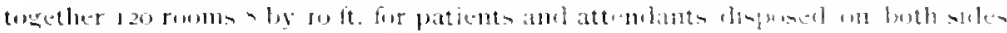

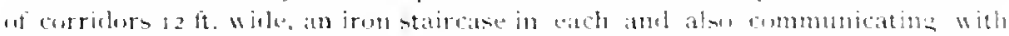

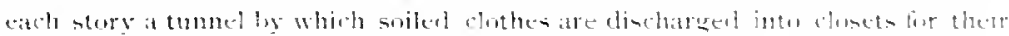
reception in the biscement.

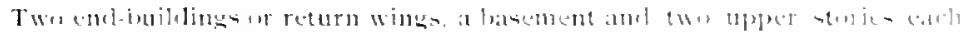

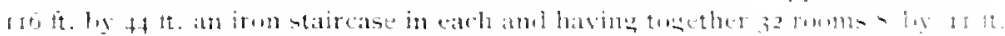

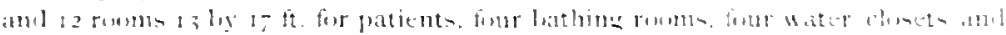

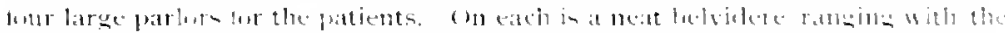

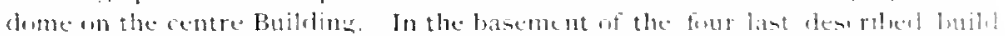

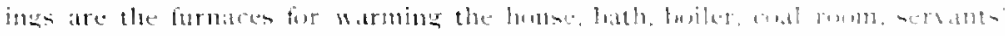

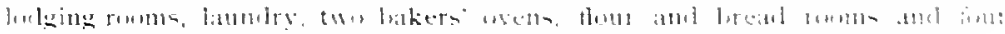

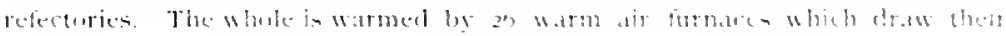




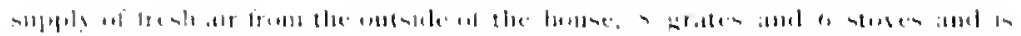

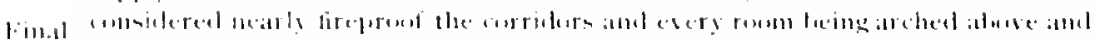

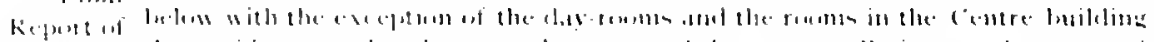

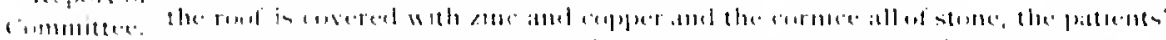

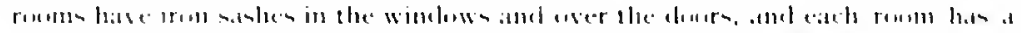

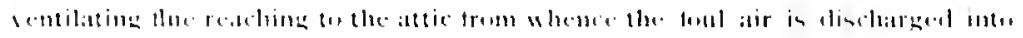

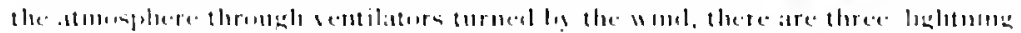

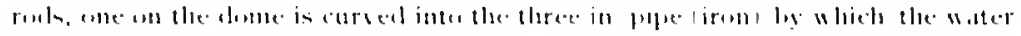

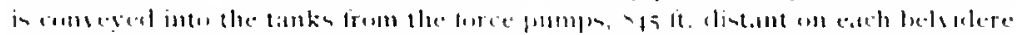

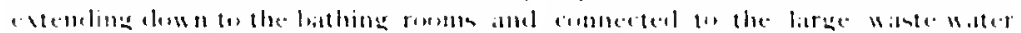

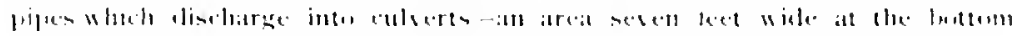

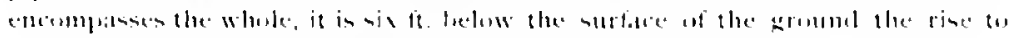

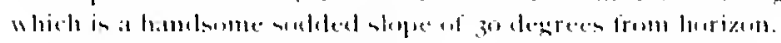

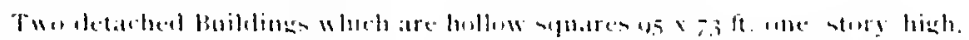

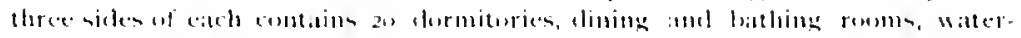

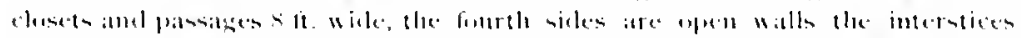

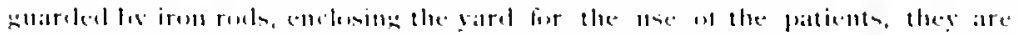

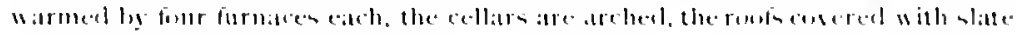
and rach rowm is well remtilatert.

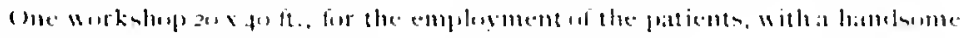

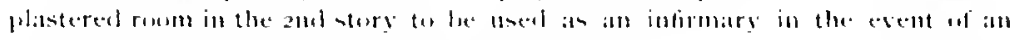
epialemie in the main lualdmes.

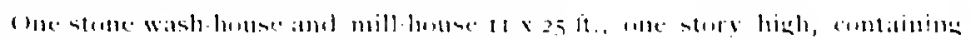

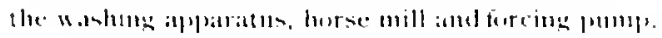

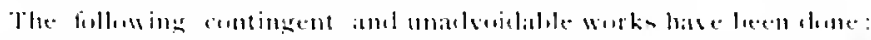

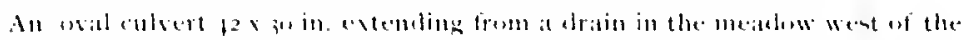

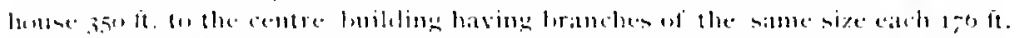

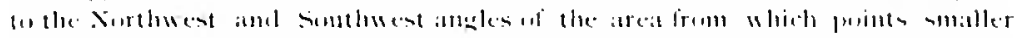

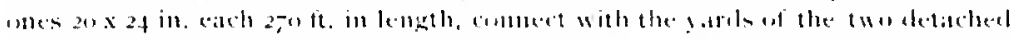

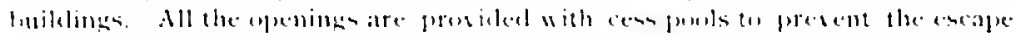
of eflluisia.

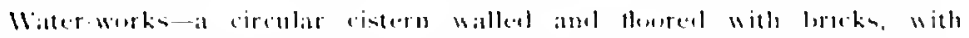

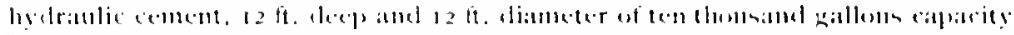

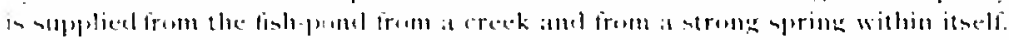

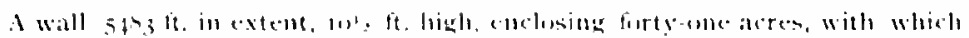

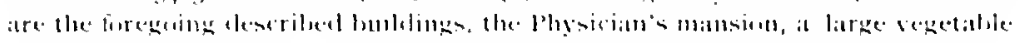

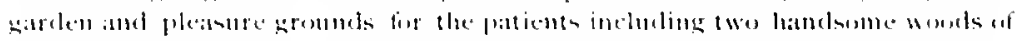
linest ites

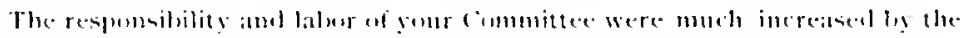

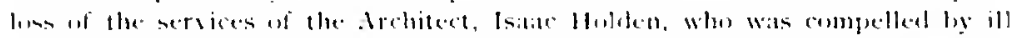

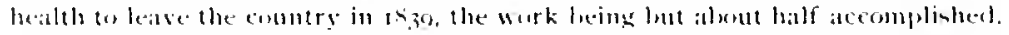

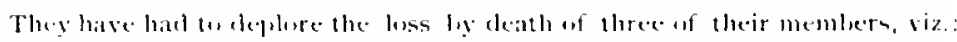

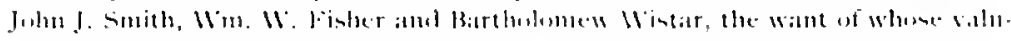

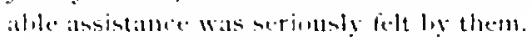

inth mo, 19th, in 12.

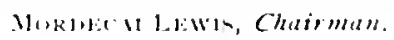

The report was accepted and the Committec discharged.

The opening of the new llepartment for the Insane suggests a brief review of their treatment up to this time. 
The Nedical treatment appears to have heen directed principally to the acute or sthenic forms of lunacy, or cases of so-called Treitument... "Phrenzy." These were lonched or llayed upon, alternately with the Imome warm and cold water. (whirh may have accounted for some of the pulmonary fatalitien elsewhere mentioned.) Their scalps were shaved and blistered: they were bled to the point of syncope : purged

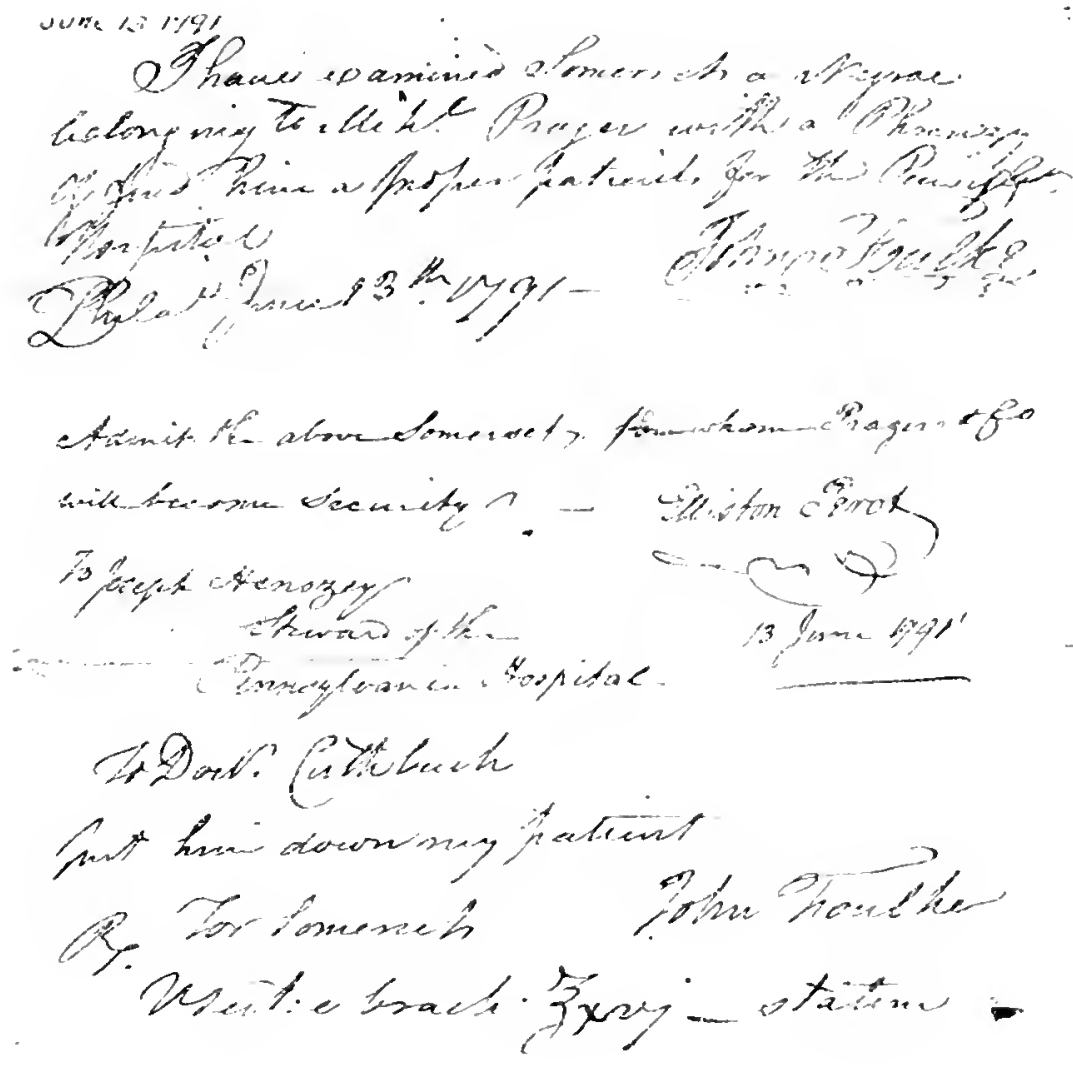

Prescription, whtten in 1 - by br. Foulke, for bicedus a lunatic patsem.

until the alimentary canal failed to yeld anything but mucus, and. in the intersals, they were chained by the waist. or the ankle, to the cell wall. Under this heroic regimen, some. probably the most "sthenic." recovered their reason. This general plan of treatment strvived the remosal of the patients to the l'ine street Hospital. There alpears 


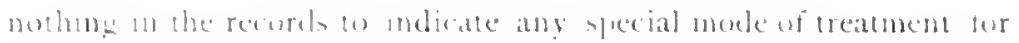

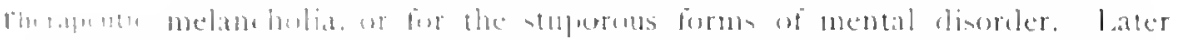

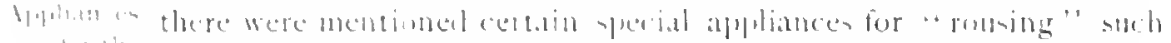

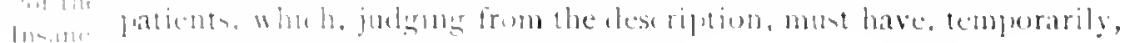

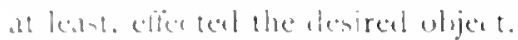

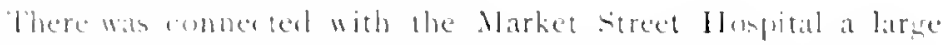

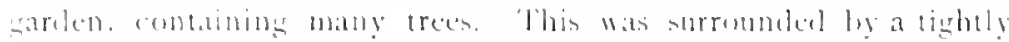
lo sarked high fence upun the sieke of Market street, the end loned

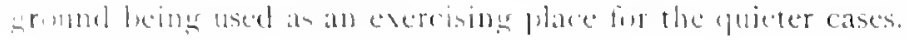

"The following briet and interenting memoranda. alpgearing on the

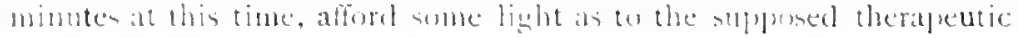

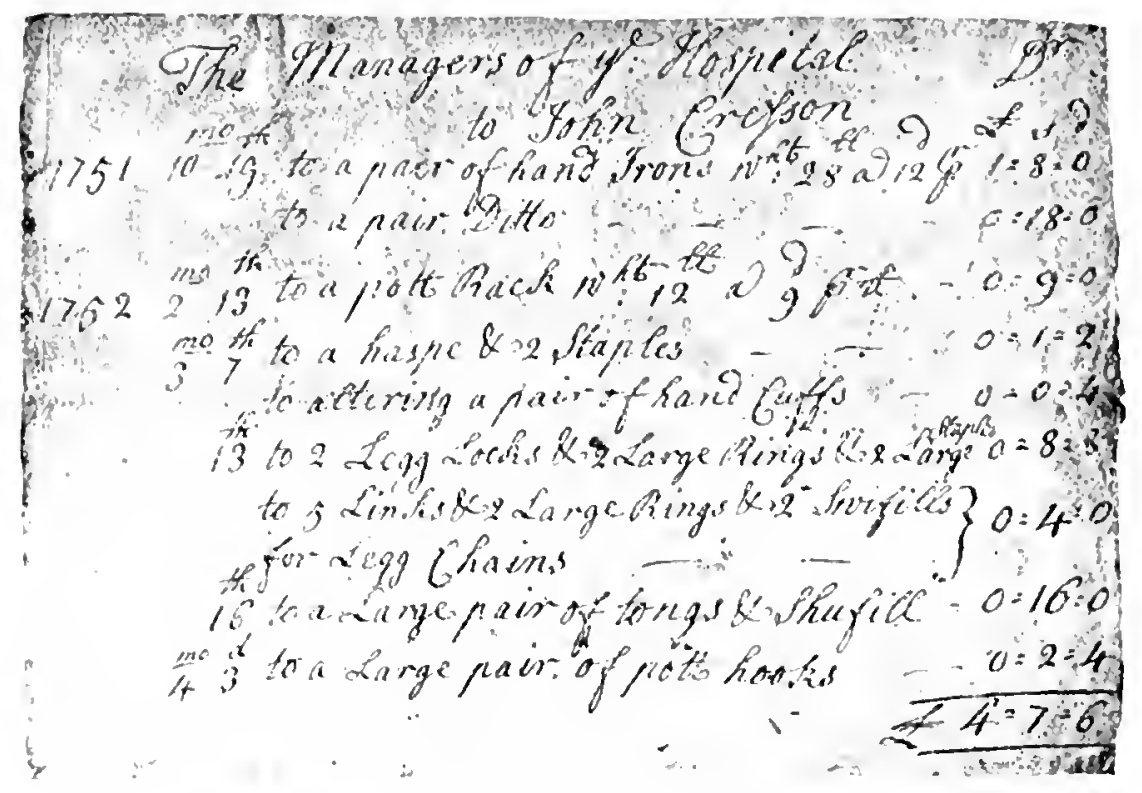

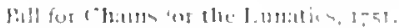

repturements in treating the incine. Ilere, for instance, is a blark-mith's acoount of Natre 7 the 1752:

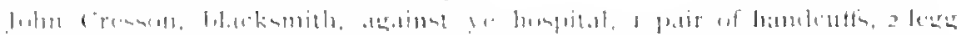

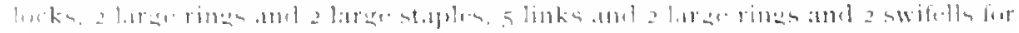
lond boum.

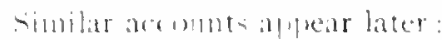

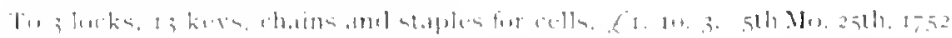

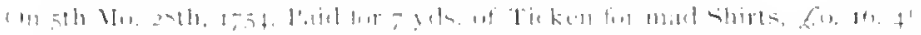

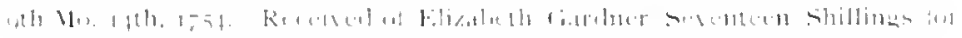

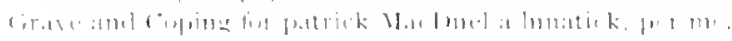


In the earlier days ${ }^{1}$ of the Hospital. even down to juite recent times, the mode of commitment of the insane was so easy and free from formality that a few words hastily scribuled upon a chance scrap of paper was sufficient to place a supposed insane patient in the Ilospital and deprive him of personal liberty. If he did not remain passive, chains or some other form of mechanical restraint were uned. A sufficient number of such scraps of paper have survived to show the astonishing informality of the lunacy proceedings. The friend (or it may in some instances have been the enemy) of an allexed lunatir. applied to the Nanagers, or to one of the physicians, for an order ot admission. If, as now. the friends or custodians were able to jay board, bond was taken for its regular settlement and, in the earlier years of the Hospital, this obligation contained a provision covering the funeral expenses of the patient if he died while under treatment. If the patient was indigent he was admitted as a free case, after being seen by one of the physicians and upon his report to the Manager. that the pratient was a fit subject for detention. Once in the cells. or quarters for insane, the patient had no appeal from the opinion ot the attending fhysician.

The following are the very brief records on the minutes of sume of the early admissions and discharges.

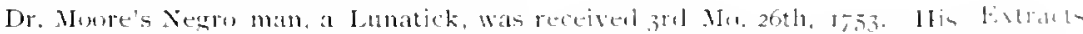

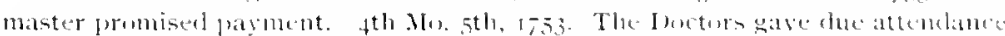

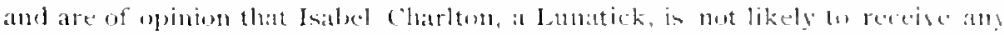
further Benefit in ye IIsplital, untill there are more convenient appartments and

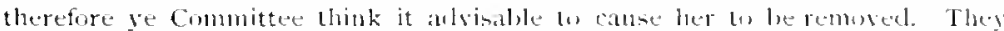

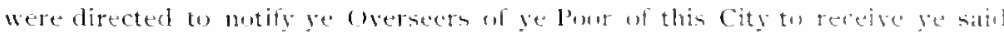
Isabel Charlton. 1st. Mo. 231. 1754. Admitted Xegro Adam, a L matick and paly pattent helonging to Mrs. Margaret clymer, under the care of I r. Thus. land.

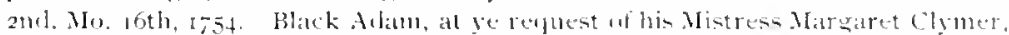

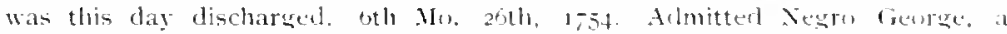
Lunatick belonging to Mr. Carrington of Barbadues. a pay patient at sus a bete. under ge particulas care of lbetor shiplen nhe engages for his luard.

The "Temporary Hospital" was in charge of a matron. I "male Keeper of lunaticks." was employed to guard the cells formen. The females were attended ly the matron, assisted by such help from sane inmates as their condition permitted.

Relatively little survives in the way of available records illustrative of the daily loutine of the lemporary Hospital, but it is known. however, that the house was shortly afterwards found unfit for the calre

\footnotetext{
'In the provincial history of our State, no general law was enacted for the commitment of insane to places of detention: whatever legal proceedings were requiste for their guardianship. estates, etc., were derved from the English statules. The charter of the Pennsylsana Hosputal conferred power upon the Contributors 10 make all needful rules and regulations for the government of the Hospital and admission of patienta.
} 


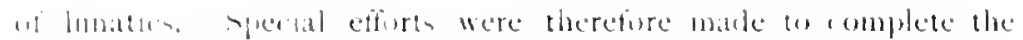

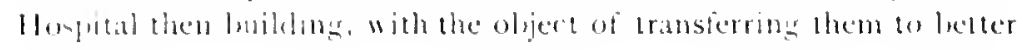
tyiartere

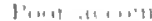

$131+1,1,11+1111$

1. 1319119.11 เ

|limpl1.11

$1,1+11111: 11,11$

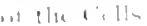

1. Inis in 1,110

Si, $146.11 \mathrm{~h}$

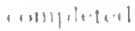

It hile at the lemporary Ilmphal the insane were confined in the rellar, in rells " under the warels for the sieth," which was the only

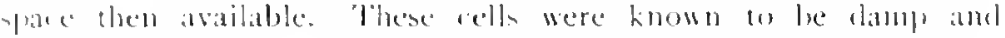

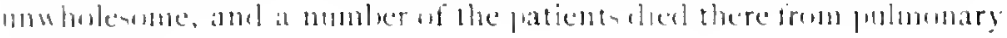
discalec.

To make the aysartment halitalile, it was orderest

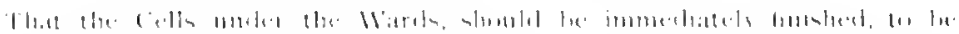

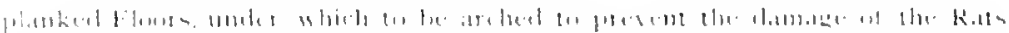

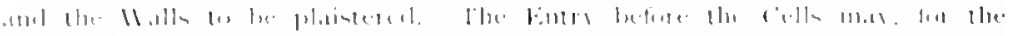

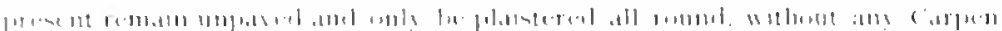

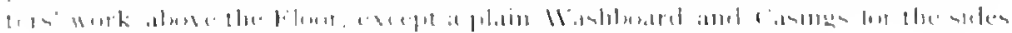

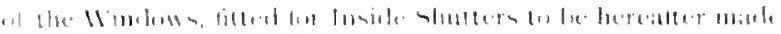

"There conkl have lecen ne was of wamber the " cells." and as

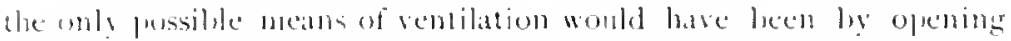
the wibluws, the patiente must hate giten suffered from dampuess, ruld, amb insufficient light. The Hesplat wats, as in mont private

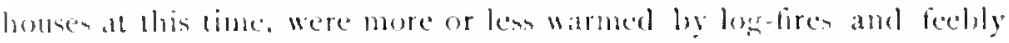
illuminated by amelle or twe. Peor an such accommolations now alpear, it was the lese the times afforded, and far betier than was cxperienced in the exintence of the arerage lumatic pros to it entahlish-

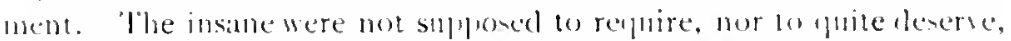
the matral comforts of life at thin peried, when even the same doelt in cold hemses, slept in cold apartmentw, and at through the long winter eveninges ly andle or lire-light.

In 1756 , the edts for lanatien, in the batsement of the bine strect

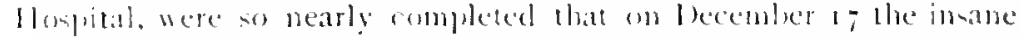
were transfersed to their mew pharters. The cells in this buildumg

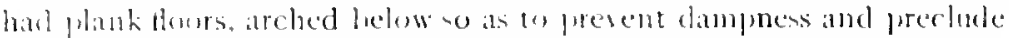
anturtion with rats. They were now very mus lo more comfortable than in their former fluaters: Int notwithetanting the ileen fresalent

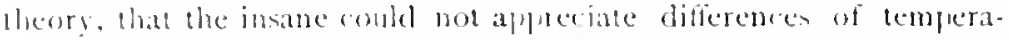
tule. the long winter nights most have brought them much suffering from colk. Wind fires in rell were imposible, and eplatly so the attempen warm them from lire-plares in the corriclor upen whin they upeneel.

The minules of Jantiars $25,1-62$, ren ord:

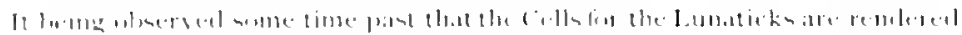

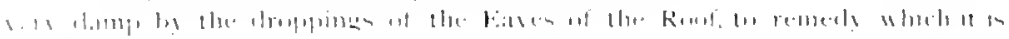




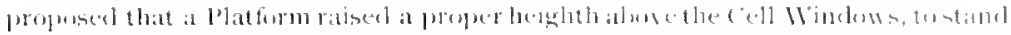

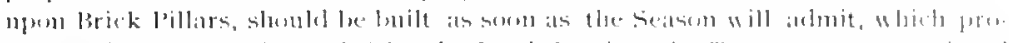

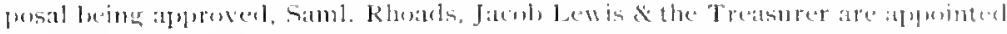

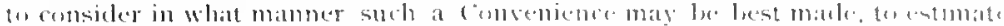
the cost, provide Materials ex emplesy Workmento do it

In 1767, "the sitting Managers are denired to employ Workmen to build Pillars for supporting the Floor of the l'iazka over ('ell W'indows." Nineteen years later, on May 29, 1786: "The Committee

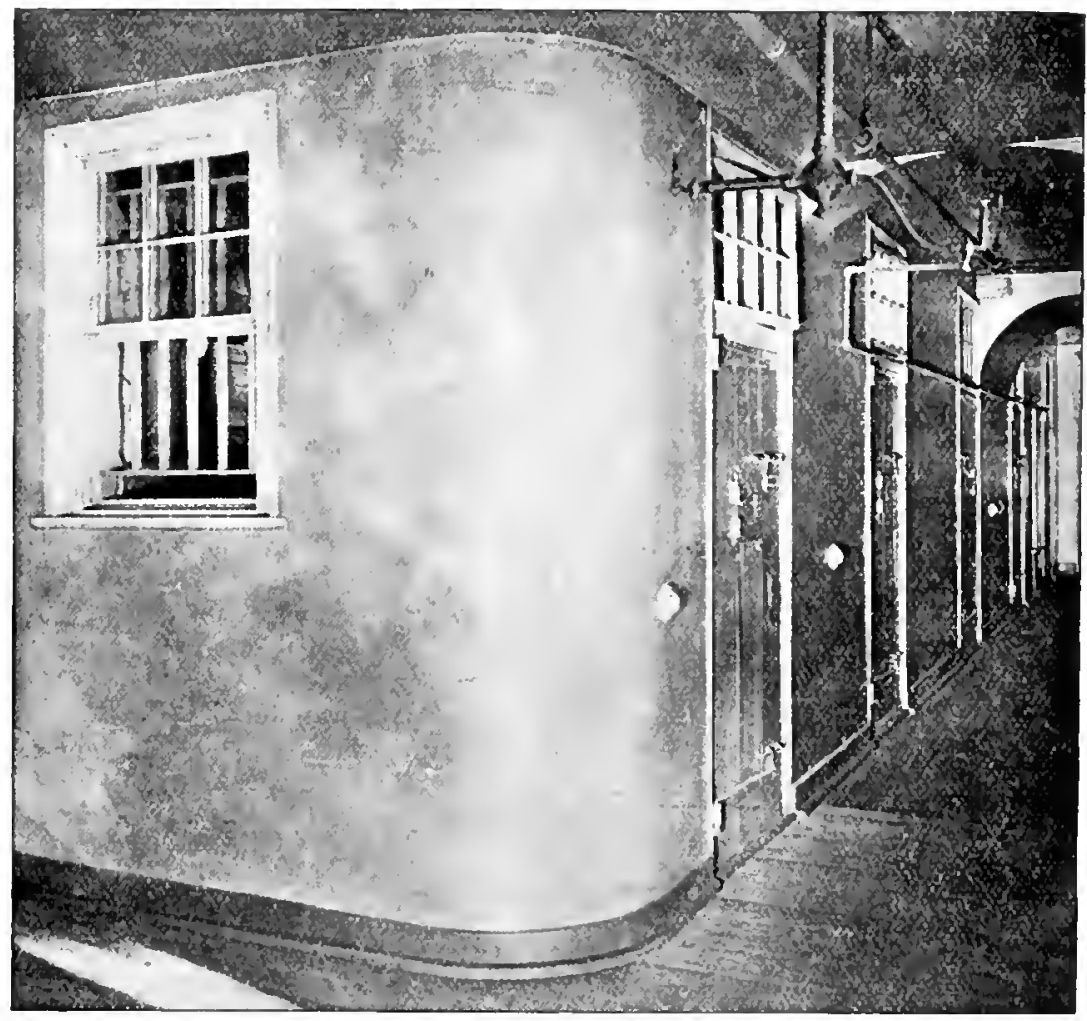

Colls as on inintly constructed in liascuent of l'ue Stree Huspual.

appointed to get ye shed built over the Cells" reported, "the Work is begin, but the late rains prevented it being finished." it was reported as completed in Iune, 1786.

It is not remarkahle that the cells for insane remained without adequate heat from the opening of the institution until alout 18.3 .3$. when the sole reliance for the production of artificial warmth wa- 


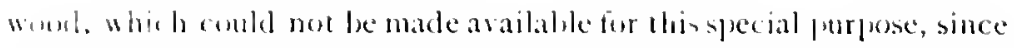
weth wool tires a large propurtion of the heat went up the chimney. while the remaineler furimsty heated only a limited area a few yarels dintant. The lest and only known means for warmth were provieled. and. inaleapuate as they were, the Managers themedres enjoyed no better in their uwn homes.

1. Mndiemth

ln: 11: $11111: 110$ ( i.ll

In righ, some of the Mandegers thoughe that the cells should be mate warmer. As no obluer meam were available. it was decided to adop the expedient commonly employed in Eirope, of selting a rharcoal hrazier or furnace in the corridors, outsicle the cells. Infortumately this device, though prompled hy the most humane motives, was fotunel not to work sery well liverybody, even the kevpers, who could stand almost anything, nearly perished in the atmosphere of carlonic atiel gas, and sur h a remonstrance arese from the lower foor of the house ats to caluse these elearly gat generators lo le specelily remesed. But the llanagers were not elisconraged ; the same year. 1794. the luilding committee were instruced to clevise a plan "by which the cells could be safely anel properly warmed by lurning woul in stures or ollerwise." "lhe tove of that periol was an iron lox, four feet long hy two and a half feet wiele. It is mot probalsle that the eells were heated to any great degree ly these wosed-lourning stoves. bu it is likely that being plared in the corricler they may have tempered somewhat the litter cold in the rooms.

l'rom minutes and memoramela that hase survived, it is apparemt that these alls were not entirely sitisfactory, for on A Aril 24.1758. occurs the following:

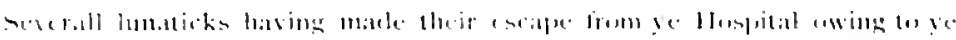

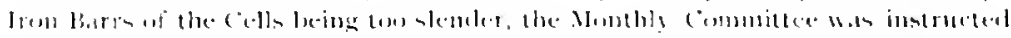

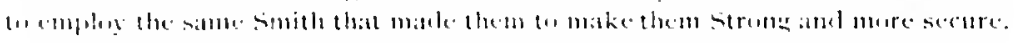

$1+1,1 \times 111111$

Is the Hespital steod on elen wround, without fence or wall

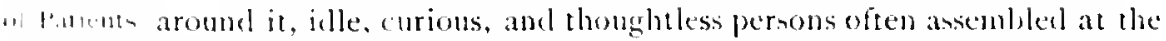
monl winclows of the cells, which were level wilh the ground, to look at the Intrumion lumatics, and finally they began to tease and annoy them. This finall! developeel into such al muisance that, on April 8,1760 , it was propused:

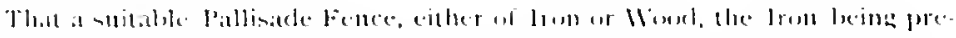

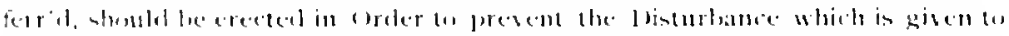

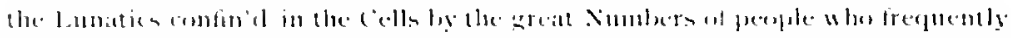

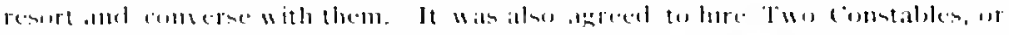

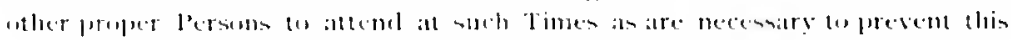
Incentenience nutill ye Fence is erected.

()n May 12, 1;60, a commitlee was appointed to procure materials and erect this " Pallisade lience hefore the Winclows of the 
Cells, to prevent the Isisurbance given to Lunaticks." lirom an accomt rendered for materials this fence was probably of iton bars resting on a brick foundation. This kejt the populace from the windows, but apparently did not abate the nuisance as it was noted:

May foth, 1-60. The ureat crowels that invaled the I Iompital give trouble

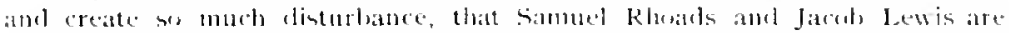

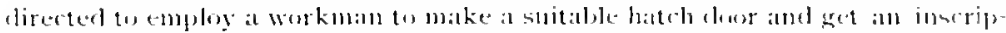

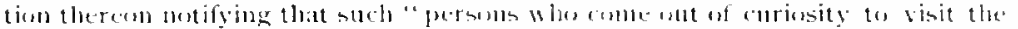

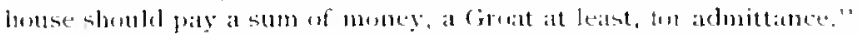

Iater, this rule seems to have fallen into \&lisusc, as, on April 27 , $1767:$

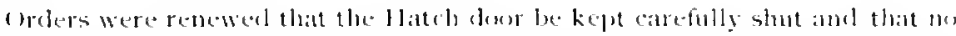

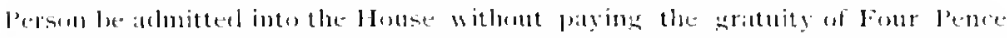

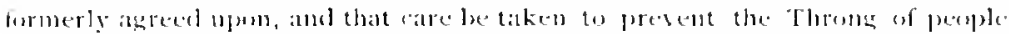

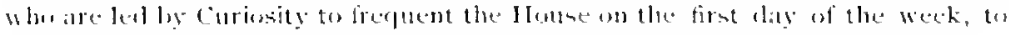
the greatt disturbance of the Patients

From time to time other measuren had to be taken to preserve order. On August 30.1784 :

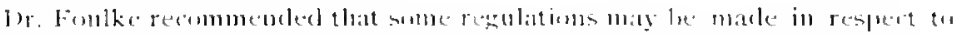

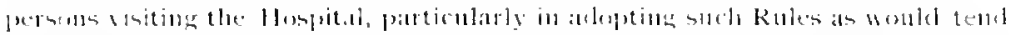

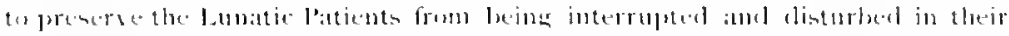

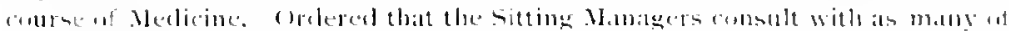

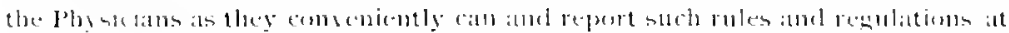

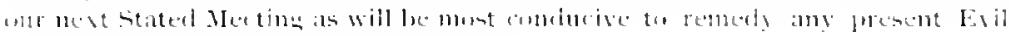
ult that beatl which that wow exint.

\section{Wherenton, on October $4,178+$ :}

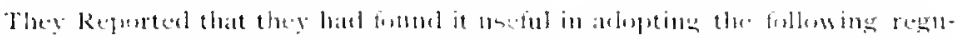

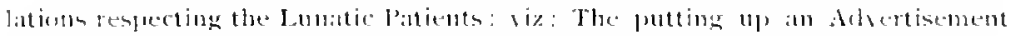

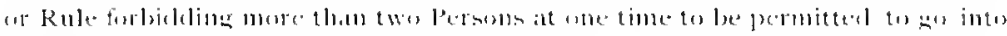

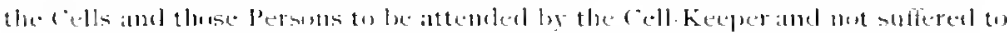
sperak tosuch l'atients.

In I791, as complaints had been made ly the Physicians that company was too ireely admitted, to the great injury of lunatics, it was resolved:

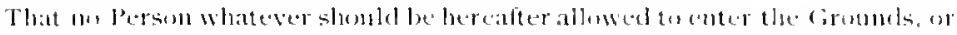

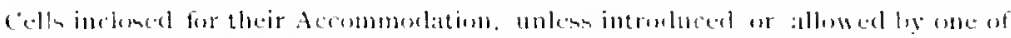

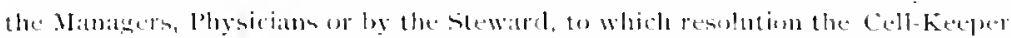

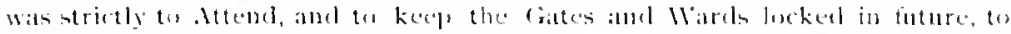
present all lutruclers whomight attempt tosuter therein, withut such permission lecinger first intaned.

Slaves were sometimes admitted at the request of their owners. who arranged for the payment of their loard.

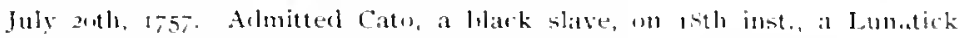

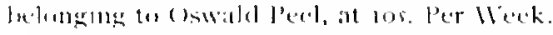

Comnties, townhijes, hundreds and boroughs arranged to have their insane almitted, as vacancies occurred in the cells by discharge 
or death of fatsents. Some of these canes gave great trouble and did more damage to the preperty than their friends could pay for. (1n April $1,175 \%$.

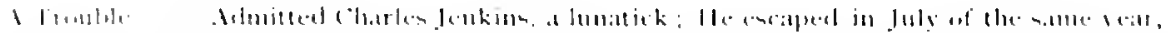

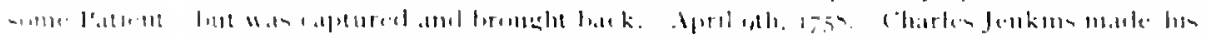

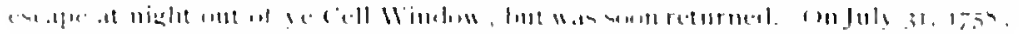
le. ،

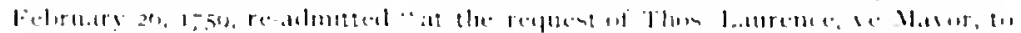

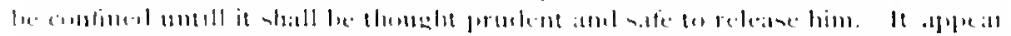

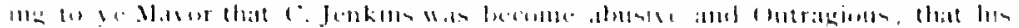

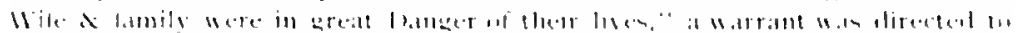

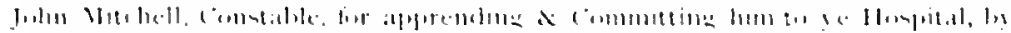

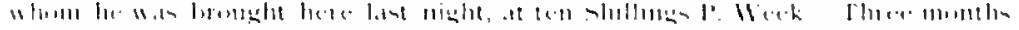

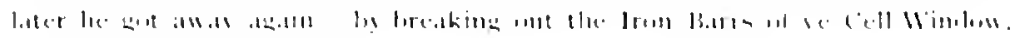

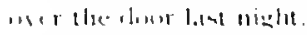

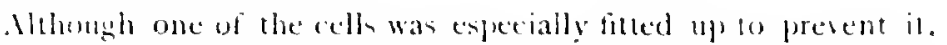
he exalfed reveral times afterward. In the interim le probaldy enjoyed himedf, as he was invarially returned " in a state of l)runken madness."

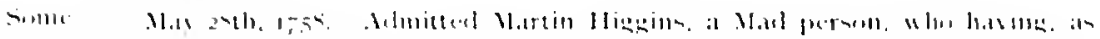

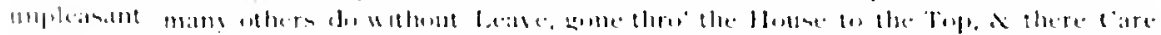

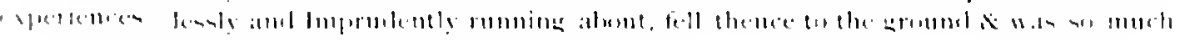

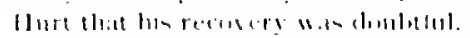

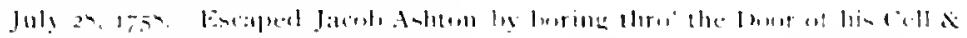

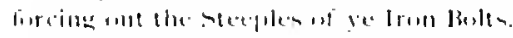

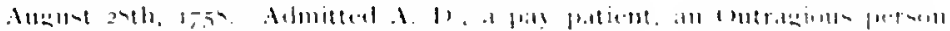

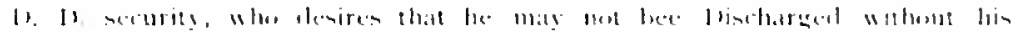
kinmoledele.

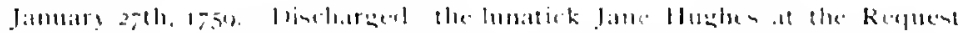

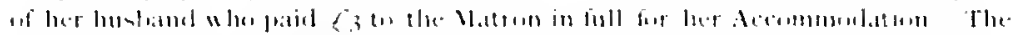

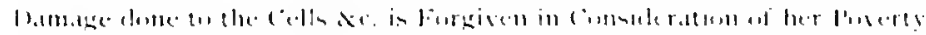

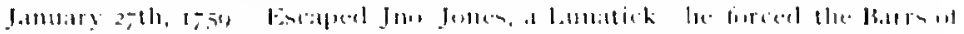

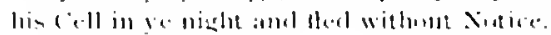

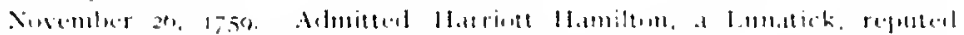

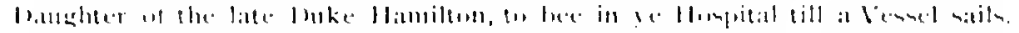

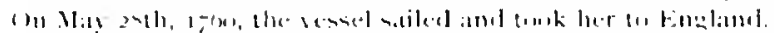

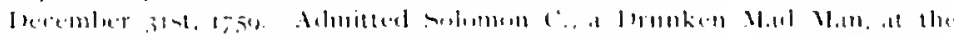

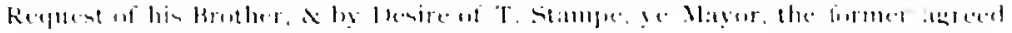

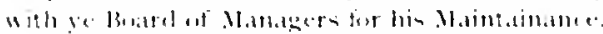

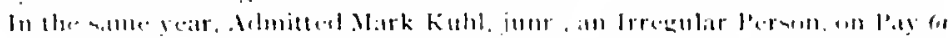

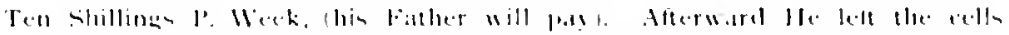

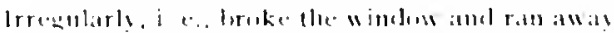

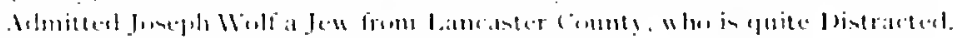

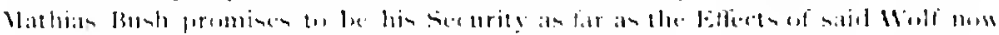

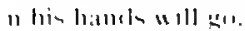

Probilly: the first instance of a patient having a private attendant ocrurred in this year:

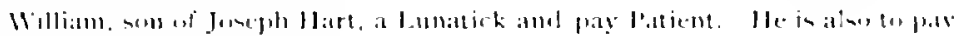
for a Xegrom man he has to hensl him. 


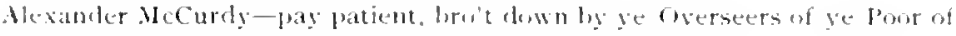
1he Tom mahips of New Gulfhaboppen Alias tpper Hanover.

Thomas Dougan, a Lunatick, take-11 ujpon the Streets naked the 20 th inst. Saticl to come from ye East Jerseys.

These quaint entries illustrate the kind of cases commonly received and the mode by which they were admitted, as does also the following ancient manuscript order:

("ITY of PHLADELFHA, ss.:

Several Persons of good Reputation havine alpeared befire me ye subscriber whe of ye Justices of ye Peace for ye city of Philada. \& complatued that Thmol Ackleg, Chairnaker, hath frefunenty behaved in a very disorderly. manner to ge great Terror of his Family $\mathrm{N}$ Annogance of his meightuma. Wherefore. Apprebend ye sil. Thoman de take him to ye Workhome of thin lity, the heeper whereof is herety reguired to receise $\mathrm{x}$ Emply him in ge Common Lalnur of the House. till furtlaer arderm

But if ye sol. Thumas or his llife shall when he is arrested. requent thitt bis Confonement may be at re Pennsylania Hospital, in that case detiver him tor ve

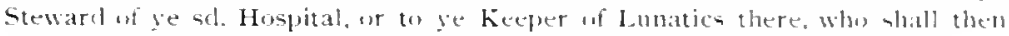
receive and safely keep him till he is discharged by proper Authurity.

Given wnler my Hand s seal December ye $2201,1-63$.

Tir Ang Constable.

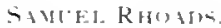

The following are copies of manuscripts addressed to the Managers on behalf of the reception of two insane patients. The first one cited shows that the question of the legal settlement of a patient was then as much considered as at present :

We whuse Names are underwritton, Inhafitants of the Torwn of Xew castle,

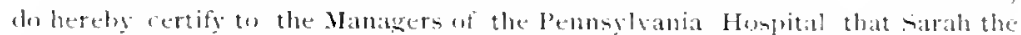
wife of the Revel. Elueas Ros the Sinciety's Missionary here, wh the ance of thirtynine yeatrs or the reatenats, hath during her residence in this plice. fur near tive years past. been Lunatick, bereaved of her unrlerntanding and wholly dinguali. fieel to manage her Household affairs. Therefore, at the regutent of Br. Rums we

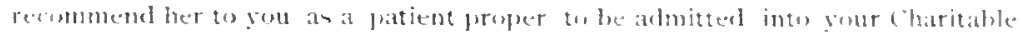
In-titution.

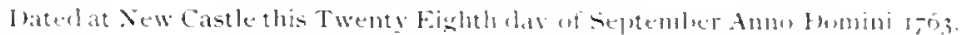
(Here fillem signatures.)

Rithard McWilliam, Esquires one of his Walenties Juntices of the Peace fur

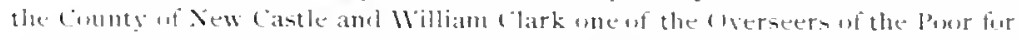

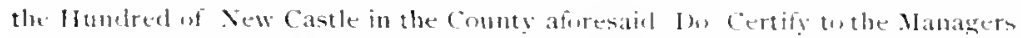

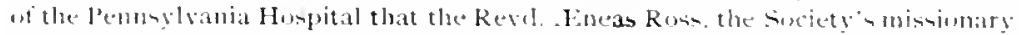

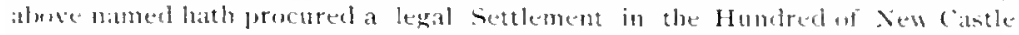

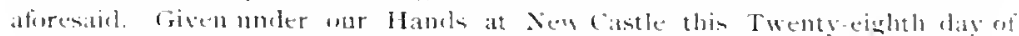

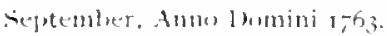

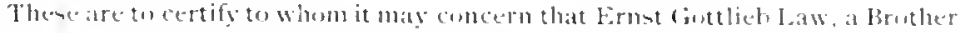

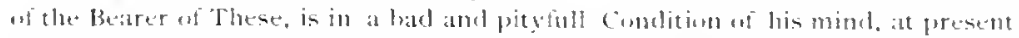

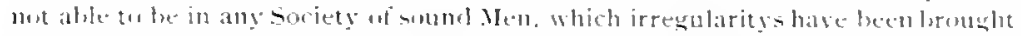

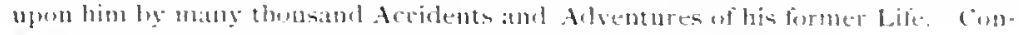
secpluenty be wathts to be pityed on and put in the Hespital agatin.

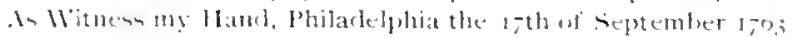

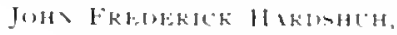

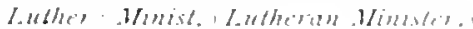




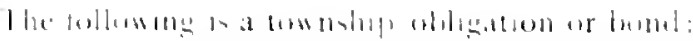

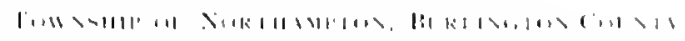

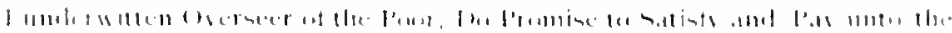

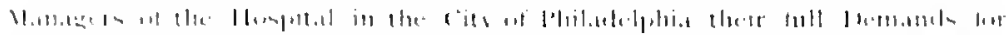

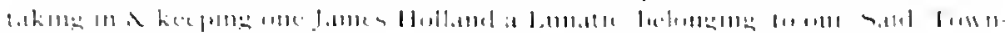

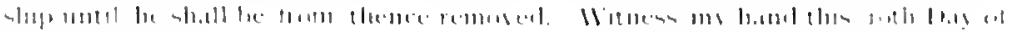
$.111318+1,12$

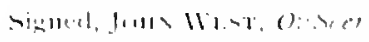

It the foret of thi gaper the visiting plasician writes what wats

(1) 1911, ate

(1) I 12,11111

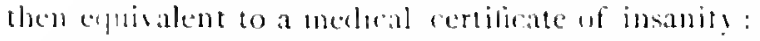

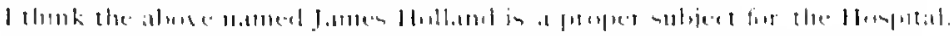

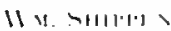

I calse which alout this time attated much atcention in the

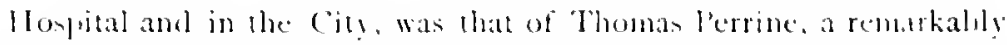
neat and tidy sailor. who was admited as an insane platient in Mareh. 1765 . and died in 1;it. For a briet period he lived in the a elle, where he proved very tronblesome, gtarrelling with the kecper and with the oher gatients. He finally escaped from the hasement and ran through the houne, rear hing the cuprola of the bist wing. from

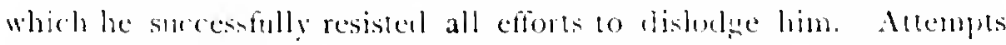
(1) do so being abandoned, lkeleling was placed in the apola and there he lived and died. It is recorded that

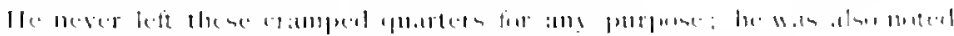

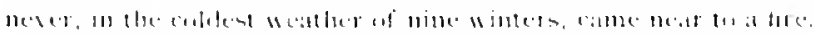

l'bere survises a beantifilly written and most pathetio petiton

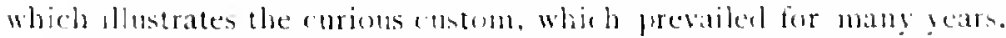
in the infont commonwealth of selling peser white persons, or enture

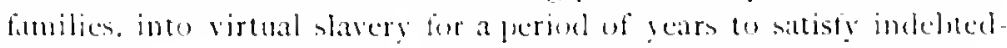
nes.

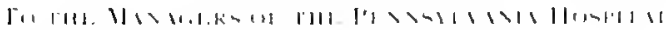

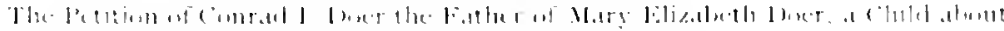

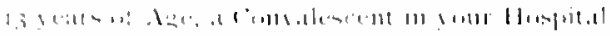

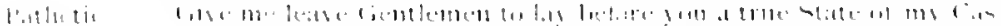

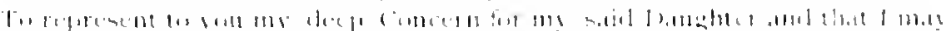

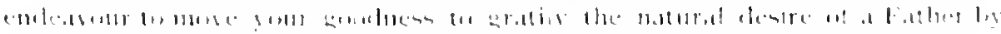

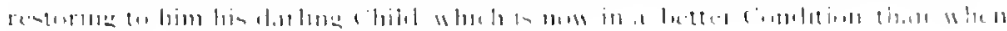

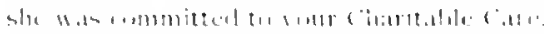

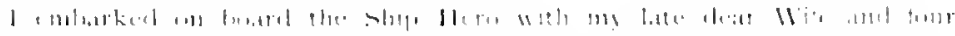

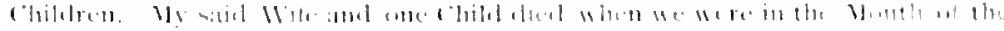

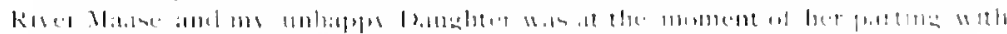

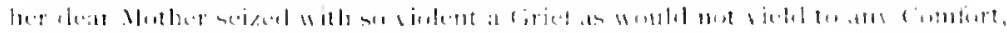

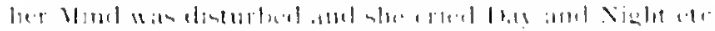

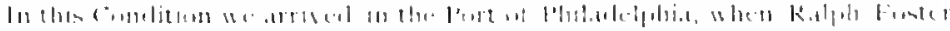

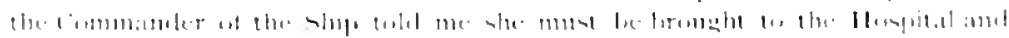

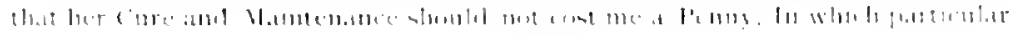




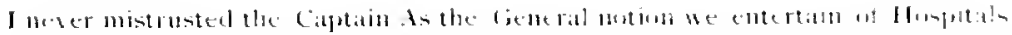

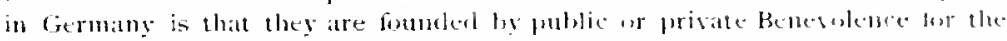
relief of the pour unhajpy sick and that never anything is chareed to theit

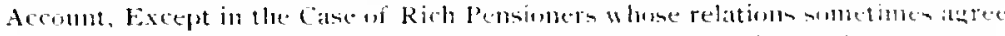

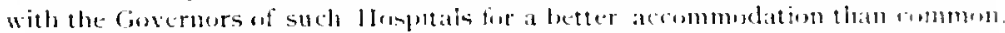

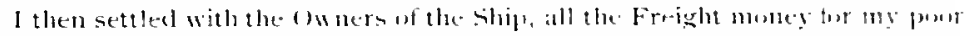

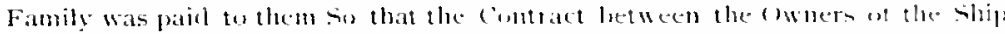

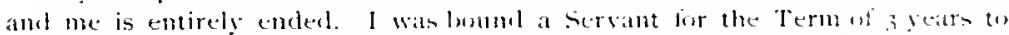

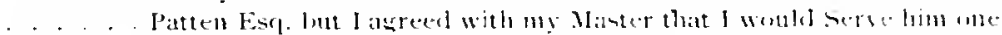

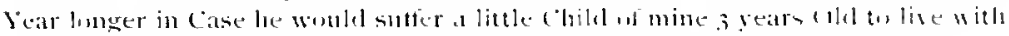
his Family during the Term of my servitucle.

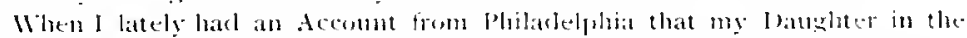

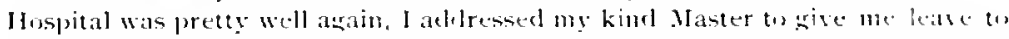

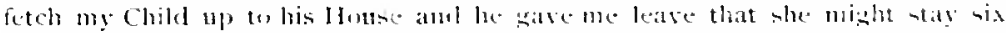

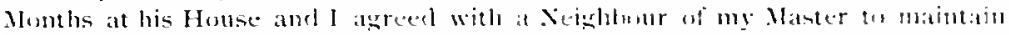

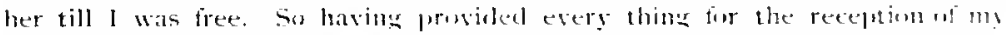

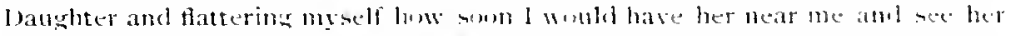

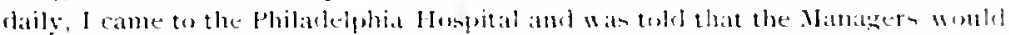

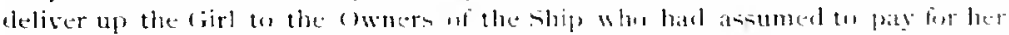
cure and Accommudition and that these. Merebants watd sell her for the chargen

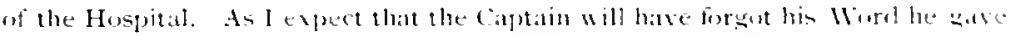

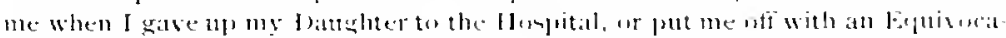

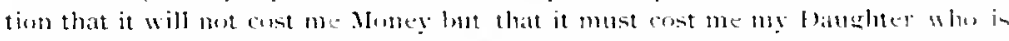

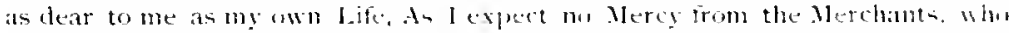

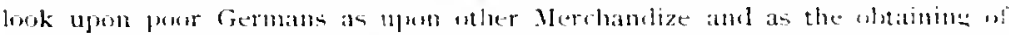
Justice against them if they shonhl attempt to sell my Child algaime my will in

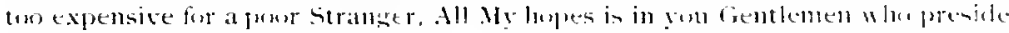

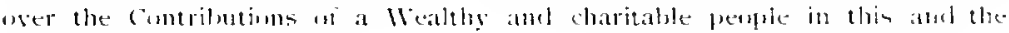
ne-ighlouring Provinces.

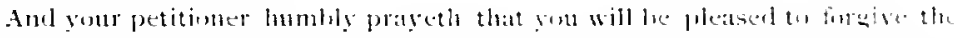

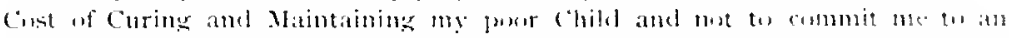
Arsument with Verchants in wheld they might get the better of me when 1 being

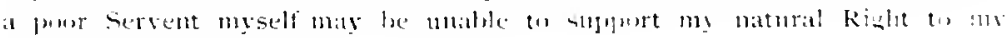
I):insher

Ancl your Petitioner shall erer prily.

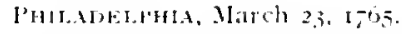

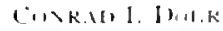

Although no action appears upon the minutes. it is reamonable w suppose from their previous acts of kindnens towards patient- that the Managers did not refuse to grant this pathetic appeal of a bather for his child.

Amntitants have always been noted for longevity: and the rocord 1.manty furnish such an instance of tenacity to life in the case of lusegh llluntratne Mountz. or Maunz. who aplears to have heen mildy insane. Inder the plea of furnishing him with a comfortable home for the remainder of his declining years. the Managers were induced to consibler hiadmission into the Hospital as a lorarder.

The first entry upon the minutes relative to his case occurs on November 26,$1 ; 64$, when 


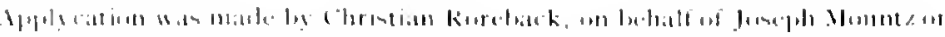

1 P.1t 1e'llt milkias litit (intetrat lan

lingrital (atre

(inmplatinims

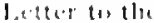
Yatritigers.

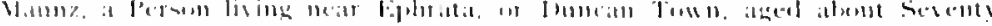

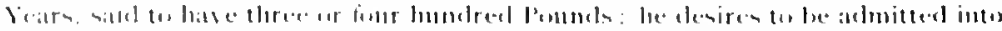

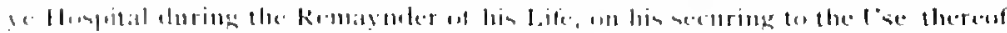

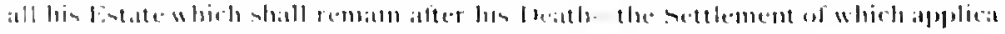

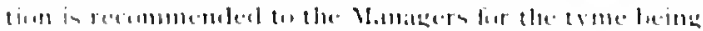

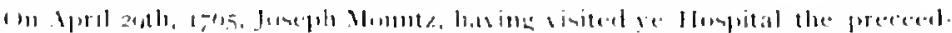

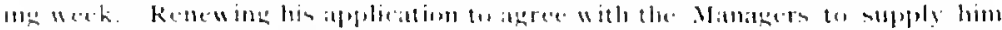

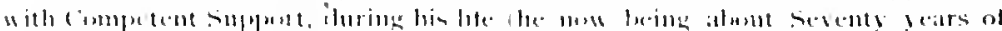

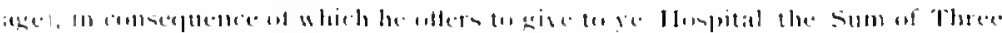

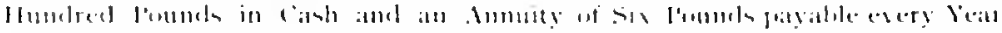

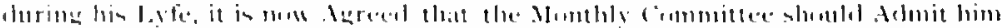

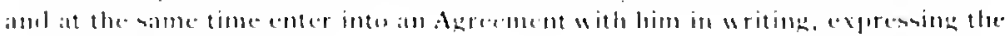

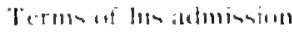

Haing made all arrangements be departed: but reappeared at the Iospital on June zth, alout two months aflerward, with the propmsition that he le allowed to enter and to remain. "For three or four lleeks, in order to try if ye llouse will prove Agreealle th him to resyde the remainder of his l Days in." This was also granted and his experience having proved agrecalole, on luly 29.1765 , it wa reprted that

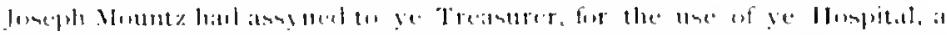

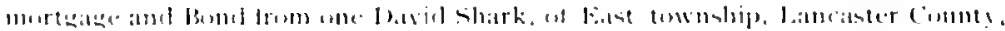

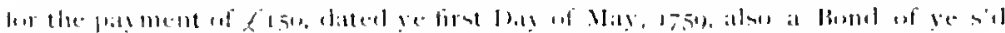

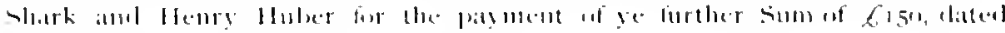

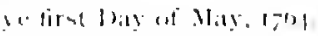

On . Ingust 26, 1;65. Joseph Mountz was admitted. In 17 is 3 . he aldresued the Managers as follows:

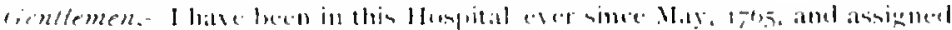

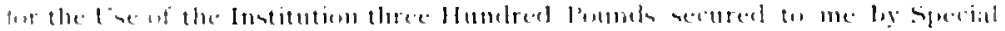

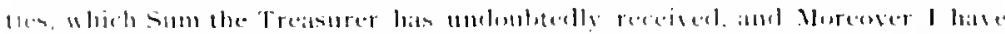

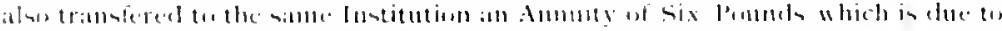

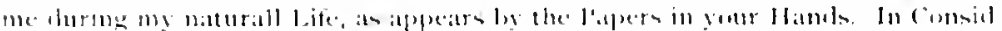

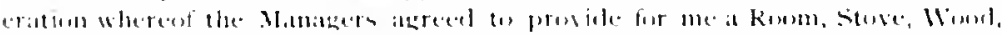

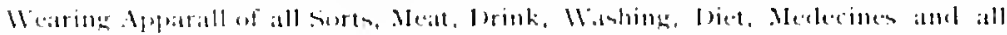

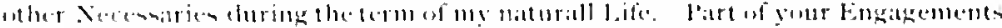

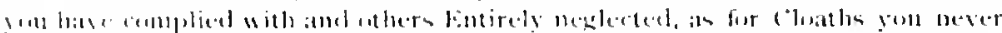

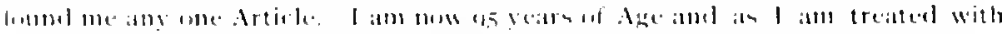

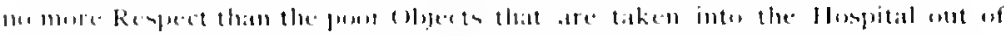

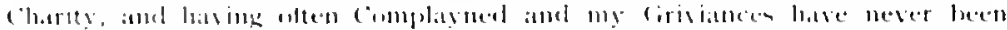

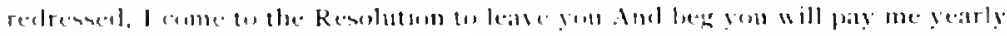

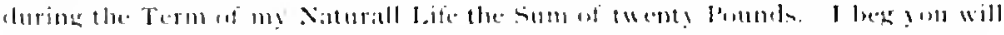

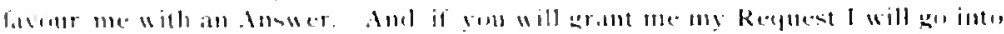
the collutry in alont twe Mustlen hence.

Joeph did not gee ines the country in two months, as he did nue receive an answer to his proposition until five months after its receipt. It is likely that the Managers were as weary of Monntz's 
presence in the Hospital as they must have been of the original agreement made with him, as their tardy reply was in these terms:

The Managers of the Hospital are Willing that Jos: Nountz may go and live Annuit: ameng his Friends and they will engage to pay Twenty pounds per Anmum, dur- fir:antet ing the Remainder of his Life, Provided he with his Friends will Indemmify the Ifopital from any Chains which may arise ly reason of the contract they enter into with him, when lee first applied to be artmitted into the Hospital.

The Treasurer reports, November 5 , i 789 , that

He has paici since last sleeting, thirty-four loumls, ifs $6 d$, leeing the balance due on the life. Annuity of Twenty pounds for the Support of Joseph Irountz, who cutereal the House the 1 gth flaty of August 1,65 , as a l'atient and was atterwards Buarded ont jursuant to agreement mate the 27 th of November

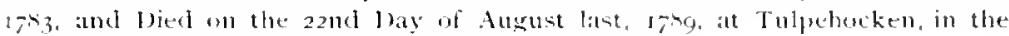
county of Berks, ated about One huntred Years.

The following are some of the very numerous instances illustrating the generous spirit of the Managers in dealing with poor patients:

These being a charge against the Security of Catherine Eshricle of 17 Beds, Pon?

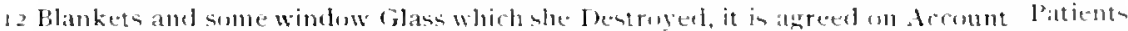

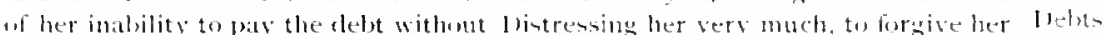
the charge for these Aricles.

The buart in consideration of the Poverty at the Party onments to Furgive

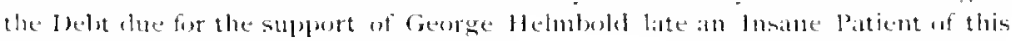
Humer.

The following official request from the Overseters of the Poor of luwer Chester County was granted:

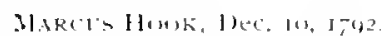

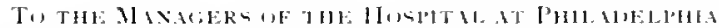

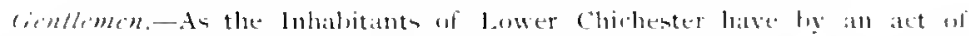
Ilumanity taken an Coknown leren whe Alpears to be sery lmalle in minl

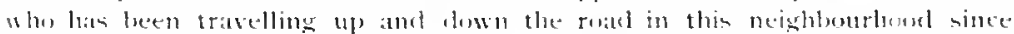
fuesty last and has severall times attempted to dentroy himself, thetefore as the luhalsitats have apsolyd to me an a Justice of the peace for the comuty of Delaware fir the Retief of Saiel unknown Persoll, think it most Acliseable an there is mo Comsenieney to Aecommolate stoch a Persm in the town ship, where Humanity has Induced them to receive him, to prevent the llorrial delea of self bestruction/ to Recommend him to the Hospitality of the Gentlemen Mantaters of the Hospital of the City of Philadelphia. Hophe that the same principle of Humanity that has luducerl those people to prenerve life, maty also furbere the Mathager to receive such a Persen in the Howpitat of the city uf philatelphia, at it is a cimsenient plate fur that t'urpuse.

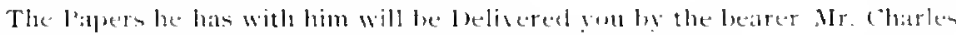

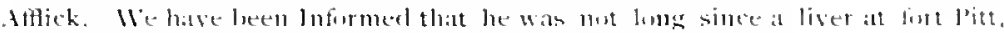
ly the Name on Robert Ricklle, als lis l'apers seems to. Appear.

The subject was admitted December 12 th as a pay patient, Lut charges for hoard and funeral expenses were alated. The poor man died December 29. 1792 .

Annuitatnt

I jies a

(') l'atientit

Almitterl

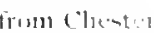

(inunt! 
Comparatovely lew citiens of Philaclelphia are aware that the

$\mid \forall+1,1) \cdot 111$ $12,13,111$ wite of Stephen Girard revided for many bars as an insathe pateon in the l'onsyluania llospital: that she gate birth to a doughter while there. shurty ated admision: the latter died in infanes. The

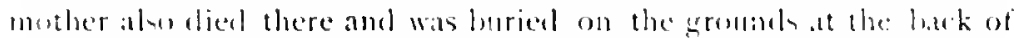
the llowpital building at Eighth and l'be sitrets, where her remains toll reat, the spert leing ummarked by monument or seme. on

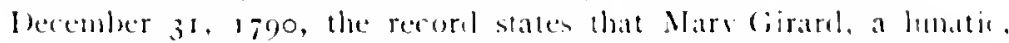
wife of stephen firard was almitted as a l'alsing l'atient.

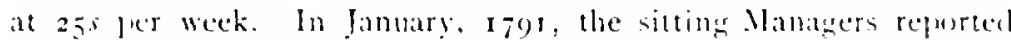
we the lisard heir apprehension that she was enceinte and the?

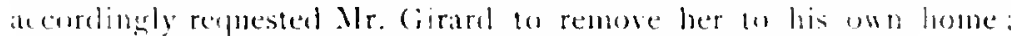

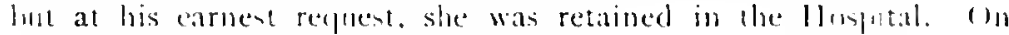
Marrh as. rost, the minules state, that

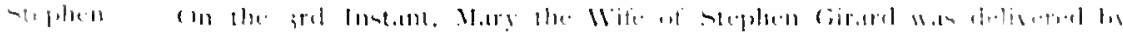

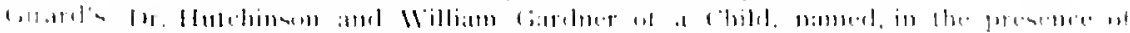

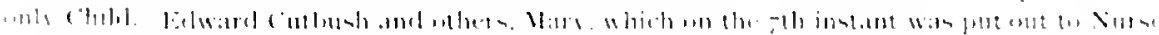

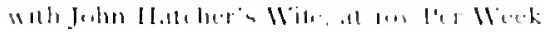

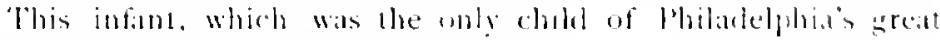

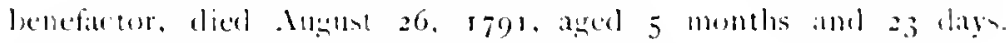
The fumeral expenses, which were paid ly the steward of the lluppital. are recorded an follows:

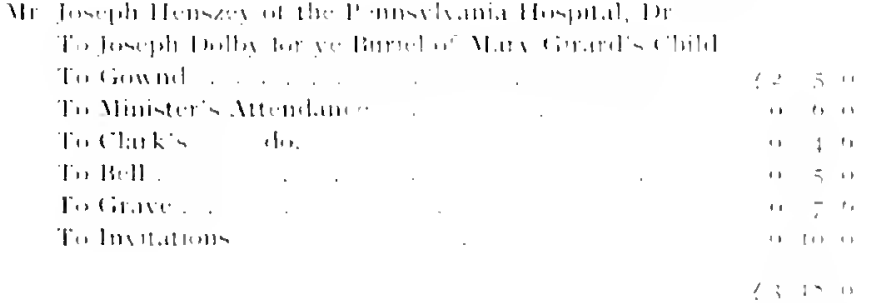

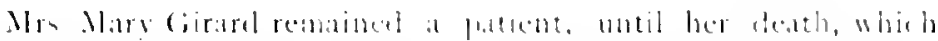

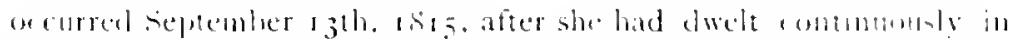

lint 11111110

iा) 11

$11,10,912.1$ (.1, indidis

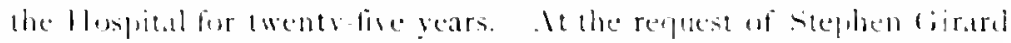

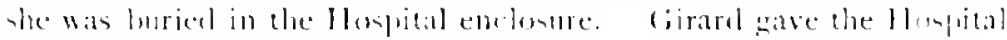

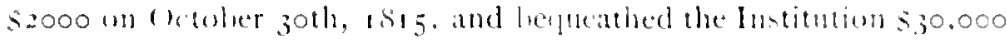
ley his will.

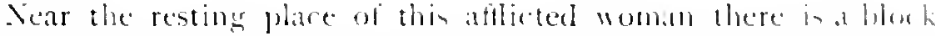
"f marlile. surmounted hy an urm, whirh marks the grave of ("hatles

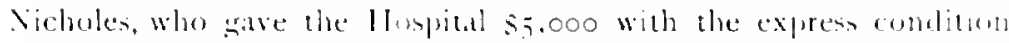
that he should be buried in the llowntal gromols. The marble has encraved upon it the followise inscription : 



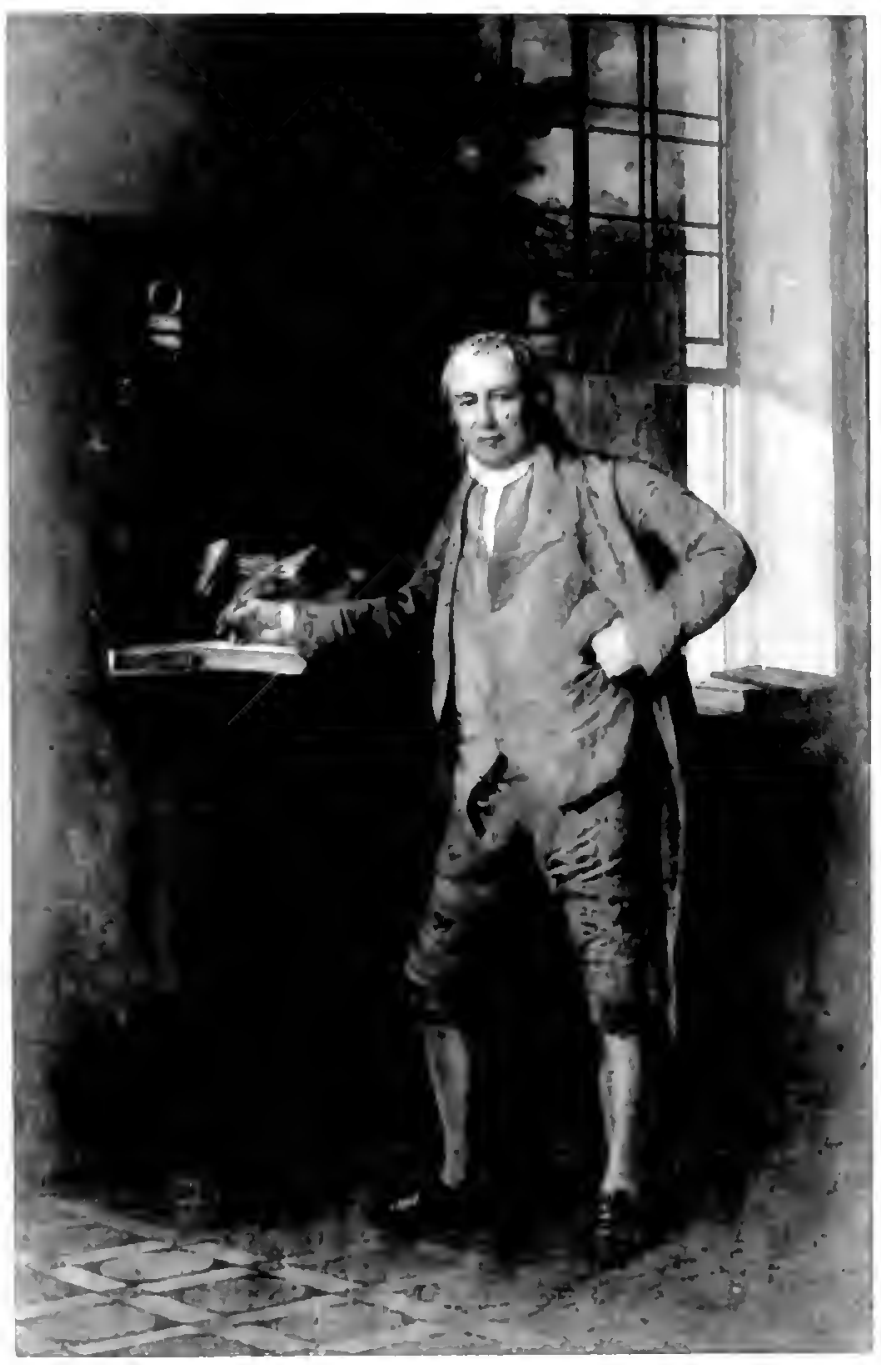




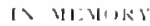

CHARLES NICIIUI.FS

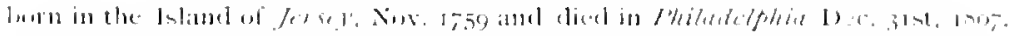

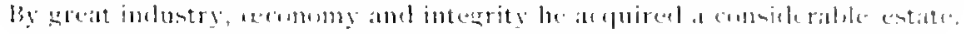

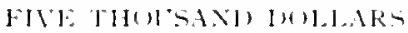

of $แ h i c h$

he bergeatherl on the

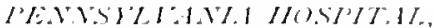

and the resielue in wher ehatritien

amel lesatcies to his frientols.

IIis lexty is interred

In compliane with his respent

in this place.

Amel this momment is erected wer it.

by permision of the Mancigers of the Ilospital.

in oreler to perpentuite his nitme.

ly une of his Execulurs.

Samtel Coates, who was a Manager from 1785 to 1825 , always A Varta. carried with him a rather large. leather-bound memorandun look. in which he noted, in jnk, his reflections upon madness and his deductions drawn from his olservations, with notes of the histories of especially interesting cases and incidents. which came under his notice in the cells, and the wards for the insane. Mr. Coates prenented this look to his son, Benjamin H. Coates, who was one of the attending

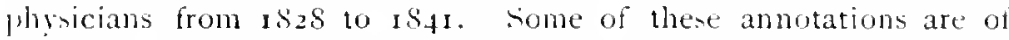
mustual interest and show marked ability in Mr. Coates as an acute ubserver. (See also prage 72 for other Extracts.)

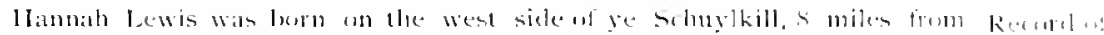

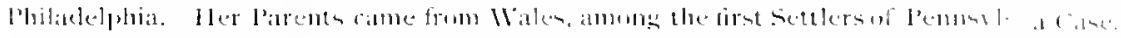

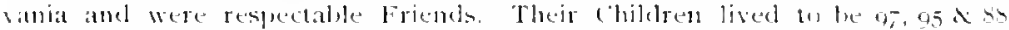

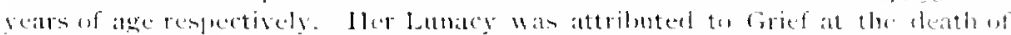

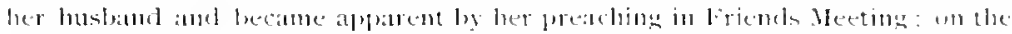

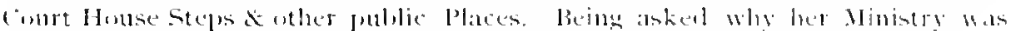

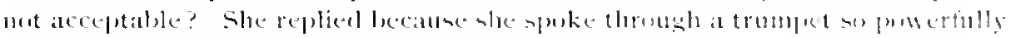

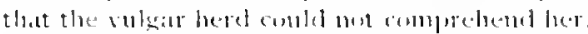

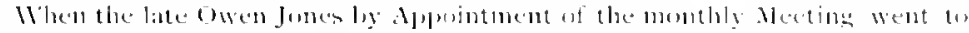

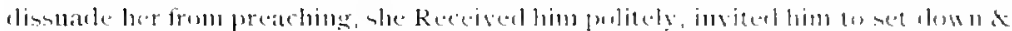

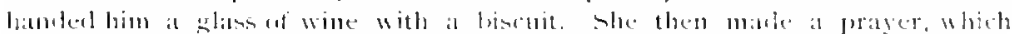

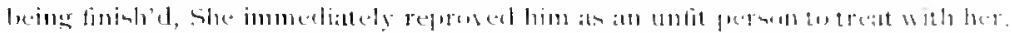

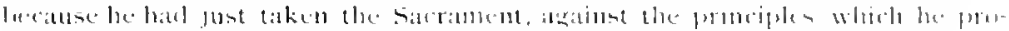

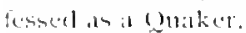

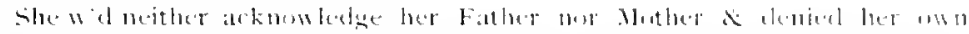

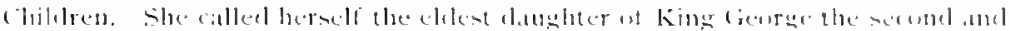

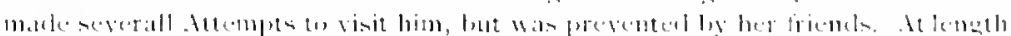

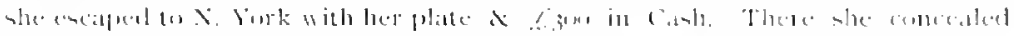

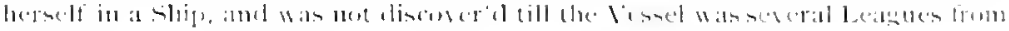
the l.ancl.

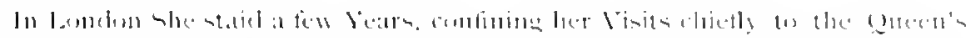

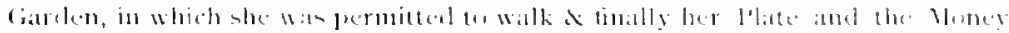

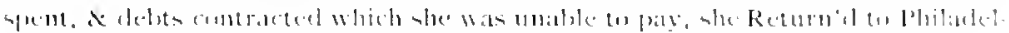

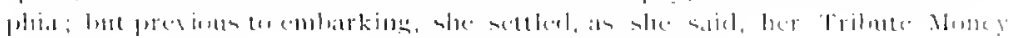




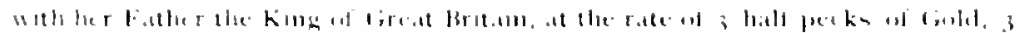

119erti.1t10119 1190111.01 . 140 (1) IIIm.111!t!

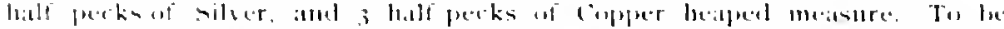

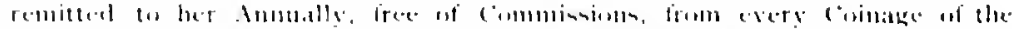

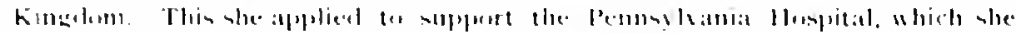

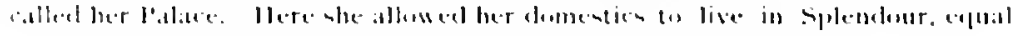

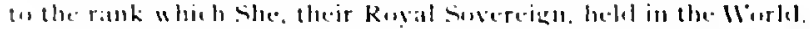

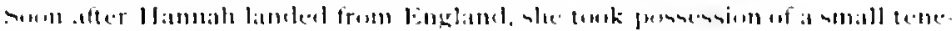

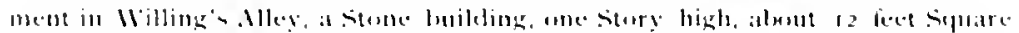

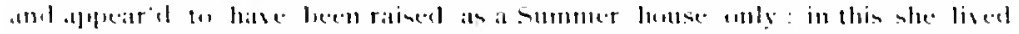

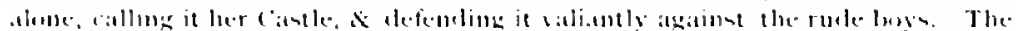

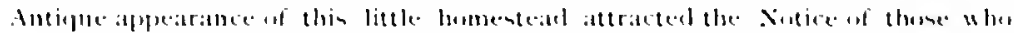

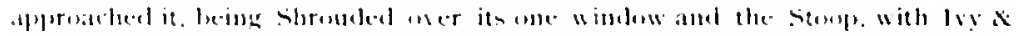

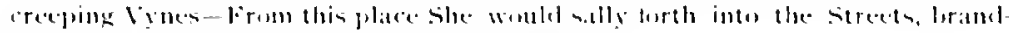

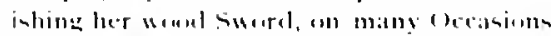

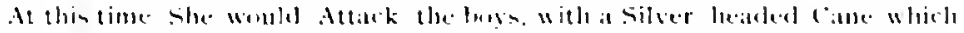

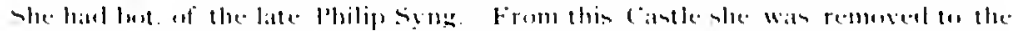

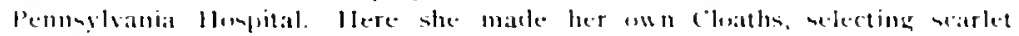

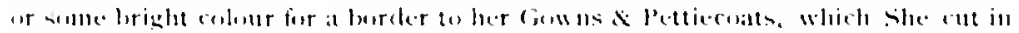

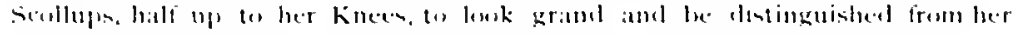
suljecets.

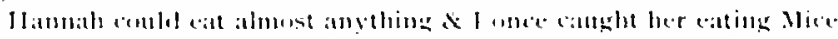

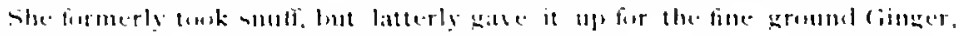

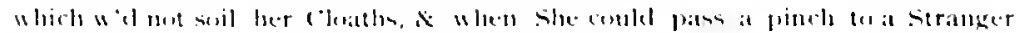

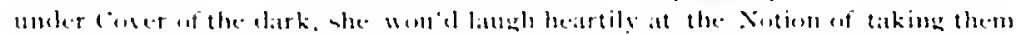

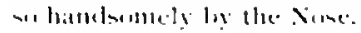

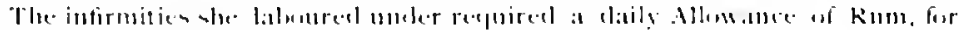

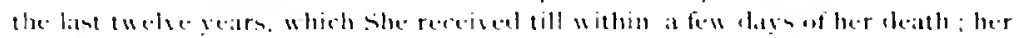

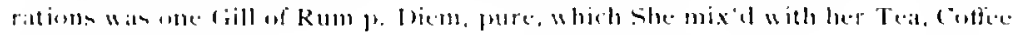
and litaly at dintert

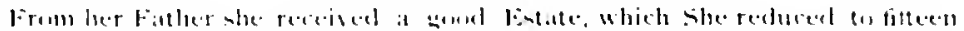

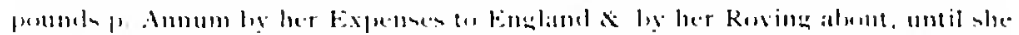

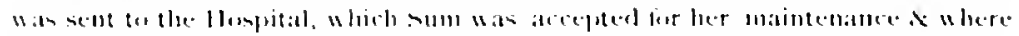

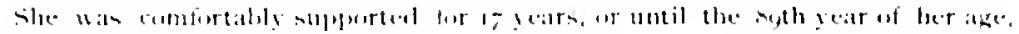

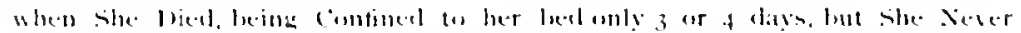
renuserid her keatems

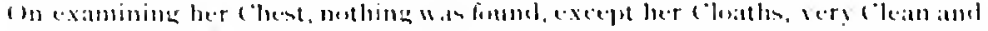

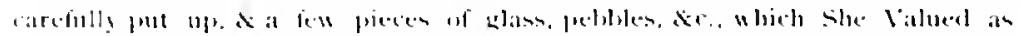

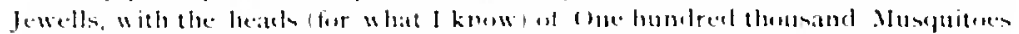

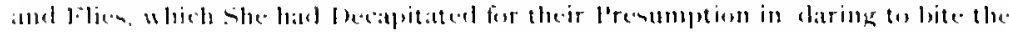
kine's I 1110lue.r

S. (indris.

Another patient named " tolly" Mr. Cuates considered one of the most interesting cases of insanity in the Hosplital:

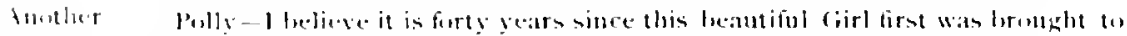

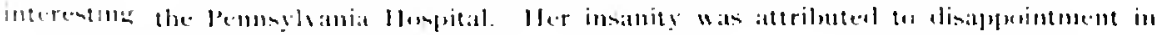
i.ise. 1.1120.

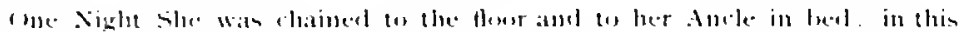

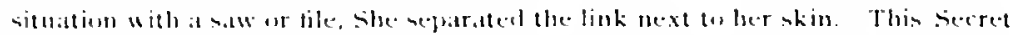

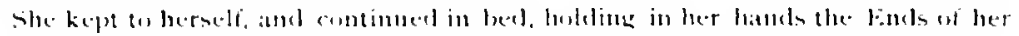
hains.

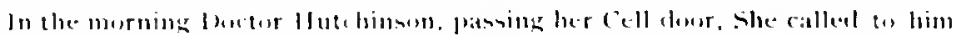

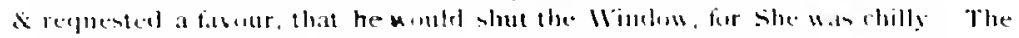

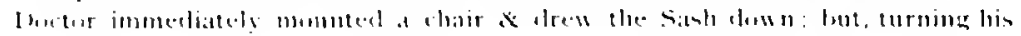




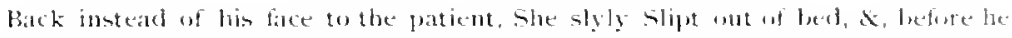
could dismeunt from his high Station, she was out, d bolting him in, endaped there he was cletined the best part of an homr, calline on loike. Tom on Harry any whe he cou'd see to deliver him from Prison.

The hue and cery for Polly was sonn made: at length she wan finmd, malline

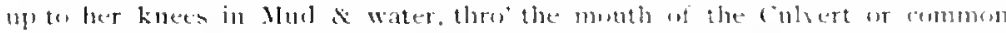

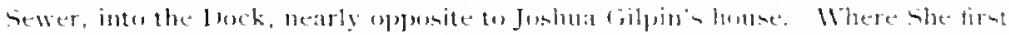

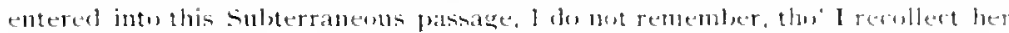

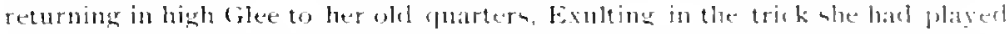
upen the doctor.

The apparently mild and attrateve ("hamm of thim beatutiful Wimall were

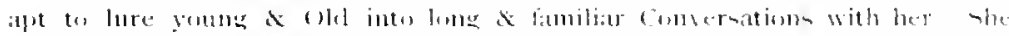

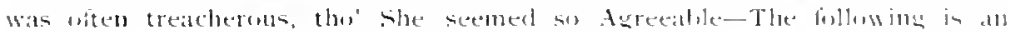
Imatance.

one day, in the line wi his duty, In. Parke paid her a Visit-she wan then br. Palke

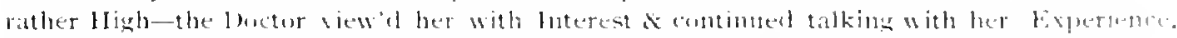

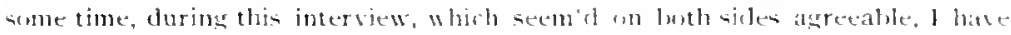
no Doubt but Polly was preparing an finish; for, having her hand in her peeket. while he was spe:akng to lues, she sudkenly thrusted a long knife at his leody which she pulled ont unobserved o pierced thro' his cont and Jackett: and entering the Wall, it drew from it a triangular plug of llortar, aleout an inch in length on every sicle \& even scraped the very lirick, leating the mark of the knife upon it for severall years till the Chasm was filled. The lenctor. I expect

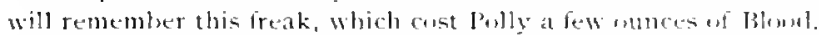

Nany Vears since, I was walking un the commons a hearcl a great Xisise. Interesting Where it came from I combl net tell, but list'ning Attentively, I diseovered it wat Case Related

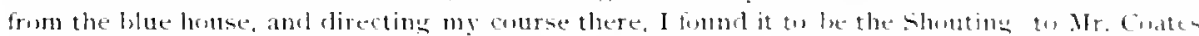
of a sreat number of penple. They were Assembled to a Bull baiting. which in by Timuly those dilys, wats a common practice.

The Animal appenred to be in a great ritge, the much exhausted by the lougs, before I reathed the scene of Action. Soun after I gut there, a smalli

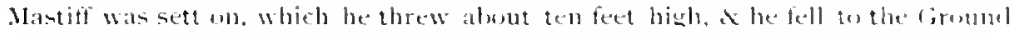
with his upper Jaw loroke \& Fiery twoth out.

A short rest wats now again givelu to the Bull, when a presumptioun bittle Van, to shew what he con's do, run towards the Anmal, lat Returned fintes

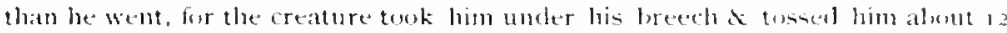
feet from the end of the Rupe.

A New pack of digg being procured torenew the fieht, every Fye was turnest tis the (1) inct.

At this moment, Polly scaled the high fence, thre' the Crack of which the

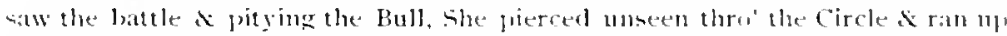
rlinectly to the Ring; and without Shues or Stuckings un; with her Busm all "pen: her neck bare And her beatutiful Ringlets willly dangling eser her

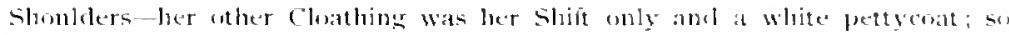

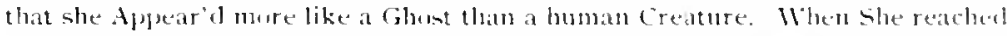
the 13ull, (tho" previously \& almost immediately before, les wan in a kage) she

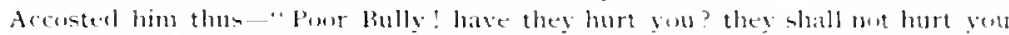

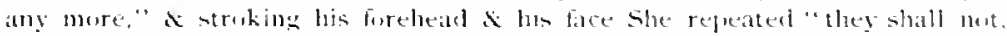

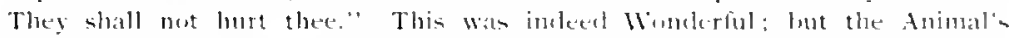

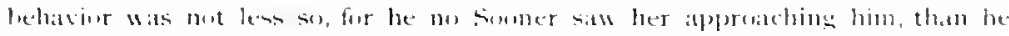

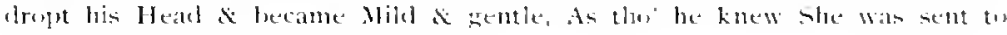
deliver him. 


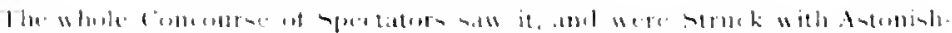

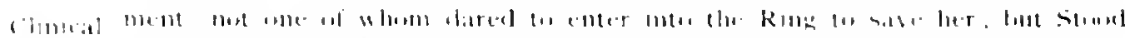

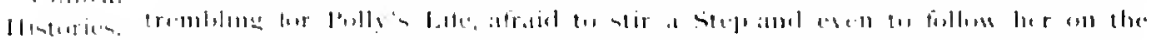

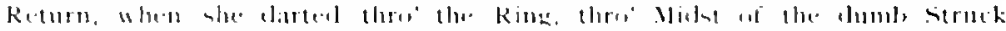

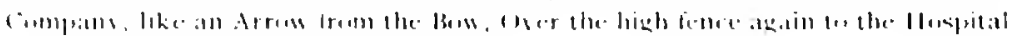

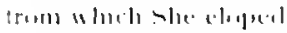

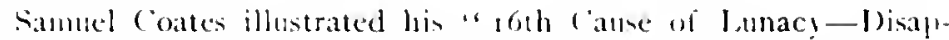
frintment." by the following narrative of continteus misfortune:

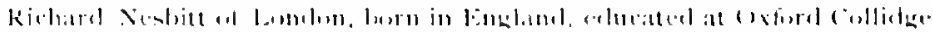

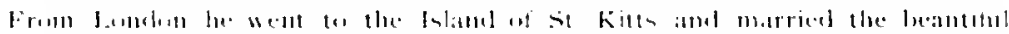

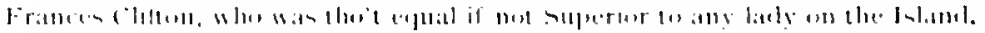

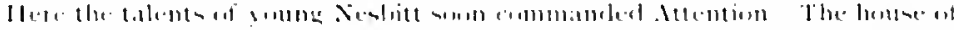

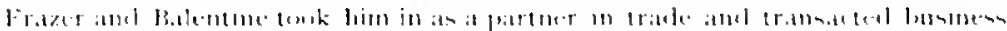

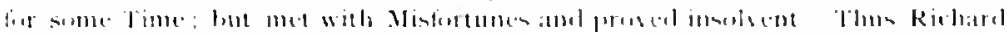

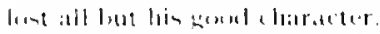

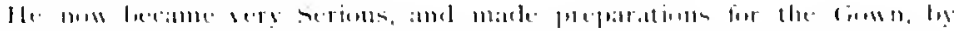

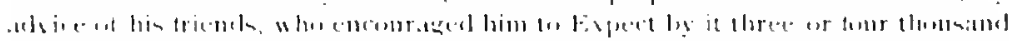

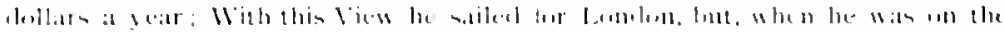

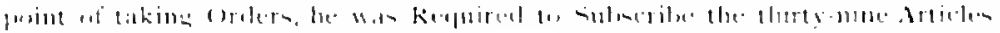

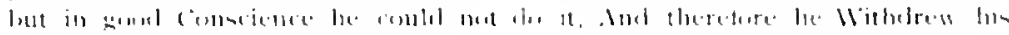

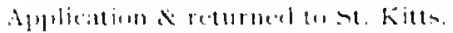

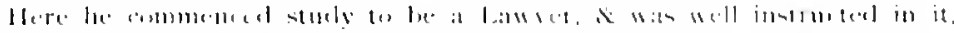

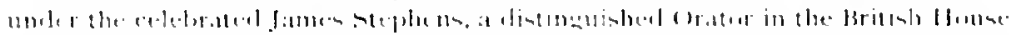

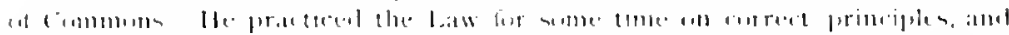

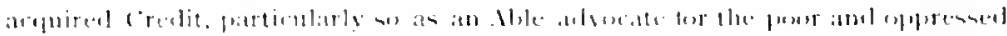

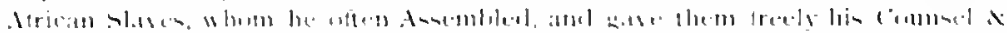

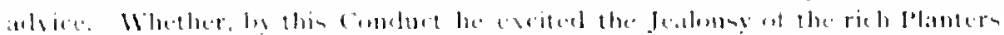

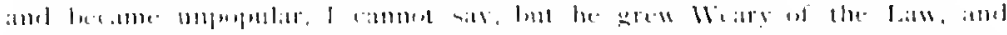

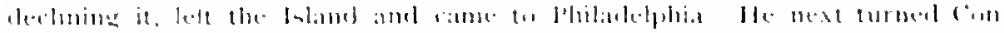

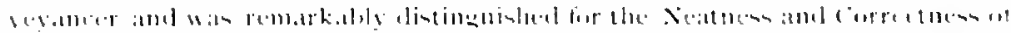

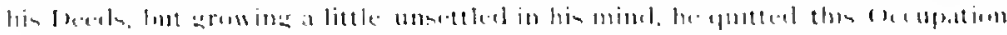

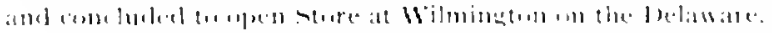

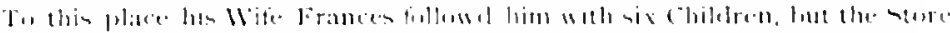

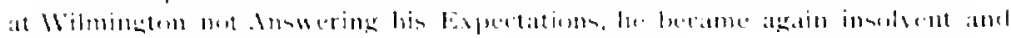
सil1. it 111

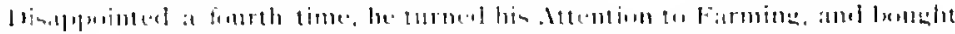

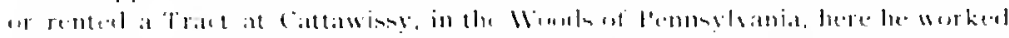

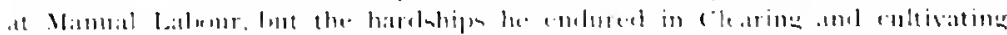

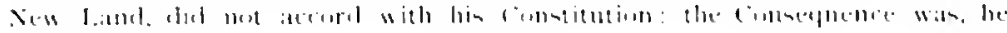

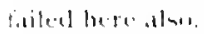

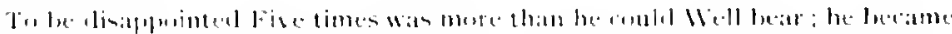

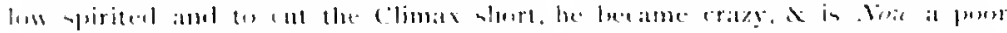

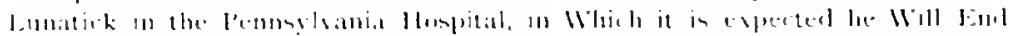
bis Ju,

Prembin sion after he was admitted. he wrote the following touching lumine lines to his wife: 
As buritend with my lirbet, I sitt to monras.

Thy Letted tame- Al why unt thy Return?

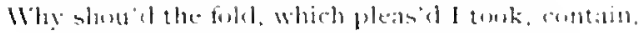

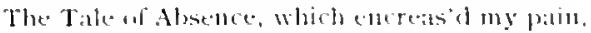

While I a domble weight of surrous bear.

severd from the'e, and kept a t'ris'ater here!

Vet if 'Tluough dirguish of a tortur'd mined,

My thenghts, my dets were fiubly or unkimel,

Though wreat my eprors, great has leeen my ciried,

And Richard lowks to Fritues hor Reliet.

Think then in lity. Lowe and indet care,

lpan the stherings 1 :m le.t to beat

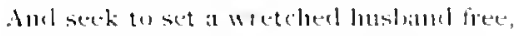

Wha loses hut tow much, in loming there.

Tu our I teat children nuw let me return,

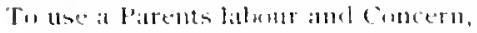

Lang have I telt beth able and inclined,

Tutry the punets of Borly and of Mimel,

In fit empley to prish thy tediente stity,

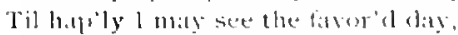

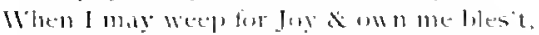

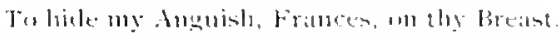

Nan! other extracts from Mr. Coates notebook might be made. but the above will be sufficient to show his great interest in the patients and in the stucly of insanity.

Any account of work among the insane would be of litle value if it failed to record the earnent, cealous efforts in their behalf maxle by the eminent alienist, J)r. Benjumin Rush. This distinguinhed philanthropist entered the service of the I Iospital, as attending physi-

IImman llirk ot B). Bentiamm kinh. cian, in $\tau_{7} 8$, and served the institution for twenty-nine years and ten months continuously, during which, uncler his personal effort, example and infuence, the humane and judicious treatment of the insane received an impetus which unquestionably prepared the way for the adoption of that high standard of care which now prevails.

Upon entering the survice of the Hospital. his philosophical mind was attracted toward the practical study of insanity and his adranced ideas upon this sulject impelled him to protest forcibly against the many prevalent aluses and obstacles in the way of rational modes of treatment. In this connection, the following extract is worth quoting.

On November 11,1789 , a communication was received from Dr. Rush complaining of the Cells as improper places in which to confine the Insane. It was alddressed to the Board of Managers :

fendlemen. Vuder the conviction that the pitients afflicted hy Maluens.

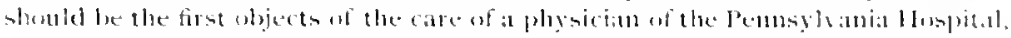

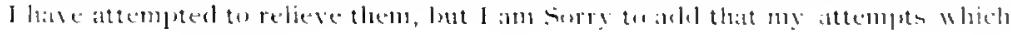




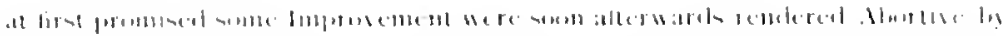

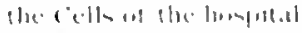

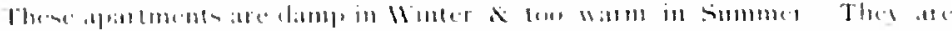

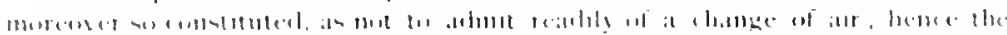

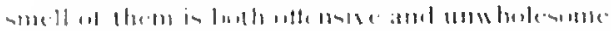

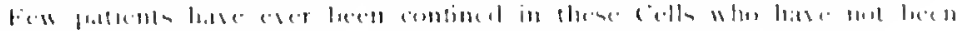

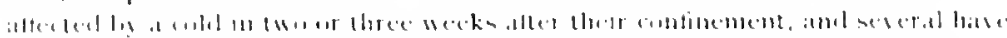

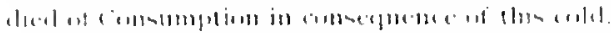

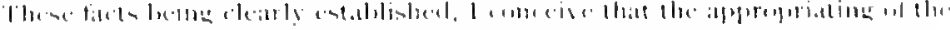

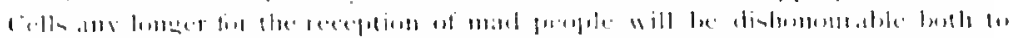

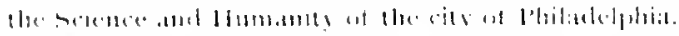

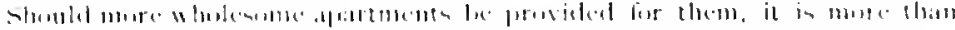

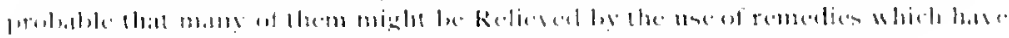

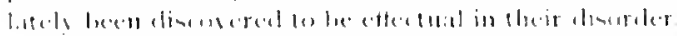

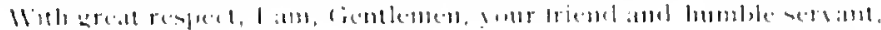

() lambary 7,1792 , it wan resolved

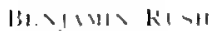

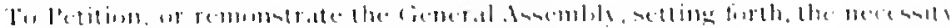

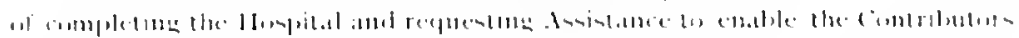

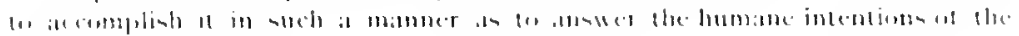
iriginal finmolers.

The fatoralle action of the Arsembly hat alrealy been men tioned. (siee pare 66.)

An olligation, in the form repuired ly the (iovernor. and furnishing the reguired security was prepared, and was read and approved. at the contributor' Meeting, Nay $13,139.3$. The 'Treasurer hasing ber.e. reporled later that he had secured from the State Treasurer the sum of priatin f, 10.000 ; this with other sums, which had been contributed and paid, kerencel. were placed to the credit of the Building Committee for the " Extended buiklings."

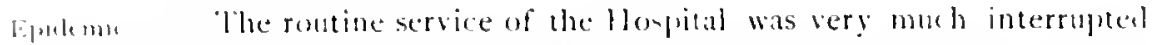
"rellow alent this lime by the presene of an epidemic in the city, which fowr nhiged many of the Managers and physicians to leave the city. business wats in great measure stmpended owing to the breaking out of yellow fever, which prevailed from August, 1793. to the gth of september, during which "upwarels of 4.000 persons died in the ("ity and Lilierties." (see accom of Villow Fever, 1. 69.)

Wecember 30,1793 , the sulject of huilding the west wing wa resumed, and the committec was instructed 10 complete as soon as pusible an estimate of a plan " which will include a double range of "ells underground, and on the two first floors alwse, in the western division, with an area on the north and south sides."

(on Peloruary 27,1797 , Drs. Kub and lhysick, in adelition to their usual duties, offered to take umder their own care every lunatic in the Hospital who was not the particular patient of any olher physician 
of the house, for one year, "provided it meets with the approliation of the managers and physicians."

Tilatingent

A copy of this proposal was handed to each of the physicians, rif the Insine. "who, if they approve thereof, are desired to signify their assent l": subscribing their names to it," which was accordingiy done.

For the period, these were most excellent accommodations for the insane; but the more turbulent were kept in the basement cells. directly underneath; which, however. were superior to the cells in the eastern basement.

Until towards the close of the last century the same simple and informal mode of commitment of insane to the Hospital prevailed as during the carlier years. The Managers were authorised to receive patients, after reading a line of opinion from one of the altending physicians that the sulject was a proper one for admision, and, a bond was recuired of the patient's next friend, as in the form hereafter to be quoted. No comprehensive lunacy law appeared on the Statute Book untif i 860 . The common law and the unwritten law of necessity and humanity regulated admissions: while the word of the attending physician afforded the only means of discharge, save by death, or. excejtionally, by escape.

Hastily written upon a little piece of chance paper is the following commitment :

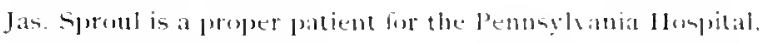
Bisiry RI- RI.

Very little survives concerning the treatment of the insane during the stormy period of the war of the Revolution and especially during the time when the British soldiers occupied the Hospital wilh their sick and wounded. The insane remained in the cells, and were cared for in some fashion, under great difficulties, by Dr. George Weed, the Steward and Apothecary. How nearly the Hospital approached absolute ruin and dissolution at this time, and how heroically the Managers hehaved under the infliction, and how courageously they carried out the work of restoration, is elsewhere recounted.

In 799 . Dr. Rush, in pursuance of his plans for the amelionation of the insane, again addressed the Hoard of Nanagers upon the sulject which lay so near his heart :

$$
\text { April } 3 \rightarrow 11,150,
$$

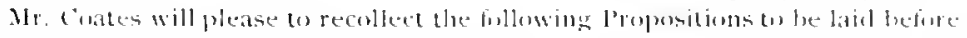

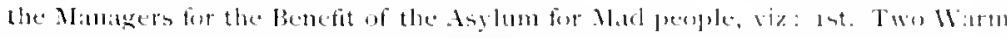

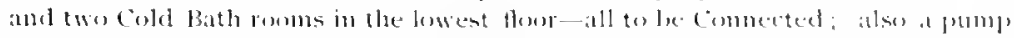
in the Area onsuply the Baths with Witter.

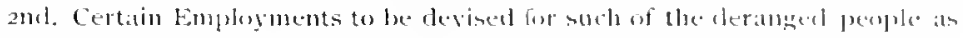

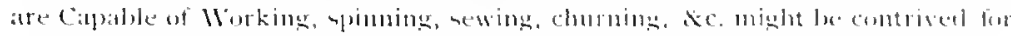

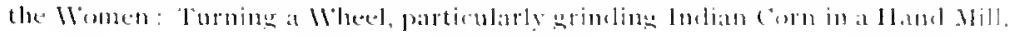




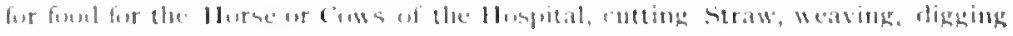

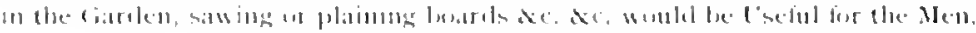

IBET, RI:II,

Trivial as such an entry may read in a historical work, these propositions, as 10 sanitary cleanliness, bath-treatuent, and congenial employmens, were steps in a great, and until then, almost unheard of reform in the care of the insane. l'ersonal cleanliness and daily occujation for the inane, as a class, had nol been allempled in this country frevionsly, although now the rule in all repualile institutions for the insane.

The character of the attendants upon the insane at the period now under consideration, was guite in keeping with the class of accommodations provided. The following minute gives an apt illustration of the demands made upon the time of the murse in charge of the ward.

Diverse

berviecs retpuirend

from the Suendants.

In 1757, the Managers appeared to he impressed with the necessity of selecting a man as Cell-keeper with some reference to his special fitness and to define his duties, as the following minute records:

(ret. 6, : : 757

After some (inversation with Juma. Sorton (he being willing bo take Catse of

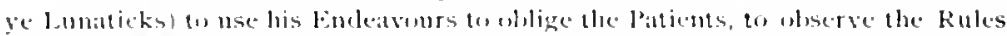
of the llubse, as assist the Matron in the generall cate of the batichts, $\mathbb{E}$ in

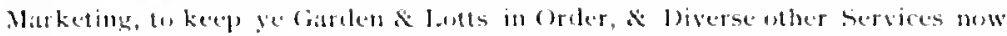
memtiomed so him, agtees with him fer the Term of one rear certain, from the

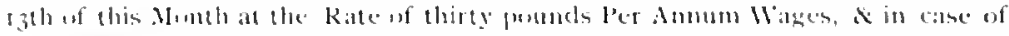

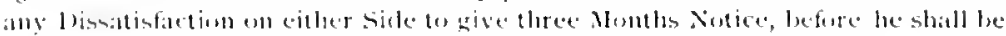

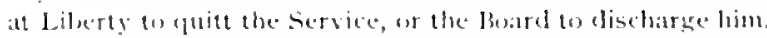

Norton found these "Liverse Services" wearing, and, on July $31,175^{k}$, demanded an increase of wages to 250 jer year, otherwise he would "quitt." Ilis request was complied with. What the insane patients were doing, or who minded them, while he was assisting the Matron, going to market, digging in the garden, etc., is not stated.

sursumt In the year 1755 , it appears that an indentured servant acted as

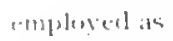
acell keepint

in ithont athority. the Cell-keeper for some time. lefore the Managers discovered it.

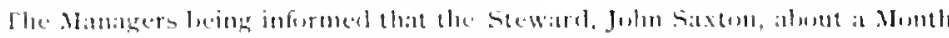

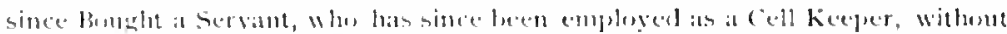

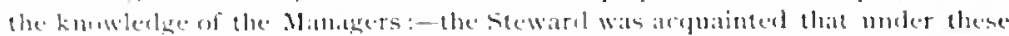

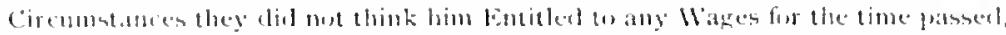

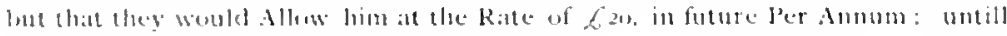
his time is ont, which he ingreed (1).

The salaries faid certainly were not extravagant. On Ajuril $260 t$, 1779 :

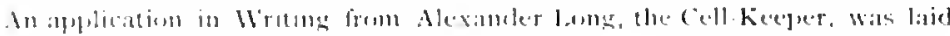

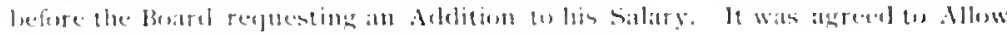
him eighteden bullats ber month from this liate. 
Mr. Long soon after this advancement resigned and was succeeder by Thomas Little and his wife. The term "Keeper" perhaps exactly described the function of persons then employed to attend the insane. They were hired to keep the patients and their cells clean, to perform Inities of kevert of Insanc. all the menial drudgery which that involved, to watch the lunatics when they exercised in the yard and keep those who worked about the garden and lots from running away. One of their chief duties was to preserve discipline and order among the unruly, which was done with a strong hand and in a punitive spirit. The insane were chained to rings of iron, let into the floor or wall of the cell, or were restrained in hand-cuffs or ankle-irons; and the straight-waistcoat, or "Madd-Shirt," was in frequent requisition. This was a close-fitting, cylindrical garment of ticking, canvas, or other strong material, without sleeves, which, drawn over the head, reached below the knees, and left the patient an impotent bundle of wrath, deprived of effective motion. In the earlier years, it was not considered improper or unusual for the keeper to carry a whip and to use it freely. These methods begat violence and disorder in the insane, who were then, for that reason, a much more violent and dangerous class than they now are, and the keeper's life was neither an idle nor a happy one. From the number of his duties, about the house and grounds, unconnected with the care of the insane, it is evident that the patients must have passed the greater part of their time locked up in the cells.

In 1782 , a patient, in a letter addressed to the Managrers, says: "I am Confined here in Chains at the instance of a Relative of $m y$ Wife's-I hope you will Desire the Steward to unchain me; but, as his Duty, he could do no Less." Later he writes-" The present serves to Inform you that pursuant to your Orders, I am Unchained." The spirit of humanity was donbtless as strong in those early days as it is with us; but the ideas as to what constituted humane care were very different; they were in process of gradual evolution from primitive modes of life and crude social customs to the advanced ideas of non-restraint and kind treatment which now prevail. Some curious old hospital bills that have been preserved, throw a side-light itpon the methods of management of insane patients at that time in use:

Mr. Iliggins (the Steward)

Xisember a sith.

To l'eler Ficlo, Jr. is s. d.

To making a strait Jackorat . . . . . . . . . . . . o 1t

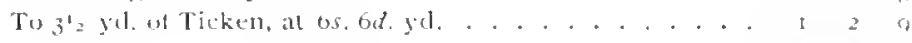

"This is entorsed "Straight Jacket for Bowey."

Illustrations of Treatment a century. ago. 


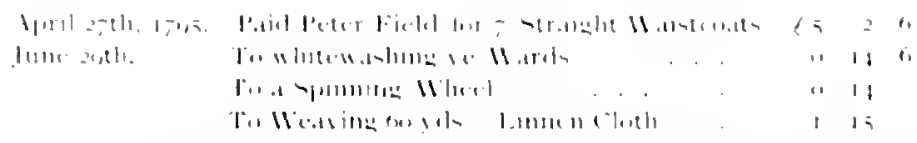

111421.11143 1: the. (1)11111811411!

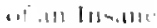
l'a I III

ln-1.1111. (1) - sivile

th in interenting to note hon kemiently dispened were the early jowle iary tomarl im ane persins who were charged with crime.

ln 17s:, l'. 1. of Pancke Comnty, was tried for murder and

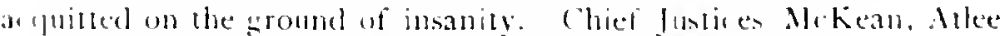
and lirtan wrote 6 the Managers in relation to this rase:

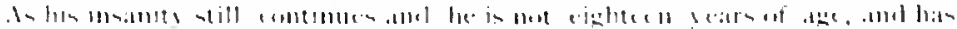

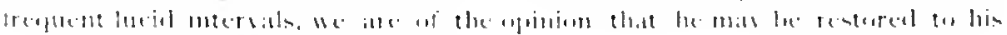

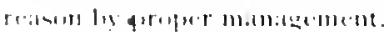

Ile was received into the llospital.

The recorit de not inelicate that sulcile anong the insane was of more frejuent occurrence in these carlier das than all the frevent time. One of the earliest instances. however, in the Hospital history was on $A$ pril 20,$1 ; 65$ :

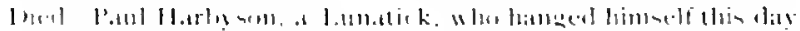

foje of commitment be fulge Mekean, written on the back of the whal exrifieate of insanits.

In:Mー1.1 MII

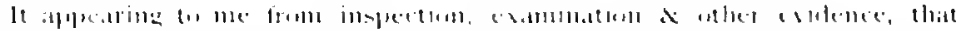

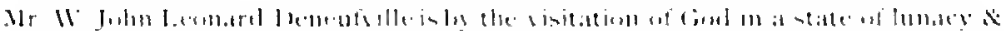

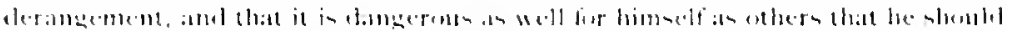

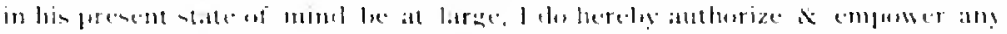

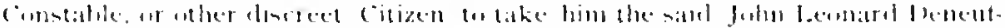

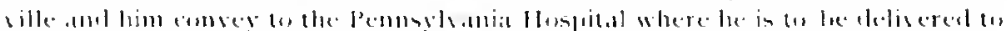

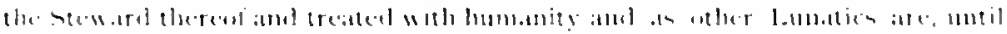

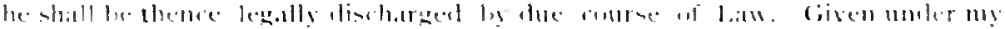

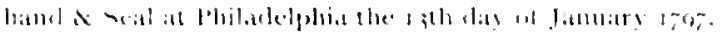

THN. Wkin.

The alove is the enclorsentent on the back of the admission paler -igned ly kush, as shown in the illustration.

The guiding spirit of ly. kinsh was frepuently manifested in initiating reforms, as will be noted in his suggestion to the other member of the statl to unite with him in the following :

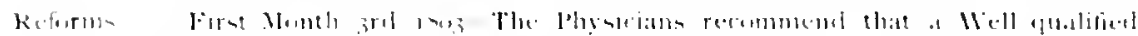

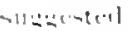

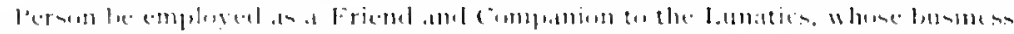

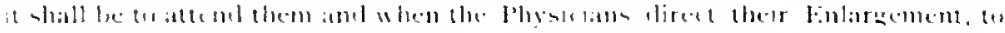

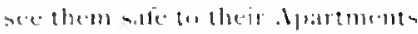

The Nanaters acceded to this reasonalle request and the steward was direrted to hire such a person. Again, on septemler 24. 1810. lie addresed the following letter to the loard: 


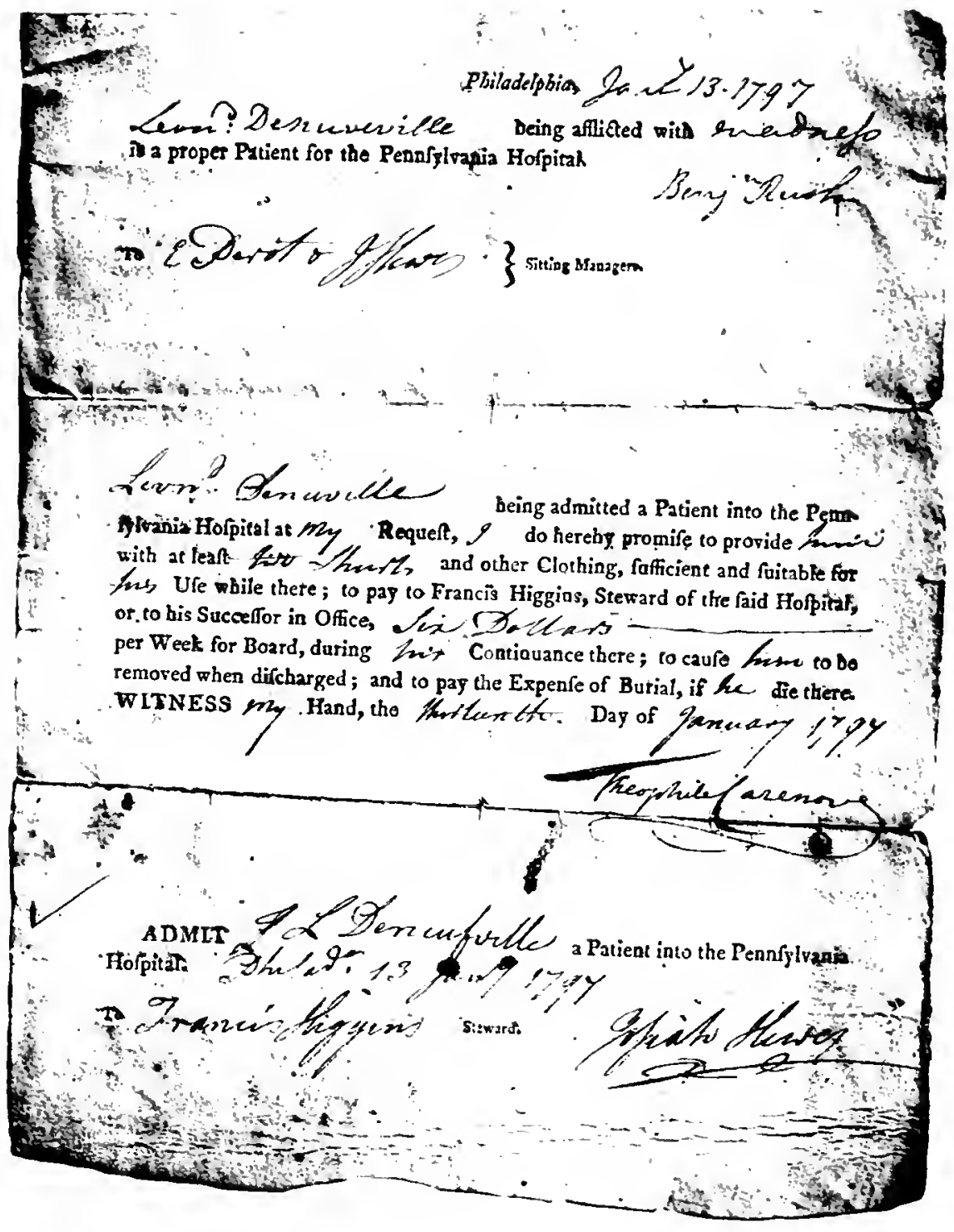




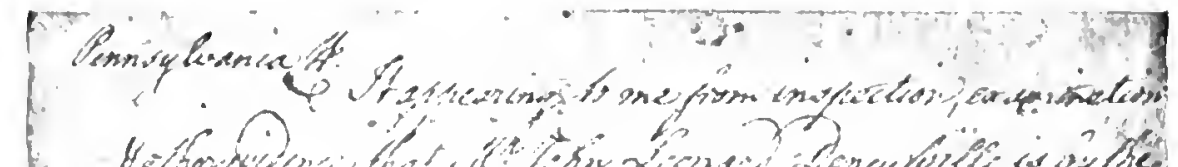

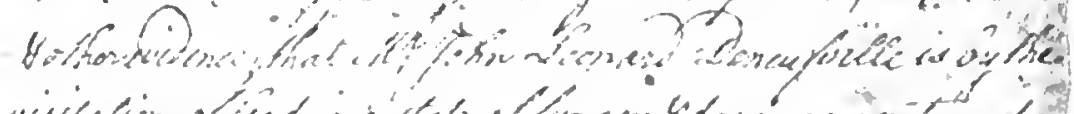

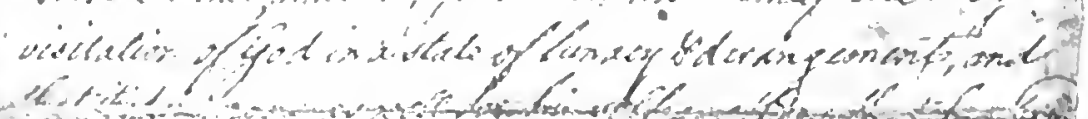
16.

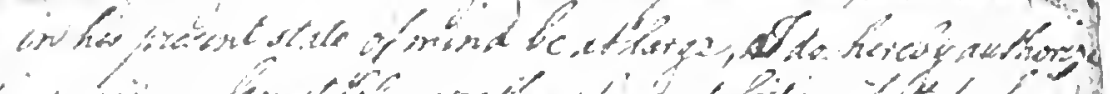

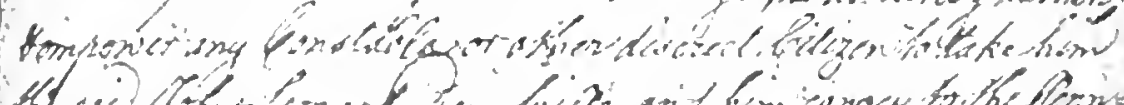

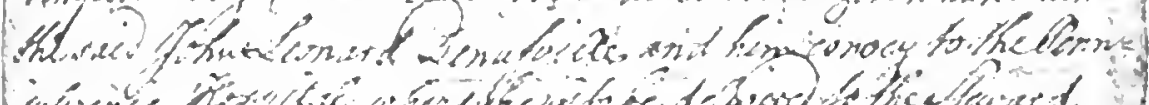

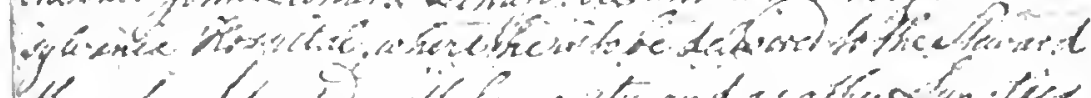

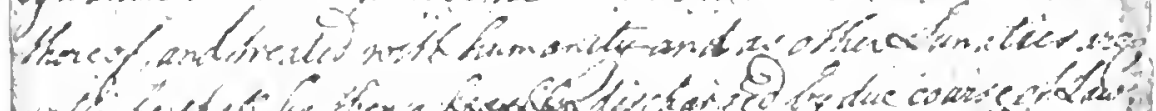

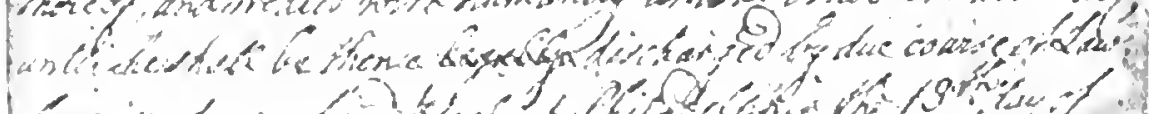

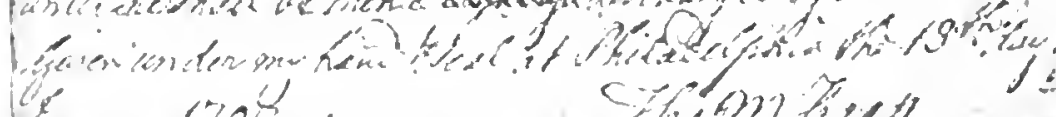

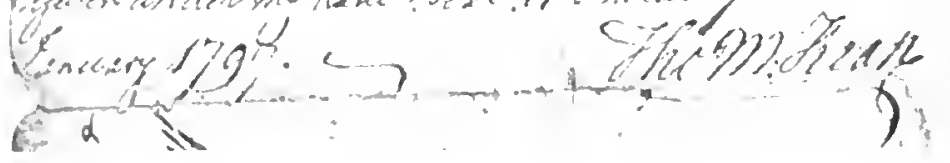




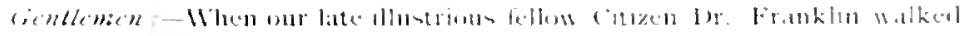

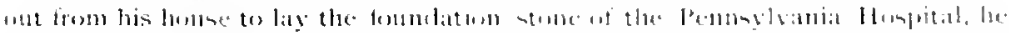

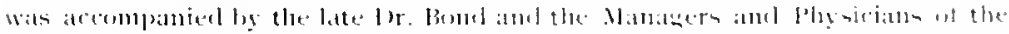

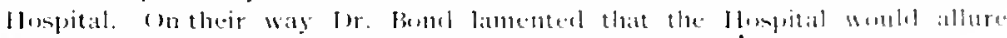

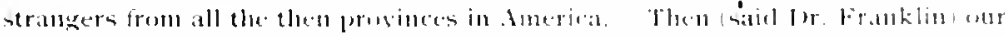

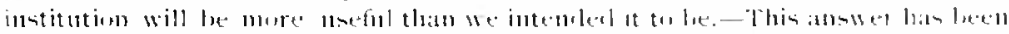

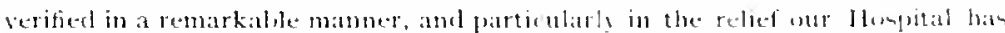

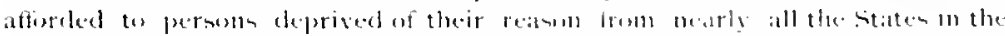

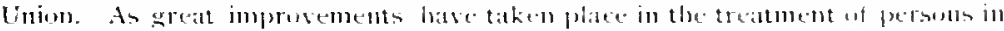

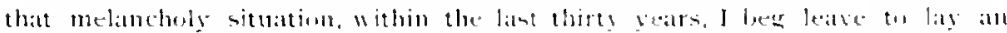

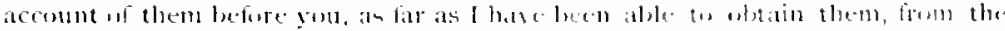

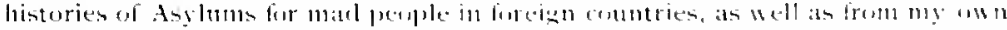

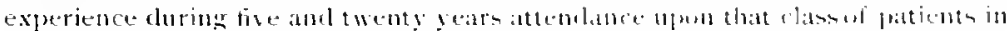
the Pennsyluatuia Hompital

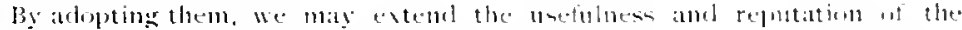

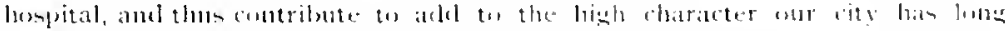
sustained for wise and hemerolent institutiun

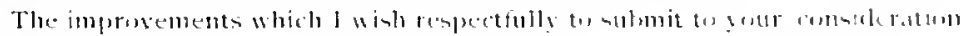
are als follow:

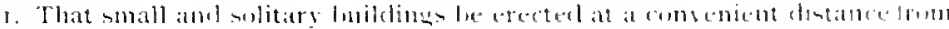
the west wing of the lospital. for the reveption of patients in tise high amel rlime

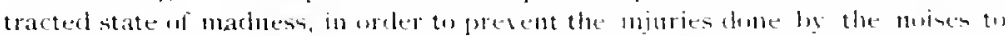

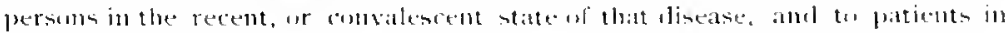

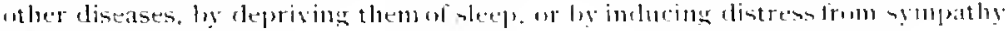
with their suffering-ry

2. That separate thurs be appropriated for e:ach of the sexes

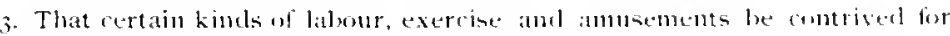
them, which shall act at the same time upuntheir bueliesamel mimels. The artian-

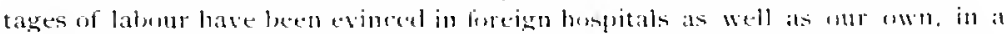
greater mumber of recoserien tathing platec, amomg that class ot people who are

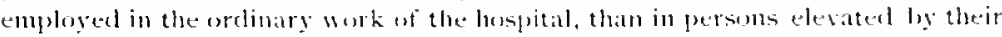

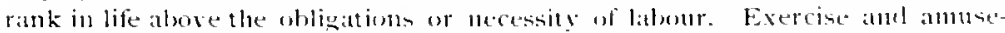

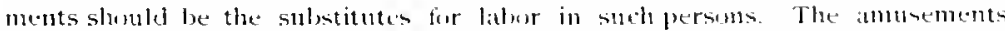

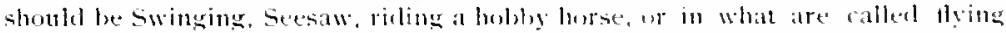

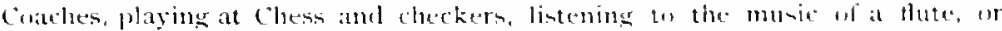

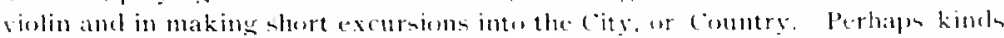

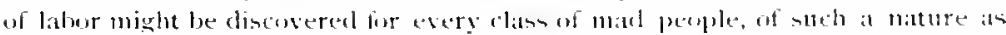
to atford a small adiliton to the funds of the hospltatl.

4. That an intelligent man and wentat be enpleged to attend the different sexes, whose business shall be to clirect and shate in their ammsements alld to disert their numds by (anversation, reading, and obligins them to real and urite

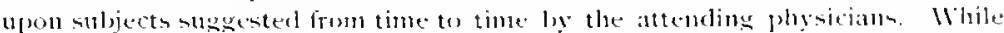

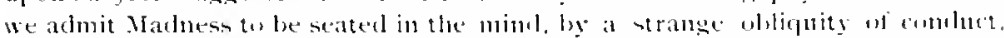
we attempt to cure it mly by corporeal remedies. - The disease atferts buth

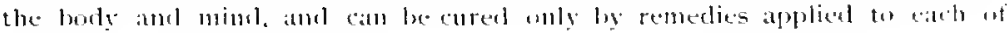
thein.

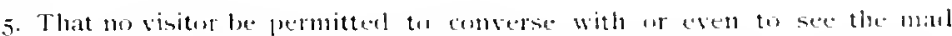

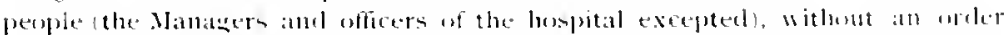

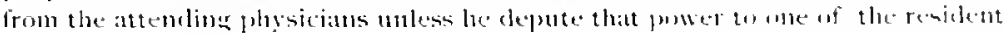

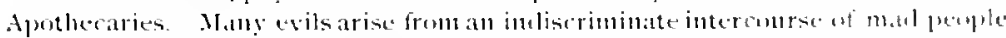

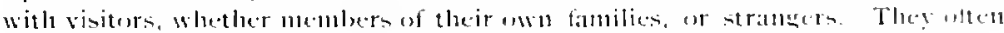

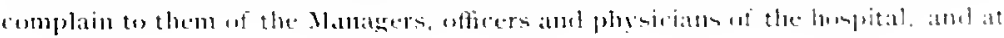

$1.011+1+11+11)$ l) Kunl (1) hlic Matiagetro nitl fupgurtatut sllegentions 


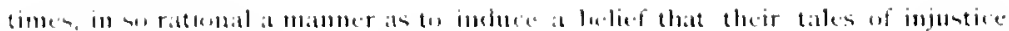

Kefortum ingent lis lor Rumb

and ingereminen are true

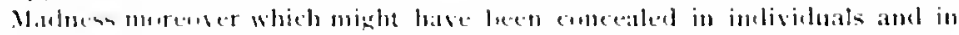

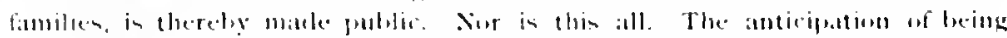

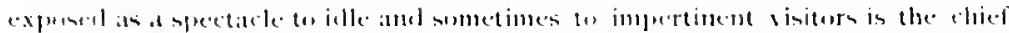

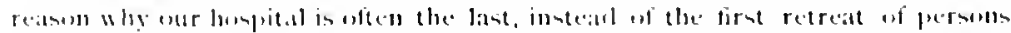

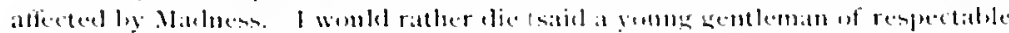

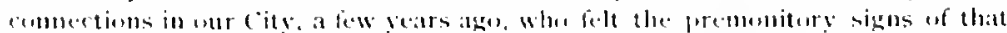

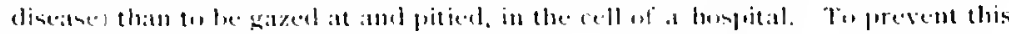

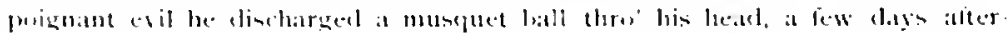
witrls.

b. That a mamber of feother beels and hatr matrames. with an arm chair he

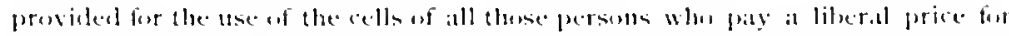

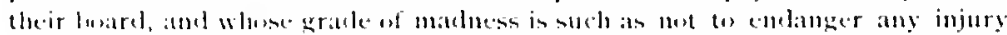
being dente so these articles.

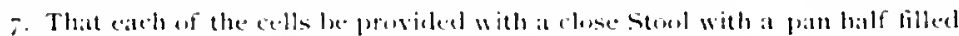

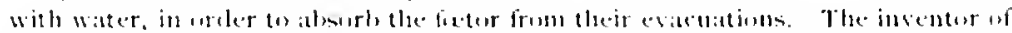

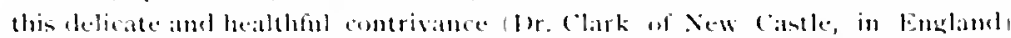

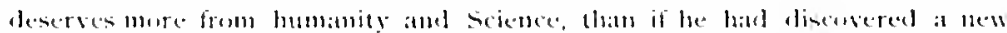

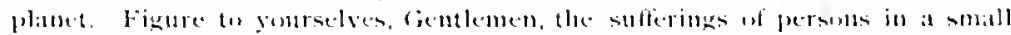

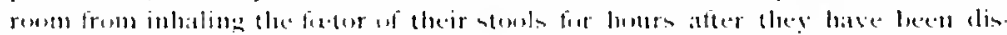

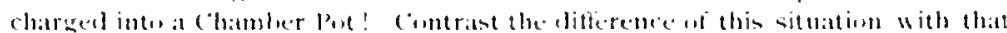

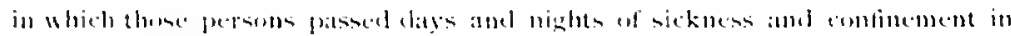

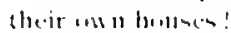

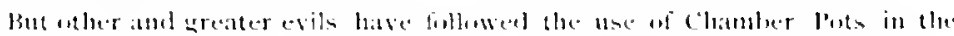

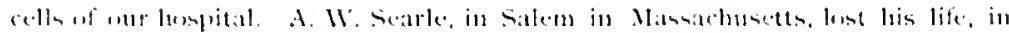

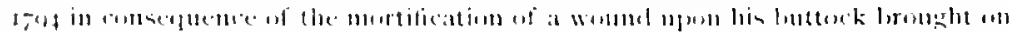

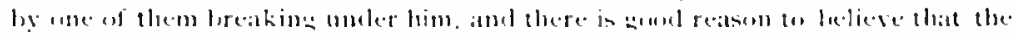

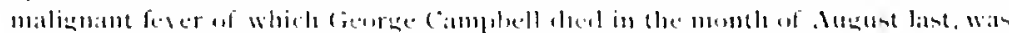

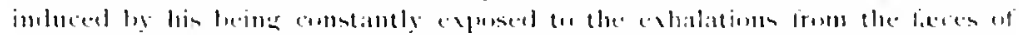

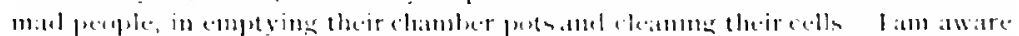

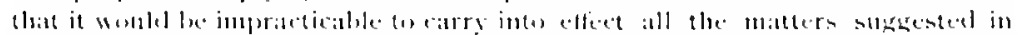

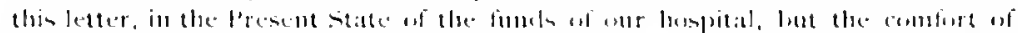

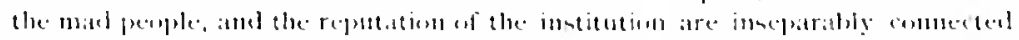

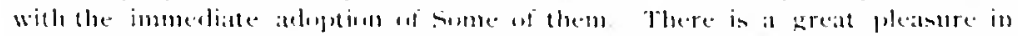

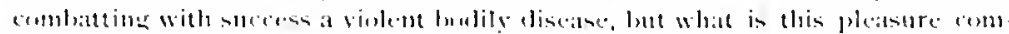
pared with that of resturing a lellow creature from the anduish anel folly of mat

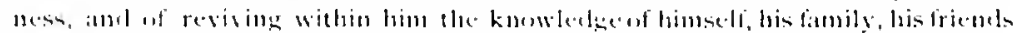

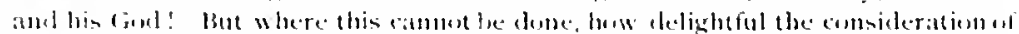

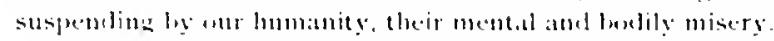

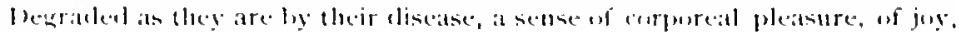

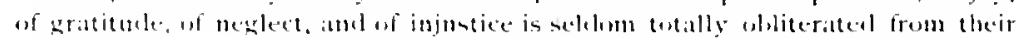
minils.

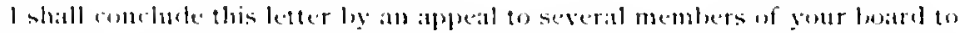

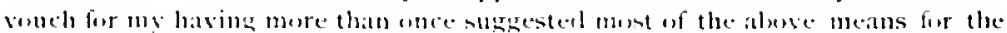

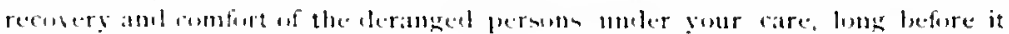

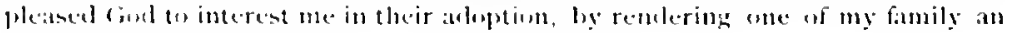
objece af the-1n.

I am, fintlemen, with great respect amb enteen

lener sincere frienel and servant,

Segutembler zath. Isito.

BEXJ. Rish 
A committee was immediately appointed to consider this communication and report to the Board. On October ro, isio, their report was made, as follows: Rush feed a Satisfaction in hasing to state that many of the subjects therein enumerated appear for a lone time past to hate claimed the attention of the Mamagets. Order.

As We find them Classed under seven distinct hearts, our Repurt is in like

Ist. Small solitary Buildings at a convenient distance from the West Wing of the Ilospital for the reception of patients in the ligh and distracted state of Madness, in urcler to prevent the injuries dune by their moises.

We understand that many of the Contributurs lave for lears past thought a separate building would adel greatly to the general comfot of the patients in the Hespital, hut the funds of the institution not being arlequate to such an expendi. ture, has prevented their bringing the subject forward for ensideration.

When there are funds and such an Apuromiatien is anterel upon, it may be a more proper time than new to consider whether one building ondel wot be constructed to answer every purpose in preferenct to a number of small solition buildings.

2. Separate floors for each sex in the present llumse.

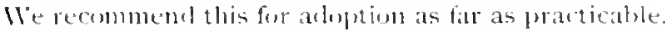

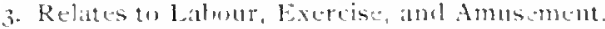

These are alrealy practicel as fall as we believe combintent with the lloull orolering of such an bustitution.

4. An Intelligent Man and Woman to attend the difterent Sexes wh dired atul show in their Amusements to abert their minds by Consersation, Readline, and obliging them to write apon sublects stegested to them by the Physicians.

A Man in alseanly engagerl for this Service as far as 20 direct ind shate in their Anusements, flud as al separate enclosure is now palted in loo the Wromen it no dush will claim the Comsicleration of the manager whether a Female may

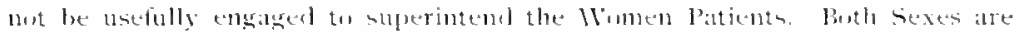

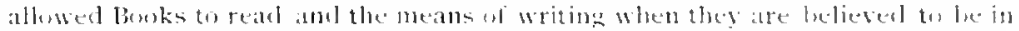
such a state of mind as w render them proper.

5. That mo Visitur be fermitted to converse with or teren an see the Masl People, the Hanagers and officers of the Hosprital excepted, without an Oreler from the attending physicians.

Except very near Connections, Visitors are nut permitted to see or converse with such l'atients.

6. That at number of feather Beds and hair matrasses with an Arm Chait loe probided for the use of the eells of all those who paly a literal price and whese grate of Naluess is such as not to endanger any lnjury being done to these Articles.

We do not understand that Objections were ever made to the Patients having feather bede and Natrasses, in proper Cas's, hut Greater Ohjections sometimes decur to sucls a regulation than the Injury which might be dune to the Articles, such as furnishing them with the means of injuring themselves or others.

7. That each Cell he furnished with a Pan hialf filled with Water in ureler to absorb the factor from the Evitcuations.

This is in part carried into effect and we suggest the propriety of furnishing each Cell in like Manner where it can be done with safety to the Patients. 
libe lant and tombing paragraph of hr. Kil-b's lecter to the

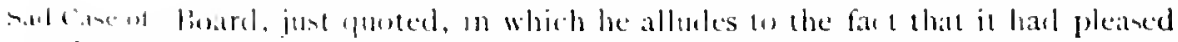

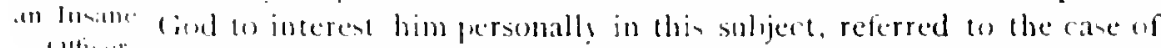
Htim.t.

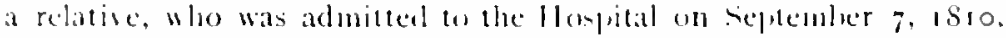
and clied there on dugust 9. 18,37 , alter a comtinums hospital residence of twe nly-seven ! ears.

Ie harl heen a talented and puphlar lieutemant in the Cnited states Nary. While stationed at New Orleam he fought a duel with his intimate friend, a broher officer. whom lae killed. It is said the affiar was raused hy a light and thughtess remark: that the speaker was really not w hane: Ins that the pwint of honor anmelled him to meet his friencl. From that lime forward he was a case of melancholia: rejecting all companionship, and all friendship, and was, at times, very moruse. Ile was a most confirmed peripaletic, walking the loor, to and fro, every day and almost all day, until the planks of the ward fluring and of at rertain flare upon the loard-watk of the gard were worn intu deep gutters; these were always called "Rush's Walk." Sammel coates, in his manuscript book of hoppital orcurrences and phitosophic memoranda as to the caures of insanity, tells the following anectote:

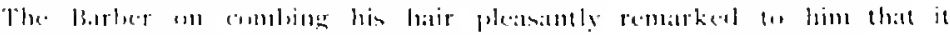

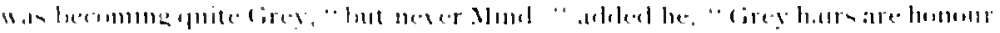

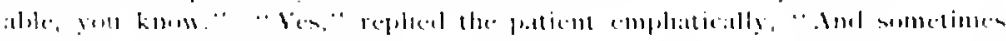
Homour maken Girey hair-."

Samuel coates innocently writes down ". Inelling" amomg his "Caunes of Insanity" and rites the above race as a satisfying prool of his theory.

Inceralice lis

One of the fluaintest anectotes told ly samuel Coate relates how his father rescued him, in infancy. from his nurse, who had stdelenly gone mad:

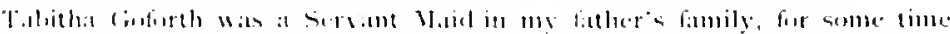

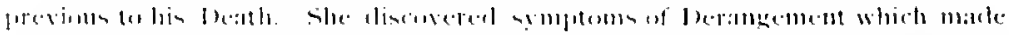

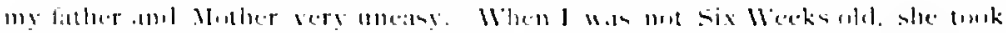

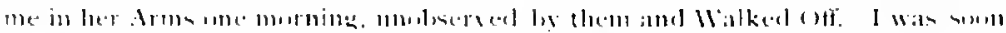

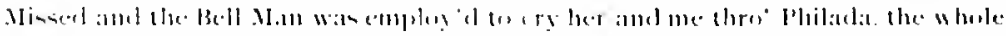

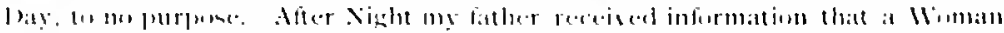

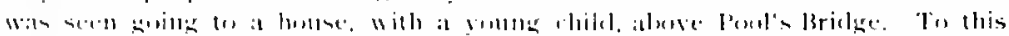

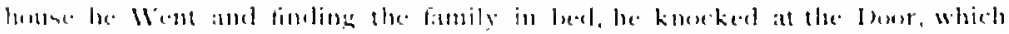

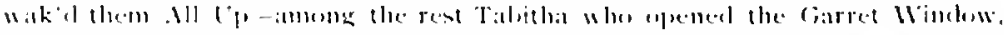

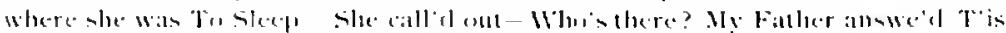

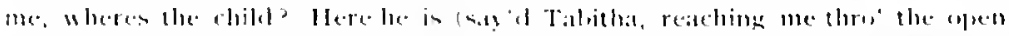

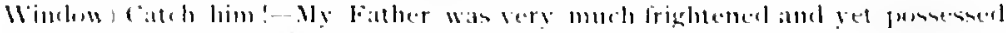

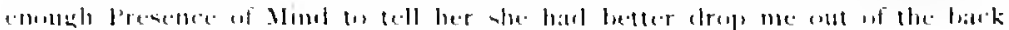

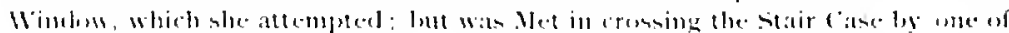

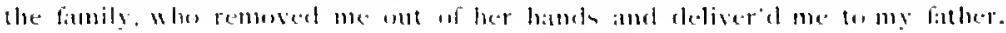




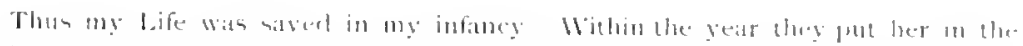

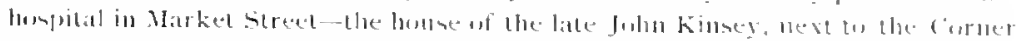

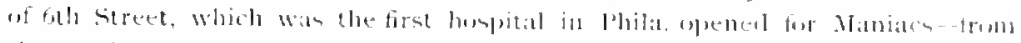

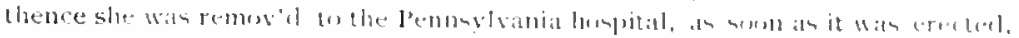
atrol Diect in it.

(1) Narch 25, 1822, a plan for an improved method of warming in the Lunatic Cells having been submitted, it was ordered that the " commitre make the experiment. "And as the late Josial Hewes" bequeathed four hundred dollars to this Institution for the expres purpose of making solid improvements in the house, it is further ordered that the amount he placed in the hands of the Committee of Economy to be expended in the more effectual waming of the apartments."

How this was accomplished is not now known; lut eleven year afterward, on January 28,1833 , it is recorded that an experiment was to be made of heating six of the cells by a contintous flue and pipte from the lasement wo the upper story.

From this period the Hospital was doubless comfortally heated in all the departments.

On June 24, is22, when

A written repont was received from the commitlete alpwinted on the suljeet of the indiscriminate visitation of the Itouse, whish atter dedilseration wis pont poned for further comsileration. The committee of bonomy atre in the interim

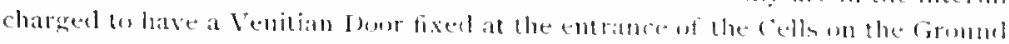
Flum of the ffospital. And another al the entrance to the (ells an the secomel

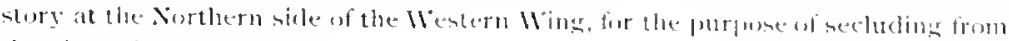
the view of strangers

This was done; the employees were directed to keej, these doors closed and it was ordered that no visitor should enter the department for insane, unless accompanied by a Manager, a physician of the house, treasurer of the same, or by the steward.

In order to further check the curious visitation of the insane patients, the rule was adopted to increase the fee for admission to the house from twelve and a half to twenty-live cents, and the gate-keejer to inform visitors that they were not permitted to enter the insane departments.

These extracts from the records are evidence of the fact that the

Vutistitus ti. exerdunle Insille trom sien of atringtoris. bisuimion

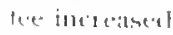
(1) jerevent -urions lisitation if Insalne. I'Alituls Managers adopted every expedient and used all possible effort to render the institution as comfortable for the patients as the circum. stances of these early priods would admit. 
A communication addressed to the Managers in 1828 , entitlet Communic. "Remarks on the present state of the Pennsplvania Hospital and a (u) irum thea for the neressity of providing a separate asylum for the insane,"

IIII, ( Malin int the Tread

ment of the ly the Clerk and Librarian, William (i. Malin, is interesting as illustrating the advanced icleas on the subject of treatment of the insane. at the l'ennsyluania hospital. On account of its historical value it was republished in the Annual Report of the state lioard of Public

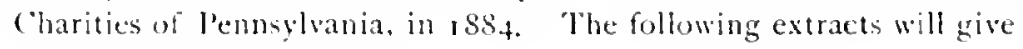
the tenor of the article:

"The l'ennsyitinia llospital was founded at a period when the cure of insanity and the comfort of its irrecoveralue victims were less studied than they have since been, and its arrangements were far from perfect; yet, if we take into consideration the models offered by the then existing institutions and the general state of knowledge on the treatment and cure of insanity, we must admit, in justice to the worthy founders of the lfospital, that it was construeted and regulated on the lest known princigles. A reference to its sulseefuent history will pove that it . Managers have encleavored to keeplace with the progress of modern improsement. Ilumanity lavever pervaled the r counsels. The comfort of the unfortunate lecings commited th their care has been regarded lig them with decp interest, and they have alwags heen disposect to listen to any practical sugesention for its increase. Neitloer has thin interesting portion of their charge heen negled ted hy the distinguished men who have filled, with so moch credit, the medical offaces of the institution. In particular, the philosophir mind of the veneralle Rush. puwerfully attracted by demestic misfortune, was long and anxiously devoted to the consideration and inprovement of the moral and medical treatment of the insane. Thus, for a long series of years, have the Managers and I'lugsicians of this IIospital succestully lalured to ieserve that praine whose public expression they have never courted. Tlhere are, however, disatvantages, not, we believe, unconsidered or unestimated in aught exrept their urgency. comnerted with the public situation and contracted space occupied by their huildings which no system of management may hope to obviate. which preclude the possibility of keeping up a salutary discipline: and which have long pointed out the ultimate neessity of remoring the insane patients to a more favoralle situation. $\% *$

"Vxercise of the body is universally allowed to be necessary to its health, and wilt, no less generalty, le arlmitted to have also a salutary influence upon the mind. We have daily opportunities of owerving how much it conduces to mental tranquillity. But habor, to be beneficial, must be in some measure suited to the rank and prejudices of 
the patient. Insanity which admits of cure is seldom more than partial and, while some of your patient's faculties are disengaged from the grasp of his judgment and incapalsle of their legitimate application, he retains the full command of others; it will not, therefore, be jroper to treat such an individual as though be were totally irrational. Servile domestic offices are usually considered degrading, and are calculated, in a majority of instances, to do more injury, ly wounding the feelings of the individual, than any advantage to the bodily health can overlalance.

"Agricultural labors, on the contrary, are associated with independent and ennobling ideas, and are considered as reflecting honor, rather than disgrace, even upon the man of fortune. Such a distinction ought not to be lightly treated, as everything which encourages a proper self-respect is useful in promoting, and, on the other hand, whatever unnecessarily attacks even the prejudices of your patient tends to diminish, his chance of recovery. Some persons may, indeed, argue that madmen ought to be subdued; that their high spirit should be broken ; and it is certainly possille. in many instances, to coerce a very insane man into a state of ruiescent obedience, and make him almost as sulservient as a piece of machinery; but sucla a man is not cured; on the contrary, the few faculties left him are depraved; the whole man is degraded, and his restoration rendered tenfold more problematical by the jrocess. Before subjecting a human heing to such dixcipline, try it upon a spirited horse; break his spirit-inspire him with fear-subdue him thoronghly-and who wuld wish to possees so dogged an animal?

"It may be asked, why not employ the insane in some species of manufacture? Now, it is much easier to ask the question than it would be found to devise any employment of this nature at once proper, healthful, and safe. Supposing, however, for a moment, the posilifity of employing these patients in some other than field labor; let us inquire what facilities the 1 ospital presents for their recreation and proper sejaration into classes.

"In the country, the excursions of patients, in a proper state, need not he bounded by the extent of the premises, but small parties, under the guidance of an attendant, might walk in to the surrounding country ; in such excursions, a variety of oljects would tend to awaken attention, and engage, at least, the observing faculties, while the exercise and fresh air contributed to refresh and invigorate the body. $* ;$

"Is classification desirable? How can it be effected while more than roo persons of both sexes, and every grade of insanity, are crowded into the west wing of the Hospital, and while the space they 


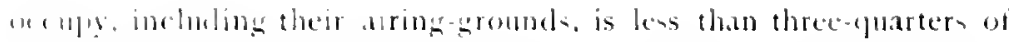
an are?

"'the great puldicity of the thoppital is, aloo, an evil of no mall magnitule: its stuation, indegentently of its connection wibh a Hoyplat for the sirk. is sul has mun clefeat all attempts at a proper nechom of its loufortunate inmates. The morlid curiwity dinplased ly a majority of the vistors to the llowptal is astonishing, and their pertinacity in attempting, am fertility in pretexts and expeclicnts, to frain admission to the 'mad people' is no less so. Fien females who have tears to lestow on tales of imaginary distress, are importumate in see a raving malman. and do not hesitate fo wound the dineased mind ly the gase of idle curiosity, by impertinent flestions, and thoughtles remarks, forgetting that alienation of mind is etelom more than partial, and that many uf these unfortunates may he ats keenly sensible to insult or exposure as the moit perfectly sane inclisiduals. linitors whose only fretext is curionity, if strangers to the lumse, do not so frepuently gain almission into the imane department of the Hophital, unaccompanied by some of its residents, as formerly: lut when it in considered that every jerson in any way connected with the intitution, from its cellar to its cupela, has fricols or acquaintances whose vists cannot lut le injurious or improper, at any time. or to any patient; it may be well comceived that the total amomt of inconsenience from this soure is com-iclerable. is is

"In asylum situated a few miles from the eity would not he a convenient founge for idlers. It womlel only be resorted to ly those who really felt an interest for its inmates, and this is a class who might substitute weeks of alsence for days. with advantage to all parties.

"The admission of cares of mania from intemperance has a mischicrous cffect upon the imane. and ought to be discontinued in a new asshum. In their delirim, their cric alarm and excite other patients until the house resomols with moise. In a state of convalesrence. their impratience of restraint furnshes fresuent examples of insubordination to ald to the effert of their precepts, and their hospital career is often closed by a practical exemplification of the means of elopement. This is, in fact, a class giving and exciting more trouble than the really inane-a clans reguiring active medical treatment alone, and which onght never to be admitter into an arylum for the insane, except only, when confirmed idiocy or insanity has supervened. To expeet a radical cure of habits of intemperance to result from mere continement is vain and hopeless. All experience frosen that this is a field in which the laborer can only reap disappontment. $\quad \therefore \quad \therefore \quad \therefore$ 
"Having shown that the present situation of the insane is replete with inconvenience and evil, and that the vacum nccasioned by their removal from the Hospital may be readily and profitably occuphed, let us proced to infuire what are the principal oljections which may lue urged against that measure. And here it may be permitted us to olserve that a confined situation in a city is so manifestly improper for a lunatic asylum that few would argue in its favor was it not already occupied. Many, however, will assist in the support of an existing evil who would have recoiled from its creation. Such may contend that the Hosfital, situated in a large open space, mites the advantages of a country atmosphere with the peculiar conveniences of the city. * * * *

"The founders of existing asylums for those afflicted with mental maladies do not alyear to have been sufficiently impressed with the importance of providing for their curc. [nfortmately to secure seems (1) have been, in most instances, a paramount consideration. A proper classification of the patients is everywhere admitted to be of the first importance, yet nowhere has sufficient provision leen made for effecting it. Other radicaldefects exist in nearly all institutions of this kind. In fact, it is not too much to assert that no existing asylum is worthy to be rereived as a complete model. Circumstances, therefore, invite the contributors to the I'ennsylvania Hosjital to place themselves upun a proud eminence by achieving a glorious advance in the sacred cause of humanity. The reflections which a review of the errors of their predecessors and contemporaries will suggest to their enlightened minds will enable them to found an asylum for the cure of insanity in which this great olject shall not succumb to splendicl ustentation or sordid economy-an asylum which shall prove a lasting monument of their wisdom, benevolence, and pulblic spurit."

In a subsequent communication on the subject of the employment of the insane, sixty years ago, Mr. Malin, shows the same loroad view of the subject, and from this we quote the following paragraph. $1 t$ was sent to the Managers December, 1834 :

"The employment of the male insane patients has never been general. althougl attempts have frequently been made to introduce some species of useful industries, which, for a time, and with indiviclual patients, have been partially successful, and, apparently at least, uneful. But nothing has yet been introduced in which the patients could be generally, usefully, and continuously occupied.

"The following are occupations which have heen attempted:

"Making straw or sea-gras hats-sereral patients became tolerably expert in plating, and one succeeded in making hats. This lade 
fair to be meful. but was not fortered. The material was furnished at necupations individual expense, and with its supply the manufacture also ceased.

for the

"Silk-culture was tried one season. Very few of the patients would handle the caterpillar, but many assisted in gathering and preparing the leaves and in feeding the insect. This occupation would have leen continued. hut we had to go nearly two miles for mullerry leaves, we found that the patients had not sufficient steadiness for reeling silk, and, at that time, there was no market for the cocoons.

"Shoe-making and segar-making have been practiced, occasionally, when we have had shoemakers or tobacconists in the house who have been willing to work.

"Weaving has been attempted, lut not very successfully, with the large loom. The weaving of fringe, however, still continues in our list of employments, and a little is occasionally produced.

"Cutting and sewing rags for rag carpets is a standing occupation. Sometimes tow has been spun for chain, (by the women), but not lately.

"Formerly, several respectable-looking carpets were prepared in the house. A quantity of low-priced wool was purchased, which was cleaned, picked, carled, and spun, and the yarn dyed in the house. But nothing of the kind has been done for some years.

"Sawing and splitting wood, when 600 to 700 cords per year were used, gave employment chiefly to old, permanent patients; benefiting them merely as far as appetite and rest were concerned. This has not a very good substitute in the necessary labor amongst the coal, which is dirty and disagreeable.

"House-work, such as scrubbing floors, assisting the nurses, cooks, and other domestics in their work, cleaning kniscs, etc., furnishes steady occupation to a few patients of both sexes.

"The hair mattresses used in the house are made by one of the keepers. The hair, being bought on the rope, is picked and prepared for use by patients.

"The filling-up of the yards in the west portion of the squaresome years since-furnished accupation, in whecling the earth some distance. to several patients: two appeared to be very much benefited by this species of labor, which has also been strongly recommended by I)r. Knight, who has charge of an asylum near Lancaster, in England. In general, we have no means of employing our patients in out-door labors.

"The women are chiefly occupierl in sewing: occasionally a little spinming and knitting is done ly them. And a few, as already men. tioned, are employed in house-work. 
"A principal reason why some of the above-named occupations have been abandoned has been the want of some person of intelligence and ingenuity to take an interest in and direct the labors of the patients. Under present arrangements, this cannot be expected, as the superintendents of the Pennsylvania Hospital have so many other duties to attend to (and it is the same with the physicians) that they can give little more to this department than such a general supervision as is absolutely necessary to secure proper treatment and attention on the part of the attendants. * * *

"With regard to amusements, we have had in-doors, books, Amusements chess, draughts, backgammon, battledores, the graces, dumb-bells, and music. Of the latter we have, at present, a piano, harmonicon, futes, and a violin. Out of doors we have had nine-pins, quoits. and velocipede. The two former are still in use. The quoits afford a good means of exercise, but require to be used with caution, and ought not to be lying around when not in use. It is very seldom, indeed, that one of the patients will designedly injure another, but accidents from carelessness may easily happen with quoits. Nine-pins afford an excellent exercise, which, with a set of smaller balls, may be enjoyed by females also, and, in a properly constructed alley, accidents can very rarely occur. We have tried a set of nine-pins and balls of stuffed leather, but found playing with them a dull affair; it is true, there was no danger attending their use, but then there was no noise of the rolling ball and rattling pin, not much exercise, and no fun. The patients were consequently very soon tired of them. The velocipedes being worn out, were abandoned here, as elsewhere, like the kaleidoscope, and yet one of the former might be occasionally useful for exercise, and one of the latter for amusement. Do they deserve to be entirely forgotten?

"The amusements of patients, equally with their employments, require the regulation and encouragement of a superintendent. Left with the patients and servants merely, amusements of almost any kind become, for a time, a business, one might say a rage; they are followed up unreasonably, until, after a while, satiety follows, and all parties subside into downright indolence. 'This has been the case here, almost invariably, and particularly with regard to in-door amusements.

"With respect to carriage riding, I have seen no very special effects from it ; it is, however, very agreeable to many of the patients, and is so far useful that it gratifies them, and promotes cheerfulness. As an exercise or remedial means, I am disposed to think much more highly of riding on horseback, which has certainly been of service in the few instances in which it has been tried at the hosjutial. 


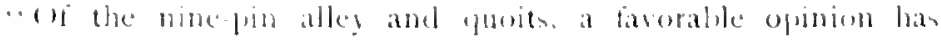
alrearly lecon expressecl.

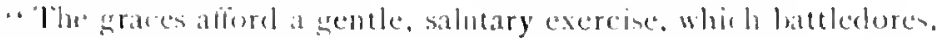

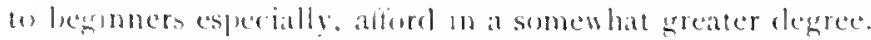

- liont-ball womkl. I should jublge from old experience, be a dan-

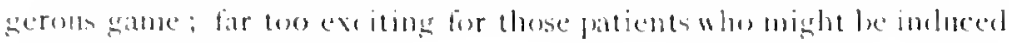
to chgage in it.

- Irchery aloo appears as though it might be safe. It any rate.

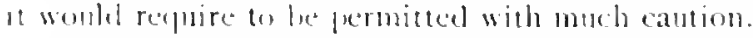

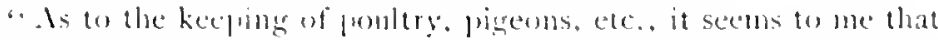
there an be bat one opiniom. I hose to see a paticnt adopt some animate pet, if it be hut a monse: it appears to have a homanging and haply inflemere: attention gives to the insane an ocroprotion and interent in something ont of themselves and their telusions, while, in their inolated situation, it is a source of pleswme to feel that some creature is depenclent return, loves thems.

“ Iith regard to a gumasium. I can only say that it all carn as thomgl such a means of exereise, so arranged as 10 prenerve patients irom dangerom ponitions ar elevations, most prove highly uneful. That properly indulged in. as they would le under the direction of a

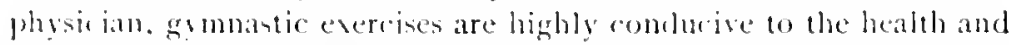
vigot of the lody there can le no loubt, and that a nound state ot mind is often, in a very erreat degree, dependent mpon a sombl state of the body, is equally unquestionalsle."

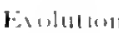

in the

(it) illit

I) in the lis.111e'

Medern reform ${ }^{1}$ in the care of the insane in England legan at The York Retreat in 1792, under the leaklership of William Tuke. .mol wa initiated in linance ly l'mel in the year 5795 . Although there is a correspondence in the direction in which thene great reformers balored, it does not appear that either was acjuainted witls the work of the other. The essentials of the great reforms proposed were hased 1 poron the recognition of imanity as a disease to be treated and managed he physicians; the prominent changes being the adoption of humane measures, the alodition of aluses and of all harsh measures of restraint: the employment of attendants, and the crection of improved accommodation. This movement may be said (1) hate indicated the earliest beginnings of the stuly of mental dineane in Fongland and liranes.

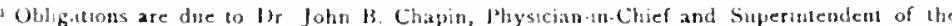
Departmen for the Insane, for contributing a review of the work of the Insane lepartuent, from 18 su 10 the prexent date, which constitutes the remaining porton of this section.
} 
Forty-one years frior to the great work undertaken ly 'luke and l'inel, or in the year $175 \mathrm{r}$, the l'etition was presented, to the l'rovincial Iegislature of l'ennsylvania, representing "that with the numbers of people the number of lunatics or persuns distempered in mind" had increased, also affirming the great need existing for the proper care of the insane, and that many people of this class might he cured and restored to usefulness.

The law creating the Pennsyliania Hospital was the pioneer attempt in America to create a hospital for the care and treatment of the insane, and it is a noteworthy fact that at that early date-fortyone years before the reform was legun by Tuke and Pinel-its founders recognized that insanity was a disease, and proposed to establish an institution, to be in fact, as well as in name, a hospital where the insane should be treated by physicians.

As has already been stated, such insane jersons as were committed to the care of the Pennsylvania Hospital, from its opening in 1751 to $18,1-a$ period of ninety years-were received at first in temprary quarters at the Hosplital on Market Street, and sulsequently in wards in the Pine Street Hospital building, standing in the square bounded ly spruce and Pine, and Eighth and Ninth Streets. During the latter portion of this period the insane were cared for in the west wing, which was specially prepared and assigned to this class of patients. Here they were attended by the resident house-staff and by physicians: residing outside of the Hospital. Of the many distinguished physicians, who in various ways rendered valued medical and surgical services to the Hospital during this early period of its history, one stands out preëminently as an alienist and author. The name of Dr. Benjamin Rush must always be held in grateful remembrance for the signal service he performed for the insane during his connection with the Hospital, which lasted twenty-nine years. In the year i $S 12$. while attending upon the wards devoted to the insane, J)r. Kush pullished his work, entitled "Nedical Inquiries and Ohservations upon the Diseases of the Nind." Many of the principles and suggestions it contains for the moral nanagement of the insane were far in adrance of the practice of his day, and are worthy of commendation in the present age. He announced his belief that "diseases of the mind can be brought under the clominion of medicine by just theories of their seats and proximate causes." Although the principles of general medical practice then prevalent were applied to the treatment of the insane, and have been since much modified, he is justly and properly regarded as the father of isychological medicine in America. As professor of the practice of medicine

1). Rush': Eminent services 
in the Medical Department of the Universily of Pennsylvania, he imparted freely of his knowledge and experience acyuired in the wards of the Hospital, to the students who altended his lectures, and made many valuable contributions and suggestions calculated to promote the interests of the insane during his long term of service.

A visitor to the l'ennsylvania Hospital in $17 \% 7$, who acempanied lunpted Dr. Kush in his regular visit through the wards, furnished the followin $1 \%$ ing account of what he saw in the house. especially that part devoled to the insane. whic h has an incerest at the present period:

"When we came to the Iluspital. I)r. (larkent left me, and went intor the

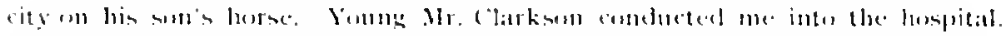

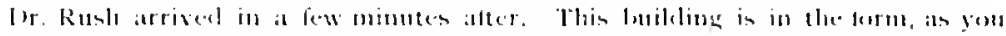

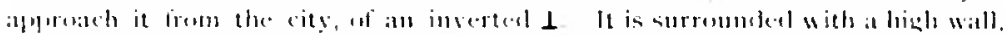

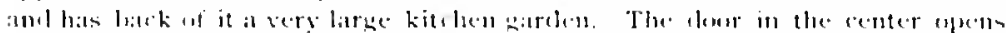

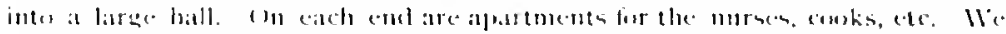

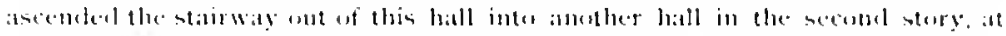

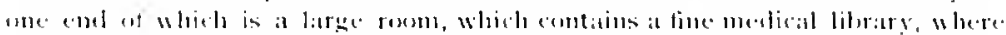

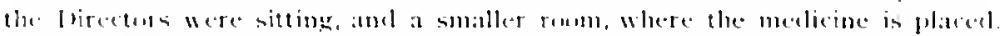

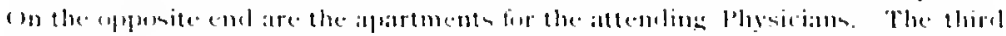

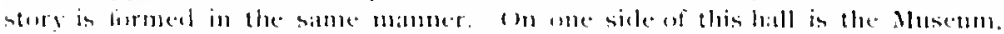

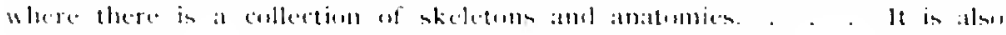

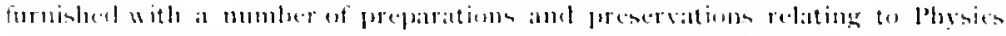
imel surkery.

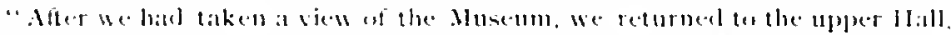
"here aceral physicians and all the young students in lhysic in the city were

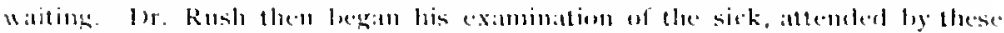

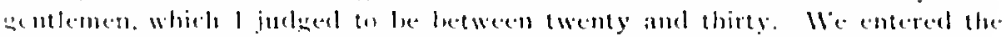
upper thamber of the sick, which is the lege of the 1 . It is a sparions romen.

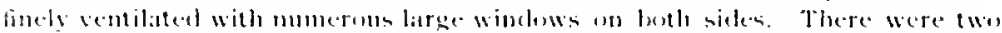

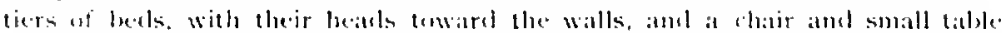
between them. The roum was excedingly dean and niee, the beds and bedeling

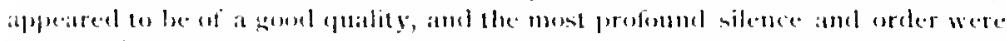

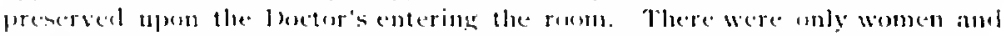
dwot forty in mumber. Ir. Rush makes his visits with a great deal of formality.

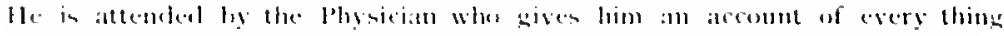

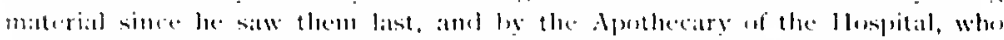

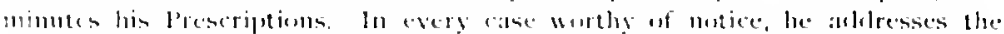

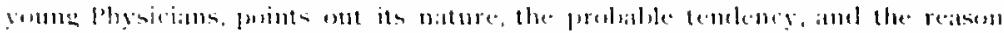

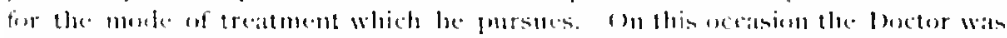

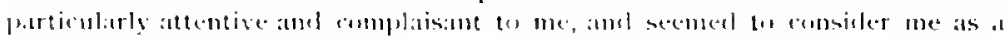
plly-ixim

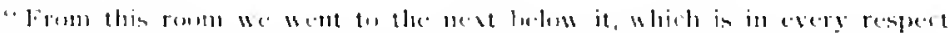

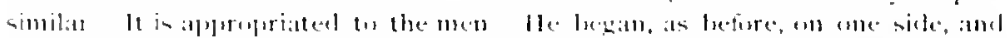

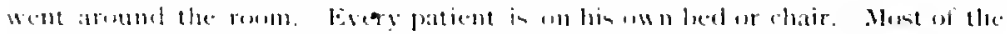

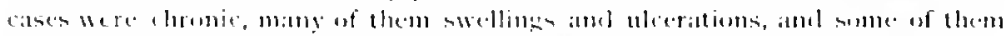

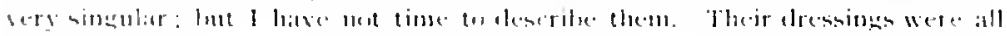

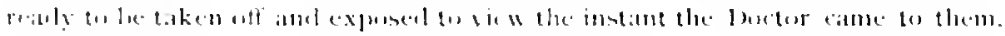

SFrom the Journal of Rev. Manaweh Cutler, Philadelphia in 1797. Vol. 1. P. 253 . Memorn of Matuliew Clarkson, 1735-18000. L'hil. 18,0 


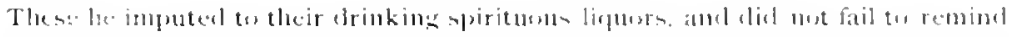
then of it. He told me the greater propurtion of his patients in the eity were similar cases, and originated from the same callse. There were between forty and fift in this romm. We next towk a view of the Maniacs. Their cells ane in the hower story. which is partly unclergmound. These cells ate about ten bet separe, made as strung als a prison. On the back patst is a long entry, from which a dows opeens into eachof them; in each dour is a bobe large

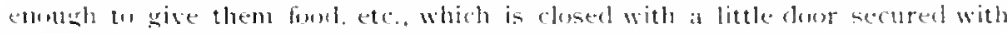
stroner bults. On the upposite side is a windom, and large iroul grates within to prevent their loreaking the glass. They cill te darkened at pleasure. Here were buth men and women, hetween twenty and thirty in number. Some of them hase beds; most of them clean straw. Sume of them were extremely fierce and raving. nearly or quite naked; some singing and dancing: some in lespair: some were dumb amol would bot apen their mouths : others incessintly

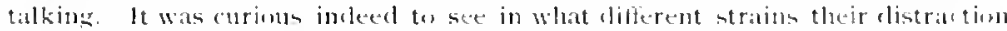

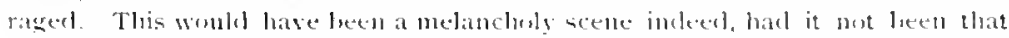

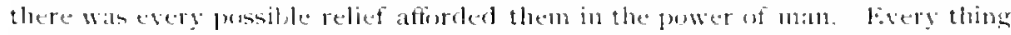

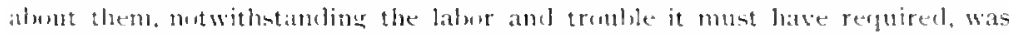
neat and clean. From this distressing view of what human nature is lialele to. amb the pleasing evidence of what humanity and lenevolence can do, we returneed to the rom where the birectors were. . . Such is the elegance of these muldings, the care and attention to the sick, the spacions and clean apartments. and the perfect order in erery thing. that it secmed nure like a palite than at lomplatal, and one would almost be tempted to be sick, if they could be so well proveled inr."

In a hook on "Diseases of the Nlind," by I)r. Kush, containing Treatment also some fugitive contributions from other physicians, are references to the medical treatment and management of the insane in private practice and in the Hospital, to which a brief reference may be made since it serves to show the practice of that day. In his view the remedies for general mania should be:

"[. Such as shuld be applied to the mind througl the medium of the burly. ancl

"11. Such as shoulal be applied to the budy through the medium of the mind."

The first remedy, he thought, should be blood-letting, and anong the reasons given for this practice were that this "grade of madness" is an arterial disease, a great morbid excitement or inflammation of the brain: that an unrestrained appetite caused the blood ressets to he overcharged with blood; that it is important to relieve the congested brain before obstruction and disorganization takes llace; and that experience has hown blood-letting to he attended with extriordinary success. Rules for blood-letting are given according to which twenty to forty ounces may be taken at unce. IFive cases are mentioned terminating farorably, from one of which two hundred ounces were taken during a jeriod of lwo months, and from the other four hundred and serenty ounces by forty-seven lileedings. between fune and April. Two mechanical contrivances were intro- 
dured, one called a "grater," or revolsing machine, to be used in

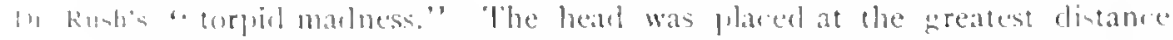

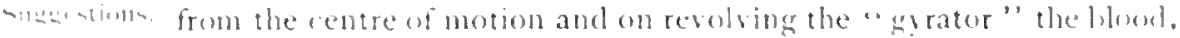
ly the rentrifugal artion was caused then to the heat and atreclerate the astion of the heart from seventy to whe hundred and twenty heas in a minute. 1, hair called a "tranpuiliner" was devised in which a patient might be confined. It was supleseed to ontrol the imperus of the blood toward the lrain and, by lessening muscular action on reducing mutor artivity, so redue the foree and frequency of the

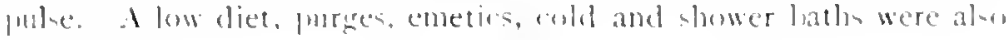
presentiberl.

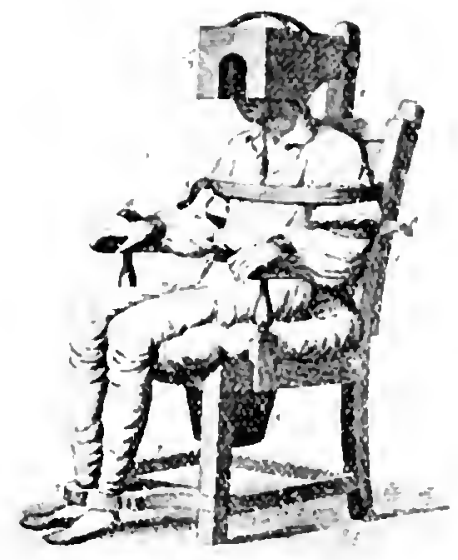

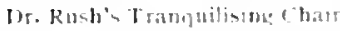

All of thene measures were supposed to exert an influence in some way upon the arterial circulation, and were direded with this sole object, which was believed to be ensential to the succesaful treatment of the insane. It is easy at this day to understand how such means of treatment, even if sanctioned hy the weight of professional authority, might become, as they actually clid, in the hands of unskilled and unsympathetic keepers, a source of aluse and were therefore finally abandoned and prohilited.

All influences which could lee exerted upon the lody thromigh the medium of the mind, ly means of occupation, amusements, the excitement of the emotions, and thone measures which in more recent times are embraced under the term of moral means in the treatment of the insane, receised the comideration and approsal of 1$)_{5}$ Ruh. 



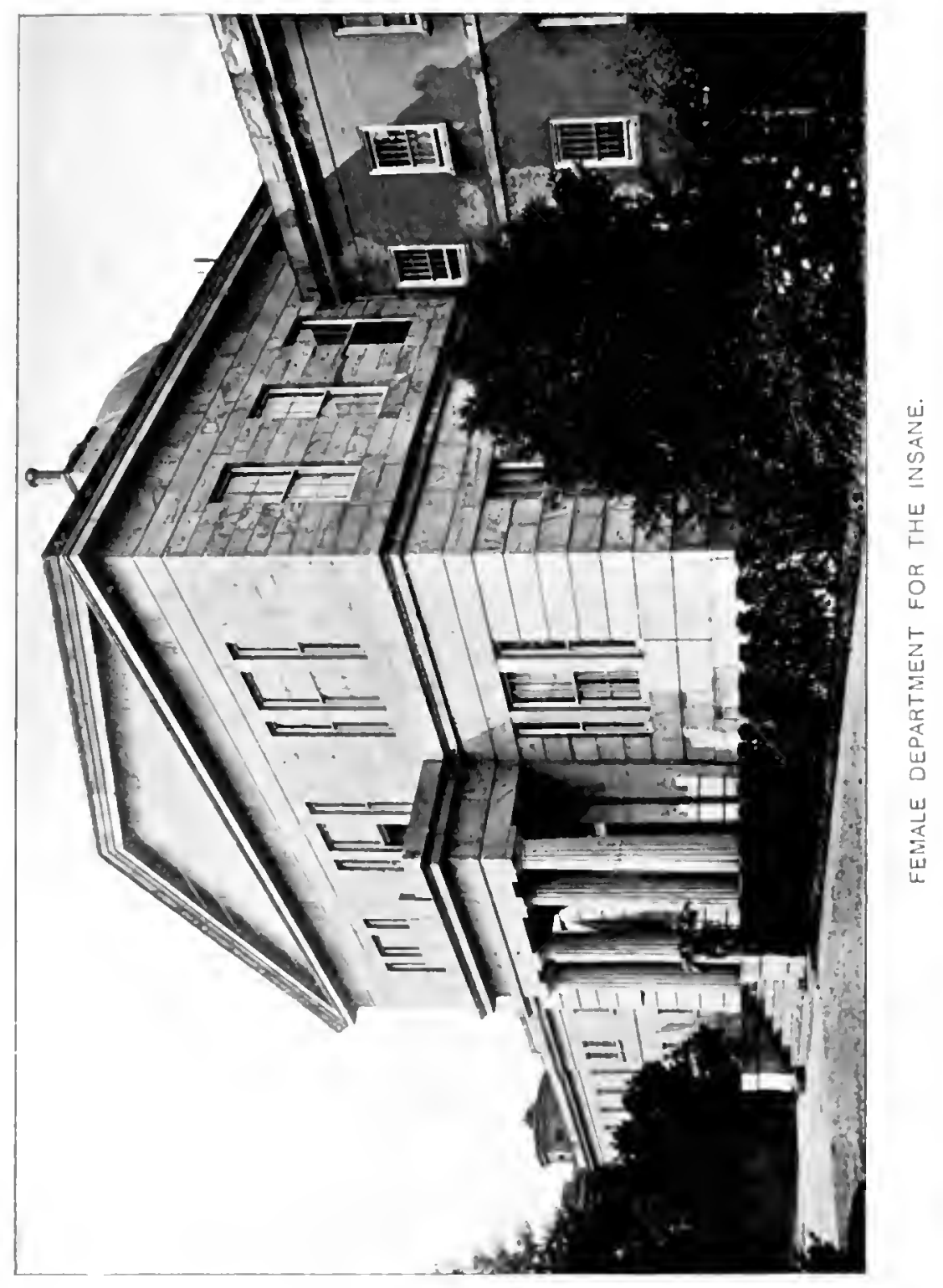


Ilis recorded views and recommendations were not only far in advance of his contemporaries, but they contain the earlier thoughts expressed upon a branch of the subject, which were destined to have a prominent and enduring place in modern treatment and in the administration of hospitals for the insane.

While the depleting practice, such as was followed by Rush and his contemporaries, has long since heen abandoned, it must be remembered that he had received instruction in the school of Edinlsurgh and imbibed there, and elsewhere, the principles which then governed thysicians in their general practice and which he mainly followed in the treatment of the insane.

The plans of the Hospital were prepared by Isaac Holden, an architect who came from 1 lanchester, England, in ${ }_{1} 8 z_{3}$, and practiced as an architect and builder in Philadelphia with his brother, from 1826 to $S_{3} S$, when they returned to England. ${ }^{\prime}$

The new building in West Philadelphia was so far completed as to Insane. be ready for occupation on the first day of the year, is $8+1$. The period of construction had extended over four years and six months. The amount expended was $\$ 265,000$. During $1 \$_{4} 1$, the Contributors authorized the further erection of detached buildings-two for each sex-thirty-one feet north and south of the main hospital, and nearly on the line of its eastern front. These detached Juildings were subvequently connected with the main hospital by an intervening ward and a connecting corridor. They were intended for patients who might be noisy or turbulent - no suitable provision having been made for the proper classification of this class in the original plan.

The first patients were received January gth, is $8+1$. lietween that date and the soth of the third month, ninety-three of the insane in the city were transferred to the new Hospital. (of all the officers of the Hospital of that year not one now survives and of the patients then transferred, only one is still living, having been con-

1For the purpose of obtaining some mformation of the hiviory of the phu made by lraac Holden, a letter of inquiry in relation to it was addressed to his son, John Holden, of Manchester, who stated in reply: "As to the Hospiral referred to 1 have alwa's understood that the plan uds obtaned on a limited competition, one of the competitors being the late John Haviland and one other I believe named Strickland. I have a strong idea that the window's were made with iron sanh bar instead of as was usual at that time-wood bars and iron outside bars in addiston. I do not rementher ever hearmg what model or system he sudied, but I should hardly think he had any information beyond what he could gather an America. I have compared the view ot tbe old part of the liosptal with a drawing in my possession and they agree, and 1 assure you th is a great satus. faction to me to know that a lowlding deaigned and terected? by my father so long since is in existence and still doing good work. I may say" that atter returning to Eogland in $183^{3}$ the two brothers commenced practice in Ilanchester and one of thelr earliest works was the county lunatic asylum at Prestwick, near Manchester. I would have been nuch pleased condd 1 have given you further information tut unfortunately your request comen too late, as my father (baac) died in I 934 . and my uncle in spo.". 
tinuomsly under care for a period of iffy-three sears. Intil the year 1 istr, no extended report of the operations or manner of treatmemt of the insane in this Hospital had leen mate, nor had any attempt

Kepold shem

Resil al

[iा $\cdot 1+11)(\cdot 1)$

|iitu:miti.t Stallentull.

ilject in publisbingr kepurts.

Inlilic

$6+1,5$

$101110,11+11$

1)...1 ment

wille. II)

bit lle lentlits

titin

maprosed

amelition

il lilvialle been made to collect facts and statistirs. The ustal annual report which had been published and fresented to the Contributors at their meetings, showed the number of admissions and results, together with a financial tatement of receipts and disbursements, the whole being spread upon a single printed shect. It this period there way lout a limited experience in the medical treatusent of the insane, and the pullic generally had such knowledge of the subject only as might le gained by visits to jails and almshouses where the insane were detained. I'rejuclices were to be combatted and overcome; medical skill and thought, combined with the exereise and application of human sympatly, were to be concentrated 11 pon a special class of cases; medical experience was to be accumulated ; the public mind was to be edurated and a hmmane semtiment was to be created in behalf of the insane. T'lo llanagers wisely considered thath all of these oljects might le promoted ly the pullicition of an annual report which would show the operations of the year, present statistic and results, and discnss puestions of treatmem, management, plans of comtruction and the various prohlems that would arise from time to time in a licld as vet comparatively unexplored. Is these report were issued anmually, and were prepared by J)r. Kirkbride, from $18+1$ to $1 S 8_{3}$, they furninh the principal material fior any history of itoperations during this period.

The first report of the leepartment for the Insine was isoled at the elose of $I S+1$. It is devoted to a lorief sketch of its histor, luildings, and operations. From this we learn that the government of the IIospital was vested in the Mlanagers of the Penbsylvania I Iospral, elected annually by the ('ontributors. To this lioard wa entrusted the general management of its concerns; the selection of its officers and the regulation of the admission and discharge of patients. At the organization of the Hospital, the Nanagers electerl a physician, an assistant physician, a steward, and a matronassigning to each the duties usually performed by such offecers. Thi hasis of an organization has leen followed to the present time. the staff heing enlarged as the exigencies of the service recpuired. followed by an increase of admissions, by an improvement in the condition of the paticnts, with leeter results than had been attained under the previons system of care, began to be realized at an carly date. For a period of five years prior to the onening of the new 
Department of the Hospital, the average annual number of admissions was sixty-six. At the end of the second year atter opening the new Hospital, the admissions for the year amounted to one hundred and twenty-three. For corresponding periods there was an increase of sixty-four in the average number unter care: and an increase of thirty-nine in the number of recoveries. These results are to be fairly attributed to the extension of the means of usefulness of the corporation, by the erection of a distinct hospital for the insane and an enlargement of the means of relieving an increased amount of human suffering.

As the time lengthens since the opening of the new wards, it is I'rinciples a subject of increasing interest so ascertain the nature of some of the earlier questions that presented themselves to the Managers and the lhysician and superintendent The second annul report is devoted to the removal of erroneous views npon the whole subject of insanity. and gross and prejudiced opinions regarding the treatment pursued, as well as to the following topics: The Importance of Early Treatment, which is stated to be well understood by professional men. but not fully appreciated by the friends of patients; The Economy of Treatment in the First Stage; The Tinits of Friends and general Visitation; Avoidance of Deception in Treating the Insane: Outline of Treatment pursued: The use of Restraint; the Qualifications of Attendants; Charity l'atients received. These various tolics were filly discussed in this and succeeding reports. They embolied the principles upon which the Hospital was to be managed and were the means of laying the broad and humane foundations upon which its internal administration was to be conducted and the pulslic confidence assured. The subjects of the treatment of insanity and the use of mechanical restraint, are given a proper prominence. Insanity is recognized as a disease due to physical derangement, which may lee removed by medical treatment, although no specifics for the disease are known. General depletion by bleeding might be considered necessary in the commencement of a case, but it has rarely been resorted to because it had been amply employed before the patient reached the hospital. A note of warning oceurs, that medical men would do well to prevent the prejudices of friends from leading them to pursule a course of treatment by bleeding, a treatment that might be proper for inflammation of the brain, but which, if long persisted in, in cares of insanity, can hardly fail to produce serious and irreparalule injury. A low cliet is repuired only for states of physical disease: but for the majority an invigorating one has been found most advantageon. No (1) which I) patrtinent is comblumeder

Merlinil anil Wor:al Truesturemt of In-ink: amenable. at. Vealia;it Treolment less stress is laid upon the mora/ treatment of the insane. It cmloraces dmome. 
an extensive range and in every case is advantageous, while in some it is sufficient aleme to effect a cure. The construction and architectural arrangements-the furniture-the number and kind of persons employed-minutest details in the regulations-exercise in the open air-occupation and amusenents-all have something to do with it. The moral treatment, or management, of the insane embraces all means calculated to substitute mild measures, kinduess and sympathy, in place of an inflexilse, rigid system of internal discipline to which all are expected to strictly conform. which so often presails in public institutions. It was with this object in view that the interior of the Ilospital was made as attractive as its means would permit-that trees were flanted about the grounds, fleasane walks and roads laid out ; walks to the comntry and to places of interest in the city planned-all of which were in the direction of increased personal liberty and calculated to convert the thoughts of patients from their distracting delusions into healthy channels of action.

1110116h1114

slowilat

lie llie

(imlinaniont

(1) Insine.

It was urged that attendants should not be "keepers" only, in their relations to the insane, but attendants and compranions. Nuch stress was laid upon the inportance of mildness and kindness in the care of the insance as substituten for the use of mechanical restraints and confunement in strong roons. The year 1792 . Which witnessed the nolile labors of P'met in striking of the chains of maniacs and abolinhing the abuses which existed in the French asylums, was aho the period at which members of the Society of friends in Eingland. united in establishing the "Retreat" at lork, which has since been w) justly distinguished, and from which, soon after its foundation. emamated a code of moral treatment and mildness which exen at this day can hardly he surpassed. From the active interest felt in the l'ennsyliania llospital by members of the same religions hod,-the Mile and mild and rational system pursted at the Retreat was soon alopted in katimat this institution-long, indecel. hefore a radical seform was more than syatem thought of in many of the establishments of a similar kind in other parts of Gifeat liritain. While absolute non-rentrant was not annemued as a dogma, actual restraint wats seldom resorted to: and. indecel. several patients who had been restrained for years before their adminson to the Honpital, were, moler the new sysem, with its better facilities for clasification, cared for, without a resort to such sesere meanures, and wholly cured.

fumblumb Another feature of the eatliest report was the preparation of statintin tables of statintics which were likely to have an importance in ascer. it) Anturs kejenter

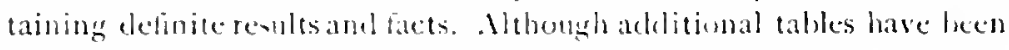

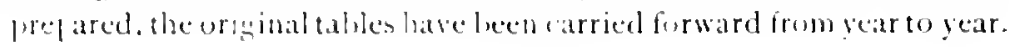


The various topics that are presented and discussed in the earliest reports with such candor and assurance, convey to the minds of readers of the present day, the impression that the gravity of the responsibility was apjreciated to a degree that may well excite surprise and admiration. They contained a code of principles which were to become a guide in the conduct of the affairs of the Hospital in later vears and were calculated to bring the treatment of the insane within the domain of medical science, and to elevate the standard of custodial care to a higher plane. They have to-day a recognized place and force in the administration of every hospital throughout the country. So important were these principles regarded that they were reiterated in succeeding reports in order that the community, in which the Hospital was located, might be thoroughly impressed and assured. Popular errors respecting insanity were also met and combatted. The doctrine that insanity was a visitation of wrath and sengeance, or a reproach, was upposed. It was urged that the brain, like the lungs or other organs of the body, was liable to disease. As it was a common thing, for the treatment of various accidents and ills of life, to create hospitals, involving the erection of costly mildings and the employment of expensive means of treatment, it wan especially proper that disorders of the brain should be so treated. I special plea was made that such institutions be called hospitals, and the name Hospital was properly affixed to the new institution. for the second time in this country, in order that a name, familiar to all as at place for healing, might popularly designate its character and purpose.

It an early period in the history of the lepartment for the Insane, the diversion of patients by various methods received the attention of Dr. Kirkbride. In $\mathbf{I} \$+5$, a systematic effort was male to add, to the diversions they already enjoyed, a course of instruction ly means of lectures. For this purpose a room was prepared with a stage, seats, and other fixtures for a lecture-room, and a beginning was made toward a collection of apparatus and illustrations. On two evenings of every week an audience of about one hundred patients assembled, listening with marked propriety to the different suljects brought to their notice.

Not only the selection of attendants had received attention, lut their regular instruction was now proposed upon the nature of their duties-mbracing some general views of the nature of insanity-the principles which should regulate their intercourse with parients and cach other-the proper mode of pruceding in difficult cases. and such orther matters as would be likely to give them a just sense of the importance and resum ibility of their calling. 


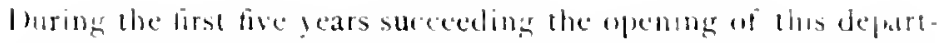

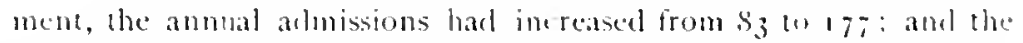

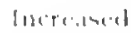
. 17. a) Blice

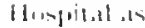
heis in in .11กแ11.1 nimiminnts
I.litional whele number trealed in one year from $176 \quad 110328$. While the recoveries during the lan twelve years, previons to the remusal of the insane from the city, had heen three hundred, the number of recoveries, during the five years succeding the removal, wan three hundred and thirteen. These results were regarded as extremely kratifring. as shewing an increasing appreciation of the work of the institution. the results cecry year confirming the wistom of the change that had been made. I glance al the tinancial results for the same perind show that this part of the administration hard prospered as well its its departments for the sick and injured.

The expenditures from $1 \$$ \&1 to 1845 were $s 12 \$ .908$. on, and the receipts during the same period were $\$ 105.752 .89$.

Fre. The amount expended on free patients during the first perind of

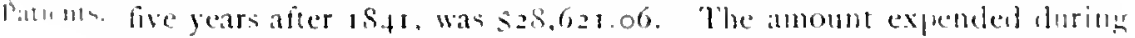
the same period loy the llesigtal in loe city on free patients was at leats $\$ 55.000$ - the total amount expended on the indigent pattemts in the two departments was $s, 8,621.06$.

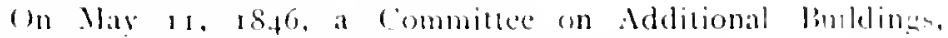
alpointed to take in comideration a communication from lir. Kink. bride, reported:

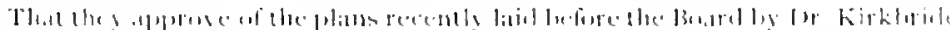

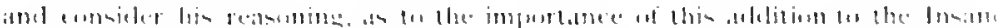

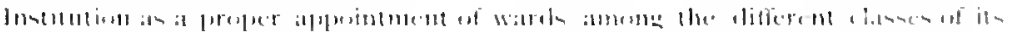
inmites, ats comblusise.

The North wing, devoled to men, was somereroweled in as.fo, that the Managers anthorieed alditions lo le made on the north and south sides of the murth, or men's, lodge, as being the most convenient position for the purpuse. This adotional accommolation was rempleteel and occupied in istz. It mnited the Sorth loolge with the main hospital structure.

virh ()casional requests had been made for separate and private Wing arcommodation for a single patient, somewhat detached frum the main editice. The proposition was approved ly the Managers and an enlightened and lileral gentleman, from another state, jarticipating

buit in some of these views and andions that a friend might have line benefit of such a renidenceduring the existence of ber mental disorder. contriluted the sum of live hundred dollars toward the comstrur tion of such a sermeture. This liberal act led to the construction al a cotlage. which for many years wat devoled to the use of une, ar two paticuls. 
The crowded state of the wards for women, a steady increase in the demands for admission, the want of proper means of classification. and the great convenience which had followed the additions made to the men's lodge, led the Managers to authorize the construction of two wards, one south and one north of the women's lodge, to conform in all respects to the plan that had been carried ont at the north end of the men's wards. 'This addition was occujped in the year 1849 . and with the other parts of the Department, furnished accommoration in the aggregate for two hundred and twenty patients, and this wan looked upon at the time as the completion of the whole plan.

This formative period of the Department is notable also for the erection of a museum building and reading-room. the gift of interested friends. This building became the repository of specimens of

lin aldilitminal 11:irits

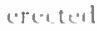
liir Fendile. pitivisto

Vistil

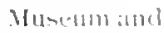
Realling.

1ำเา

Frected les privalte (is) (ril)tiliut)

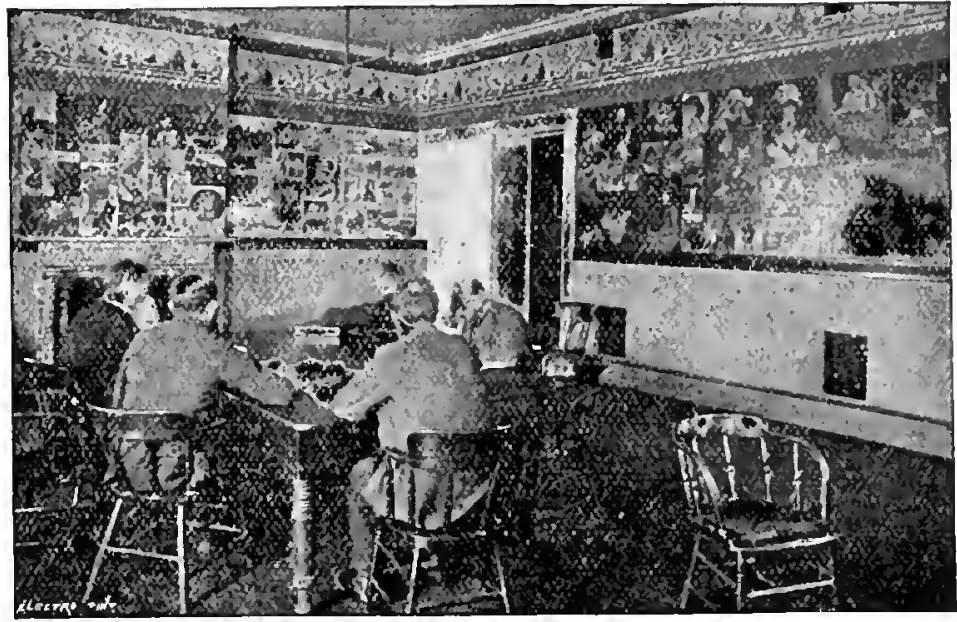

Ketdiug-Room.

natural history, minerals, shells, etc., and was also intended as a readingroom and place for retirement. Other suggestions for adding to the contentment and mental occupation were put in practical opera. tion. Reading and sewing classes were formed and persons employed to lead them. liooks, to the number of eleven hundred volumes, harl been collected and flaced on shelves accessible to patients. All of these means were properly regarded as progressive steps in the treatment of the insane.

At the close of the year $185 \mathrm{I}$, the Pine Street Honpital had completed its firstcentury of charitable work, and the dejartment for the insane the first decennial period of its history. The Vanagers wele Wrk. 
mow able te congratulate themedres upon the sucesestul completion of their original plans, the organization and succesful administration of this thepartment, its gratifying results, and the pulblic confidence it enjoyed. It was already making its influence felt in behalf of the interest of the insane throughout the state ame from beyond the loorders of the commonwealth came frepuent viviturs and officials anxious to ntudy itnoperations. Principles of medical treatment and administration, which had been alopted after lecing tried and found to lee excellent, were returning genel fruit. Of the Managers who were connected with the Pine Street Honplat in 15,36, when the romer stone of the new lepartment was latid, hat a single one wats still connecled with the institution. lisen of all the members of the hoard. which acted at the organization of the bepartment, there were hut two remaining in connection therewith at the expliration of ten years. Amid all the changes in the lioard of Managers, however, there hat been no change in the excellent princifles and purposes that were sought to be estalslinhed, nor in the hearly interest felt ly its members, nor in the enlightened spirit with which every suggestion had been thet and carried out.

It was a fitting period to survey and note the good work of a humdred fears. The founding of the lhosptal was suibahly commem. urated ly a centennial address delivered by Dr. George H. Wood. June 10,1851 . In this address there was presented a history of the Ilospital to this date, with an allusion to the events leading to the creation of a separate department for the insane. As an extract has already been taken from the notes of a traveller and inserted in a frevious page of this historical accomnt, of what he observed of the state of the wards of the 11 ospital in 1787 on the accasion of a visst m (omp).my with l)r. lBenjamin Rush, so it is a satisfaction to quote from the aldress of lor. Wood his impressions derived from a visit te the new lopertment sixty-four years later.

Impinemingle dericest from a Vicit s. 1/k

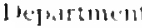
firg Insittle

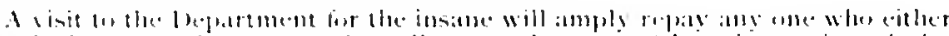

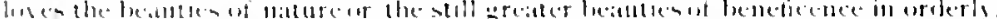

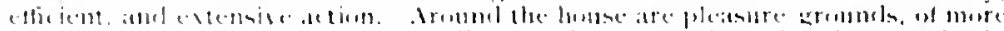

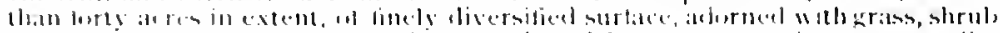

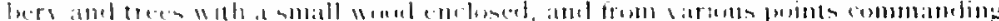

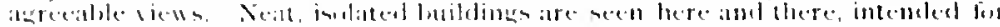

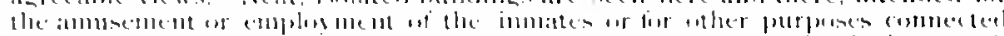

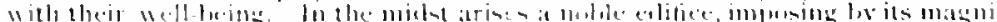

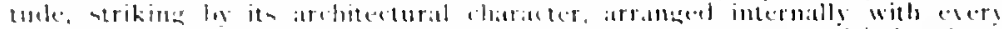

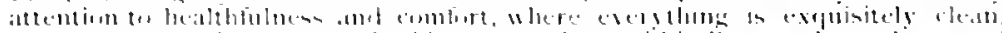

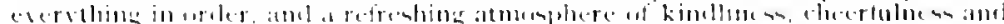

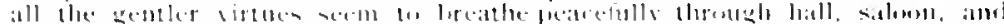

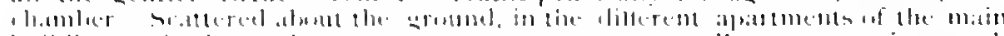

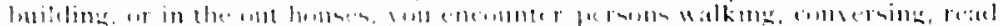

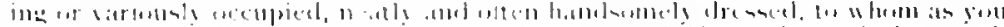

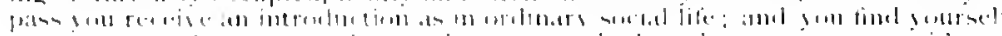

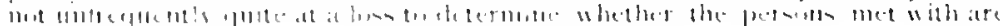




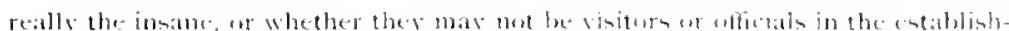

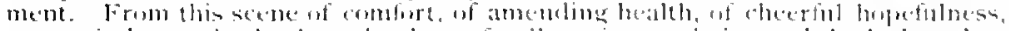

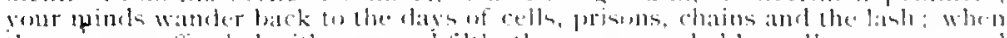

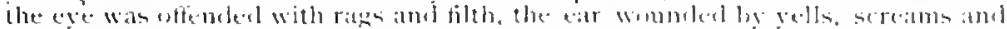

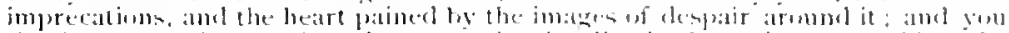

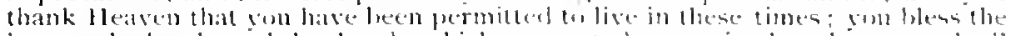

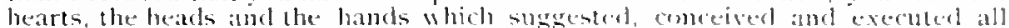

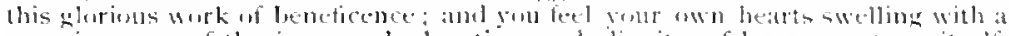

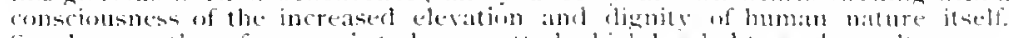

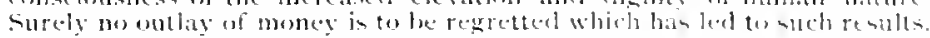

Evidence of the interest felt $l y$ friends in promoting the combor of patients, and in supplementing the means designed for the entertainment and moral treatment of patients, appear in all the yearly reports. Acknowledgments were regularly made to numerous persons for thoughtful gifts, concerts, lectures, readings. etc., which could not have been provided from its own resources. They had a secondary effect of exciting in the minds of many persons a sympathetic and intelligent interest.

There was no abatement of improvements and minor additions as the means permitted. New walks and roads were planned and made; summer-houses were located and erected to afford rest and shelter, as well as permit of views beyond the grounds. The extension of the city gas mains led to the introduction of gas as a substitute for oil lamps in $1 \$_{52}$; and in 1854 , the steam heating plant was so extended that this method of warming buildings, then but seldom resorted to, became a sulstitute for the hot-air furnaces. These important changes tended to add much to the safety of the buildings from fire and materially increased the comfort of the patients.

The range of lectures, with lantern slides, held three times weekly, was extended and Sunday was observed by a suspension of unnecessary labor and the assembly of patients to atrend some religious exercises deemed appropriate to the day and place.

Notwithstanding the addition to the original plan that had been made by the erection of four wards-two for men and two for women-the added accommodation was fully occupied during $185 \mathrm{I}$. For several months of this year the wards were inconveniently crowded. 1)uring the year 1852 the daily average number under treatment was 224. The relief which had been expected to be afforded from the opening of the new state Asylum at Harrisburg, during this year, was not realized. In 1853 , the daily average was 229 . and applications fur admission, to the number of fify, were declined.

In his report for 1853 , Dr. Kirkbride wrote as follow:

\section{Gititu if}

Friknis

artal to the

fintertatin-

brent and

Minal

treatuntell of

the Ins:ulde

Improse

memts, ete.

which

Prommete the

cimtiont it

pallitonts.

.

All our experience yoes to show that any material extension of the hulding of the present llospital is undesirable: but at this lime, l deem it imporl.mb fur the best incerests of the atileted, that the increased acrommunlations that are

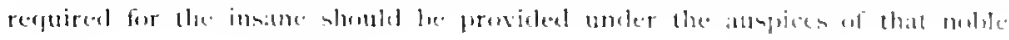

J.1.21115: inth Tolntern slides.

Ninda oneranderedExperterl Relief met Realifed.

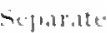
Builaling in Male I'aticut Silyzeletent. 


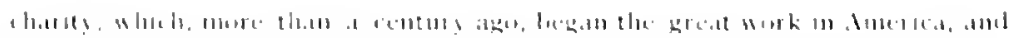

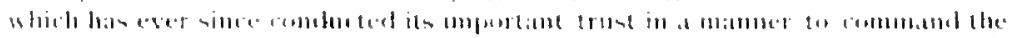

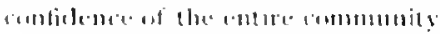

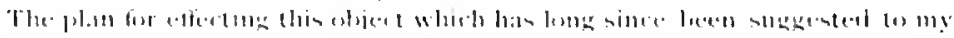

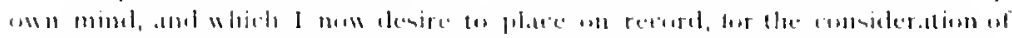

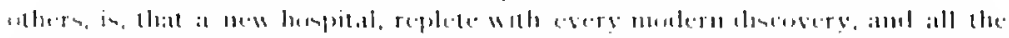

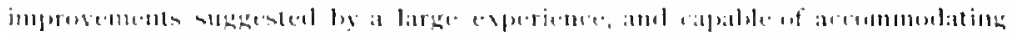

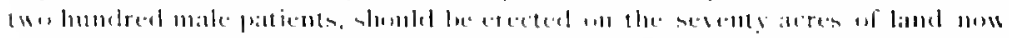

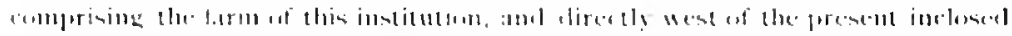

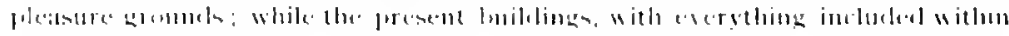

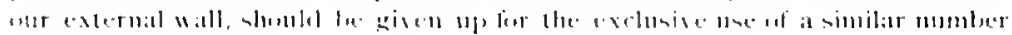
i.l bem.loles

In-11, 1,41 i.,1) $1+1$

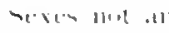
111.1112.121.

Ailditinild frasision

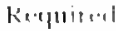
1, II, I, matiale 1lut linatie

Fifections 1.1. X Xen binllinge, inml

arparallints

al tiese .19umanter

11.117.1211

It was urged that no special alvantage existed in the association of the sexes in the same hulding lout that there were many actual disalvantages. The separation would give to each sex enlarged liberty, freedom of movement with greater privacy, while the grounds furnished an unexceytional site for the new structure. fior several yars the wards had leen crowled and applieations had heen declined. 'I here was not in the city or state sufficient provision for the number of insane then out of hosplitals, without taking into consideration the expected repuirements incident to the ammual increase of popm. lation. It had been the hroad and liberal policy of the Managers not only to conduct a hosplital for the sick and injured, but to receive for care and treatment the insane at a time when no other provision was made for them by the city or state. On account of the limited facilities of the parent institution, a sejarate department hat been created in the vicinity of the city, and now (1854) at another period of its history, it was again confronted with the cmbarrassments of over-erewded wards and the necessity of turning from its doors many worthy persons for whom admission was sought. It was not probable that any other organization or institution would come forward to undertake to sujply their needs.

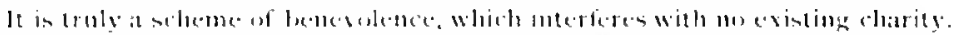

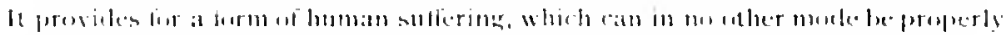

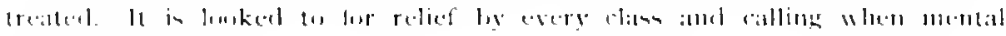

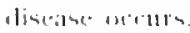

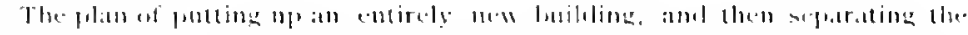

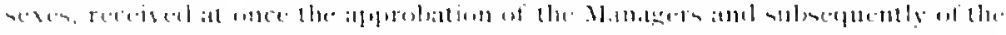

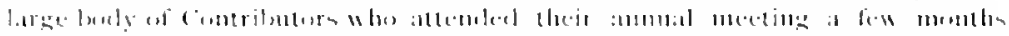

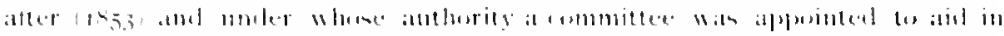

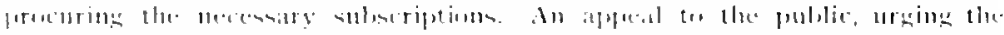

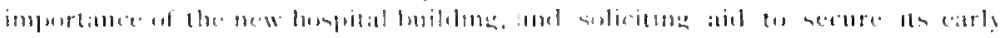

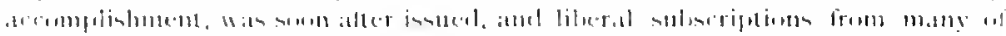

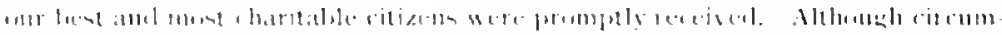

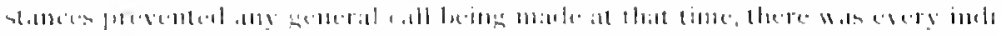

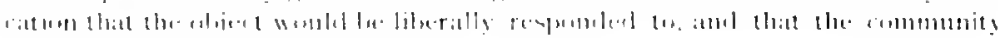

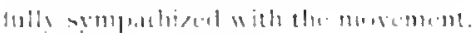


The amount of money required to complete the new wards was e-timated at $\$ 250,000$, and it was resolved to commence the building as soon as $\$ 150,000$ were subscribed.

Although but a compraratively small number of citizens had been called upon during the year, it is gratifying to be able to state that at the end of the year 1854 , the sum of $\$ 127,000$ had been sulsscribed by two hundred and sixty-nine individuals-a fact that was considered most honorable to the community and encouraging to the Managers and to all concerned.

The printed "Appeal to the Citisens of Pennsylyania for Means to Provide Additional Accommodations for the Insane," may be found as an Appendix to the annual report of the Hospital for the Insane for $\mathbf{1} 855$. In the same report is printed a copy of a "Circular," with a list of 269 subscribers and the amounts contributed ly. each.

At a meeting of the lioard of Managers held March $3^{\mathrm{d}}, \mathrm{I} 856$, the following preamble and resolutions were unanimously adopted:

WHEREs, from a report made this day to the Board, it appears that there has been suldscribed lowirds the fund for erecting new huldines for the insane department w the Hospital, the sum of one humdrect and forty-four thousamel dislars. is

WHEkEs, it is impertant that preliminary arrangements should le made. to enable the work to be commenced when the sum of ome hundred and fift thousand dellars hats been subscribed.

Therefure, Resolied, hat a Building Committee of Five members be now appointed, whose duty it shall be to superintend the construction of the Building and adopt such measures as may be requisite w lave the work faildully executed.

Whereupon, the following Committee was appointed, viz.: James R. Greares, Samuel Welsh, John M. Whitall, Alexander J. Derbyshire and $\mathrm{Wm}$. Biddle. It was further "Resolved, that Dr. Kirkbride be requested to co-operate with the Committee."

(n motion, "the President, Mordecai L. Dawson was added to the Committee."

It was also further "Resolved, that the Committee alove named have no authority to enter into any contracts until the sum of one hundred and fifty thousand dollars has been subscribed.

Samuel Sloan was elected as Architect, and John Sunderland as superintendent of Construction.

The first foundation stone was set in position July ith, by Dr. Joseph !. Kirkbride, and the comer-stone was laid October ist, ly Richarl Vaux, Mayor of Philadelphia, in the presence of a large number of ladies and gentlemen, when aldresses were delivered by George 13. Wood, M. 1), and others. 


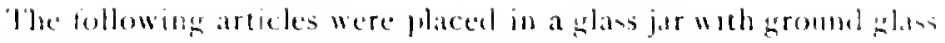

liegetrtiment ior VI.tlen thumblet. stopper, which was deposited in the eavity of the granite hlock. of which the curner-stone is mate. The opening in the stone is covered

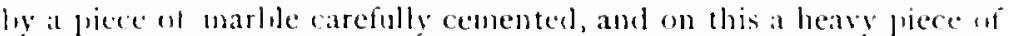
grante is laisl. The corner-stone is placed in the sutheant cormer of the centre building and about four feet hedow the unface.

Articles degesited in the corner-stone:

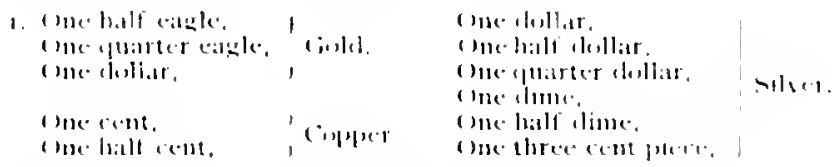

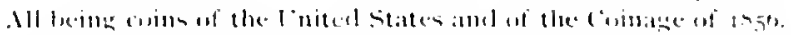

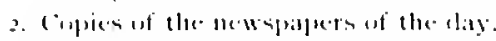

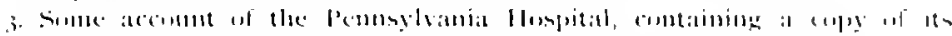
('hater. and other chouments anmerted with its early histury.

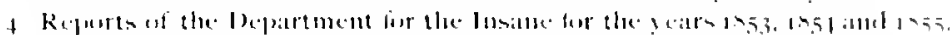

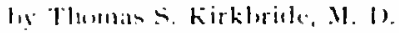

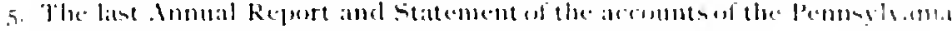

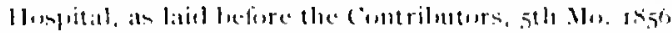

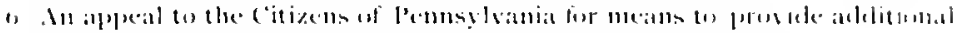

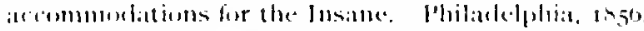

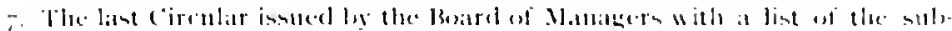

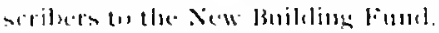

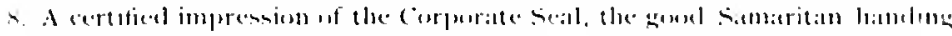

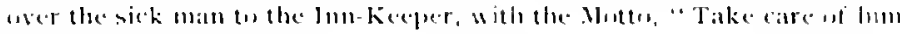
and I will repaly thes."

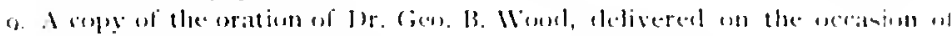
laysing the corner-stume.

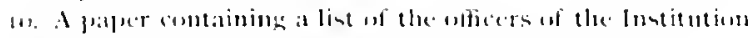

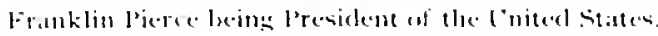

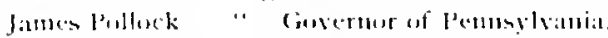

Richarel Vians " Magers of l'hilatelphial.

Fin:il

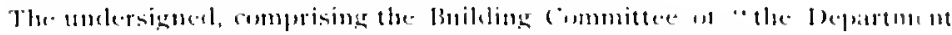

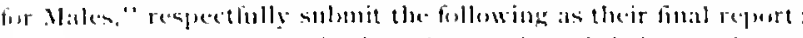

oi the.

Buildingr

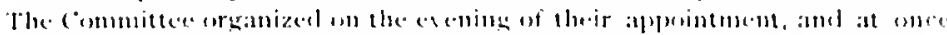
culcerel an the preliminary arrangements for an early and vigurens prostention

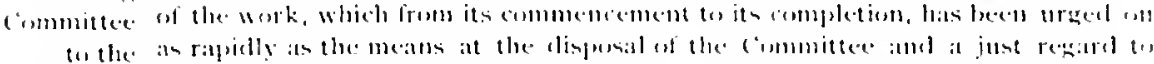

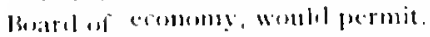

Matiagers.

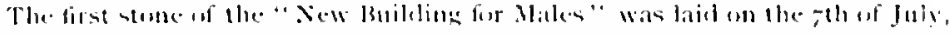

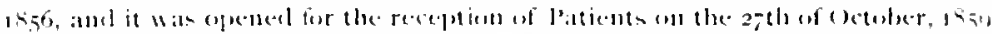

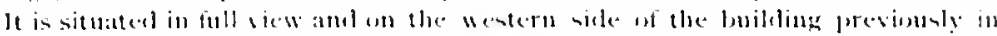

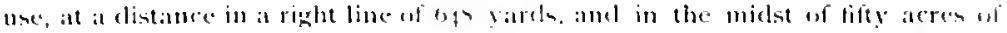

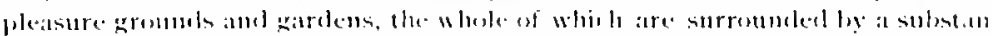

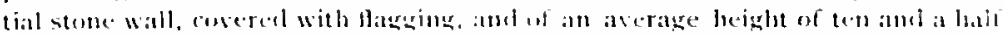

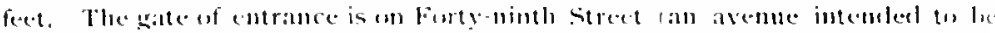

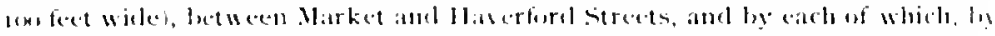

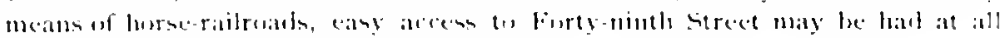
neationsts. 


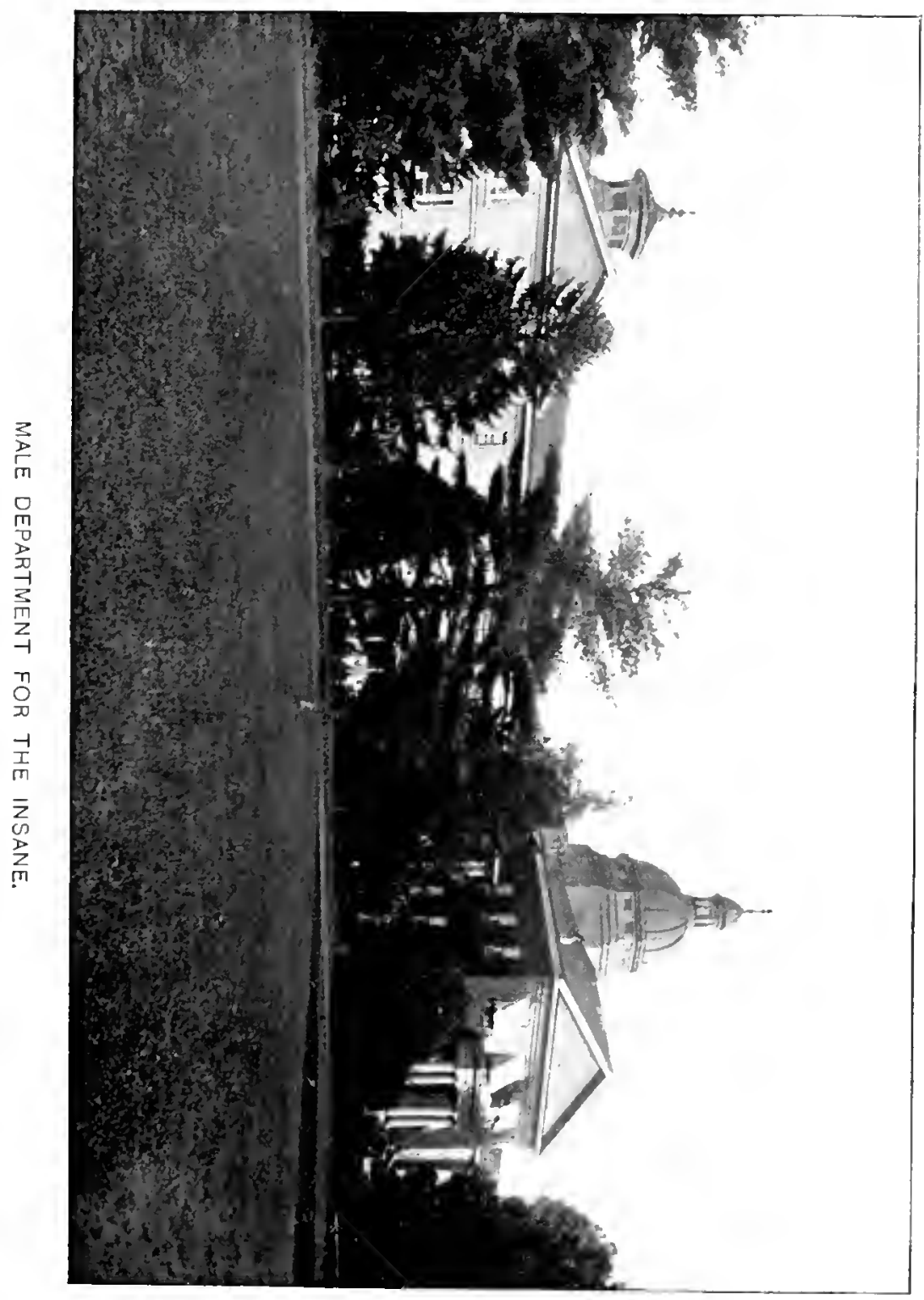



Notwithstanding the financial depression of $1857-58$, the work of building was prosecuted witls so little intermption, that it was sufficiently completed to receive patients on the 27 th of October, unverul 1859 .

The amount of money paid on account of the new building was $\$ 322,542.86$, and further liabilities had been ineurred to the amount of $\$ 30,000$. This total sum included, in addition to the erection of the building, the expenditures for the boundary wall. carriage-house, carpenter-shop, machinery of various kinds, heating and ventilating apparatus, grading about buildings and furnishings. A few ladies, impressed with the noble character of the whole work and actuated by a desire to secure the greatest possible efficiency in the new institution and its arrangements, generously undertook to give their valuable aid in providing funds for furniture.

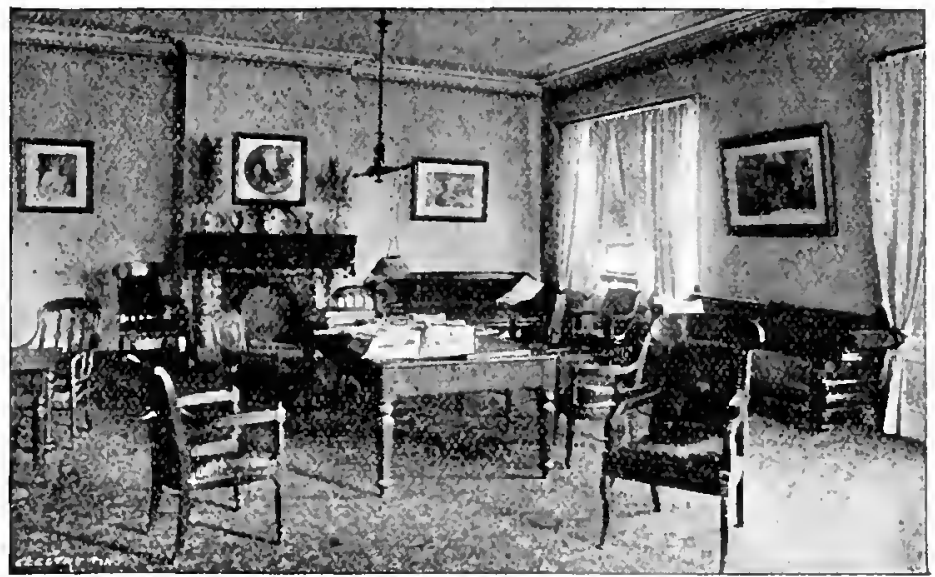

Parlor-Department for Men.

"There has lieen expended in the buildings and wall enclosing fifty acres of pleasure ground, the machinery for supply of water, warming and ventilation, the laundry, stable and other out-buildings, the improvement of the grounds and furnishing the wards of the department for males, three hundred and fifty-two thousand. one hundred and eleven dollars and fifty-one cents $(\$ 352,111.51)$, of which amount there has been received from contributors, three hundred and twenty thousand five hundred and forty-one dollars and thirty-three cents $(\$ 320.54 \mathrm{I} \cdot 33)$, and interest for temprorary investment, eight thousand two hundred and seventy-seven dollars and sevent $y$-two cents $(\$ \$ 277.72)$, leaving upwards of twenty-four thousand

(im) Report an cont ut Puildingr. Rethatrs and InIm) ments. 
dollars $(\$ 2+.000)$ set to be provided, in addition to which we shall le dejendent on the liberality of our friends for twenty-five thousand dollars $(\$ 25.000)$ to meet the cost of the repairs and improvements at the departinent for females."

bepartment The lepartment for Men was organized loy the appointment for Muk of lr. $\therefore$. Preston Jones, as assistant fluysician, the Ihysician-in. creanizet. Chief having the general supervision and direction of hoth departments.

The dily on which the first male patients were transferred (October 27, 1859), was observed ly appropriate ceremonies, and in the presence of a large number of the contributors to the llospital and others interested in its welfare and progress.

Repuir and The warls at the Department for Women. which hisd been in Imıฺn...

$111111=$ nitele comstant use for a periud of twenty years, had deteriorated from much use. The remuval of male patients from the north wing furnished the opportunity to make needed repairs and improvements. Although fir Femalen the financial condition of the clepartment would hardly admit the outlay, the sum of $\$ 25.000$ wis considered necessary, and was expended to restore the wards and furniture to thcir best state.

"lent.w The enlargenent, completion, and occupation of a new depart-

Seristis!

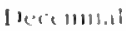
Periu! 1 !

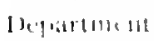
tiri Insalle. ment building for men fittingly marks the close of the second decennial period of the lepertment for the lnsane. The simple record of the work accomplished, but faintly represents the labor, the anxiety. the attention to details, and the time expended by the Managers and linilding Committer, the Collecting Committer, and the l'hysician. in-Clief in reaching the result. The contribution of the large sum necessary was a manifestation of pullic sympathy in the undertaking and the practical benerolence of the citizens of Philadelphia. During the twenty years during which the Department for the Insane lad leen in operation as a separate institution, the whole number almitted was 357 I patients, of which number 1754 were dincharged cured, 807 in various stages of improvement, and $27+$ remained under care. The sum expended for the maintenance of this depart. ment, no part of which was a tax upon its capital, for the year 1860 , was $\$ 8.4,14.16$, an average weekly cost of $\$ 5.47$ for each patient. At this moderate weekly charge there was open to any citizen who minht he compelled to seek a retreat or hospital in a time of affliction and sickness, one of the best approinted institutions in this or any other country.

It was observel as a part of the medical experience of this period ly. Dr. Kirkbride that "a very liarse proportion of all the cases received, when carefully examined, gave evidence of impaired 
general health and that a majority repuire a tonic and invigorating rather than a depletory coure of treatment." "Of all the cases that have been treated, no one, after entering the institution, has seemed to require or had general bleeding performed, nor has a head been ir kirk.

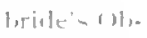
shaved, while cold and shower haths have been almost entirely abandoned." "Reference may also be made to the great advance made in other details of what has been called the moral means of treatment. Mention may be made of the improved character of rooms and furniture, the much higher ratio of attendants to patients, the regular courses of reading. lecures, or entertainments, held during the evenings of nine months of the year. All these latter, with good musical instruments, ward libraries, varions facilities for riding inside the inclosure, and a large number of additional means for occupation and amisement, were fomerly almost entirely unknown."

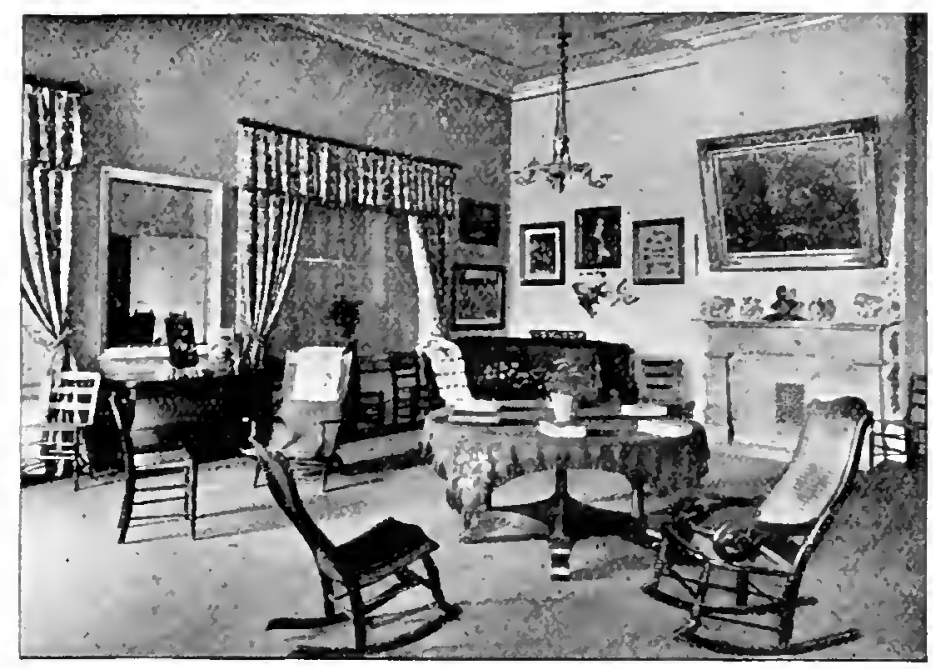

I'arior-Depatment for Women

"Other changes have been gradually occurring within the lavt twenty years, not les, worthy of note. the importance of which, as regards the welfare of the insane generally, can hardly be overestimated. Public sentiment has unquestionably been murh enlichtened. the errors and prejudices of a part lay have leen prasing away. and insanity is gradually coming to le regarded in the ame caterory as other diseases-one to which every peron having a lirain is liable. but often, as other diseares, amenalule to treatment and cure." The 
improved sistem here and elewhere meant the sulstitution of intelli. gent medical treatment and management for simple custody; nursen and attendants for keepers ; that comfortalile rooms and wards, open to inspection and visitation, should take the place of cells and strong rooms in sechluded places; and, that the law of love and human sympathy should be supreme in dealing with this afliction.

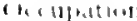

:1nil

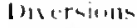
on l'allents.

livery year's experience and observation secmed to emphasice the importance of adlitional means for the physical and mental improve. ment, or the occupation and diversion of patients. Dry walks were extended during 1862 , and 1863 , in order that regular and sistematic use of the muscles in the ojen air might be encouraged. Out-door recreation was insisted upon because of the acknowledged adrantage of securing fresh air and sunshine, and because it can le more regularly carried out than labor or games of any kind. During these years, light w!mmatir exercises, as recommended by Dr. Dio lew is were introduced. 'They wereconsidered to be the true system of securing a proper development of the muscular system. For many laclies whe have suffered from the want of proper muscular exercise in the open air. light gymmastics proved valualule aids to the restoration of health, and they posse's the advantage of adding another means for breaking the monotony of the long evenings of winter. Fwo evenings of each week were set ayart for 2 mmastic excreises and, during the year I $\$ 6+$, Dr. Kirkbricle was enabled to announce that every erening of the weck was occupied in some manner that contributed to the enter. tainment or benefit of the patients.

The sucessful institution of light grmnastics and the grool results that seemed to follow this system of mild and regular exereise suggented the erection of a hall or room affording sufficient room for the class. Again was the Hospital the recipient of a donation. this time from Mr. Samuel Welsh, amounting to $\$_{3}, 000$, which was increased by others, for the purjose of building a gymnastic hall and assembly-room. 'The hall was completed and furnished in $186_{4}$ and has proved to the present day an important and useful building for the purpose for which it was originally intended.

Arlitional

drenmmor. ditions rerpuireal fior

Femalecs-

Finher llated erented.

The apartments at the department for women. made vacant by the removal of male patients, were so far occup,ied by the armission of women that the limit was reached in 1867 . The number of male patients in this 1)epartment, in 1859 , was 132 . In 1867 , the number of female patients had increased to 172 . Fortunately, about this time, a highly esteened citizen of Philadelphia. Joseph lisher, lisp., in the disposition of his estate, furnished the Managers with all the funds necessary for an enlargement of the 
accommodation for women. The bequest was made specifically for "extending and improving the accommodation for the insane." The erection of the structure which received the name of " Fisher Ward," in honor of this liberal benefactor of the insane, was commenced in r 867 , and completed December $6.1 S 6 S$. It is located south of the southern extremity of the mam hospital luikling. It was " intended for a class of cases of the deejest interest: for very sick jersons: laboring under acute affections of the brain. accompanied ly high excitement, and yet, for obvium reasons. not must comfortably situated in the omlmary wards." The cont of the Fisher Ward (South) was s24,850. On several accasions in the history of the lluspital, when some pressing want was found to exist. relief han conce

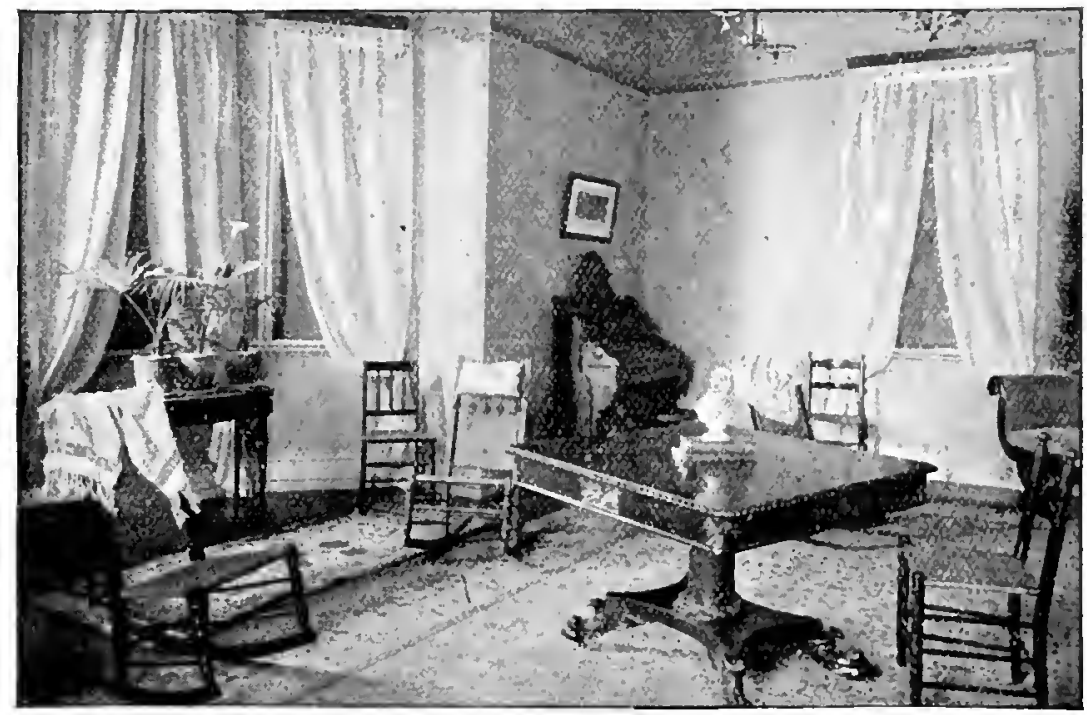

Par], Fisher Ward.

from some unexpected quarter, so now at another period of embarrasment. When all beds were occupied, and it seemed proballe that new patients would be refused except as vacancies occurred, means had been providentially furnished to make a valualle acldition for increased ward accommodation.

The year is7o marked the close of the thirtieth year of the operations of this department. 'the ten years preceding had heen marked by the erection of a gymantic hall; the South Fisher Wards from a heynest of Joseph fisher: and various improvements which

$(\operatorname{lom}, 11)$ Thirt I lectomist Periulul:1

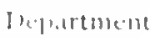

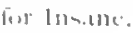




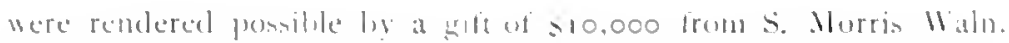

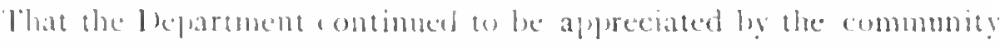
and was fulfillong its purpuese is shown by the statiotus of the year 1870. during whirh two hundred and sixty-one patients were admitted, a total of five humeled and seventy-four treated, and at the clone of the ear there rematined one hundred and sixts-nine mates, and one

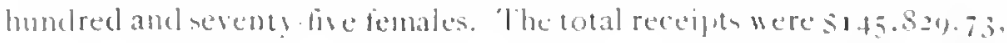
and the amomt expended for mantenance was $s 1+4.165 .51$. The

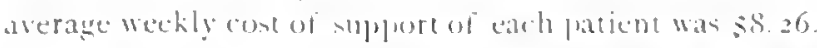

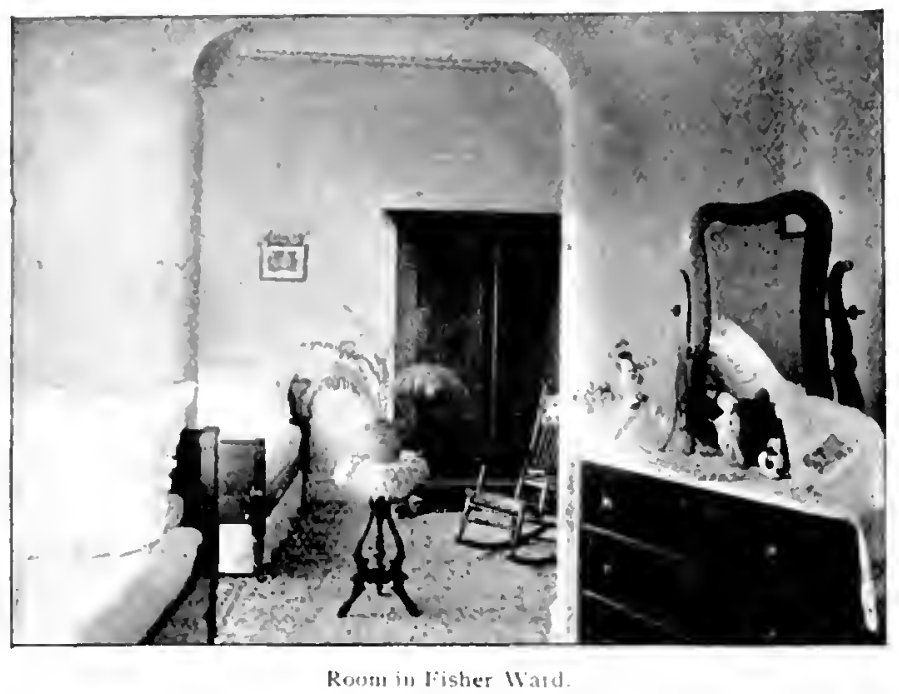

Firecions of Nortla Finlier

IV:ard fin Fentilen.

-121111 if fic.niamin reanklinin at

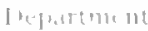

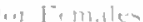

Juring the year 1972 a further endurgement for thirty adlitional female pations seened necensary and to render the departmem for women enjual in capacity to that for men. 'lhis adduion was commenced in 1872 , and completed in 1873 . "The cost was elefraved in great part from the remainder of the legacy leat ly foseph fisher. and it amomented to $\$ 43.209 .12$. The addition last marle have heen stykel the foweph fisher Wards, Aorth, to dintinguish them from similar wards ereatesl at the south cud of the south wing. from a portion of the same lenetiaction.

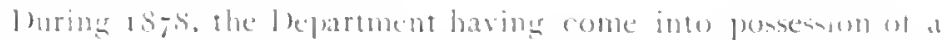
statue of fenjamin framklin. six and a half feet in height, it was flaced on a perlental in a prominent ponition in the grounds of the department for women. It would reem only right that homor houkl

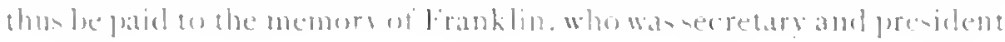


successively of the Board of Managers, was ever active in promoting the objects of its establishment, and was the author of many of its official documents, and especially of its appeals for legislative action or public benerolence.

The constructive period of the material, or structural, portion of cimpletim this Department may be said to have extended from the opening in isfi to is8o. During the latter year, the Mary Shields Wards. commenced in $\mathbf{1} 879$, were completed. This addition is connected with the South wing of the department for women and can accommodate thirty patients and attendants. It was intended to correspond in its location and arrangement with the North Fisher Wards, ercetel in $18_{73}$. When this building was projected the hope was expressed that, before its completion,

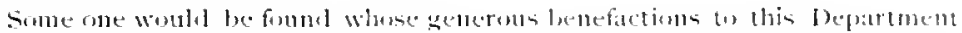
woukl make it right that the name of the donor wetule ever be held in enateful remembrance by being given to this new struclure. This lupe was fially funtified by the reception of a noble legacy from batry Shieds, which seemed on warrant the permanent comnection of her name with the wew warda. whicls were bar the special benefit of ber wh sex.

It is nut too much to say that in all the future lle Mary shichlo Wark will

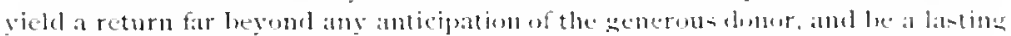

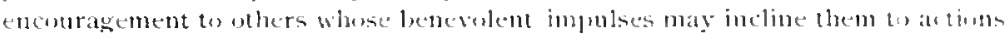
of a similar clarateter.

The cost of erection and furnishing the new wards was $\$ 25.806$.

During the years intervening. between 1870 and 1850 , this Defartment reached the hirhest number of inmates during the forty years of its history. The number of admissions averaged two hundred and forty-nine annually. The State Hosjutal at Norristown, which opened for the reception of patients during the closing years of this decade, afforded needed relief to many worthy persons and served to relieve the Hospital from a pressure for admissions which it was unable to meet. These ten years were remarkable for the degree of prosperity it enjoyed, and the enlargement of its work. In addition to the wards just referred to above, five ormamental summer housen and two green houses were built. Lxtensive municipal improvements on Market and Haverford Streets were completed at a cost of many thousands of dollars, involving also re-arrangement, re-building. and additions to the houndary walls; internal modifications and renewals were made, and the whole property improved. This perion was memorable in the history of the leprartment for the nolble henchar. tions it received from persons who by their practical symathy with its work, and confidence in its management, enalled the institution to enlarge the sphere of its usefulness. It wat memoralle alow in the

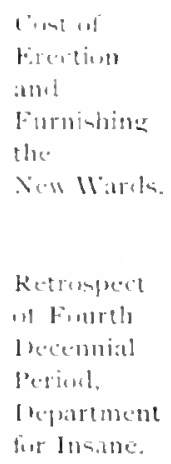

Municipol : Inis at lie.t Im11010 111 11ts 
1) ilian.

kirklorula's

foinil Rolwit

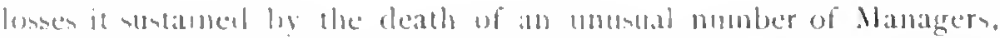
friends and benefucors of the lepartment. Whose names always cleserve to le held in grateful remembrance for the material at they contributed. and the valualse atel thes rendered by their jullicions roulsel and (1)-operation.

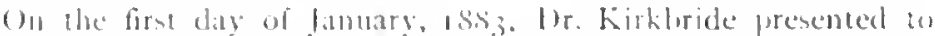

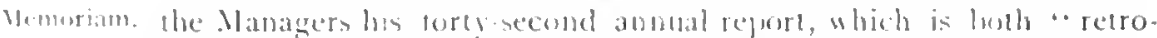

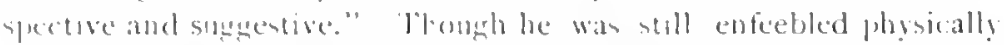
from the effects af a severe illuess, from which he suffered in 1879. there was an pereprible alstement of mental vigor to be olsersed. mor

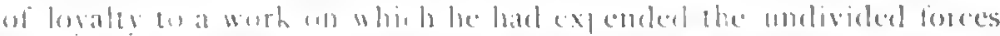

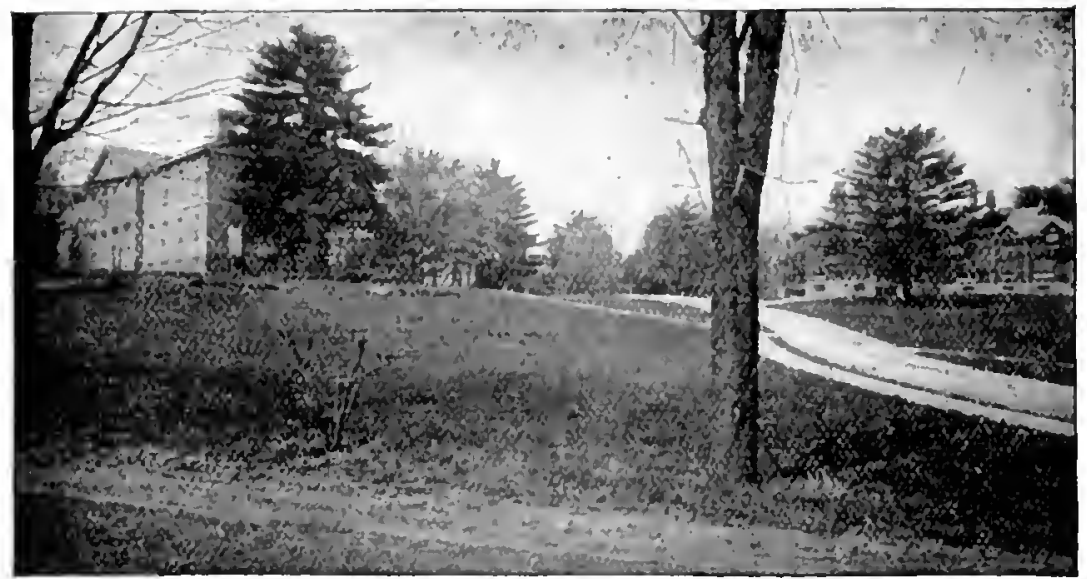

The Mary Shicdds Wards-The Villa.

al his entire life. In chosing this, which proved whe the last of a long neries of reports, Dr. Kiskliricle uned the following language:

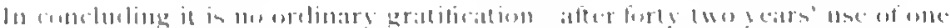

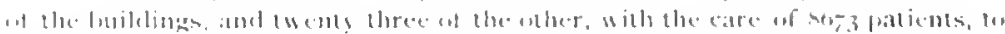

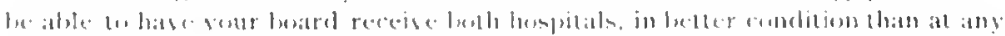

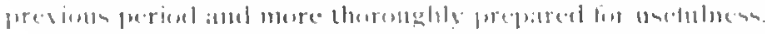

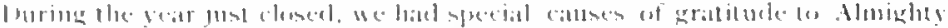

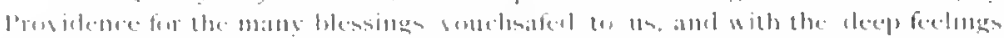

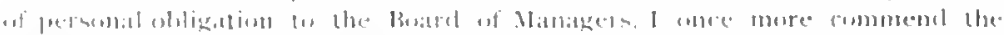

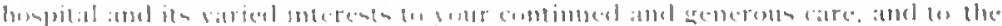

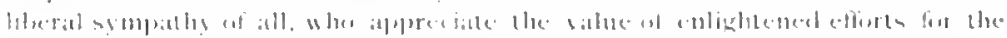
reliel of alle ring loumanits

1)r. Kirkbrite died on the woh of lecember, iss. A brief biographical sketrly of lor. Kirhbricte will appear. separately, at the rowe of thin sertions. 


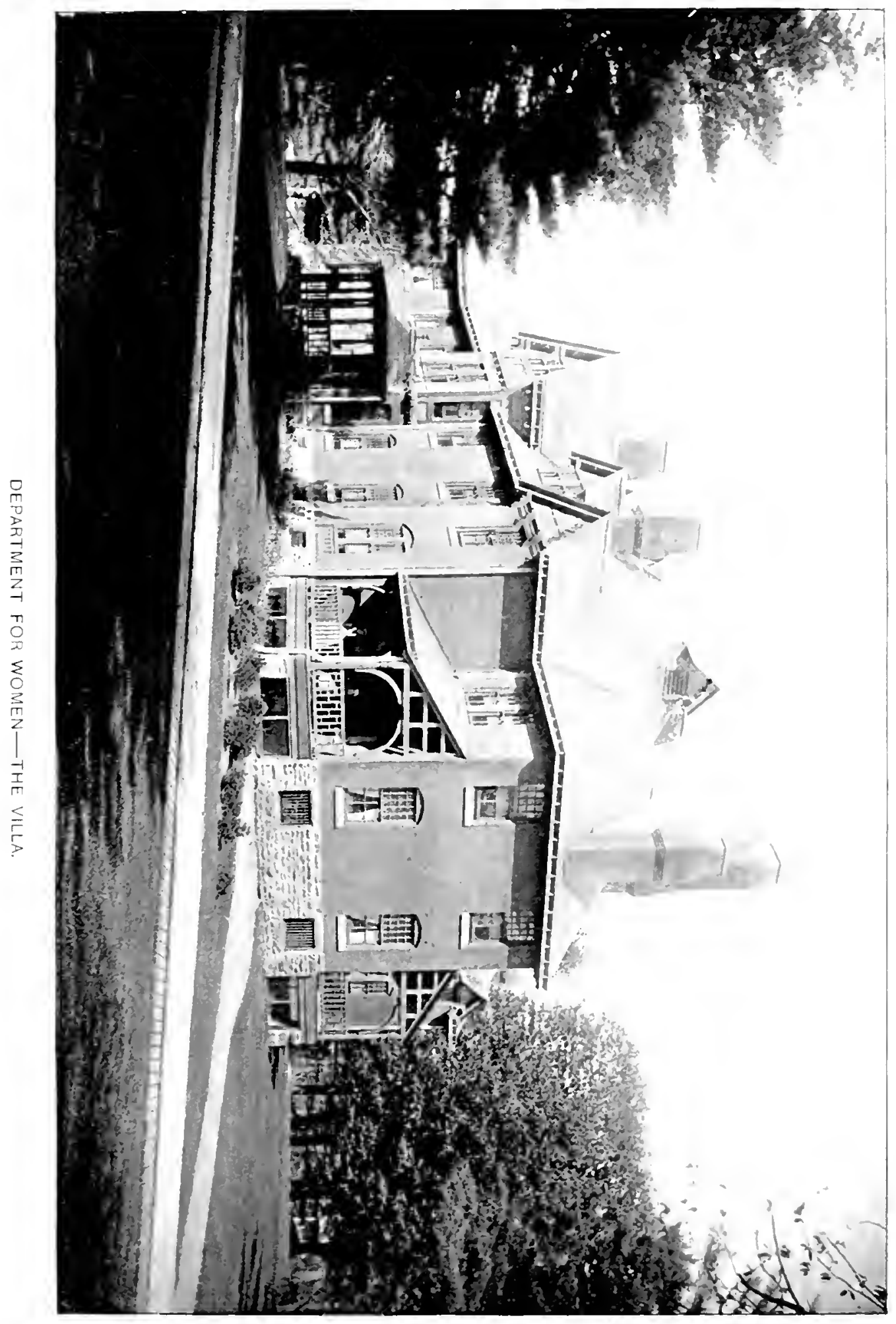



The vacancy in the office of Physician-in-Chief and superintendent was filled ly the election of Dr. John B. Chapin. Medical -iperintendent of the State Hospital at Willard, New York, who commenced his service Sejtember 1 , 1894 . There was much doubt in the minds of the Managers as to whether the interests of the Honpitals would be best served by dividing the departments into two distinct and separate administrations with independent rhiefs and staffs of officers, or whether one general scientific and administrative head would not produce greater work and economy with enlarged fields of usefulness. The opinions of the most eminent alienists were carefully sought and considered; many institutions visited by special committees of the board, after which the conclusion was reached that the continuance of the separate departments under one head gave reasonalle promise of continued usefulness.

For -everal years following 1856 there had been oberwed to be a gradual decline in the mumber of patients admitted. and the whole number annually treated, although the daily average dicl not materially change. This experience did not arise from any decreane in the number of persons hecoming insane. but the opening of new hospitals created ly the State, at Corristown and 11 arren, and the addition made to the Western Pennoylrania and Danville Hospitals, doubtles. furnished accommudation for many patients who otherwise would have been lirought to the I'ennstrania Hospital. At the opening of the Department for the Insane, in $18+1$, the hospital accommodation in this state consisted of that furnished hy this Hospital and the Friends' Asylum, amounting to about 275 beds. At the present time the other hospitals of l'ennsylwania accommodate altugether over 7000 patients. The rapid accession to the whole huspital population was largely due to the state policy during recent years, which enconraged the transfer of the insane poor from almshouves to State care in State hospitals.

In all movements for promoting the better care of the insane in the Commonwealth, the Contributors, the Managers and officers of this Hospital have been deeply interested. They have by jersonal service: by encouraging a sentiment fasorable to the recognition of the claim of the insane: br seeting to educate the public mind through the medium of annual reports; and by the exhilition of the results to be olstained from the liberal administration of a well-conducted hospital, which has been a constant object-lessun. contributed largely to bringing alout a better -tate of public sentiment "n the sulpiect of l Iospitali for losane. 
On the first of November, 1885 , the Manaters exfended the

1 Mut lintient

degrartinent

Fitemeleat

11. Ireitlmeglt

int Interient

Me*nlal

dingerine. operations of the out-patient department of the line street lloppital si) as (1) provicle a dispensary service for the gratuitous treatment of fernous suffering with incipient mental dinease. This medical attendance is griven by the physicians of the depurtments for the insanse in rotation. The serviece was regarded at the time as experimental, wn! so far, that it was not certain that patients would attend. 'Thw coisk only be determined by ar tual trial. It was undertaken under a conviction that in a city of one million inhabitants, a large number were suffering from premonitory symptom of insanity. as nervous prontration and depression, who might receive timely advice and treatment. and that a further development of mental disurder might thu be arrested. The strain and worry incident work in shops and fattories and moles of living in a city, are often followed by plysical deterior atien and a foundation is laid for nerrous and mental disorder. The relations of the twe conditions are not al ways intefligently appreciated and the hope was entertained that persons would avail themelves in the opportmity of receiving treatment. It is the experiesuce of alt honplats to receive patients every year who have drifted into a state of acute anental diwerder from neglert or jonorane of plain warningwhich should have beco heceled. Sotwithstanding the existence in this departusent has been extensively published, the altendance hav not been as great as might have been antic ipated. The whole number of persom who have been treated is two hundred and fifte. While come have not been of the class for whom the department wat intended. a large number have hees restured to ilueir usual health. or relieved. It is contidently believed that if the existence of thi dispensary were more gencrally known, its usefulness would be much enlarged. This department, segarded as a useful and important work (1) be done for the poor, cannot be regarded now as entirely an expers. mental froject, but it is set uncertain whether the friend of the persons for whom it is intended will be disposed to take advantage of it.

It had leen the practice of the bepartment for the Insane for

fincultin: (i) niter) lugint. man! years to ask, in luhall of rertain patients whowere women, the merlical commel of one of their own sex. In 1886 , the Managers established " the office of onsulting gancecologint, to be connected with the deratment for the insane. to be filled ly the appointment of

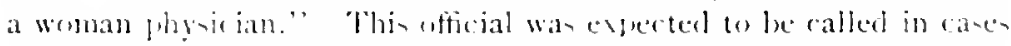
where it reemed her sperial synecologion knowledge might. Wuh great propriets, le an advantage to the patient, amel an important and

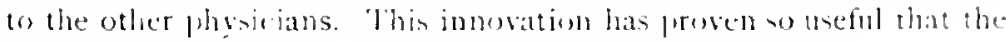
effice in mow a furmaneme ane 
For the better protection and observation of patients during the night, several of the wards have been placed in clarge of special attendants. This duty is repuired in arddition to that rendered ly the regular attendants and the watchmen and watchwomen. who patrol the wards at night. There are always a number of sick and feeble persons, also patients who are disposed to suicidal attempts, who need for their care and protection more or less constant attention at night. 'The practice was also begun of congregating suicidal patients in the wards where this special night service was maintained. The danger of self-inflicted injuries has been considered by this precaution to be reduced to a minimum-but one suicide having occurred in the department for women in fourteen years, and but one in the department for men during seven years, notwithstanding the fact that during these periods many patients known to have suicidal impulses have been constantly under care.

The sulject of imploving the standard of care of patients has constantly received attention. Classes composed of attendants were organized in $\mathbf{8} 886$, who received oral instruction as to the nature of the various diseases treated and their duties to patients. (iood, natural qualities of heart and fair intelligence, combined with a willing, teachable, sympathetic disposition, will usually furnish the lest promise of an acceptable service. Nuch of the instruction of attendants has been, and must continue to be, imparted to them in their daily services in the wards, yet they have been still further trained for the performance of their duties and the standard of care generally elevated by such instruction in the class-room.

In the summer of 1887 , a cottage-house, or villa, on the plateau ninet $y$ yards east of the main building for the women, was built, to meet a demand that was supposed to exist for a more liberal accommodation, for a limited number of patients, than the Hospital building furnished. Occasional inguiry was made for better accommodation, comprising several rooms, in order that those seeking a hospital, shonld le furnished with comforts and furnishings to which they were accustomed, which they might still have the calacity to enjoy, and for which they were able and willing to pay. In another sense this homelike structure was supposed to represent a tendency toward individualization in the hospital care of the insane, which seemed now to be practicable to a greater degree than at any former period. 'This house was opened formally June 16,1888 . It possesses the advantager Al[end]11]lis ("alle al l'otivent iinporitel. of reasonable provimity to the main hospital and the fuiet and retirement of a private homse. from which it does not materially differ in its external appearance and interior arrangenents. 
The cree turn of the cottage Hense, or Villa. for a clase of pattents He l'emu for whose care a proportionately larger rate was charged, was by the Wh.um, cits of lobladelphia made the hasis of a municipal clam for water Henpit.1 supply, which renlted in a decision ly the supreme conrt of the State e.t fintels Inum that."The l'ennsylvania llospital is a purely public charity in the "h.um highest sense of the term." The citation of the case is as follows:

The court held that " this was a municipal claim for a water gitpe filed anganst a portion of the premises of the Went Philadelphia branch of the lemsylsania Hoypitat. Ihis partirular branch is devoted to the care of the insane. Whule it was conceded that the

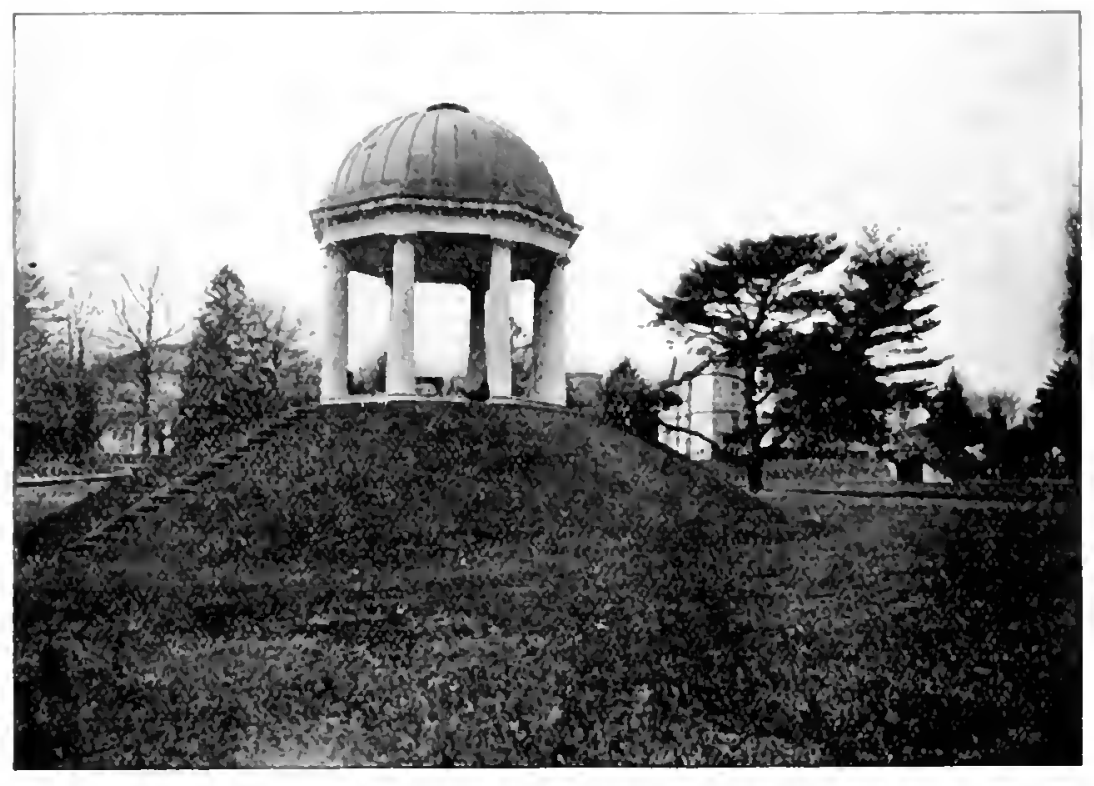

Doric Summer llouse.

building and grounds are exempt from taxation for the reason that the defendant is a purely public charity, yet it was contended that within the portion of the grounds charged with this claim there was a large building reserved exclusively for the use of patients payng a higher rate than any other; that these parments must exced the cost of maintenance assignable to themselves, if the original cost of the property and any estimated rental be excluded. It appears to be con cerled that the object of the trustee in mantaining this department of the in-titution in to make profit. W the we of which to extend the 
Institution's capacity for good among the destitute members of the community.

"It was not contended, nor is there anything to show, that there was any actual profit realized in this department after taking into consideration the value of the ground and improvements, and the costs of the maintenance. The apparent profit is applied to the general objects of charity, and no portion of it inures to the lenefit of any person concerned in administering the charity.

"The Pennsylvania Hospital is a purely public charity in the highest and best sense of the term, and under all our authorities we think it is exempt from the species of taxation attempted to be imposed in this case. Judgment affirmed."

The Supreme Court very clearly stated the facts that all the income of the Penns lvania Hospital is expended in charitable work,

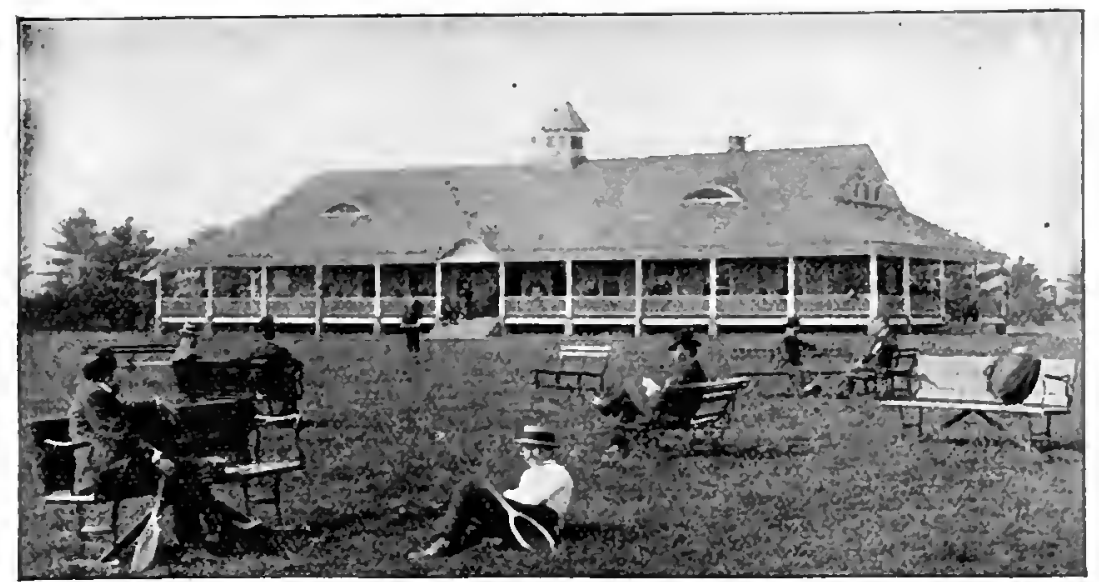

Gymnastıc Pavilion.

and it cannot be regarded as a muney-making institution, for an! excess over maintenance which is paid by rich patients is used to support others who are destitute of means to make any pecuniary acknowledgment.

The prescribed term of service of the Resident Phrsicians in the Department for the sick and Injured (P'ine Street Hospital), for some years prior to the year $188 \$$, had been fixed at sixteen months. During this year the Managers cleemed it expedient to enlarge the usefulness of the institution by extending the valuable opportunitic for obtaining a knowledge of insanity at the Department for Insance to each newly elected Resident Physician. The term of the Resident

supreme cinuredeciden in tawor of the Itumpital. 
Physutall was evended so as en inchuele four monthe service at the bejartment for Jnsane. L'neler this arrangement it was betieved they would have an opportunity to ulserve the various forms of imanity, the treatment of the insane, the administration of the bospital, and to become generally letter yualified to discharge their duties ats physicians anch citifens.

The year s syo wan marked by the completion of a gymnastic

(.) $11311.1 \times(1)$ Hollitus lil

Male

1) teiththent (in) lubdung on the grounds of the l)epartment for .Men, and the opening uf a new entrance and apjoach to the trepartment for Women. The gymmastic pavilion was designed to entarge the means of diversion, to break the monotony of life in the wards, and to fromote the phistal traming of mate patients. It was believed that being detacher from the main lubleling, there wombl be an increased

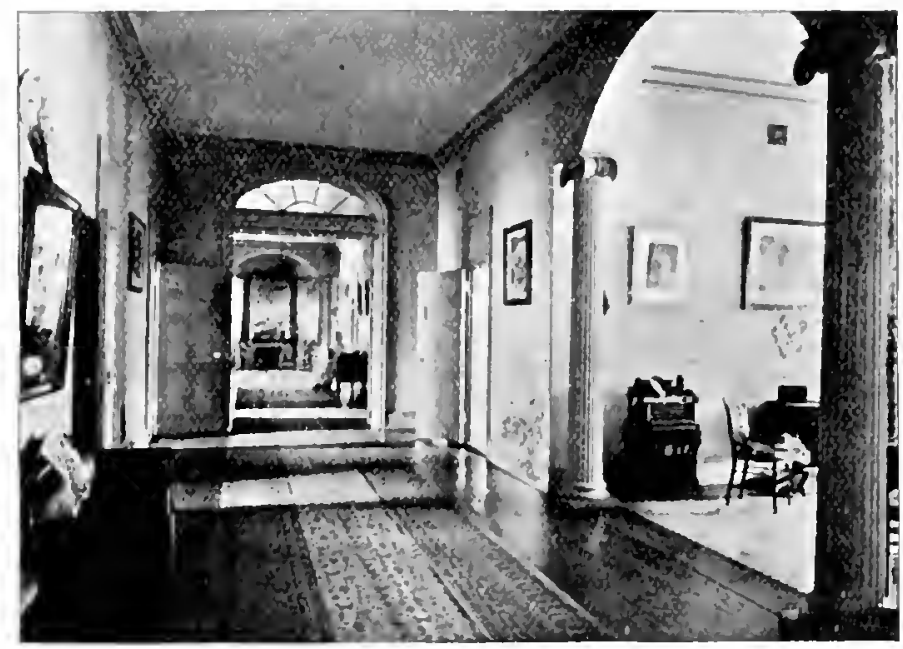

Hatl in the liemule 1).partment.

inducement to leave the ward and their asticiations for a time. It overlonks a well-kept lawn, prepared for out-of-door games. The building is of wood. one hundred and five feet long and forty two fect 1 ide. It is surrounded by a sheltered veranda, twelve feet wide. It contains a reading-room, billiard-room, a bowling-alley, a sitting-

Xin remm and a room for eymnastic exercises. The buildings and grounds Embance are muler the direction of a competent instructor who conducts the

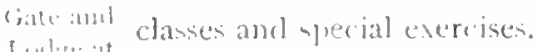

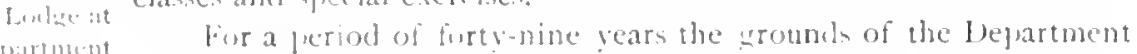

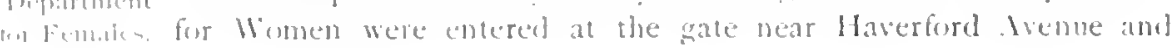


Forty-fourth Street. During the year 1800 , a new entrance gate and lodge were erected at the junction of Market and Forty-fourth Streets and Powetton Avenue. The change seemed desirable to rencler the Hospital more accessible to lines of travel and centres of population. This great improvement was rendered possible by the gift of a benevolent friend. (See illustration page i 3 $_{3}$.)

During the year 1889 , sixty-one lectures were delivered to Lentures lis attendants by the assistant physicians and seventy-four lectures on Botany and Natural llistory to classes of patients, taking for this purpose a morning hour. This work was undertaken by the physicians in addition to their usual ward work and the regular evening

Assintint I'lusiciants to Atteritints ind l'aticuts.

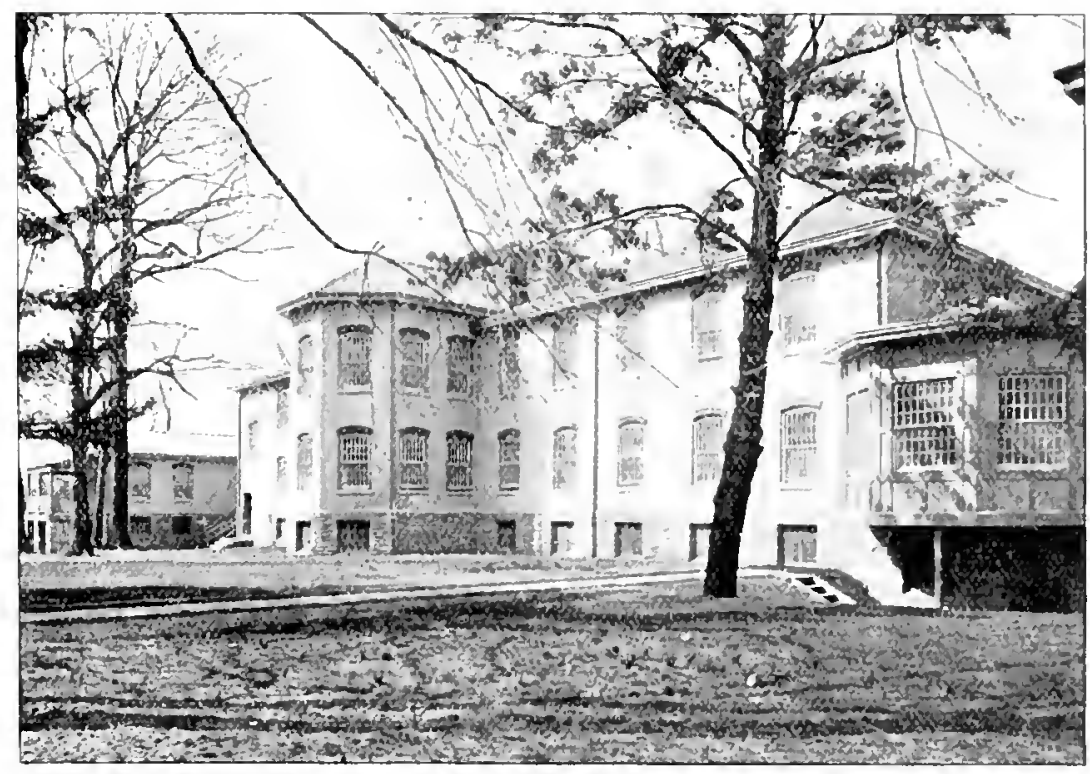

The 1. V. Williamson Building.

entertainments. It is mentioned specially, as it exceeded what had been previously done in this direction.

In the anmual reports for $\mathrm{s} \$ 90$, it was stated that during the preceding three years the lepartment for Women had leen fully occupied, so that any arcession to the number would have heen mpracticable, or attended with inconvenience. This condition continued for the succeeding year. As the daily average numler of patients seemed to be maintained withont a pronpect of speedy diminution, the Managers were confronted with the problem of over-

Thlo. l) pilltutent lim remales |11) y arempicel 


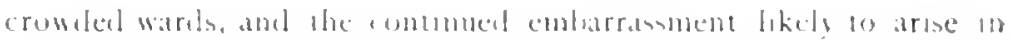
the classification of paliente and medical administration. I hospital

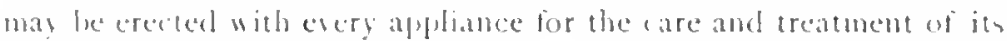
alletted number, but its operation ats a medical institution may !xe cflectually paralsad by overorowding, with the risks and discomblonts that maty altend such a condition. It wats wiscly resolved to endarece

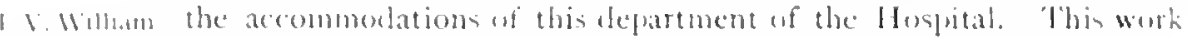

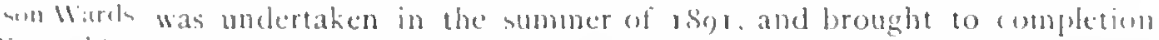

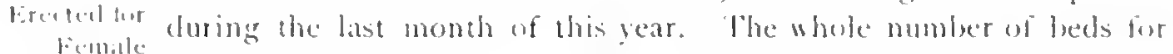

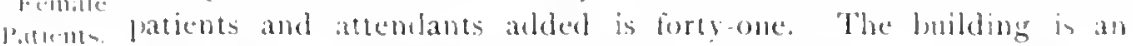
evencion of the North wing of the original structure. The'se wards

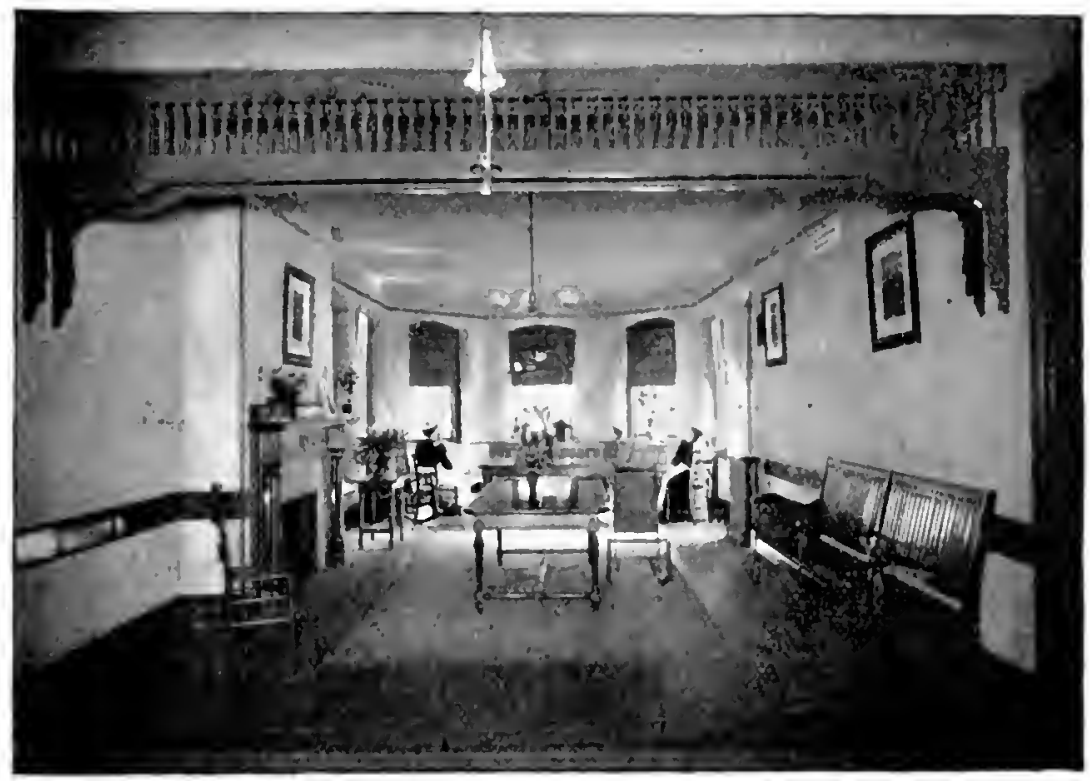

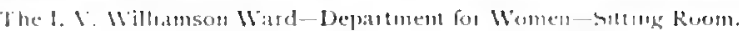

bave been named the "1. V. Wiblianson Wards." in perpetual remembrance of one of the eminent lenchactors of the Hospital.

In 1.891 , the Namagers made a concession of a strip of land fiith if extending from Narket Street to llaverford Avenue, so fect wide. to waty, the city, on condition that a sewer shond be constructed withous minduremed cost to the Hospital, atlong the course of Mill Creck, to connect at (n) both points with sewers already frepared. 'I'his construction divides the 11.3 acres of the Hospital property into two nearly crpual parts nif upwards of fifty acren each. 
In 1889 , the Nanagers actuired possession of a tract of land in Delaware County, which it was thought might in the future be desirable for the purposes of the Hospital.

At a Contributors' meeting, Mlay 3 . 1886 , it was resolved: That the Board of Managers le authorized, whenever in their judgment it may be expedient, to purchase such area of land, within a reasonable distance from the city, not exceeding 500 acres, in order to prepare a site for such future adjuncts or additions to their Hospital as ma! hereafter be required or found desirable.

A committee was appointed, on June 7, I $\$ 86$, with power to carry out the purposes of the resolution, who duly reported the making of contracts to purchase several farms at Newtown Syare, Delaware County. This purchase secures for the future all the elements of space, pure atmosphere, elevation and convenience of access, which may be required for enlargement of the department, corresponding to the increasing demands upon its resources.

May 4, ISgr, "during the year, the Ty"son farm, containing $53 \cdot 4$ acres, was added to the Delaware County Estate, making the whole acreage about $607.9+$ acres, and enabling us to control all the water courses which have their origin in and flow through our territory: the deed was made and confirmed by Court, the negotiations being conducted by our late I'resident, at a cost of $\$ 10,800$. These farm, are made available for milk and produce supplies of the Hosjutal in West Philadelphia, furnishing 500 quarts and upwards daily."

It was considered practicable and desirable to prepare one of the farm-houses on the premises for the accommodation of a small family of patients, who were in a stage of convalescence, and for thuse who wuuld alpreciate a change from hospital existence to the freedom of the cum try and family life. The colony was changed from time to time. In addition, a carriage conveyed several patients daily to the farm as the weather permitted, who spent the day there, returning at the close of the day. The number who also had the opjortunity of spending a week or more at the farm and have had the ride to and from the farm, has ranged from two hundred to two hundred and fifty, during the season of three or four months of each year the house has been occupied. It has thus been shown that with moderate preparations, a large number of patients have had the benefit and enjoyment of a change from the city to the country; that in a large number of canter a decided change toward recovery commenced and continued: ancl that the farm-house at Newtown square has made a contribution w experience, which must have weight whenever plans for a new hospital come up for consideration. 


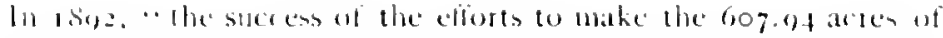
our belawate county farms avilable by offering the enjoyment of rural life to the comsalesent patients, has leat to the designing uf a

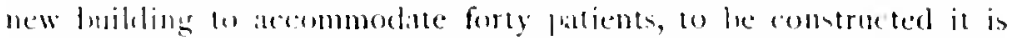
hoped in the near huture. It will le ror feed long, $37^{-1}$. feet wide.

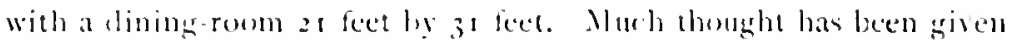
to the sharacer of this new ediffe. Imhth in relation to it internat accommodation and its future relation wadditunal structures. The

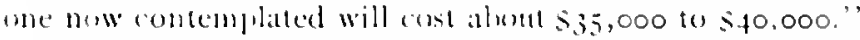

kenthen keriewing the work in the bepartment for the luane, since the

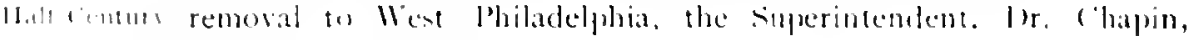
stums if ul an folluws:

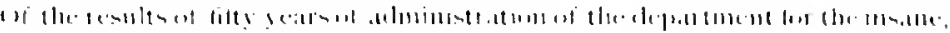

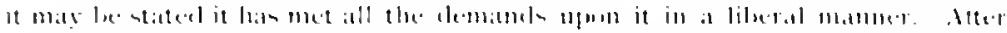

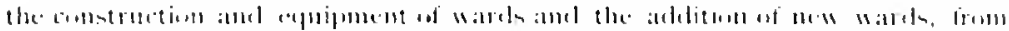

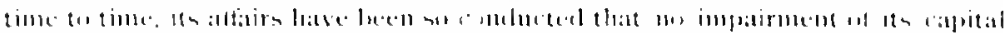

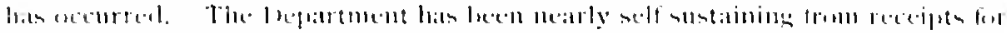

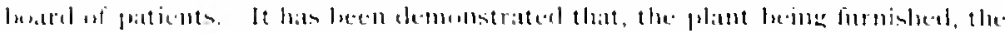

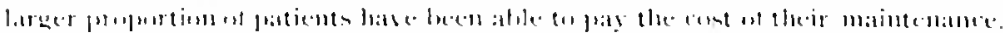

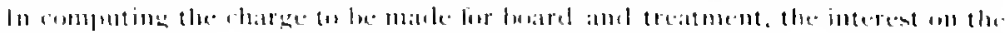

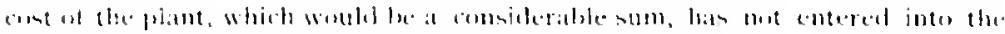

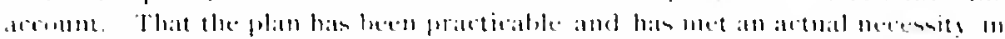

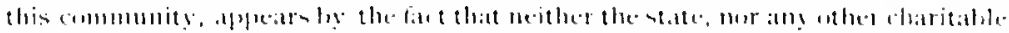

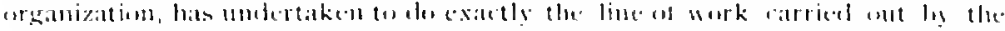

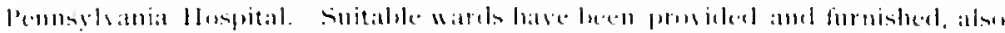

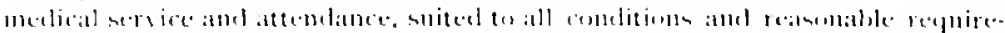

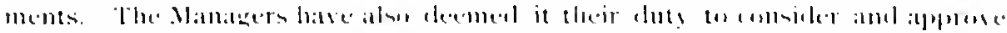

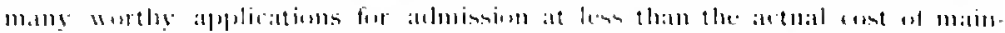

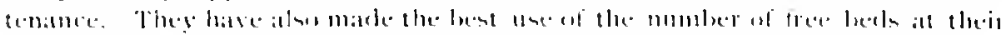
(1).jman.

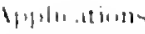

loir kieliet intumence to livent the

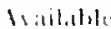

$11: 111 \%$

1).เ111!11,111,

i.) lopratst

nite-lit lint

liln, III)

le prentelent

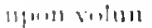

t.115:aitt ind hinguente

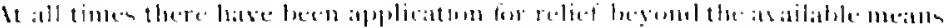

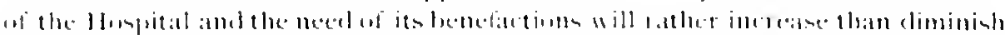

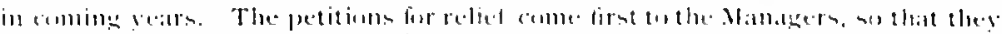

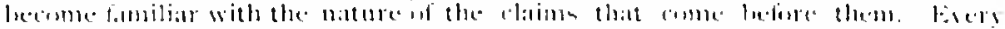

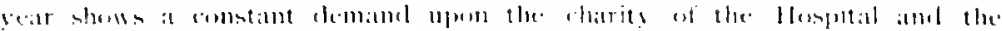

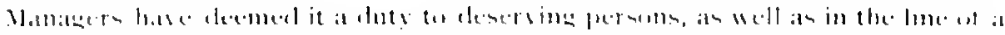

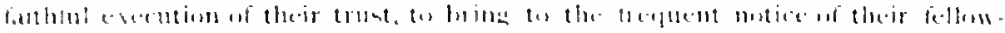

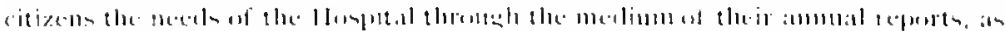

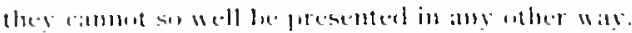

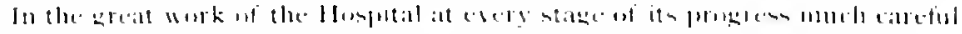

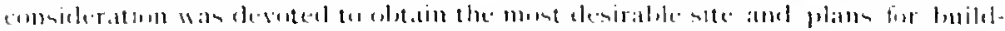

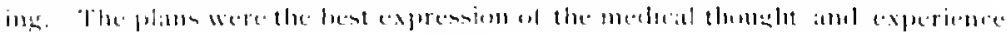

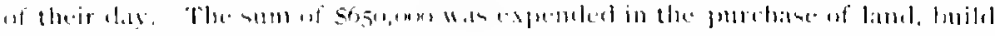

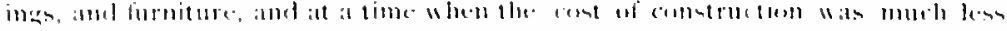

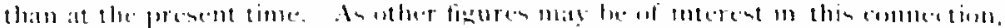

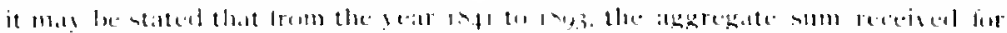

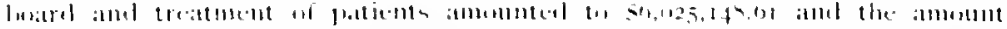

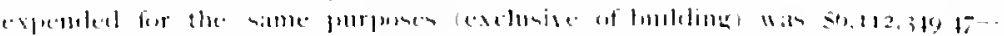

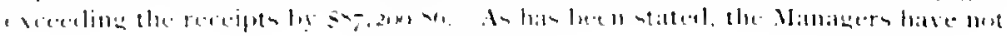




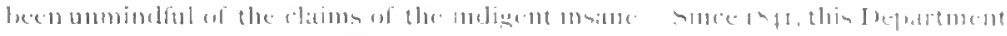

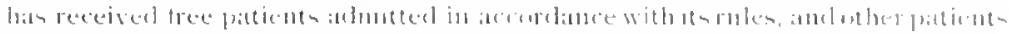

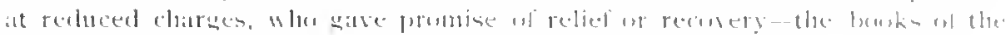

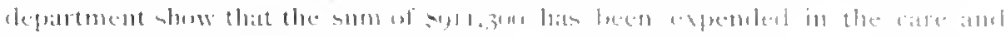
treatement of these clitsures.

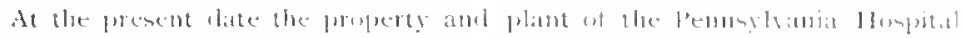

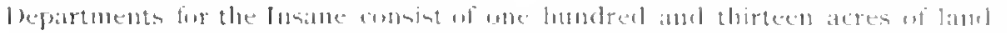

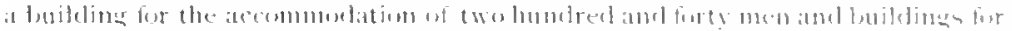

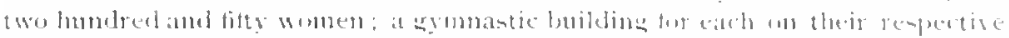

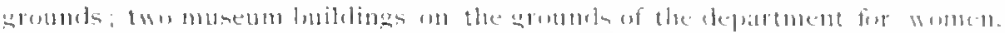

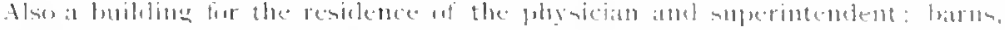

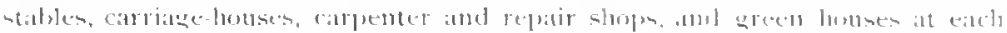

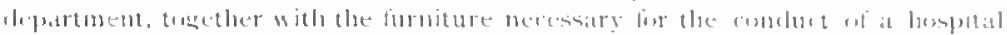
if the first class.

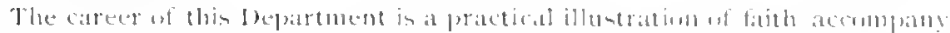

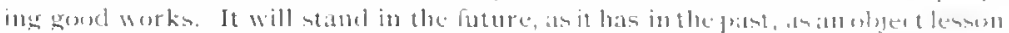

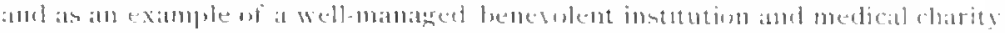

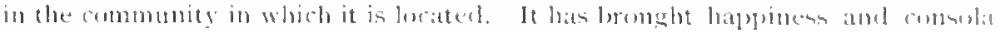

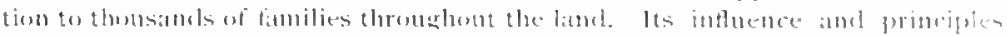

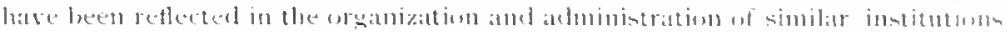

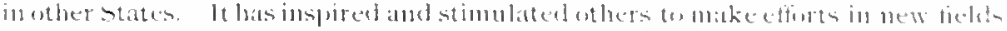

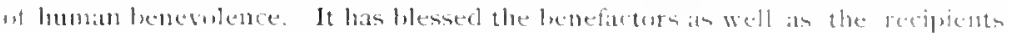

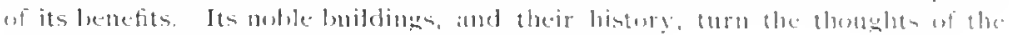

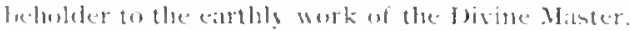

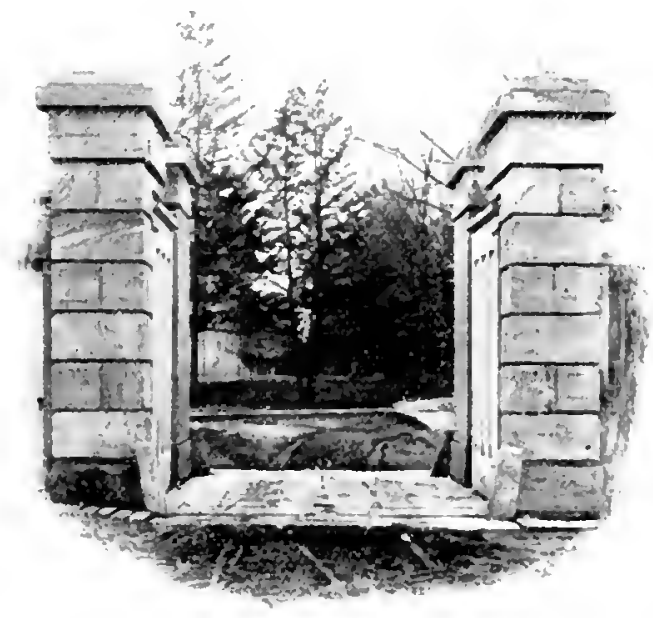


THOM.SS STORY KHRKBRIIH. M.11.. I.I.I).

\section{IN .MF.MORIA.H.}

Thomas story Kirkbricle was born near Morrisville, Bucks Comnt, Pemmetrania, at the paternal bome on the bank of the l)elaware, on the int of fuly, son. Ilis ancentors. like bimself, were members of the sucicty of liends and hoth hanches of his family were among the first settlers of l'ennsylvania. Who a ame to this country with Williamlenn. Il is father's ancestors were from the parish of Kirkbride, in the comnty of Comberland, lingland. On setting in America, the touk 10 land in the lower part of lincks county, much of which remained in the poseswion of their descentants until 1867 . His father, fohn Kirklude, huilt. before hin marriage, the houne in which he lived until his death, in 180.4 . Hin mother was lidizaleeth, daughter

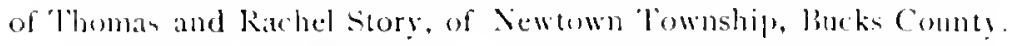

Viter atterding schools in the neighborhoud of bis home. he spent four exar an a noted clansical school in lienton, $\mathrm{X}$. I., and afterwarels devoted a vear to the sperial study of the hisher mathematies at lizelington. N. I. 'The following year was yent on his father's farm in practical pursuits which he felt in later years whabe heen of permanent advantage to his health. Wt the clone of these agrienlanral months. he rearl medicine with 1)r. Nicholas de lielleville, of 'Trenton, a dintingusbed physician and surgeon. who cane from france with the forces under l,afayetle in the American Revolution.

In $18,32,1$ )r. Kirkloride graduated in medicine at the University of lennsyliania and was immediately appointed Resident l'bycician of the lriends' Asylun for the lnsane at frankford, remaining there until his ciection an Resident of the l'enusydania llospital. While at the liriends' Is lum, he was artive in everything relating to the care of the patients and the managenent of the lnatution, and on leaving he received a flattering testimonial from the lioard of Managers and privately fom individual members a confidential request to return and take charge of the Institution.

He then spent wo years at the l'ennylania Hoppital. Wuring the second year, bis colleague was l,r. William W. Cierhard. 


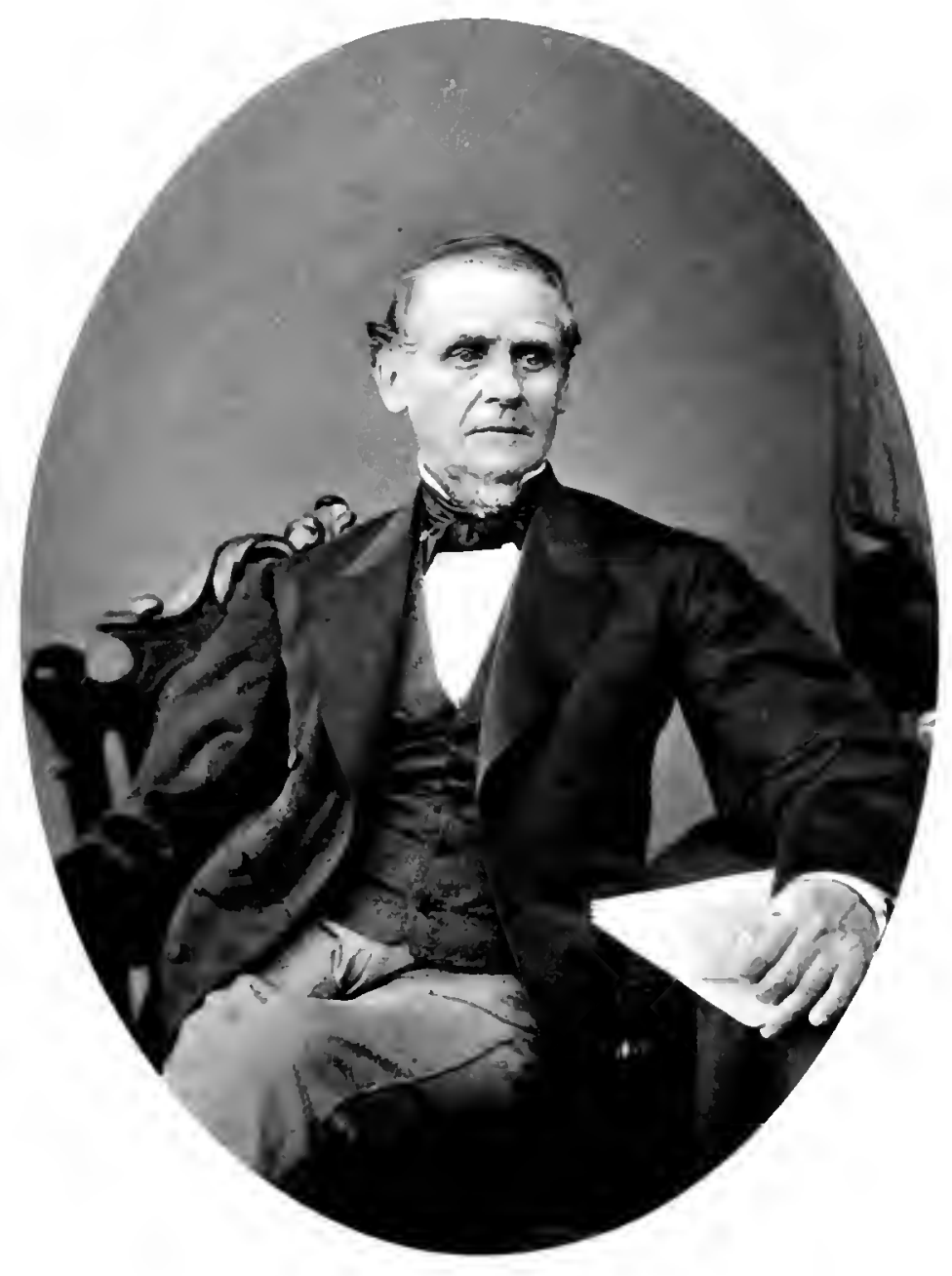



Buth Residents were diligent in the careful examination and noting of and cases under treatment: their ubservations, which were pullished separately, were among the early Hospital reports issued in this country.

In 1835 Dr. Kirkbride hegan greneral practice in l'hiladelphia. In I 839 he married Ann West, danghter of Joseph R. Jenks, a wellknown merchant and a Manager of the Hospital. She died in 1862 , leaving a daughter and a son. In 1866 he married Eliza, daughter of Benjamin F. Butler, of New York, Attorney-General uncler l'residents Jackson and Van Buren, who with four children survives him.

Ir. Kirkbride was a constant visitor at the Hospital, keeping up, his intimacy with the Medical Staff there engaged. The resignation of his friend, l)r. John Rhea Barton, led him to anticipate an appointment as his successor as Surgeon to the Hospital in the autumn of I 840 . One summer morning, when walking in Race street, he met his friend John Panl. an active member of the lioard of Managers, who. to his entire surprise, asked what would induce him to relinquish his long cherished plans and accept instead the office of Physician-in-Chiet and Superintendent of the new Department for the Insane.

It was a matter for very serious consideration. His profensional friends regarded the change as ill-advised, indeed almost without justification. On the other hand, in the opportunity of starting a new institution, of developing new forms of management, and, in fact of giving a new character to the care of the insane, Dr. Kirkloride finally: saw inducement to forego his prospects of distinction as a surgeon. Without any solicitation, or even application, on his part, he was elected Octover $12,1 \$_{40}$, to the post which he occupied until his death.

After visiting institutions for the insane to the north and east of Philadel,hia, he moved the following lecember, with his family, to the old mansion house within the Hospital grounds.

From this time l)r. Kirkbride's ability and varied gifts were consecrated to the insane. His energy and enthusiasm never Hagged and his duties kept him always at his pest. His forty-two Annual Hoyptal Reports give the record of his life. They are at once the history of the institution and the story of his own untiring service. Sio completely indeed is his career identified with the medical care and cure of the insane in hospital, that some knowledge of this subject is necessary. for any true conception of his character and work. He represents a great idea, which he found worthy of life-long devotion. Eyes trained by knowledge to see his own ideal and to descry the Hospital of the future as it stood before his vision, can alone fully perceive the value, or 
the meaning of his lalwers. Ilivearlicht reports are peculiarly interesting in charideterstudies. Written shortly after he had entered the sperialey. the reveal marvelous maturity of thought and form graspl of the latest principlen in the care of the insane, while the emtire serien of Repurts form a valuable treatise on insanity and the relations of the commonity to the insame.

Ir. Kirkhricle was ane of the "original thirteen" physicians,

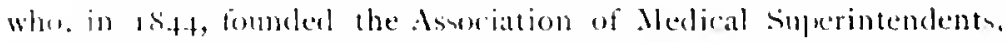

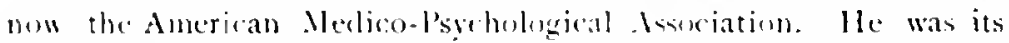
firet secretary. serving even vears: its Vice-l'recielent, for seven year. and its President from 1862 to $18 ; 0$. He thok the greatest interent in its procecelings. and was rarely alnent from the metings.

The interests of the lemsilvania Hospital in its great work of caring for the sick and injured, lay next in his heart to the proserity of the lepartment for the Insane. Ilis puwer of winning friendship, was great and his relations to the lioard of Mamagers were always characterian ly unbroken confieleme and motual regard, which ripened in momerous instances into warmest intimacy. Ile ensured their w-operation ly strict conscientiousness and unceasing habor.

In $1.55 .$, after passing through a period of ill-health, hut not of cenatum from active dety he felt that his " term of service had heen nearly at protracted as can be repluired of one individual," lut he worked on with the same artor thirty years longer-and this with a physifue filr from rolust.

Within the wards he found his thief delight in the exercise of that lenign puwer over the insane in which he was unrialled. 'To know hum thoroughlyone needed to see him surrouncled by those to whom his life was devoted. Dignity, tempered hy gentleness, invariable courtesy, tenderest sympathy and tact marked all his intercourse with his paticnts. Ilis "tramplit grace of tone and look" and mamer, his womelerful fatience and his genial disposition lorought healing influches, which were strengthened by the resolute firmness. the unvielding perseverance and fortitude of his character. The sane and the insane recosnized within him a rare spiritual force.

In 1.54 . the warels were so wer-crowded that further admissions were neressarily refused. Ile then suggested the crection of a separate luileling. for males only, and publinbed an "Alpeal for the Insane," lesides writing many articles for the newspapers. He imparterl his own enthusian to oblers, and many citizens. including the whole lioard of Managers, threw themselves most heartily into the work.

For thirty years, although not always prominently before the fmblic, his coumel was constantly sought hy the medical societies and 
successive Jegislatures of Pennsylunia, in every movement relating to the rare of the insane.

His yearly Reports and his work on the Construction of Hospitals for the Insane are his principal writings, lout he frequently contributed essays, reviews, and noticen to the medical journals, and wrote frequently for the newspapers. esperially the old ". United States (razette" and "North American." Nemoirs of his valued friends, Dr. William Pepper, Sir. P'rofessor of Theory and Practice in the University of l'ennsylvania, and Hr. Isaac Ray, the author of the "Medical Jurisprudence of Insanity." were written by request of the College of Physirians.

1r. Kirkbride was a member of the College of lhysicians, the Philatelphia Comty Medical Society, the Franklin Institute, the Historical society of Pennsylvania, the American Plailosolnical society, and an honorary memler of the lritish Medico-I'sycholosical Association, etc, : he was for ten years a l'rustee of the State lunatic Asylum at Harrislurg. l'a. and for more than forty years a Manager of the Pennsylvania Institution for the Instruction of the Blind. In 1880 , Lafayette College, Pa., conferred on him the degree of LI. D.

In i880, after recovery from a severe illness of several months, he returned with renewed ardor to his accustomed work. Three years of active duty followed, during which, with less of physical strength, but if possible, with more energy of spirit than before, his presence was again the life and hope of the Hosp,ital and of his home.

In March, $188_{3}$, he was prostrated ly typhoid-pnemmonia. $\mathrm{Hi}$ illness lasted nine months. He died peacefully lecember ioth, in the serenty-fifth year of his age. The late Profestor S. 1). (irosi. in his Autobiography, thus dencribed Dr. Kirkbride's appearance:

-In personal appearance 1 r. Kirkluride was eminently attractive. He war of medium height, with a fine physique, a well-shaped head. and a countenance highly expressive of lenevolence and warmth of heart. His roice was sweet and gentle, and his presence and deneanor were such as to win at once the affection and confidence of his mont waylward patients."

One of his oldest assistants, Dr. John Curwen, wrote as follow:

"Lahoring with a single aim for the relief and welfare of those tu whose care he had deroted more than forty years of his life, he has left behind him, in what he has written and in what he has clone, a monument which will stand so long as the care of the insane will reguire the aid of those Institutions with which his name and hiv fame have been so closely connected." 


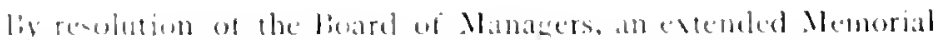

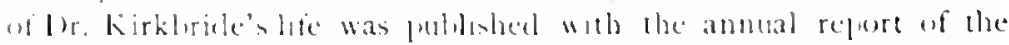
Hosplat to the contributor for the year 164.3 .

Al a secrial meeting of the linard of Manager of the llexpotal,

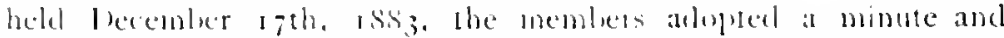
rewalutions expresive of their seme of the great loss they had sustuined and of their estimation of the value of his services they also directed that a talide le placed in the (entre thall of the lepartment for Wonen. learing the following inseription:

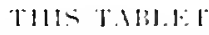

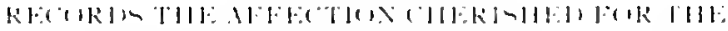

$111 \mathrm{NI} / \mathrm{k})(1 \mathrm{H}$

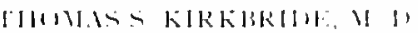

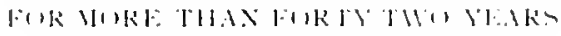

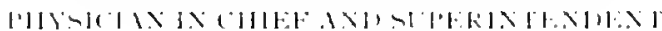
1,1: T115:

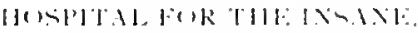

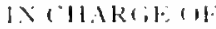

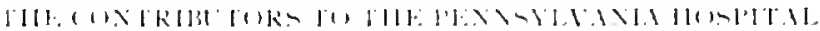

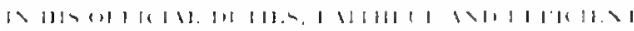

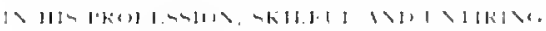

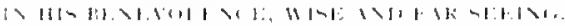

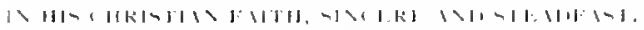

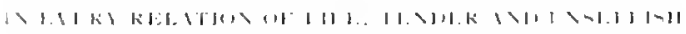
$111: 11: 13$

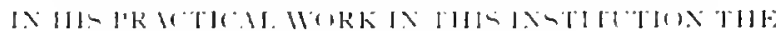

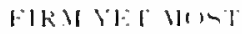

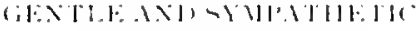

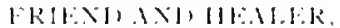
ixil

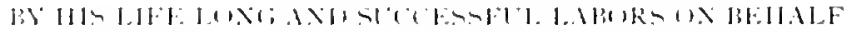
110 III: IX-1,1:

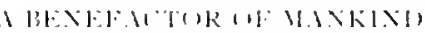
IIt: BII 1,

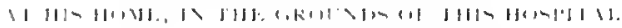
i1) 1111 .

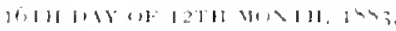

1) 1 ill.

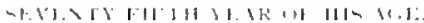




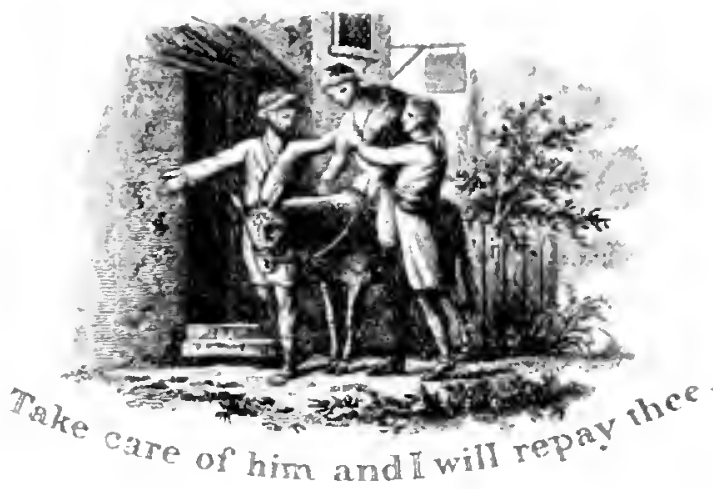

\section{PATIENTS.}

At the time when the Hospital was opened, the present customary distinctions between medical and surgical practice, and other special departments, were not generally observed, and jatients were attended indiscriminately, ly any memler of the Hospital staff who happened at the time to be on duty. Each member apparently was considered competent to treat all classes of cases that came into the institution, and in grave cases the entire staff was required to be summoned in consultation. It was the specialty of olstetrics which first was officially recognized in $\mathbf{s} \mathbf{S} \mathrm{O}$, when the Nanagers elected l)r. 'Thomas Chalkely James and designated him especially as "Jhysician to the lying-in Department." With this exception, the members of the medical staff, in the minutes referring to their appointments or resignations, are designated either as "physicians" or "physicians and surgeons" collectively, until the Managers at the meeting held Septemler 5, r $82 \mathrm{r}$, were led into making this distinction a permanent one in the institution, apparently, by the wording of the resignation of I)r. Joseph Hartshorne, daterl August 27:

Be pleased to accept the resignation of my whe as one of the surerents of

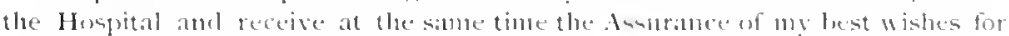
the prosperity of the lostitution and for the health and happiness af each indivilual of your boned.

Ordereel, that at the Stated .leeting in the foth month next, the Buard will

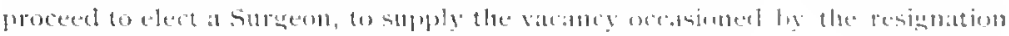
of Jr. Hartshornc:

Tlue Mtollicial Stittf allemeal all clissises of P'atients Indiseriminately.

Sperial pratctice lintrisluced. 
It the meeting in Oetoler. the followng aplears

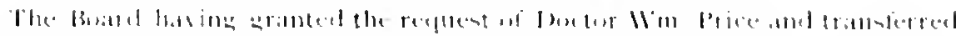

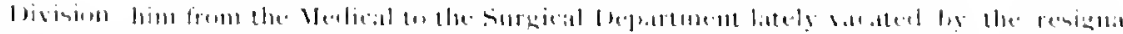

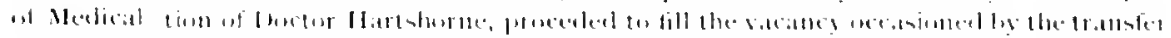

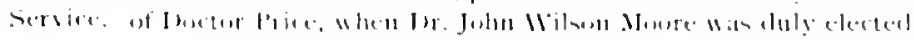

It aplear, from this minute that, in $1 \$ 21$, the stati had already male the distinction between phusicians and surgeum, and the Managers now officially recognized a surgical departument as existing, although no previous reference to surgery as a special branch of prartice accurs on the recurds.

When the anmual election of Physicims and surgeom was held. on May 12. 1\$23. the memlers of the stafi were officially divided. for the liret tinse in the history of the llospital. The results of the eleccion were entered upon the minues an follows:

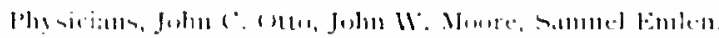

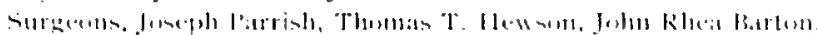

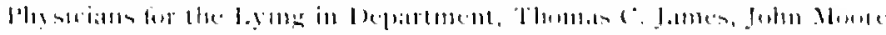

from this time forward the same system of classification has been followed. except, that when it was decided to finally clone the lying-in wards, in 1854 , physicians to this deparment ceased to be elected at the annual meetings. In 1852 , an additional physician and surgeon were added to the staff, making it consist of four physicians and four surgeous, which is the number at present composing the medical stafi of the bine street deparment.

In 8 to. Wr. Thomas S. Kirkbrike was elerted Nedical Superintendent of the Insane Department, thus recognizing another specialty in medical practice. Sulsequently, the Managers elected a comsulting

Spe.1.11

bepartsments of Mealie.t

Pritrice. staff, representing various specialties, in connection with the Insane Department. In the Out-latient Department, also, lae service is divided up among the recognized departments of sperial practice.

From the begimning of the lenevolent work of the Hospital, no invidions distinctions of race, nationality, or color among patients were cuserved or permittel. in fact in the matter of nativity nearly every country and people appears to be represented. No fuestions with regard to creed or religious belief were asked of those who sought assistance within its walls, the spirit of the institution being expresed ly the emilem of the Cond Samaritan upon its seal, who was willing ter find a neighlor in every one having need. Many interesting extracts might te made from the llospital records of rare and curiom ases of disease and injury, but for the the reader is referred to the "Reports of the l'ennsylvania Honpital," Vols. I and I) (puldished in 1868 and 1869 ), and " surgery in the lennsyluania 
Hosprital" (published in Isso), also to reports of clinical lectures published in the current medical journals. Many fuaint record of cases leelonging to a former era of the history of the Hospital apsuear uron the minutes of the Board of Managers, some of which ma! be found in a previous section.

Among the earliest patients were houschold servants. man! of kewnikn: whom were African slaves, belonging to citisens of I'hilarletphia. Farly lim The first to be entered was, "Aug. 6.1752, a negro of Robert Rawlinson's admitted at ten shillings jer week under the care of l r. 'Thos. Bund." The second on the minutes, however, was not of this rharacter. The entry was as follows: "Nhay 3. 1753. a puor free

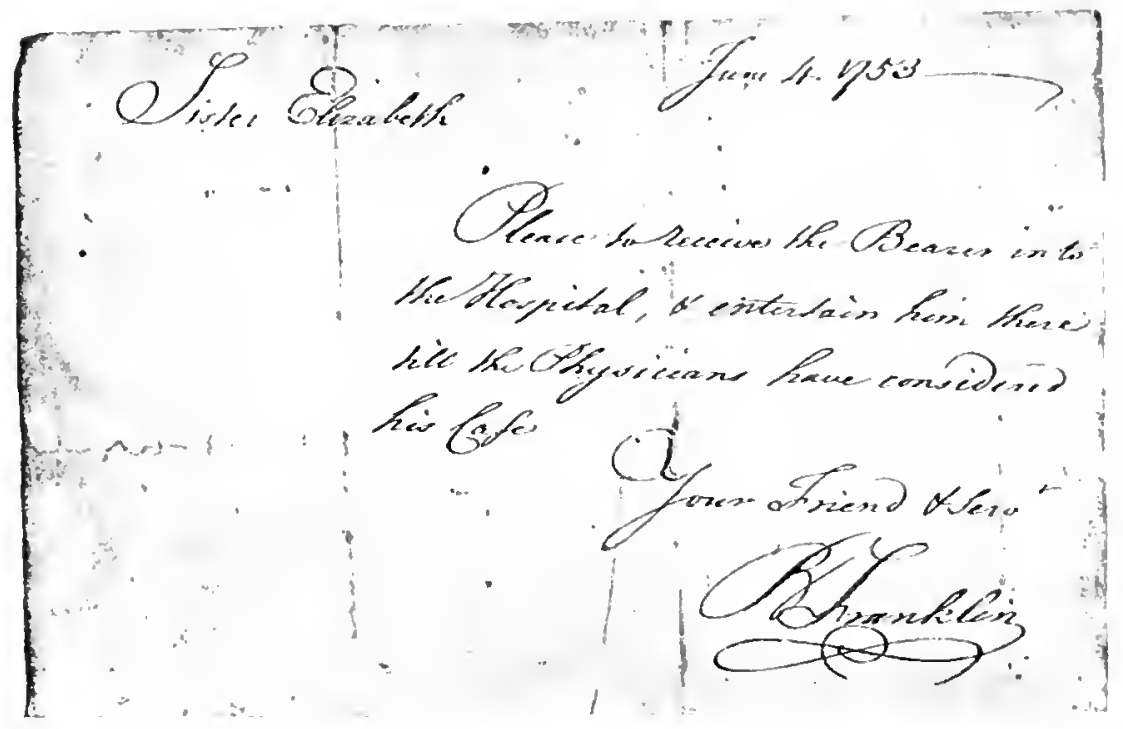

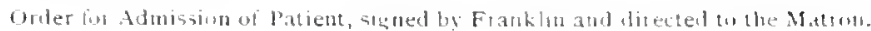

negro man named Sambo admitted as a charity jatient on application of buctor Shippen." May" rath, "A negro man lelongng to lenju. Sweet of New Cantle. named Mingo, was admitted at ros p. week. a private patient of Dr. 'Thos. Bond's, who engager for pryment. ctc." A curious discrimination, as it appears at the present day, was mate ayainst a common skin disease, in the following case: "On lan. 5 , 1754 , Conrad Ambruster, a poor man apyly'd for almission, luit leing examined by the boctors, wan not admitted, having the Itch." It appears that lepros! in those days wa considered more anemilile 
to treatment thun the itsh. for we read. "Nay 28, 1759. Ailmitted

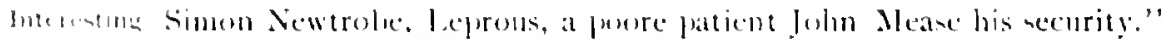
The present intem of convalencent hespitals focated in the

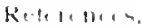
sulurb. or out in the country, wa forehatwed in the nest rane. which also slows that hygicuic remedies were not despised. Ally. $21 \mathrm{st}$, I5.t. "The lhyscians being of opinion that tiat-air and saltwater woulel he of steat service to kebert barrington, the matron was orelered to provite him some necessaries and samuel Rowland consented to take him to lewes."

the slimpes of historieal fact afforded be the next items give

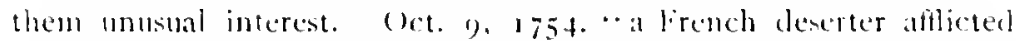

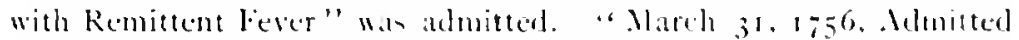
havid llowell, a proor latient from lerks County, having a cimblot wound and fratented bome in one $1 \mathrm{rm}$ done the 6 th inst. by the lonemy Indians, James lidelle of said county security:" Also. later, (1)t. 3. 1764. "Almittel Margaret Sinclair, a poor paticut, with Dininess in the llead having been much abused by the Indians." (1). $3^{\circ}, 1759, "$ Admitted Wm. Bourdeaux a por patient whe of the french Nentrals dangerously ill of the putrid fever." lieb. 25, 1760. "Almitted Michacl Butler, a poor l'atient, with foul Clecrs he cane lately ous of a French Prison, the present Managers hi-

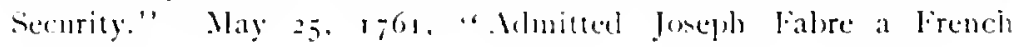
l'risoner."

latients, it appears, occasionally neglected to olserre the formality of a regular discharge. Thus. "Mlay 6. 1756, John Whourn, being cured, marched off on the 1 th instant, without being regularly dismisied," and "Iunc 28, 1765. Sarah scott kun awa! Cured." January 8, 1757, "Alsconded. William (Fraham Eloped sth inst. from the Hospital." Some of the diagnoses appear a linte.

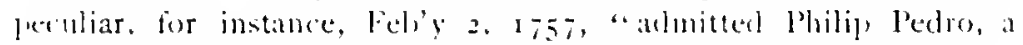
foor paticnt labouring under a lecuophlegmatic, at the reguent of lor. Kiaraley, scrior," he soon afterwarels "dyeel." March 2. 1757 , "Almitud Andrew Way, a poor loy with a Bloskly Excresence on his liack, Mary Wistar, his security." June 20, 176r, "l)yed,

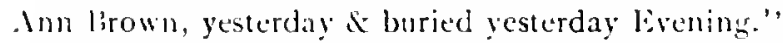

fome of the patients were polite enough to return thankis on leaving the Hospital, and the fact is thought of such importance (perhaps as establishing a precedent), that it is entered upon the minutes. The following is an illustration of this and also show that the Nanagers could he inpuisitive at times. "Jan. Is, 1758 . Dincharged Michacl Aspen as much relieved as the lir of the Hoppital would arlmit of: he returned thanks. \& is continned as an 
Out latient. X. B. His Master Jacol Mller afterwards apuearerl and acknowledged that Mirhael was his. Iyrentice. Guery, how came he admitted as poor \& without pry?" At the present day, the question might be asked, if this was a reflection upon the character of the "Air of the Hospital" or was the observation intended to apply" merely to the unsuitability of the patient to his surroundings?

The first time that the words " dollars" appears in the minutes is in connection with the admission of a patient January $26,176 \mathbf{r}$, "Elizabeth Bashfull a poor patient and an Asthma \& Rheumatim. paid the Steward + dollars for security."

On April 25 th, there was admitted "William leree a Soldier of the Royal American with an Hydrops Ascitis Siccus, or "Tympany," also on October 26, 1762. "Admitted a Negro boy of John Gilliland's with Guinea Worms in his feet." July 6th, "Adnitted Joseph Walker with a Scorbutic Habit a sinuous Lleer in his Thigh." his board is to be recovered if possible, from "Cajt. Ino. Mlorrison, who (as he says) has been the cause of his lliness by beating and other hard Treatment." 'The case' were primcipally acute diseanen and accidents. Chronic disease, however, was no bar to admission. The first case of phthisis was received lugust 3,1757 , as we learn from the following minute, "Admitted samuel steel (a poor patient) in a Consumption. Mrs. Franklin his Stcurity."

In 1758 . several poor Indlans were admitted, and the records state that one named Noses 'Titany died, Octoler zoth, of a "Tumor in his "Throat." I lec 26,1785 , there was. "Allmitted: liucksam a chineve." July 30,$1 ; 8 ;$, " Levi Hollingsworth, having been charged for the board of Gho Wassing one of the Chinese strangers now represents the hardhip thereof; an it was entirely thro' humanity he was induced to give such security which leing considered the Board unanimously agree to extinguish the debt."

The case of $1 \mathrm{Wm}$. Samuel should serve as a warning to all refractory fatients; he was (November 27,1758 ) discharged "for refusing to submit to the advice of the Physicians." Subsefuently. several other patients have had a similar experience.

The following is somewhat ambiguous: "March 31, 1760.Dincharg'd James Romage being too Ancient to hope sinccess from the Uperation he returned thanks." likewise. "June 30, 1760, Dyed Catharine McCormick Juried this day." Also, "May 28, 1764, Admitted Elizalueth Bryan with a Female Fever," On the same date, we learn of the admission of "Alexr. lreeze a poor sailor with the Rose Drop the Matron's Security," also of Leonard Baker a poor Patient having his lowels much Bruised:" also (ieorge 
(iillinger "with the diry (iripes." The following in a rare but not

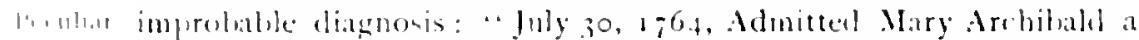

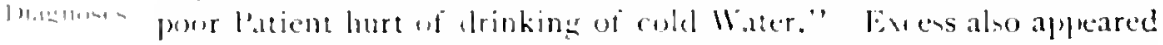

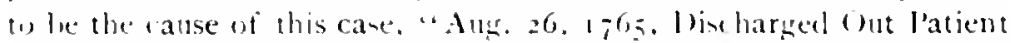
foln (iarnwood a mirleit ur stain;" lun the record is not explicit as (1) its exaut character. lantary $2 \$, 1-6 \$$, furnishes several items of interest, thun: "Peter forster cured went away $\alpha$ twok no leave." " Blwanl MeCormick Cros'd in love gave a nrte to pay when able." It would be eurious to trace the subsequent career of this fatient to find out if he was eventually cured of his mataly and if so

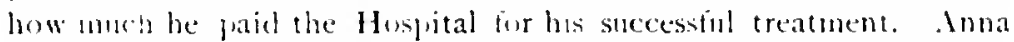
Goel hal "Histerick l'assions her soln John Goet her Security." 'The Managers' carefin guardianship, over the interests of the Hosjutal is reveated in numeroms instances thus. (March 26, 1;65): “ Richard lay admitted on pay his law Broke heing moly abused by Philip lienh wh is hound over by the Mayo on whose recommendation Day is reseived and it is expected he will (Mligge bush to pay the Charge." Oct. 3. 1;64. "Nameless a poor Patient much Wounded by persons unkmown in this city in the Night."

surgical operations were intended to be recorded in the operationbook and rarely fouml their way to the minutes, but the following was deemed sufficiently important to record in this place: "May 27, 1765. The Operation of Cutling lames Child jun'r. for the stone was this day successfully performed by l)r. Thomas Bond; when the stone alpleared to lee as large as a llen's ligg $\&$ weighed wo ounces, two drachms and one half."

firt . Bto December 10, 1765, "On the 10 h day of Hec. 1765 , a

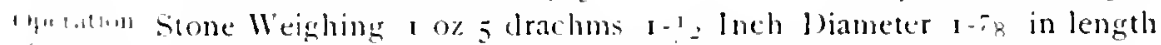
was extracted hy ir. li. liond from a lad of about $;$ years old."

The tollowing is the first case of complete blindness recorded on the minutes, and well illustrates the humanity of the Managers. A minute under date of 1 pril 2 .' 1 760 , reads:

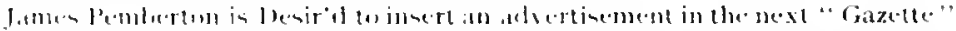

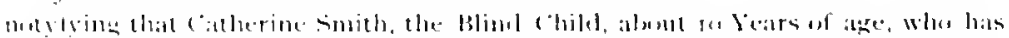

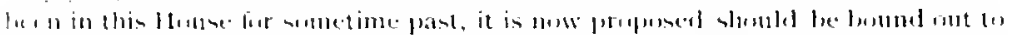

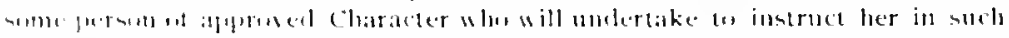

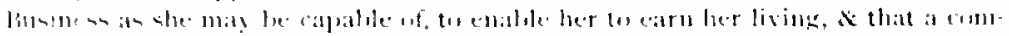

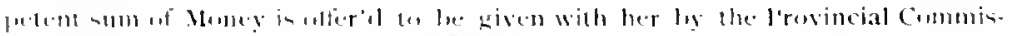

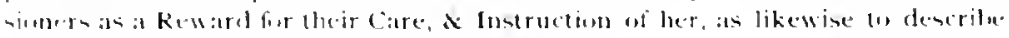

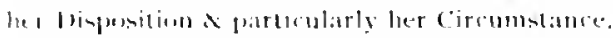

The following correspondence and official action thereon, show runclusively the feelings of the Managers 10 on the subject of intemferance and the direct connection between aluse of alcoholic drinks 
and disease, pauperism and crime, at a very early date in the prenemt century.

lutemutmance

The Managers received the following communication from the Guardians of the Poor:

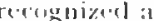

a cimbe in

lll lin:iltl

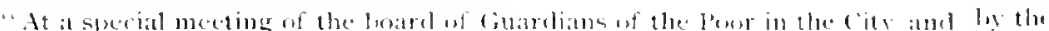

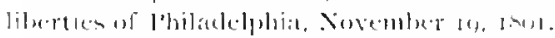

Mitlitigerer

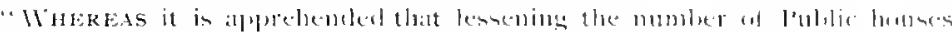

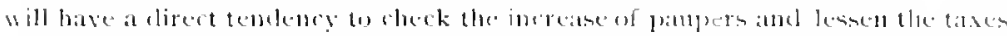
mecessilly fin their sulpurt.

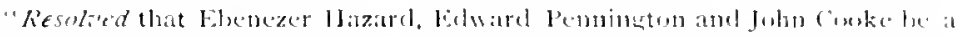

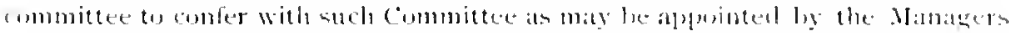

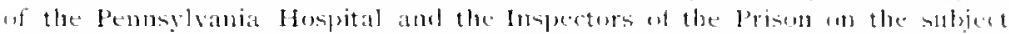

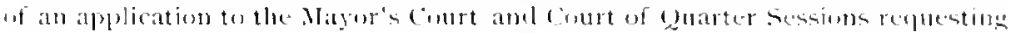
theme to lessen the nmmber of public houses in the city and liberties and that

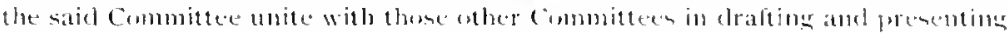
such address.

"Extract from tize" minutes.

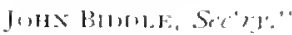

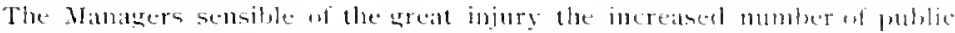

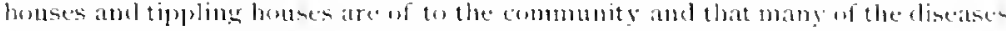

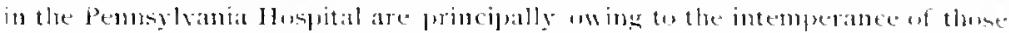
who frequent them, flo agree in sentiment with the fuardians of the Pour an the propriety of presenting a remomstrance aganst them to the Magor's Coumt and

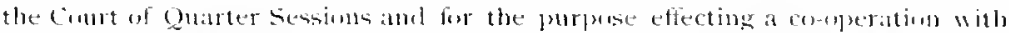

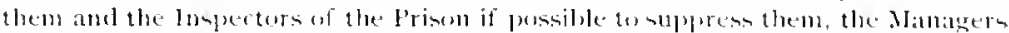

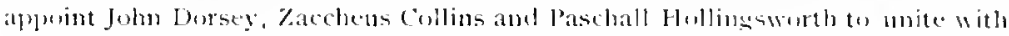

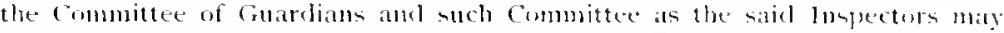
name to prepare at suitable remomstrance on the orciaiom.

The Committe on the memurial to the Courts of (yatrter Sessions and to the Nayor's Courts repurt-they presented the following which was afterwarls anp, proted by several petitions to the same effect from at number of eitizens:

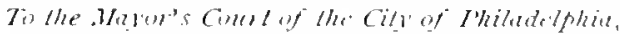

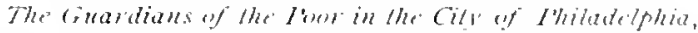

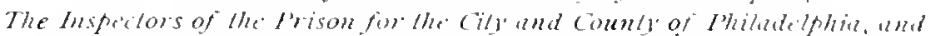

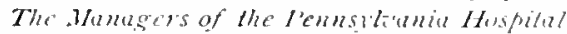

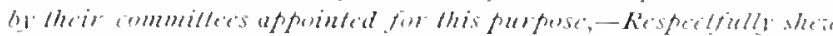

Alupeal to Authurities tid lessent the mimber of Prublic

That your llemorialists are seriously alarmed ly the rapid increaned the Honses. mumber of the objects of their calle and have been berebs led to a comsideration both of the causes therest and the comserpences necensarily resulting therefrum.

Among the former they find intemperabe to be the principal and mos com. mon: and that this is greatly promoted by taterms and other licensed Houses fis retailing spirituous liguots having become unnecessatily momernus. The later

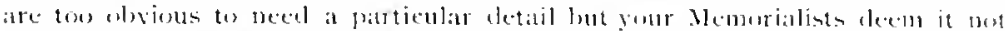

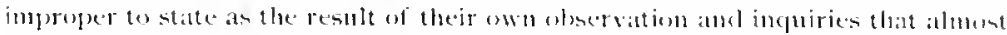

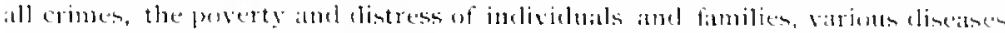

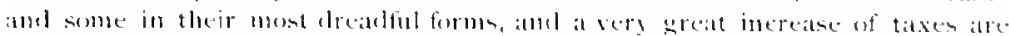

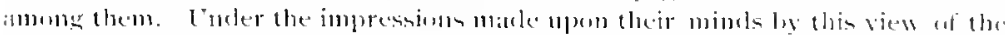

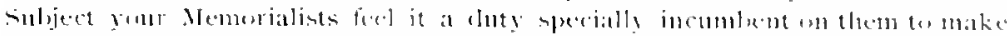

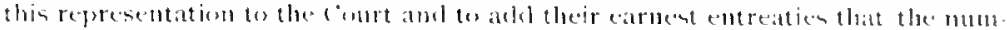

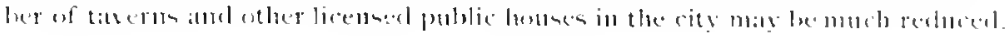




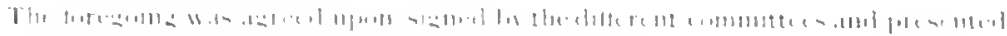

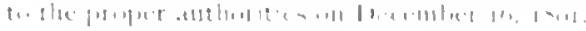

$$
\begin{aligned}
& \text { 1.) }|1,+k=1| \text {. }
\end{aligned}
$$

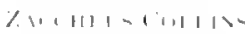

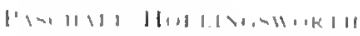

The illuatration is a cols of one of the carly adminsion cardh:

$1.11^{\prime}$

$1 \therefore 111, \ldots$

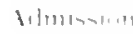
$1,11,1$

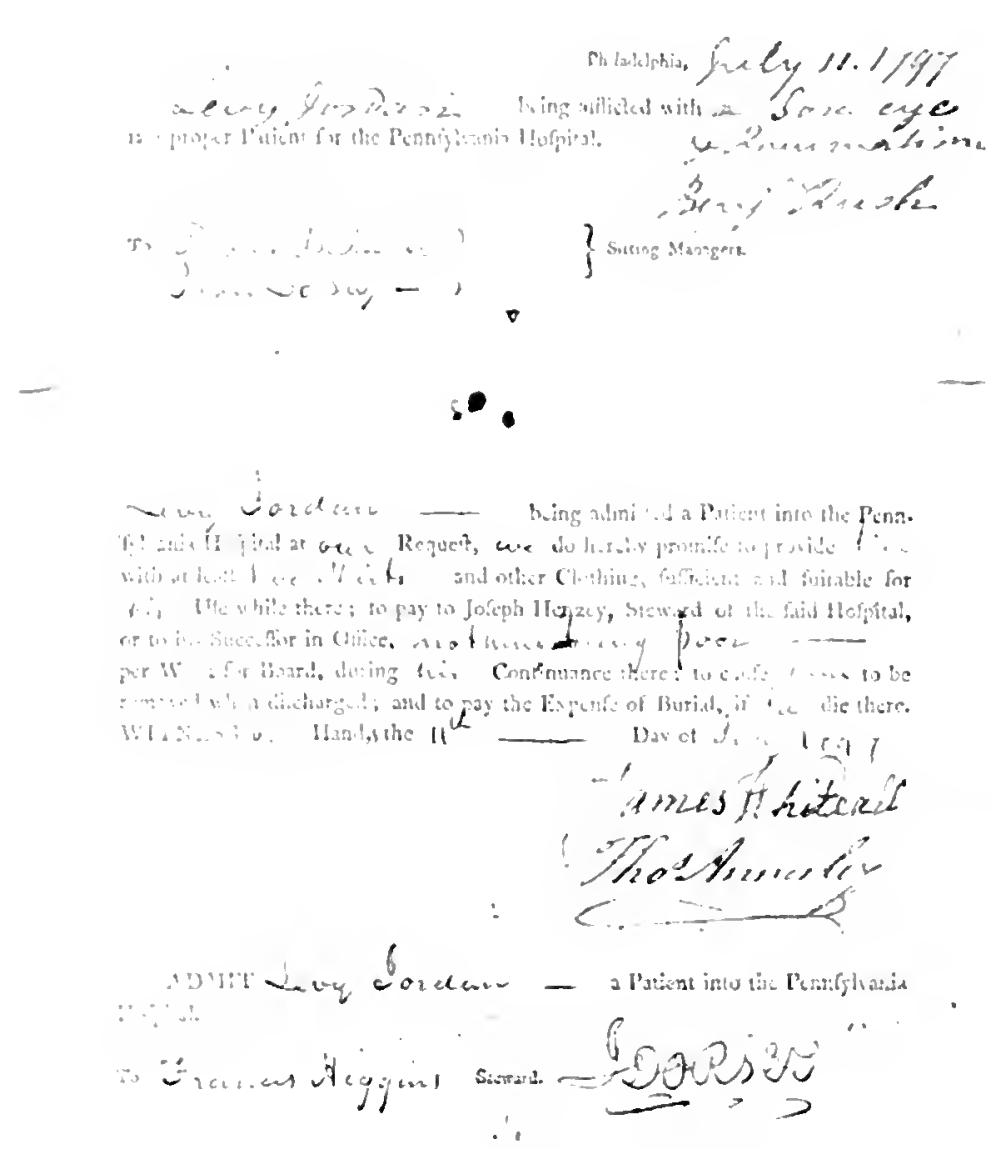

The billowing is the ext of the onginal rules regulating the

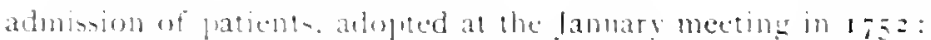

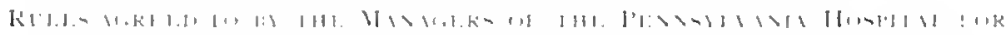

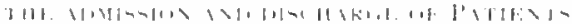

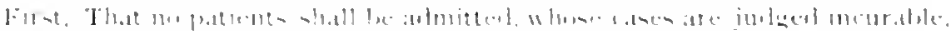

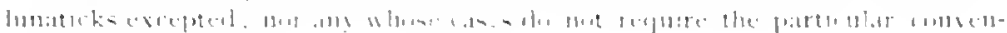

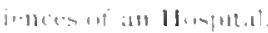


Secondly, That no person, having the smalipox. the it ho w other infertinus distempers. shall be andmitted, until there are proper apartments prepared for the reception of such as are afticted with those distases; and if any such persons slowhl be inalvertently admitted, they shall forthwith be discharged.

Thirelly. That Women having young chiliren shall nut be received, unless their children are taken care of elsewhere, that the Hospital may not be hurtheneal with the mantenance of such children, nor the patients disturbed with their moise.

Fonrthly, That all persons desirnus of being almitted into the Hospital (not inhalitants of Philadelphial must, before they lease the place of their abode, have their cases drawn up, in a plaill manner and sent to the Managers, together with a certificate from a Justice of peatce, and the overseer or werseers ent the punt of the

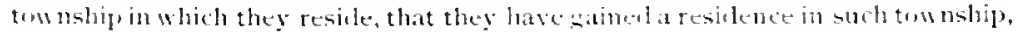
and are unable to pay for medicines and attendance: to which an answer shah speedily le returned, informing them whether and when they may be alnitted. All persons employed in drawing up their cases, are desired to be particular in enume rating the symptoms, and to mention the patient's age, sex, and place of athele, with the distance from the city uf Philadelphia.

Fifhly, That all persuns why hase thus obtained a Ietter of license to be received inte the Hospital, must be there at the time mentioned for their recepthen and bring with them that letter, and must likewise depusit in the hamls of the treasurer so much muncy or give such security, an shall be mentinned in their respective letters of license, to indemnify the lospital, either frm the expense of burial. in case they die or to detray the expense wi carrying them back to their place of atwole and that they mat not becone a charge to the city.

sixthly, fit the several persons, net exclueled by the preculing exreptions. ire applying when they cammet be received, without exceding the number allowerl by the managers to be entertained at one time in the Hospital, the preference will be given, when the cases are equally urgent, first to such as are reconmended ly one or more of the contributors, members of this corporation. residing in the township to which the powr persuns belong: secomlly, to those whe stand hire in the list of applications ; but if some cases are uresent, and athers can almit of delay, those with the nost urgent symptons shall be preferred.

Serenthly. Xotwithstanding such letters of license, if it shall appear hy a personal examination of any of the patients that their cases are misrepresented, and that they are improper subjects of the Hosprital, the Nanagers slatll have the puwer of refusing them admission.

Eighthly, That at least one led shall be provided for acedents thit reguire immediate relief.

Ninthly. That if there shall be rum in the Hosplital to spotre, alter as many per patients are accommolated as the interest of the capital stexk call support. the managers shall have the liberty of taking in other patients; at such reasonalle raten as they can anree for: and the profits arising from boarding and mursing such patients, slall be appropriated to the same uses as the interest

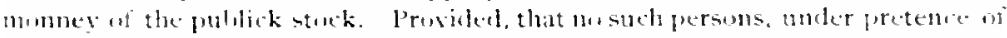

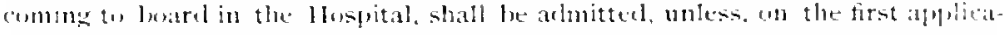

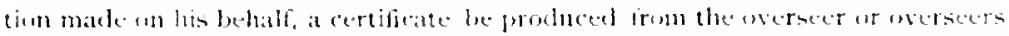
of the gun of the township in which he lives. of his having wathed a residente in

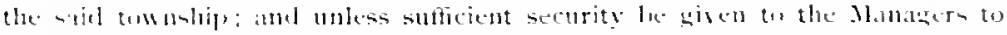

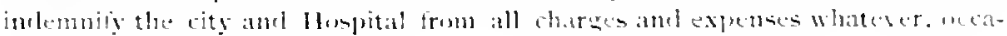
sionded lig his remushe hither. 


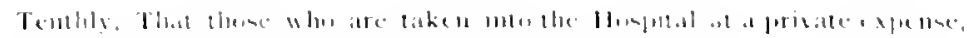

M.initu+1,

kulem in

l'alie 111 .

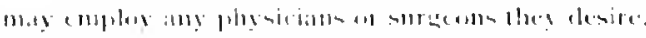

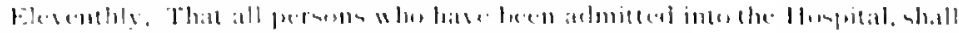

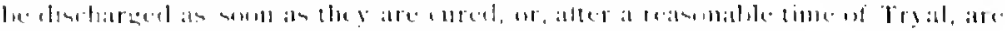

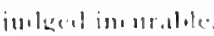

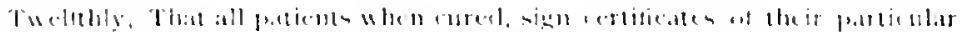

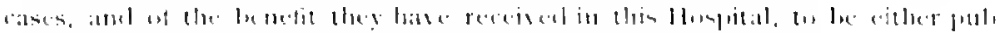

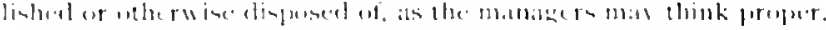

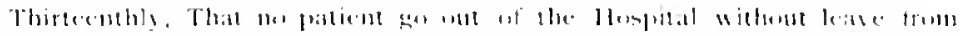

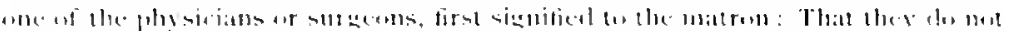

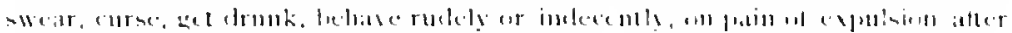
llice lirst almulition.

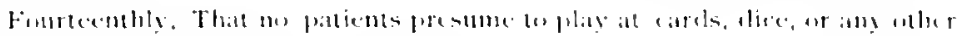

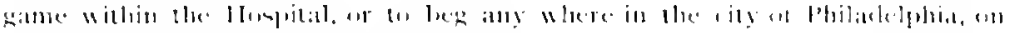

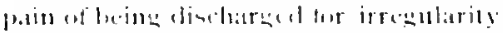

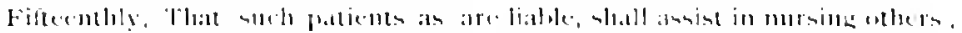

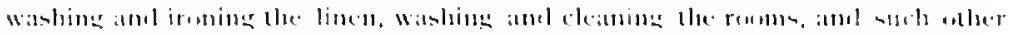

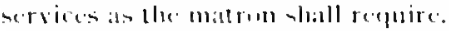

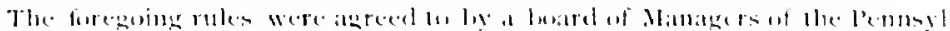

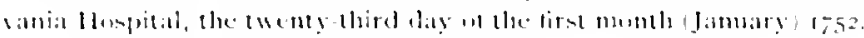

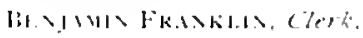

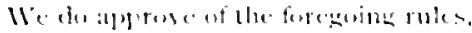

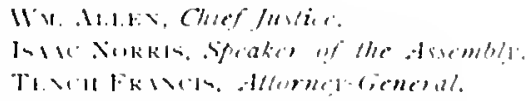

1 rule was estahlished hy the Managers Jamuary 25,$1 ; 62$, which enlarger the scope of their charitable work. It was

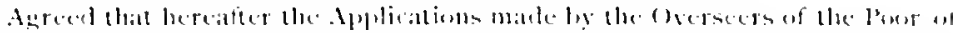

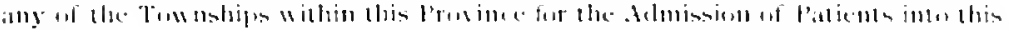

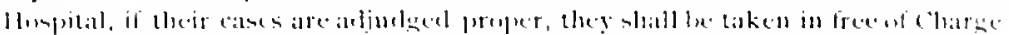

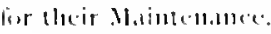

While such hat not been the original intention when the Hospital was founded. the Managers hat heretofore exacted from outlying townshigis a certain guarantee for board of the poor sent to the imstitution. This had leen the rule, even with the indigent of Mhiladelphia, none were admitted without reguiring some security, in case of death, for the removal of the body. Often when sone pour stranger claimed the hosplitality and calse of the institution, with no one to act as security, one of the Managers or some other charitille citien, froforma, signed the admission payer.

N1lditinets riared tiur alike.

The desire of doing good to all. irrespective of color or condition, secmed to animate every one connected with the Hosplial from its beginning. That no difference was made in favor of pay patients "ill he evident from the following minutes made lebruary 20. $176,5:$ 


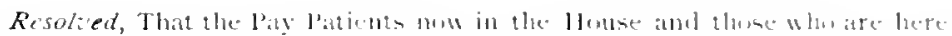

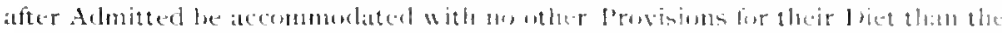

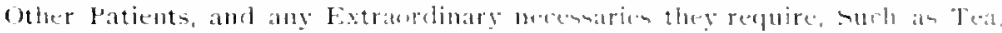

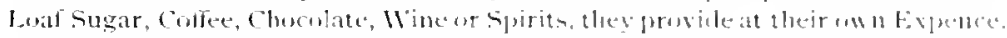

It is recorded on the minutes, Nay 7,1752 , that an Indian having been found ifl near the home of lsaac Norris, the latter rejorted the case to the Managers, who immediately took action in the matter, appointing John Reynell and Samuel Rhoads in conjunction with the physicians to consider it. " and if they find he cannot be otherwise suitably provided for, it is agreed that he may be admitted into the IIospital." Upon investigation. Samuel Rhoads reported that John Reynell and he had risited the sick lndian amd that "Isaac Norris had provided a place for him."

The want of personal security did not deter any deserving, poor person, however, from receiving the benefits of Hospital treatment. Here are two of the many instances on record: October 3, i.6.4. "John Bryan a poor person was admitted with large ulcers, a pair of luckles his security." On September 28 . I $7 S_{5}$, "a pour sailor was admitted with Rhemmatism, his chest of cloathes, his security."

On June 23,179 ,

The Managers in full consitleration of the Fith rule for the admismiun and discharge of Patiems, atree that the same be repealed s, fatr ats relates to

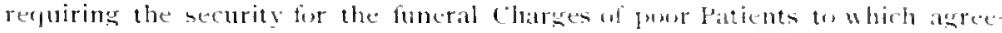
ment the approbation of the (laief justice, speakers of the Assembly and sitte Atturney is sulicited.

On February 26, i 810 , the following amended rules were adnuted. making more easy the admission of poor patients in future:

1st. Recent Accidents such as wounds and liruises may be receivent at all

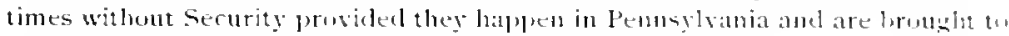
the House within twenty-fon hours atter the accident.

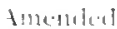

Rules firs

Arluitioniuts.

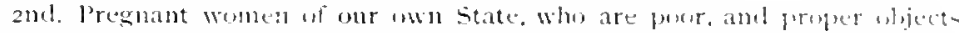

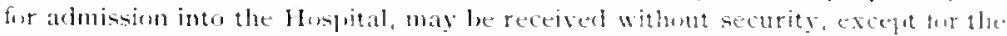
remusal of themseties and children when discharged. The Mainendnese of the

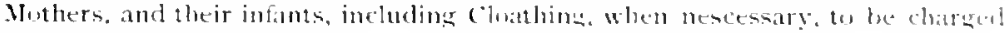
to the income of the cavalry Fund, and in catse that fropes insufficient, to the general fund of the Hothe.

3rol. The Atendimg Manazers may sian in behalf of the Muspital as aecurizy

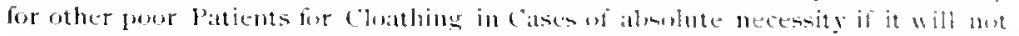

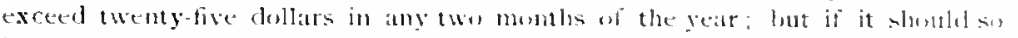
happen that a part of the said ablowances of twenty-five dollars for any ewo months shoubd remain unexpended the supplus may he expended in the surcedi

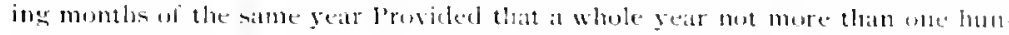
drefl and filty dollars be allowed for chathing and the boual security be alwaty

lixor l'atiente atrat in: taken to remove the bationts when required. Hospital.

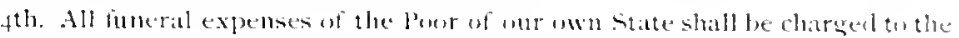

1. sispitill ti) proving? (listhisu ind pay lentertel Fingentises. 
The lilecral spirit of the Managers is shown by their course with Free regurel to free vacination. March 28 . ISos, the secretary of

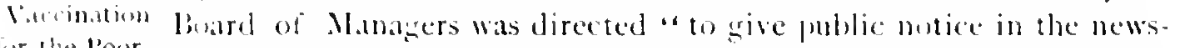

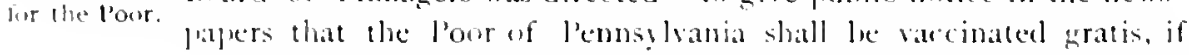

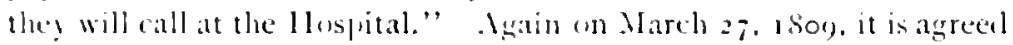
"to alvertise the l'oor from the City and County to come to the llospital where they will he vaccinaterl eratis." l'revious to this Inculation time, inoculation wan practixed by the physicians of the Hospital,

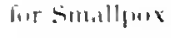
: (nite-Patients. composing the Medical stali: Imt as infections diseases were not admitted, the patients were treated at their homes. 'l'he statistics are inc omplete. lout the following in of some historical interest:

During the yeur 1799-1900. among the outside paticuts were treated: 109 cares of "incenlated" stmallpos. of which 6.5 were (ured. I failed. 6 catses of "natural" smallpox were also attemeled.

(lenturnes from : ine Viratio. 11 1.mm!

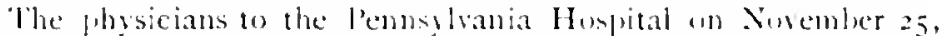
1sis 2. resumended the managers "twaply three hundred dullars of the medical fund towarels clothing of such poor paticnts, whe cannot lind the usual securit! for that necessary anticle" ; again on April 25 ,

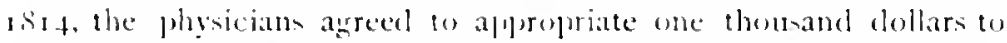
lee taken out of the medical fund "for supply of clothing to indigent patients."

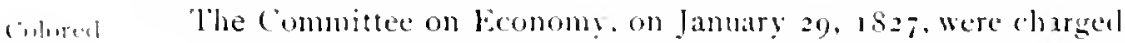
Fenale to "prepare an apartment for the accommodation of colored female P'ationtpatients in which they may le more nitably provided than they are at present."

birectine April 9.1757. Tom, a negro, lelonging to Joseph Wharton, "an concernime honest slave," was the lirst patient who died in the new lluspital. On beresed November 26,1766 , the matron was given particular directions that Piticinte hodies of the patients who die. should be taken into the liper Hall to be latil out in a sutable apartment there to le provided for that purpese.

It was "-Resolved, that when the Physicians shall conclude it Aunpien. nee essary to open the hodies of any of the dead, that they previously consult the sitting manages thereon and oldain their consent."

In the course of years, disputes have cecolsionally arisen between The L.u whe physians of the llospital and the Coroner of the (ity of lhilacimenc delphia, with regard to the relative rights of each party to mate

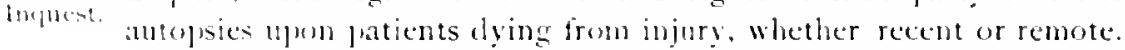
The following valualule contrilution to the discussion of the duties of the office of the Coroner arose in this way' in the cane of a woman named Elazheth Taslor, who had leen accidentally burnt about her losly and died in the lloyplal, in conserpence thereof, a weet after her 
admission, the Coroner of Philadelphia asserted his right to make a post-mortem examination.

The latter in an official communication, dated September 28 , 1840, addressed the Board as follows:

The responsithility of an wath makes it an imperative duty on my part to call (ommunicayour atention to the fact, that many persons who die in the Hospital, the victims tion from the of accident, are buried without my knowledge. Sow I believe that the law lintomer. makes it the duty of the Coroner o lold an incuest wer the bodies of persons who die from casualties.

In another letter he grives a list of authorities in support of his claim that "all deaths from accidents or casualties fall under the notice of the Coroner," withont regard to "the nature of the casualties or the time that may elapse preceding death."

This claim was opposed by the Managers and Horace Binney. Esq., of the Philadelphia Bar, was requested to inform the Board concerning the utmost limit of the duty of the Coroner.

Mr. Binney, in a full report dated November 7, is +0 . (which will here be given in a somewhat condensed form), denied this chaim and declared that the authorities cited did not support it. The suddenness of the death is more essential than its accidental character. The right to jurisdiction of the Coroner, therefore, in a death from casualty, is not inherent, but in each case is due to attendant circumstances.

After briefly reviewing several points raised by the Coroner's correspondence, Mr. Binney proceeded to summarize the law upon the subject and then advised the Managers with regard to their duty in case of violent or accidental deaths, as follows:

The office of Coroner, it may be remarked, derives its nane from the circumstance, that it has principally io do with Pleas of the Crown, or such in which the hing is more immediately concerned.

The judicial powess belonging to the uffice, have altugether perhaph al reference to the rights and duties of the crown. If the death uf a person involves a bomicide, the curoner intervenes to hold an inguest. that those who ate culpalde may be brought to justice in the king's cuturts; and if the case is ane 11 which the party is felo de se, the induest is necessary or expedient to secure the for teitwe which follows the act: and if it be a calse neither of homicide nor silcide, it

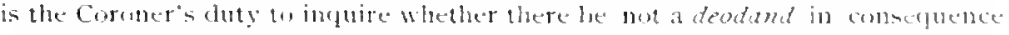
of the death, to the king, or to the lorit of the franchise under him.

These objects and enck of the offee, may he regarded as limitations of its judicial power in England. except in the catse of fersons dying in pintm, where. from a salutary suspictom that the death of all persons who are in the cuntedy of

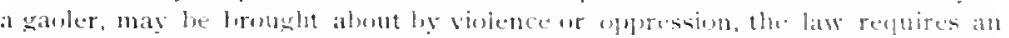
inguest by the comoner in every ease, withut regard to its circumatances. With repect to prisuns, Eeneral sumpicion supplies the place of portionlar suspicium.

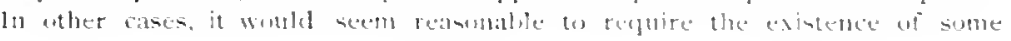




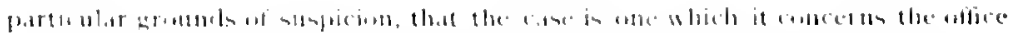

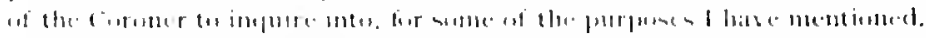

VI IBHAles

111 t1,

Intion the

(iir.11.1.

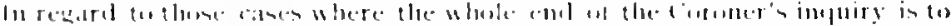

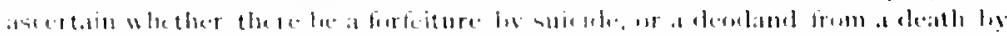

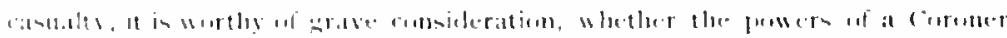

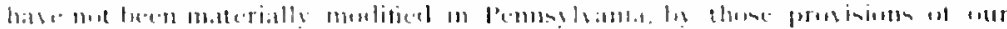

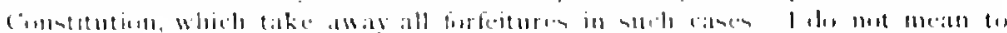

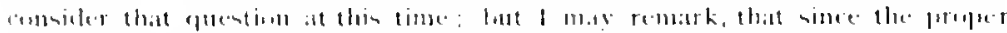

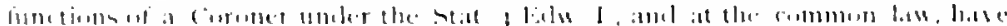

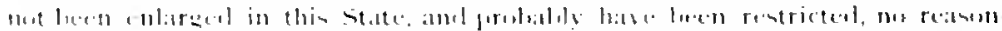

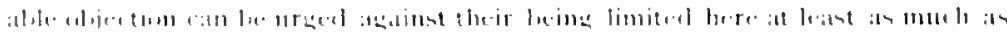

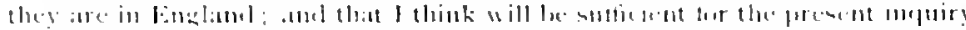

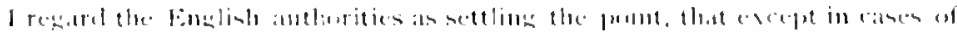

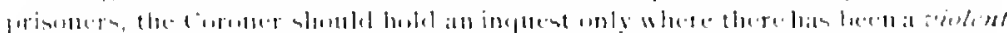

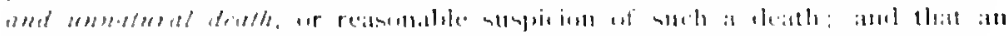

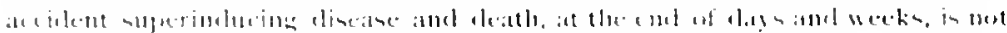

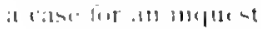

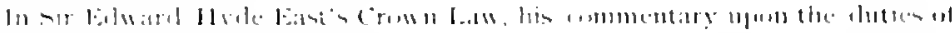

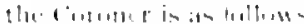

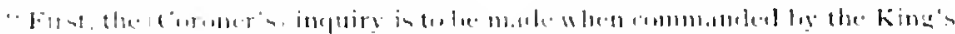

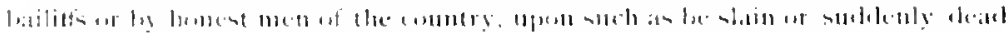

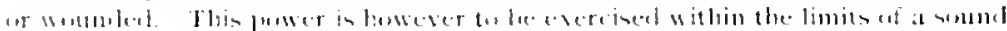

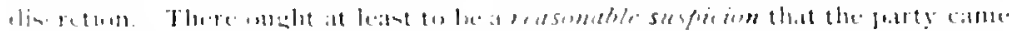

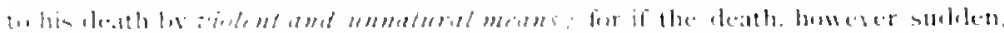

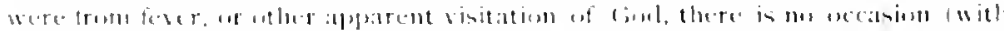

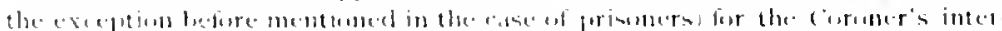

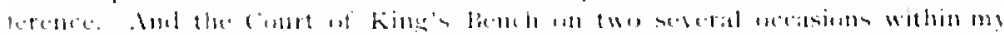

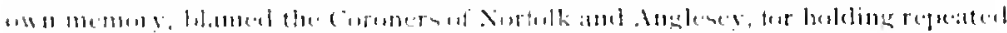

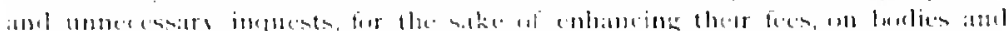

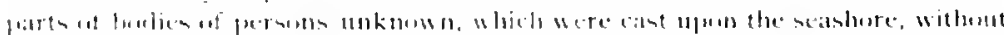

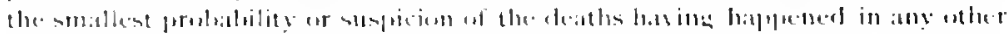

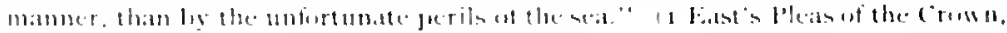

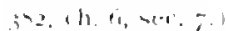

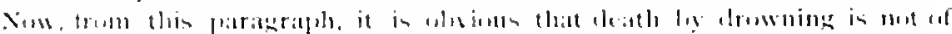

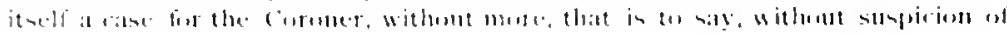

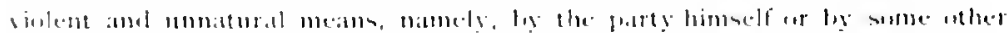

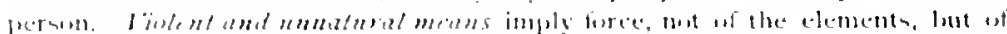

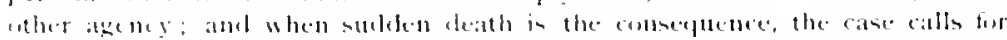

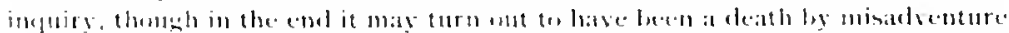

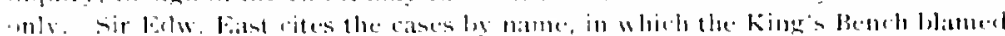

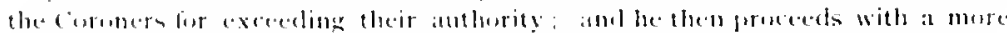

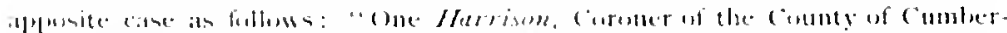

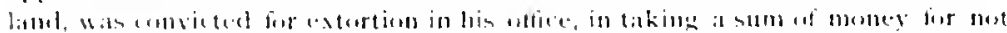

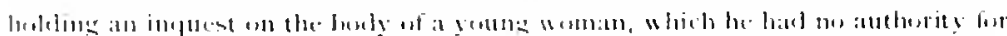

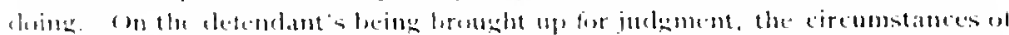

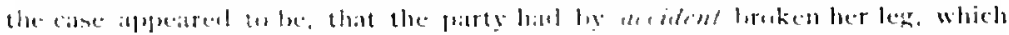

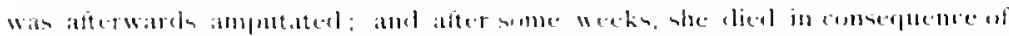

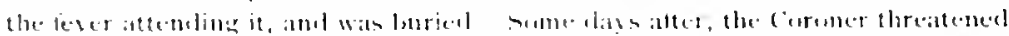

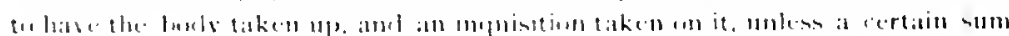

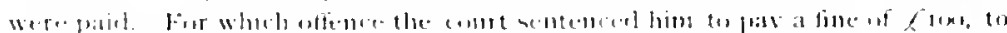

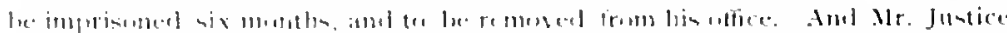

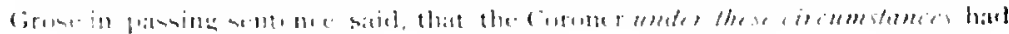




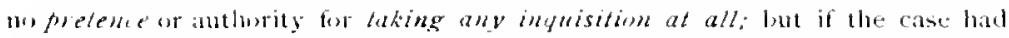
warranted his so doing, be was equally erininal in hatring exturted money to

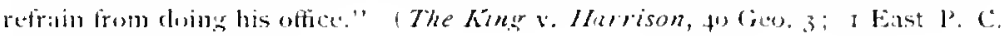
ch. vi. see. 7,1 , 3 , 2.1

I need not remark how full this anthority fand it is the authority of the highest erimmal court in England), is against the (uroner's claim of juriseliction asserted in his letters, where he admits mo exception from "the nature of the casualty, ur the time that may elapse preceding death." Nur need I show hew

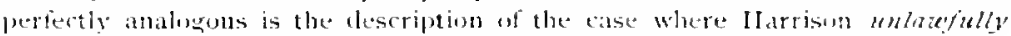
asserted his anthority, th that of the girl who was acedently burned, and deal a week after in the luspital.

This is mot a molern law. The doctrine is Lord Hale's also whose name is uf itseli anthurity. His language is as follows: "Regularly, the cirvoner batl m, fmwer to take inguisitions, but touching the death of a man, and persens subito

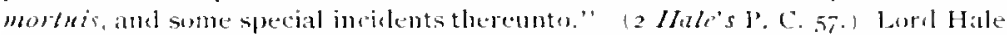
then cite the following case. "If any person dies sulelenly, though it be of a leater, and the tuwnship bury him before the Conomer be sent for, the whole town-

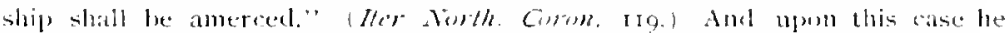
rematks: " Vole, this case is misprinted. l have seem an anvient transeript at latge of the lter of Surthpton and perased this very case. Which in libro meo f. 52, b., is morrest de ferme, viz, starved by hunger; for thumbl a man dien sublenle of a fever or apeplexy, or uther visitation of fiod, the township shall nut be amerced: for then the coroner should be sent for in exery cone: last it it

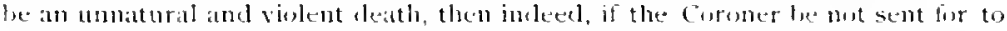

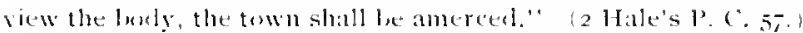

He proceeds, at pine 62 , "Now sudden wient deathe, whith are all within the Coroner'sofice to inquire, are of these kimb: 1. El adritatione dei. 2. per

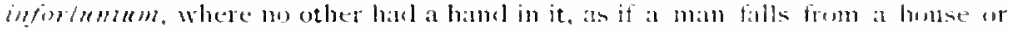
cart. 3. By his awn band, as fele de se. f. By the hand of another man, where the effender is mot kmom. 5. By the hamd of andher, where he is kmown. whether hy murder, manslatighter, se defendeme, or per infortunim,"

There may be thought to be some inconsistency between these two ritatiuns, an visitations of foul alre excluded by the first and included by the second; lint there is no inconsistency. In the first, lord Hale speaks of sudlen deaths in the kllown course of nature, as fever or applexy; in the sccomel. he speates of sudden riblent deatlos which are out of the usual course of nature.

The audden deaths within the Coroner's jurisdiction, maty be infered from amother anthority dited by Ilale, 2 wol. st. to this effect. "li the curomer lase motice, and comes not in convenient time to view the besty, and take his inquisition unn the death of him that dies sucldenly, and therefore upun a presentment hy the grand inquest of a death ly misade'nhwe, if the like presentment

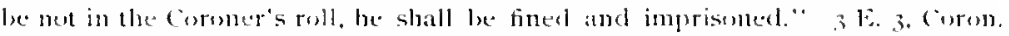
292. Su that the sudelen deaths cugnisable he the cormer, must be, at leatst. death ly misalventure, per infortunimm, which in one of the classes of sudtent

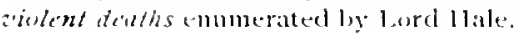

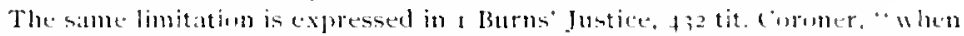
it happens that any person comes to an annalmal death, the townhip) shall pive motice therew to the coroner : otherwise if the borly be interred he dere be come, the tuwnship shall be amereel." And by llolt, C. J., " it is a matter inlitalle tolury

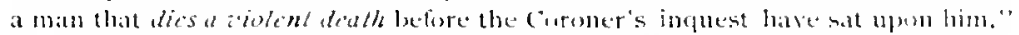

I hase alteasly remarked how all the directims of Stat. \& Edw. I, imply the

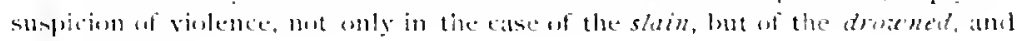
stribule deat. 


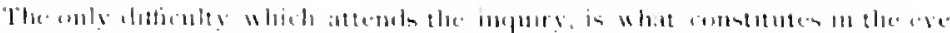

Vi Hism. (1) 4 lı

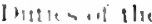
aritier

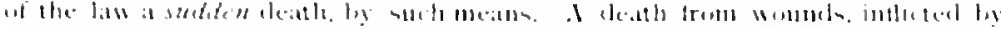

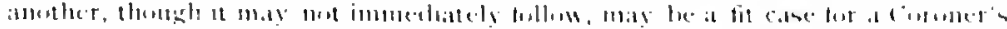

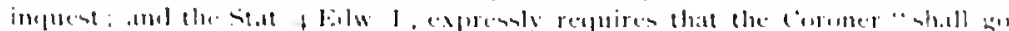

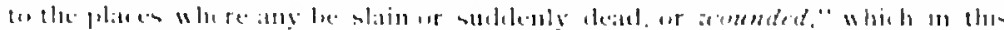

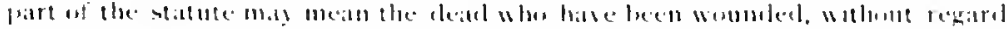

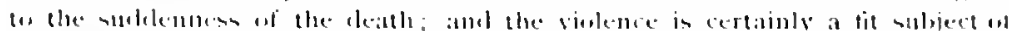

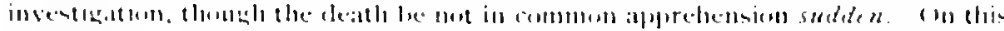

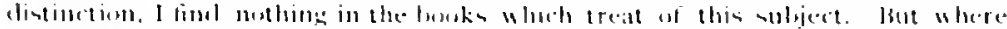

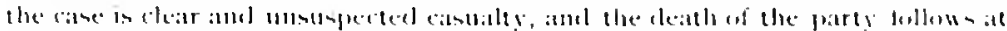

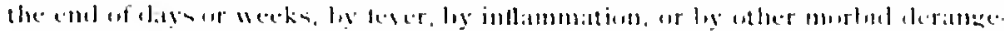

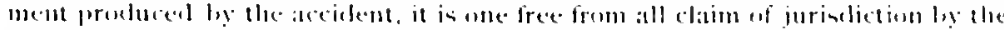

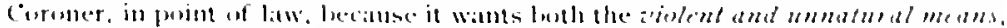

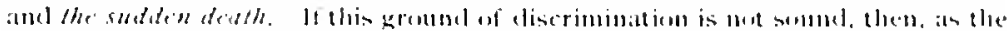

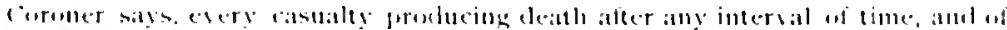

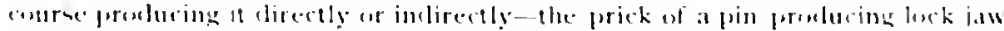

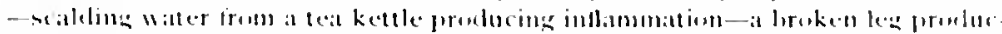

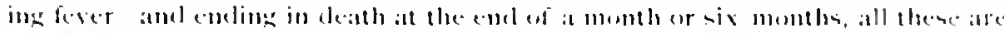

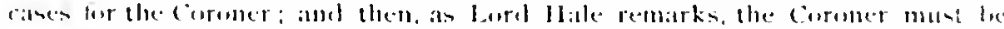

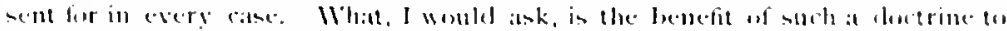
the community? And it in for the pulstic that the office is instituteel ammone 14 .

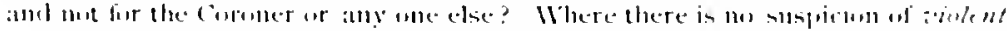

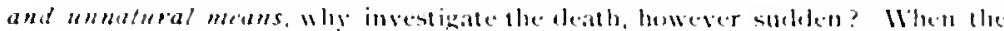

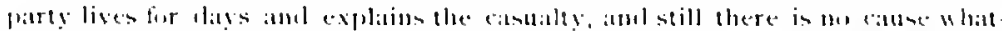

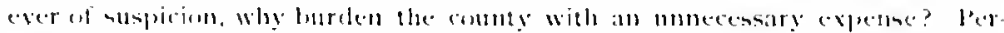

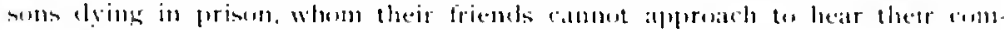

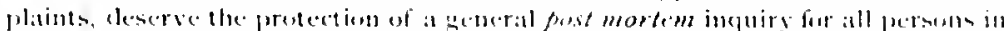

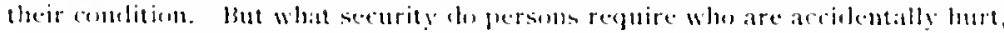

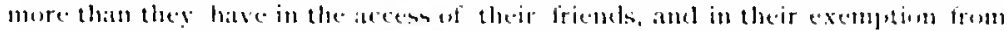

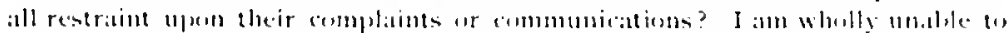

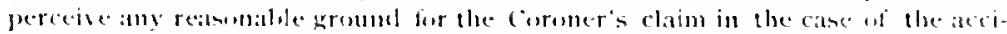

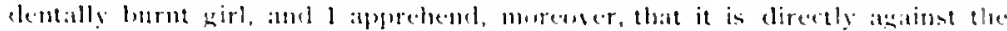

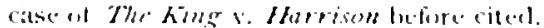

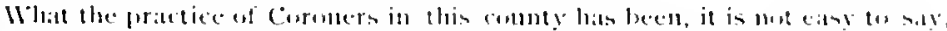

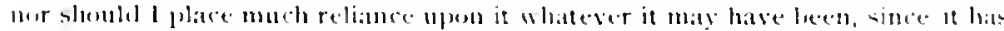

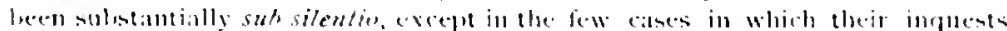

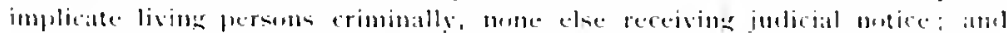

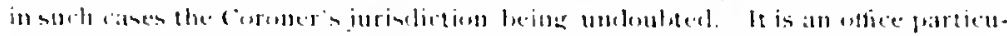

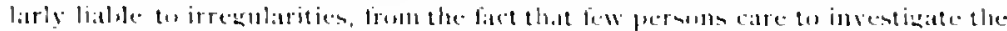

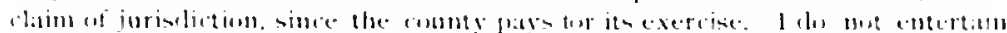

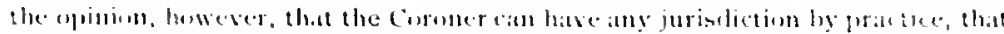

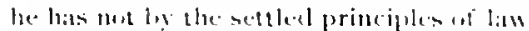

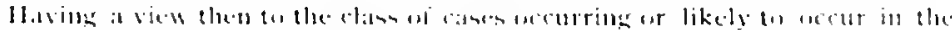

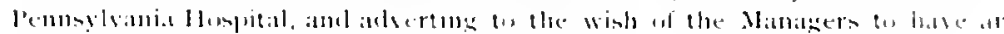

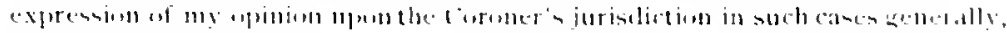
I that it ist follusw:

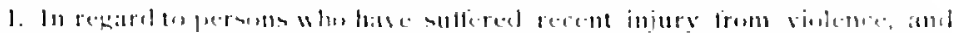

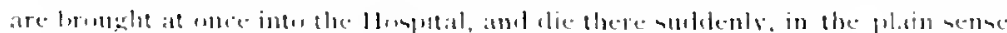

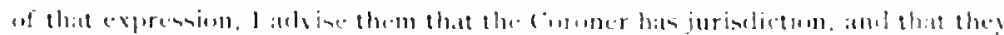

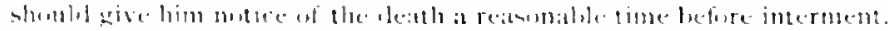

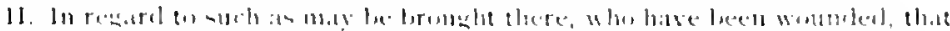

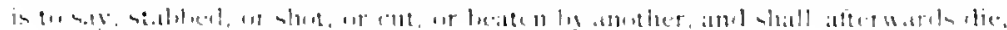


I atvise the ldompital in like mamer to give the untice, and to submit to the Corences juriseliction, whout regard to the time that may elapse before death.

III. But in regard to cases of accidental injury, broken limbs, burns, bruises. and the like, where the patient dees mot die sublenly, but lives diays or weeks, and then dies from fever, inflanmation, or otler morbid affection caused by the injury, and where there is no grumbl of reasmable suspicinn that the injury involves any persun in criminality, 1 advise that the Honptal is under an whligation to sise wetice of the death te the Coroner, and that the Coronter has now right to hold an incpuest on the borly.

1V. In cases of sudden death by apoplexy, and the like, among the patients in the bouse, there being 10 canse whatever to suspect vielence and unnatural means, the Coroner lus clearly no right to hold an inquest, and I do mot understimel him to assert such a right.

At the next meeting, held Norember 30,1840 , the above opinion was presented.

The Sectary reports that, in pursuance of the resolution of the Board at the last statcal meeting, he has obtained the written opinion of Ilorace binney, Esq. on the jurisdiction of the Coroner; and that, in answer to a note from the Secretary as to his fee for the same, he has received the following from Mr. Binney:
"G. Ruberts Smith, Esq.
November 13 , rsto

"Dear Sir:-I beg the Huspital to aceent my opiniun as a contributim by" me to their work of benevolence.

$$
\text { "I remain truły yours, }
$$

"HOkBCE BINALY"

On motion, Resoled, That a copy of this ()pinion be inserted on the minutes, and that a copy be also furmished to the Coroner.

On motion, Resoned, manimously, That the thanks of the Managers be temelered to Mr. Bimeg for his Opinion and the generous manner in which it has been given.

The following brief items will exhibit the aid extended, by the Hospital, to lunatics and indigent patients:

Jin'y 2-, sin6, That is bunatics may be admitted, as proupers, in ail: but mu sitting manager to excect that number.

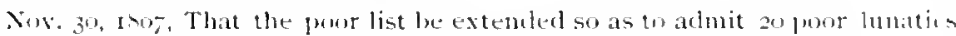
at one time, making on the whele fo poor paticuts wo be so almiteel.

Iray 9. Isus, Agreed that 50 pitupers may hereafter be admitted inte the

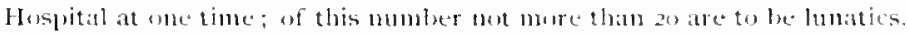

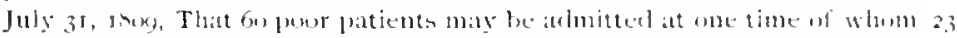
only are a be lunatics.

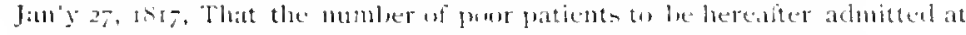
any time intu the Hosplatal be increased to b5 w when 25 may be insane.

July 2\$, 142.3. The sulyect of increasing the number of Pour pattents to mol whom 32 may le insime was again callet up and after combideration, adtsptet

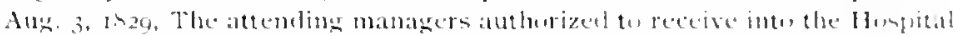

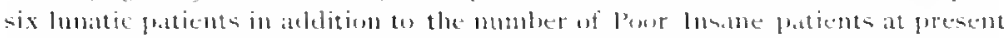

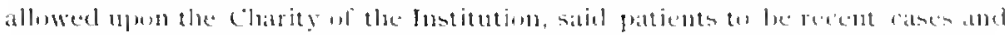

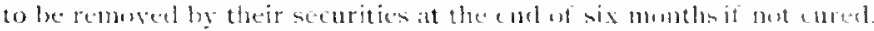

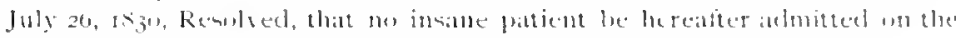

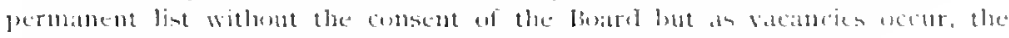

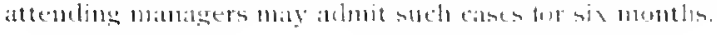


A dispenstion being manifested by the City anthoritien to hase their pauper patients treated at the llospital, an exlended correspondence arone on the subject which is here considerably condensed from the several entries as they appear upon the Ninutes of the loard of Minagers:

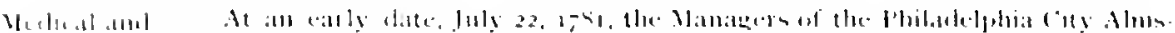

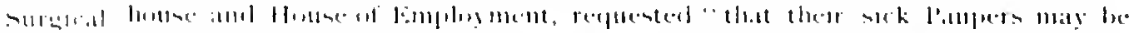

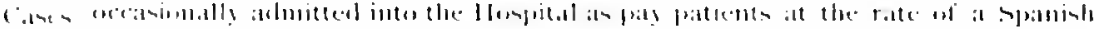

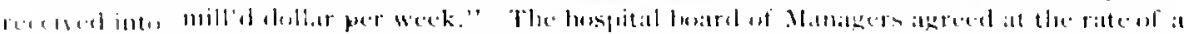

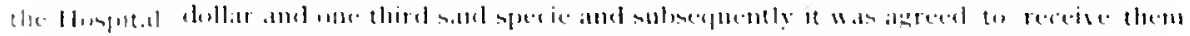

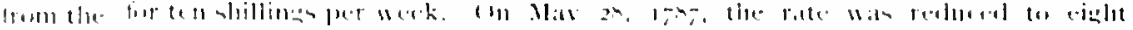

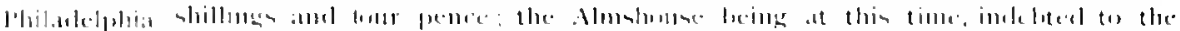

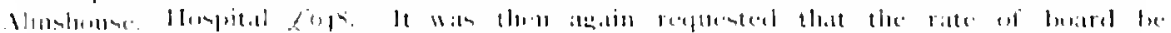

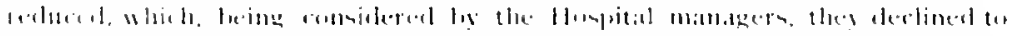

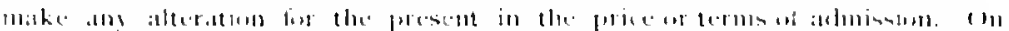

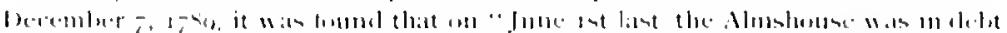

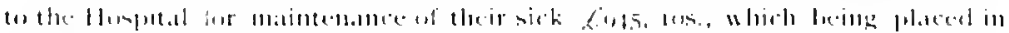

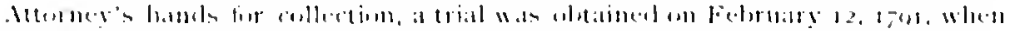

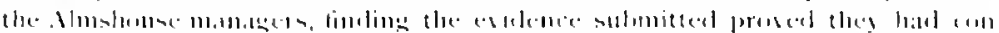

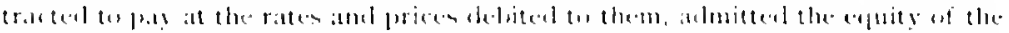

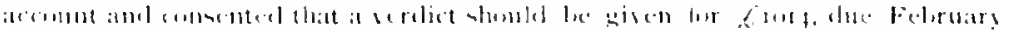

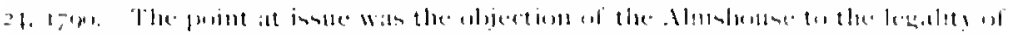

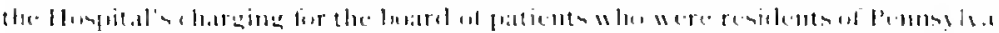

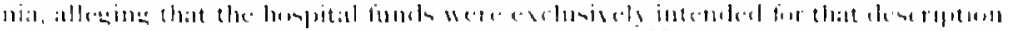

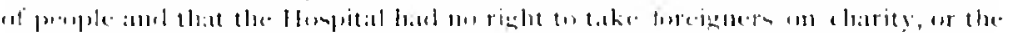

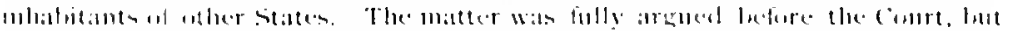

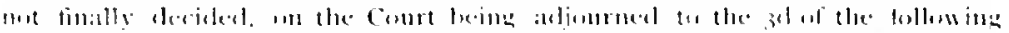

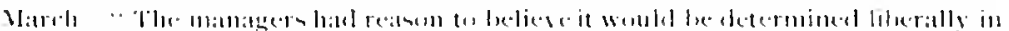

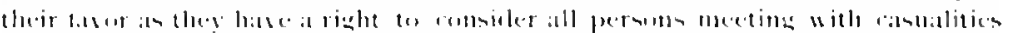

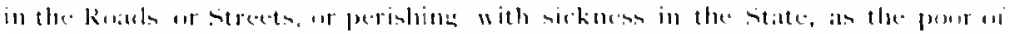

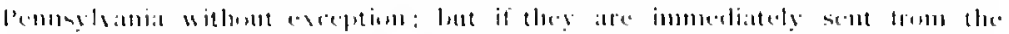

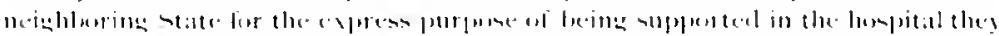

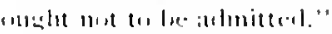

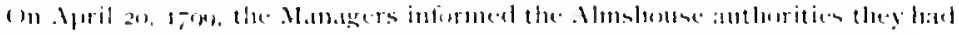

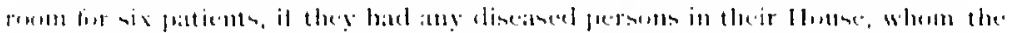

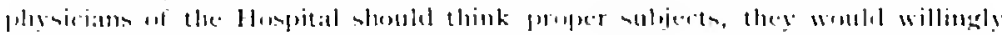

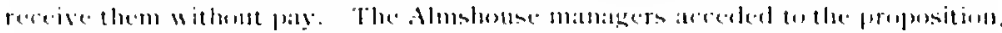

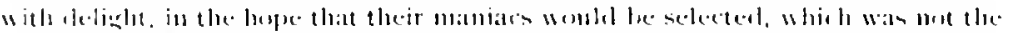

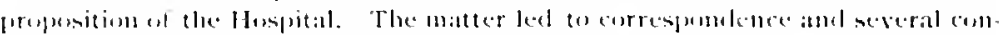

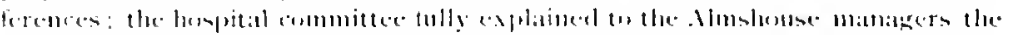

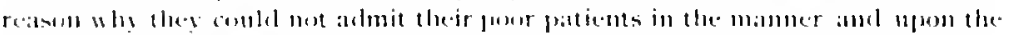

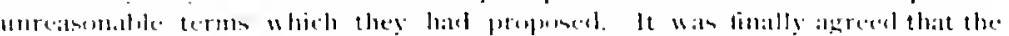

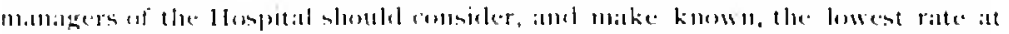

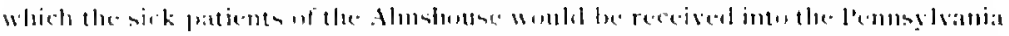

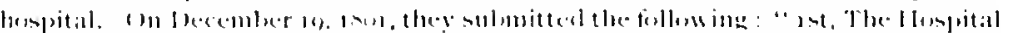

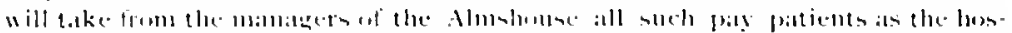

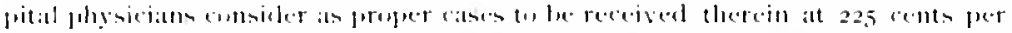

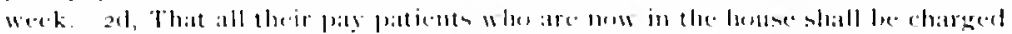

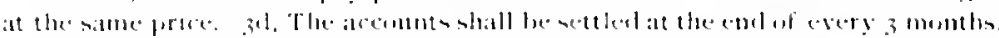

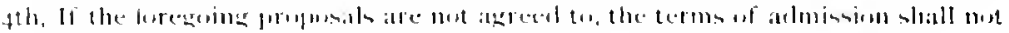

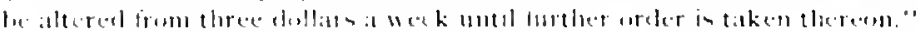




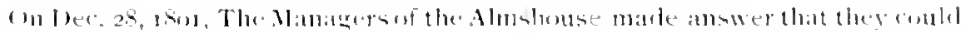

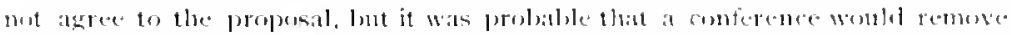
the imperliments. At a conference, helel Jany 12, thing, the objections male wo the

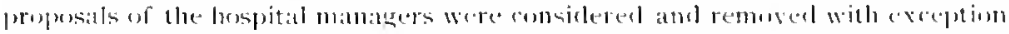

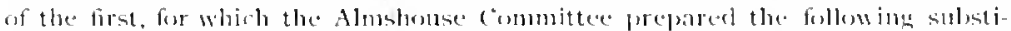

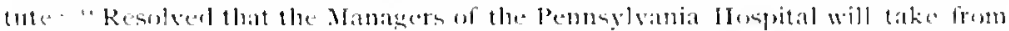

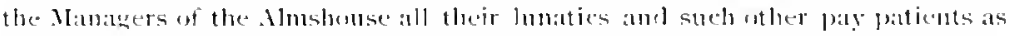

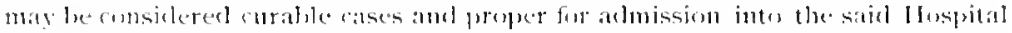

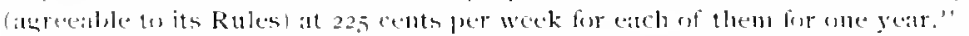

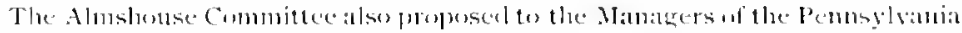

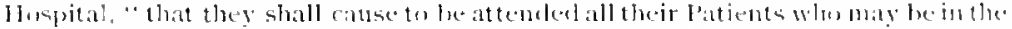
Almalunge, by the inospital lysicions, gratis: and that they shall be supplied with merlicines except liquors at the experuse of the thospital."

On Jany 25. inn2, all conference on the sulject was terminated by a minte

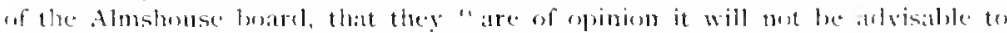

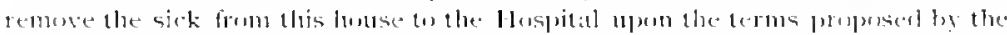

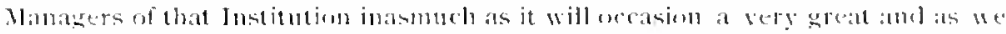

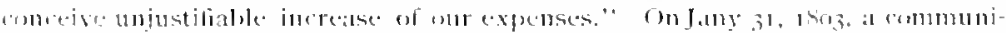

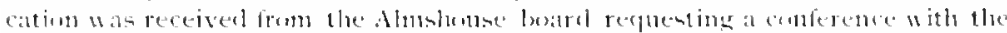

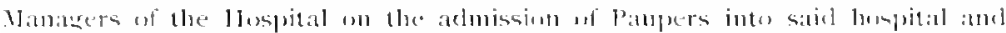

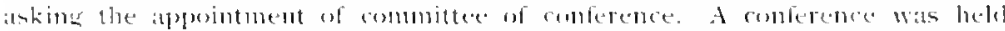

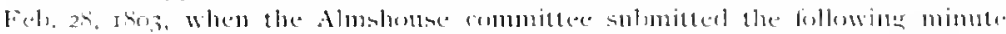

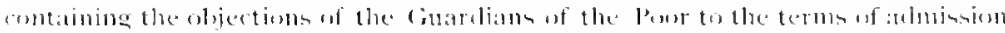

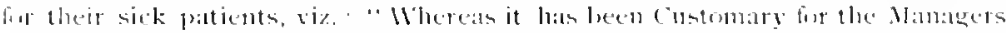

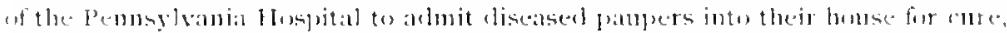

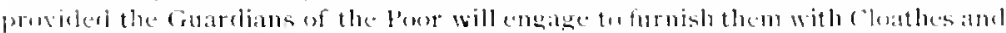

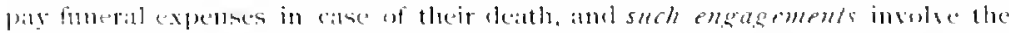

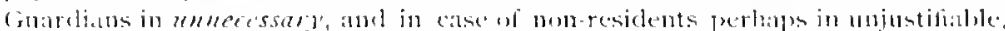

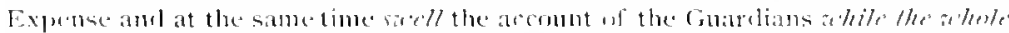
"redil yesults to the Manasers of the Iluspital. Resolved, lhat in Future Xo

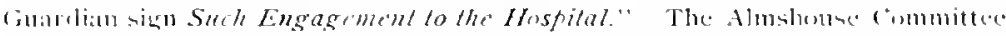

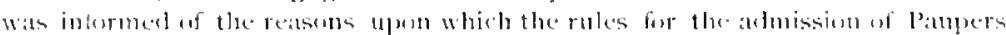

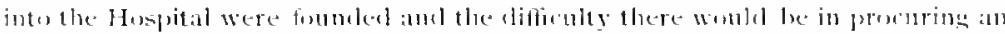

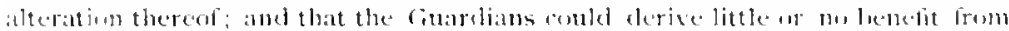
the profused alteratims, inasmuch as chothimg and lurying their pattents at the

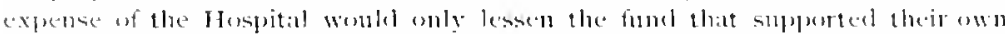

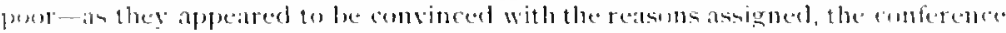

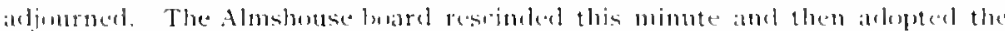

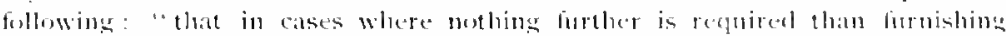

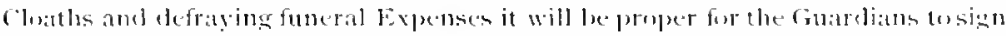

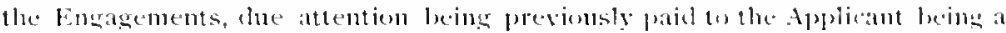
Residemert."

This arrangement being satisfactory to the Managers, the Committee was discharged July 25 , r.So 3 , it mot being consilered necessary to have any further conference, at this time, on the sulject.

A subsequent communication from the Guardians of the Poor was read February 27,1804 , in which they offered to transfer two panper lunatics to the Hospital, on condition that the Managers " in future provide them all and every Necessary, without any bipense to this Institution." "To this proposition the Managers made a reply, stating that 


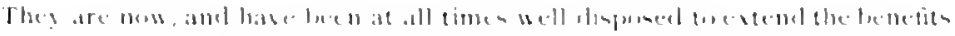

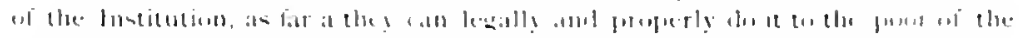

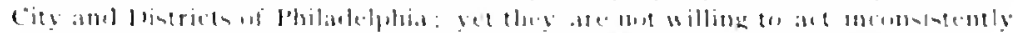

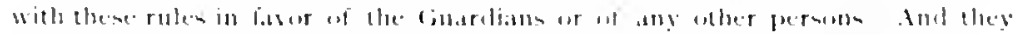

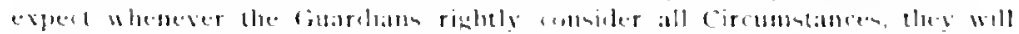

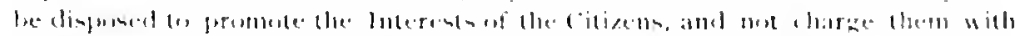

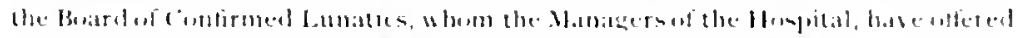

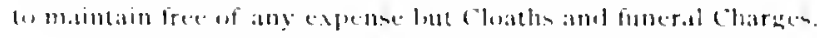

On July 31,1855 , the following was received, showing an andicalbe feeling letween the two institutions:

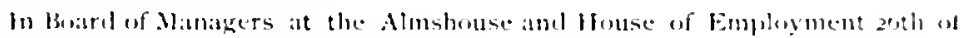
Jutue 1 itis.

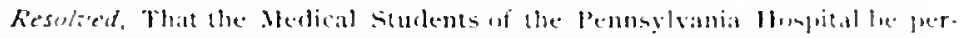

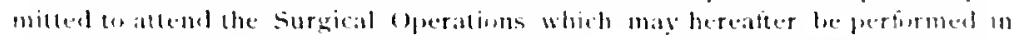
this llinse.

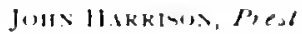

From the aloove it is seen that the claim that the excellent charitalle institution known as "The I'hiladel,hia Hospital" now existing in connection with the Philadelphia (Blockley) Almshome, is "the oldent Hospital in America" is evidently etuite incorrect. Hecause it now exists in comnection with the I'hiladelphia Almshoure, it can not le admitted that it was so from the leginning, or that its organization dates back to the establishment of the first City Almshouse in $1730-31$. There are wo facts to sustain such an aner. tion; on the contrary, it is seen that the Amshouse Ilospital wa not estatlished until some time between isizand is $S_{15}$. In the numerous communications between the Hoard of (Buardians and the Managers of the I'ennsyluania Hospital, until the last alove quoted, no alluim. direct or indirect, betrays the existence of such a medical organiration. Ilarl such a hospital, in connection with the Alm-home existed, the ciuardians of the Almshouse would not have made an arrangement fur the Nanagers of the Pennsylvania Ifospital to tuke their curalle sick paupers as pay patients, thus inereasing the expen-e of the Almhouse. Finally, that such Medical Hospital did not exint as late as 1 1802. is evident from the proposals of the Almolioune lioard to wit: 1st. "That the Managers of the Pennsyliania Hospital will take from the Managers of the Amshonse all their lunatics and sich other patients as may be considered curable cases and proper for admision into the Hospital." zd. That the Managers of the l'ennsyluania Hospital "cause to te attended all their fratients who may he in the Almshouse ly the Hon ital I'busician gratis:" and that " ihey be supplied with medicines except lingurs cic. at the expense of the Ilospital." It is evident that the sick and insane paupers at the . 1 monhonse were not previonsty under the care of an! medical or tam -

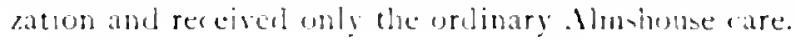


At one period in the history of the Hospital, many Acadians were arlmitted for medical treatment. These people, in the early part of the last century, dwelt in the territory now included in Nova Scotia, New Brunswick, and the adjacent islands, and were a peaceable and industrious, agricultural community, originally a colony of Bretons, who came from France under l'ierre du (iast Sieur de Monts, a wealthy Huguenot, who had been commissioned viceroy of New France, with full power to settle and rule over a region extending from Cape Mlay to Quebec. This domain was “Acadie," their chief settlement was at Port Royal, where they cleared the primeval forest and built their cottages, sixteen years before the Pilgrim lathers landed on the shores of New England. At the conclusion of the war between England and France, the British Goremment confiscated their lands, and deported the unhappy Acadians to the colonies. In September, 1755 , a ship arrived in the Delaware with nearly 1 too of these unwilling immigrants on board. After some delay, they were allowed to land and were placed in some small buildings on Pine street below sixth, especially constructed to provide for their accommodation and shelter.

Mrs. Elizabeth W. Levick, ${ }^{1}$ who was born in $17-89$ and died in I $\$ 86$, in "Recollections of My Early lays" (1981). says of the "Neutrals":

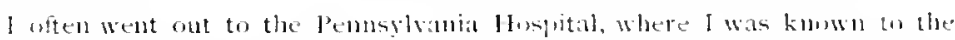
steward and Natron, and to others there. The insane patients ocoupied one part of the building, and ameng then was the wife of the rich merchat steplen Girarl. She frequently had something to say to me, ant 1 remember her bright. Hack eges to his day. We made it a mule to lease the hospital carly in the afteriwn on account of ils lemote siluation and cur fear w walking from it near

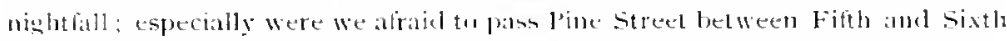
Sirees, where the Neutrals had their luts, of whm we were dreadfully afratid. Either justly or mujusty. Lhey were bot howrtes, and by us regarted ats at clangerous set of people, to be studinusly avoicled.

An entry upon the minutes, April 26,1763 , reveals the fact that some of the patients were of this class:

Admilled as 1 ul Patients Seven French Xeutrals accidentally poinumed by Eitling Poke Root which they hat mintaken for Horse Radelish.

They were admitted on the 1oth inst. and discharged on the 23 d. "leing all recovered." Although no further reference appears in the minutes to these unfortunate people, there can be no doubt but that, on account of their destitute condition and their residence in the vicinity of the Ilospital, they were often treated within the wards of the institution, as well as by the Gut-Patient department.

The mother of the late Dr. James J. Levick, formerly one of the Physicians to the Hospital. 
Althoush the fommers of the imsutution could mot have anterpated that is would ener be lecel as a Military llomplital. for a time. durnes the carly years of the kevelutionary war, it wats furcibly ancopied for this purpone, be the linglinh troops, and both kefore and afere the liritish occupation of the city it was called upon to take a are of mang of the patrios who had been lireken in health. ly exposure in the field or while encamped at lalley linge, or wonneled in varions engagements wh the conemy. Previous to this tune, however. the lirench and Indian war had furnished patients. Afer ciencral lunbar returned to Pholatelphia from bradklock's dinatrous expedition, we find the following unfortunate case anong the achinions, weteler 1,3. 1755: "Mlichael higgins a soldier, wan almited. having his ander jaw shot off in the late lingagement under cieneral liraddeck." A soldier of the koyal Anericams was admited April 25,1757, "for whose loard his Pay and Subsistance Money is to

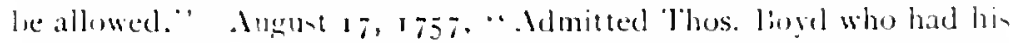

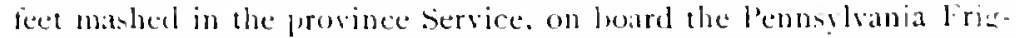

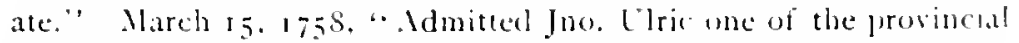
Sollicers disharged ley order of Col. fno. Armstrong. very harel uf hearing. Prest and Manaters Securit.." In this caxe it aplesu that the symplathy of the board was suecensfully appealed to, posslly the fill diagnosis was not recorded and he wat also suffering with general debility and it was thousht that the llopsital treatment misht restore his strength, even though bis hearing failed to be improved. The Manasers and plassicians were obliged to obey their own rules of almision and provide security for a pationt. and. where the sick peroon had no friends, they signed the oldigation themselves. Thus June 26,1758 , "Willian Elliou, a poor patient one of the J'oviscial soldiers with a continual fever. Joctors and Managers security."

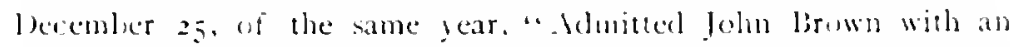
autumnal fever and fico. Wood with a fever: these two are Captives lately released from Canada." June 25, 155\%. "John barlean a French l'riwoner was admitted. an a lay jatient," and on the same dity, "Idmitted Richard Knuwles an a Pour Ont-latient with Rheumatic l'ans he was a Soldier taken at Gewego." (On Vorember 26, same year, there was "Admitted, lames Pendererass a pay l'atient. who lost his leg in the l'rovince Service recommended ly. lon. lex. who fromises that the l'revincial Comminsioners will pay. if necensiry." "lhe victims of prinon dincipline were received from time to time, thus February $25,1,6,0$. "Mlmitted 1 lichacl liutler a loor Patent with Foul licers. He came lately out of a Fench Prison, the present Managers hin security." Jane 30. 1-60. ". Achitted 
John York, a Poor Patient with a bad Leg, had heen a Provincial Soldier and taken Prisoner to Canada and made his escape." August sullier 27 , I 764 , "Henry Fowl a poor soldier (from Fort Stanwicks) with a l'ittum Gun-Shot Wound in his Leg."

When the war of the Revolution began in earnest, the Hospital was of great service both to the wounded patriots and to sick or wounded captives. Thus it is recorded in the minutes December 5, I 776, " that seventy soldiers were admitted the fifth of 'Twelfth month, by order of the Council of Safety," and twenty of them went away at different times in this month. Many of these received their wounds in the defence of Fort Washington, and sulserpuently at Trenton and Princeton. This was the most trying time of the Revolution. General Washington had been forced to retire to the west bank of the Delaware, and General Howe was marching through New Jersey with his victorious army on his way to take possession of I'hiladelphia. The Pennsylvania Hospital now became a Military Hospital. It is recorded in local history that "The Council of Safety cleared a wing of the Bettering House for a hospital, and the lennsylvania Hospital was set apart for the use of Continental troops. - The Senior and Junior Drs. Thomas Bond rendered efficient aid in organizing the hospital system upon a proper basis and securing competent surgical and medical aid.",

In December, Congress hurriedly removed to laltimore and Washington appointed (ieneral I'utnam, Military Governor of the city. Nlartial law prevailed and all male "citizens between sixieen and sixty years of age" were enrolled. On December 30,$17 ; 6$. nine hundred Hessians captured ly Washington at Trenton, were brought to the city on their way to Lancaster. Part of these, being unable to continue their journey, were received into the Hospital for treat. ment. The Committee of Safety was dissolved and martial law rielded to civil goremment, on Varch 4,1777 , when the sul,reme Executive Council took control and its President, Thomas Wharton. Ir., was proclaimed Captain-General and Commander-in-Chief of Iennsylvania, and the Courts were reorganized. "Soon after the beginning of the year there were twenty-two hundred Militia in the City awaiting arms and fourteen hundred sick in the Hospitals." = At this time the capacity of the institution was tested to the utmost. but the Managers were equal to the situation and continued at their post, faithful to the trust which had been placed in their hands.

I Scharff \& Westcott, Vol. J, p. 332. Also this History, page 5i.

2 Scharff E Westcolt, Vol, J. p. 343. 


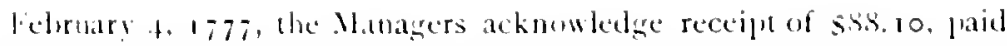

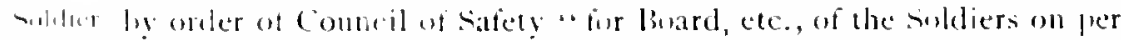
l'ateme Acot rentered." March fth, a commitlec was alpuinted to conter with the phesician epectally "retating to the tse of Mledicines for the soldiers and stators lately introduced." and the following mecting (.)areh 31) entatins the report of the committee, which " informed

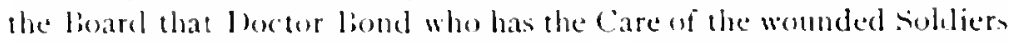
and sailors, angess w pay lor or replace the Medicine of the house used for such as himself is paid for."

Dfer the period of military oreupane the authoritics ocasionally found it convenient to send invalid soldiers for treatunent:

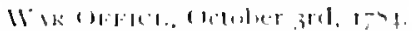

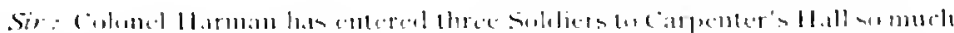

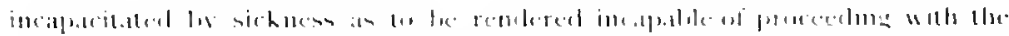

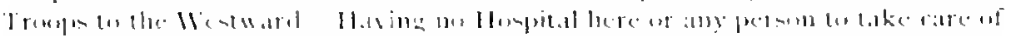

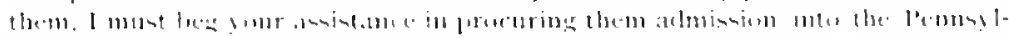

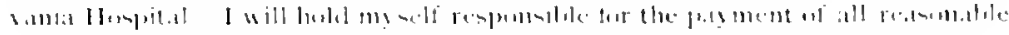

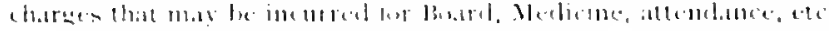

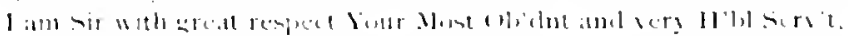

1. (

Neer the war the Nanagers had a number of soldier patients on beir hands. aven for screral gears, as we learn from the following minute of Jumary 30,1756 :

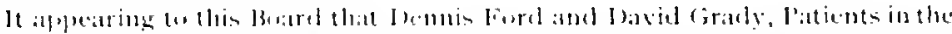

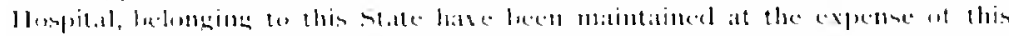

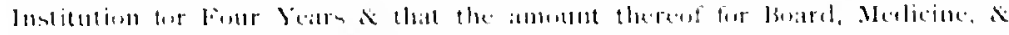

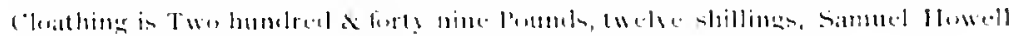

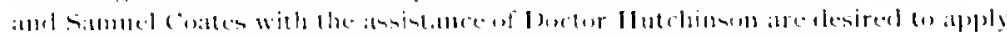

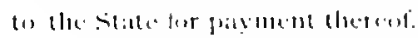

The Managers were finally snccessful in having the claim paid:

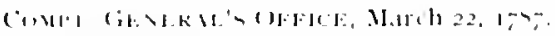

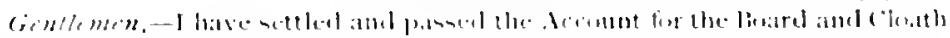

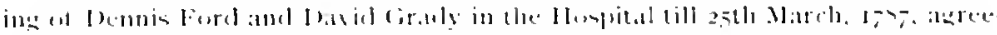

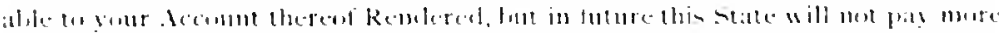

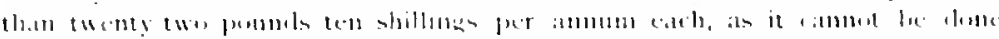

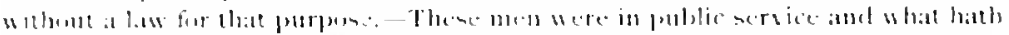

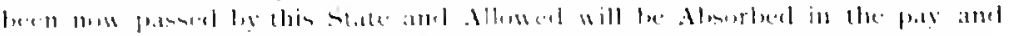

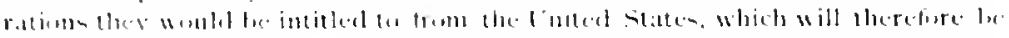

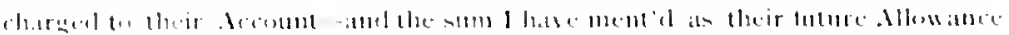

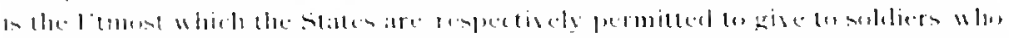

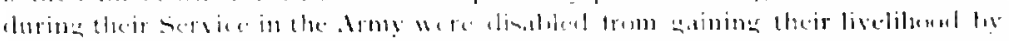

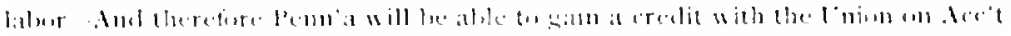

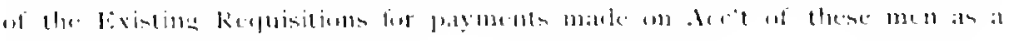
jentinall

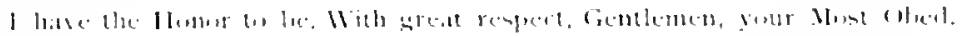
S.r.ust.

I. X゙14+1,nd), 
'Two years later, the following communication was received from the same writer. informing the Managers tha: the authorities had discontinued the payment of pensions to persons disabled in the service :

Genllenen,-The clisabled persons in the Hospital who were heretofore paid for by this State cannot longer be so paid for-as the laws for paying pensions to such persons as were disabled in the Service of this lonited States now cease to have their operation-Acourding to a law passed last session.

It appears that soldiers continued in the Hospital for several years as lay patients, however, as intimated in the following note of March 26. 1792 :

There being a number of sick soldiers in the House at $8+4$ Per lleek, which the Managers are convined is lower than the average Cost of the Patients, it is agreed that Ten Shillings Per lleek shall hereafter be charged for them and the sittiny Managers are desired not to admit any Patients who have the means on making payment under that price in future.

The following belongs to a later period:

SAYTET. Costris, Eso.

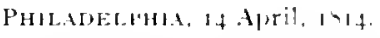

Sir.-As Britisli Agent for Prisoners of War in this district, 1 Hate paid two Bitis at the Pennsyliania Hospital for the maintenance of and attention to wounded prisonets amounting together to six bundred and twenty-tive clollars and twentyetght cents, which Sum Col. Barclay our Comm'y Genl. tells me he does not leet himself athorized to repay me, and seems to doubt whether I shali be able to recover it from the British Gisernnent, no charge being ever made to any Xitinn for sick or wounded Prisoners of llar admitted to any Hospital within his Majesty"s Dominions. Col. Barclay" also tells me that his recommendation in lehalf of British Salors has often met with attention from the Managers of the New lork Hospital unacompanied with any expense.

Ile has requested me to mention these circumstances bor consideration of your board and has desired me to assure the Hanasers that if ally oplortunity should present itself of his being serviceable th the institution le will gladiy embrace it - it was his goud fortune ter repay the obligations he was unler to the Directors of that at New York, by obtaining permission from the British Admiral for the admission of a sessel containing their winter's supply of fiel.

I thatl be obliged by your answer, I am very respectully Sir Yime Obid h'ble Servt.,

A. WALKER JK.

The Managers at their next meeting directed a reply to be sent to the above, insisting upon observing the rules of the Hospital and stating that, although

indivichuals who are strangers and destitute of money and friends are frequently received, maintained and relieved at the expense of the Hospital, yet that in all cases where there are private friends or public ayents the Hanagers take security from them and receive the price anreed for the support of the patient.

A number of years later, during the War of the Rebellion, the Managers were called upon at various times to make extraordinary 
jereparations for the reception of sick and wounded soldiers of our - hdiers army and a large number were admitted and treated. '

the cisil

llar.

At the Contributors' Meeting, May, I 861 , the Managers referred to the impending, terrible scourge of civil war threatening the country, and the necessity of having alditional funds to care for the sick or wounded soldiers who might be l,rought to the llospital. Contributions were frecly offered. The first reception of womeled soldiers wits on Inly 7,1862 , and in Octoler following all were removed. 'The cutire number treated was 124, frincipally surgical cases. On varions occasions since that date, soldiess have heen almitred, both into the medical and surgical wark, and hase been maintained and treated at the expense of the 1 lospitat and no sperial record mate of them. As the occupation of patients was not formerly recorded by the
Ilamagers, it is often only from the nature of the injury that the fact

Sailore and the lnited Sitlen Marine

ltompliti

service biticilla may le infered that the patient in such cases is a seaman, while in a few the fict is incidentally stated. The first to appear in the Minutes. although probahly not the first to be admitted into the Iospital, was "John Anderson (a poor sailor)." admitted May 30,1757 , "with ulcers in his Toes occasioned by (bhigers in his Fect," the discase having heen acquired probably either in the West Inclies, or Central America. William Walker, almitted July 6. 1757, suffering with a "Scorbutic Ilabit and sinuous Cleer in his Thbigh," the result, it was alleged, of "beating 2 other liard Treatment" by Captain Jno. Morrison.

Acridents incidental to a salor'> life also sent patients into the Hospital, thes August 13,1757 . Admitted Jno. Rirhardson (a peror I'atient) who fell from a Ship's Top a broke his thigh." . Ind on the igth, "Thos. Boyd (a poor laticnt) who had his feet mashed on board the l'ennsylvania Frigate." 'The interest of the Managers in the wellare of the patients, especially the poor and friendless ones, is evidenced by the following (Decomber 25, 1758): "Admitted Cicorge Saunclers, a negro boy, with a wound in his $\mathrm{Am}$ an engagement at Sribor Sea, Nicholas Jones his security as a pay patient; the boy being called Lindly a free Negro care must he taken on his discharge that $\mathrm{N}$. Jones takes cared for no advantage of him for his entertainment here." Their sympathy is manifest also in the following entry on their book, January 29, 1759 "Admitted Richard Taytor (a poor Sailor) witl a very bad Wound in his single Eye, the Doctors are apprehensive the Eye is destroyed." It was more substantially shown in the following caie,

See page 95. 
Iune 25, 1759: "Discharged, Edward Dickett a poor Sailor at his request in order to go to London to his Friends. The Managers contributed the sum of $f_{3} 3.17 / 6$. towards paying his passage $\&$ he produced a Receipt from Capt. Nicholson for $\mathcal{E}_{5}$. paid in full for his Passage."

As it is not stated that the Treasurer was directed to pay the sum, it probably was contributed personally by the Managers and not taken from the funds of the Hospital. Among the admissions were several Chinese and other Asiatics, who probably came here as part of the crew of some vessel. Further notice of individual cases would take up too mueh space, and the relation of the Hospital to the United States Marine Hospital Service will now be briefly reviewed.

There were sailors under treatment in the Hospital during the latter part of the year 1776 . for in the entry of January 1.1777 among the admissions for the preceding month, their were "two Sailors, who came in with a number of soldiers and Hessians." On Narch 4 th, "a Committee appointed to confer with the Ihysicians on several matters relating to their Practice in the Hospital, gave an account of the Conversation they have had with some of them in respect to the Pay Patients, but there remains some further conference necessary relating to the use of the Medicines for the Soldiers and Sailors lately introduced there, they are desired to confer further with them thereon," etc. The result was that Dr. Bond, who was then Acting Director-General of Hospitals for the Government. "who has the care of the wounded Soldiers and Sailors agrees to pay for or replace the Medicines of the house used for such as himself is paid for" which the Managers were obliged to be satisfied with. After the British army had evacuated Philadelphia, and had taken their sick with them, Dr. Bond again made arrangements with the Managers for the reception of Soldiers, and, probably, of Sailors also.

By Act of the Congress of the United States. of July i 6, i 798 . masters of vessels were authorized to deduct twenty cents a month from the wages of seamen to be paid to the Collector of Customs, this money to be applied, under direction of the President, for the relief of sick and disabled seamen; provided, however, that it shall be expended in the Distriet where it was collected. This froitso not being satisfactory to the Southern States, Congress by Act, March 2, I 799, authorized the President to have the money expended either in the State where it was colleeted, or the next adjoining one ; the NewEngland members were so tenaeious of their rights on this oceasion, an exception was made of the four New-England States. By Act, passed May 3, ISO2, it was declared, that all the monies so collected 
shoukt form one general fund to tex expended under direction of the fresident, without regard to the l)istrict or state in which the sane wats colleted : provided, however. that fifteen thousand dollars should leappropriated to the building of a llospitil in Massachusetls.

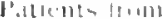
the Varine

llisplit.1 S.1111\%?.t111

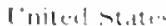
S.IS

The lirst reference in the minutes to the United States Marine Hoypital sersice, appears in the fullowing correspundence, which con tains a jroposition to the Nanagers, from the Lnited states Custom Ilomse. to take Saibor latients from the Lnited states liary and Merohant rervice. On June 24.1799 , the following communication irom the Collector of the l'ort, wa prenented:

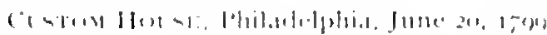

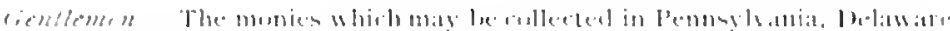

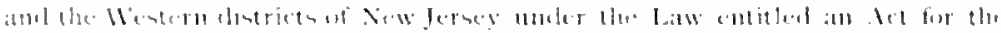

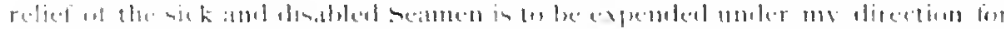

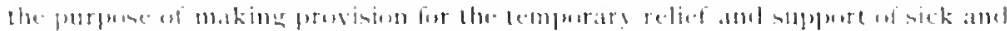

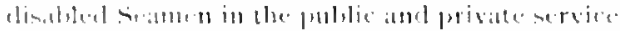

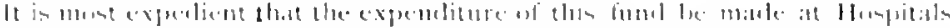

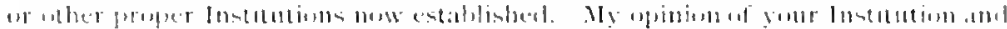

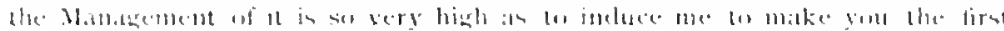

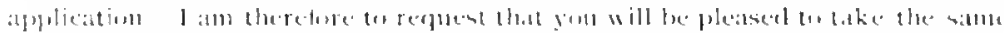

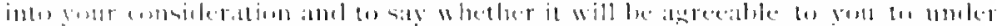

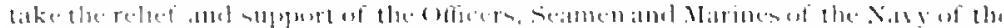

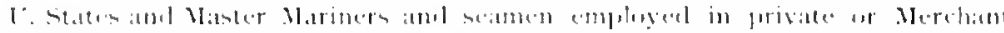

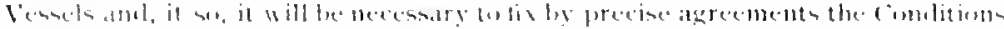

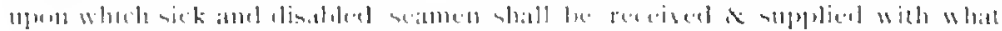

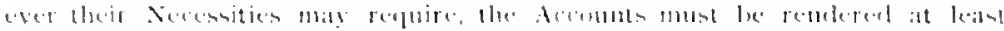

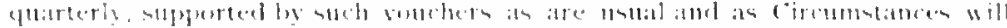

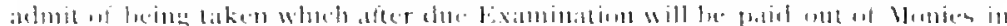

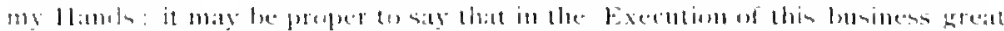

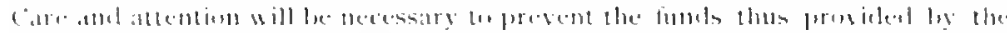

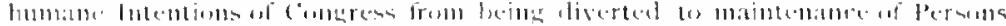

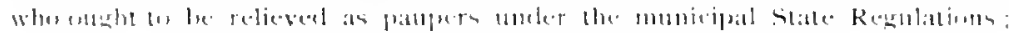

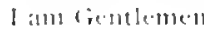

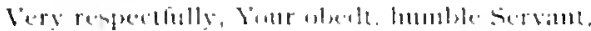

riETRIE: I. IIMI.K

On Julv 20, t 799 . The following action was taken:

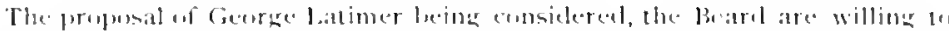

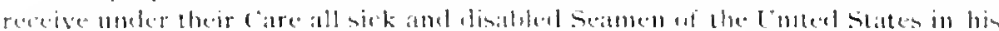

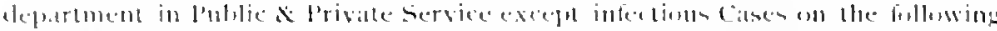

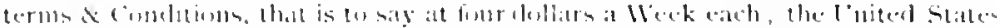

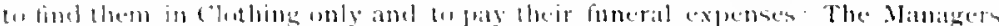
of the lbopital not 20 be surelies for the return of any seameen but these who come inte the Ilonse; all of which they will inform Gesurge Latimer of as they are

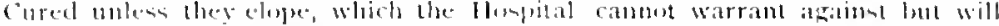

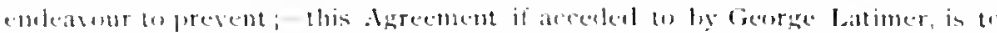

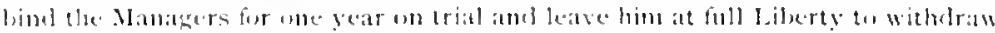
all thme seamen at any time within that periosl that he pleases to make enthe arrangements. 
This arrangement, however. was apjarently not consummated until another overture had been made by the Custom House authorities. May 26, I 800 . George Latmer, renewing his proposal to the Nanagers to take charge of all the sick and disabled heamen of the United States in his department at $\$ 3.50$ per week, " it is agreed to accept the proposal for one year on trial, all infectious cases to be rejected."

The arrangement proposed ly Mr. Latimer was carried into effect, and worked smoothly for several years. The Sailors were examined by the hospital physicians and, when consilered proper stubjects for treatment, a certificate was given which, on presentation to the Custom House authority, was exchanged for an order for admission. They were treated by the Hospital staff and the government officials were notified when they were ready to be discharged.

Soon after the opening of the century, it appears that the Government regularly contracted with the Hospital for the treatment of the sick and injured sailors, as is seen from a communication sulsequently received from Peter Muhlenberg, then Collector of the Port of l'hiladelphia :

$$
\text { (19s'Ton Horse, May } 25,1805 .
$$

Dear Sir:- Will yon have the Goudness to furnish me with a list of such seamen who have been atmitted into the llospital and discharged since the first of April last?

I an requested to state the reason for continuings sone of them in the Hospital -ince 1303 . It seems the relief afforded to disabled seamen by the Lnited States, is considered temporaty and not permanent, and not to be extended to incurables: wherwise in a short time, those who want an immediate and temporary relief, will be excluded by the mumber of those who remain for a length of time. I will thank you to enable me to account for those remaining since 1803 and 1804.

The answer from the Managers is as follows:

PENNSYLYNIA HOSPITAL, sth mo. 30, IRos.

To Peter Muhlenberg Esqr. Collector of the Port of Philadelphia and Agent of the Marine Hospitial.

Respedet foriend:-Thy Communication of the 2sth Instant to the Steward of this lustitution being handed over to the Managers, IVe were requested in their behalf to reply to it and therefort have enclosed agreeably to thy Winh at list of the Patients adnitted by thy order who have been received in the house

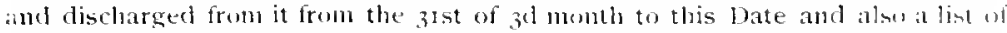
those who bave been long there, say those almitted in 1 boz and 1 so., irom which thon wilt perceise that several of the last have either died of been discharyed sinde the last quarterly Account and that from the nature and evidence of the disente of those who were long continued as patients and of those who remain of this description that they were and are in a State of lnfinity which prevented the possibility of their assisting themselves and if deprived of the bencfit of the Iospital fund must either have heren supported hy some other Charity, or perished in Nisery. 


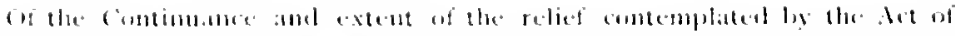

(interan. dence 311

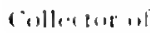
thit lint

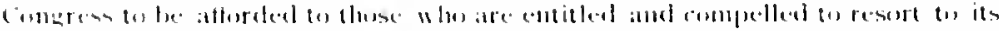

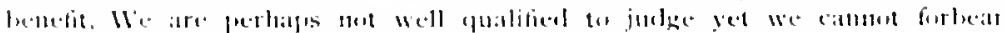

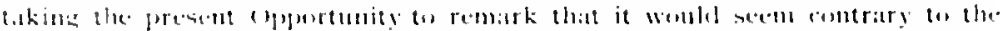

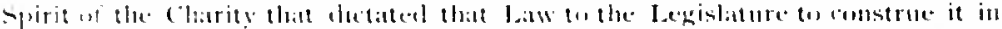

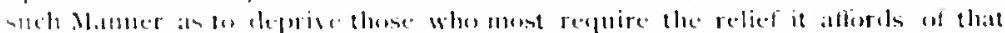

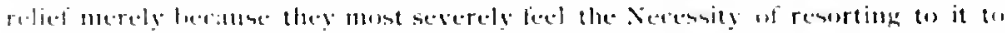

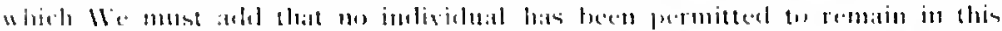

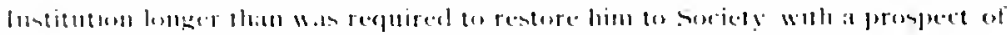

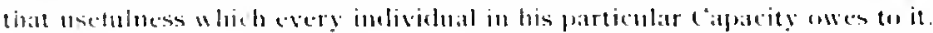

rlis iriensh

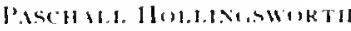

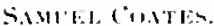

The following letters to the Collector of the Port have some histurical interest :

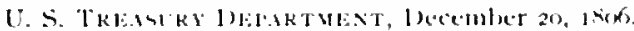

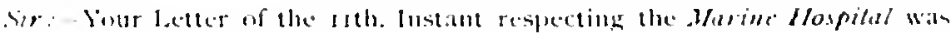

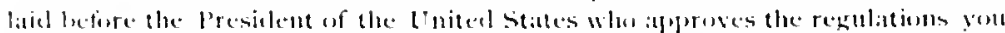
propuse for the reduction of the expenses of that establishunent to a level with the reveipts of the fumels. Ile athe that mo Civil Magistrate can dictate to the louted states who shall he the cobects af their charity.

I all very respectiully sir Sour obulient serst.

AI.HET GiM.ATIN

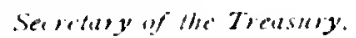

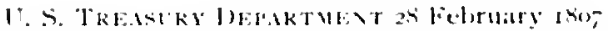

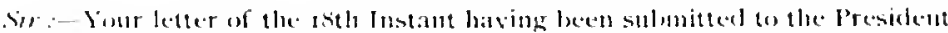

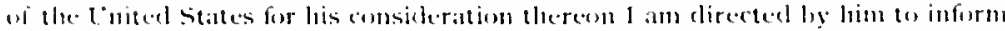

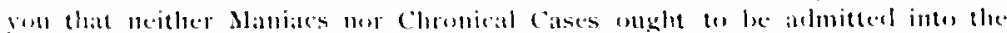

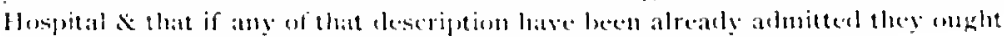
wut tureretatined.

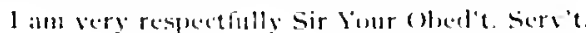

$$
\begin{aligned}
& \text { AIBEKT CiBl.1.1TI: } \\
& \text { Secrefily of the Treasury. }
\end{aligned}
$$

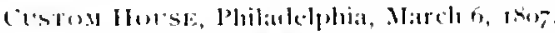

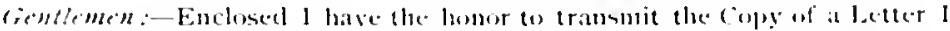

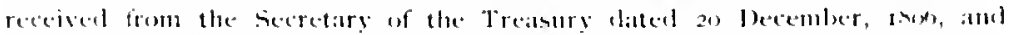

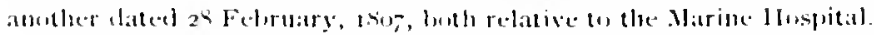

From the lustructions contained in the latter I presume it will be necessity :hat the Ilospitat phystians should in their certificates precisely state the Nature

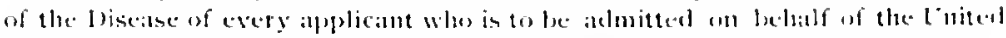

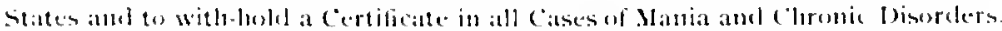

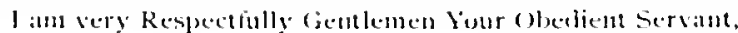

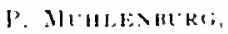
Collecter of the /int.

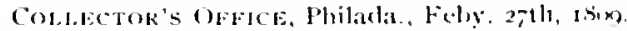

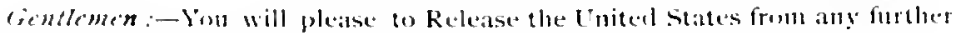
Expense hy dischargith from the Marime llospitat the persons whose Namus are contaned in the inelosicel l.ist.

1 am very $R(x)$ eetfully Gentlemen Sisur olult Servant.

Jut STELER.

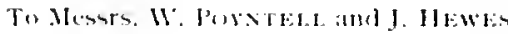

Cilletor alld fgent .1/urine /lespital. 
This letter and list of patients was referred to a Committee of the Sitting Managers "who are requested to procure in Writing from Dr. Rush, his report on each of those Cases for the Collector's information, and if he insists on the patients leeing discharged, the Committee are to require the Collector to remove them (agreeably to the terms of Admission) as expressed in the Notes he signed for each of them when received in the House."

The Committee to whom was referred the Collectur's better of the $2-$ th Uitimo bring before us a Report and better of Dr. Rush, of which the following is a Copy:

PENit. Hosprtal, 3 mus. f, thikg.

In Conformity with directions the Janaters Respect fully inform the (ullector of the Port of Philadelphia and Asent fir the llarine Fund that they have obtained the Annexed Opinion of Jr. Rush on the Cases who ly the Culfector's Note of the 2-th Ultimo are ordered to he discharged; If alter a Reconsideration of the Subject with this document lefore him the Collector should persist in his. determination the Managers will unquestimably comply at the same time informing him that the Rules of that Inouse in compliance with the pur laws of the State which make it necessaty that the Security of every Person received into it should engage for the Patients removal when discharged must be complied.

If therefore the Collector should believe it right to remove these misterable Objects the Managers have directed the Steward to deliver then to him or to such Person as he may authorize w receive them.

$$
\begin{aligned}
& \text { JWIAH MEWES, } \\
& \text { THos. MJokkIs. } \\
& \text { Nhech yth, shog. }
\end{aligned}
$$

Tothe Managers:

l lave Carefully examined the Cases Viz. Isaa [lavis, Wm. Johnson, John Roberts, $11 \mathrm{~m}$. Barker, John Moore, Thomas Churchill and Jolun Tree and am of Opinon that it will he incompatible with the duties which the Mindigers and Physicians of the lluspital Owe to Humanity and to Society to discharge them at the present time and for the following Reasous.

Isatac Davis and William Barker are aftlicted with a arulent Dised se of such a Grade as 10 render both of them hathiome Objects of Comprassion and wholly unfit to maintain themselves hy atny kind of labor or to be admitted into any House but a Hosipital.

Whllam Johnson is aftlicted with lameness and Epilefsy the latter of which has reduced him to a state of fatuity so complete as to place him more upm the level if a hrute than a Man.

Juhn Moore. Thomas Churchill \& John Tree are all insane and unable not unly to support themselves by any kind of labour lout if enlarged from their present place of Confinement may pussibly injure themselves or others. Thomas Churchill is lame as well as deranged.

John Roberts is afflicted with a sore lorot athended acith a Curies of ane of its bones: he is unable to walk or work, tine and the Medieal Aids of the Hospital may Cure Him.

(Signed) BExyAMX RISH.

The preceding Minutes and Letters were delivered to the Collector. It is not known whether this reply was satisfactory to the Collector or not, but it appears to have terminated the correspondence. 
I keter taled May $2 \$, 1821$, from John siecte. Collectur of the thensut l'ors, stating "that he is atuhorized hy the secy, of the l'Teasury to

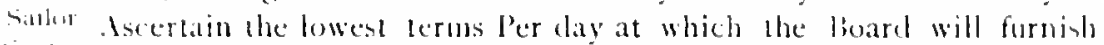
Potiente. Herthe P'atients with the necessary Medical s surgical aid lodging nursing for their Comfortable Accommodation," was read and referred to a commillec which made the following report:

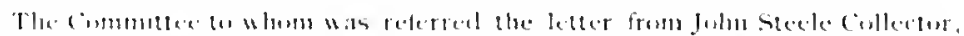

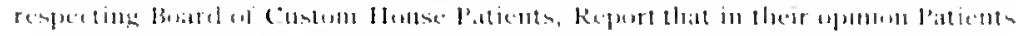

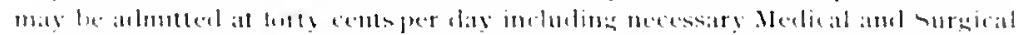

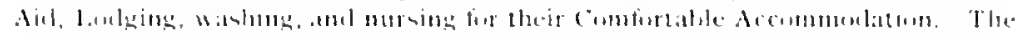

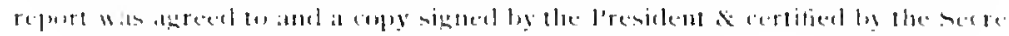
tars dirented to be hormislued the cillectur.

On (Octuber 31,1825 , the Managers concluded to increase the rate of the sailors' board:

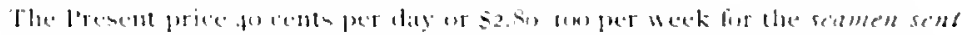

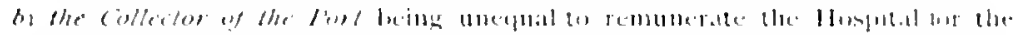

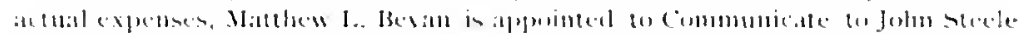

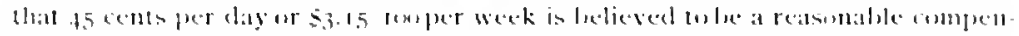

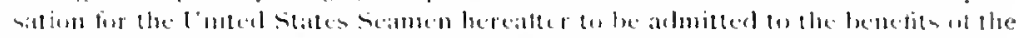

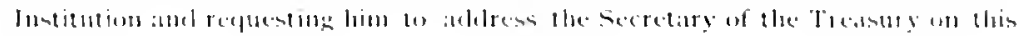
Sulijert.

May so, is 30 , the Collector made an attempt to have the rate renluced again :

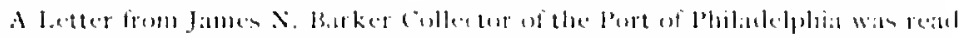

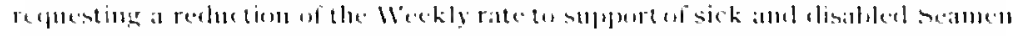

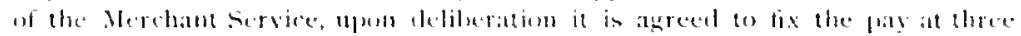

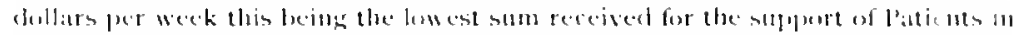

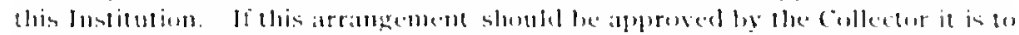

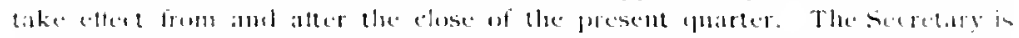

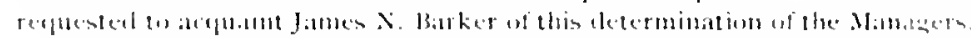

I'his arrangemenl was continued will the Marine [lospital service, until it was found inexpedient to comlinue the yearly combact, which was annulled finally, Nay $3 \mathbf{I}, \mathbf{1} 880$. by the Managers declining to bid for their support. Scamen, however, are not excluded by this action. American sailors appear among the recent accilents aml also among the sick, as free patients, whenever deemed suitable fur admission. English sailors are admitted by order of the liritish Consul, and seamen of other nationalities are likewise received on Consul's order, or as free palients.

rle. At the lime that the lennylyania Hospital was organired, in Muthm 1751, midwifery was in disrepute among physicians, partly lrecause it

Win. Was usually practiced ly ignorant old nurses, but principally herause olstelrics as a science had not yet heen born. In fact, it was gener- 
ally considered improper even indelicate for a woman in labor to have a male attendant. A healthier state of public feeling was soon to be created upon the suljject. Dr. Wm. Shippen, Jr., with all the Neglecet of Midwifery. enthusiasm of youtl and fresh from his studies in the European Hospitals, determined to remedy this deplorable state of affairs ly. delivering public lectures upon Midwifery; he accordingly began his first course to men and women in $\mathrm{I}_{7} 65$, and opened a private lying-in institution in l'hiladelphia, the same year.

In the "Pennsylvania Gazette" of January 1,1765 . appearel the following moving apjeal:

Dr. Shippen, Jr., havine been lately cilled to the assistance of a number of women in the country, in difficult labors, most of which was made so by the unskillful old women alwut them, the ponr women having suffered extremely, and their innocent little ones being entirely destroved whose fives might have leetl casily saved by proper manarement, and being informed of several desperate cases in the dificent neighborlowels which had proved fatal to the nuthers as ${ }^{2}$ their infants, and were attended with the most painful circumstances too dismal to be related, he thought it his duty immediately to bexin his intended conrses in Midwifery, and has prepatred a proper apparatis for that purpose, in order to instruct those women who hive virtue enourh to con their ignorance and alphy. for instructions, as well as those young gentemen wow engaged in the stucly if that useful and necessary branch of surgery, who are taking pains to quallify themselves to practice in different parts of the country with safety and advantate ti) their fellow citizens.

The Legislature, in 1793 , proposed to extend the nsefulness of the Hospital by authorizing the Managers to establish a Lying-in and Foundling Hospital whenever moneys should be placed in their hands to do so. The following is an extract from an Act of April i1, 1793:

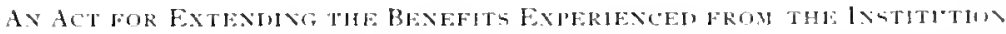

$$
\text { WF THE PFXNILVANA HUSHTAL. }
$$

A.t Autlou izing the

WHEREAS the extencling of the usefulness of the institution to the further

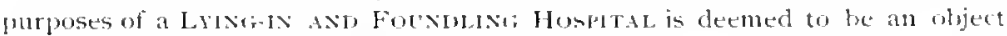
clestring of pulslic encouragement :

THEREFORE, BE IT F[RTHER EXACTEI hy the authority aforesaid, THAT

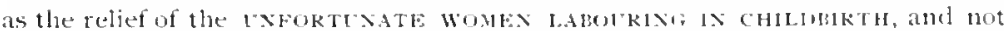
able to provide for the expenses neessarily incident thereto, and also the misfortunes of suftering and forsaken infancy, are ofjects very deserving of some humane provision, it shall and may be lawful for the Managers of the Pennsyl. vania Iospital to provide commodions apartments, for the purpose of answering the ends intended by a Lyins in and Foundling Hospital, wheneser monies shall be placed in their hands for such a purpose, and that they are hereby authorized to call for any such sums ats maly now be destined for such an use, whenever they shall be in such a situation to carry the benevolent design, for which such

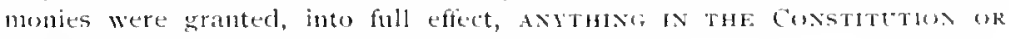

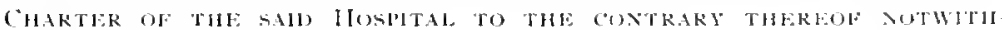
atsines.

Approved April the I Ith, 1793.

THOMAS MIFFI.1X,

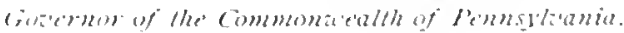

Establishing of : Lying-in and Foundling Departnent in the Iuspital. 
It is of historical interest that a lyingrin ward was estahlished in Lyine in 1802, at the Almshouse, by 1)r. 'T. Chalkely Janes, assisted ly Deparment lor. Church. Subsepuently, after Church's early death from Veliow Amshnime. lever, the work was continued by l'r. James in conjunction with 1)r. Cithaniel Chaman. Dr. James gave his annual course of lectures at the city. Almshouse, in connection with the. Medical bepart. ment at the College. On the death of I)r. Shippen, in 1sos, olstetrics was aeparated from anatomy in the college curriculum, at the instance of Dr. Caspar Wistar, who had been raised to the chair just vacated, and the new chair of Midwifery was given to I)r. James. with Dr. Nathaniel Chapman as adjunct. This arrangement continued until is ${ }_{3}$. When Dr Chapman was elected Profesor of Nateria Medica, and midwiery devolved solely on l'rofessor James. It was not, however, until is $s_{+3}$ that the Trustees of the Cniversity fully recognized the standing of this department of teaching by making attendance upon the lectures on midwifery olligatory upon the students. who expected to whain the medical degrec.

The necessity, in the very early period of the llospital history, of a Lying-in department was not recognized by the medical profession and the Managers were averse to it, because they did not wish to appear to encourage immorality. They were, moreover, opposed to establinhing a foundling asylum, which was thought to be a necessary adjunct, but which did not come within the scope of the Honpital plan.

There was no reason why obstetrical cases should not occasionally have been received, yet no mention seems to be made of any of this class until thirteen vears after the institution had been in active First birth at operation. The lirth of a child first occurred within the walls of the the Hompitil. Hospital July 17,1765 . It is recorled under this date: "Born a female chile of Nartha Robinson a poor jatient."

"The advantage of having accommodation, for these cases was not realiced until some thirty-seven years after the first birth had occurred, and some fifty years from the beginning of the Hospital's active operation. On December 27, I 802 , Samuel Coates "proposed the opening of a lying-in Department:" lut the subject being "considered of too much importance to decide on without a full lioard it is agreed to refer it to he reconsidered at the next Meeting. at which the Physicians are all requested to Attend and James Hutchinson is to notice them accordingly." It will be olserved with what extreme caution this new departure was received and acted on. The next mention made of the matter was on Jantrary 3, I803. when: "The Propusal to admit L ying-in Patients came under con- 
sideration, after which the Physicians withdrew to confer with each other, and when they returned they informed the Board they all agreed as to the propriety of opening the Lying-in Department, and if the measure was adopted they would undertake the care of such pregnant women as might be admitted and to attend to their calls in every case of emergency as they usually do to other patients."

Ihovesicians in fiscor of Establish. ment if 1-yingrin bepartmuent. It is evident that the physicians had become by this time fully impressed with the necessity of just such a provision.

It was, therefore, not until nearly ten years had passed, that the Contributors accepted the provisions of the act of April 1 I, I 793 , establishing the department, and agreed to receive presnant women on the same terms as other patients.

The following announcement appeared in the "American Daily" Advertiser" 'for February 22, 1803:

"It is with great pleasnre we inform the public, that the Hanagers of the Penusylvania Fospital, pursuant to the puwers granted to them be the state legislature, have agreed to open in the house of a lying-in department and that the first patient has very lately been admitted therein.

"The terms of admission are to be the same as in wher cases: that is, a woman may be admitted as a pauper, when the number does not exceed, what the income of the caprital stock, and the profits arising from pay patients which is expended on the poor, will maintain; the number at the present time are forty persons.

"When the poor list is full, those who send a patient, will have to pay from three to six dollars a week. Wversects of the poor, of Pennsylania, are alwas to be charged at the lowest rates, but panpers sent from anuther state, will be charged four dollars a weet.

"Good security must be given in every case to remove the woman and inild, when required.

"The usefulness of this branch of the inatitution, will be evident (1) every person who feels the importance of provieling a comfortable astlum for poor lying-in women, and of rearing proper Surses and slidwives, under the care of able Plysicians, whereh the lives of many may le saved, that would be aracrificed in the hands of ignorant or unskillful practitioners.

"As the enlarement of the plan of the Hospital and the extension of its care, to the female part of the fimily in particular, will involve the contributors in further expenses, it is to be hoped that donations and legacies will be given, commensurate with the ereat design which is herein contemplated.

"To express the nature and uses of the l'ennsylvania Huspital in a few words. it is an institution, not founded on la ralion, hut on woluntary comtributions for the benevolent design of curing or alleviating the miseries of the lunatios and sick poor of Pennsylvania and fir the care of iyine in women.

"Can any objects be more propes to engage the attention and command the resources of evely class of our wealthy and charitably disposed citizens, through the State of Pennsylvania?

"For the information of those, who feet an impression of cluty to assint the classes of poor alowe mentioned, it may be riglt to observe the ustail wity of doing it, is

"First: By calling on Juseph S. Lewis, Treasurer, who is always prepared to receive contributions, and

"Second: By legaties ton the contributors in their corporate name, as folluws. viz: I give ten, twenty, one lundred, or one thousand, pounds, $\& c_{\text {, }}$ to the com tributors to the Pemsylvania Hospitaj, for the nse of that institution."

The Lying-in ward was opened May $10,1 \mathrm{SO}_{3}$; the first admision being on the 3 oth of March, and the first birth was that of a female child, on the $27_{\text {th }}$ of April of that year. 
The following partial list of subscribers to the laing-in Departsimcial unent was repurted:

Sulmitiptions

(1) 1.yills in

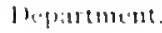

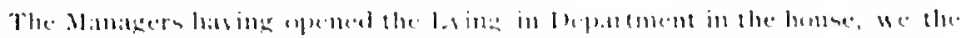

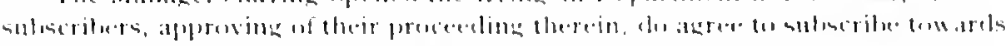

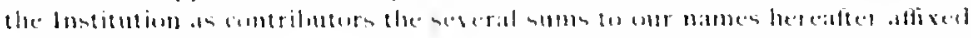

\begin{tabular}{|c|c|c|c|c|c|}
\hline Stephen Giratrel & - & & & & $\therefore(3 k) 1$ \\
\hline Sinmuel Rliosucls & - & & & & $3 " 11$ \\
\hline I:Iונs & . & . & & . & 30,131 \\
\hline 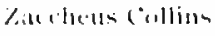 & - & - & & & $1(x)(M)$ \\
\hline Nilliam Viı:or! & & . & & & (3) 13 \\
\hline l'hilip smyth & & & & - & 30103 \\
\hline $111^{\circ} .0^{\circ}$. & & - & & . & (i) (n) \\
\hline Jeremiatl 11 irelex & 11. & & & . & in 130 \\
\hline 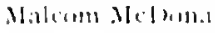 & & & & & $30(x)$ \\
\hline
\end{tabular}

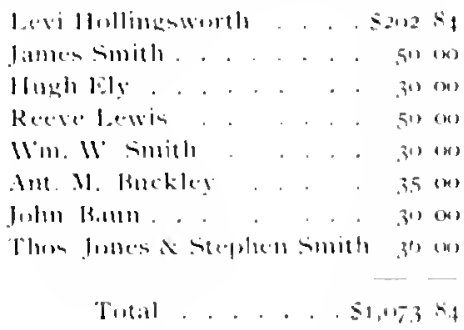

A very interesting, historical fact, in comnection with this depart. ment, now to be related, will illustrate the high estimation in which the Hospital was held as a well administered charity.

firat city"

In 1807 , an offer was made by the First City leop of Cavalry to

Trumpuif contrilute certain securitics, which they held as invesments and Philathlihil which represented the amome received by the officers and privates of itfier a lineral

Ihollinis. the City lroop for service during the Revolutionary War. The conditions and purpose of the donation are expressed in the following agreement :

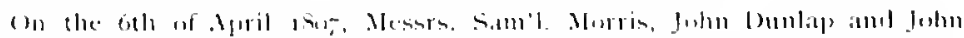

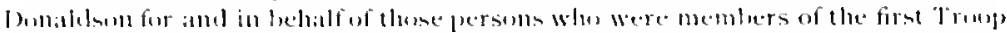

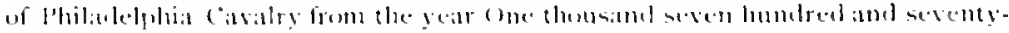

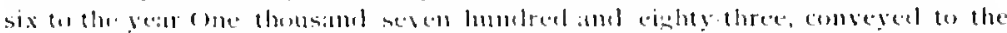

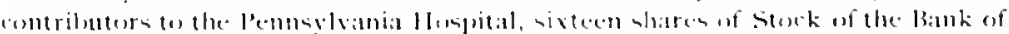

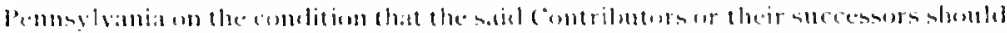

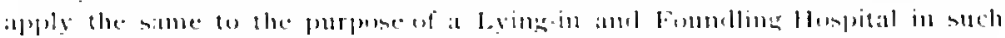

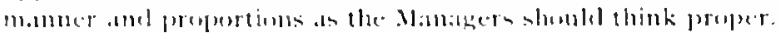

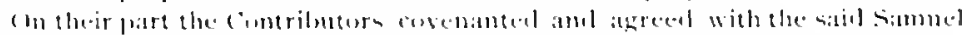

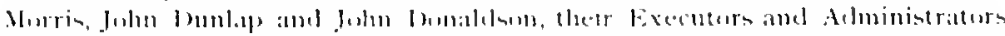
thet they will well anel truly apply the proseeds of the sitid hixteen shates of

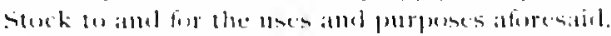

The Deed states that the above sixteen shares of Bank Stock represented the amount awarded by the United Stales Government to the Troop, which had been allowed to accumblate since the Revolutionary War.

At a meeting, on April 27,1807 , the 'lreasurer reported having received a transfer of sixteen share's in the Pank of l'ennsylvania. These were creditcd at par and the amount accepted as a special contribution to the lying-in and Foundling Hospital. These shares of bank stock represented a capital of $\$ 6,400$, and yielded an average annual 
income of $\$ 456.50$. The funds of the Hospital being considerably increased by those shares, "the hoard agreed that forty-five poor patients (in all) may be admitted at one time of whom not more than eighteen shall he Mlaniacs." Among the rules subsequently adopted (February 10, 1810) was the following: "Pregnant Women of our own State who are poor and proper objects may be received, without security except for the removal of themselves and children when discharged. The Maintenance of the $\mathrm{M}$, thers and their infants including Clothing when necessary to be charged to the income of the Cavalry fund and in case that proves insufficient, to the general funds of the House." On September 29,1845 , the rules on admission and discharge of patients, were altered to read: "No woman shall be admitted to the lying-in warl without producing satisfactory evidence that she is a respectable married woman."

A communication was received, April 30,183, , from John Sargeant, President of the Preston Retreat of Philadelphia, enclosing a request from the Board of Managers of that Institution, that the Lying-in Fund given in trust by the First City. Troop should be turned over to the Preston Retreat. To this the Managers replied, May 28, i $\delta_{3} S$, as follows:

On an investigation into the state of the bying in fund given by the First City Troop of cavalry to this Institution, it appears that the said fund butl principal and interest, was expended previously to the year 1831 , and $5 \mathrm{r}, 656.29$ besides.

This is the last note with regard to the Cavalry Fund, and it is a satisfaction to know that it was fully expended for the relief of suffering women, even if the foundlings had to be provided for elsewhere.

As previously mentioned, the Managers elected Dr. Thomas Chalkley James, the first physician to the Lying-in Department, in I 8 ro.

Dr. Janses served until November 26, 1832, when he resigned after twenty-two years of most acceptable service. Dr Hugh I. Hodge was his successor, and served until the department was closed in $18_{5} 1$. At the request of Dr. James, an associate physician was appointed in 1820 ; Dr. John $\mathrm{W}$. Moore being the incumbent, who was succeeded in 1829 hy. Dr. Charles Lukens, who resigned in 1839 , when Dr. Charles D. Meigs was elected, who in turn resigned in 1840 , and Dr. Joseph Carson succeeded him.

On March 27,1815 , it was agreed "no resident physician or pupil shall at any time undertake to deliver a pregnant woman in the house without sending for the principal physician of the lying-in Department." 


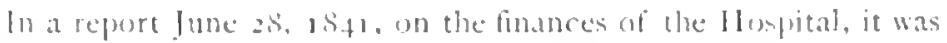
(Toxims of stated :

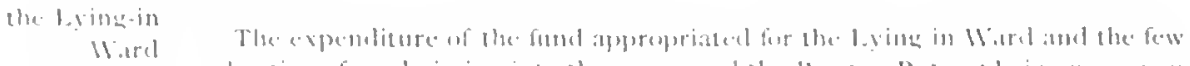

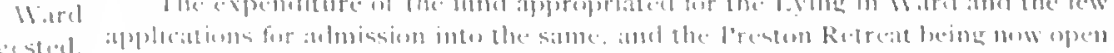

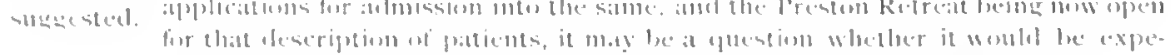

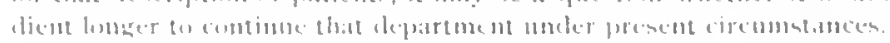

The I, ing-in Jepartmest was opened, in $\mathbf{x}$ So 3 , on the second Hoor of the bist Wing. Jamary 27,1817 , the Managers directed that the Contributors' Room shoukl be littect up for the purpose, which was thus occupied until february 23, 1824 , when the bookcancis were directed to be removed from the second story of the centre bullting, so as (o) appropriate this chamber for the use of the Lying-in l bejarment.

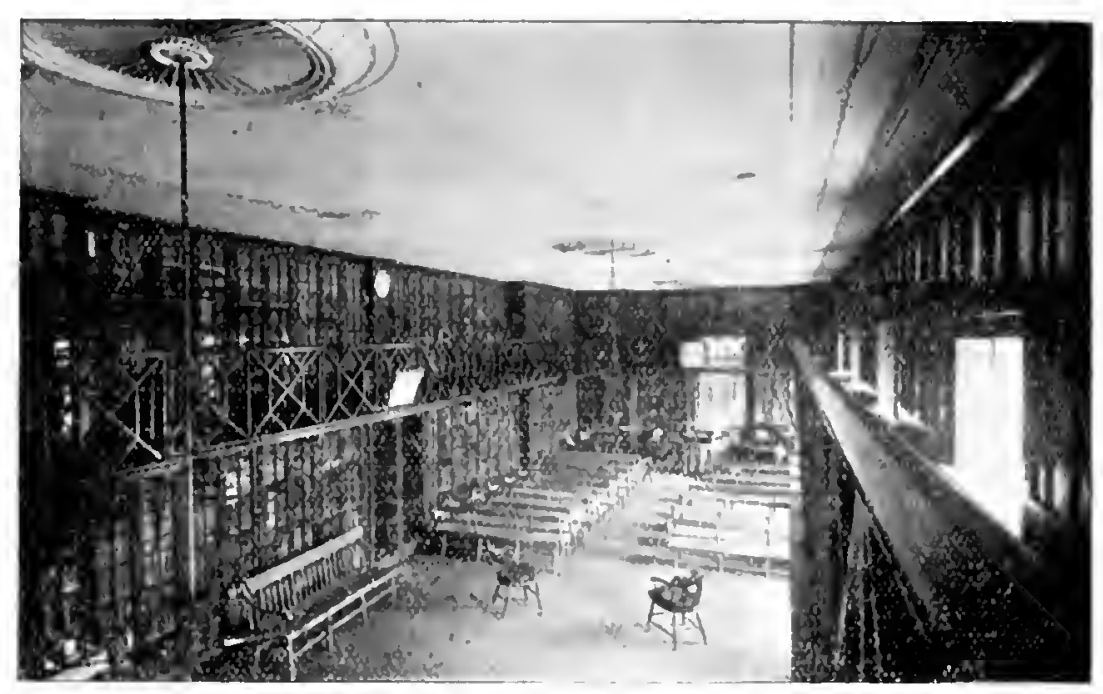

Rom usen fon L?mg. in Department from In 24 to 1835 . Since occupied by the Libraty.

linerperal Fexer :tmong the the

P.utients.

Fowards the latter part of 1830 . the physicians called attention to the frequency of puerperal fever. On December 2 th, the Lyingin Department was ordered closed until otherwise directed. The next fall it was decided that the wards could lee safely re-opened as they had been thoroughly cleaned. On October 26,1835 , it is agreed to open the new Lying-in ward in the Picture House, and the department continued its work in the same place until 1851 when the physicians came to the conclusion that the poison of puerperal fever had become endemic, and they, in wise use of their discretion, 
closed the wards, and the department was finall! abandoned, Mayz. I $\$ 54$. It had cost nearly $\$ 20,000$ in excess of the whole fund, principal and interest, received from the City Troop.

During the period it continued in constant operation (with the exception of parts of the year 1830 and 1835 ) for forty-eight years until I $85 \mathrm{I}$, there were I 330 women safely delivered, I 30 removed by friends before delivery, 67 died; total number confined, 1397 , the rate of mortality 4.79 per cent. The date of the admission of the last patient was February 15 I $85 \mathbf{1}$, and the last birth occurred on March th of the same year.

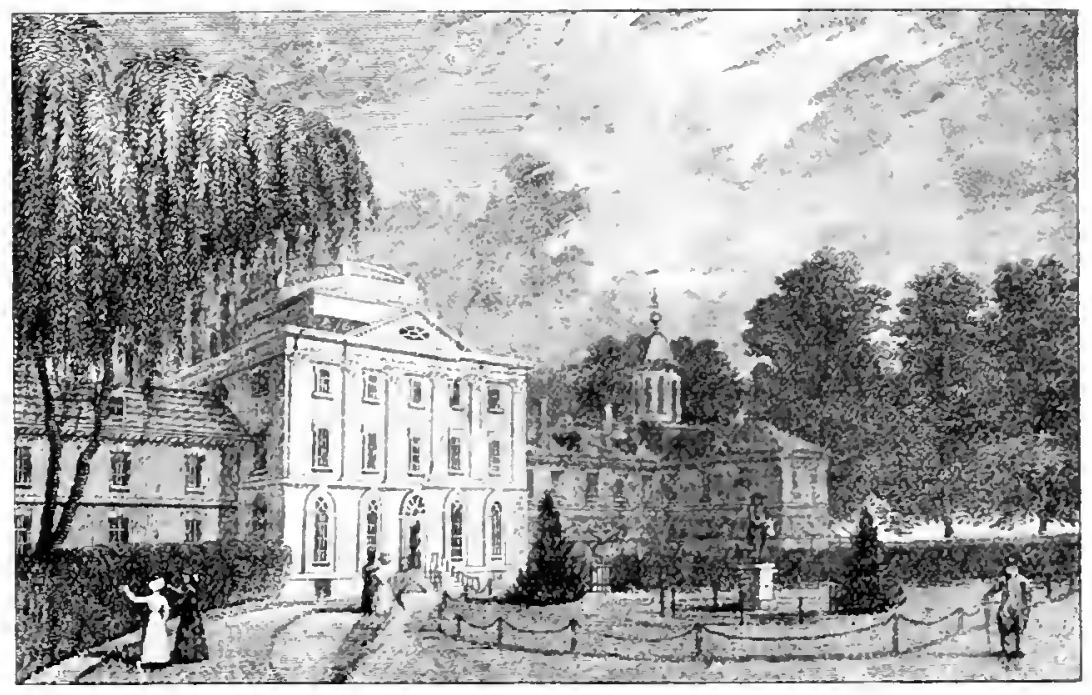



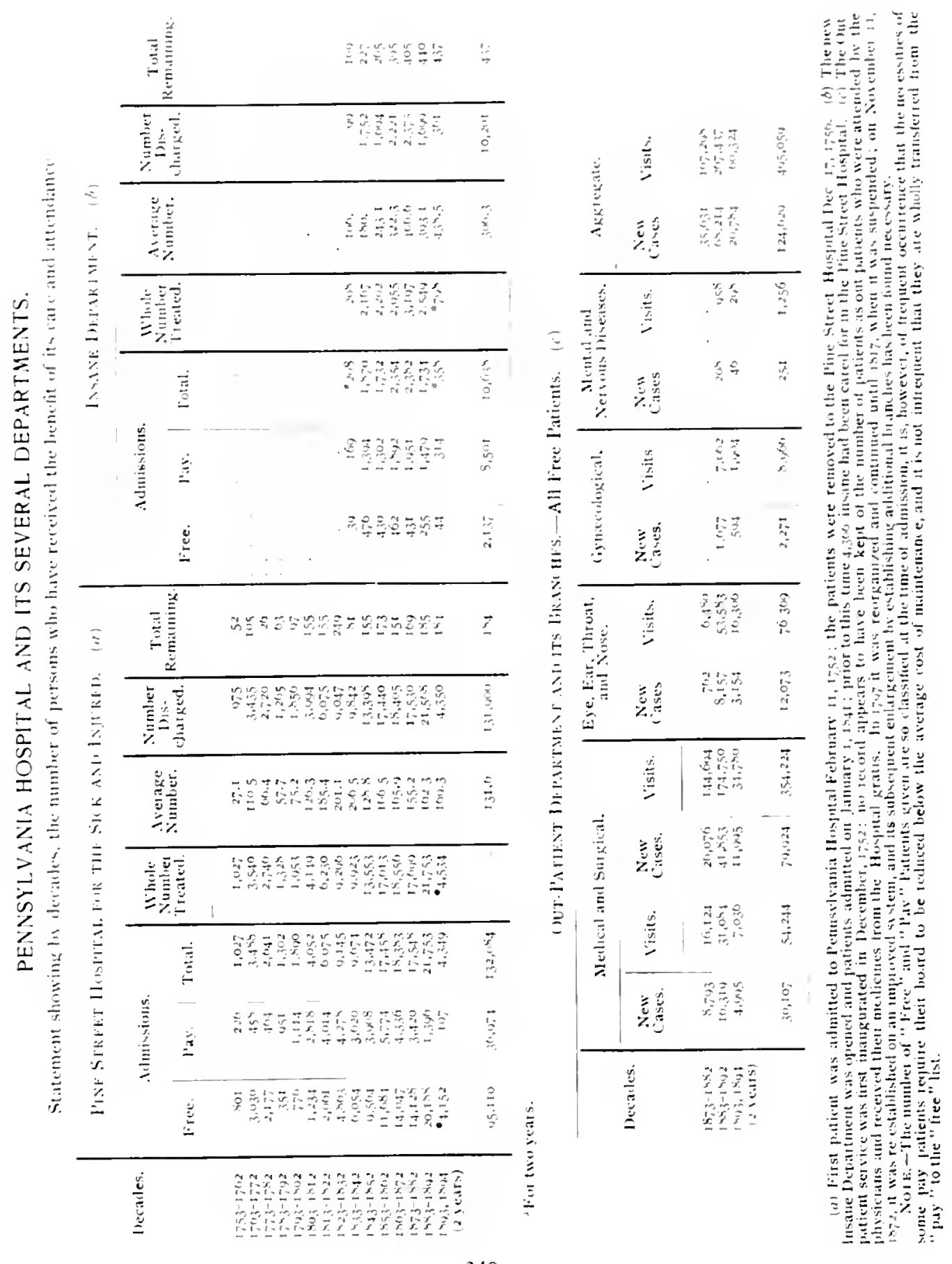


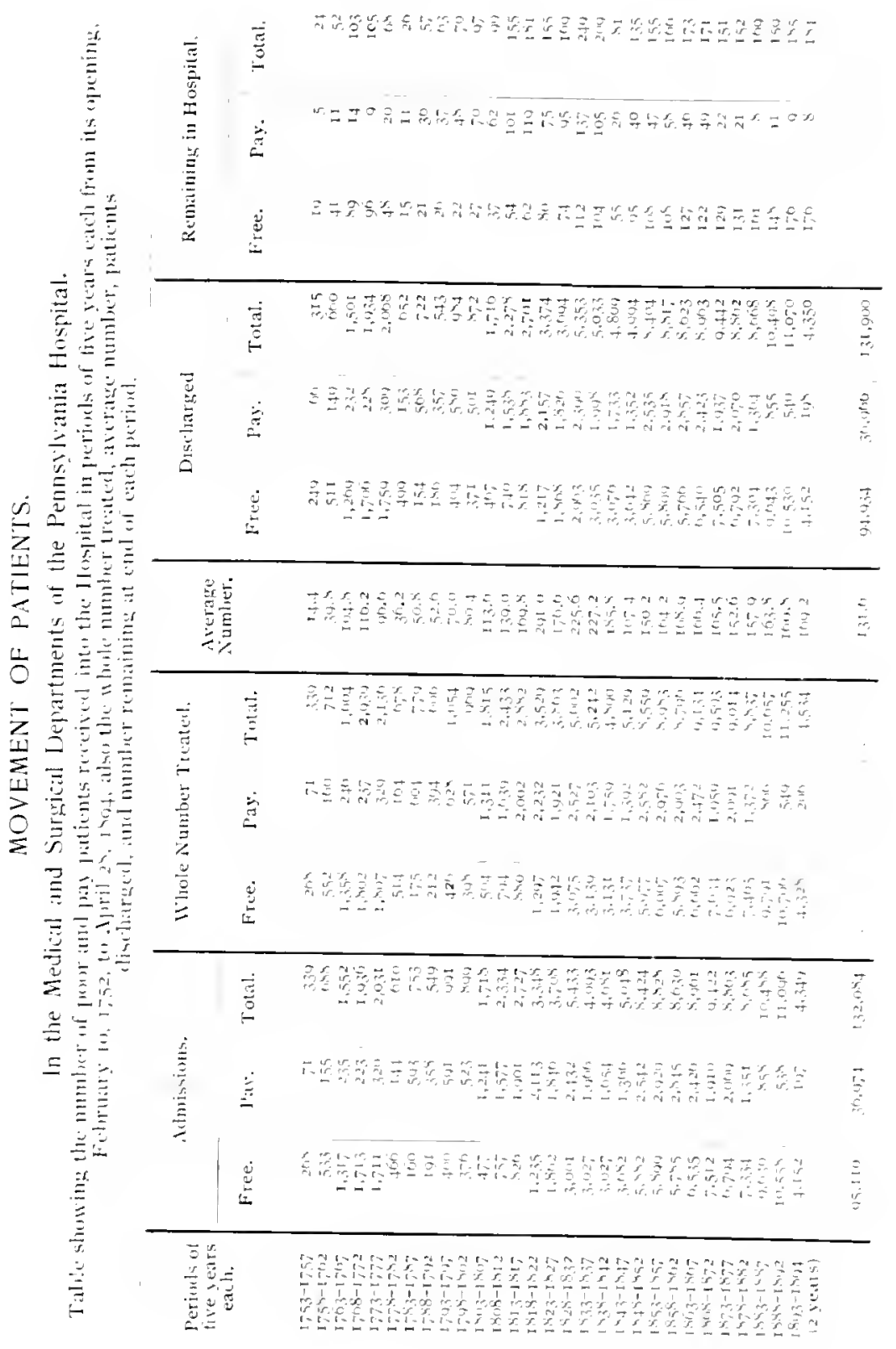




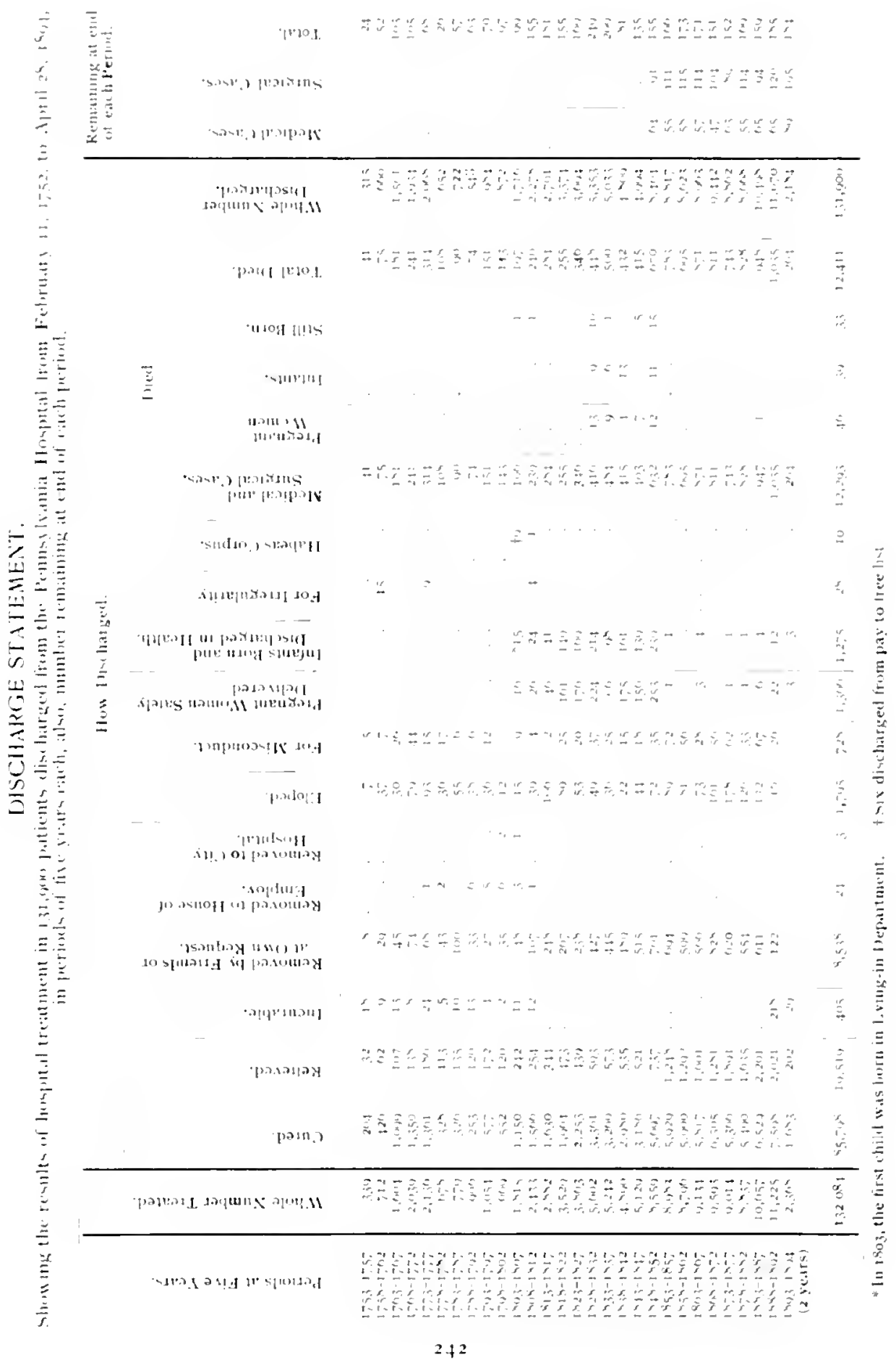



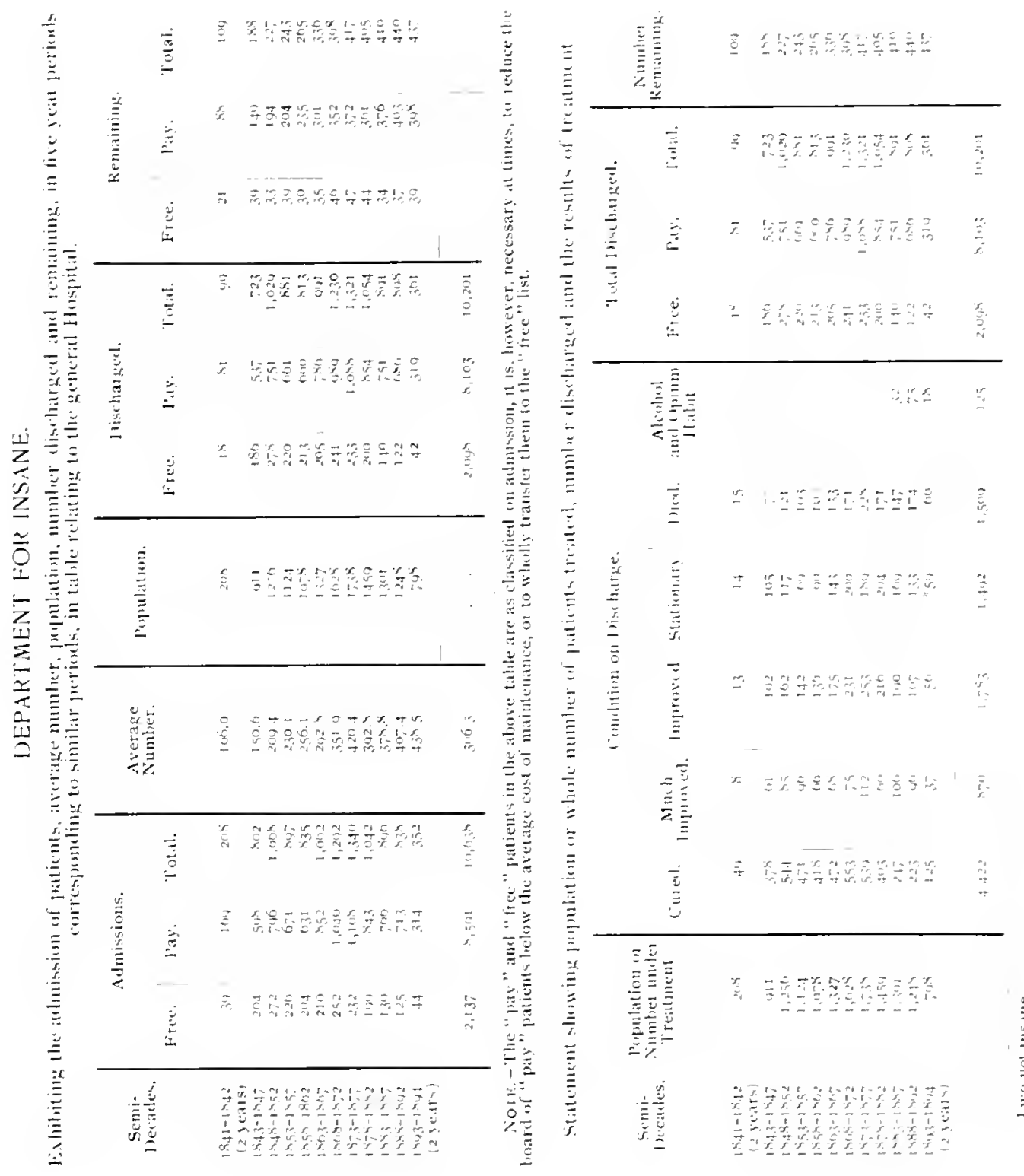


\section{RECAPITULATION.}

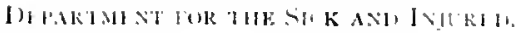

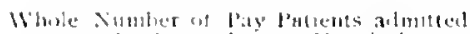

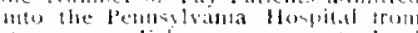

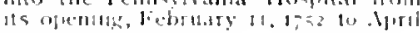
$24,1+2$,

$3+15,4$

\section{it tent}

kellesid

Inemalile:

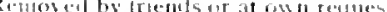

kentised to lfome of Enploynent

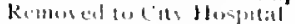

1. Loperi

For miscondant

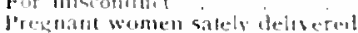

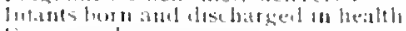

fin urexulatity.

Ko But in IJulieas iorme

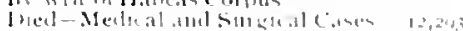

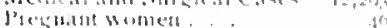

lintiknta

(i) (1) boll1

Whote number of loos l'aticuts admuted

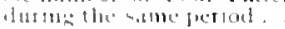

Whole number alisch.trieas

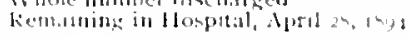

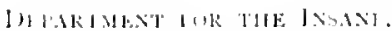

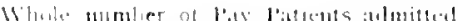

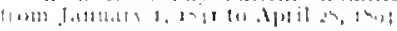

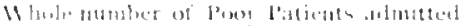

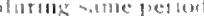

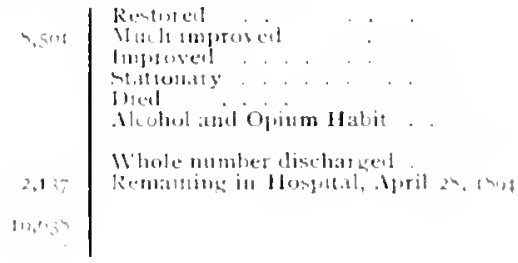




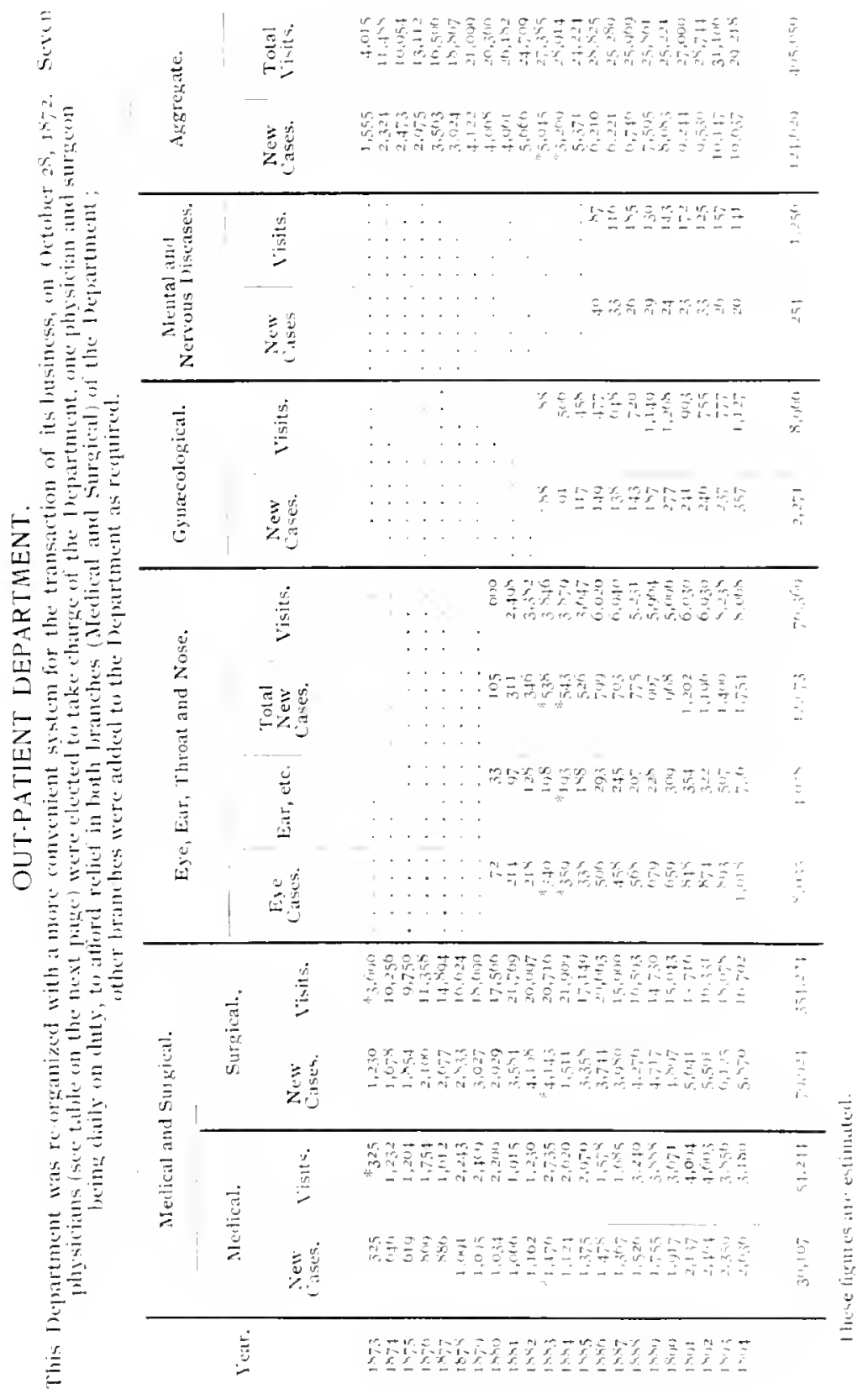




\section{OUT-PATIENT IUEPAR TMENT.}

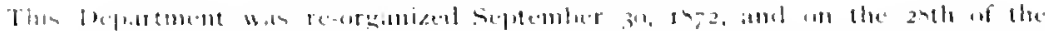

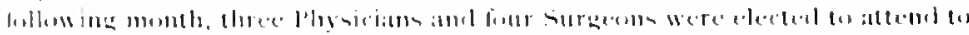

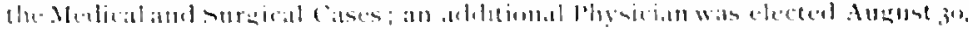

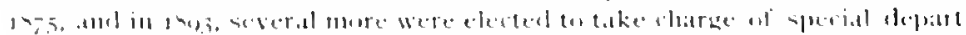

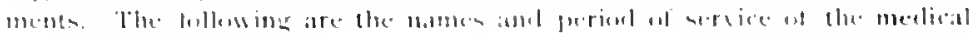

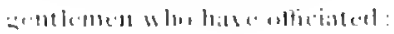

Mubis iams.

When Elented
Term of Sictse.

Kenignea!

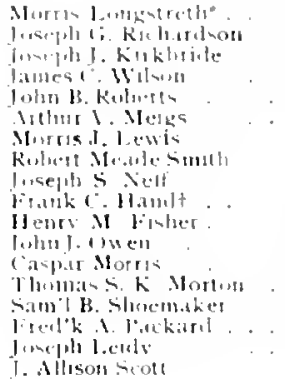

I. Allison seot

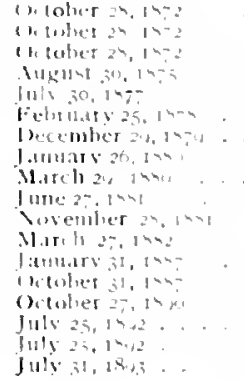

July $21,1,2$
Surgens.

When Electer l hew

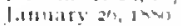
inclolet 31,149 lule zow ing

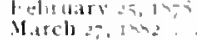

linge 25 , ing

M.trcli $29.1 \mathrm{nmol}$

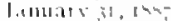

Vorenalier in int

Iแ1 $25,10,2$

I uls 25.1012

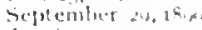

$\mid$ |ind $2,1<2$

\section{Ieatra Minth}

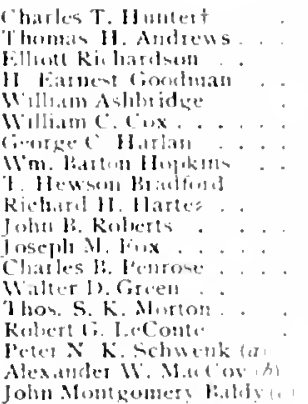

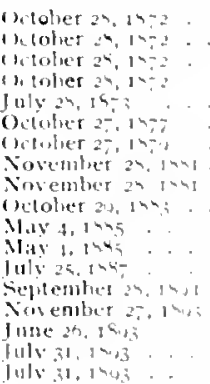

()ctober 30,1213
Resifilled.

Tersu of Service.

Vears, Muntho.

Apllil 2-, land

Belotset 2\%, 14:

Nivember 2h, Ina

listy:24, $19=3$

Aivil 29, 124,

(1) tober 20 ing:

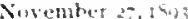

fille 25,1 an

Sejpenther 25,101

Julle $21,144.5$

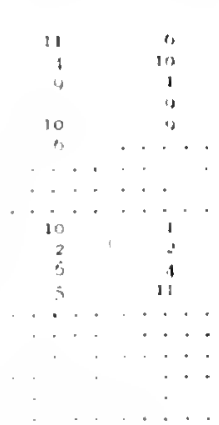

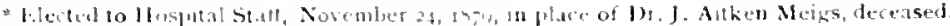
+ lived

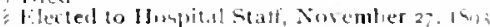

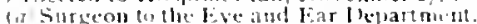

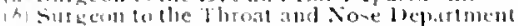

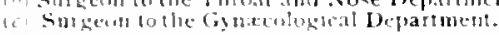

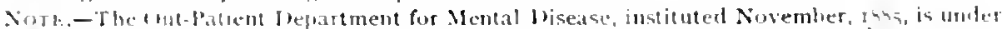

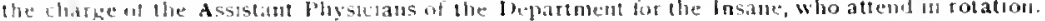




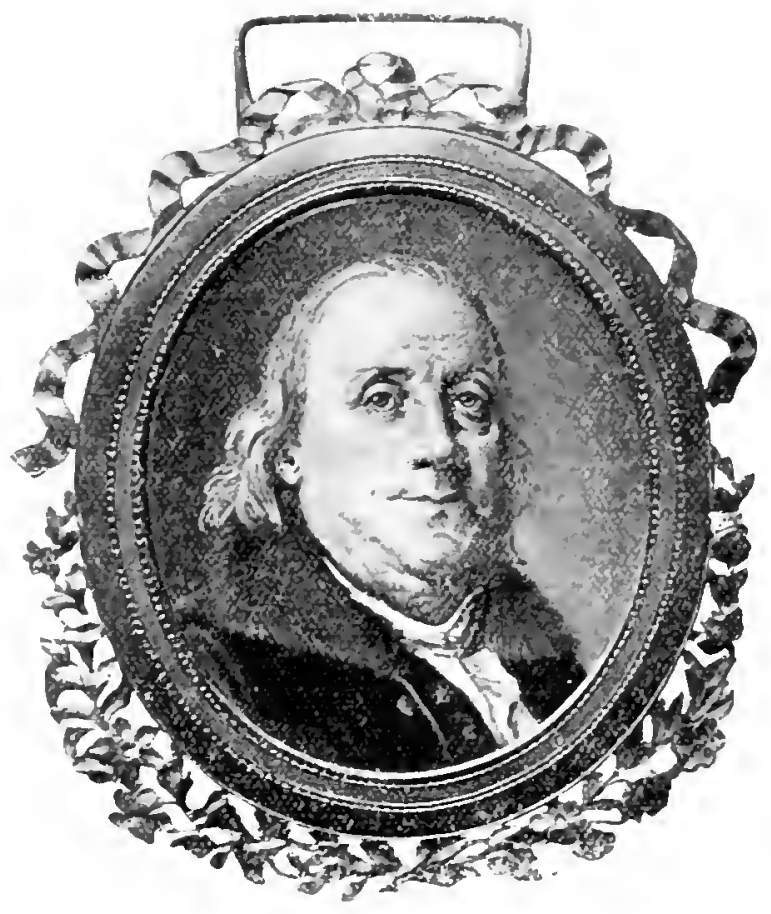

FINANCIAL AFFAIRS AND ADIINISTRATION.

The income of the Pennsylvania Hospital, in its early days, was principally derived from appropriations by the Provincial Assembly Early and from the contributions of charitable citizens. Iater, the State l.egrislature voted to the Hospital unclaimed shares of prize money,

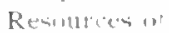
the Hompltal. also certain arrears due the Commonwealth, under the Loan (office Act of February 26, 17,6, and unclaimed dividends of bankrupts' estates. In addition to gifts of land, there were special donations of money from the Penn Family. Among the occasional additions to the income are enumerated the proceeds from the exhibition of West's picture of "Christ Healing the Sick," also from a Stage Play, from a Charity Sermon by Rev. George Whitfield, from Webster's Lectures on the linglish Language, from a Sacred Concert, from "Charity boves," and from fees of signers of libls of Credit. Money was also received from legacies, donations fron private individuals, Associations. Railroads and various other corporations, and the interest from invested 
funch, amb other vurces. (Duite a large ambunt was olutained from the astets of the l'con!lvania lant company, london, which will le expecially referred to on a succeeding paye.

$1,1,1 \mathrm{I} / 1,1, \mathrm{r}$ $1+1,11+\cdots 11$

The act of the l'rovincial Asembly, May a 1, 1751, in establishin the lennss lania ILospital, made the Contributors a corporation and provided: 1nt. Authority to receive and take lands, tenements or hereditaments, not exceeding the yearly value of one themsand pounds, 1 of the gift, alienation, bejuest or devise of any peren or jersons; ad. Noney, or other estate, expressly given or arlded to the capital stock of the Hospital, whall not be expended in any other way than ly alplying its annual interest or rent towarls the entertainnent and are of the sick and distempered poor, that shall be, from time to time. brought and placed therein for the cure of their diseases, from any part of the province withomt partiality or [reference; id. If at any time, hereafer, there should not he a constant succesion of Contributors to meet yearly, and choose Managers as specified, then the saicl Ilospital, and the estate and affairs thereof, shall le in the management and under the direction of such jersons as shall $x$ from time to time appointed by act of ceneral Assembly of this l'rovince for that purpose.

Erovincial The sime Act of Assembly appropriated two thousand pound. Amembly currency, to the Capital Stock, towards the furnishing and support lirant. of the llospital, provided an equal amount were subscribed by individuals towards a permanent fund.

creininal ()n April 21,1759 , was paserl "An Act to prevent the experta"rmrces if tion of had. or unmerchantable, staves, heading, hoards and timber." Revente. One-half the jenalties prescriled ly this Act was made payable to the "Contriluturs of the Pennsylvania llospital for the use of that insti. tution. the other half to the inspector of lumber, or to hin or them who shall sue for the same." The lIospital's share under this ict aggregated $\$ 21+53$.

The Assembly also granted to the llospital three-fourths of the fines or penalties levied by the Inspector of Flour on those who mixed corn-meal with midelings. The share of the llospital under this Act aggregated $s 6,31.90$.

In 1562 , in response to the Mlanagers' ajpeal to help the found of the Ilospital, the l'rovincial Assembly made a further wrant of three thousand pounds, to replace the amount taken from caputal for maintenance of lluspital.

Among the mircellaneous sunces of revenue it is noted that, in $176_{3}$, the l'rovincial Asembly Commisioners appointed to palce the

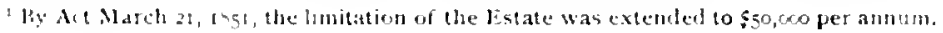


streets of Philadelphia, having no immediate use for the funds, loaned to the Managers, on their individual security, four thousand pounds, for one year withont interest. The Hospltal gained by this loan $E_{3}, 608 s .6 \%$.

March 27, 1780, the Assembly granted an order in favor of the IIospital for ten thousand pounds, Continental money. This grant was misconstrued into a loan, but afterwards on appeal of the Managers. it was corrected and again voted as an appropriation. So great was the depreciation of Continental money that the grant of the Assembly was worth only 2163 iss. $s d$. in hard money. The correspondence regarding this has already appeared (see page $6_{5}$ ).

Jantuary $27,1_{7} 8$, Francis Hopkinson, Juclge of the Admiralty, paid to the [Inspital, per Act of Assemb]y, the unclamed shares of prizes taken by the Continental ship "Saratuga," (amounting to f. $\$ 8+$ I $\left.3^{s} .6 \%\right)$; also, the proceeds of a prize made by the ship" "Daniel cireene" ( $E_{3}+8$ os. od.), also shares of jrizes taken ly the Brig "Neptune" ( $f 89$ I Is. $g l)$; also, an additional share $(f .378$. 6 6.), and on May II, 1784 , several unclaimed shares of the prize brig "Ajax," captured by the brig "Friendship" ( $\left.E_{3301}\right)$ making

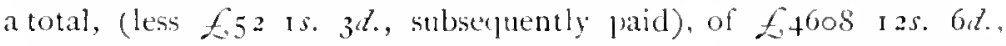
received by the institution in State money.

The Assembly, for the purpose of aiding the Hospital, granted to it the fines imposed upon its members, which had amounted in 1786, to $E 76$ i2s. iol.

A number of contributions were received from members of the l'enn family:

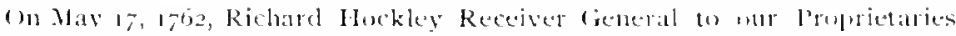
Thomas and Ridiat I'enn Est'rs, attending, aceptuinted the Buard that the Preprietaries from the ir regard to this tharitable Institution a a l lesire to promote

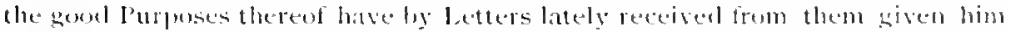

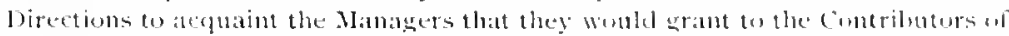
the said Ifospital the Lott of Groumel adjoining the Nurth Side of the futt on which the Hospitial stands extending the whole letngth thereol bom Eighth ton

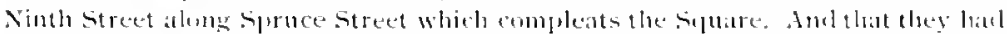

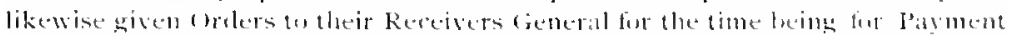

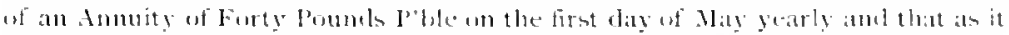

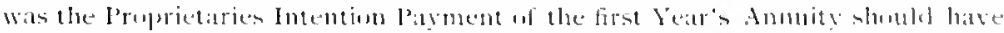

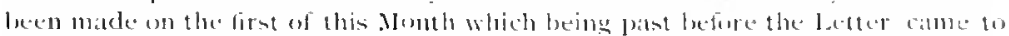

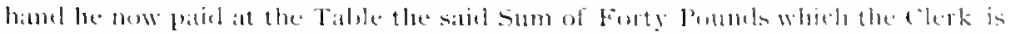

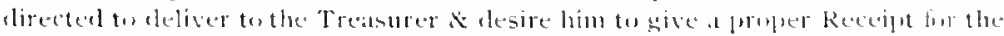

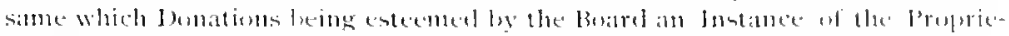

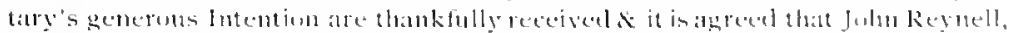

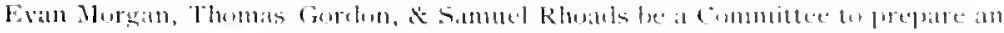

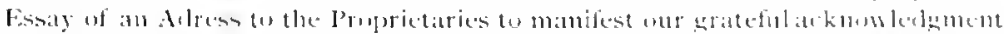

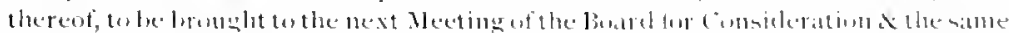

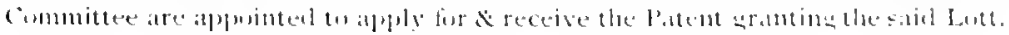

\section{Státe}

lecgislattale irinte

Airl.

["inclanimed]

prize Maney

Awalled.

Assemling Memilers' Fines.

(iontrilu tions of the Penn Fandily in Cift of Latula and i an Anmuity. 


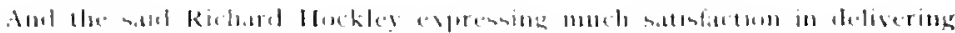

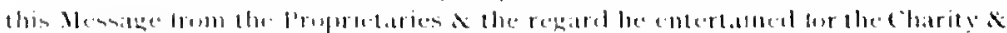

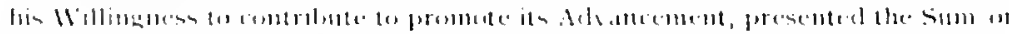

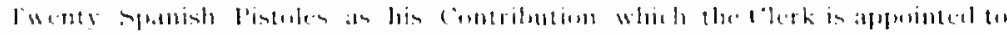

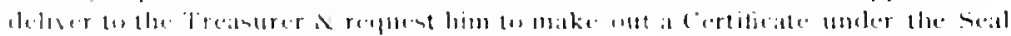

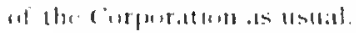

The annuity of forty pounds wal contimned from 1762 to 1775 , and, in all, amounted to fis60. The correspondence between the Malmagers and the Penn family, with the patents for the land, will be again relerred to when considering the sulject of the Real Estate of the Ilospital, in the next section.

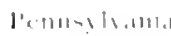

1..1111!

i iग1196.111

il) 1.1111 lin

The Nanagers were informed ly letter, dated June 7,1760 . from Thomas 11 : am. ' that an act of Parliament, entitled

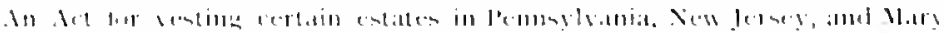

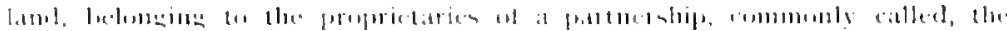

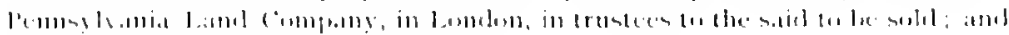

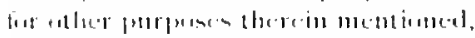

hatd lately pansed. Mlso, that he

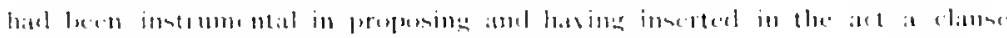

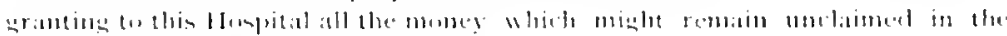

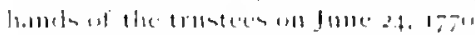

1)r. John fothereill" and Mr. latvid liarclay acted in conjunction with l)r. Franklin, as Aturneys of the llospital in England.

At the meeting of May 26,$1 ; 66$, an important decision of the lomel Chancellor of England in fame of the llowital is recorded,

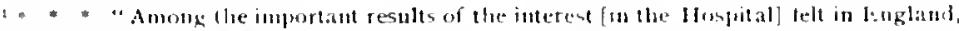

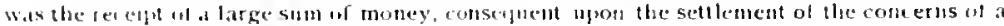

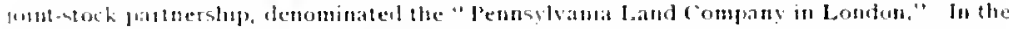

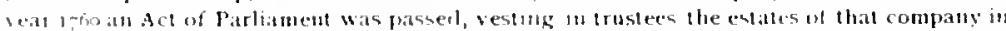

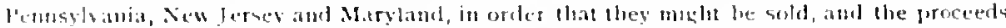

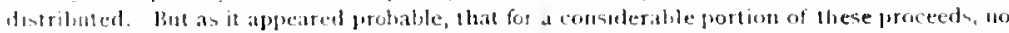

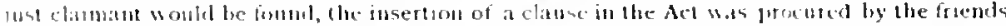

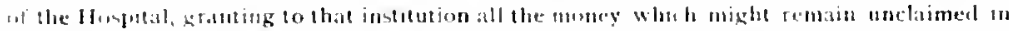

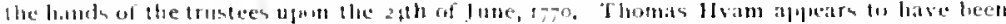

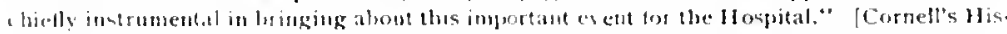

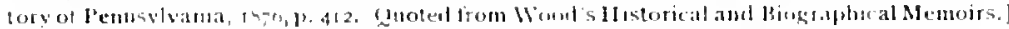

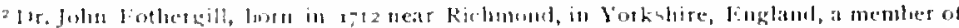

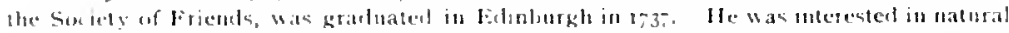

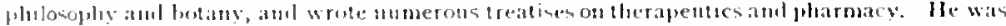

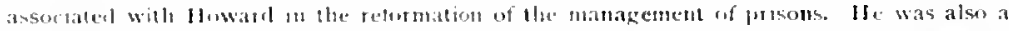

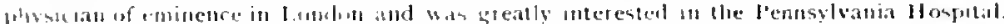

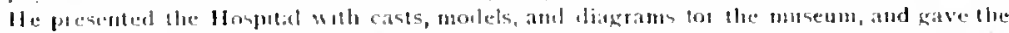

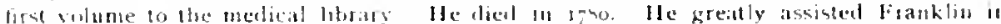

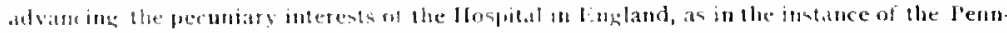

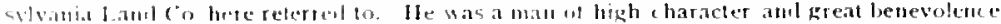

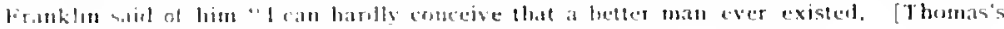

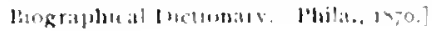


which was obtained chiefly through the friendly offices of Dr, Fothergill. It is in reference to the above mentioned unclaimed shares of the l'ennsylvania I and Company, the proceeds of which were to be given in trust to the Nanagers to hold for possible claimants. 'The decision is as follows:

Thurstug the zsth day of June in the fth Vear of the Reign of his Majesty King

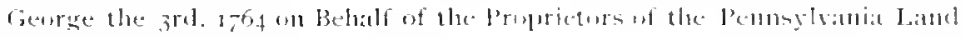
company in Lomdin.

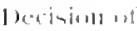
the loret

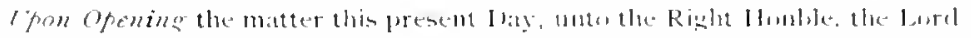

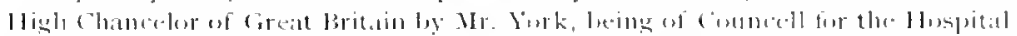

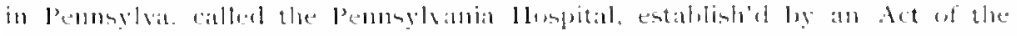

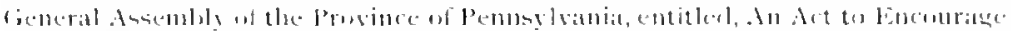

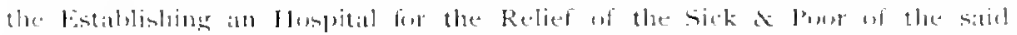

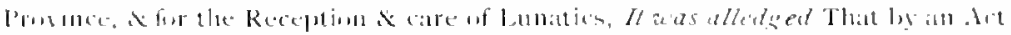

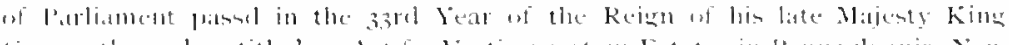

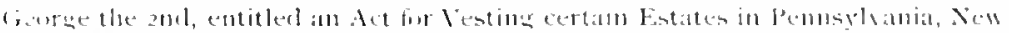

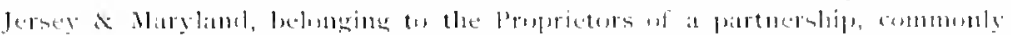

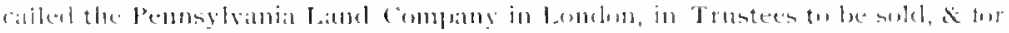

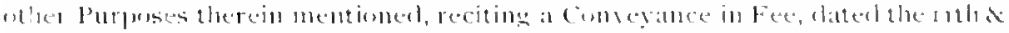

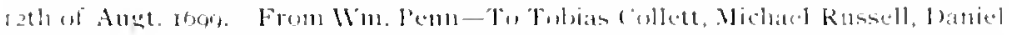

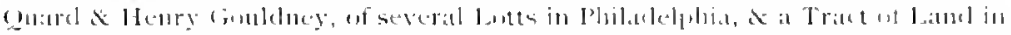

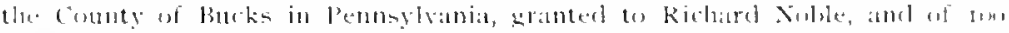

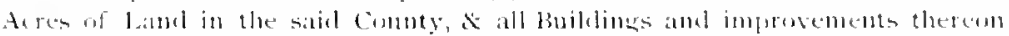

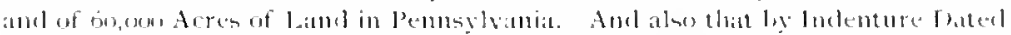

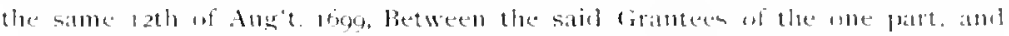

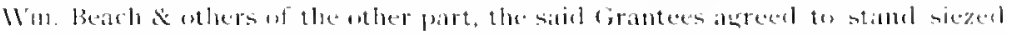

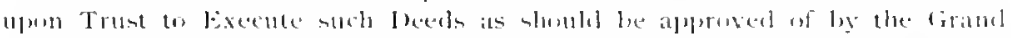

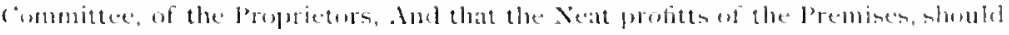

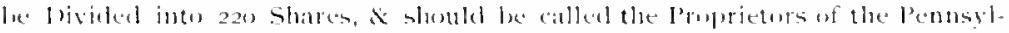

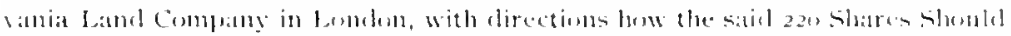

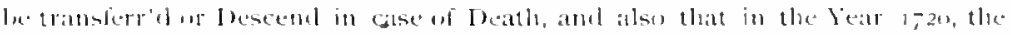

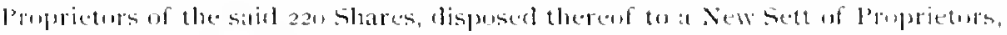

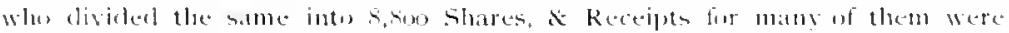
Gigmed, and given out by Thomas stores the then Treasurer, and recilime that

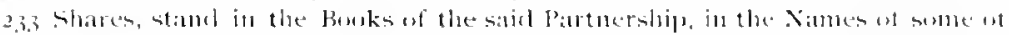

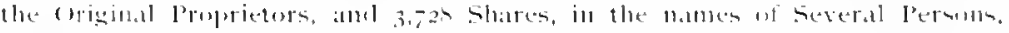

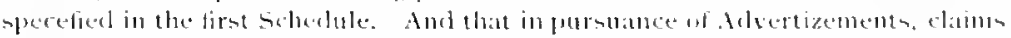

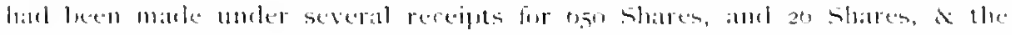

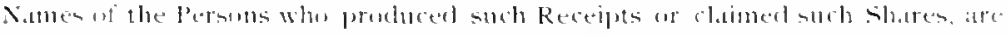

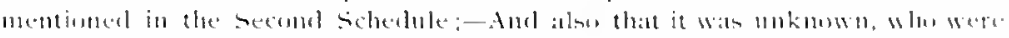

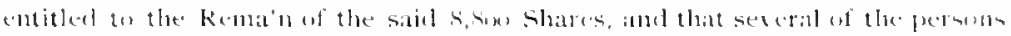

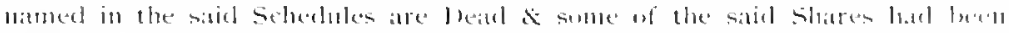

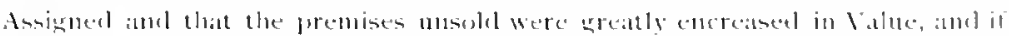

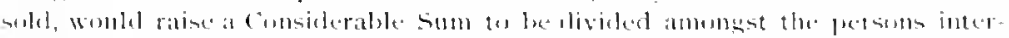

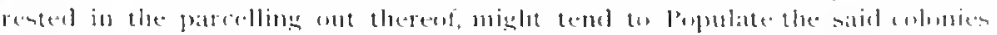

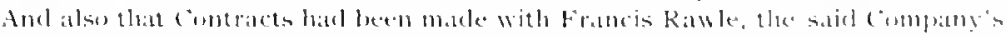

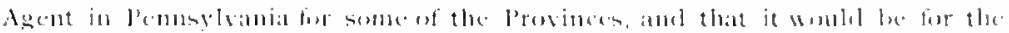

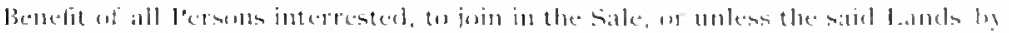

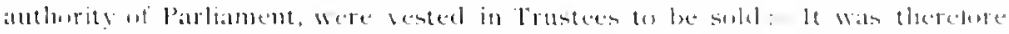
Enated, that all the premists, exregt what had been weld, 2 confered by the

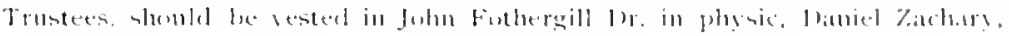




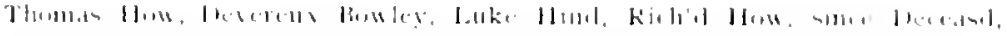

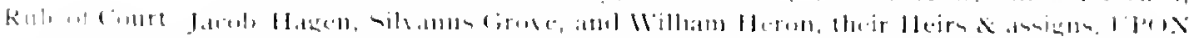

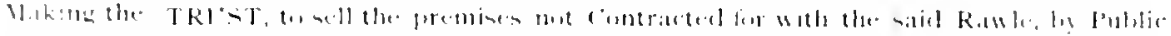

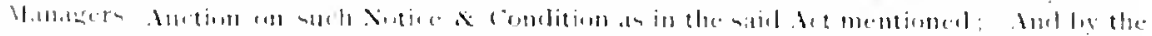

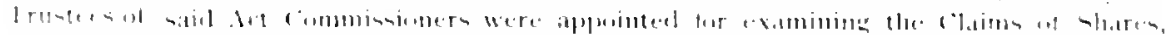

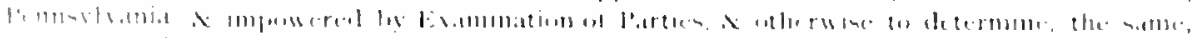

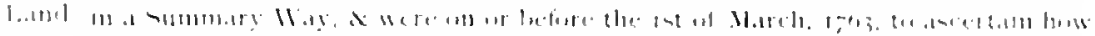

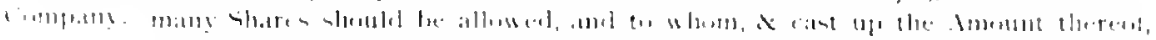

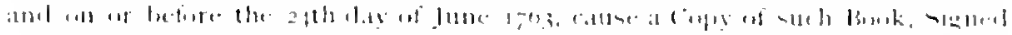

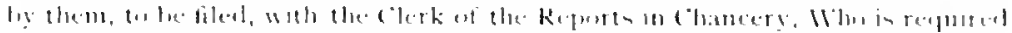

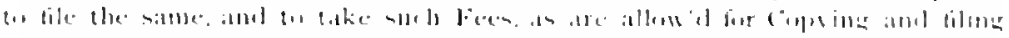

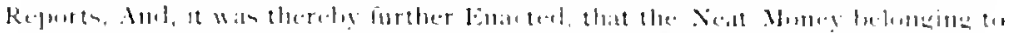

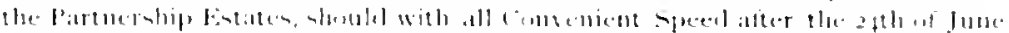

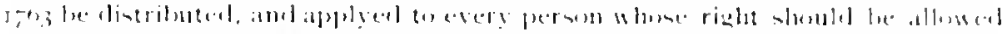

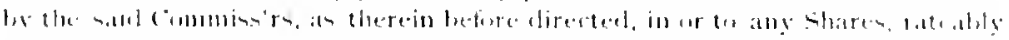

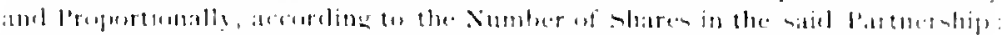

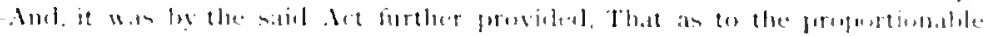

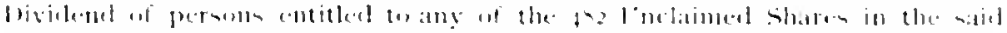

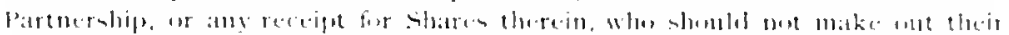

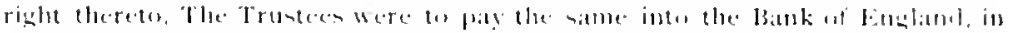

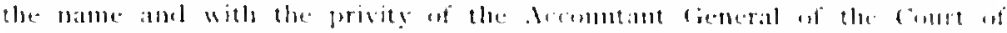

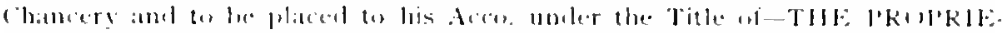

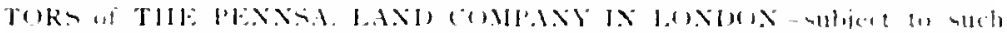

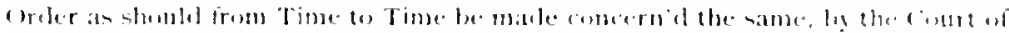

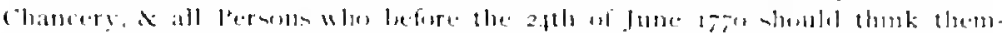

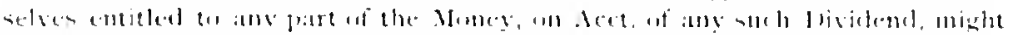

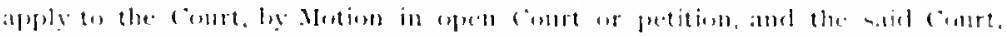

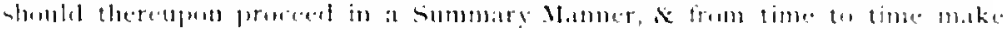

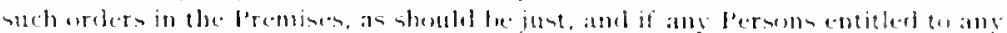

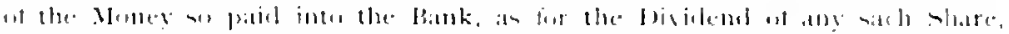

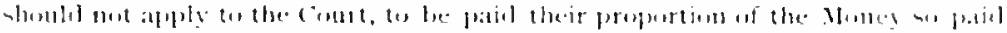

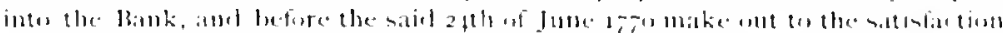

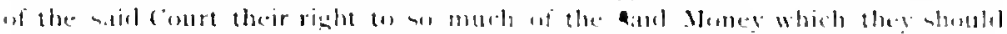

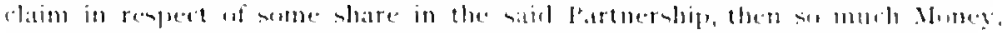

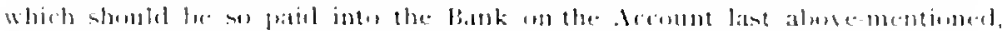

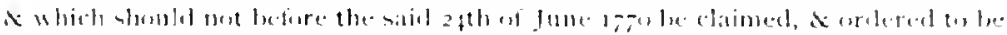

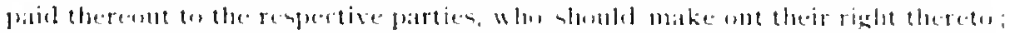

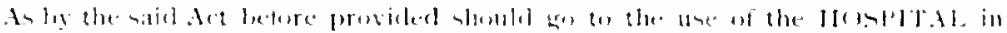

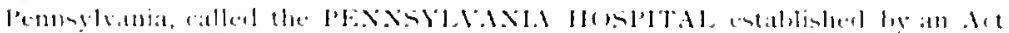

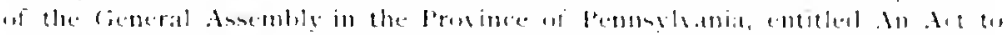

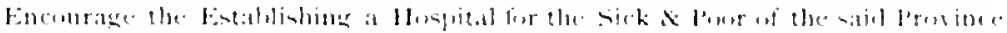

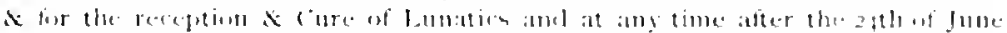

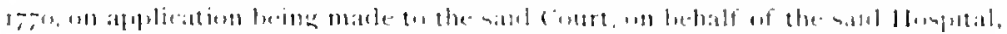

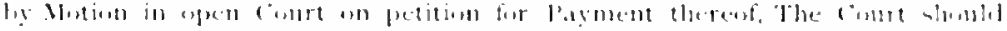

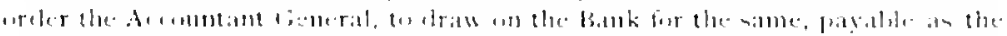

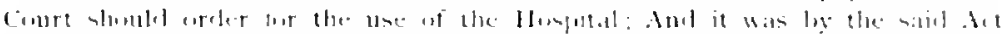

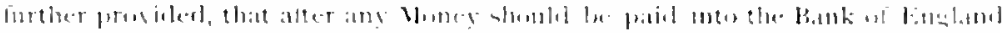

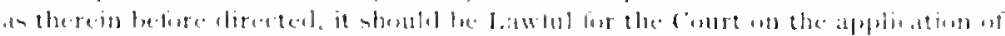

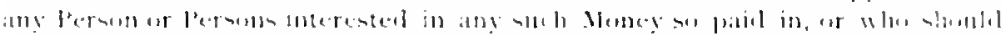

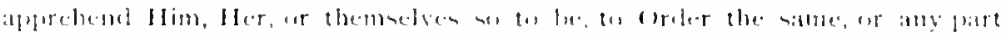

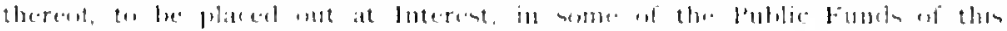

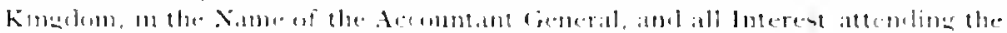

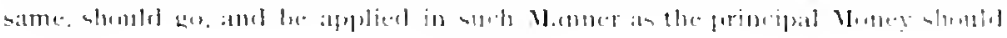




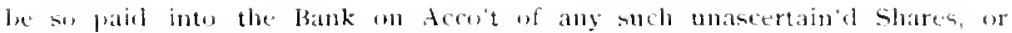
Receipts. in the said Partnership, as aforesalid. Wherehy the said det befere directed to go, and be applied, That the Commissioners named and appentent by the satd Act certified by Writing wnter their hamds, at the fort of their proceedings, entered into a Book for that purpose, lursuant the saicl Ait, that they latal proceeded to Execute the powers \& Autheritys therelog vested in them. agretalle to the directions in the said Act, and as for and concerning the $30 \pi 3$ Shares, in the first Scledule. referr'd to by the said det. which by mintake are there cast 11 , and set down 3960 Shares, 3795 shates and 4 thth of 22 shares, theren, having been claimed before them, and such Claims made out to theit satisfaction, they hat adjusted, and ascertand, the said jass shares $x+$ stlas of 22 Shares, to belong to the several Persons, and in the propurtions mentioned in the tirst Schedule:-The Remaining $\$ 60$ Shares, and I 5 th of 22 Sharen of the said 3273 Shares. having either not leen claimed before them, or the claims in Respeect thereof, having been alisallowed by them for want of sufficient Fvidence to make out the same to their Satisfaction, and as for 8 concerming the $6-6$ Shares in the and schedule, referr'cl to by the satid Act 672 Shares theren hat ing heen Clamed hefore them, \& sueh claims male cut to their satisiantion, they hatel

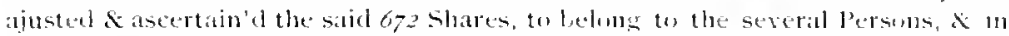

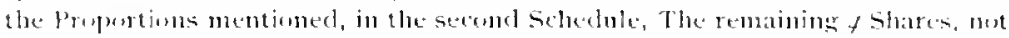
having been clamed before them, and ats for and croncerning fio shares, whids Remaind Lnelamed at the Time of passing the said tet, but wheh by Mlintake are therein called filz Shares, $13^{3}$ shares therent having been clamed before

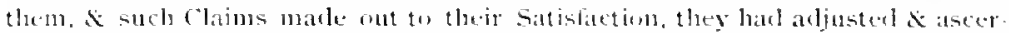

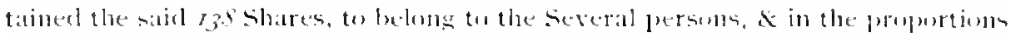

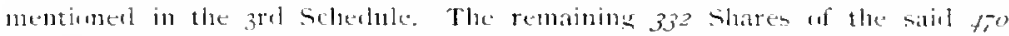
Shares, wot having been clamed before them which sajel $3,053,6,0$ shares 8

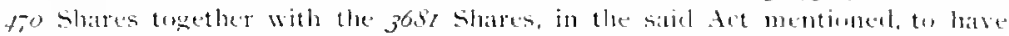

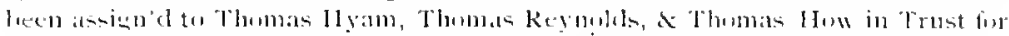

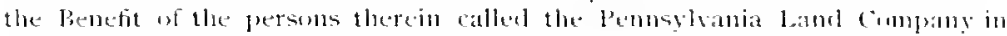

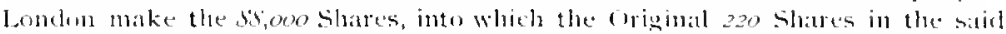

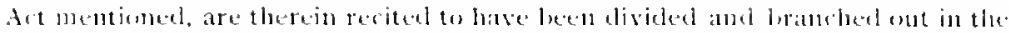
Vear 1-20. At a general Meding of the l'mepricters then belel. they were

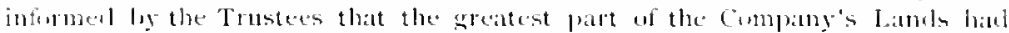

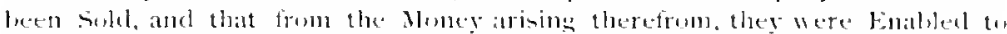

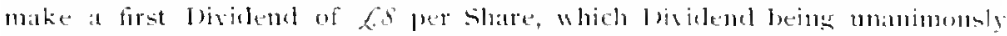
anreed to, he the proprietors then present, was dectared atecordingly and hath

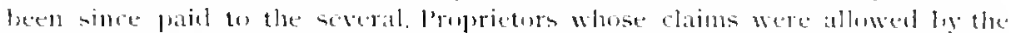
Comminsiners:- That the surving Trustees in the said det of parbanent have

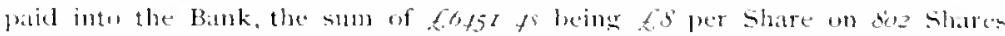

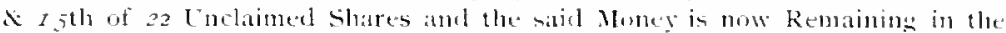
sad Accomtant General's Nane in this matter, under the Title of The l'roprite-

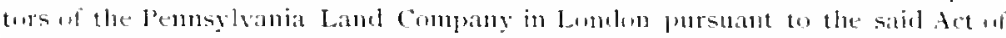
l'arliament, that it will be for the beneft of all parties to have the saicl 60457 , 5 laid wat in stock \& Carry luterest-1T Was therefore praved that the sum in forts ts Cash in the Bank, nuw rematining in the name of the Acoullutant

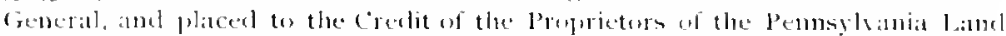
Company in Lomelon, maly be laid ent in the purdase of 3 pee Cent. reduced Bank Anmuties, in the Name and with the privity of the sidel decomutant Generat, unem the Trusts mentioned in the sald Ale of parliament and that he

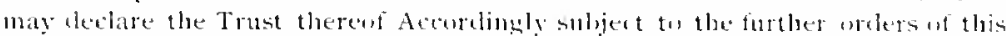

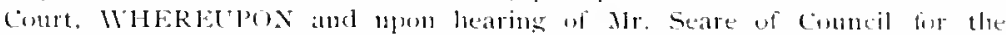
surviving Trusteds, in the saicl Ad of Parliament, whe conscnted thereth, and 


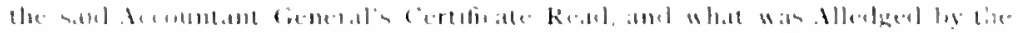

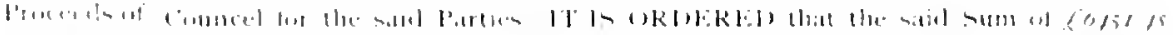

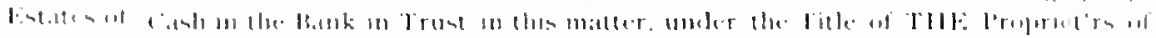

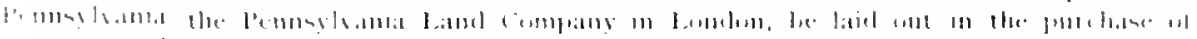

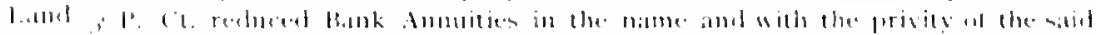

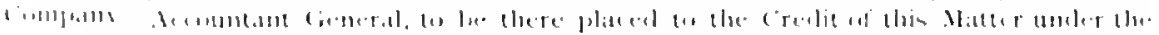

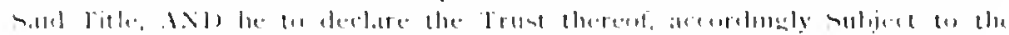

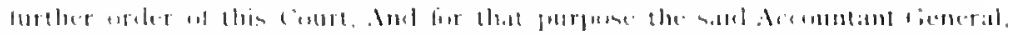

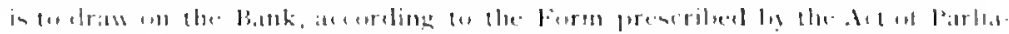

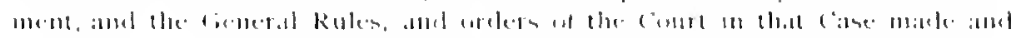
firinistal.

The drats were signed lye eight Vanagers. The amounts realiect were as liblows:

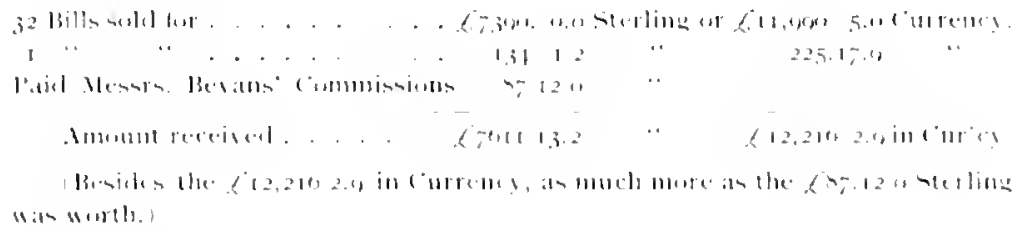

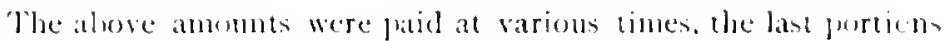
not being received until after the close of the Revolutionary War.

Jinude |renti

By Act of A pril 11, 1793, entitled "An . Act for entending the

Arratur benefits experienced from the institution of the Pennsstrania

Ban chin. IIuspial," twenty-six thousand six hundred and sixty-six dollars

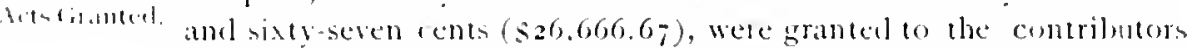
out of the arreas due the ('ommonwealth under the loan Office to th

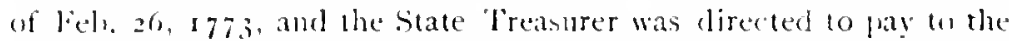
llospital all moneys on that arcoun received hy him since the first dal of fanuary peceling, and to assign to the llospital the mortgages and securities upon which anything remained due. The managers were required tu give security, and to tase their utmont endeavors to colled the money and, after satinfying the grant, to gay the surplus to the State Treasurer. The Managers were appointed trustees of the I oan office, etr., and were directed to apjity the money granted to crect additional huildings, and to render an account anmually to the legrislature. Also any unclaimed dividends of Bankruju' estates were

1 "11, latima.4

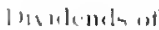

Fintales at Mimkru!sth. directed to be paid to the llosprital by the Commissioners of lank. rajuts. the Hosprital of be lialsle therefor, if subsequently clamed. The Managers. loy the same Art, were empowered to estalilish a Lying-in and foundling Deprartment in the llospital.

On lecember 16, 1795 , the Commissioners in Bankruptcy paid to the Nanagers on atcount of unclaimed dividenels and surpluses $\$ 20.044 .64$, and on Marrh $2.8,1796$, s6og 2.08 . 
The following correspondence is of considerable historical interest. It is recorded in the ninutes of a meeting held November 22,1796 :

The Governor having lately paid a visit th the llospgital and signified at will inguess in his next address torecommend w the lecgislatture tu gront a further sum to findsh the centre builaling, it was agreed that Rolert Maln, Salml. M. Fox S Saml. Cuates be a committee to tatke him the following adelress and we requent he will introfluce thetein steh prats of it as he may conceise will be laseful on the urcasions :

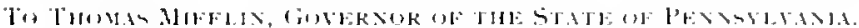

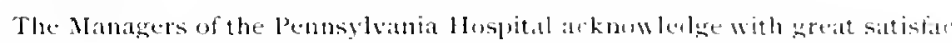
tion, the benefit derived from that part of the diovernor's last address, th the senate and lionse of Representatives of this state, in whith he was folteilsed to recommenel that Institution to their attention for airl and stlpourt. The grant of money which followed this recommendation hats enabled the .hanagers to tinish serenty roms in the Whest Wing and thus th provide snitalsle and convenient

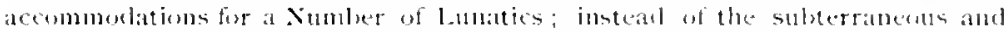
damp cells, in which they hase hitherto been ronfined; the pleasing hine of administering more effectual pelief to this adlicted class of pattichts is much

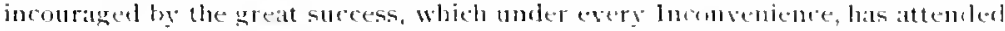
the Eflurts of the huspital physicians, during the last year : acourding to the original plan some progess has been llate towards comnerting the two llings of the Ifospital le the center bulding, the found:ation of whith has been latid, the

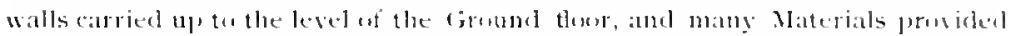
for completing the Same. In the expenditure of the numey intristed to the llanagers they bave observelthe strictest ecollonly, but the sum granted being

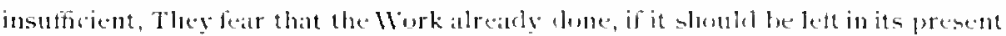
unfinished state will sutfer areatly from the weather; other indureniences will greatly attend it the Stewart and hatron will be tow remete from many of the l'atients, to afforl the necessity attention, The Number of nurses and serwants must be increased, and conseguenty the Expencesor the Institution. The rom where the Nanagers meet, the Museum, the aprobecarles Shop, and the apart-

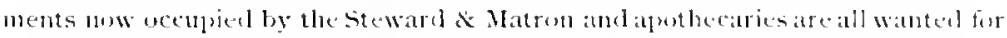
the more confortable acconmuselatien and better sepatration ef the sirk, untill the

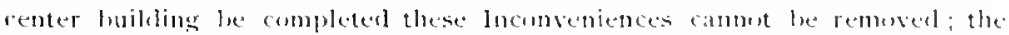
Ilanagers forbeat to enlarge on this subject: it is unnecessiry they think to dis. eant an the relief, which has been extended to many al the Citizens of pennoyl vaniat, as Well as te distressed Strangers by Means of this Hospital the fovernor having some yeats ago beesll a Mandger thereof, has hat a full olpurtunity of knowing the usefulness of an lostitution, which among ather chatritable Endow-

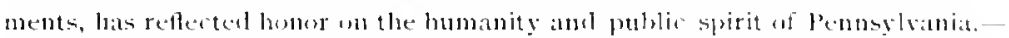

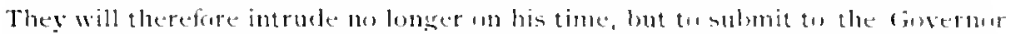
the propriety of mentioning the present situation of the pennsylyania llabpital in his next Adelress to the lecyislature of this state.

signed en behalf and at the repuest of a buard of Managers of the Penmeyl. vania Hospital, ath month 22, 1795 . 
A supplement to Art of April 11,1793 , passed April 4.1796 ,

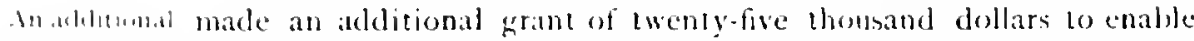
(iraut $11, m$ the contribuluss to finish the buildings according to the original Acomplitetins Buildinsw. flan, els.

Al a sectal meeting held at the house of Josiah llewes, lecember $28 t h, 197$. the draft of a second address to the Governor was prondued, agreed upon and directed to be forwarclet.

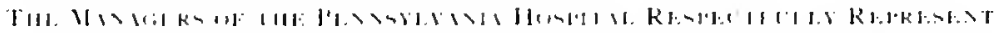

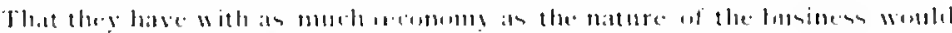

M.IThigerta kejuth il liristeren

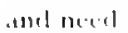

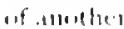
Aprupuri at11, 111

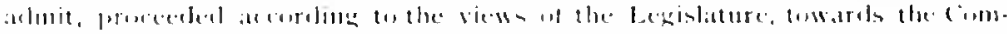

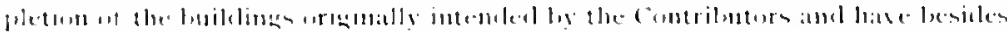

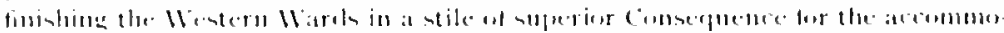

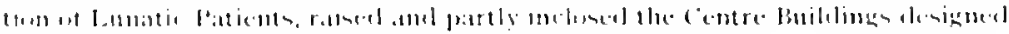

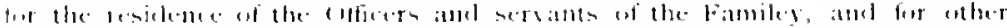

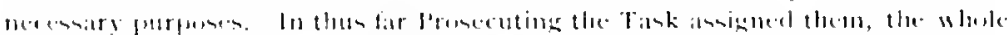

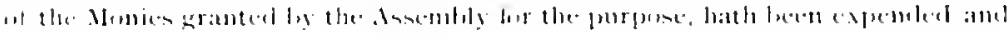

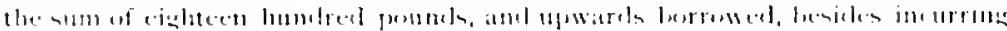

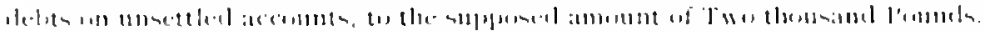

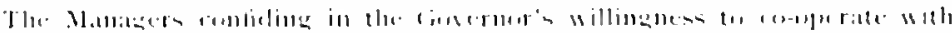

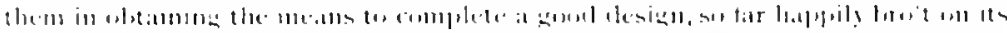

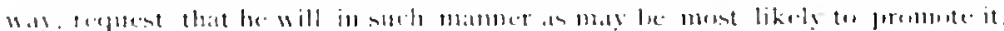

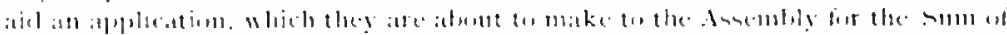

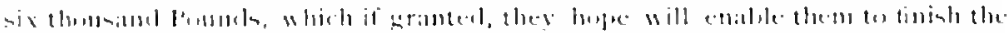

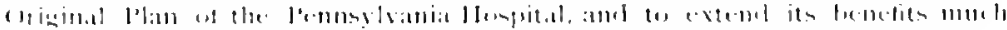

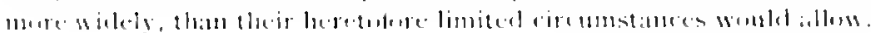

signed

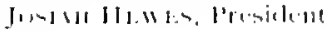

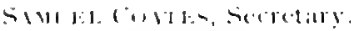

An address was also directed to be prepared to le presented to the lectiviature to second the (iovernor's recommentation. It appers in inll in the minutes of the same meeting.

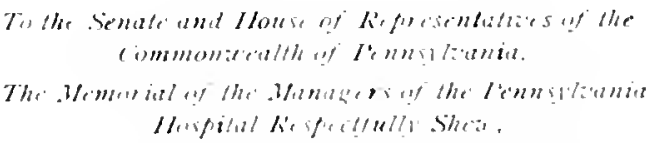

Alliren

ti, the

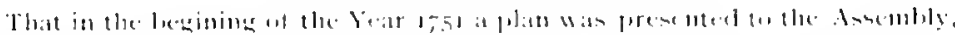

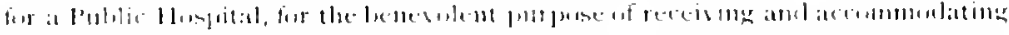

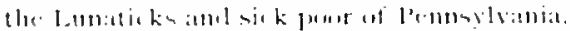

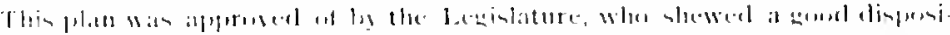

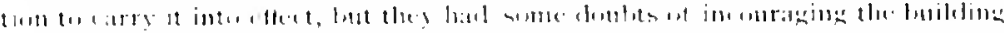

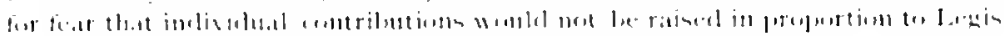

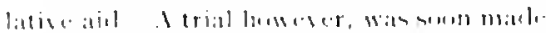

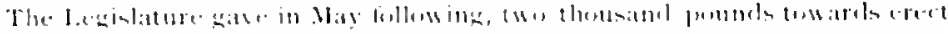

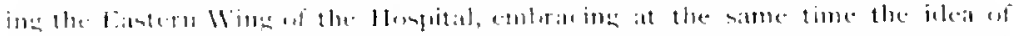

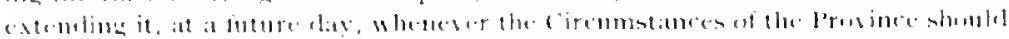

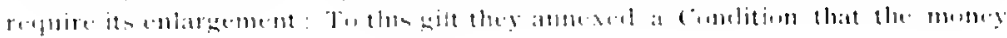




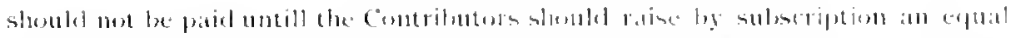

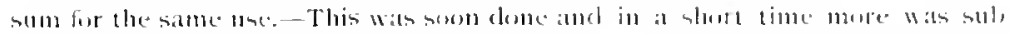
seriberd thath the Aet regutired.

A1pu:at Liv the

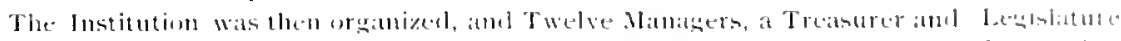

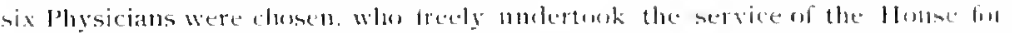
the silke uf the sick and sulfering lour

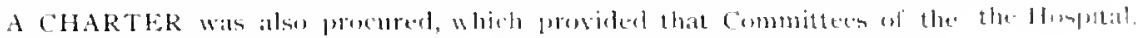

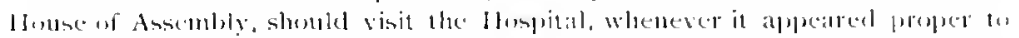

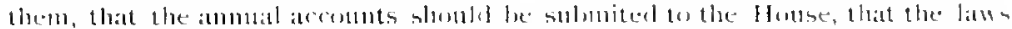

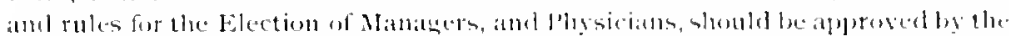

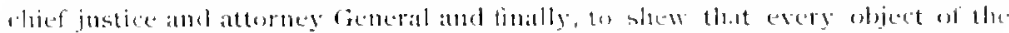

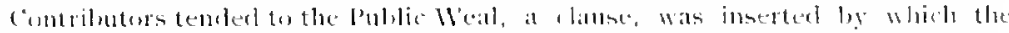

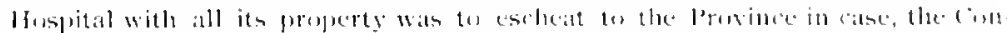

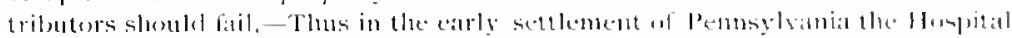

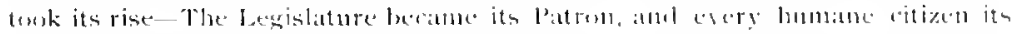
friend.

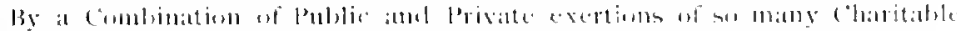

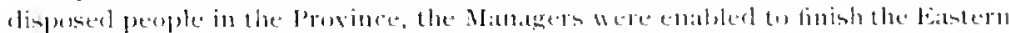

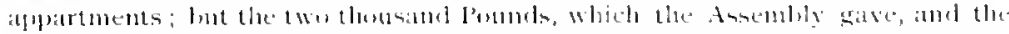

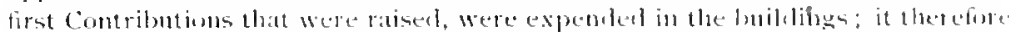

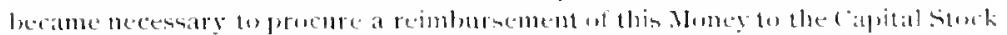

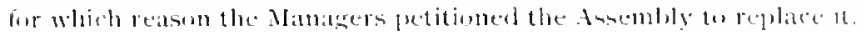

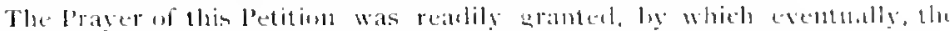

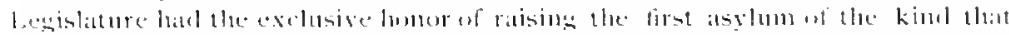

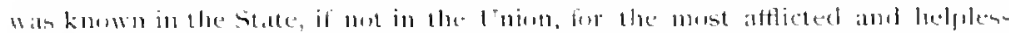

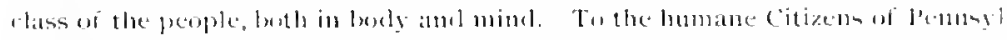

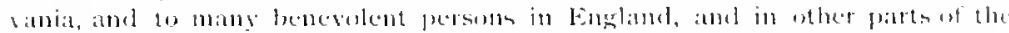

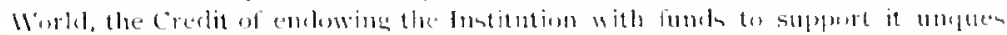
timalsiy beloums.

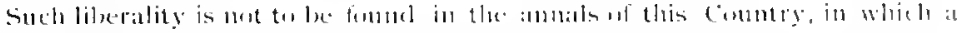

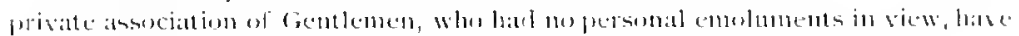

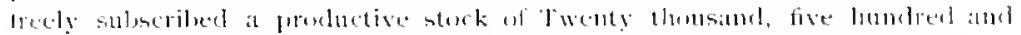

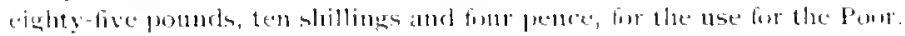

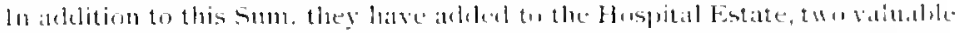

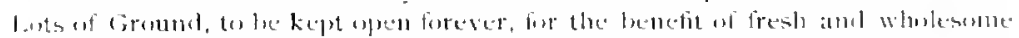

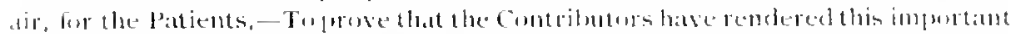

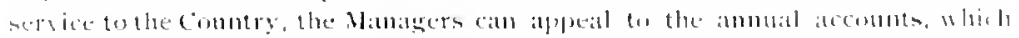

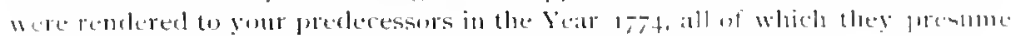

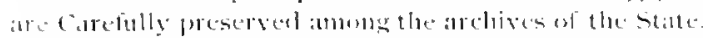

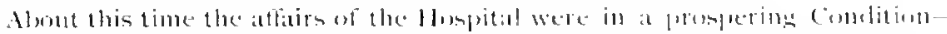

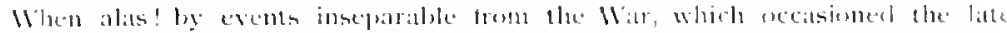

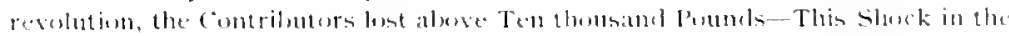

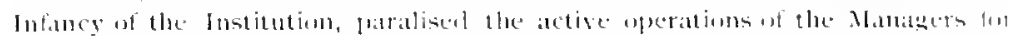

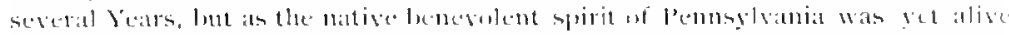

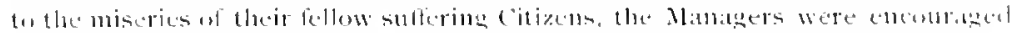
ture-assmonc their lalumes.

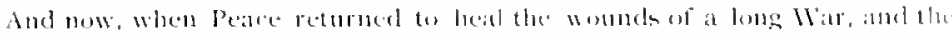

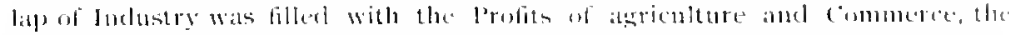

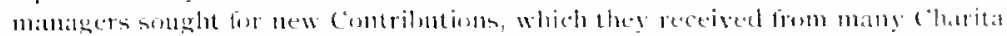

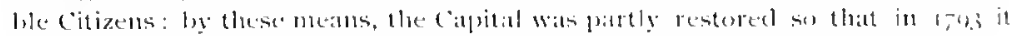

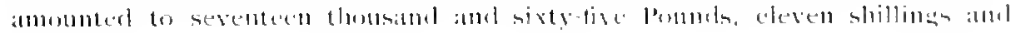
teinjerice 


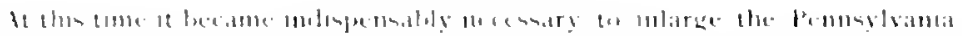

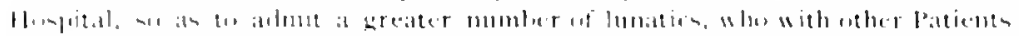

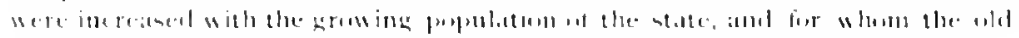

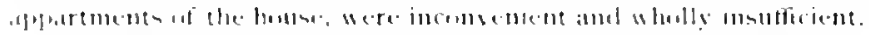

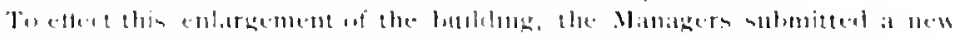

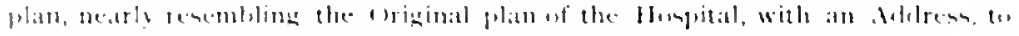

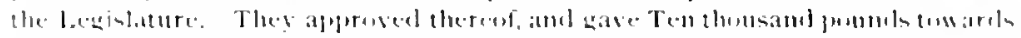

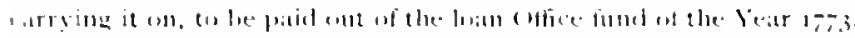

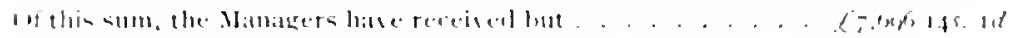

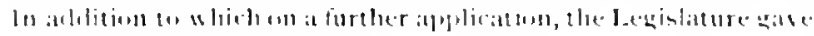

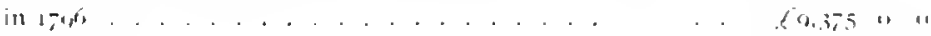

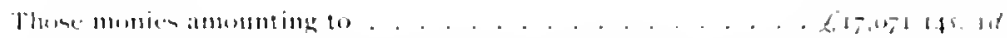

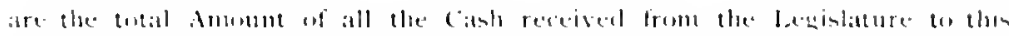

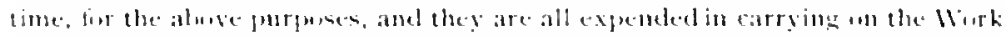

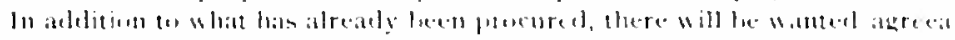

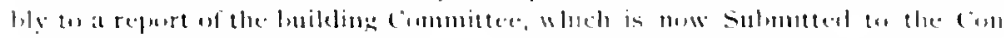
- eleration of the 11 uldse:

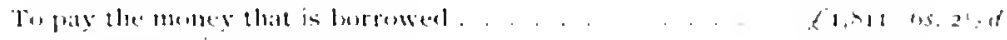

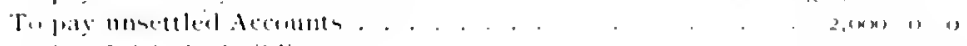

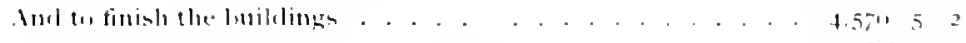

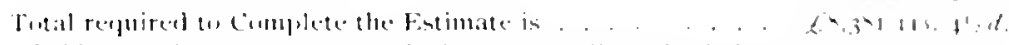

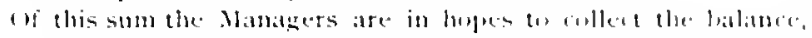

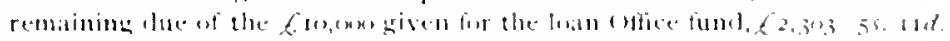

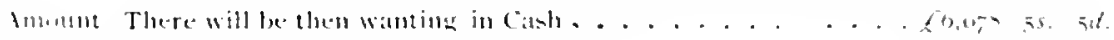

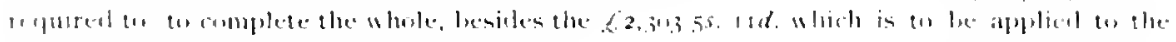

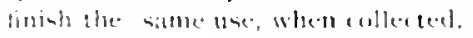

biulelinger.

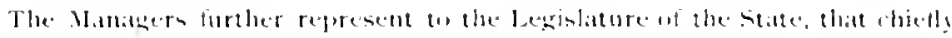

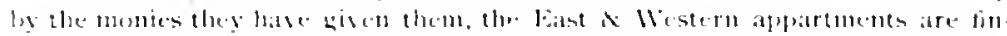

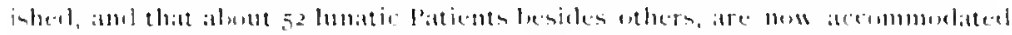

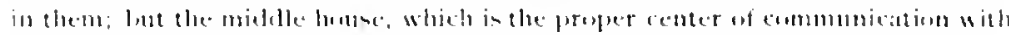

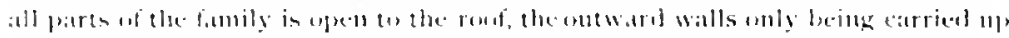

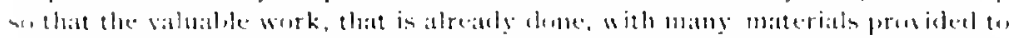

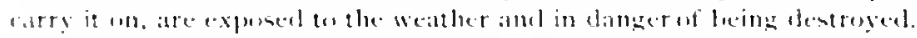

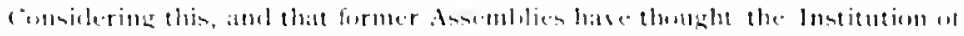

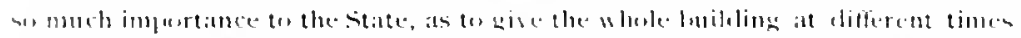

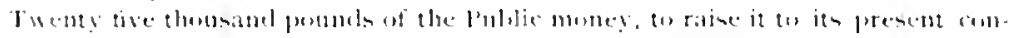

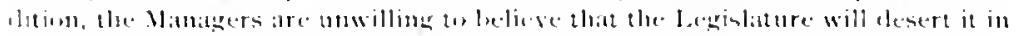

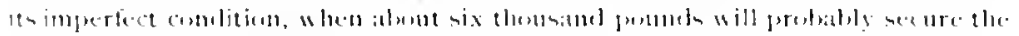

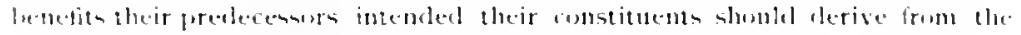
liberal comeributions the hate alreaty mate.

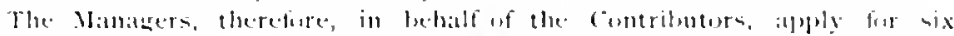

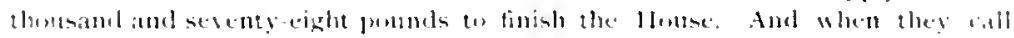

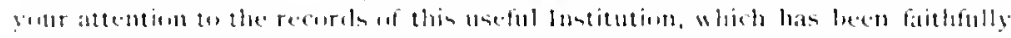

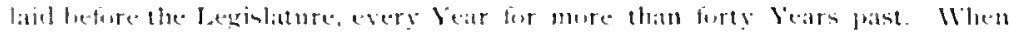
they remind foul that the numerous amel various cases, which are attencled in the Hespitat, have been the means of alluring stuctents from every state in the

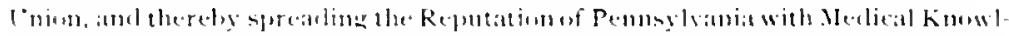

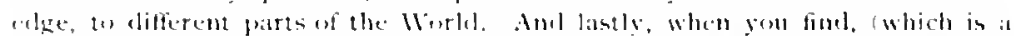
froth upen recordi. that the contributions to this Imetitution have assisted

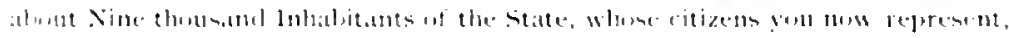


who have been attlicted with madness. (asuatties atmol almost every disease that affects the minds and hodies of Men, and that they lowe been the means of preserving several thousand of the lives of these distrested people, they trust and believe you will nut require a more powerful addrens to four feelings. thatl this appeal to the l'rayer of this, their earnest Petition.

Signed by ureler of a Bend isf Matnagers.

JWABU HEWFs, Jrestitent.

I2th month 2ith, 1;9;

Sivule Cortes, Servetary.

Several other attempts were made and petitions presented to the Assembly. Nospecific appropriation was given, but the proceeds of the Loan Office Funds, as they came in, were used to complete the work.

On March 6, 1799 , an address was prepared, directing the attention of the Assembly to a deficiency in an appropriation previonsly made:

The Committe on the Loan office Funel repurt the following Memorial to the assembly which being read by paragraphs and consiclered was approved, it was then ordered to be transeribed signed by the managers and laind before the Legislature without delay. The accounts which are nut on the Memorial were directed to be copited on the rough minutes.

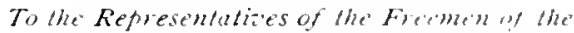 \\ Commonatealth of Iemsilin'anid. \\ The . Wemorial of the Subscribers. Wanagers of the l'ennsylingia

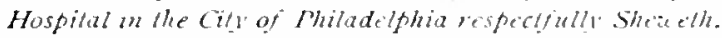

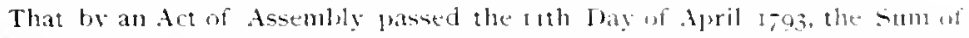

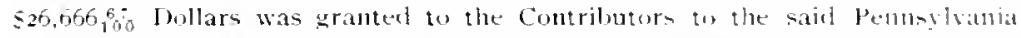
Huspital fer the uses in the said Act mentioned, ollt of the l'rincipal and laterest due to the Commonwealth in pursuance of an Act pased onth of February its entitled an Act for emitting the Sum of $\$ 150,000$ in hillm of Credit an lom. and providing a funt for the payment of public Debts.

And vour . Memorialists further shew that under and by virtue of the satid det the State Treasurer at the request of the Treasure of the said Contriluturs, did

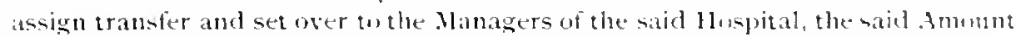
and more in the Mortgages for Money loaned at the said Luan office ander the said Act of 26 th of February 17.3.

And sour Nemorialists further shew, that by the said Act dated 26 th Felptuary 1733 , it was provided that if it shunld appear an the settlement if the Accounts of the Trustees of the said Loan office, that any Peficiency had hajpened by any Borrower or Hortgages not having Right to the l.onds mortsaged or in the Value therenf or by any other way or Weans whatserete to puy the slonites and the Interest accrmed therem with the Cists of the suit which should be prosecuted for the sinne, that in every such Case the Trusteen of the said Loan Office having an Oreter from the Assembly fur the purpure should draw in order on the Treasurer of the Connty in which steh lociciency shumd hatpen, for the payment of such Deficiencies, if so much Muney shuthl then be in the Treasury, and if not that the sait Trustees should issue their precopt to the Commissioners and Assessors of the said County, enjuininer them tis ause the

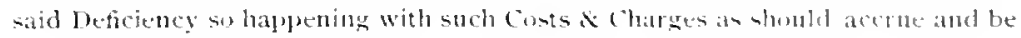




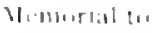

I.e.sulatise, $1111 ! 1020,11,1$ (1) $1,1,111$ () fina.

1.1 .110

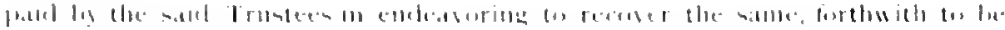

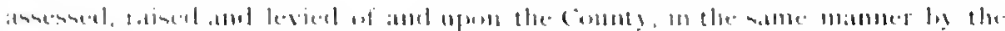

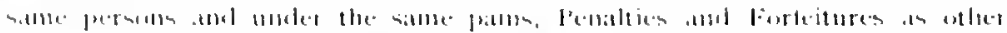

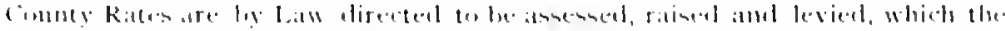

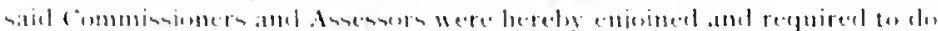

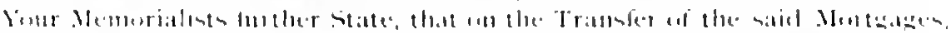

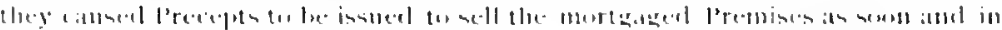

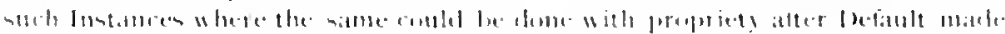

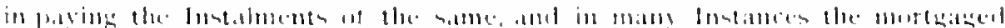

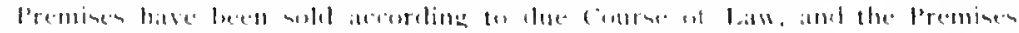

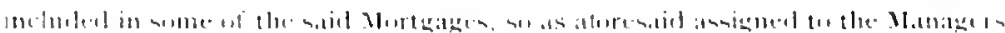

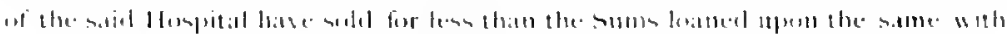

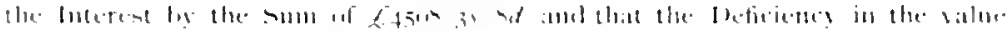

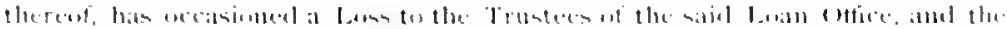

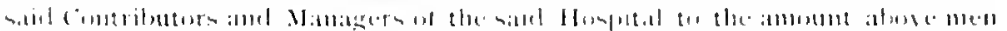

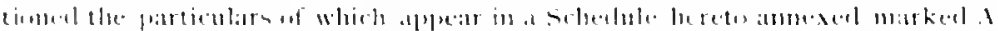

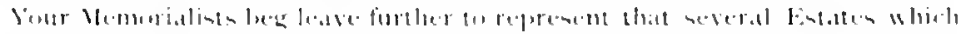

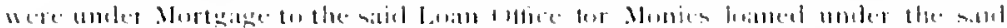

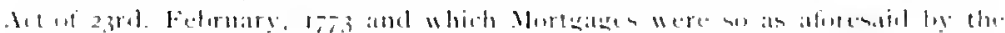

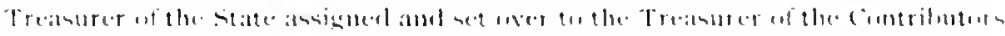

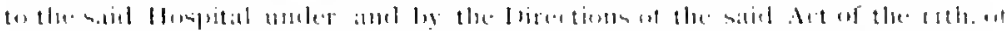

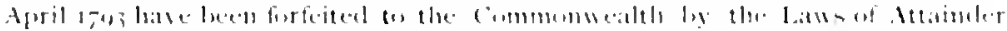

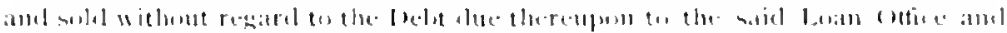

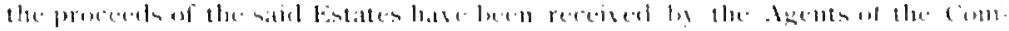

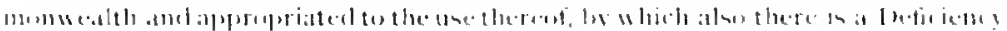

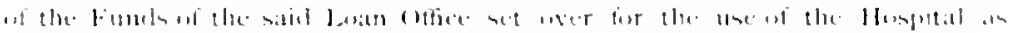

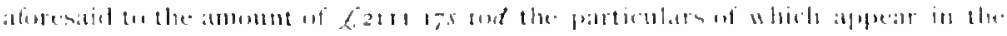

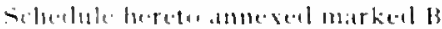

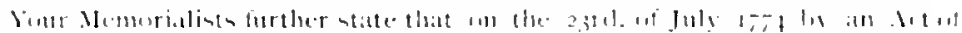

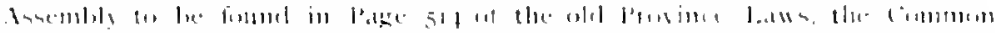

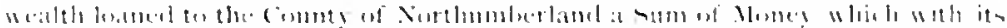

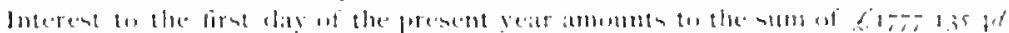

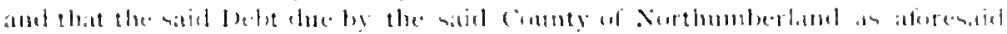

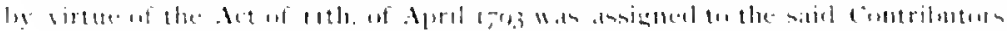

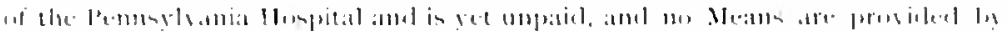

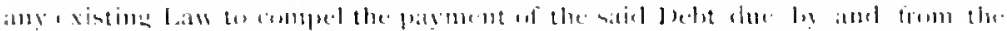

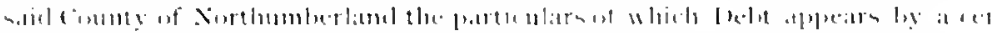

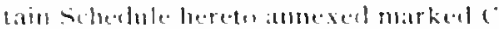

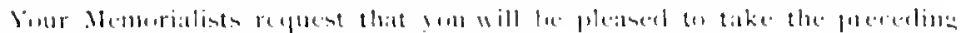

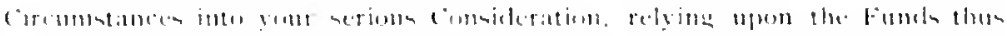

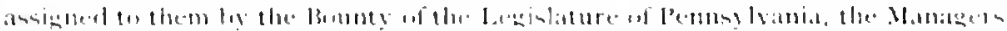

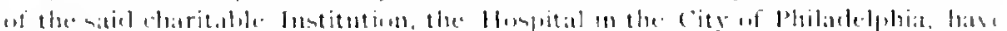

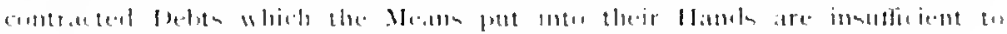

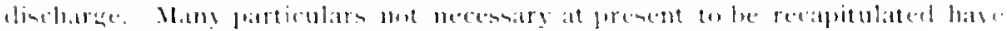

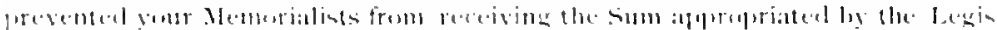

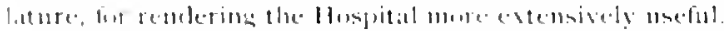

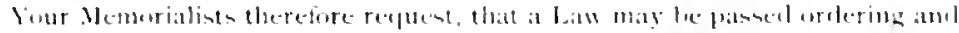

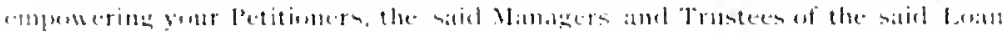

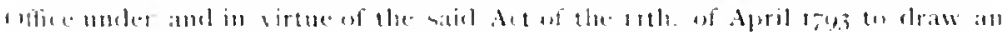

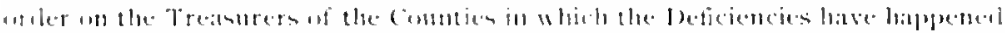

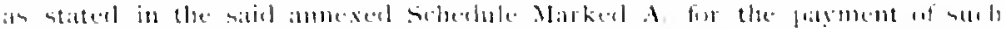

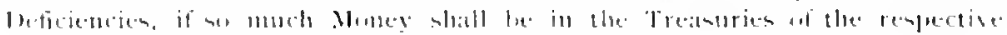

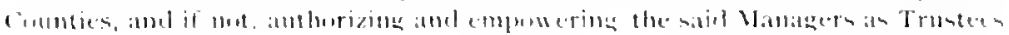




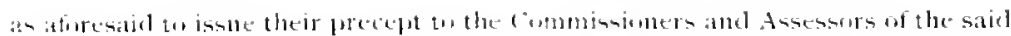
everaj Counties to cause the said Ineficiencies with Conts 8 Charges to be forth with assessed raised and levied uf and upon the said several counties in the same manner as uther cintuty rates are assessed, raised and levied.

And your Vemorialists further request that a Law may le Passed anthurizing ancl directing the Treasurer of this commonealth to fray to them the Amount stated in the said annexed silechule B. being the deficiency in Mortgiges assigned for the use of the said Hospital and which [eficiency has been ocosistured by the attainder baws of this commonwealth, under which the said mortgaged land have been sold and the proceded therenf pad into the Treasury of the State.

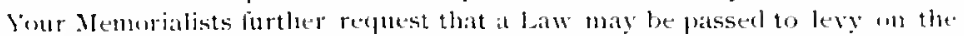
Cinunty of Northumberland in matuner ats directed by the said Act of 26th. of February 1723 the said sum of $f, 1.72,13,4$ being the principal sum borrowed 1, the Commissioners of the sidil contuty for the use thereof, and the interest thereupon, the whole whereof is yet che and owing from the said County to the com-

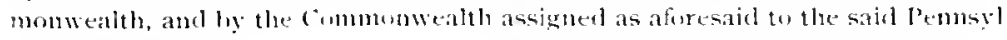
vamia Hospital.

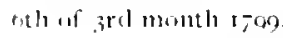

Signed by all the Man1:1:20\%

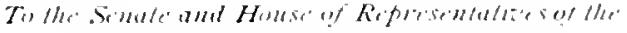

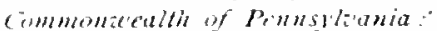

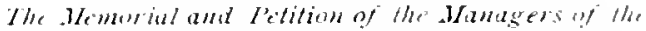

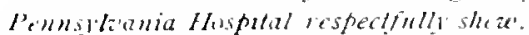

That Vuur Memorialists have heretufore submitted to the (ieneral Ansembly a Report of the Receipts for and Expenditures upron, the new mildings, tw the Intl, of the 12 th month 179;. With a Petitiun dated the Isth. of the same month. for Six thousand and Seventy Eight pertucls 55 to finish and furmish the sime :

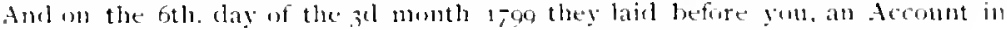
detail of the boan office fumbl of the Year 17.3 , and requested your Assistallet. th (mable them to recover, the Arrears thereon due to the state.

In adclition thereto, they now offer you a Report of the receifits for and evpenditures upon the huldine, continued to the 25 th. of the 1 ith month 1 -og.

Sour Memorialists forbear urging at this time to your Consideration, the usefulness of the Institution under their Care, referring fon to their former Mtemotial

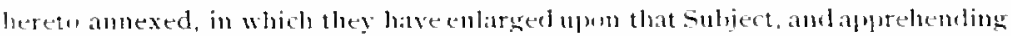
the Assembly must be convinced of its l'tility from their having already granted near twemty-five thousand pounds in all towards it.

Sour Memorialists think it may lo proper to mention, that hefore the contributurs engased in this [nelertaking, they presented you a plan of the conten. plited Erections, with an Entinte of the costs that would probahly attend them, from which they have nut devitted : they acrompanted these with a fair and plain dectaration, that the funds of the Institution were insufficient to stpport more than a few porr patients) and that ly the charter mo part of the capital stock could tre expended an the buiblings. Assurances were given you at the

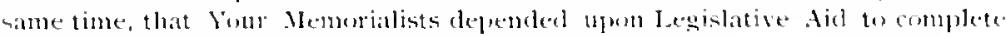
them.

With a knowledge of these Facts lour Nemorialists expect you will mot hesitate to perfect, the Work which hy your anw Acts you atuthrized them tw

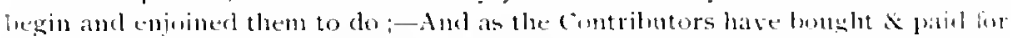
the lets upun which the IImpital stands, and enclowed it with a capital at

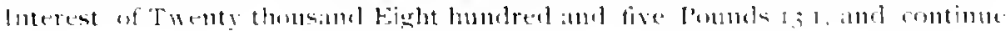

Busether velurens tor the lengislat ture asking a Settlement "f L,nan futice Fitud. 


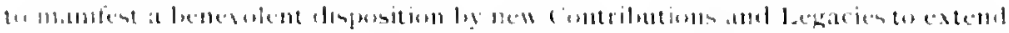

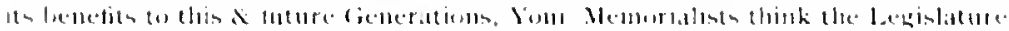

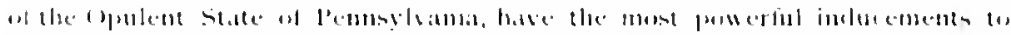

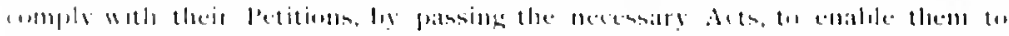

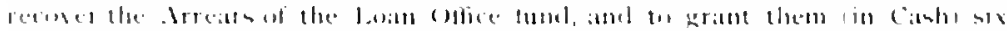

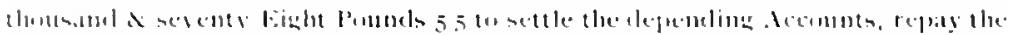

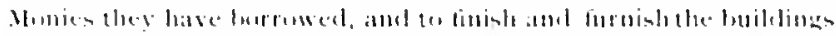

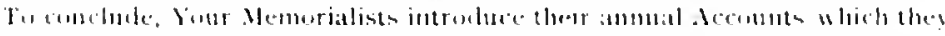

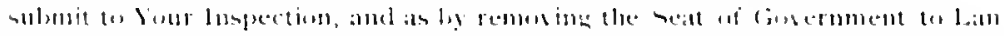

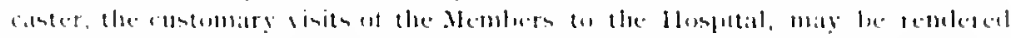

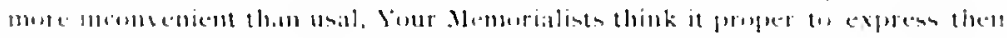

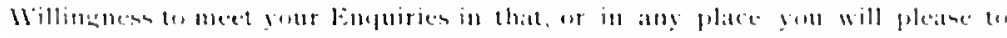

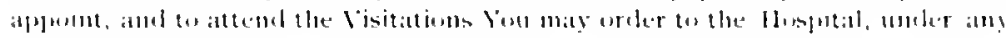

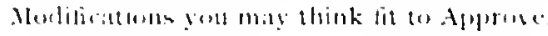

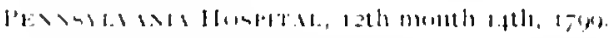

Signed by the Mith.12erts

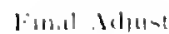
ment if 1, sith Hition. Find

The above was presented at lancinter by Saml. Coates, whowent there as a Commitlec of one for that purpose.

Acling under the authority of a special Aet of the Legislature of l'emsylumia, passed in 1 \$o, an amicalle adjustment and final settle. ment of the account between the Commonwealth and the Managers. acting as Trustees of the I oan Office Fund, was made. The minuter of the Nanagers' Meeting, held June $25,180.4$, contain the following report of the Managers' Commitue on the I coan Office Fuml. which was accepted and the Commitle discharged:

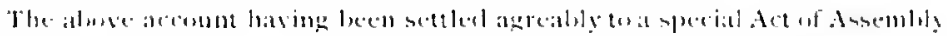

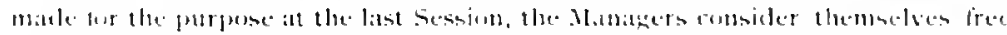

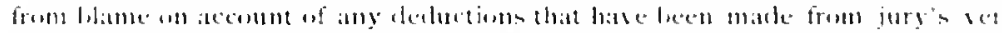

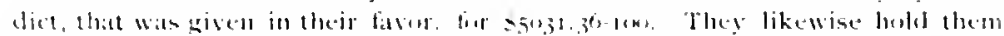

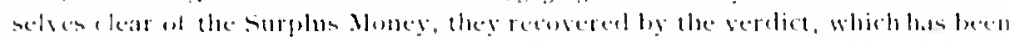

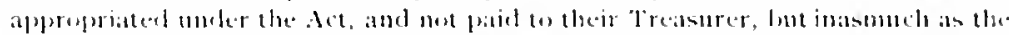

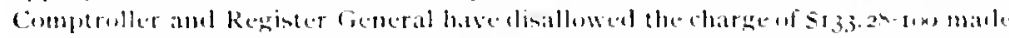

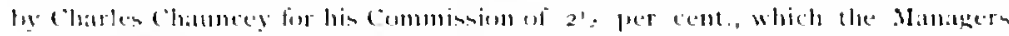

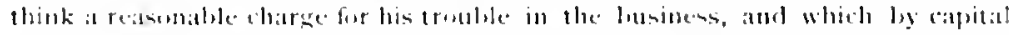

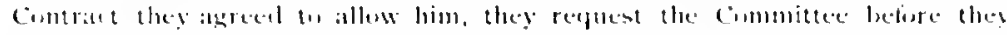

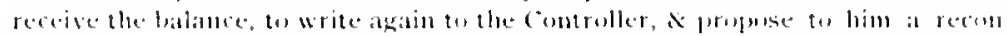

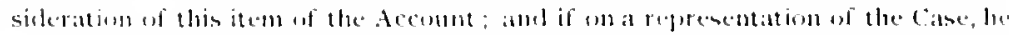

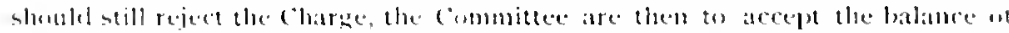

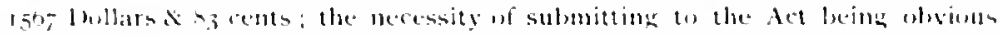
aithe in this instance the eperation of it appears unreasmolle. and meets with the distyprobation of all the Manasers.

In conserfuence of the fact that they had collected the entire amount, the Legislature by Act of April 4 , 1805 , directed a re-assignment of the remaining mortgages and other securities.

The Rev. Cieorge Whitfield, a dissenting clergyman, of great oratorical alitity. came to this country from England, in the early 
days of the province and held revival services, which created great popular excitement. As one of the substantial results of his preaching there was built for him in Philadelphia one of the largest churchen then in the colonies. He is said to have preached while here to an audience of 15,000 persons. After a successful tour in the South, he returned to this city, where, prior to his departure for Europe, he preached in St. Paul's Episcopal Church, Sunday, October 22, 1764, a Charity Sermon for the benefit of the Pennsylvania Hospital, taking his text from Rom. vii. 4. The amount realized, including his per. sonal contribution of five pounds, was $\mathrm{I}_{\mathrm{r}} 74 . \mathrm{I} 4$. o. (or $\left.\$+65.86\right)$.

On March 2d, 1786 , the Managers received word that Mr. Noah Webster had made a public offer in one of the newspapers to give a benefit lecture on the English Language, to the Pennsylvania Hospital, provjded he was waited on for that purpose. The Board agreed to accept this offer, and Josiah Hewes and Reynold Keen were appointed to wait on Mr. Webster and acpuaint him therewith, and also to thank him, in the name of the Board, for his politeness. The following notice was read:

"Next Tuestay evening at zocinck, in the liniversity of Pennsyivana, 3t Webster athor of the Grammat icat lnstitute will begin to reat a short conrse of lectures on the English Language, and on education in general. Tickets fur the whole course (uf six lectures) at 15 s and for an evening 39 . sold by M. Carey \& Co. R. Aitken and F. Bailey, at their Printing offices. A serentls lecture will, if reguested, be delivered for the benefit of the I'ensusylyania Hospital. The ereninge proposed for the Lectures are Tuestliys. Thurstitys and situriays."

As Mr. Webster generuslycomply it with the request of this Board in wiviner a Leeture for the benefit of this Institution Josiah llewes and Regnold keth are appointed to conlect the Itoney arising from the Sale of the Tickets and pay the same lo the Treasurer.

The Committee for collecting the money for the tickets sold for attending Webster's lecture, on June 26,1786 , reported that they had received the entire proceeds, amounting to thirty-five pounds, two shillings, six pence.

On May + 1 786 , "a Grand Concert of Sacred Music" was given in the German Reformed Church for the benefit of the Pennsylvania Cinntut. Hospital, Philadelphia Dispensary, and the Poor.

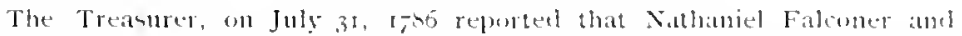
Regumd Keen had paid him forty onte poumds, twelve shillings and two pence on

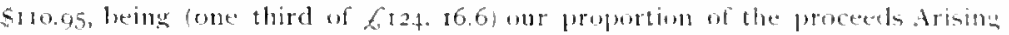

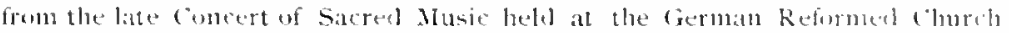
which the undertikers agrete to give for the I'se of this Institution for which they are requested to return the Thanks of the Butrd.

Early in the career of the Hospital, at the suggestion of Franklin, frmm ("hurity who fully appreciated the value of small things and the maxim with Busen 


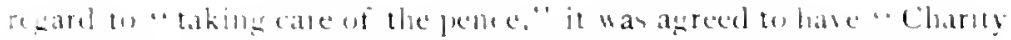
lines:" mate and set up to rescice the donations of wh has may be whlling to give anghing towards this purpose. Ilugh koluerts and sanl. Khorals were alpointed a committec to bave them make.

fonder date of lebruar! tst. 175,3 , it is noted in the mimutes:

(1011. 1110112 1, 1 histis in.

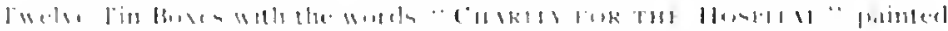

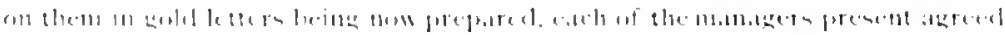

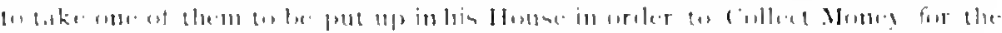

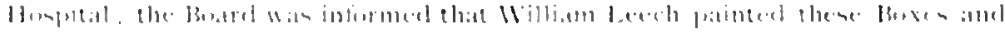

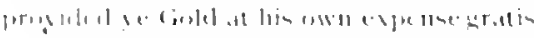

1)r. lianklin in speaking of there loxes in his book, "sone

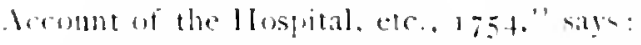

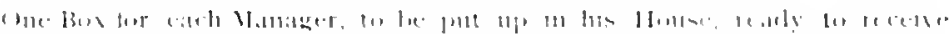

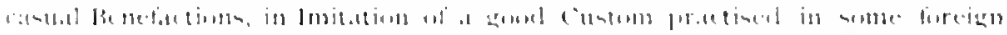

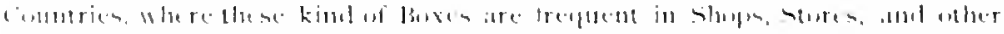

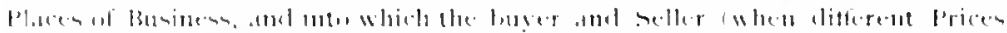

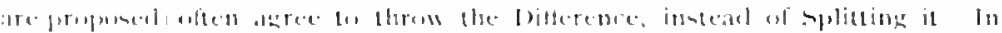

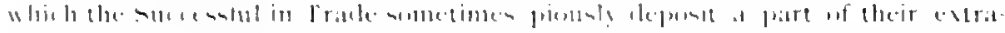

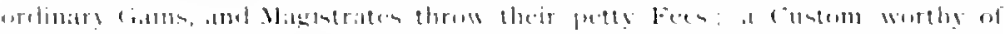

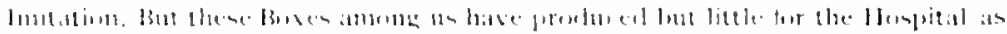

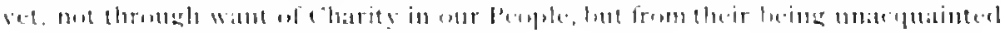

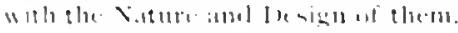

The latier remark was premature. has ing been made lut a short time after the boxes were gut up and their purpose not leing fully unclerstend, the puldic had not become accu-tomed to recing nor perhap thinking of this innowation, lut it alpeared that in due rourse of eime connielerable sums nere thats collected. The following entries will show some of the benelits clerived from this sontee.

"Jan'y 26. 1765, There was collected from the Charily lox uf

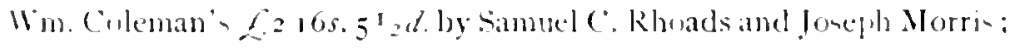
this amonme win handed to the Matron to le accounced for in bonsehold expenses." The same day was paid to the Matron E.3 $165.8 d$. , casla received from the Issembly's ("harity lox ly Daniel Rolectean and delivered to John kevnell for the use of the llospital. Who "faid 2.. 3 . to the Matron, cash found in the charity lox of the Hospititl."

It is stated May 3,1765 , " that benjamin Marsh was paid Ten shillinge for a large Charity Box." where this was placed or for what furposes, is not mentioned: it may lee inferred that it was for the hall or dour at the llonpital, the small one then in use having leeen found insuffie ient. May 27,1765 , this item occurs: "By cash for entrance

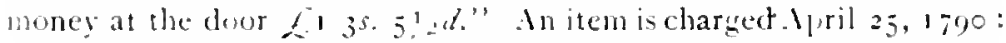

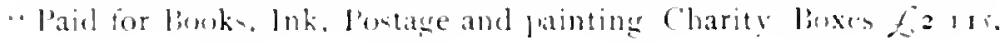


9 'zd." thus showing that these receptacle, were kept in good order and received the necessary attention to make them attractive and conspicuous to the public.

On the recommendation of the Committee on internal economy. I tune 29, 1812, a notice was placed over the Charity Box as follow: "Money not to be given ly visitors to servants or patients," to prevent if possible the charitably disposed persons from giving money to the inmates instead of depositing it in the box.

The aggregate anount of money received from the Charity boses kept in the Hospital and at the residences of Managers and other friends of the Institution, was $\$ 19,093 \cdot 44,41$ to the year $19+5$, as the minutes record. Several old time Charity Boses are yet to be seen in the wards of the Hospital, in which small amounts are still octasionally deposited.

Before the invention of the numbering machines, and fac-simite reproductions of signatures, it was necessary in the early days when
paper currency was insued by the I'rovince, to employ persons to sign the bills. (See also page 49.) 'lhe Managers, ever on the alert to secure contrilutions for the Hospital. saw an opportunity for securing money and addressed the Legislature as follows:

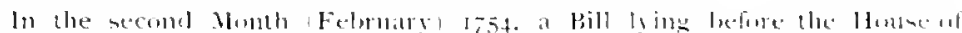

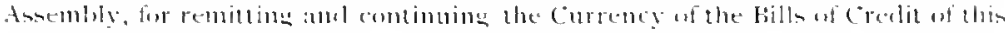

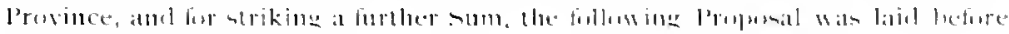
the Hollse, vis.

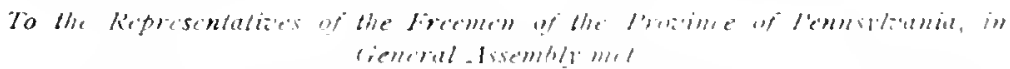

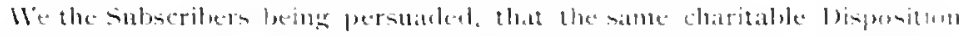

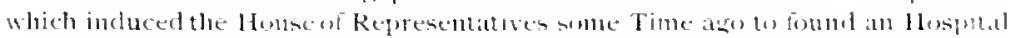

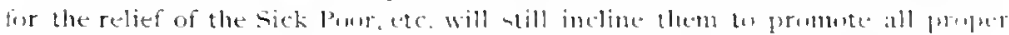

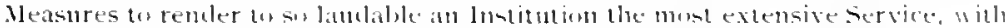

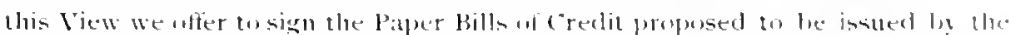

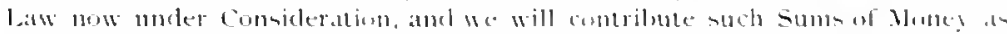

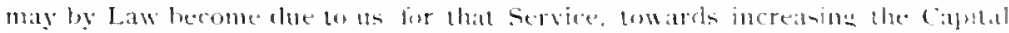

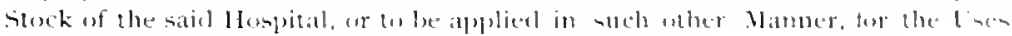
thereuf, as the Manager may think most propert.

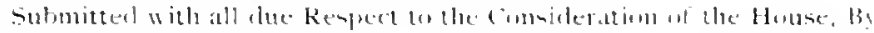

\begin{tabular}{|c|c|c|c|}
\hline W'illiam Lugatn & Jas. Pemlertum & Jomcollo king & Jomat. Eyatum \\
\hline Fentes & John l'ule & lim Fix & Jum satmolere \\
\hline Judah Foulke & 1"lu, sing & thom drombs & Intatel Jolle- \\
\hline Will. Pars & The circenterate & folno Irmite & lbanl. Williann \\
\hline
\end{tabular}

Sam Hazard.

Many of the signers of this proposal, it will be noticed. were also contributors. As might have been expected, the measure was strongly antagonized by the politicians of the dar. and as the bill failed to pasi. nothing was obtained at this time. 
The Managers and contributors sulseiquently succeded in their efforts to oluain money from this source. In a rejort made ly the linileling committee on fichruary 23,1756 , it is stated.

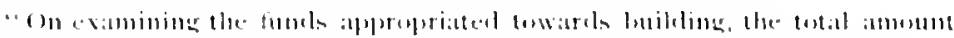

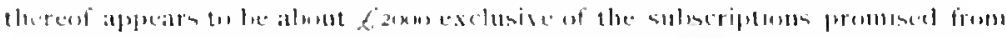

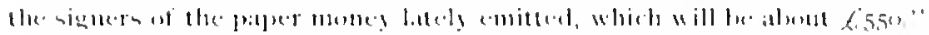

The Managers for the ensuing month (Iuly, 1757) were denired to procure an Order on lhe l'rovincial Treasurer from the Signers of the late 245.000 , bills of Credit of this l'rovince for the sum doe to them by the Act of Assembly, which they generously fromised to comtribute towards building the llospital.

laried Pemberton informed the loard that

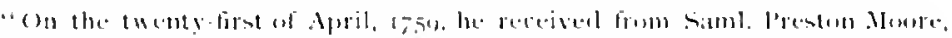

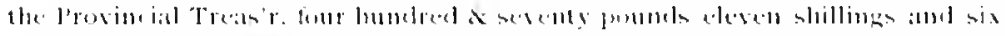

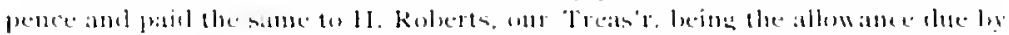

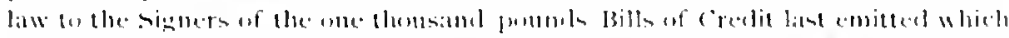

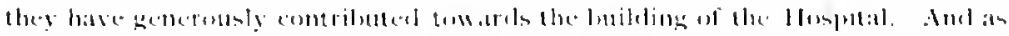

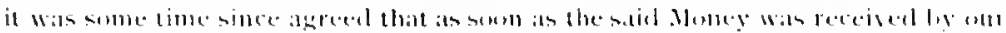

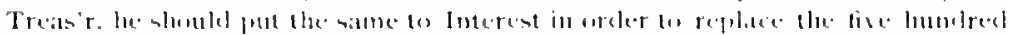

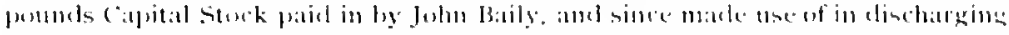

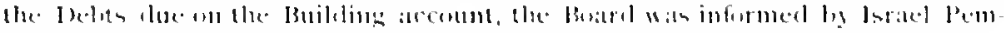

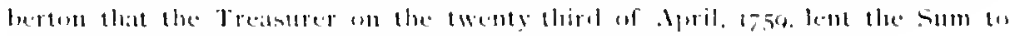

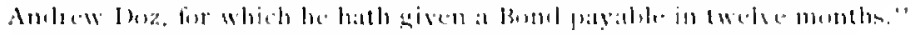

Signets in

On Mlay s. I 762 , the following entry ocelus:

laper llomey.

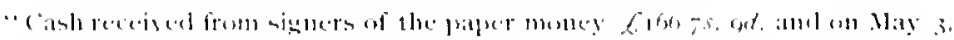

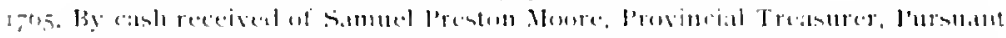

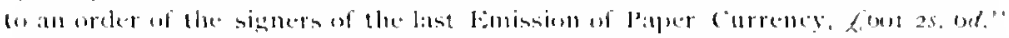

A very interesting docmment was found among the old fapers which will show the magnitude of the labor insolved in signing lills at this time, as well as the amount realifed ly each individual signer; the paper is worcled as follows:

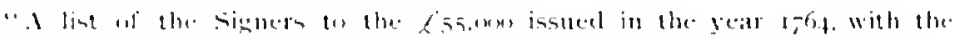

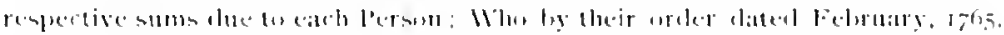

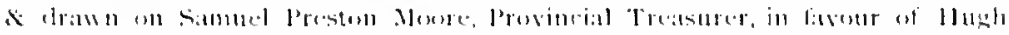

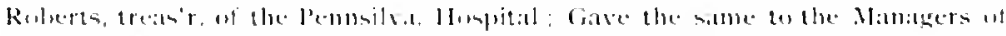

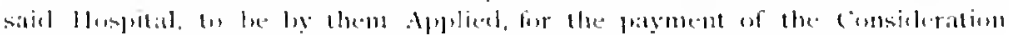

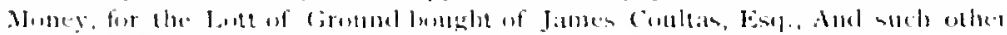

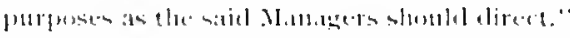

The signers were paid fifteen shillings per thousand signatures for the tickets and forty-five shillings for the same quantity for the bills.

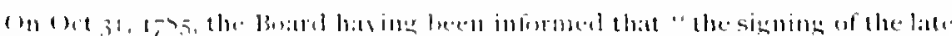

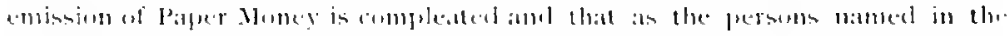

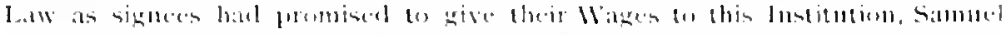

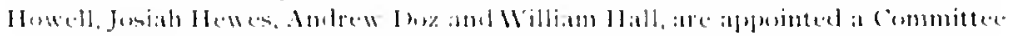

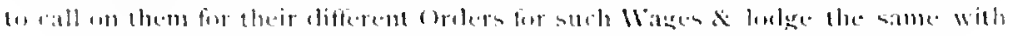

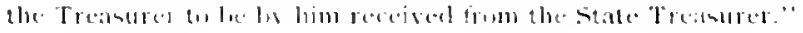


The Committee were as a rule successful in canvassing the signers: but the following, on April 30.1787 . proved an exception :

The Committee appointed to call oll as the first delinguent of

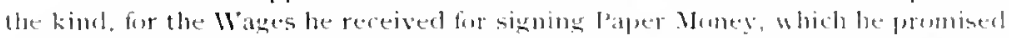
In sive lo the Hospital, repurt they hate disers times waited on him for at and he derlines paring the same: they are the refore reguested to call on him again ancl if le persists in refusing to pay it, they are recommenderl to take such Neames to reroser the Money as the Foxigence of the cant may reguire.

All measures which were thought might le sticcessful in bringing the celinquent to terms were employed, hut without avail. Subsequently it became not uncommon to refuse to ray subscriptions; and yuite a Iong list of these delinquents is found among the records of the Hospital.

The following sums were received from the signers of paper money in the years specified and the statement shows to what extent the Hospital was aided from this sunce:

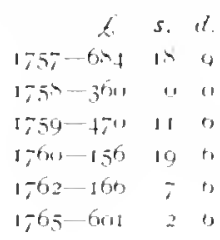

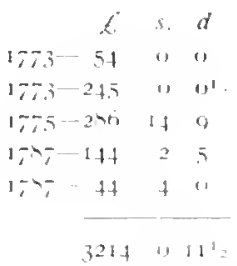

As an item of historical interest, it is noted that the Physicians of the Hospital charitably supplied the inmates with medicines gratis until December, 1752 , when an assortment of drugs were prucured from Lonclon at a cost of $f_{1} 12 I_{5} s$. 2 2 d. sterling, to pay for which William Griffiths, a Manager, made a special alpeal to the "rich widows and other single women" for a subscription. The widows contriluted $f_{111} 5 s$. 6\% and sundry women fis ros, making a total of Eir 26 15s. 6\%. in currency.

It became guite popular among the charitable to donate fees. Feen and etc., received for public services, to the Hospital. Among these. Jury fees were received as follows, to wit:

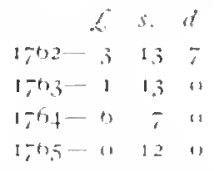

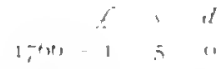

$$
\begin{aligned}
& 17+5-214 . \\
& \text { Tu1.1. } 10+\text { - }
\end{aligned}
$$

'The Underwriters at Wharton d I, wis' Insurance (Iffice, in 1792 , gave their fines, amounting to $\delta 4975.4 \%$

Assignees also contributed. Rolert Waln. Ir.. and Mordecai Lewis Freas, in 1792 . gave their commissions as Assignees of a bankrupt's estate to the Hospital. E1 $1 S_{1} 5$ s. each, or together $E_{3} 6210 \mathrm{~s}$. o. 
In ant uf wift, retributive justice. ly which the Jospital lenefited peouniarly, in commenorated ly this curious entry in the l'reasurer's accoums:

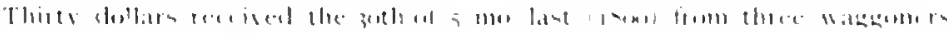

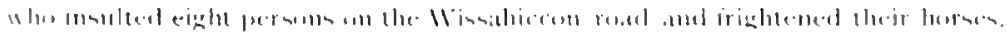

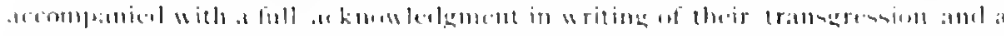

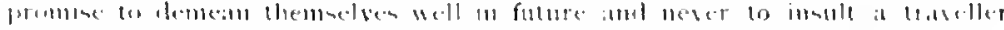

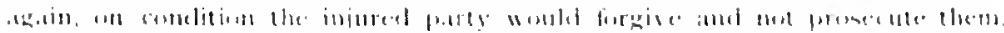

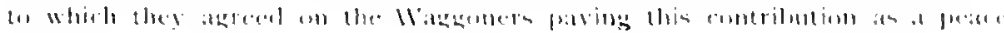
witring.

I num-1.1 An undsual source of a donation to the Itospital in mentioned in mindtum the records for April 25,1 sog. The Managers ordered the followin: entered 11 on their minuten:

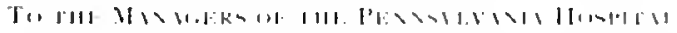

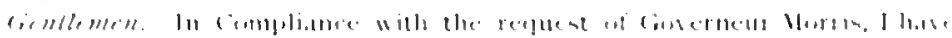

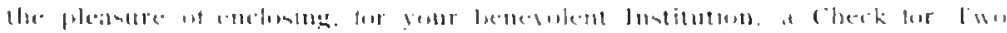

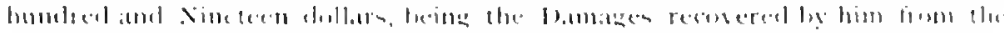

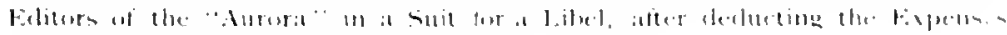

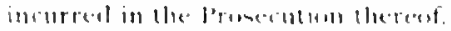

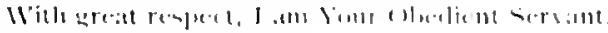

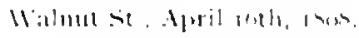

$11111.11131 \% 1 \% 111$

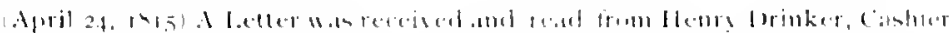

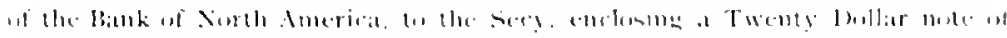

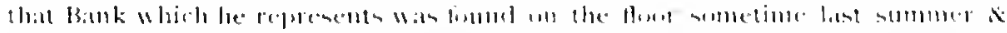

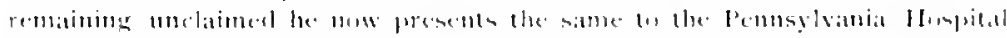

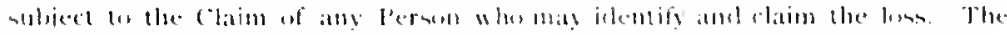

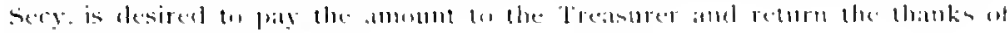

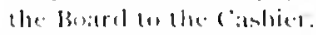

Flie Ifupitil ememely

leperencene

11] 13

1.1011.2110)16

9"1u privale

soneress firr -iljpure

Since the Art of April, t7go, mating an alditional grant to finish the west wing and center of the l'ine street Iospital, the instiution has been entirely supportenl hy donations, legacies. and hepuest from private sources. No legislative grants bave leen made during the present century.

Jegacies intended to promote the interests of the d'emmylrania Ilosplal should he given in its corporate name, viz. " I herelsy give and berpeath to "Ihe Contributurs to the l'ennsylumia Hospital" and their successors and ansigns forever (it real sotate) all that. che. (if personal property). the stm of, etc."

Iegacies intended for the lepartment of the lmane boukd yecify in addition " to le devered to extending or improving the an commodations. and for the care of the in ane."

Every contribution or legact of $\$ 5.000$ alds one free bed to the number alreaty in une for indigent. reant and supponed curable, ciance. 


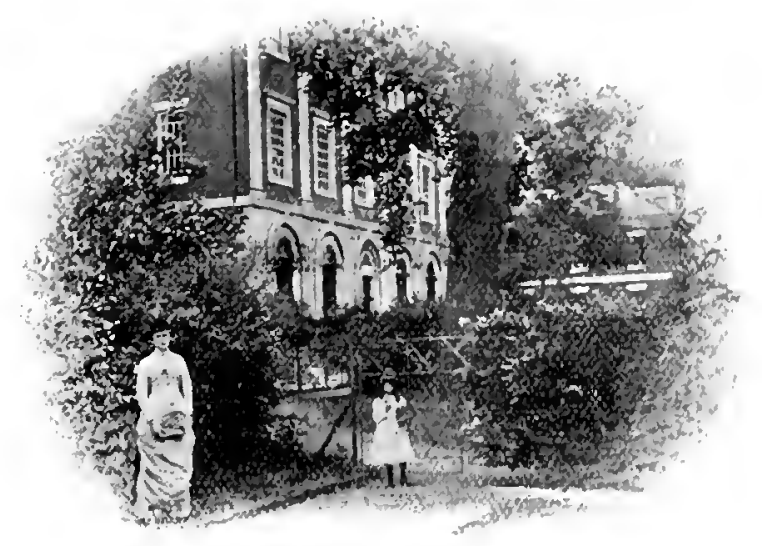

REAL ESTATE.

The hirst piece of real estate owned by the Hospital was located IJutliatn in the prart of the city known as Northern Liberties, on Germantown kiplin's Road. It was donated by Mathias Koplin. September 2, I 751 , as " his contribution, accompanied by a complimentary letter (see jage 26). This was leased for a time. until the Nanagers. July $3^{\circ}, 1764$, agreed to let upon ground-rent.

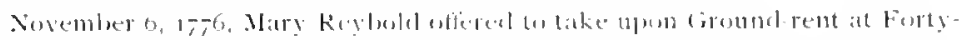

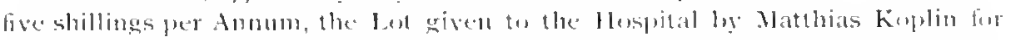

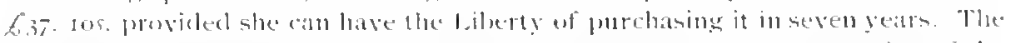

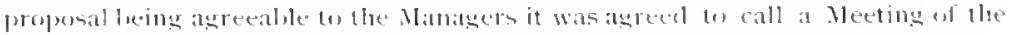

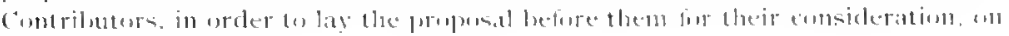
Jeecember $0,1 \%-6$.

The contributor asreed:

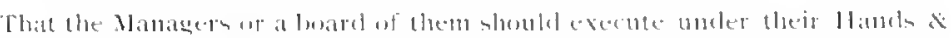

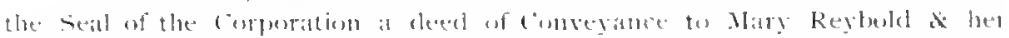

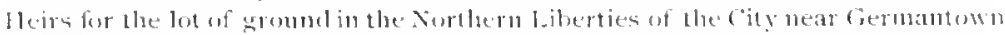

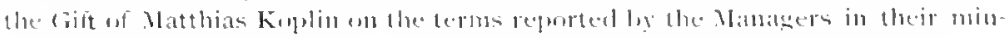

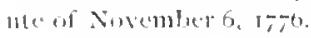

The first real estate purchased by the Managers of the Pennsylrania Hospital was the site for the erection of the Hospital buildings.

(n) September II, I754. they learned that Socjety Square, Finat lour "ristise on Real rintate extending from Eighth to Ninth, and north from Pine Street, conld be olstained for $£ 600$. It was sulsequently ascertained that the offer of sale was limited to the holdings of William Hinton and Richard 


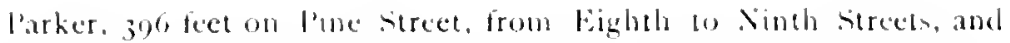
consmblos 366 leet northward to a strip of ground on siruce street. This strip on Spruce Street, extending 396 feet from lighth to Ninth, and 10 i feet sonthward, belonged to the I'roprietaries. Thomas and Richard lenn (who sulserguently donated the same to the Hospital by patent. dated cosember $10,1,67$ ). The Society sipuare was hought lecember i. 155t: the sum finally paid by the contrilutors to Hinton and Parker, for the ground, being 5500 .

The area of gromul purchased was $3 \cdot 32+$ acres and the portion conated h, the Penm, 0.97 acres, or altogether about 4.30 at ren.

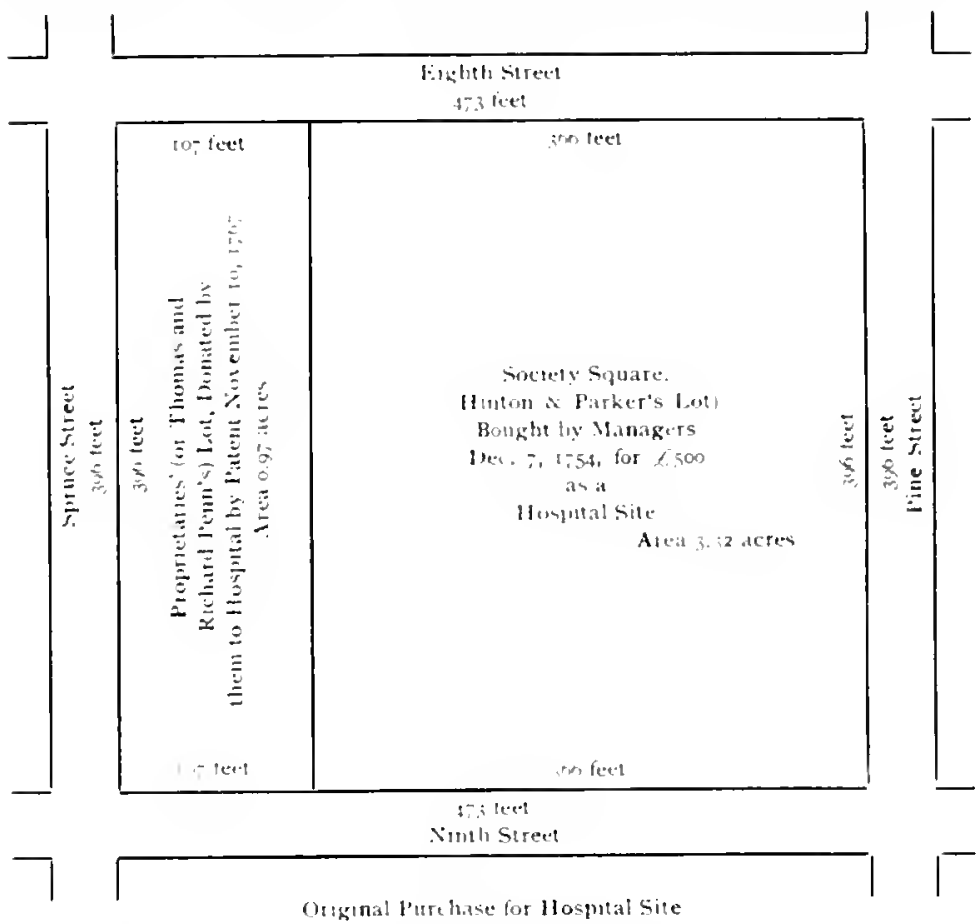

The leed for the ground purchased reath as follow :

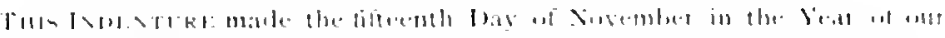

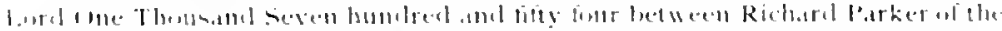

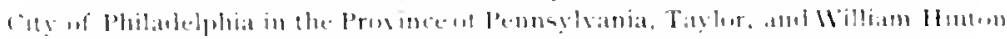

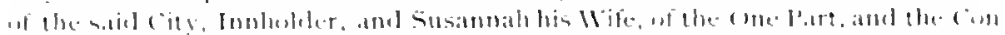

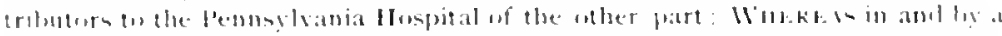

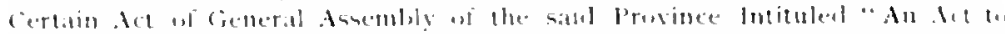

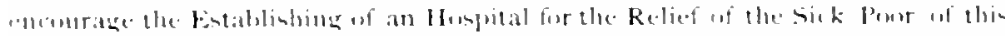

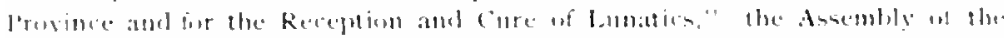

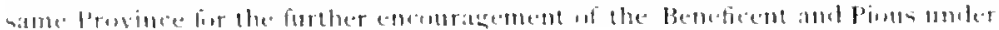


taking of the said llospital did grant Two Thousand Prumds for the Fonnding Building and forishing thereof Mn MHEk date the Twenty-Eighth Day of January in the Vear One Thousind Seren hundred and Twenty four Recorded at Philadelphis in Bork G. Vol 2 page 221 etc. marle betwen (harles Read, Job Goudson, Exan Gwen, George Fitzwater and Joseph Piclgeon then of the City of Philadelphia aforesaicl Merchants (Trustees appinted hy an Act of General Assembly of the satd Province mate in the Ninth Year of the Reign of the late King feorge the First lntituled "An Act for vesting the lands and leots commonly called the Lands of the Free Society of Traders in Pennsyluania in Trustees to be sold for the payment of such sums of Honey as Were paid into the public Stoek of the said suciety for purchasing the said Lands and Lots and carrying on the Trade elesigned by the said Society" of the one patt and Richard Parker then of Latby in the Cunnty of Chester, Yeoman. IWho was the father of the first named Richard Parker) of the other part They the said Trustees for the consideration therein mentioned diel grant barkain sell and confirm untw the said Richard Parker the Elder and to his heirs and Arigns an. THat Lot or piece of ground Situated in the said City lbelonging an the said Society and then vested in the said Trustees by virtue of the said Act Bounded Fastward, with the Eighth Street. from Delaware, Three hundred and Sixty six feet: Sonthward, with Pine Street three hundred and Ninety six feet; Westward, with Xinth Street, from I belawarethree hundred and Sixty Six feet and Xorthwird, by a vacant lot. Three hundred and Sinety Six feet: Comtaining Three Acres and fify two perches with the Appurtenances to hold to him the said Richard Parker the Elder his Feirs and Assigns forever. Awn Wutreas the said Richard Parker, the Elder, and Wartha his Wife by Indenture Datted the twenty fith loisy of march in the Year one Thusand Seven hundred and Twenty five for the consideration therein mentioned granted one mil and equal Molety or half part ibeing the Westermosst part) of the said described Lot uf (iround with the Appurtenances unto David Thomas then of the Tomship of larby aforesaich,

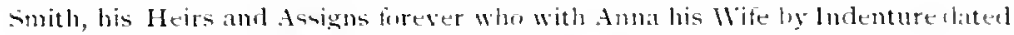
the Twelfth Day of Miy in the year one Thousand seven Humbed and forty for the consideration therein mentioned erranted the same Monety ur elual half part of the said Lot of firound with the appurtenances unto the alnse named William Hinton and Jane his then Wife their lleirs and Assigns forever $A$ in and ly the several recited Indentures Relation being therenuto Respectively had more fully and at haree appears and the said Jane the Wife of the said William Hinton, dying, the sitme Moliety of the said Lest devolved upon her said husband William by right uf strvivership; AND WHEREA, the sad Richard Parker the Elder, died seized of the Eastermost Mnsicly, equal half part or residue of the said described Lot of Ground with the Appurtenances as in his Fstate aforesaid having first made bis last Will and Testament in Writing bearing date the Twenty Eighth

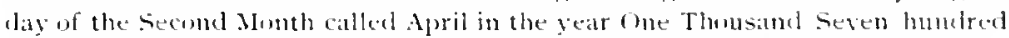
and thity six And therein devised the same unto his sun the said Richard Parter his lleirs and Assigns forever As by the sime in part Recited Last Will duly Proved amd remainimg in the Register feneral's office at Philatelphia aforesaid

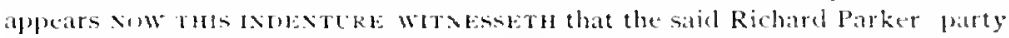
lereto William Ifinton and Susannah his Wife for and in consideration if the sum of Five Hundred P'ounds Current Mneyey of Pennsylyania part of the atheresaid Two thousand Prunds granted ly the Assemblv unto them in hand paid by the Contributors to the l'ennsylyania Hospital aforesad at and before the sealing and Dedivery herenf. The Receipt whereof is hereby acknowledged, hase and each and either of them hath granted bargained sold aliened enfeoffed releatsed and

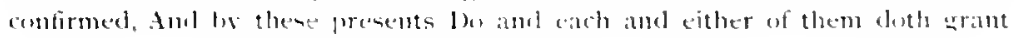

Deterl of

Hospital len on Eighth st. 


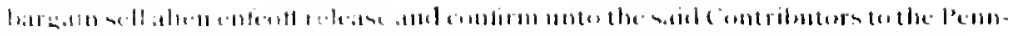

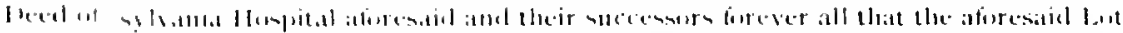

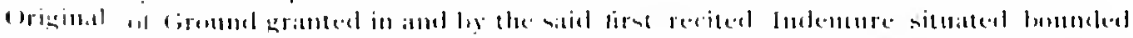

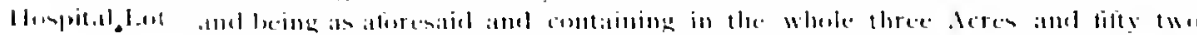

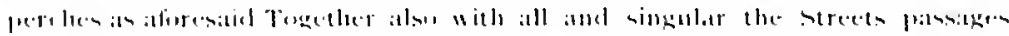

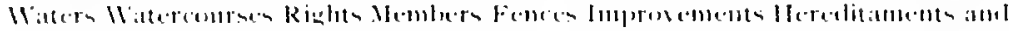

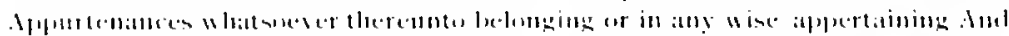

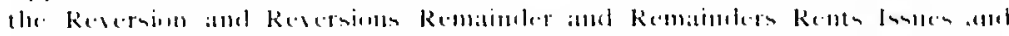

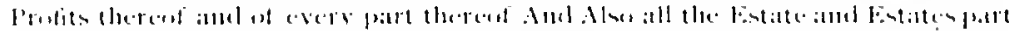

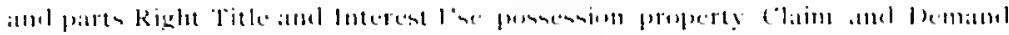

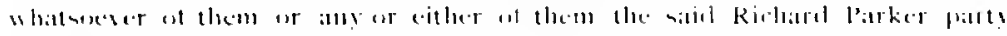

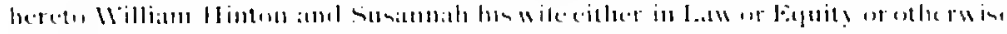

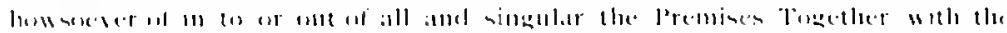

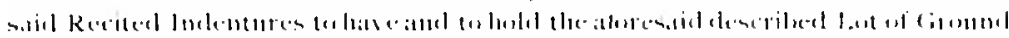

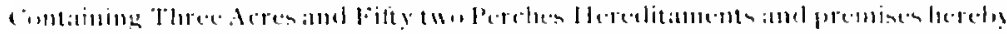

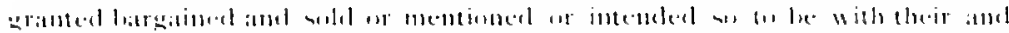

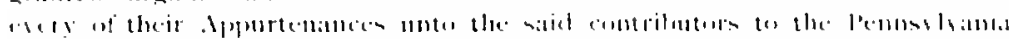

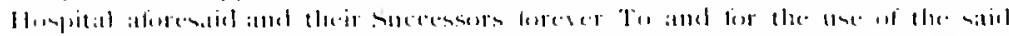

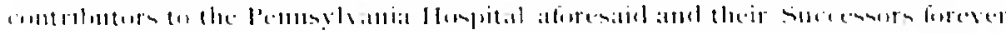

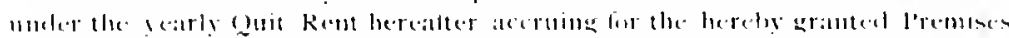

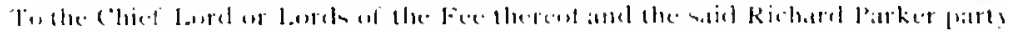

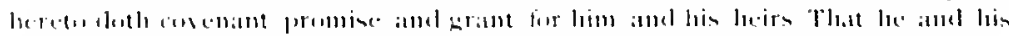

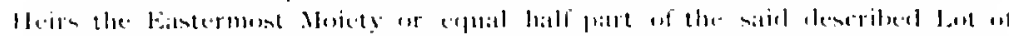

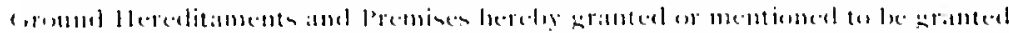

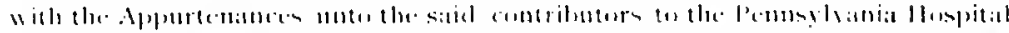

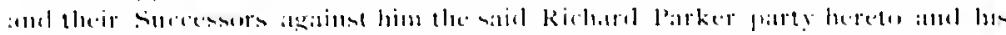

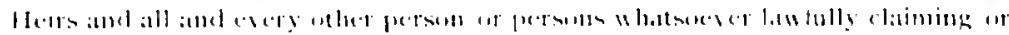

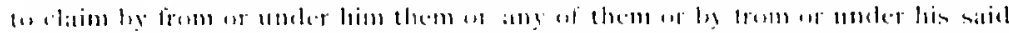

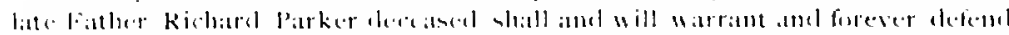

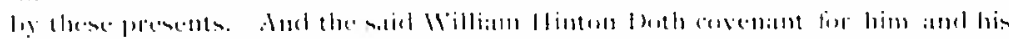

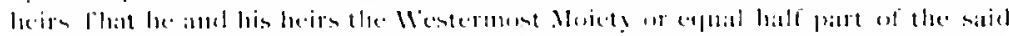

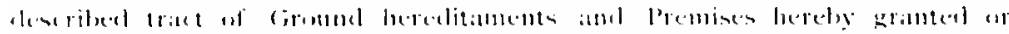

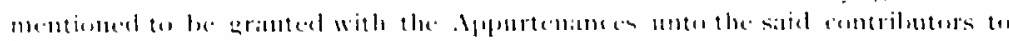

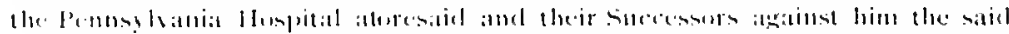

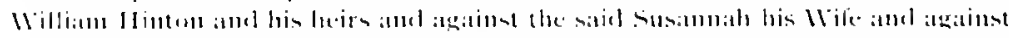

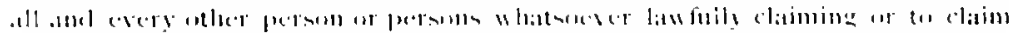

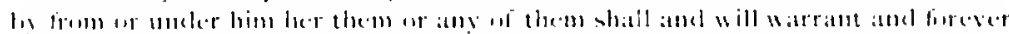

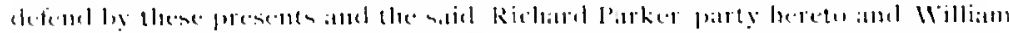

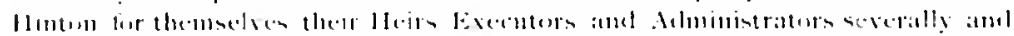

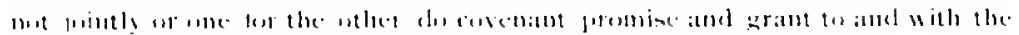

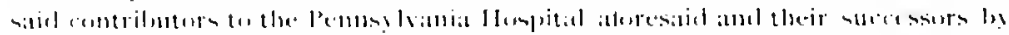

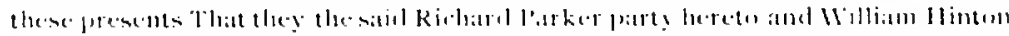

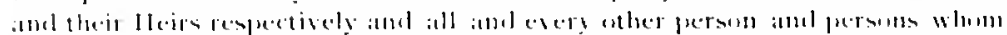

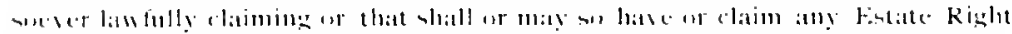

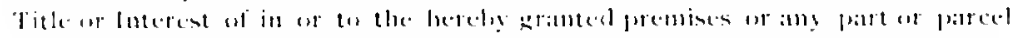

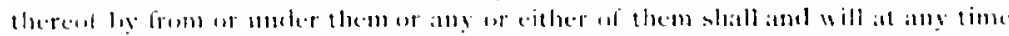

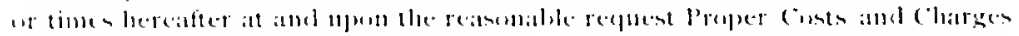

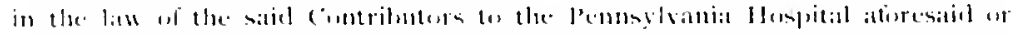

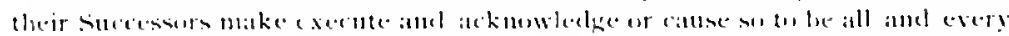

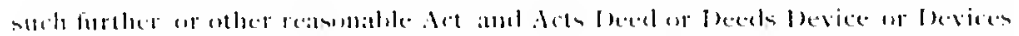

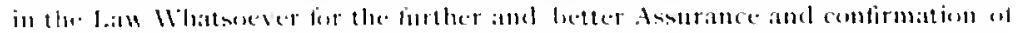

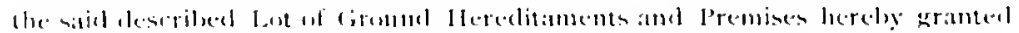

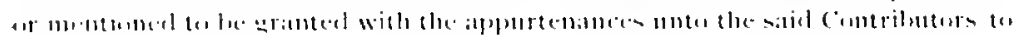




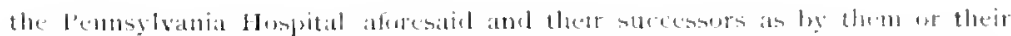

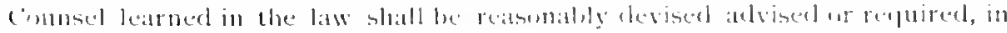

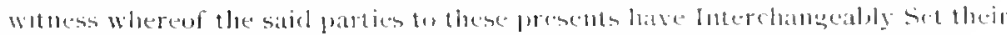

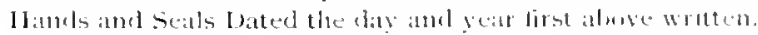

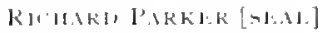

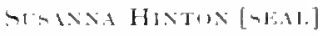

$$
\begin{aligned}
& \text { his }
\end{aligned}
$$

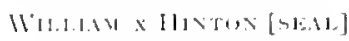

$$
\begin{aligned}
& \text { mark }
\end{aligned}
$$

At a meeting held september $2 \$$, i 765 , the Warrant for the lot "bounded ro7 feet on Eighth and Ninth streets and $39^{6}$ feet on Spruce Street," above referred to, as the gift from the Proprictaries to the Hospital, was produced. It was signed by Governor I'enn and was addressed to the Surveyor-General. The patent was finally presented to the Managers, at a Neeting held November 30,1767 . It is as follows:

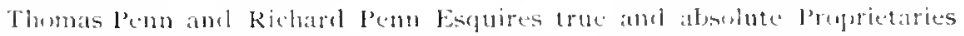

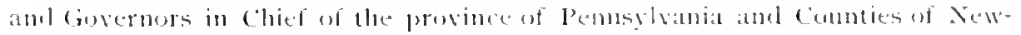
cantle kent and sussex upun lelaware To all unte whom these presents shall

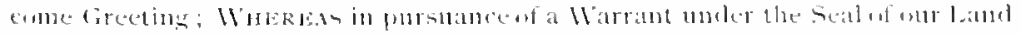

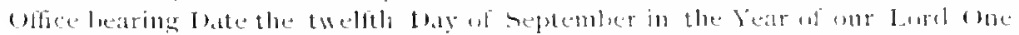
themsand Seven humbed and sixty live there was sorvereal on the thirel bity

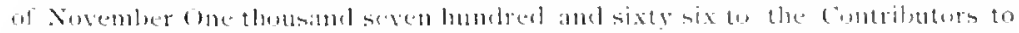

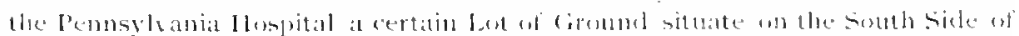

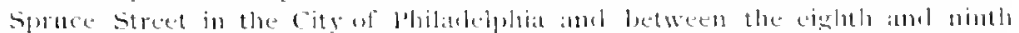

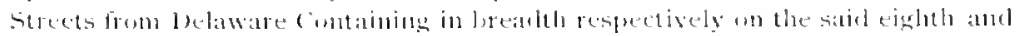

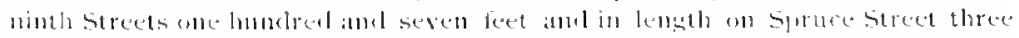

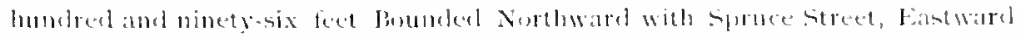

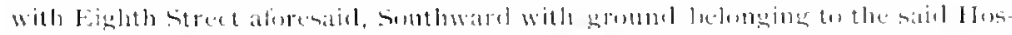

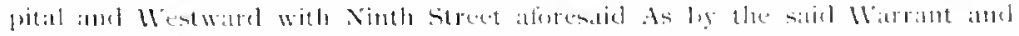

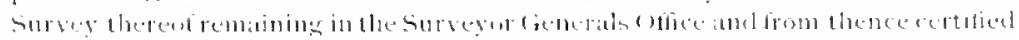

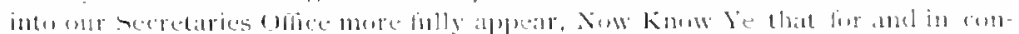

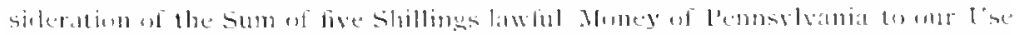

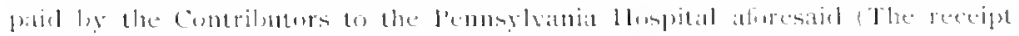

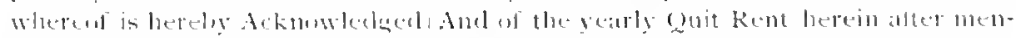

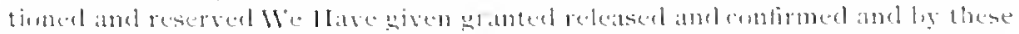

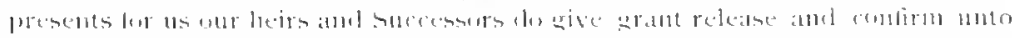

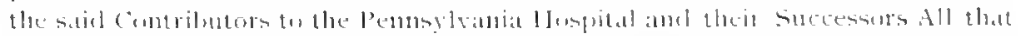

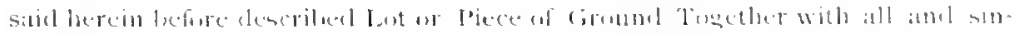

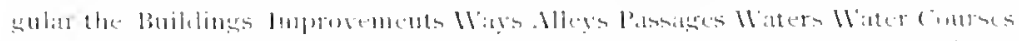

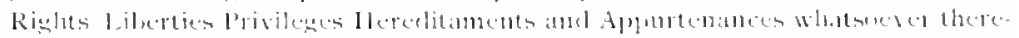

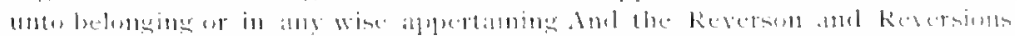

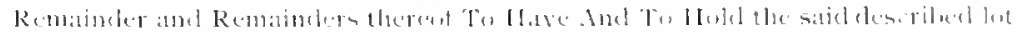

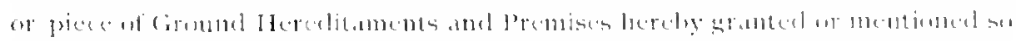

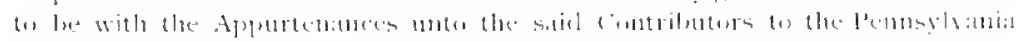

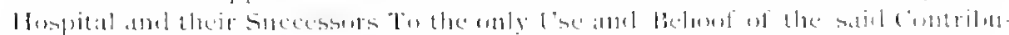

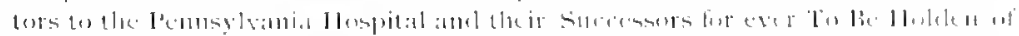

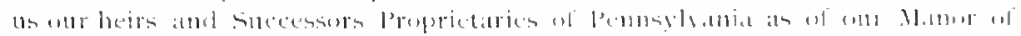

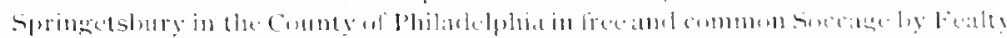

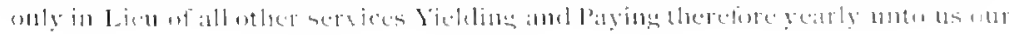




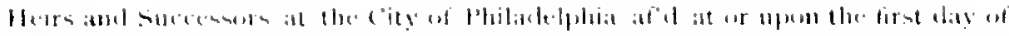

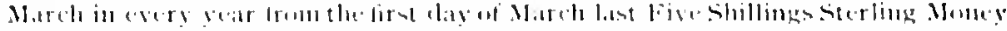

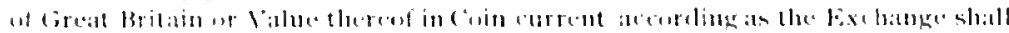

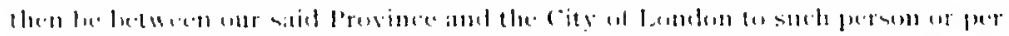

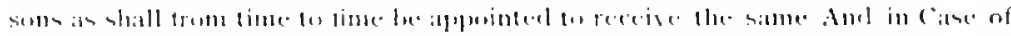

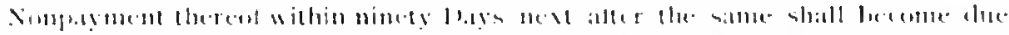

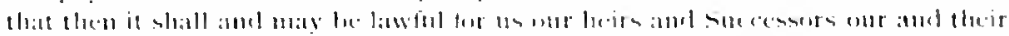

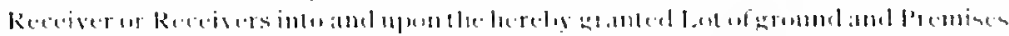

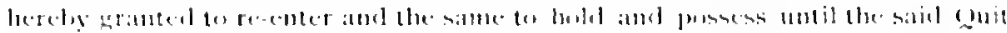

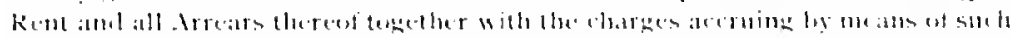

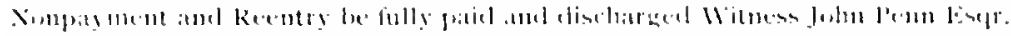

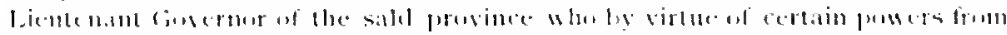

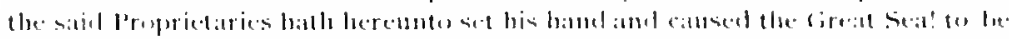

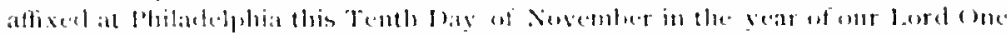

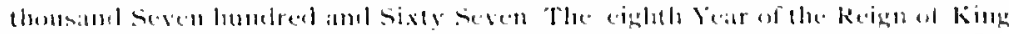

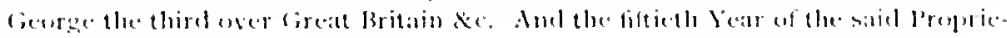

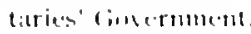

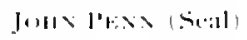

The l'enns also donated to the llospital, ly patent in 1769 , al lot on the suth side of spruce sirece extending southwarlly in ikphth to feet. to other land of the IIospital, and "sest from Ninth sitreet 198 fect.

Misterth foul

1,eised

(I) lecember 27,$1 ; 6,3$, the Managers learned that a lease for thirleen years could be olstained un a lot (on part of which a lirick Lenement was erectedl), being part of the square next west of the Hospital sile, "which may le useful for a pasture," elc. A committee, consisting of the Treasurer and Jacol, Jewis, was appointed to use their conleavors to get it secured for the benefit of the lospital. (1n Jantiary 31, 176.4, the Managers were informed by the committe that

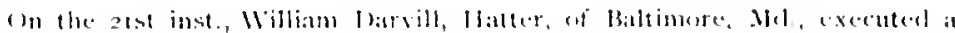

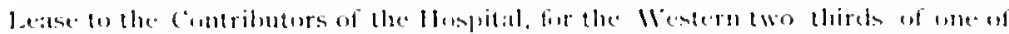

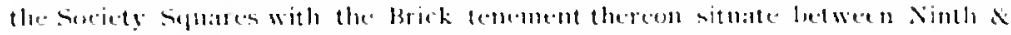

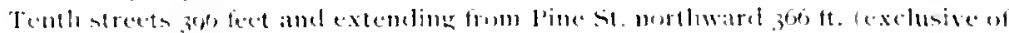

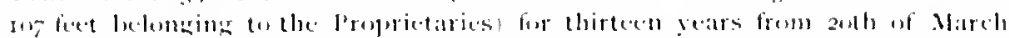

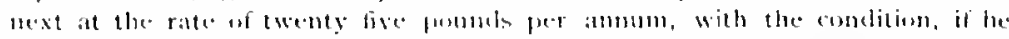

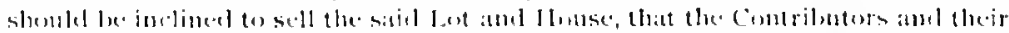

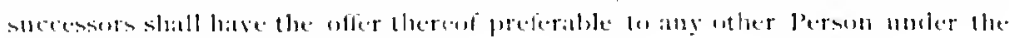

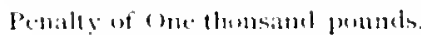

As some difficulties were experienced ly the Managers in oltain ing possession of the lol taken upon lease of William Darvill, and a favorable oflormity offered of purchasing it, the Committee who transacted that affair reporled (June 27,1764 )

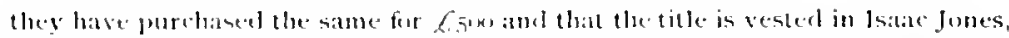

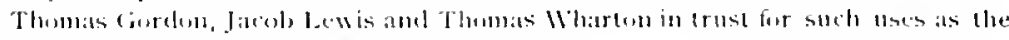
Managers lor the time lecing maly alireet. 
On February 24, 1766 , the Managers " Ayres had expressed an inclination to dispose of her lot contiguous to that purchased of William Darvill. A committee, consisting of Jacob Lewis and Thomas Wharton, was appointed to treat with her and purchase the same and report to next hoard, provided she agrees to take the sum she has mentioned of about $\notin 3^{\circ 0}$. The committee reported March 26, i 766 :

that Mary Ayres demanded a price for her Lent so much exceeling the sum men. tioned in the minute of last muntl they have not been able to make an aterement with ber, therefore the burd declines any further treaty at present.

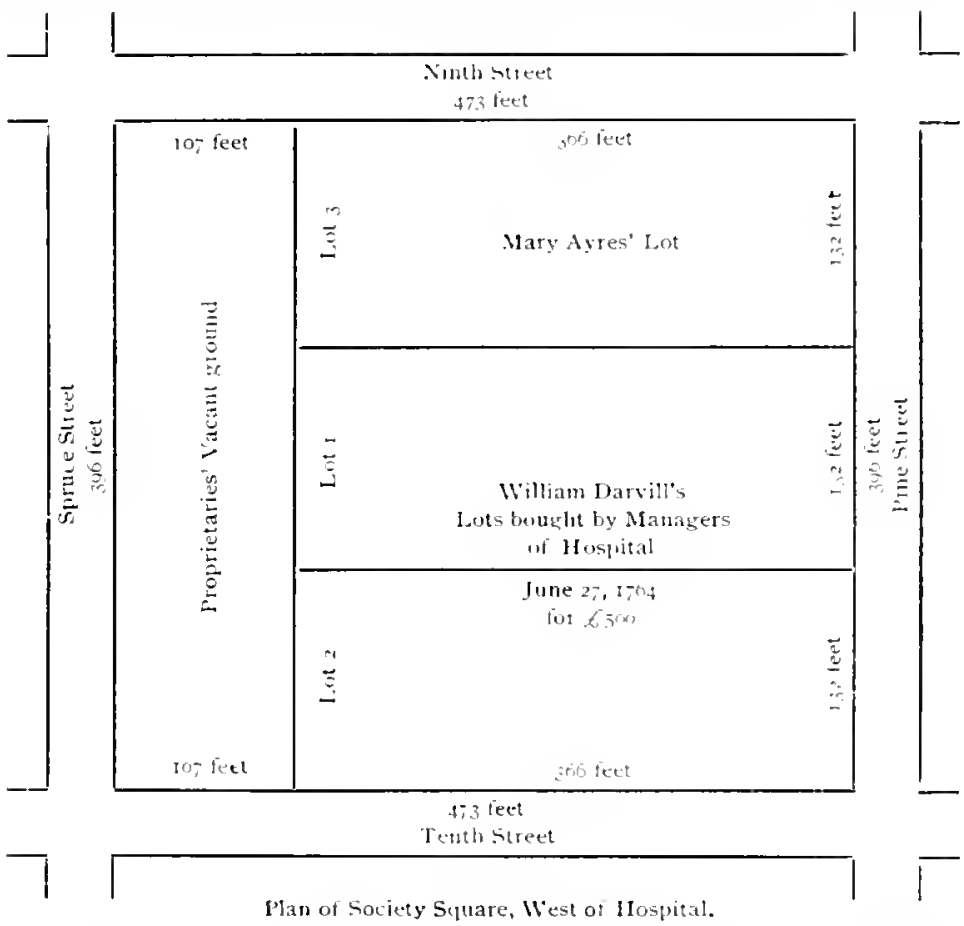

On August 26, 1766. the foard being informed by several l'mpersit of Managers of the House then erecting for the " Better Employment of Almshume the Poor of this City of Philadelphia, the district of Southwark and Townships of Moyamensing and l'assyunk and the Northern Liberties," that they have lately agreed for the Fasternmost third part wh the Syuare, whAuthorities tu Exehothec Iruperty. tignous (Mary Ayres fot) to the Lot lemint of William larvill by the Managers af the Hospital, it is now propesed that the consiclestion Money for luth purchatses being atded together and the Lot copally divided, the Eastermmest part should be allotted for the Ilosital ans the Westermusst for the House of Employ ment and an equal pitt, of the cost of the whole borne by each Institution, which the Managers agree to propose to the Managers of the House of Empluynem. 
(iindirentin of Mativiserers alial $11,110+\cdots$

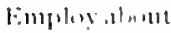

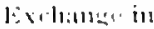
HesternI I.,

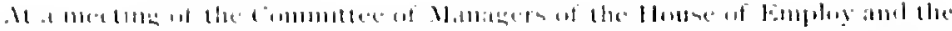

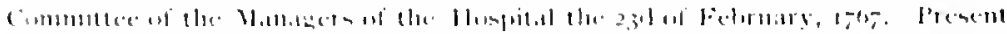

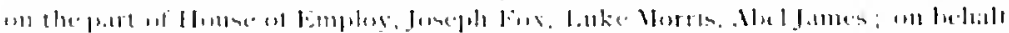

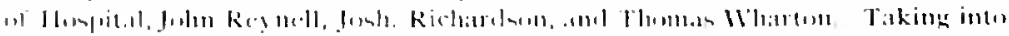

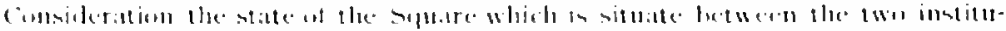

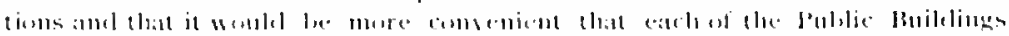

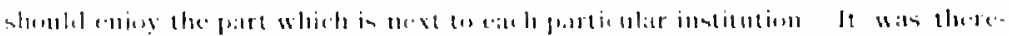

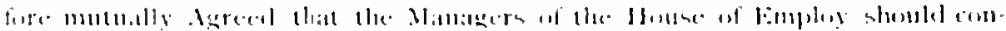

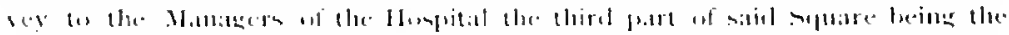

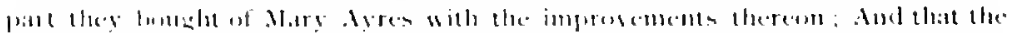

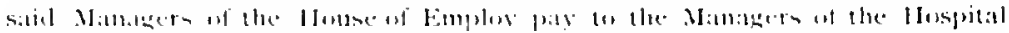

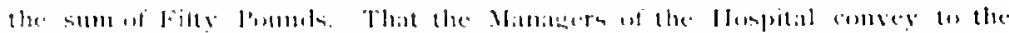

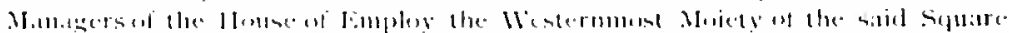

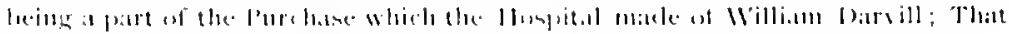

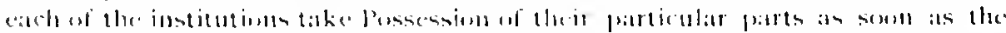

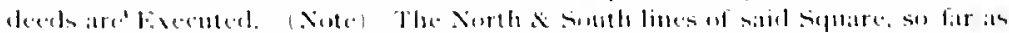

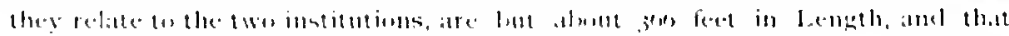

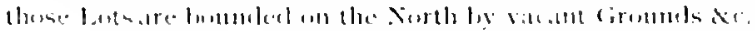

The lowed was prepared and exerned, Mareh 23,1767 , and the consideration money of filty P'ounds paid to the Treasurer of the Honpital.

Proprietaries

lowitle a

l'mt1011 +1

$11 \cdot \operatorname{sich} 1,1,1$

The P'roprietaries, Thomas l'enn and Ridhard P'em, donated to the Pennsbliania Ilospilal ly jatent, in 1700 . a bot situated on the sonth sicke of spruce Street. Between Ninth and Tenth Streets, coutaining cast and west on spruce street one lundred and ninetyeight feet, (west from Xinth street), leing execoled under the great seal of the province and recorded in the rolls office.

It is as follows:

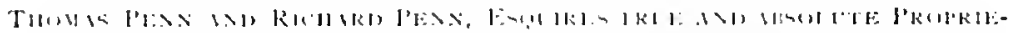

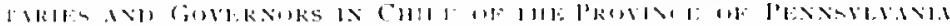

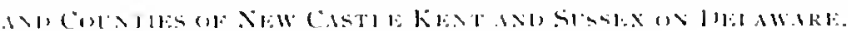

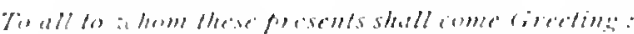

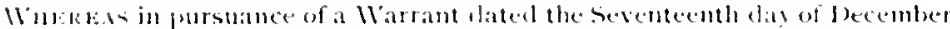

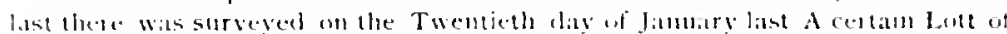

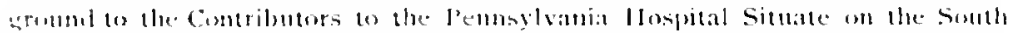

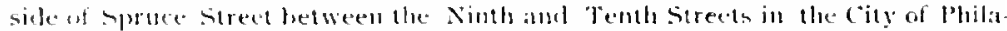

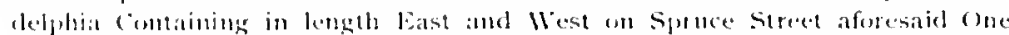

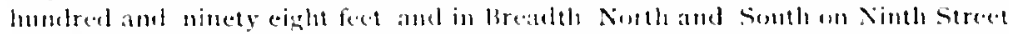

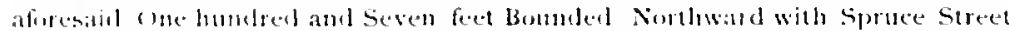
Fontwad with Ninth Street Southward with oher ground of the said Hospltal

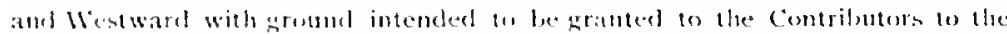

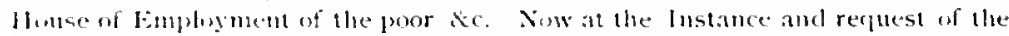

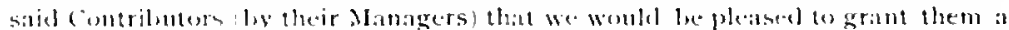

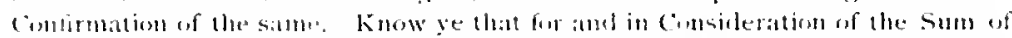

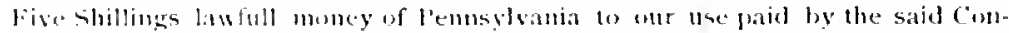
trihutuss the reecigt whereof we herehy ackmowedge and thereof do acquit

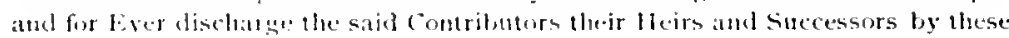


Presents) And of the yearly Quit Rent herein after mentioned and reservel We have given granted released and Confirmed and by these presconts for us uur Heirs and Successors Do Give Grant Release and Contirn unto the said Contributors their Heirs and Successors the saixl clescribed Loth of Ground as the same is now sel forth bonucled and limited as afuresaid Together with all and singtuar the Buildings Improvements Ways Waters Vater-Courses Rights Liberties Profits Advantages Hereditaments and Appurtenances whatsoever lo the said Lott of Ground balonging or in any wise appertining and the Reversins and Remainders thereof To have and lo holl the sad clescribed Lot of ground S premises hereby granted or nentioned so to be wilh its Appurtenances unto the Contributors of said IIospitai their Heirs and Successors To Lle only Use and Beloof of the said Contributors their Heirs and successurs for Ever To be holden of us our Heirs \& Successors Proprietaries of Pennsylyana as ot our Minuof of Springetsbury in the County of Philadelphia in free and common Soccage liy Fealty only in lien of all othet Services lielding and Paying therefore learly unto us our Heirs and Successors at the said Cily at or upon the first clay of March in every year from the first day of March next-Five shillings Sterling for the same or Value thereof in Coin Current according as the Exchange shall then be between our said Province and the City of London to suth Pessun or Persons as shall from Time to Time be appointed lo receive the same. And in Case of Nonpayment thereof within Ninety Days next afler the same shall become due that then it shall and may be lawful for us our lleirs and successors our and theit Receiver or Receivers into and upon the lerely granted liand and Premises in re-enter and the sane to have again repossess and enjoy until the said Quit Rent and all arreats thereof together with the charges accruing by means of such monpayment \& Re-entry be fully paid and discharged Witness John Penn Esquire Lieutenant Governor of the said Province who by virtue of certain Powers and Aluhorities to him for this Purpose inter alia. Cranted loy the said Proprietaries hath hereunto set his lland and caused the Great Seal of the said Province to be hereunto affixel at Pliladelphia this Fourth day of Feturury in the Year of our Lord One thousand seven hundred \& Sixty nine The Ninth Year of lhe Reign of King George the third over Great Britain \&c. and the fifty first year of the said Pruprietaries Government.

[R.corded 6th May 1760 in Deed Bouk 1. Vol. 5 page 34 . Se.]

$$
\text { JOIN PENX }[1, S]
$$

The Managers, on Octolser 27, iss (inardians of the Poor in charge of the City Almshonse, communi. cating a plan for the improvement of the lot owned by them, aljoining the western ground of the Hospital, if the Managers of the liuspital would give twenty feet of their ground towards a forty foot street propased to he opened through the Amshouse lot. On consideration the Secretary was directecl to reply that the Board had no anthority to make any arrangement in the premines, and do not deem it judicions to convene the Contributors at this time.

At the meeting of the Contributors, hete May 10, 18;0, the Managers were, by resolution, directed to purchase of the Managers of the Almshouse their moiety of the stuare lying westward of the Hovpital site, provided the same can le obtained for $\$ 50,000$; and it 
the purchase can be mate, the Managers of the Honsital are authorised to lay out a thirly fou street to extend from Vinth to 'Tenth sitreets, at the distance of one humblest and fify feet sumb from Siruce strect, etc. On May 31,1830 , the Commitlee authorized to ofler the (Buarclians of the loor the sum of $\$ 50,000$ for the Almshouse lut. regerted having done so, and that this body had officially declined the propusition.

$1.31,1112$ $1.11,19$.

Dece 27, i $8 ; 0$, the Managers received a proposal from Thomas Mitchell, instrucled ly John savaye, to exchange the western lot for that of the Gitardians of the Poor, so als to give the northernmost 160 feet of the IIospital tot th a 30 leet street for all the Almshouse lot south of said street, lecing $2 s_{3}$ feet.

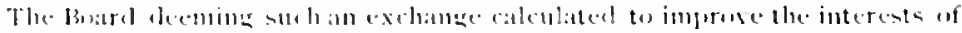

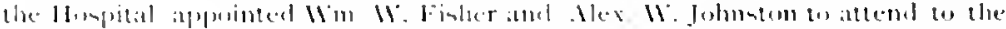

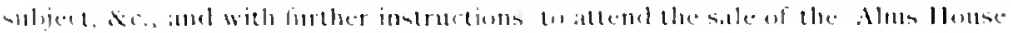

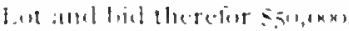

The Committec on January 12,1831 ,

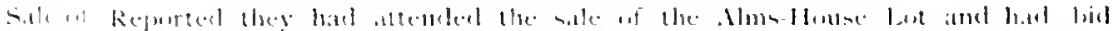

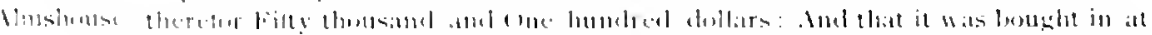

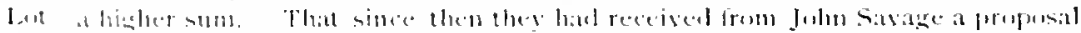

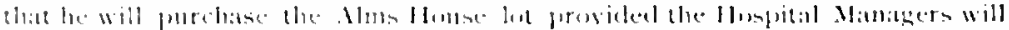

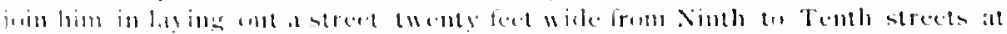

$1+1+\cdots+i(j, 1)$

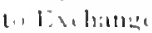
l't.pert!

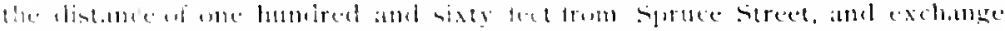

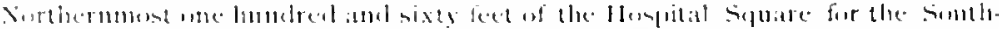

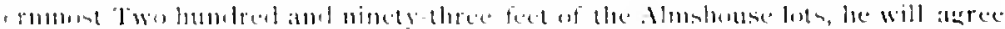

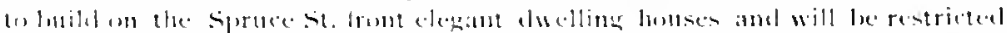

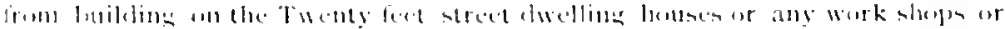

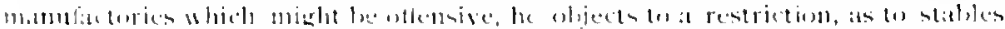

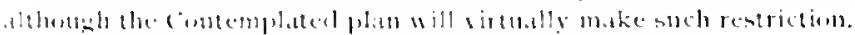

The Managers arlopted the following resolution :

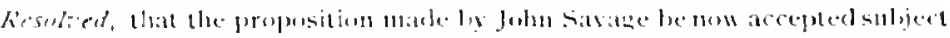

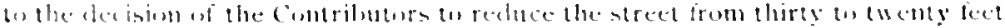

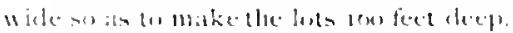

It a meeting of the Contributors of the Pennsyluania Hospital it $11 \mathrm{il}$

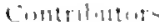

fieselect, that the Managers of the said lluspital be and they are hereby Huthrize

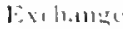
$1,1,110$ anthorizet and directcd in the name and on bebalf of the Contributurs to the l'ennulsania fluspital tuenter intosuch contract and agrecmeat with the said Juln Sastage as shall be sufficient 10 secure lhe performance of the following milects. viz.:

"i. "Tu lag sut and open a street to extend from Ninth St. to Tenth Sitreet at the distance of one hundred and sixty feet suthward frum the south line of spruce strect which said strect so to be laid out shall be lwenty feet wide and shall be called lond street and shall be and remain upen as a public street or lighway foreser. 
"2. To effect an exchange with the said John Savage of all that part of the Square (westward of the Hospital and now belonging to this Corporaton which shall lay northward of the said twenty feet street and is believed to contain in front on Spruce street igs feet and to extend from the said Spruce St., southward to length fronting on Ninth St., 160 feet to the said $20 \mathrm{ft}$. Street, bounded North. ward by Spruce St., Eastward by Ninth St., Southward by the said twenty feet St., and westward by a part of the said Alms Honse lot now belunging to the said John Savage, and to grant and convey the said lot just now described to the said John savage in fee subject to such restrictions as are herein after mentioned in exchange for all that part of the Square (westward of the Hospital commonly called the Alns House lot now belonging to the said John Savage) which shall lay Southward of the aforesaid twenty feet strect and Containing in front on pine St., One hundred and ninety eight feet and extendung from the said l'ine St., Northward in length fronting on Tentl Street about two hundred and ninety three feet to said twenty feet street. Eastward by other part of said Square now belonging to this Corporation. Southward by Pine St. and westward by Tenth St, afore. said, which said last described lot is in execution of said exchange to be granted and convered by the said John Savage to the Contributors to the Pennsylvania Hospital their snccessors and assigns furever in fee.

"3. That as well that lot of Gronnd so to be conveyed to the said John Savage in exchange as aforesaid as also that other piece of yround which be purchased from the Gnardians of the Poor and which lays Northward of the said twenty feet street shall be conveyed and made subject to such restrictions as to buildings to be erected on the said twenty feet street as the Ninagers of the said Hospital shall think proper-having regard to the safety and quiet of the Hospital and the purity of the atmosphere.

" 4 . The Mlanagers of the said Hospital are hereby invested with full and ample power in the name and on behalf of the Contribntors to the Pennsylvania Hospital to do and execute all such tcts matters and things in Deed or in Law as shall be necessary to carry the objects and resolutions into full and complete execution."

On motion, it was unanimonsly "Resolved that the twenty feet street Memmy if intended to be laid out as stated in the preceding resulutions shall be a amed Bond Inr. Bnul

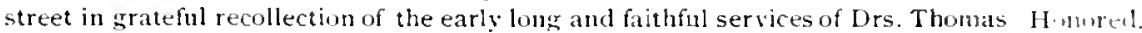
and Phineas Bond as Physicians to this Institution.' A deed for completing the exchange of lots embraced in the minnte of the Contributors was read and approved, the same Conmittee was continued to superintend the Conclusion of this business. On February 2h, 18,3t, the Committere reported that the Deeds were lnly cxecnted by the respective parties and those instruments placed upon record.

(1) October 3. $1 S_{35}$, the Committee for the sale of the western and southwestern lots presented a draft of an agreement between Charles F. Lex, Samuel Browne, Samnel Robb, Thos. C. Cash \& William H. Hospital Garrignes of the other, which being approved wats directed to be executed. Site December 16,1835 , a part of the Western lots baving been retalecl out by the parties with whom the managers have made a contract for the whule, it was agreed that the Committee appointed on the sale of said luts apportion the amount of the purchase money to be inserted in each of said deeds in conformity

The name of this street was subsequently changed to Cinton. 
with the original atereesment and when the sadd deeds atre drawn they are

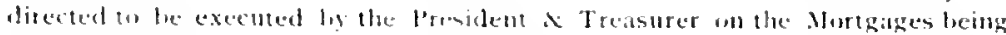
duly cexer ateal.

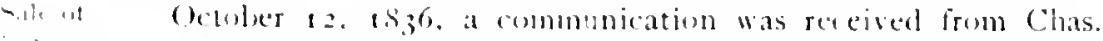

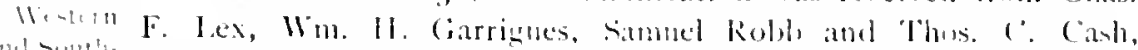

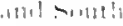
we $1+11$ "offering mortgages, which with those lefore received from then

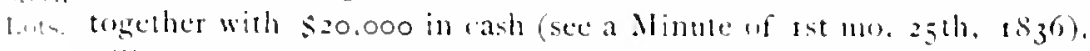
will complete the amount of the purchase made ty them of our western and sinthwestern lots (sec Minute of roth mo. $3^{11}, 1,8,6$ ) for $\$ 120.000 . "$

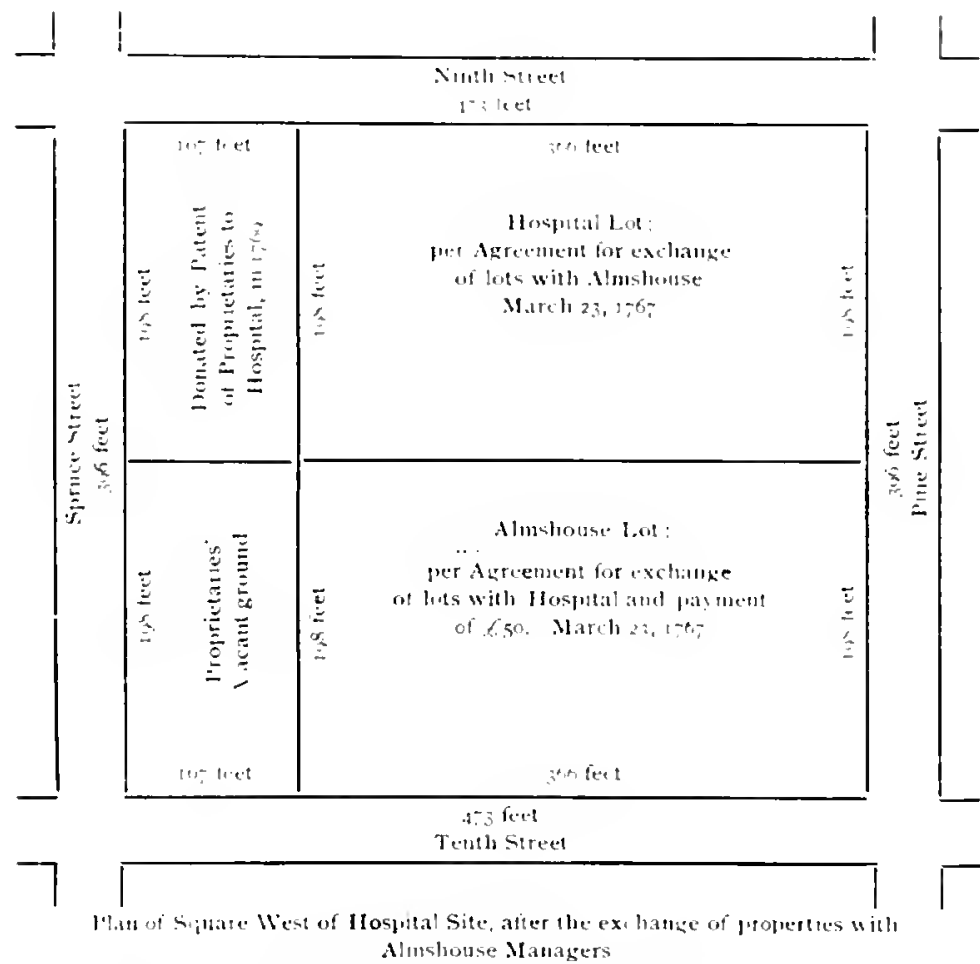

The following is recorded on the Minutes for Octuber 30. 1.,37,

"The Treasurer reports the execution and delivery of all the deeds for the Western and south Western lots, srold to Charles F. Lex, Samud Brown, Samuel Rubh, Thomas (C. Cash and William H. Farrigues for the sum of 8120,004 ; twenty thousand dollars of which payable in cash fovember 20th, is 35 , and the balance one humbed thousand dollars, in honds payable at any time within 5 yeurs from that date, with interest half yearly at 5 per cent per annum, to be crmputed from April ist, 19,36: and that he has received for the same cash and bumls secured by Motgages." 
On May 28, 1764, an agreement was made with Reuben Haines for an

Assignment of bis term of One Year : cume on a lease fur a certain l'fece of Pasture Ground being the Square opposite the Hospital to the Eustward between 8th and zth Streets \& line is Spruce Streets for Seven Pounds Ten Shillings-an urder was drawn on the Tieatsurer for the amount.

The Managers being informed on April 29, 1765 :

That Renben Haines hath lutely purchased of John Whityain one Wowety of the next Square to the Fastward of the IIompital for 6500 ; $\&$ that he applohends he will consent lur the accommodatuon of the llospitil to sell it tothe Contrihuturs, for the same price, it is therefure unamously agred that it will be expedient to purclase it, in order to prevent any inconvenient Buiddings beingerected thereon, \& John Reynell, Joseph Richarchon, \& I saac Gieenleafe are desired to treat with him, and agree for it if they can.

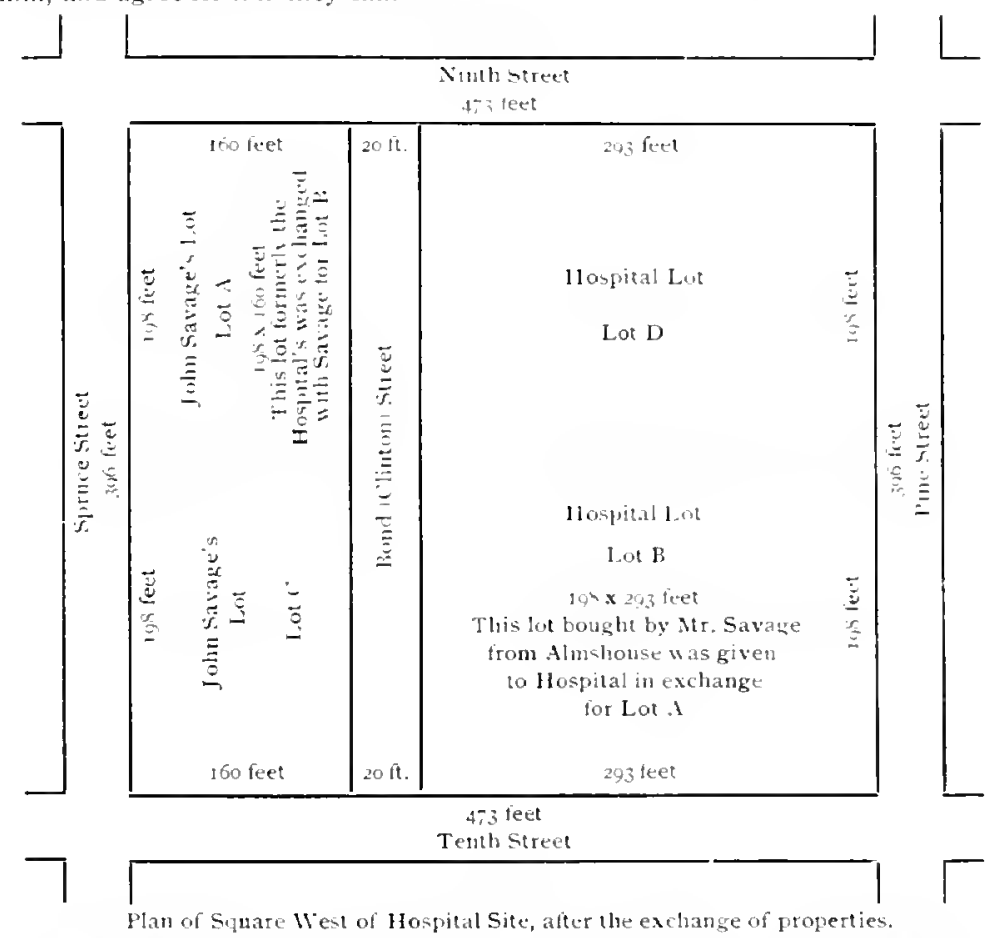

(Ninth Month $26,1-66)$, Joseph Richardson proposes that if the Maningers will purchase for the use of the Hospital the Lot of Ground, being one-half the Siguare between Seventh Street and Eighth Streets opposite the Hospital Eastwarl that he the said Joseph Richardson will contribute towards payment of the sime, the sum of One Hundred and Fifty Pounds.

Fourh Month 2, 176 7 ), the committe appointed to confer with Reuben Haines, about purchasing his undivided hoyety of the Square of Grund, bounded by the th \& sth Strets from Delaware, \& Spruce \& Pine Streets upposite the Penna. Hospital Eastward, which he purchared of John Whitpin, which he 
agrees to sell $x$ convey a the Corporation of Contributors of the Hospital for

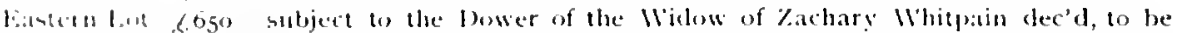

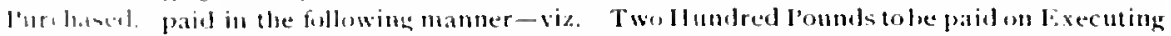
the peed, "Two llundred punds more in two months from the date thereof, and the remainder in three months from the date, and he further agrees to contribute Fifty putuds, to be discounted out of the last payment, to promote the Chatritable design of the Hospital which being considered $\&$ approved, the same committere are desired toget the Title examined, and the deeds of comveyance drawn, and when compleated to call a boud if they find it necessary

A Deed was produced April 27,867, intended to be executed ly Reuben banes $X$ Wife for the undivided Mosety of the Square of Giomd purchatsed of him, fronting the llospital Eastward, which was read \& examined \& requiring some alteration the care thereof was committed to the same committee who informed the Board that on a late conference with Rewhen Haines, he prefers having the consideration Money to be patid imentioned in the conveyance, slould be ne more than six hundred Punds, and that ner Notice he takentwis proposed cintribution of fifty lounds as at hist proposed, which was agreed to. On May 25, ro-g, report was macle of a beed from Reuhen Haines $x$ Whife lor the umdivided Moyety of the Square of (iroumd purchased of him, satuate foantward of the llompitat, which was exeeuted and deposited an the hands of the Treasurer.

Tenth Month 2h, 17-2:, Thomas forrest offeted for sale his undiuded fourth p.ort in right of his wife to the Soluare of (itomul between Seventh $\alpha$ bighth strects butuded Nintlward with Spruce Strect and Southward with pine Street for the sum of three lumbed punds out of which he angees to Contribute 'Twenty five pounds (1) the Hospital. The Boad cuncluded to purcliase the satid lot of him on the Terms aluse mentimed and to pay him the money as soon as we are able to r.dse it which we have expectation will be in onr power in a short time.

The sheriff of lhilatelphia county, on Nusember $28,1774$. served a Writ of Partition on William Whitpain and the Contributor to the l'entusyluania Hospital respecting the Sequare of (iround to the eastward of the Hospital, and Isracl l'emberton. Edward l'enington and the sitting Mamagers were appointed to take the necessary care relative to the fartition of the said lot and purchase of William Whitpain, his share.

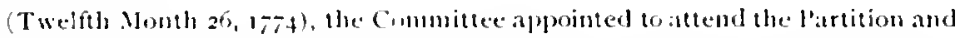
purchise IIm. Whitpain's Share of the Syuare of Ground th the Eastward of the Hospital reported that Joseph Stamper Attorney to Willam Whitpain (who

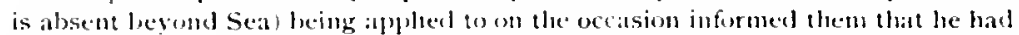
110 Authority to sell Whitpain's Share of the lot for less than l.t5o which not being anreed to by the Committer, nor wn by the Bourd, the matter is contimued undertle care of the said Committee. And the Action at lat commenced for the lartition of the said Lot is withdrawn.

(1) Fourth Wunth 2\$, 1775/. Milliam Whitpain owner of an undivided Quarter part of the Sifuare of ground to the Eastwatd of the Hospital attended the Board and offered to dispose of his part of the said loot for the sum of Three lundred am seventy live lounds which the Board agreed to give him and appointed Thonas Wharoun and Isaac $\operatorname{cox}$ to get the deed for it drawn and executed and they are authorized to draw on the Treasurer for the purchase money, which being less than the said Whitpain first demanded it is arreed to present him with a certificate for $f$ zo as a bonation from him to the Ifospital. 
Fourth month 1,$17 ; 6$ :

The Treasurer reported that the leed from Wiltiam Whitpain to the Contri. Deed Fu. butors of the Penma. Hospiat for his undivided share of $1 / 4$ th of the Lot of fround atted for was duly executed and delivered at the Rolls Office to be recorded and that he Fanterti 1 . nt paid th the said Whitpain One hundred and seventy five pounds gave his obliza. two in behalf of the Contributers for two hundred pounds and delivered a Certificate for thirty pounds as a bonation from said Whitpain being the amount of the stm memtioned in the Deed for the said Lot viz. 6.375 and a Certificate of 6.30.

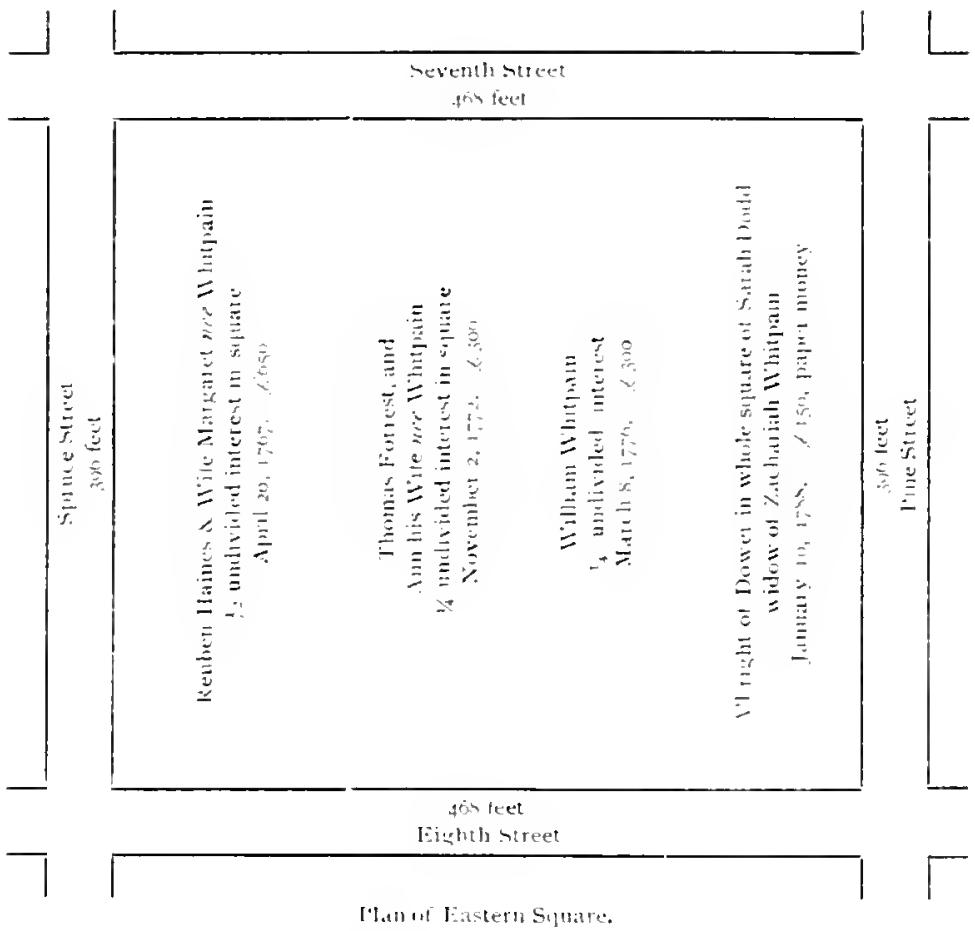

lebruary 22.1769. Doctor lond applied to rent the lots lying to the eastward of the Hospital sifuare; it was agreed that he might hase them "for the rent of twelve pounds in specie Per Inmum for seven Years, putting them under good fence and leaving them in the same Condition at the expiration of the term."

A letter wai produced, November $27,1,86$, from Thomas Forrest in hehalf of Sarah loodd (formerly. Whithain) claiming her dowerin the lot eastwarl of the Hoyptal, late the property of her husland, Zachariah Whitpain, whercupon Rernold keen, Thomas Moore and Joseph l'atchall werc appointed to investigate the merits of her claim and report at the next meeting. 


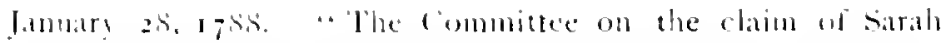

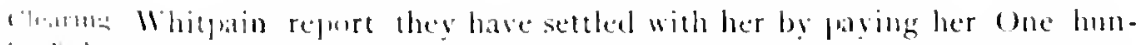
the I.the dred and lifty loundi liager Money for which she hath signed at keleate le all her right of dower to the lot last of the llomplatal, and the whote irrears alue thereon which the board approve and the "Treastrer in clenired to peet it recorded."

The Managers finding it neressary to provide increased accom-

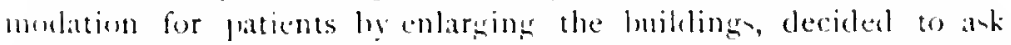
autherity from the contributers fior them to sell one or more of the

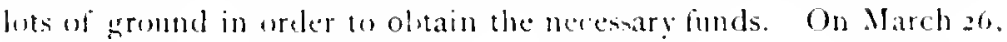
1,32 :

It is arreed li. submit to the next Amual Meeting of the contributors the propriety of selling the kastern lint.

At the Contrilutors' Mecting in May folluwing it was

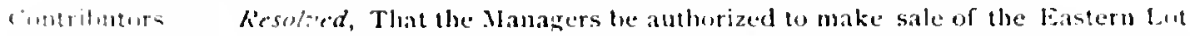

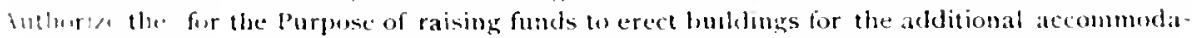
- blentluin. tien of the lluspital.

May 14, the contrihutors having anthorized the Sale of the Eastern Lot, John J. smith, Bartw. W'istar and Charles Roberts are appointed to receive proposals frum purchasers upon a plitu of building now approved and submit offers the Boarel.

Jum 25, it is mw argreed thist when the Committee on the sale of the Fastern lot hall in any ease conclucle an arrangement with the purchasers, the tresident and Treasurer be and they are hereby authorized to convey the same in sulficient deeds agrecably to the restrictions determined upon under their signatures and the seal of this Corporation.

Sile of July 16, is 33 , the Board assembled at the request of the ComFistern Lat. miltee on the sale of the eastern lot, which reported

That six lots hat been sold un spruce street, and a like mumber on the Street and proposed that authority now be given to make deeds to the purchasern. whereupon it was resolved "that the erenilent of this lsoard with the Treasurer of the Contributors be, and they are hereby empowered to execute sufficient conveyances to the pressons who have hought, under the seal of this Corporation with such reservations as have been agreed upon in the general plan; this pwwer is to extend th the purchasers of the remaining part of the lot, as sales may he matle."

The street directed to be opened through the eastern lot having been proposed wo be callect liarclay Street, and that designation beins previously thet in this city. the board agreed that the avenue be called Citron (now Barelay) street, and that it he forty feet in width. and that it be entered njon the record.

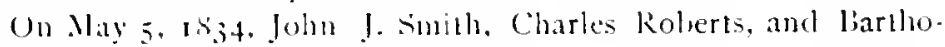
lomew Wistar. were continued to attend to the care and sale of the eastcrn lot. 
The spuare on the south side of the P'ennsylvania Hospital, from Eighth to Ninth Streets, extending from Jine to Lombard Street, ( 396 feet), being the whole front of the Hospital and opposite to it

Is in the opinion of this Board absolutely necessary 10 be secured to the Institution, for the benefit of the southern air, as opportunity may offer to buy it, A minute, dated Sept. 21 , 1795 , states that "it is therefore the unanimous Opinion of all the Managers present that a part of the Square which Richard Rundle owns of 12 feet on Eighth Street by $\mathrm{r}^{2}$ s on Pine Street to Blackberry Alley, which lot he offers for One thousand pounds Cash, should be bought as soon as possible and added to the Capital Stock; and that any Monies given towards this purpose or other Monies may be paid for the said lot. An order was drawn on the Treasurer for the amont in favour of Richard Rundle, which he is desired to pay out of the monies rectived from the Commissioners of Bankruptcy when the title is delivered and approved in writing by William Rawl or any other Counsel learned in the law."

On Feb. 23, 1791, "Josiah Hewes, John Dorsey, Robert Smith, and Samuel Coates are appointed a Committee to wait on William Lewis, to know if he will accommodate this Institution agreeably to the expectations he has given us by exchanging his lot on the South side of Pine Street for the lot bought of Isaac Snowden in the name of Samuel Coates on the north side of Suruce Street, which lot was bought with a view of exchanging with William bewis and for no other purpose; his definitive answer will be expected. On Feb. 22, 1\$o2, William Lewis contrary to the expectations of the Hanagers after encuuraging them to purchase the lot on Spruce Street and promising to excluange his own for it to accommodate the Hospital has cone to a conclusion not tu exclange on any terms but offer his lot at a very exorbitant price as will appear by the following letter of which it is agreed nother notice shall be taken than to insert it on the Minutes."

\author{
Siflate vinltip \\ of line \\ necessiaty lint \\ Hyitent \\ Hovpital.
}

$$
\text { "January qth, } 1802 \text {. }
$$

"Grntlemen.-I have concluded either to sell my lots near the Pennsylvania Hospital or to let them on gronnd-rents or to erect Iuildings on them in the Spring in order to render them productive, but not to exchange them for other lots, and I teem it proper to inform you of this before coming 10 any particular conclusion respecting them in order that the Managers if they think proper may have an opportunity of becoming the purchasers. I am but a very indifferent judge of their value, but from the best information 1 have been able to procure, I suppose it to be twenty-two hnodred and fifty puods. This sum 1 am willing to accepl for them hut $I$ believe that $I$ shall not take less. If the Managers are not disposed to take them at this price nothing furlher need be said on the subject, but if they are, I wish to know it som for the reasons mentioned

"I am, Gentlemen, your friend and humble. Servant,

$$
\text { WirLAAM LEWIS." }
$$

I proposal was received March 5.1Sor, from John Taylur. in which he offered to sell his lot frunting on the south sicle of line sitreet $19 \mathrm{~s}$ feet, and extending from thence 292 feet along Xinth Street to Lombard street, for the sum of fifteen hundred ponnds. layalle without interest in twelve months. On receiving this offer the Managers adjourned to view the situation of the gromel and having returned reported that they were all of opinion that 


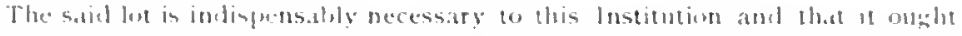

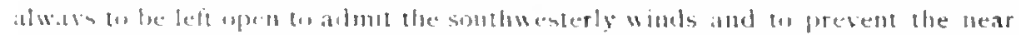

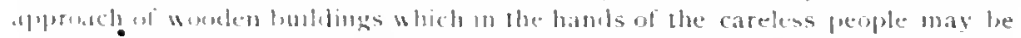

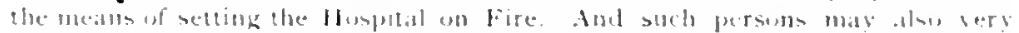

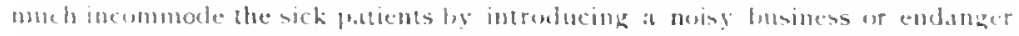

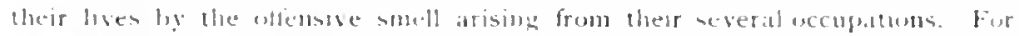

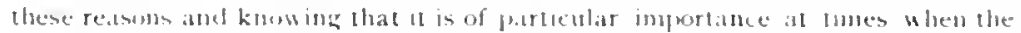

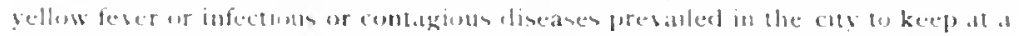

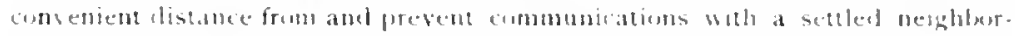

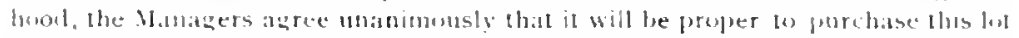

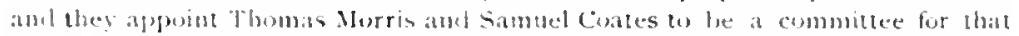

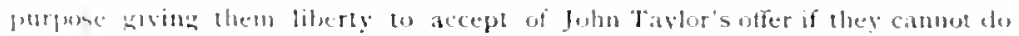
better and if the contract should be made for cash. the Treasurer is desired wo pay

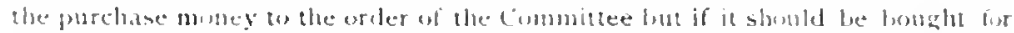

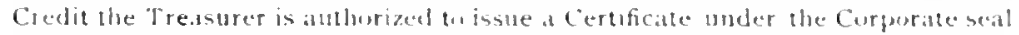

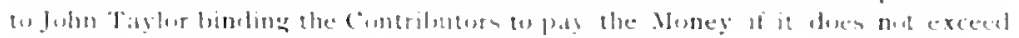

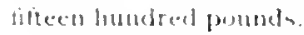

() March ;0, 1tion, the ('unmittec to purchase the lot of fohn laylor rejourt,

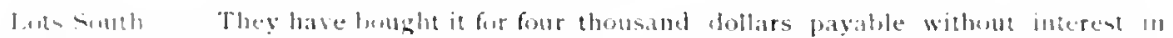

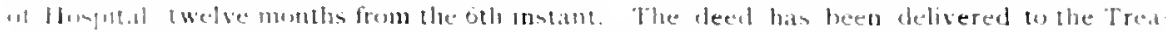

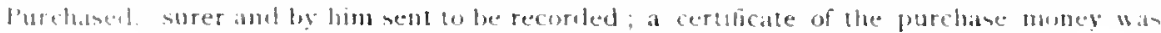

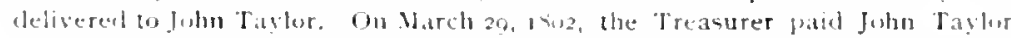
for the lin and andelled the certificale.

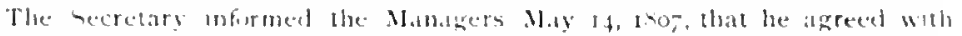

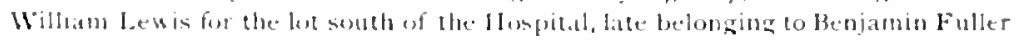

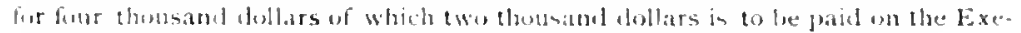
cution of the leced and two thumand in Sixty lays from the Date thereot.

St the meeting hehl felormary $23,1 S_{24}$, a writen application from the l'ennstvania Anglum for the beaf and lombl, was read, in which they propose the purchase of one of the vacant lots sumth uf the Iloypital, on which to creet a building for that entablinment. which proposition was manimously declined.

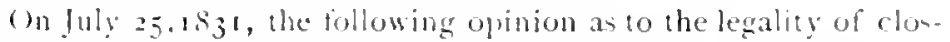
ing Blanchard's Alley, was ordered to be recorded on these minutes.

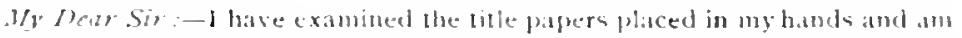
satisfiel that Blanchard's Alley romming from oth Streed in Blackberry dlley between Pise and lombard Streets is a private tlley ladid ont for the use of the

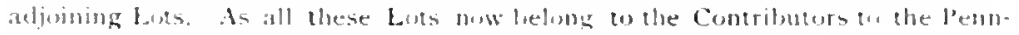
syluania llospital, they can close it wheneser they think proper.

Renpy. !olts.

Ihilit. Deet. 1, 1931.

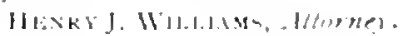

Sovemler 28. Is; 1 , the lreasurer reported:

The payment un gll, inst., of $\$ 10,000$ w Juseph Straban and others for a lut of ground with the improsements therem situated on Delaware nth Street between Pitue and Lombard Sts. purchased of them l'er Deed to the Contributors to the I'enusyivania Hospital dated Oct, Itha, Is 31 . 
On July 9, 1832, an exemplification of the record of the Court of Quarter Sessions for the County of Philadelphia in the matter of vacating of Blackberry Alley from Pine to Lombard Streets, was yresented and ordered to he handed to the Treasurer to be placed with the title papers of the lot.

On February 13, 1 850 , a special Meeting was called as to the sale of the South lot, to lay before the board drafts of a deed provided to be executed to the purchasers of parts of said lot with particular covenantis as to restrictions.

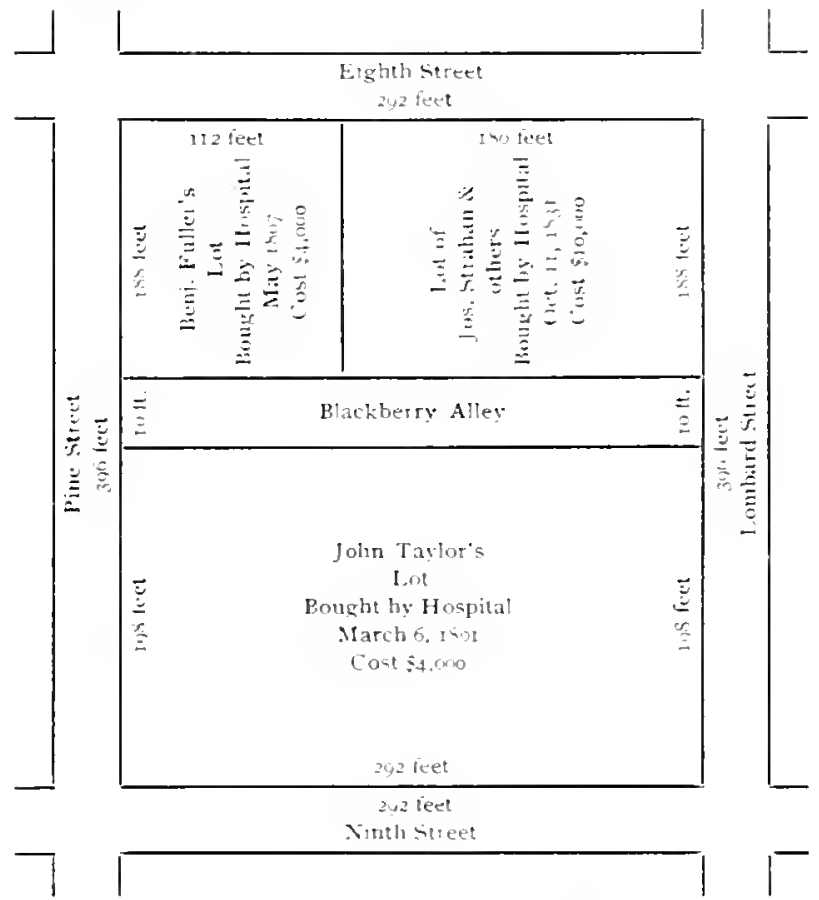

Plan of Properties purchased by the Managers of the Pennilsinia Hospital on Square south of Hospital bounded by Eighth, Nintl, Pine and Lombard Streets.

"On motion, a plan was adopted opening a $30 \mathrm{ft}$. wide street through said lot from $S$ th to $9^{\text {th }}$ streets, $162 \mathrm{ft}$. South of P'ine to be called Keble Street ; and the following restrictions were agreed upon, Ist, That the lots on Pine Street, shall throw ont i $2 \mathrm{ft}$. on the North

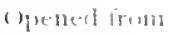
Eisluth tu sides thereof, so as to widen the parement to that extent; and andly. That no buildings other than Stables or offices shall be built on said Keble Street. with a reservation of power to enter and abate any. buildings erected contrary to said restrictions."

Strtete

Vacaterd in

Humpitial Lrit

sinuth if

Pine stretet. 
(m Nowember $3 \circ, 184$, a neeting was called by the ('ommittee for the sale of the senth lot which made a preliminary report, asking instruction regarting the terms of sale. This report was sulstantially as folluw:

Report of the Commitle on llee sile of the I,ot

The committee appointed ly the lioard at the last meeting (1) prepare the way for setling the sipare on line between Eighth and Xinth and Pine and lomblard sicese reported that it had frepared the annexed flan and advertixement which they recommended to the Board for its adoption.

the Committec, furthermere, deened it of importance to insert in the deeds certain restrictions with regard to the kind of lnildings to be ereeted on satid sefuare as might best secure the interests of the llospital and those who purchase lots: viz. One gented lowelling honse 4 pen each lot. Stables to the l'ine street lots, or not, according to the opinion of a majority of the line street lot holders.

The houses at the comers of lighth and Ninth and lombard sirect were to be allowed to hase the privilege of a store, and it was stipulated that the home's on bine sitreet should recede twelve feet from the line of said street.

The following advertisement was issued for the sale of the above lons:

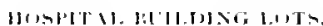

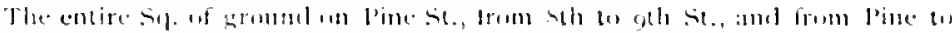

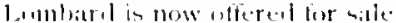

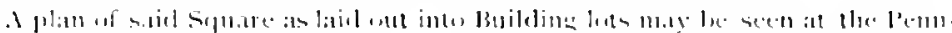

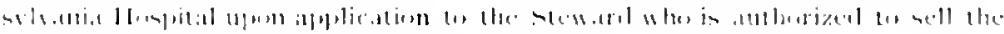
n.me.

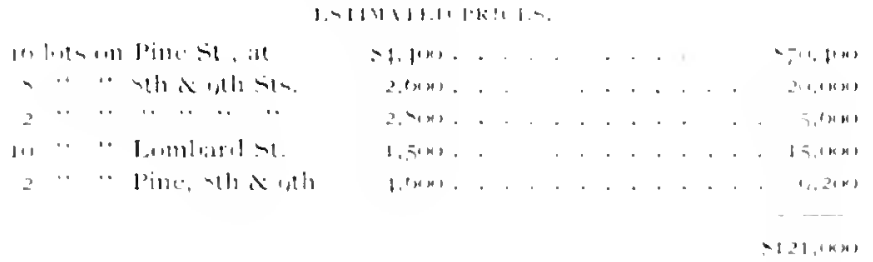

(In motim. the alove repore was adopterl.

Whe Maroh 5.1592 . This meeling was called lo the commitec on

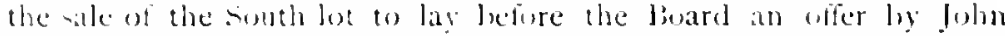

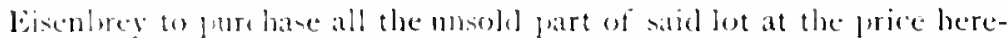

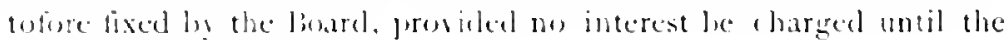
first of March neat.

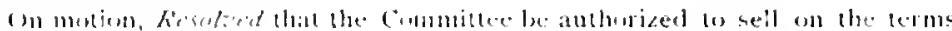
spre itieal in the satid ifter. 
The lot was sold for $s i 20,000$, of which sum, $\$ 78,000$ was expended in repairing the Pine street llospital and $\$ 2,000$ was fruments of carried to the capital account.

At the Contributors' Meeting, in May, 1831 , it was decided that a separate Hospital Building for the Insane l)epartment was expedient and the Managers were authorized to sell vacant sround, in order to obtain necensary funds, and to select and propose at suitable site at at future meeting. 1

In 18,35 , the Nanagers purchased the arm of Natthew Arrison, of 10 acres, for $\$ 29,289$, situated in Bluckley township, West Philutelphia, about two miles west of the "ity of l'hiladelphia. between Went Chester and Haverford Roads, on the latter of which the entrance was made. In 1838 , an arlditional murchase of $9 ! 2$ acres adjoining was made for $\$ 3500$. which they considered deniralile to include within the walls to be erected as a place of exercise and recreation for the patients. In $18+5$, two lots adjoining the farm of the l'enns!vania Hospital for the Insane were purchased and cunveyed to the Contributors for $\$ 2.35^{\circ}$ In i 849 , the thanks of the Managers weete presented to G. Roberts Smith for his gift to the contributurs of a strip of land 70 feet in width, along the whole eantern fromt of the gromnds, extending from Haverford Road to Market street, containing about three acres, making the whole tract $113 I_{2}$ arres. The Hospital

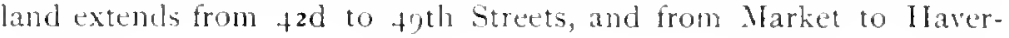
forl. ${ }^{2}$

The minutes of the Managers state that warch 28 , r SoS. Rolert Wharton, Hayor, having ly his proclamation informed the citizens of the regulations proposed on the ground plots of Philadelthia, from lifth Street westward to sichuylkill, and called upon such as conceived their interest affected $1, y$ those regulations, to state their objections to the Mayor, Aldermen and City Commissioners, Joseph Lownes, Zaccheus Collins and Peter Browne were appointed to inspect the proceedings of the Commissioners, etc.. and

If they are of opinion wor estate is likely to he injured they are lemired to attend

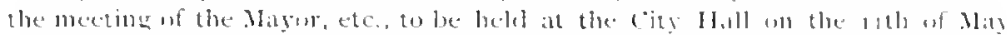
next, and shate their objections on behalf of this institution.

A mecting of the Contributors was held on August $12 \mathrm{th}$, $180 \%$, in pursuance to the alove call published in two public Gazettes, inserted daily for ten days previously.

\footnotetext{
The grounds surrounding the Hospital property on bighth street, which were putchanel

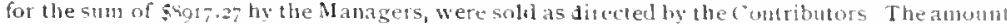
ultimately realired, by theti sale, agrregated, including interest, \$\$25,000

"These puchases have been referred ro more fully un payce in antr.
} 


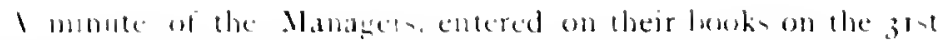

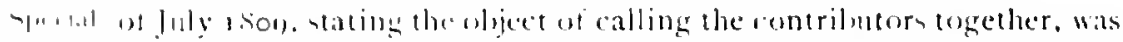

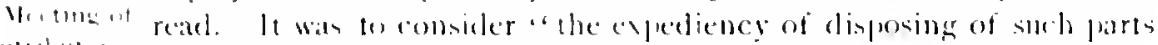

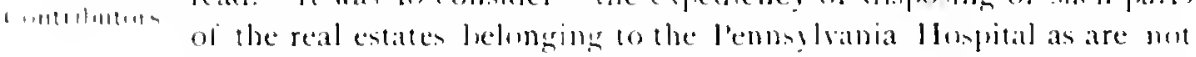

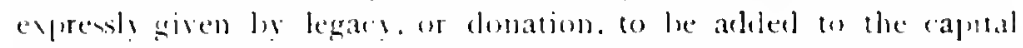
etock of the in-titution. ablatos excepting the lots surrounding the

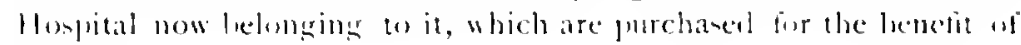
ireah air."

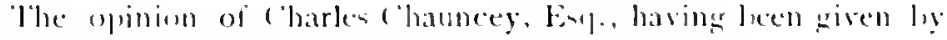

Dine-ion an tor the - ate. if re.il ent.1te.

"pinion.."

(liarles Cli.111mey,

$\therefore \rightarrow$.

$$
\begin{aligned}
& \text { Est } \\
& \text { ine } \\
& \text { ine }
\end{aligned}
$$

\section{in}

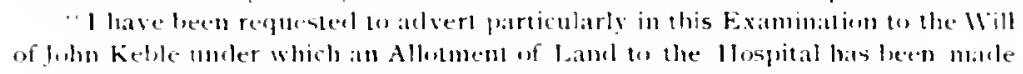
which it is new Comtomplited lo sell: he very full and ample terms of the llill

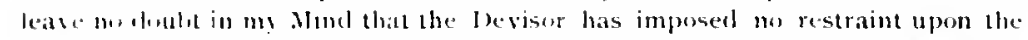
poner of Alienation which the Corporation upon gellerai principles ponsenses in relation to the listat. he has teviseol to it."

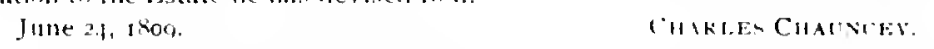

M.17.renters 1.minimered be cintrila$111011+11,-4,11$ R...1) $1,-4,11$.

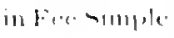

11. (1).13:11

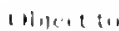
Ini InImis

IInimplt.1 lenperts in

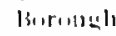
al $110 \times 1$ mplitelelphn.

The Contributors having empowered the Managern to dispone of sarious ground rents, and real estate in lee simple, in Philadel hia and elscwbere, this duty was entrusted to a committec consisting of Thomas stewartson, William l'eyntell, and Zarcheus Collins. This ('ummittee. between the years thon ant $18 j \mathrm{j}$, sold all the real estate. and ewejt that specially reserved hy the Contributor's resolution, and the money was turnet in to the capital stock.

The Managers deemed it inexpedient and opposed to the lest interests of the Hospital to have its property occupied by the Insane bepartment incluted in the proposed horough of West Philadelphia. Acorelingly they prejared a remonstrance against incorpurating the Penmslania Hospital land in the Borough of West Philadelphia. ( ) F Fels. 25 th, 1850 , on motion. a respectful memorial was directed w be sent to the senate and Ilone of Representatives of the Commonwealth of Pennsylyania, to be signed by the President and secretary of the loarel, against the incorporation of any part of the property of the Hospital with the lorough of West Philadelphia and this forwarded to the lecgishature. 
On March 25, 1850, the President and secretary laid lefore the Boald the fulluwing memorial which they addressed to the Iegrislature on Pennsylvintia anreeably th the directions of the Burd at the last neeting.

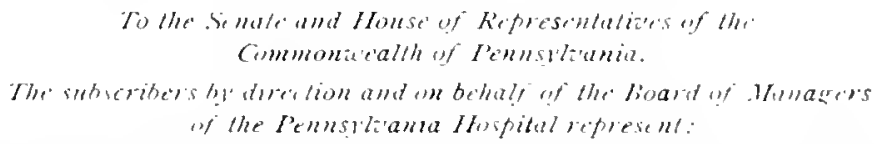

That they have learned that a bill has been reported to your honorible Budies enlarging the limits of the present borough of Ilest Philadelphia so as to include therein about $1-2$ of the premises known as the Penusylvania Hospital for the lnsane. Say so acres and all the buildings connected therewith. Your memorialists lave no wish or intention of interfering with any necessary or proper enlargement of said horough ; but they feel it their duty to represent that the Borough can in no wise be benefitted by its extension over any part of the Iospital property : whilst on the contrary the laying out of streets or any other exercise of Hunicipal functions within the said premises would at once destroy their whole vilue as an Institution for the Insane and the burten of Borough taxes and charges would be needlessly heavy am deduct so much from the charities of the Cirporation.

They further represent that this Institution has unly been in operition nine years after an outlay of nearly $\$ 35^{\circ}, 6$, for the purpose of its foundation and that its site was then chosen for, and still remains valuahle wo wor for isolation, between the West Chester \& Ilaverford Road. and its comseyuent sepatration from neighboring properties; and that hence the exclusion of the whole of the sair Hospital property by name from within the limits of the proposed extension of silid Borongh can in no way effect a conflict with any interest or guod purpose mublic or private su far as your memorialists know.

They therefore pray your I onorable Bodies so th amend the proposed law as to exclude the said premises now belonging to the Pennsylvania Inspital for the Insane from the linits of any such Borough or town Compration.

And they will ever pray.

$$
\begin{aligned}
& \text { 1.AWKI:XCE LEWts, J'resident. }
\end{aligned}
$$

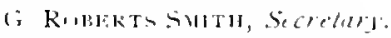

The fullowing draught of an . Act was sulmitted the next year:

To change the name of the borough of West Philadelphia to the District of West Philadelphia, and relative ${ }^{\prime}$, highways in the Dintricts of Kensington and Richmond, in the county of Philadelphia

Section $r$, Be it enacted, Ec., That from and atter the first day of luly next the municipal district incurporated by an act of Assembly passed February serenteenth, one thousand eight hundred and forty-four, by the name and thtte of "The bormugh of West Philadelphia," shall be known by the name and title of "The bistrict of IVest Philadelphia;" and the name of the councilmen shall be changed to that of commissioners, and that of hurgem to president of commissioners, but that they shall have all the powern and be suliect to all the restrictions conferred by existing lans on the burgess and town council.

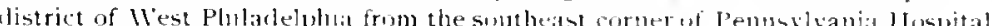




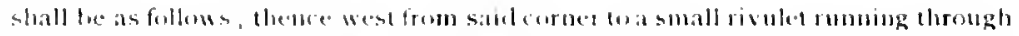

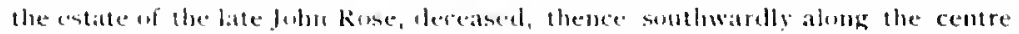

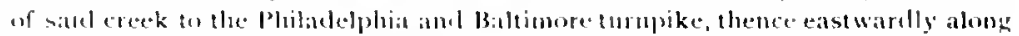
the sidid turnpike, and thence as described in the act appowed the fourterenth dity

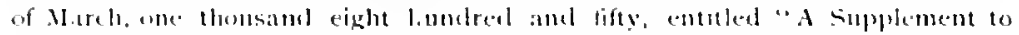

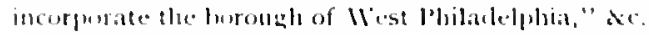

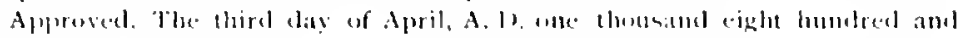
iifty une.

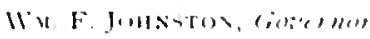

Is the result of this timely action wn the parl of the hoarel. there was no curroachment upon the property of the llospital hy the forough of West bhilatelphia and the grounds were kepte intace for the unes of the insane department.

City in the upening of cily strects thromgh the ground of the

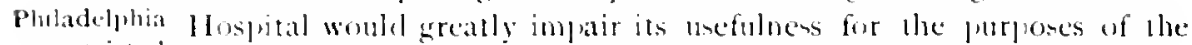
restricted

from indening

streets

Jurough

Eroment of

Iepartmest

fur linsane.

busane hepartment. the Managers delermined w prevent this intro. sion by legal means.

To restrict the plower of the eity of Philadelphia to thus injure the froperty cicenpied ly the beparment for Insane. the Mantgers. voluntarily offered to throw oul and dedinate to public we the gromb refuired for strects on the eastern and western boundaries of the Hospital property, if the lesislature wotld thereafter forever exempte the grounds occujied by the ldepatument for Insane trom being inter sected, or cut inlo. hy any public strects. The legiviature accepted the oller and passed the following Art:

An ict to "Section 1. Be it enacted se. Thit nostleets, alleys, rond ot hines, shall ever prevent be opened through the property belonging to the Corporation af the controbutots to the letusylania Ilospital, sithate in the Twenty-fourth wad of the city of pholatelplia, withont the consent of the said corporation, so long as the said

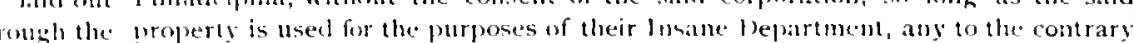

grounds notwithstamding: I'rovided That said corpmation shall contribute one hatf the

withut the ground for an avenue, on their east, and one on their west, line, each, one hundred onsent of the feet in width, without chatge to the ('ity of plibulelphia

Uamagers, filty-four."

"Approved. The seventeenth day of April one thousand eight humdred and

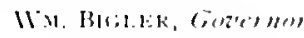

The proper deeds of dedication of the ground for the streets on the said east and west sides being execuned, were acrordingly clelivered to and accepted by the city authoritics, thus creating a legistative contract, the consicieration for which has been furnished on the Hospital side, which can lee safely relied on to protect the grounds in the future.

The sufficiency of the contract has been stustained by a jurlicial inquiry in the caxe of the improvement of Haverford street, which it was proposed by the loard of surveys to widen, by taking a strip off 
the Hospital property. Upon objections, on behatf of the Contributors, being made, it was held by the Court, that, except with the consent of the Contributors, no part of the ground was liable to be taken for any public street, the protection under the above legislative contract being absolute.

In the ravine separating the male from the female department, a sewer of very large calacity, extending from Haverford hoad to Market Street, was luilt by the city of Philadelphia; the Hospital having donated to the city, in 1591 , a strip of ground eighty feet wide from Narket Street to Haverford Ivenue, provided that this sewer should be constructed without expense to the Hospital, (see pase ig2 ante). The attempt of the city authorities to open a street over this sewer subserpuently, was successfully opposed by the Managers

The Managers, foreseeing the rise of a contingency in the growth of the city and the erection of many buildings around the Huspital property in Mest Mliladelphia, which in the future might make it expedient or necessary to remove the Insane Department out of the city linits, have recently purchased a farm in Delaware County. in a favorable location. This is now used for convalencent patients and as a source of dairy and garden supplies for the Hospital, as already mentioned. (See page 193.)

The relation of the Hospital to the City Govermment and the Commonwealth, with regard to the question of taxation of its property, is of sufficient interest to warrant the devoting of the remaining portion of this section to its consideration.

Towards the close of the last century, the city of Philadelphia levied a special tax, the proceeds of which were to be devoted to building a hospital for cuarantine purposes at the station on Little Tinicum lsland. As this was known popularly as the "Hospital Tax." the Managers feared that the income of the l'ennsylvania Hospital might he affected by a general impression that their institution was to be the beneficiary of this tax. Accordingly, at a meetin: of the Managers, held January 26, 1795, the Secretary was directed to have inserted in the papers and distributed in hand-bills throughout the city the following minute:

The Vanagers being informed that many of their fellow citizens entertain an erroneous "pinion that the Tax, commonly called "The Hospital Tax" which they have lately pitid, is for the Use of the Houst, think it a duty they me 10 the Contributors to inform the public that the Institution receives no benefit therefrom; the said Tax being laid for the said purpose of erecting a building w accommodate persons with infectious diseases: which is not to be within the limits of Philadelphia. The Principal Dependence of the Contributors to the Pennsylvani: Hospital is on the Legacies \& volumary Contributions of their charitable \& humane fellow citizens, throughout the City and state.

Taxillion of llospital l'puperty.

A Hospital Tax levied hy City of Phladelphia. 


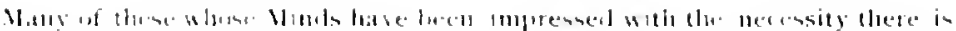

This Homplitit montutament aldely h - hatritalive. (11)/211?

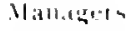
chaim

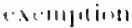
forr llompritial firm the prit: ine.tit ii riseren

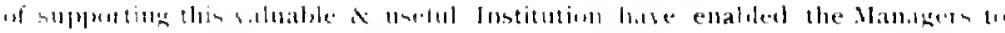

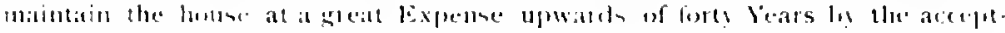

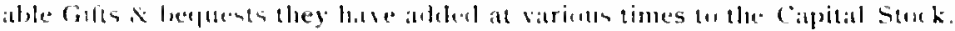

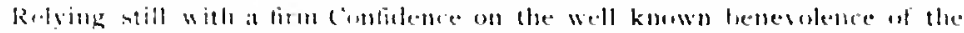

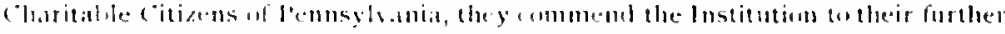

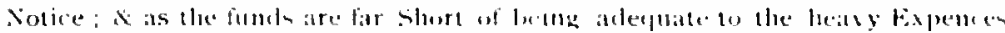

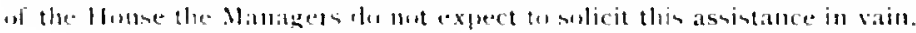

Durits: the eatl! struggle of the Huspital. when it so frepluentl!

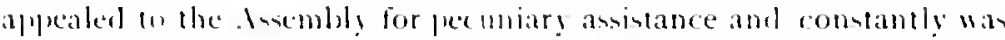
held up hefore the henevolent as a denerving charity, all men knew of it goud work and its pressing needs, and even loe lemevolent single women and rich widows acknowledged its claims, there wan lhen no thought. in the communit!, of demanding that it should deplete

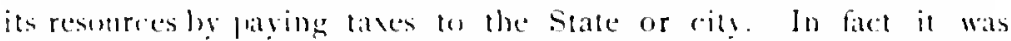
declared a pure charity and therefore properly evempe from such taxa. tion. There cance at lime, however, when an attempte was made t. assess the properly, and the Manager for a time were fut to considerahle trouble and some expetse before the guestion was finally decidfed in their fasor.

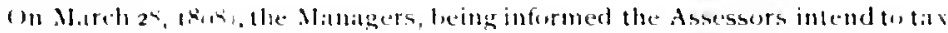

City of the real lestalle of the llongut contraty to the usige \& practice of their prede.

l'hiliadelphis (r)mpts all the listattes, including

Cirmonst rent

of the

Houptal from Tine.

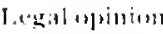
114e:tul in abiandion Firmplum

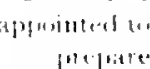

Ne.11011.1 to

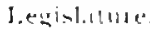
cessurs in office since the foumdation of the Institution; are unamumbs in thell Opinion the said tax slund be repelled by every legal means in onl pwwer, amb

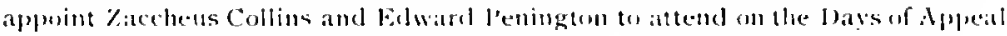
and claim an lixmeration therefrom.

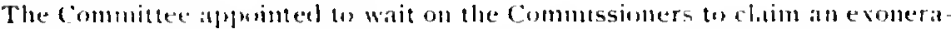
tion for the llospital of the layment of Tax, Report April 25, Ikok, they liase performed that service and that all the listate including the firound rent hase been exempted from the raxes.

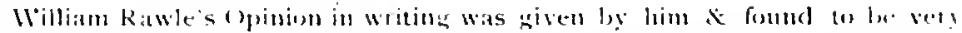

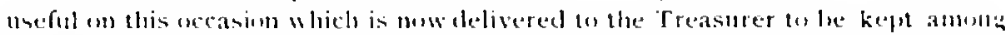

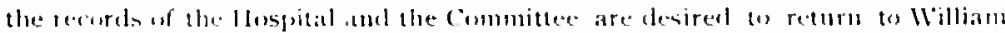
Rawle thatsks for his setvices, lo Bdward Tillghman, alse for the ofter w his Opinion gratis an this Sirbiect

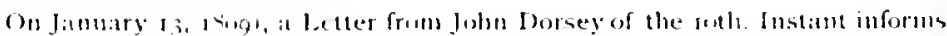
the besal that the (anestion is likely to the brought on in the lotgislature as it regards the forperiety of tacing this and other charitable Institutions throughout the sitate

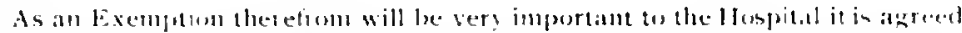

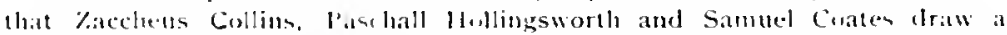
Memorial to express lle sentinents of the Managers on this Subject and stute

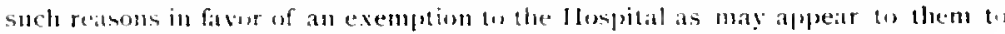

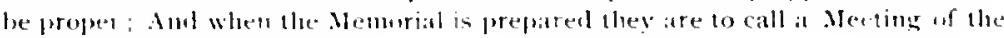

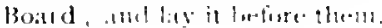




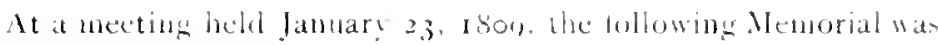
read and apjosel. vil.:

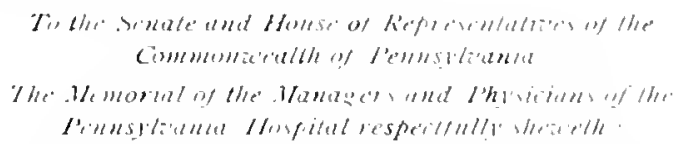

That a part of the Estate of the said Institution Cisntrity to the [hase allud practice of more than fity yearn from its foundation has lately been assensed for the Payment of Taxes to the injury of the sick poor of the stale; and Cintrary a your Memorialists apprehend to the nature of the Establishment and withont adequate benefit to the Citizens of the district in which such assessments have been made. That the funds of the Pemsylsania llospital hate msariably lecen applied to the lenevolent and charitable purposes for which they were designed, Vour alemerialists need only refer to your own filen contianing Acculusts which have leen every year submitted to leegislative inspection; that they deem it supertluous to dilate on the Ltility of an Institution to the Commonwealth at large which experience has tested and the merits of "hich have on scyeral necastoms been honorably noticed on the Minutes of the Legislature. Yisur Memosialiat believing as they do that the Commonwealth nevermtended that a Charity raised by the bounty of Govermment and of provate persons for the relief of the Sick and Miserable of Pennsylvania should be taxed for any purpose, earnestly requent and

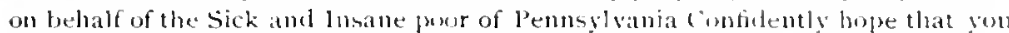
will in such way as may appear bent, exempt the Entate and Fund of the sand llospital from laxitum.

When the above Memurial in lanty transeribed the President and Secretary are desired to sign it on behalf of the Managers: and boctors Rush and llistat are requested to sign it on lehall of the Piysicians. -ind when signed leter Browne, Zaccheus Colins and samuel Coates are appointed wo go to Lancaster and present it to the Legislature witl the last Anmual Accounts.

Peter Browne \& Samuel Coates report on Felruary 27 , hon, that they proceeded to Lintaster is waited there One Week, during wheh time they presented to the Legislature the Annual Accounts to the fth. Wonth (April d Aos, also the Memorial to botis houses; the Houne of Representitives referrel the Ilemmal to a Committe who reported ly a bill in favor of exempting the hosputal from the payment of Taxes which bill war debated and rejected in the said House.

On March 27, Isog. the Assembly not having legislated on the Memorial (iaming an Exemption from the payment of Taxes it in agreed to refuse payment and to have a Case tried in the Supreme Cunt. Zacchens Colluns, Thomas Stewardson \& Samuel Coates are apponted a Committe to engage any Three Attornies they may approve to defend the lustituton an any suit, which may be brought for at Tax ly the collectors.

Robert Allen the Collector of Taxes for Nen Market Ward is an Collector fir Cedar Ward has sent w an Account for City, County, lour a Health Titxes fur the lear Eighteen hundad 2 Eight Amounting altogether to Three hundred is Eighty One lollars $\mathrm{k}$ Seventeen cents the payment of whol he demanded and being refused he has levied on Haty on our Eastermmost Lot and saly he wall call

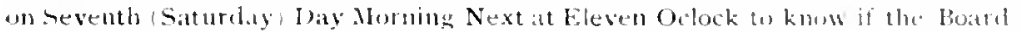

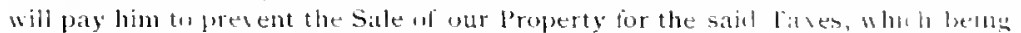

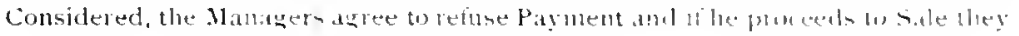




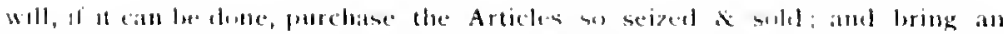

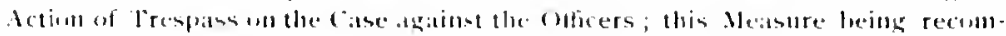
mended hy Willian kawle except so far as relates to the Taveson firound Reuts ; "bich it is agreed the Tenants may pay and the Treasurer may efsocunt them irum said ciround kents

(i)1) ("i)

Inimionte'

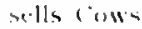

11 is, e.te. 11 the IImput.ll

Actuili fin trempars limenght:

lecioint against the II 1 spititit.

July ji. lion. "Rolert dllen having seized for the Taxes and sold cur Cows, llay $\mathrm{N}$. the same were purchaned ly Captain $11 \mathrm{~m}$. Vicary of whom the seward alterwats hought them for the Ifouse. The Commiltee are continned to bring the Aetion for Trespase in the Catre anreealhy tu the Minute uf sixh Month (June) last."

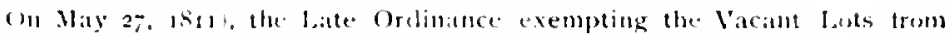
Faxalion in the City Tax is directed to be inserted in un Manuseript cipses of the t.atws.

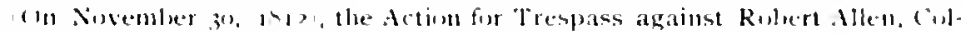

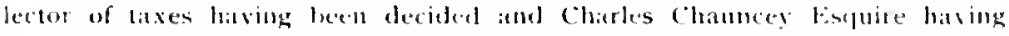

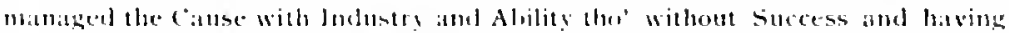
declined to receive pecuniary sotinfaction for his Services the huard direct this

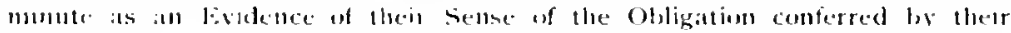
Coltusel.

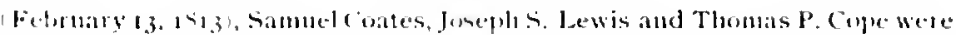
mpunted a commitee to drall a Memurial to the Legislature now sitting at Ilarrishoresoliciting an Exemption from laxation of the buildings and lons the

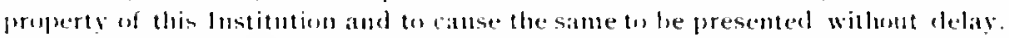

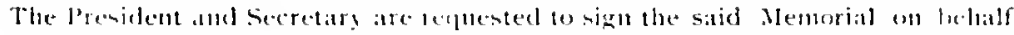

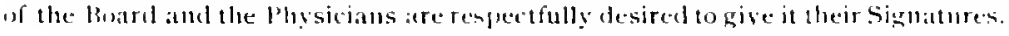

On the 22d. the Commitle appointed to draft a Memorial to the legrislature reported that one had been forwarded, of which the following is a copy:

\footnotetext{
Menorial to I.enislature twexenli)t llospital irisil laxitien.
}

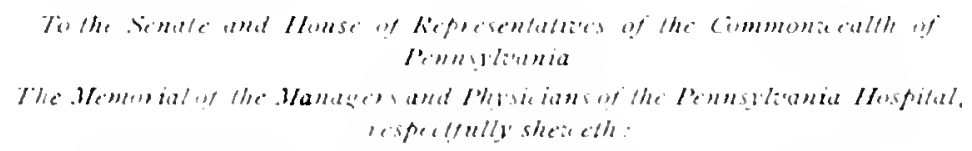

That the leeginhature of l'enmslvania. have at diterent perionts mate very"

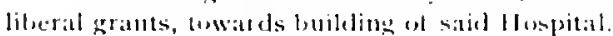

That the few vacant lots belonging to the said l Iospital, and which are only separated from it ly the Intervention of Streets, were purcluased by the contribu(ors fier the following lises,

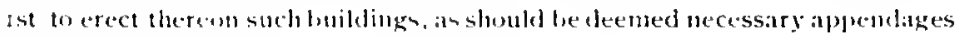
to the listaliblinent.

2ud to kecp the lluspital at a proper tistince, from the dwellings of private: Citizens, as a grecaution aganst the ravatges of tire.

$3^{d}$ to keep the bublings sufficiently upen to fresh Air. Which the l'heicians, conside indispensably necensiry to the Restoration of the Patients.

fuh Topreserve a small range for the Cows belomging to the Hospitat, fresh Milk being deemed of great impurtance in dressing the wonnds of the Patients $\mathrm{X}$ being mosenser a principal srtiele of diet for the sick. 
sth for small Plots, on which to exercise occasionally the convalesectut Lunatics, fir whom moderate Labor is sometimes recommenderl, as a means in recolery.

Such have been the motives for purchasing these lots.

Duly appreciating these Hotives, the City and County Commissioners were in the practice for nearly fifty years of exempting these Lots from Taxation but lately, the assessors have returned them and the Taxes have been enforced, to the manfest Injury of the Institution, and contrary as your memorialists apprehend, to the Spirit of the Charter, and it must be obviuts that in proportion to the extent of these Exactions, must the Institution be deprived of the meins of difusing its Charity to the suftering stranger, and the atflicted of the Comnon. wealth at large.

On a suitable representation to the City Councils, they have by ordinince exempted the Hospital property from assessment for City Purpuses, but the County Commissioners continue their Assessment.

Fonr memorialists therefore respectfully request you will be pleased to take the premises into your serious Consideration, and exempt the pennsylvinia Hospital. the lot on which it is erected, and the vacant lots of the Institution from taxation, so long as they shall be retained for the purposes set forth in this Iemorial.

Signed by the President and Secretary, and all the Physicians.

Nothing having resulted from the above petition, the Managers a year later determined to make another appeal. On Octolser $3 \mathrm{I}, \mathrm{I} S \mathrm{I} 4$,

Samuel Coates, Samuel W. Fisher, and Thomas P. Cope are a Commutec to essay a Memorial to the Legislature to be submitted to the Board at their next Stated Heeting, Craving an exemption of the Hospital property from taxation.

The Committee appointed on the Tenth month (Uctober). $3^{\text {Int }}$ commutet last, to prepare a memorial to the Iegislature craving an exemption to prepare of the Hospital j,roperty from taxation, reported, December 26,1814 . Memorial t" an essay which being read and considered was with some small altera- Legislitume tions agreed to, and the President was requested to forward the same. signed by himself and the Secretary to the Legislature.

\section{T" the Senate and Fouse of Refresendatites of the Communatalth

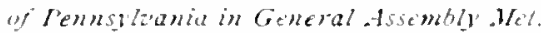 \\ The he morial of the Wanagers of the renustlania ITospital Respectiullin she'se'th,}

That by the hounty of fovernment \& the liberality of Individuals the Hospital \& Buildings appurtenant thereto were erected \& paid for, the Square of Ground on which the same stands having been in part the Gift of Thomas $\alpha$ Richard Pem and in part purchased by the Contributors without Governmentil Aid So the several Vacant Lots in the Neighbourhood being all neirly Contiguous and separated only by the intersection of Streets were purchased and paid for by the Contributors without pulblic aid. That the last mentioned Luts were purchased with a view to the health of the Patients $\&$ the Security of the Buildings and are so kept not yielding to the Institution any income whatever and saving only so much as would otherwise be necessary expended in hay and pasture for the Cows and Horses belonging thereto. That the Number of poor
Venntial assigns reasuns for exemuting Hospital from Taxation 


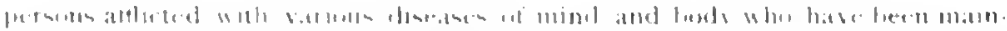

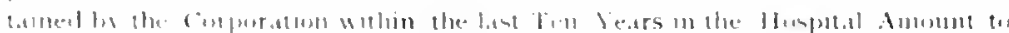

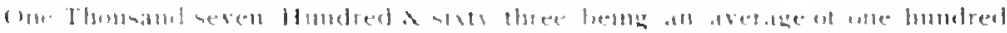

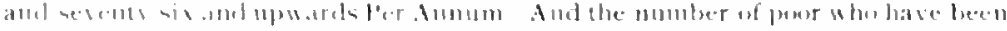

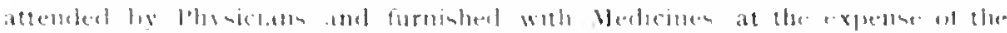

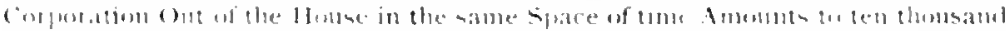

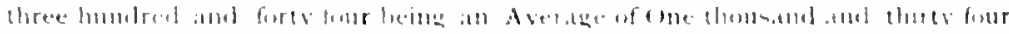

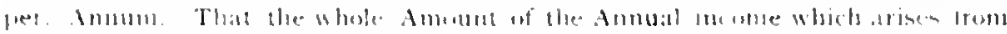

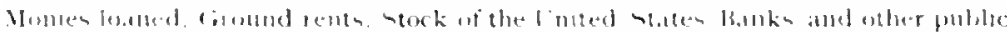

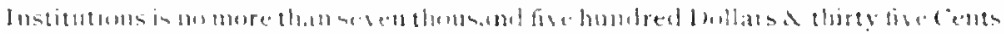

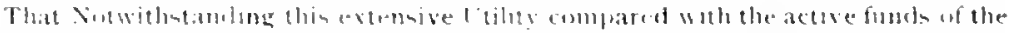

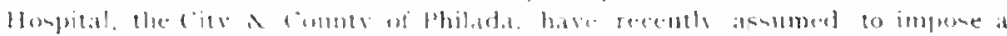

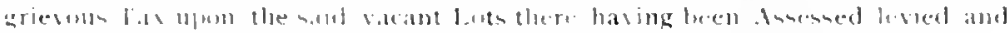

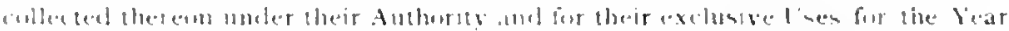

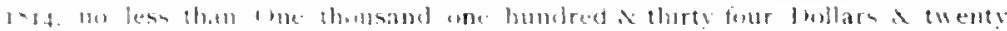

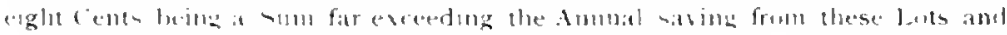

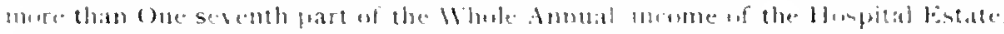

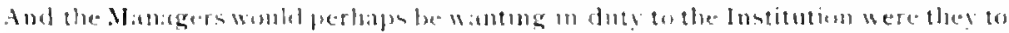

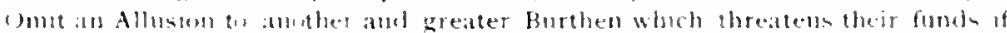

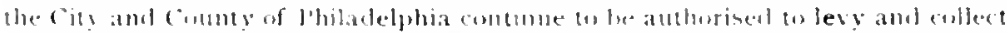

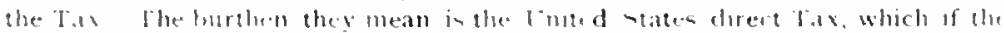

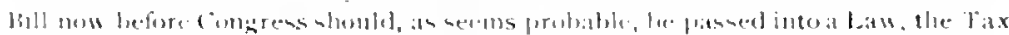

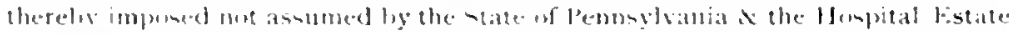

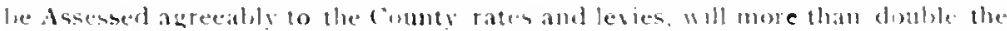

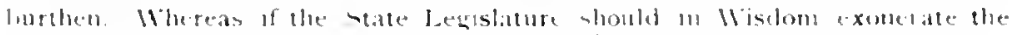

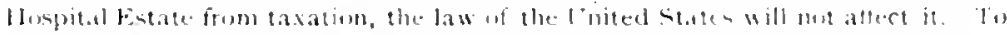

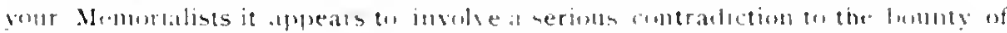

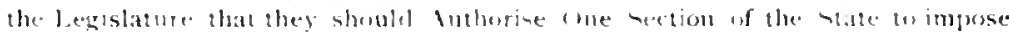

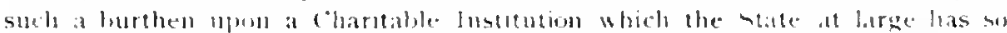

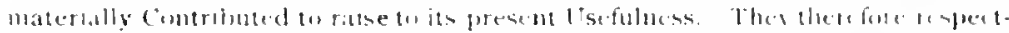

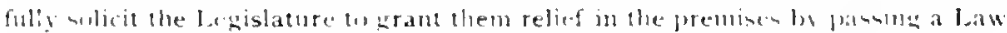

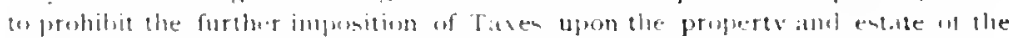

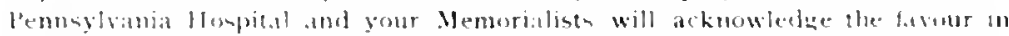

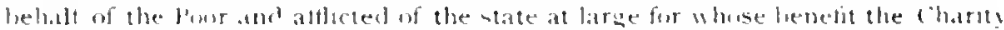

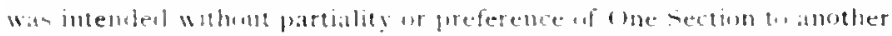

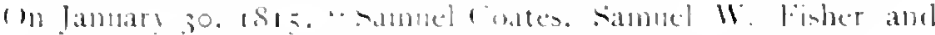

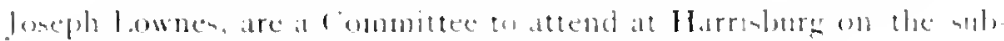
jee 1 of anr Menorial now pending lefore the legislature."

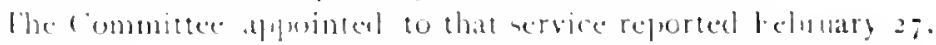

(i) $111+1100 \mathrm{cos}-\mid 1\} \mid$

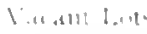
inithe 6,1 , Hire the

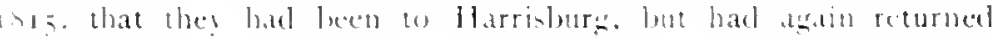

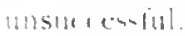

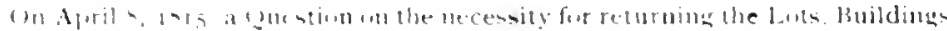

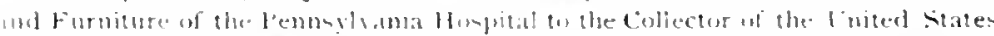

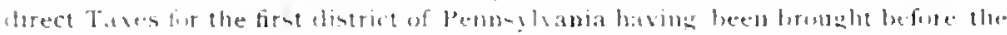

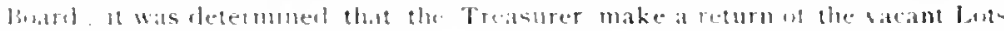

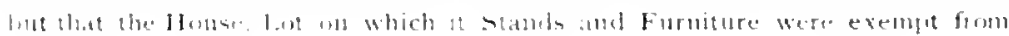
1.antina.

The Commeil of Philatelphia were next petitinated to exempt

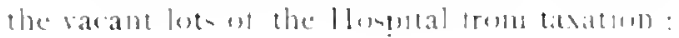


October jo, Iris! the Managers apponted a conmittee, to petition the select

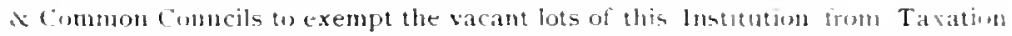
They are likewise to prepare a Memorial w the state leceislature on the same subiert.

in Covember 27. 18 is the Committet appointed at the list Meting to petition the select \& Common Councils to exempt the Viacant Lots uf this Institution from Taxation report that they had done so.

The same Cummittec reported that they had not yet fuepared a Memorial an the stitte Legislature believing it better to wait the Insue of the application tw the cincinuncils.

Un I lecember 25. Is 15 , the Committec on the Nemorial to the eit? Council report the succesiful rewlt of their application and that Councils had pased the followiner:

An ordinance for cxempting from Taxation certain vacant Lots of ground the property of the Contributors to the Pennsylvania Huspital appropriitted to the purposes of the Institution.

WHFREA the Contributors to the Pennsylvania Fospital assisted by the benevolent conations of the Legislature of the State after having made large expenlitures in erecting valuable and commodious Building and in establishing the institution wpon a liberal and philanthropic plan, deemed it necessary tumbtain possesuin of various lots of gruund adjacent to the lot on which the buildings of the llospital stand and acquired the same by purchise for the purpuse of providing for a free circulation of air and for securing a site for the additional buildings which the encrease of population might render necessary. And WHEREAs for a long series of year the Huspital was unmpressed by taxe; by Common Consent ut the Authorities who Assess and Cullect the same; and it being manifestly inupulitich to diminish by taxation the funcls of an Inntitution derived from Public and Private Mmmificence and subservient to the cause of humanity s benevolence. an Institution in which the friendless and destitute of every nation nay chaim an interent, and derive comfort and assistance: Therefore,

Section I. Be it enacted by the Citizens of Philadelphia in Select and Com mon Councils assembled. That the several lots of ground belonging to the Contrilutors to the lentusyrania Hospital, situated n the immediate vicinity of the luts on which the buildings of the said Hospital are erected and only separaterl therefrom by the intervention of Puhlic Streets shall be hereafter wholly exometated and exenuped from Assessment and taxation of any sum or sums of Money which hath or have been or may hereatter be directed by ordinance of the Select it Common Councilo of the City of Phuladelphia to be Assessed, raised, leved, ur cullected fur any use or purposes whatever upon the estates real or frersonal within the said City, which exemption from taxition hereafter granted shall Continue in full force and operation only so long as the lots aforesaid shall remain as they now are unuccupied by buldings or may be occupied by buildings appropriated exclusively and alone o promoting the Comfort of the Patients or the Convenience and improsensent af the Institution but from which no income rent or revenue mas be derived therets

Section 2. And he it futher enacted That if an tay heretofure Assessed ln the City Comminsioners un the lots aforesaid or any of then now remain due and unpaid by the saint Contributors to the Pennsylvatit Hopital an the cullectur atpuinted to receive and Collect the sante the said tax shall be and is herohy

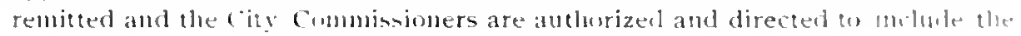

Philuleifliti Counucils, liy Ordindelu. extoupts vacant lot $-1,9$ Huspint: from lal 


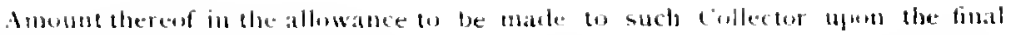
sertic-metut of his duplicate.

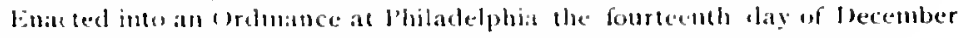

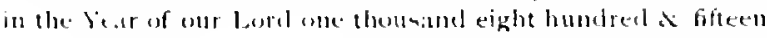

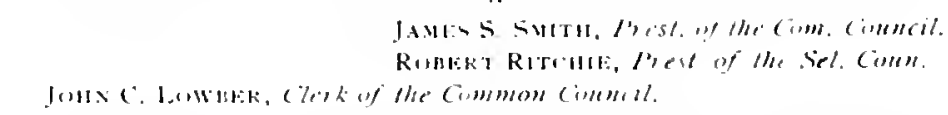

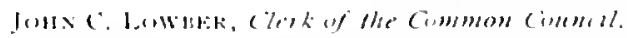

becember 2s. 1815, the committee appointed at the last meeting, (1) frepare a Nemorial to the state legislatue, sulmitted the same, which was adopted and the l'resickent requested to sign and forward the same to Harrishurg:

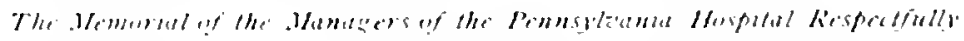 sheaseth:}

That :pplication was mate at the last session of the leginlature to pass an

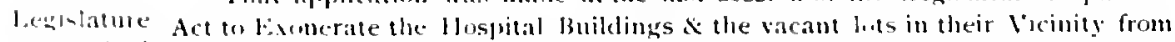
[2.ut] askerl (1. e.exempt IIomital lorpesty.

inllectir of lasation, on several grounds stated in a Nemorial then presented; and although your Menurialists forluear to trespass on the tinc of the Legislature by repeating

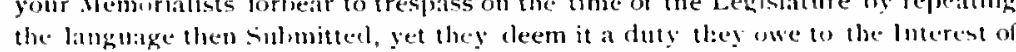
the Institution and may they non add, to the comfort of the sick and Indigent, to renew their application. That the Pennsylvania llospital afforls a charity uf no small Importance to the Citizens of Jenusyluania, and especially to these of the City and county uf plibalelphia lrecause of their vicinity to the llospital, is a proponition which canmot he farly comtroverted; and that indepenclent at the fostering hand which has heen from time to time cxtended by the legislature itself, all the funds of the Corporation are derived from the lurses of humine and benevolent Indoviusls. That it appears to your Nemorialists evtracrelinary and jerbaps witbont example that a llospital founded and maintained by the liomty of Govermment and of its Citizens, should be cleemed a proper Obiect of Taxation and they beg leave to present it as a question worthy the inguiry of the Representatives of a great ant free state, whether there is to be found in the Aunals of any other one of the Cinited states or of any Section of Furojes, or, in a word, of any Govermment in the civilized Morle, an instance of imposing or permiting to be impered, a tax on the Liberality of their awn Acts, or of their subjects or Citizens. Vinur Memorialis!s feel the mure encumrageel again to adelress you on this interesting subject, as it bas engaged the attention not only of the contributors lo the lluspital Funds, but of the (Citizens of Philadelphia and its Vicinity at large, who, as your Wemorialists understand are prepared to express their sentiments to Puir respective lJumses. Vuler all the Circumstances they shomld think themselves fully warranted in asking an entire exomeration of all their Corporate listate from Taxation; but they Content themselves with repeating their request, that the Husputal Buildings, the bot on which they are erected, and the vacant loots in the neighburhoos thereof and separated therefrom only by the intersection of strects be su exoncrated : and this they earnestly $\&$ confidently sulicit.

Tax macle

(1) February 5 , tsi6) the President stated that he lad called this Neeting in Consetpuence of the information received from the collector of the l nited sitates lirect Tax that there had becen Assessed on the Vacant Lots of the IIospital for the lear 1815 the sum of \$53.31 500 , and having doulus in his mind whether it might not be expedicnt to apply to the proper Ambority for a remission he had vicant lots. thumeht it right lo comsult the Board on the subject. After some Consicleratuon it is ayreed to make mo such application for the present. 
The Committee reported. March 25. Isis, that the Legislature of the State had just passed the following Art, exempting the Pennsylvania Hospital property from taxation, and for other purposes:

Pennsyluaniz

Legisliture. exempits

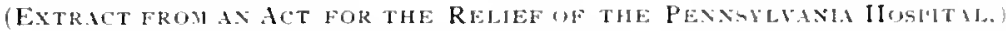
IIuspitial

“The Pennylvana Hospital, together with the lut or square whereon the same is erected, and the acljacent lots now emplowed in direct aid and occupation of the said institution, slatl be and remain free from the pryment ol taxes as long as the same shall be directly occupied and employed as at present for humane and claritable purpuses.'"

Approved the nineteenth day of March, one thousand eight hundred and sixtern.

(Signed) SIMON Sxirmk.

On the 2gth of April, the Committee report that they had forwarded to our Representatives in Congress, this Memoria! requesting exemption from taxation:

$$
\begin{aligned}
& \text { To the Sinale and Rouse of Representaties of /hr. } \\
& \text { riniled states in compress tssembled. }
\end{aligned}
$$

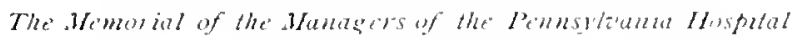

$$
\begin{aligned}
& \text { respecthully bhere'th: }
\end{aligned}
$$

Nemerrait Congress recpuestin: exemptin: frum Taxation.

That the said Hospital was founded by an Assuciation of Benevolent individ uals, endowed by them and by the leyislature of the state, has been supurrted during all the Term of its existence hy private Contribution, and that its funds are immediately or remotely applied wholly to the relief and maintenance of the indigent who are afflicted either with Corpural or Mental Maladies. That the Institution having had its Origin in Charify, and its funds having been uniformly applied to Chatritable purposes, it seems to Your Memorialists Consistent with sound reason, policy and humanity, that Government should Cherish rather than distress it; nor can they believe that the National Legislature had this or similar Institutions in view, as ubjects of Rerenue. The Assessor of this District, how. ever, finding no exemption in favor of the Institution in any Law of this State, cansed the property belonging to the Pennsylvania Hospital, including the Hos. pital itself, to be assessed, in the same namner as if it were private property, and productive of profit to the owners; And in consequence of such Assessment a demand has beels made by the Collector of the revenue of the tirst district of Pennsyla. for the sum of $\$ 633.33$ being the amount of the Tax for the year 1815

Your Memorialists deem it proper briefly to State for the further uformation of Congress that the City and County of Philadelphia did within a few years inpose a Tax on part of the property of the Institution other than the Hospital Buildings and the Lot of Ground on which they are erected, but that the Buildings and Lot on which they stand were never considered objects of Taxation. That the property which was so assessed consists of varant Lots in the Vicinity of the Hospital and separated therefrom only by the Intersection of Streets; and that Your Memorialists applied to the City Conncils, and the Legislature of the State, to exonerate this Institution from the burthen; which applications they have the pleasure to state were deemed so reasonable, that those bodies respectively since the Act of Congress imposing the Isistrict Tax, passed an Actgranting the reupest of Your Memorialist: : so that now neither the Lospital Buildings, the Lot on which they are erected nor the Vacant Lots in the vicinity, are liable to ally demands in the nature of a Tax in Pennsylvania. 


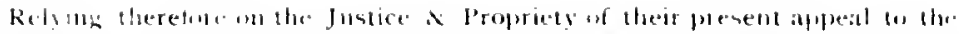

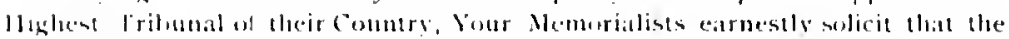

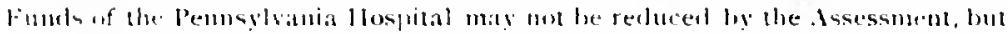
thet congrens will grout them relief in the premines; lig no doing thes will in

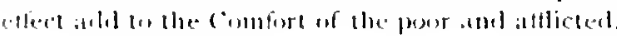

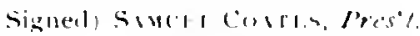

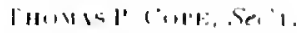

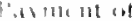

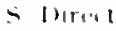
[1, In Estitle (if) llisplititl.

$1 ; r+1111,1$ Jurchaned

for lienlia 116intill for Issane.

A.t 1.11,h 10, isie, I vemptims

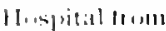

T.1 dicl not include Silatingal l'reprerty' in?

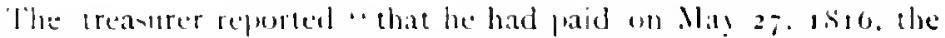

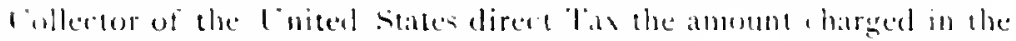
Hompital estatle." which was alpprosed.

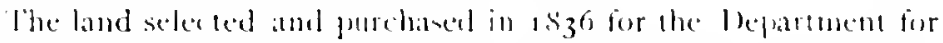
the Insance was Netthew Arrison's farm of one hundred and ane ale res. (1) "hich achlitional purchases of alout ten acres, and some uster small lets aljoining, were located ewo miles west of the eill at

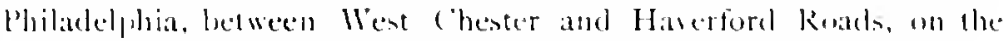
latler of whinh "as the entrance. (all this locality in now included in the "Twents-fomrth Mard of the city of Jhiladelphia.

An the set of asto exempted from taxation unly the properts then

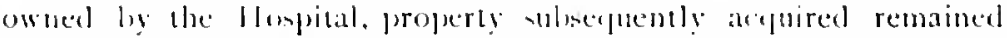
subject to taxation als uher real estate. Jo furocure the benefots desired

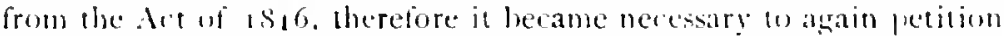
the legeristature to exempt from taxation all the Estate of the Ilosplital.

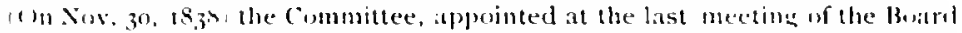

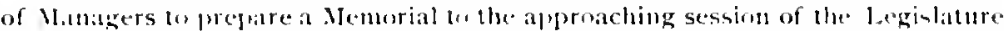
rectuesting oo have exempl from laxation all the Estate of the corporation, now produced one which was allopled, athd the President requested tosign and firward

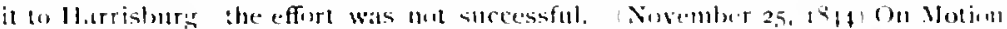

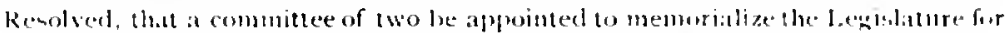
the remisutin of the Ilospital properts from taxation-Lawrence Lewis and i; Roberts Smith were appointed.

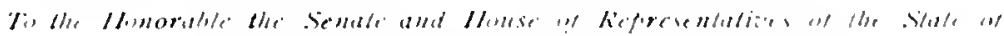

Weminisl lo

I. egistature

:o exemijt

fim Tares

all the triluture lu the lennsylsania Hospital" for the purpose of saving and resturing

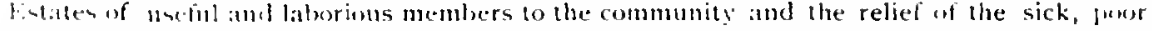

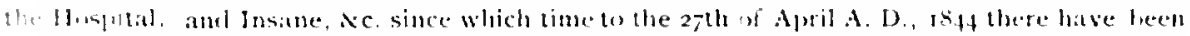
received therein $f 1,4+$ fatients of whom 22,595 have been powr, and maintained and treatcil wholly at the expense therenf. Sour boworable bodies are referred bo the anmmal -t.tements of the atioirs of the lastitution. regularly latid before you for furlber information an regard to its usefuluess.

Vine pretitioners represent that in order to further so ereat a charity, yuur bumorable bonlie- besides furnishing pecuniary assistance, passed a law on the lohl, uf Murch, tsib exemplumg sald llospital and its adjatent lots from the payments of taxes, on lon as the ame should he employed for humane and charitable purposens 
That in 19.36, in conscouence of the increased number of patients and of many improvements particulariy in the cure of the lusane the Contributors enlarged their institution by the crection of a separate estiblishment fur these unfortunate beings on one estate bought for that purpose in Blockley Township. Phila. County which was finished in 1 st and to which yuur petitioners point with satisfaction as one of the noblest Institutions and most efficient charities in the Enion. The funds with which this impurtant improvement was effected were the proceeds of sales of the lots adjacent to the Hospital in the City sir as aforesaid exempted from taxation: so that thene lots beame tavable at that time atrain, and socontinue, the assessments of them and the improsements thereon being now considerably over $5475,000.0 \mathrm{n}$.

As the wrords of the exempting art abrve recited do mit coser purchases marle by the Ilospital after its date, the new acquired property therent remains taxable and is taxed as ordinary property. And yus petitioner- respectinily sedulust a further and general exemption from tavation of their estaten for state connty and poor purpunes on the specific grounds that the whole income from permanent sources is innually expended upon the poor patient of the Institutions by their charter oruvided, thereby telieving the state and county in exercising the chirity. of their foundation, by maintaining carins for and curing a large number of the sick and insane por theteof: and further by the change in their lustitution as abose set forth they have contributed to the taxable property of the coumty an amount twenty times as great at that for which they ask an exemption

I'nder these comvictions and with the belief that every dollar saved for the Pennsyliania Hospital from extrancous outlaty will be directly applied to the benevolent purposes expressed in its charter. yur petitinters respectuldy request Sour honorable bodies to enact a law exempting their property from taxation.

- This was approsed by the hoard anl flirected to be folwarded to the Legislature. January 2\%, 14.5.1

March 31. Ist5. $11 \mathrm{~m}$. B. Fling laid hefore the lioard a certified copy of an at of Assembly, to exempt from taxation the estate of the Pennsyliania Hospital, which reads as follow:

"Be it enacted by the Senate and Houne of Rejresentatives on the Conmon. wealth of Pentsylvania in General Assembly met and it is herely enacted by the authority of the same. That from and after the passing of this art, the estates and property, real and personal. now belonging to the corpuration w the cuntribution to the Pennsylvania hospital, shall be and remain free from the payment if taxen of any kind whatsoever. Provided, that nothing in thin act shall extmpt from the assessment and payment of road and poor taves, so far an any part of the property of said Pennsylsania hospital is lecated in Blockley Tuwn-hip.

"Approsed. The nineteenth diy" of Warch, "ne thousand eisht humbed ant forty-five."

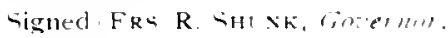

Thanks of the Bourd in (iim) mittere 111 ohtining the act of to $11 \mathrm{~m}$. B. Fling, for his exertions in procuring the above exempth which however does not appear to have heen final, for on $A$ pril 25 . 1853 , the committee appointed on the 3 [it of the first month lant. in

l.egislatitu exellipts all the Fistatem properts, rt: hud persunal. nf llomplta? frim T.uses at ally kind 
endeavor to procure the pasagge of a law exempting the property of thi, Instutution from taxation, mate the following report, vis:

That they have atlended to the duty assigned them and in oreler that the legiblature should be mate fully acpuanted with the reasonableness and the proprety of granting such exemplion to this lustituton, it was theught proper that one of the commitlee should proceed te Harristurg, Mr. Win. B. Flin: kindly ullered to perform that duty, and the Commutece have mow the satisfaction of reputing the following bill on the sth inst. and its approval by the Givernor.

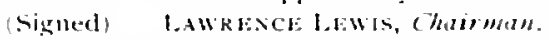

All Act lo incorporate the state fouc Railsoal company; authorizing the

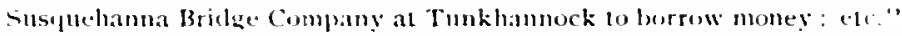

"Sicotion -. That the estates and properly real and personal, belonging to the

l'emarlbanias

Ihospitis:

iroperty

Simlinable cuntribulurs a the Pemsylvania Hospital, shall be and remain free from the payment of taxes of any kind whatsoever, so long as the income from said estates and property is used for the relief of the sick and insane poor, any liw to the contrary notwilistanding."

"Approved. The eighteenth day of April, one thousand eight hundred and fifty-three.

(signed) WM. Buglak, Gu'enum,"

The Constitution of Pennsylumia, of $187+$ repealed all laws evempting property from taxation, except as stated in the following section :

"Art. IX, iec. I. All taxes shall lee uniform, ujon the same class of subjects, within the territorial limits of the authority levying the tax. and slatl he levied and collected uncler general laws; but the Gencral Assembly may, by general laws, exempt from taxation, public property uned for public purposes, actual places of religions worship. places of hurial not used or held for private or corporate profit, and 1 1 ) institutions of a purely public charity.

"section 2. All laws exempting property from taxation, other than the property above enumerated, shall be roid.

"(1). In the case of ex farte l'ennsylvania llospital. I Phila.. fls, it was decided that property exempl by law cannot be taxed until the exempuinn is repealed." 


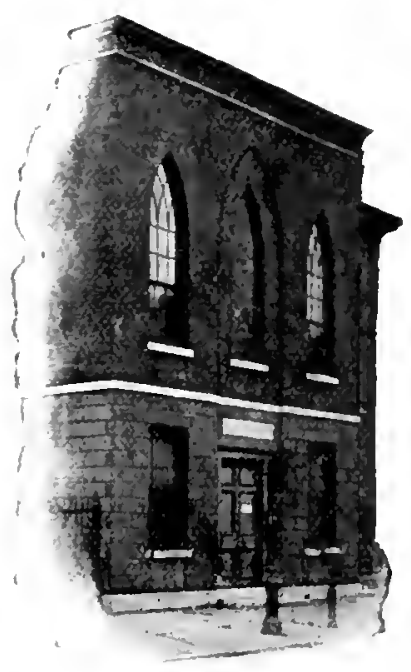

WORKS OF ART, MEMORIAL FURNITLRE, ETC.

In Septemler, 1800. Benjanin West, President of the Ronal Acalemy of Arts in London, was addressed hy the Nanagers asting for a contribution. It was said, in their letter, that the lloupital building, " than which none. in this part of the world, united in itself more of ornament and the" was then nearly completed, and, after a due compliment to the liberality of linglish contributors and an appeal to the affection which he could not but feet fur the place of his hrth. it concluded with the sentiment, that the works of an artist which ornamented the palace uf his king. could not fail to honor him in his native land. This rerguest received, in the following sear. a lavorable answer from Mr. West, who sugrented as the subjert of the painting the text of Sipture: "And the blind and the lame came to IIm in the Temple, and He healed them." Certainly no stuly more apropriate could have been selected and it was one which the Managers heartily approved. In August, 1810, notice was received that the painting might soon le looked for and expecta-

II $x \rightarrow t^{\prime} \leq$ Panting in? "robrint Iteiling tive sick in the Temple." tion was raised to a high pitch, not only among those especially interested in the Hospital. lust aho in the whole community. Ilowever, for the present, their hopes were doomed to disalpwintment.

The picture. When exhibited in lingland, excited such general admiration, that patriotism took the alarm and nolles and commons, 
with one accord, agrecel in making a determinest effort to retain it in W...t - timt the country. Mr. West, who could not resist the various inlluences exP'dimm erted, was prevailed upon to allow the painting to remain; lsut he imme. pild liated hit diately leegan the work of making a copy, which he resolved should excel the original. Considering the fact that he undertook this work at a lime when the two countries were at war and consiler. ing also his comnection with the rulers and prominent men of his adopted conntry, we may fairly aseribe to him the merit of extraordinary independence and lilerality of feeling, as well as of attach. ment to the place of his birth. It was not, however, until October. $18 \mathrm{r}$, that the Painting reached this conntry. It was taken to a building which had been especially erected for its reception. "lpon the

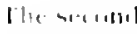

linintiner arricen.usel - placerl on Piribition.
Hospital wrounds on Spruce Street, and placed on exhilition ; being duly mentioned in the newspapers, it attracted such a throng of visitors that it yielded for several years a consideralsle income to the institution. The money received from the opening of the exhibition to its cluse in $18+3$, amounted to somewhat more than twenty-live thousand chollars: and as the whole outlay on aceount of the pirture was not chitil to ten thousand dullars, the profit, declucting the cust of exhibition, amomuted to no intonsiderable contribution. and approsimated the amount gaid West for the first copy of the picture. which was $; 000$ gnilleas.

The earliest mention on the minutes, of the l'ainting, was septemler 1, 1800, when it was recorded that the following letter was to be sent to Benjanin llest:

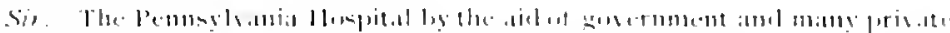

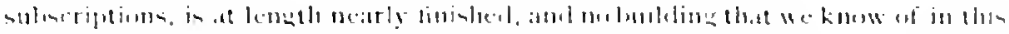

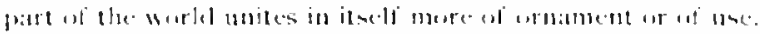

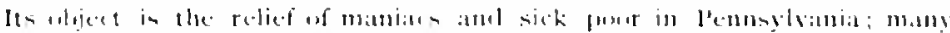

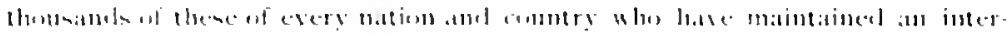

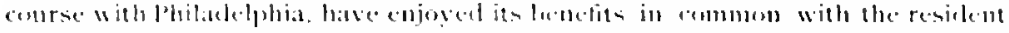

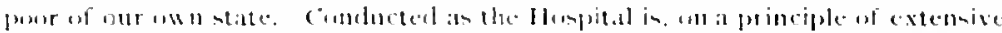

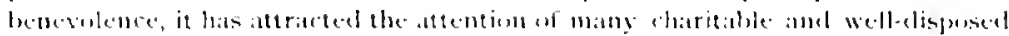
perple at home and atbroatl.

Amene theme individuals in England who have contributed to its support, we

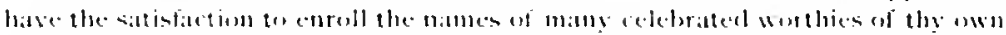

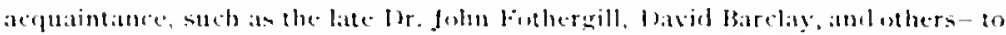

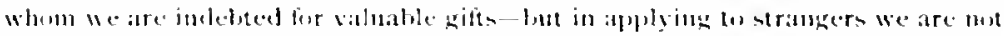
bo forget cher on en collutry men

However long they may hase been aldent, and busever remote from the

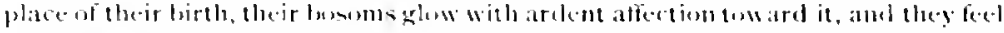

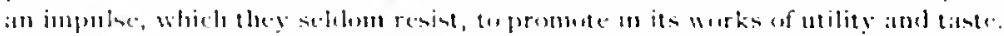

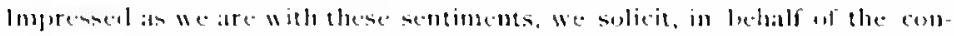
tributors tar the Manterere rentm, a painting from West.

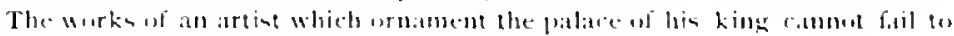
houser him in his native land. 


\section{To this highly complimentary letter, Bir. West replied:}

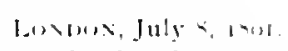

It is whth satisfaction that 1 embrace the opportunity by the return on

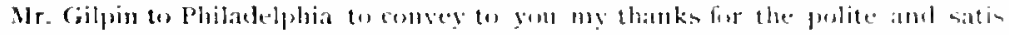
factory letter written in me by the arter of the president and Mamagers ef the Pemosylvania Inospital.

The gratification it has lone afforded me in lacaring of the celebrity of thome

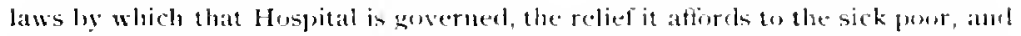
the benign aid it gives to the afflicted in gemerall, lats phated it ammothe firet of institutions.

The proposal of phacing a picture of my patinting in a situation su humorable.

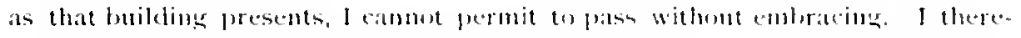
fure accept the offer.

The subject I have clossen is andogenus lo the situation. It is the Redecemer of mankind extemeling bis aid to the atflieted and of all ranks and conditions. The Passage is from st. Matthew chapter 21, versen 14 and 15 : "Ambl the blind and the lane came to Him in the Temple: and lle heated them. Amb when the chief priests and scribes saw the womberml thinge that He did, and the chibled

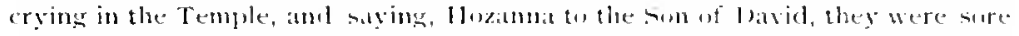

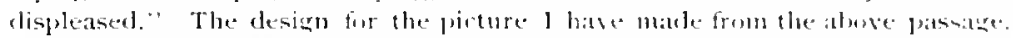
The pieture will be sixteen feet long by tert test high, inclusling the frame.

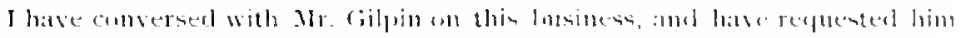

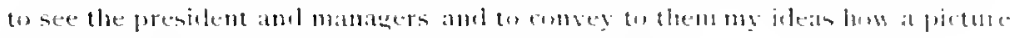

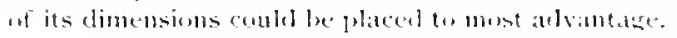

On October 29, ISor. the following was sent to Mr. West:

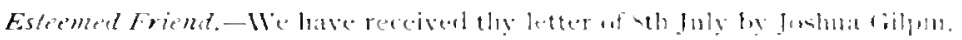

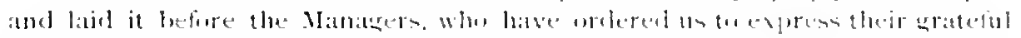

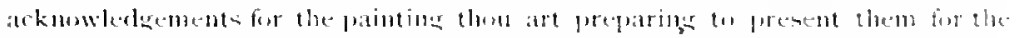

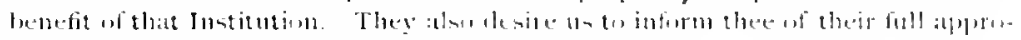

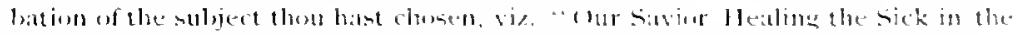
Temple."

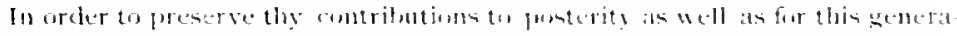

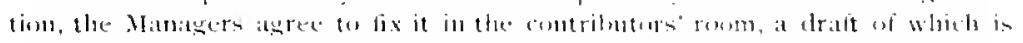
inclosed with the Committees remarks fir thy information.

Peace being now restored between fircat brition and France, we anticipate with increasing pleasure the prospect ref receiving the panting withont injury. and that instead of gracing a Paris musetum. it will lumor the artist in his native country.

From 1802 until 1810. no word was received from Mr. West, hut in August of the latter year the artist apologizes on account of his sickness for not having finished the painting and mentions his intention of resuming his labor, and proceeding therein till he completes the work.

\section{Under date, April $24 t$, i 81 , Mr. Went sent the following:}

Sir.-1 embrace the opportunity of writing you ly the return of Mr. Sint we

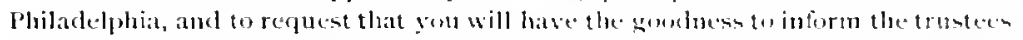

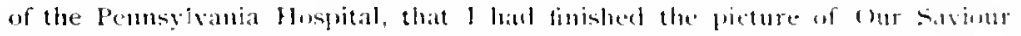
receiving the Lame and the Blind in the Temple tor heal them, with that success. 
$11 \cdot 24+1 \cdot 211,:$ will rentil 11. 1 h

lollutalle

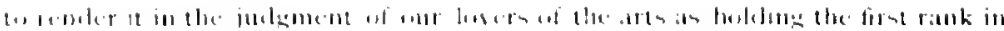

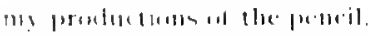

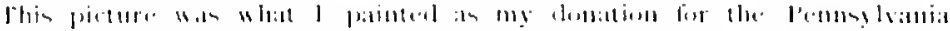

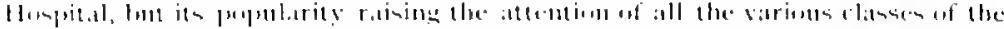

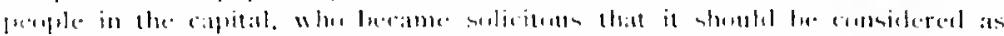

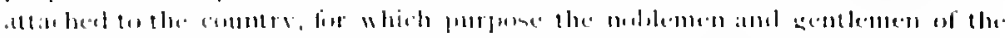

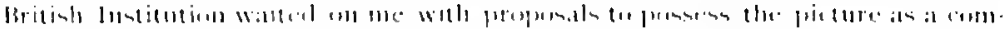

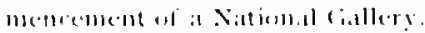

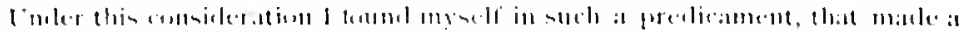

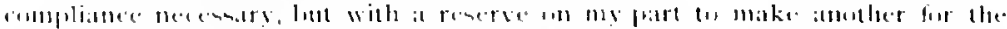

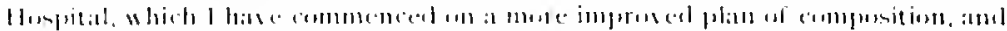

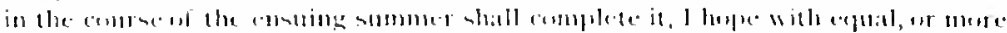

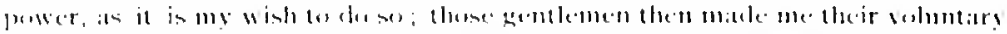

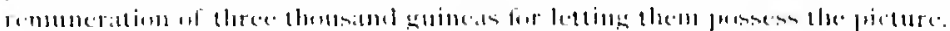

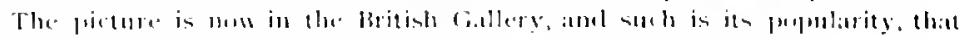

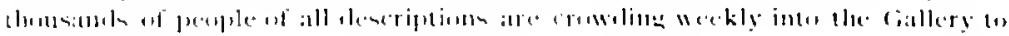
h.110: a nighllt at it.

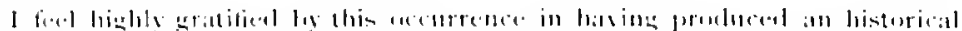

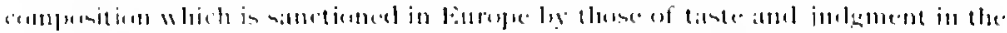

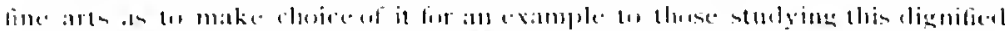

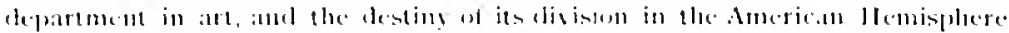

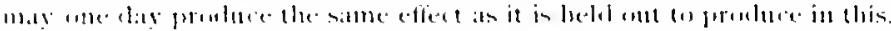

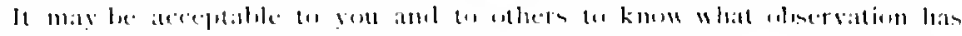

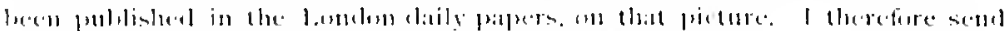

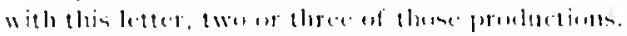

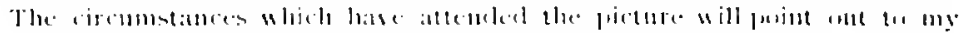

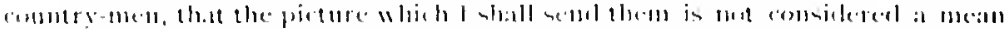

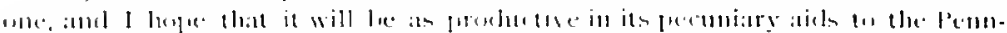

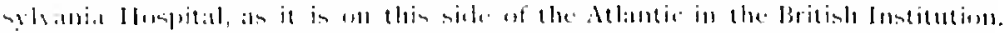

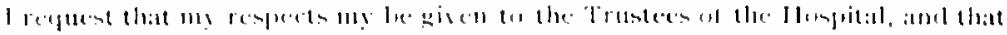
1.t12, your with sincerity?

Th this, the l'resident of the Board of Managers made reply. lugust 26, 1811:

Fuched livend. Lienjumin II:st:

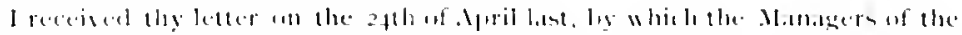

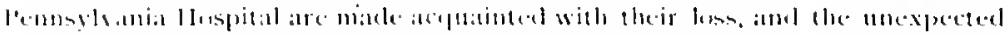

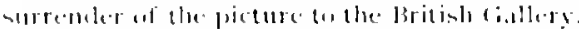

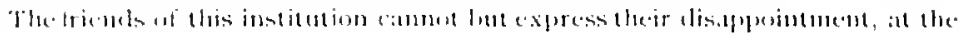

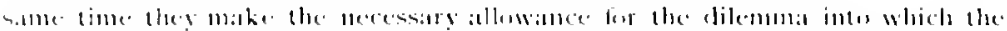

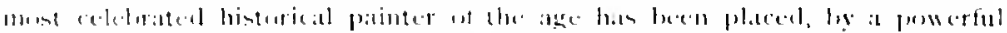

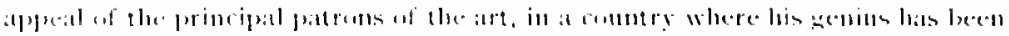

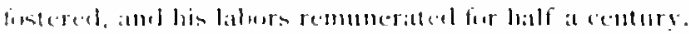

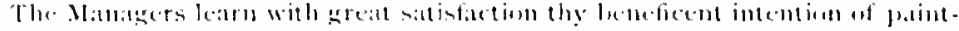

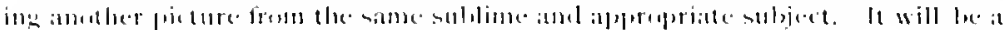

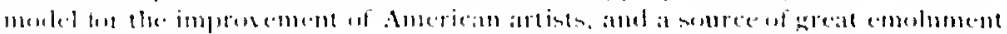

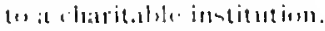

In Ieccmber, ISı, Mr. Iubua Gilpin wrote that he had visited the studio uf Mr. West, and that rapid progress had been made in the ficture. which he had reason to hope would be finished before spring. 
In view of the possible early arrival of the lainting, the treasurer of the Ilospital was requested to comfer with . Whert Gullatin, the Secretary of the Treasury, on the means to he pursued for improrting it, and, if possible, free of duty. (See page 312.)

In May, $18 \mathbf{s}_{2}, \mathrm{Mr}$. (

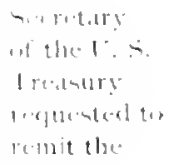

lititi:, 11

IIentis

Fintilie

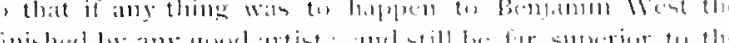

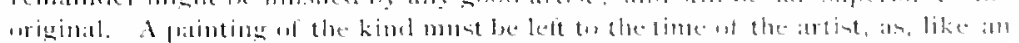

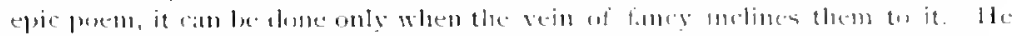

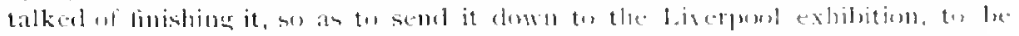

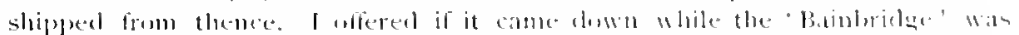

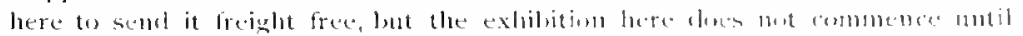
Septemlint.

In 1815 , the Secretary of the Hospital wrote Mr. West that the original proposition of the Managers to place the picure in the rentre building of the llospital was abandoned, and that it was their intention to erect a building in conformity with the views of the artist on the grounds, especially designed for it reception. The flan "ai subserptently carried out.

Lnder date of September 5, Isi5, Mr. West wrote:

I received your friendly letter of 2 thth of Jume lant, and I am pheated ton limel

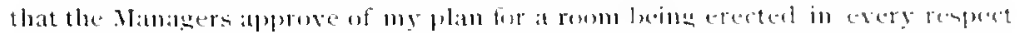
appropriate te the pieture of Christ receiving the lane and the bind wh the Temple to lue:al them.

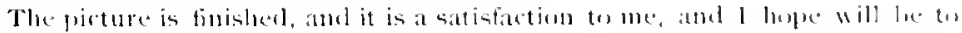

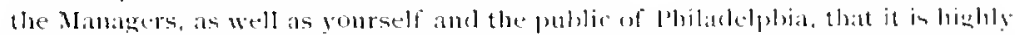

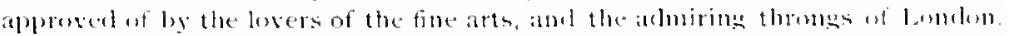
This testimonial in its faver I believe the mblement and gentlemen of the Briting

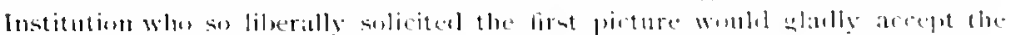
seconel in its place. But the latter I think my creptione are more compleqe in

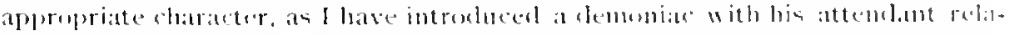
tions, by which cifeumstance is intronluced mome of the maladies which were bealed by (tur sivinur.

l trust on this oecasion my liberal combtrymen will mo be angry $n$ ith me in

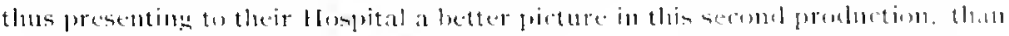
it wold have reaceded in the firet instince.

Some months later, the President of the lioard of Maniger received the following letter from Mr. West:

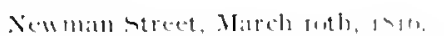

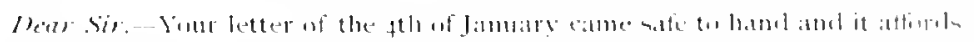

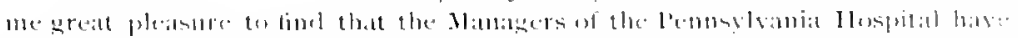

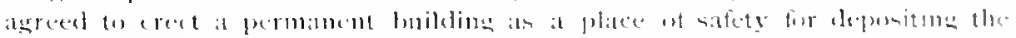

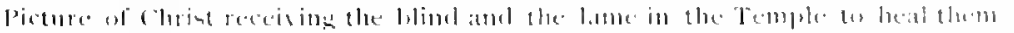

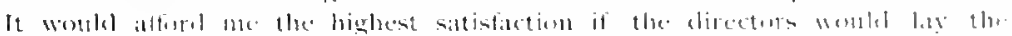

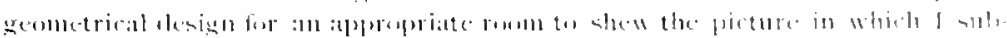

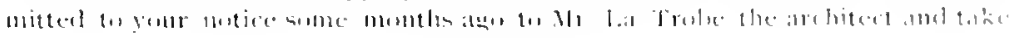

$1+111.1+16+116$ P:uliling (1) 1,10

1. 10 led fin (1) vilitinu Qlu. l'aintines. 


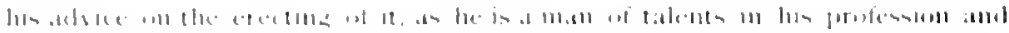

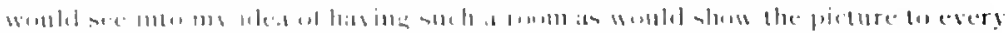

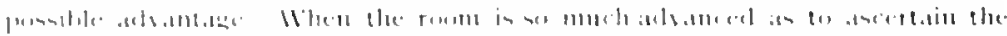

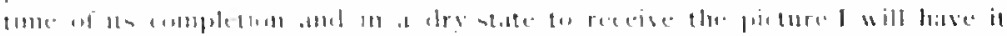

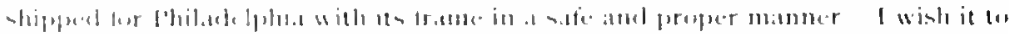

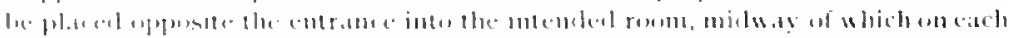

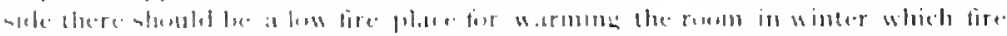

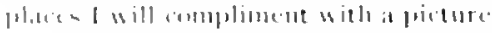

The huileling esprecially ererted to arcommodate " ITest's I'in ture" "as upon the spruce sireet side of the Honjital grounds. H.h- milway letween lighth and Ninth sireets; the glatint old beilding was constructed alter sugrestions from the famous painter himself, for the ehibition of his pieture. "lhe construction of its walls, stamps it an a product of the olden times. The bricks that compose them. instead of teing laid enct to end after the modern fashion, alternate with an endwire, and a cropurse lairl brick." Then, too, the long pointed winclum, seserely plain, threw over the whole an air of reverence. "Ilent's I'icture llouse" was sulusequently uned, (after the removal of the painting to the bepartment for the Insane), as a meeting-rom by the (college of l'hysir ians, the l'bilaclelphia lathological societs, and. sulsequently. hy the Historical Suciety of lennstlania. In later years it was altered into a Nurses' dormitory. (Sce page 105.) The luitling was erected in part from voluntary subwriptions and it is interesting to note the fact that Stephen Girard's mante is first on the list of sulserilers, and for one thousand dollars.

The visnetle at the heat of this section presents a view of the spruce street front of this bulding, and the rear view is given upon page 319. The picture holse was enlarged by the Ifistorical Soriety in 1870 . (see page 99 ante.) 111893 . the picture house was finally worn down in order to make rnom for the new Memorial Wards.

The following letter was also written ly. Mr. West while in london:

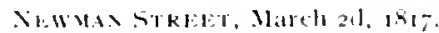

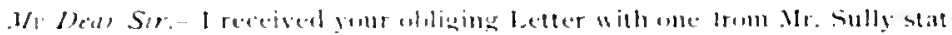

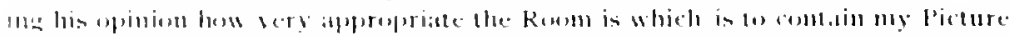

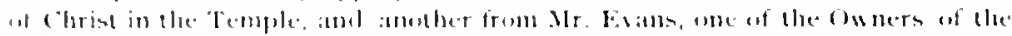

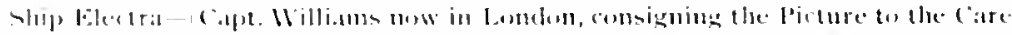

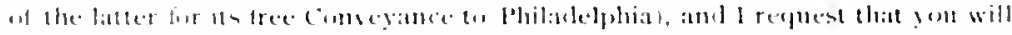

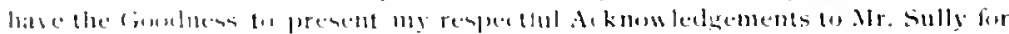

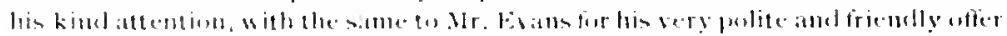

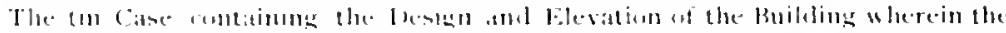

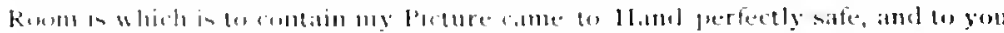

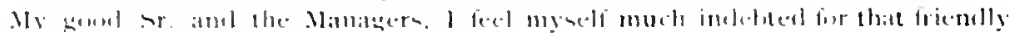

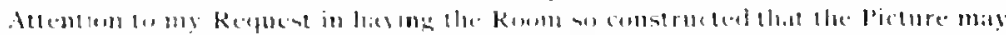

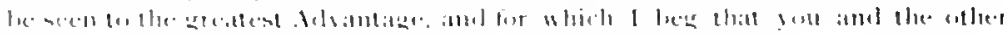

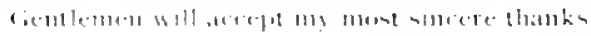


1 am preparing two Pictures. Which accompang that of christ in the Temple

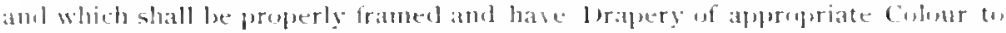
place aremol them when they are put up, for be assured that a funation to the

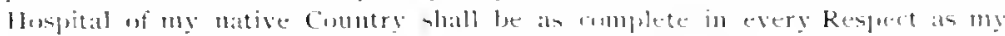

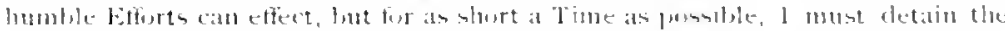

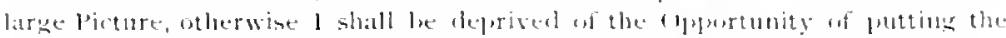

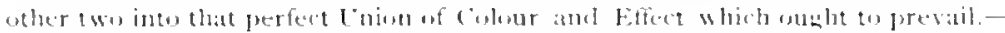

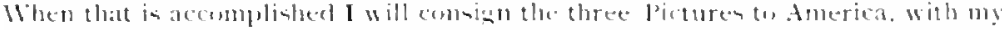

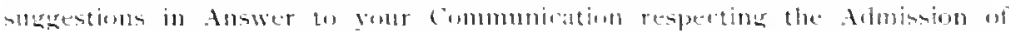
Artista and others te view the l'ictures when placed in the Hompital-Respecting the Bubling which is to contain my pictures, 1 mont take leate to observe that it in vers rellute from mo Intent ino to deprectate the Werits if the Architect whe crected it, in making the following obervation, hut 1 think there is a Misafphli-

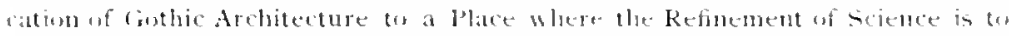

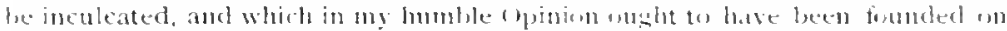
thene cleatr and self evident principles adopted by the freeks-an attention to which in the afpropriate Chatacter if all subequent Buidlings ratioed in Phila-

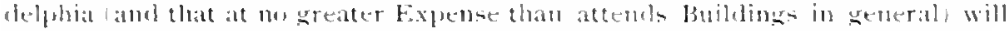
in a short time make that city as the scite of Flegance and science in the wentern World, and impress on the Mind of the Beholders the mental Refinement of its fitizens-such is the Effect produced an Pesple of lufirmation tratellins through (ountries where they behold that propriety of Boblding in exery public Work and city, and which stamps the Character of Cisilizatum-ln wiving my

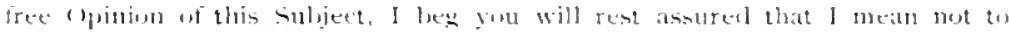

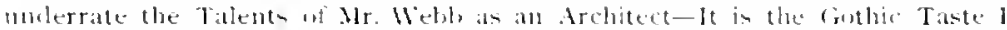

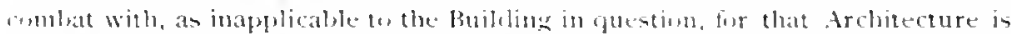

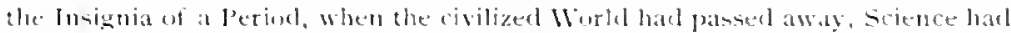
Hed. and the Mind of Man lay in llarknen-Tlatu arone monkish Superstition and munkish Tante-hut new, that seience has arisen, let the cities a America in their streets and in their limplwas proclaim its Ascendancy by every visible Mark of its etermal Truth-1 feel an interest that the State of Pembrlwania should keegl the lead in all mental Refinements, as her commencenent was founded an thene Principles of Equity and true Feelings towards an unoflending people in a then Savage state, which gave her an Ascendancy and lignity in the Minds of the

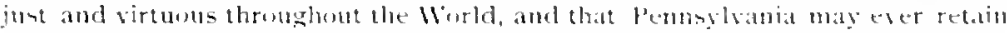
that Preininence, buth in Truth and science, is the most ardent Wish of My learsir.

Vinurs lery sincerely.

Ti, the l'resiclent.

B1:N.1. Mis

The following note was sent by the Shipping Igents in 1,ondon:

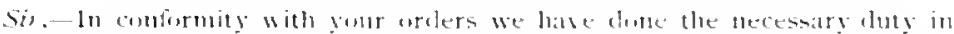

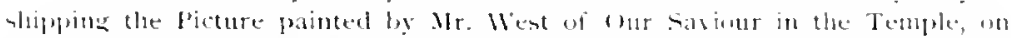
hourd the ship Electrit, Captain Willians, fur your purt, the pricture and frame are packed inte two cases and especially directed at pere the encluserl bill at

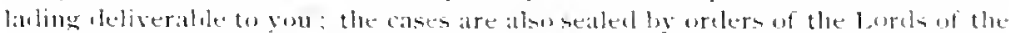

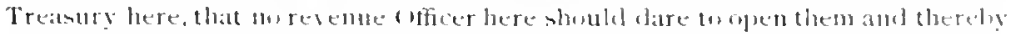
(h) any injury, and we bope you will obtain the same indulgene fom four reventure ufficers.

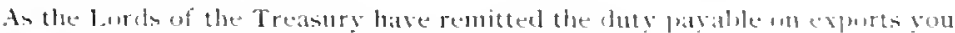

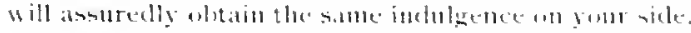

Lomklum, Alus oth, int- 


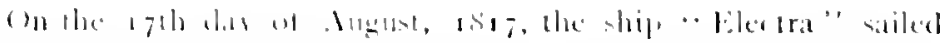

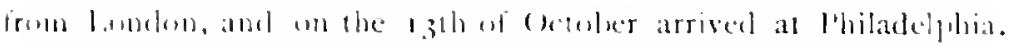
The Mlunters' minutes state:

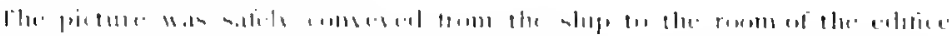

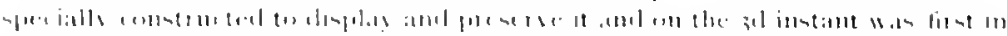

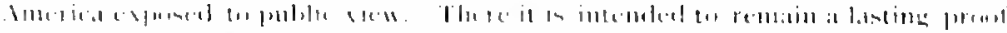

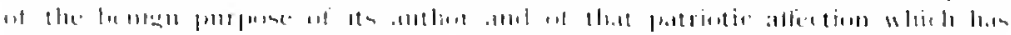

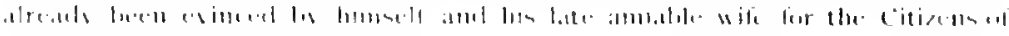

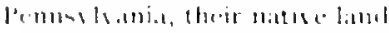

The following formal ontifiation of the completion of the lainting and its donation to the llospital accompanied the pir bure:

$1,11+1.11 \cdot$

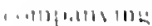
the l'otmting.
$11,111,1218$ . $11114+11+111$ ilitis thl the P.11111119.9.

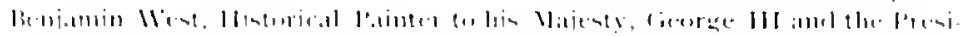

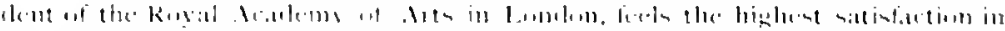

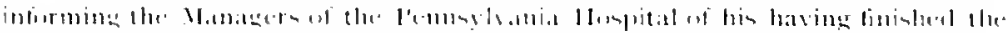

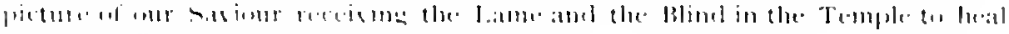

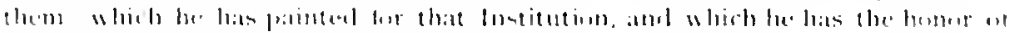

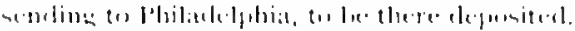

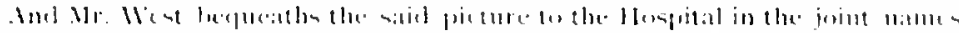

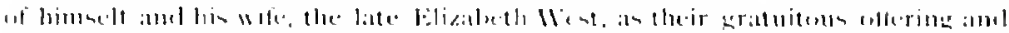

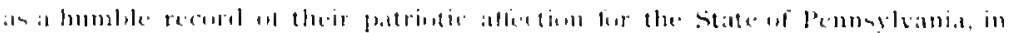

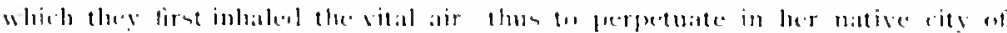

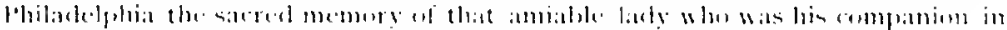

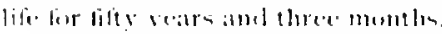

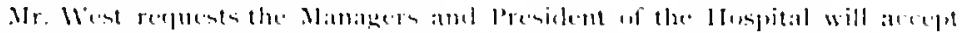

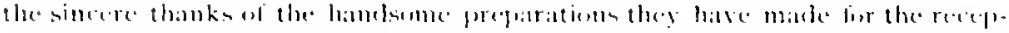

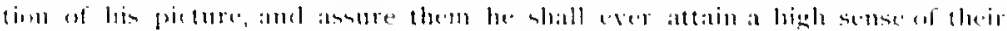

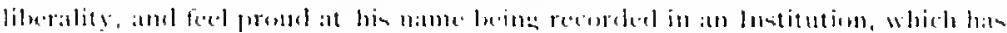

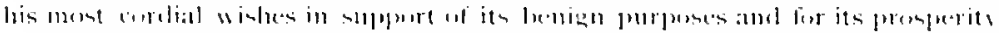

The Mantgers. in acknowledging 10 Mr. West the receipt of the jiclure, state:

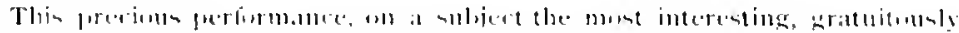

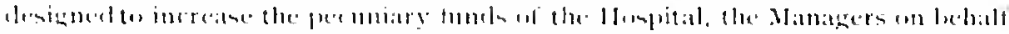

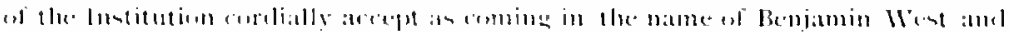

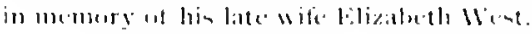

In I lecember. sisi, a suceessful apleal for the remission of the duty on the piclure was made:

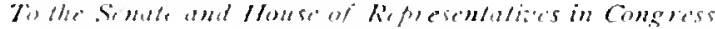

$$
\begin{aligned}
& \text { af the linted states }
\end{aligned}
$$

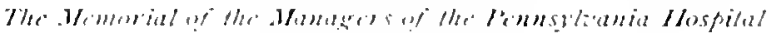

$$
\text { lespertinlle theneth. }
$$

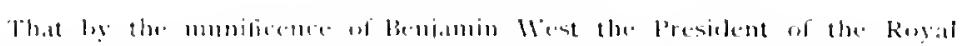

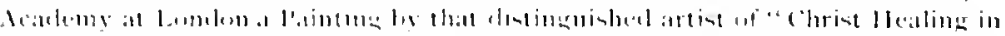

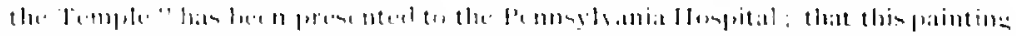

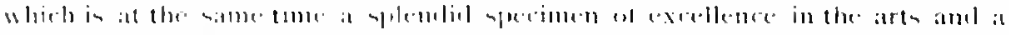

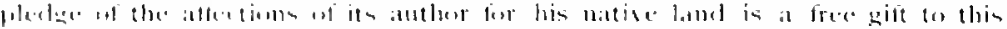

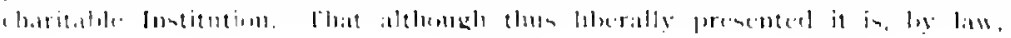




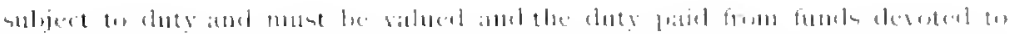

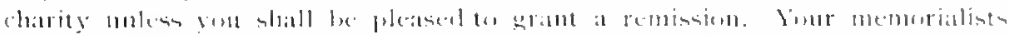

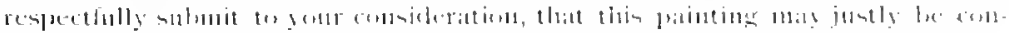

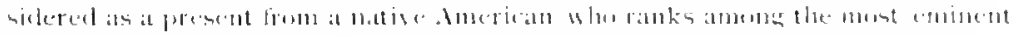

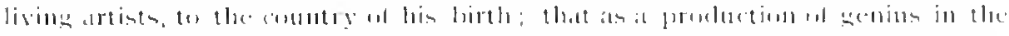

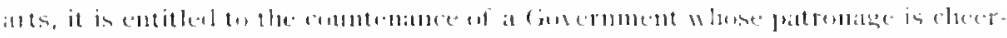

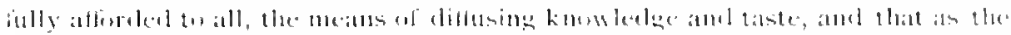

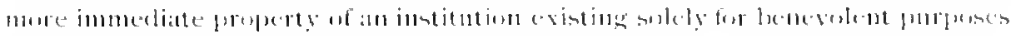

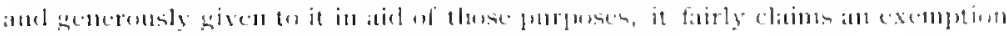

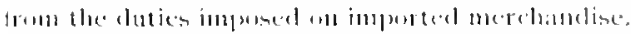

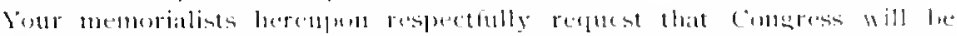

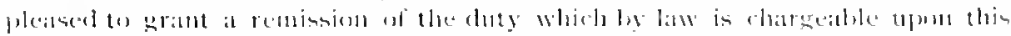

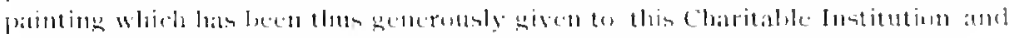
to the Cinutry:

The petition was favorally arted upon by Congress, as the following shows:

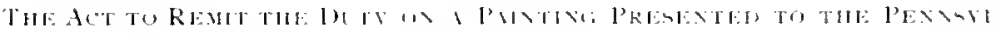

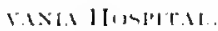

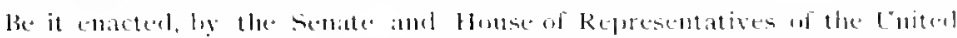

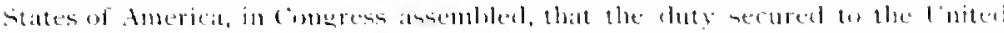

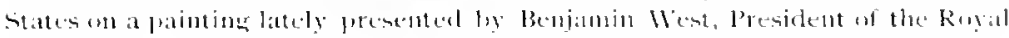

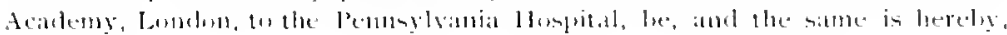
remitted.

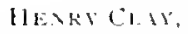

spiake' of the House of kepresentutio's

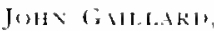

Alprovel, Jamuary 1. 1sis.

Jime- Mlonkul:

locsilent of the sinale pro trm.

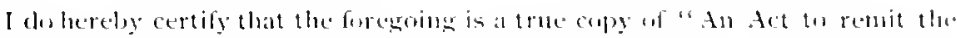

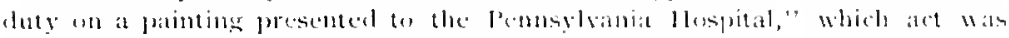

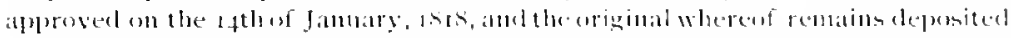

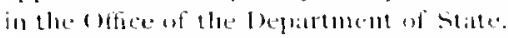

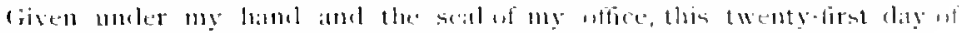

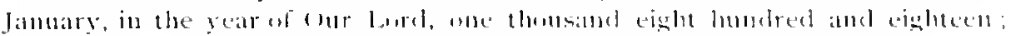

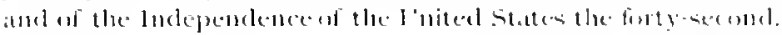

$$
\begin{aligned}
& \text { Ju11 (31) } \\
& \text { sectefere of shate. }
\end{aligned}
$$

A description of the Painting was prepared to be presented to each visitor to the Exhilution:

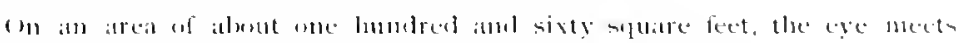
between lifty and sixty figures, all findselel after lising models.

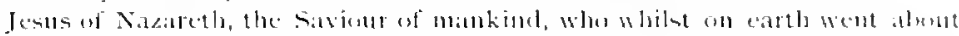

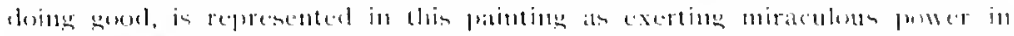

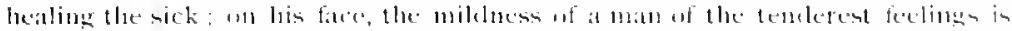

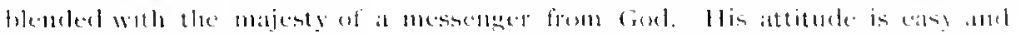

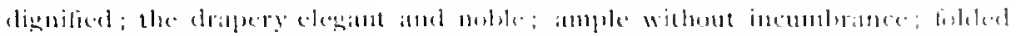

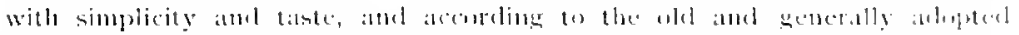

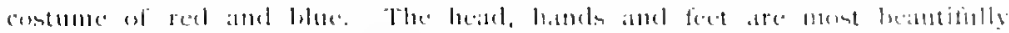

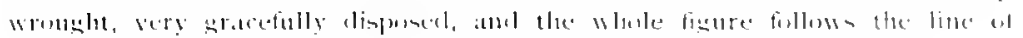

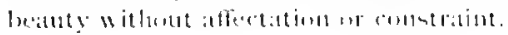

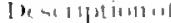
tlic l'onitin: 


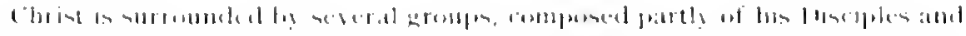

$13-1111+11+11$ al this

l'ililil11

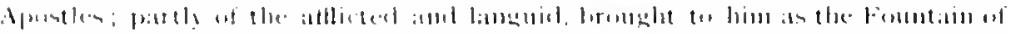

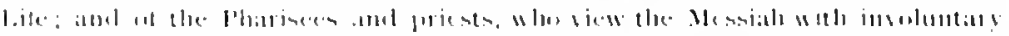

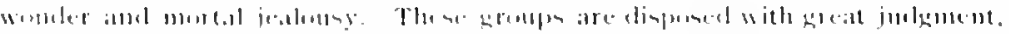

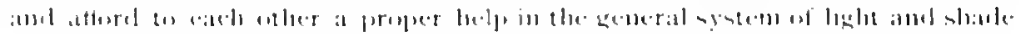

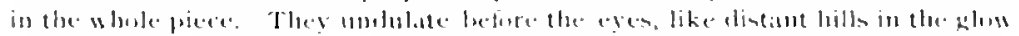

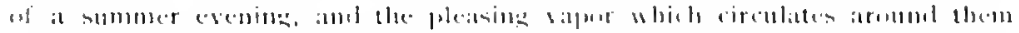

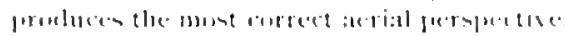

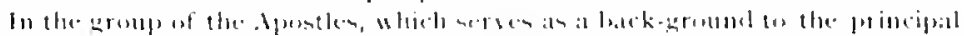

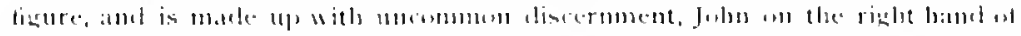

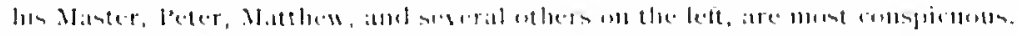

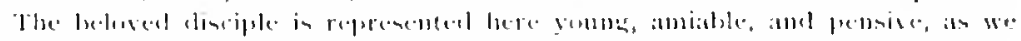

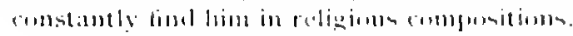

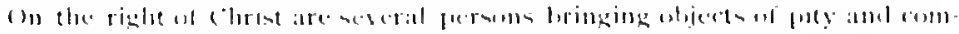

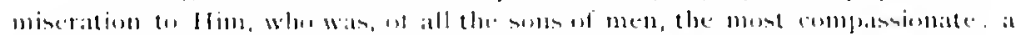

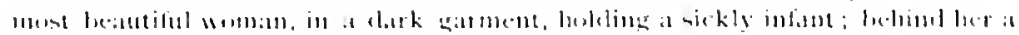

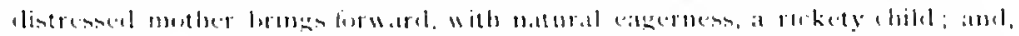

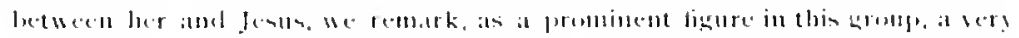

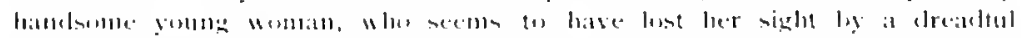

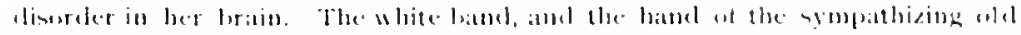

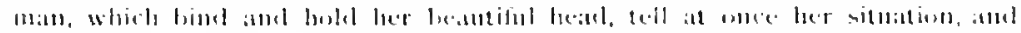

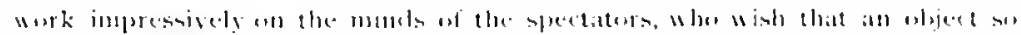

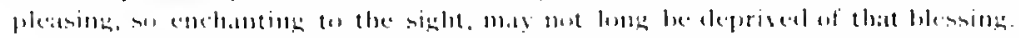

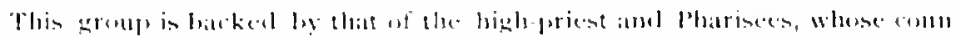

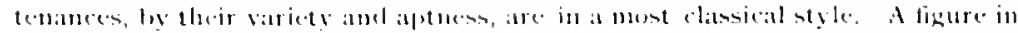

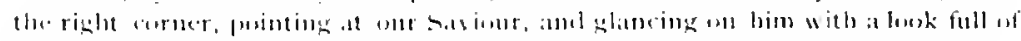

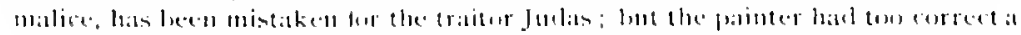

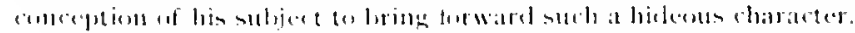

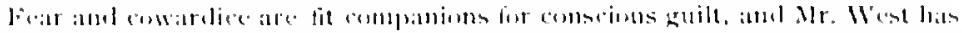

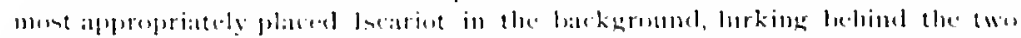

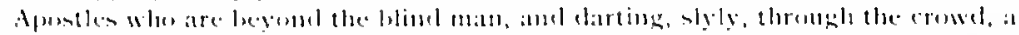

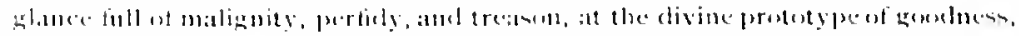

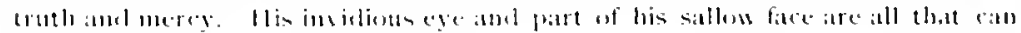
hu. $\rightarrow \cdot(1)$ al bim.

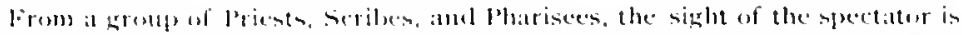

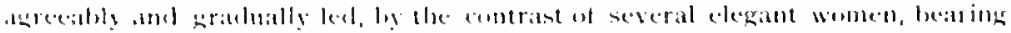

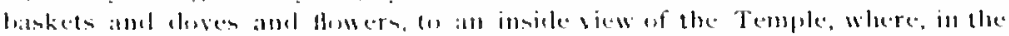

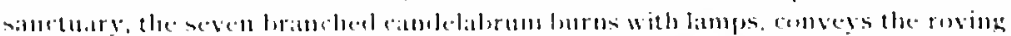

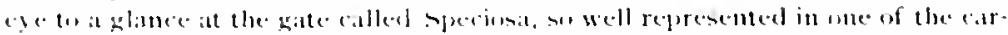

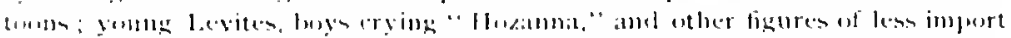

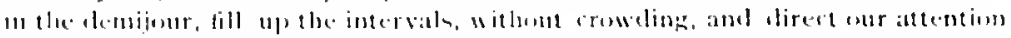
(1) a more interesting part of the pieture.

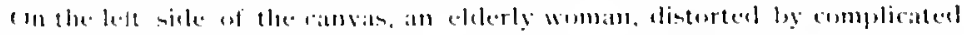

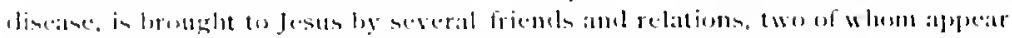

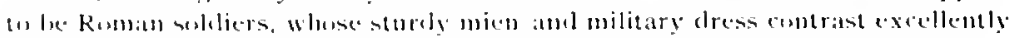

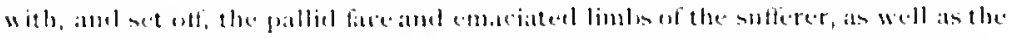

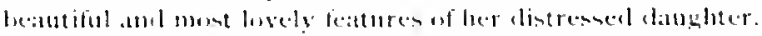

In the trollt at this aflecting sectle a centurion is in the act of kneeling : his

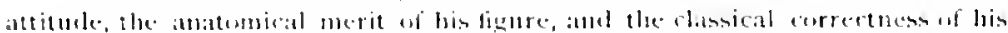

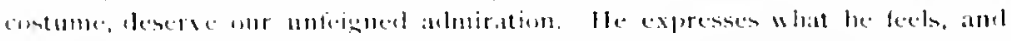

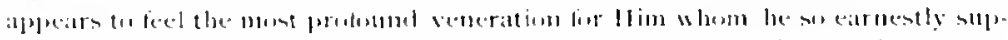

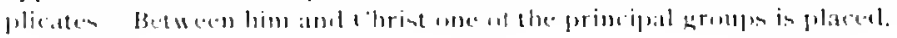




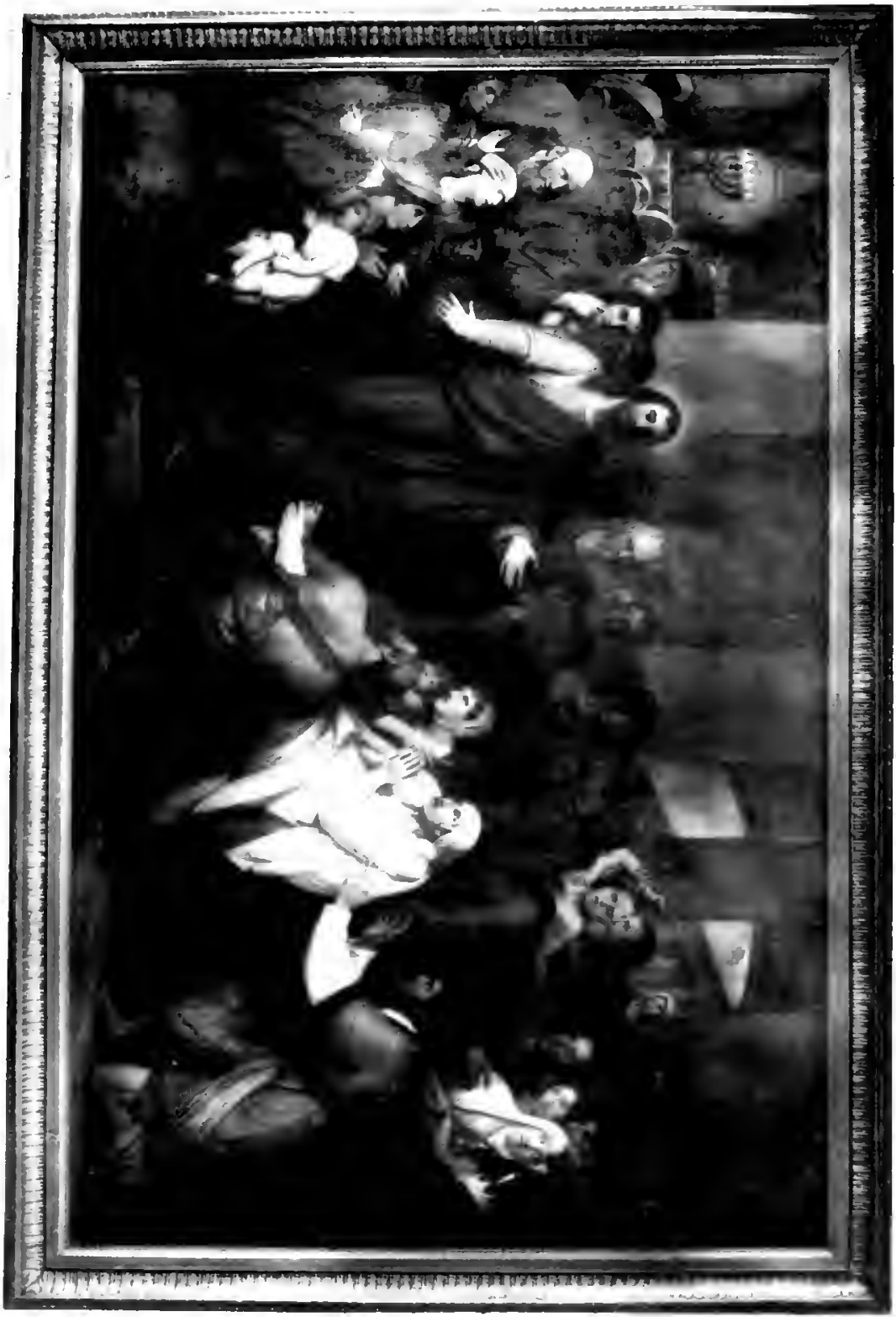





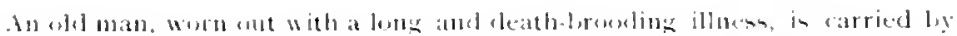
tow strong porters, whe staneling at the beasl and suppouting the superior part of

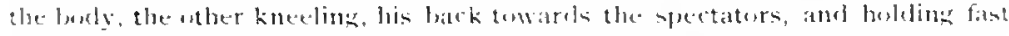

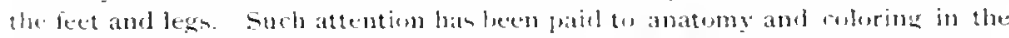
surking up of theme tus figures, that buth, and especially the stameling ene,

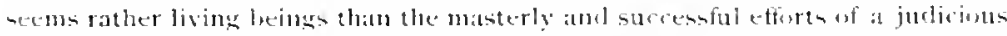
proil. What shatl we say of thesick man intrunted to their catre? The inperen. sin still remains, and it will me be easily removed from wor minds. Surely the

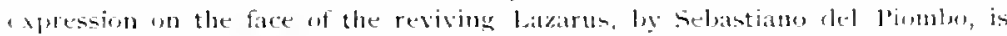
alduirable: and it ha been whispered that the restoring hand, whose criginal womlers we are relating, hat womewhat to dis there with making up for the repacity of Time; here the expression is greater still: we read in the hall-sunken

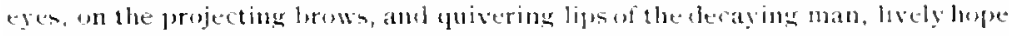

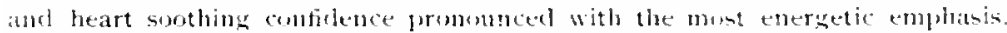
IJis steleton, arms and hansls are raiseal towards the real seurce of bealth and chmort, and his feet. which happen naturally to le nighest the healing power, by at erente glow of returning blusel. Which distinguishes them from the genteral tint

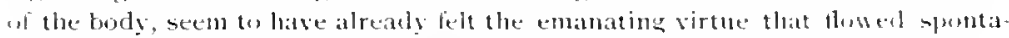
nentusly from Him whe alone conlel sits, in truth, "I am the life."

The heautiful woman who bolk the crutes of her dying father, the leathy ramplexim of her face and the glaw of her extemeded neck; the figureof a young

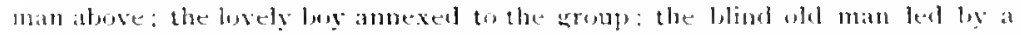

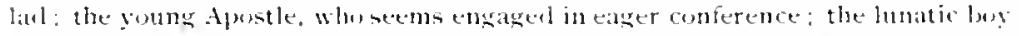
in the arms of his afflicted father: the impassoned air of lis two sinters, whe are lowkung towards our saviour; -all heredeserve the most umplatified approbation. and make the centre of the picture the ficus on interest.

The last group constitutes, with the persin of Christ, the entire subject. All the rest is accessory. No eprosde, mo digression is idly introbluced which might letrict in the least from the full attention of the beholder: and, althongh the son

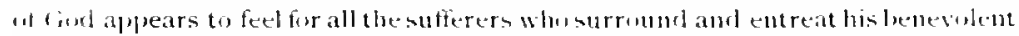
attention to their respective infirmities. vet the ent ire scene consists in the and of leating the sick man.

On October 28, $18+3$, the Directors of the Pennsylvania Academy of the Fine Arts sent to the Board of Managers of the Huspital a flattering proposal for the loan of the picture:

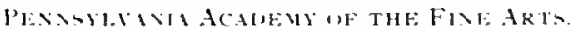

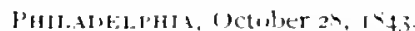

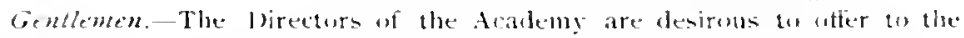

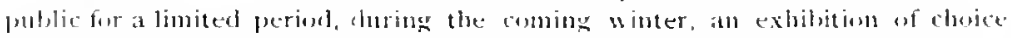
work of art, connected exclusively whlt religins and scriptural subjects. They propuse to exhibit only a limited number of pietures, and aming them to give a

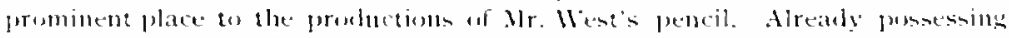
themselves his greatest work, and having male arrangements for several ot her w his large and masterly productions, they are particularly elesirous to white o ith

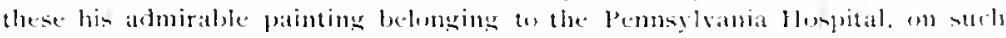

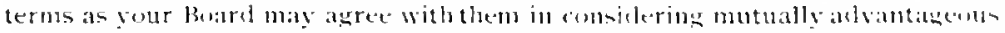

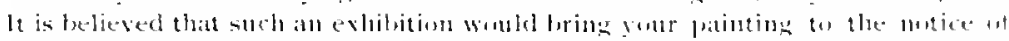

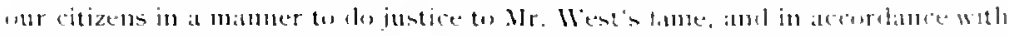

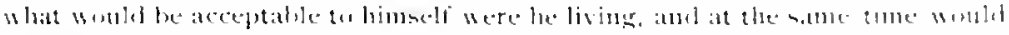

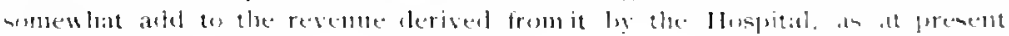
ahibited.

I'ripumal to hians Painting 2 "n Alakemin! in Fille tith 


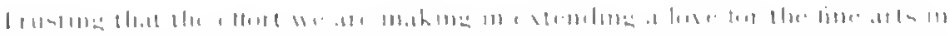

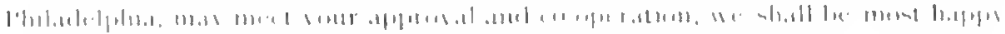

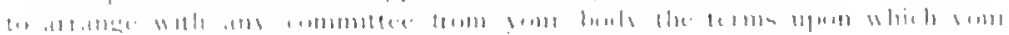

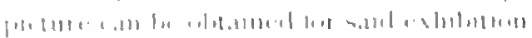

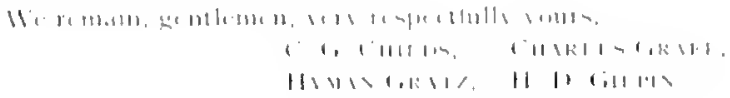

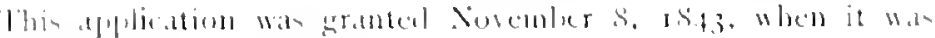
restreal:

$|1+1,11,4,1|$

$1,1,1,1,1$

$1+1111111=$

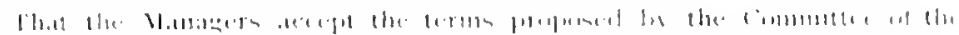

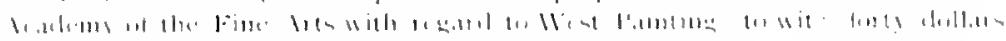

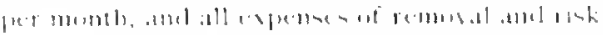

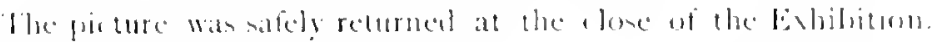

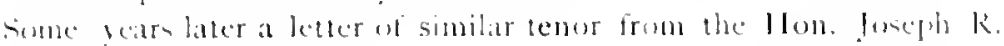
Ingersoll, wain received:

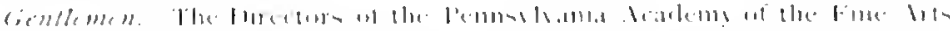

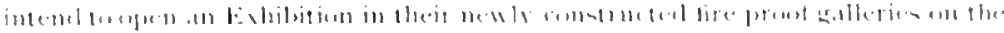

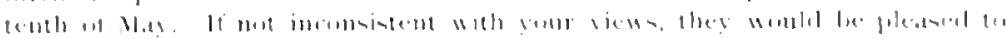

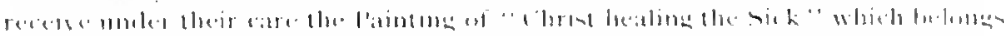

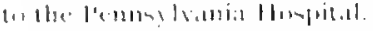

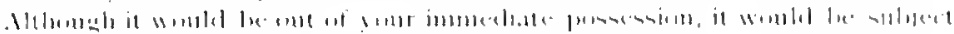

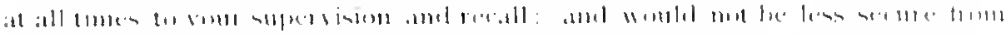

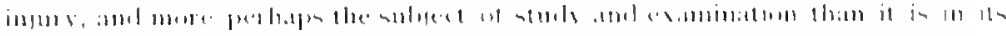

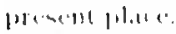

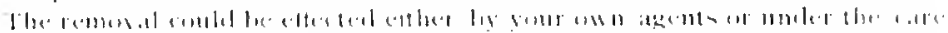

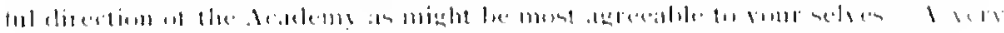

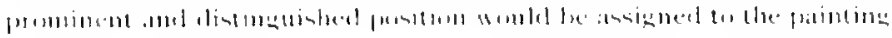

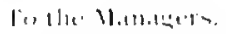

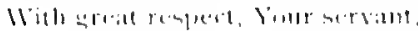

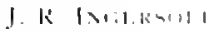

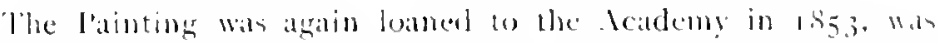
returned, and mbenpently it was planed in the Hall of the Depart

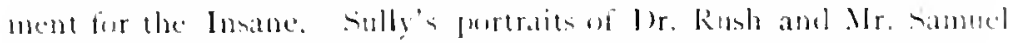
Coater. which were also baned, nere relurned to the Centre laulding of the line street llosplital, where the still remain.

l'.1111111:

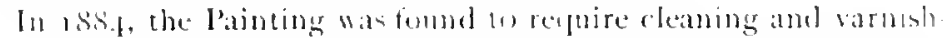
ing. Afterwards it was remereed from the Insabe begartmeent to the

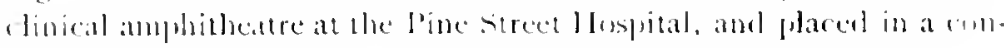
spictums position, above the operating talle, on the sourh wall. The

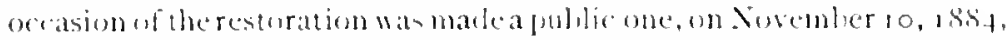
and sereral formal addreses were delivered lefore a large amblienere collected in respronse to all invitation from the bisard of Managers.

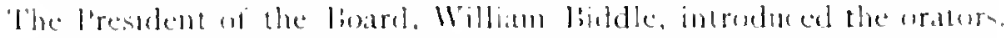

the address of be. Morton wat mainh devoled lo relating the

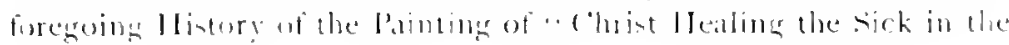
Tromple." 
The Address by Mr. John B. Garrett is so appropuriate as to warrant its introduction here:

Arlilienalll

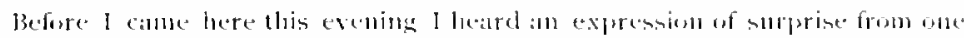

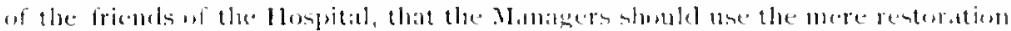

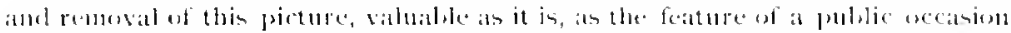

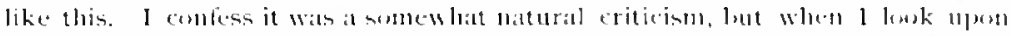

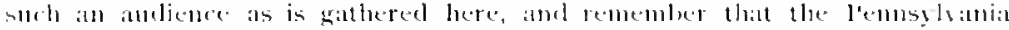

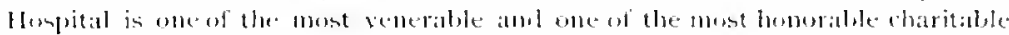
institutions of Americat, when I remember the history of alais pireture, which we

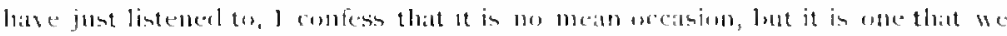

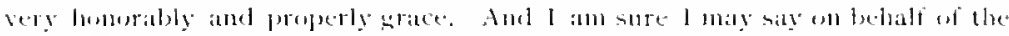

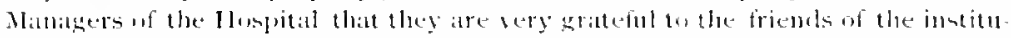

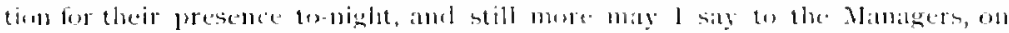

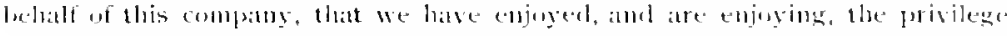

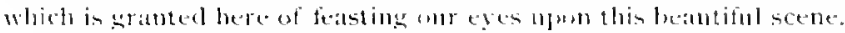

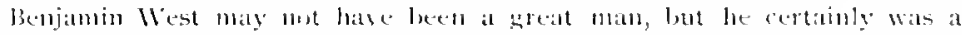
rembertable man: he was a mall of gendus; le wils a mall of patience and

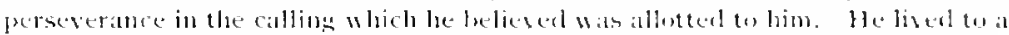
womclerfully green ola age. From the early age of seven until he labd filled ont the

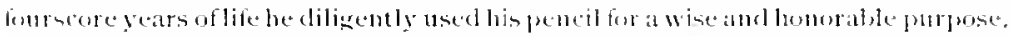

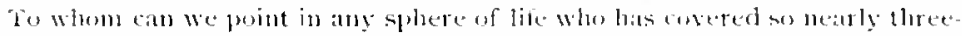

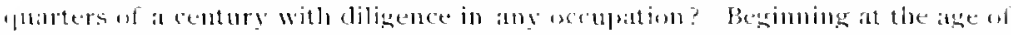
sesen, atud manifesting a wemblerful gift at that catly perigel, duing a piece of

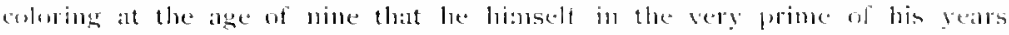

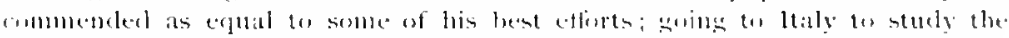

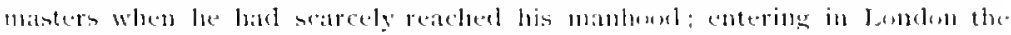

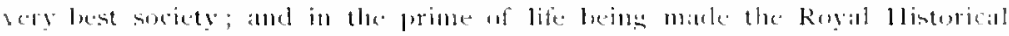

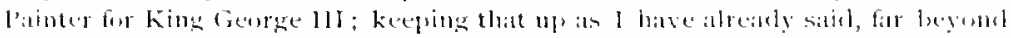

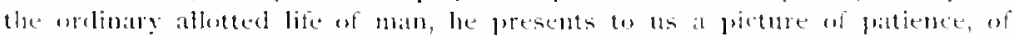

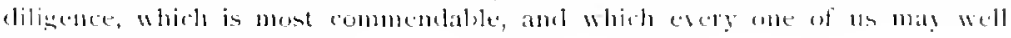
sturly and well cmulate.

The listory of this partioular pieture fovere the whole af this corrent

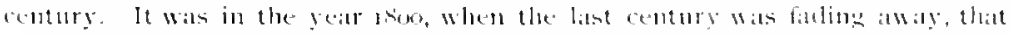

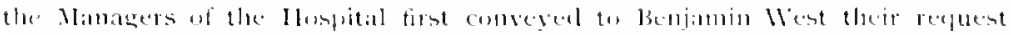

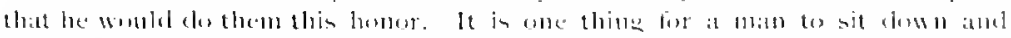

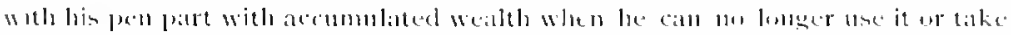

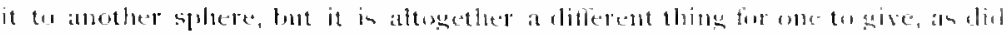

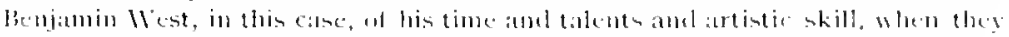

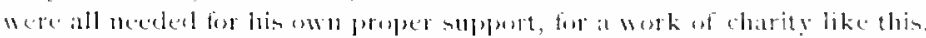

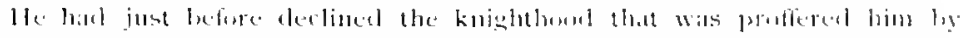

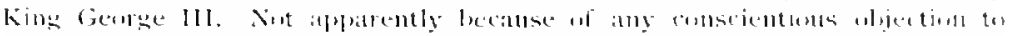

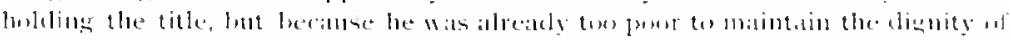
such a pustion. I think when we resollect this fact, we have an abled sabue

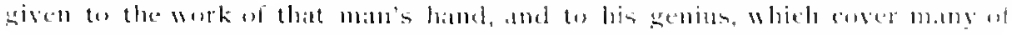

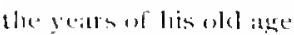

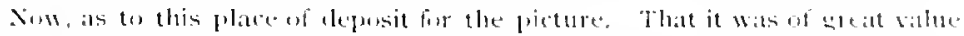

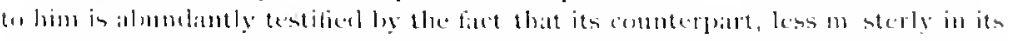

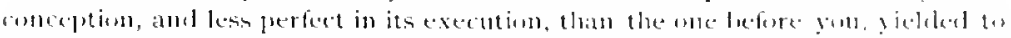

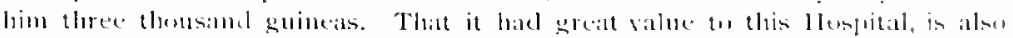

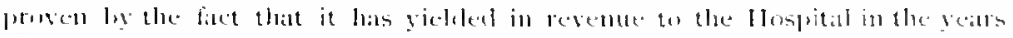

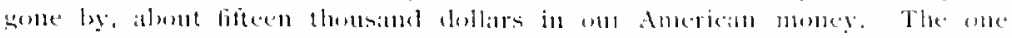

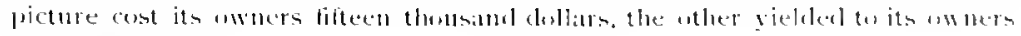
110 leme it $\$ 11 \mathrm{~m}$. 


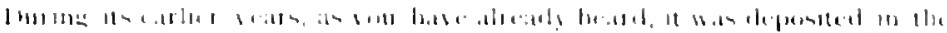

II Tiatteld is Malirion

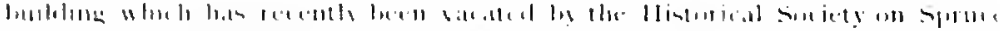

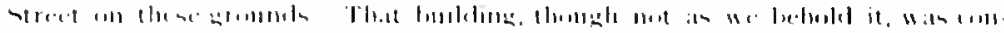

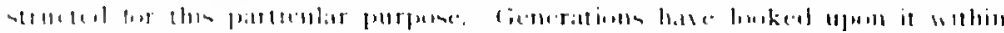

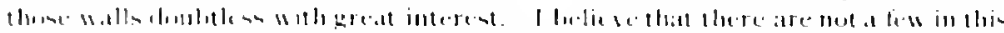

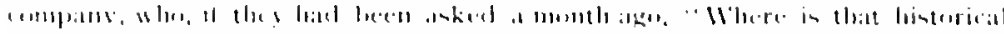

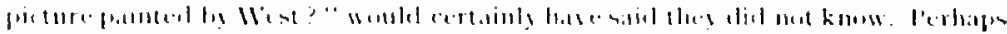

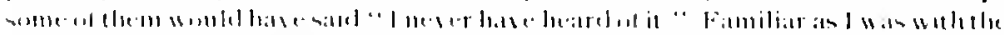

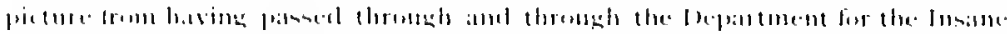

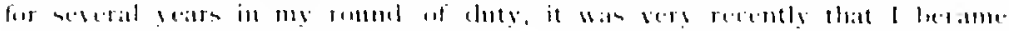

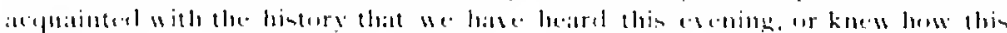

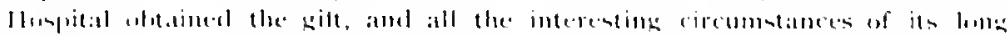
liintrits.

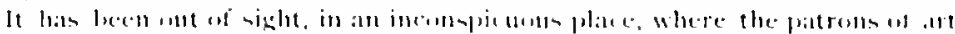

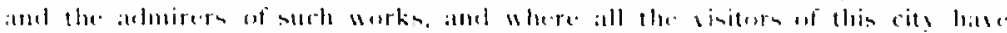

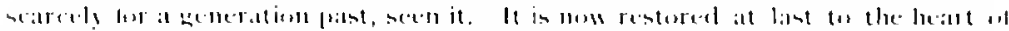

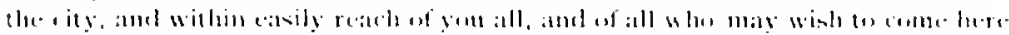

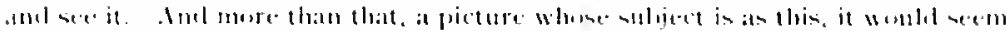

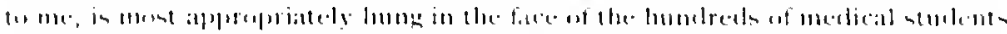

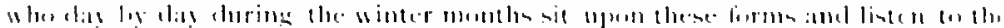

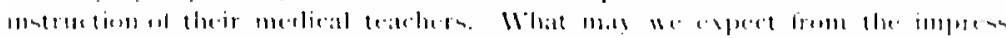

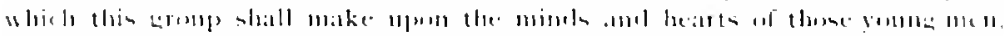

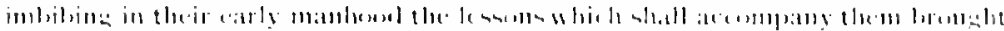

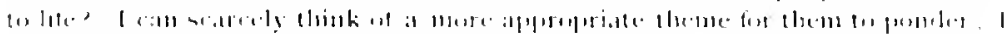

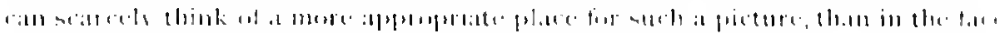

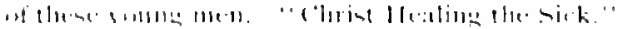

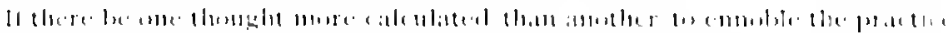

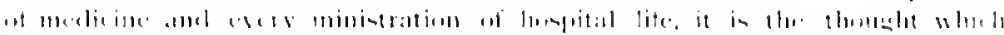

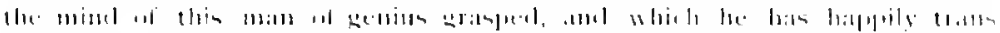

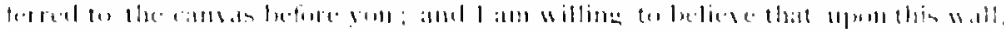

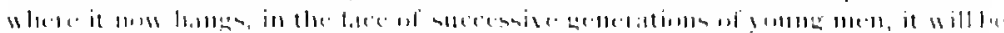

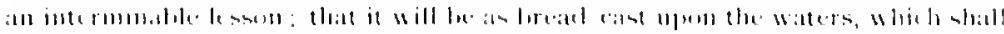

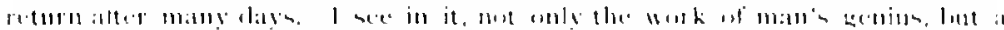

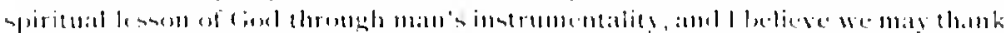

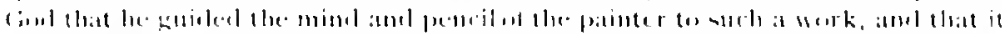

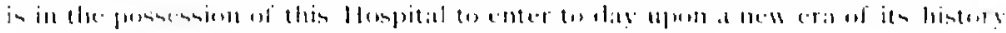

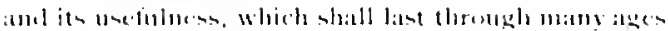

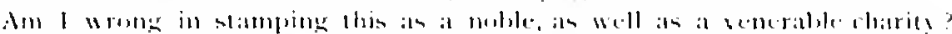

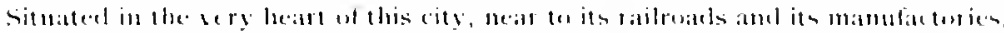

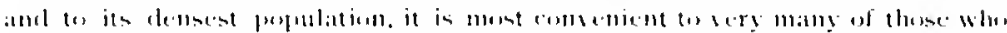

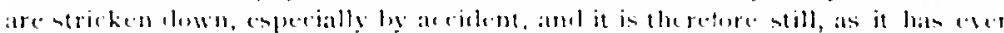

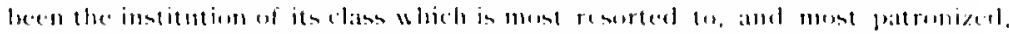
within our lurelers.

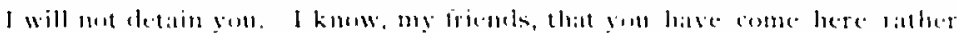

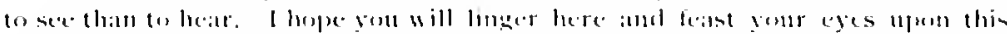
pieture, thatt you maly take an:y with you from it some true instruction, which

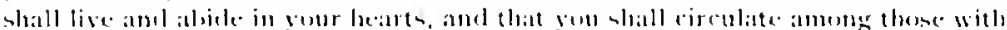

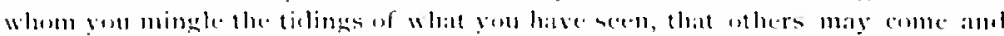

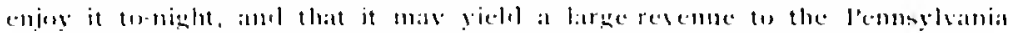
llompital in money, and astill larger relume on mankind in the goud it shall

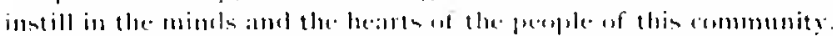

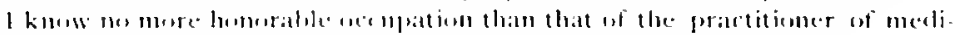

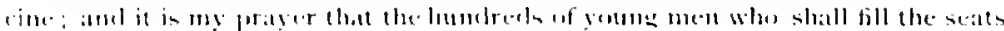




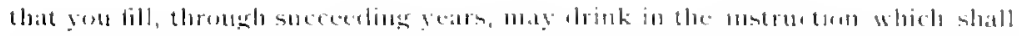
be got from that wall; that it maty be imstrumental in fordts band in giving them a nobler conception of that work whith in intrusted to their hauds ; for that ats

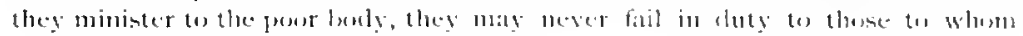
they minister almo th their sollk.

At a slated meeting of the lioarl of Managers, held November 24, 189.4 , the following resulutions were atopled:

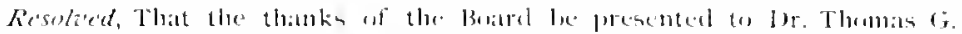
derton and John B. Gatrett, respectively, for the sery interesting disconses formal

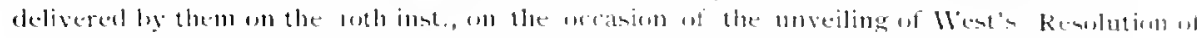
painting of "Christ Ilealing the sick," in the clincal lecture roum of the pint" "lianks. Street Huspitial.

Resoléd, That the Seretary be directed tuank from them, respectively, a copy for publication of the discourses thus dedivered for circulation andong the friends of the Hexpitial.

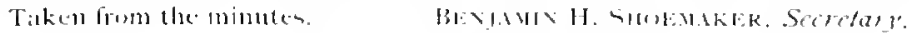

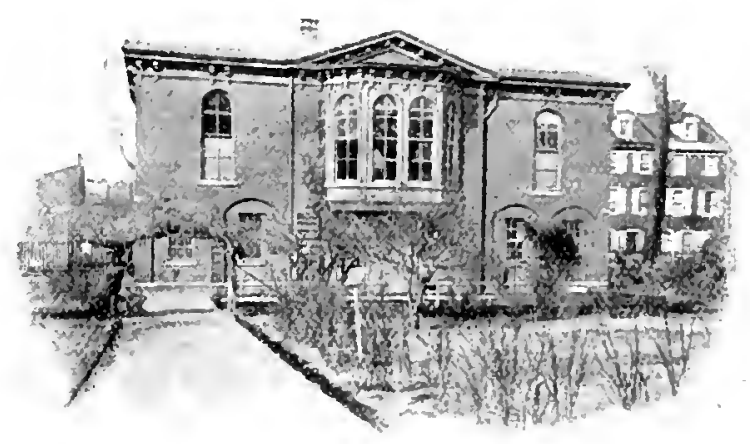

Rear View of Punture House.

The Picture House ceaned to be used for eahibition purposes in 184j. After the Painting was brongh back from the Pennsylvania Academy of Fine Arts, it was deposited in the lepartment for the Insane, where it remained until restored finally to the Pine Street llospital, as just stated.

The valualse services rendered ly West to the Ilospital will justify the introduction here of a brief sketch of the life of the Philadelphia artist, who became l'resident of the Royal Academy, and who laught Englishmen to appreciate American Iainlings.

Benjamin West was born (1)tober In, 1735, within a few miles of ['hilatele.

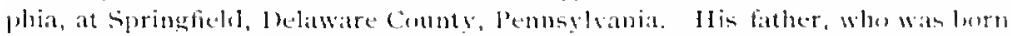
and educated in Englawe, belonged to the Guaker family of the Mests of lende crendon, in Burkinghamshire. When beniamin West was seven reats of age be

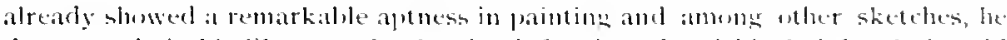
Bried Biography uf Benjamin clew an almirable likences of a slecpine infont in recl and biack ink. It is sairl 


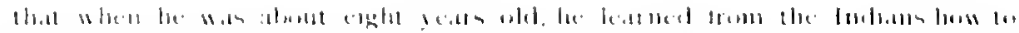

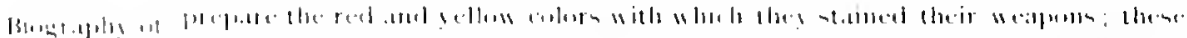

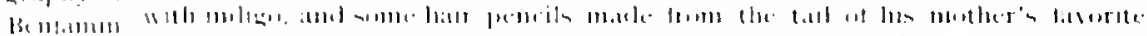

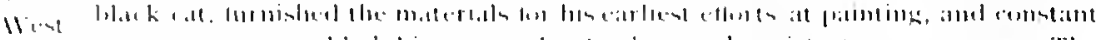

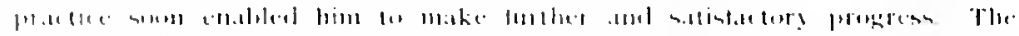

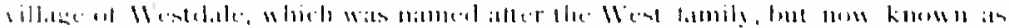

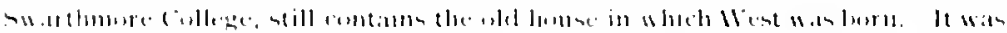

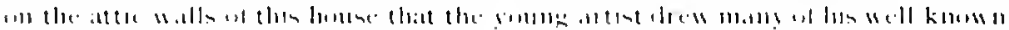
- hatrouil stetelires.

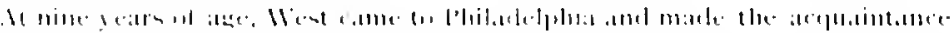

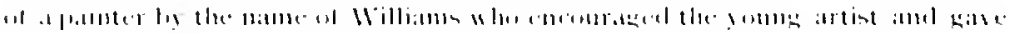

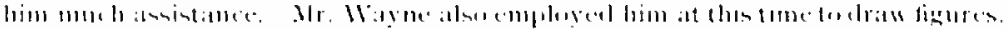

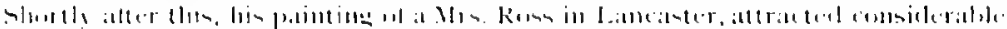

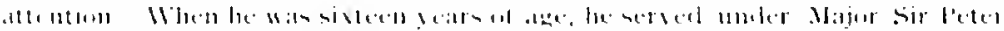

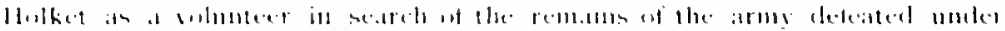

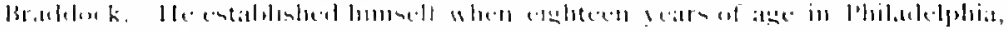

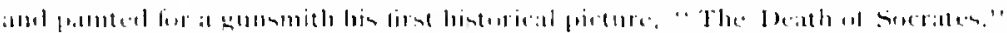

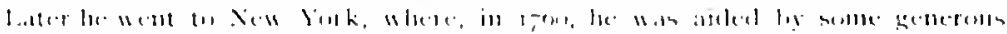

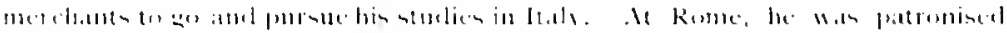

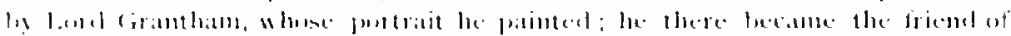

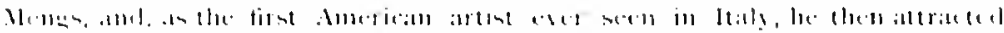

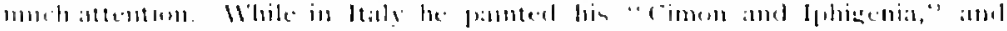

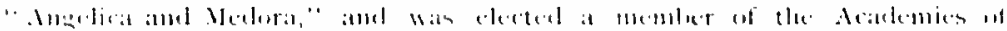

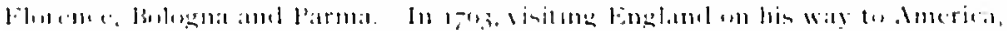

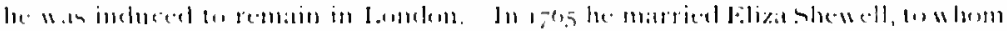

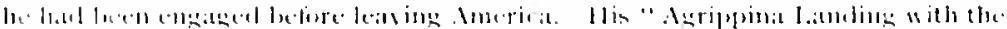

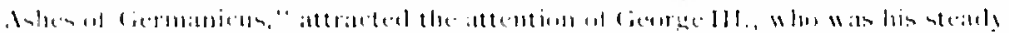

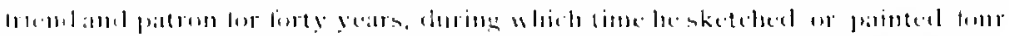

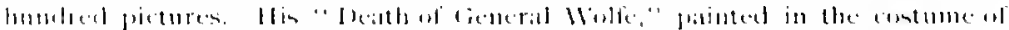

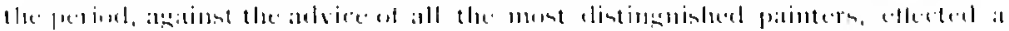

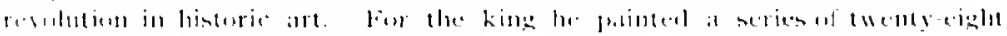

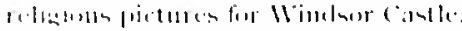

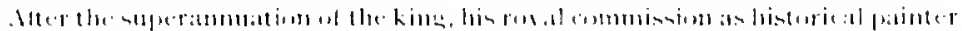

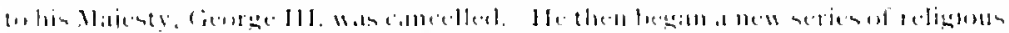

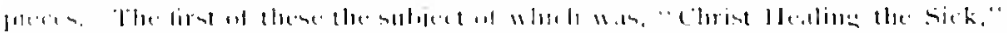

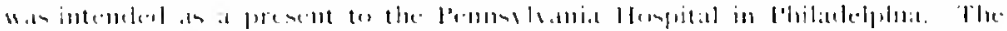

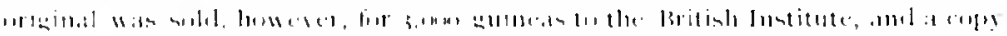

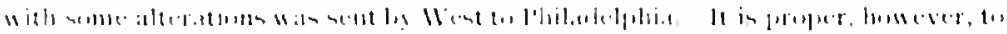

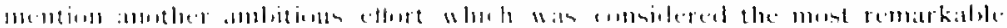

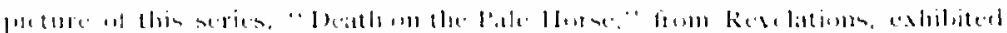

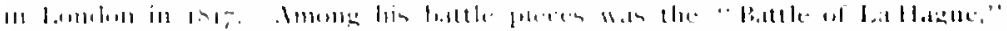

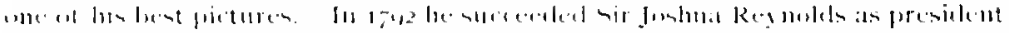

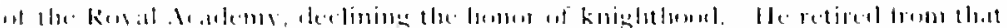

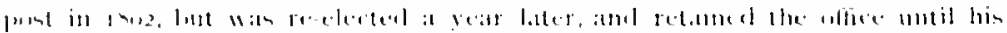

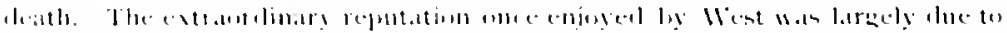

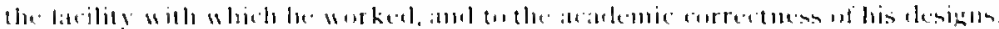

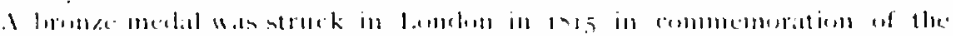

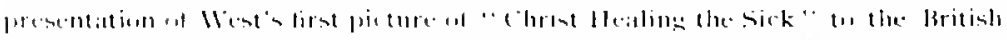

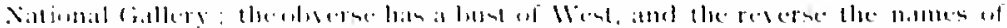

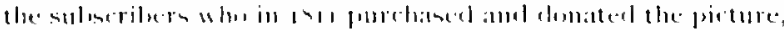

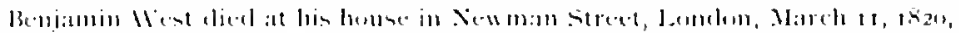

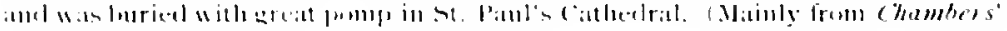
Entriepritit. 



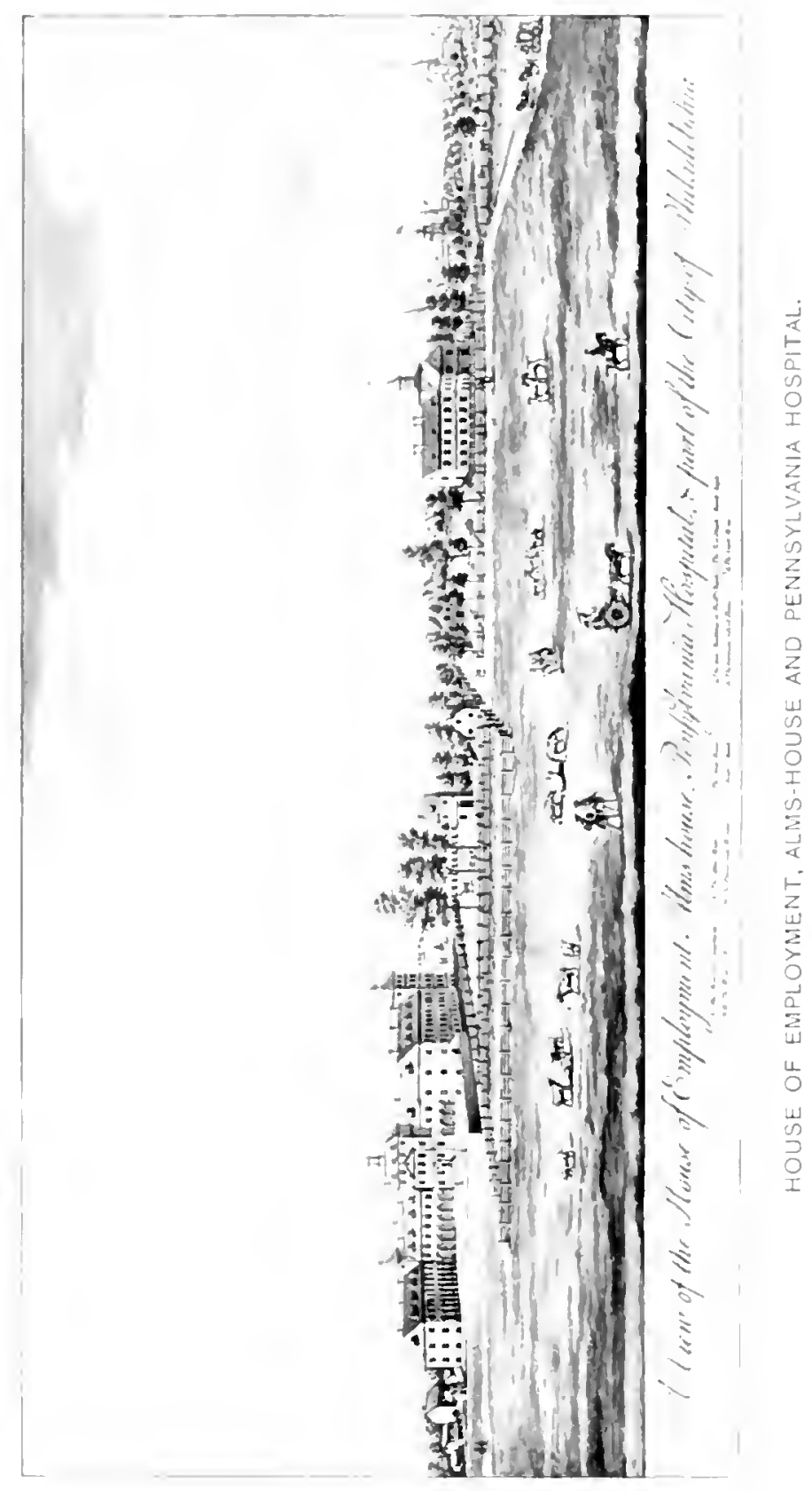


For more than fifty years the l'ainting has been freely exhibitud within the Hosplital buildings. After the Picture House was vacated it was leased to the college of Physicians, and sulsedpuently the the IIstorical society (as mentioned on page gy). It is also interesting to note that the Philadelphia l'athological Society was permitted the use of a lower rom for its meetings during the thute that the luilding was ocrupied by the college.

The first mention in the Hospital records of prints or engravings of the institution, occurs in the minutes of a meeting of the lioard of Nanagers held in May, 1762. when the suggestion was made that a plate should le engraved in orter that a picture of the flonpital might accompany a formal rote of thank, or address, to Thomats anst Richard Penn, in Lomblon, who reprenented the Proprictaries of the l'rovince at that period. Accordingly. in Octolier, it in recordert that "two prints, framed and glaised." were sent tugether to Richarsl Hockley to be forwardecl to Thomas and Richare Penn. with an addrese in acknowledgment of the lirst instalnent of the annity of forty pound sterling. granted ly the l'roprictaries, who, an the same time, had given assurance that they would aloo grant a fratent for a lot of ground contiguous to the llospital property, which wa much desired by the Managers. It wandenbeless an occasion of much sincere congratulation amons the friends of the infant charity. when this substantial assurance of interest and appreciation of the l'em family was received, as it not mly furnished moch needed aid, lnt also was an evidence that the l'roprietaries had become friendly to their henevolent enterprise, to which the! had formerly been indifferent and neglectful, owing to an unfortmate mismderstanding at the legrinning. Aprit 26,563 , anuther lot of prints of the Hospital was received and the bill of Es ordered to be jaid.

The earliest engraved view of the llospital, showing only the east wing. as first built. is an engraving, by I fulet. " of the "House of Limployment. Alms Honse and lennsylsania Hospital." 'This print was given by Cecil lercival, 2 of Henlmry, near liristol, England, in July, 1 s $S_{3}$, to Anna L. lipplincott, of Hacldonfield, New lersey, who presented it to the Hospital, April 5, r $\$ 84$. (See illustration.)

It was subsequently stated in the minutes that, in 1768 , a large, colored engraving of the llospital and Poor House, drawn h: Nicholas Crarrison, was presented to the Honpital. 'lhe Poor llouse, at that period, occupied the adjoining lot west of the Hospital

'The Engraver, Hulet, worked from 1750 tw d7m, according to G. Reed, Keejer of l'rints and Jrawings in the British Niuseum.

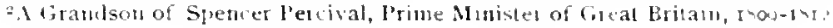




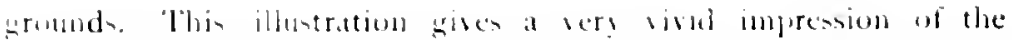
starsely ecteled comdition of the aty, espere ially in the vidinity of the

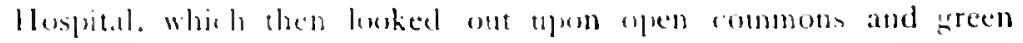
lielels.

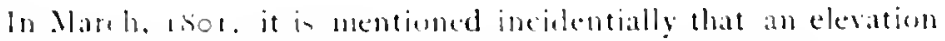
of the llowital hanl heen drawn ly larkyns.' but the artist

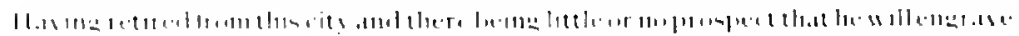

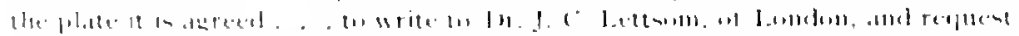

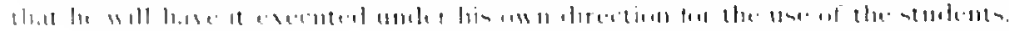

(ini

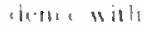
$11,1,412+111$ (1) 111? linerobing

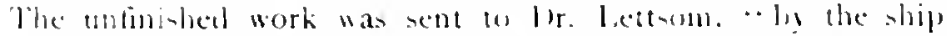

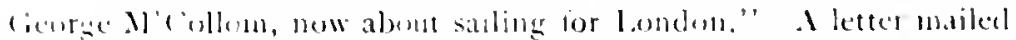

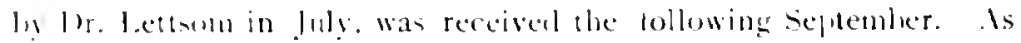
this letter ilhotsates the friendly sentiments existing between the

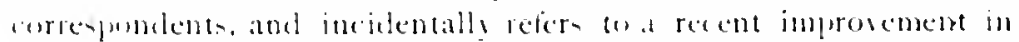
paluer-making, it is cophed bereserlatiut. The beal-lines were printed

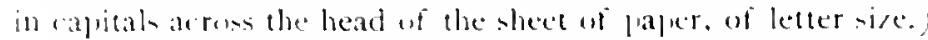

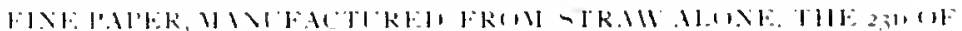

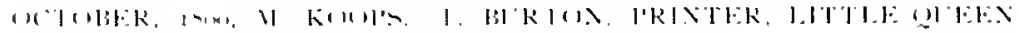
-lk!r. I

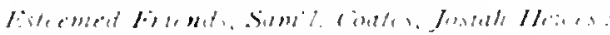

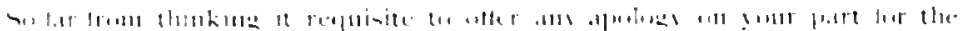

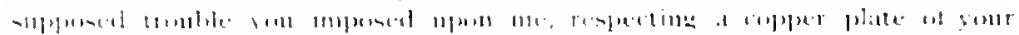

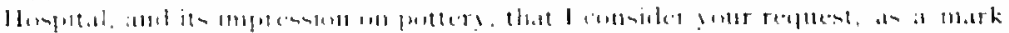

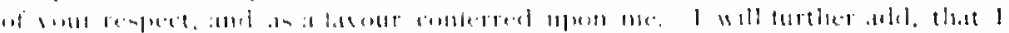

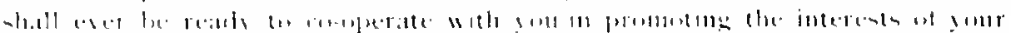

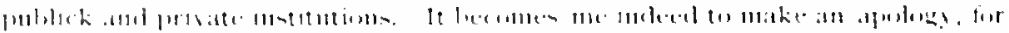

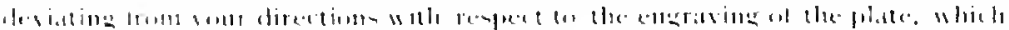

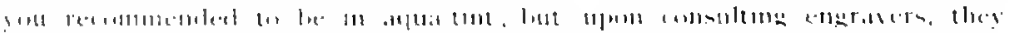

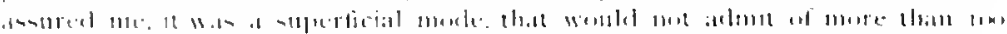

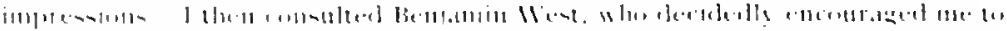

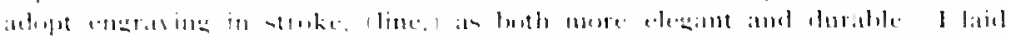

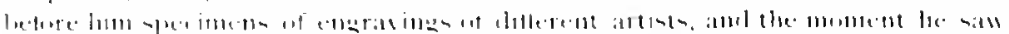

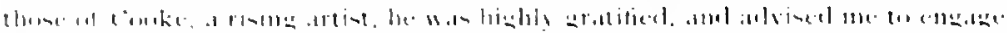

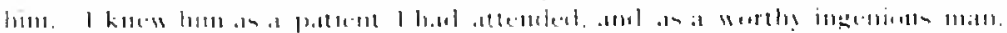

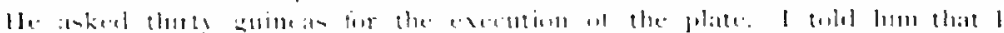

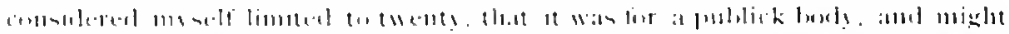

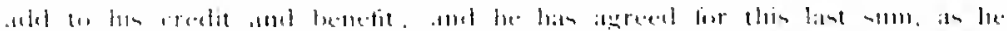

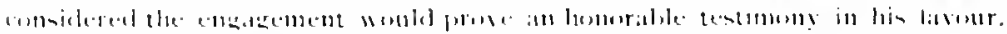

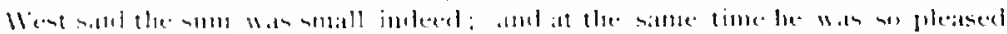

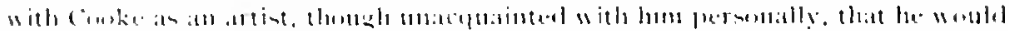

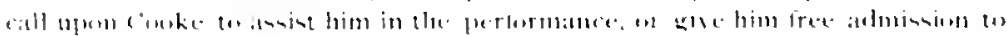

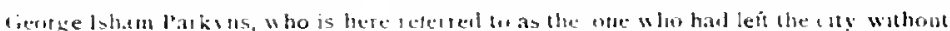

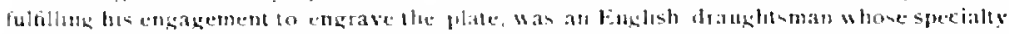

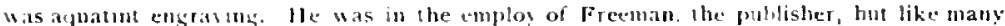
other artatiof that siay and this, was somewhat erratic lit his lite and inclined to nomadic habils. The work that he was engaged to exe ute by the Nanagets was an elevalum of the

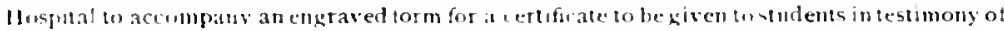

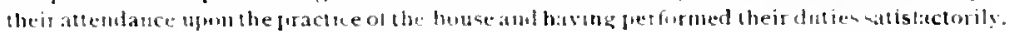




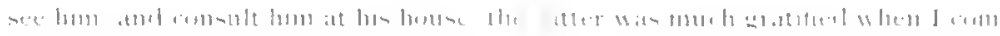

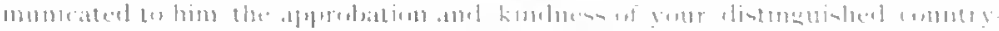

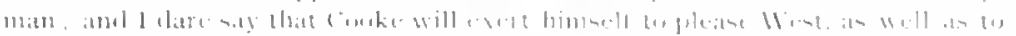

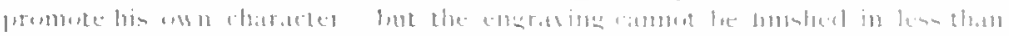

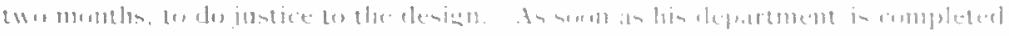

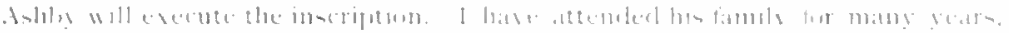

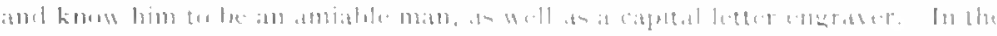

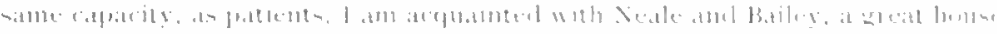

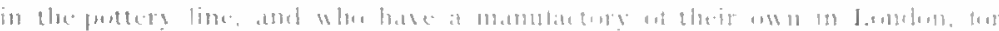

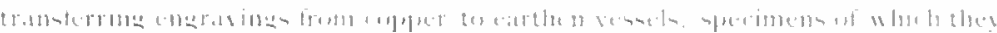

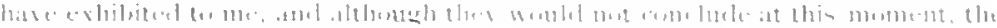

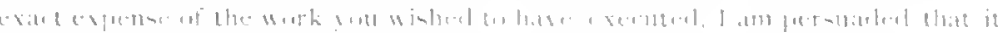

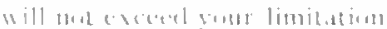

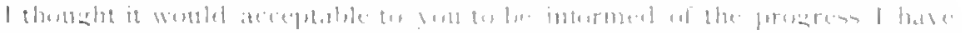

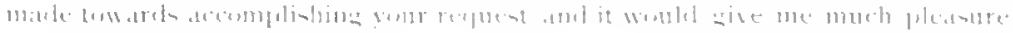

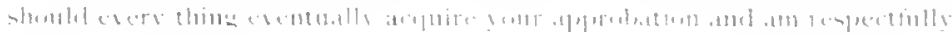

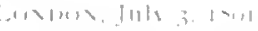
wiur linemi.

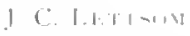

Ma! 10, 1802, two letters of - peecial interest were received from In. leetsonn" one of thene was written on paper made of "India Sugar Bales." as the Managers had it. lout the arlvertisement printer on the one sheet on whis th the letter was written declared the material to lie "an Eant India Irticle q alled paut or jute (or Crotolaria

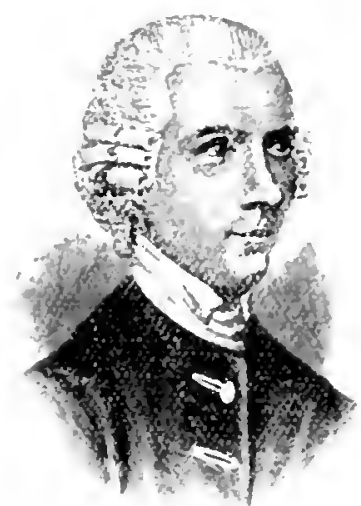

[B. Lettsom Juncea, or l'aut which wrows in India; it in the same from which Gumner bagn are made." The learned dow secmed vert muh interented in new discoveries anol improvement of all kins as well as in benevolent institution. Thi. letter continue the discumion of the whjert of the coplet-piate griven in his rharge to be engraserl:

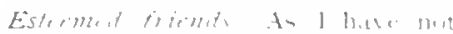

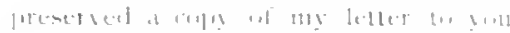
reapering the plate at the Homptoll in

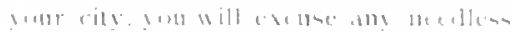

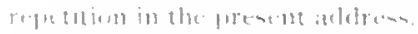

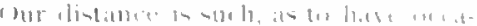

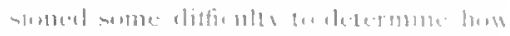

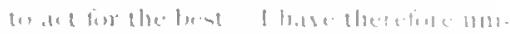

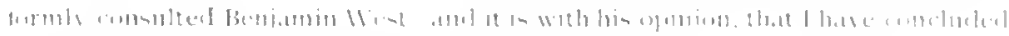

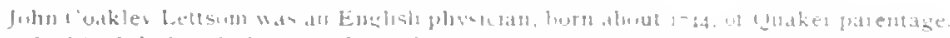

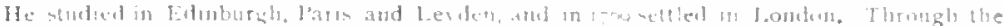

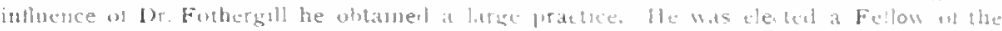

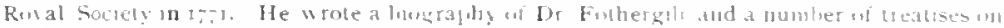

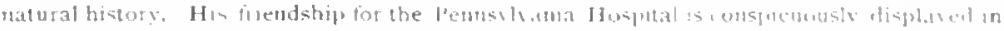

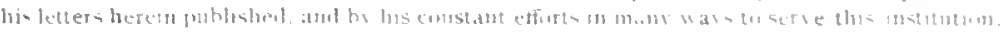
He lierl an ista. 
1. Yyolum at

liner.121112:

$1 \times 1,01,1,1$,

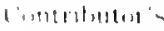

(i) jilli, th

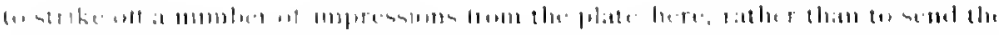

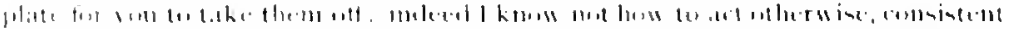

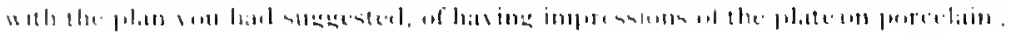

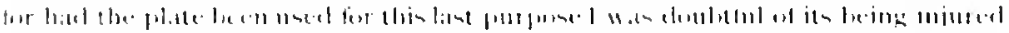

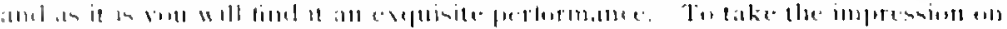

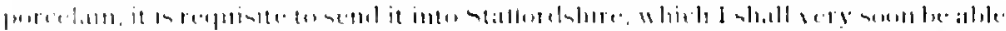

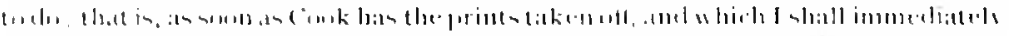

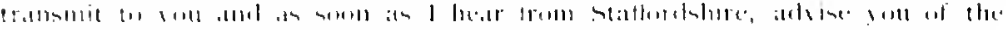

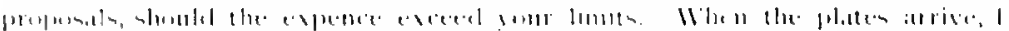

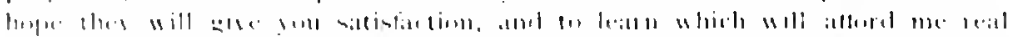

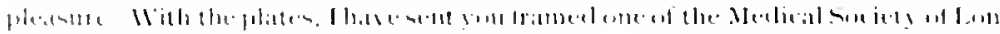

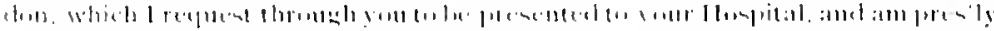

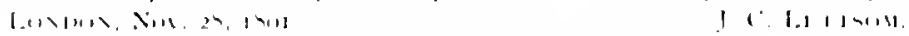

l'he other letter, abose relereal to, in as fibllows:

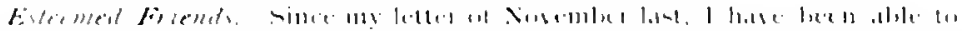

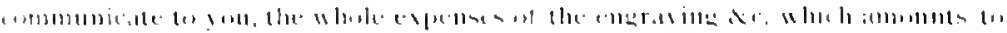

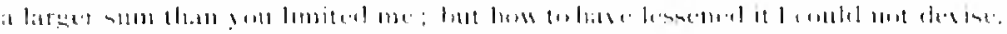

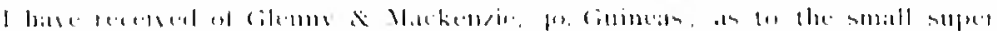

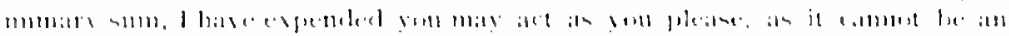

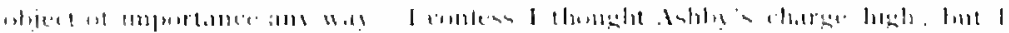

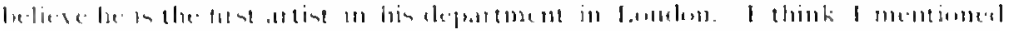

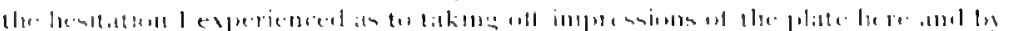

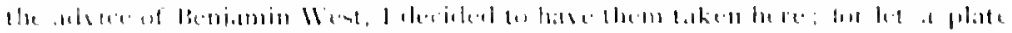

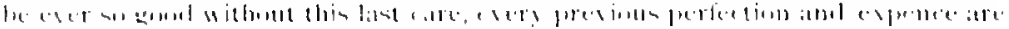

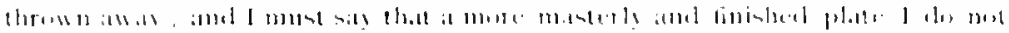

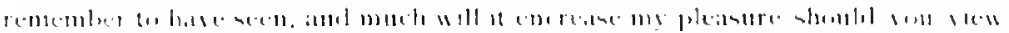

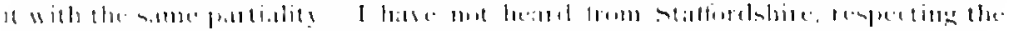

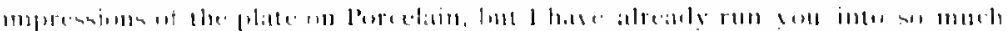

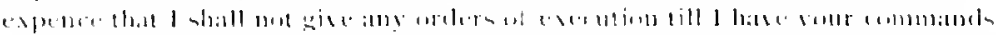

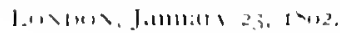

In this leter Dr. Ietteon enclosed his final account with the renchers. These bills will show the out of this fine plate and the provotin ironll it.

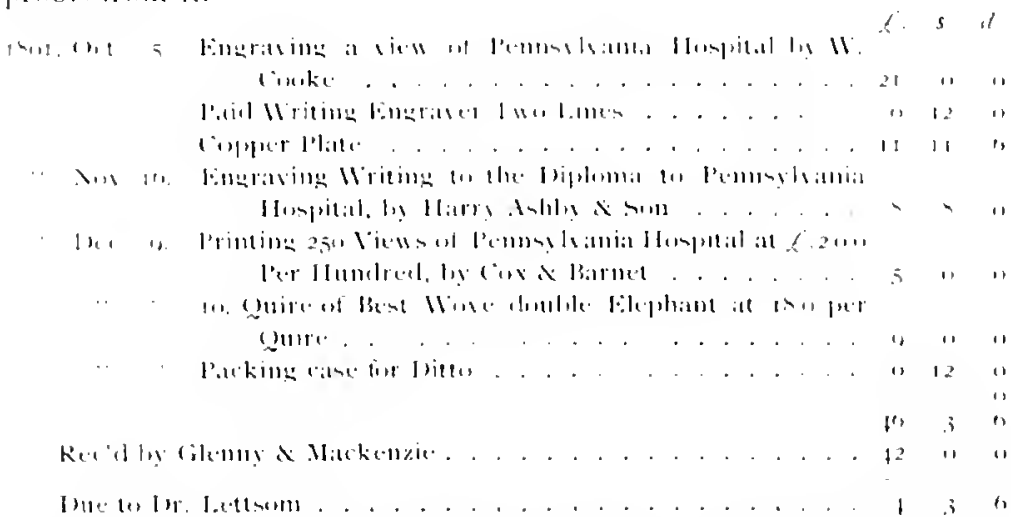

After reading Dr. Lettsom's letters, at the meeting of May 10 , Isoz. it was decided io request the 'Tranurer to remit the amomnt 
which had been paid ly " James Mekensey and 1 . Cilanney" tw the I octor, as well as z zo sterlmg, hipping charges, dinbursed hy Mck. ․ G. "for engraving the l'late for the l'upils of the Hospital."

Thanks were returned to Dr. lettsom for the "elegant print he has sent the Contributors, of the Medical Society in London."

The students who were entitled to "a Certificate with an engraved siew of the Hospital "were to be charged two dollars earh for them.

The Managers were apparenty quite proud of their engraving, Enaminaand no doubt it was a very fine piece of workmanmip, probal,ly the prenement. very best which could be obtained in those days. Seeveral of the engravings were neatly framed and, in the name of the Contributurs, one was presented to Thomas Mr Kean. (iovernor of the state of fennsylvania, one to the Lniverity of Pennsyluania, and one the the College of Physicians.

The Lniversity of l'ennsyliania acknowledged the recelpt of the "Elevation of the llospital" and expresed their satisfaction with it and their wishes "for the Prosperity of the Institution."

'The following letter was reveived from the Governor of Pennsylrania :

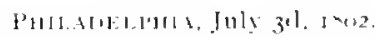

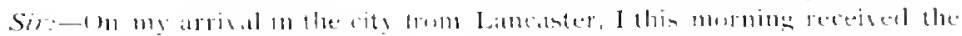

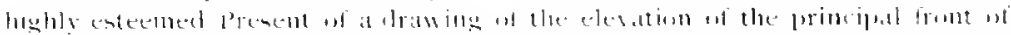

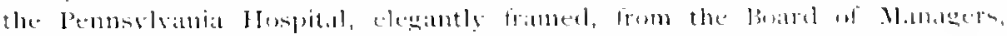

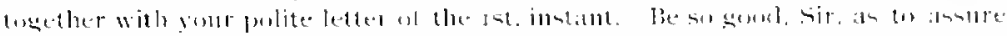

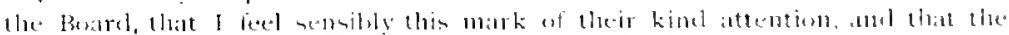

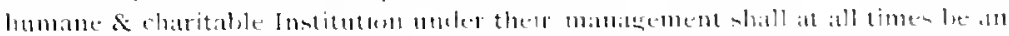

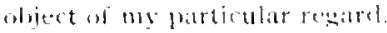

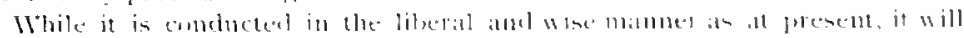

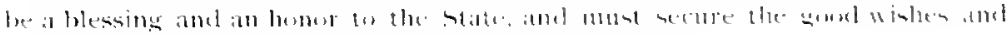
pittrollate of all groed ntell

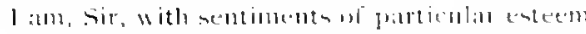
Ventr mont uldedient homble sere'

THM. M, Ki:ル

The College of lhysicians male acknowledgment. as follown:

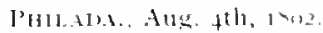

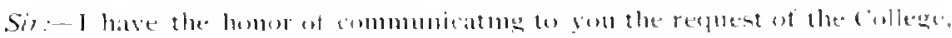

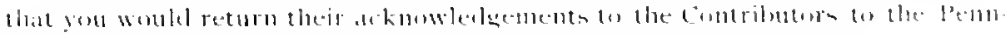

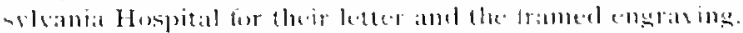

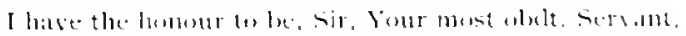

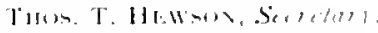

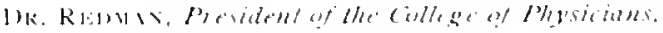

Dr. Lettiom wrote, in a sulmerfuent letter. with regard to a cet of engraved porcelain for the Hospital:

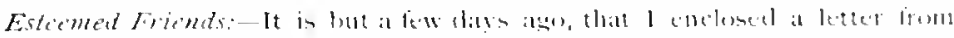

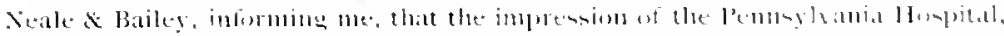

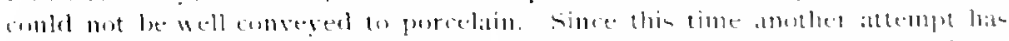

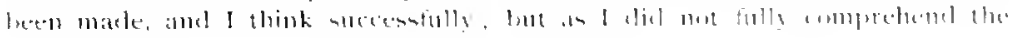


1) $1.811+10111$ (i) $18 \cdot 1 \cdot y+1)$

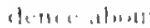
Fingraing

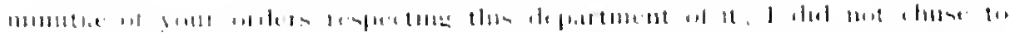

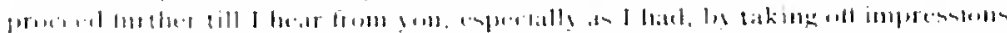

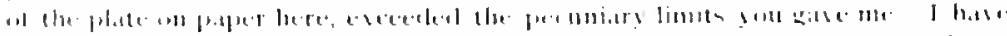

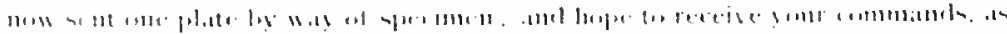

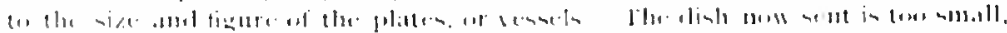

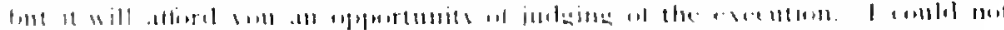

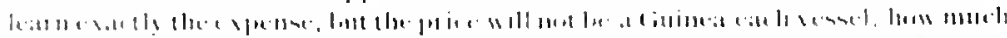

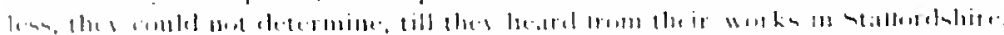

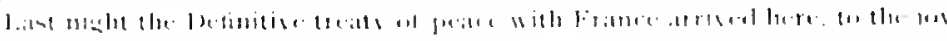

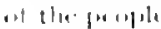
$1,11+11,11,1, \pm 1,19+2$
$11^{\circ} 1.81+a+11$

Mlthongh no mention is made in the looks of minulen. wh the " impressions un purcelain" it is evident from the lenor of lor. lelltsom? sellers that the Manager were desirions of hating the engrav. ing of the Hospital transferred, ur printed, upom a service of tives for the institution: at least they desired thene ale used at the officers' lable might be thus derorated.

Two more lellers were received from I)r. Jellsom, relating to the matlers confirled to his care:

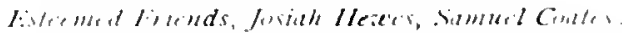

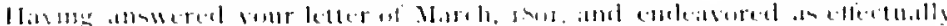

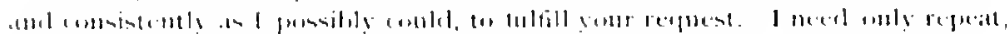

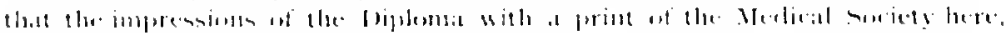

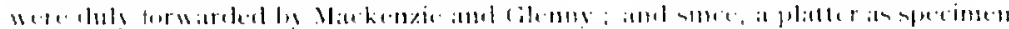

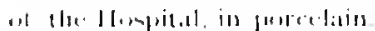

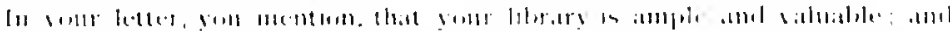

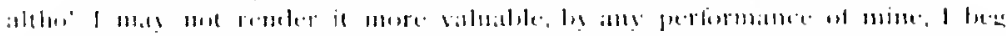

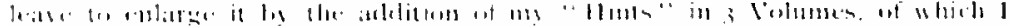

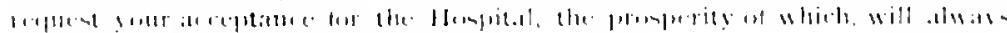

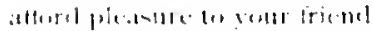

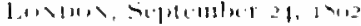

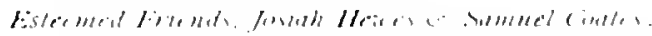

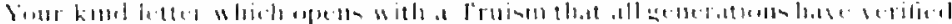

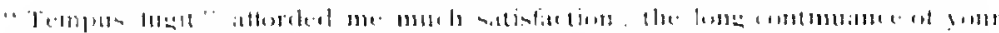

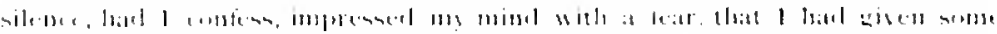

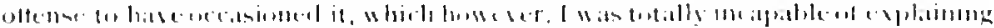

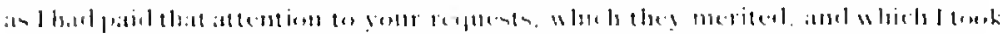

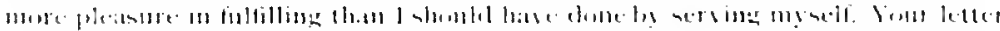

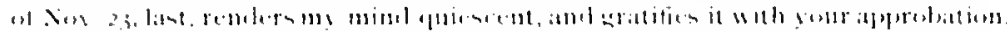

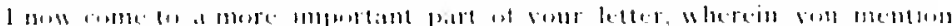

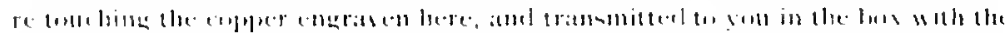

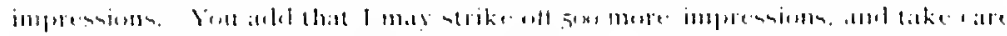

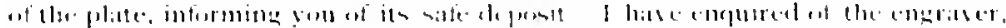

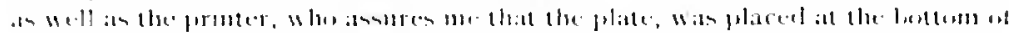

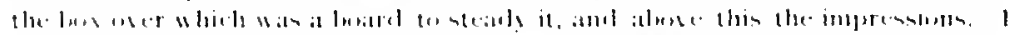

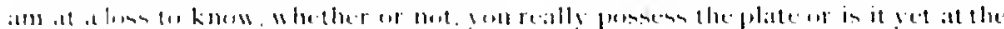

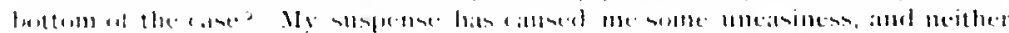

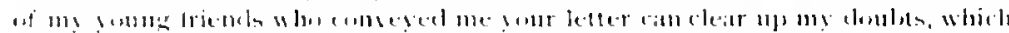

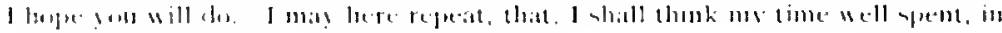

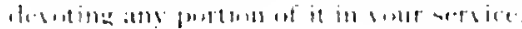




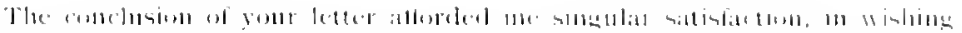

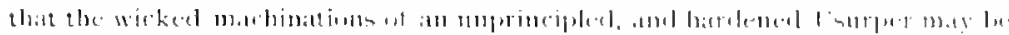

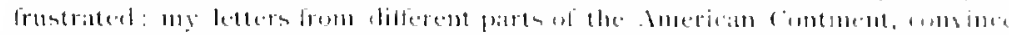

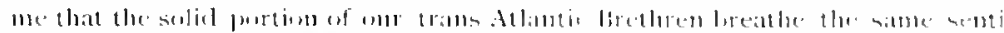

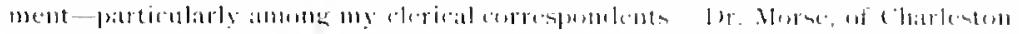

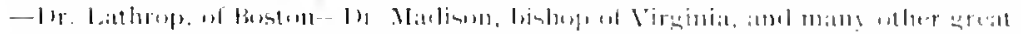

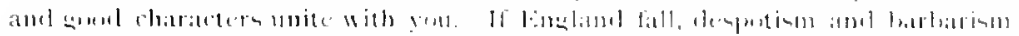

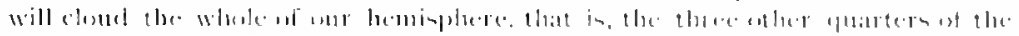

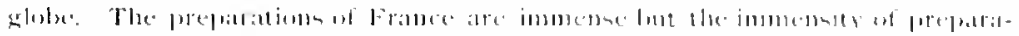

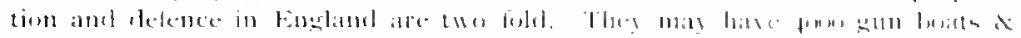

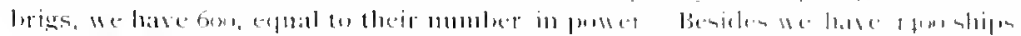

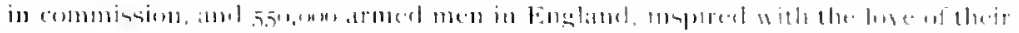

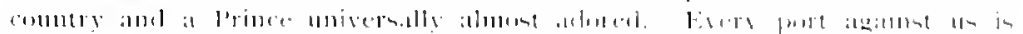

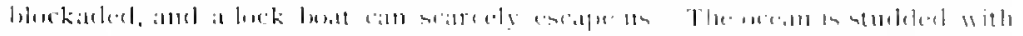

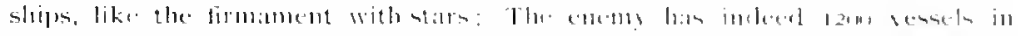

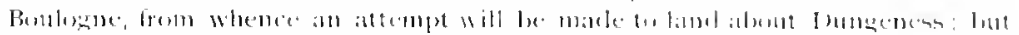

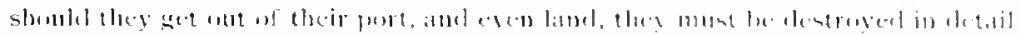

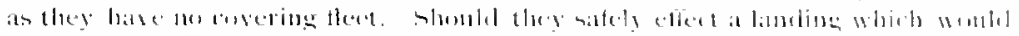

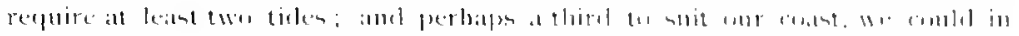

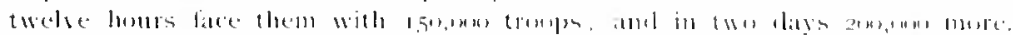

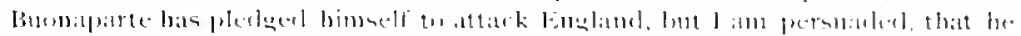

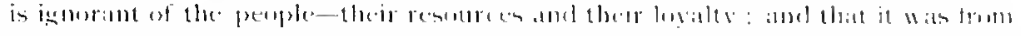

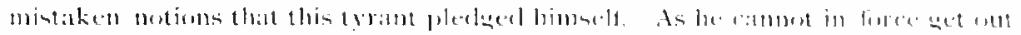

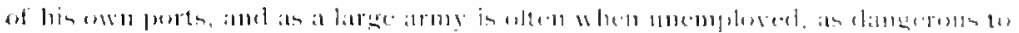

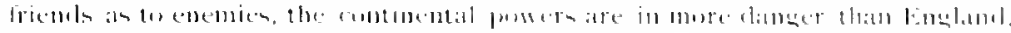

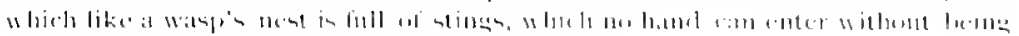
wanmlenl.

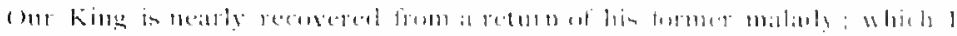

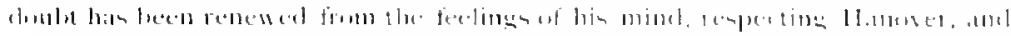

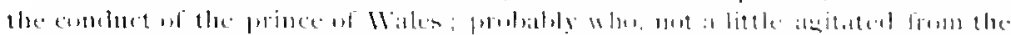

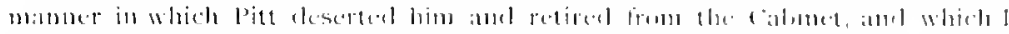

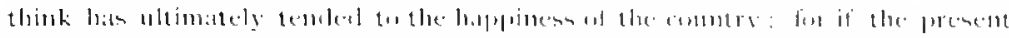

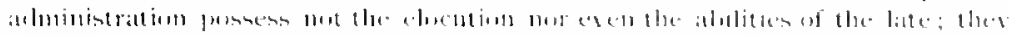

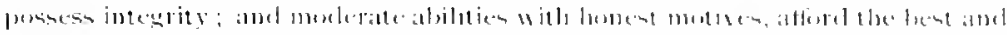

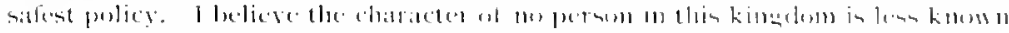

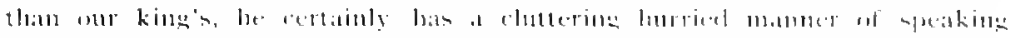

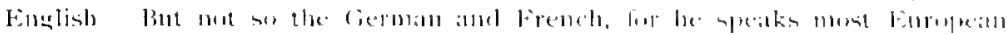

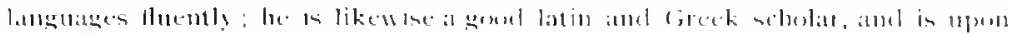

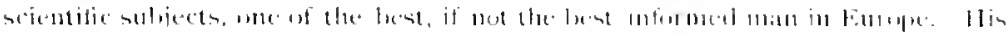

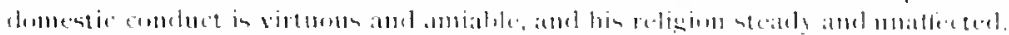

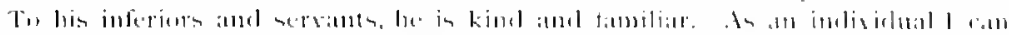

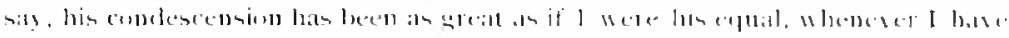

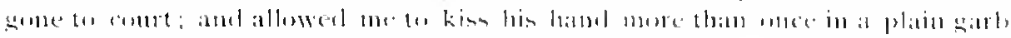

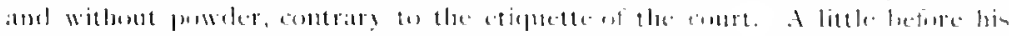

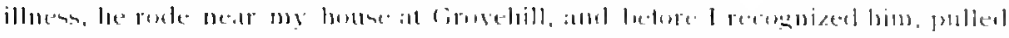

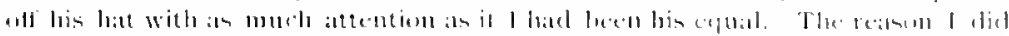

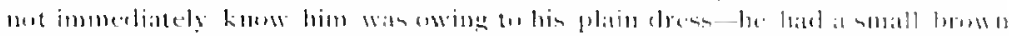

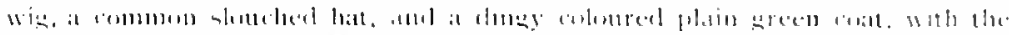

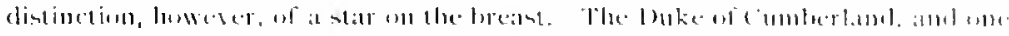

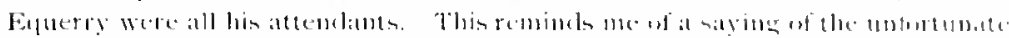

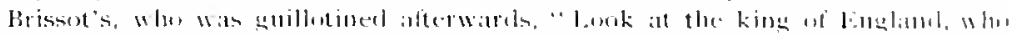

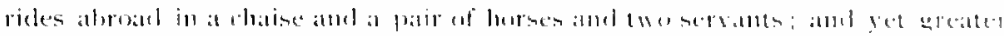

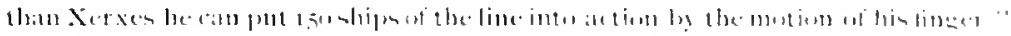

1. 11,1 wimtatome

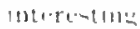
IIsturit Keteremex 


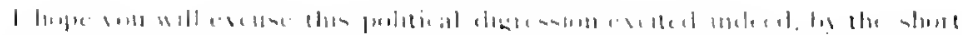
f

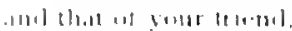

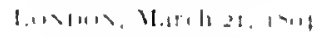

$1+1,1+1,1,8$

$1.11=1,11 \cdots 1$ 1,11111, at八

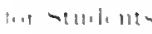
$11,1,1,11$

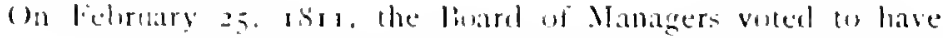
- I sew of the l'emmsylsania Iluspital taken, and an lingrasing of lhe same with a certificate for the stodents shall le grepared lefore

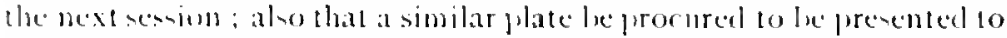
ever! contributor of "len l'umels amel mpards." Whether ur mothis

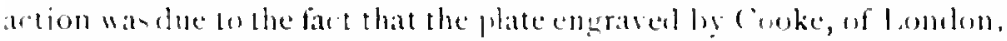
hatl leen lont. or beenme deferetive, or worn out. de en mol appear.

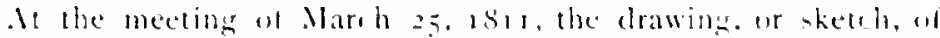

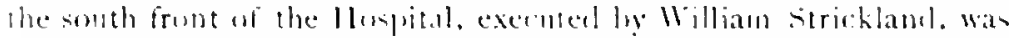

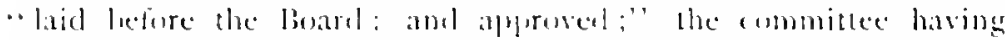

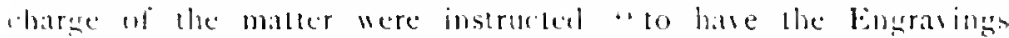
limished." "lhe price paid to Millam strickland " for a drawing a

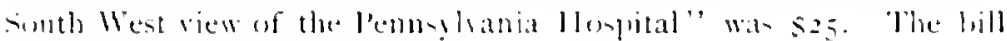
lecars date. April t, tsis

Fur some reason which does not appear on the recurds llilliam strickland. archited, althor and artist, als well als engraver, was not fermitled to enerave the drawing he hat mate of the Hompital. We fiul that on . lpril 21$), 1$ sis.

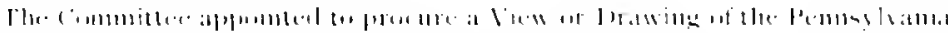

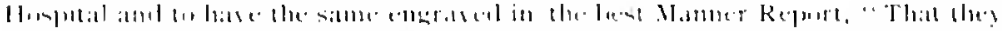

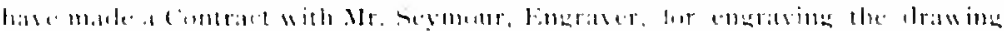

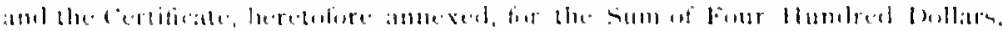

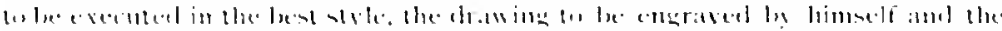

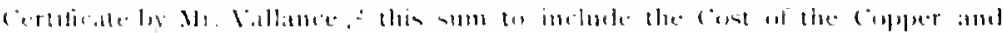

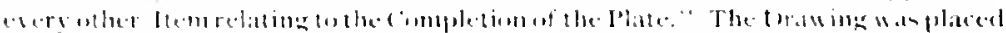

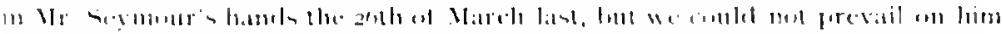

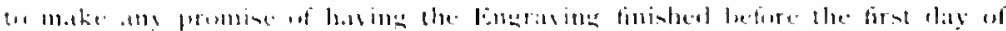

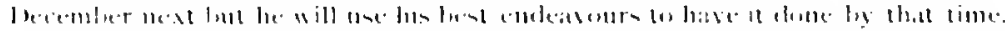

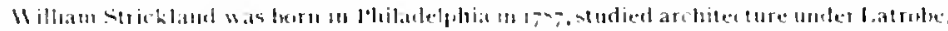

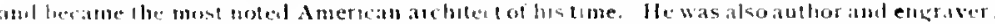

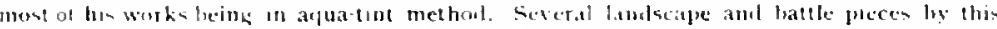

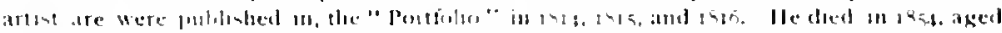

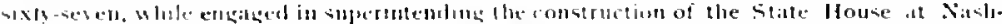

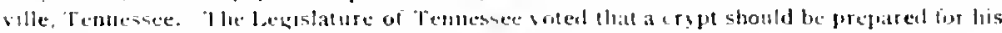

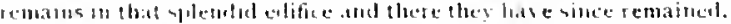

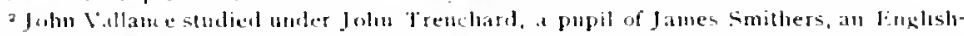

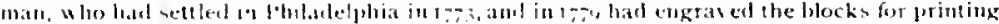

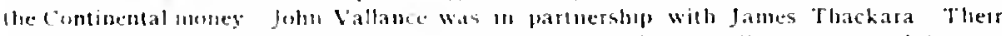

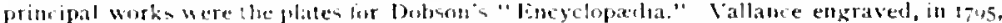

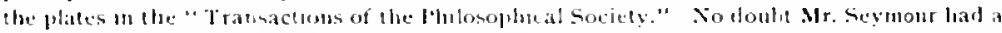
well establinhell rejutatisn this would alconut tut the pros iso of the work helng done lw

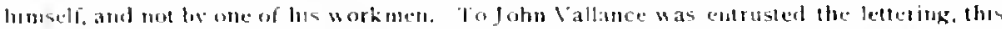

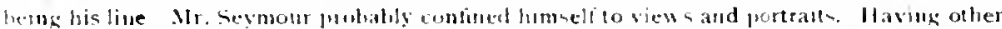

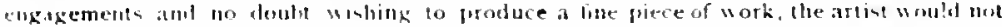

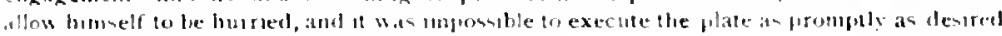
i.r before lhe alesighaterl tume. 


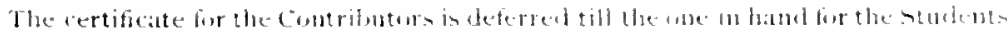
in linisherd.

A copy of this fine work was neatly framed and presented t" Simon Snyder, then Governor of P'ennytrania, May 25, i\$12, and one was sent to lienjamin West.

May $27,1 \delta_{11}$, re-considering their determination of April 2,th, wo defer the engraving of the plate for the Contributor's Certificate. it was decided to consider the prop,riety of employing John Exilius, ${ }^{1}$ formerly a patient in the Hospital, to do this work.

Holatillation iontritutur

The superior work done ly Seymour, who had an established ritritiate. reputation, would not allow of association with any poorly executed engraving for the Contributors certificate by an olscure or comfaratively little known artist. Hence, the wislom and necessity of the Managers assuring themselves of the subtitute' alilities. That these were found satisfactory is evident from an entry made on the minutes, June 2 8, I $_{1} \mathbf{3}$ : " An order was drawn on the Treasurer in favor of John Exilius for One hundred Dollars in part jayment of the Engraving for the Contributors on which he is employed." Inother payment of Fifty dollars was made on september $27, I_{1} 3$. and a further sum of one hundred dollars " on account of the Engraving" was paid. The Committee to superintend the engraving for the use of the Contributors reported. Iune 27. I 14 , its completion by John Exilius. The sums recorded as having been paid to Exiliu for engraving the plate. therefore, was $\$ 250$. These particular in regard to the engravings of the Hosjital, while of no great historical importance. may serve to convey to those especially interested, an idea of their cost, should any copies be in their possession, or seen elsewhere.

January 27.1812 , the Committee on the Engraved plates presented their final report which was substantially as follows:

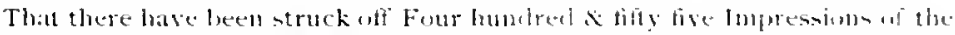
Certificatles and View on the same Sheet and folly fond Impressions of the liewn eparately: all of which have beeth delivered intw the peression on the steward

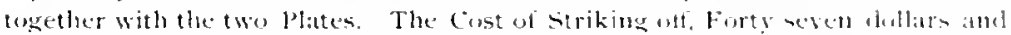

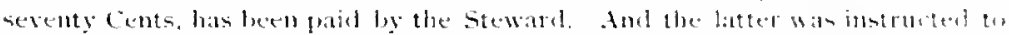

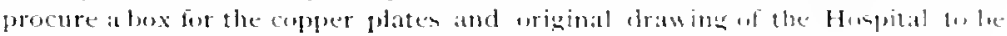

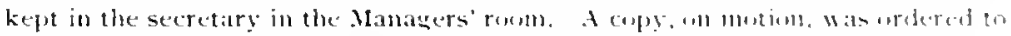

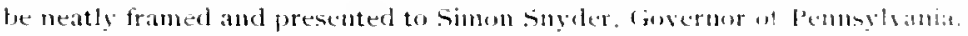

October $3 \mathbf{I}, \mathbf{I} 8 \mathbf{I}$, eighty impressions of Exilitns engrasing of the Hospital were laid before the Board, when Edward Pennington wan requested "to have the whole number completed and together with the plate deposited in charge of the Steward." In consideration of services rendered to the Board, the President was requested to prenent

"John Exilius drew landseapes and local views with decieled aristic merit: amm!r the more notel are "A View from Flat Rock Bridge looking up the schuylkull Rwer." "Culr.tl's Paper-mill on the Wissahi kon." "Egelestield, the seat of lichata Rumbe." Isis". 


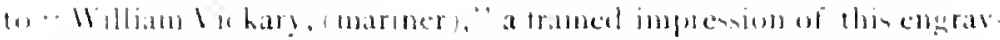
ing. (aptain lickary commanded one of the "Pachets" at that lime lying letween lingland and lhibalelphia and, besides being a contributor os the lluspital, he had in his socation, freplently rendered buluble and underpited services. He thus made it pussible for the

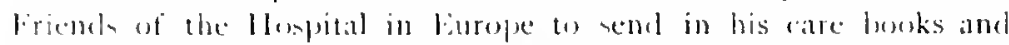
wher contributom without any eypense and he alo conseyed, for the M.magers. messages aml wher infiormation, or procurerl artieles and performed mans wher small commissioms, which could le belter sime hareed in gerson thin by letter. It does nut appear that an!

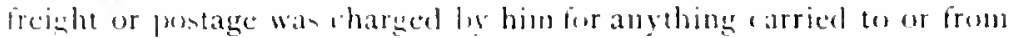

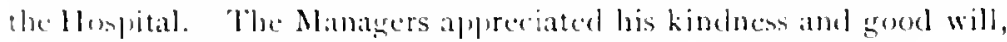
and manifested their statitude he this when of their enterm.

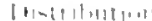

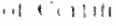

$.11+i=1$

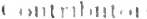
1111 $\rightarrow[11+1 \cdot 111=$

(i, Intmun i

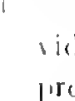

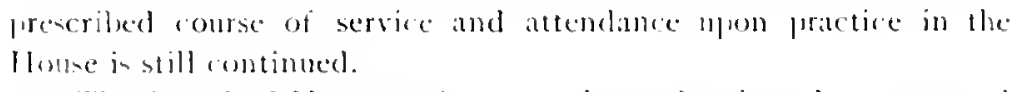

The lisurd of Managers in aszo, also ordered a plate engraved for inste to comtributore certifyng to their memberbip in the corperation. This plate wan engraved lyg . Mr. W. E. Tueker, and is bent dereribel by an illustration. The anmual reports for many yar bave heen combellisbed by handsome plate engravings of the llospital. some of the fllustration are given in this work of the engravings thus anmually sent wat to comeributurs and the public. In $189+$ the report if the llospital for the sick. contatus a new engrabing showing the nurta elevation. Thi beantifal frombispiece was presented to the Nanagers by une of their own munler. Mr Johns. Jents.

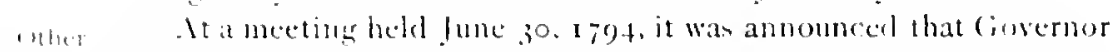

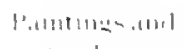
$-111,1111$.

11. $11 \cdots+1,1,1$

fint mitur.

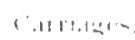

Thoma lliflin had presented a pieture, in oil colors, of an " lusane IIoman." hy his daughter. Emilia Hopkimson, and this rery creditable work of art wa- then receised and areknowledged ly a rote of thanks. 'This faimeing new hangs on the wall of one of the Residents' rooms.

Mr. Josegh larker Norris presented a painting, also in oil, of

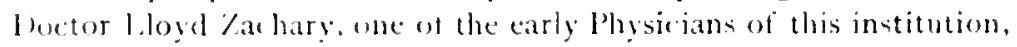
fior which he received the thank- of the Boitd.

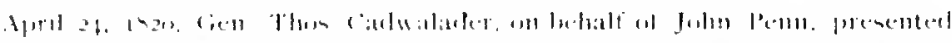

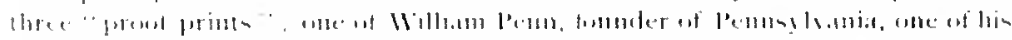

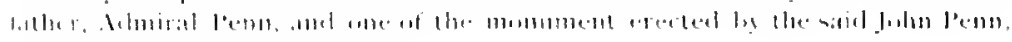

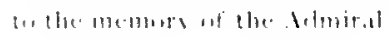


In Hecember. 1871, Mrs. Mary Ann Marnhall presented a like

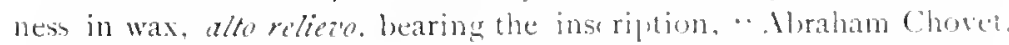
born May 25, 1704, drawn May 25, 17st, by his servant, lor. Lckhout." It had heen given ly Lr. Chovet's daughter, Susanmah Maria Penelope Alsinglon, to Mrs. Marshall's grandfather in 1793.

November 29, rsoz, Juhn Penn, throngh his attorney, Joln Reynell Coates, offered to the Nanagers, for the Hospital, a portrait of William Penn. requesting at the same time to know in what position it would be placed. John lorsey and Samuel Coates were appointed to melect an appropriate place for the picture of the distinguished founder of Pennulvania. Information as to the position chosen was to le communicated to John Penn. Whether or not a suitable place was found is unrecorded. The following dat the committee reported that thes had sent to John l'enn " a plan of the Contributors' room." and had written him on the sulject of his froposed gift ; it is probable the location assigned to the picture was therein designated. This picture, however. was nerer prewented.

September 24,1804 , it is recorded on the minutes that "A statue in Lead of Willian l'em is arrised in the Ship 'I'igon' from london." No letter accompanied the gift of John Penn, which was accepted " in lieu of a portrait which he had, at first, proposed giving to the Hospitial.' There being leing no letter of alvick accompanying the statue one is led to wonder how the Manasern knew that the statne was " in lien of the fricture," or, indeed, that it came from John Penn. Subsepuent action, however, shows that proluals! John Reynell Coates, Pemn's attorney. had verbally conseyed the information. Ioseph Lownes and Simmel Coates "were appointed to enter it at the custom house and see that it is brought to the Hospital."

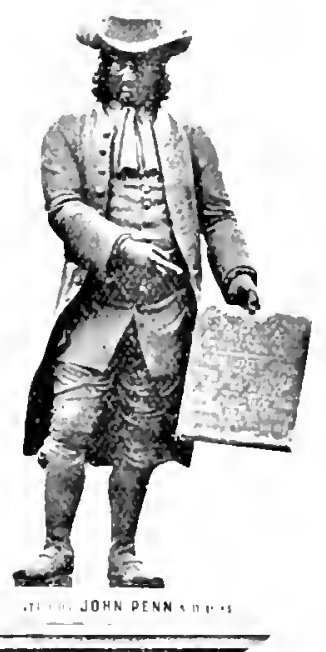

$41.1611 .2+1$

IVilliam Hur

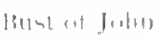
[?:1) e L 


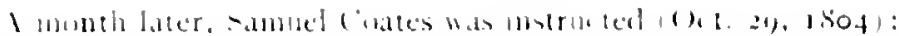

$-2.12111+19$

P. 111 $1, \ldots, 1, \cdot 11$

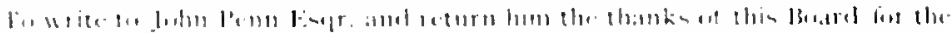

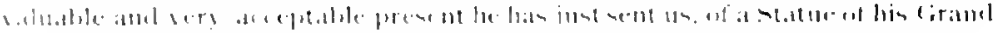

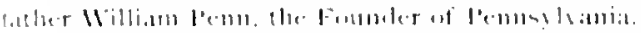

Two position were regarded an eligible for the location of the -tatue. and these were reberred to a commintee. for final decision. the preferred site were. lirst, in a "Xitch" lo lxe made over the front loor on the wouth side of the entre huildinge or serond.

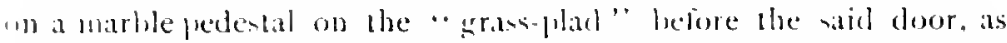
they may approve, "n whith gedental they are to have inserted such "In- riptions as are approved ly them, after consulting these perom "on whe judgment they maly think fit to rely on this occasion."

It aterwards aplears. in the minutes. that folun keynell Coales. fohn lemn'attorne! had peronally made application for the statse. ind grolably had privatels informed the Manalger of this : heme, the

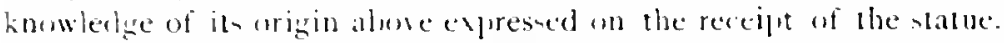
simuel coates wan expressly repluested to reburn the thanks of the

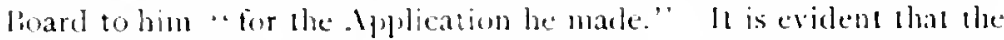
Managers prosed dings were now marked ly undue haste, for the followins letter of thank- (ordered a month lefore). Wrillen two monthe after the receipt of the statue, was reat and iffic ially alplored:

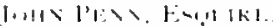

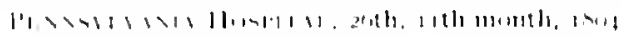

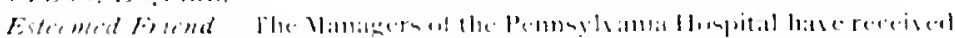

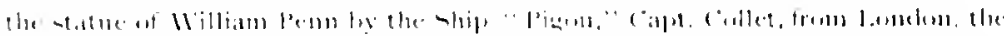

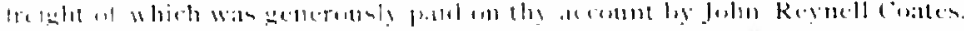

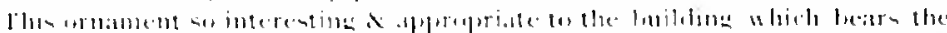

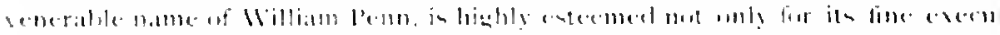

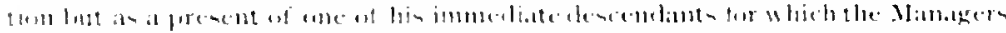

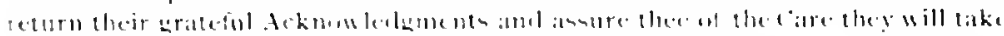

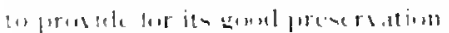

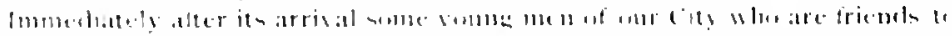

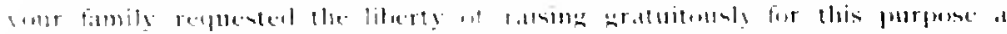

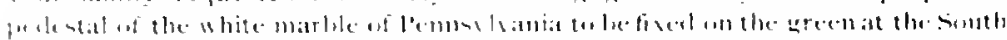

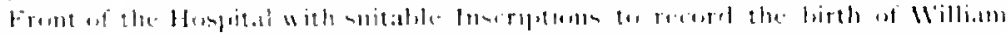

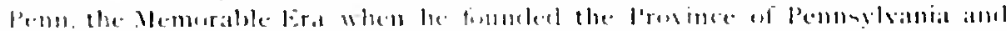

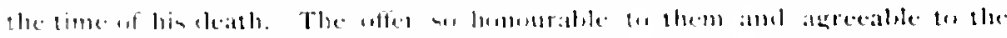

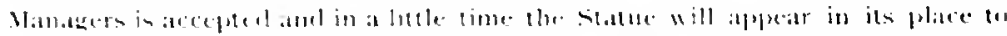

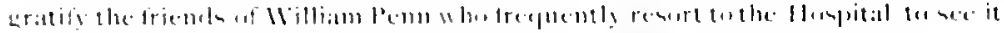

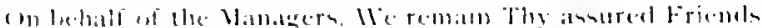

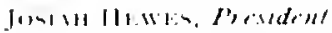

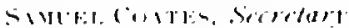

The following interesting letter relating to the pedestal received ly the Managers also was found amon: the old papers. although it is not mentioned in the minutes:

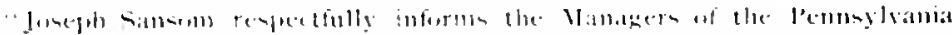

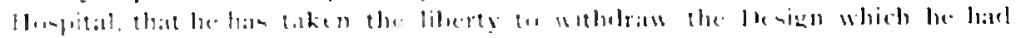

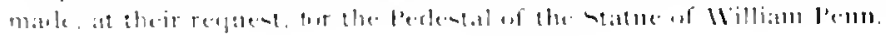




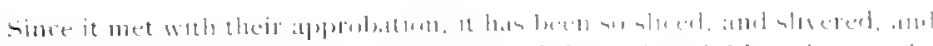

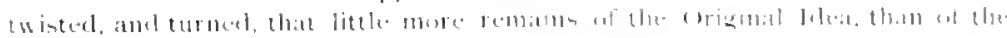

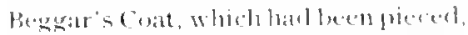

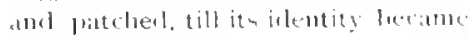
problemational.

"The finiming -trokides

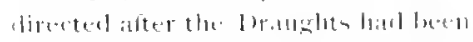

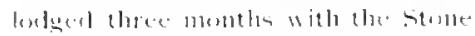

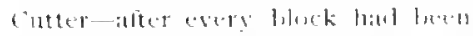
tut to the sifuate ant withent the anmunom sivility of romsultime the l'aw1."

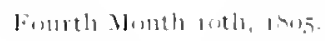

'This communication show: that Mr. Sansom was aplarently hishly incensed and not without reason, if, as he states, some one had taken the libert! of materially altering his design without first consulting him. Whether the pedestal had leen completed hefore the design was withdrawn, of nol, cammot now be ascertained.

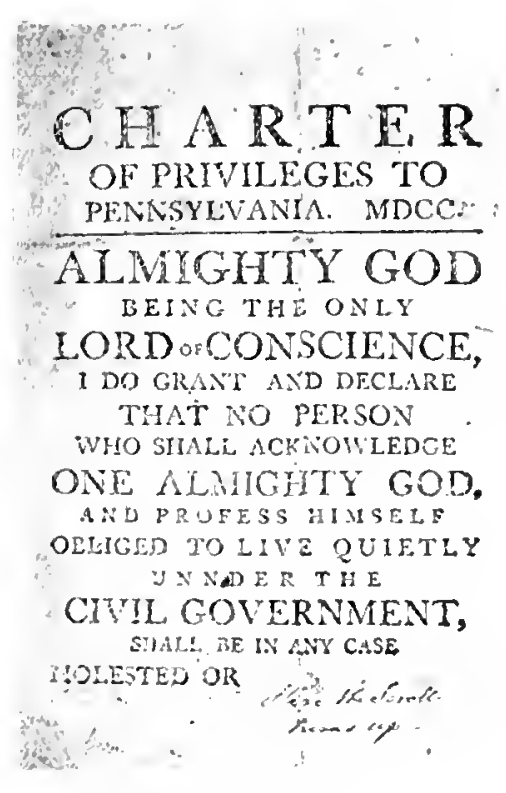

CHARTER OF PRIVILEGES TO PENTSYLVANIA. MDCC: : ALMYGHTY GOD BEING THE ONLY LORD OCONSCIENCE, DO GRANT AND DECLARE THAT NO PERSON WIO SIALL ACK BOYLEDEE NE ALNIGITY GOD, AHO PRUEESS HIMSELS CIVIL GOVERNMENT, STALE DE IN $\angle$ NYY CASE I:OLESTED OR

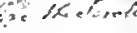

The insriptions which were caved on the sides of the pedestat are as follow:

(On the Joth sitle.t

(6) the East site.)

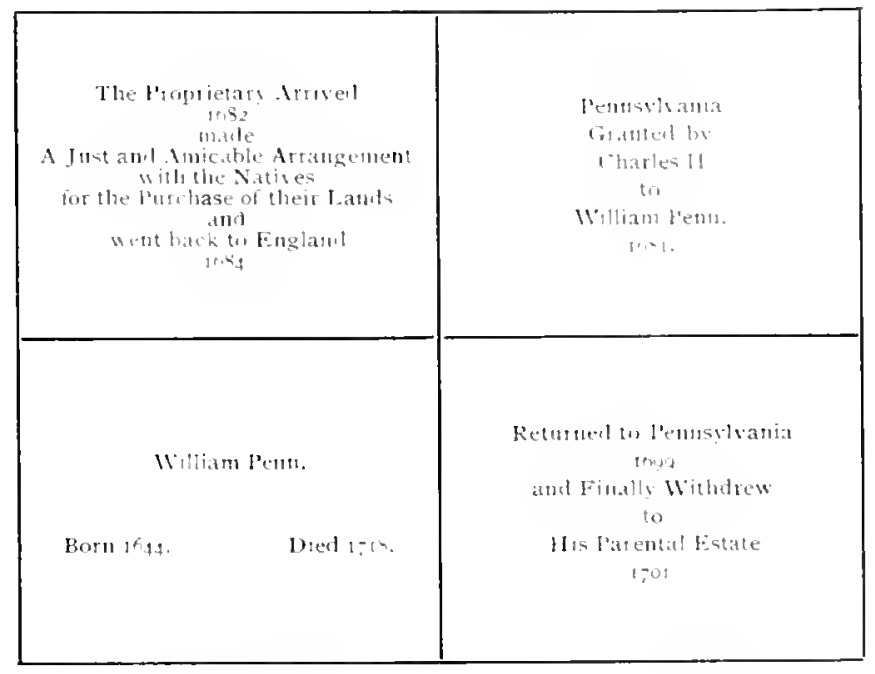

(1) In the Sonth side

irm the lleat sule, 
Angust 26. 1905. Peter lirown. one of the Managers, mate a

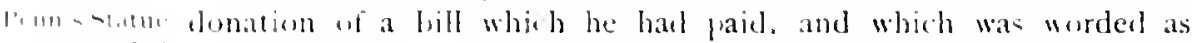
-

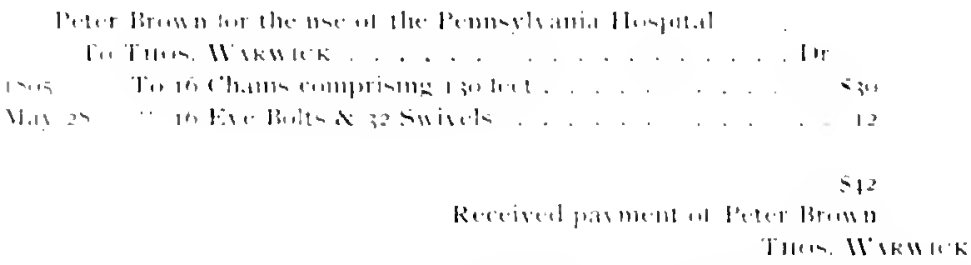

"The minute eyplain that the were "to encircle the statue of William l'em:" and also that the smm .Manager Brown hat paid was presented to the Hospital,

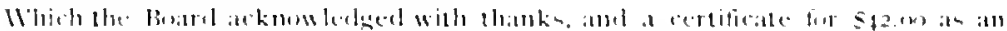

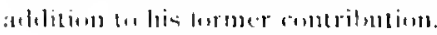

Jul! 27,1812, the only time a fart of the kimel is mentioned in the minutes.

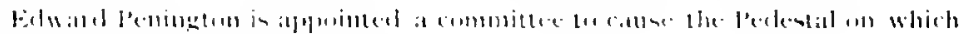

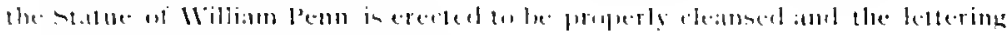

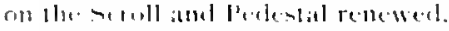

Ihis wis reported done. September 25, 1812. It is prossible, that. in alfter years, if ever repeated, it was not considered of sufficient impurtance to mention upon the minutes.

Ilom 1850 , during a severe storm. the statue was hown wer anul fell prontrate. It was found, unon examination, that the support of une firot had lierome corroded and dewayed. In order to restore it to its former position, it required a high heed and sole. the statue was then securely placed now the peclestal again, and since that time, has remained there, facing l'ine Stret in the centre of the lawn on the south front of the Hospital. The illustration on page 239 , shows the poutiom of the statue and also the chains, which originally surromeled it, lut which were removed some years later.

Curiously enough, the history of the statue was cleared up by the presentation, June 29, 1846 , ly. Mr. Danicl B. Sinith, of Ihiladelthiil, of an original letter, accidentally discovered ly him in making some historial researches. It was a letter from lienjamin liranklin, probally written soon after be had made a visit to Lord le Despencer. in 175, where he had seen the statue and was so impressed by it that he expressed a wish for a duplicate to be placed in the State House grounds in thiladelphia. Franklin enclosed a printed copy of the 
inscrigtion on the scroll held ly Penn, and the original letect, wh the printed inscription, are now anong the archives of the lonspital. I.the thin

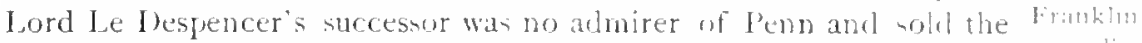

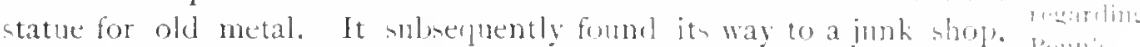
where John Penn saw it and bought it for prenentation to the lionpital, yoult where it has since stood, holding the charter of our Commonwealth in perpetual remembrance of his famone treat!. which was ueber igned and never l, roken.

I. ranklin's letter reads as follows:

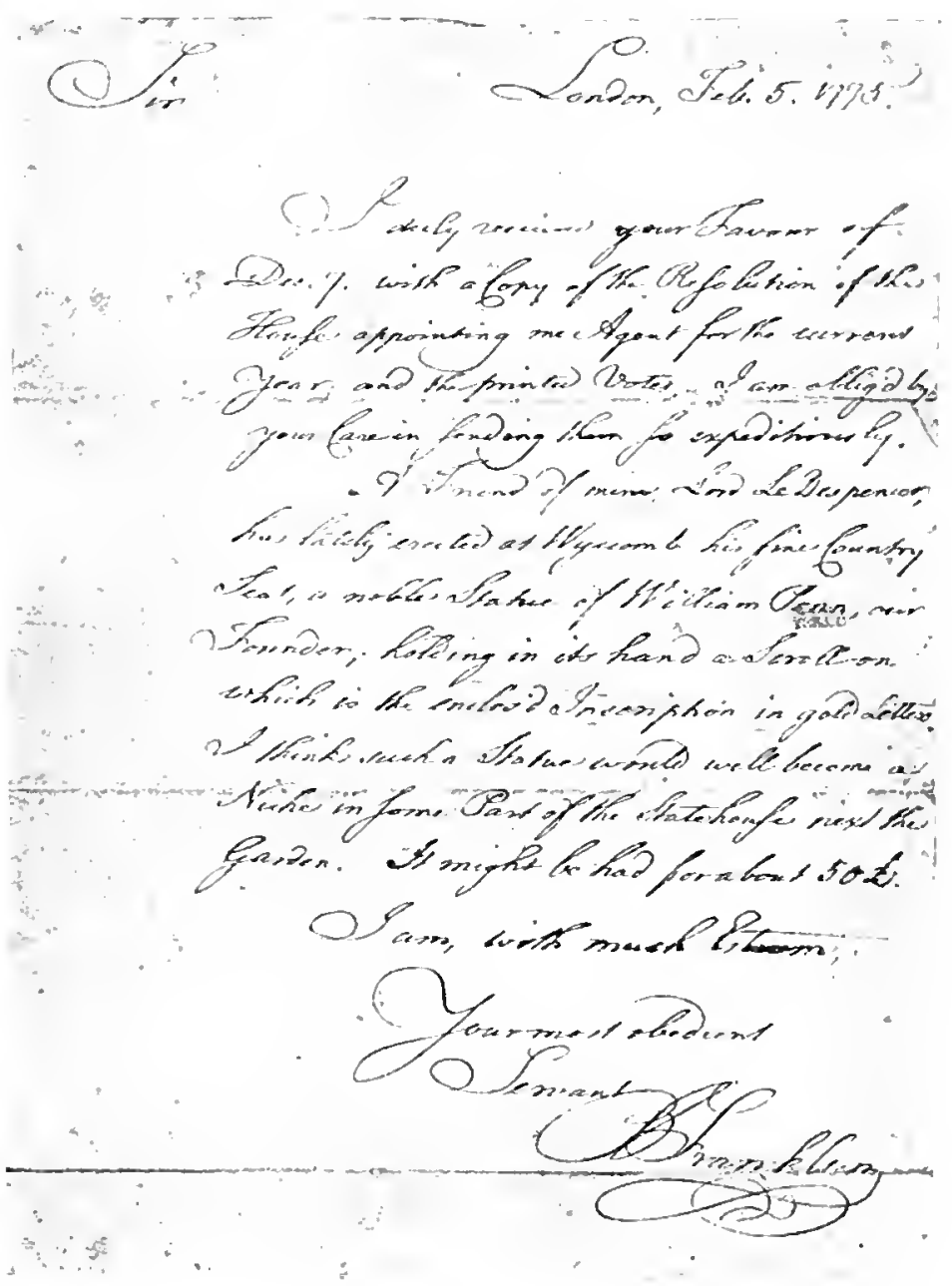


II, I11 111111111

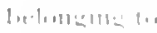
11111 1'11111

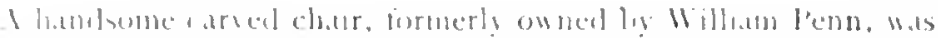

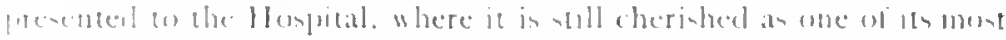

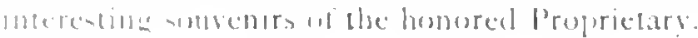

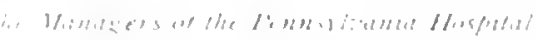

$11,11,-11,191,1$

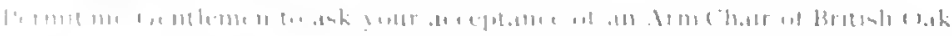

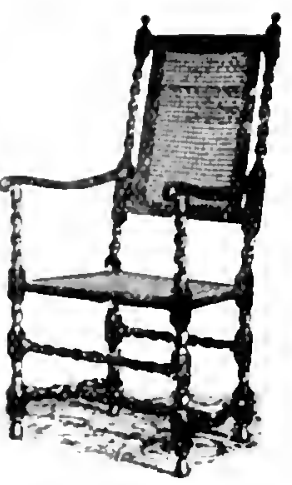

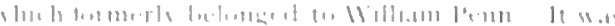

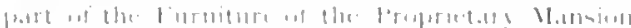

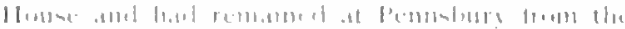

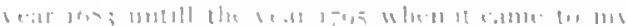

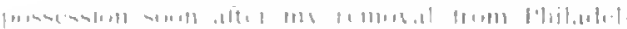

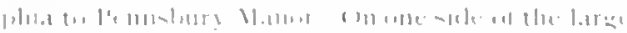

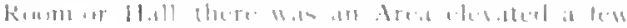

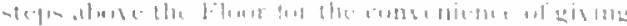

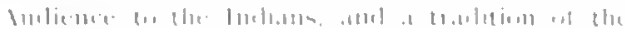

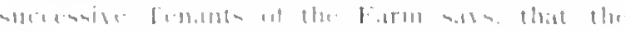

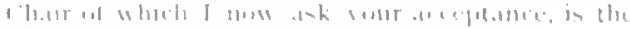

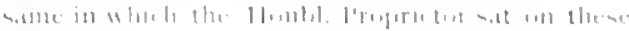

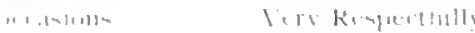
$\| 1 ! \backslash k)=\mid$ | $1 \backslash k i k$

"I Aceditn chair and chamber llorne" Was perented April 30, 199, for the use on

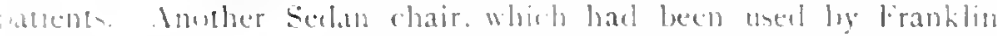

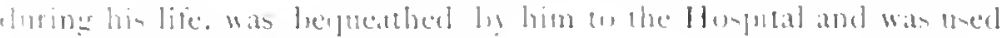
1mand limally lomten and de-erosed.

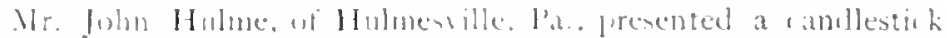
which had formerly belomged [n the l'repricetry, with the following luiler :

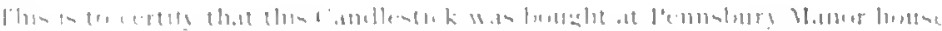

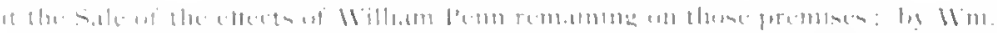

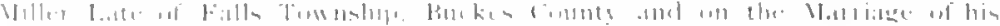

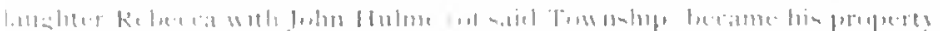

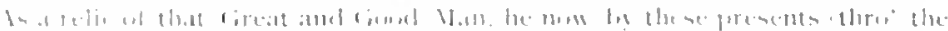

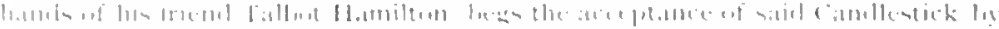

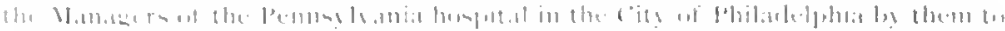

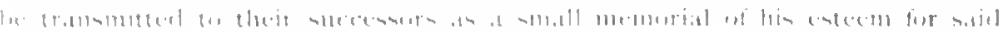

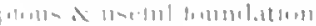

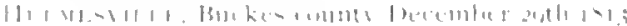

$10.1111111 ., 11$

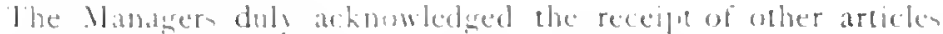
mentioned in the minutes :

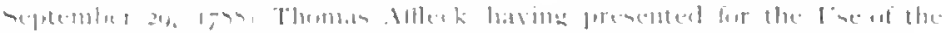

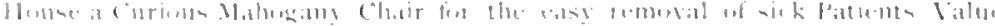

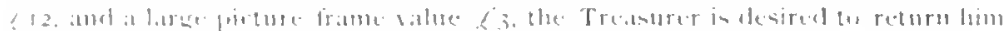

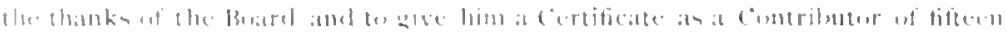
ponimils.

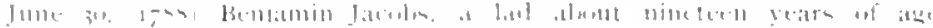

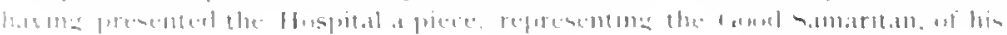




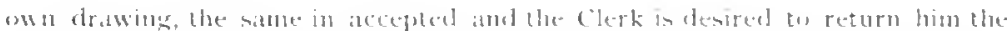
"lhanks of the buard for his ingenious prefformance. of Joseph Henzey is bu plate it over the Charity los in the Hall.

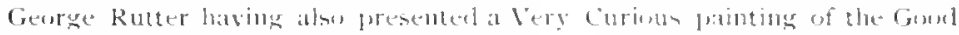

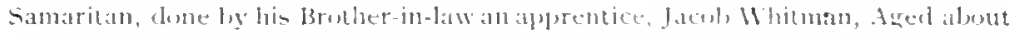

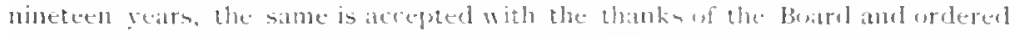
to be placed over the Breat work in the Mimagers' nom, and the Treasurer is

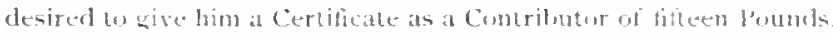

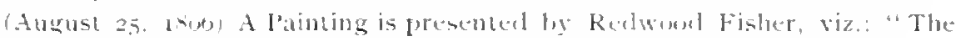
Physicians Attemping to cure a love-sick Molid" in al gilt frame-nhich the steward is ordered lu grut uj, in the Teit Roum.

Carriages have been on varions occasions presented to the Hos pital. Inne 26, 1 786 . Thomas and samuel Mliers presented a family carriage, which was put in sood repair, and the next september was sold for E6o, as had been directed by the domors. November 26 , 1794 , Samuel Cinoper, of Detaware, beepeathed a carriage and horses for the patients' use, whth a fund for their wuprort. July 29, 1811 , a well-made carriage war prenented by kolert Fielding for the use of patients. The attending Managers, on Iugu, zoth, were directed " to hereater mention the condition of the carriage in their monthly rejorts."

Mlwical instruments have aloo been prevented for the entertainment of ilue sick and insane.

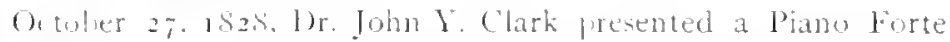

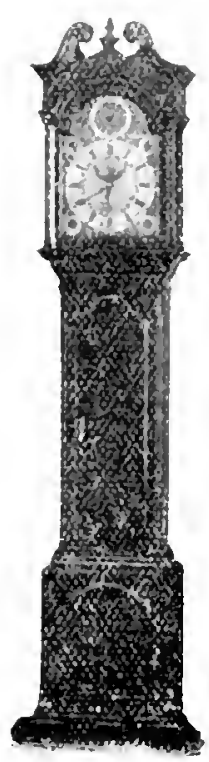
for the use of the Insane l'atients of this House.

November 24, r\$z\$, I)r. Wahington presented to the lnstiution, for the llae of the Inrane lepartment, a muical instrumest called "The (irand Hamonicon."

In the nuain hall of the l'ine Street Hospital, meder the west staircine, stands an eight-day high care liak, which attracts the attention of every vintur, and which deserses special mention on anewnt of its hintorical associations. It was construted by Mr. I avid Rittenhouse. of Xorribu, almut 1780 , and is of a larger sige than watul, whiring winding only twelve times at year. It was depusted in the Hospral, March 2., 1819. he Mlins carah Zane. Subequently, Ly her will, it was bejpeathed to the institution; her death coured in sis;o. The following description is supplied In Mr. I. I. Gropengesier, who for a long time has had charge of the cluck. some yars ago he was called npon to make extensive

E) Ils. Clacks and ulder Menturial Fundure 
repairs, on acomat of an ancirlent calued lis the breaking of a cord

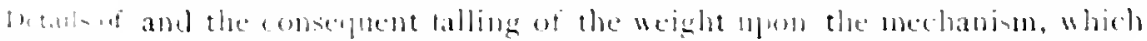

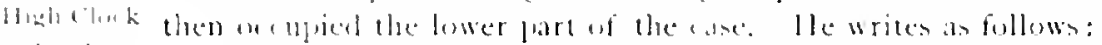

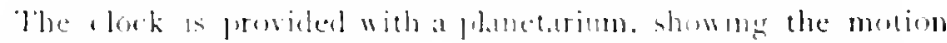
around the sun of the beavenly bution-t ramss. glapiter. Saturn, Mar, lenu, amel the barth.

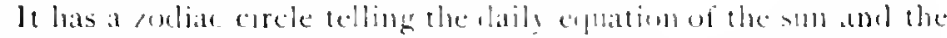

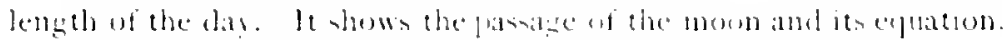

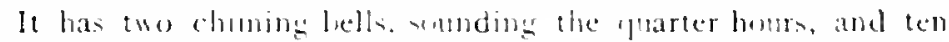

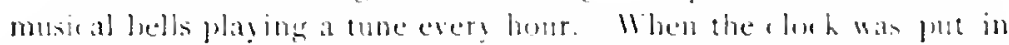

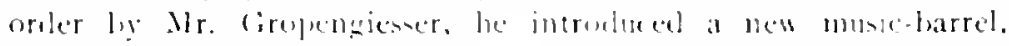

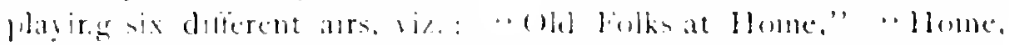
sincet llome," "Aulel lang sine," "star spangled lamer,"

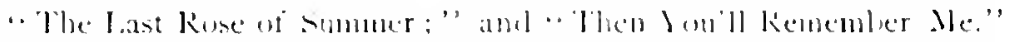
"lhere in no recors tellune what airs were formerly played by this

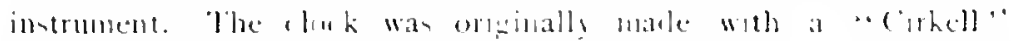
(cirrular) or "(iraham" esapement. Which has no manataining

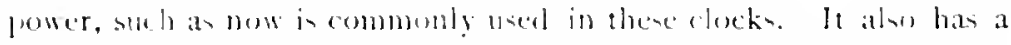

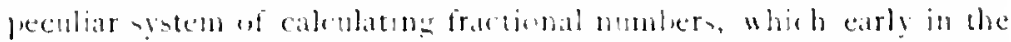

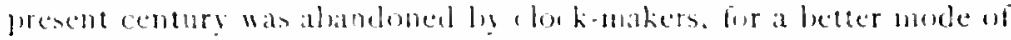
dividing equal numbers ly higher numbers of eose an the caldenlation. The cleck has a wo den pendulum, leatng ecounds. The diat is of

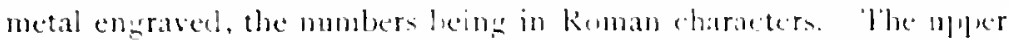
central fertion abose the dial evbibit the planetariem. on the left hand ulper cormer of the dial is a small dhal giving the tomir pesition of the mown, the right uljer comer hows the suld explation, ly at

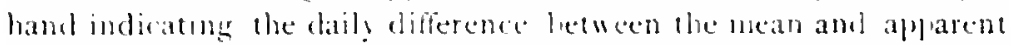
time. In the left lower comer is an arrangement to control the mechanism for striking ; on the rithe side ind dial indeating the succession of the six tunes. (On the inner hour corele of the dial is the moon with an especial wisige of the joution of the same. It also shows the movement of the earth imelependently of the moon.

When the musical portion of the clock was renewed by Mr. Gropengiesser, new connertions with the planetarium were aho introrluced. l'reviously to repairing, it hat heen only uned for several years as a silent timejice, lut since the restoration, the chimes are now regularly heard: the musical airs, however, are fenerally kepe in reserve, in order to obriate anmonance by their constant repetition.

The Hospital clock was made under the personal direction of Ritcenhome, and cont at that time considerably more than one

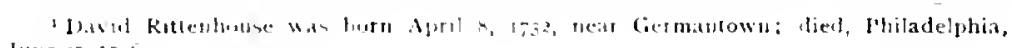
Juse $z=1$ wath. 
thousand dollars, lut its intrinsic vahe so zreatly increacel ly its historical associations with the development of the institution, of which it bas been an inmate tor the greater part of a century.

In the Hospital records mention is masle of other clocks:

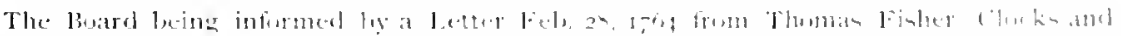

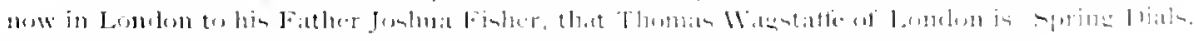

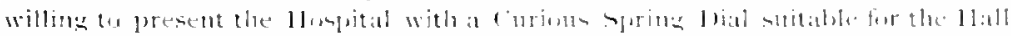

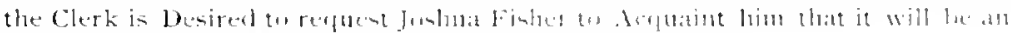
Acceptable joresent a 2 ratefully recoived by un.

The letter received in reply was the following:

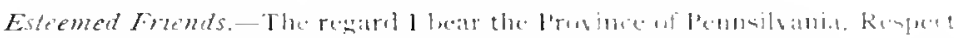

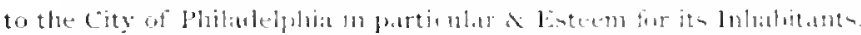

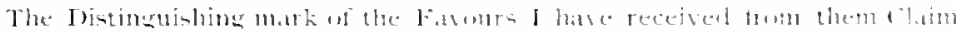

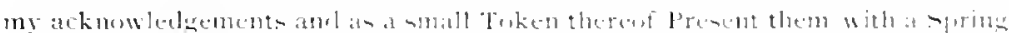

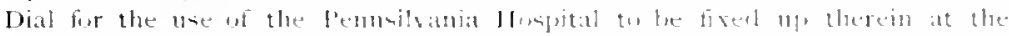
Direetion uf the Matnatgers.

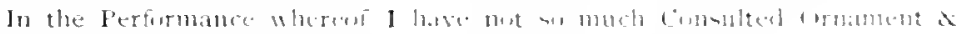

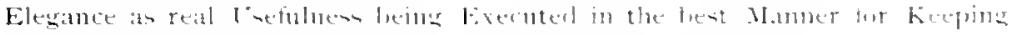
Time.

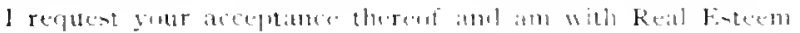

$$
\text { Vint Amutell Frd }
$$

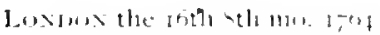

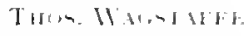

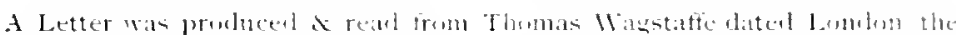

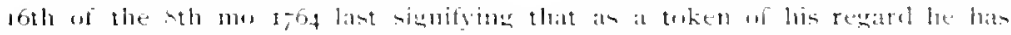

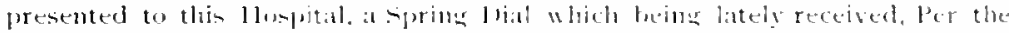

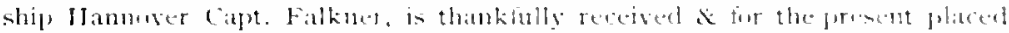

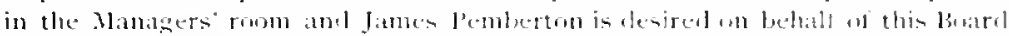

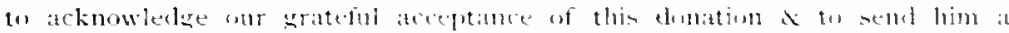

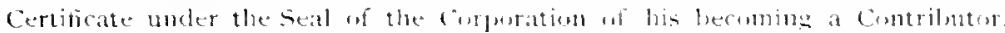

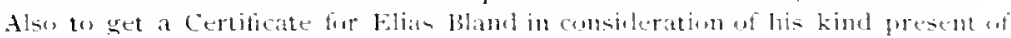
the fire Engine sumetime since presented ly him and receivert.

This timepiece is circular, $8 \mathrm{I}$ inches in circumference. It still keeps fairly correct time and is contmued in use; it hangs on the wall of the Women's surgical Wird, on the landing. yoing to the second floor.

Other clocks have been at various times prevented, but no special note appears to have been made by the Managers in their minutes. The local disposition of the timepieces is indicated in the folluwing:

On July 3o. If ro the Committe for repating the chos and procuring at new

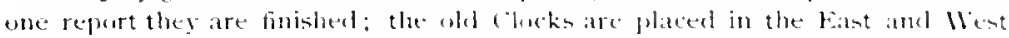
Halls and the new One in the Mattiger's Romm.

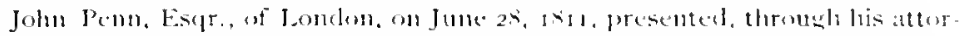

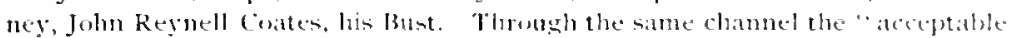
present" was acknowledged and thanks of the lowal returned.

James Traquair, a stone-cutter who had some tane in sculputure. produced a bust of William l'enn. in white marlle. which he 


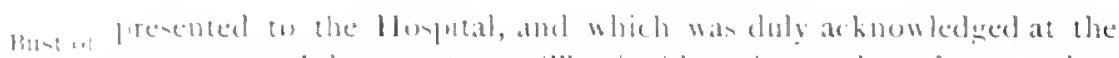

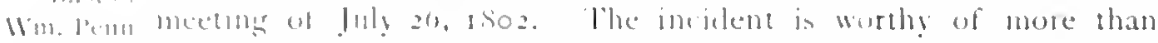

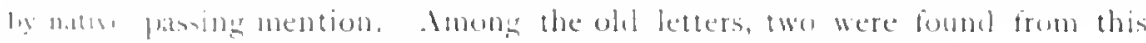
sculpur. orierinal indublual which mat le well reproduced here:

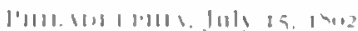

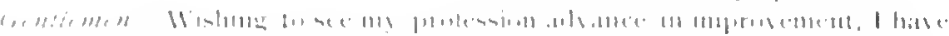

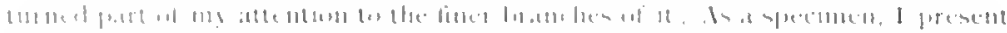

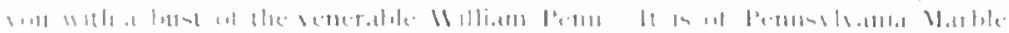

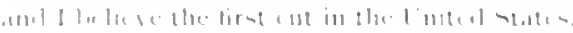

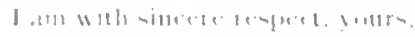

|и।

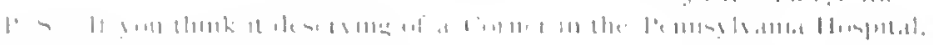

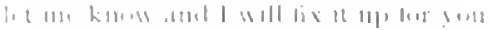

J. 1

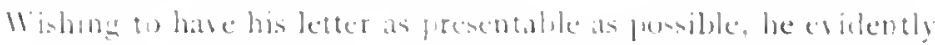

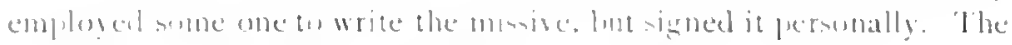

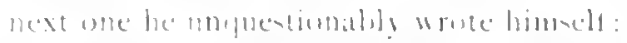

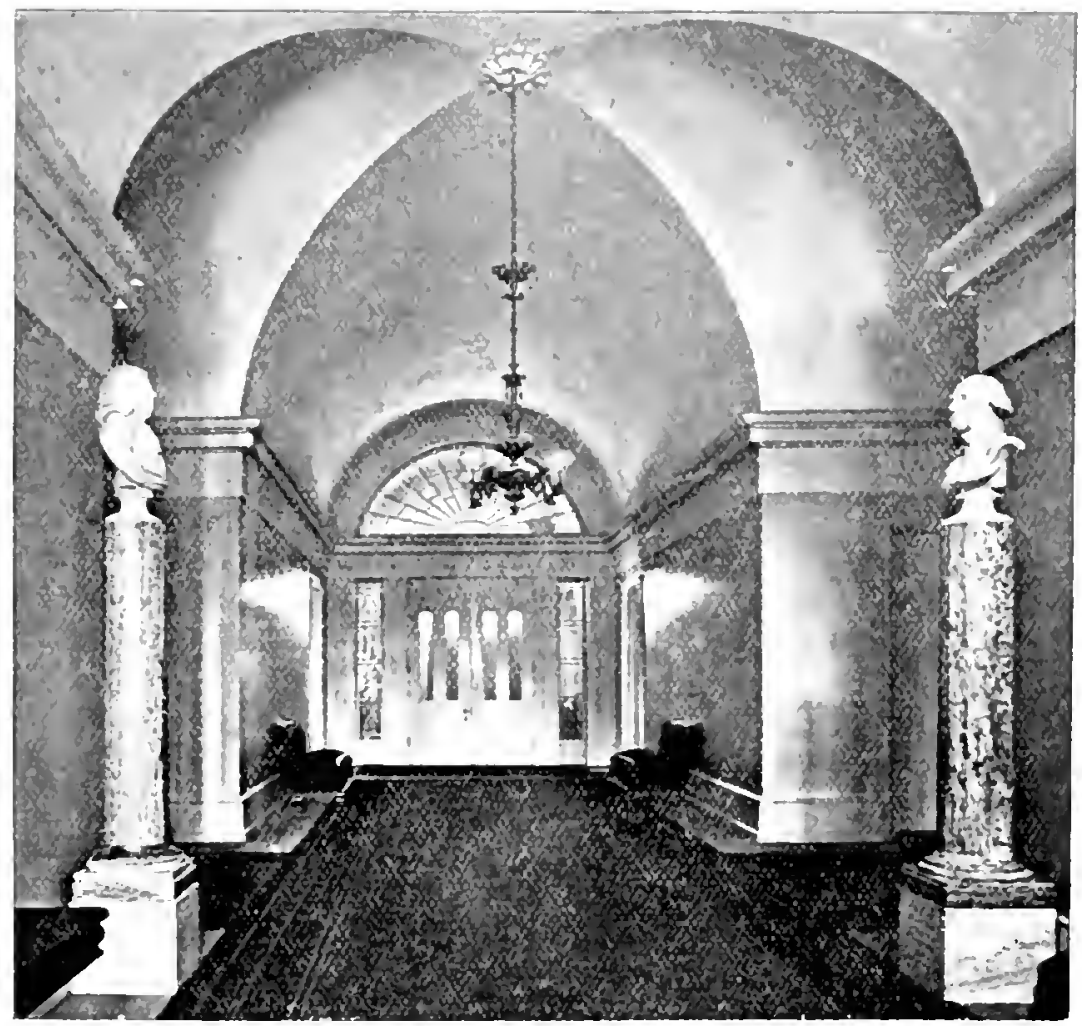

M:tn Jlall on fienale Dumirtment for the Insalle. 


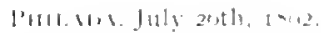

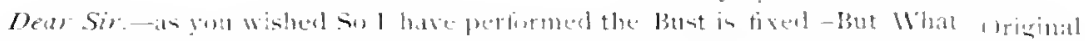

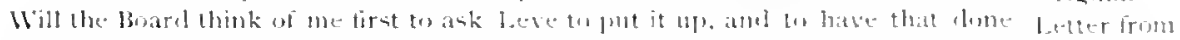

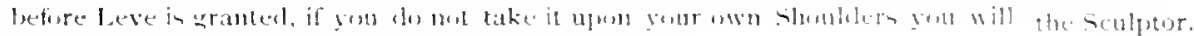
hurl the pride of at soutch $\mathrm{Yan}$

I atu Sir with Sincear Renpert your irimal

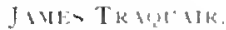

"The jride of a scotchman" was not to lee "hert," for, in the minutes male on the day the second letter was written and reteived (luly 26, 1802), it is recorded:

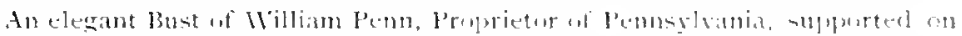

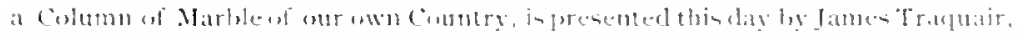

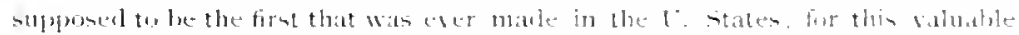

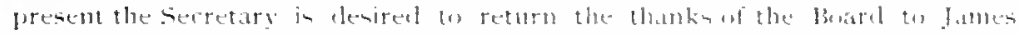

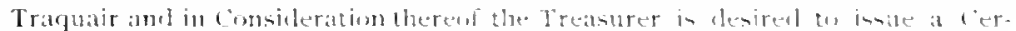

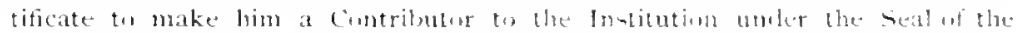
Corporation.

John Dorser was desired to get the fllowing inscription put upon the plinth. viz.: “This linst of William l'enn was presented w lamen "lrapuair, to the l'ennsyliania Hospitit, anno r soz."

Igrain, eight years afterwards. June 25,1810$)$, we find it recorded on the minuter, that

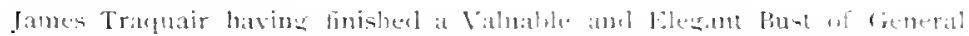

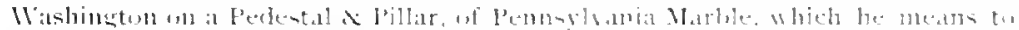

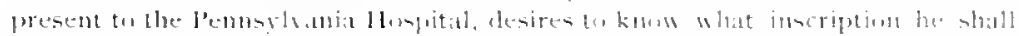

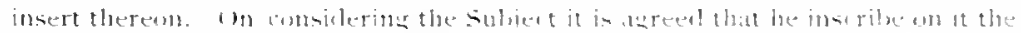

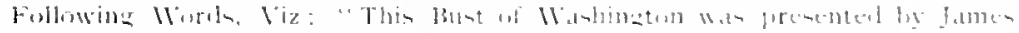

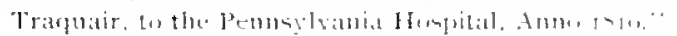

'l'rasuair felt highly honored ly the reception of his firt lont. presented in 1802 , and took great pleasure in the attention hentowed on him; sis that it is not surphising that he son tendereel a sew und lust to the Managers. Another fat which served tis still further arome hiv pride and feeling of self importance we tind in the wrols following the alove minute: "The Ilanagers attended James lrapluair to the Contributors' Rrom and fixed with him the plates where he should put the Busts of Penn and Washinerton." The mere hut on the Managers formally aljourning to accompany him to the roum in which the busts were to le placed, and cunferring with him in regard to location, and no doule very deterentially comulting him as to the most suitable position for them, munt certainly have heen most hattering to his pride and made him feel himselt the lion of the onason. After placing the sculptures in position, a bote of thanks was manj. monsly tendered to Mr. Traquair ly the Board.

These busts now orculy a prominent position in the hall w the Female l)epartment for the Insane. (See opponite page. 


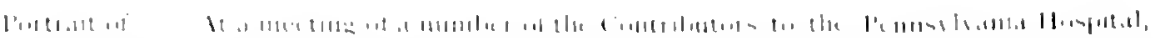

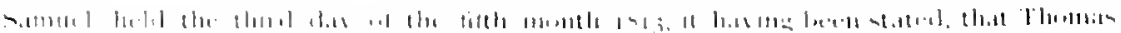

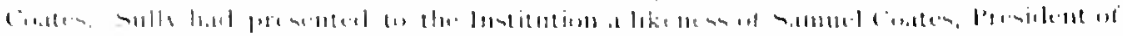

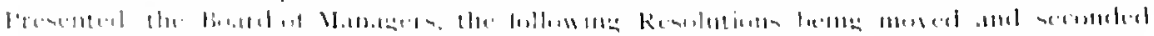

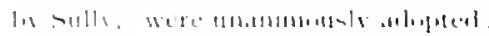

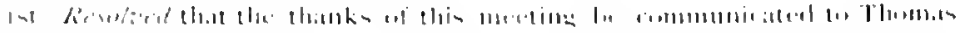

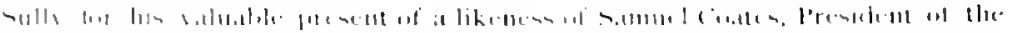

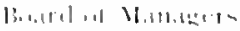

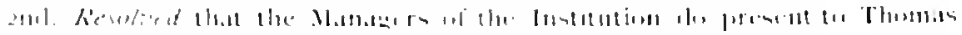

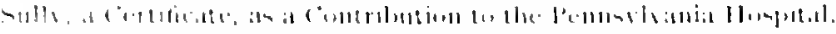

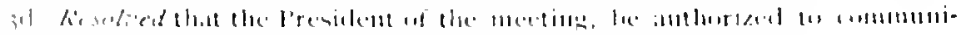

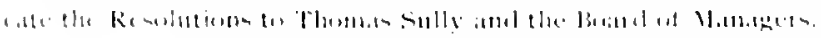

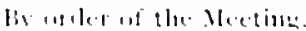

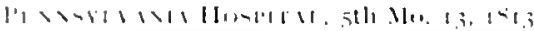

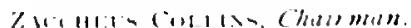

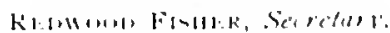

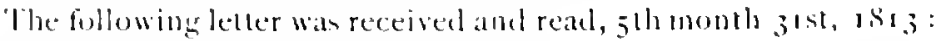

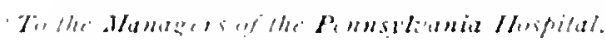

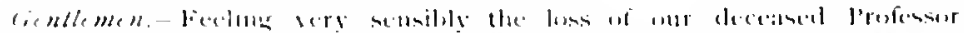

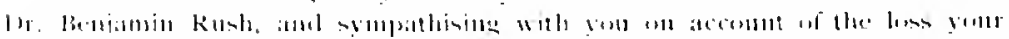

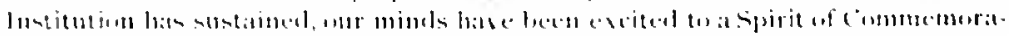

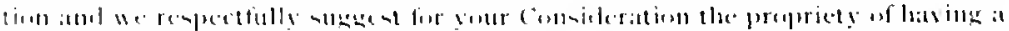

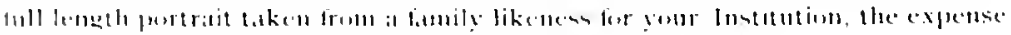

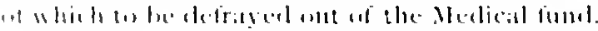

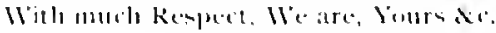

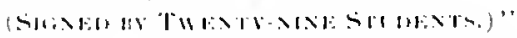

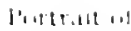

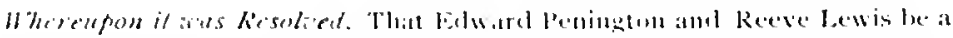

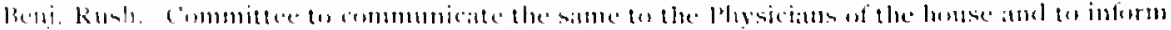

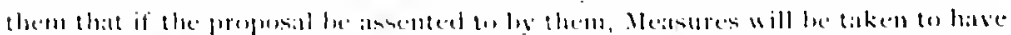

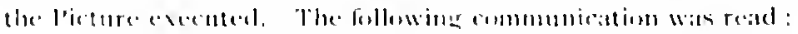

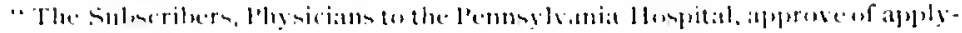

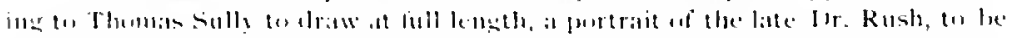

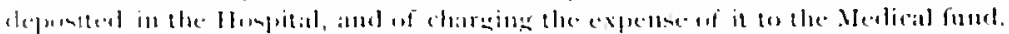

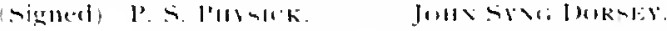

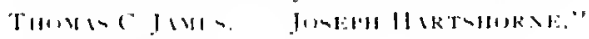

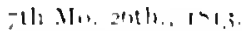

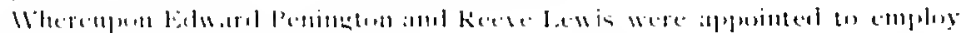

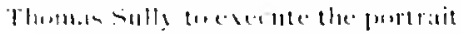

l'se fatinting mow ocrupies a commanding position at the side of the duor of the lilirary, on the second flour of the Centre building of the line Street IIospital: the life-sise portrait of Nanager samuel

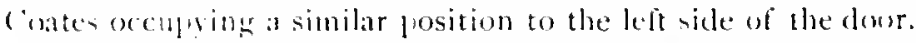

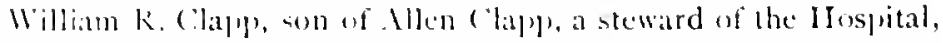
Was apminted clerk and librarian llecember 28,18 fo, and he served acceplably until March $20,18+9$. when he resigned.

He was much merested in the lJopital, and after leating it, he

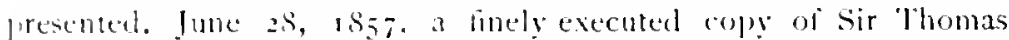

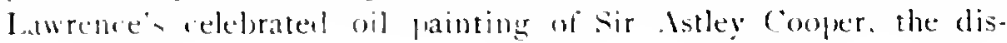


tinguished surgeon, which has since adorned the hall of the Hospital. The lioard accepted the gift with a vite of thanks (June 29, 1857), and made Mr. Clapp' a contributor.

1 bust of lhe late Dr. Benjamin Rush, executed in phaster Wy William Ruh, carver, was presented Octoher 25,1813 , Wy Joseph $\mathrm{s}$. Coates, and one exectuted in like manner, and by the same artist, of Doctor l'hilip, S. I'hsisick, was presented by John R. Coates. The secretary was requested to return the thanks of the lbuard to the respective donors.

On February 23, isis. Zaccheu Collins presented a bust of Doctor (aspar Wistar, for which the Board thanked him, and lirected that it le placed in the library.

The principal Works of Art owned by the Managers and deposited in the l'ine Street Hospital are:

Puxtries: Christ Healing the Sick. Sir Istley (inimer.

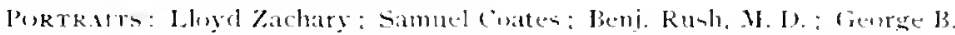

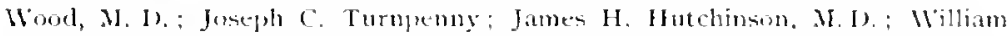
Bidlle: Wintar Morrin: Jacol, I', Jones: Sir Aslley Pasten Conper: William Gumn Malin.

Cowors: James Ifutchimsm; Alexander Derlyshire; John conrad. Also the Fothergill Crayoms. and uther misellanems pictures and diagrams, deposited in the Museum.

The following works of art bejonging to the Hospital adorn the walls of the Insane Department.

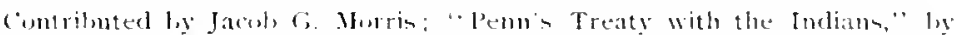
Witman from Mest's fointime: "Views on the Gramd canal, Venice," after Canaletto: "Viens of Xaphen": "Madumn," after Corregio: "Magdialen," after Titian; "The Fornarina," atter Raphate "Charity", alter shichome; "Bfwnlight scene," an original la challi.

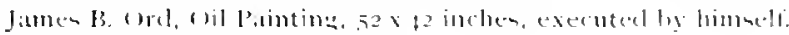

Julu Formum, wil l'aintins.

Alraham Miller, wil painting

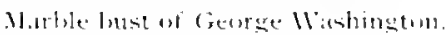

Marlie bust al William Peoms.

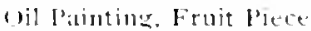

Wil Fianting bit fohn Wright

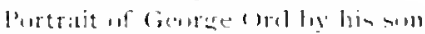

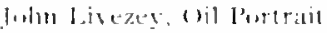

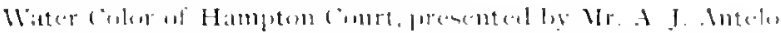

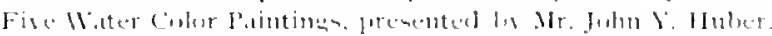

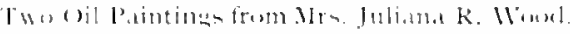

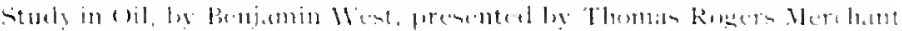

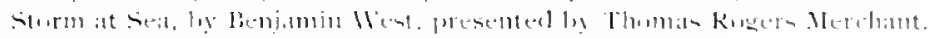

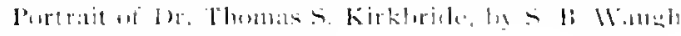

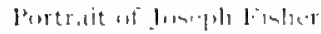

Wirtis in it belomxing to the Herpital. 


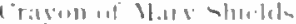

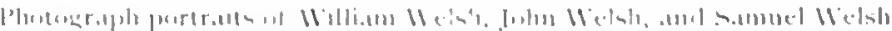

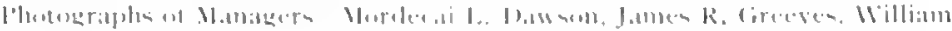

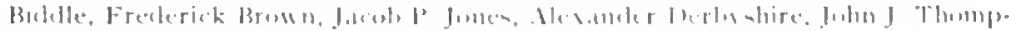
sul, ancl S. Mlarria $11:$ ill

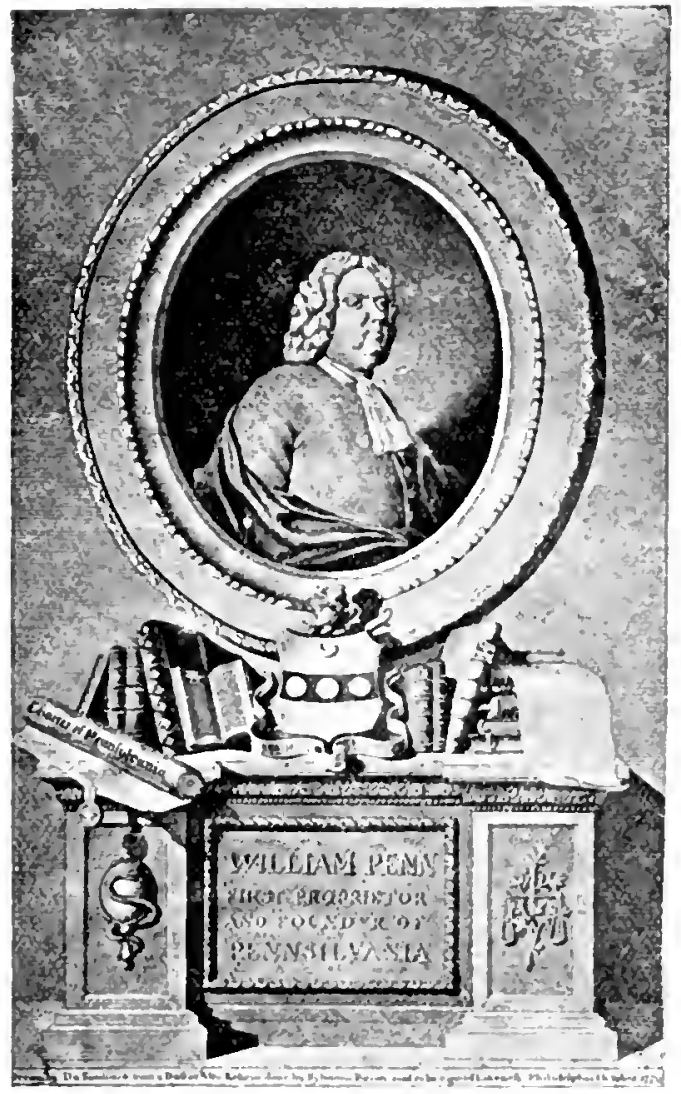




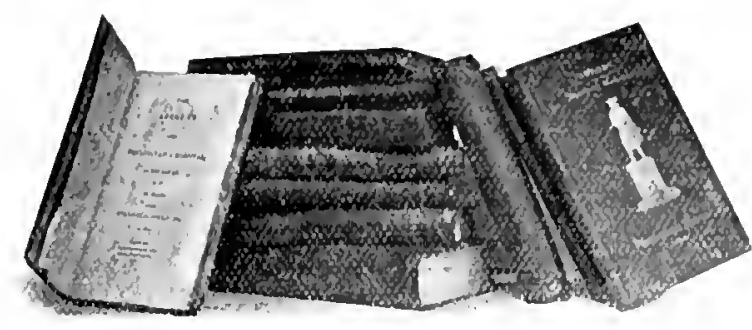

\section{THE LIBRARY AND THE PATHOLOGICAL MUSEUM.}

Incidental reference has more than once been made in the foregroing pages to the Medical Library of the Pennsylvania IIospital. From what is known of Franklin's projects and associations for the "promotion of useful knowledge among the British l'lantations in North America," and the able and active assistance afforded, in furthering his ideas, by the lwothers. Thomas and Phineas liond (who were prominent members of his famous Junto), it is only natural to suppose that the Hospital. Which they were foremost in establishing. would sooner or later he brought, in some manner, to contribute to the cause of education and the advancement of medical science. With the Bonds on the Nedical Staff, and Franklin as Siecretary. afterwards President of the Board of Managers, and also Secretary of the Provincial Assembly, a library of reference would seem a natural sequence. In his official pusitions, Franklin could. and cloubtless dit, improve many opportunities of soliciting donations of looks, woth directly and by suggestion, especially after the hibrary had actually: come into existence. The first intimation. however, which is to be found upon the minutes, of ansthing of this kind, and which provided the nucleus around which the idea of a medical library subequently took shape, appears to have come from Tr. John Fothergill, in Iondon, who for many years was a warm friend of the Hospital. l'robably his personal interent was at first aroused principally on account of his acquaintance with Dr. William Shippen, Ir. during the visit of the latter to lingland; the elder Dr. Shippen leing at that time one of the Managers of the new institution.

The first suggestion of the future medical library on the minutes occurs in a communication to the Boarl of Managers arcompanying 


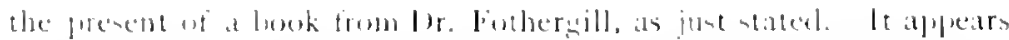

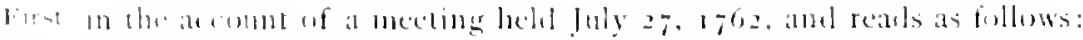

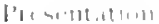

1.t linh 1, ,

(1) $1.11,4.11$,

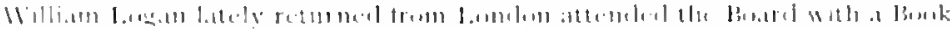

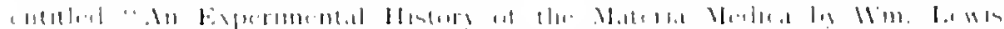

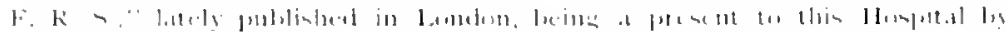

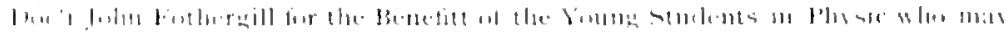

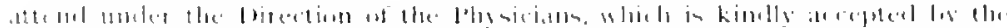

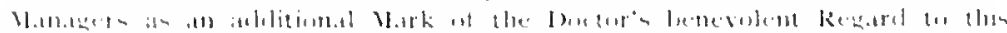
[1]

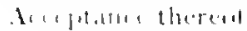

The delea of estallishing a complete library of works of refereme for the :mung stukents in flugics and likewise for the use of their greecelurs, luwerer, originated with the physician of the Ilospital. In fau the library received its first wreat impulse from the mediral staff of the institution, umeter cir umstances, which will be referred to sumen lat in lletail, in the sulsepuent section.

In Iay, $1 ; 63$, the Nedical staff informed the Managers that

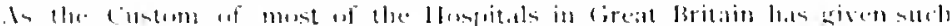

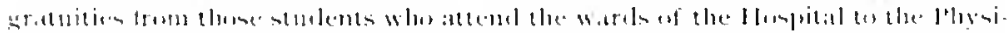

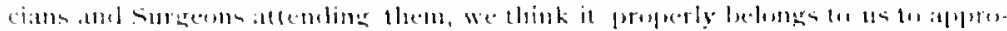

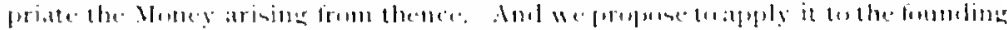

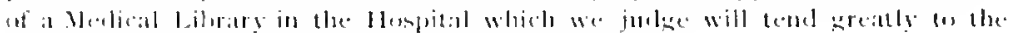

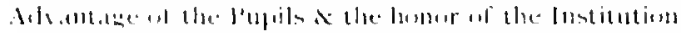

'llis proposal of the Acedical Staff was adopted by the Managers and from this lime forward the permanence of the Nediral librars was ansured. Indeed, the fees from the students supplied more than suffirient fonds fo establish and maintain the growing collection of medieal and scientifir works, which afterwards for many years was the mont comsiderable and important in the country. In addition to the alove source of incone, whirh was known ats the ". Nedical pund." many domations and beguests of books from friencle to the instilltion materially assisted in increasing the stuck of books, anmone which were many wheh were bolh rare and valualle. The first atudition of this kind has been referred to: this, several bears later. Was followed ly a secomel from the same donor, whose gift has

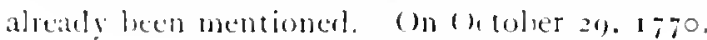

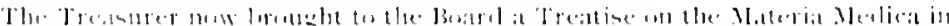

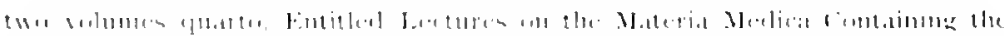

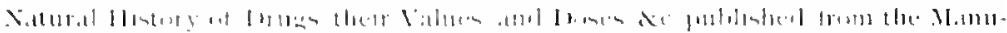

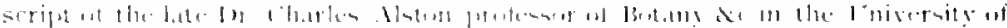

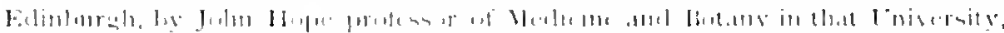

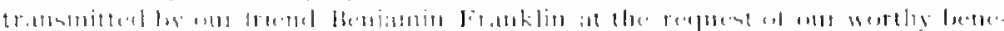

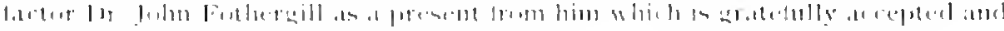

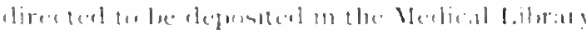


The library of Dr. I,loyd /acinary, (a member of the first medieal staff of the IIospital), consisting of forty-three volumes, and a number of pamplilets, was presented to the institution liy his Executors, Hugh Rolerts and Samnel Neave, with the consent of the residuary legatees, "towards fomding a Nedical Library." 'These looks were received on the gth of Jinnary, $r_{7} 67$, and a week later, on the $r$ th, we find also that

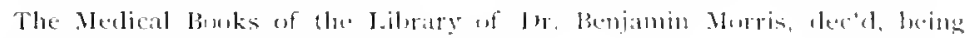

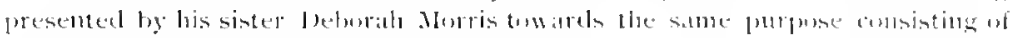

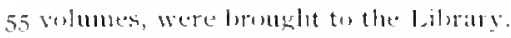

The latter were principally standard medical works, collected by Dr. Morris during his attendance upon the Lniversity of leyden. Mr. Wm. Strahan of London, England, in 1774 , made a donation of books to the value of one hundred pounds. This gift was perhaps prompted by the following letter to Mr. Strahan, which the Committee to procure books for the medical library laid lefore the board. July 25, 1774, the list of needed books having been compiled with the assistence of the merlical staff.

1'H11.1. fth $140,1:-1$.

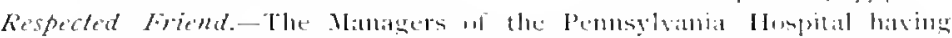

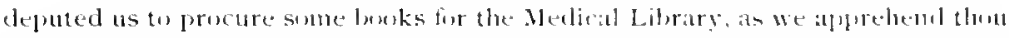

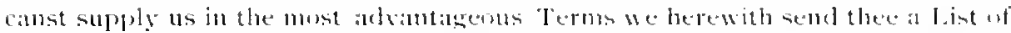
them desiring thee w prepate and ship them loy the first lisset comine th this l'ont that they mate bere befine the winter. This we are very desirinus of as the peung students who from the neighluring l'rovinces attend the Leetures al

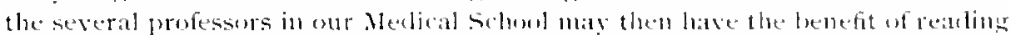

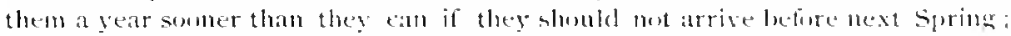
fir the Cost of them we will semd thee a timety Remitance. When any new

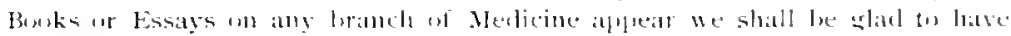

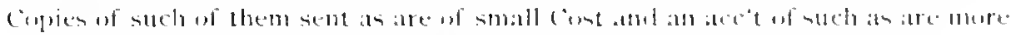
motly than if we judge them neeressity we may sembl for them.

The desired medical looks arrived the following lecemler.

In 1;90, the Managers opened correspondence with the celebrated Ir. John Coakley Letsom, in Iondon, reyuesting and authorizing him to select and purchatse medical works for the Library. This confidence was not misplated. I). Lettom was a firm friend to the institution during his life, and the library is indebted to him, not only for the judicious manner in which he discharged this trust, bu also for many presents of looks which wreatly increaserl the value of the collection. (1)r. Lettem's portrat appears on page 323 anti)

some individual donations are of sufficient interest to deserve mention. 3)r. lothergill's have leen acknowiedged. (In March , in, 1 Soo, the board returnesl thanks to lor. Willian Curre for a prenent

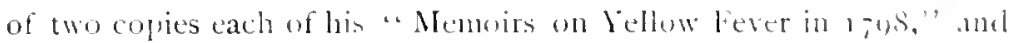




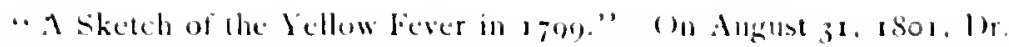

Varinus Mcase presented a pamphlet " ()n the discance produced by the lite of

lunk a mad dog:" aloo his inaugural dissertation on the same subject.

mented september 27, soz. 1)r. John Redman presented his "I'ractical Ohservations on Vacrination or Inoculation for the Cowpex." lor. John Redman coxe, editor, and Mr. "lhomas lhlson, printer, ealch presented a coly of the ". American I lispensatory," which hat jut been pullished. The library of Dr. lienjamin S. harton, dereased. was purchased for $\$ 27 \% 0$, from his wiclow, Mary Bartun, as we learn

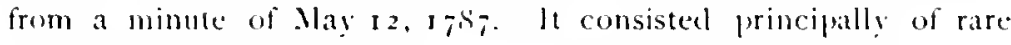
works on Natural History.

A saluable present of books was received in the year 1800 , from Sarah Zane, a wealthy maiden lady, who inherited an cxtensive library. the medical purtion of whic h she lestowed upon the Itospital. 'This donation comprised twenty-three folios, nincty-one fluarton, sis octavos and twenty-two duoderimos, in all one hundred and fort! two volumes, some of which were rare. l'bey formed an actuin. tion of undeulecel value tis the already respectable collection of books in the possession of the llespital.

Pline of The orginat place of deponit thesen for the Meclical l,ibrary was, lwoment of naturally, the meeting-room of the Managers, and. al first, and ats the knok in lans $11 \mathrm{mg}$ long as the numler of books was not tou great to furnish the room appropriately, this was the most comvenient arrangement. April 27 , $1-67$. it is recorded on the mimules that "Samuel Wetherill paid fior luiluting the houk-case in the Managres' room, $f_{5}$ o. 2! .." 'Thu was in the east wing of the Ilospital buildings, as the Centre had nest not get leen linished. It was suberpently Octoher 28.1799.

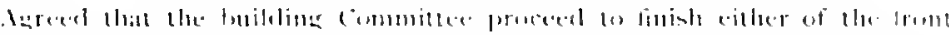

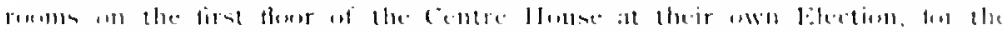

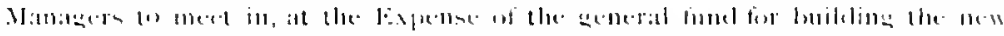

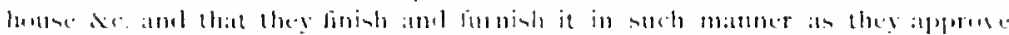

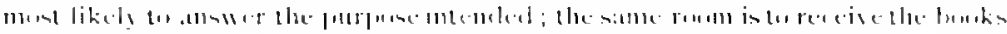

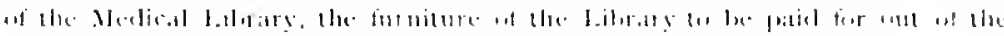
Nertical Fumb.

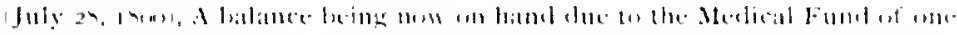

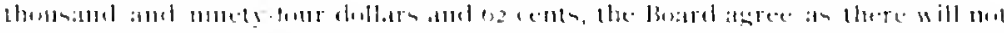

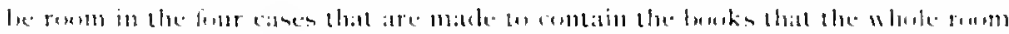

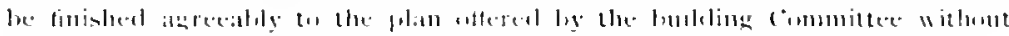

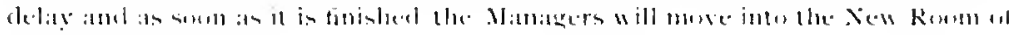
the centre House.

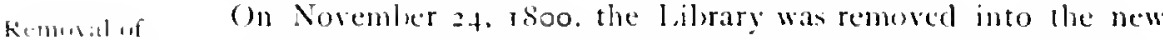
J.1hing to room and, at the next meeting (1)ecember 29 th), an order was drawn cintre on the l'reasurer for \$1500. "of which \$1000 is to he charged to the Building. Medical Fumel and s5oo to the general fund of the Hospital." After 
the Centre building was olened, it was considered expedient and desirable that other rooms should be made ready for occupancy, so we find on February 23 , I\$or, that the Board agreed:

To fit up the atloining rom for the drus department, the Expense of fonishing and furnishing the Aputhecary shop, in the Sunth. East room of the centre Inilding, to be defralyed by the Medical Fund and the procededs of

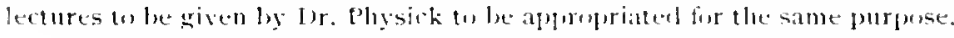

As the attendance of students apon the lectures continued to increase, additional clinical room was demanded, and, January 3, $1 \mathrm{SO}_{3}$, the physicians recommended the finishing of the circular, lecture rom and wo private rooms adjoining it, towards completing which they agree that $\$ 300$ per annum should be al'propriated for the next four or five years out of the Medical Fund. This suggestion, or proposition, was accepted, and the Building Committee reported, at a subsepuent meeting ( February 27, i 804 ), that "the 3 rd floor circular room had been finished some time and Lectures have leen given and Circulitr Letitine. kimill one operation performed therein."

This is of interent in this connection, for it was found necessary some years later to place additional hook-cases around the wall of the seneral office to accommodate the constantly increaning accumulation of books. Octolier 26. 1807, the lons rom on the second floor in the Centre bnilding was fitted ny an a library and used for this purpose until Felonary, $x s_{2}$, when it was resulvel that the

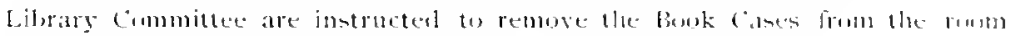

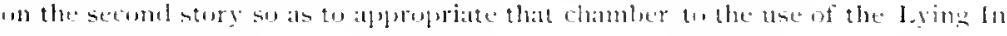
lepartment.

This was reported as having leen carried out, at the nest meeting (March zgth), lut it does not appear where the hook-cases had been removed to, unless it be taken for sranted that the rooms on the first flons already mentioned, were utilized for this purpose. Amgust zoth of the same year, it is noted, however, that the

Aproment in whith the Library is placed repuiring some repars the com-

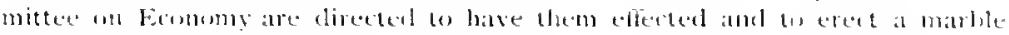
Mantel aner the Fire Plate.

When the Lying-in Ward was transferred to the Picture Home. in 1.935 . the cases were returned to their former position. and the books have not since been disturbed.

At the present time, the library is deposited in its old place. Which is alwo lued ly the Nanagers as their meeting-room. on the second floor of the centre building. When the clinical amphitheatre was huilt. in s 868, the old lecture-room at the top of the Centre building wanconverted into a dining-room for murses, the walls being lined with cases. 
in which were placed many of the oleter and less ened books. simne are also in the cases in the room on the first floor, originally fitted up for the library in thos, but now ased an the general ultice of the llempital.

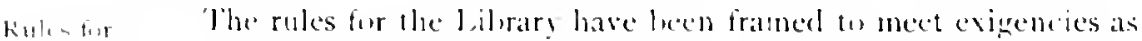

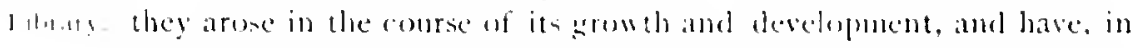

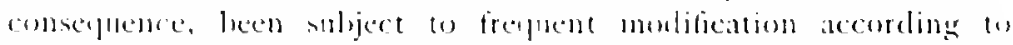
rireumstances. Is a matter of hinturical interest, the linlowing

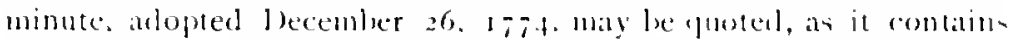
the first mention of regulations concerning the lemelugg of beroti:

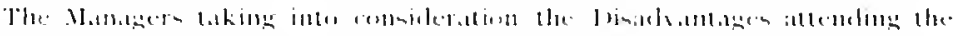

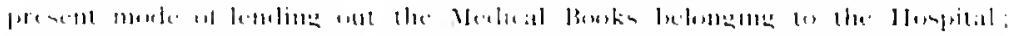

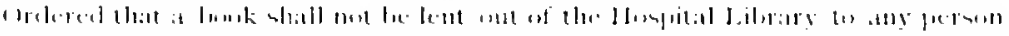

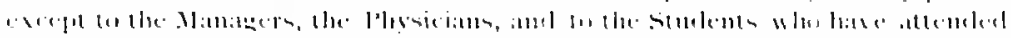

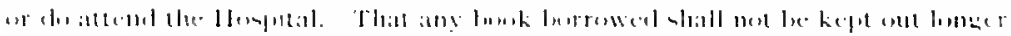

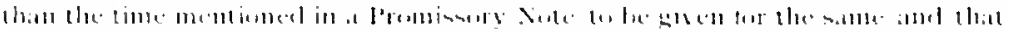

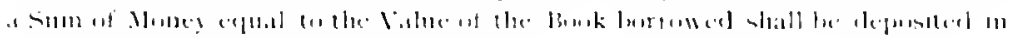

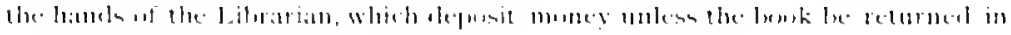

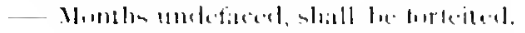

"The encreme carefolness and prodent foresight of the Manager and their wine and julicious superintendence of the Jibrary, are freguently manifested in their correpondente, of which the following is an example: July 31 , 17 so, "lthe committee appointed to import the looks for the Medical libary report that they have wrote the following letter and ordered the hooks ler the invoice encluned."

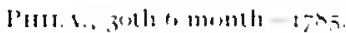

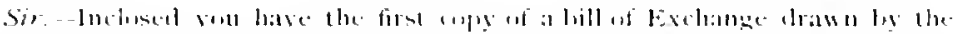

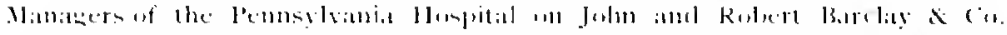

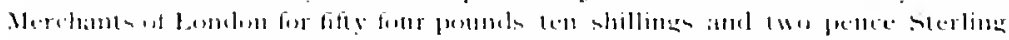

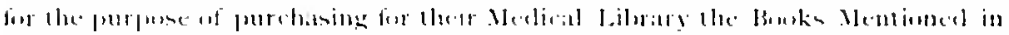

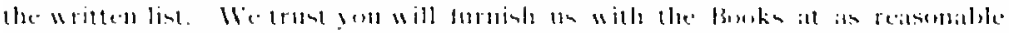

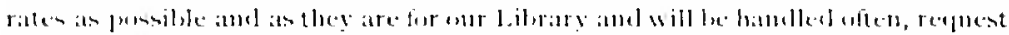

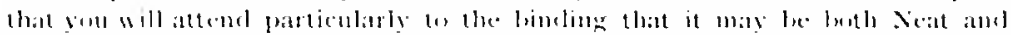

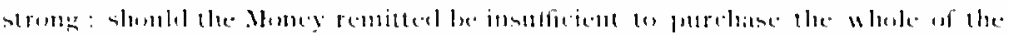

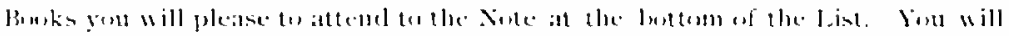

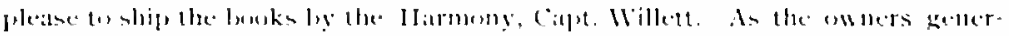

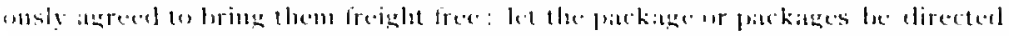
fur the l'elllsylyanial Impital.

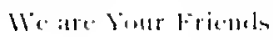

$$
\text { (signed) SWIEt. Howlit., }
$$

rolitir Hinne Esq.

WII.IW HI.ML.

In spite of the watchful guardianshij, of the lithary, it appears that hooks were missed from time to time. According to the catalogue made and dated the 27 th of lecember, 1787 , the Nanagers discovered 
that there were a number of books therein not accounted for. "They then made the following rule, January 28, r $78 s$ :

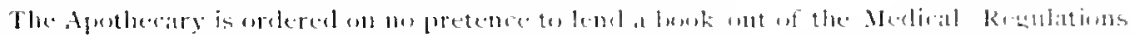

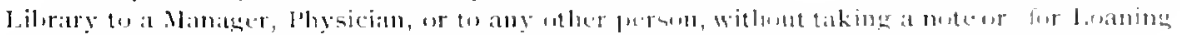

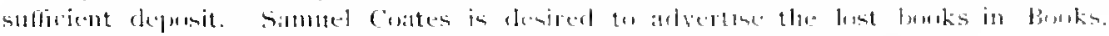

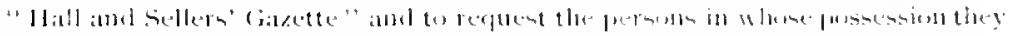
are to return them.

It is gratifying to learn that the committe was abie w report, at the meeting February 25, i 788 , that the lost looks harl been duly arlvertised and that one had been restored.

I comprehensive system of regulation was asreed to by the Managers at the meeting held lecember $28,1785, "$ by and with the advice and Consent of the l'hysicians when the rules for the preservation thereof" were adogted, and the Rules for the Library were printed and dintributed.

At a meeting, held Nay 31,1790 , the Committee on preparing a Catalogue reported that "ilue husiness is completed, and six hundred copjies are printed, and now hrought to the hotse." "The following interesting item aho appears under the same date:

It is agreed that each of the Managers. Treasurer, and lphiciam may have

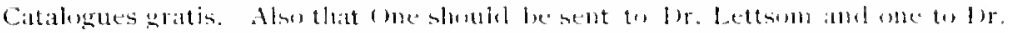

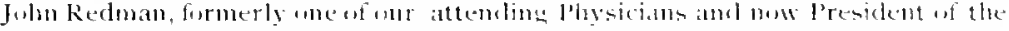
Cullege of Ibisicians.

'The money value of the work was, at the same time. fixed at a moderate sum:

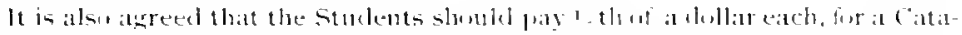

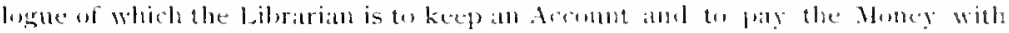
the fines an Bunks to the steward when the Attewding Mandgers reguire him to duit.

A standing resolution was aclupted. August 30,1790 , to the following effect: "It is now agreed to be a Rule that the lireasturer is always to be allowed the Lise of the Library." "The fees for the Students were increased. May Io, risoz, to ten dollars for a single season, and twenty dollars for the perpetual privilege, "with a copy of the Catalogue gratis."

It had been expredient to slightly modify the rules after consultation with the medical staff, lefore their fmal adoption, and the fact that the physicians had been duly consulted and had approved the regulations, made the Managers less disposed to favor further changes, consequently it is recorded in the minutes of a meeting, held Octolver 31,1791 , that the

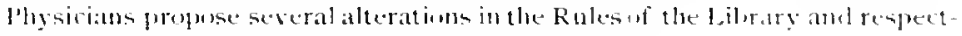

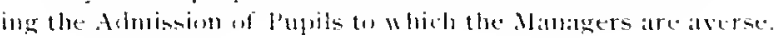


What the proposed changes were does not appear upon the minutes. but they were goolsably comidered tor unimportant to be recurileil.

Fint The firt catalogue was published in the year 5 7yo, and represented "itubisue enenty-one folio volumes, seventy-seven puarto, three bundred and indle?! forty-une octawo, and eighty-nine dunder imo-total, fre hundred and twenty-eight volumes. An addition, or supplement to the Catalogue "as compiled printed, and issted three years later.

The Library having been greatly enriched by gitts and purchase, it was decided on January $2 \$, 1805$, to prepare a new Catalogue which was finally issued the following year.

"lhe industry and eal of samuel ('uaten, secretary of the library committec, was manifested in his interest in the library and ansistance in preparing the cataloguce The Managers, (lichnasy 24. 1tio6). tendereal the Committe the thanks of the looud for

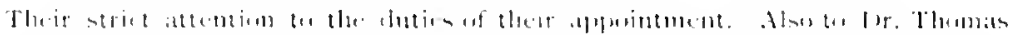

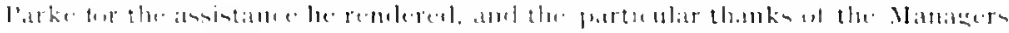

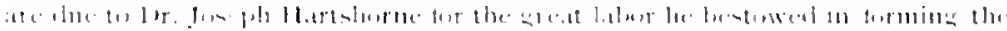

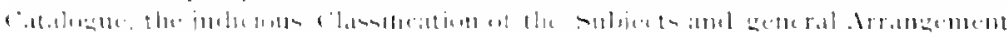

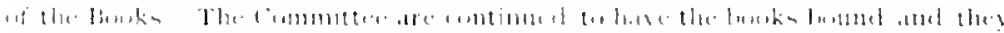

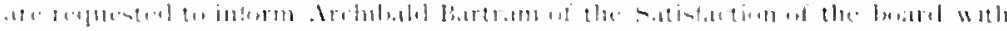

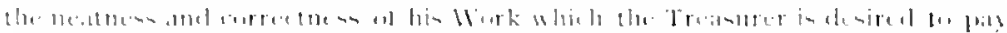

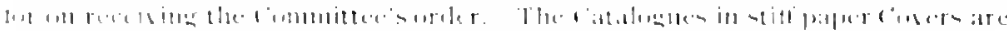

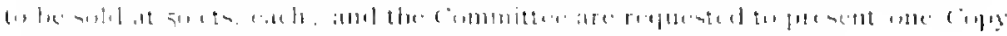

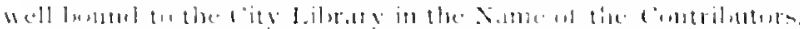

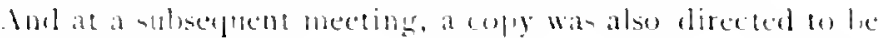

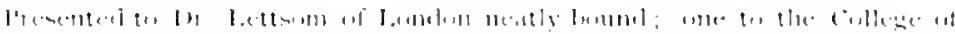

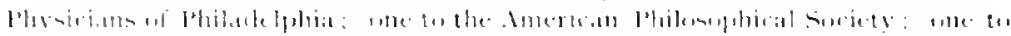

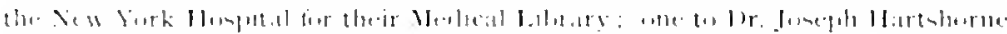

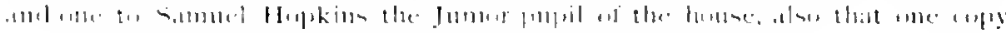

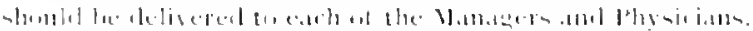

I new regulation was adepted, May 26 , tho6, "hich indirates that the lifirary wats coming inte more peneral tose for reference and

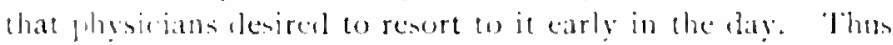

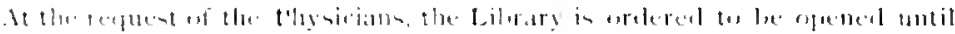

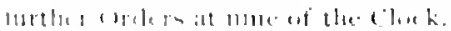

It wat discusered that looks were taken from the library without Bivatin froper records leing male, and this irrewalarity fonally grew to sueh propurtions that the Managers were compelled to take at ton mon it. Accordingly we re:id. under date wi lugunt 2\%. 1808 ,

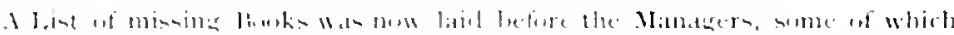

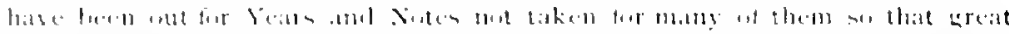

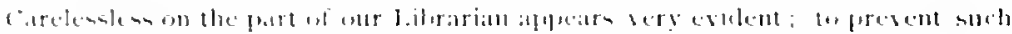

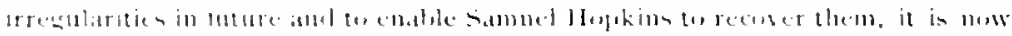




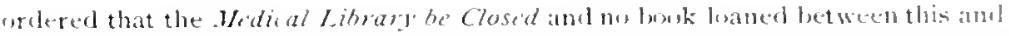
the next meeting of the Buard, m the meantime he is desired to staty a few day

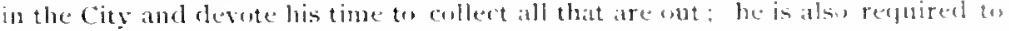
furnish the Secretary witl a complete List of what remains wut alter he hats mate

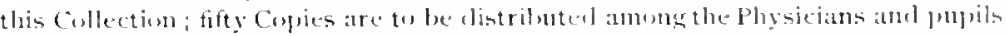
and One Cing is tube inserted in the lublie News Papers with a request that borrowers will return the Buoks withut delay.

At the following meeting (September 26 ) it was

Agreel the Library is not to be opened until further wrders, as John Howe who is now appinted Librarian must enamine the bustis lefore he gives a receipt for them.

It is presumed, as soon as the new Librarian had made out the list and receipted for the books, that the library was again opened, but greater precautions than before were now observed in order to prevent further loss of books. The Managers (November 28, 1808). passed the following rule, which indicates that the Library had leen again thrown open under the regulations then in force:

It is agreed to dispense with the depersit for luoks sio far as lig the 5 th mule it is required of the Nanagers Plysicians and Treasurer and nu further.

The gratifying annomeenent was made July 27 , I $\$ 12$, that

A considerable number of the buoks heretofore missing bave leen recovered and placed in the Library. The Secretary is recpested to make wut a list of such as are still missing and publish it with at reduest that the persons intu where hands they may lave fallen will restore them to the Institution.

This duty was promptly performed by the Secretary who reported at the October meeting

That he had made out a list of the missing Bonks \& placed it in the hands of Zacharial Poulson for Publication.

As an additional precaution, it was decided to direct the bookbinder to mark the books so that they might be more readily identified. (Nurember 30, r 812 ),

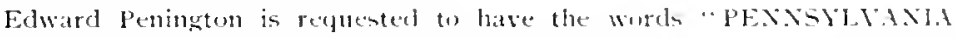
HoSPITAL" printed at least on two pages of each rolume af the Burke belonging to the Nedical Library.

Shortly after the acquisition lyy the Library of the books of Prof. Tenjamin S. Barton's estate, a supplement to the Catalogue was issued, containing the titles of works added between I 806 and I 818 .

It was found that the additions since the last edition of the Catalogue had been so numerous that a new edition had to be taken into consideration.

It is stated in a minute of January $26,1 \$ 29$, that Mr. William

\section{G. Malin}

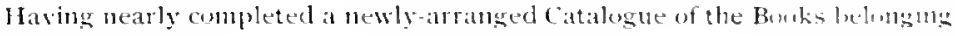
to this Institution, 


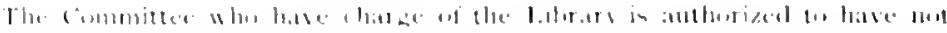

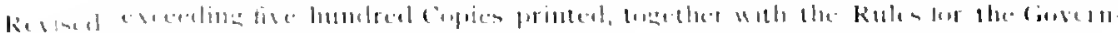

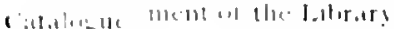

laned St indicating the money salue of the buess and furniture at that time the following is of interent:

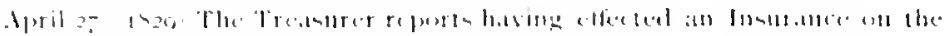

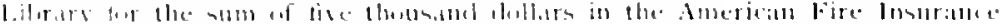

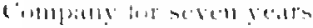

The newly-arranged catalogue was compleced ly the following

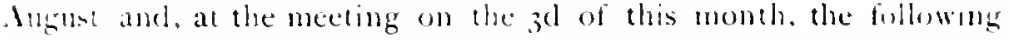
record wan male:

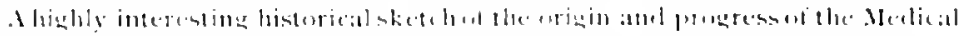

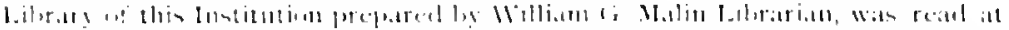

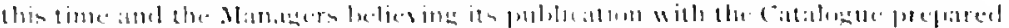

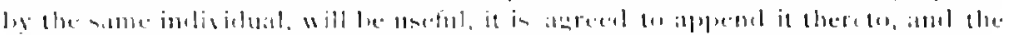

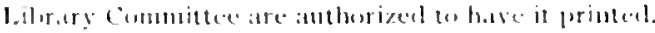

The Library (committee was atsthoriged and reepented (1) porenent copies of the catalugue to each bhysitian or surgerm who is or has lecen in attendance at the Hospital and to the Rerident lhysirians: also, one cops to each of the Managers and the Treasurer and the

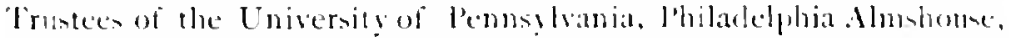
the Philusophical Society and the lew Jork Hespital. A coly was subergently presented to the l'buladelphial Jibrary Company and the Athenatum. It was resolved to sell the catalogue at use dollar fret (a)

Silnibirient (iminlent?

Vis leslitus 1)

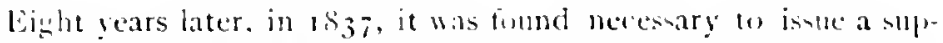
plement th the last Catalugue, which was abo compiled by the liburian. The Library at this time comprined 7,300 vohmen and was growing at the rate of mure than 150 titles fer annmm. In 1556. it was found that the collection had increaned 21 over ten thowand volumes, under the careful wiperintentence of the lioard of Managers and the excellent grardiamhip of Mr. William G. Malin, who had deroted himself to his dutics and took great interest in caring for the looks, both while actually in charge as librarian and sulseifuently while Steward of the Honpital. It wab cleemed aclvisalile to frepare another elition of the Catalogue at this time and the Managers were so fortunate as to secure the servides of l)r. limil fincher. Whose literary and scientific attaimments well fitled him for the lask, which he undertook with zeal. The peculiarities of the new claswifed Calalogne are lest explained in the words of 1 r. Fischer in the preface to the work, in which he pars a deserved compliment to his predecessor in office:

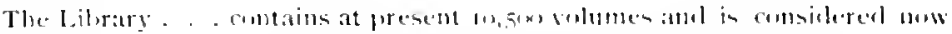

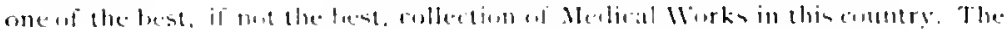


perusal of its Catalenge will simw tiat it is at fair regrestentative uf mealical staudaud literature, particularly in its English and French part, a ralt areatly owing tu the interest taken in the cluice and purelatse wf works by Mr. Malin, the former librarian and present stewated of the jluspital, and hy sument the meelieal wfficers of the llouse. The present catalugue is an entirely new wor and has been compiled independenty of its predecessurs. For the old plan of dispesiner J). Fincher's plitu of $>$ onew the works in alphabetical waler uf the names of their authers, a classitied arrangement atcorrding $(1)$ subjects has lecen substituted.

Dr. Emil Fischer did this work entirely ly himself while he was subjected to many interruptions, for, during this time, the lihrary was open and the books, owing to their being in use for constant reference, were liable to disarrangement in the regular order they. should occupy upon the shelves. His views as to syitem and details of classification are also given in his preface to the Catalogue from which we have just quuted:

For the classificatim used in the prestont Catalinute, the compriber is essen-

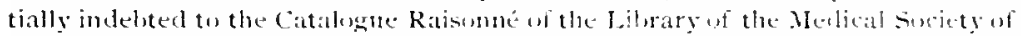
Edimbursh, the arrangement of which has beco followed ont as tar as some litterence in the compass and chancter of the two libsaries would permit.

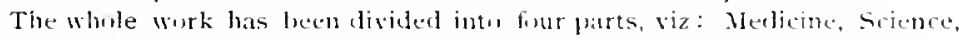
Literature, and Miscellanics. Each part has been subelivieled intu chapters, the first and most inportant part entaining eight es them, viz: 1. Anatonsy, includ-

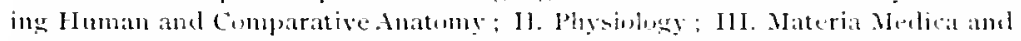

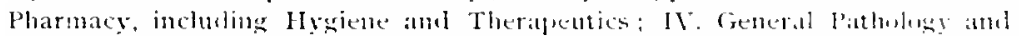

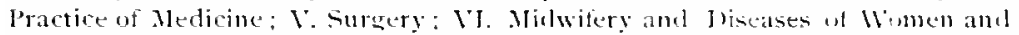

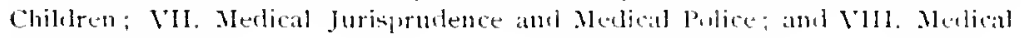
Jiterature.

It will be found, that the classifcation and sul-classification of the difierent chapter coincide, as far as can be in a work of this kimel, with thuse adupted in most systematic works on the ditlerent branches uf merlical and general soienec. Only in those instances where no scietitific eromul for classification cumbl be fombl, the alphabetical arrangenent has leen bad recoutse to.

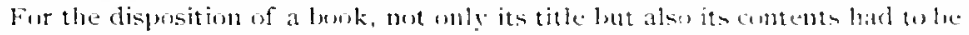

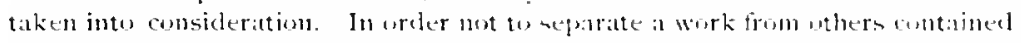
muler a certain sub-head, and treating on the sime subject, Int frum diflerent

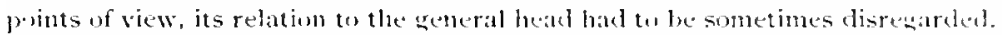

Titles which had to be repeated frequest ?y, were albleviated in accordance to the head under which they were placed, and by this neasure unthedestify

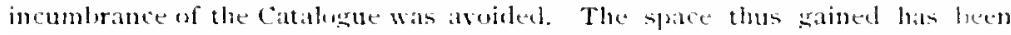
taken advantage of for the quotation of momographs, essiys, \&c. comtaimed in collective works, or in appendices to laterer treatises. These quetations have been necessarily confuned tu suell essays, wheh either wert known to hate been published in a separate furm, or which, from the nature of their contents on extent, seemed to be of sine importance. Sume of these points land to lue ancertaiued by the aid of biblingraphicat worlis.

The Catalugue Raisonne of 1857 , with the supplement isued in I $88_{3}$, is still in use as the official catalogue, and has been found to facilitate reference and to greatly increase the usefulness of the Library. It was received with marked evidences of appreciation, both ly the 
Minagers and the Medical staff of the institution, and I). Fischer had 13e prome satislaction of accomplishing a useful and laborions work in a manuer which retlected the highent credit 10 en his industry and literary shill.

l'rescint

The ardlitions to 1 Sy, liring "u, the agyregate number of volumes

I.ctler from

to If.Siz.comprisod as follows: octavos. I1,103: duodecimos, I 452 ; yuartos, เ s2s; folios, 39\%.

It was poladely a part of the original design of the Managers and

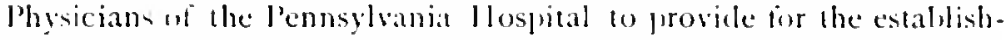
ment of an Anatomical and l'atholugical . Inseum in connection with the justitution, or if this had not lecen their intention originally, it was suggested by them shortly after the new luilding was opened.

It is recorded that on the zoth of April, 1757, Deloral Merris presented a human skeletom, for the purpose of medical teaching. In 1772 a sticleton and preparations of muscles and arteries were pur. chased from the estate of l)r. William logan. deceased and ayain lecember 28, to so, the executors of a l)r. Carter, of Virgina, presented a skeleton to le used for the purperse of instructing students and others attending the practice of the homse.

An important event in the listory of the Ilospital occurred at a meeting of the Managers and Freasurer, which wats held in the Warden's Room at the Court llouse, Philadelphia, the sth oth munth, 1762 :

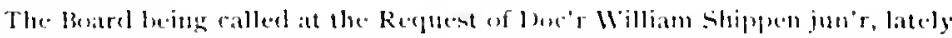

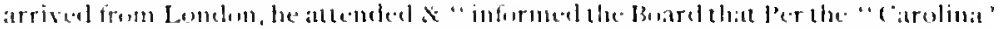

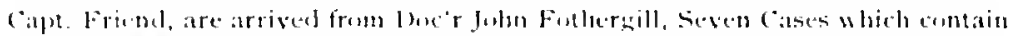

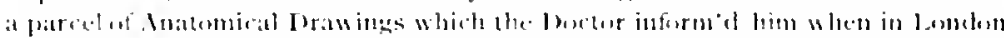

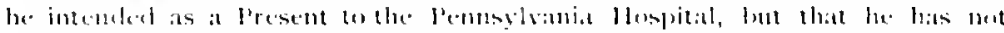

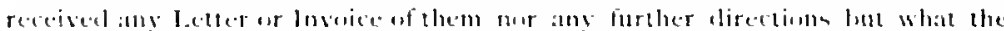

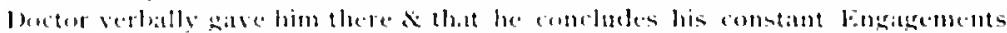
had presented his Writing Per this Shiph But ly a Lether from him to Jantes

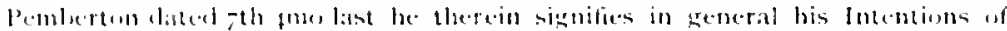

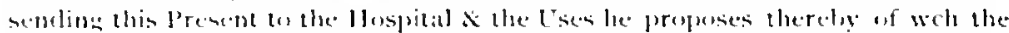
frillom in: is atl Alstratet :

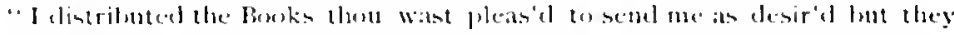

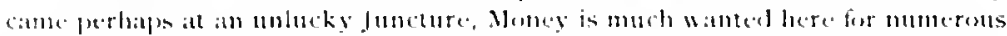

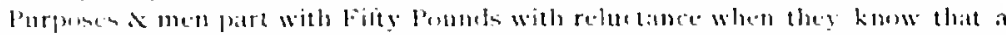

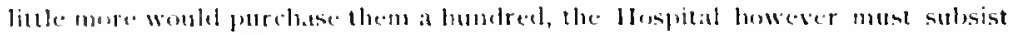

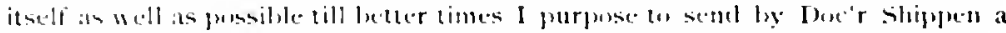
present an it of some intrinsie value the not prohaldy of immediate benefitt, I

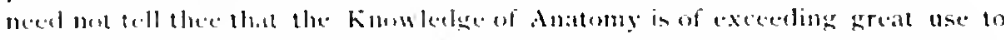
Practitumers in physie $x$ Surgery $x$ that the means of promring suberts with

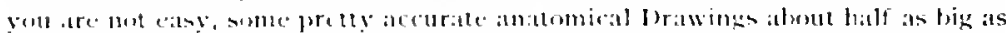
the life have fallen into my latuls is 1 hich 1 purpene to seme to gour llospital to the tuder the care of the l'hysicians to to be hy sume of them explained to the stuclents ur pupils whe may attend the lbuspital. 
"In the want of real Subjects these will have their Cos \& I has e recommended it to Lr. Shippen to give al Courste of Anatumical Leeturestu suth as maty alteml. he is very weil qualitied for the subject \& will smoll be followerl by an able

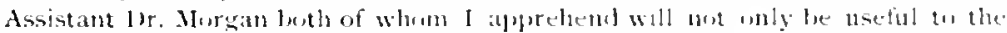
Province in their Employments but if suitably countenanced by the Lenislature

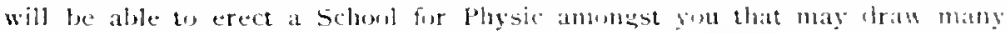
Students from various parts of America o the llest Indien \& at least hurnish them with a better fleat of the Rudiments of their Profenaton than they hase at present the . Weans of acquiring an your side of the Water.

"Slould the Managers of the Huspital think proger I could wish that if the

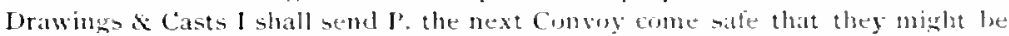
lodged in some low Apartment of the Huspital nut to lne seen by every Persin but with the Permission of a Truntee \& for some small Gratuity for the Benefitt of the llonse. The Drawings are in Crayons 8 sheuld therefore not be kept in too dry a place nor shaked about wo much."

And bector Shippen proposing to exhibit a Ciurse of lectures on Anatomy this Winter requested he might have recuntse to the said lowings \& Casts the Managers ieing desirous of countenancing him in his umlertaking agree he maly have the use of them in such manner and place as after consulting the physicians may be thught most convenient \& least prejudicial to the lorawins as they require to be handled with the greatest Delicacy \& Care after constilting with the flhysicians, who on Notice being sent them attended on the occasion viz. Thomas Bumd, Phineas Boncl, William Shipen, senr, Johı Redman, \& Cadwalader Evans, to whom the proposal of [Dr. Shippen junr. of his exhibiting a course of Lectures $\mathrm{Nc}$. being communicated they unanmously express'd their approbation thereof $\&$ it wis concluded that the several Cases shoubl be comveyed to the Hosplital 8 that the Physicins 8 Manaxers Would attent there to-murtuw 3 o'duck P. .t. to view the Contents.

The Board met November 9, 1762, and

open'd three Cases containing Eighteen ditierent curius Views of various parts of the Human Boly in Crayons framed a graized: three Cases of Anatomical Castings, \&une Case containing at Skeleton \& Futus

It is atereed that the preparitions should be depusited in the fiorth Rom on

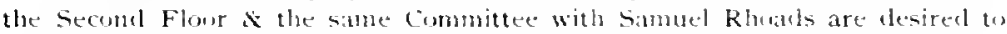
empley Workmon in affix at Partition in that Ronm $\&$ make it comenicnt fint the Purpuse.

In order to comply as near as possible with the lutention of the buntor it is

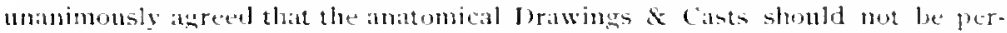
mitted to be taken out of the Rom, the Key of which is to be put under the particular Care 11 the Mantigers in attemance.

And if any l'rotessor of Anatomy is clesirous to exhitit lectures he is to apply to them fir Liberty.

All such Pupils as attend the said Leteturen intencled to be exhibited by 1)r. Shippen or any other l'erson shoukd pay a l'intole each.

And such Persons whe from curiosity may apply to view the said l'antings Sc. should pily a boltar each.

Doctor William Shippen. Junr., met the Managers at the London Coffee House May $17,176_{3}$, and proposed that an adrantage may arise to the Hospital by the Anatomical Drawings and Casts and offered his service to attend twice in a Month to give some general 
cxplanation to such persons who may le desiroun te sew them. The lir. Wm. following advertisement was agreed to be publinted in the next

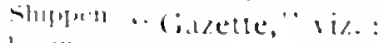

lon.

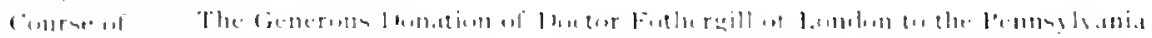

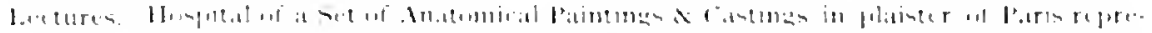

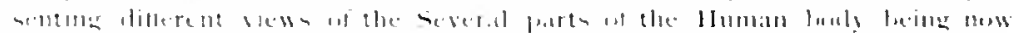

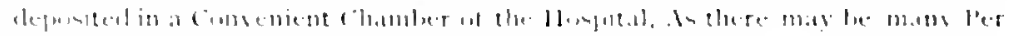

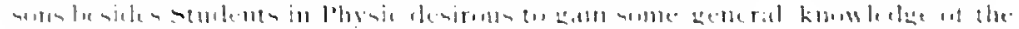
Sirue ture ni the J Jumantumis:

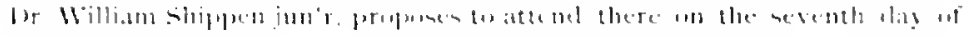

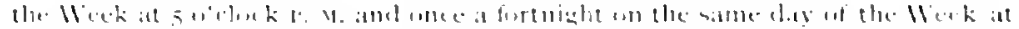

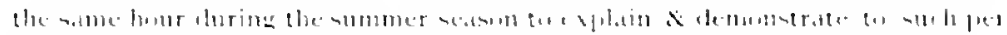

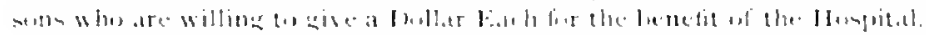

the Manasers male the following actinewkelement to the donor:

letertion

Il. 11 iatserstis Jir. Fintlier. :ill.

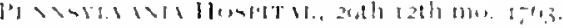

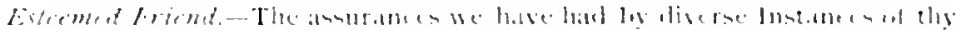

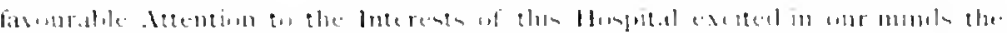

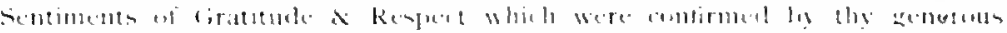

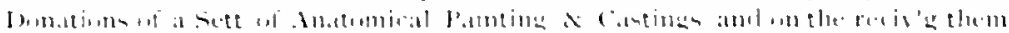

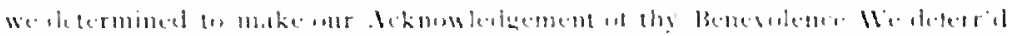

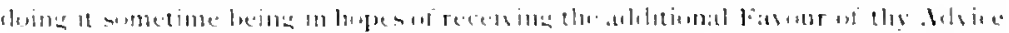

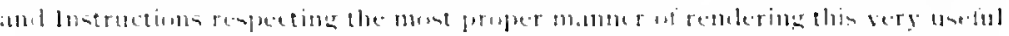

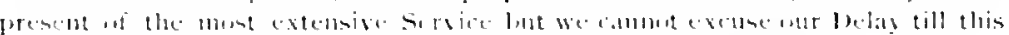

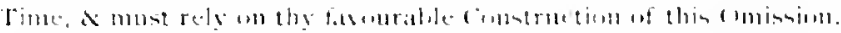

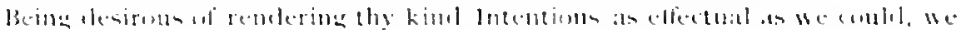

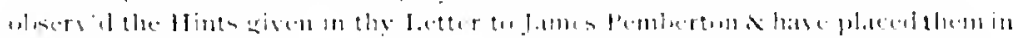

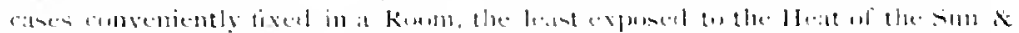

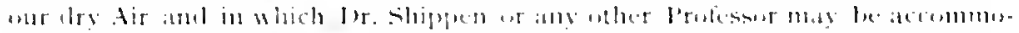

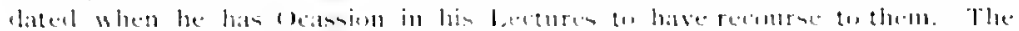

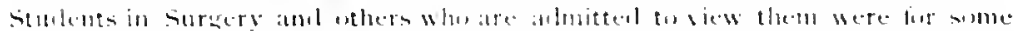

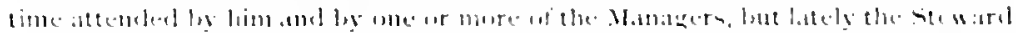

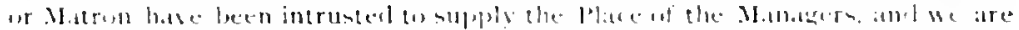

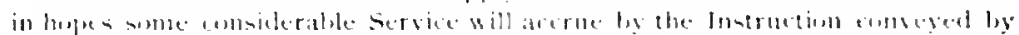
this me.tis.

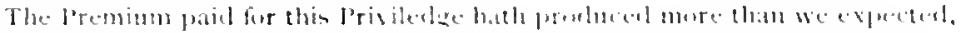
atul when -uch o;

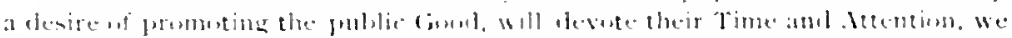

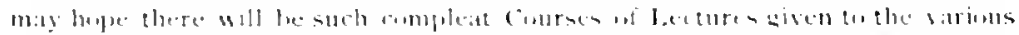

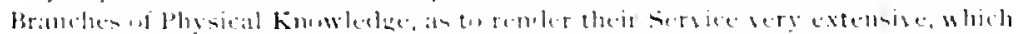

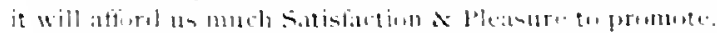

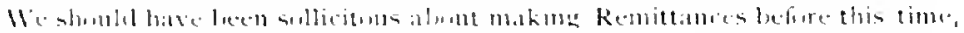

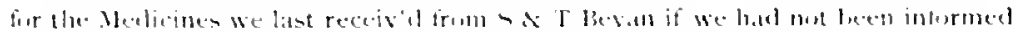

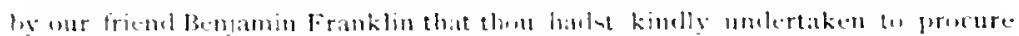

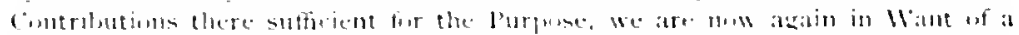

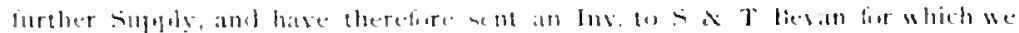

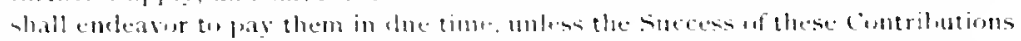

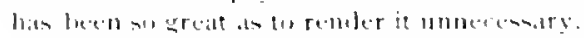

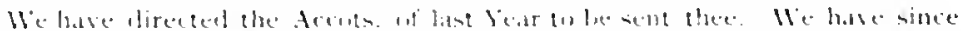

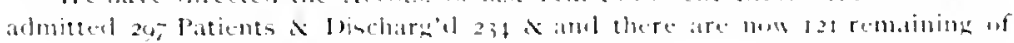

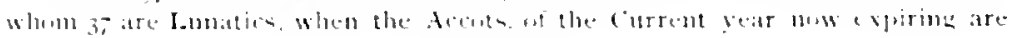




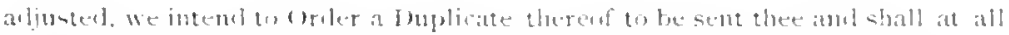

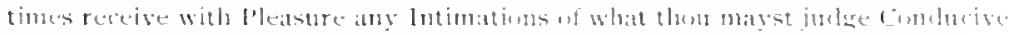
if the lnterest ar tending to promote the purpuse of this lustitution.

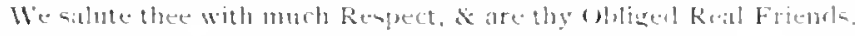

Si) further communication having been received from lir. Letter to

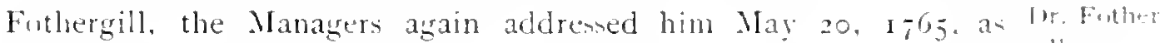
follow:

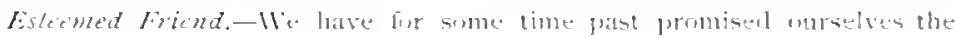
pleasure of receiving a lecter ifom thee en the aftates of this Hespital but ate as yet rlisipprinteel.

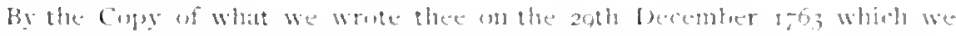

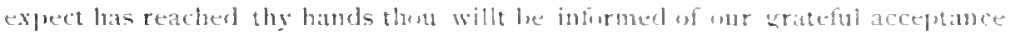
of thy generous innation of the Anatomical bantinge and Casts the manner in

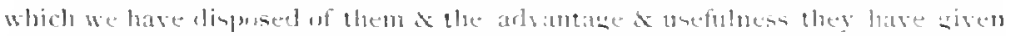
us, as likewise the state of the Institution what the: since which the salme

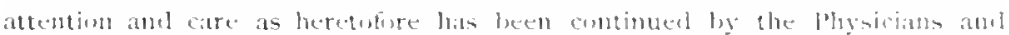

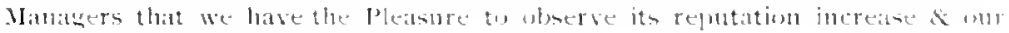
atfilirs in a satisfat try stuation.

The value of the grift from Dr. Fothergill. more enpecially the drawings, which, indeed, compare favorably with any anatomical illustrations of the present day, was very considerable, heing estimated in the schedule of the stock of the Hospital at $f_{350}$. The subsequent history of the Fothergill Collection will be found a few pages further on.

In 1793 . the Managers acquired for the Museum a very remark. able collection of Anatomical preparations, including dried, injecied In diraban and painted specimens. together with a series of lexatiful wax models ly. Chun. Dr. Aliraham (hovet, ly purchase from his heirs. The collection, especially the was preparations, were regarded at that time as masterpieces of art. A medallion portrait in wax made $b y$ Ir. Chovet', in a glass frame, was presinted to the Hospital later.

[1). Chuset was burn in Englankl Mlay 25, 1,04. He was calleated in Lubden and sub. sequently derated several yearsw the study

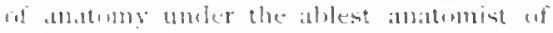

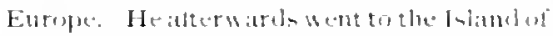
Jambats where he conthued his antemmicat disneetions and studies: from here he tled

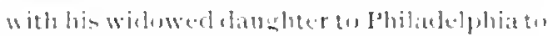
escape an insurectimal slaves, sme years befure the Ameriean Resiluting.

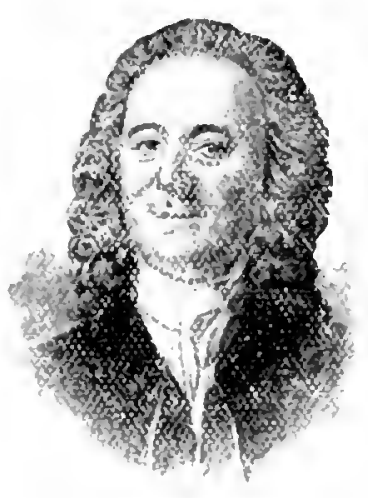

11. Abraham Chovet.

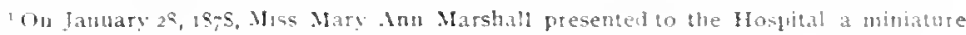
likeness of Dr. Chovet, which was executed on his eightieth birthday. 


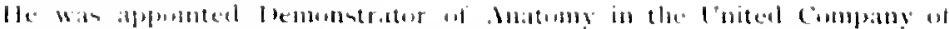

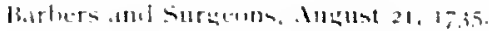

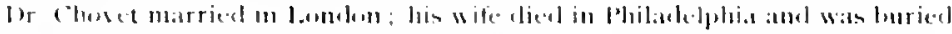

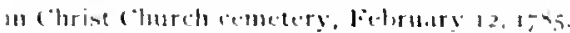

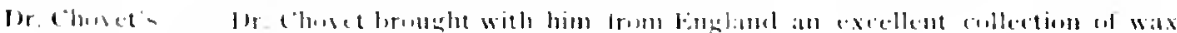

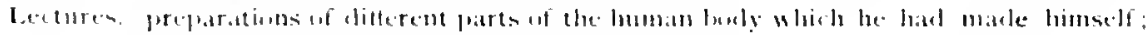

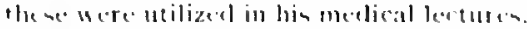

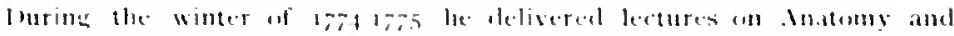

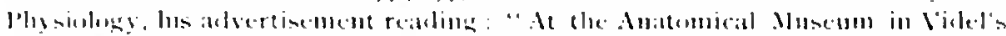

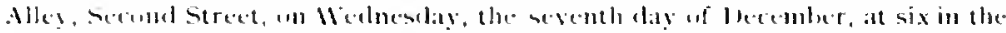

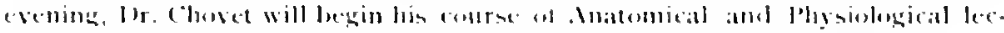

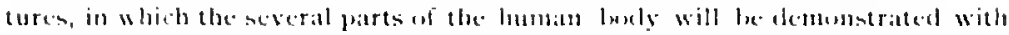

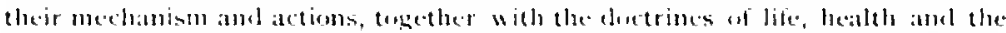
seseral ellects resulting from the antions oft the parts, an his curiens collection of anatomieal wax-works and other natural prepatations: to be contuncel the whole winter until the course is completerl.

"As this contse commot be attemeled with the disagreeable sight or sulell w recent deceased and putrid carrasses, which olten disgust even the sturlents of

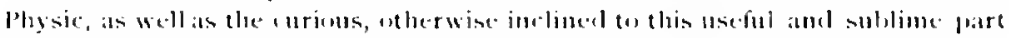

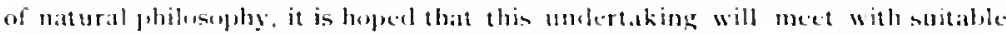
encouratgement."

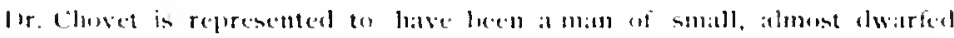

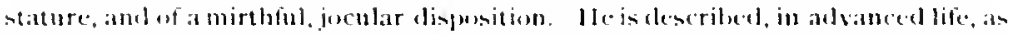

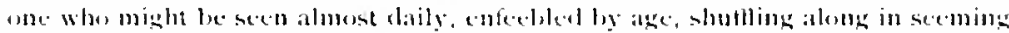

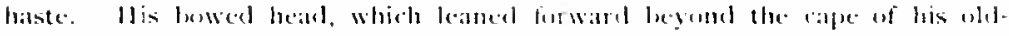

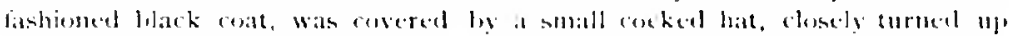

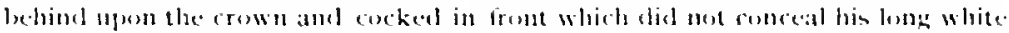

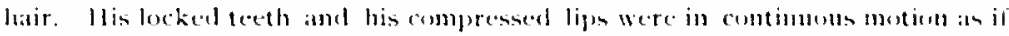
be were crumehing something. Ite carried a gold beated lodian came, secured

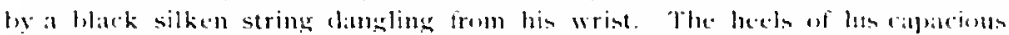

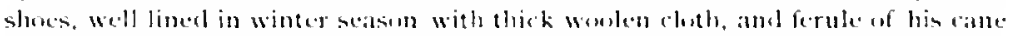
might be heard jingligy and seraping the pasement at every step. ( m the street

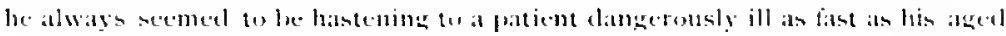

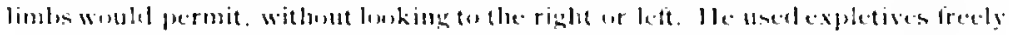

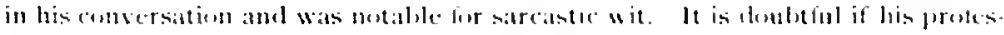

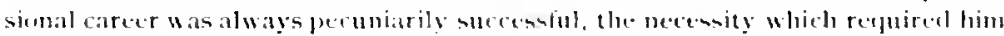
at him alsoured age to within a tew weeks of his death, to vist patients in all kinels of weather, wumbl melicate he had not met with linancial sucess. IJis

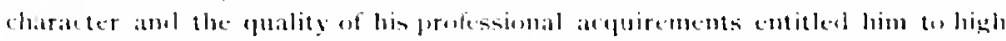
rank amone the medical professiom, and with them to respectful remembante.

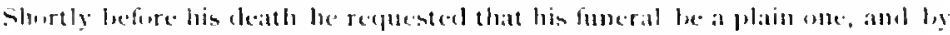
me means to have the bell rumg fut him, as was the custom of the thmes when at

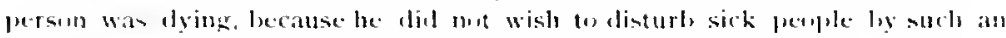

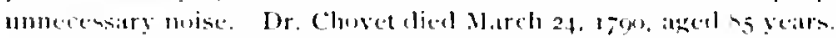

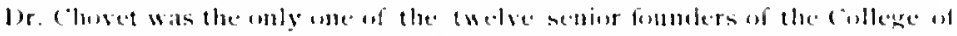

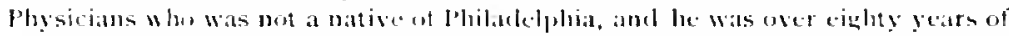

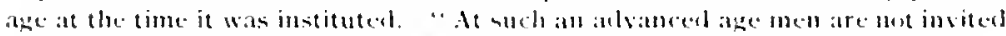

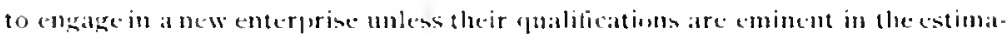
(ii), of their colleagues. "

In 797 , Dr. John Reelman presented to the collection a representation of the bones of the ear, made of bras. 
August 26, 1799, the Manager entered into the following arrangement :

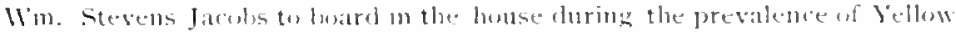
fever and whle here lo put the musemon in ared order. an pay st per week hir his

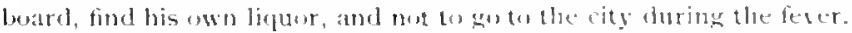

Dr. Jacols apparently was in no great haste to complete his work or had great dread of the epidemic, for we find four years later, May 28 , r $80_{3}$, he presents a bill "for putting the museum in good order and making a skeleton." I'ossibly the museum required more attention than was thought necessary previously: but whether the services of Dr. Jacobs were continued, or occasional, it appears that he was the first official curator of the collection, unless Dr. Shipplen may be regarded as the first to fill that position.

January 28, 1805 , a Catalogue of the Museum and Lilirary was compiled and printed. A month later (February 25) a committee was instructed to remove to the new museum room the paintings and castings, etc., under the inspection of Irs. Physick and Wistar. This work appears to have heen done leisurely, for the committee did not report the work completed until June $24,1805$.

A special caretaker of the Museum having been appointed, the following receipt for the preparations was given. which in of interest as an inventory of the 1 luseum at that time:

l'Exis. Hospltat, 25 h amo. 1906

Received under my care and resmonsibility from the .lanagersof the loupital all the articles of the Anatomical muscum comtanes in the list therent vith

Imitations of the internal parts of the human buly in sax ly the batte Dr. Chwet from No. 1 to No. inclusive.

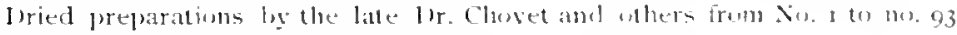
inclusive

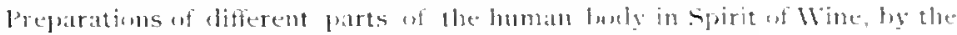

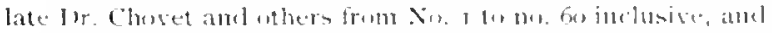

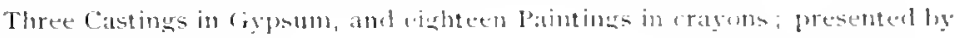
Th. Finhergill of Lomdin.

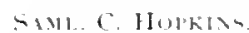

The nusem rapidy increased in size and importance, and steat interest was taken in adding to the collection ly all of the members of the medical and surgical staff. When in $x 8 x z$, the building was erected for the exhibition of West's painting, accommodations were made in it also fur the anatomical and jathological preparations.

In $182+$ it was decided to part with the museum. which had now become so large as to refuire special provision and care. It is also to be considered that medical instruction no longer occupied such a prominent prosition in the minds of the Managers, since other institutions had sprung up in the community which relieved the Hospital of 


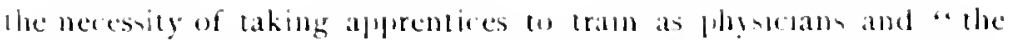
frit lice of the bonse" ceined to bold its former impurtant place in medical instruction in this comntry. On April 26,1824 , thercfore, the following wats adophed:

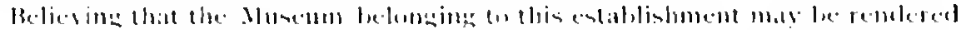

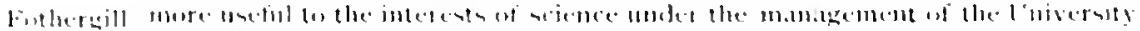

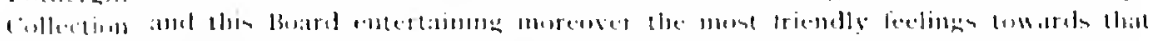
[x.punitiol m

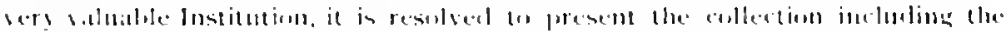

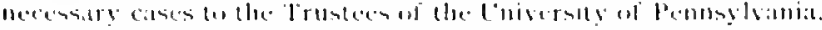

Sulsecpnentl the following wan received by the Managers:

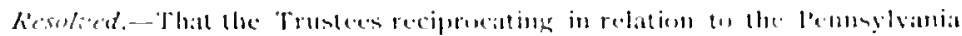

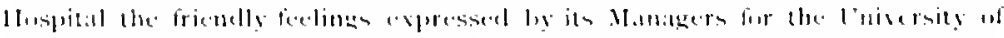

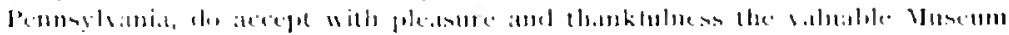

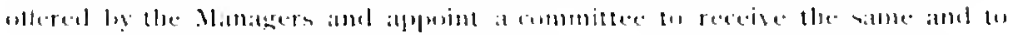
furninh the Ilompital with a colly of thie minute.

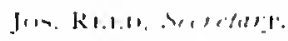

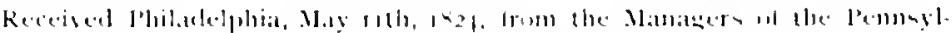

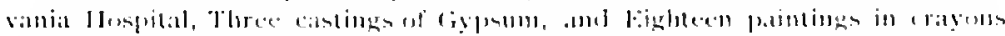

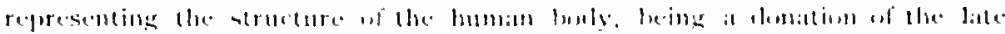

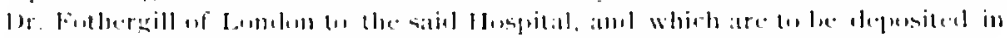

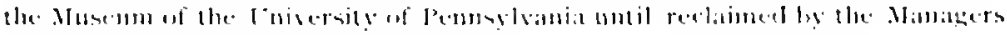
of the sitid Ilespoitat.

$$
\begin{aligned}
& \text { Jutk ditlind }
\end{aligned}
$$

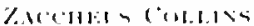

$$
\begin{aligned}
& \text { (it)mmille's t) the Histal .Huwam. }
\end{aligned}
$$

The last clanse in the alove receifl was inserted lecaltse it was leclieved that the feller accompanring Dr. John Fullergill's domation would preclude the collection from being permanently alienaled.

11 was several years before any systcmatic allempl was made to make another collection. Rare cases orcasionally creurred, and interesting specimens wete ollained by surgical operation, or dissection, lut no special place leeing supplied by the Managers, they were usually regarded as the private property of the surgeon, or physician, who discovered and retained them.

On December 26, is53, the members of the Surgical Staff requested that a room be appropriated and properly fitled up for a pathological museum. This was agreed to and some specimens were securcl, but the allempt to establinh a musem at that time was ahandoned shorly afterward.

Sulsecptently, Dr. Thomas (; Morton especially interested bimself in forming a collection and, after serving a term as Resiclent llysician, he was formally appointed, in 1960 , Curator to the Musem and lathologist to the llospital. A series of rules were framed by him with the approval of the Managers, for the regulation and development of the Museum, then located on the first floor of the l'icture llouse. 
The Managers, on April 27, 1863. having inspected the Mlusem and leing much gratified with their visit, unanimously adopter! the following:

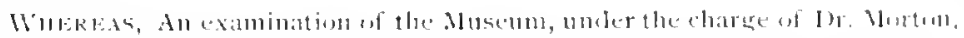

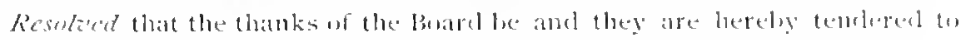
J). Mortun fir the sery eflicient mamer in wheld he has discharged the important luty entrusted to his cart.

Ir. Norton held the office for three years, when he was elected to the staff as one of the Surgeons, but during those early years he labored with such zeal and industry that he gathered a valuable collection of several hundred pathological specimens, both wet and Ury. These are the foundation of the fresent museum, " which owes its existence." as a sulmequent curator has declared, "to his zealous interest in pathology." After lr. Morton had resigned. the position was acceptably filled by lor. Willian Pepler, who was aprointed Curator and lathologist by the Managers, in $186_{3}$. In 1869 , when the new clinical amphitheatre was opened for use, the Museum was transferred to the first flowr of this lublding, in a room with northern exprosure, well lighted and commodious. (Seevignette on next page.) The drawings and casts presented by br. Fothergill were returned from the University of Pennsylvania, and still occuly a prominent position in the Hospital Muneum as objects of conspicuous interest. Dr. lepper compiled a lescriptive Catalogne of the Pathological Museum which was pullished by the Board of Managers in 1860 . Ile stated that this was:

"Basted upun one witten hy Dr. Muntun which contaned the descripdins on three humbled specimens, each of which, however, has been carefully re-eximined and more fully deseribet."

The system of classification and numeration followed that in use in Guy's Hoppital Museum; the name of the donor being affixed to the description of each specimen, and if an account of the case has been putblished, the reference is duly given to author and flace of publication. In compiling this Catalogue, I)r. lepper acknowledged his obligation to the kind assistance of Dr. Charles Retz, Resident Physician in the IIospital.

Dr. Pepper resigned in $\mathbf{1} 87$, wherempon the Managers appointed as Curator, Dr. Morris Longstreth, who served until r\$go, when he resigned and Dr. Ilenry M. Fisher was made "l'athologist, Curator and Microscopist."

Dr. J. Forsyth Meigs in his History of the "First Quarter of the second Century of the Pennylvania lfospital," pullished in 1siz. remarked: 


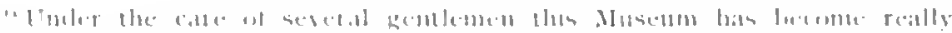

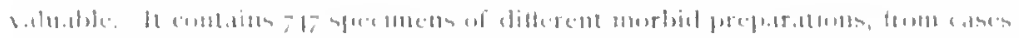

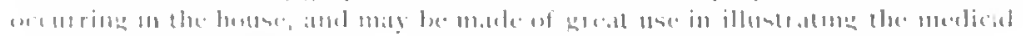
teilliting at the Hompll.1]."

In 1.975, a regular course al lectures on Pathological Anatomy. illusirated by specimens in the Insem, the only one in the city at that period, was griven ly the Curator of the Ilospital, lir. Longstreth.

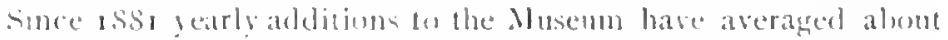
fifty a year. Al this lime (1Syt) they bave practically reased, at the room for their accommodalion has heen entirely filled and further growth is mot pessible. Lectures are annually given by the l'athehogist, and the morlisl and antomical prejarations are constantly in demand to illustrate clinical lectures, which are dedwered lefore large classes of meelical stutents every year, from (Motoler to . Varch. inclusive, in the clinical amphitheatre.

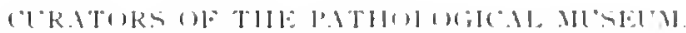

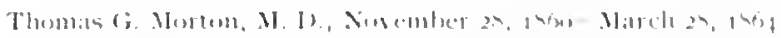

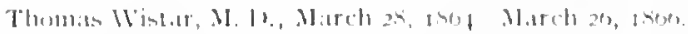

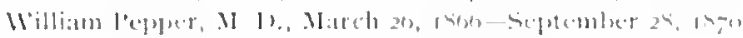

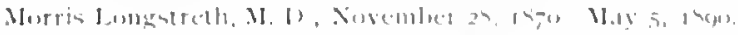

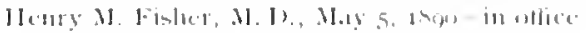

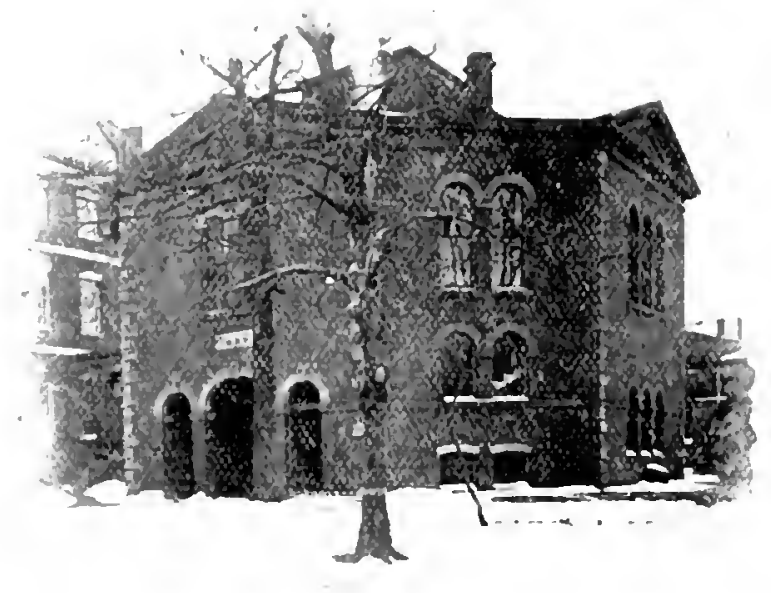




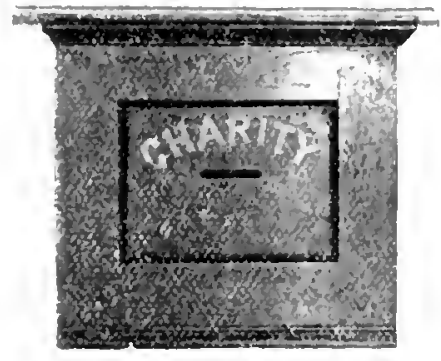

\section{LEGACIES, DONATIONS, AND CONTRIBUTIONS.}

The capital stock of the Hospital, from time to time, has lieen aided by legacies, which have materially increased its resources and its means for carrying on its charitable work. Among the larerer sums received by bettlest, were legacies from the following:

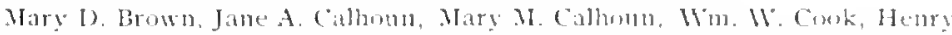

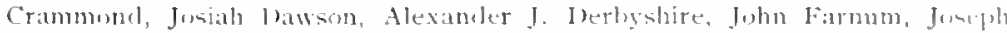

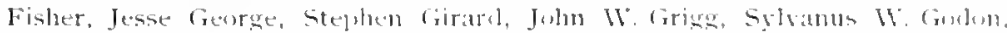

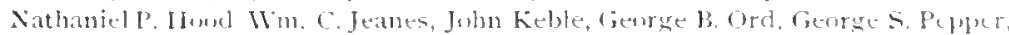
Mary Shields, Itenry T Stont, Samuel Welsh and Isaiah V. Williamson.

The family of the late l'resident of the lioard of Managers. Mr. Wistar Morris, made a munificent donation, which has been already referred to. (on prage Iro.) Mr. $\mathbf{W m}$. E. Garrett and the Misses Hlanchard have also made very generous contributions.

The organic law of May 1 r, r 75 r, creating the Pennsyluania Hospital. made it lawful for

"All persums wh had contributed ten puonds or more tow:urels the Ilospitat Powers and Inties af Cimbributors or any number of them, formet on the secomd dity of the lirst week, in the month called May, yearly for ever, to etect hy ballut, ewelve, fit and subtable persons of their own number to be managers and one sther person to be treasurer w the Ifospital until the next election: tomake such laws, rules, and orders, at whill alpear necessary, for the well governing, ordering and regulating the satil Hospital, and for the regulation of the future elertions uf managers, tratatret,

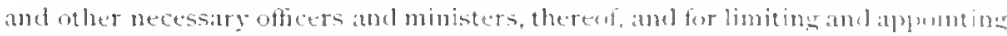
their number, trust, and authority, jorsided they be nut repunmant to the lans

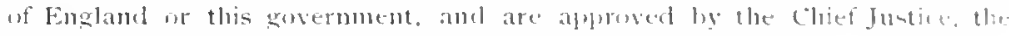
Speakerof the Assimbly, and the Attorney General. 
Other provisiom of the let were, that the cintributors to the

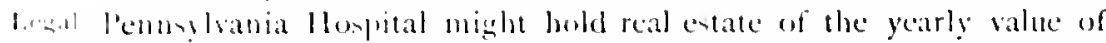

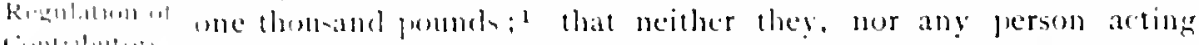

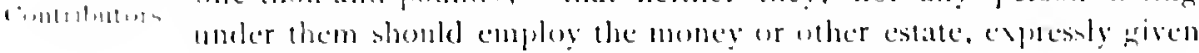

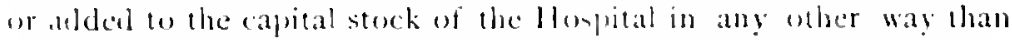
lis alphying its anmol interests or rents toward the entertainmem ant are of the sick and distempered proor: and that patients should be recereat from any part of the l'rosine withom partiality or pref. creme : that an anmal statement should be renclered to the leginlature, also. if at any time the Contributors should tail to make yearly elections of managers, the Hospital, its estates and affatrithereof and the management should devolve on the (ieneral Ascombly.

The flace of hemor among the contributors belonge to becters

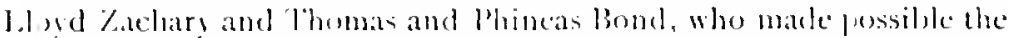
establishing of the llespitat ly semeromsly offering to ateond the lloyital wratis for three years.

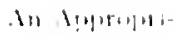
$: 11+211: 13+1,1$ l'ipliliu $-113+191+11$

As som as the law extablishing the llospital and granting the sum of two thousand pound towards the foumding, building and furnishing of the same was formulated and its condition made known, that an expal

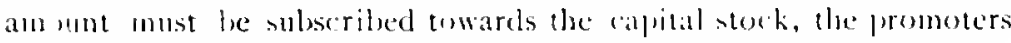
of the design promptly set on foet a sulmeription, which in a short

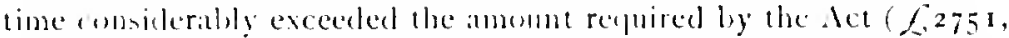
16s. Sil). The subscriptions varied in sums from ane pound to two hundred and fify, the latter being contributed by William Itlen, Chef Justice of the Province, but for the most part this amount was made ul of stmons of from ene to thirty poutsds.

The earliest and first gift of land, abont four acres, lowated in Surthern liberties, near l'hilatelphia; on the (iermantown Ruad, was donated september 2, 1751, as a subeription of twenty-four pound by a Cerman. Matehias Koplin, wh was aceordingly made a

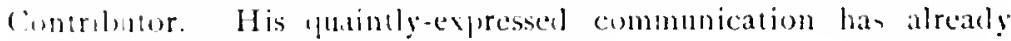
lecen ynuled (jage 26).

Hwing to the vigilance and constant importunities of the llanagers, the cuitom was introduced into the community of contributing jury fines, contested sums of money. moneys in the hand of trustees. arignces and other sums not claimed. leceased strangers' effects and valuables were also turned orer to the llospital anthoritics, the Managers griving bonds to protect the donors and others, and to inclemnify them in case of clam from heirs who might appear to denand a rentution. 


\section{LEGACIES, CONTRIBUTIONS, AND GRANTS FROM 1751 TO 184}

The Pennsylvania Hospital from the year 175 i up to the fresent time, has received numerons smms of money from various sources.

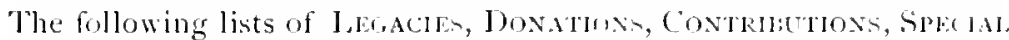
1)EMostrs and GRANTs include the amounts received, with the dates and names of donors. Those persons who contributed the sim resuired to constitute the individual a member of the Corpuration, will appear in a separate "l, IsI or ConthIb mas."

\section{LEGACIES.}

A

1512 Albingtom, Susamma I".

175 Abrabins, Enorla

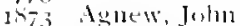

r 65 Allem, ifamiah :

1,61 Allen, Mally.

I7-1) Allisin. Rubert.

I.6I Andrews, Mary

1706 Armatt, Antalderent

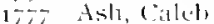

inity Asli, (atel)

$1 \rightarrow-0$ Ashidiclé, Aaron

I to Ashetom, Marsaled

1310 Aston Cienrige.

I 94 Atmore, (allel)

B

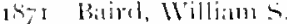

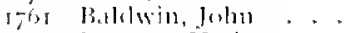

15i-2 barlett. Ninthan.

litere Bartoll, lsibal . .

1,56 Balyoton, Peter...

rifle beck, Hant, Ji.,

1,65 Benzel, or bensill,

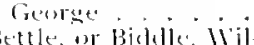
li:In1

Itig, Biclalle, Maly Jivingston cistiran

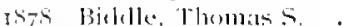

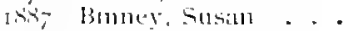

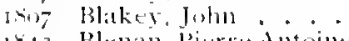

1,43 Blenan, lierre Antoine

1s-3 Buker, chatrless.

sion Bullen, Villiam II

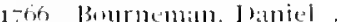

ros Bumplet, Gen'] Henry

16is Brallumi, Nilliam.

1503 Breack, Sitnumel ...

17.20 Briglut, James. . .

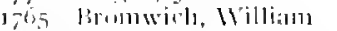

whot Brown, Benneville b)

i-n.5 Brown. ("liristopher.

Inz:5 Brown, Mary I)..:

Ition Buller, Benjamin F. C

1753 Cadmalater, Juhn Rolverts i c.

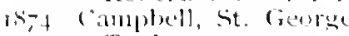

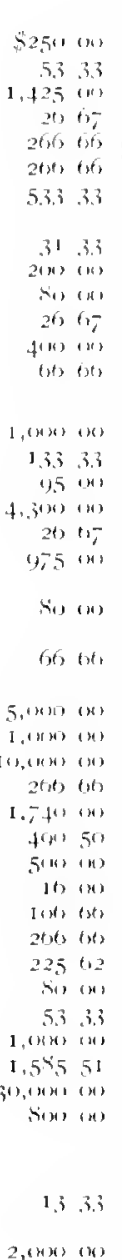

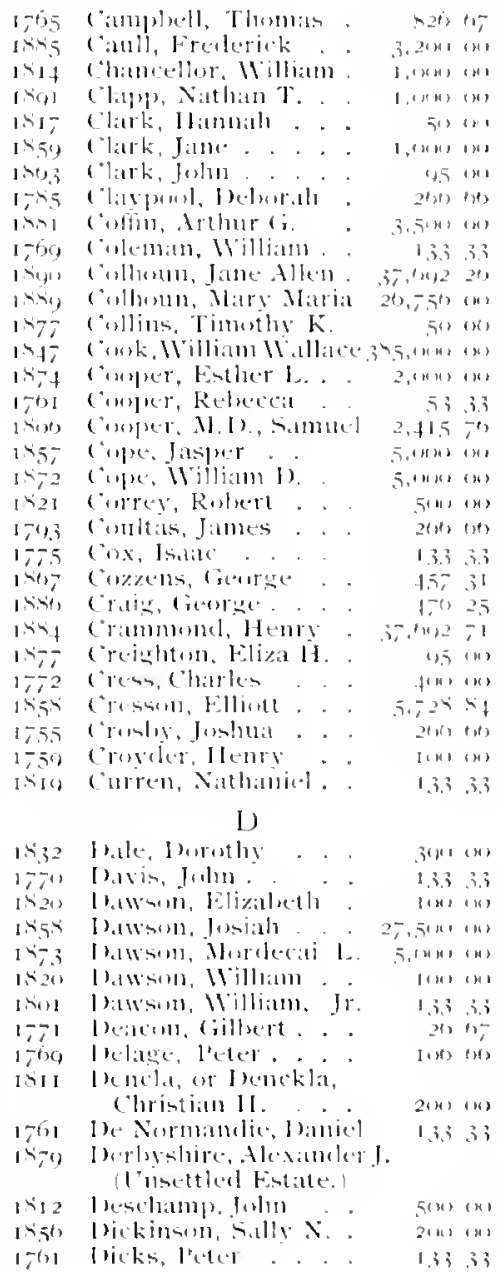




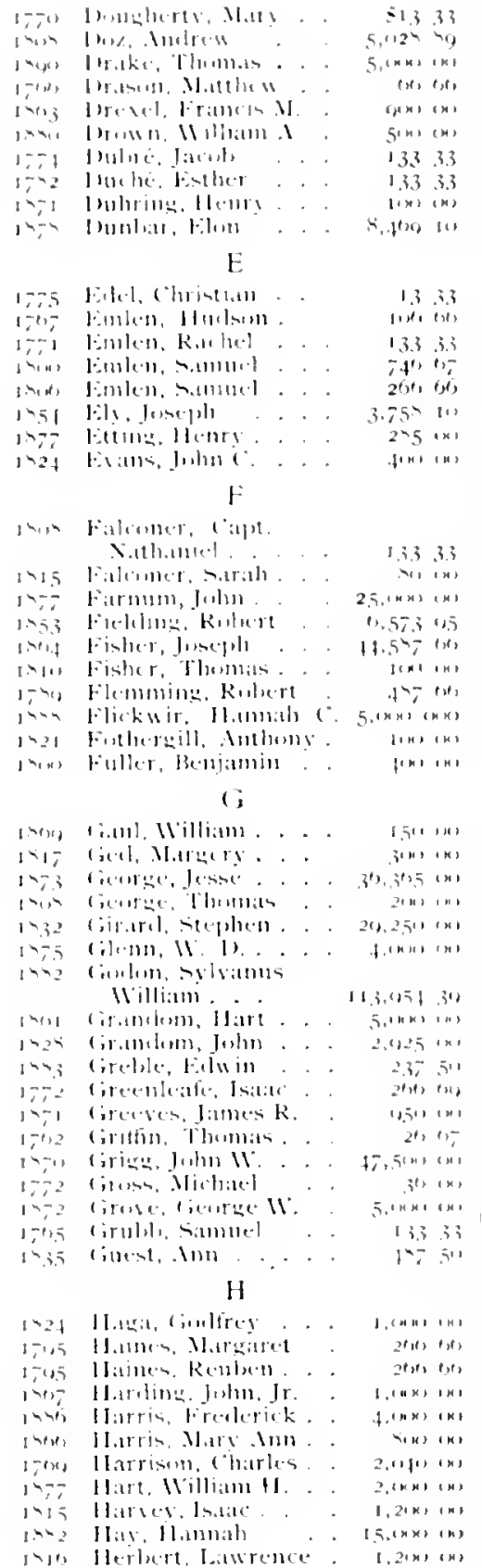

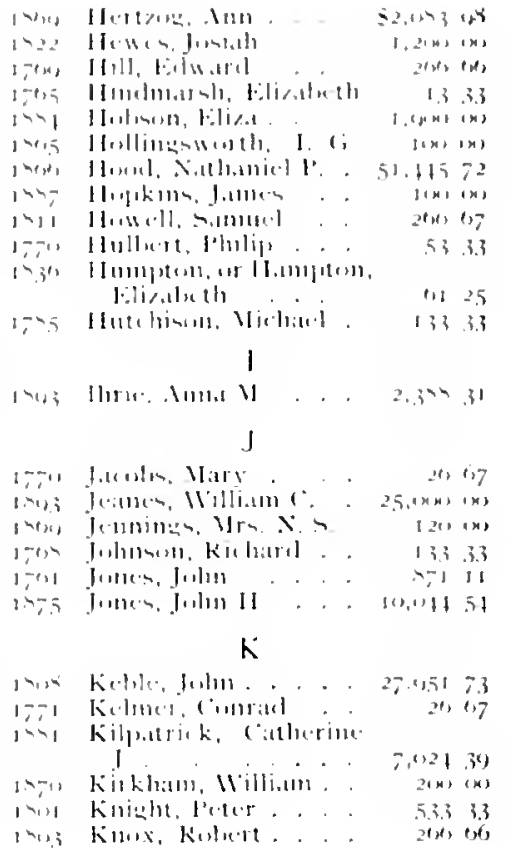

\section{1.}

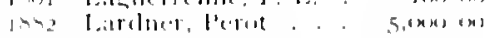

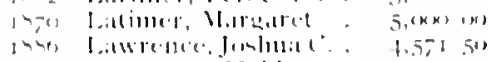

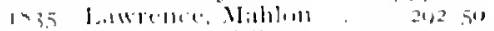

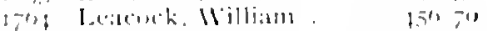

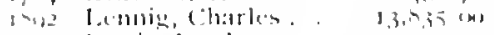

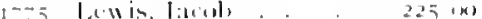

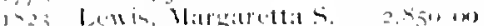

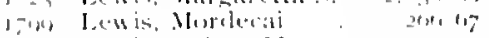

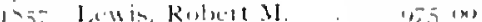

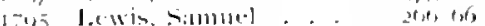

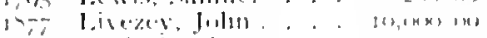

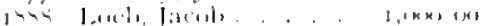

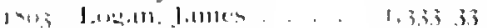

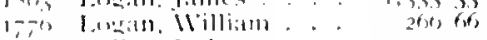

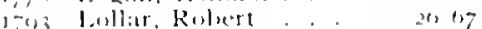

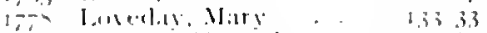

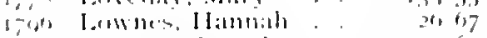

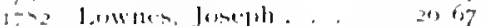

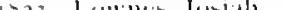

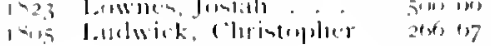

\section{$\mathrm{MC}$}

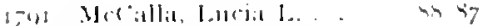

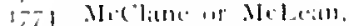
Arohilsilal. . 2667

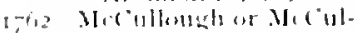
link, fomes. . . 2301

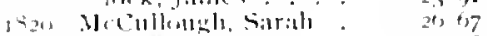

1 thit Nelintre. Pintick. 2, is 


\section{M}

\begin{tabular}{|c|c|c|c|c|}
\hline 16 & Nobur, tlexander & & $=26$ & \\
\hline 45 & Marriatt, Sitral & & 66 & $t i t$ \\
\hline in & Marslatil, Benjamin & & , on & \\
\hline 765 & Marshall, Josejulu & & $I, 3,3$ & \\
\hline (ivi) & Nenall, Jishne. & & & \\
\hline 92 & Mereer, Alexamuler & & & \\
\hline-66 & lerkle, Frederiok & & 29 & $4^{10}$ \\
\hline-1 & ick, Samnel I. & & 2.50 & \\
\hline 6,5 & $l_{e}$, Siln & . & bo & \\
\hline$i 59$ & Abrahit & . & 16,393 & tha \\
\hline-7 & Johin S. & 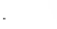 & $9,5,11$ & \\
\hline 96 & II, Millian!. & & 1.33 & . \\
\hline 10 & $\therefore$ Ruln. & 1 & (1)in & 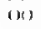 \\
\hline 2.3 & & . & 59 & 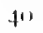 \\
\hline 1.3 & 的 & & $1,21,5$ & 3. \\
\hline$(n)$ & , Cathirine & 11. & 1 (g) & i \\
\hline$n$ & 13 & . . & 222 & 2 \\
\hline 55 & Jacols $G$. & & 507 & $5 r$ \\
\hline 4 & ) & . & 13.3 & 3. \\
\hline 70 & & & 66 & $t$ \\
\hline 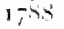 & $t \cdot I^{-1}$ & & 13,3 & 3 \\
\hline 7 & 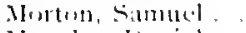 & . & 133 & 3. \\
\hline 68 & , I)anitul & . & 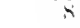 & a \\
\hline & John. & " & 5 & 0 \\
\hline & & & & \\
\hline & & & 33 & 3 \\
\hline & 4 & 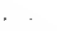 & (6) & 0 \\
\hline 96 & uhlin L. & * & 5.7043 & 0 \\
\hline 37 & ; Charles. & 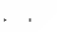 & 5.4019 & 1 \\
\hline & n, Cisntent & 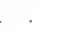 & 66 & $(x)$ \\
\hline & & 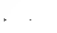 & 260 & bt \\
\hline-2 & n, Cluales & & $2(n)$ & $a$ \\
\hline & . & & 225 & 1 \\
\hline
\end{tabular}

\section{$\mathrm{O}$}

14i, (M.lkman, Isatel...

itify lole, citharine

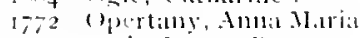

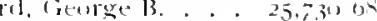

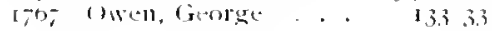

$$
\mathrm{P}
$$

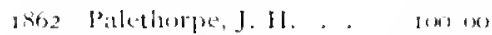

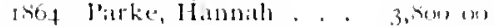

183.3 Patke, Thomats. . . 59 of

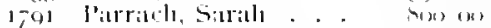

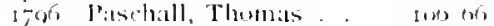

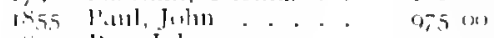

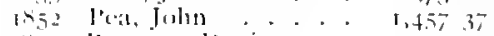

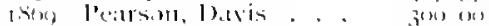

1,01 lembertun, Esther $\quad 1.33 .33$

1.12 lembertun, Juln] . I is

1795 lemell, Joseysh . . bis of

liso, l'emseck, Casper II. II. 11.

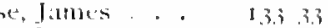

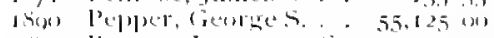

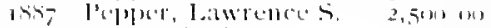

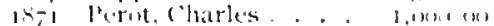

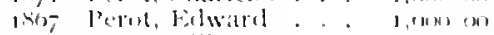

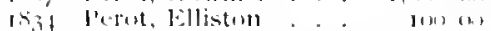

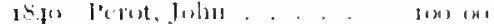

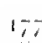

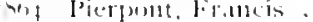

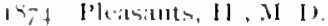

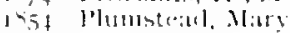

17,76

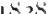

Isiti-

inti

Potts. Nintian

Pumell, M.11hlia.

I'rica". Jiselel

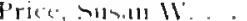

$R$

17- Ratiostram, Milliam

1) R R

$110^{*} 1$

I, fol Rawle, Finucis

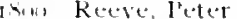

tong Richards Flimaliet

(iti

$1,-613$

1,60

1)

1 iest

1,65

$1-10$

$1>1$

ITI

1 $19-1$

$\{x-6$

$1+i g n$

$1-0,0$

Itisi

197

Rehards, Elizalieth

Richardsion, Juseply

Rislatlinger, Jacoh.

Ruserts, livinal.

Ruberts, Hugla...

Ruberts, Julun. .

Rulusmo, Rudnatn

Rubringur, septimma

Rulinsmo, Thomas

Ruclue, 1.

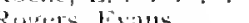

Russ, Alllal fox

Ruelisill1, Ante M.

Rumdle louret

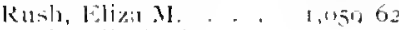

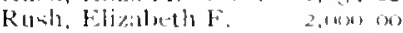

\section{s}

I $1>0$

I 1,2

$\lim _{1 \rightarrow-1}=2$

1706

1702

[ 120

154

I, -4

I $\sin 3$

intis

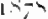

$1>313$

140.3

I 19

ixis [

1 iोis

$t \rightarrow(0)$

1,03

17in

saterer. Arlelaticle

Sager, ciatliarine $\$$.

1,125 tot

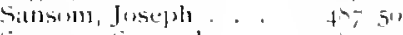

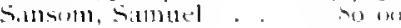

s.tuer, chriatopher , 5.3.33

sulunelermsu.

(")rintuplice. . . 2 2666

Soutt, silmuel. . . St be

Sonten, samulel, . . 190 6-

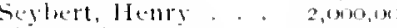

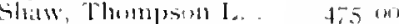

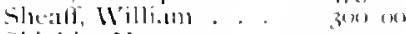

Shitels, Mory . . M 15,3104

Sienar. Peter . . . 1,103 33

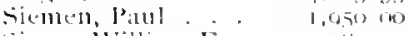

Simes, William F. 5.06333

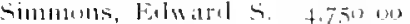

Simmuns, simmel K. $5.040,100$

Simpsisl, Janles. . 2, 5in m

Sims, l3uckriclge, , 2066 6-

206,60

surith, Jamesi.

lo,

$1,2111.917$

$1,4 \times(0)(M)$

$5,3,3 \quad 33$

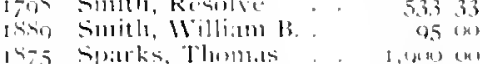

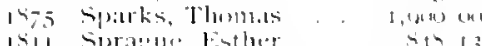

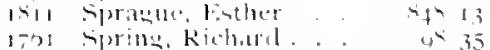

1 Rewiluary hequest.

"\$noo tor "Henty M. Ihillips" Free Berl. 


\begin{tabular}{|c|c|c|c|c|c|c|}
\hline 17 ists & 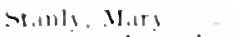 & & $=(x)(x)$ & 173 & $11: 11$. Joln & $=113330$ \\
\hline $17-1$ & t.umline, |lontel & & zp) (it) & 101,2 & $11:$ all, $\therefore$. I.inle & $(1,1)$ \\
\hline 1 & stovenaill, Millath & & $5.1 \times x), 1 \times 1$ & $1=-1$ & Mallun, Salmutel & $5(\mathrm{~m})(\mathrm{m})$ \\
\hline$-i+1$ & Stuip) Jamids & & $1, n+4,31$ & 175 & 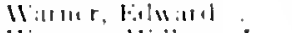 & 3.9210 \\
\hline $7+$ & $S t, 1, t .11, n) !$ & & $25,(x),(x)$ & 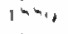 & Millian Jr. & $\theta(n x)(n)$ \\
\hline$\because 1$ & 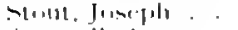 & . & $2 x$ in & $=11$ & l). IVilli.um & $1,7.511$ \\
\hline$\because 2$ & Sitrettell, Inn & & 5.3 .3 .3 & $-1,1$ & h, Sitmuluel. & $5(x, 1 \times n,(n)$ \\
\hline & a 50 & & & & herill, fieverge 1 t & $5(x)(x)$ \\
\hline & & & & 5 & all. ( "h: & $5(x, 1, x)$ \\
\hline 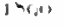 & 11 & & $4.51 \mathrm{ki} \cdot \mathrm{Mr}$ & $\cdots$ & tim, K: K & $2,-4,10$ \\
\hline$\because$ & Teriofele. Juene joh l: & & 11.5255 & $n+1$ & Ihatlan. INilhats. & 1.54 .3 .3 \\
\hline 11 & lis, \1111:1! & - & $\therefore 11.11$ & $\because 2$ & . Milliam. & $21 ; .3 ;$ \\
\hline$S^{p}$ & s, lol,11 k & . & $1 .(10,11,4)$ & 91,5 & 11. l'tet & $1,1,1,1$ \\
\hline is & in. Marearet & & $1,3,3.3$ & $x=$ & $-2 x+1+1 \cdot 11$ & $\left.m_{1}\right)$ int \\
\hline 1,1 & ill. Tlı, & . & $2,3.3$ & $\sin$ & dinder. Imolials I & $(1,5,1 \mathrm{HN})(\mathrm{N})$ \\
\hline $4 \times 1$ & isplist. Milli.tm. & . & $3 . i^{+}, 07$ & ne:- & & $|(M)| N \mid$ \\
\hline $17-3$ & $t^{2} r, 1$ teder. & & $2(x)+t_{3}$ & $-1,=$ & י. Kulnert. & (2) 4 \\
\hline$\because 1$ & Turatel, Flumbers & & $f(x)(n)$ & $1,-71$ & A111. Mill & $5|x|(x)$ \\
\hline & $y$ & & & 1912 & 11. AnII,1 11 & $(O), A N \mid, \alpha)$ \\
\hline & & & & -7.5 & chertesteper & $f(x)(n)$ \\
\hline 1,1 & (c. 1, 1, XI & & $4.7-2+$ & $-1,-$ & min & $2(x)(x)$ \\
\hline $1=-11$ & , Fil\% || & & $B, A M)(A)$ & $12+12$ & T. 11 illi & 1.3 .3 .3 .3 \\
\hline $1=-3$ & Vatux, Williams $=$ & - & $1.1 \mathrm{man} 1 \mathrm{100}$ & 17,0 & $111-2.11,1,134, ; 1$ & $5.1 \times \times 1 \times 1$ \\
\hline & 111 & & & 1015 & 18 & $5.0 \times \times 1, \times r$ \\
\hline 1925 & Withamuth, Julu & & & $1=-1$ & $\begin{array}{l}\text { li:11,| |l } \\
\text { li:and }\end{array}$ & 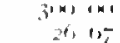 \\
\hline & 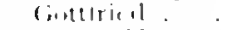 & & $1,0,50+10$ & $1-1,2$ & & $(4,0)$ \\
\hline 5 & r. Mary & . & $I, \mid M R)\{H$ & & & \\
\hline 5 & r. Tuloish. & & $110.011 \div$ & & & \\
\hline 3 & were, Aliral & litm & 53.3 & 1,55 & 131.111 & 1,11212 \\
\hline at & Cy, Simned C. & & $(1,20+1), 0,5$ & $1-1,2$ & Jatlaill & $x=1,1.5$ \\
\hline ines & Nilley, somtuel st & $e+c \mid e^{1}$ & & $1=-1$ & \%ablue, sillabls. & 110, ton \\
\hline
\end{tabular}

\section{CONTRIBUTIONS TO THE HOSPITAL,}

\section{FRO.H 1751 TO ISO4}

\section{A}

\begin{tabular}{|c|c|}
\hline 14 & Nlandt, recogere \\
\hline $5 \%$ & 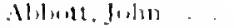 \\
\hline 14 & 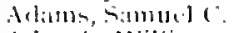 \\
\hline $1-\rightarrow 1$ & Adrock llilliantw \\
\hline $\operatorname{lint} x$ & Aertant). Mins. \\
\hline 1,55 & Age, Mirhatel \\
\hline 1756 & Akinges lohn \\
\hline $17 f(x)$ & Alferto, Jhilig. \\
\hline 1,55 & Alexinteler. Jiamen \\
\hline 1007 & Allen, (hatris J \\
\hline 750 & Allew, (ajt J) Jow \\
\hline 1554 & Allen, Jolin $\mathrm{K}$ \\
\hline $175+$ & Allert. Nitthanitel \\
\hline 17,2 & Allen, Xeluemials \\
\hline $1=51$ & Allumane, Filmust \\
\hline $1,-21$ & Mricks, Milliam \\
\hline inou & Anulle, Bliss. \\
\hline $1,-21$ & Ansus, catpt Jahn \\
\hline 1005 & 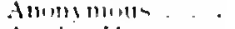 \\
\hline $144^{4}$ & Allut, llenry \\
\hline 15.59 & Ariber \& llirmer \\
\hline$(7 x)$ & Arell. Rirlatrol \\
\hline $17-1$ & Armat, Thumas \\
\hline 1791 & Ant) $($ illtel). \\
\hline
\end{tabular}

'Reviduars kneatuest

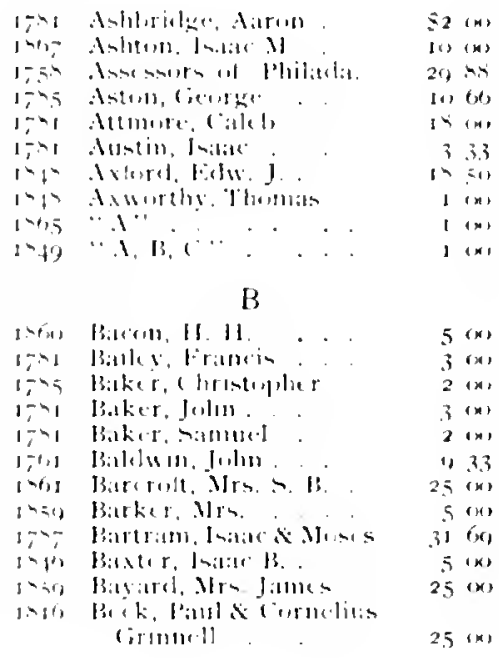




\begin{tabular}{|c|c|}
\hline 1781 & Benczet \& Baclaman \\
\hline 1750 & Benezed, Jolan \\
\hline 1865 & Benssu, Edwatrel 11 \\
\hline 1859 & Bensun, .l. $(; .$. \\
\hline 1701 & Bevath, B):aris \\
\hline 1755 & Birkerdike. Esther \\
\hline $\sin 60$ & Biddle, wise A. E. \\
\hline 1775 & Birlalle, ()we-1] \\
\hline $1-85$ & Billingtom, Thombas \\
\hline $17+1$ & Blackintum, l'riestly \\
\hline 1754 & Blakey, Juhn \\
\hline $1,-\infty$ & Blane: Folurain \\
\hline 1860 & Busline, samurel J. \\
\hline 1459 & Buggs @ א kirk \\
\hline $18+9$ & Bustwick, II. Xi \\
\hline 17.57 & Bestede, Thumbin \\
\hline 17,3 & Busers, Berrjamin \\
\hline $17 \div 5$ & [3⿻上丨।, ]:mene . . \\
\hline 1459 & Boull, lliss \\
\hline $1 \times 92$ & Bust, llilliam A. \\
\hline 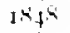 & Boşil, IVillawn J. \\
\hline 1,64 & Braclfurel, cimnetiun \\
\hline 1721 & Bradfiord, Il d Thom \\
\hline 1860 & Brewster. Benjamin 11 \\
\hline 1755 & Brittm, Benjamin. \\
\hline 1,53 & Breminu, Nichulats \\
\hline 1560 & Brown, Mrs It, G \\
\hline $1 \times 59$ & Brown, Dovid l'aul \\
\hline I.561 & Brown. Mim Finny \\
\hline $1,-6,5$ & Brown. Jacul \\
\hline $1,-603$ & Brown, John \\
\hline $1-5 i$ & Brown, John \\
\hline $17^{4} 5$ & Brown, Mary \\
\hline$[.3611)$ & Browil, Mary Jl \\
\hline $1-31$ & Budilen. James \\
\hline $1,7,5$ & Bulley, Ruluert \\
\hline 1760 & Bunting, Calpt Silmule! \\
\hline 1859 & Buplam, Mrs s \\
\hline 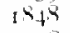 & Burk, John \\
\hline $1,5,8$ & Burkelose, Silmusel \\
\hline 1791 & Burkham, Gerrege \\
\hline 1495 & Burr, 11.s. \\
\hline 17.55 & Burr, Juhu \\
\hline 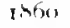 & Burruigh. Mrs. \\
\hline 14.59 & Busly, Mrs. \\
\hline I is & Buntiy, IE 11 . \\
\hline 1459 & Bushy ciedurge \\
\hline 1559 & Busliy, Juhn \\
\hline 1659 & Busliy, J. I. \\
\hline $18 \overline{20}$ & Bussier, Mrs I) f'. \\
\hline 15.54 & Byerly, J:arols \\
\hline 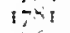 & Borlues, Patriak \\
\hline 1 वरा & 13.11 \\
\hline & 13. II. .1. \\
\hline
\end{tabular}

\section{C}

ISful Camplell, Mro Jats K.

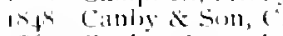

rao, Canbs, simmel

atri caner, Michatel

(xis) (Arl, S 11 .

$1=56$ Citmick, stephen.

in. Carner, Hasin.

s=7 Carney, Maria .

1735 carroll, Thmmis. .

1757 Carrol, Thomis.

1759 Carmon, John. .

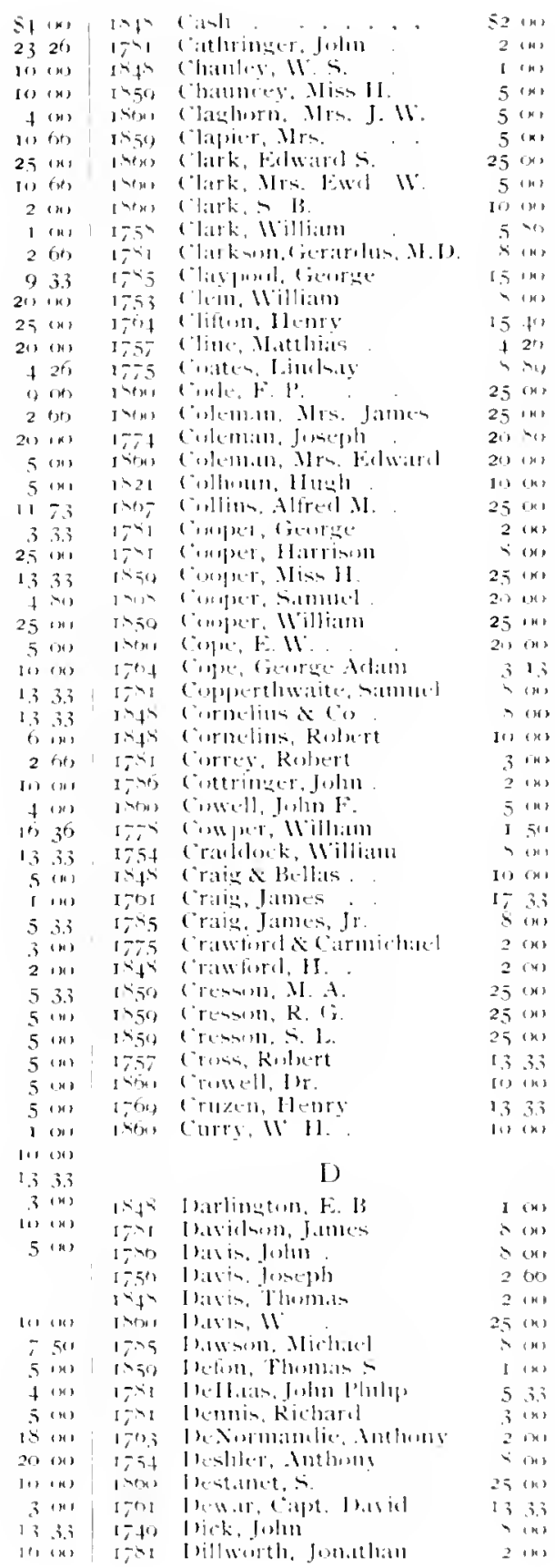




\begin{tabular}{|c|c|}
\hline & \\
\hline 1754 & 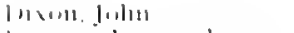 \\
\hline $17-\infty$ & 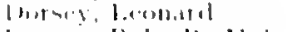 \\
\hline 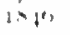 & llolnel. Kold K, U U \\
\hline $1 ;-1$ & 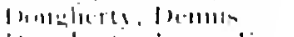 \\
\hline $10 \%$ & 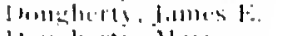 \\
\hline 1,55 & lanklucti. Maty \\
\hline $1 \rightarrow+1$ & In,wler, Jannl, \\
\hline $1-5.5$ & lorinter, llems, It \\
\hline 14 & Josistate, II \\
\hline $1,-5$ & Hume :H. Juln \\
\hline $1,-1$ & 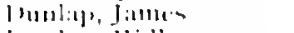 \\
\hline 1,$0 ;$ & 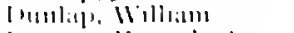 \\
\hline $1 \times 12$ & 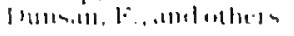 \\
\hline & $\mathrm{E}$ \\
\hline 14.51 & Iall, Mrs. Marrisan \\
\hline$I_{H}$ & 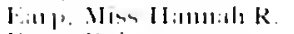 \\
\hline 14. & I:Ar), Kalsetet \\
\hline $1 \times 1-7$ & $\because 1,1 \therefore c^{*}$. \\
\hline $1 \% \div$ & lekelt, helam \\
\hline$\therefore$ & Ektalt, 1, J k \\
\hline $17-2$ & Jolusirds, Nexameler \\
\hline $1 ;-1$ & lolriclace lahou \\
\hline $\mid v(x)$ & Eltreth, Nary. \\
\hline$|x| x \mid$ & lis, Nins. \\
\hline $1-21$ & linglis, sommel \\
\hline $1-7,2$ & 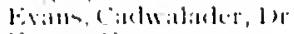 \\
\hline $1,7.5$ & Finls, Fratu \\
\hline $1-\infty 1$ & 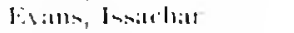 \\
\hline $1,-1$ & livins. Peler. \\
\hline is & $1: 1111$ s an \\
\hline $1-1,2$ & linols, Thumllos \\
\hline $1,-1,4$ & I:wall, chartes \\
\hline Insi & $1=11$ \\
\hline & $E$ \\
\hline$|\vee| x \mid$ & $1+11$, Mre I : : \\
\hline $\ln (x)$ & 1:11, Miss M.tr! 11 \\
\hline 1 ind & Hannel. II \\
\hline 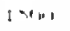 & 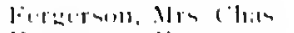 \\
\hline 1414 & fergersent $1:$ \\
\hline $1,-\infty$ & finluer a jais \\
\hline $17-5$ & Finlecr, Junciph \\
\hline lent & limber, Mto siblly \\
\hline $1,|n|$ & Jinher. Mism \\
\hline 1. in & Finley $\mathrm{C}$ Cu. \\
\hline $1 \times 14$ & Hirth, $\mathrm{F}$ \\
\hline $17-1$, & Fillims, (anflat \\
\hline $1 \div-1$ & follosimmondm, lownols \\
\hline 1214 & Fulsell, 1 \\
\hline $1 * 1=$ & Funder, fromeis \\
\hline $1,-\infty 1$ & $\because \cdots, \quad F l u, 101$ \\
\hline $1 ;-\infty$ & fix, Jumelo II. \\
\hline $17-1$ & 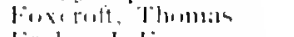 \\
\hline 15.54 & Fralcy, I li. . \\
\hline 1917 & Frilejolon lo \\
\hline $1,5,52$ & Fr,ubliin, Bs-lll:amian \\
\hline 1790 & 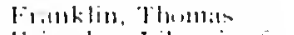 \\
\hline $1<14$ & 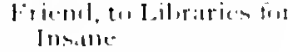 \\
\hline 170 & Frice, lohincis \\
\hline $1-\div$ & Fulles, Jinginmin. \\
\hline & i \\
\hline $17 \div 5$ & Giallandel, Jeter IIm. \\
\hline $1-111$ & Ciorturd, Jarol, . \\
\hline $1-15$ & Giscluet 19illiam \\
\hline $15=4$ & 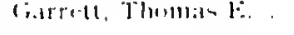 \\
\hline
\end{tabular}

\begin{tabular}{|c|c|c|c|c|c|}
\hline 1.3 & $\therefore$ & $\mid v(m)$ & Gillisoll, J litis K & 5201 & (4) \\
\hline e & (n) & 1.2 .5 & 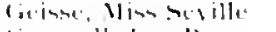 & 201 & $(x)$ \\
\hline 21 & $(n)$ & 19.8 & Gicmmoll, J.1s. K. & $\because$ & (n) \\
\hline 2 & ine & 10.5 & finmrik, I II & 25 & (n) \\
\hline 5 & $(x)$ & 1,57 & liblufret. Mr luley s & is & bo \\
\hline 2 & (t) & $1-96$ & Cill, Juhu & 4 & $(n)$ \\
\hline 5 & $3 i$ & In & Gille-gne, Mathallet & $i$ & $(x)$ \\
\hline 1 & (n) & $\mid\langle(x)$ & (.llk-pie Nis Nin & 25 & $(x)$ \\
\hline 1 & $(n)$ & 1.4 & 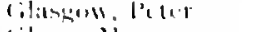 & (1) & $(M)$ \\
\hline 3 & $|n|$ & $1+54$ & $\left(i \mathrm{l}^{\prime} \cdot 111, .1\right]_{\mathrm{r}}$ & 5 & $(m)$ \\
\hline 3 & 3.3 & $141^{4}$ & Cinlalind, J. H. & 1 & in! \\
\hline$\therefore$ & ins & 1) in & G,uslmam, Jahn & 3 & 25 \\
\hline 3 & $1 \times 1$ & $1,(x)$ & (ionuluing. Pluthe & 5 & (n) \\
\hline & & Ant & litall, Miss & 2 & $(x)$ \\
\hline & & $1, a+n$ & Cirall, Mins & 2 & (H) \\
\hline 111 & $(x)$ & $1,-, 1$ & 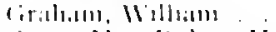 & 4 & $(x)$ \\
\hline 111 & $|\times|$ & Intmint & dirate. Mrs Koluet II & 111 & $(x)$ \\
\hline 25 & $(x)$ & $1-\pi 1$ & cituse, Juhn. & 2 & 3.3 \\
\hline 25 & IN: & $17(x)$ & 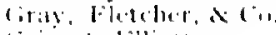 & 1 & $a t$ \\
\hline 16 & 101 & $1 \times 14$ & ririge a tillindl & 5 & $|k\rangle$ \\
\hline 5 & 1,1 & $1-\div 5$ & linent, liconget & 7 & $(m)$ \\
\hline s & $|n|$ & 1715 & Guilhmard, J) & 20 & (n) \\
\hline 2 & (m) & the & Rilillun, Reni: & 211 & $(m)$ \\
\hline 2 & $(m)$ & $17-1$ & 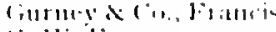 & $\therefore$ & $(n)$ \\
\hline 25 & $(x)$ & 1 ant & $1: 11 \mathrm{j}$ & 10 & $|n|$ \\
\hline 1 & $1 \%$ & & H & & \\
\hline 11 & \&' & & 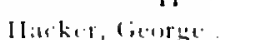 & & \\
\hline 5 & $i$ & $\begin{array}{l}1 \times 50 \\
1 \times 58\end{array}$ & 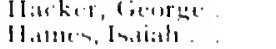 & 25 & (N) \\
\hline 2 & $(n)$ & & 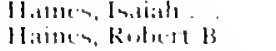 & 2.5 & $(N)$ \\
\hline 1 & $(x)$ & $\begin{array}{l}\ln (n) \\
\ln (x)\end{array}$ & & 15 & $(M)$ \\
\hline 211 & 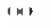 & & 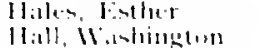 & $!$ & (H) \\
\hline 1.3 & $i . i$ & ithin & 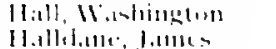 & 26 & $(x)$ \\
\hline 7 & 213 & $1,-(x)$ & I1.111,1.111, 1.11116= & 20 & $(x)$ \\
\hline 5 & $|n|$ & $1, \infty 1$ & H:1miltum, 1,alin & 1 & Gis \\
\hline & & 1,75 & llankey, lindlrey & 1 & 60 \\
\hline & & litis & Handin, Nl|real & 25 & (m) \\
\hline 25 & $|n|$ & $\ln 15$ & Howlinge Jolm, Jr. & 15 & $(M)$ \\
\hline 25 & $|x|$ & $1-\sum \leq 1$ & 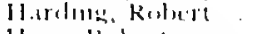 & 3 & $(x) 1$ \\
\hline 2 & $5^{\prime \prime}$ & $17+1$ & Il:are. Kulu-gl & 8 & $(x)$ \\
\hline 5 & $(n)$ & 1717 & 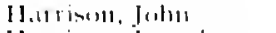 & 12 & $(n)$ \\
\hline 6 & 67 & $1>-1$ & Ilatrimols, Juseght & $s$ & $(x)$ \\
\hline$\therefore$ & 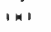 & 14 & II:Ir, J. II A II. H. & 5 & $(x)$ \\
\hline s & $(x)$ & 1451 & Ilortley \& knight & 11) & $(x)$ \\
\hline 211 & $(x)$ & $1,7,5$ & Handunge, Simbuel & 2 & 9,3 \\
\hline 111 & $(n)$ & $\therefore 9$ & lligules, Robelt. & 1 & (x) \\
\hline 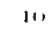 & $(n)$ & $1,-\infty 1$ & 1 lilis, fientrice. . & $\therefore$ & $(x)$ \\
\hline 1 & $|n|$ & 1231 & Heifenslein, S. . . & 5 & $(H)$ \\
\hline ; & $1 \times 1$ & $1,-\infty 1$ & 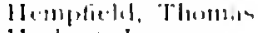 & 3 & (n) \\
\hline 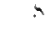 & an, & $1,-5$ & Jerliert, Lenurente. & 3 & $(x)$ \\
\hline 1 & 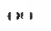 & 14.9 & llerklless, A. M. & I & $(x)$ \\
\hline 1 & 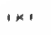 & 1917 & 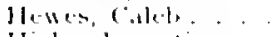 & 14 & 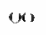 \\
\hline+ & ( $\cdots$ & $17.5 ;$ & 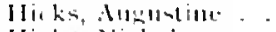 & 1.3 & .33 \\
\hline $1 \times$ & $\mathrm{H}_{1}$ & $1,-4(1)$ & Jicks, Nichorlis. & $\therefore$ & $(x)$ \\
\hline () & Ime & $1, x+1$ & Hill, 1 ;orrge 11. & (1) & $(\mu)$ \\
\hline 25 & $|n|$ & 141 & llibletorm, Milliam . & 3 & $(x)$ \\
\hline$n$ & 7.3 & in & Jillery s libute. & 5 & (x) \\
\hline & & 1,751 & in, Willim & 5 & 3. \\
\hline 21 & $+x_{1}$ & $175 \%$ & 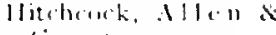 & & \\
\hline & & & 1.1. & 9 & \\
\hline 25 & $(n)$ & 1,752 & 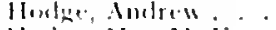 & in & \\
\hline$\because 1$ & $(")$ & 1.50 & Hulge, Mrs. M. I: & 10 & $(x)$ \\
\hline 1 & $t x$ & $1,5,1$ & Hotger, Uilliand). & 16 & a \\
\hline & & Inter & Hollawid, Mr. . . & 25 & \\
\hline & & 14 & Holfowell, Ifambals & 1 & \\
\hline$\therefore$ & $m$ & Intming & Mnlsman Mr. & 10 & $(x)$ \\
\hline 4 & $\cdots 1$ & 12.50 & Hunc, Mrs. & 10 & \\
\hline 17 & $t_{x}$ & 1. 51, & 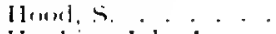 & 5 & in \\
\hline 1.5 & $(x)$ & $1 \% 1$ & IIntim, Juln Ir. & & \\
\hline
\end{tabular}




\begin{tabular}{|c|c|c|c|c|c|c|c|c|}
\hline Iירו & lopkins, Kiohores & & $\therefore=1$ & $(n)$ & $1<+1$ & K:rn, II M Milliam Il & $=341$ & $(x)$ \\
\hline $\sin (x)$ & fluper, Thomas & . & 111 & $(\mathrm{H})$ & 1 Sil & kirkputrick, J. " & {$[1$,} & in! \\
\hline 1450 & luormer, Mr. A. . & . & 5 & $m r$ & I nasis & Kitchen, 11 illitnln k. & 25 & (x) \\
\hline $1 \times 4$ & Ionsh, Rolvent. & & 1 & $(x)$ & バす & Klenum, Frentarth A & 5 & $|n|$ \\
\hline $\ln (x)$ & [Hubitr, James s. & & 11 & $(n)$ & $1-20$ & kniglut, Jo:s in & $\therefore 5$ & $(\mu)$ \\
\hline 17.54 & lludille, Joseph. & & 1.3 & 33 & $17-1$ & Kinex, Rolient & ; & $\{x\}$ \\
\hline $17 \mathfrak{1}$ & Iludille, Jusephlo. & & $i$ & (n) & $\mid x, 1$ & Kutur, J1., If:trtmotu & $\therefore 4$ & $|n|$ \\
\hline $1, f(x)$ & IImaly. B. F.... & . & আ & $(w)$ & 174 & Kulon, leter & 1 & $(n)$ \\
\hline $1, .56$ & Iniluers, lhilip: & & 1,3 & $3 i$ & $1>x+$ & 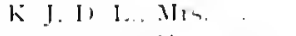 & 5 & $\{\mathrm{H})$ \\
\hline $17-1$ & Humplaress, Bcmyinm & & 2 & $(x)$ & & $M$ & & \\
\hline $17-1$ & Ilumphreys, (a)kels & . & 1111 & $(m)$ & Intmint & Mitraltenter, Mim lity & 2.5 & “"' \\
\hline $1-1$ & 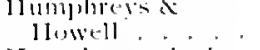 & $\cdot$ & 11 & 1111 & $1, \geq 1$ & Matalley, Juhn. & 5 & $|x|$ \\
\hline $17-6$ & Humplareys, J, Ir. & . & 3 & 1, & 1754 & Markey, jimmes li & $2 "$ & in, \\
\hline $186 n]$ & Hunter. Miaty & & 1.51 & (n) & Intion & March, Benjanmin 1) & 25 & 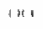 \\
\hline 1791 & Hutchinsom, Walilin & & 1 & (1) & 1.54 & Mlario, l. R. & 29 & (n) \\
\hline $1<50$ & 11. 1). 11. & & 11 & (") & $|>| x \mid$ & Matrin, Mre 1$)$ & 2 & $(x)$ \\
\hline & 1 & & & & 141,7 & Milan, Jimbers & $2=$ & 141 \\
\hline $1 ; \div 1$ & Inglis, Silnuted & & & & $1-21$ & Motlick White & $!$ & its \\
\hline 17.46 & Irvin. Jinntes & & 1 & bit: & 1.7\%" & 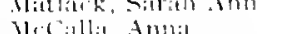 & $\overline{5}$ & (n) \\
\hline 1781 & Irwin. Thonnis. & . & 21 & $(n)$ & $\lim _{1-4}$ & 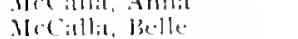 & 1 & $(H)$ \\
\hline & . & & & & $i^{2} t^{4}$ & Mecallit, Chatrlem & 1 & $(n)$ \\
\hline & & & & & $1,2,1$ & 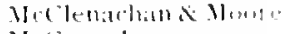 & s & $\mid x)$ \\
\hline Thi & Jacksoll, l)r. & & $\therefore$ & 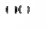 & $\ln 14$ & Mecrea, J. & 1 & $(n)$ \\
\hline 1951 & Jackson, William & & 2 & $(x)$ & $1,7,1$ & Wecolbin, Jomben & $\because$ & $\mid x_{1}$ \\
\hline $1+59$ & Jaculss, Mrs. C. S & & $24)$ & $\{n\}$ & $1,-\infty 1$ & Heculluch, I) & 11 & $\therefore i$ \\
\hline 162 & Jacolos, Joseph & & $t$ & in & 124 & Neculluminh, J. & 1 & (") \\
\hline $1->1$ & Jacoly, leenteal & & t & (1), & $\operatorname{lin} f 17$ & Nelomonish, A & $"$ & 511 \\
\hline $1 \times 59$ & Jalmess, Mrs. & & 2 & $5+1$ & 1.47 & Mclitres, A. & 1 & 111 \\
\hline $1-64$ & James, James & & is & 5.3 & itine & Nollugh, Mr. & .5 & An \\
\hline 1,460 & Janney, 13. & & 5 & (⿻) & INFt & 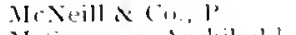 & 111 & $4 m+$ \\
\hline 1,58 & Janvier, lsate & & 15 & i 1 & $17-4$ & 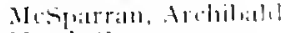 & i & $1+1$ \\
\hline 1762 & Janvier, Thombin & & 5 & 40 & $1-5 I$ & 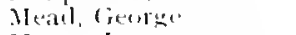 & $\checkmark$ & in 1 \\
\hline $17-8$ & Jenkins, Mary & & 111 & th & $1-81$ & Weilse, Jalnen & v & in) \\
\hline $137+$ & Jervis, chatles & & $1 \mathrm{~b}$ & (i) & $1-6,1$ & 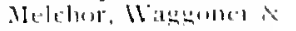 & & \\
\hline $175 \%$ & Jervis, Juln. & & It & 4 & & (ii) & 12 & $n+1$ \\
\hline 17.54 & Jervis, l'lommas & & $1+$ & 4 & 145.5 & Mellar A Rittenimothe & 25 & and \\
\hline $18 f_{x}$ & Jesistly, Mtrs. & & 25 & $(n)$ & $1 \times 6 n$ & Meyers, 11. 11. & ร & (n) \\
\hline $1 x_{4}: i$ & johnsom. (iceorye & & 2 & $(M)$ & INition & Mereds, Martin Ju & 5 & (n) \\
\hline $1+50$ & Johnson, Matry & & 25 & (n) & Intul & Wuldle-tun, lsillullit & 5 & (n) \\
\hline 1667 & jolnusin, Mrsi, M. I & 'l'. & 2.5 & (11) & 1.thin & Midrlletwn, I, yelite & 2 & 54 \\
\hline Wh & Johnsun, Rolert & & 1 & (') & $17-1$ & Mintlin 2 Hutlen & $\checkmark$ & $|x|$ \\
\hline 176,3 & Jolly, charles. & & 12 & $1 . ;$ & 心51 & Milen, linluard & $\cdots$ & (n) \\
\hline 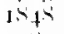 & Jones, Filward 11 & & 5 & $(x)$ & $17-4$ & Mlillor, ("hatgles. & $\uparrow$ & 15 \\
\hline $\mathrm{I}-\mathrm{SI}$ & Junes, Earil & & ; & (n) & I inte, & Mlller, I1:mm:th. & 114 & | IH, \\
\hline $1+7$ & Junt's, Jintites & & 1 & $r m 1$ & $1 ;-1$ & Miller. Julun & 1 & (n) \\
\hline 1,001 & jumes, jolnu & & 22 & fu' & 1450 & Noller, Juluese. & 34 & (4) \\
\hline 19 & Jones, Julur & & 1 & (i) & $1-704$ & 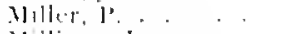 & > & 101 \\
\hline $17 x$ & Jumes, Joln \I I. & & $\because 1$ & (n) & $1 \%$ & Mllligill, Jamum. & $;$ & ins \\
\hline $175 x$ & Jones, owen & & (1) & 1 & inson & Minchall $\mathrm{x}$ I.1(u)l. & $\therefore$ & (in) \\
\hline 175 & lones, leter & & 2 & $\{n\}$ & $1,-1,7$ & Minsliall. Tiknuism. & 2 & ins \\
\hline $1,-2$ & Junes, koluet strecte & (1) & 12 & $(n)$ & $1,-1, n$ & Mitchell, Alutaluan & 1. & $\rightarrow$ \\
\hline inth & Jordin, John & & 1 & $(x)$ & 1754 & 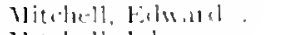 & 1 ; & ; \\
\hline isine & j. 13. Nim . & & 5 & $(x)$ & 17,11 & Mutched], lohn. & $1 *$ & ' 1, \\
\hline $1<(x)$ & J. R. L. & & 111 & $(n)$ & $1,-6+1$ & Vitchell, johne. & 2 & $1 m$ \\
\hline $1,7,5$ & J. .11 & & .5 & $(x)$ & ing & Vit, lotell, is lis. . & i & $(\mu)$ \\
\hline 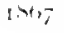 & I. I. S. : Imi H I & II & $2 n$ & in & $1,-1,2$ & Mock, Julun. . & $\checkmark$ & $|n|$ \\
\hline & & & & & $1,-\infty 1$ & 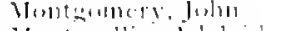 & 1 & (n) \\
\hline & & & & & 140,1 & Mentamollin, Noletatile. & & 14. \\
\hline $1 ; \rightarrow 1$ & Keals, Jutur & & + & $(x)$ & $1,-41$ & $\ln x+1, .11,-11$ & $\therefore$ & 411 \\
\hline inth & 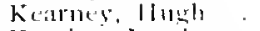 & & $\mathbf{I}$ & $(x$ & $1 \div 5$ & Monere lohin. . & & ins \\
\hline anit) & Kenting, foimletel & & 118 & $(n)$ & 15,5 & Vande, Matry. & $1=$ & $=7+1$ \\
\hline $1+14$ & $k+11 y, 11.11$. & & 1 & an & $1 ;-4$ & 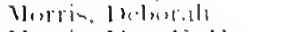 & 1 & ( (n) \\
\hline 14t & Kenincels, Ililliam t & W & 5 & (n) & lintsind & Norlis, Mre 1111 & $\therefore$ & ' In' \\
\hline 1250 & Kenmey, John ls & & in & $|n|$ & Intmi & Vomris, H.1n11, 1 . & $1+1$ & ( In) \\
\hline 1701 & Kentzins, Ahrah.tm & . & 51 & 3.3 & 1 then & blutris, Vlin labus & 3 & , a \\
\hline $17-1$ & Kelple, It , Hetros & 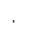 & In & $x_{1}$ & $1,-m i$ & Magris, Miclans. & & $=1, n$ \\
\hline
\end{tabular}




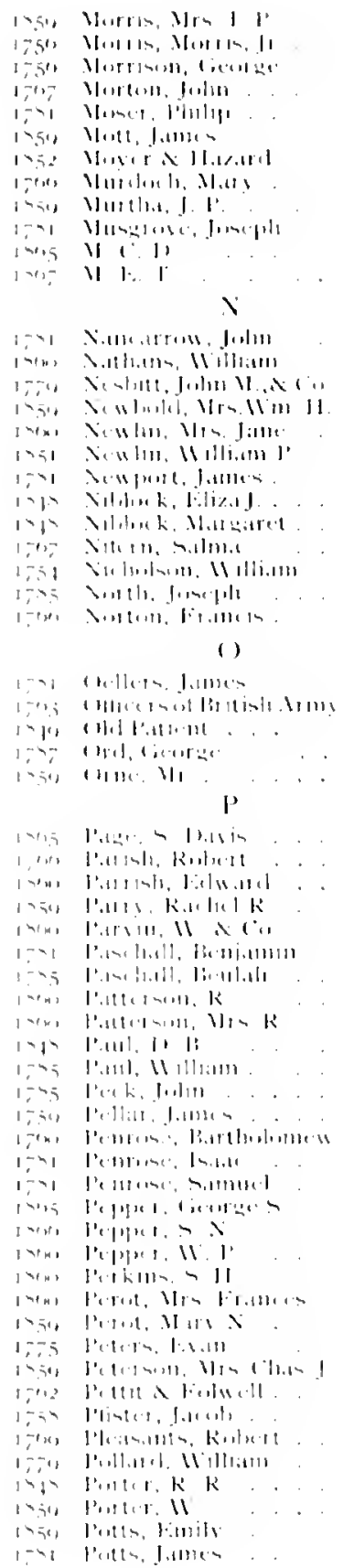

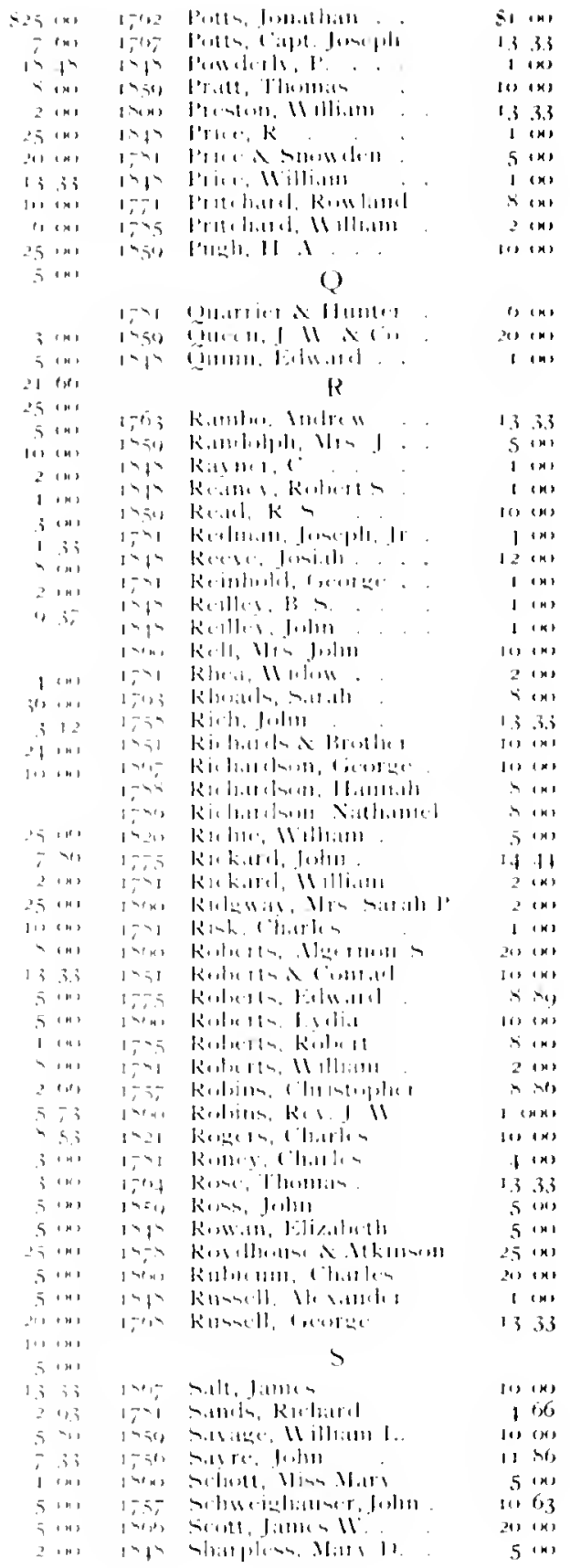


18 fis Sluaw, 11.

I Th2 Sheatf, Milliam

$17^{3}$ Shields, Thomas

17 , Shartliff, IVillian

ipls Slusemaker, Benianum

i,to shortall, Thomats.

I,62 Slublenlerger, Fredericit

i, th2 Slutiz, Gerige

$1,-1) 6$ Slutitz, Melelinw

$1, \mathrm{O}_{2}$ Slute, Jolnn.

1757 Slunte, Joseph.

Izisl sijekle, Lawrence

is- siddons. Jostoplo

thine Sill, Mrs. Josepulu

It Sims, Wumbly

1, th Singer, Cimpitt

isf slemins, fames

itif Slo:tr, Jith

I 51 Sinith, I).

l,ĭ Smoth, Juhn.

ifon sinitl, J. J

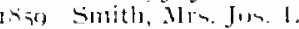

Inet simith, Mlss Mlatyl'

isgo smitl, Milliam

172 Smith. Rev. Nilliam

17\% Snith, IIIlliam, M. I\}.

$1,-5$ simith, IVilli.mo (;. .

tog simyth, Nilliam

ist' smive. Clarles

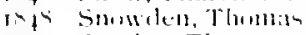

iste sempler. Thumbs

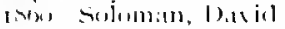

isf sipencer, oliver

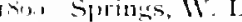

Inos Stiley, Miss A.

1, -xis citary, Jalles

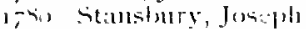

rín stenlman, Elizolutil

17-4 Steinmet\%. Julm

1, sy stevens, Juhn

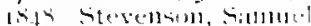

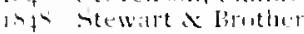

ing stevist, Rulert

i) fir siles, N.1)

Isin Stiles, Mr.

1-45 Sitille, John

1.hen, Situcktom, fienrye

1,02 Stuffer, John Caspot

1.555 sitrkes, C.

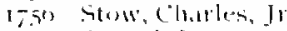

1,54 Sifetch, Isitila

Izt sitretih, Petor.

I7.55 sitrettell. Robert

$1,-56$ stromel. Isam

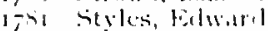

likf, styles, ] [emy.

istos stylus, H. A.

Isis soluger, Mrs

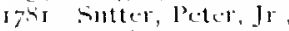

Isise Simin, Mls.

1.50) Siwaln. Riclatrol

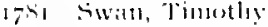

rity swatz, A.

ititis Swereny. Amm

I T55 Swetman \& Rublph

1756 Swift, John

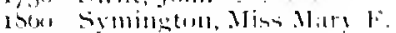

$\$ 1,1 \cdots$

36,5

3 (x)

( $(3)$

2.3 .3

44

1) is

1333
260

I. 3.3 .3

(1) (1)

4 (i)

$3(N)$

i $(\mathrm{m})$

(1) तो

I $x$

( (n)

5 (1)

a) (iis

(1) II)

[11 An

2h 21

1341

1 (it)

2.500

I (n)

(1) (n)

5 ( )

25 (n)

i (n)

5 내

ביו

I. 3 i

1333

3.

1t, 131

$2(n)$

1 in,

$5(n)$

I $(x)$

I t

(A) I H

$15 \mathrm{k}$

5.3 .5

111 13:

$1+4$

15 f"

1 ता

242 2t)

1; 33

(1) 111.

[11 1

$5(x)$

2 (n)

2 (II)

2.5411

200

3 (it)

I (11)

1 (x)

$3(x)$ is an

5 1
Jin, Simington, Mattikla $11 . \quad 55$ m

Itil sing Charles. 3 an

15,2 . 5. . . . . . . . 5 (n)

\section{$\mathrm{T}$}

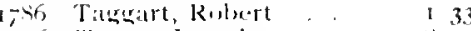

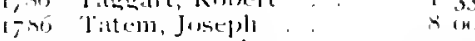

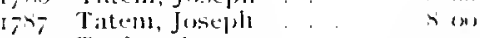

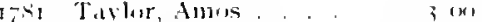

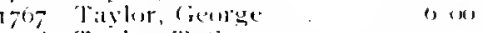

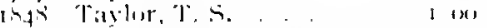

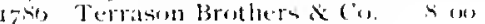

is, levis, Mrs. B. . . . 5 o

liton Thumat. Anma : . 25 (w)

1755 Thomals, Thumats. . 2 ols

riffe "Thompsom, John . . I (m)

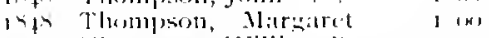

isiso limampend Milliam $\mathrm{K} . \quad 25 \mathrm{~cm}$

inme llowmsem, lavinial of

1772 Wluther, Mary. . 2 \%

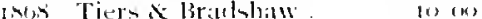

s tim, Tilge, Mrs. Itenry.

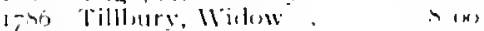

sthe Tingley, Mr.

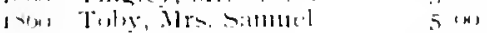

it7 Tim, Barthilinalew is

1 thi Tinten, Rolnett. S m

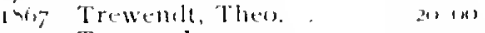

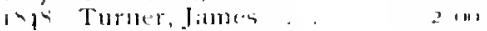

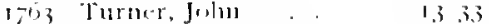

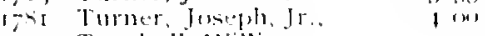

$1,-1$ Turuland. Milizun ons

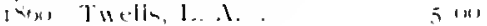

\section{U}

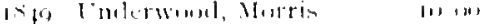

\section{V}

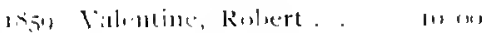
II

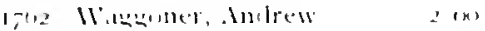

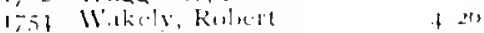

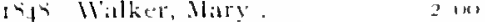

itit $11.1 \mathrm{ker}, 1^{2}$. . . I

ints 11.11 , sambal.

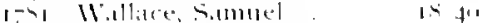

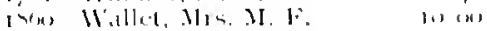

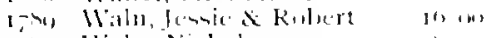

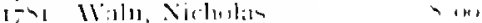

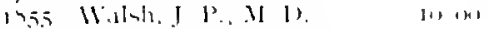

Isin, 11 ind 8 Bris.

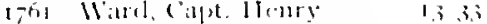

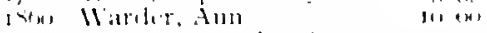

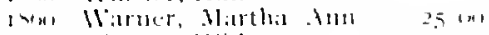

I

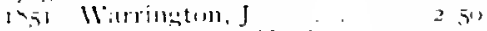

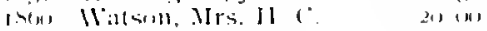

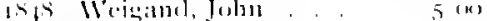

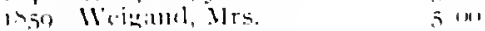

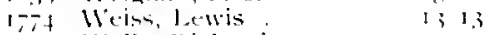

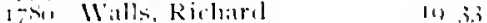

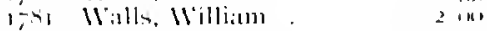

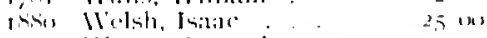

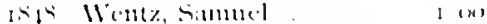

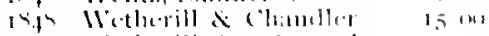

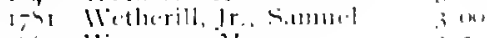

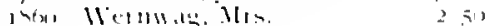




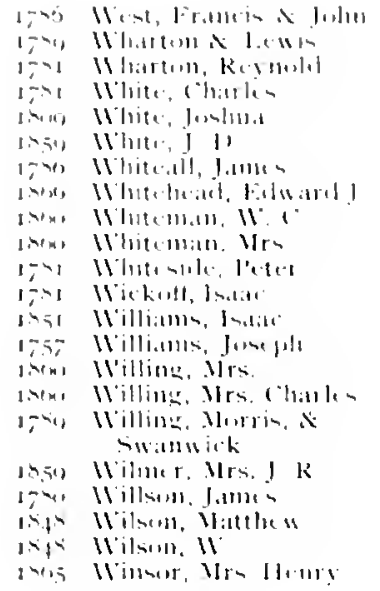

\begin{tabular}{|c|c|c|c|c|}
\hline$=2 t r$ & ene & Ints & 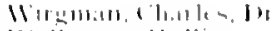 & $\because 51 \mathrm{mo}$ \\
\hline 1 & $i . i$ & はララ1 & 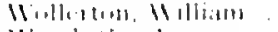 & +13 \\
\hline 1 & ine & 14.511 & 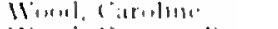 & l一, \\
\hline 2 & $|n|$ & In: & $11+\cdots, 1,1+1,1, k$ & 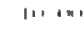 \\
\hline 17 & wh & 1414 & M+ш⿻1, Milliam & $1 \mathrm{in}$ \\
\hline 川 & $(x)$ & $1, .5$ & 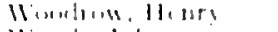 & $\therefore \ln$ \\
\hline 5 & $3 i$ & $1,-1$ & 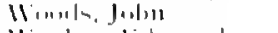 & 1101 \\
\hline 35 & In! & $1: 53$ & 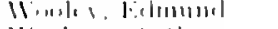 & $1 ; i$ \\
\hline$\overline{7}$ & $(n)$ & I ting & Nirkmand $101 \%$ & Han $1 \mathrm{n}$ \\
\hline ; & (n) & 1 and & Ninkminll, Nin & $\therefore 511$ \\
\hline " & $\therefore ;$ & $1 \times 53$ & 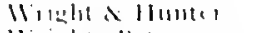 & $21, \ldots$ \\
\hline () & $\ln 1$ & $1=19$ & Mright, J'tor & $31 \times 1$ \\
\hline (1) & a & $\ln (x)$ & Noute, Misen lifien & $111 \mathrm{~cm}$ \\
\hline I; & $3 ;$ & 35 & II:-ili, Joln & $\overline{7}+11$ \\
\hline 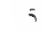 & '4. & \multirow{2}{*}{\multicolumn{3}{|c|}{ 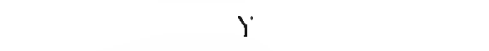 }} \\
\hline 25 & InI & & & \\
\hline & & Jhen & 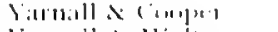 & $3+\cdots$ \\
\hline al & In & 19 & 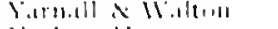 & 112110 \\
\hline$\therefore$ & 5,1 & 175 & linkes, Hallminll & 1223 \\
\hline 21 & $\mathrm{in}_{3}$ & $1,-x_{2}$ & Yinו112. Milliam & $13 i$ \\
\hline 1 & $1 n$ & \multirow{2}{*}{\multicolumn{3}{|c|}{$\%$}} \\
\hline 1 & $(n)$ & & & \\
\hline 35 & $\ln )$ & $1,-5$ & Kantzingers. Alutu & 1114 \\
\hline
\end{tabular}

SPECIAL INEPOSITS OF (NCLAMMEU FUNISS.

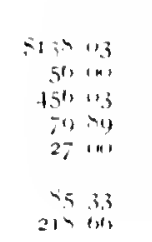

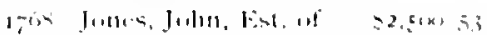

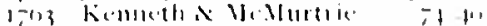

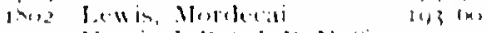

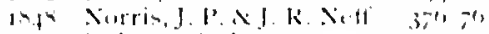
inz2 Kilstuti, Ruluert. 11, 211

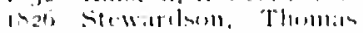
illitl Jalul atiley 19.31) stemin

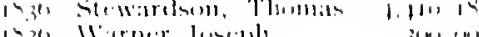

\section{GRANTS BY ASSEMBLY ANI AN ACT OF PARLIAMENI.}

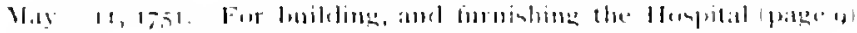

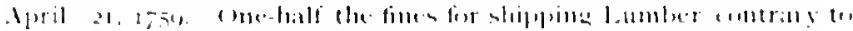
Law fritge 2 -

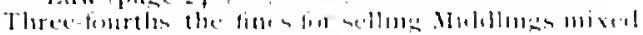

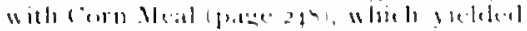

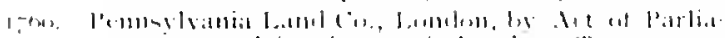

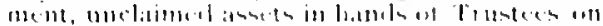

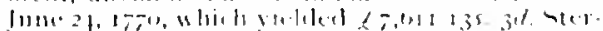

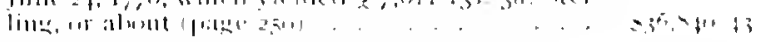

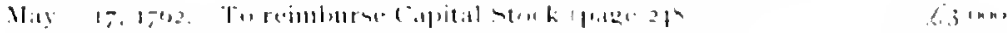

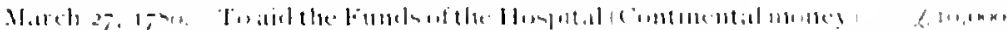

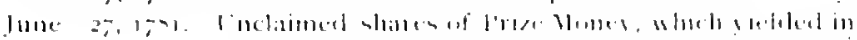

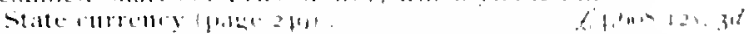

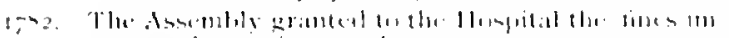

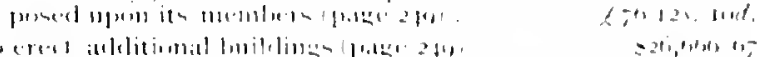

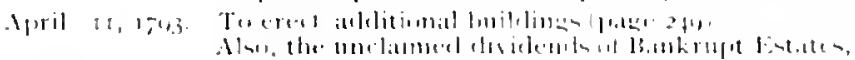

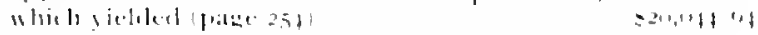

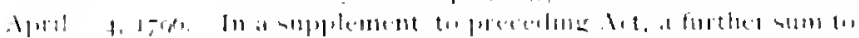

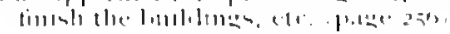




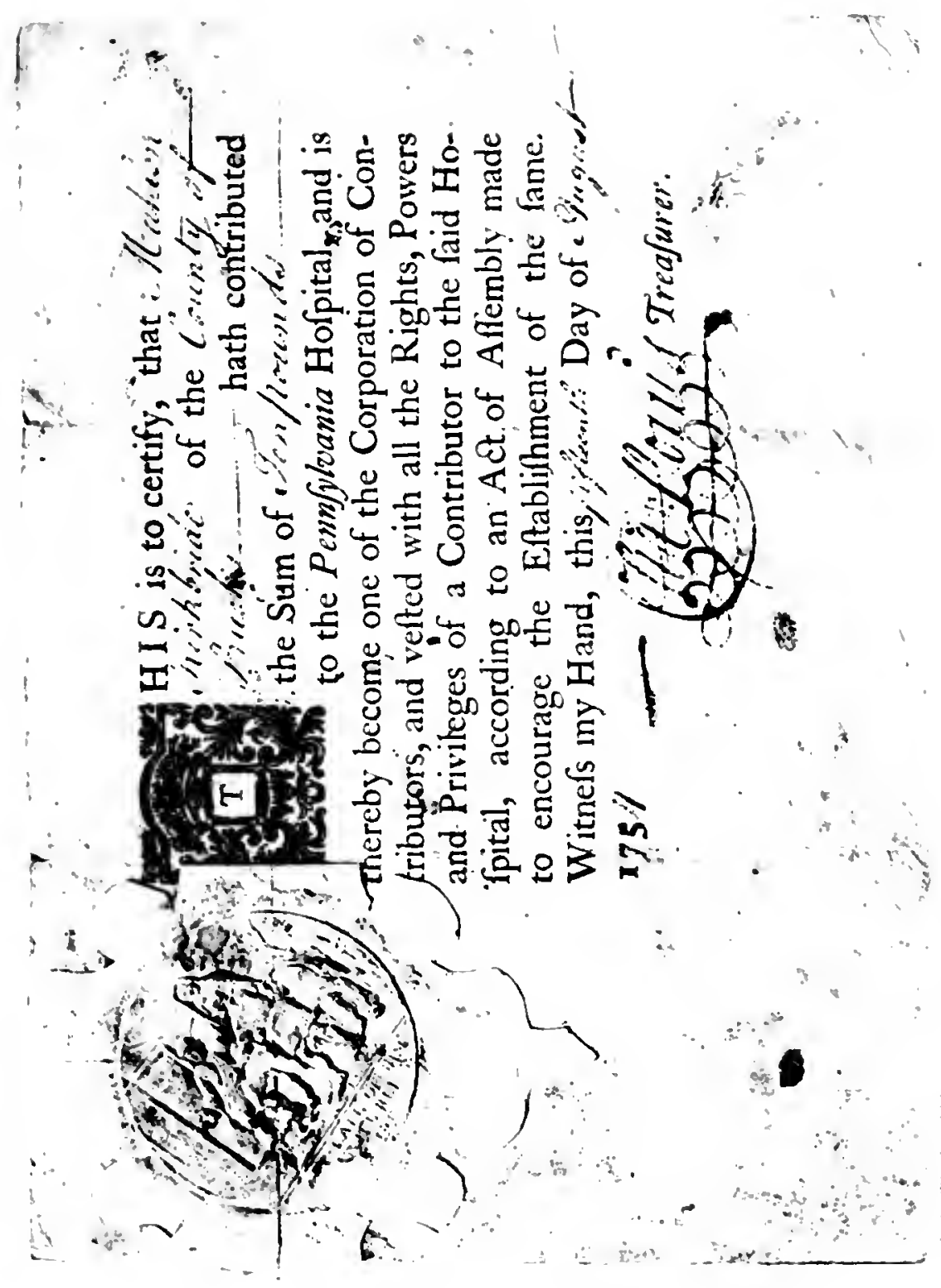




\section{CONTRIBUTORS TO THE PENNSYLVANA HOSPITAH,}

FRO.11 1751 TO 1804.

A.

15. Ablute Hawrance

1h21 Iblott, Willian

1 is. Ablutt, William 1.

$1,-5$ Allum, Richitrel.

ins Arlanm, Rubert.

1-xis Atlketk, Thumis

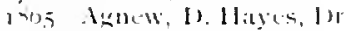

inso Alnew. Joln

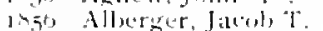

175t Allitir, Aleximuler

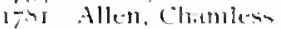

1.59 Allen, John (.

1.5.5 Allen, Joseph . .

17.5 Allen, William

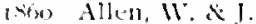

1456 Allibone, Stom

ints Allibone, Thombs

1956 Alter, Jacots.

1767 Anderson, Lawrence

19.3 Anderson, W'illiam I

1456 Andrate, Joseph .

ubo Anelrews imel Divon

ingt Andrews. Jimes

1545 Andrews, Joseph B.

14:32 Andrews, Rolnert

17 An Aneres, John . .

1, thet Anmesley, Robert. .

in56 Anspacli, John ...

1,50 Anteln, A.J.

1,05 Anthomy, Joneply

1,51 Anthony, stephen

ror Anthony, Thumas l'owejl

1556 Archer, Ellim s.

IN50 Archer, Mary Ann.

1755 Armitage, Bemj. S., Jr.

175I Armitt, John ...

1754 Asloriclere Gowrage

1759 Ash, ("apt Henry

1-9I Ash, James

ifhe Ashe Joshou

Is5 Ast Jushua X...M

Is59 Ashloridge, Jate

14.59 Asbluridge, Tlumbine

175t Ashloridere, llilliam.

int5 Ashbridge, M"iblian

bor Anhurm, Nartin

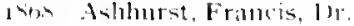

int Aloburst. Jahn .

18. Asholurst, Juhn, Jr., In

int Anhburst lewis $k$

18tos Achlmurst, Mrs. L. K.

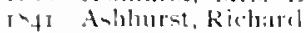

isso Anhlumet, Richatrel, Jr

soso Ashburst, Samule?

ivig Anhluerst, Wibliam 11

Inte kolnorst, Milliam l..

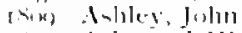

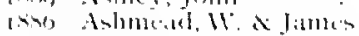

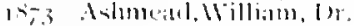

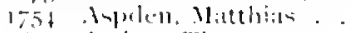

ins Antley Throman.

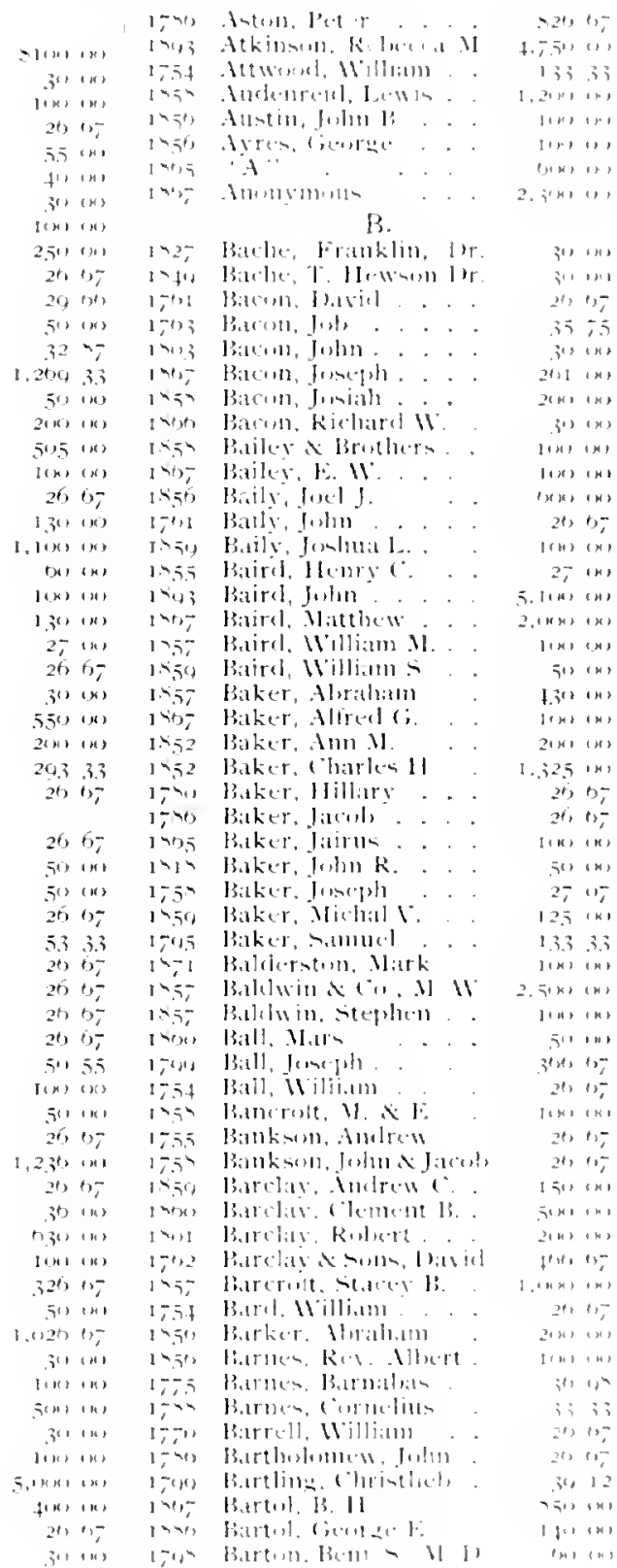




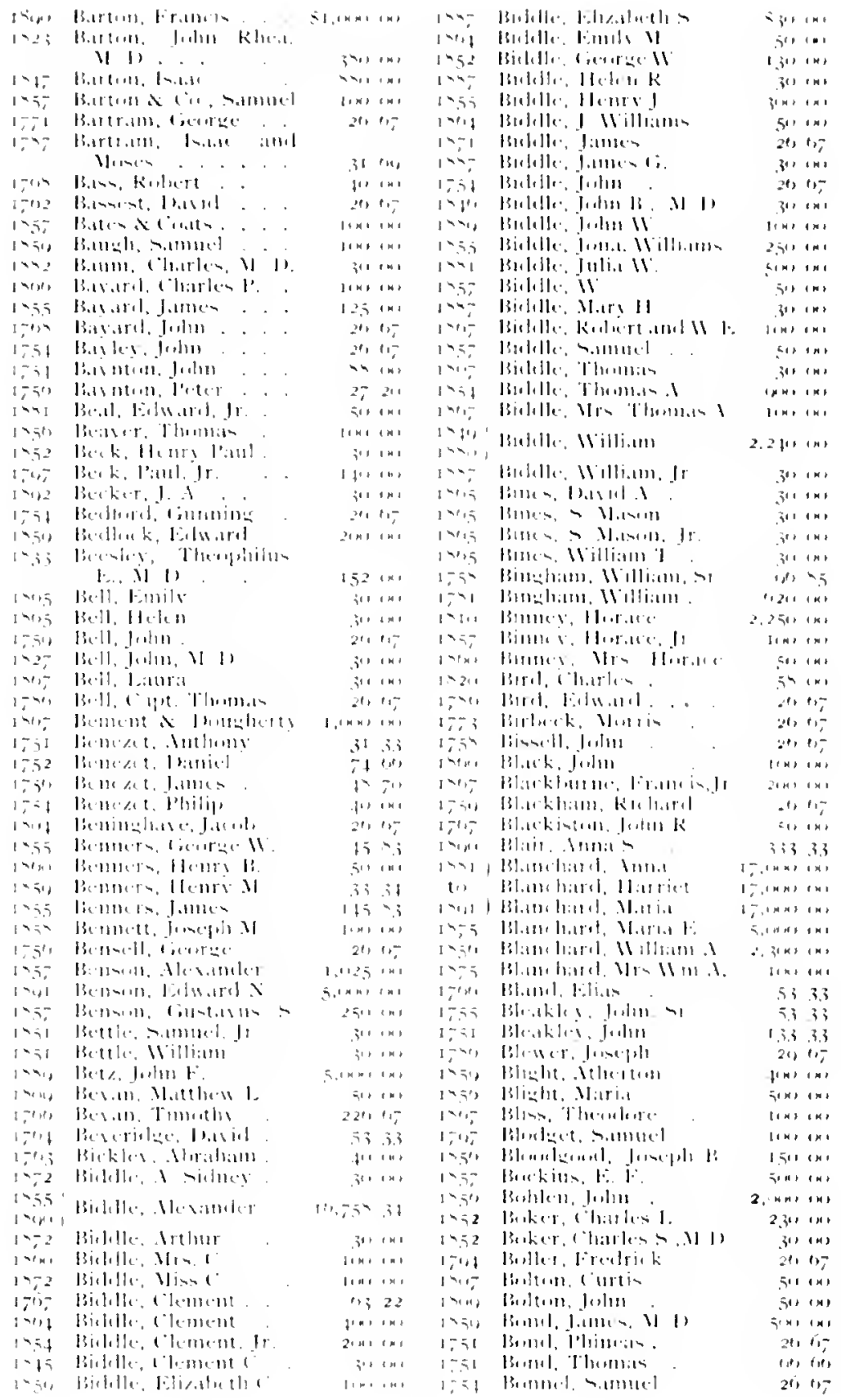




\begin{tabular}{|c|c|}
\hline 75 & Bumsall, Foward \\
\hline 159 & Buokhimaner..Allen il \\
\hline 1.464 & Boric, AclulpleE. \\
\hline 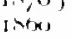 & Burie, Mrs, A(lolph l... \\
\hline $1 \times 6 \%$ & Burie, $C^{\circ}$ and It. \\
\hline 1056 & Berre, Clatrles I. \\
\hline $1 \times 5$ & Burie, lentry l' \\
\hline $1-5,3$ & Bussiler, Heriry \\
\hline 1907 & 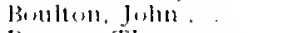 \\
\hline 1751 & Burtre, Thumals \\
\hline $1 \times t, 1$ & Hensicer, Michasel \\
\hline 12055 & linwenミFux. \\
\hline 195 & Bustell. Nilland \\
\hline$(x)-$ & Busber, Henry \\
\hline $1,7,52$ & Bнw matr. Jolim \\
\hline 1 ing & Buyd A llingls \\
\hline 1,71 & Bingel, Plunuar A. \\
\hline $\operatorname{lin} 50$ & Pingal, II $\theta$ \\
\hline [xtons & Buyd, Milian $\rightarrow$ \\
\hline 1.64 & Buyer, William II. \\
\hline 1.764 & Bracken, J. H \\
\hline $1 \times 41$ & 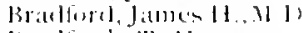 \\
\hline $1,-7$ & 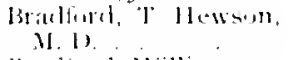 \\
\hline 17.55 & Bratlond, William \\
\hline $1-i n$ & 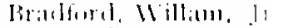 \\
\hline 1 ind & 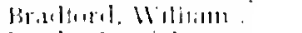 \\
\hline 1.57 & liraty, l'atriok \\
\hline 1418 & Bramilete (ientere \\
\hline 1450 & 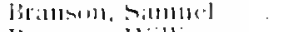 \\
\hline $1,7.52$ & bramentu. William \\
\hline ריבריו & braly, Maty. \\
\hline $1,-1,4$ & Breintmalt, lhatal \\
\hline $1,-\infty i$ & Brivlses, Kustert \\
\hline $1-\infty i$ & lirillghuret, Jamber \\
\hline 1.54 & Brintolnt Jubn \\
\hline $1,-1+9$ & lirinulumal, Juhn \\
\hline $1-131$ & Brimelourat. Junepis \\
\hline 1814 & Brintun, f; \\
\hline $1 \times 79$ & Brintort. Jane . \\
\hline $\mid a f(x)$ & [iresel, Julns \\
\hline 19.50 & 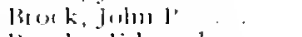 \\
\hline $1-i$ & Hromks Filuarol. \\
\hline 1754 & linotis, Thomis. \\
\hline$I \backslash .50$ & bromn, Al"samber. \\
\hline $1<, 6$ & Brown. Nlexambler 1 ' \\
\hline $1,-(n)$ & Brown, Indien \\
\hline $1 \times 5$ & Bromn, Bsomeville 1 l. \\
\hline $14 i n$ & $\begin{array}{l}\text { Btumu, Charterte } \\
\text { Ausustas }\end{array}$ \\
\hline $1,-0$ & Втими, ("lensent .I. \\
\hline 1,34 & Brown, l)asid S. \\
\hline 175 & Buwn, \& Hubls \\
\hline $14+1$ & lirown, Freverick \\
\hline $1 \times 92$ & 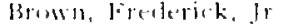 \\
\hline inti: & 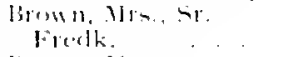 \\
\hline inti- & $\begin{array}{l}\text { Brown. Mis } \\
\text { frodk. It }\end{array}$ \\
\hline $1-6$ & 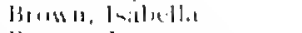 \\
\hline $1 \times 24$ & lirown, lamles \\
\hline 1754 & k10w⿻, jolemial \\
\hline 1.it & 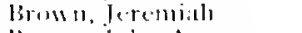 \\
\hline $1>50$ & Bronst, jolme A. \\
\hline I thin & Brawn, Mre. Jalus A \\
\hline 14. & B⿵⺆⿻上丨, Joln A \\
\hline
\end{tabular}

\begin{tabular}{|c|c|c|c|c|c|}
\hline & \multirow{2}{*}{$\mathrm{CH}_{3}$} & 1413 & Brown, Johin couthes & \multicolumn{2}{|c|}{$\therefore 1520$} \\
\hline & & $1+21$ & Jorown, Josefph l]. & $\therefore,-911$ & (x) \\
\hline & \multirow[b]{2}{*}{ (4) } & 1964 & Brown, J. Nimtar & 313 & $(x)$ \\
\hline $\begin{array}{r}=2(1) \\
30) \\
0,(4) 1\end{array}$ & & $1+22$ & brown, latwrence a & 57 & $3^{6}$ \\
\hline$(1, \pi)$ & $(x)$ & $1,4+3$ & Bमwकn, Mlaty 1). & $1.3(x)$ & $(x)$ \\
\hline $.5 \%$ & (11) & 1. $(x)$ & liruwn, Mary foarmandi & $5 .(n n)$ & $(x)$ \\
\hline $5+14$ & (x) & $1,9,-11$ & Brown, Mitry 4 & .3" & (N) \\
\hline $24 \pi$ & (H) & $\mathrm{J}(50$ & linewn, Mlases & $4 M$ & 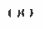 \\
\hline$(1)$ & 67 & Intur & Brombl, Mly, Mlanes & $5^{\prime \prime}$ & $1 \mathrm{HI}$ \\
\hline 53 & (1) & 174 & Bruma, lecter & 123 & -2 \\
\hline+1 & $7 \%$ & $1,+2$ & [srums, Sillumlel & 111 & $|N|$ \\
\hline ]14 & $(n)$ & $1 . \bar{x}(1)$ & 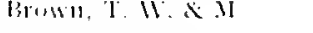 & 14H? & $(x)$ \\
\hline $1, n$ & (w) & lain & Jrunn, T. Mintia & $\therefore 1=5$ & $(A)$ \\
\hline $\begin{array}{l}\ln (x) \\
5,121\end{array}$ & (n) & 1253 & 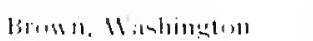 & 1方仙 & $(n)$ \\
\hline 32 & 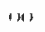 & I the & 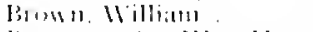 & 70 & (n) \\
\hline $1, n 1$ & $(H)$ & 1456 & 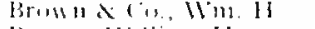 & $J(n)$ & $(n)$ \\
\hline 31 & (11) & $19 ;$ & Brusu, Milliam Hemy & $-(t)$ & 0 \\
\hline$[1,1]$ & (n) & $14+$ & Brems, MUllian J. & in & $4^{\prime \prime}$ \\
\hline$[1,7]$ & (11) & 1,47 & 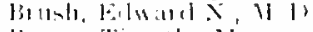 & in & in \\
\hline$[a x]$ & (11) & $l_{n} \bar{n}^{2}$ & 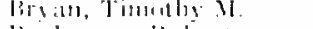 & {$[n]$} & (n) \\
\hline$[n+$ & $n$ & 171,3 & 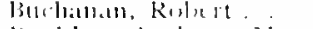 & 15 & in \\
\hline \multirow[t]{2}{*}{2} & (H) & 14132 & knekley, Anthony II & $3 i$ & (H) \\
\hline & & 1407 & 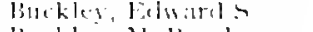 & $1\{n\}$ & (H) \\
\hline 2.34 & (n) & 145 & 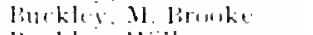 & (nns) & (n) \\
\hline 26 & 4 & $17.5 \%$ & Buckley, Milla:m & i & $\{;$ \\
\hline 24 & $n$ & 1455 & bucklledl, Milliam & $1.1 \mathrm{kM1}$ & $(n)$ \\
\hline in & 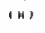 & 14511 & linetinell, Mla Mn. & 125 & 14 \\
\hline $1+n \mid$ & $(n)$ & Inラ゙" & 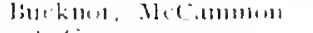 & & \\
\hline 1.33 & $3 ;$ & & $\therefore 1$ & 201 & ' "' \\
\hline$(111)$ & m & 1年7 & 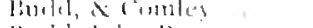 & 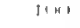 & '"I \\
\hline 1.3 .3 & $3 i$ & 145 & 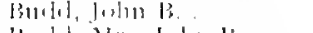 & . $(4 n)$ & $(n)$ \\
\hline in & wa & $14+1$ & linilel, Mrs Inlun H & 53 & $(n)$ \\
\hline 20 & $1 \%$ & 1450 & linelel. Jimetidi & in & $m$ \\
\hline$i^{4}$ & (n) & $17 x$ & 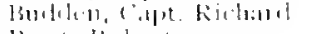 & $\therefore 1$ & $t ;$ \\
\hline .11 & $6-$ & $1 \times 51$ & 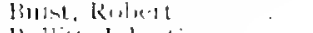 & $1+n)$ & $1 \cdots$ \\
\hline 42 & Th & 19.53 & liullite, Jubur & 211 & ins \\
\hline $2+1$ & 6 & 1451 & kullork, Bstubattum & -7.1 & tn: \\
\hline 24 & 17 & Inin & Bulluck, clmolle = & (n) & 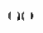 \\
\hline $1 \cdot \mathrm{kr}$ & ('1) & $1,-54$ & linllack 1; & $\therefore$ & 4 \\
\hline 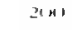 & (n) & 19.57 & linntu. Kitigud s lin. & 111 & ‘ \\
\hline $2,1 \mathrm{HH}$ & (H) & $\ln 40$ & ikanting. Heory lis & S.1 $11 n$ & $4 " 1$ \\
\hline $2 \leqslant 11$ & 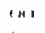 & 144 & Bunting, Jacenl I & $1 . \overline{5}$ & $s "$ \\
\hline$\therefore$ h & $n-$ & $1 \times 21$ & Bumtine. Jumiall & तi & in: \\
\hline 20 & n & 1924 & buted, Finuard. & $1 \leqslant 4$ & an' \\
\hline 254 & (H) & $1,-412$ & [3ar, licel], I.]. & $2 *$ & 3 \\
\hline $3, i$ & $3 i$ & $1,-50$ & Burne. Salmulel & $1 \omega_{i}^{-}$ & $2^{2+3}$ \\
\hline 513 & $3 i$ & $1=51$ & Barsin, (; & 1י & (n) \\
\hline \multirow[t]{2}{*}{$2+n 1$} & (n) & Inji & 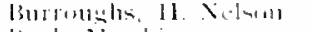 & 1213 & $\therefore 1$ \\
\hline & & $1,-31$ & Bund, Matthiatn & $2 t$ & 0 \\
\hline $\mid[n \mid$ & (n) & 145 & Buteler, Joln & $\mid(n)$ & $(x)$ \\
\hline 3.3 & 34 & 14,7 & 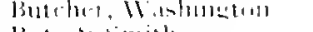 & las & 131 \\
\hline 124 & $6-$ & 145 & Bute a sinith & 2511 & $\cdots$ \\
\hline $2(x)$ & (11) & $1 \times 5$ & H3utker, John 11 & $\mid 1 n 1$ & ; \\
\hline $1+4$. & (11) & 1751 & 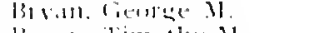 & $t^{\prime \prime}$ & 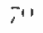 \\
\hline \multirow[t]{2}{*}{ I for } & (11) & 16511 & 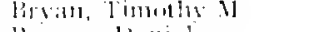 & lens & 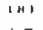 \\
\hline & & $1-70$ & Hones, louniel & 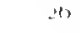 & $n$ \\
\hline \multirow[t]{2}{*}{ 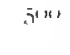 } & "n & 1412 & litrint Jowlinat & $\because 1$ & (11' \\
\hline & & 1414 & $3 \mathrm{l}$ & 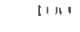 & 141 \\
\hline \multicolumn{2}{|c|}{$\begin{array}{l}\therefore \times 101 \\
3333\end{array}$} & \multicolumn{4}{|c|}{ C } \\
\hline $\begin{array}{l}3.3 \\
40\end{array}$ & $\begin{array}{l}n_{n}^{3} \\
(x)\end{array}$ & & $\therefore i n$ & 35 & int \\
\hline 26 & 0 & $1 \times 5 n$ & 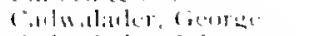 & {$[x$,} & $(x)$ \\
\hline 26 & 6 & $1,-1$ & (:alsiolater. Julu & $1 ;$ & 33 \\
\hline $8.5+x+$ & $(n)$ & $1,7,1$ & 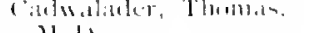 & & \\
\hline$\frac{14}{14}$ & a"? & & (') & (x) & $a_{1}$ \\
\hline & Thr & & & 3 & \\
\hline
\end{tabular}




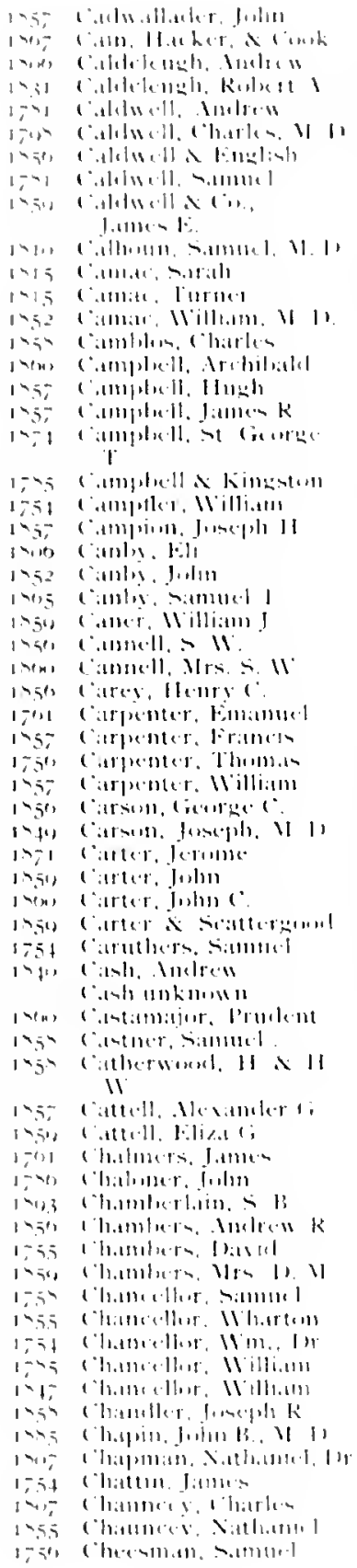

\begin{tabular}{|c|c|c|c|}
\hline $1.511 \mathrm{MO}$ & $1,-34$ & (11.1.11110. He & $-2+5+11$ \\
\hline$\$=1, n$ & $1-50$ & 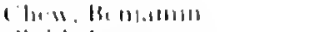 & ene ent \\
\hline $5+114$ & $1 \div 31$ & cholal. Jomen & 141.5 \\
\hline i+1 InI & $1=1,1$ & ( hollo, lisurge 11 & $\therefore|I M| N \mid$, \\
\hline it 1 ; & (si, & 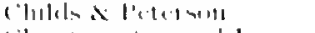 & $|+x|+x \mid$ \\
\hline $\operatorname{lon} 1 \ln 1$ & an' & 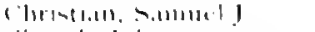 & $2 n+1 n$, \\
\hline$|x|+|x|$ & $1: 51$ & chur, lo, lohne. & $24,+5$ \\
\hline \multirow[t]{2}{*}{3524} & Ineip & 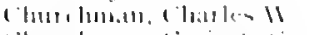 & $2(M 1+N)$ \\
\hline & 1454 & 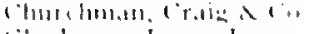 & (1) (k) \\
\hline 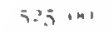 & 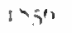 & (1.1:-1morme. Jome- 1 . & $15+1 \mathrm{MI}$ \\
\hline $1+1+x$ & 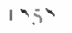 & (1.121101111r, J.1t11k $>11$ & 501 \\
\hline Ans in & and & (1.1peler, l.tuin & $\because n I M$ \\
\hline 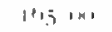 & $\ln 10$ & (I.I)י. . N11, & in in \\
\hline 沙化 & Sin & 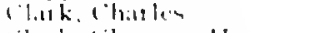 & Sar in \\
\hline 1,211101 & ais & 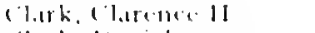 & 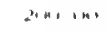 \\
\hline $\ln \mid$ In & -101 & (1:uk, l':unit & $3+1,-5$ \\
\hline IMI InI & Inis & $(1.1 \% \times(1,1511$ & $i, 51+1 \mathrm{k}$, \\
\hline \multirow[t]{2}{*}{11.5111} & .54 & cluk. I:Aluad 11 & in $\cdots$ \\
\hline & in & (1.11k. V11, N & $1.14 n 1(n)$ \\
\hline NNI INI & $1 N(n)$ & 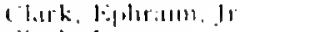 & $\mid A M)+N \mid$ \\
\hline 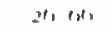 & 1.52 & ( lituk, J.111" & $4 \times 1,19$ \\
\hline$|11| x \mid$ & $1,-\infty, 0$ & $(1.1+\mathrm{k}, J, 1 \mathrm{ln}$ & स" \\
\hline 501011 & 14 & iluk, Juhn & $501+\cdots$ \\
\hline fHINI & $1 ;-7$ & clath, s.tmulel & 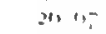 \\
\hline in (N) & $14 x$ & (latke, I Y, U I & 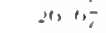 \\
\hline $3 m>(x)$ & 17.50 & (latkmin, Matthe w & $\because 3$ \\
\hline (n) $(n)$ & $1 ;-\infty 0$ & (l,1), curtio & $\because \mathrm{OH}$ \\
\hline $5(x)|n|$ & 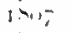 & 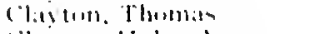 & lain \\
\hline $5+1 \mathrm{x}$, & $1 \times 1,3$ & 11. I $\cdot 1$. & $\therefore, 1 n+1+1$ \\
\hline (t) ik & $14+3$ & nil. J:11 & (i) $1 \times 1$ \\
\hline $21,6-$ & $1,5.51$ & 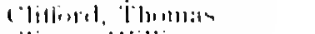 & 21115 \\
\hline 501181 & $1 \div .56$ & (littun, Milli,am & 121, \\
\hline$\because|x|$ & 14 & is.t. Imilill |l & $31+\ldots$ \\
\hline $511+11$ & 17.51 & . J.1111, & 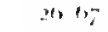 \\
\hline$\{(n)|x|$ & $1-601$ & T, 1 ; & $0 ; 72$ \\
\hline ;n (n) & 155 & instles. Mlusthitul & vins in, \\
\hline$\{1\rangle|n\rangle$ & 14 & 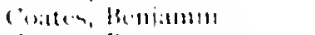 & whe in \\
\hline$\therefore 31, \omega\rangle$ & 123 & Jit & \\
\hline 121,111 & & iser. If I, & $\because x$ \\
\hline$|1 M||M|$ & $1 ;$ & $\therefore$ Cicotrate 11. & (i) (n) \\
\hline $211 \%$ & $1--21$ & ("intles, Isit:se" & an the \\
\hline $3+1 M 1$ & $1,5.5 .5$ & cinttes, folnt & $32 x_{1}$ \\
\hline $3 i^{t}=22$ & 17.55 & - Inhin, I1 & INI I M \\
\hline $5 n+14$ & $17+1$ & (inates. john kevalle & (1) 15 \\
\hline \multirow[t]{2}{*}{$|101| H \mid$} & $1 ; x$ & 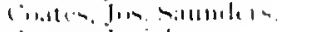 & $2 t)$ \\
\hline & $1,-5$ & (in.1tex. Jumials & $2 n+1 n$ \\
\hline IOHIIMI & $1-2$ & inatlen Juntials l. & 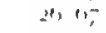 \\
\hline$|, N 1| N \mid$ & an & (inater. $x$ ( & $11 x \mid$ in \\
\hline 5114 & $17-1$ & 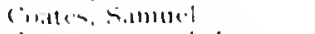 & $\therefore ; 2 ;$ \\
\hline $5 ; \quad 3 i$ & W1 & (intles solmusl. It & $\therefore \mathrm{C}^{2}$ \\
\hline $2-201$ & 5.5 & 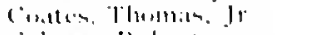 & 20) 6 :- \\
\hline 1001101 & ans & 11. Rulurert & 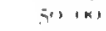 \\
\hline$|0 m|$ ins & 1nits & lintiram \& $\mathrm{k}$ & lind in \\
\hline 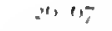 & 145 & 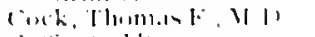 & ; \\
\hline i'lu & 1 vingt & 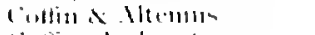 & 18014 \\
\hline $21,1=$ & 1159 & cinlin, Srthure, & HA in \\
\hline $20,5,1 \times$ & $1,-4 x$ & 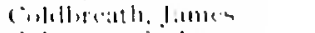 & 240 \\
\hline 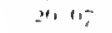 & $1=51$ & 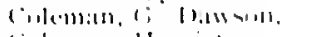 & Sוn 1 \\
\hline$\Rightarrow n$ & 14.50 & Cishomall 1latriet & $\therefore m+1$ \\
\hline 沙 1 & $1 \div ;$ & 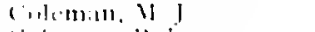 & $\therefore \div 1$ \\
\hline$|n|,|1|$ & sin & in. Kalutt & ; i । \\
\hline il In & $1 ;-51$ & m. IVilliam & 11,711 \\
\hline$\therefore+\mathrm{P}_{5}$ & $1 \times 15$ & 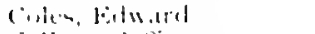 & 15012 \\
\hline 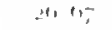 & 19,3 & Cilket. Contrin & 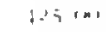 \\
\hline$\{1+$ in & $1 \times 5$ & 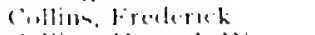 & $5 \times 1$ \\
\hline 形IN1 & 1014 & (illind. Ilammals U & 1 in. \\
\hline$\because+1,-$ & 149 & ritlim, I K & 1,11, \\
\hline
\end{tabular}




\begin{tabular}{|c|c|c|}
\hline $1 \times 4$ & (ollins, Justphli $1 \mathrm{I}$. & $\therefore 51)(\mathrm{N1}$ \\
\hline $1-\mapsto 2$ & (inllins, Stephen & $52(x)$ \\
\hline $1=50^{\circ}$ & cillins. T. K. $A$ P. & {$[(x)(x)$} \\
\hline 1,95 & ciollins, Ziscebtein. & $(1+1)(x)$ \\
\hline 1259 & (iolwell. Stephtun & $5(x) \cup x$ \\
\hline 1722 & comber, Thumats & $30,6 y$ \\
\hline 1457 & Contexs. B. B. & $50(x)$ \\
\hline 195 & Consly, Franklin A. & $(1, n)(n)$ \\
\hline 1467 & Comly, Franklin A., Jr & $501(\mathrm{H})$ \\
\hline $19-0$ & Comarroc, fjew. .1. & (3) ( $\mathrm{k})$ \\
\hline $1<51$ & Conrad, charles. & (N) (N) \\
\hline 1452 & Comrad, Jolnen . . & in (3) \\
\hline 14.52 & comrat, Solomon. & $275^{\prime \prime}$ \\
\hline$1 \longdiv { 5 9 }$ & sontributors & $5,5(x)+x)$ \\
\hline 1766 & (anyngham, Lavial & \\
\hline & Migfield & 320 \\
\hline 1756 & Conymurban, Redmond & $3+67$ \\
\hline 1801 & Cuote, Alexander. & 2657 \\
\hline $1 \times 57$ & Crokte, Jay. & $1,26 \mathrm{k}) \mathrm{ms}$ \\
\hline $3 \times 67$ & Cooke SCin. Jas. & $2.561,04$ \\
\hline 1222 & Conke, John & in oks \\
\hline $1 \div 56$ & Cisuley, Aaron B. & $1(x)(x)$ \\
\hline $1>59$ & Cisuler, Aligail & $(y)(x)(x)$ \\
\hline $1 \times 55$ & copoter, Enther I. & $(M) \times(N)$ \\
\hline 1754 & Cooper lacols & it 3.3 \\
\hline 179 & Cupler. Samuel, Ml lo. & for (x) \\
\hline 17.54 & Cinper, William & 2607 \\
\hline $1>50$ & Cinpe. Alfreal . . & $5.6 x+10 x+$ \\
\hline 13,33 & Cilpe, Calel. & $160, r_{k}$ \\
\hline $1>-0$ & cope, Frlwin R. . & $f,(x, x)$ \\
\hline I T⿱一⿻上丨冖 & copte, Flias : & $(1, x)(x)$ \\
\hline 1456 & Cinte, Francis R. & $\$ 2 j|M|$ \\
\hline 1.56 & Cope, lienry. . & $2,1(x)(x)$ \\
\hline $1 \times 17$ & Ciple, lsratel . . . & $501 x$ \\
\hline $1 \rightarrow 13$ & Cope, Jasper . . . & $451 \times 1$ \\
\hline $\ln 56$ & Cope. Joln E. . . . & $.33 \quad 33$ \\
\hline $\operatorname{lng}$ & ('ope, Thomas P. & $620(x)$ \\
\hline 1567 & (ope, Willianl L. . & 11430 \\
\hline $17+2$ & Coplerthwaite, Jusels & 2607 \\
\hline 1,59 & Corbit, I anticl. & (1, 3$)(n)$ \\
\hline 17,3 & Corlsyn. Tlumas & t4h tho \\
\hline 1860 & Cornelius \& Baker. & $1,2(x), \infty$ \\
\hline Ifol & Cornelins \& Ruwland. & $51(x)$ \\
\hline 1,01 & Correy, Johns. & 20,07 \\
\hline 1757 & Cowplank, Jonathan & 21) 6\% \\
\hline 1,755 & Cimltals, James. & $3(x)+x$ \\
\hline $1 \times 19$ & Cimultas, John. & $+10+1$ \\
\hline $1 \times 67$ & ("ix, James S. & (n) $(1,3$ \\
\hline $1 \times 57$ & (ins, Jolin)... & $3(\mathrm{M}) \mathrm{KS}$ \\
\hline 17.46 & cos, Vhilliam & 1.3 .3 .3 \\
\hline $1 \times 54$ & (inxe, Alexander 1 . & in $\mathrm{AN}$ \\
\hline 1954 & (uxe, Brinton & in (n) \\
\hline 1759 & Cince, Charles & (,6) 137 \\
\hline J5t & Cince, Charbes 13. & (3) (w) \\
\hline Ist & ivxe, charless. & $1,1+30 \times(n)$ \\
\hline $1+5$ & (wxe, Ibuniel $11^{\circ}$. & $51 \times(M)$ \\
\hline 155 & Coxe Eckley B. . & $31(\mathrm{~N})$ \\
\hline 1559 & Cine, Folward $s$. & {$[,(M), I M)$} \\
\hline 1554 & Coxe, lenry 13 & $i n(M)$ \\
\hline $1-6 I$ & Coxt, Istate & (3) 56 \\
\hline $1,-61$ & (ine, John, MI I) . & 32.14 \\
\hline 1795 & 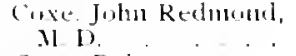 & os 10 \\
\hline $18 x$ & Cuxe. Relueca & $2+x+4$ \\
\hline $17-2,3$ & finse, Tench . & $5.36 t)$ \\
\hline $176 \mathrm{~J}$ & (aste, llilliam . & 53.33 \\
\hline 1,266 & ("ist, Milliam, Jr. & 2567 \\
\hline
\end{tabular}

\begin{tabular}{|c|c|c|}
\hline $1 \times=6$ & Grists, Andrew $0^{\circ}$ & $5 ; 11148$ \\
\hline$|7 p|$, & ('ralle, Il'illiam & is on \\
\hline 170 & Cralig, Jatme-and John & 20.3 .3 \\
\hline 1340 & ("rammund, 1Iellry" & is ( \\
\hline $1,1,5$ & Craben, Thumas & $(i x)(x)$ \\
\hline 1 intur & (retly. Georare R. & $45 x+1 \times 1$ \\
\hline Intoin & (recighton, Himiltum & Jim $|x|$ \\
\hline $1,7.54$ & (reightun, Rolutert & $(A, A)(N)$ \\
\hline 1017 & ('ressin, (calel). & laxpors \\
\hline $1+52$ & ("resarsu, Charlesi. & $\operatorname{lol}(x)(x)$ \\
\hline $15+7$ & Cresorill, Flliote & $30(x)$ \\
\hline 1404 & Crustill, Fmlen & $50(\mathrm{~kg}$ \\
\hline $1-63$ & ("ressin), Jantes & $26 \%$ \\
\hline 125 & Cresson, Jatmes & $y(x)(x)$ \\
\hline $1-54$ & Cressull, Jahn & 2607 \\
\hline 1255 & Cresson, John (". & lifkes ins \\
\hline $1 \times 57$ & Cresaun, Juseph. & 5301010 \\
\hline $1,-2$ & Cresson, Joshuad & 4" (x) \\
\hline I 5 & Cressul, Villiant". & $1,504 x$ \\
\hline 17.5 & Cramelien, feorge & IU: A H \\
\hline $1 \div .51$ & ("rostoy, Joshusa. & $27,06,6$ \\
\hline $1-52$ & Cromby, Thumas. & $129 \times 1$ \\
\hline 1,56 & ("roskey, Henry". & $f(n+(N)$ \\
\hline 19.5 & Cronkey \& Cir. & $\xi(x) i x)$ \\
\hline 140.5 & Crussman, Jatmes .11. & $2100(x)$ \\
\hline 1455 & Cruziter, linh P. . . & $6,(n)(n)$ \\
\hline $1=59$ & Crozier. Mlrs. & $50(n)$ \\
\hline 1 - ints & cruiksllank, Jinnes. & for (x) \\
\hline 1775 & Cruikshank, Josepll & 211211 \\
\hline 1 - int & Cruikshank. Raclicel & 2667 \\
\hline $1-54$ & Cull, Mattluias & 2067 \\
\hline I -1 & Cummings, A. Bosd & $5.54 \pi)(x)$ \\
\hline Istog & Cunumings, A. 11 & $50(n)$ \\
\hline $18 y^{7}$ & Cumomings, Cbarles H. & 5()$(x)$ \\
\hline $3 \times 57$ & Cummings, Inniel $\mathbf{l}$. & $(1+x)(x)$ \\
\hline $1 \times 60$ & (unnminys, Mrs. 1), B. & 5()$(N)$ \\
\hline 1.19 & Cummings, Richard $\mathrm{P}$. & 5500 \\
\hline $1+56$ & Cummings, IVillians. & $150(\mathrm{~m})$ \\
\hline $1>56$ & Curren, Martin. & $5(x)$ \\
\hline $1 \div 57$ & Curtis, Benjinnin $\mathrm{T}$. . & $2 x)(x)$ \\
\hline $1+45$ & (urwen, Juhu XI, 1). & $5,30(\mathrm{mo}$ \\
\hline 1.59 & Curwen Stouldart a & \\
\hline & Brus. & $31(x)$ \\
\hline $1 \times 5 x$ & (utlibert, Allen & $I(N)(N)$ \\
\hline 1) itos & Cuylet, Theos... & $511(n)$ \\
\hline & $\mathrm{D}$ & \\
\hline I 465 & J) (istal, Jacol, M. & \\
\hline $14-3.31$ & $11.1 \%$ & $3(x)(x)$ \\
\hline 1210 & I abluren, Bernard & (i) (K) \\
\hline 1.57 & bitle, Richatric: & (B) 191 \\
\hline $\ln 6 \times 1$ & Wale, VIrs. R. C. & $501+1 \times 1$ \\
\hline $1 \times 56$ & I) illete, Brothers & $\{(x)(n)$ \\
\hline$\left[\begin{array}{ll}4 \\
37\end{array}\right.$ & I) lltett, Fliz.l. & $\ln (x)$ \\
\hline IN5; & I) allett, rillies & {$[1 x)(x]$} \\
\hline $1>t x y$ & 1)allett, Mrs. Juhm & $5(1)(m)$ \\
\hline Isin 6 & I):lla, Jatry il. & in' \\
\hline $1 \times 59$ & 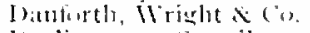 & {$[1 x+\{x)$} \\
\hline $1 \times 65$ & batrlingtion, Smeolley & $501 \times 1$ \\
\hline ISto & 1)arricli, Jamess, lor. & (1) (x) \\
\hline 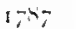 & lbavid. Julum & 沙( $x)$ \\
\hline I. .56 & Iblis, Benlanuin & 250140 \\
\hline 1757 & 1).tis, bavid . & (2) 17 \\
\hline 1415 & I avis, Inavid Jones & \\
\hline & . 11. & $|m|<n \mid$ \\
\hline & Ir & 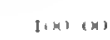 \\
\hline
\end{tabular}




\begin{tabular}{|c|c|c|c|c|c|c|}
\hline 1.56 & lowis. Fillwant & Slin, & int & 19,518 & 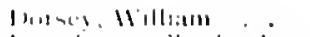 & $\because 311 \%$ \\
\hline 155 & 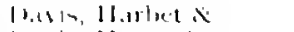 & $2|x|$ & $(n)$ & 10.5 & 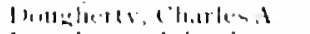 & $i 31 m$ \\
\hline 12.41 & Is.1,in, Item, 1. & $\therefore, 51$ & $1 * 1$ & Insen & 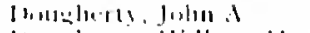 & $31 \mathrm{M}$. \\
\hline $1 \times 27$ & In:tis, Inolus & 21 & 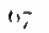 & (1).51 & 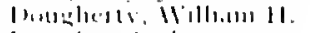 & $3,3 \mathrm{Ax}$, \\
\hline $1 \times 54$ & $11.1614,15.1 .11 \mathrm{k}$ & $11 \mathrm{mo}$ & in & 1,111 & 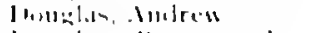 & 2t) 1 - \\
\hline 1454 & lo, is, Jellne. & Jun & $1 \cdots 1$ & ISSi & 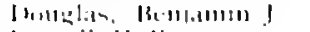 & $2(n)+n 1$ \\
\hline $1,7,51$ & 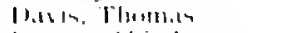 & $\because 2$ & 1.5 & 1,51 & In, 11 111,1m & ens ins \\
\hline 1791 & 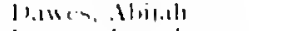 & 11, & an & 101.3 & 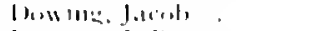 & $513(\mathrm{H})$ \\
\hline $1,-1,5$ & $11.114,4$. J111.11/1.111 & 313 & $(x)$ & $1 \times 51$ & 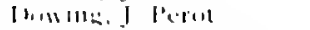 & (5) $1 \mathrm{NA}$ \\
\hline 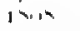 & 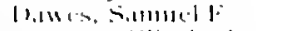 & 311 & (n) & $1-31$ & $11, .11,1+m$ & $z^{\prime} t_{1}$ \\
\hline 14512 & 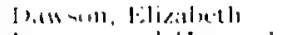 & $2(x)$ & 1"1 & Itoms & llithe, Tlunllom, Mis & $11 x \mid$ in \\
\hline 15,3 & 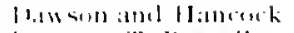 & $\mid(m)$ & (w) & $175 n$ & In, sim, Nonthen & is \\
\hline inti, & 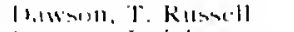 & in & $\ln x$ & 19.5 & Iri!lu, II illusm! & \\
\hline $1 \times 513$ & [1,1wsol1, Jusial]. & $($ INA) & $|x|$ & & Ili! w.1til & line in. \\
\hline 19.31 & 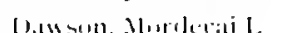 & & & 145 & Herer, loceleriot I & $355 \mathrm{~cm}$ \\
\hline $19-1+1$ & 1 & 5 & 1 & 191,5 & 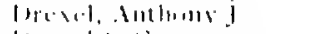 & $35,5+(n)$ \\
\hline 1,09 & 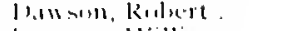 & $1 \div 1$ & $(n)$ & 141,7 & $11,0.1 \times 1 \times$ & 51010103 \\
\hline $1,-5$ & I vimsun, Milli.m & $2 t$ & 137 & $1,7,1$ & Jomker, I)anded & 20,05 \\
\hline 1352 & I t.14men, II illiam II. & f"' & 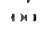 & 1.50 & lomker, H, ms & $3 \times 1$ \\
\hline 1537 & 11.19, Mreholel. & lin: & $(M)$ & 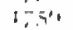 & Jriukere, Juint & $(x, y)$ \\
\hline 1 ⿻ो & lowin, Julun. & il & ; & $\because \rightarrow 2$ & 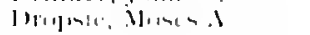 & 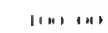 \\
\hline 1255 & 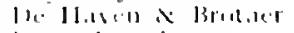 & $\operatorname{lin}$ & (M) & 15.5 & 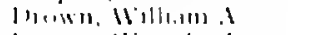 & $3(x)(x)$ \\
\hline $1,7=$ & 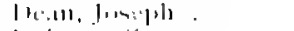 & 19 & 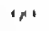 & $1 \times 14$ & $11, m, 11 m, 1$, Ir & 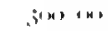 \\
\hline 177 & 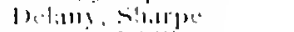 & $2 i$ & $1 ;-$ & 1.51 & 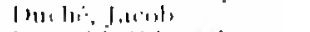 & ot is \\
\hline $17=41$ & 1) limy. Milliam & "n & $n$ & $1=1$ & 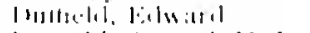 & 5 in \\
\hline 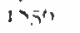 & 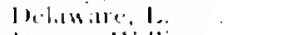 & $14 n 1$ & (x) & $1 \div-1$ & 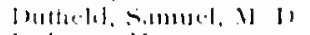 & 21,15 \\
\hline 1751 & 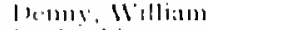 & 270 & $t$, & $\therefore 57$ & lulume. Hemy & $(m x)$ in) \\
\hline 14551 & lintersluile. & & & 小ら” & linlles. Jumepli 11. & $1 ; i, 31$ \\
\hline $1,-21$ & Alexinuler J. & $8,(1,1)$ & $(x)$ & 155 & 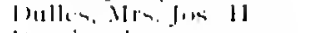 & lax in \\
\hline 1 ant & lerlushire, Matry 1 & $5(4)$ & $(H)$ & $1+14$ & lumilas, Jinnes & $2,1,30 \mathrm{~cm}$, \\
\hline $17.5=$ & beslifer, lowid : & 11 & $|n|$ & 1715 & l:t). juhn & 133,33 \\
\hline Jorns & 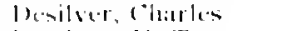 & 54 & $|n|$ & $\therefore x$ & laip, 11 llliam & $2(x)(x)$ \\
\hline 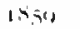 & $11, \cdot 41 \times c r, I 1 . T$. & .511 & $(n)$ & 1933 & 11, X.1lin:111 & (3) $(x)$ \\
\hline $1 \times 5$ & lneverent, folm & 511 & $(x)$ & $1-51$ & $11 y, 1): 1111.1$ & $2 t) 67$ \\
\hline $1 \times 45$ & Ihences, Milliam I". & & & $1 \times 1 \%$ & lolis,ur, f*lorimunul & (x) in) \\
\hline & ). . . & 511 & $(x)$ & 145 & lutilh, ('h:1l's & $J(H)(n)$ \\
\hline 171,1 & 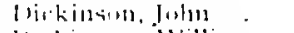 & 14.5 & (t) & $1+3$ & blatilh, Jlary (; :and & \\
\hline $17+5$ & lyakinatu, Williallu & .33 & $\therefore i$ & & $11.119 \mathrm{gln}$ ler & $1,(n)(n),(n)$ \\
\hline$[450$ & lickimatu, fimmes $x$ & $10+1$ & $\because$ & $1,1,7$ & $11 . \mathrm{M}, \mathrm{B} . \mathrm{.}$ & In, in , \\
\hline $1,5 i$ & l)hkimsm, l,cri & $2(x)$ & (n) & & F & \\
\hline 173 & J merims, I I & $3 n$ & $(x)$ & & $\mathrm{E}$ & \\
\hline $1+x+a$ & l)ll:arl, IJeury $k$ & $3 t$ & $(x)$ & (⿻is's & Esarl, Siamued 11 & .3 .3 .3 \\
\hline intt & lollimulu:m. & & & $1>(x)$ & Furl, Tlumbers & $\operatorname{lin}(x)$ \\
\hline & lited II. & in & $(n)$ & $1+50$ & 1arp, lhimats & $1,(1 x)(x)$ \\
\hline 17513 & Jilmorth, Milliam & ?t) & 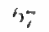 & $1 \times 57$ & 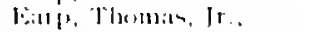 & {$[1 x)$ in: } \\
\hline $18=1$ & I illisurth, IJilli.um & (1): & $(n)$ & $1,-106$ & Fintlintru, J'lesuli,on & 30157 \\
\hline $171 ;$ & 11, ciecterse & $\sqrt{2}$ & $31)$ & 14 & Funaluk. Mmlren M. & $52.5(n)$ \\
\hline $1 x_{i}=1$ & IIIlwyı. Nilli,um & $f(x)$ & $(n)$ & 14511 & ㅂols, IIilli:un & $f(x)(x)$ \\
\hline $1-x \mid$ & $\therefore$ charles & $2 i s$ & 07 & $19-7$ & 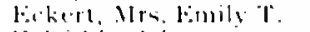 & $5,(x),(x)$ \\
\hline 1952 & $\therefore$ Justph & 30 & $\ln 1$ & 16 & bokelule, Arloms & $3.5(x)$ \\
\hline $14, y$ & 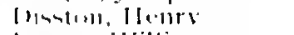 & $5(x)$ & int & $1-2$, & Fildy, ,icurase & 21,6 \\
\hline 1,50 & 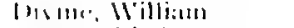 & $1, x)$ & $(m)$ & $1,7.5 \%$ & Fildy, I: & 4.51 .5 \\
\hline $\ln 2$ & 115111. Biwin & $3 n$ & (n) & 1915 & Ealliy, I, Itry II. & $(1, x)$ in \\
\hline Intwi & Hixn, Miss M. & 511 & $\cdots$ & $1-\div$ & 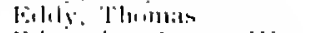 & $26,6-$ \\
\hline $1 ; 511$ & loim, kuluert & $\therefore i$ & 15 & 145 & Fitwionds, (ixoutge 11 & $|(x)| x \mid$ \\
\hline (Thin & llum, llisst. & 50 & (H) & 1), & olurey it soms, Jahis & $5(x)(x)$ \\
\hline 192 & lixum, Simulal (;., I) & 识 & $(n)$ & $1 \times 5$, & Finembrey, Julan, jr & {$[(H)(M)$} \\
\hline 1,404 & l halisals, Jenhis & $5 n$ & (n) & $1,-1,2$ & blam, Cinvis & $50(\mathrm{~m})$ \\
\hline $1, \times 1$ & Juntaluan, Jushn & 31 & 6 & 170 & El:m, Rolurt & 5111,14 \\
\hline 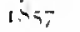 & lulst, Sinplui:l & 503 & (ii) & $1,7,4$ & 1:1:m, simmuel & $50(3)$ \\
\hline 1.57 & 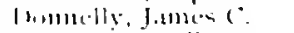 & $3 n$ & $(n)$ & 1,51 & EHreth, Jesemials & 2007 \\
\hline 172 & lhorsey, Bomedict & $x$ & (x) & $1 \rightarrow a t$ & lilkins. Milliam I.. & $(1 x)(x)$ \\
\hline $1,-4$ & $1), 1-4 \cdot 5.101+11$ & ;i & $t,-$ & けに & IElkinten, (ientrge M & $1.3 .5(n)$ \\
\hline $14 \%$ & 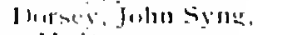 & & & $1 \times 4$ & lolkintun, lhombls & $30(\mathrm{~N})$ \\
\hline & & 7 & 5 & $1,-1,1$ & Fllintt. Amlrew & 21,67 \\
\hline 175 & lorses, Jemnard & $2 t$ & $1 \%$ & $15 ; 3$ & lillintt, Isilate & $30)(x)$ \\
\hline & 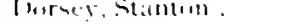 & $i^{\prime}$ & $(n)$ & 17 & Jollieste, Juluin & I" \\
\hline
\end{tabular}




\begin{tabular}{|c|c|}
\hline 1965 & Elliott, Jollu \\
\hline $1-\mathfrak{r}_{2}$ & Elliott, John, Jr. \\
\hline $1+5$ & Ellis, charles. \\
\hline 1456 & Ellis $\mathrm{x}$ Co, (borles \\
\hline 145 & Ellis, Exull T? \\
\hline 1754 & Ellis, Thommats \\
\hline 1,452 & Ellis, William \\
\hline $1 \div=6$ & Ellison a Sons, Jolno $P$. \\
\hline 1465 & Elmoley, Ann \\
\hline 1465 & Finsley, Elizalueth \\
\hline 1465 & Elmostey, Refuecil \\
\hline 1.865 & Finstey, William \\
\hline Inog & Fimblie, Aleximulet \\
\hline 1.493 & Elkingtom, Lindkey $\mathrm{Xl}$. \\
\hline 1.484 & Elwyn, Alired. \\
\hline $1.40,3$ & Ely, IItwi \\
\hline I S6gon & Ely. R心 \\
\hline $1 \cdots 5$ & Eintily, Juhn. \\
\hline 1.426 & 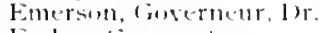 \\
\hline 1754 & Ende11, Gentge, ar. \\
\hline 1756 & Finle-1, George, Jr. \\
\hline 17.55 & Emlen, Jomhuit \\
\hline 1754 & Emlen, Somuei \\
\hline $1+22$ & Emlen, Simulel, N11). \\
\hline $1,7,5$ & Engle, Pitul \\
\hline 1950 & Erroksm, Mirdatel \\
\hline 1459 & Erringer, J Livingetur \\
\hline lathen & Erwal, Mrs. Jolnt H \\
\hline 1000 & Erwin, Mary \\
\hline $175^{\circ}$ & Erwin, Roliert \\
\hline $1 \leqslant 50$ & Estlitck, Thomits \\
\hline ingt & Evins, Allen. \\
\hline $1 \sin 7$ & Evats, Clath C \\
\hline 1.5 .33 & Eviths, (harles, , 1 ). \\
\hline $1 \otimes-11$ & Evalus, Charles. \\
\hline 1,754 & Exidum, Eidwaral \\
\hline I thess & Evams, Jilwatrd \\
\hline Insth & Evitus, llorace Y', II 11. \\
\hline [atis & Evalls, Miss Jalle \\
\hline 1772 & Esit1s, Jix-1 \\
\hline 177 & Exans, Juhn \\
\hline 145 & Evans, Julan \\
\hline $175^{\circ}$ & Evans, Jonathan \\
\hline$[\rightarrow(t)$ & Exatns, Junatlantl \\
\hline $1 \omega_{5}$ & Evann, foseph $k$. \\
\hline Ithes & Eviths, Junith \\
\hline $1 \cdots 17$ & Evalls, J. Willitm \\
\hline Ititod & Evans, J Wistar \\
\hline $145=$ & Exalls, Kowland 9 \\
\hline Inq" & Exims, Tolumats \\
\hline 19.57 & Evims d Watsum \\
\hline $\ln (x)$ & Evans, William, Jr. \\
\hline $1,5.51$ & Eustorn \& Wetr \\
\hline 1.664 & Everly, Adam \\
\hline Ihot & Eves, Juseph Benotet \\
\hline $1 \times 57$ & Ewing, Rollert \\
\hline $1-45$ & Ewing, Thumbe \\
\hline 1810 & Eyre, Ann K. \\
\hline I?55 & Eyre, Joshuma l'. \\
\hline $1 \times 17$ & Eyres Lawrence \\
\hline$N_{1} 3$ & Eyre, Haria $\mathrm{k}$ \\
\hline Isirz & Eyre, Sathatn \\
\hline & $\mathrm{F}$ \\
\hline $1+65$ & Faran, Jolun \\
\hline 1957 & Fahnestrick, B. A \\
\hline 1959 & Fithmestock \& 80 . \\
\hline & $\mathrm{F}:$ \\
\hline
\end{tabular}

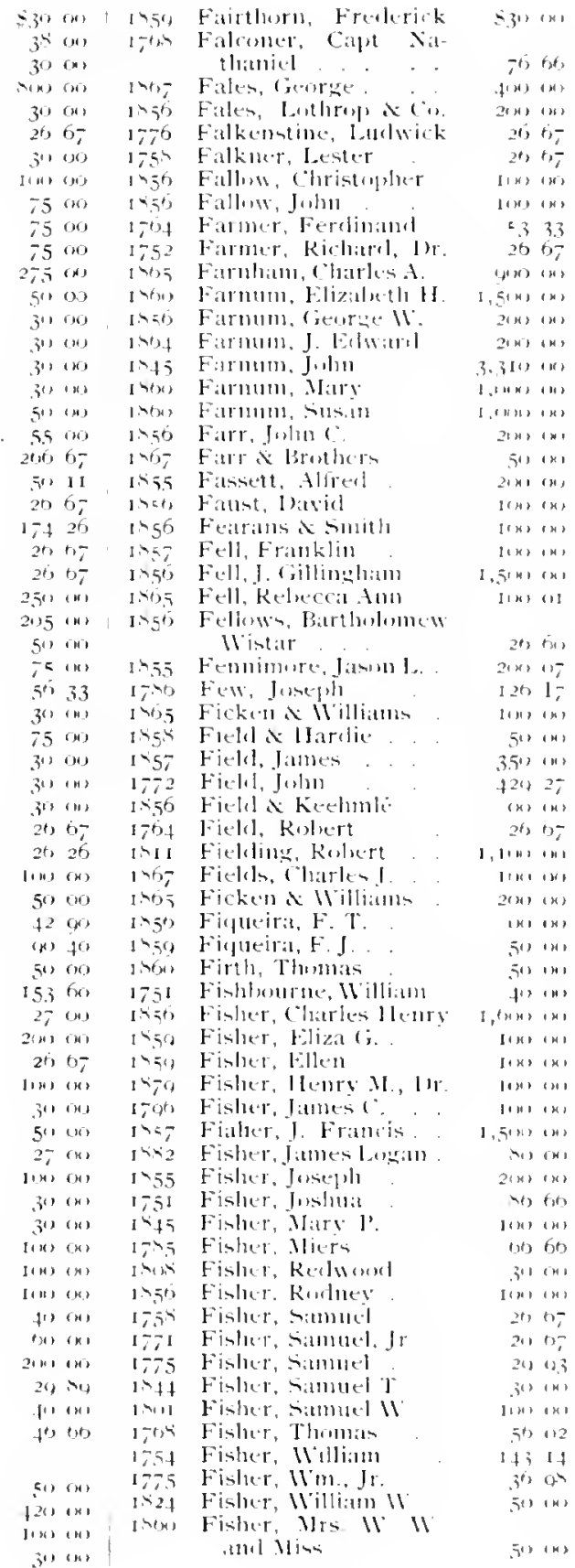




\begin{tabular}{|c|c|}
\hline 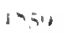 & 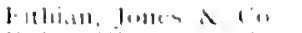 \\
\hline Me & 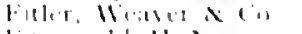 \\
\hline 1 Sin & lilererald $\| x$ \\
\hline 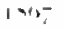 & 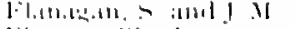 \\
\hline 17.83 & lilasill, l'lunket \\
\hline $1 \times 5$ & 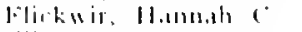 \\
\hline 1957 & Flinge, l lowrs \\
\hline $1 \div 57$ & Jilimen Millanm \\
\hline $1 \times .5$ & l.11112, Min 11111. \\
\hline $1 \times 213$ & Flan:- Willinm K \\
\hline 195 & Fling, Mts. Mim. IF \\
\hline $1 \times 50$ & 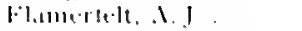 \\
\hline $1 ; \div 1$ & lolomed, Fondi \\
\hline In: & Fitum $180+10011$ \\
\hline $1>\lceil 2$ & 1며․ 1.1Tan \\
\hline ו方 & l一in, \\
\hline $1>111$ & 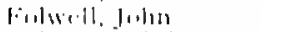 \\
\hline 1773 & linlusll, William \\
\hline 1751 & liurlecs, J I11kli. \\
\hline $1-3:$ & Jarlus. IVilliatu \\
\hline 15,52 & 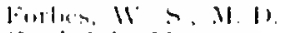 \\
\hline 1大5 & Find, Jinh MI \\
\hline 1,55 & forthes, seandinte \\
\hline Into & lintroy, Julan 11. \\
\hline 1772 & lineres Thumbis \\
\hline 145 & Fislat. Nilliam W \\
\hline intion & Iumler. IInt 13., Ir \\
\hline 1,705 & 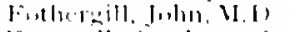 \\
\hline $14,3.3$ & 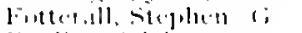 \\
\hline $17-1$. & Finlles, (caldet) \\
\hline $1-1$ & 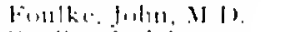 \\
\hline $1-5$ & fintlee, juclisi \\
\hline $1 \times 5$ & IAs, (hiorlest'. \\
\hline $1-21$, & Jind cienterso \\
\hline 143.5 & 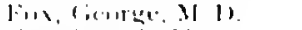 \\
\hline $19+4$ & 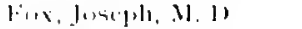 \\
\hline 1.5 .51 & lin, jumplot. \\
\hline IVin, & IAS. VIine Many. \\
\hline and & $F(x,-, 1111),-1$ \\
\hline $1-(1)$ & Fox, s:mm11.1 W. \\
\hline Is 21 & 1N. Simmal M. MI।. \\
\hline 1,407 & 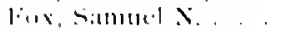 \\
\hline $15 \div$ & fromein, flumiat 11 . \\
\hline $1-51$ & Fronklin, Buniman \\
\hline 14,2 & Finukilin. Nialtur. \\
\hline 1751 & jranklin, Nilliam. \\
\hline $1,5.5$ & 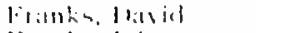 \\
\hline 1,511 & Franke, Julun \\
\hline 14 & lerilus, fircoleriets. \\
\hline $1-2+1$ & Jiricier. Nillotu \\
\hline 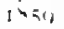 & 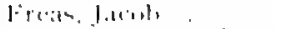 \\
\hline $1,-1$ & liromin, Nrt, Eliza \\
\hline $1.5 x$ & landul Kioliards \\
\hline Intin. & Jirellud, Nilliam 11. \\
\hline$|>p|$ & 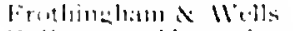 \\
\hline ル゚リ & Fullegton, Mlevimiler \\
\hline $1-31$ & 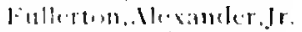 \\
\hline 1457 & 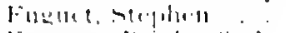 \\
\hline $1 \times 54$ & Fimmon, Brimleysin. \\
\hline 1,52 & J"unall, silumbill. \\
\hline & Fringers \\
\hline & i) \\
\hline $1, n$ & 6;.ll. Milli.1m. \\
\hline & 1; illiaril l.tmen \\
\hline 1,54 & 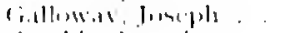 \\
\hline 1,55 & fictmline. Jineculi . \\
\hline
\end{tabular}

\begin{tabular}{|c|c|c|c|c|}
\hline (n) in & 9; & 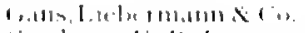 & $=1$ & \\
\hline 350101 & - & 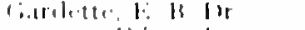 & $3 n$ & \\
\hline $1+x+1 \times 1$ & 56 & 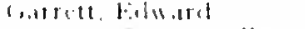 & $1 \cdot 41$ & \\
\hline $5 * \| \times 1$ & $=-9$ & 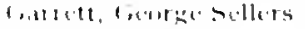 & 31 & \\
\hline$\because 12$ & 4 & 'stredt, [mitit]'. & $3 m$ & \\
\hline$M A X \mid C X)$ & $\because 5$ & Contedt, lohn 13 & $5+1$ & \\
\hline$|\geqslant| 1|M|$ & at, & licurecte, Milter & $5(\mathrm{MI}$ & \\
\hline 1311 & 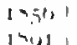 & 1;irrell. Nilli.nt1 I: & $52,4 \cdot$ & \\
\hline 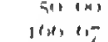 & 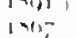 & Goterett. $11 \| 1 \%$ J & $5 \mathrm{n}$ & \\
\hline $150,1 \%$ & ain & 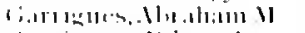 & in & \\
\hline$|M|$ InI & $F y^{\prime \prime}$ & 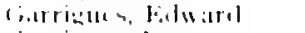 & $2 \%$ & \\
\hline$=7 \mathrm{ck}$ & 6.51 & liorrigullos. Isol.14. & 2fi & 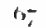 \\
\hline limb in. & 3 & liarrigules, s.tmulu-1, Ir & 2f & 0 \\
\hline $30,1 \times 1$ & $5 \%$ & Gatriman, lolut & $f(m)$ & \\
\hline 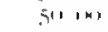 & 9 & 1;iteluell, Frinteis R & 1.511 & \\
\hline $3 \times 1 \times 1$ & 5 & tinul, Nilli,m & $3+1$ & \\
\hline in & ais & 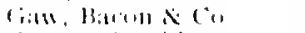 & $\operatorname{lin}$ & \\
\hline $24,1,-$ & 55 & finorace lowid & $2 t y$ & 17 \\
\hline 53.37 & 50 & ficorge, losid & $1,(x)$, & in \\
\hline 3 in: & 4 & ficotere, Janse & $1,4 \times 1$, & in \\
\hline 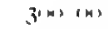 & 511 & 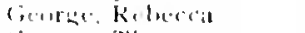 & $(1,134 \times 1$ & in \\
\hline 21,15 & $-1,1$, & 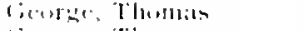 & 311 & $1 k$ \\
\hline $2+\infty 1, i n$ & $3 n$ & 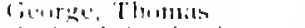 & 34 & in \\
\hline (x) on & 12 & all, $\mathrm{Me}$ & -4 & 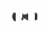 \\
\hline$|(x)| x)$ & $a, 7$ & art. 11 & $3^{\prime \prime}$ & in \\
\hline $50,(x)$ & 35 & 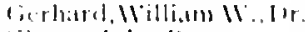 & 4, & in \\
\hline $\ln x+\ln _{3}$ & 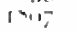 & lubu $k$ & $2 \mid W$ & in \\
\hline in $(x)$ & 51 & 114, Mrfallatim & 3511 & $i x$ \\
\hline is & $; 3$ & im, (liatt & $231 \%$ & in \\
\hline $32 \mathrm{ln}$ & 5 & 114. 1:11 & $2(4)$ & r \\
\hline $3,1 \times 1$ & 54 & IIs, Jun & 213 & e \\
\hline $51 \mathrm{N1} \times 1$ & $-1,2$ & $111,11 i$ & . & \\
\hline (N) IX) & 50 & S. $13 \cdot 11 \mathrm{i}$ & fu & in \\
\hline $2 t, 12$ & $-1,1$ & (iilalm, Jumiali IIIlloral & $2(x)$ & $t$ \\
\hline 50$)(\mathrm{ni}$ & in & 1;ilin, lolull & .52 & 5 \\
\hline $112 x$ & 4 & a. Jinn & 10.5 & in \\
\hline Sil (N) & 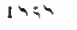 & 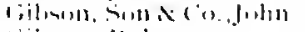 & $5.7=1$ & 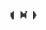 \\
\hline S'l (x) & 7 & 1. & $S^{(n)}$ & in \\
\hline $316,1,-$ & 21 & m, Milliam, M.I) & gn & in \\
\hline $3(x)$ & 513 & $\mathrm{rt}, \mathrm{H}: \mathrm{H}$ & $2+\cdots$ & in \\
\hline$f(x)|x|$ & 5 & t $心(i)$. Juln & JIN & \\
\hline$[1 M,(M)$ & PHs & t. Mitly. & 50) & in \\
\hline$\left(x, t_{2}\right)$ & 3 & leqpite, Julu, 11 () & $3 x$ & 4 \\
\hline 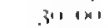 & 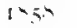 & 1le-mpice I $1 .$. & S1) & 4 \\
\hline 26,15 & Sis & ix: Milli,un Is. & 50 & $1 x$ \\
\hline 24,0 & & phl一.. & 151 & \\
\hline (a) 13 & 54 & $r=1.118$. & $J(x)$ & 1 \\
\hline $1,301 k 1$ & 12 & mbilai & 510 & \\
\hline 21,115 & $=4$ & , ilcur, 1$)$. & $2(m)$ & \\
\hline$\left.i^{n}\right)(k)$ & & Juhn $\because$ & 5.50 & \\
\hline$(K M), M)$ & 5 & $15, a 11,1 \mathrm{~J} . \%$ & $f \prime$ & \\
\hline 3010181 & (1) & 1. steplueil. & 4.227 & 3 \\
\hline $251,1 \times 1$ & Sits & liam & $(4)$ & is \\
\hline IINIIMI & & I: Itturts & 42 & 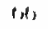 \\
\hline 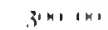 & int & I. I. & $1(x)$ & \\
\hline in un. & 1): & 1 & J 24 & 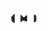 \\
\hline$\ddot{\| N}, \mid N$, & 5.51 & alti.r & 26 & on \\
\hline Jax in, & $7 \overline{7}$ & 111, Jolum, It & $2 i j$ & 6 \\
\hline $2 t_{2} 127$ & 3 & $\operatorname{tic}(x)+x^{\circ}$ & (3) & \\
\hline $73(x)$ & $1,-1,5$ & . l.urd Wram & 13 & ( \\
\hline & $-\bar{\downarrow}$ & $\%$ & 150 & \\
\hline & & & lans & \\
\hline 21.3 .33 & $\$ 1$ & Thumats, M I & 53 & \\
\hline$|m|$ & & $1 \%$ In! & $\mid(x)$ & \\
\hline 50,12 & $1 ; 1 ;$ & i', Jikrials & $2^{\prime \prime}$ & 67 \\
\hline$(x, 1,-$ & $1,5,7$ & 1, rall, Sillotstian & 5.3 & \\
\hline
\end{tabular}




\begin{tabular}{|c|c|c|c|c|c|c|c|}
\hline $1+\operatorname{tin}$ & Graham, tlenry thate & $\leqslant 2 t ;$ & 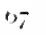 & $17-1$ & Ilalluwell. Isratel & $=24$ & $6 \%$ \\
\hline 1599 & Graham \& ( & $5 \prime$ & $(n)$ & $(x, y)$ & Halfuwell, Vorris I. & $5 "$ & (4) \\
\hline IST & Giraham, James & $2(m)$ & $(x)$ & 1057 & Ialluwell, Xl L, \&(u, & lin) & $(x)$ \\
\hline $1, y 2$ & Graham, Johu II. & 30 & us & $1-55^{t}$ & Ilallowell, Thomas. & 26 & $1 \%$ \\
\hline $1.5 \mathrm{I}$ & Grandom, John & 26 & $6-$ & $1,-00$ & Halnecker, Georot & 20 & 67 \\
\hline $1 \times, 00$ & Gratut, Samule], Jr. & $1(H)$ & $(N)$ & $1, \infty, 1$ & Hannilton, Cotorge l'. & $3^{\prime \prime}$ & ins \\
\hline 1754 & Grant, Milliam : & (1) & $\therefore 1$ & 1,59 & Hamilton, James & 200 & 07 \\
\hline & Grasshuld, Christian & 20 & $6-$ & 1,59 & Hamiltun, Roluert. & 53 & 33 \\
\hline 65 & Gratz, Miss Reluecert & 50 & ois & Sil & Hamiltun, Tallest. . & 34 & ons \\
\hline $150 x$ & Gratz, Ruluert H. & $2 i x$, & ( $k)$ & 1.390 & Hamilton $\mathrm{E}$ Sons, & & \\
\hline $1 \prec 15$ & Giratz, Simmn. & $3 "$ & $(x)$ & & Nilis:m C..... & $\left.f_{x}\right)$ & $(A)$ \\
\hline 1754 & Gray, Georse . & $f^{\prime \prime}$ & $(x)$ & $1 \times 46$ & IIamiltın, Nilliand & $2(\pi)$ & $(n)$ \\
\hline 1755 & Gras, Georse, Jr. & 5.3 & 3.3 & $1 \times-2$ & Hammersly, georet 11 & 2.50 & $4 n$ \\
\hline 1.55 & Gray, Josepll & 20 & 67 & 1ant & Iammitl, Barmaluas & 2.54 & 61 \\
\hline 1655 & Gras, Robert $\mathrm{E}$. & 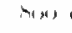 & (i) & $1-+24$ & mitt, Bengatmin & 133 & $3 i$ \\
\hline 859 & Sireble, Edwin & $(x)$ & (A) & $1>07$ & nitt \& Neial : & $5+1$ & ins \\
\hline 51 & Greabes, James R. & $1,1,20$ & (II) & I th & Hanconk, Samuel!'. & 215 & $\ln )$ \\
\hline$x(y)$ & (ireten, Walter I), MII) & $3 n$ & (n) & $19+3$ & IIand. James C. \& Cu. & $4(x)$ & $|x|$ \\
\hline 1751 & Jeate, Isaac. & 101 & 9.5 & 145 & Hatul. James 1 . . & $P(1+1)$ & in \\
\hline 1754 & ans, Ruluert & 24 & $\rightarrow$ & 1431 & Hidmily, liedrues. & $3^{\prime \prime}$ & $(x)$ \\
\hline 54 & Freeres, Elizaleth & 511 & $(n$, & $1 \times 54$ & Houncly, Margatet I. & $24 \times 1$ & $|x|$ \\
\hline 1012 & Grectes, James R. & (x) & $(n)$ & $1-\sin$ & Hamosis, Andren. & $2 "$ & $0 ;$ \\
\hline$\checkmark 6 \overline{\bar{s}}$ & fireeles, Jambes $\mathrm{R}$. & Tan & (w) & $1,-1 \times 2$ & Ifatuntim, Jwhtr. & 21) & 67 \\
\hline 795 & firectes, Thumas & 511 & $(x)$ & $3 \times 4$ & -ell, Kolnert. & 165 & ins \\
\hline .52 & as, $T\}$ bulntis & "w & $\operatorname{lng}$ & $1 \times 5$ & eil, Millinam & $1(x)$ & $(x)$ \\
\hline 57 & r $\mathrm{E}$ Harkmesin & $\ln x)$ & $(m)$ & $1 \times: 5$ & an. Nilliam k. & $i^{\prime \prime}$ & $(x)$ \\
\hline $14+1$ & let. l'etct & in & an, & $17+9$ & H), Benjatman & 2t) & $n-$ \\
\hline 1717 & 1. Julu K. & $-(1)$ & $(x)$ & 1250 & 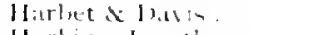 & $2(m)$ & $|n|$ \\
\hline 17.51 & 1,11 illiam & 1 & 33 & $-2+1$ & th:ıl & $2 n$ & $0-$ \\
\hline $1 \div 50$ & 1. 11 illiam 10 & 301 & wax & $14 y$ & $t=1 ;$ & 2511 & $\{n\}$ \\
\hline $1-9$ & Hs. Sambut I'. MI & 1. 20 & 37 & $1-5$ & lice, Cinpt. Rerlnedt & 23 & w7 \\
\hline $1 \times 51$ & Julin & 2.125 & $(x)$ & $1-52$ & 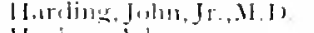 & 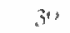 & InI \\
\hline 1 in & in, Samutel & $3 n$ & $(n)$ & $1-51$ & ocr. Adam & 20 & $i j$ \\
\hline 1455 & m, Nilliam A. & (n) & (x) & $=4$ & klless, Allted MI. & 30 & $|x|$ \\
\hline 1,55 & Andrew IJenry & 53 & $3 ;$ & $=05$ & :III, (sene. C., M.I). & “ & (m) \\
\hline 1 ×リ5 & abrither. & 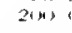 & in: & 1234 & tan, Richaril . . & i" & $(\pi)$ \\
\hline 145.5 & Henry. . & $f(x)$ & $(x)$ & $1-1, x)$ & Marmatn, Jaciot) & 217 & 70 \\
\hline $1-72$ & Growdon, Liwrence. & 1,33 & $i, i$ & 105 & ner, James & lint & $(n)$ \\
\hline 1,55 & b, Satbingit. & 27 & 15 & 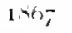 & r, IVilliam & $2(34)$ & $1 n$ \\
\hline $1 \times 55$ & wes, Returcil & 3.51 & $(x)$ & $1,0,3$ & teall, licorge $\mathrm{k}$. & I (W) & $(n)$ \\
\hline $1<5.5$ & Curnes, Eliza P. & $5(4)$ & 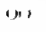 & $1 \rightarrow(-(H)$ & t. Jannes & $\ln x$ & $(x)$ \\
\hline 1,90 & Gutues. Francis & 30 & $m$ & $17-1$ & fer. Ilumbas : & 413 & $(n)$ \\
\hline & 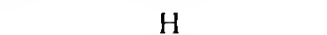 & & & $1 \times 1,3$ & Itam, Jr. & 50 & $(n)$ \\
\hline & & & & Inn & wles J. & $3+4$ & 34 \\
\hline $80 ;$ & r, Flizil & 19 & $|x|$ & ハニ & 1 & $\ln (x)$ & $(x)$ \\
\hline 965 & Hacker, Hannali MI. & $4+1$ & $(n)$ & 1950 & s. ficorge 11 & $2(x)$ & as \\
\hline-57 & Hacker, Isiatc $T$. & $2(k)$ & $|n|$ & $19+1$ & is. Jisephic: & 30 & $(x)$ \\
\hline 45 & Hacker, lsaiali. & $5.31 \times$ & $|x|$ & $1 \times 4$ & 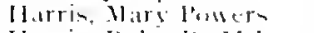 & 2,30 & 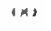 \\
\hline 6.5 & Hacker, J. Barclay" & 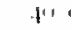 & $1 \times 1$ & 45 & I. I'..M II & 3 & $(n)$ \\
\hline-1.5 & eer, Jeremiali. & $5+x+1$ & $|m|$ & 1424 & 1s, Thumats. Ne. t). & 31 & 64 \\
\hline$\infty .5$ & et, Dlurris & 50 & $(x)$ & $1 i^{*}$ & is, Nilliam, M. M & $3 "$ & $1 \times 1$ \\
\hline r & Hacker, N. I'. & $1+x+1$ & $(m)$ & $1<.54$ & Mon. A. $11 .$. & $3^{\prime \prime}$ & $(x)$ \\
\hline atjo & Ilacker, l'ascliall. & 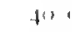 & $(x)$ & $17-4$ & n, chatrles. & $3 n$ & $v_{j}$ \\
\hline 6 & Iiam & t'i & $(x)$ & $\ln 4 i$ & 1. Frazier exco & $5(n)$ & $(n)$ \\
\hline 1,45 & cr, Milliath E. & $|n| t^{\prime}$ & (H) & 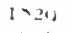 & 1, Genrye & $3(n)$ & $(x)$ \\
\hline 1755 & Gixltres & 1201 & $(y+)$ & 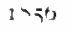 & 1, fectrote 1 . & Iak, & $(x)$ \\
\hline $1-4+3$ & $\therefore$ (atspar $11^{\circ}$ istats & 20,1 & $3-$ & $1=\ln 1$ & isuln, Mrs Gien, L. & $I(x)$ & $(x)$ \\
\hline $1-2,3$ & Cittiartone. & $2+30+$ & 3 & $1-\overline{2}(1)$ & & 111 & 11 \\
\hline 1,05 & Hunry. & $.94+4$ & $(x)$ & 19:3 & 1, Jasclili, Jr. &, $1 \times x$ & $(x)$ \\
\hline istor & ․ Jalue K. . & $\overline{7}, \mathrm{Ml}$ & $m$ & ば” & Alifisions & $2(n)$ & $(k)$ \\
\hline Ixint & $s, X e w l$ dald K. & 30 & (H) & $12+5$ & . IItnry, . I. I). & $1(x)$ & $|x|$ \\
\hline$-6,2$ & Reulsen & $1 ; 3$. & $.3, j$ & $1,-96$ &. & $m$ & $y_{3}$ \\
\hline int & es, Reulen & $11 \times 1$ & $(k)$ & $\sin 1$ & Mitrse & 30 & (n) \\
\hline 1757 & If: & 513 & $3 t$ & $12=12$ & 1. Nillian H. & $f(x)$ & $1 \times 1$ \\
\hline $5 h$ & A. I M, malims, M.1 & $f_{x},{ }^{\prime}$ & (n) & 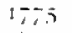 & thes. Jatules. & $3 n$ & 111 \\
\hline 5.51 & lball, lousid. & 152 & $1 \mathrm{~s}$ & ins & cla:ules & $1: 10$ & $(x)$ \\
\hline-75 & Mall, Nilliam ... & 12.4 & 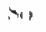 & 147 & Haluatri.. & . & $(x)$ \\
\hline
\end{tabular}




\begin{tabular}{|c|c|}
\hline Inst & 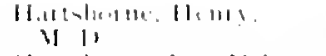 \\
\hline 191 & 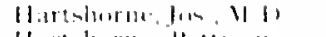 \\
\hline $1 \% 5$ & 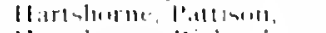 \\
\hline $1 ;-\infty 1$ & 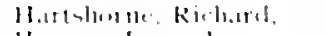 \\
\hline $1,-1, n$ & 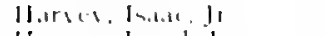 \\
\hline 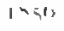 & If.ursel, Jumleli l. \\
\hline $1 \times 17$ & $11.11604,111$, J1181.1 \\
\hline $19+17$ & 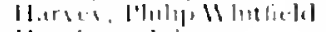 \\
\hline in & HI.1-thlile, J,olill \\
\hline $\ln 11$ & 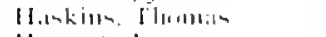 \\
\hline $1,5,5$ & H:ivert. Aremt \\
\hline $1,5.5$ & If.utkinand1, Julnt \\
\hline 1450 & If:uled Julen \\
\hline 14: & If.II], flermin \\
\hline in:? & 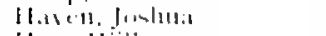 \\
\hline 14511 & fl.is. II illa, \\
\hline $1,-54$ & 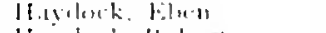 \\
\hline $1-23$ & Ilovelunk, Kaluelt \\
\hline $12 \times 1$ & II:I! lank, S.munel \\
\hline $1=50$ & If:il numbl. Wrs \\
\hline $19=0$ & $18.11 \times 1,1,1,11=$ \\
\hline In $\|^{\prime \prime}$ & If:is.trol, \& finll, itunl. \\
\hline in 24 & $|1.1 \ldots 1 \mathrm{r}|, 1$ trakmo \\
\hline 1,592 & 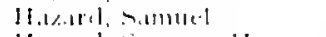 \\
\hline $19+1$ & |f:1\%art, S|m $11+\mathrm{el} \mid 1$ \\
\hline $17 \pi$ & 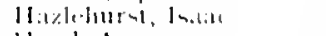 \\
\hline 171,5 & Hearl. Amn \\
\hline 1751 & Hean! Jalun \\
\hline $1-2,5$ & Ifeinl, Jum I I \\
\hline $15 \%$ & 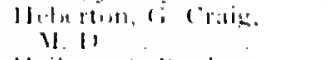 \\
\hline $1 \times 54$ & H, ilman \& R:ank \\
\hline Iেう & 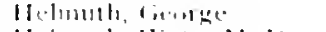 \\
\hline Iেラン & 11 umuth. $11=.11 \mathrm{l}$. \\
\hline is, 11 & $\begin{array}{l}\text { If:Hmith, Urs. } \\
\text { Uilliam }\end{array}$ \\
\hline 1415 & [1.mI) 1. Milliam \\
\hline 小行 & 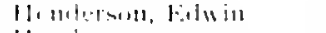 \\
\hline 155 & 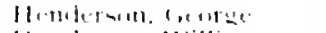 \\
\hline IVIn) & Hemelesten, Milliam \\
\hline $1,-1,2$ & Ilemelriek, Almallam \\
\hline 101,9 & Ilemelrie. I):naied \\
\hline 10111 & 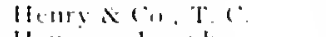 \\
\hline $1-2$ & 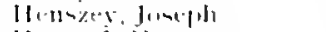 \\
\hline 17,4 & llents. J. Henry \\
\hline 170,5 & H1.n/el, Marminall \\
\hline 1701 & 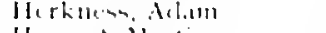 \\
\hline 1950 & Herunt \& Mntin \\
\hline 1959 & Iterring. Slas $\|^{\circ}$ \\
\hline 1.5 .5 & licues, llugh \\
\hline 17.59 & Iteren, Jusialt \\
\hline 14.51 & 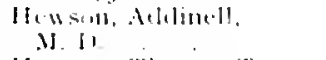 \\
\hline $12+1$ & 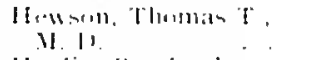 \\
\hline 1422 & 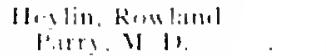 \\
\hline 13512 & Mhliari, Mary. \\
\hline 17.51 & lli,ks, Jilmatrid. \\
\hline 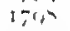 & lliggion Frandis \\
\hline $1 \backsim 50$ & 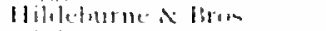 \\
\hline $1 x^{4}+1$ & 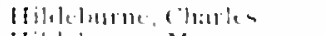 \\
\hline $1+x+1$ & 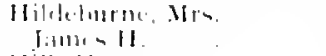 \\
\hline $1-1$ & 11 ill, $11,111 \mathrm{x}$ \\
\hline & 11 ill, $11.11-1, .1$ \\
\hline
\end{tabular}

\begin{tabular}{|c|c|c|c|c|c|}
\hline & & $1,7,5$ & 111111 worn. Hollom & $=13$ & \\
\hline $5 n$ & $(n)$ & $1,5.51$ & llilllatill. lomepols & 83 & 12 \\
\hline f' & $(n)$ & $1,5.51$ & Hillegars. Mirhicel & 32 & 53 \\
\hline $30 \times 1$ & 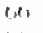 & $19 \times 1$ & Holtalemerto. Jinul, & 2 & $3 i$ \\
\hline $2 h$ & 1,7 & ing & llatehle, Joblin & $11^{i}$ & $1 \%$ \\
\hline$>1$ & (m) & $14 \div 5$ & llimalm. Ke. Wills.um I' & $1,1 M \times 1$ & in. \\
\hline$\because x$, & $m$ & $1 \ln ^{2}$ & 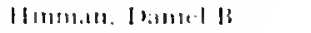 & $1, \ldots 1$ & $|m|$ \\
\hline $3(x)$ & $1+1$ & $1-51$ & 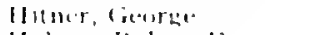 & 21 & 心- \\
\hline 143 & (1) & in lis & 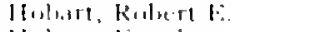 & sus & in. \\
\hline $3^{\prime \prime}$ & (n) & 1,751 & Holsul, linulu & (1) & $P_{1}, 7$ \\
\hline 511 & (n) & $1 \div 5$ & 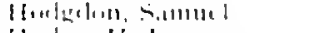 & $2 t)$ & $1,-$ \\
\hline $\begin{array}{l}\text { ins } \\
\text { In }\end{array}$ & $\begin{array}{l}x_{1} \\
x_{-}\end{array}$ & intis & 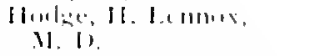 & 41 & 103 \\
\hline $\ln x$ & 111 & 1.27 & 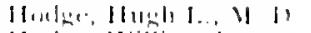 & $23+1$ & In) \\
\hline 154 & (n) & $\ln 23$ & Ilutar. Milliam 1.. & 511 & $6 x+$ \\
\hline $3 i$ & |k) & $1 \ln x+1$ & Iforleratil. Mre II I & 511 & In: \\
\hline an: & 14 & 15,5 & 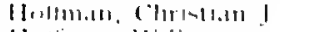 & $31 \times 1$ & in. \\
\hline $2 t$ & 17 & $1,-10$ & 11.olfimans. Milli.ul & $2 t$ & $1:-$ \\
\hline $2^{\prime}$ & 13 & 17.51 & 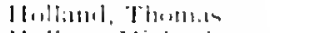 & If & 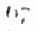 \\
\hline Prt & 1,1 & $1.5 i$ & Inis, Mir bint & $2+3$ & $0 ;$ \\
\hline $51 \times 1$ & $1 \infty$ & 1931 & 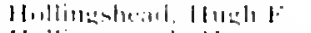 & 30 & 1 \\
\hline ڤ” & ( w) & $18+1$ & 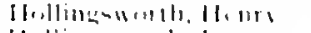 & 40 & in' \\
\hline $3 \cdots$ & (n) & $1,-1$ & wrotli, I.e.1 & $2(k)$ & 17 \\
\hline $3+$ & in. & 17,7 & 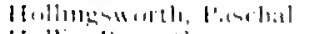 & 51 & in \\
\hline 21, & $1,-7$ & $\operatorname{lin} 4 x$ & Hallis, l'elet" & $5 n$ & in \\
\hline 5 & ; & $14+5$ & ere, ( & 2in & in. \\
\hline $2 t 3$ & -11 & -1 & 1. Jothn & 27 & an \\
\hline $2 t x$ & $n_{7}$ & inti: & Howpes $\therefore$ Pommenel & -5010 & In! \\
\hline$e_{1}$ & $t+1$ & $1 \cdot 12$ & 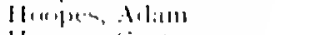 & wis & 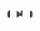 \\
\hline $2 t$ & 13 & $14 \therefore 1$ & ires. I Intis & $\|(m)$ & $1 \times 1$ \\
\hline & & 15.57 & 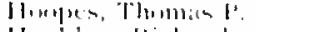 & $\operatorname{len}$ & $1 \times 2$ \\
\hline $2+n$ & (n) & $1,-12$ & 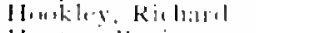 & $\because$ & in \\
\hline 513 & $(n)$ & $17=11$ & 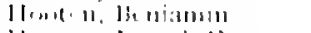 & $2 t$ & $1 \%$ \\
\hline Ink & $(n+$ & Intis & Jlander. Jomegla b. & .11 & $1 \times 1$ \\
\hline||$k \mid$ & int & 15,53 & phim. lisluaril M. & 5.511 & $\mid n$ ) \\
\hline & & 193 & kins. J:tmes & . ins & ＂！ \\
\hline $1(x)$ & $(x)$ & $1 \times-1$, & llorkim, Jamues II. & lan & $(n)$ \\
\hline $11 x$, & an. & -511 & Hripkin, II lliom & $1 ; i$ & (n) \\
\hline l" & 01 & $1=-1$ & Hopkm, IIn Jatlan. & & \\
\hline in & (") & & 8 & $f^{\prime \prime}$ & in' \\
\hline $7 \pm$ & " " ' & $1-f_{2}$ & llopkinsong leram in & $i^{4}$ & $($ it) \\
\hline 24 & $1 \%$ & 13 & 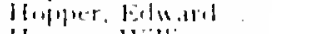 & $3 \prime \prime$ & $|m|$ \\
\hline 12.5 & $\therefore$ & I vins & Herier. Willimm & $\mid(n)$ & $(n)$ \\
\hline (n) & $(x)$ & 145 & Horn. Alenamele $F$ & (ind & (n) \\
\hline$i 2$ & $m$ & 19,3 & er, [inelliamin & 56 & $t_{1}-\bar{i}$ \\
\hline Sol & $(n)$ & 1412 & florner, Jusephls". & $i n$ & (n) \\
\hline 31 & on & 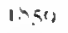 & Iformer, Mrs lis & $2|x|$ & $(n)$ \\
\hline $2 i_{1}$ & 67 & 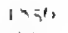 & Ilormer, lits X E. & $2(x)$ & $(n)$ \\
\hline $14 \times 1$ & InI & $1 \times+25$ & Horner llime li. 11 & $\ln n$ & an \\
\hline $11 n 1$ & $1 \times 1$ & 31 & 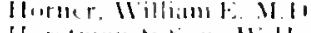 & 3 & $a n$ \\
\hline 2h) & 1,7 & arin & 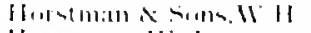 & Ains & (x) \\
\hline $37 t$ & (ip) & in & Ifuाman, II. I & this & $(n)$ \\
\hline & & 15 & Nman, 11.11 & $21 m$ & 4, \\
\hline 3 & (m) & intio & 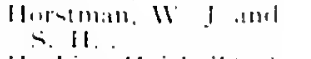 & (1)1, & on \\
\hline it & '"' & $-s_{1}$ & Humkins, Heinkellint & $\ln (\mathrm{m})$ & $(m)$ \\
\hline & & $-33^{p}$ & Juln I; & $3^{\prime \prime}$ & $(m)$ \\
\hline $2 f_{1}$ & 1,7 & 175 & •. San & $2 t 3$ & $6-$ \\
\hline 1.5 & $1 \times 1$ & $I<t_{2}$ & 1,11, Ilonts 11 & 1.5 .513 & $(x)$ \\
\hline 26 & $1:-7$ & 175 & tum. William i & 1, वा मा & $(n)$ \\
\hline-1 & (11) & 145 & $(11) \therefore(1)$ & $I(x)$ & $(n)$ \\
\hline$|0 M|$ & $\ln 1$ & $1,-1,5$ & Iril, l, IhI! & 26 & $n_{-}-$ \\
\hline in & in & I & 1. I'hilip, R & $2(m)$ & (k) \\
\hline & & 19511 & -11. Artlutr II & $\operatorname{lon} 3$ & $(n)$ \\
\hline $3 \cdots$ & ' $m !$ & |VI & 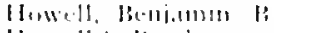 & $5 n$ & $n+$ \\
\hline$\therefore$ & 'n & IX) & Honell \& Brothers & זיזיר. & 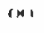 \\
\hline $\ln$ & $(x)$ & 159 & Hontedl. Gitersece & in & 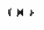 \\
\hline
\end{tabular}




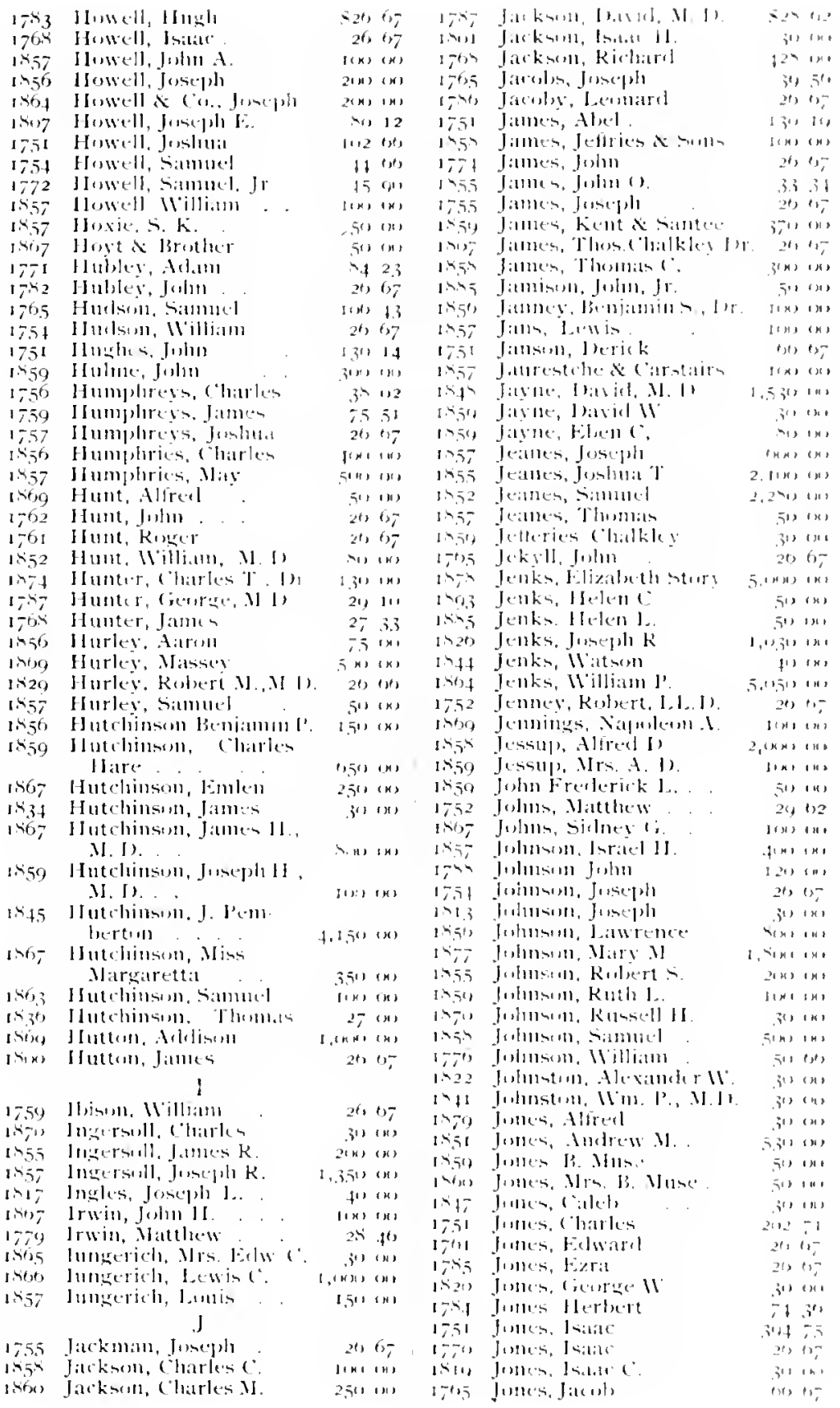




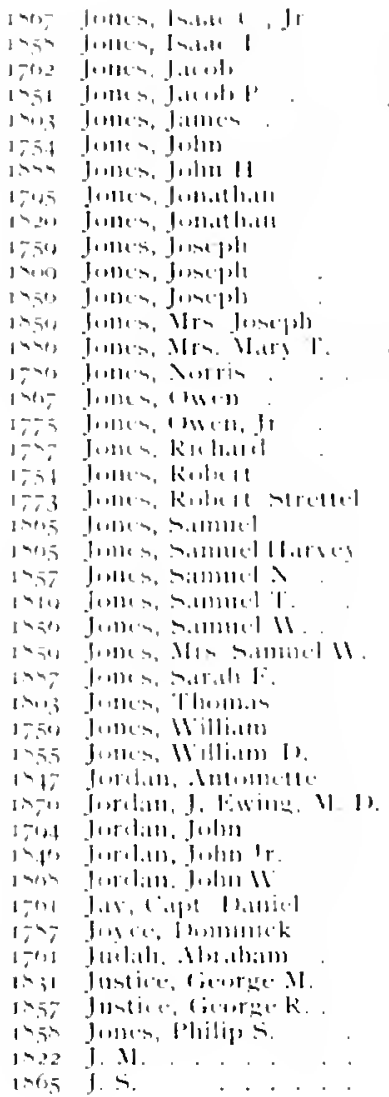

\section{K}

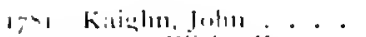

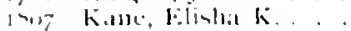

ints: Kiss. Hltand

1,50 kecture, lolmumbl

1755 Ki:male, Juhu, .1. I.

$175-1$ Kiden, J'cter

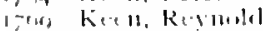

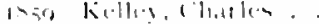

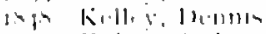

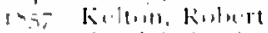

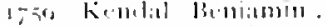

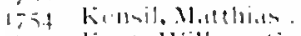

iss. Kent. IVillatme.

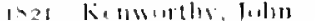

1, kel Kelpwi, Hent?

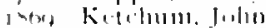

1.1.t Kimluel, Jimmes

un kimber. Tlumis

ingo Kimbler. llusmis, Jt

ton King, (bolrles.

1,51 king, louncpls

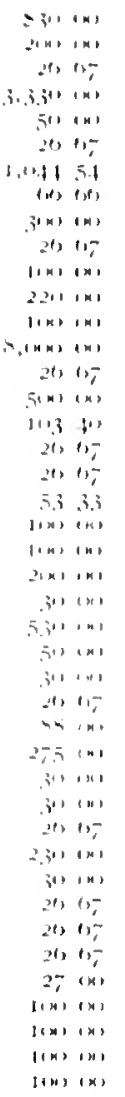

it

III) in

in (x)

it the

an (a)

in 19

$\because 5.5$

6.55 (n)
$31 x)$ (n)

it in

प्र 13

32 is

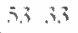

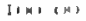

$301 M 1$

i.

f(x) (N)

in ixs in (3)

\begin{tabular}{|c|c|c|}
\hline וי & 12, Kotil. & $\$ 3 n,(w)$ \\
\hline 113 & 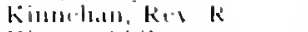 & $t(x) \mid x)$ \\
\hline$-\infty 1$ & kins's, l'hill,. & 2067 \\
\hline 8.5 & link. IIllinm. & 12,5401 \\
\hline 95 & Kuklunle knolentes & $105,4 x$. \\
\hline 5 & 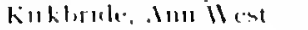 & $f(x)+x)$ \\
\hline (a) & irklirule, folıatu & $i(x)(x)$ \\
\hline 412 & oklitide, Jabn & 140,10 \\
\hline .54 & iklefide, Jus I, II I & $1151 x$ \\
\hline $9 i,-$ & 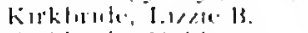 & $\mid(x)$ in) \\
\hline & (le, 11.11$\}, 1)$ & $26 \mathrm{lig}$ \\
\hline$\therefore$ & 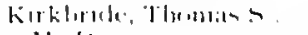 & \\
\hline 11 & II. &., $3.34(\mathrm{n})$ \\
\hline 5 & Hh.tm, II illiant & 7.50 in \\
\hline जis & rict, lla & $2(x)$ in \\
\hline (1) & trick, Ile. ll,ate & $\{(M) \mid A\}$ \\
\hline ifis & tuा & $|(M)|(n)$ \\
\hline $5 ;$ & 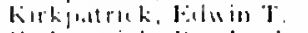 & 50101 \\
\hline .77 & riok, kis & lat in \\
\hline 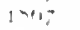 & irak, II ills. & J(M) $|M|$ \\
\hline i & 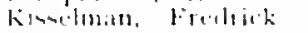 & 20,106 \\
\hline $5^{4}$ & lor.ul, lismi. & $311 \times 1$ \\
\hline 1 & $1,1) X$. & 1 \\
\hline & Mind & 5.51310 \\
\hline$=13$ & t. Hetes & ints on \\
\hline$=$ & Kasul. & $f(x)$ (n) \\
\hline$\therefore 5$ & $16 n$ & $1,3.3 .5$ \\
\hline $4 \%$ & $\because 1$, M.1.111 . & Sin ini \\
\hline$x=-$ & intas & $10 x)|x|$ \\
\hline 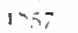 & 1 & $1, x+1,4$ \\
\hline 1.51 & 1,11 & $101 x$ \\
\hline $1, \cdots$ & $k$ & $3^{\prime \prime} \mathrm{CH}$ \\
\hline $17+2$ & K & 2667 \\
\hline 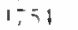 & $r$ & 20,05 \\
\hline (3) & i. $\mathrm{k} 1$. & $\operatorname{lix} x$ in \\
\hline 7.54 & & $5,33$. \\
\hline & arick & for in \\
\hline & 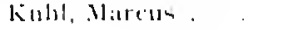 & 206 \\
\hline
\end{tabular}

L.

Ingh d,it kinhe, Relle, M. 1). 30 ang

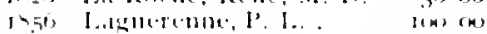

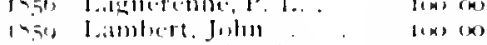

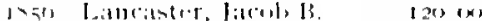

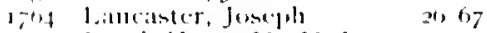

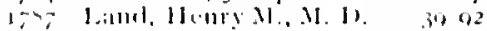

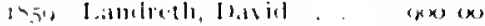

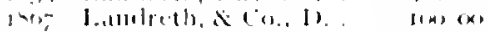

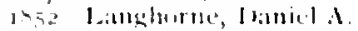
11. 13.

2675

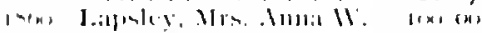

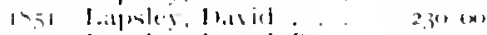

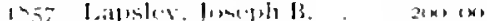

1. -

140, 1.atread, William II. 7.50 (n)

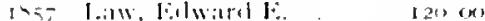

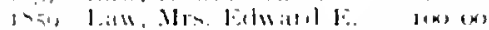

inel l.twreme. Ilenty. $30(x)$

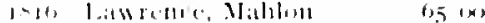

1.5. L.awrenec, Thomas, Ir. 2667

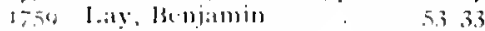

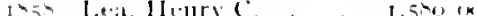

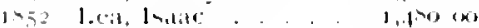

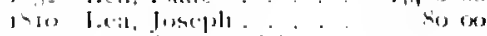

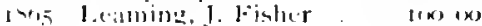

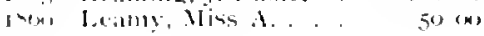




\begin{tabular}{|c|c|c|c|c|c|c|c|}
\hline Isist & l.collry, Mian $\mathrm{N}$ mintel & in & $(x)$ & $1-5 i$ & 1.4n is, 11 illians & $t_{2}$ & 2 \\
\hline $1,9,3$ & Lec conte, Ruluest i. In. & .311 & 131 & $1+i, 7$ & I-x, charles fo. & $\operatorname{lin} x$ & $(n)$ \\
\hline 1402 & I,ec, 1):xinl & 42 & $(n)$ & $1-40$ & 1,11dian, Al,rillanu & 213 & $t 7$ \\
\hline 1751 & Lecech, Jomeph & 26 & fi: & $1-5.5$ & 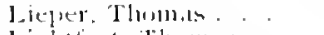 & 25 & 67 \\
\hline 701 & Iecects, Thomban & $2 t)$ & 17 & 17,81 & 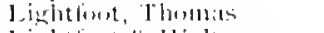 & qu & Ins \\
\hline ito 7 & 1, tеed, Milli.um & $5 x+$ & (M) & 145 & ] iglotlint $\& 11$ inltum & bi: & ||$n \mid$ \\
\hline 1.55 & 1.cerelins, B. I. & 1311 & 131 & -5 & ],ightfout, IVilliam & 26 & 1, \\
\hline 1706 & Iteigh, Rove fientrest & 16 & "11 & 45 & I inculn, Alecl & 31 & ' ' н, \\
\hline $185 \%$ & le eituramit, frecleriok & 2.511 & (n) & $5^{\prime 3}$ & l.jurlsey \& Blokkston & $2(n)$ & ans \\
\hline $1 x^{\prime \prime \prime}$ & letiec, IVilliam R. & $1,1,311$ & (H) & 50 & Limolsity, Juhr. & 1111 & $(\mu)$ \\
\hline$\times 57$ & letend, chatem & iin & $1 \times 1$ & in & 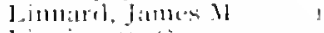 & $1,1, \ldots 1$ & in \\
\hline $1 \times 6)$ & lenmier, ("harles & $51:$ & $1+1$ & 97 & 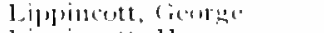 & $\mid 1+1\}$ & $(n)$ \\
\hline 1579 & min. Frecleriok & 511 & (1) & 4.3 & lipplucott, llurion & $\therefore$ & $\mid 141$ \\
\hline 6in: & nige Frectrick & .54 & $m$ & .51 & 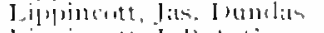 & i! & (s) \\
\hline $\operatorname{sg} 2$ & 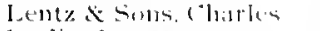 & 31 & 1,1 & 35 & J.ippineste I. B. su. & $1,-7.5+1$ & 1111 \\
\hline 1432 & 1.teslic, Jinusen & $\because 7$ & (n) & $(1,1$ & 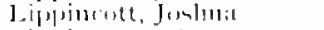 & {$[1 x]$} & , in! \\
\hline 1456 & Ievick, Jamen J, U I. & in & $1 m$ & .59 & Jiplinente \& larr & $|n|$ & ' in! \\
\hline $1,5,57$ & ict kirlutil x(us. & 14k & (1) & iI & little, Amos R Ni & $11 m$ & , n' \\
\hline 1671 & Iteris, Richard I , II l I. & $3 n$ & $(n)$ & $4^{4}$ & A S Sh:?mmun & $4 . i$ & ; an \\
\hline $1 \times 4.5$ & $\therefore, \mathbf{J}, 1,1] \mathrm{J}$ & 5.5 & $\mathrm{OHO}$ & 3 & 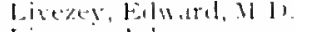 & in & ON \\
\hline $1-96$ & $\therefore$ Minstos & I" & (n) & & $z(y$, l,hon. & 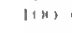 & $(x)$ \\
\hline 16.5 & $\rightarrow, A 111: 111$ & 3.511 & 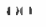 & i) & Key, Sil & 511 & (H) \\
\hline 1.556 & $\therefore 1^{\prime \prime}\left[1: 10^{+} \mid \cos x\right.$ & fin: & $|n|$ & & zes, Thmons, Jr. & $\because$ & 67 \\
\hline 1795 & S, ] bivid & 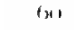 & (w) & 32 & 1. J Sitito S. & 31 & 191 \\
\hline $1 \$ 63$ & 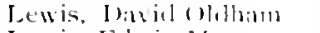 & 5 & (n) & 5 & (1, Marial I). & $1(x)$ & ||$\left.^{\prime}\right)$ \\
\hline 15.57 & is, Folwin M. & $(x+1)$ & $(x)$ & 50 & 1. $S: 1$ & f"i & (4) \\
\hline 1,65 & $\therefore$ Elizaluetlill. & 11118 & (II) & , & d. Sil & $3^{\prime \prime}$ & $(n)$ \\
\hline-0 & Eillin & $2 t$ & 17 & $-6,5$ & d, IVill & +3 & 32 \\
\hline 1552 & is. Francin Alluert & 311 & (x) & 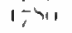 & 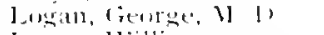 & ¡i & $3 i$ \\
\hline 15,59 & Jewwis, Fratucin $\rightarrow$ & $1 i x \mid$ & $(x)$ & 5.54 & an. Nilliam & $1>1$ & in \\
\hline 1451 & Lewis, framcis 11 , II & 1,341 & $(x)$ & 59 & a. James. & 15,1 & $(2 n)$ \\
\hline $1+(x)$ & is, $l$. Mntimel & $(4)$ & $(n)$ & 56 & gitreet, IIn, 11. & $2(x)$ & , Im \\
\hline+4 & is, (sentsol & 534 & (16) & 57 & 1], Jumlluis. & 1.50 & 131 \\
\hline 112 & $\therefore$, Hamililı, Jr. & $(1 x)$ & in: & 5 & 11, Mitry Am & 2.50 & an \\
\hline 1464 & is, l]entry . & $\ln x)$ & (w) & 7 & 11, Mhortis, & in & 14 , \\
\hline 751 & is, Ju(cul) & 137 & $f^{\prime}$ & 57 & stredl, 11111.11 & , & , ix) \\
\hline 1759 & S. Jephohit & 24 & 67 & 32 & hey Rulert & in & 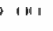 \\
\hline $1 \div+5$ & is, I. Smith & $.1{ }^{\prime \prime}$ & $(m)$ & 5 & $\because B$. & (111) & ( an: \\
\hline 10 & s, John I" & 1,1 " & 7 & $6-$ & $\therefore$ "Tlumbis c & 511 & (19) \\
\hline 6.7 & s E Bro., Juhn T & $\bar{s}(n)$ & (iin) & $5 \hat{~}$ & cring. Ju, & 6.5 & $\{(n)$ \\
\hline 1870 & $\mathrm{~s}, \mathrm{~J} n \ln \mathrm{I}^{*}, \mathrm{Jr}$ & 1.311 & (n) & $i=0$ & $b+t, 11 j$ & $3 \times s$ & 31 \\
\hline 1790 & 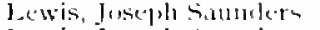 & $-t^{3}$ & 17 & $51)$ & Kr, Mls allul Mion & $5+1$ & 14 \\
\hline $14+5$ & S. Juscoll samulere & 1.319 & $(M)$ & 13 & .11. & 511 & , " , \\
\hline 28 & s, l,awrence & $2,5.511$ & (H) & & $T, f, 1 w i 1,1$ & 1.231, & , in: \\
\hline 65 & is, Mrs lamrelute & ifus & in & & (2), Jit & $2 t$ & $1 \%$ \\
\hline I & is, Jawrence, Ji. & 2411 & (x) & $\because$ & 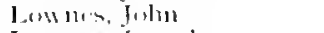 & $5 ;$ & $; i, i$ \\
\hline 2 & $\therefore$ MIary & I(1) & $m$ & 52 & $\therefore$, & 3 & ins \\
\hline ixo & is, Mism Mar? & $2(11)$ & (11) & 14 & $\therefore, 1$, & $f^{\prime 3}$ & $(x)$ \\
\hline$\therefore 5$ & is, Mrs, Mallhak & $10 \cdots 1$ & $(H)$ & 16 & nes, Jualits 11 & ㄴ. & 1111 \\
\hline 75 & In, Mencleriai & 1.114 & $\therefore$ & & l,nxley, Benj:mnin & 32 & (11, \\
\hline & $.1 \%$ & $1+\cdots 1$ & $(n)$ & 1.1 & $\therefore, 50$ & $\therefore$ & $s_{i}$ \\
\hline in & leverii, II & $\therefore(1,-1$, & (m) & 12 & 1 & 24 & 115 \\
\hline 7 & is, Mnuris I..M M & 31 & in & 5 & 20 & 31 & $1 \%$ \\
\hline 50 & is, Mr-and Mlins & 51 & In: & 58 & 11,]^{\prime \prime}$ & 15 & $5.3 i$ \\
\hline$-\$ 0$ & $\rightarrow$ Nithlandiel & $2 f$ & 137 & 60 & ntuplne- & $\therefore$ & 107 \\
\hline 753 & $\therefore$ Rnsl & $a t 3$ & $(n)$ & 56 & $(11$ & $>11$ & 1,141 \\
\hline itis & S, Rulvert II & $7^{\prime \prime}$ & a & & 111 & 213 & 6 \\
\hline 51 & is, Ruluert M, li & in & $c x$ & 56 & 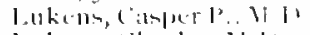 & $\mid\{x \mid$ & $1,1 \times 1$ \\
\hline 65 & is, Mlus. Kunlu. II & 264 & $(x)$ & 24) & $\left\{\right.$ llarles, $\left._{1}\right) \mathrm{I}$ & in & I $1 \mathrm{~A} \mid$ \\
\hline 112 & $i s, k c e v e$, & 511 & ( $\cdots)$ & & 1 & $i 2$ & $2+41$ \\
\hline & is, Siamuluel & $2 t\}$ & 07 & -5 & $M$ & 1115 & 5 ans \\
\hline Bats & 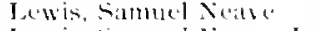 & $(1 n)$ & $(n)$ & 1120 & loyle, J:1 & $\bar{n}^{\prime \prime}$ & In \\
\hline 53 & is, Sommure Xeast. It. & 3 & in & 1831 & ].jurh, Williantu & ;" & 11 \\
\hline & $\therefore$ Sill & $24 n$ & (n) & 1,50 & 11. Juhu & in & an \\
\hline & is, si & 1,711 & $(m)$ & 17,1 & l. 1011 & 2ex & 97 \\
\hline & is, simnders, II & $3^{\prime \prime}$ & (w) & & "I Isalds" & $\therefore 15$ & 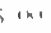 \\
\hline-46 & :is, Milliam & $\therefore$ & 15 & I h & "Twa Lamelic & ¿゙ル & , , । \\
\hline
\end{tabular}


.11

\begin{tabular}{|c|c|}
\hline$=0$ & 11.1 .12 .1 .16011 \\
\hline ルラン。 & II, alinted, I hatilem \\
\hline$z=1$ & 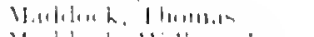 \\
\hline 4 & 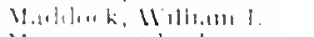 \\
\hline 9 & 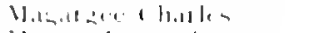 \\
\hline 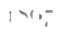 & $11,12,1,1,141,>1$ \\
\hline$\because-$ & $11.1210 \%, 111,11.1011\}$ \\
\hline$=9$ & $11.1212,111111: 1115$ \\
\hline$\because+1$ & 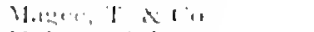 \\
\hline 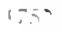 & 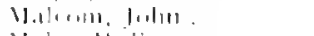 \\
\hline$\because$ & $11.1111,11+11,1111$. \\
\hline 5 & $11.1 \% 116 \times 1.11714$ \\
\hline$a \div$ & 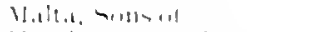 \\
\hline$=i$ & 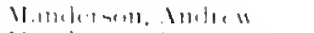 \\
\hline 以: & 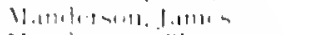 \\
\hline $1=5$ & 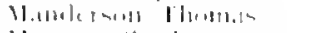 \\
\hline$\cdots$ & 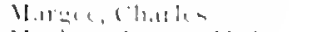 \\
\hline init & 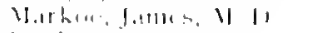 \\
\hline$\because i$ & M.1the, I.tu \\
\hline $1 ; 31$ & 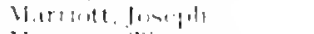 \\
\hline 17.5 & 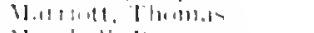 \\
\hline 1795 & 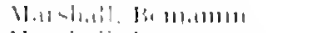 \\
\hline 1251 & V.11-11.1II, Iic.111.1111111 \\
\hline $1-2=$ & M.tunloli, (Horlen \\
\hline $1>101$ & 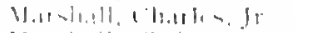 \\
\hline $1 \%$ & 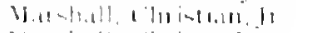 \\
\hline $1 \div=$ & 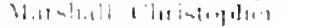 \\
\hline$\because 1$ & 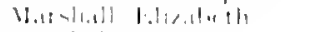 \\
\hline $1-4$ & 1I.11 $41,111,1,1,11$ \\
\hline 195. & H.11 Sh.til M.11 \\
\hline $1 \%$ & 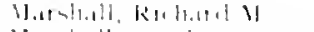 \\
\hline 1 & W.11-41.111, $-11,111$ \\
\hline $1 \cdots$ & $\begin{array}{c}\text { W.1tuli.11! } \\
\text { minla1. }\end{array}$ \\
\hline ant, & 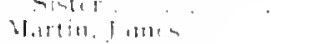 \\
\hline $\mid-1,1$ & M.1noll, Nhath.111 \\
\hline $1=\sum 1$ & 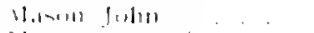 \\
\hline $101 ;$ & $11.14+11,-9.111111,1$. \\
\hline 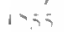 & 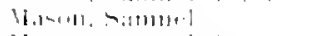 \\
\hline $2=1,5$ & 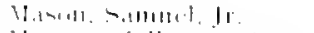 \\
\hline いえ, & 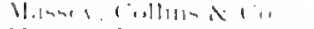 \\
\hline $12+0$ & 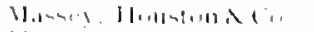 \\
\hline $1=$ & IImal Kidull \\
\hline 75 & 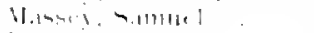 \\
\hline 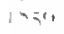 & Mamer. 11 aliiam \\
\hline$\div ;$ & $11.12011,11,114.1131$ \\
\hline 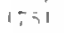 & M.andi. Mright. \\
\hline$=1$ & $11.14+1,11,111.1111$ \\
\hline & Helther. Jume ph \\
\hline$\therefore$ & Notihe is $-1,1] 1,1$, , I I \\
\hline if & $11.11114,11=.1142 \mathrm{~h}$ \\
\hline $1 ;$ & 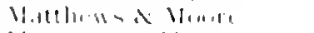 \\
\hline . & $11.1 t 1-111.11$ \\
\hline$\therefore$ & Ilatide firlu.ald \\
\hline 5 & $11,111+11,131$ \\
\hline “1 & M.1111. I-1:1,1 \\
\hline & Wank Itrumats \\
\hline & 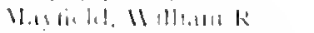 \\
\hline & Whin+ri, Hhomas \\
\hline & 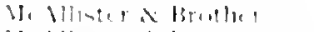 \\
\hline & 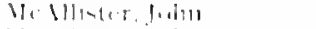 \\
\hline & 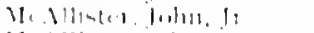 \\
\hline & 11, N11-2, r, Hholl, II \\
\hline & U. Mlliner Millinm S. \\
\hline & U. liride l'utrak \\
\hline & $\because 1,8,41,1,1,11,11,1$ \\
\hline
\end{tabular}

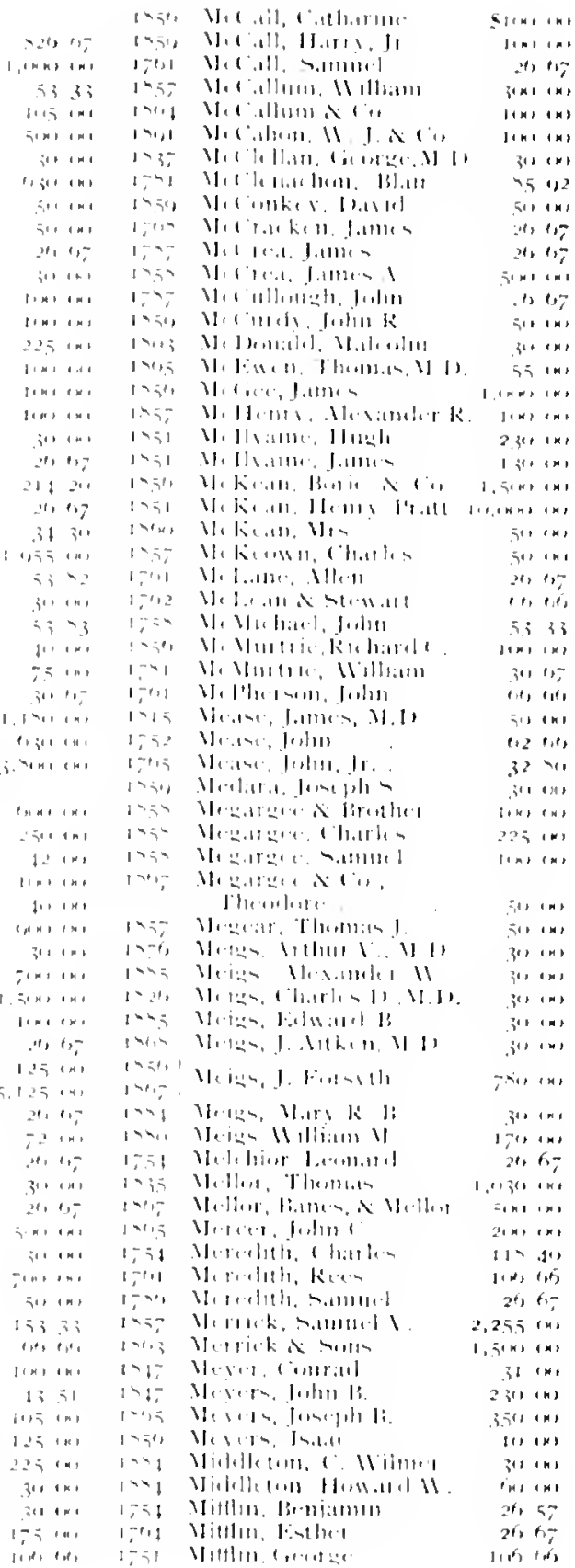




\begin{tabular}{|c|c|c|c|c|c|}
\hline 1701 & Miftlin, Jolus & $51+112$ & 17.31 & Morris, Anthong & is \\
\hline 175.4 & Miffin, Jolın, Jr. & $206 \%$ & 17.51 & Morris, Anthoul, Jr. & 50 \\
\hline $27+4$ & Miftin, John F. & $32(11)$ & $1-5$ & Murris, Betliaminillómall & 1,7 \\
\hline $17.5 i$ & Miffiin, Jomathatn & 201,67 & 170,5 & Mutris, Cadwalacled & 119 \\
\hline 17.55 & Alifhin, Jonatlinto & for on & $1,5,5$ & Murris. Catharine & (1) \\
\hline 1775 & Miftin, Jositply & 3115 & 175.5 & Mutris, Cathatine W: & (1) \\
\hline 1319 & Mifflin, Llog̣cl & 27 (3) & $1 \times 34$ & Murre, Casjer, N1,1, & $m$ \\
\hline $1.5 i$ & Mistlin, siminel. & (1) (16) & 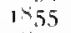 & Murris, Casjer 11 . & 143 \\
\hline 1751 & Millin, Simmuel. & $2+1,5$ & 1403 & Murris, Effingluall ls. & $(x)$ \\
\hline $1-57$ & Mifllin, Jhomaks & Int $x$ & 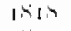 & Murris, Georere & $(n)$ \\
\hline 1702 & Mildreil \& Rulnets & 17467 & נ,hn. & Morris, feorire ${ }^{\circ}$. & (n) \\
\hline 1,50 & Miles \& son. Jacol, & $1(x)(x)$ & 18,52 & Morris, Genthe 11 . & $(\omega)$ \\
\hline 17.7 .5 & Mliles, Simminel. & 31271 & 18.5 & Murris, Gousernear & (4) \\
\hline 14.50 & Miller, Alrabinim & Sit) $(x)$ & Intse & Murris, 11 it & (n) \\
\hline $1,-1,1$ & Miller, Chatrles Ii & $3^{3}(x)$ & 1,11 & Morris. Het & 4, \\
\hline 146 & Miller, le sinendrar & $.51,101$ & $1+i$ & Morris, lsotac l'. & $(x)$ \\
\hline 1754 & Miller, fiecorge & $2+36$ & 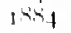 & Murris \& Cu, I. I'. & 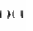 \\
\hline 14 & Mliller, lliram & $11+14$ & siser & 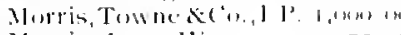 & (n) \\
\hline 140,2 & Miller, lsatint 1 . & $511 \mathrm{dx}$ & 1.to. & 11 & (i) \\
\hline $1-7$, & Miller, Jimes & $2+3117$ & $\therefore 4$ & is, Is & ( $H)$ \\
\hline $\operatorname{lin}(3)$ & Wliller, Juhn & $1.5 .5(1)$ & 5.1 & $\therefore 3.5 \times 11$ & (ii) \\
\hline $1,5,5$ & Niller, Johm s. & $2(x), 11)$ & $\therefore .5$ & Morris, Jor & (n) \\
\hline $1,-26$ & Miller, Mitgrute. & $2+3$ & $1+1$ & Mortrin. Jacoubri & (n) \\
\hline 1,07 & Miller, leter . & $2 f+7$ & $\$ 2$ & Murrin, Jaculs $1 ;, J 1$ & 15 \\
\hline Ix-14 & Mliller, Ricinitucls & $1+n+1,4$ & 41,5 & Mlorris, Jas & (B) \\
\hline 1.xists & Miller, Thumas. & 1.511112 & I & Morris, Jane . & (II) \\
\hline $1 \times 5$ & Miller, Williann. & $(20)(n)$ & 7.57 & ris. Juhn & 33 \\
\hline 1.550 & Milne, lo:trul . & $(x)(n)(n)$ & $7(x)$ & Murrio, joln, M $1 \mathrm{l}$ & 1,7 \\
\hline $17(x) 1$ & Milner, Eluaral & 20) 67 & -96 & Mrneis, John .]. & (n) \\
\hline 1,701 & Nilner, Elwaral & 2607 & 219.5 & in, John $\mathrm{I}$. & (n) \\
\hline 1.5 .7 & Miskey, $A$. & lant the & 1707 & I. I. I I. & an \\
\hline thes:- & Minkey, Mnrill $\propto$ & & $145 \%$ & 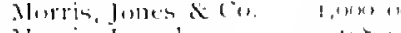 & 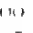 \\
\hline & "Thackitra & 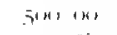 & 17.51 & 104 (1) & $4 . \overline{3}$ \\
\hline 14 & Mitchell \& lire. & 30,51 & Ixin & is. In & 4"1 \\
\hline 1,607 & Mitchell, J. F. & $5,1 \mathrm{nin}$ & 17.54 & ris fomlunis. & $3 i$ \\
\hline 122.5 & Mitcliell, J. K., M. II & $30,4)$ & Isten & morris lecil . & (111) \\
\hline $1 \times 51$ & Mitchell, 3 . Weir. W11. & $3+11$ & 17.51 & Murrin, luklic & $1) 1$ \\
\hline $17(x)$ & Moland, Juluts. Jr. & 2604 & $1, x+5$ & Murris, l, sliat & (ii) \\
\hline Inst & Malluy, Minluacl & $\{11,\{x\}$ & $5-11$ & rim, I' Iellulurtur & (11) \\
\hline 1521 & Montelius. Millian & 4011,4 & 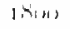 & is, Richirilllill. & 3 \\
\hline 17.51 & Mrxule. William & 24,157 & 7 & Mlarlia, Robert. & 115 \\
\hline 50 & lomin. Malluln & $5 x+x)$ & 17.54 & lorris, Sammelel. & 72 \\
\hline $1+4,5$ & $C \mathrm{C}$ & lins InI & 17,54 & $\mathrm{ut}+\mathrm{J}, \mathrm{l}$ & $f^{\prime \prime}$ \\
\hline 54 & Mlowe. Chionles & $2106 \%$ & 8.5 & $1,(x) 111$ & $1 ; 1$ \\
\hline-11 & Honte, Clattes, MI & $2+207$ & 14.50 & $1+x+1$ & (n) \\
\hline inj & Honre, Henty is. & w1 & 820 & is, $S t$ & ax \\
\hline 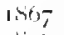 & ES Sin Jamlen & 5111110 & 位污 & ris, stepluen 1' & (11' ? \\
\hline $5 i$ & Monre, J. Milsint. Ml.11. & 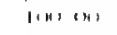 & 14 & mis, I:aker \& Mn & \\
\hline 211 & Woure, John. M. J. & $3+14$ & & $3.4 n\} \times 1$ & $(1,1)$ \\
\hline 16 & Moore, Jolnn $11 ., 111$, & $1,511 \mathrm{kH}$ & $+x_{11}$ & lutris, Tho & 17 \\
\hline 1757 & Mowre, pat & 2407 & Sil & ris, Tlu & ir \\
\hline 1751 & Mlowre, Rulect & (a) 0,5 & nis 4 & lel & $4 \%$ \\
\hline 17,52 & 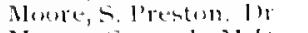 & $1+226$ & $4+1$ & 36.79 .51 & $4 n$ \\
\hline 5 & Musme, Samute], II 1 , & $2(x)+1)$ & 1756 & Morris, Nilliam. & 4,3 \\
\hline ais & lloore, saltall & $1 \overline{x+2}(21 j$ & 1.493 & Murris, Mistar (limily & \\
\hline 5.56 & Moure, $\mathrm{Tl}_{\mathrm{u}}$ & $1,26 x_{9}$ & & $1=0,4 k+1$, & $(1)$ \\
\hline 1557 & Mluote, Tlumbia 1$]$. & $501+111$ & $\therefore .5$ & ryestian הn & (m) \\
\hline 5.57 & Mlnser, Milliam & (si) $(x t)$ & $\therefore 12$ & , 沙 & (n) \\
\hline 0 & Misore, Willinn II. & $5,5.50,131$ & $\therefore \rightarrow 4$ & 11. (") & 1,1 \\
\hline .50 & 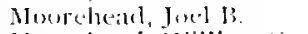 & $(x)(n)$ & inigit & $n, 1$ lukn K & $(n)$ \\
\hline 59 & Muntelestel, Milliamsi. & $|(x)| x \mid$ & 1711 & $11, J, 1, n$ & (n) \\
\hline 7.59 & Morgan, Benj:anin & 1.3 .376 & $\dot{G i n}$ & 11. I, I1 & (4) \\
\hline 7,57 & Murcatn, Es:atn & $1,-x ; 1$ & $-S 1$ & (111, Rul, Ret & $3 i$ \\
\hline-7.5 & 1) Julnt, lu. & 2407 & $12+5$ & Morton, Robert I'. & $(x)$ \\
\hline 65 & 11. John R. & $20010 x$ & 1700 & Nortate, Sommel. & (n) \\
\hline 45 & Morrell, Kotrert, M. II. & $11+16)$ & 1433 & tum, Sitmont & (n) \\
\hline-61 & Murrell, Milliant. Cilft. & (3) 140 & $1<31$ & Blonton, Salluted li & 1n \\
\hline
\end{tabular}




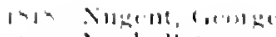

$1,52 \quad D ! n l 1$, leter.

()

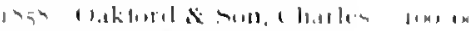

145) 1 1.16, timergek

$7.51 \times$

follit its

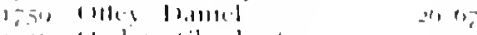

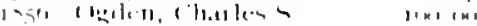

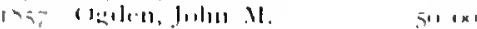

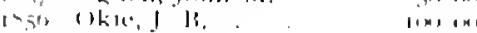

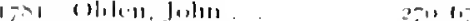

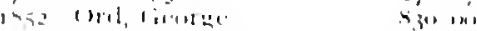

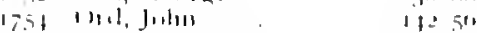

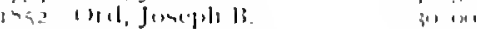

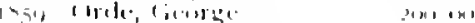

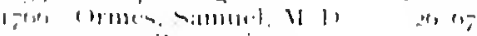

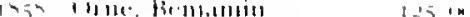

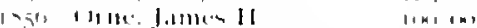

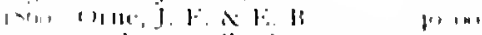

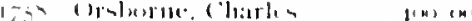

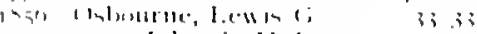

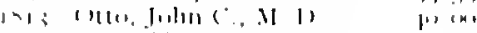

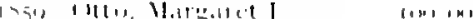

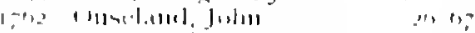

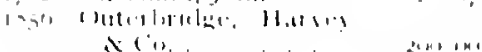
a $(i)$.

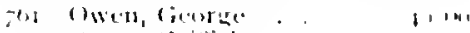

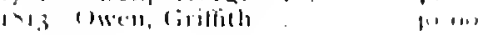

$p$

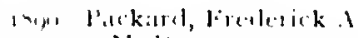

M. 1\%.. 31, int

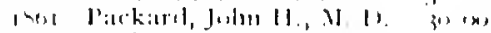

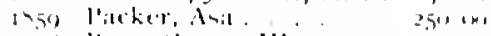

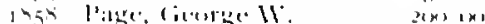

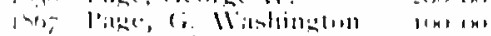

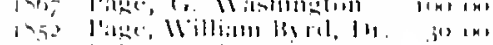

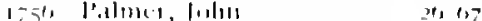

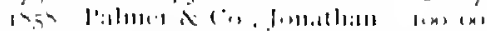

1
$;$

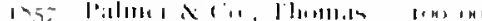

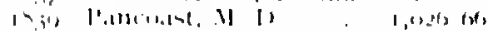

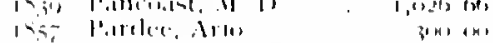

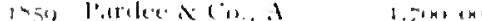

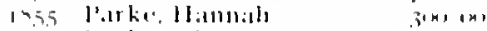

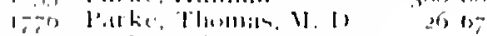

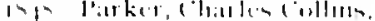
$11 \mathrm{ll}$

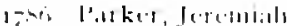

;i 33

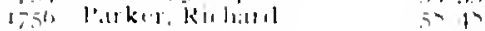

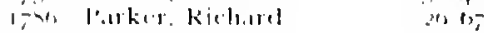

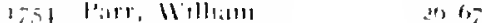

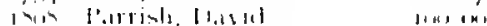

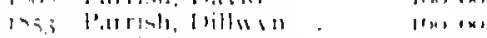

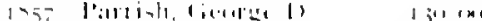

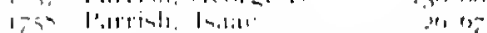

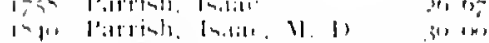

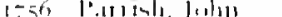

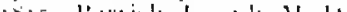

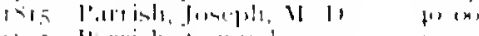

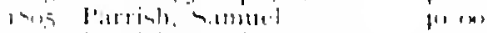

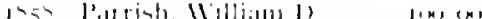

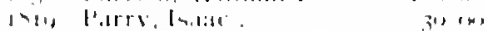

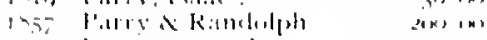

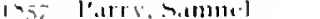

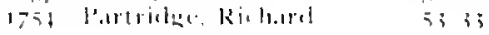




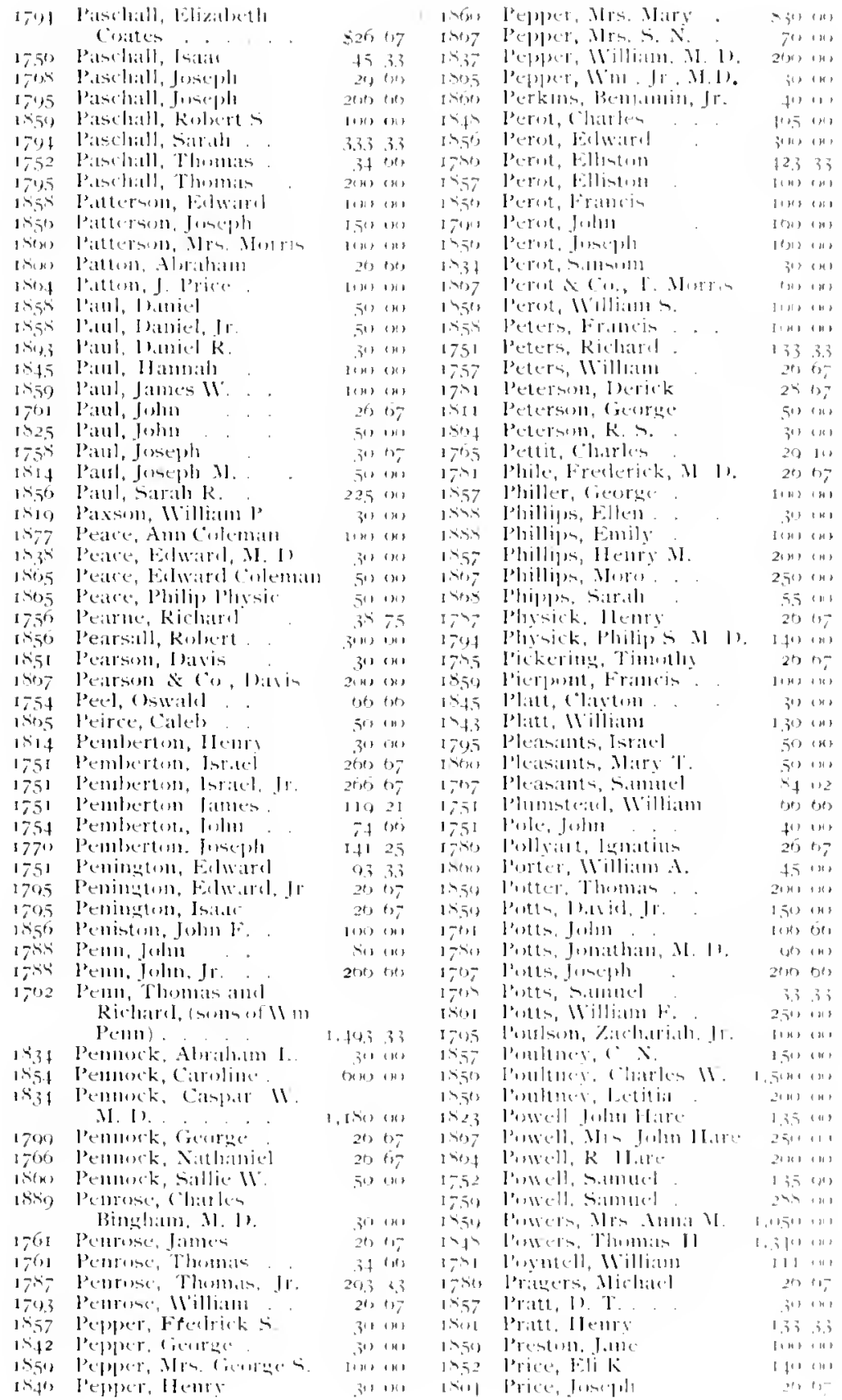




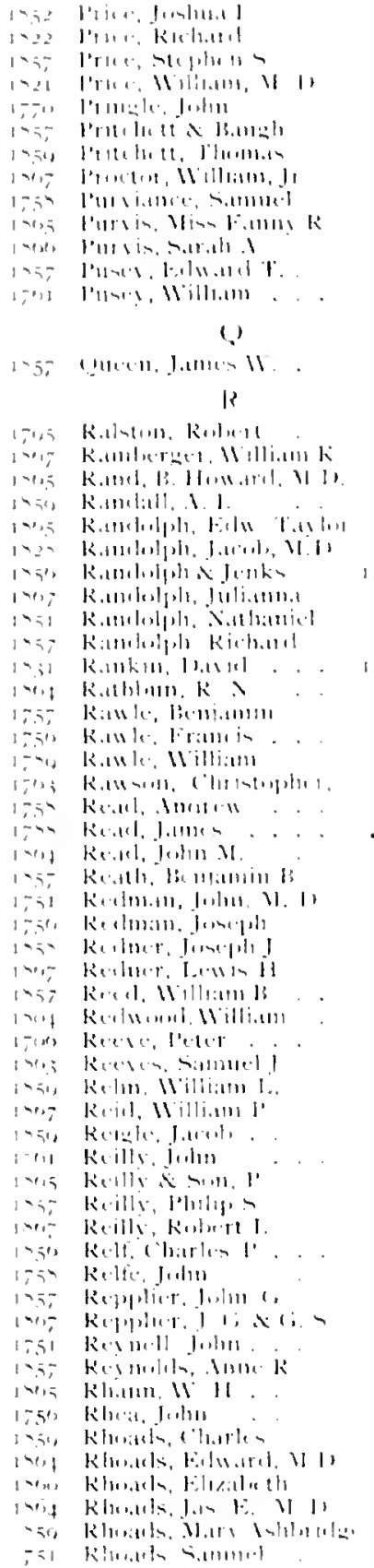

\begin{tabular}{|c|c|c|c|c|c|}
\hline$=1$, & & $1 \%$ & 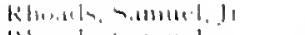 & $s y^{\prime \prime}$ & 1,5 \\
\hline$n+1$ & $4 m$ & $145 ;$ & kho.kim, s.111111.1 & $\operatorname{lin}$ & in. \\
\hline$\vdots 1$ & $|x|$ & +1 & 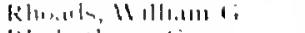 & i" & (n) \\
\hline .1 & in' & 齐 & 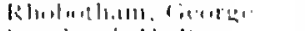 & 24 & 15 \\
\hline 52 & $4 n$ & $1 x^{\prime}$ & Rlinalantil. II li & $i^{\prime}$ & $4 \pi$ \\
\hline $2 n$ & $\cdots 1$ & $5 n$ & Kkst. Jullst & $2,1 m n)$ & 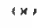 \\
\hline$\| m$ & ins & 列 & 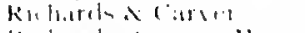 & $33^{\prime \prime}$ & (n) \\
\hline in & $(n)$ & i: & 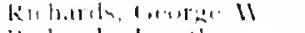 & $2 x)$ & $4 x$ \\
\hline 24 & $i$ & 9. & 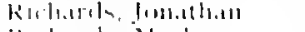 & 311 & $|k|$ \\
\hline$\therefore \prime$ & $x \rightarrow$ & $\therefore 1$ & 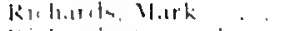 & "1" & $1 m$ \\
\hline i'n' & 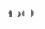 & $-1,2$ & 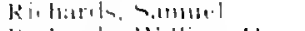 & $i^{\prime}$ & in \\
\hline$; 1$ & In! & 14 & Kollanls, Milli.um II & 115 & (k) \\
\hline 213 & i: & 7.1 & 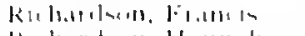 & ;i & ix. \\
\hline & & 51 & 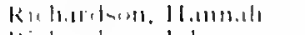 & 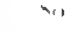 & $(x)$ \\
\hline & & $(n)$ & 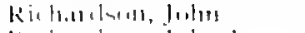 & י & , n' \\
\hline$(1 x)$ & $1+4$ & 145 & 11. !nln1! & $5 \%$ & $4 n$ \\
\hline & & $1-51$ & Int11, Insepili & 3i1 & 20 \\
\hline & & ain & 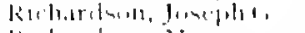 & in & in) \\
\hline 511 & $n !$ & Sint & 11, Vari. & $5 i$ & i3 \\
\hline $11 \times 1$ & 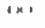 & $=1,1$ & 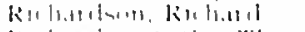 & $S^{1 n>}$ & $|n|$ \\
\hline$\| x \mid$ & 1,1 & $\because ?$ & 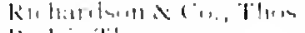 & 1,2511 & $(n)$ \\
\hline$c_{11}$ & $(n)$ & $\because 7$ & linlue, Jinmols. & 24 & $a 7$ \\
\hline $2 n$ & I & ○一 & $10.111,11$ & .511 & $(x)$ \\
\hline$i^{\prime \prime}$ & $(\cdots)$ & $5,-$ & is. I & $\| n$ & $|k|$ \\
\hline$\because \cdots$ & (4) & $\overline{7}$ & $11 . .11$ & $10 x)$ & $|n|$ \\
\hline$n \ldots$ & $(m)$ & 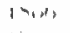 & $11,1 !, 1.11,1, \ldots$ & Sin & $(n)$ \\
\hline in & $n 1$ & $4:$ & naly, l1 & 1,530 & $|n\rangle$ \\
\hline 150 & $(n)$ & 5.5 & I.ti. I & ion & $\{k\}$ \\
\hline $3 \times$ & $1 \times 1$ & 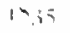 & Kanlutulu & 211 & 17 \\
\hline Ifä & 1,4 & $\because, 5$ & 1.1. I'in & $一$ & $(n)$ \\
\hline $2+$ & (in) & 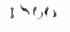 & 11,1 & 71 & $(x)$ \\
\hline ais & 12 & $17-1$ & $\mid 1,1,1,1$ & i) & $w_{7}$ \\
\hline$i 2$ & in & ;n; & 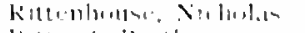 & $\because 1$ & $\because ;$ \\
\hline-1 & ; & $n+1$ & $\therefore$ & in & $(n)$ \\
\hline 21$)$ & 1.7 & 々 & $1: 1$ & Sn & $|n|$ \\
\hline$" ;$ & i3 & 51 & $1 \cdot 1$ & 411 & $(\mu)$ \\
\hline 510 & ' $n$ & Nit & IIn steplicen & 31 & $|k|$ \\
\hline$\therefore$ & $1 x 1$ & $\because=$ & $\ln (* 1) .11$ & [n] & ( \\
\hline ." & 15 & 5 & $1+\ldots 1$ & 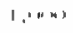 & inl \\
\hline 11 & 91 & 1,5 & 19.11 & $10 x \mid$ & ' '1' \\
\hline 71 & $5 \cdots$ & 11 & a. & 10 & ew \\
\hline$\therefore$ & $|n|$ & 23 & $\ln$, & (n) & $(n)$ \\
\hline 511 & IN" & ii & $\ln , 1$ & 211 & 17 \\
\hline $1+x \mid$ & $4+$ & 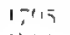 & is 1 ; & $1 ;$ & 37 \\
\hline $10-$ & (1) & $\cdots 1$ & ents, 1 & & \\
\hline$\Rightarrow=1$ & (m) & & & $2 m$ & $|x|$ \\
\hline$\therefore \cdots$ & $1 M 1$ & 51 & kululer. & as & 11 \\
\hline 计 & (n) & ;' & I?. 1 & $\mid(n)$ & an \\
\hline$\overline{11}$ & $1+1$ & $: 5$ & 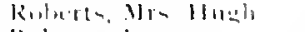 & $|n|$ & $|n|$ \\
\hline $2 *$ & $1 \%$ & $1, .5=$ & rts. In & ? & $(x)$ \\
\hline $\ln \mid$ & (M) & 1.51 & atwets John & 5 & (Ni) \\
\hline का & $(n)$ & $1 \div 1$ & Hello, Jalull l: VI & 1313 & in \\
\hline ' & $(x)$ & $\because 1$ & 《ा 11 & $1,2 \%$ & $i_{7}$ \\
\hline$n(x)$ & ind & 191,1 & $1,1, !$ & $2 f)$ & $1 x^{3}$ \\
\hline (f) & ine & $1,-1,7$ & an. & 5.3 & $.3 i$ \\
\hline It m & '"' & イミの & 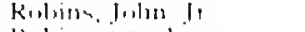 & 325 & $n$ \\
\hline$|+k|$ & (n) & $12 x-5$ & in. : & $s \cdot$ & $(n)$ \\
\hline $51 \times 2$ & $\therefore$ & 5 & ki & IIn & $\sqrt{x+1}$ \\
\hline $1+4$, & $m \cdot$ & 17511 & in. Nrs Pllum & $5+1$ & (n) \\
\hline$|1,1|$ & $(n)$ & 小彺 & 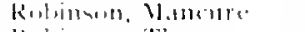 & $1,1 \times 01$ & in! \\
\hline il & $\because$ & Vin & 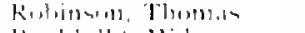 & 24 & $\therefore 13$ \\
\hline in & on & IV & linll \& 11 ilsuri & $\therefore M$ & $4 x$ \\
\hline in & $\cdots 1$ & 1957 & $|i x| 1 \mid$ & $1.1 \mathrm{KMN}$ & , In \\
\hline 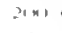 & 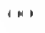 & 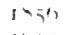 & 121.1 & 1.1111 & I $i m$ \\
\hline in & $\{n\}$ & $1 \times 13$ & $r=11$ illi:tur & 511 & , in \\
\hline ₹० & $\cdots$ & 1011 & 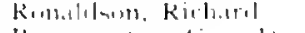 & $(1, x), 2)$ & , in \\
\hline 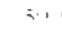 & 川 & $1 \times=-$ & 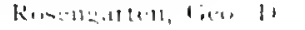 & $\$ 25$ & 5 \\
\hline
\end{tabular}




\begin{tabular}{|c|c|}
\hline $1-51$ & Ross, John \\
\hline 1,50 & Kuss, kolett J. \\
\hline $1-5 x$ & Rouse, John \\
\hline 1.5 & Rralland, Benjannu \\
\hline $1.7+1$ & Ruwl:und, Eclw:ol \\
\hline 1.64 & Rowland, Iames \\
\hline I (xin) & Rowland \& (1) Jantem \\
\hline 1 ints & Kuwland. Nithan \\
\hline intif & 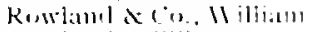 \\
\hline 14.50 & Rowland. Milliaun \\
\hline $1 \times 50$ & Rue, Juln K. \\
\hline $1 \times x y$ & Rugan, Charles \\
\hline $1-70$ & Kunalle, lsomiel \\
\hline $1-x$ & Kuntle, Ricluarel \\
\hline $1 \div-i 1$ & Rush, B(mianuin. M. I \\
\hline 1913 & 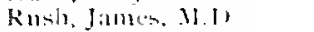 \\
\hline 192 & kush, IIHliam, W \\
\hline $1,-54$ & Kust, Milliam \\
\hline $1-i t$, & Russell, Extwathl \\
\hline 1,5 & Kutter, ( lement s \\
\hline $1,-4 x$ & Rutter. (ientise \\
\hline וצר & Rutter, Newliall, a 1 . \\
\hline $1,-6$ & Kutter, Themas \\
\hline 1,59 & Ryerss, Juneply 11 \\
\hline 144 & 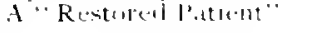 \\
\hline & 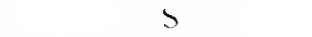 \\
\hline ind 1 & 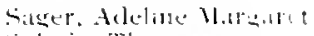 \\
\hline $1,5,5$ & Soltitir, Themots. \\
\hline $15 \mathrm{~s}^{2}$ & Sinnsom, Hammall \\
\hline $1,-61$ & Sindsim, Jouefh \\
\hline $1,-5 i$ & Sintsinl, Simmucl \\
\hline $1,-1,4$ & Sanson, sannuel, It. \\
\hline $1 ; 7$ & Sansem, Williams \\
\hline 15.52 & 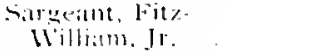 \\
\hline 17.52 & Sinter. Clarintuplues \\
\hline 1914 & Situnclers, Ann \\
\hline $1 \times 5$ & Sommcless I. N M \\
\hline 1350 & Saunolers, Julun \\
\hline 1.54 & Siluncters, forceplo \\
\hline 1) & 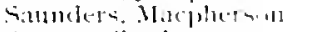 \\
\hline 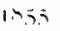 & Sintuter, charles \\
\hline I \ו & Saviger. Julut \\
\hline 14.50 & 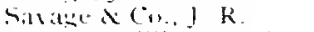 \\
\hline 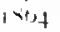 & Savery. IVilliam, of 11 \\
\hline 1412 & Sawger. James \\
\hline $1,-80$ & Say, Benlamin, M. I \\
\hline 17.51 & Say. Thumils \\
\hline $1 \div 50$ & Scatterersuml, Jus ph \\
\hline $1 \times 5$ & Scatteronarl, S.lmutel - \\
\hline $1,-, 2$ & soattersusl. Th+ntsu \\
\hline 15.50 & Sehrlfer, Juseph l. \\
\hline 15.5 & selaster. Willianul.. \\
\hline $19+25$ & Sclicelt. Alurilhim \\
\hline $1 \backsim=4$ & Silnicalt tisteliels \\
\hline $141 ;$ & 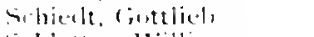 \\
\hline $1>1.1$ & Schlittor llillintu \\
\hline $1,7,3$ & Sibmiclt. Ilenry \\
\hline 1421 & Sielwet, Jiturem \\
\hline $14+2$ & Siluott. Jamene. It. \\
\hline 147 & Soott, Sima 1). \\
\hline 17.50 & Scott, Jubn \\
\hline isise & Siont, Juhn XI \\
\hline $1 \times 5.5$ & Sientt. I, ewis A. \\
\hline 1,55 & scull. Isavial. \\
\hline 195 & Siull, rident \\
\hline
\end{tabular}

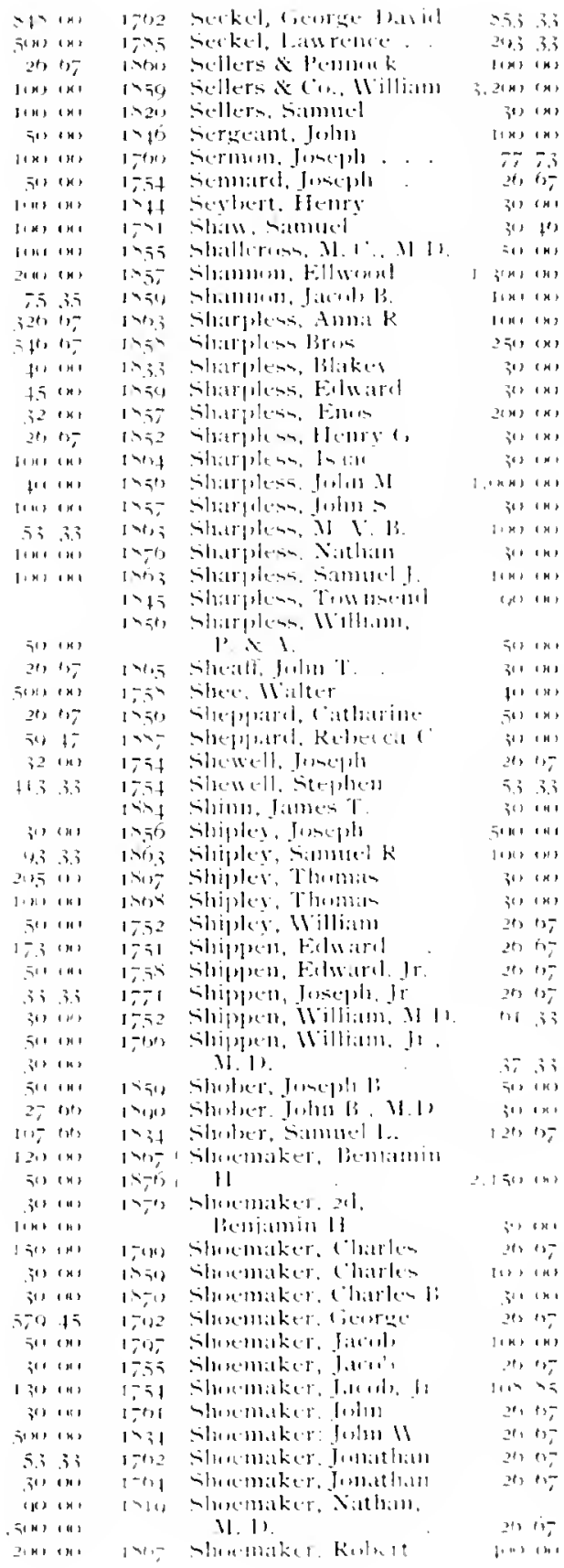




\begin{tabular}{|c|c|c|c|c|c|}
\hline inlin & -linkouiker, K & 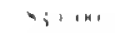 & 14.31 & th, 10 & an \\
\hline IX:- & 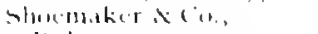 & & sing & SIIIII, M, Ni & 55,1 \\
\hline & kinlere & $q M A 1 \mathrm{H}\}$ & Jרו & sillitli, Vlanten. & $\Rightarrow m, 1 \ldots$ \\
\hline $1,-1$, & Slurelnaker, Simulu.l l?. & in un: & 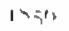 & 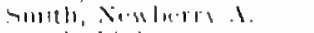 & $5 n)(n)$ \\
\hline $1>0.1$ & 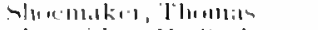 & 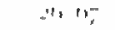 & 19,$1 ;$ & smill, J"hluा & $311,1 \times 1$ \\
\hline $19+3$ & 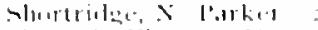 & $2,1+n+1 m$ & $1 \times 1$, & 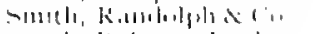 & $\mid(m)\langle n|$ \\
\hline$x+1$ & 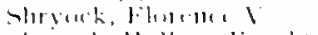 & ind in & 1395 & 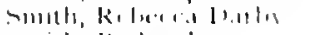 & $31 \times n$ \\
\hline 1 ind & sliriant. II llo.m kinght & 到 In. & $1,-||$, & 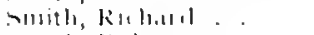 & cisters \\
\hline $15-5$ & 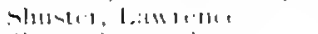 & IInI an & $17, \vdots !$ & mmill, kintult & 215 \\
\hline $1-511$ & Sholl, . Ittwan! & if 10 , & 1,7 & smith, Rutiert & $3+201$ \\
\hline $1,-511$ & $\therefore$ Homletsy & 9,101 & Intip & 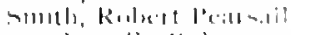 & $311 \mathrm{CH}$ \\
\hline $1-., 5$ & Shote. Milli,anim & $\therefore+1,-$ & 140 & 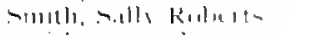 & $31,1 \mathrm{k}$, \\
\hline 3 & stemes, lieter & $1+\cdots, \ldots$ & $1,-5 !$ & smith, s,tm11, l & it i \\
\hline 15 & slicer, Junthls & $|1 k+| n \mid$ & $1=518$ & 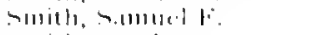 & hen ine \\
\hline $1,4,1$ & sllugeris, Millsam W & $1, \cdots+1,1,1$ & $1+1+3$ & smitis. stoplocis. & $21+1$, \\
\hline 1215 & simes, llesaluter & $3 n \cdots 1$ & ai & -llith, Jlonthisu & $2(x), x)$ \\
\hline 19.5 & 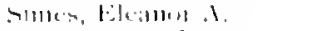 & 513131 & 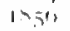 & 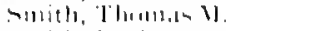 & 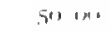 \\
\hline ins & silstes, >.111110.l & $11 \mathrm{~m}, \mathrm{Ans}$ & $1 \times 17$ & smith, $11.11+1 \cdot r$ & $3+1 \mathrm{HA}$ \\
\hline $4,-7$ & simes a sum, Milliam & & $19+x$ & h. Nillet & 2hind \\
\hline & & $1 \cdots 1,1$ & $1,5,51$ & $11,11 / 11 i .111$ & $2^{i}, 11-$ \\
\hline .3 .5 & Simmmus, Rel & $\because \cdots n$ & 17,1 & $11 \times 11 ., 11.18$ & $311+14$ \\
\hline 25 & 11,9 & $15,1 n)$ & Inet- & smith \& $(11,111)$ & 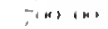 \\
\hline Sis & 11,1 & $\| x, \ldots$ & $19,5 \%$ & 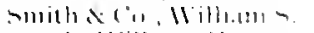 & $\{n, 1,1$ \\
\hline in & - lintitiel & $1,57 . ;$ & $14 i 2$ & 1.11 ill1.11m 11 & in $\mathrm{CM}$ \\
\hline$-(1,1$ & 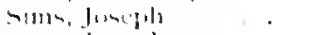 & 1) in & Insin & sminli, limbla. & $3 n+1 \mathrm{HA}$ \\
\hline $\sin$ & 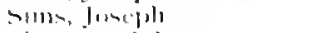 & $3 n(x)$ & $\ln 4,5$ & 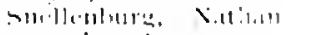 & $|x| x|x|$ \\
\hline רii & 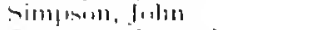 & Fn in: & 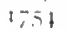 & 1, $11,1=5.11$ & $2+1,7$ \\
\hline 71 & 11), Sitmunel & $3+13-$ & $17+2$ & |av. Ineleadials & $32 \ldots 1$ \\
\hline 13 & alu & in in & 175 & 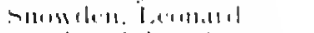 & $2 t, 1 ;$ \\
\hline 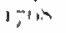 & Nin. 11 & 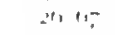 & 1デー & snveled, lobur linereses & $2 p+\cdots$ \\
\hline 4 & 1, Jan & 1 & $1,-7$ & 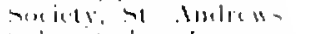 & $11 x+1 x$, \\
\hline+1, & t. IIi & $\therefore, 1 \times 1$ & I जiा & Sidnu- I & $5 x+4 x=$ \\
\hline 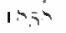 & 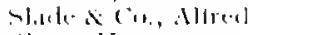 & $\operatorname{lin} \mid \mathrm{AN}$ & 8.52 & 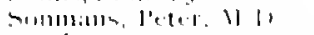 & i2 $1 \times 1$ \\
\hline 27 & $1,1[-111 y$. & land In & (1) & mirlelecr $\&$ siol. 15.1 & $3 M 1$ ON \\
\hline 5 & $s \ln x$ & $1.311,1$ & 912 & 11. kexlingmol & $2+1,-$ \\
\hline 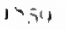 & 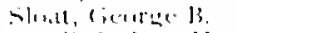 & $\operatorname{lin} 1 \ldots$ & $1,-1,5$ & ili, simmur. & (x) क्रा \\
\hline $451 \times$ & 111 & 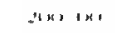 & intis & 111 & Sol $1 \mathrm{~ms}$ \\
\hline $4 ;$ & 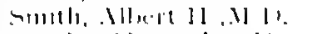 & $5 n 1 \mathrm{nl}$ & IU & 11211, S.tmong. & ind \\
\hline 1.5 & simitis. . Iles & $15111 \times 4$ & 1 & 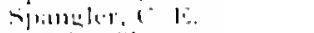 & I Bu In \\
\hline it & Smith, Be & i' $1 \times 1$ & 145 & tis, Hhumlas & $2,51 \mathrm{~m},(\mathrm{~m})$ \\
\hline$a+1$ & h. ( ) & $\because 4+14$ & $1-\infty$ & 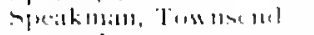 & 21,15 \\
\hline S'י & sruntli, llamicel, Jr. & $2 n+1 n)$ & Nis; & $.1,11104$ & Sin (x) \\
\hline+13 & sulth, 1) ( 11 latet+11 & i I ( H) & $-i$ & 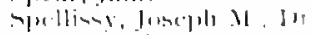 & ;aln. \\
\hline an & smotl, leclnamulal. & $\ln x|+n|$ & $(x)$ & (1) Clorles & $1,25+11$ \\
\hline$\rightarrow 1$ & Smith, Findrel & $11 \cdots 1,1 \mathrm{~A}$ & $h+1$ & 'I, Nillı, & $7.5 \mathrm{~m}$ \\
\hline 5 & smith, Flu,ats 1, II. & $2+n+141$ & $t \div, \ldots, 1$ & sincer, iantil & $211 \times 1$ \\
\hline 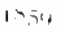 & $\|11,1 *, \quad\| 11$, & in & $19 x$ & 1,1 rakinl & Sn in \\
\hline$-5 \overline{5}$ & smlll, Cinctore, MI & $2(n+1 n)$ & 195 & $r$, binin. & $\| x|| x \mid$ \\
\hline 新 & smille, ricouras & 121,14 & $145 \%$ & r. Millı:m s. & 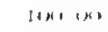 \\
\hline (1) & k. & 㳻 I & $t=i n$ & $\because 1 \div 1111 \cdot 1$ & 1214, \\
\hline \% & $1 ;$ & $|(B)| A \mid$ & -1 & ikle, $11: 11+.9$ & 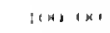 \\
\hline$\because$ & i, iscorger Roblu its & $, 19,1,1$, & ris: & 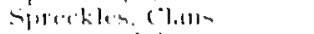 & and \\
\hline $1-$ & $11 ., 11.11$ & $311 \cdots$ & 7 se. & I. Juhn & 1.333 \\
\hline an & k. & $|\hat{B}+1 \mathrm{H}|$ & -51 & 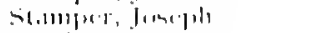 & 11743 \\
\hline 41.5 & I. Is & in' 11 & 1751 & Ilusan. & 24,67 \\
\hline 412 & 1, J:111 & $31+11$ & $1,1,1$ & simlio, 1 & $21,+1$, \\
\hline 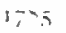 & $\therefore \mathrm{Jt}$ & 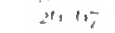 & 751 & Simluy, II. & 21,1, \\
\hline Nis & i1. & נים & 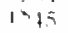 & $\because, \ln 1: 16$ & in $31 \mathrm{~ns}$ \\
\hline$n \rightarrow$ & i, lotrmes $x$, It & $\therefore 101 \times 1$ & $\because$ & St:IrI, Juillt, It. & Fil in, \\
\hline 7.51 & i. Juluse. . . & $1=2 \times 1$ & SIxi & siatr, Jes Inaliti & $5001 \times 1$ \\
\hline$T_{111}$ & 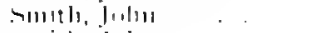 & 21,10 & 97 & $\rightarrow 1: 4 r^{r}$, I.111ich & 151,100 \\
\hline $4,-$ & smith, Juln & 5114. & $15 \%$ & 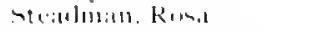 & I Intotes \\
\hline का. & Juln F. & InXI 14. & 145 & Stonll, kuluert & WU, \\
\hline $4+13$ & smith, Juhn lasy. & $3^{\prime} \cdot x_{1}$ & 1452 & I, finlly & 1 $=10$ \\
\hline 47 & Snuith, Juhn $\mathrm{l}$ & IIXI IN & 17,1 & Strommed/, J 1minel & 24,17 \\
\hline$-1,-$ & smith. Jumatlian V: & $\therefore P_{1}$ & 1,58 & 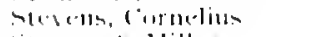 & $\ln x)$ in \\
\hline . & 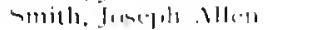 & in In & $1,-5$ & Geandis Villos & $5,11 \mathrm{~h}$ \\
\hline
\end{tabular}




\begin{tabular}{|c|c|c|c|}
\hline 14511 & lat1h.11n, R & $=1,3,311$ & (H) \\
\hline $1, x+y$ & litllinus, fiterrge N. & 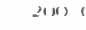 & (H) \\
\hline $1 \quad b t\rangle$ & littlatm, Itenty $\mathrm{B}$. & $2(10) 0$ & ( H) \\
\hline $134 t$ & "latlinam, Williams l". & 0,10 & (H) \\
\hline in & l'attum, Elluatul. & $3+1$ & (m) \\
\hline intot, & liats, lewis . . & $11 n+6$ & $(n)$ \\
\hline Insto & "loiglor, chatres & $1, r+111$, & ("1) \\
\hline 1557 & 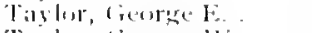 & 30 (1) & (H) \\
\hline 59 & 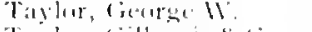 & $5+1$ & (ir) \\
\hline $\operatorname{lin} 5$ & Tallor, rillesplescu. & $4(x)$, & (R) \\
\hline$i, 40,5$ & litylut, fillespic & $2(1)$, & (n) \\
\hline I. & Tiablur, Jamber. & 1,5 & (n) \\
\hline $1 ; 50$ & Virllir, Julnen. & it & $(t)$ \\
\hline (5t) & linglor, John 1). & 541 & (M) \\
\hline $155^{\prime \prime}$ & Tinglur, Jus, M... II I). & $2(n)$, & (n) \\
\hline $1(51)$ & laylur, Mary A. & 11016 & (n) \\
\hline 1459 & liuglur, Natluall. & $\mid(x) \cdot$ & : H \\
\hline $125 x$ & Tilylur, Virmunial. & $(1,1)$ & $(n)$ \\
\hline $1 \leqslant 57$ & Pilylur, Millialn & $1(x)$, & wi \\
\hline $1 \times-b$ & leimplo, Jusciols b. & $4+1$. & .35 \\
\hline $1 \leqslant 50$ & 'Tustere, Mrs. & 54, & (H) \\
\hline $1-05$ & 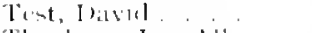 & (t) $t$ & $1,-\%$ \\
\hline 1,510 & Thatekiaril Jits Alled & , 31 & (n) \\
\hline I. 4.51 & Thatekatra, Milliam & $\| 1$ & (n) \\
\hline 1,57 & "lianime, l lasial & $5 " 1$ & $(H)$ \\
\hline Iลร2 & linsllas, fieorege, hl l'. & 3110 & 1111 \\
\hline $1 \times \$ .5$ & llonluats, fientere & 2III, & (⿻) \\
\hline 1.512 & 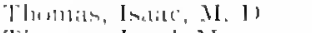 & $3 \cdots$ & in \\
\hline 14.15 & 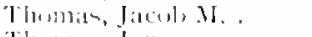 & 301 & $(n)$ \\
\hline $15 \cdot 13$ & Thontals, Jatue, . & Fin, & $1 \times 1$ \\
\hline 1,54 & 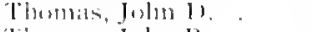 & .3 .5 & $(m)$ \\
\hline 1452 & Jlundrats, John R. & ; & (n) \\
\hline 1,61 & loumats Jascpll. & 32 & $(n)$ \\
\hline $1,-1+5$ & 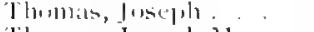 & Ithe & bt \\
\hline $1\langle t(n)$ & 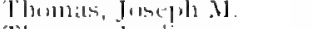 & 511 & $|x|$ \\
\hline 1967 & Thinniss, lyolial. & 1131, & (1) \\
\hline 15.54 & Thommats, Mloses . & 325 & (10) \\
\hline I. & Thimits, Muses \& Sin & 1501 & (H) \\
\hline 1 sin.s & 'llumbls, Richaral s. & 30 & (ii) \\
\hline 1455 & Thumals, Sammuel A. & $1,1 \| n)$ & $(H)$ \\
\hline 15,59 & 'Jhomms, Noilliamer, & 1141 & $(1,1$ \\
\hline 17.56 & Thomposon, Charles & 111 & $5 t$ \\
\hline 150,5 & Thumpusm, (houles T. & .341 & (I)' \\
\hline 17.54 & 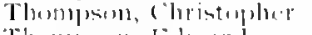 & f' & (11) \\
\hline $1<16$ & Thimplem, Filwart & 3111 & (⿻) \\
\hline 1956 & Tlusmesisu, fienteres & II $x$ ) & 131 \\
\hline $1 \times 1.5$ & Tlumpun, Jannes 13. & $(1)$ & (1118 \\
\hline $1-x i$ & 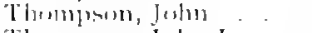 & 34 & 1) \\
\hline IS5r) & Thinglysost, Jihn J. & finl & $(x)$ \\
\hline $1,40,5$ & 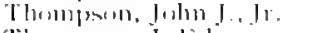 & 1.311 & (n) \\
\hline IStat & 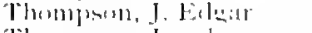 & $t x+1$ & $(m)$ \\
\hline I. 14 & 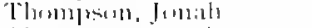 & 511 & (n) \\
\hline $1,610.4$ & 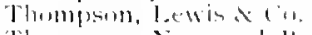 & (1) & (11) \\
\hline 14.54 & 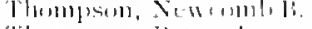 & $1+111$ & 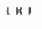 \\
\hline $1-\lambda i$ & 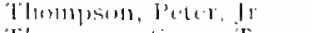 & .31 & the \\
\hline 191,5 & 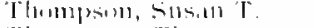 & in' & (1) \\
\hline $14(3)$ & 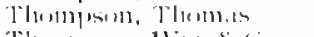 & 1131 & (11) \\
\hline 1イラン゙ & 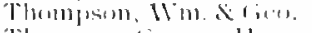 & (1) & 131 \\
\hline 1459 & 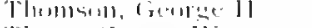 & $|n k|$ & +111 \\
\hline $14 \times 2$ & l'lustr, & 11 & 67 \\
\hline $1 \$ 17$ & l'hun, lientese & (") & (3) \\
\hline 165 & 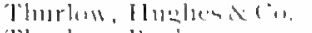 & $2+n 1$ & (M) \\
\hline 1,50 & lolurlus, l'anli & [1] & " 1 \\
\hline 1458 & libes, It Inty \& & 2.511 & $(n)$ \\
\hline $1,-0,1$ & Tilulmoman Iimle- & $5 i$ & $\therefore ;$ \\
\hline$\{7.5 t$ & Tillums, Thumbis & औ & .51 \\
\hline 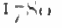 & 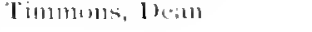 & .5, & 3,3 \\
\hline
\end{tabular}




\begin{tabular}{|c|c|c|}
\hline 55 & linkir & $\Rightarrow$ \\
\hline $1=-5$ & 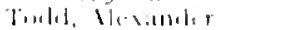 & 353 \\
\hline $1=-4=$ & l'ml, J, J, & 312 \\
\hline $1,-(2)$ & lial:and, I1,ma & 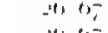 \\
\hline$|-r|$ & limels. Kuldes! & $\therefore 15$ \\
\hline $1,-1$ & 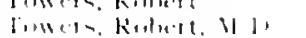 & $211 \%$ \\
\hline 12 & 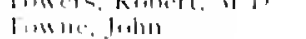 & $+1 \%$ \\
\hline $10=18$ & & $\cdots$ \\
\hline $1 \times 1 \%$ & & $5+x+1$ \\
\hline I $=51$ & & (1) \\
\hline 145 & 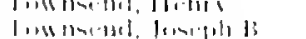 & $3 \cdots$ \\
\hline $1 \times 1$ & 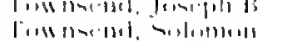 & けまい \\
\hline $1 \times 11$ & 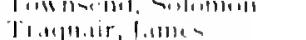 & in an \\
\hline 1957 & & in \\
\hline $14 e_{i}$ & 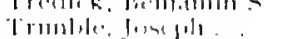 & fin\} in \\
\hline $1 \times t)=$ & 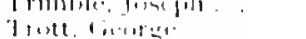 & $581 \mathrm{An}$ \\
\hline $1>511$ & & $=1111$ \\
\hline $14=7$ & 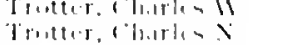 & 1., ion \\
\hline 14501 & 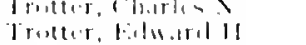 & $\operatorname{lin}$ \\
\hline In:1 & 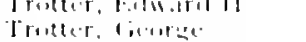 & $1.1511 \mathrm{MI}$ \\
\hline $1,5:$ & 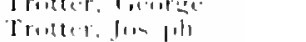 & $28111 \mathrm{kl}$ \\
\hline $15=1$. & 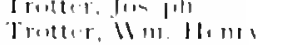 & (n) $1 ;$ \\
\hline INT & 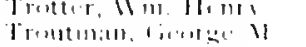 & 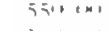 \\
\hline $1 \times 51$ & 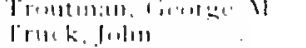 & $1 \%$ \\
\hline $1=>i 1$ & & $\ln x) \ln 1$ \\
\hline 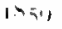 & 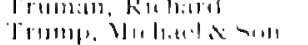 & $=112 y$ \\
\hline ISis & 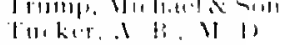 & $1, x, 1 x$ \\
\hline 1) 21 & 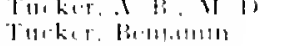 & $1 \cdots+n \mid$ \\
\hline リフラ & 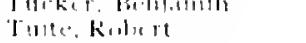 & 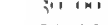 \\
\hline $14+1$ & 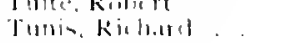 & $5 i, i, i$ \\
\hline$t-||$, & 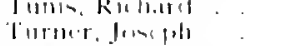 & $=91 \times 1$ \\
\hline 1,51 & 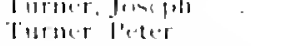 & $1 ; 3 ;$ \\
\hline 10; & 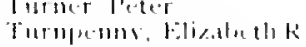 & $\because 19$ \\
\hline Ixร” & 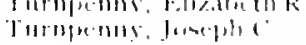 & 513 \\
\hline $1 x-p$ & 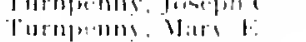 & $1.27 .51 \mathrm{Mt}$ \\
\hline 191.5 & 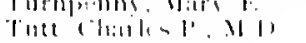 & $5(1, \mid N)$ \\
\hline 1212 & 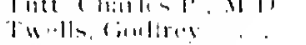 & . $31 \times 1$ \\
\hline $1-4=$ & 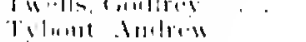 & 2117 \\
\hline 101.5 & 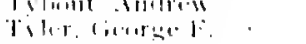 & $5 \overline{5} 20$ \\
\hline $1-45$ & 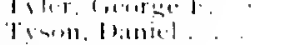 & $2511 \times 1$ \\
\hline 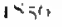 & 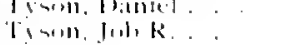 & $1+x)(x 1$ \\
\hline$|x|+\mid$ & T. & $|x| x \mid$ \\
\hline & U & \\
\hline $1-\left(x_{1}\right.$ & I ther, Ilstalkatul & $301,2+1$ \\
\hline & V & \\
\hline inn: & Valentine, John K & 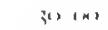 \\
\hline 14511 & Vellogitile, llim $\rightarrow$ li & $2, x+m, 1$ \\
\hline $1-1,1$ & lianslerus. Julun & $2+1,2$ \\
\hline 17511 & 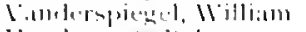 & $t=3.3$ \\
\hline $1 \times 51$ & Vinderet S Kulturn & $|\| x| \ln \mid$ \\
\hline Ini, & Vindyki, 10. M l1. & $31+101$ \\
\hline $1-6+1$ & Viase lenlurme & 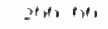 \\
\hline $1,-5$ & 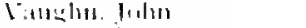 & 21,7 \\
\hline $145 \overline{5}$ & $1.411, F 11 / .111$ & $2, x+1 x$, \\
\hline $1 \times 2+3$ & $1311 x, 130+90^{\circ}$ & 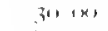 \\
\hline 1250 & 101118,$1 ; 0.10^{2}=0^{\circ}$ & $\left(x_{1}\right)\left(N_{3}\right.$ \\
\hline $14(1)$ & 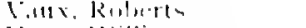 & 计 \\
\hline 14511 & $1.111 \times 11$ illi.m $=$ & $55(x)$ \\
\hline $1 \times 10$ & $1.111 \times .11111 .1 m$, & $|(x)| n \mid$ \\
\hline 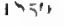 & 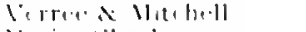 & (ren) in: \\
\hline 1450 & lezin, ("h.trles & $|M| I N \mid$ \\
\hline $1,(N)$ & Vorars. Milliam & in ind \\
\hline M-a & vizaril. Istullia & $2511 \mathrm{~N} 1$ \\
\hline $17=2$ & lin l'lsu's. Milli.um & $2 n+5$ \\
\hline
\end{tabular}

II

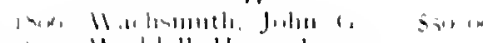

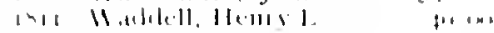

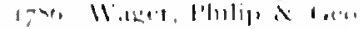
II.Ili.t k.t.

i i i

-11 19

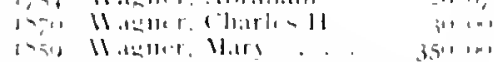

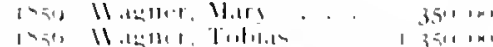

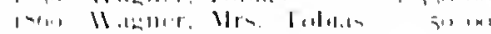

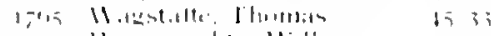

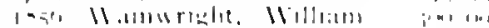

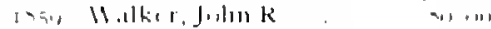

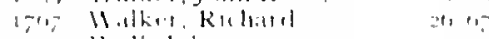

$1-11.11$, J1, 111

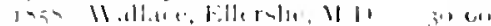

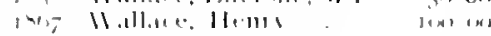

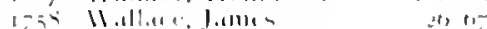

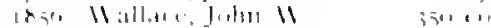

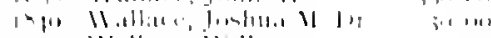

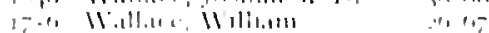

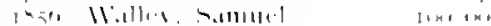

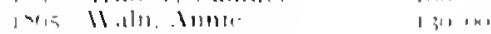

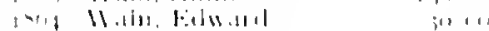

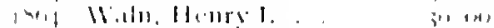

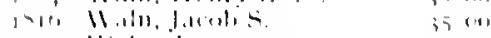

1, the 11.111, 11.2ne

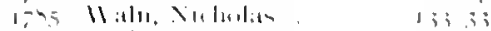

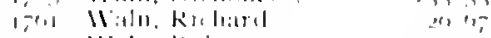

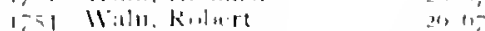

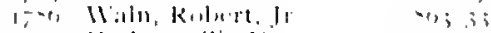

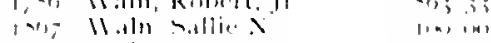

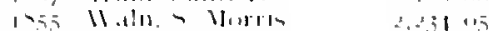

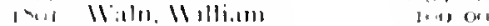

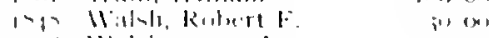

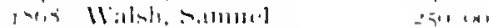

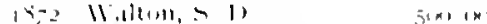

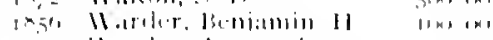

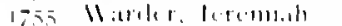

$1,-2$ M.erle.r, leremiall, Ir $\quad 32=3$

inis llamber Jeremioh. Ir in in

a

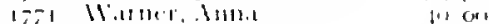

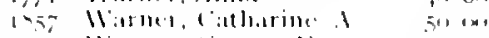

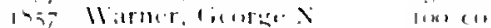

1xis ll.trmer, llatried

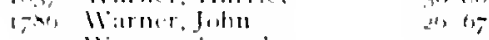

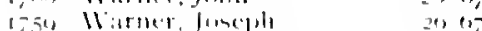

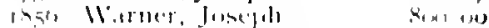

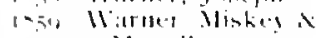

Merill

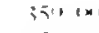

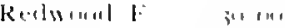

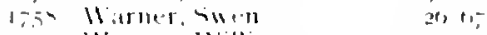

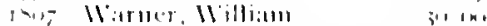

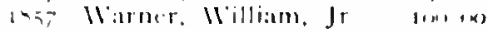

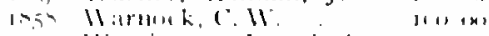

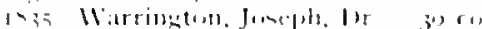

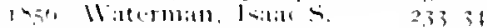

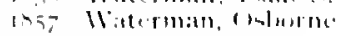
i.

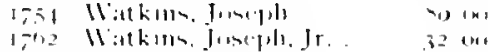

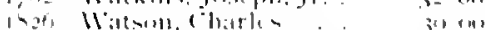

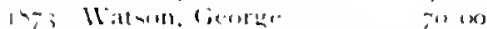

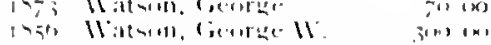

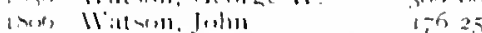

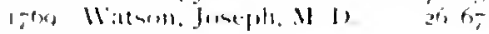




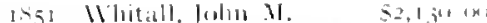

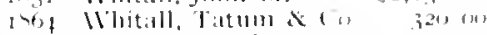

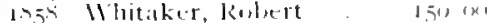

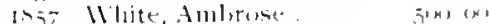

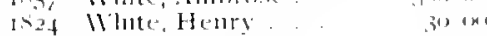
$175+$ White, Jallo, 3327

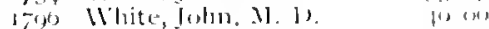

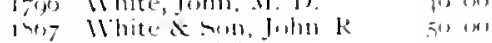

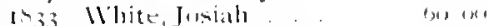

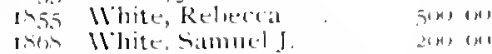

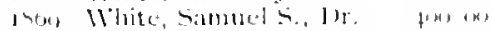

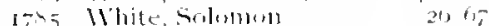

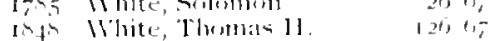

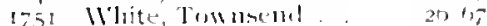
1457 Nhite, W'illiam $k$. \$125 im

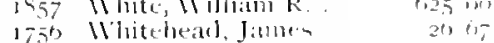

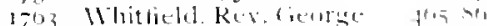

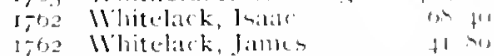

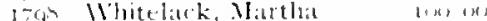

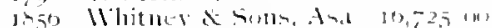

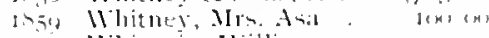
1775 Whitpatil, Milliall on (m)

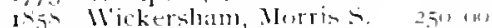

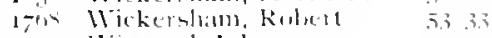

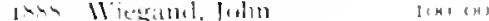
1.5t llicr, John. 20 $\mathrm{t}^{-}$

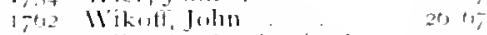

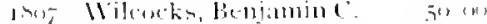
1,02 Nilcucks, Juhn . 433

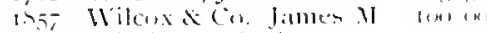
1,5.t Nilkinsill, Antlumb 20 n-

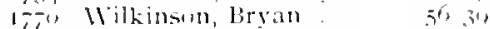

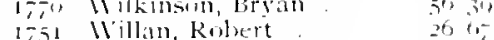

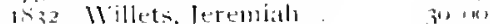

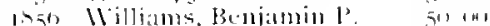

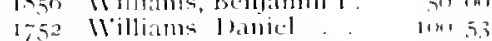

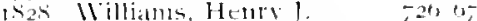
litos Villiams. Horace, I) 31 ,

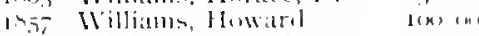

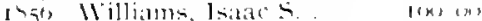

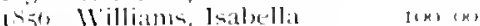

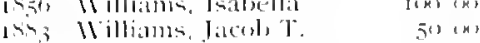

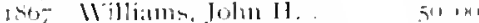

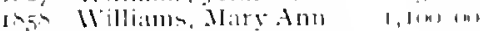

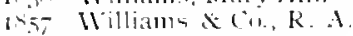
¿ I int llilliams, samutel. 20,

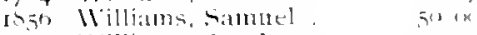

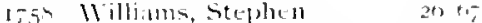

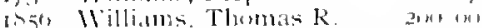

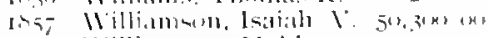

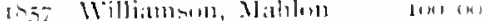

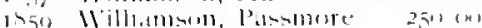

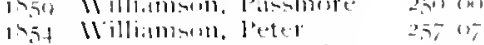

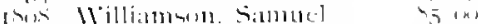

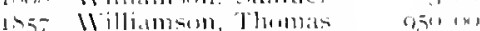

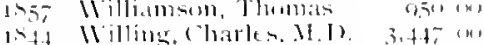
$1^{-5}$ Willime. Richarel 27 fer

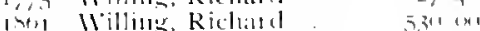

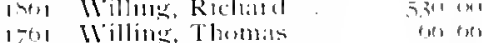

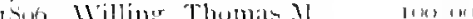

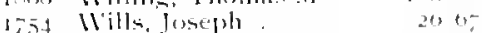

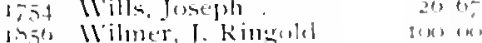

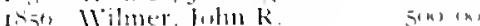
i, - ht, Wilmer, I,imbert. 2000 


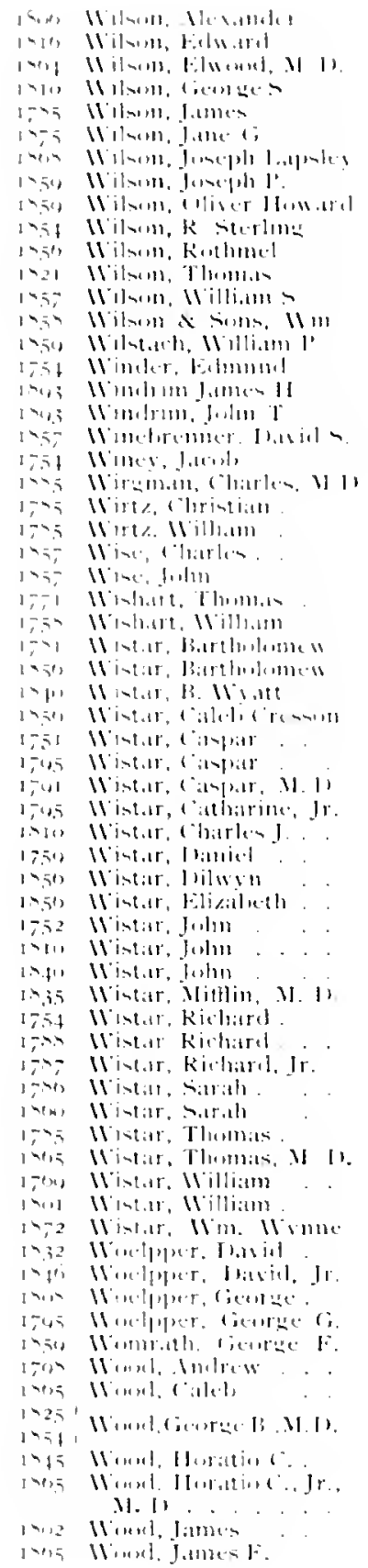

\begin{tabular}{|c|c|c|c|c|c|}
\hline$\because$ & 0.1 & $1 ; \div ; 1$ & l.nnl. J,1n & $s_{20}$ & 07 \\
\hline fo' & $(n)$ & Ints & linul, Jutunls. & .56 & In: \\
\hline in & $|n|$ & -51 & [and Joneple & 213 & 07 \\
\hline i" & an! & tins & limul $x$ l'tent. & $3.5 n$ & $(x)$ \\
\hline 26 & $n$ & 45 & linel. kielusullo. & $1,3,313$ & $s n$ \\
\hline $5 \times 1$ & in, & $\therefore 1$ & 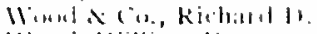 & lin: & $(n)$ \\
\hline 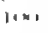 & $(m)$ & 1,5 & $\therefore$ and. II illioun l:. & 511 & $m$ \\
\hline 1.54 & (n) & 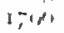 & dliollant, Jatllien, Jir. & $\lim$ & $m$ \\
\hline$i+1$ & $|n|$ & (E) & 1. Mill.1m & $(A)$ & $\ldots$ \\
\hline$\because$ & (n) & 5 & 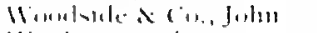 & $(1, n)$ & $(n)$ \\
\hline 5in & $|m|$ & $\because i_{1}$ & lindes, stophen. & $t^{4}$ & $(x)$ \\
\hline 511 & $|x|$ & $\because i$ & Vindiner, Joilun & 27 & 24 \\
\hline$\because \cdots !$ & $(n)$ & ani. & linkt. Mlicinch $\therefore$ in. & $1+x$, & (n) \\
\hline$\cdots \cdots$ & $|n|$ & (n) & linkmon, in foulary & & \\
\hline 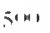 & $(x)$ & & or cisk, Hoiprer & & \\
\hline$\because$ & $15 ;$ & & 1.1:11 $\%$ & .5 & al \\
\hline Sind & $|n|$ & a 51 & Q11. M11x+rt & $2(x)$ & $m$, \\
\hline Sוn & in & $9: 5$ & 1. Julın K. & in & $1 \times 1$ \\
\hline 125 & in, & 51 & $11.1 \cdot 1 \cdot 1 \cdot r$ & $\therefore$ & $\therefore+1$ \\
\hline 12 & 1,5 & 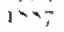 & 1. Frome in Jimute & 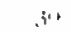 & $\ldots 1$ \\
\hline i' & in! & eni & hinglun lfonds k. & $\ddot{z}(n)$ & $4 n$ \\
\hline 24 & $1 \%$ & $\cdots 1$ & lit, lindu.url 11 & $5{ }^{\prime \prime}$ & an, \\
\hline $2^{\prime \prime}$ & 45 & 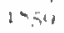 & 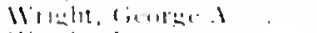 & $5 \cdot 1$ & $(x)$ \\
\hline$i^{\prime \prime}$ & in. & $\because 2$ & IIrelat, Itames & $5, i$ & i i \\
\hline y. & (n) & 51 & 111.1 .13111 .9 .1 & $51 \cdots$ & $(m)$ \\
\hline 21 & $1 \%$ & $5-$ & lit, Julun & $5 \times 1$ & 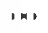 \\
\hline 51 & $\cdots$ & +7 & lu, k. $\therefore 1 ; .1$. & is, & en \\
\hline in & $1 \%$ & (iis & $1,1, \mathrm{Ki}, \mathrm{l}, \mathrm{n}+\mathrm{l}$ & $\therefore 5$ & in \\
\hline 21, & 1,5 & (1) & lat, S.11+utsel. & $\therefore 1$ & in' \\
\hline 27 & $|x|$ & nin & er, fiturges & 15 & 21 \\
\hline 20 & 1.7 & ; & 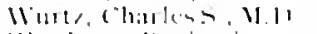 & 21.5 & Im \\
\hline 201 & $A_{1}$ & 72 & 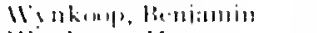 & in' & $(x)$ \\
\hline $1, \mathrm{ml}$ & 1,1 & $\therefore 1$ & ikuni, Henty & in & 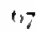 \\
\hline 21, & pis & $a, ;$ & $11 \div 1 \ldots$ & 125 & eni \\
\hline $14 \times 1$ & $|x|$ & -2 & II.k.k. . . . & 1911 & $(m)$ \\
\hline in' & $(n)$ & 72 & M. K. & 34 & InI \\
\hline $5 ;$ & .3 .3 & & & & \\
\hline $2 t$ & 15 & & j & & \\
\hline lans & $|N|$ & & & & \\
\hline 53 & $i 3$ & 50 & 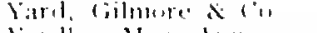 & $24 x$, & $(x)$ \\
\hline in & inl & 5 & ley, Mlays Ann & in & $(x)$ \\
\hline 27 & $|x|$ & $i$ & 11. Benilumin $\mid$. & $3 "$ & $(x)$ \\
\hline 2311 & $|n|$ & , in & 1. 6 "liturlin & $5 \times 4$ & $\ln 1$ \\
\hline 71 & 1.5 & in! & $1 \times(i n) \mid x)$ & sin & $(x)$ \\
\hline 26 & $\because 7$ & & all, fatanart & $I,(A M)$ & An \\
\hline 32 & $\because$ & $\therefore 5$ & All. Isllin. & $I(w)$ & $(x)$ \\
\hline 3211 & $(x)$ & in & 11! Jillis : & mini & $(x)$ \\
\hline lan, & $m$ & 5.5 & all, Frameio. & 26 & 07 \\
\hline $2 \prime$ & 1,7 & in & Younall, Howaral. & 50 & $(4)$ \\
\hline in & $i_{1}$ & -1 & leter, II, 11. & 27 & $\hat{3} ;$ \\
\hline $3, \cdots$ & $\cdots$ & is & an. Nilliam 11 . & $|\cdots|$ & $(x)$ \\
\hline 1.5 & $=18$ & $1-56$ & jisk, Tlumbis & 34 & 12 \\
\hline in & $\ln 1$ & 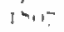 & liurke. sommer & in & $(x)$ \\
\hline 111 & .11 & (i) & 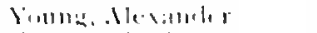 & InA & $(x)$ \\
\hline 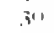 & 01 & 50 & Chates & $1: 3$ & $i i$ \\
\hline$\because "$ & InI & $+i$ & 145 & $\cdots \cdots$ & ins \\
\hline 51 & enter & 5 & IVilli,utn & 96 & $(M)$ \\
\hline 250 & 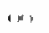 & 5 & I․ Milliam I. . & 34 & $(m)$ \\
\hline 1211 & (n) & & & & \\
\hline 3 & $n_{1}$, & & $\%$ & & \\
\hline & & ${ }^{\prime}$ & $1.1+101,311$ & -1, & $(n)$ \\
\hline & & 5 & $-1111^{\circ}$. & f" & an. \\
\hline & & 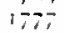 & yi. & $1 i i$ & .33 \\
\hline ו' & In) & $3: 51$ & $\because$ Junathan, & $2 \%$ & $i, 7$ \\
\hline .31 & 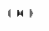 & 17,51 & Z.1ne, Nithhan & $2 t_{3}$ & 67 \\
\hline (11: & 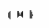 & $1,-1,2$ & \%ane' Milliam & 54 & in. \\
\hline
\end{tabular}


CONTRIBUTIONS FROM ASSOCIATIONS, CORPORATIONS, ETC. Annerciatrons.

\begin{tabular}{|c|c|c|c|c|c|c|c|c|c|c|c|c|c|}
\hline$=0,1$ & ic Refining ( $\because .$. & . & . $\cdot$ & - . & - & & & & - & & & & 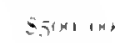 \\
\hline+34 & Phomix iron ( & 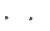 & . . & & & & & & & & . & & $250(x)$ \\
\hline 6.5 & Sanitary Commissikn & . & - & . & - & . & . & & . & . & & & $3.1 \mathrm{HAS}(\mathrm{CH}$ \\
\hline 14 & $\begin{array}{l}\text { Schuylkill Navigittum Cu. } \\
\text { Baxks. }\end{array}$ & . & . . & . & . & . & . & & . & . & & . & $3^{(x)}(x)$ \\
\hline 14 & City National . . . . & 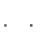 & . & . . & & . & & & . & . & . & & $\mid(x)(x)$ \\
\hline 134 & First National $\ldots$ & . . & . & . . & . & . & & - . & . & . & . & & $5(x)(x)$ \\
\hline 14 & P'enn National . . . . . & . & . & 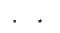 & & . & . & & & . & & & $f(x), x)$ \\
\hline 7.4 & Philadelphia,$\ldots . .$. & . . & . & . & 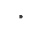 & . & & . . & . & . . & . & & $1,(n x)(n)$ \\
\hline 89 & 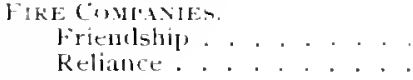 & . & $\dot{.}$ & $\dot{.}$ & & $\dot{.}$ & : & $\therefore$ & & & & . & $\begin{array}{l}2607 \\
2 \times 3 \times 3\end{array}$ \\
\hline$\because$ & C̈nion ..... & ( & & . & . & & & & . & & & & 133 \\
\hline$r, 4$ & 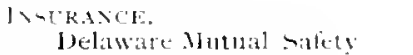 & & & . & 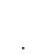 & . & & & & . & & & $1,(x+1)(x)$ \\
\hline $19+1$ & Mntual Ansurance. & . & . & & & & & & & & & & $(2,(4 x)\{x$, \\
\hline+4 & Yutual Life & & & & & & & & & . & & & $5(n)(n)$ \\
\hline m & Sintle America & & & & & & & & & & . & . & $\{,(\times n)(n)$ \\
\hline$*-\frac{-}{4}$ & l'hiladelphia $($ antributionshi & & & . & & & & & & & . & ${ }^{\circ}$ & $5,1 \times n,(n)$ \\
\hline$=7$ & 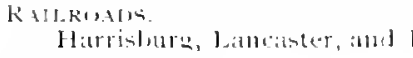 & & & intitis & & & & & & & . & & $5 x+4 x$ \\
\hline $\begin{array}{ll}0+1 \\
-1 \\
-1\end{array}$ & Lethigh Valley . . & . & & . & . & . & . & & & & . & & $2,51 x_{1}+\mathrm{H}_{\mathrm{n}}$ \\
\hline 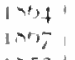 & Pennsylrania . . & $\cdot$ & & & & & . & & & & & & $1,5, x \times 1 \times(k)$ \\
\hline $\begin{array}{l}521 \\
11\end{array}$ & Philadel phia and keadims & & & & & & & & & . & & & $17,(x) 1 A_{3}$ \\
\hline 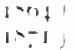 & Philadelphia, Wihminutur, al & [11] 1 & lialti & immir & & . & & . & . & . & & & $6,2(x)(x)$ \\
\hline 1,2 & $\begin{array}{l}\text { Fom } \\
\text { Xighldletionn }\end{array}$ & & & & & & & . & & & & & $1.518 \mathrm{ln}$ \\
\hline 4 & Nontmeal & . & . & . & . & & & & & & & & is ins \\
\hline 2 & dence. . . & . . & & . . & & & & & & & & & 1373 \\
\hline 55 & Thornbury . . . . . & & & 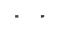 & & & & & & & & & 2507 \\
\hline $5 \overline{2}$ & 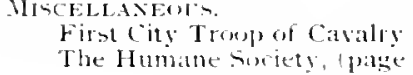 & $\begin{array}{ll}01 \\
021\end{array}$ & & & & & & & & 3 & & & $\begin{array}{l}6 .+1(\mu)(11) \\
22.47 \\
214\end{array}$ \\
\hline
\end{tabular}

FREE BEUS IN PERPETUITY.

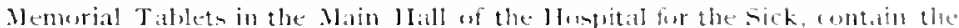
following list of nomes of persoms tor whom beds batre been established :-

JUH BARH

ALEXANIUER BENSIN

WIIS JE. BET\%

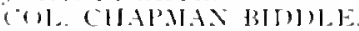

ELIZABETH BINYE'

IIURAC BJNNES.

WARIA E. BLAS(HARI)

(IIILIAY A BLANCHAKL

VIRYA A BTTISG

VIRY ('I.AYTIR

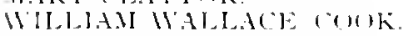

IIIARLES M. JEKLRT

WARWLK BAIIFILIE FREIMAX IFASE GIORGE

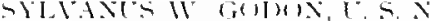

FLIZABETH SlORY IENKS

MILUJAM P'. JEAKS

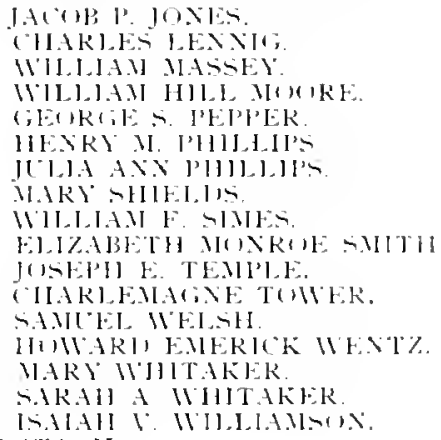

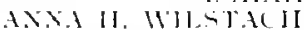




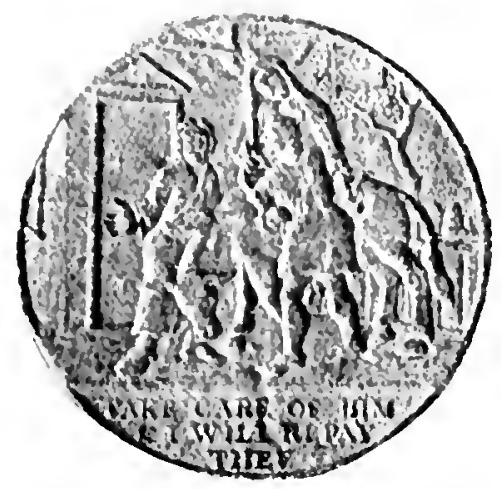

THE HOSPITAL AIMMINISTRAIION.

The hutury of the lennulvania Ilospital, an it has beend detalted in the carlier pages of this volume. consists in very large part of the acts and the achievements of the Managers, who are the representatives of the corproration of the Contributors in the administration of the affairs and government of the instimtion. Since the granting of the ('harter by the l'rovincial Guvernmemt in 175r, there has leeen a baholu constant succession of ative, carmest managers who have devoted $-91110,110$ their energies and their time to the welfare of the llospitat. So succesful and eltiont has leen their disinterested service that it has commanded universal commendation, both in this connty and in lingland, the home of the former propricturs of Pennsylvania. 'The verdict of the community has leeen well summed 12 in an addech dedivered by lor. fohn forsith Neign, a nember of the medical stafi. (n) the orrasion of the conchusion of the first frarter of the second

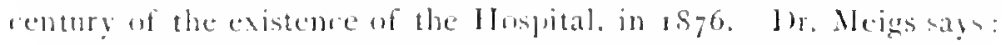

$1 / 1+11,1110$.

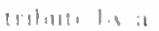
minlu: 1116. 11: ilical

$41.11 !$

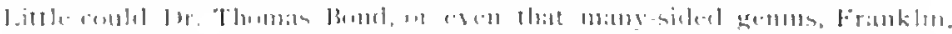

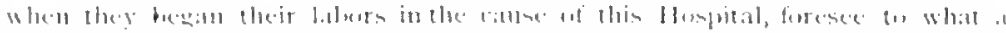

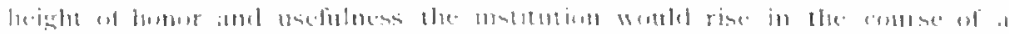

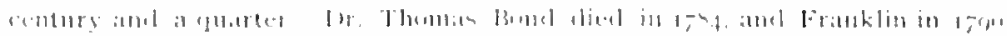

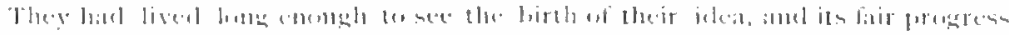

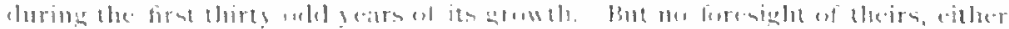

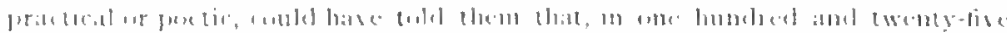

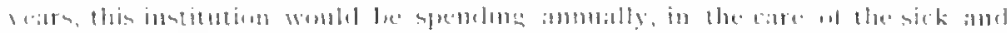

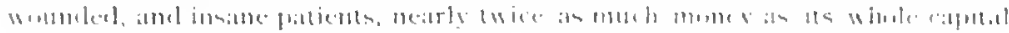
at the time of its follurlattan 


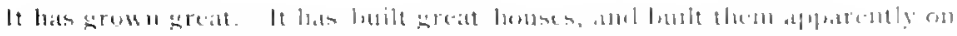

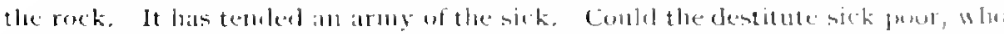

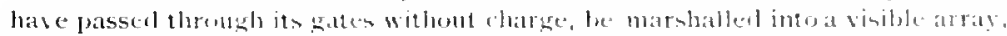

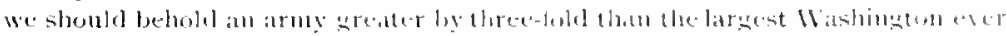

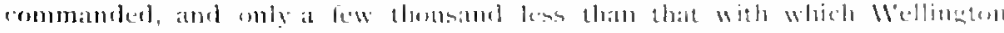

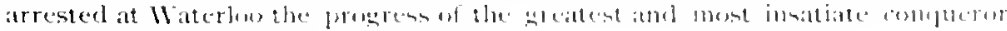
of the mollern worlal.

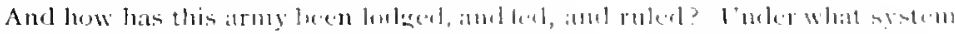

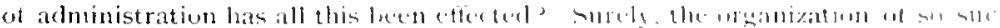
cessful a staff as this must ln. worth some stucly

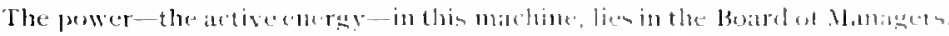

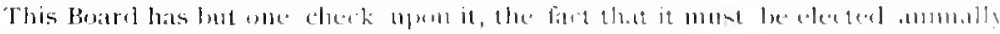

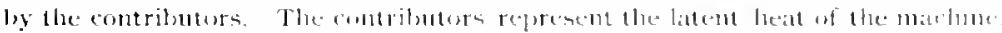

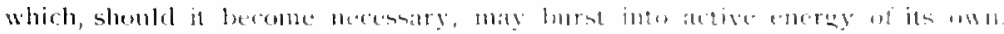

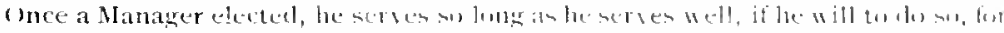

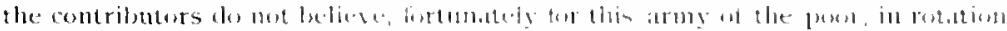

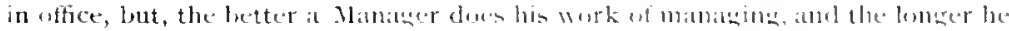

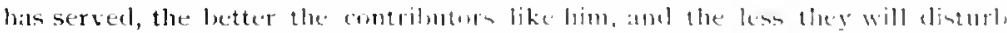

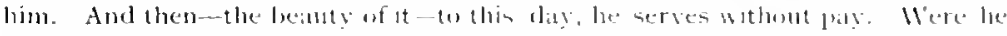

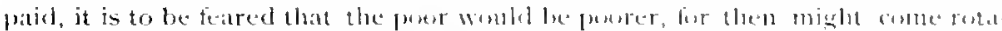

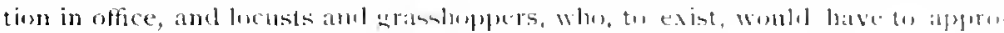
priate some of the groud things provited for the pour.

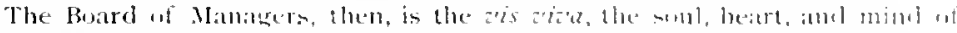

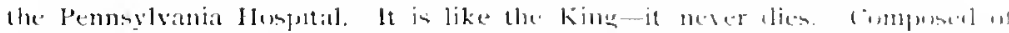

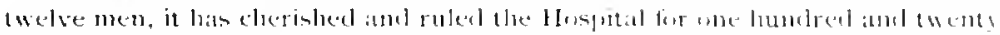
five years. It elects all the officers but the Treasurer. It collects and spende lhe money. It is responsible fir each and agery fatilure, and for every sucees

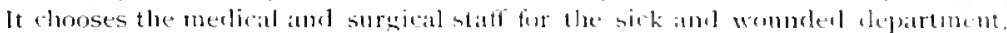

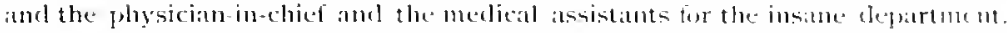

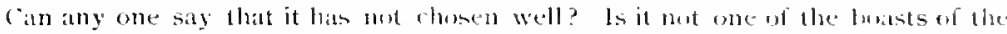
Ifospital, that it has always furnished to the purr, the bust medical atmel suratial

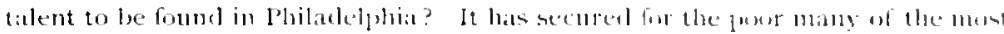

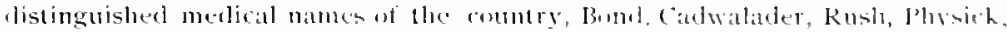

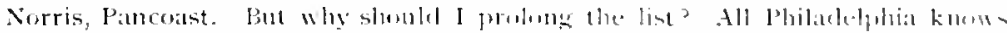

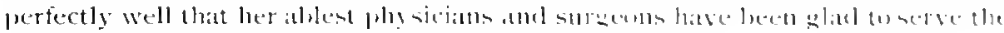
Pennsylyania Hospititl.

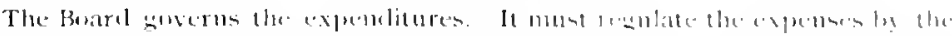

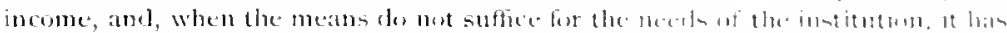

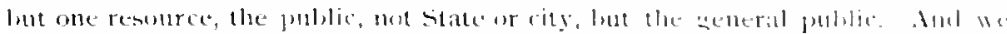

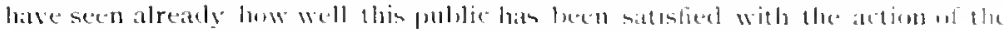

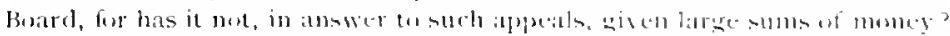

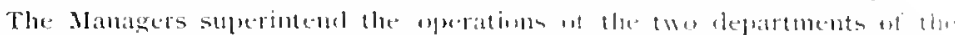

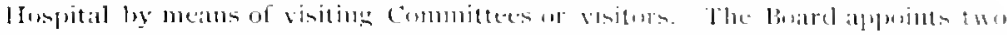

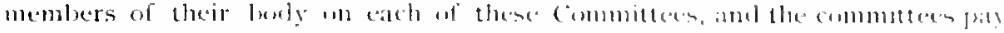

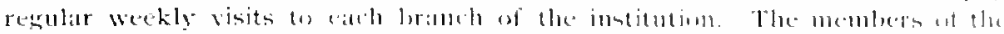

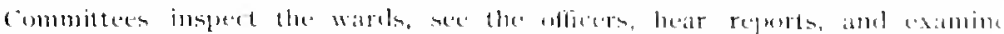

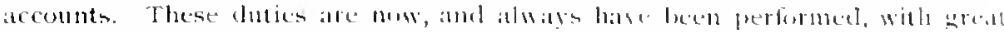

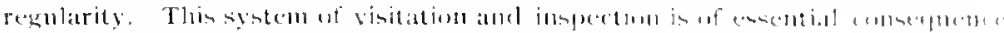

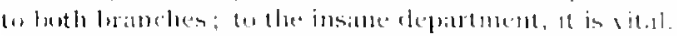

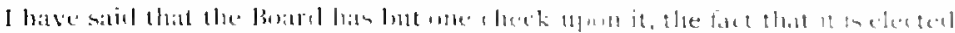

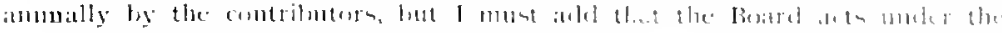

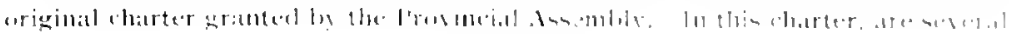

[)

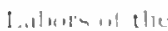
liirilinl 11.111 .1211 .10 


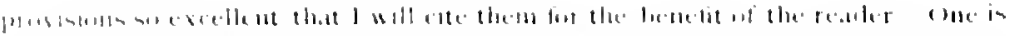

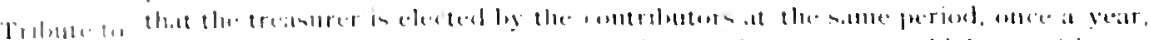

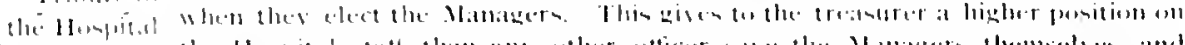

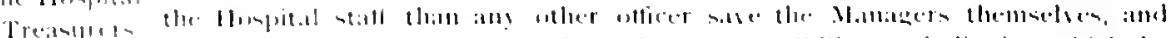

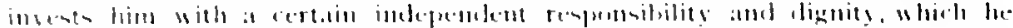

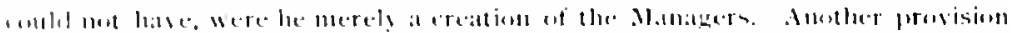

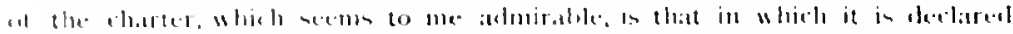

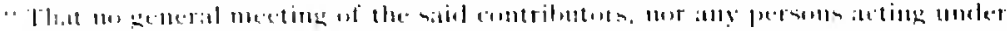

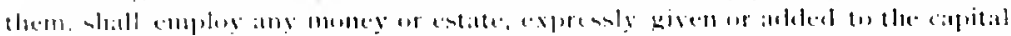

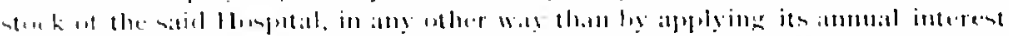

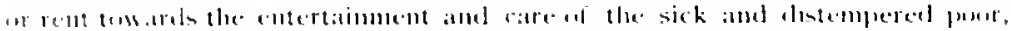

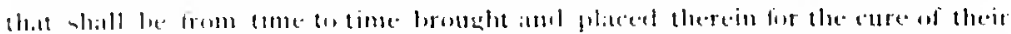

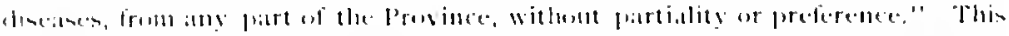

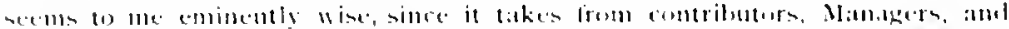

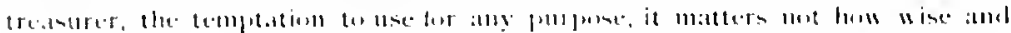

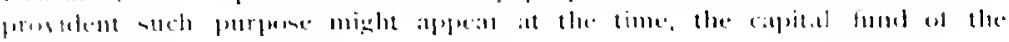
inntitutinilt.

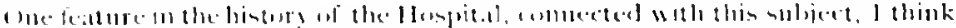

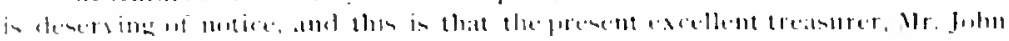

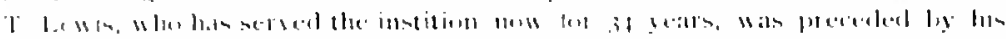

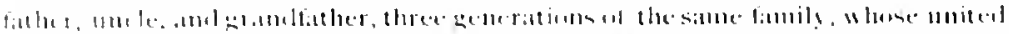

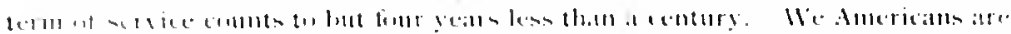

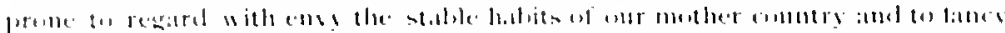

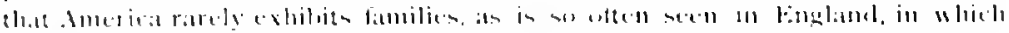

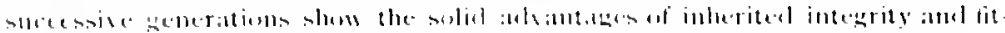

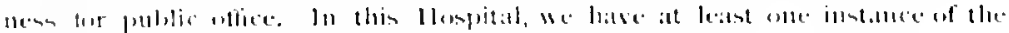

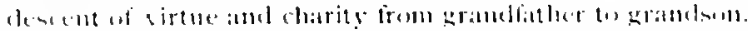

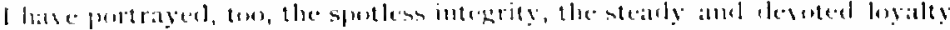

Jike l':1111 $31,1111.1$

llwistal in

d.enctilly

$.11113: 11$

andmumint $\cdot 1,01$

(liall 11

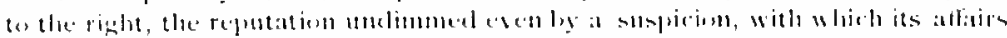

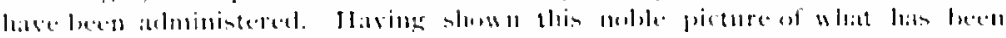

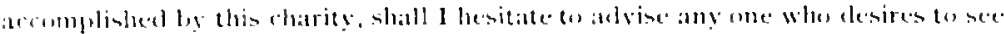

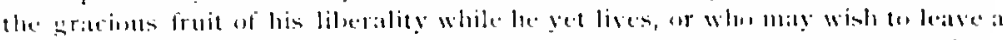

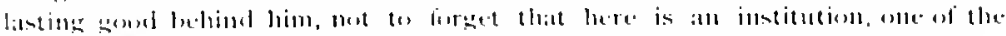

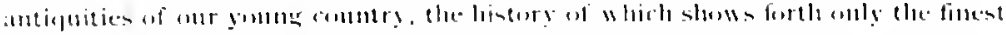
une's of tharity?

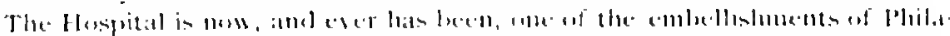

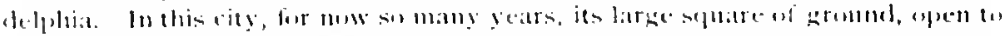

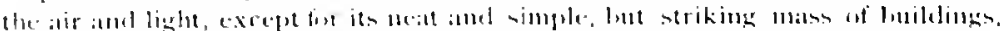

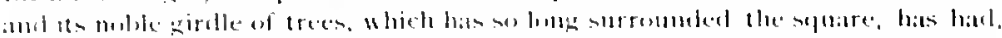

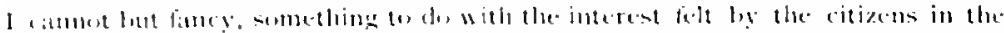

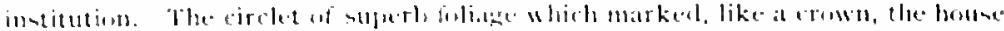

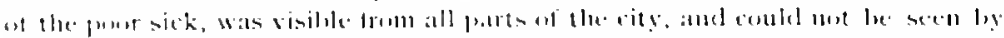

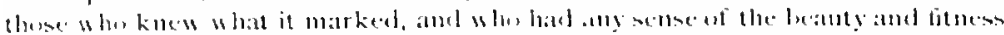

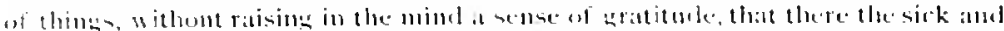

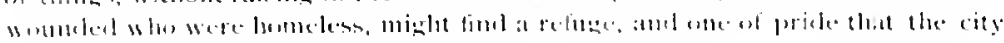

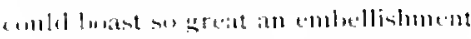

Umon reviewing the work of the Managers, it in probable that there may le many found who will echo the sentiment expressed by 1)r. Meigs in another part of the adrlews, which has just been so freely 'fueted. "hen be states that " Philadelphia is julified in the pride she takes in the management of thin Institution." 



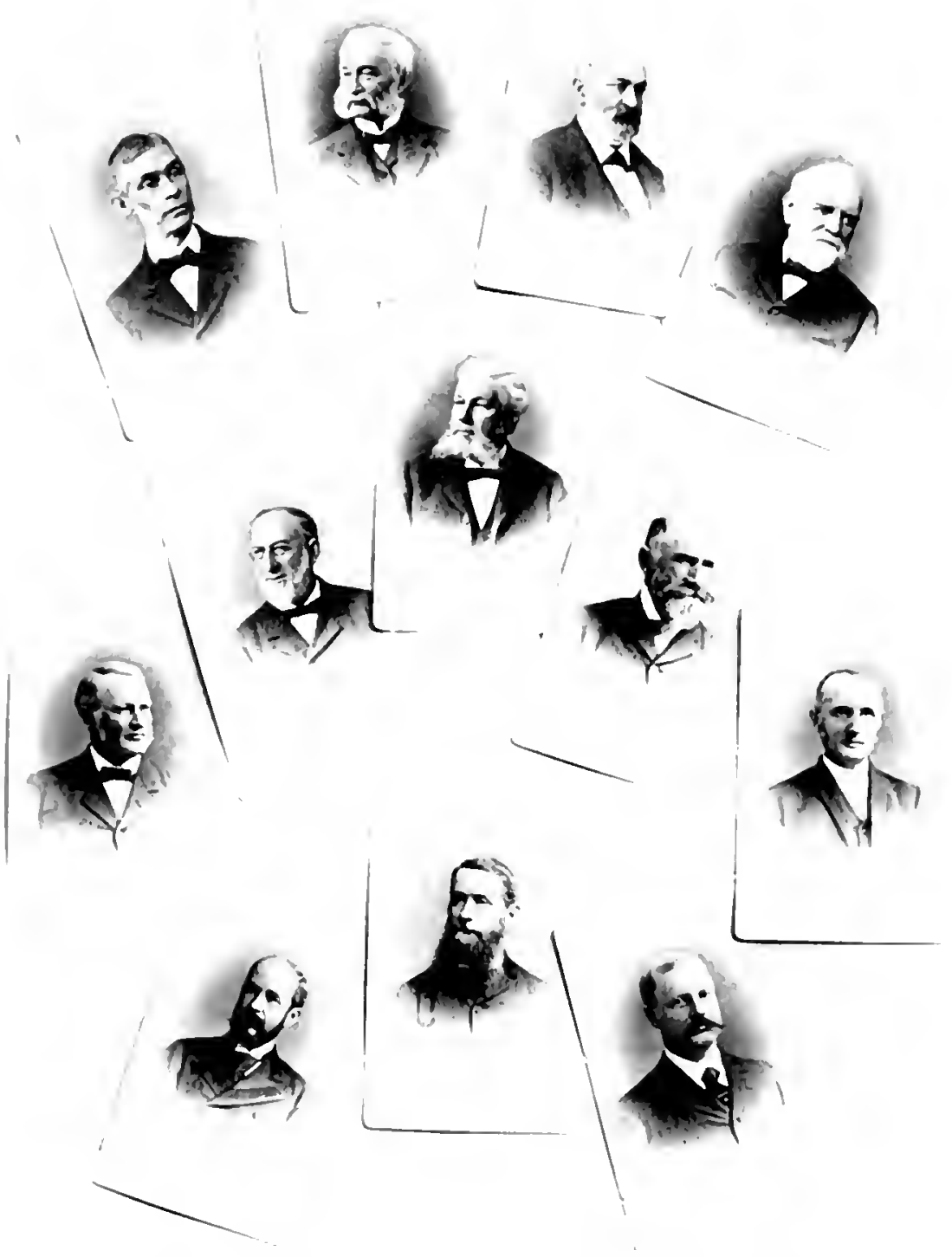


MANACERS OF THE PENISTLYANIA HOYHIA.

1751-13at.

\begin{tabular}{|c|c|c|c|c|c|c|c|}
\hline \multirow{2}{*}{\multicolumn{2}{|c|}{ Name }} & \multirow[t]{2}{*}{ Elected } & $\begin{array}{c}\text { Resigneet ot } \\
\text { Died }\end{array}$ & li & best ser & $\cdot d$ & \multirow[t]{2}{*}{ kemaths } \\
\hline & & & & $1 \cos x$ & Mo. & 11.15 & \\
\hline Barnes, Cormelius & & $1,-\infty 0$ & $(;, 4)$ & .3 & 4 & i) & \\
\hline Beneret, Authons. & & 1,5, & I一保 & $i$ & & & \\
\hline Bevan, Mattlew $1 .$. & & 1420 & 以及 & : & 11 & $\therefore 1$ & \\
\hline Jidule, Alexander. & & lish & $-\ldots$ & $\therefore$ & & & Present Mamatye? \\
\hline Biddle, Clenvent C. & & $18: 6$ & $I^{4}=511$ & c) & t. & $: 1$ & \\
\hline Biddle, John W. . & .. & $\ln 47$ & 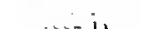 & $\cdot$ & 1 & . $\cdot$ & 'Present Mannger. \\
\hline $\begin{array}{l}\text { Biddle, Williatu } \\
\text { Bingham, William }\end{array}$ & & $\begin{array}{l}1=\{4 \\
1=-1,5\end{array}$ & $\begin{array}{l}\operatorname{lan}=11 \\
\operatorname{lin} k\end{array}$ & is & 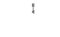 & $\therefore$ & \\
\hline Bond, Thomas, Dr. & & $17=1$ & $1,52 k$ & $\therefore$ & I & ; & Member of original Fondel. \\
\hline Rorle, Adolpli E. & . & 10,4 & Inthik $k$ & 4 & 3 & I & \\
\hline Erown. Frederick & . . & 141 & Inof I) & 22 & is & $2^{4}$ & \\
\hline Brown, Peter . . & & thos & 171011 & 5 & $:$ & 5 & \\
\hline Brown, T. Wistat. & & $17-2$ & & & $\cdot$ & & P'resell Malliger. \\
\hline Clark, Samuel & & $1,-48$ & $150 \geq 11$ & 11 & ; & i. & \\
\hline Coates, Samuel & . & 1,75 & $1425 K$ & sil & 4 & 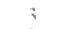 & \\
\hline Colluns, Zaccheus & . . & 1900 & $1422 k$ & 22 & & 1 & \\
\hline Cope, Caleb & . & 19तiा & $180>k$ & : & $=$ & 2 & \\
\hline Cope, Israel ". & · & 147 & I $24 k$ & $: i$ & $\therefore$ & 1 & \\
\hline Cope, Thomas 1'. - & - & 1hon & In以 & 14 & 2 & 24 & Lont at sea oll his returd \\
\hline Cox, Isaac . & & $17: 0$ & $172,+10$ & 5 & 4 & 24 & 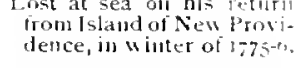 \\
\hline $\begin{array}{l}\text { Coxe, Tench } \\
\text { Crosby, Joshua }\end{array}$ & . & $\begin{array}{l}1,40 \\
1 ;=1\end{array}$ & 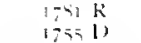 & 1 & $\therefore$ & 20 & \\
\hline $\begin{array}{l}\text { Crosby, Joshua } \\
\text { rosby, Thomas . }\end{array}$ & $\therefore$ & 1,55 & $\begin{array}{l}17551) \\
1 \div 5 \% \mathrm{~K}\end{array}$ & 3 & in & $\begin{array}{l}2+1 \\
2\end{array}$ & 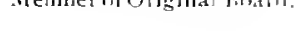 \\
\hline Dawson, Mortecail, & .. & $1 \times 44$ & $19-211$ & $2-$ & $1: \mathbf{i}$ & $s$ & \\
\hline Derhyshire, Alex. I. & & linj: & $14-4 !)$ & 24 & 10 & 20 & \\
\hline Dorsey. Johu & & $1 \% 4:$ & $1 \times 3 \mathrm{k}$ & $\div$ & - & $r$ & \\
\hline lbon Andrew. . & . & 17.3 & I和k & $=$ & & & \\
\hline Wuche, Jacob. . . & & 17,5 & $1-5 k$ & I & s & 24 & \\
\hline Dutu, Nathan & & 1535 & $1842 \mathrm{~K}$ & i & 11 & $\therefore$ & \\
\hline Elliott, lsaac. & & 1541 & $3+2 k$ & 1 & $=$ & 1 & \\
\hline Elmslie, Alex. & & Is 20 & $1 \times 27 \mathrm{k}$ & ; & & ? & \\
\hline Falloner, Nathaniel & & $I_{1}^{-2}=$ & $1,-8,3 \mathrm{R}$ & . & $n$ & - & \\
\hline & & 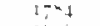 & $1: 40 \mathrm{~K}$ & $n$ & $\cdot$ & $\therefore$ & \\
\hline & & inth & $1<-21)$ & $2 n$ & ! & 1 & \\
\hline & & $\begin{array}{ll}1412 \\
10-2\end{array}$ & $\begin{array}{ll}141-31 \\
1=-6 & k\end{array}$ & $\frac{4}{1}$ & $"$ & $\therefore$ & \\
\hline $\begin{array}{l}\text { Fisher, Thomas } \\
\text { Fisher, William W. }\end{array}$ & & 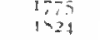 & $\begin{array}{l}1=-6 k \\
14341)\end{array}$ & 1 & 5 & $\therefore$ & \\
\hline & . & $1 \div ;$ & i $=50 \mathrm{k}$ & 2 & & 5 & \\
\hline Fline Villiam B. . & . . & 2511 & l $k=\mathrm{r}, \mathrm{k}$ & 14 & $1+$ & $\therefore$ & \\
\hline Fux, joseph . . & & $17 \overline{7} ;$ & isth $k$ & 2 & ; & 4 & \\
\hline Fox. Sambel M. & & 1704 & $1-47 \mathrm{R}$ & $=$ & 11 & $\stackrel{s}{1}$ & \\
\hline Frankhn, lienamin & & $1 ;-51$ & $1757 \mathrm{R}$ & 5 & 11 & : & 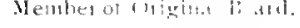 \\
\hline Franklin, Ihomals. & - . & $1-n o$ & $1 .-3 \mathrm{k}$ & ; & & 4 & \\
\hline Garsett, John B. . & & $\begin{array}{l}1<5 \\
3 \times 5\end{array}$ & ind $\mathrm{k}$ & 1 & ") & $\therefore 1$ & loestut Mathast: \\
\hline Gilson, John. . . & & $1 ; 0 ;$ & $1=1 k$ & 1 & & $\Sigma$ & \\
\hline Gillumgham, Jos $\mathrm{E}$. . & & $i=1, i$ & $1,70 \mathrm{R}$ & $=$ & '. & 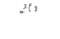 & l'seserth M.thing: \\
\hline Cinclom, Tlumas & & 1,55 & $1-\sin k$ & 4 & & 4 & \\
\hline Grant, Willatm & & 1754 & $1=\bar{a}$ - K & : & 11 & ; & \\
\hline tireenleat, is:anc & & 1750 & $17, k$ & $1=$ & & $\therefore$ & \\
\hline Greeros, Jis. R. & & $30 ; 3$ & $1 \times 3 k \mathrm{~K}$ & I & $\overline{7}$ & Is & \\
\hline
\end{tabular}




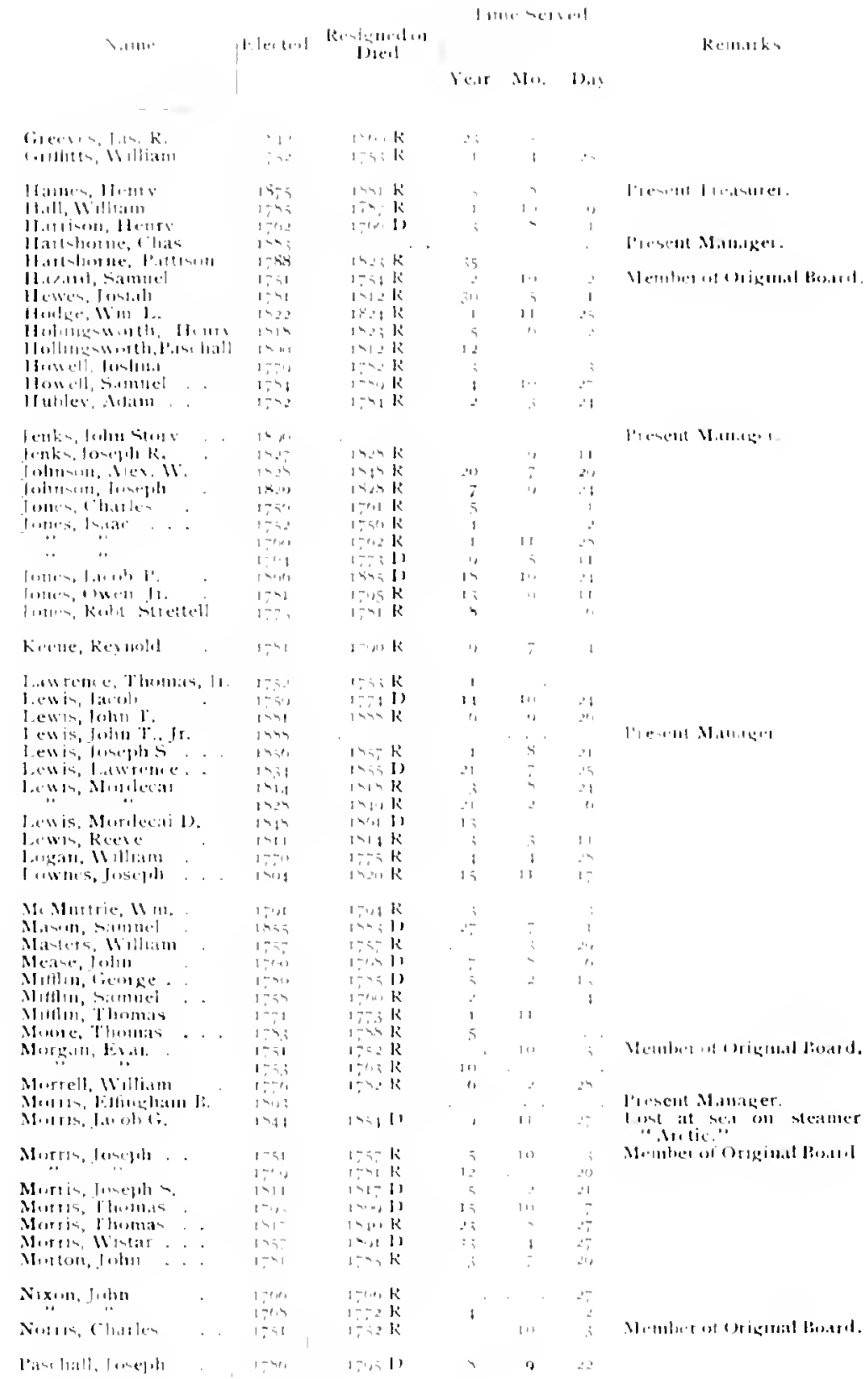




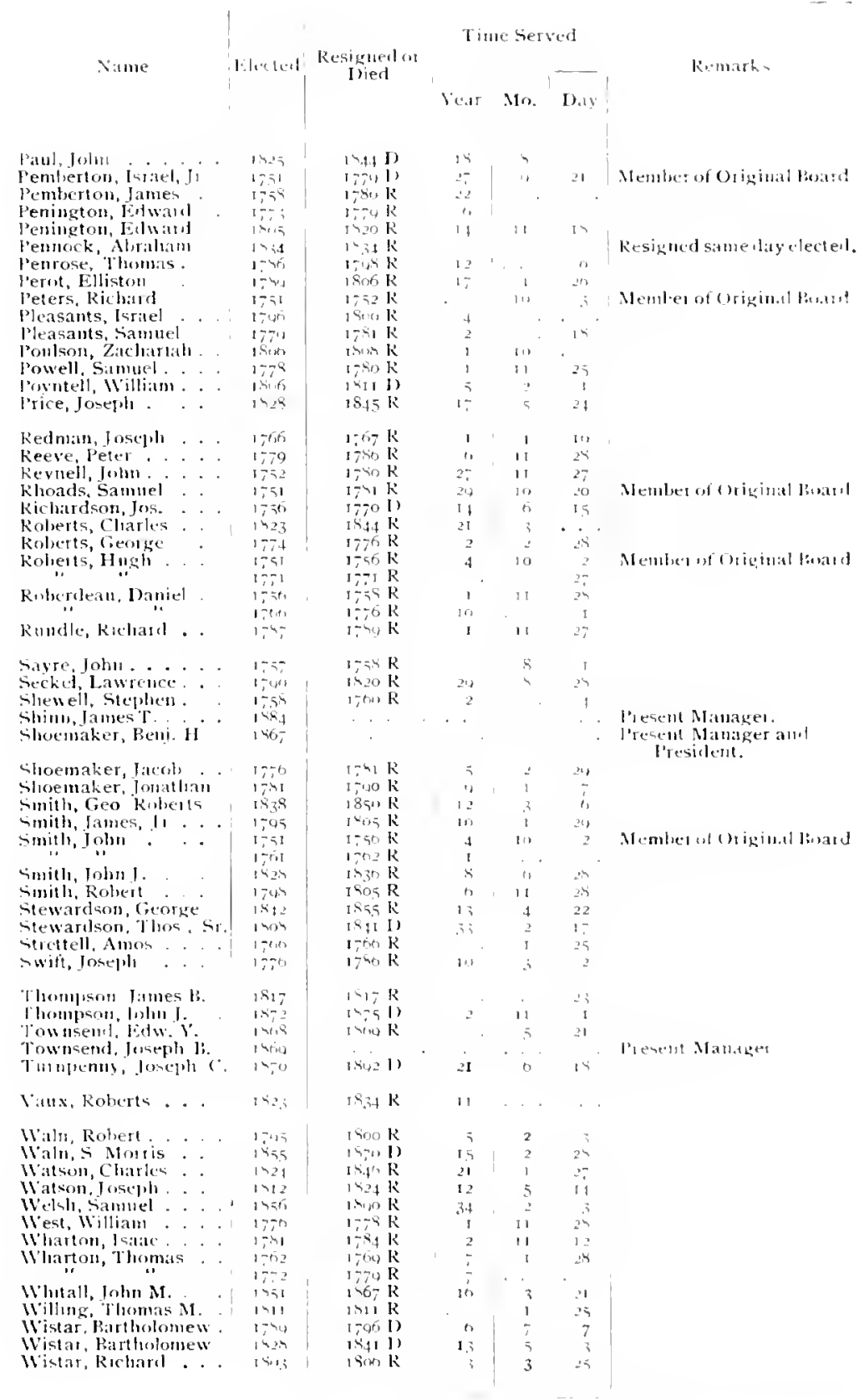


HRESIOENIS OI: IHE BOARI).

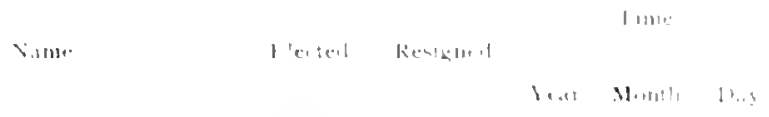

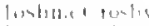

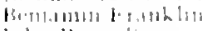

loht ken hell

Gimmel Rhouls

leter keer

Simuel Howel

kevmollal kian

Jomiall 11 e-wes

Sammels inde's

llumas siew andson, $S$

fohnt 1'.1!1

Mordet at Le wr

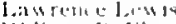

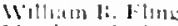

Monderall D. Manson

IVllham lindlle

Mestar Moris

Be-mamin 11 Shormake

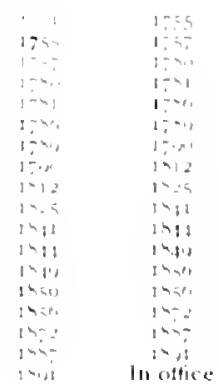

SECREIARIES OF THE BOARI).

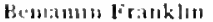

Jihli Stmith

isacic ireenteat.

James Pemberton

lhomas Mhtlin

George Koliets.

"linmas lisher

Roht. Sictetell Jone

lench coxe

Isaac lWhartoll

key mold kectle

Simuel coates

Thumas P. cope

Robelts Vaus

ihates kaberts

Bartholomew listar

George kollert Sibutl

Georde Stewiddson

William buddle.

Winter Mortic

Rew1. HI. Shremaker

I.nnes $\mathrm{T}$ - hamu.

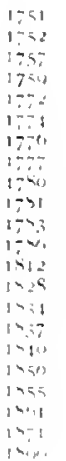

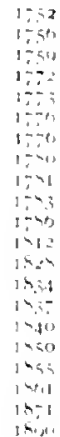

In

TREASURERS OF THE BOARH.

1.,13n Ke. Inell

Prarle Norris

llikh Roluet

Simmed P. Noore

Thermas Whate

Josel b hald

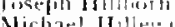

Michael IIlles

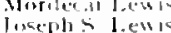

Joseph lews

jobn l' I.ews

Ilent Hatile
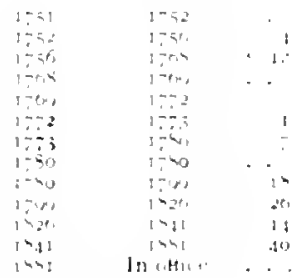


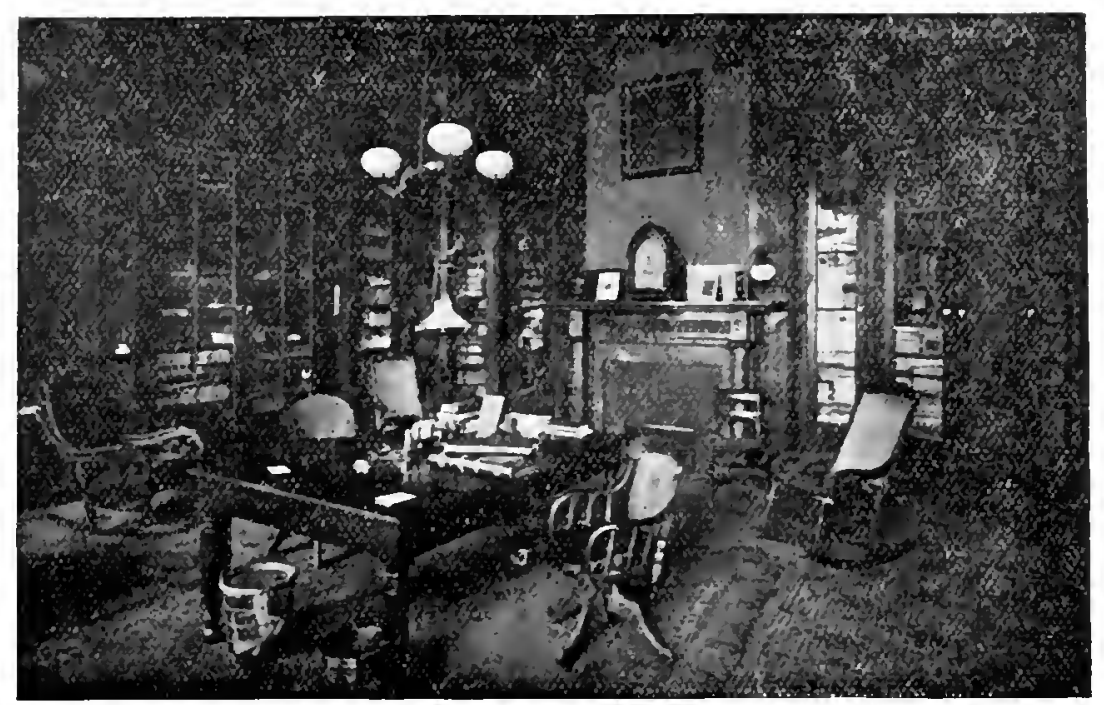

The Adminstration Office

\section{BIOGRAPHICAL SKETCHES OF FOR.MER MANAGERS.}

Jandla (crobsy wats elected at the lirst contrifuturs" meeting, foj and wats dibsen the first president of the Betard uf Nintigers. He elifed June 2-, I75. 11 e was a frominent merchant of l'liil isclephia and atcumblated a fortune: beeing of a humane, benevilem disposition, he gave fregutently alsil frecty during his lifetime an charitalble fur puses

(111 Mily 24. 175. He liall the cormer. stome of the Huspital sece pase so

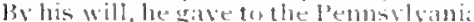
Herpital, one mombeel pounds. "for prometing of that laukbble dengen in the most useful mammer.

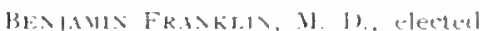
1,51 and resigneel 1,57. Among $11 \mathrm{se}$ unblic services of Frimblin there was none to whels lwe looked wits such satis faction ats his early slaceess in placine

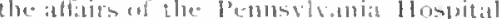

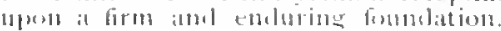
He was etert of the ariginal Buated of

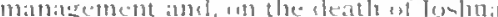
crestiv, woin elentlod d'resiclent, in which

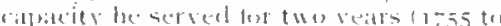
1550 . While in Eurolpe an pulplig busi thess, he still kept the interesto of the llompital in mind and atse his timb

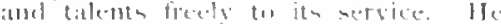

assisted 1)r. Fotherevill in ohtaining the

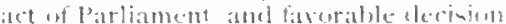
it the lond Chancellur of Fonglamel. Wy Whec the Hospital was marle the resieluary lesatee of the clefurtet Pertis. olvania lamel compang, and by which

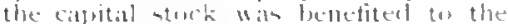

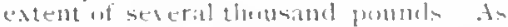
a menter of Assembly and afferuatots ato

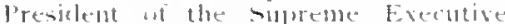
Comucil of Jemmels atuia, Franklin was able, through his wide aloguaintalue and

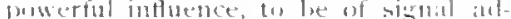
vantage to the Ihopital in matur waly.

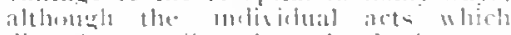
elirecty contributed to the furtherallese

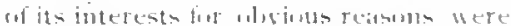
of fero inoment to the rising lontitution than lis indirent nervicen and 2/3e fricond. ship of one standing in stscle at hish lusition in the cosmonumity and casmmonts"lealth. 1"o to the time of his deats.

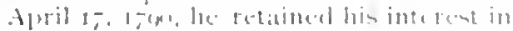
the Hesprital. Whith sween its esinfence laträly to him indrumentalits

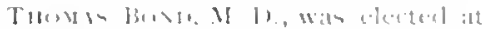

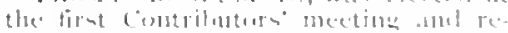

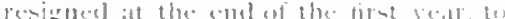

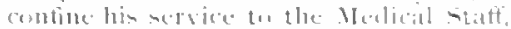

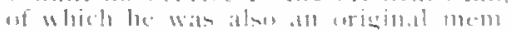

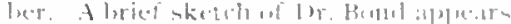




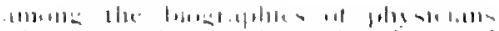

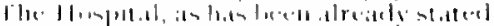

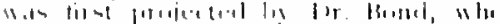

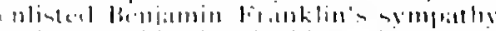

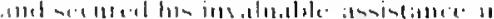

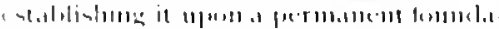
11111

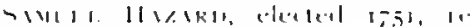

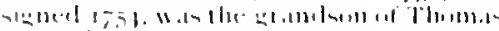

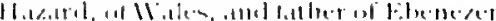

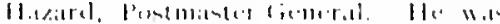

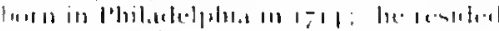

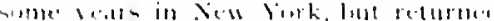

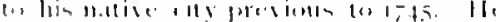

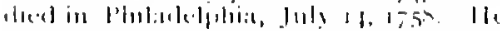

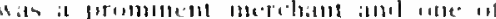

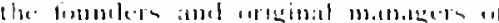

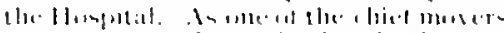

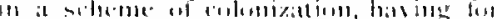

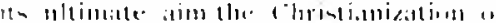

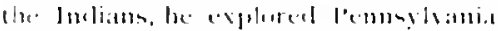

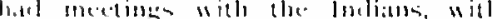

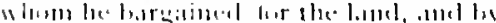

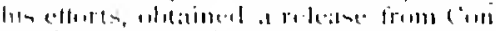

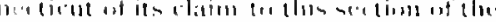
(1)umtry

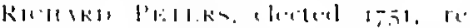

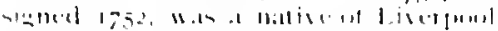

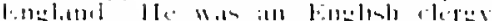

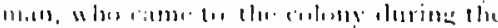

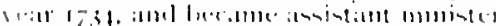

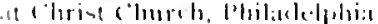

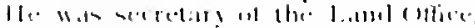

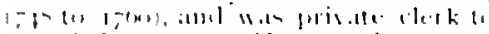

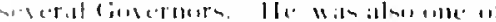

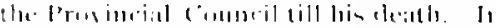

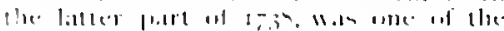
[11, I ", I)

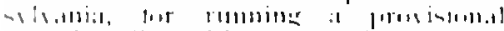

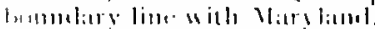

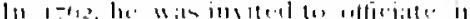

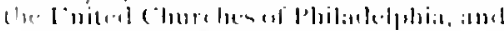

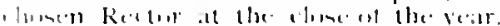

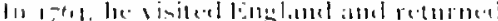

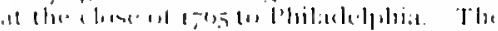

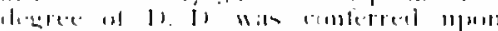

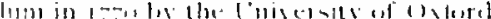

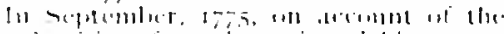

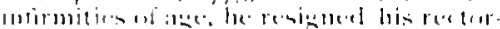

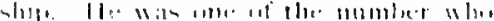
with Bentamin Fronklin, foumber the

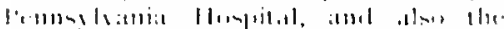

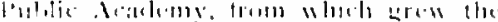

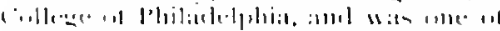

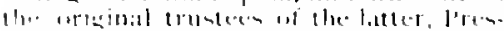

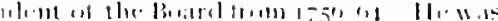

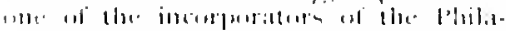
de.tphi.e I illuars

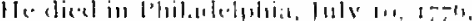

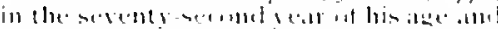

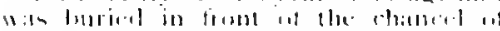
"lusine thureb.

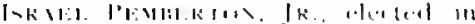
1,21, die. 1 in $1,-, 1$,

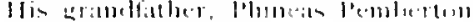

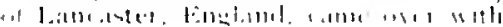

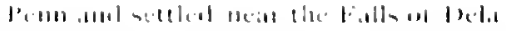
H. 1 re.

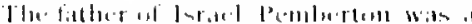

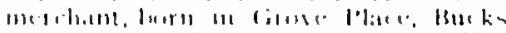

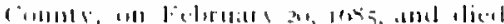

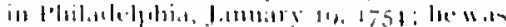

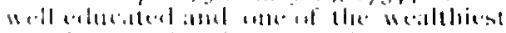

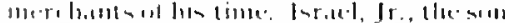

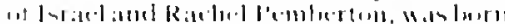

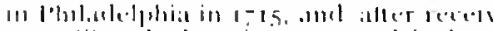

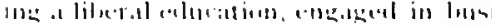

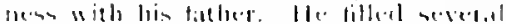

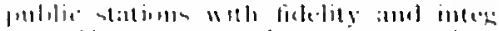

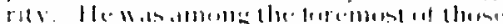

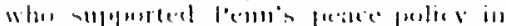

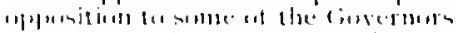

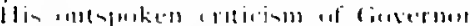

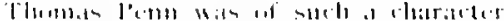

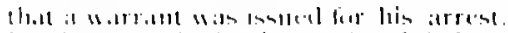

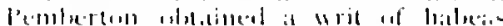

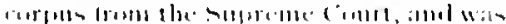

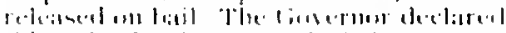

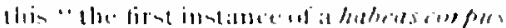

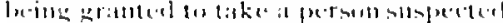

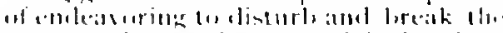

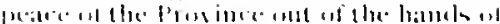

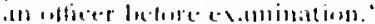

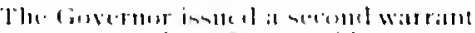

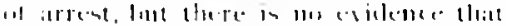

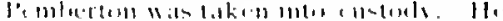

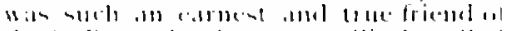

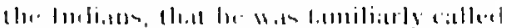
King W:เmpun.

lu

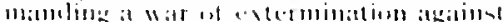

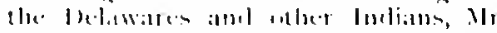

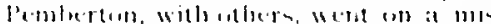

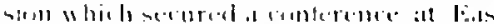

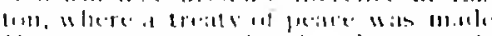

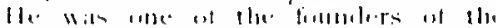

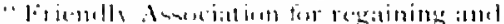

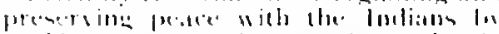

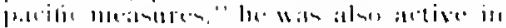

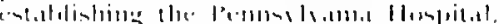

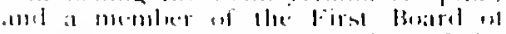

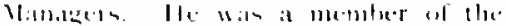

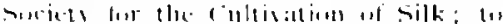

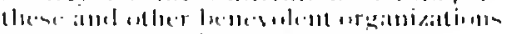
he entributed liberalls.

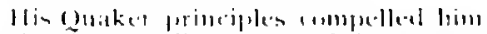

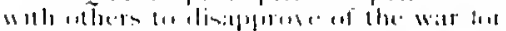

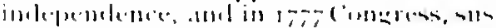

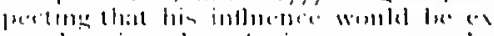

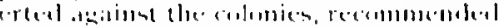

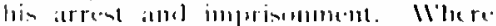

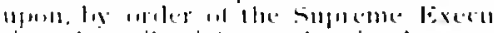

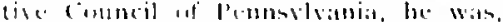

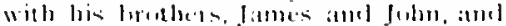

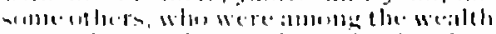
ient amel mume influemtial [eriemls al the

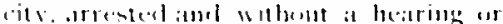
erial, selue lo statumtan, Vifuimia, anel re matimed there in evile is priseners for

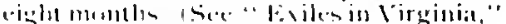

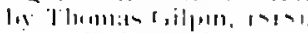

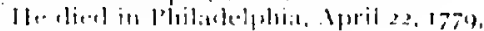

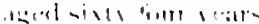




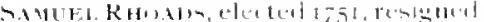

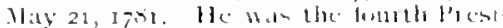

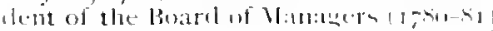

lis lather, Juhn Rlusule, allul granul

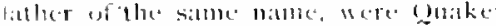

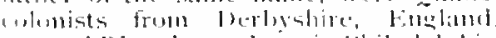

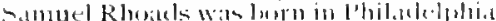
in 17 I

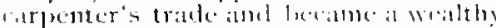

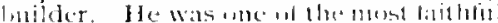
atod hated working of the members al the limard of Mlldagers. In betive acrice

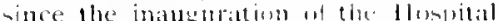

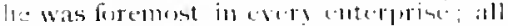

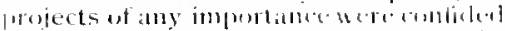

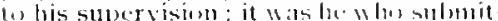

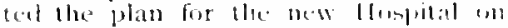

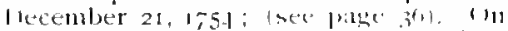

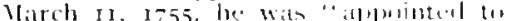
alperintend the new lublelind and pro

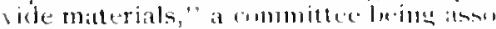

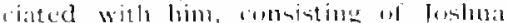

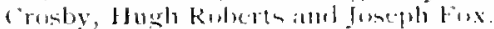

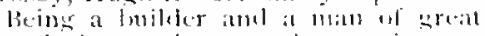
pratical experienece and aleduatutame

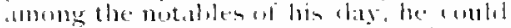
leetter accomplialy matteres relatimg in pulitical or aldministrative permits aml

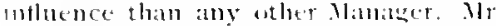

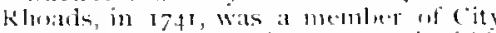
tinuncils: lust tleere is me reanded uf his lasing again helel wfice notil 1,el, "hen lue and Franklin we't chmen members af the Assembly, alsi, inain in 1-02-4,

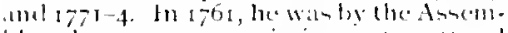
l, chosen a commosismoner to allemel

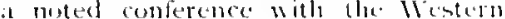
ludians, and the six Xattums at laturats

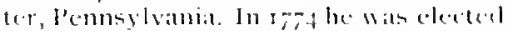

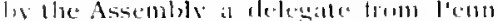
whantat to the Contincental finderest in

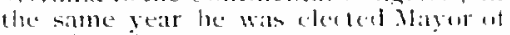
Philidelphia

$11 c^{\circ}$ wats ome of the eatrly memluets of

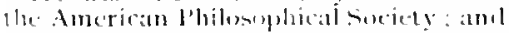
a birector for mant lears at the libilat ielphia library.

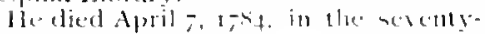
thirit vear of his ane.

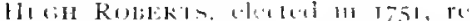

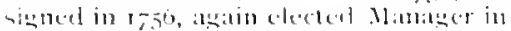
Wisy, 17, t, he resigneal the following momith, Junc 3,175

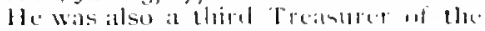
lbespital $(r-56101-0,4)$.

11. lived at "l'me sime" Ponthern

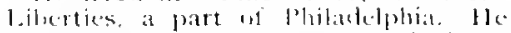

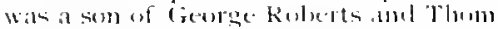

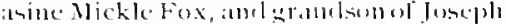

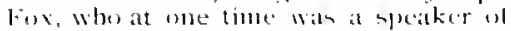
[he Asticmloly

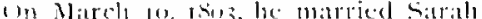

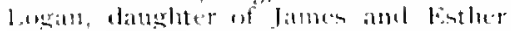

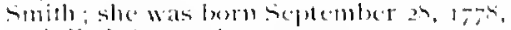

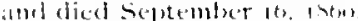

Hugl Rolects died Julle s.5, Inel, in

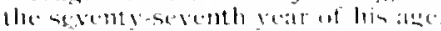

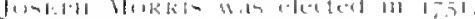

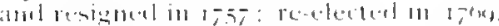
allel rominged 11:1!21,1,-1

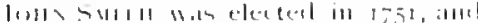

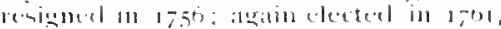

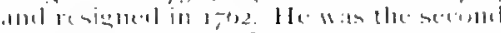

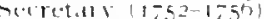

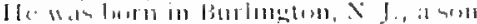

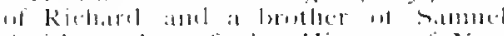

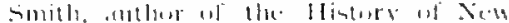

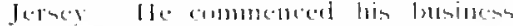

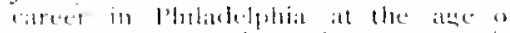

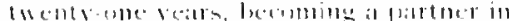

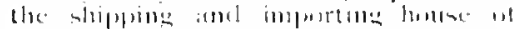
Alel lols

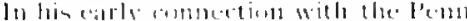

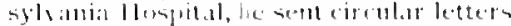

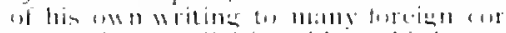

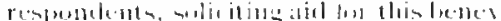

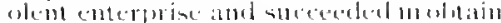

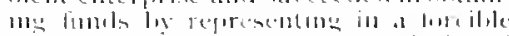

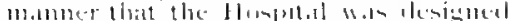

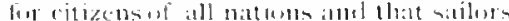

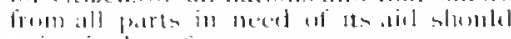
enim its lechethts

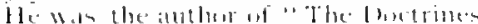

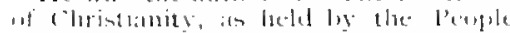

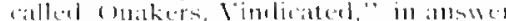

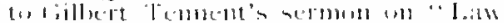

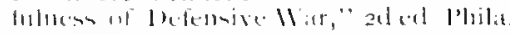
1747.810

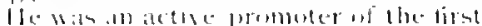

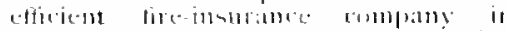

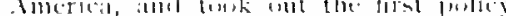

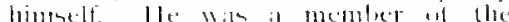

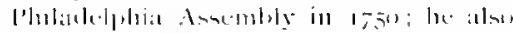

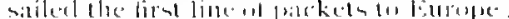

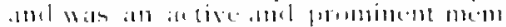

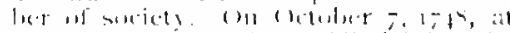

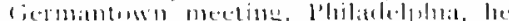

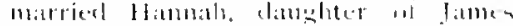

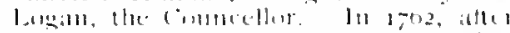

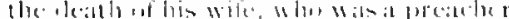

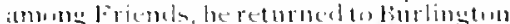
(1) end his alas an the plate al his lirtls

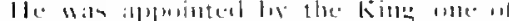

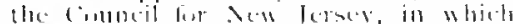

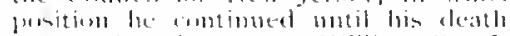

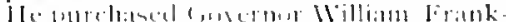

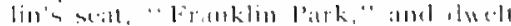

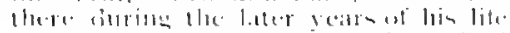

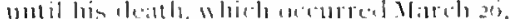

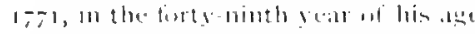

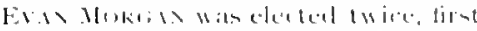
in $1-51$, resigned in 1752, atsintl in $1-58$

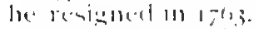

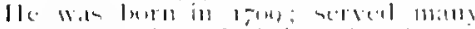

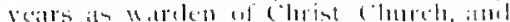

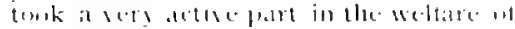
thet piaring

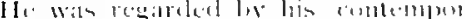

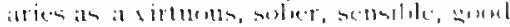

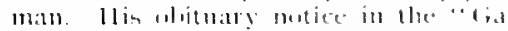

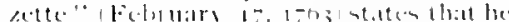

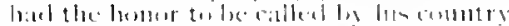

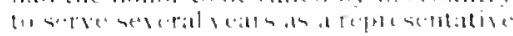




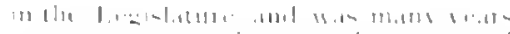

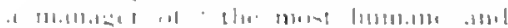

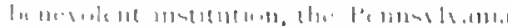

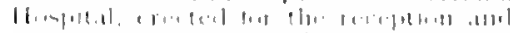

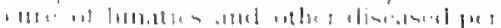

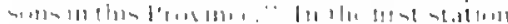

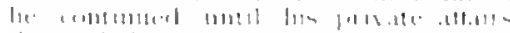

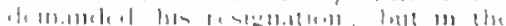

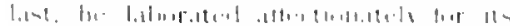

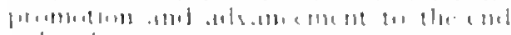
(1) I, I, 1,13

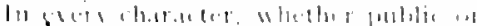

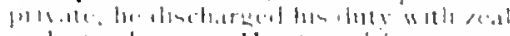

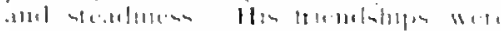

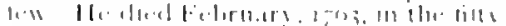

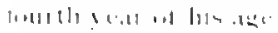

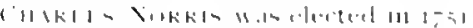

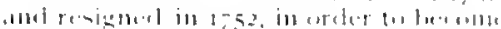

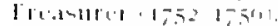

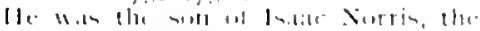

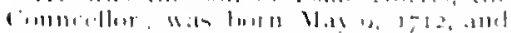

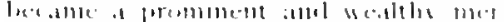

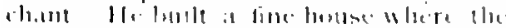

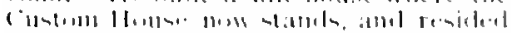

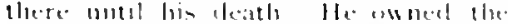

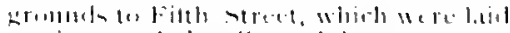

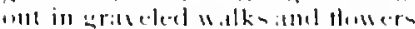

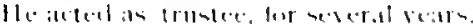

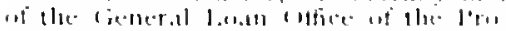

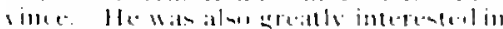

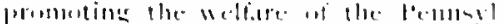
1.11i.t Ifompital.

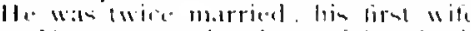

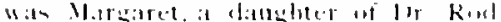

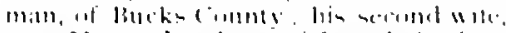

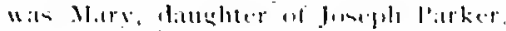

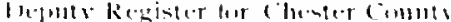

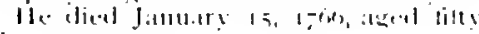
threevereste

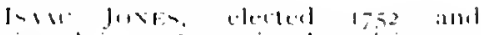

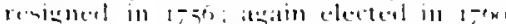
remsened in 1-0, and tor the thinel tome

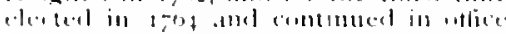

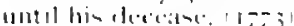

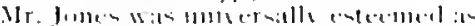

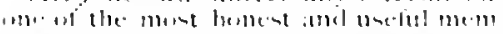

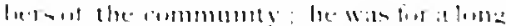

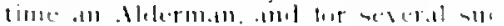

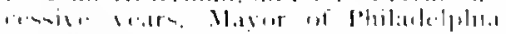

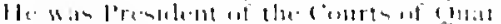

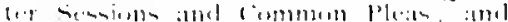

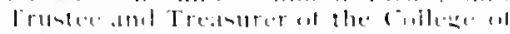

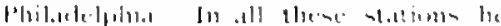

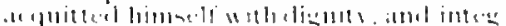

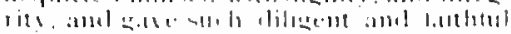

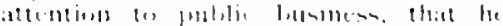

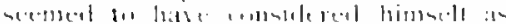

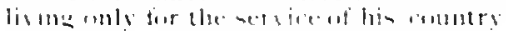

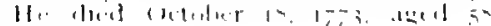
$1+11 \mathrm{~m}$

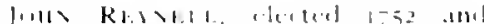

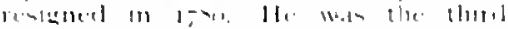

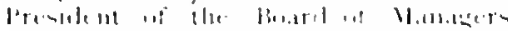

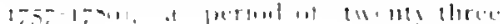

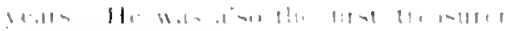
$1-5161,1-5=$

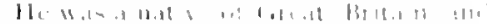

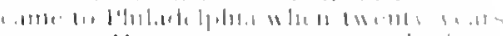

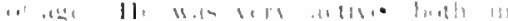

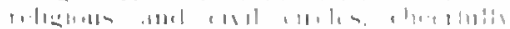

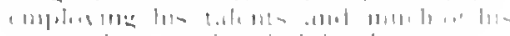

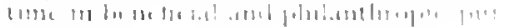
fuinter

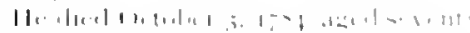

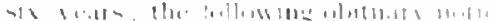

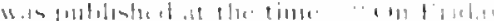

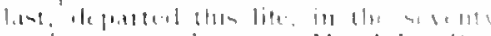

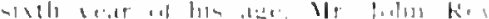

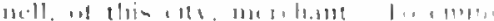

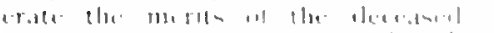

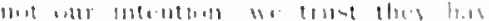

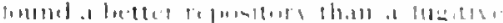

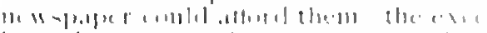

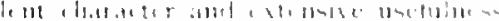

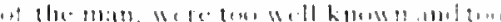

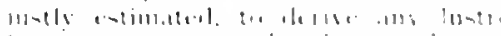

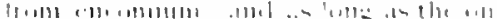

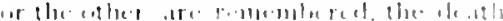

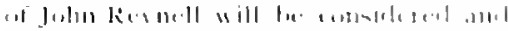

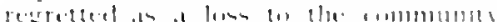

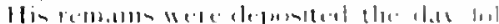

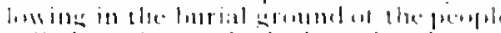

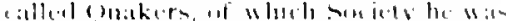

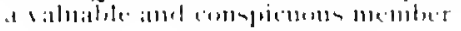

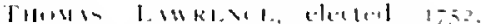

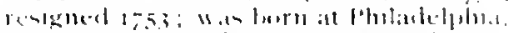

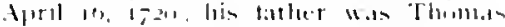
f.ewrene is member of the fromintial

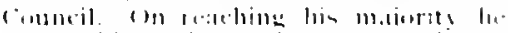

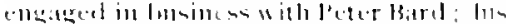

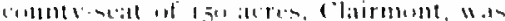

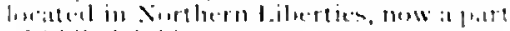
if lehilutelemial its

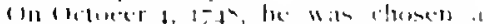

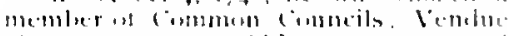

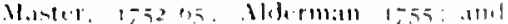

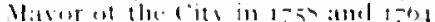

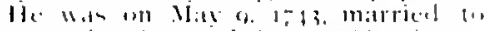

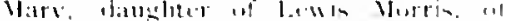

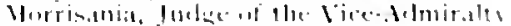

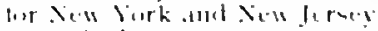

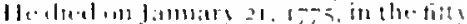

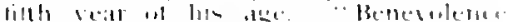

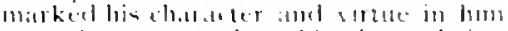

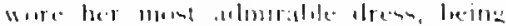

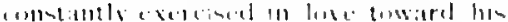

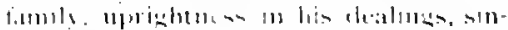

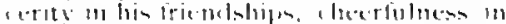

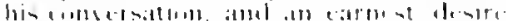

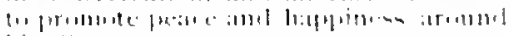
him

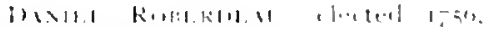

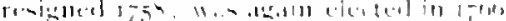

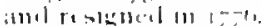

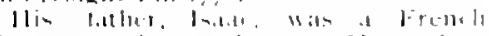

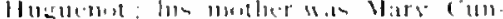

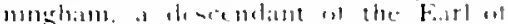

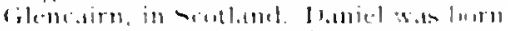

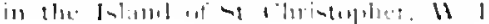


in 172 ; he eane with his mother's tamily to Philaclelphia in his susth, and becanne a merchatut. He wats early connected with the Masonic Fraternity, and asso. iated with Franklin, Alexander Hamiltun and others. He was a member of the lemusylvania Assembly from $1,56-60$. ln 1765 was an elder in the Presbytertall church. and a friend of George thit. ticelit

When the Revolutionary war liroke "ut, he joined the Pennsylvania Asso-iaturs and was elected Colomel of the second Battalion in $1-75$, and made presiclent of the Board that governed the Associaturs. He presided at a public meeting held Mas $20,1--6$, at the State House, which exerted great influence in tivor of a lecelaration of Independence. While in command of his battilion le hated out, in partnership with his friend, inl. John Bayaral two ships as priva tects, alle of which captured a valuable prize. With $\$ 22,4$ ws in silver, which he plated at the dispesal of Comgress.

11. was at member of the council of Silety, was selected on Jaly 4. 1,-6. firme Briegilier-fieneral of the Penustivania trouse whe Associators were at this time calleel to the aid of Washington in Sew Jersey. He wats a member of the intinental cungress from $\mathrm{I}^{--0-} \mathrm{-o}$ and atively supported the Articles of Con fecleration and affixed his name theretis m lechalt of I'emsistania.

In April, Iz, a scarcity of lead exint ing in the arms, General Roberdeau was arunted leave in absence by Congress in mrder to work a lead mine in Bedford (imuty, where he erected a stockade as a) protection against the Indians: the -xpense of its construction he paid ont of his private purse.

() Maly 24 and 25, 17\%9. General Roberdeau presicted at a public mecting in l'hiladelphia, called to consider the esils - if monoolizers and depreciation of the currencs. In $1-x_{3-4}$. he spent a vear in Fingland. It is related of Roberdeat that white travelling across Blackheath near lomdon, he was attacked be highway. nen who surromeled the carriage. "He secized the leabler, threw him down in the luttum of the carriage, and called to bis abalman to drive on and fire right and left. He clrove into London in this mant. ner with the robler's feet hanging out of the ratriage, and delivered him up to $\ln$ intices"

Alise the wal (ieneral Roberdealu remused from l'hiladelplia to Alexamdria. ba., where he alterwards entertaimed licheral IVishingem.

A slunt time before his death he re. moxel to llimclester, Va., where he died Jamuary 5,1795 , in the sixty-eightl yeat if his alse.

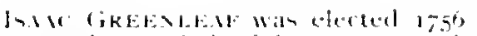
he served a period of tilteese vears; ho was alsu the thirl Secretary 1175\%-17591

fle was a merchant of the City of l'hila dielpha, a worthy and resperted member of the sucioty of Friends.

He died July rs, $1-7$, , in the fifty-sixth vear of his age.

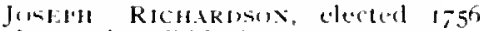
and serverl until his decease, 1 -7o.

He was a prominent merchant of the C'ity of l'luladelphia, distimbuished for his private virtues and public sporit. Ite estaldialied in $1 \times 13$ a white lead matnufilcury, which in tog passecl inta the possession of Dordecail and sammel $x$ lonis.

He served for sereral years as a Representative in the Assembly of the Province

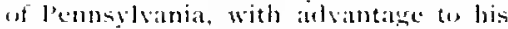
country, and acceptably tilled several wher wifices of public erust.

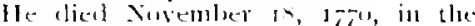
ine-furtl gear of his age.

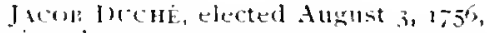
resigne-el $1-5$

lle was the sen of Anthony lumble at lluguencit refugee, who inue with

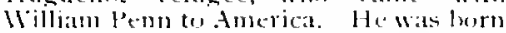
in Philadelphia in 1730 , and was graduated by the luiversity of Pemanyluatat in $175 \%$ He was licensed in 1759 by tle Bislup of londen and luecante an elo. (pent lootestant Episcopal (Tergyman. lle was Rector of Christ Church, Philadelphia, in 175 .

lle married a sister of lim classmate, Francis Hopkinsm, and at the leeginning of the Revolution espoused the callse of the (islomies. At the meding of the birst

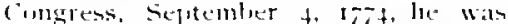
invited (1) make the openion priper. "For his excellent praver, sill wedl adipted to the present occasion," (int) ureso salve him a bote w thatuks. He

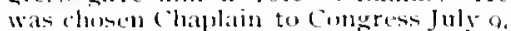
$17-6$, and he save his salary to the relief

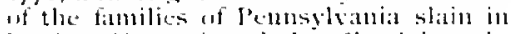

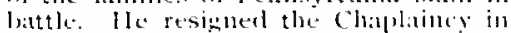
()etober.

When the British hed possessien at philadelphta, he becante alarmed at the

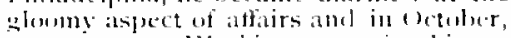

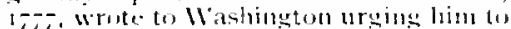

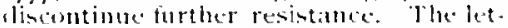
ter buing transmitted to cimeress.

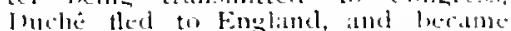

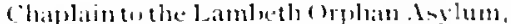

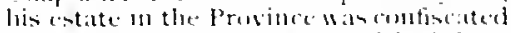
and he as a tration was handished from this inutit!s.

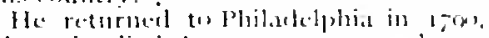

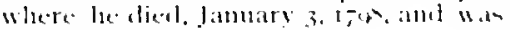
buried in chrint chareh. 


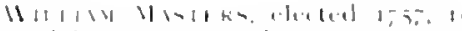

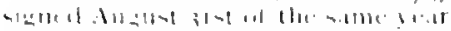

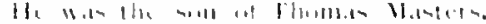

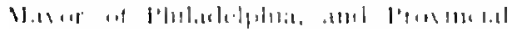

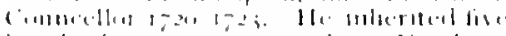

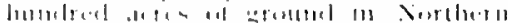

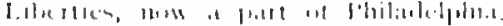

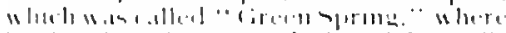

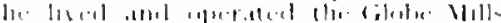

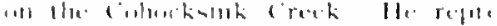

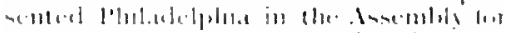

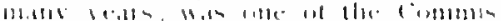

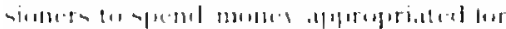

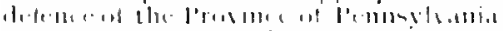

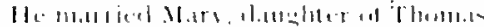

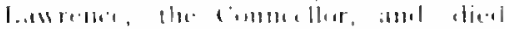

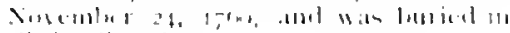
clurise clutets.

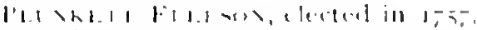

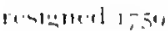

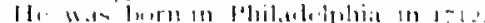

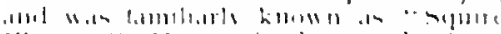

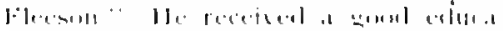
(3)!ा)

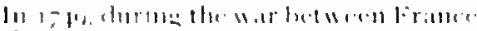

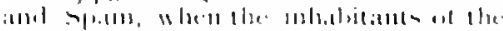

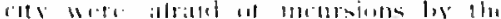

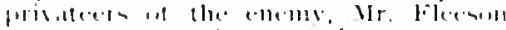

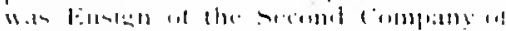

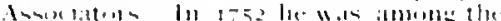

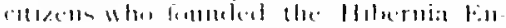

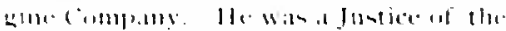

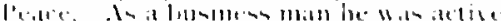

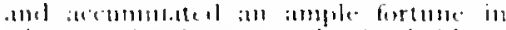

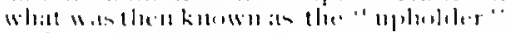

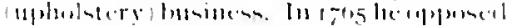

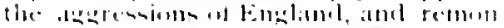

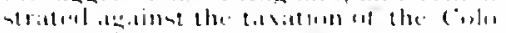

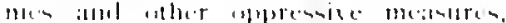

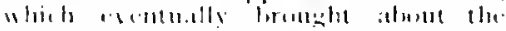
Rerulation

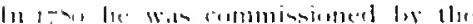

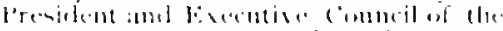

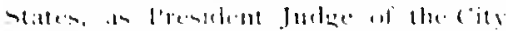

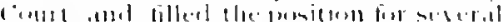

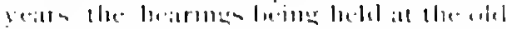

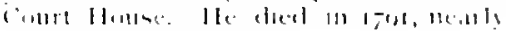

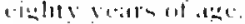

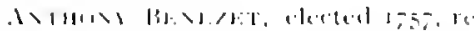
-igne.s 125 ,

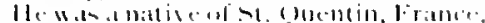

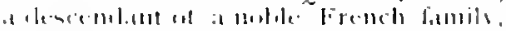

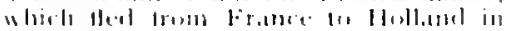

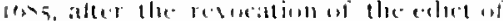

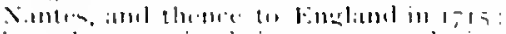

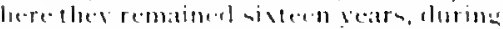

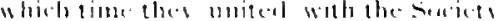

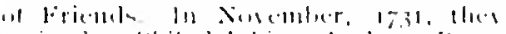

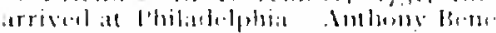

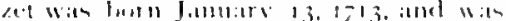

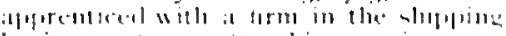

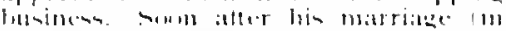

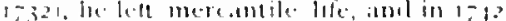

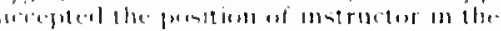

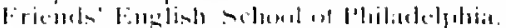

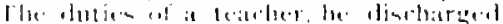

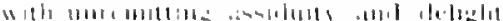

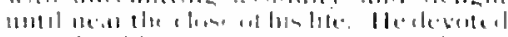

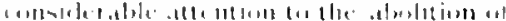

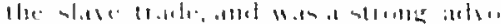

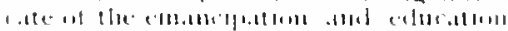

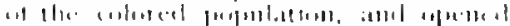

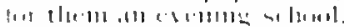

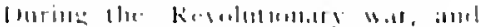

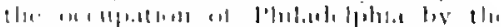

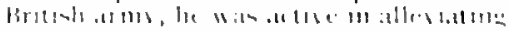

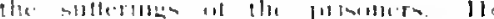

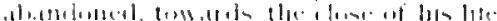

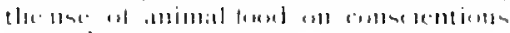
arumblo

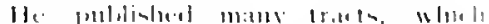

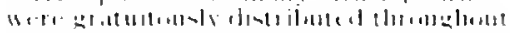

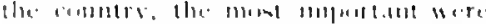

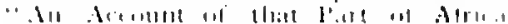

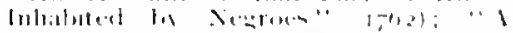

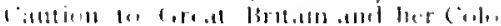

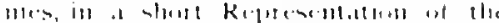

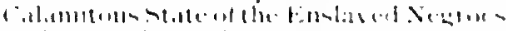

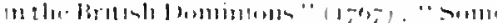

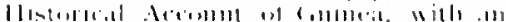

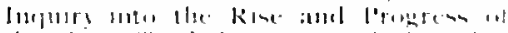

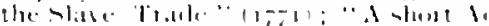

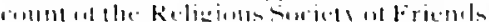

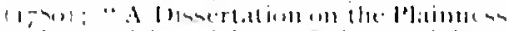

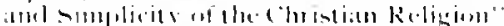

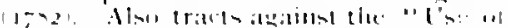

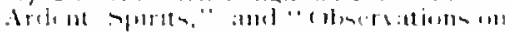

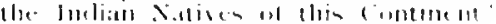
$11,-4$

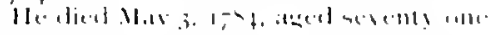
feitrs.

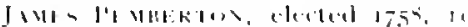

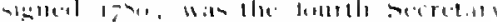
$1,-30,1,7,2$,

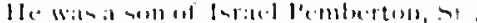

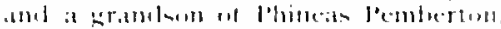

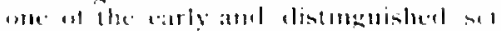
thers of leoumblatula. He was borm 111

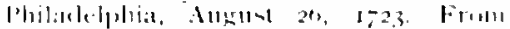

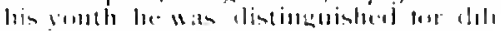

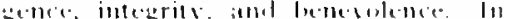

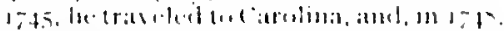

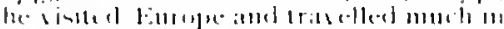

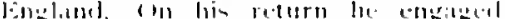

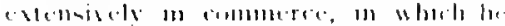

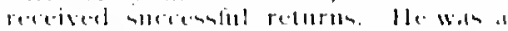

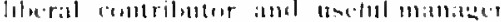

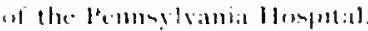

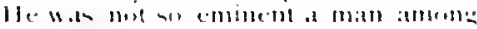

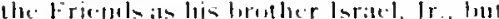

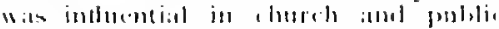

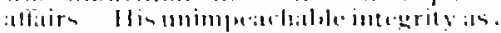

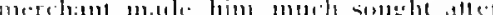

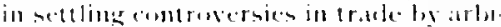

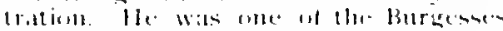

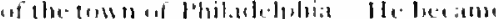
early interented in the wellore of the

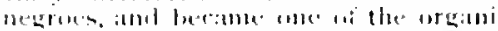

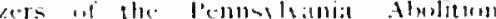

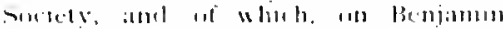

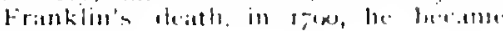
l'resiclint 


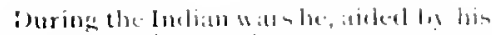

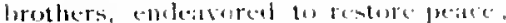
many of the lotian chiets asting lehilo delphia were lospltably entertamed by

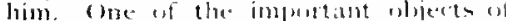

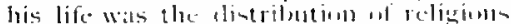
amel instructive luske In $1,-50$ he re

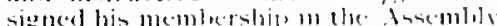

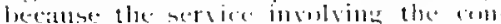
sieleratiun of militaty attiors was incen patible with him religinum primeiples In I757 he published" An Apulugy for the

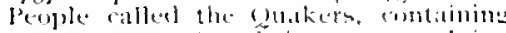

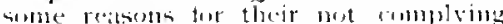
with Humall Inumetions allal lestrue tions in Inters relative to the Morship of (ind." His follatry-ante all the

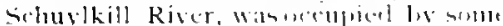

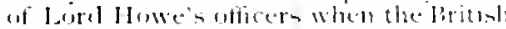

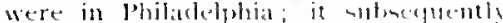

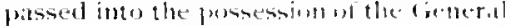
isocenment, and is now the lenited states Naval Asylum.

ln his own religions areiety he was a loned and homed member. He Was

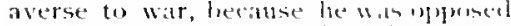
(1) the settlement if political nlifleremee by arms. He was inclueled in the sis.

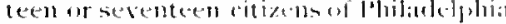
who were banished te Virumia in 1,7, "to kecp the reace" There he - pent a comple of years and woute mot a jentr. nal, some of which has lecen pulslisticel in the "Friends Miscellaws," Vul. VI

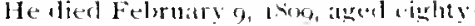
five gears.

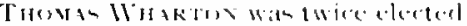
the first time 1-62, resigned in $1-04$ again in 1,72 , resigned 131 1

le was alsu Trealsurer ut the Hompital. $(\mathbf{7} 7 \mathbf{6 9}-72$.

Thomals tharton, his ancentur eni

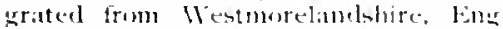

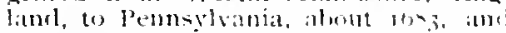

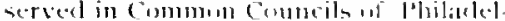
phia $(1,1,3$ to $1,-1,2)$

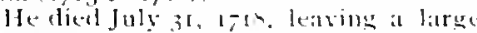
atate to be divided ammeng his chiletren.

Joseph Wharten, the lather of Themas

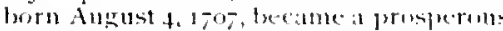
merchant of lhilarlelphia die lived at

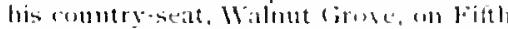
street near 11 ishomerton Arenue, Philat

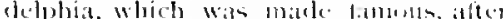
his death, as the seene uf the reletirateel Meschian\%a, held the re in ta-s

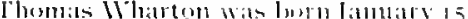
$17.36-31$. He becane al me relant of intla "rice amel wealth and inelumperl to the

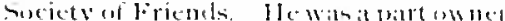

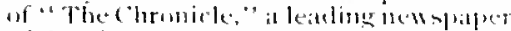
af the cits

In 17t. Mashingten wreste that le

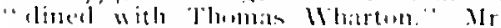

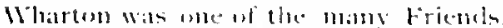
who atctively opyoued the inporessine

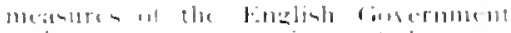
and uat 11 1

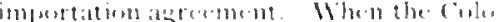

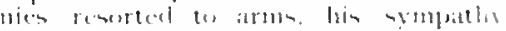

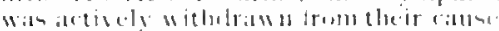

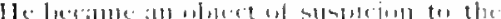

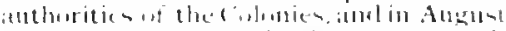

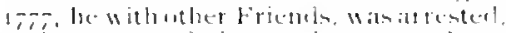

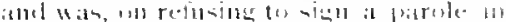

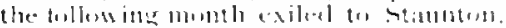

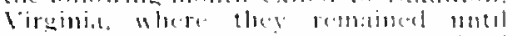

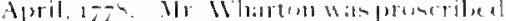

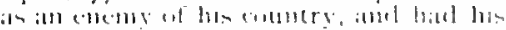

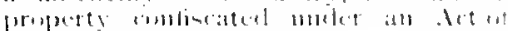
fenthalyania

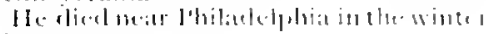
i) $1,-2$

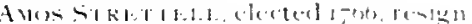

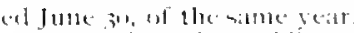

He Was burn in Imblin, 1,-20. the soll

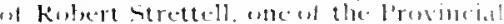

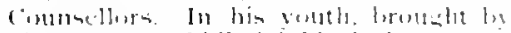

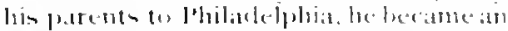

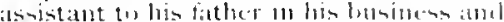
lecome an emincent and intelligent met

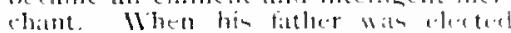

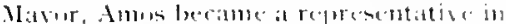

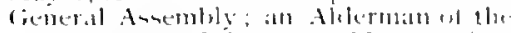

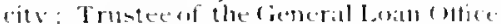
ancl of the (islene of l'hilartedphia

(1) Xonember $2,1,52$, he matried in

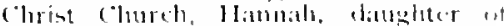

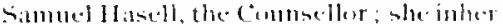
ited, from the istalkleys, reat estite in

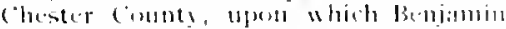

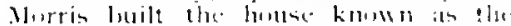

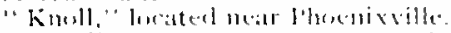

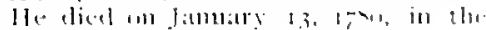
sixtictlo yeate ot bic atger.

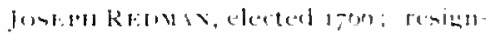

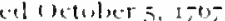

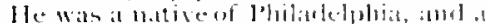

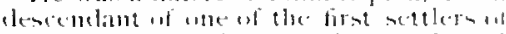

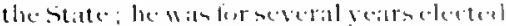
(1) the siffee of Hieh sheritt the distientel

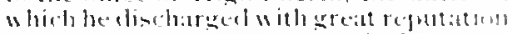

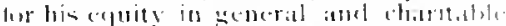

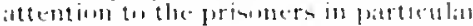

He was eldowed nith a remerkithe

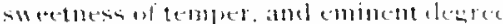

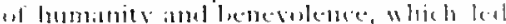

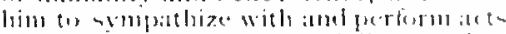

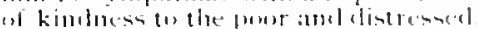

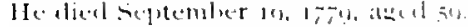

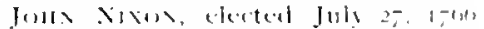

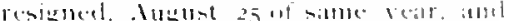

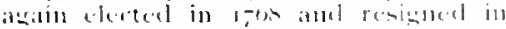
$1,7,2$.

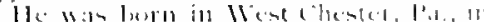

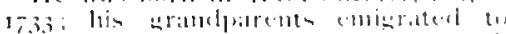

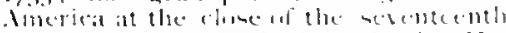

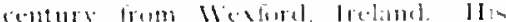

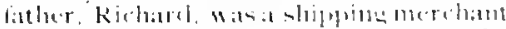

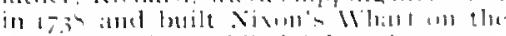

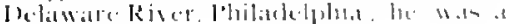




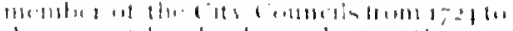

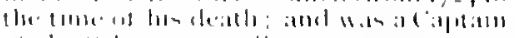

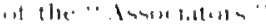

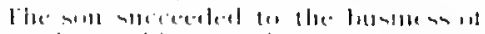

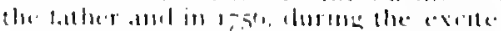

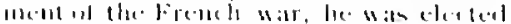

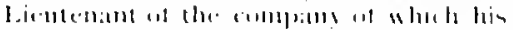

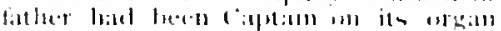

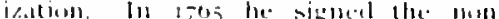

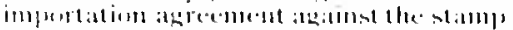
act, alul from that time lask all ateise.

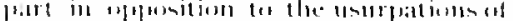

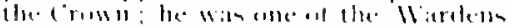

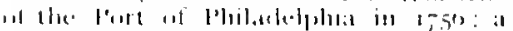

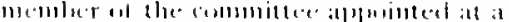

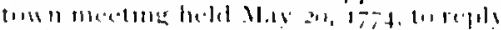

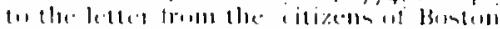

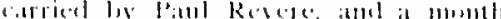
later was male a mermber af the litet

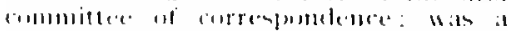

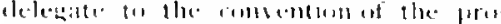
vimeren in $137 \%=5$

l'be Insuciaturs in April, 1-5.5. were

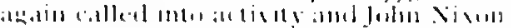

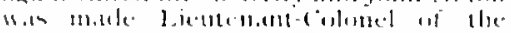

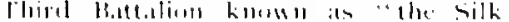

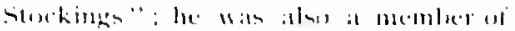

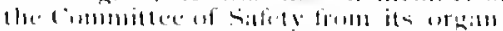
gritioll toll its dismolutient. and presided

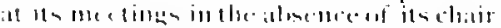

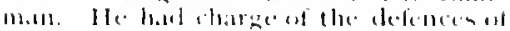

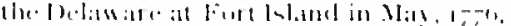

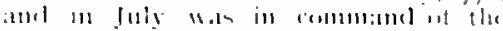

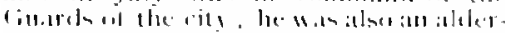

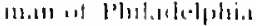

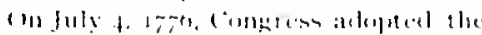

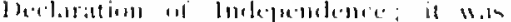

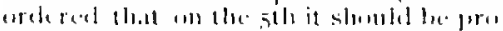

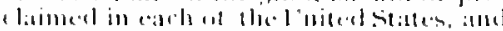

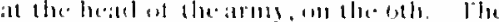

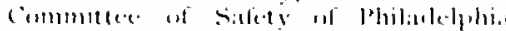

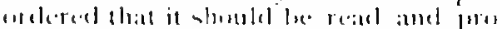

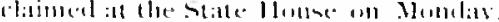
July all, at nouls: at that time amel plate.

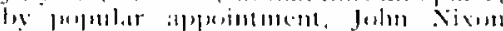

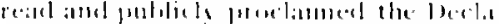

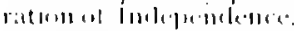

(iil. Xivin in luly touk the Batlalion

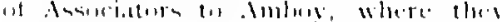

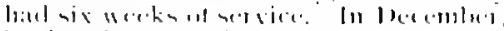

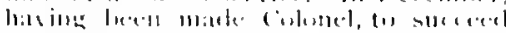

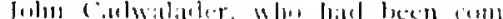

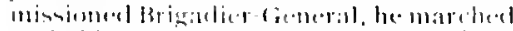

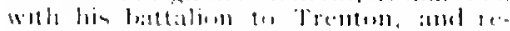

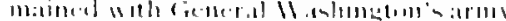

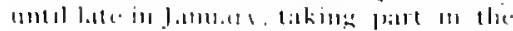

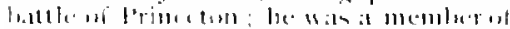

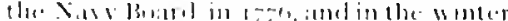

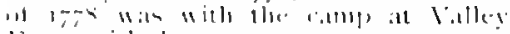

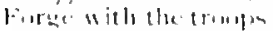

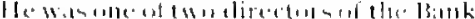

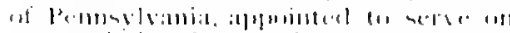

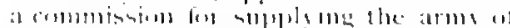

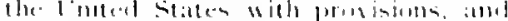

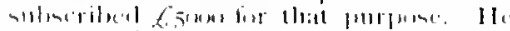

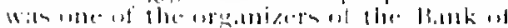

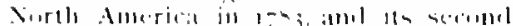

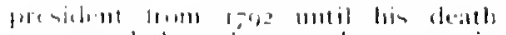

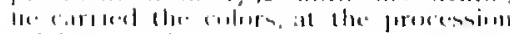

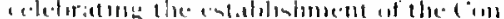

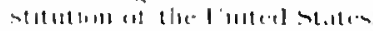

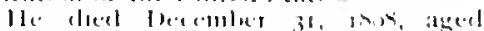
resellts five hears.

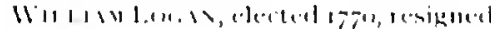
1725.

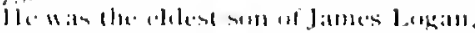

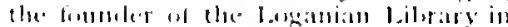

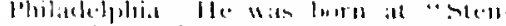

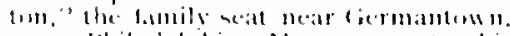

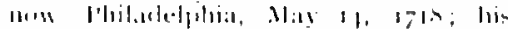

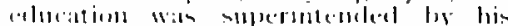

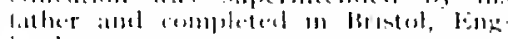
linil.

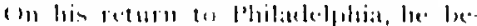

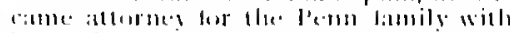
lis tathere fle wis a member if the lemencial combeil of l'bilatelphia fom

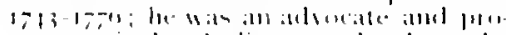

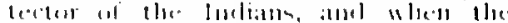

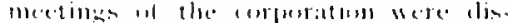

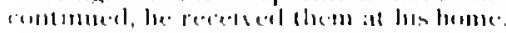

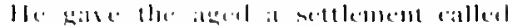

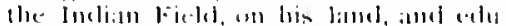

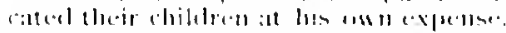

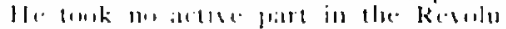

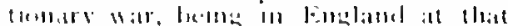

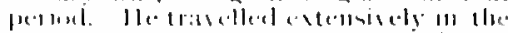

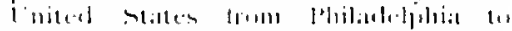
licerraiat

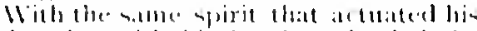

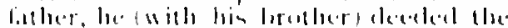

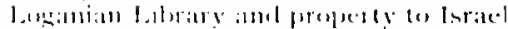

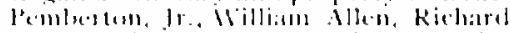

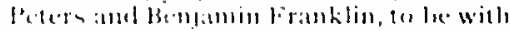

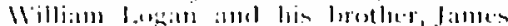

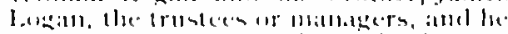

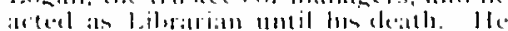

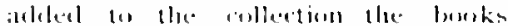

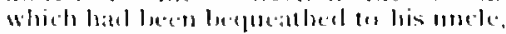

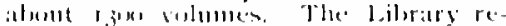

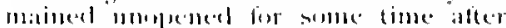

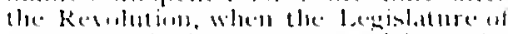

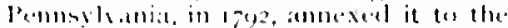

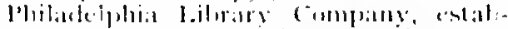

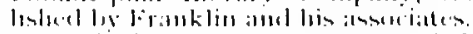

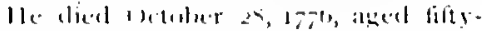
eishtl verits.

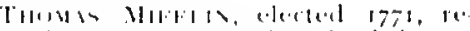

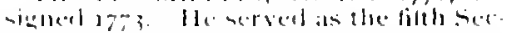
$101311017,23-1,230)$

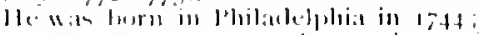

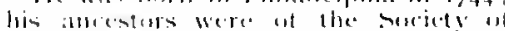

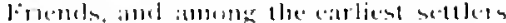

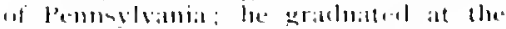

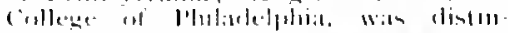

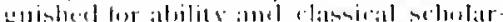

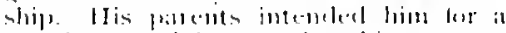

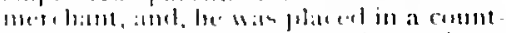

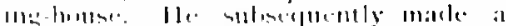

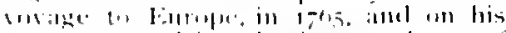

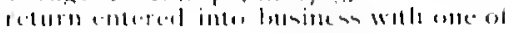
lis liritlie is 


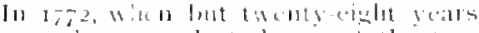

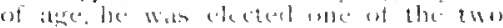

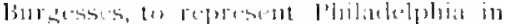

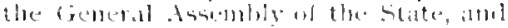

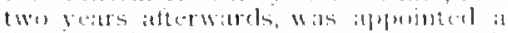

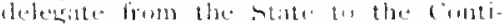
netltil timencess.

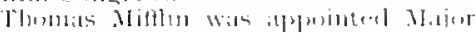
of ence of the cimbincoltal remingents

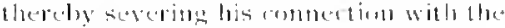

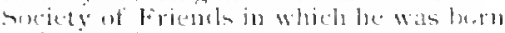
and reitriel

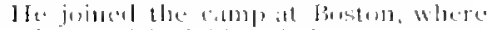

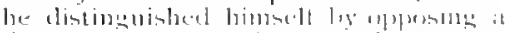

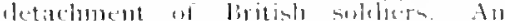

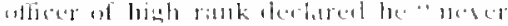

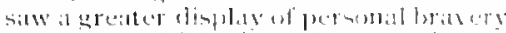

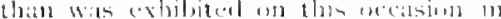

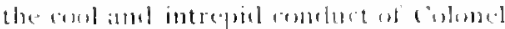
Jihlin," Atter the withlramal of the

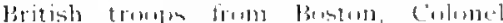

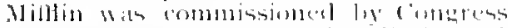

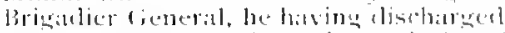

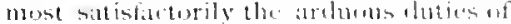

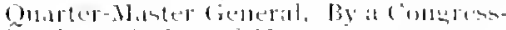

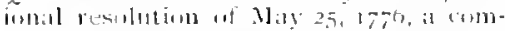

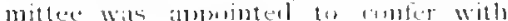

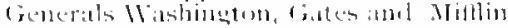

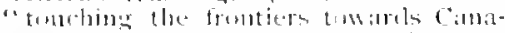

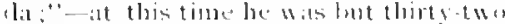

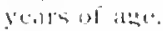

Alunt this time be wam anmmissimet

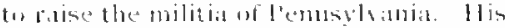

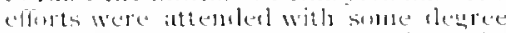

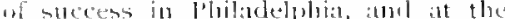

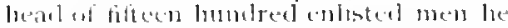
metreheal to Trentens. Feneral Misllin

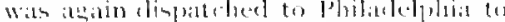

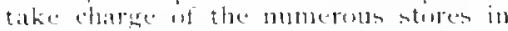

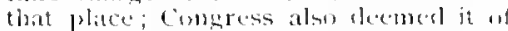

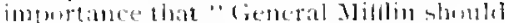

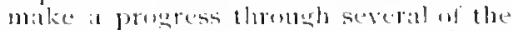

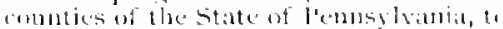

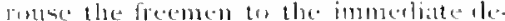
leme ref the city amel combers" ambl resolverl "ront the Asmembly be re.

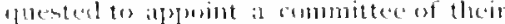

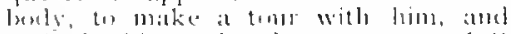

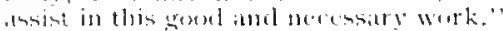

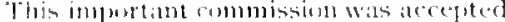

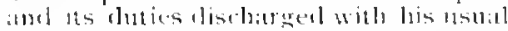

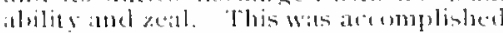

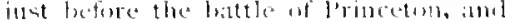
its vithry with thit of Trentom secored Americin Intepentence ln (iol. Trumlull's painting of the Battle of l'rimsetum, fiemeral Mildin makes a mosplenomts

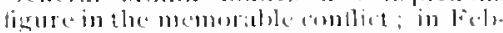

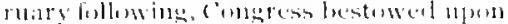
bim the renk of Majom-ticheral

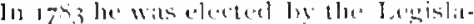

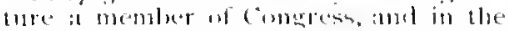

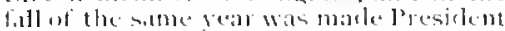

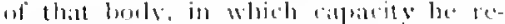

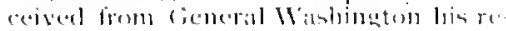

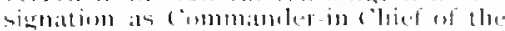

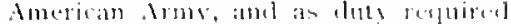

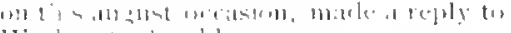

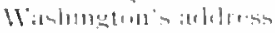

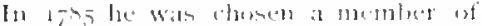

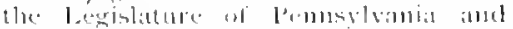

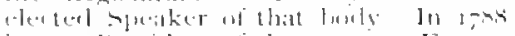

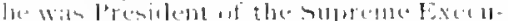

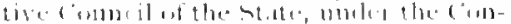

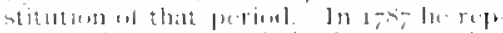

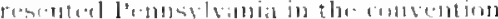

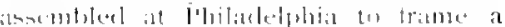
g'x

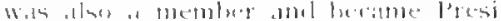

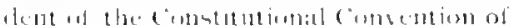

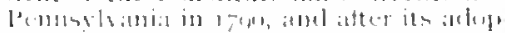

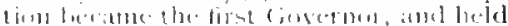

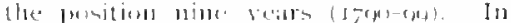

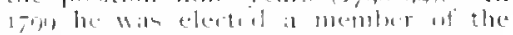

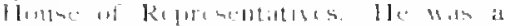

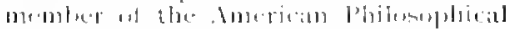

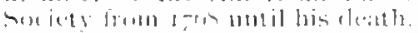

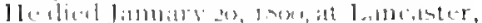

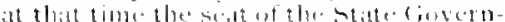

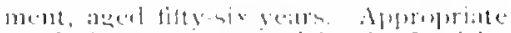

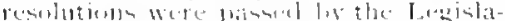

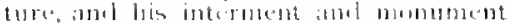

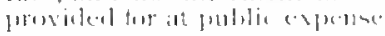

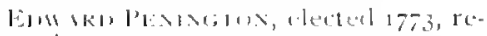
signed 1 - 50 .

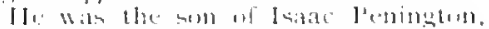

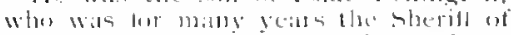

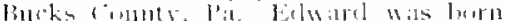

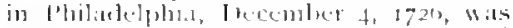
chacited in the Frients Selomi. and

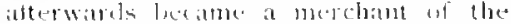
(it)

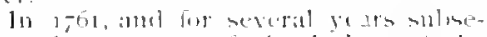

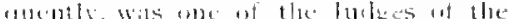

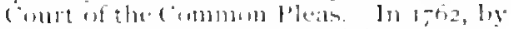
Act of Assombly, Was ense of the Trumbes

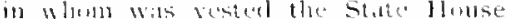

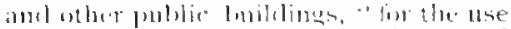

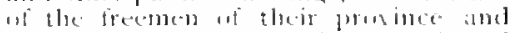

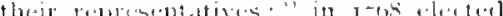

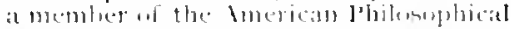

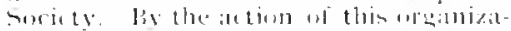

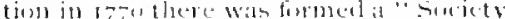
for the coltivatuan wi silk" wh whel he

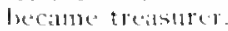

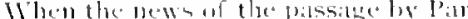

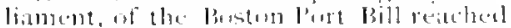

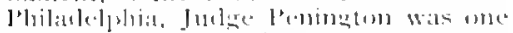

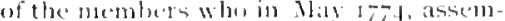

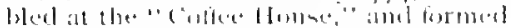

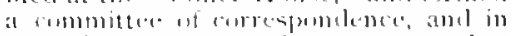

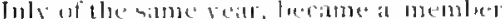

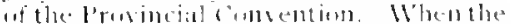

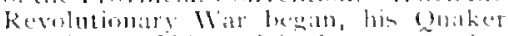

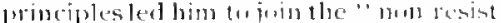

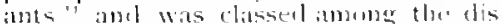

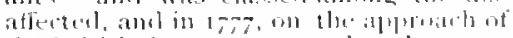

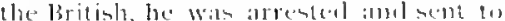

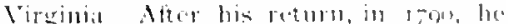

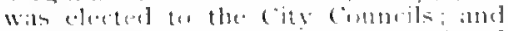

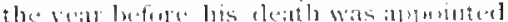

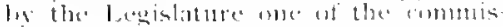

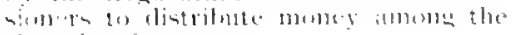
firengh retugeren 


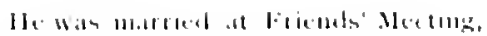

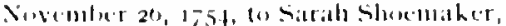
dinghter ot the comaledher.

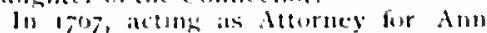

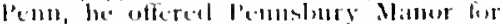
sole, publisheel a descriplent of it, giving rielet of title, allel alse somle loistorical evests entorerning it. Me also wrote a

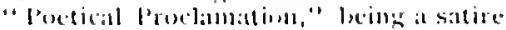
wh the (inmmittece of lospection in l'hilade. Iphiat.

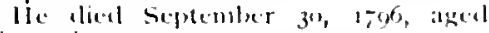
sivtr-nine veats

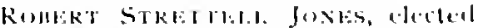
173. resigned 1-81: la was the eiglats seretelty $(1207-1-2,13)$.

llis fatler bals une of the wealthe mer-

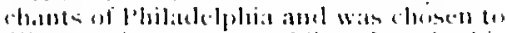
fill many important public oflices by his levinw eitizens.

kabut was botu July 21,1245 : he recoved the degree at A. Xl. from late Uni-

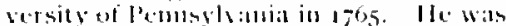
olle of the secretaries of the Americall l'hilesophical siciety a d beretor al the

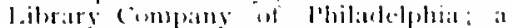
mermber of the cindumittece of Inspection

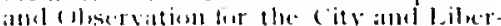
iles, Augus 17-5, athd also one of its sec-

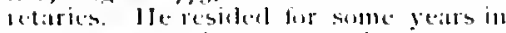

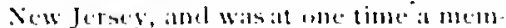
ber of its l.ckislatture.

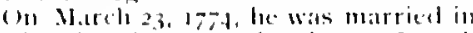

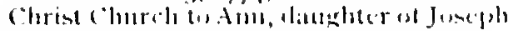
Slipurn.

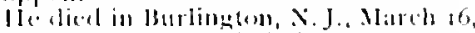
1,92, and was touried in st Natry's (irituluel

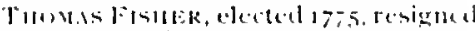

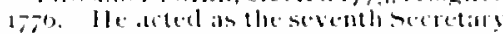
from Maly is a July 3, I-Tis.

11. wats a sell of Jushuat Fisloer, of l.cwes. Delalwalle, alterwatrals a merebint

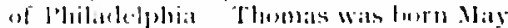
6. 174t, atad an coming of alge was taken inte portaceshig, by bis father, and be-

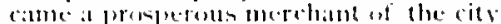

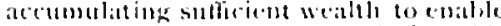
himb bu retire mally years befure his deceilste.

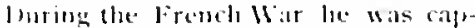
tured at sea, and ratried to spalin; after

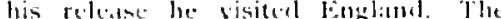
fatber and three sums were, during the

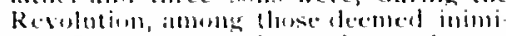
"al to the callste of Amerita amt were arrented and transferred to IVindester. Vat, where they rematimed duriug the

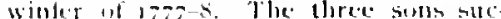
eceded (a) the business of Joshute fouber \& Sons, and in the some year the brothers Thomas and Niers loisher, beame part mers in the tirm of Hungh, Bicklatm \&

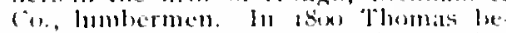
rame* il partuer will leemerd somelen in a forewers. Thumats wats owner of

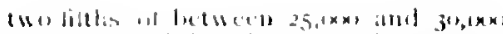

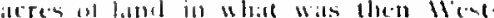

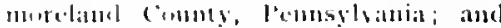

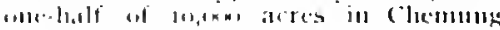

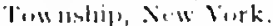

w Marde 1;, 17\%2, he matried Siarals

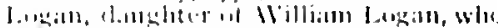

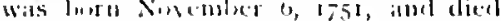

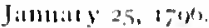

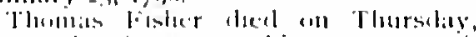

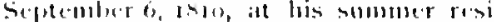

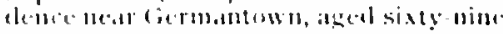
yealts.

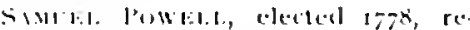
signed 1-xis.

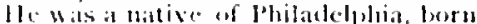
in $17.5 \%$. He matriculated at the college of l'hijoldelphia (mow ble University of

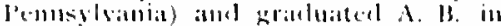
1,50

He servel several vears in the Cits (inturile: Was at justice of the (ammun

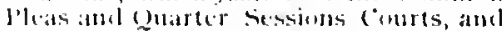

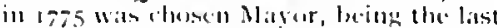

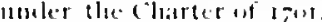

Alter the Revelution, minler the nen

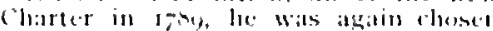
Maymo

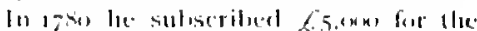

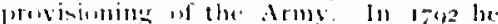

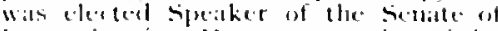

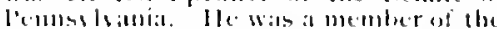
Anerifall l'hilosephital suejety tom 17.3 until his teatle, also a Truster" of

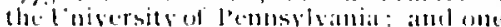

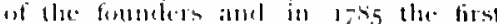

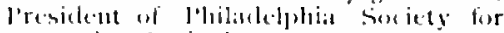
prolunting Agriculture.

He. wath of lmaker stack lume when in

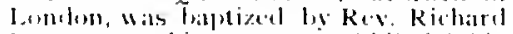

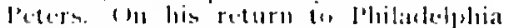

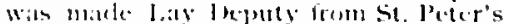

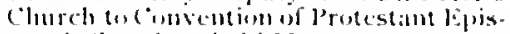

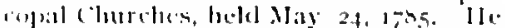
inherited a latree fatate which be he-

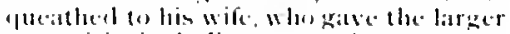
pare af it, ineluting " l'oweltum," (1) her nephew end adepted sisl, John l'awel lla1e, atud his descendants.

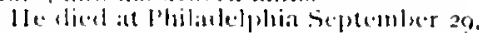
1743 , in the lifty-tometh year of his inge.

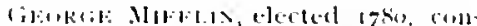

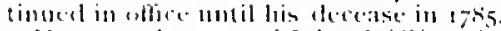

11. was the soll of Jolnt diflin, the

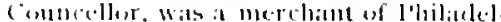
phial, alud was for a time in potrencrsbip with his elaler loruther

(1) 16toluer i5, 1772, he married Martha, daughter of Joseph Morris, a l'hilatelplui: merohant the issue of this marrigec were two childred, Thumas and fingledli the formet matried

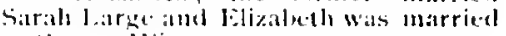
to Cinpar llistar.

11: alied July 14, 1,85. 
TFxide Coxe, elerted $1-80$, resigned

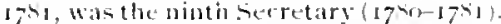

He was loorn in I'hiladelphia, May 22 175. . the son of IVifliam Ciste amb Frances, datugleter of Temb Francis, Atturnev-General of the province of peutusylyania.

Ilis ancestry were urierinally from Somersetshire, in Enghank.

He received his education at the (i)llege of Philarlelphia. On leating College, he entered the colluting-house of Coxe \& Furmats, and on attaining bis majority, May, 1776, luceme a partuer of the house, unfler the namte wi Coxe, Furman \& Coxe.

He was elected hy the letgislature of Pennsylvania a Commissomer to the Annapolis Federal Cunsution, which met on September J 1 176, to discuss the proposed Federal (institution, etc. The Commissinners recommended that a

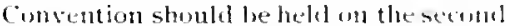
Monday of May, 1-57, which was alyproved by comeress, and the result of the Convention which assembled on that day was the present Constitution of the Enited states.

In Izos, Mr. Coxe was eleeter ly the Legislature, a menuber of the (inntinent al Congress, until the periul at which the Constitution of the [nited stittes slomlal yo intw operation. In Sentemfer, I Tho, all act was passed, organizing the Treals ury Department. The following Mas, Mr. Coxe received the alpouintment in Assistant Secretary of the Treasury. Ju Iay, i,92, he was appwinted liy the president, with the adrice and (n)sent of the senate, to the position of commissioner of the Revente: this position le held elurine the rest of the admuinistration of General Washingtou. In Isuz he was appointed lig l'resident Jefferson, Purveror of the Public supplies of the Cnited States, whicl position he held un til the office was alwolislued in 18 it 2

His witings were voluminous and tatended throush a period of ntuly yeas, the only works which were collected and republished in busk form were: "I Bric. Examination of Lord Slieffield's ()hetr. vations on the Commerce of the [nited States with Two Supplementare Dotes upon American Manufacturers" "Philadelphia and London, 1-92); "A Vicu of the [nited States of Anerica" l'hilated. phia, 1-94. and Lomduln, 1,95); "A Sitatement of the Arts and Manulatures if the

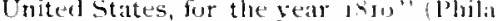
(lelphia, 1814).

In 1 - big he published a pamplolet which was read before tle society for l'olitical Inquiries, at the lususe of Be?lymin Frank. lin, (May I 1, 1757) entitled: "An Inruiry into the Principles upon which a ("ummercial system for the lonited states

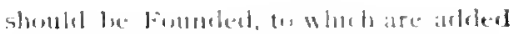
some poilitical (1) with the suljedt.

Mr. Cuse during his whole life desuted himself to the encumrasement witucrican

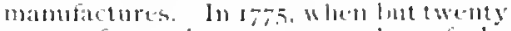
vears of age, he was a mollder of the inited comprary of l'bilatelulata, for l'romuting Antericill Manufatures. In 1.97, he was one of the mumt atetive of the founders of the Pennsylyania suciety for the Encouragenent of Artsind Domest ic Minufactures, which was inutituted at that time, and at the instancen lor. Kush. le delivered the inaunural andress, and subsequently he became l'resident if the sinciets. In ist comeress instructed the secretary of the Treasury to hase com piles a statement of the ifamblatures uf the Cisuntry. Mr. Fallatin appliced to Mr. Cuxe, as the first atutherity amenge comumists, to execute the undertaking.

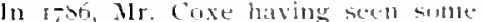
cotton growing in gardens in Maryland, wis convinced that it might he extent siscly cultivated in this cumbtry; the restilt of an examination satioficel him that all the regiousuth of littituele thirtyninc was capable of producine estum extensively. He thencefortl employed lis bell to attract pulslic attention of the rommumity the subiect, with comblete success: He deserves w lue named the Father of the American Cotton Industry 1 e it was also whofirst attemplecl to bing an Arkwright machine to the linited sitates.

Mr. Coxe died in Phibadelphia July is. Is24, aged sixty-nine years.

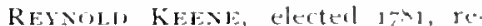
siened rzoo: eleventh secretisy izis and $1-86$ and the seventh President if buarduf Manazers

Hewasturn on the Island of bartarlous alemit Ify and was the soll uf Peter Keente. He passed mest of his life in Philatelphia and was eleted torepresent the cits and liberties of Philatelphia in the provincial Convention of Pesmsyl. lania, Januars $23-2 \times, 1-75$,

Aiter this, Mr. Keene removed to Real ing, ['a, and wastapeninted April $26,1-7$, it Commissioner for the Comme af Berks, to itudit and settle the atcontuts of the militia and flying canp of the sad county" for arms and acountrements purchasea ly the offecers of these corps and the piopert a persuls lost in actual service ilso of these persoms who latse leen killed, dieel in the servieged the statesur were made primoners

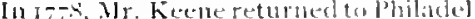
phia, thets gecthited by Genclal llowe leting his family" in Reading : this step imbluced some susplition of lits lovithy (1) the catuse of the colomits, amb at 


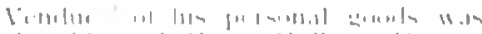

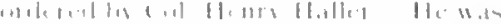

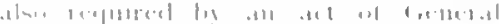

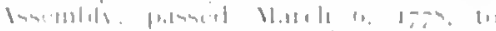

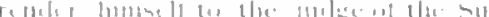

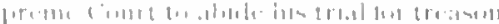

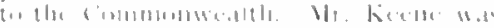

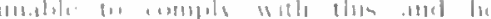

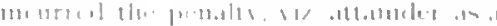

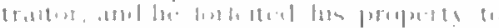
tiin. - at. 11.

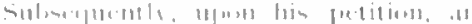

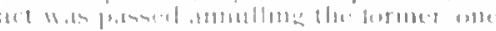

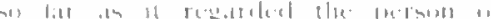

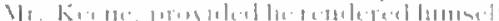

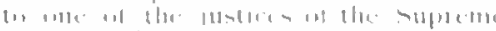

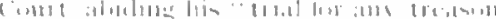

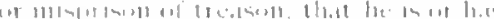

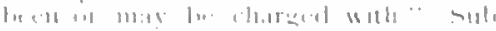

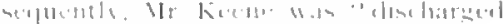

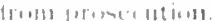

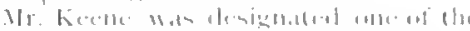

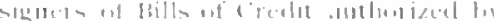

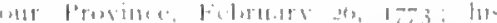

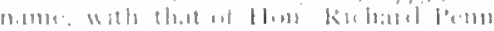

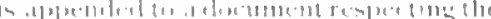

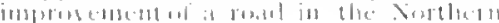
1.ifurtum $111,-2 ;$

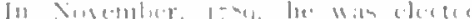

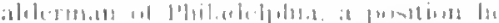

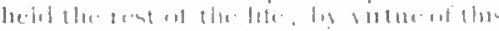

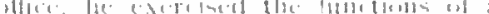

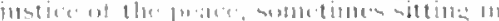

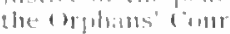

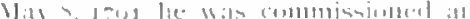
(1)

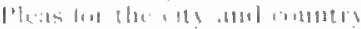

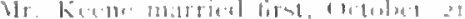

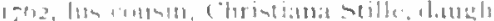

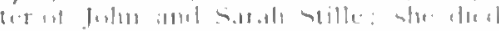

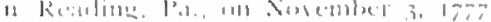

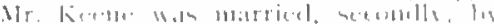

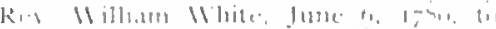

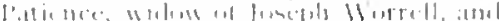

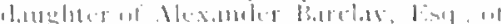

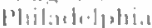

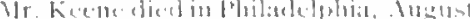

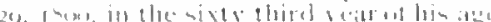

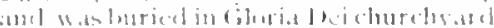

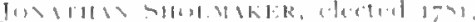
Te-ing $11,-11:-1,10$

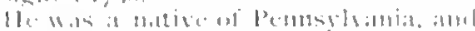

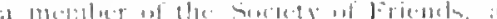

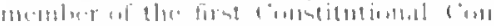

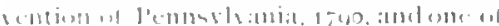

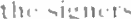

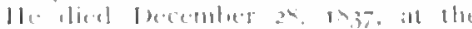

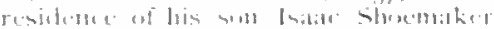

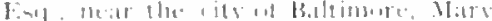

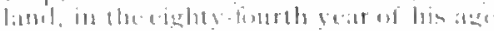

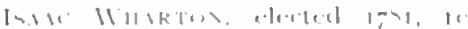

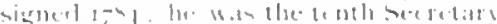
$1,-1,1,-4 ;$

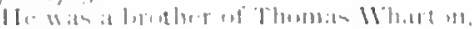

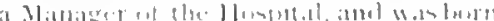

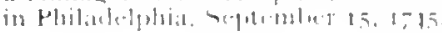

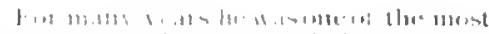

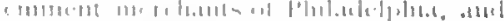

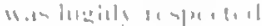

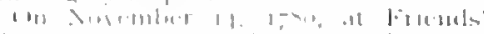

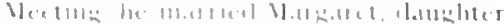

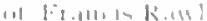

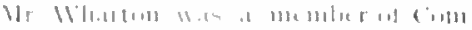

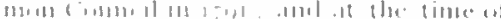

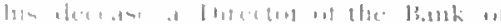

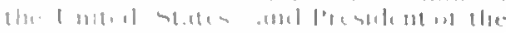

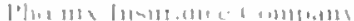

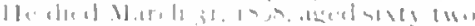
$\because .11$

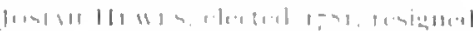

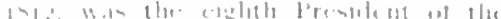

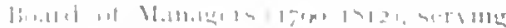

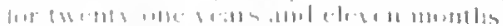

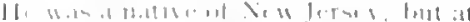

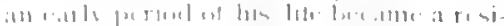

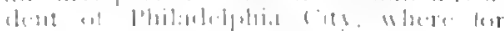

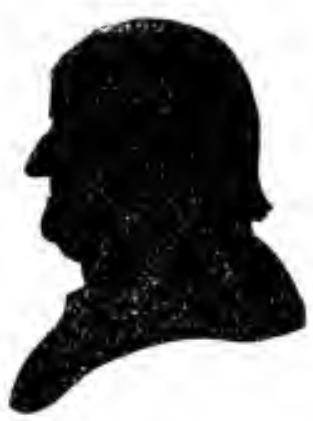

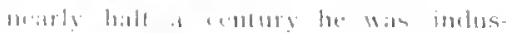

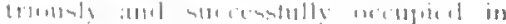

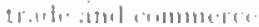

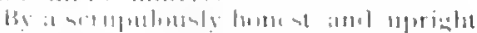

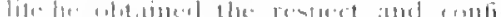

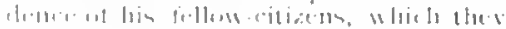

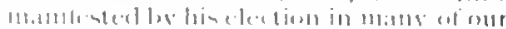

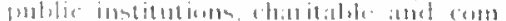
1111+1:i.t.

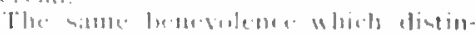

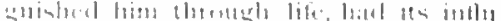

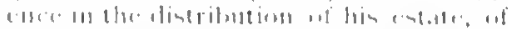

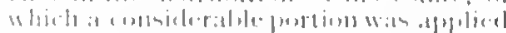

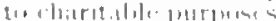

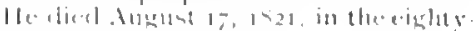
ninth bout ul his and

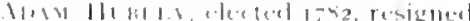

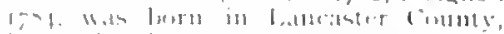

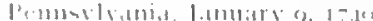

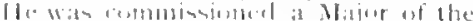

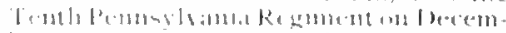

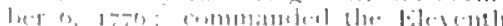

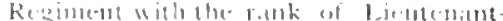

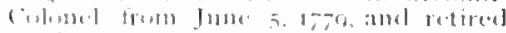

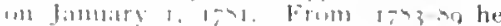

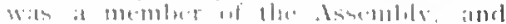

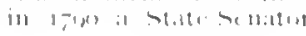




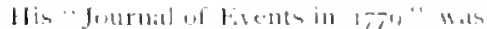

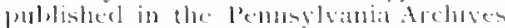
12 serices Vivl. Nil

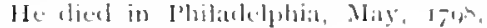
iged liftye isht yeatro

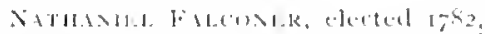

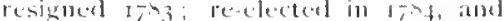

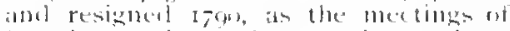

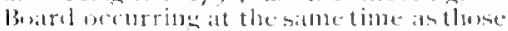

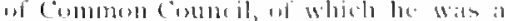
number, they interfered uith his duties to that luxly

(autatio Falconer hatel remelered rablu alble services to the lfospital in many ways. At unc time le commanted it bucket blying betucen l'bilatelphia and

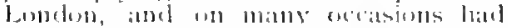

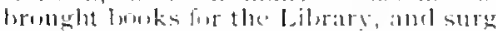
ical instruments, besides conteging let ters and atfending to matus affutes of in purtance fin the Matuagers in bimblon all of which were remembered whon al vote of thanks wastenclered hims.

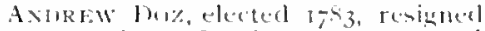

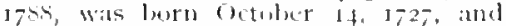
was a grandson of Ambrew liwe a lowentenot, who hatel charese of t'mon's Vinevard at Fairnomm.

His enuntry, his church, and the prost shared the betuetits of bis phatios dur ing his life and were remembered by him with peculiar literality in the lonur of his death. In his will the lennsylyania Husprital is mentionecl first as at beneficiary of his valuable testitle.

toe died on Thursdits, hecember st. 17 sx, aged sixty-one years

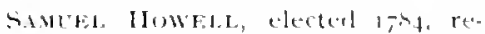
sinned ingo was elected the sistl President of the Buad of Mallagers firm 1 - T6-17to and served over three gears in that position.

He wits a successful business mall of Philadedphia and is the seats $1,-6,5$ joined

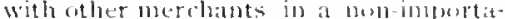

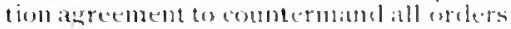
for English wourds until the stambl atet shomlef be repealed, He was also one of

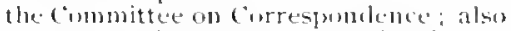
at member of the (immmitece of Sitfety.

the dieed December o, las at lis country-seat near frankford, Philalelplitia, lis.

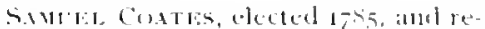

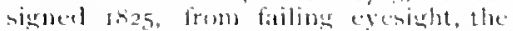
cefect of domble citarat, having stoved

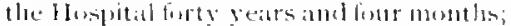
he wats the twellith sectetary (1,-50-1-212).

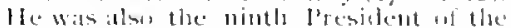

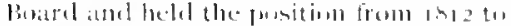
I. $\rightarrow 25$.

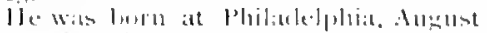

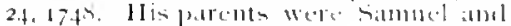

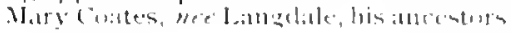

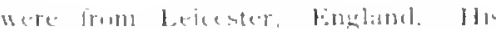

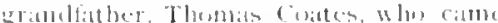

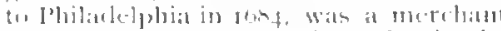

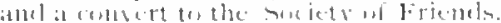

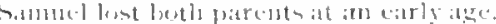
Il. was then taken in charese by hos

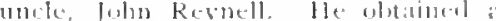
vonel chaseal ingl business alucation.

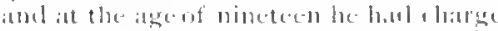

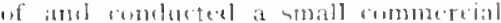

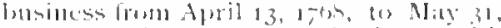
177. He then went lintre business bitl his uncle the firm lowe Revellell $\mathrm{d}$ (inatus: this comtinued until i-cis lo

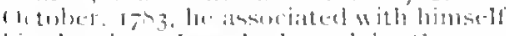

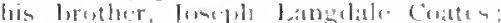
this continuted until $1-0$, when he toll

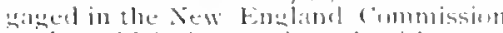
trable, which he comblueted with wreat

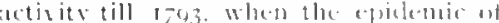
rellow fever mide its terrible rithases in this city, which enlinted his symustles and active interest in precalltimory ant charitable measllese Hin lalther in torest in mercantile affairs gave plite to his resution to public aluties, which from this time until his theath engrosenet lits

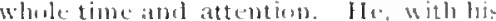
fomily, continued in memberslaje with the sinciety of Friends, and he w its resu lat in his attendance at Jouble Morship.

1]. Was twice matrica, on lanthaty 2

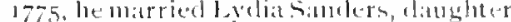

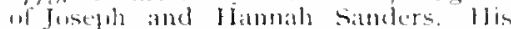
wife died octuber 24, 1-tho. It abain married on Nonember I7, I701, to

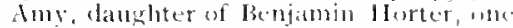
of the carliest and mose prominent on Market strect merehallts. Ifis wife ame her twe sons survived him, and fint childen of his previous marriage.

He was fermantently identified with the puldiecrentsul histime, his integrity. business coperience, alud well-kiumbl

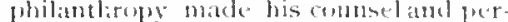
sollal services much sumglat alter low his follow citisens, who showed their confi lence in him be their (all to a sucetsing of polstir chities, which onempieal his time and attentian during the later pur tion af lis like

(1) July 2.7. 1-5.5. he was ejected at

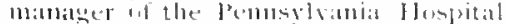

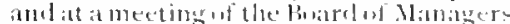
helel at his resielence Mated 3. 1-4ese he Wats come of the committece alphesinterl and instructed to report "ofl it plats of

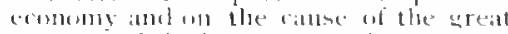
expense of the hollse." A plath liat res ported be which copenditures might lu

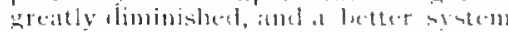

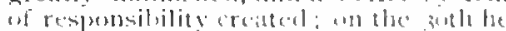

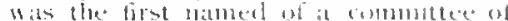
three "tu revise the nuinutes athd prepure

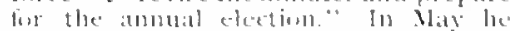

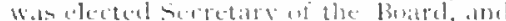

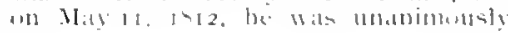




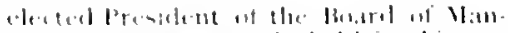

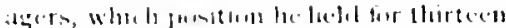

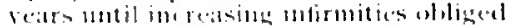

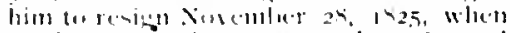

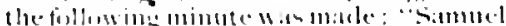
cinetes, the lenerable p'resident it the

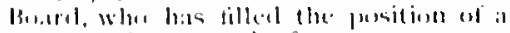

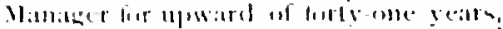
.mol setrol the institution with ze:tl amb

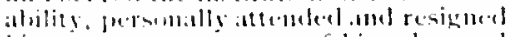

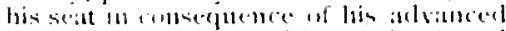

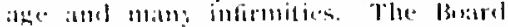
regrets the neevesity and acommpallic his retirement with sincerewishes for hie heath : aml hitplintess."

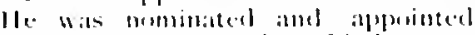
Aluoust it, 1\%t, a member of "the aser

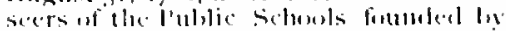

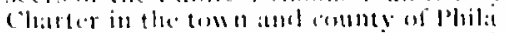

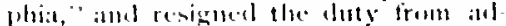

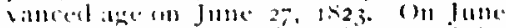

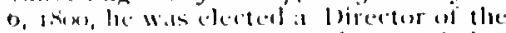
original bank of the linited states, being one of the mumber elected to sueceded those members who were reppired ly

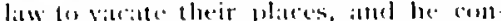
timued in this pessition tumil the close of the Batlk in int2. In $1,-4.4$ he wats elected

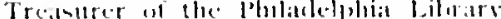
Complany, and helal this position motil

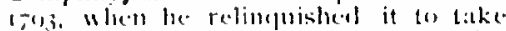

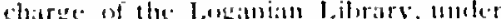
the same thectors, atsel this he held tomtil failing enesight compelle.el him to resign on April 2., 182t. having been Treasuret fol a perion as thire twe rears.

lil tis veat 1822 demble eatarate at -

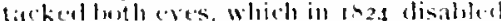

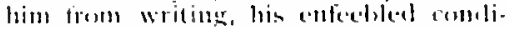
timl being suld that br, l'lysick, lhe

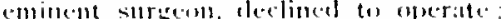
to this affliction was alded consideralde dealless: lint a rear precedimer his cleceatse he was combined to the homse, the latter half of the reat mostly to his e hianluer

"lec lermination of lis life ncented

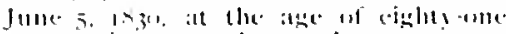
years ninc months and twenty-two dais.

In the fursession of the Itospital is

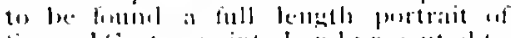

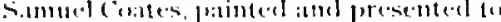
the institution ly sully, the cument artist.

The Buircl of Mamaress callsed the

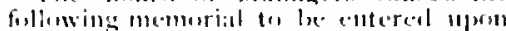
the Minnter and to be puldished in the latily papers.

. At a special meetimg of the Managers of the Pennstrinia Itospital, held 6th mumth 7 th, I 2313

“The Mlenagers having assembled for the purpose at follow ing to the grave the

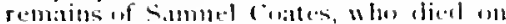
the 5 th indent in the e*iehty-sectuml year

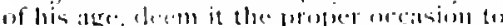

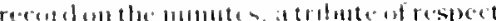

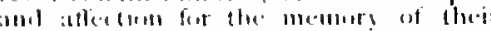

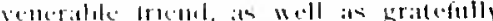

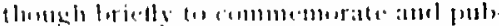

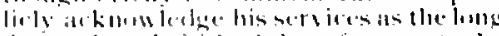

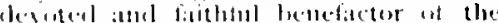

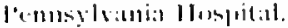

"Kesirling in hiv youtl with a relative

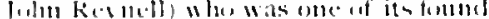

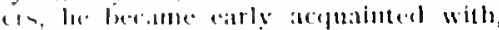

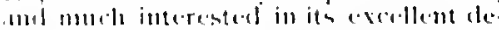

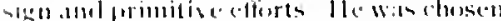
it m.thitger of the institution in $1,-x 5$ and

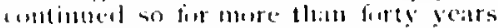
dering which perind he aceded as secerelary

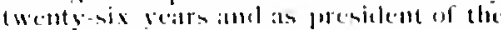
lichat enser thiteren veits.

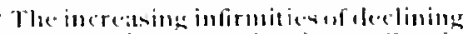
life inclucel him en retire from sffoce in

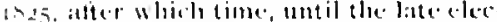

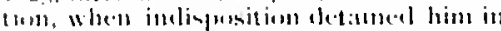
lus chamlu-r, he showed an mual,ated all

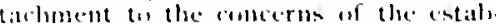
lislument, by attencling and peirticipatime

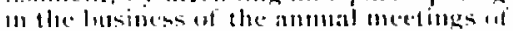
the antrilnturs.

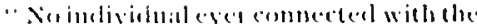
alminist ration af the Itomptial bestumed at much mersonal attention 11 mon its at fairs; and a comsiclerable portent at the

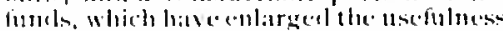
at this moble charity "sere obtatined by

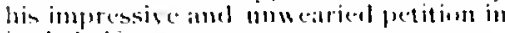
its lueliali.

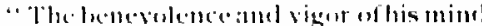
were levelopued an all ocrasions, wheo silfering humanits misele the appeal

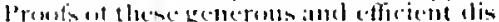
pesitinsts, are lust few, and they were srikingly illustrated in the neomurable

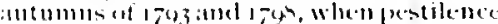
(Yellaw Fener) and death reigned in lehilaclelphia. (In the former of those awfill seamors he was assiduous in his

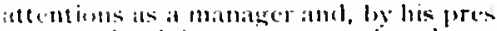

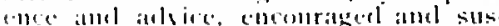

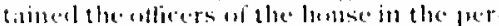
formante al theje dutics, imiclst the sur

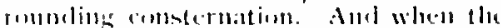

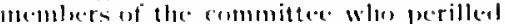
their lives for the relief ef the siek amel

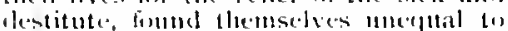
the exigencies of the nareasme and requested ajel of their follow-eitizens simmel Contes promptly uflercel himself as an assistamt, aturl continued to extemel cate over the distriet af the city and ter furnish suce'ur enthe aftheted inliabitants, mutil the reture of his health, and during the of her prerionl of calimity, he retmained in town and wats the only manderer of this institution fomtud at his pust throughemt Alse epichemic

The feirful circumstancesof that dis tressing moment induced him to propese (1) attend at the llowpital in the place of the steward, to ental, Fratcis lliggins 
whe occupped that station, to assist in keeping the consicta at the penitentiary,

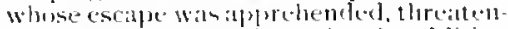
ing plunder and conllitgrat ion, in allolition to the sorrows which were dispensed to end then deveted metropolis.

"The fulfilment of atl these imprertant duties was distinguished by a remarkable single-nindedness, enersy, and simplic. ity of purpose, which at once pruclaimeed that he sisught neither influence, wor the dispensation of patronage. mor any worldly gain, as ineirlent to his pulylie functions and bentefient laburs. In this he was not the min of mere pretensions, amel his example is therefore full of in struction and wortly of intution and praise.

"In reference to higher amel purer eon sicferations, maly nut those whon now ontemplate tinese estimal,je and beatutifu principles of his character, be permitted to believe, that as they originated in his reverence of the great doctrines of Chris. tianity leading lom to dericate his life to works of mercy and kindness, su will it please the Author of all goodness to be stow upon bis departed spirit, a reatird ie'lich cannot fade' aac'al'.

"The secretary is requested (1) cause the above minute to be inserted in all the mewspilpers."

FLLISTOX PERAT, elected 17the re signed 1506, was born Narch 16, 17.7, in the Island uf Bermucla.

At the age of seven years, he wats sent to Kew lork and educated hy his uncle Ellistan, then Collector of Customs. 111 der whose care he spent five verars at school at New Rrichelle. When his uncle died before he completed his ediucatim, it necessitated his return t" Bermuclia, where he lived until his twenty-first year. when, hasing an inclination for metrall tile pursuits, he returned an Xow York and began business in the West India trisle.

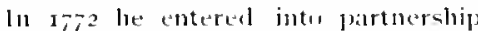
with lis lorether bohn, under the firm mitme of Elliston is John Perent. in the istand of San Dumbun, where they cont tinned antil 175, when with the prospect of greater advalutiges, they remoned to st. Christoplers lat their expectittions wot being realized, the s left that plare fir St. Eustatius, then under the drminion of the Dutch fossermment Here they remained until $1-s_{1}$, when the island was surprised and taken by the British flect and army, under Admiral Rewlney and

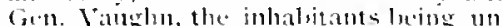
aware of hostilities existing lutweet Great Britain and Hollatul. Fllist,n and John Perue being made prissmers of walr

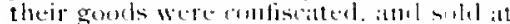

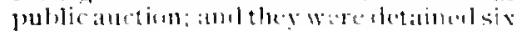

months ats prisulers of $\mathrm{kat}$, whell fiberated, they went to England, and matce an umsuciessful attempt to prosectste the military offecte for what they onsideted

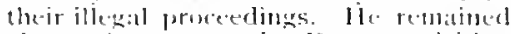
aberst three rears in Eurdu, risiting

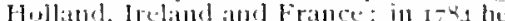
retumed to the lnited states, and recommencerl lusiness with his brother Juhn, in meriliatuts.

In $1-56,111$ was admitted a member of the Sorciets of Friends, at the monthly

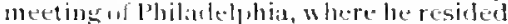
during the remainder of his life.

On January $9,1,-5$, , he was married by Friends' aremengy to Saral siansum, mily laughter of Samued and Lammah Salisim.

He enimeal excellent health unt the atumon of th2, when he was attacked with influcuza at Yellow Springs, which left him subjert to asthma.

IIe diecl xinember 24,1434 . aged eighty-seven years.

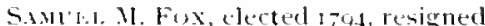
1797

Mr. Fux tilled many puhlic pusitions. being a member of the corporittion, and Presictent of the Bank of Pentssylyania; Director of the Plitadedphia i.ibrary, and Truntee of the Conisersity of Pennsylvinias. His talents. interity and in dustry, and his atteonion tis the interests of literature and art, reatered him an extremedy useful member of the community in which lee spent his life.

Ite died April 30, 1 sing.

Roblikt Widix elected r 705, resigned 190, Wiss desconded from an English Quaker limily of tettle, in the West Riding of Vurkstice. Purn in Philactelphia, February 22, 175.5, he was educated at the Friende Acitemy. He inlserited a larece estate anel embarked in tusimess in with his lerother, under the firm-nane of Jesse and Robert Waln, and continued the llowt lodia and English shipping business, which bat been estallished by

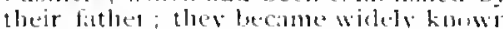
for mane veats in the fort livilia and China tratce which almost equitalled that of stephen firarel.

Mr. Wialn wats for several rears a mem ber of the state fegislature; was elected

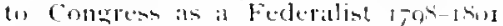
During the wat of 1his, he huilt the first cotton fictury in this cisuntry : anl was lareely interested in iron works at phos. nixville, l'a. life was a strulg protectiondist, and was selected by "The P'onm. sybania seciety for the lincourarement of Mamtatures. "tu refute the specions areuments used in a paper on free trade. He pullisherl his "Answet to the Inti Protectise Report of Henrs l.e." "while the evertement of the tatrif fue hum wats 


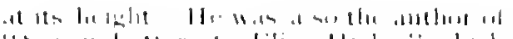

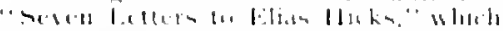

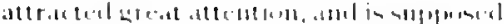

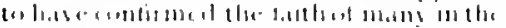

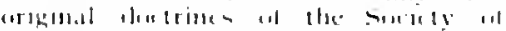

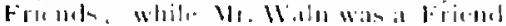

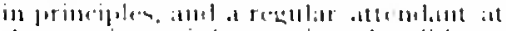

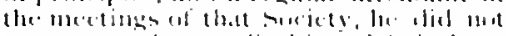

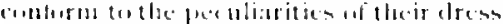
and lingendige

Ile. wals for man! yeats a membler al

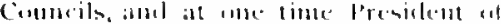

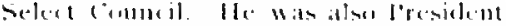

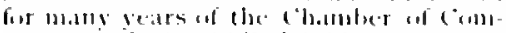

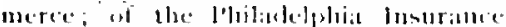

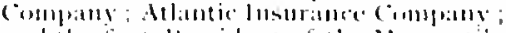

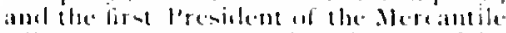
lithary (inmpats : amel a birector of the

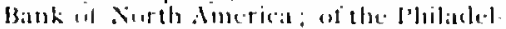
phial Lilirary (ompuns: a Trustere of the

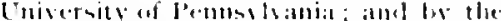
will of Steplen Girard, me ef ahe Ters leces of lifin estate.

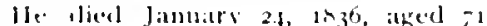
vears

Jullin Sivllu, Ik., electerl 1-us, re

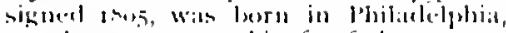
(betoluer is, 1,50, his firefathers were menteres of the Sucinty of Fricouls.

He. was whe of the represemtatives rof his porl-father, James longall, in the ad ministration of the atlatirs of the l.ibrars. which he had estathished.

llhen actively engated in mereatile pursuits he successively officiated ats it

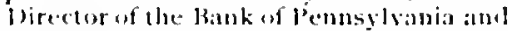
of Nurth America.

ile died sepetenter 16, 1833, ageal nearly eighty-three years

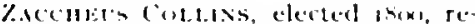
signed 1522, was born in lihilalelphial

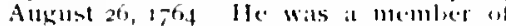
the Society of Friemds; a promenter uf and Viecelendelent if ihe Acaclemy of Natural Sciences: alss, of the Anuericat

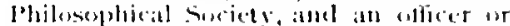
member of ming lumatue and religions societic's.

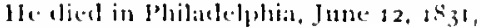
at the age of sixty-ix years.

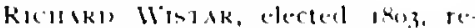

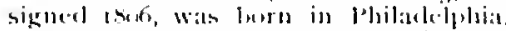
July 20. 1750. Ile was at gramelsoll of

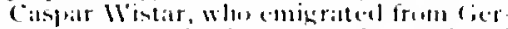
many to Aundica in 1717 , amel estalibliced near sialem. $x$. J., the litst large kliss manufactury in Nuth Americas, in the mantgendent of which he was assimted ly his soln

In early life, Richatrd llistat flevered his attention as mereantile purstets, in

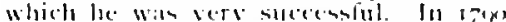

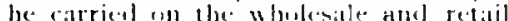

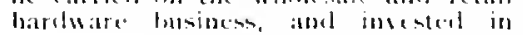

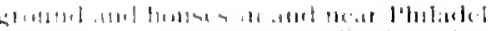

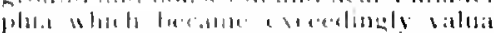
hil.

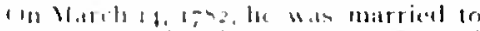

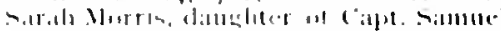
Mlurio ut l'luilatelphilit

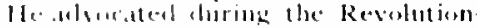

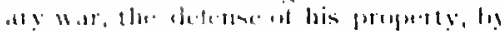

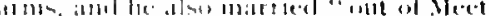

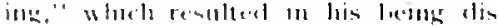

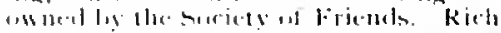

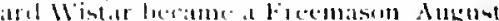

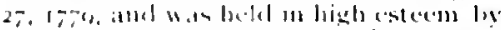

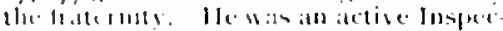

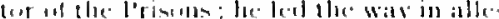

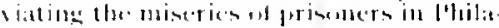

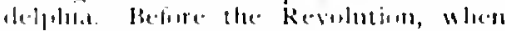

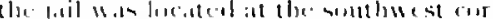
lue ul Thirel and Natrket strects, lue Was in the laclut of coltaing wholesollte sollt,

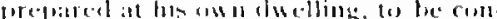
vereal to llse primoners and distriluted

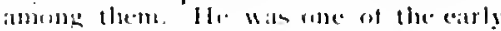

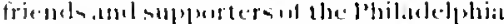
liloriry (intupans

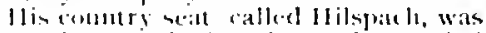

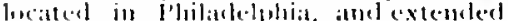

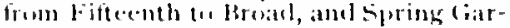

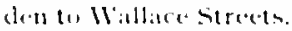

110 elied in l'hilatedphia, June 6, tsit. akeel sixty-four yeatrs.

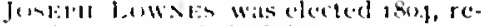

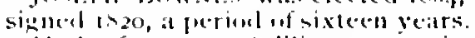

ile le forts vears diligent atrentionto

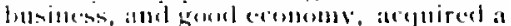
comsiolerable poperty in acholition to his patrimonial estate.

Mr. Jemnes liherality inereased with his means and he becalme a generous eom. tribntar in loth time and mone to the charitable inst itutiolls of the city : le was in the hat it of frequently giving alms zo

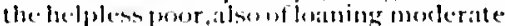
sime of money to volung traclestmen, to chathle them tor commene hasiness.

Ile died J becombet 10,1420 , in the sixty-thirel yeats of his age

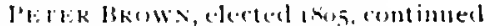

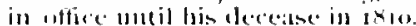

He was a self-mate matn, atud ahlumbh with some peediatiaties, attaincel some distinction: he was a lalacksmith, atud masele a firriane.

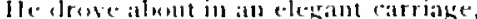
(ot) Whicl was a coaterofithts, which he

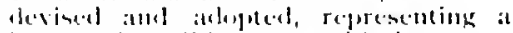
latrece atol smatl hanumber, with the sthettor, "J3y this l and ran."

An Finglishom, whes was buth a traseler allel uriter, refers to Mr. Brown, in a lumb be sllmequently pulslisheel, and preseme an illuatration of Mr. Brown's peomliat cost-of-atms.

He ried lecember 11 , Ifis, in the filtieth year al his atgen 


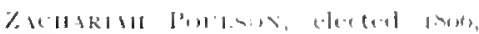
resigneel $1 \times 2 \pi$

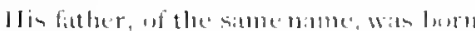

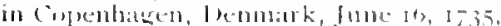

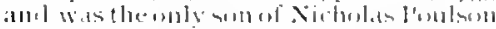

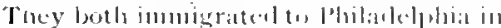

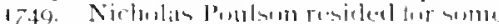

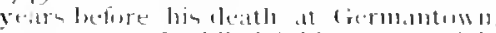

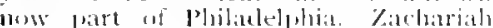
the clder sin, leatroed the printers" trate. in the otfiet of Christepher sinele, the secomel, who matr. lis moll trises ame

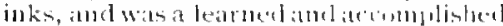
printer.

Zachariah P'onlson was lane in phila

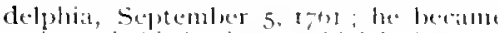
emintent in his lusine sis, whinh he levirute in the extensise orinting offore of Jostol Cruikshank, then inl Mitket sitret

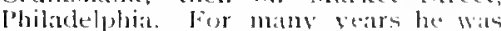
printer in the senate of Pemostrame he printed also, in folin, the "Monuten the Concention, ilpminted to gevise ame ancend the Comstitution of the state" in tha. He also printed and pulplisled "l'roud's History ut l'ennsylsindal " in 179-98: and "ipoulson's Tuwn anel Counte Almanic," which he printerl

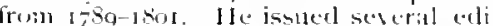
tinns of 'The American Tutur's Assist ant." He printed the curinus mystioil works of IVilliam Gerarde Brim, in wite actave volume, for the atsther: alsi, other viluable bowks; and, from time to timse, the "Jourmal of the Getleril (innen tions of Delegates from the Alublim Sucieties of the Initerl stitess," (from (-04-1801).

On Octuler 1, 1300 , le leegill the puldlication of the "Ameritan Daty Arlyer tiser," the first daty jotarnal in the l "inted States: having purchised the "guml will," printing offec, and uther materials of "Claypooles American 1)aily Arlver tiser," from J)atid (". Cliypmule", for ted thesuand dollars.

He was unt of the fommders and, at lifis decease Was Prustemt, of the Society for Alleviting the Miseries of Juldit prisons. For nearly fifty yeats le wa (e)mected with the Library Cimmpans of

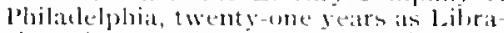
rian, six years as Trealsurer, and thits twe yeats as Directur: his portrate pidinted hy Sully, hangs in the hall of the company. llewasalsis at I birector of the

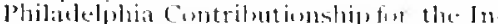

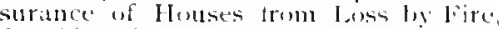

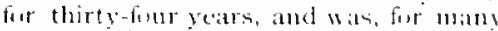
years, senior member of the butrel.

He died July 31, a 44 , isedediglity theo Jititis.

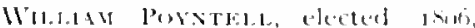
cumtinued in office until his elecente in IX'I1.

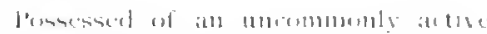

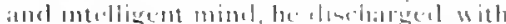

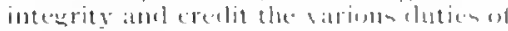

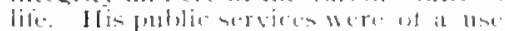

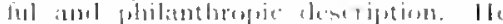

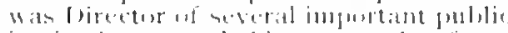
inditutions: illul his perestlal lelforts

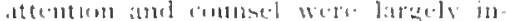
strumental in pormoting the ir pu-romathent

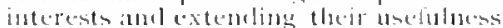

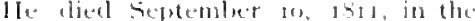
tifty-lifth year wh his aste.

T11)

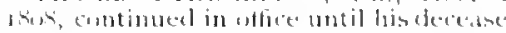

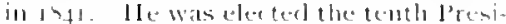
dent 1)ecember 26,1425, and situced, al allet. antil his death.

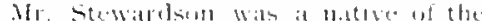

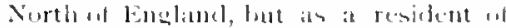
philalelphia for more that hall it rem-

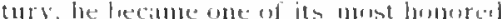
stizens. Ile was a comsistent inul lath-

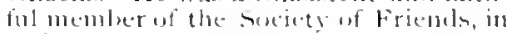

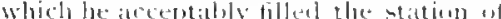

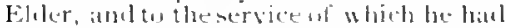
devisted the areater part al his lisule all usetill life.

He matriced Marearet 13., datughter of Renlen Hantes, of Germatuteme, l'hilat delphia.

Respected fur his elisinteresterluess and integrity, lie filled his varjums stations in cisil and religinus socitetes with quiet and fratient diligence, and his preatefid ase amel gentle death formucel at beitutiful clise ter a wetl-spent life.

Ile dieal sudelenly" at Xewjurt, R. 1.,

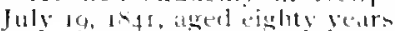

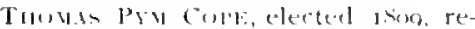
signed 1tags: acted as the thirterenth

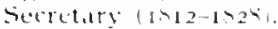

Tlumbis l'. (inge was a native of I am-

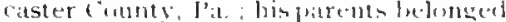

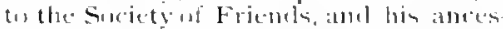

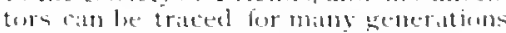
inmong the members af this socioty

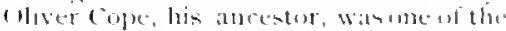

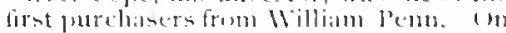
the matermal sule, be tesecoled trom the J'yme, Whe cham ats an athecentur Johm Jin. the celethated lostiamentarian.

Inaving completed his educition, Mr

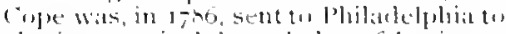
a) tain practical knowledge of lousiness,

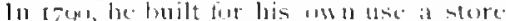

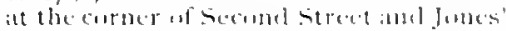
Alley then known as lewter I'letter

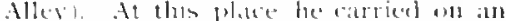
cremsive fusiness, inpurting lis awn

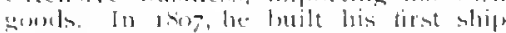
allel llanded it after his mattice cmunty "I allntister."

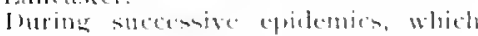

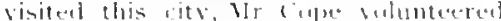

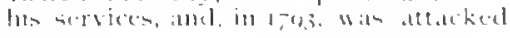




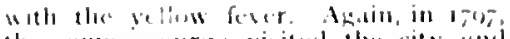

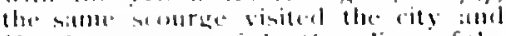

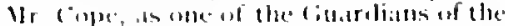
line and Namager of the Almshouse", debered much of his time in the alle-vit. tirn on the mblle rings of his lellow bejugs.

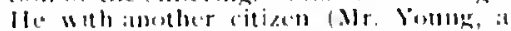

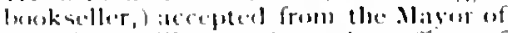
the rits, llildats Bater, the office of Almoners, to idsminister directly to the Batuts of these suffering foum destitution

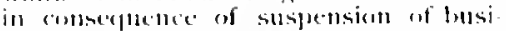
messe several thousand dollars wete thus expended lay Mr. (ene and his coul. leapule, who often persemally carried the

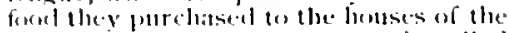

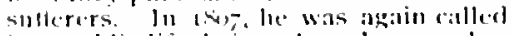
inter public life, being alected a me-mber of the leegislature.

In 18 so, Mr cope removed hishonsiness tu Walmult Street whatf, where it was sulderequently carried on hy his soms for many years, the lirm being successively Tlumats P' Cope \& Son, Thomas P' (op)

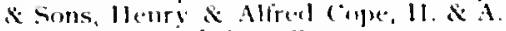

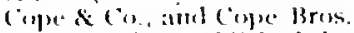

li1 R $_{21}$, he estalblished the lirst regular line of Packet shipe hetwern philidel.

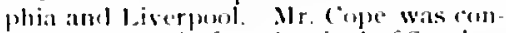
lemporary and often the rival of Stephen firard, with whom he was on terms of int imacy and friendship, and was selected by the latter as one of the executors of his will, and one of the "Trusteds of the bank. As a member of select conncil if l'hilarlelphia, Nr. Cope for at timse was l'resiclent of the Benard of (ommissioners if the firard listille; and was sulese. quently elected be solect cinuncil a ibectior of the firard college for urphans, which be declined. He wits also actively interesteol in completing the Chesilferate ancl l)elaware ('anal, and in the constrmetion of the l'entus lsamia Railtriml

He died Novemtert 22, 1 st

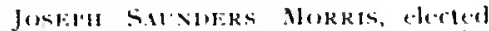
site continued in affice until his de. reatse in that

Ile was a firsmiment brewer of the cits of Philatelphia. Ile received in early life a good edlacation, and possessing at strong, artive, and well-informed mind, he genserned all his life by the striat precepts and principles of religion and morality. and wals widely known for his leenevio ience.

He dixed Febratary 16,1 sis, in the forty fifth vear of his alge

Jomenth Matod, elected Isis, resigned 12,4

lie filled several important pulstic of fices, which vained him the esterim ated resject of his fellow eitizens. Mle wats

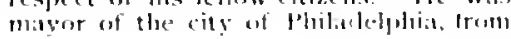

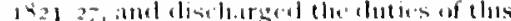
imingtant iffece with moch eredit ams

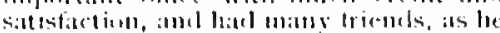
wats pussestad of conttly, ambiable, and pileikimg matumets

He diel Apris on sift, in the lifty seresth year of his age

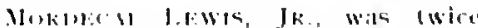
- fecled in tista and resignted grike, algan

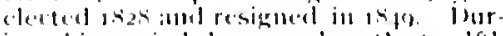
inte this periout, be served as lle twelfth

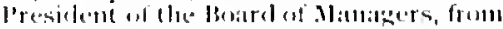

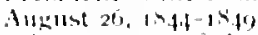

1i. win ane of the fone soms of Mlorde.

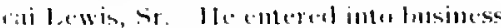
with his inother, Sammel $\mathrm{x}$., meler the tirm name af $\mathbf{~ I . ~ \& ~} 5$. N. I. W is, as ship owners and commissien nerchants Their commercial relations lestame very crensive and continated to be sofor many veats. In 18ta, they lecattere, by por Chase, the owners of a white leald mitnte. factery which had been established it Int 3, he Joseph Richardsom. They in. creitsed the prosluction of the works from

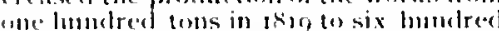
in 1634 , and one themsand in tiffe. They also crommeneed in 1817 the matulatacture at acetic aciel, and in is 30 thee marle lanseed oil. In sisothe. established their "wwn works at Riclumond, (now at part of philadelphia ("ity), and increased the ir lusiness by the insondacture of red lead litharger, mincral, aceetille of leatel and ubler pigurents. The wereold lishioned merehimts, gentlemen of the purest houbcter. most admirable manners and highest respectiability.

Mr. lewis, though atively engaged in business, wats nea neglectiul of publie in. terests, ir of the broitler interests of humbanity. In Jith he was one of the founders and the l'resident of the socicty, for ofrening soup-louses for the poor, which wats the pinener assen iattinn of its kind in Plitidelelphia.

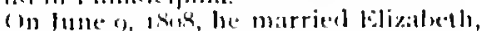
ditughter of l:mes and bisther simith.

He died Alugust 15,355 , in the sixtyeighth vear of his age: be was a member of the ivesterth listrict neomthly meeting ai firiends.

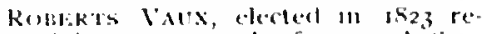
signed in tis.t. wats the fourteenth sted

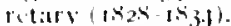

Ile was desiended from an anciemt family which emigrated from France to

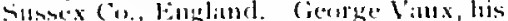
Heath gramdfather washormbear Ryegate in $16-1$. Ile was a physician, and a ment. lee il the Serieds of Friends.

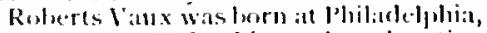
Jitumary 26, 1-56: his early eductition wats olitilined at Friende' Aculdelly. At

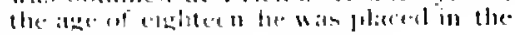


counting-bouse of Jolne ("inke, mer cluant: at the ase wir twenterome be entered metreantile lusiness

He was it member of the Society for

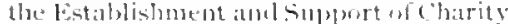
Solwols as carly ats the : and ante of the originators of the lnblic sillawl sistem of lemes: vania beine the litst l'nesident

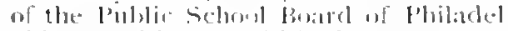

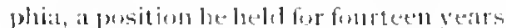

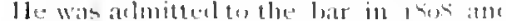

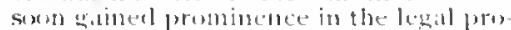
fessim. He was alse al member of the Plobelelphia societs for Alleviation the Miserics ol l'ublic l'risons: one wi the

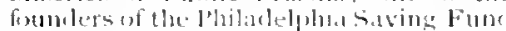
Societ of of the Institution fin the fout and Inmb, the Apprentiens' Lilurary

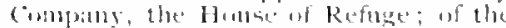
Institution for alo Instruction of the Blind, and other benesulent institutions

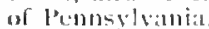

He was the of the Commissiners of the original bated fir the erections of the State Penitentiary for the Eastern Ibistriet in lentusylyalia, and became : writer of distinction un penolongy and an antive worker in the prisoll-reform mone nent. 11 wats alse a mendere of the American Philusophieal suciety ; Acade my of Nitural Sciencos: Limnitiu Societs; Famklin lustitute; qhe Athenatum alsi w a number of scientilic sociteties of Furopte the was appointed lor the Presiclent, with arlice of the senate, it d)ireatur of the Bank of the l nited states in 1tiz3: also designated bey lertesident Jackson, Cummissioner totreat with the Inclians. He was also offered the mis sion to st. Peterslurs, which be declined.

13t published, in I sog his "Fulugium on Benfamin Ricleway smith ; "in Ity "Menuesirs of the Lite of Anthony Bent" zet :" and in I 21 a Freuch translation

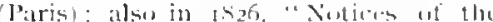
Original and Sucuessibe Fifinte to In prove the liscipline ot the lorisen at philatelphial."

He diecl at Philatelphia, Jammaty 1836 , aged firty-nime scitrs

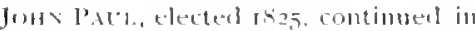

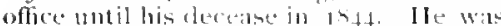
elected July 29. [s, the therenth I'resi dent, and served as such three yours.

Ite fillecl many inportant positions in

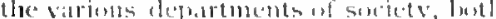
civil and leliglons: Walm a prominent

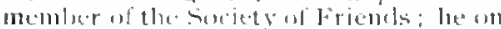

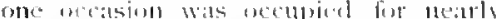

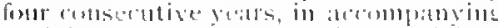

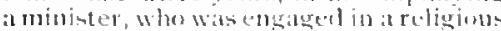

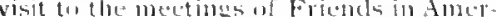

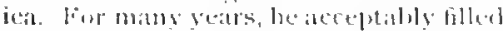
thte w firlte and responsible position al

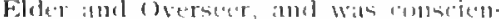

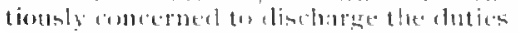

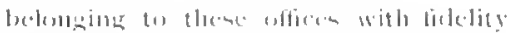

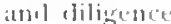

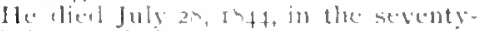
thind yeats of his atse.

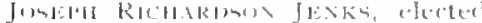

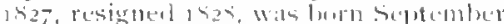
10, 1757 . in Midillelown Township, lincks

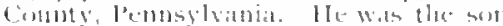

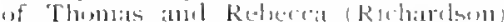
Jetiks: Lrandson of "Thumas and Neley (IVilebnald) Jenke and Justph ame Mart

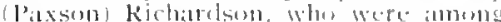
the carly settlets al Widrlletwon Township, Bucks cintuly.

'llumals Junks, his father, wats at farme't who wats the proprietor of a fulling mill in Buck cistuty which his fith her hat run hefore him: the mill heing estaly.

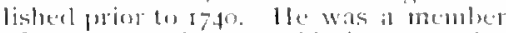
of J'ennsylumia Assumbly in $1 \% 55$ also of the cioncertion which framenl the (int stitution of Pennsylunniat in $179 x$; and was at state senclior at the time of bis de'ath, Mation, 1799.

Mr. Jenks s cilly years were spent in Bincks cimonty. IVhen a voung man, he come to philiatelphia and established himself in lusiness on Dulaware Avenute.

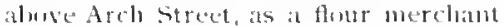

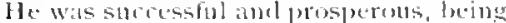

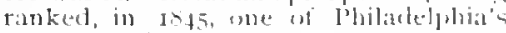
weilthy citizens

He was matried three times: on (boto ber 10, I792, to Saral Watson, who died lonember 5, yous. His secund marriage

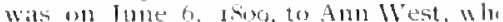
ditol Januaty 17 , A42. The issue of thi natriage was three deughters, (n) in when elicel in intincy. of the remaining two, Hantmah and finn, the fotmel was mitried te stace B. Cullins, of New Jork the latter to br. Thumas S Kirklude

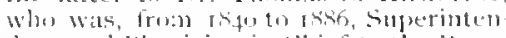
dent and l'lusician-in. Chief to the l'on-

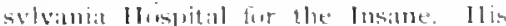

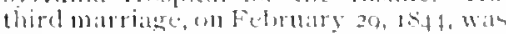
(1) Ann Ely, who dited Junt is, 185

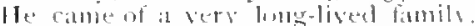
his grancliather, "Thumbs Jenks, lived to

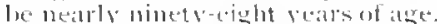

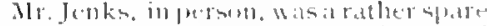

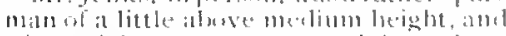

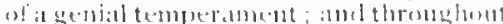
his atctive life lue was a prominemt amol intherejal ritiment

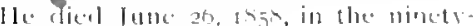
first year al his agec

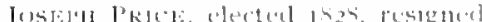

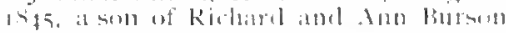

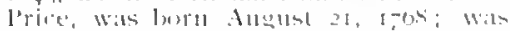

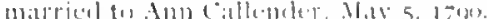

He wath a merelant, hat retirebl fram business arty in his marricel life, ami

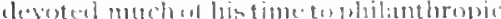

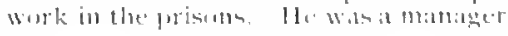




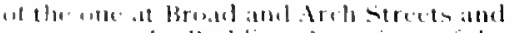

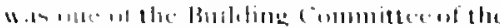

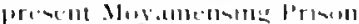

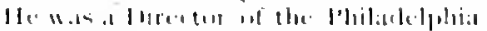

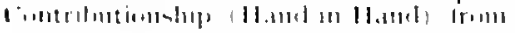
$1 \times 1 \times\left(1,19 f^{\circ}\right)$

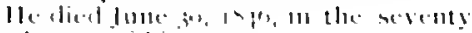
sixth seatr of his ase.

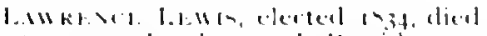

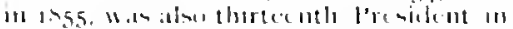

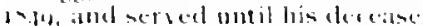

Holle tather's side. Wr l,ewin Wis al

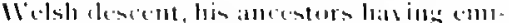
yrated fiom llates in the Jatter balf at

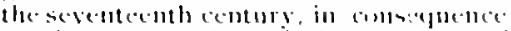
at the peracention ai the siectety Fiemels, if which he whe a memlet. llis mothers fatmlly, the l.atutelles.

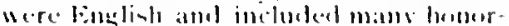

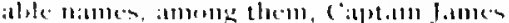
Lawrence, wi the [enited States Niab and lieneral bawresue kearmes of the Armo.

l.anrente len is Mas furn in l'hilatiel phia, on the 1, th wl fuls, 179-, Sim after his birth. the limily remosed to

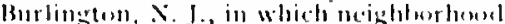
ho lised and received his elusations. Ambitions on impresement, le cance to Philarleluhia, when alust twenty reats al age. and entered the inumting-fomse nf lis limether-in-law

(I) the fth of April Mo he married Ann Maria, daughter of John clements stoeker, Ese, af philadelphia.

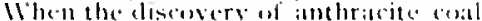
was mate, Mr. lewis wats early in tlu field and became a lamd-awner in sichuyl. kill (intusty From that time be (ain tinned to be largely interested in the cheselopment of the mineral resources at that contuty

In the municipal, tinancial, charitahle. and religions terenth of l'hilaklelplita. Mr lewis alwass louk a promment bart, atud he was electeal a me-mber al

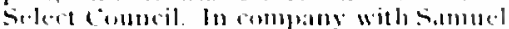
V. Merrick amel athers, he steceoded, in

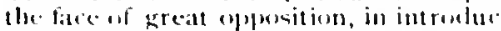
ing gas inte this cits. After serving an councilmate hor a munber al revass he" resigned Mlr. Lem is served as l)irectur of the Bank of the Lnited stattes atud sede retary uf the Mutual Asturatuce (im patuy, remannime with the formes com panis until its dissolution.

lior thint font yours le was a Manager

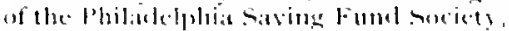

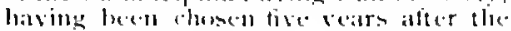
surely wals oryanized.

Mr, bewis frecame a Wanager of the Penusylunia lluspital in the vear Isit. and contiment his cummertion witle the

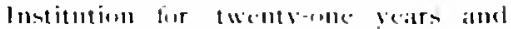

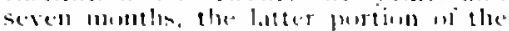

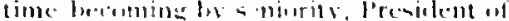

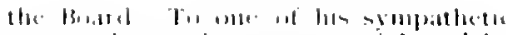

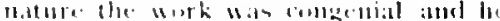

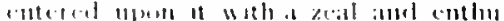

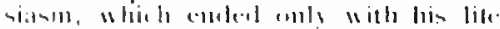

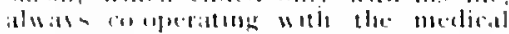

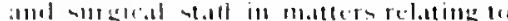

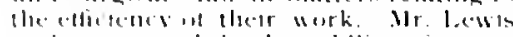

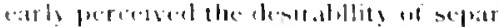

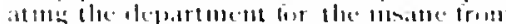

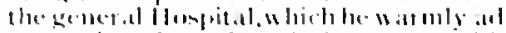

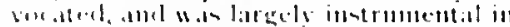

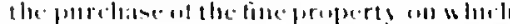

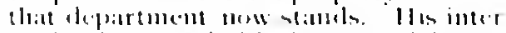
est in the Iluspital is illustrated lis the

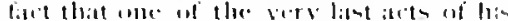

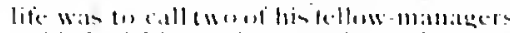

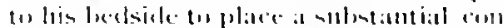

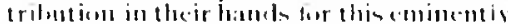
warthy whetet

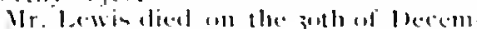
ler. 1.a5s, in the sists gitith vear of his itie.

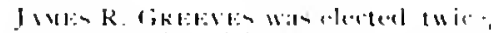

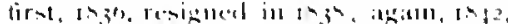
remierlecil inots.

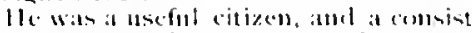

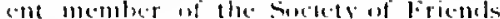
llis imparied lealth, lowever, makle it

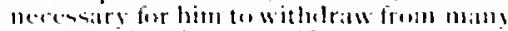
of the ative aluties of life.

Br. tireeves was thatimath of the

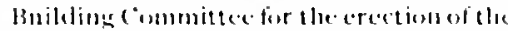

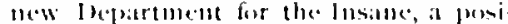
tion he helat fert four geats, bis service

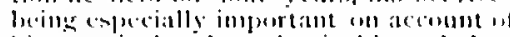

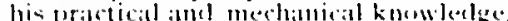

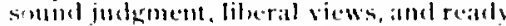
appreciat int of the varied reguirements aithe lustitution ju his servicen mul at the excellence and completeness of the 11 ospitial was ilue.

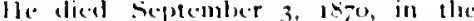
seventy-sixth year ut his atge.

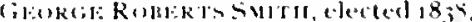

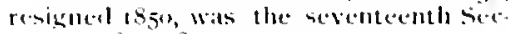
reqatry $(18,10.1850)$

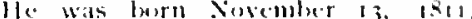
received the degree ul $A$. î. from

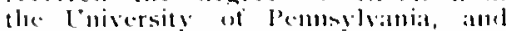

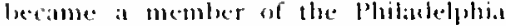
lisir

lite made a cemsiderate amel gencerous sift to the leounselvamia llospital for the

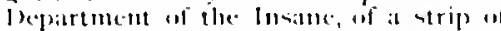
lamel seventy fect wide and extemdius the whole aistern fromt of the IJuspital erounds, from llanerfierd Road tes the Mest cliester Roble comtaninge about

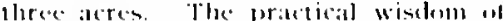

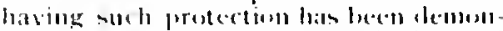
strated by the fart that since his times all

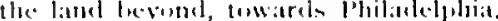
has heen laibl out in luildime lot

He dienl Why of then, aged lifty-six vacurs 


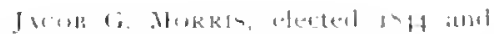
sersect until his deeth in 1254.

He was born in prilackelibial, July 20.

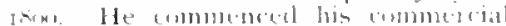

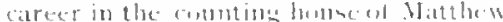

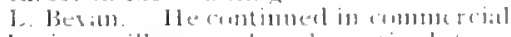
buminesstill ang, when he retireal trosm

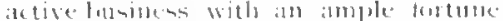

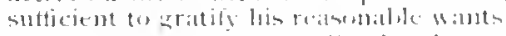

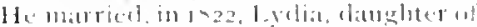

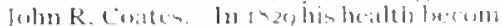

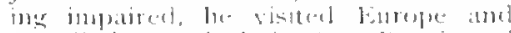

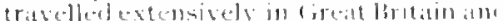

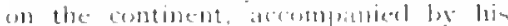

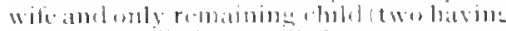
presioms diest. In little oner a reall with bealth rentured, lite returnerl to

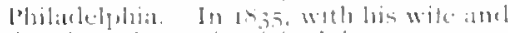

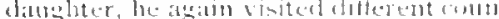

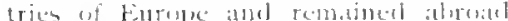
until as' an thin trips his wite thed at

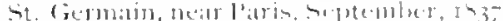
He pissed co maideralsle part of the veats

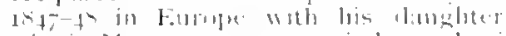

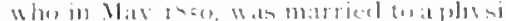

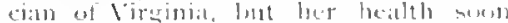

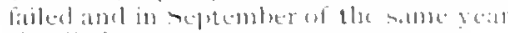
slate diet

Axain, in M.5. Mr. Murris embartien for Europes atrised in liverpmed and

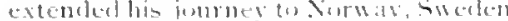
and benmatre, alterwath vintect Paris

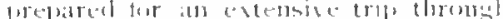

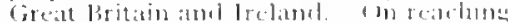

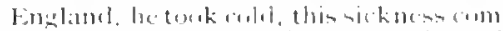

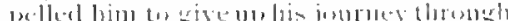

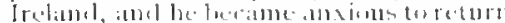

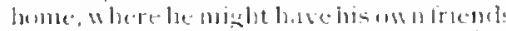

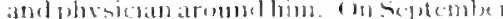

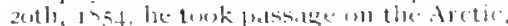
which steamer, when seren dass cut

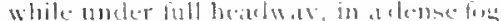

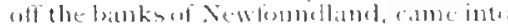

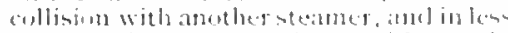

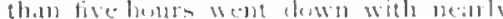
three bundret pasmensers.

The activity eneres and enoud jucler

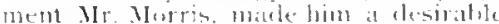
manater in the charitable motitution

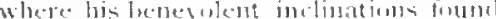

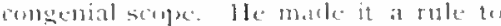
expend all his incomes ancl as him ann

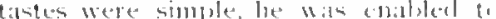
dewele a ereat furtuon of it to dhardty

Jis ancesters were memllate of the

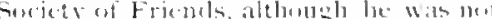
himkedf a member : be was in accosed with their fomdamental ductrines amel frimriples and at combtant attemblant itt their religitus worship.

Iir. Norris att the time of his deatth wa

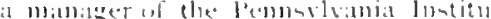
tion for the Instruetoon af the tBlinal

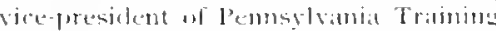

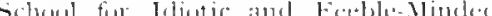
children : and a membes at the peoma

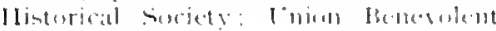

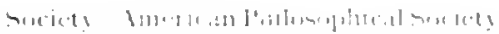

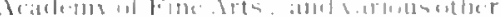

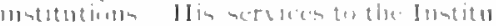

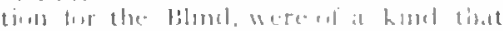

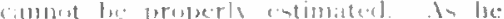

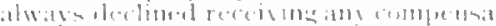
tim.n. the andeributure at line at their

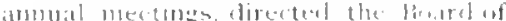

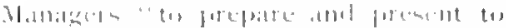

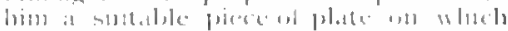

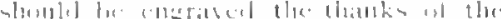

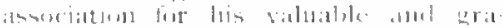

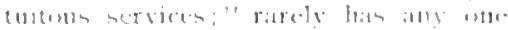

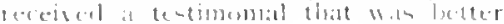
dencotint

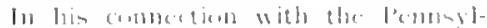

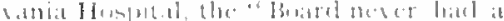

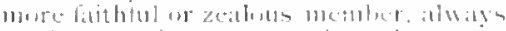

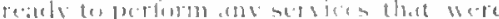

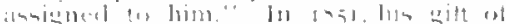

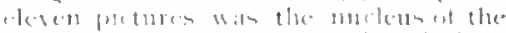

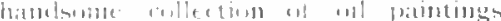
"hich achorn the walls at the ll molutil for the linsille

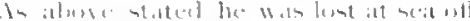

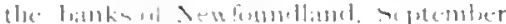

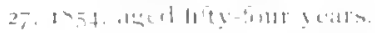

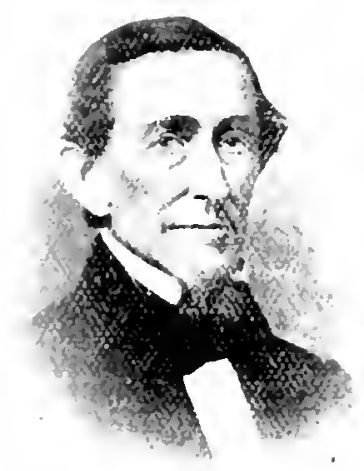

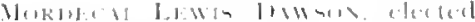

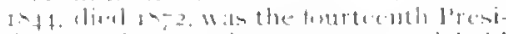

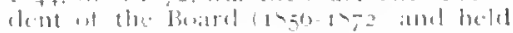
the pumition until the time of loin death

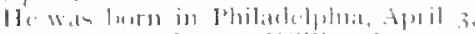

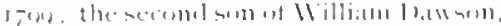

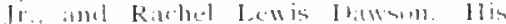

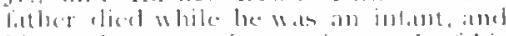

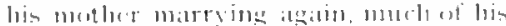

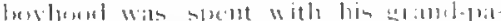

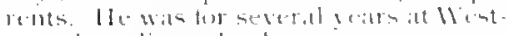

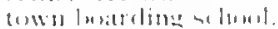

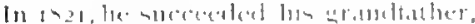

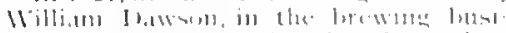

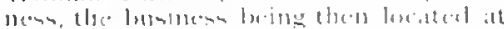

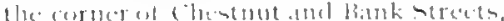

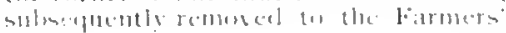


lifewers, at the ander al lenth amel

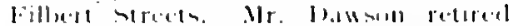

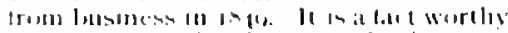

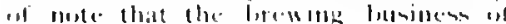

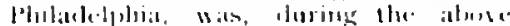

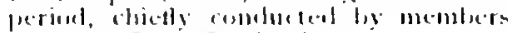
ut the sise ets at foriende

cot a must humbere ame dharitals

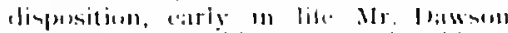

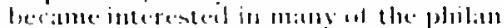

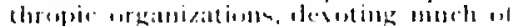
his time lo, them and actively pittici

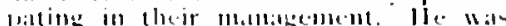
deeply interested in the eatese of edu ratiute atmel wate eprectilly interested in

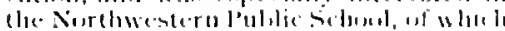
fie Wils a Jlited tor her mally veats.

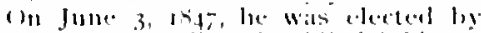

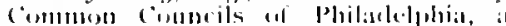

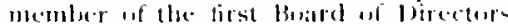
of Girard cullege when it was corgatl

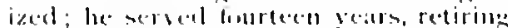
spril lo, sobt, when the direetien, his

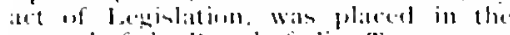
anerel if the Bubltal as city Trusto

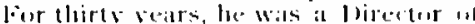

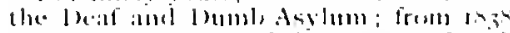

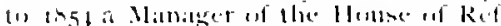

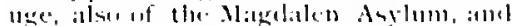

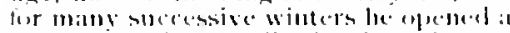

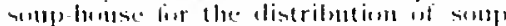

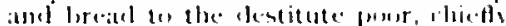
matontamed ly lis privite means, amil from which was estaldisherl, on a more

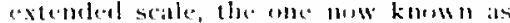
the IVesternsimp Sisciety.

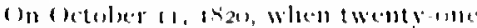
vears at age, he married bizitude

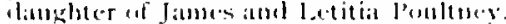

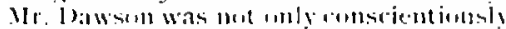
devited le mans latge and valualle [mblic trusts, but lis apuen-lomaled fort

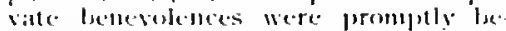

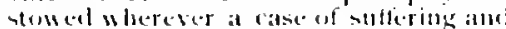
poserty came la his kmoledge. Ilis sompathetic and eenial nature mate him

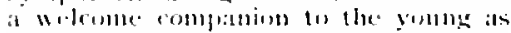
well at thuse of riject vears,

doring the late civil llar lac was and

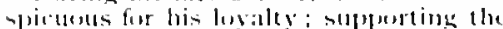
fisinermment, with in moguestioned fath in its ultimate triumph.

1I. ledel the lighest principles of itl tegrits amel mpriglatmess, atml wats a com sistent and fatheful menuler of the cortho

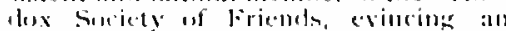

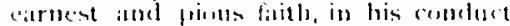

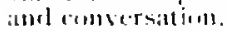

At a meeting w the buard of Mamilgats. in the early batt of the veatr ris. when

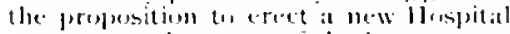
(1) sepatrite the sexes ot the bejartment

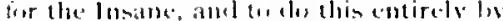

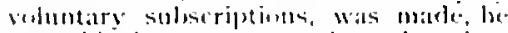
Lave his learty appromal to the plan. amel bhowerl his sincerity ts making the

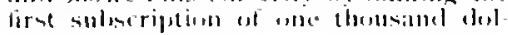

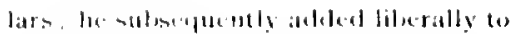

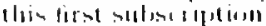

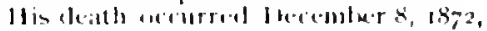
at the alde of sebelly there yeatrs

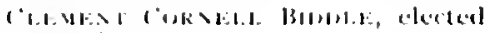
1.940, fliect 1.55 .5

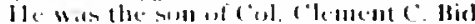

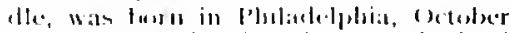

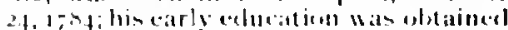

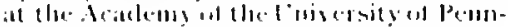

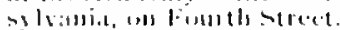

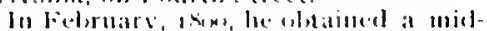

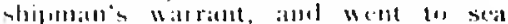

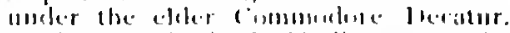
Huring a eruise in the He diterraneath. he was plated in chergent a prise, which les

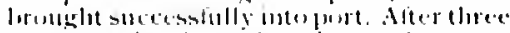

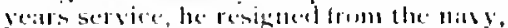
atul afterwarels bisited binglauel. on his

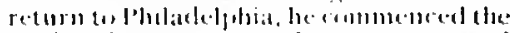

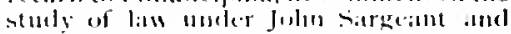

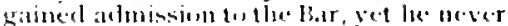

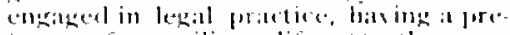
lerence for a military life. In the ocea -ian of the "Clesilpuake" atfatr in

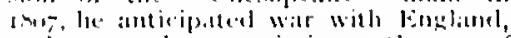

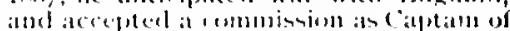
loracums, from l'remident Jelfermest, and was statiented at Xew lifleats. Hhen

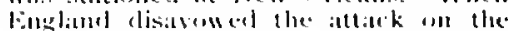

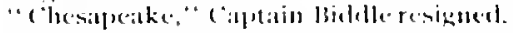

In the war of ats, he raised in l'hila-

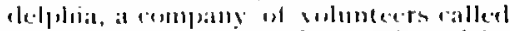
the state Fenelderes, and was elected its

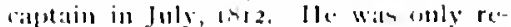
rently marricel amb met wealthy, yeet he sive during the periend uf the war, his whole time and abilities to the service of his cunntry" (m) the argathization of the

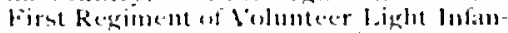
15y of the lemmothania line he was

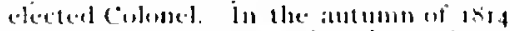
the regiment was stationsed at ciampl

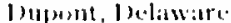

At the elose ni the watr, Mr. Midlile returned to I'bilatelphia, amal wat aj)

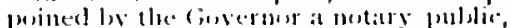

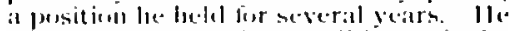
eclited the Americall edition of the

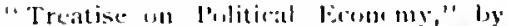
Jean Baptiste soys, translated intu Eng lish ly Prinsej) and with the adolition of nutes inel a tramslation of the intrescluce (ur) essity, (which bact lecell omisted ly tha Fogtish elitur), the werk wats faverably received amel passed througle sesceral elitions. He was an inlluential arlvisor of the goverument in its fondmeial policy at that time.

lu september, 1s31, the frue Trate Comvention assembiled in loibmelphia, and Mr. Bicldle tuek an antive part in its deliberations. lo the lue was elected a

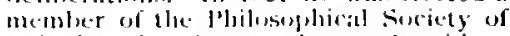

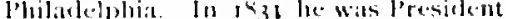

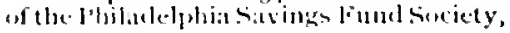


an institutou be lated been instrumental in estallishing and over which be presieled until the time of his death. Inthe spring ol to 3 , lee astain visited Europe, this jourmey, listed about six montles.

(n) lis return to philadelphia, Mr. Bicl-

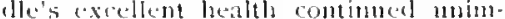
patired until Miay, 1.54, after which he, for many months, suffered from a distressing malady, which prevented him from a.d gabing antively in his public duties, lat his deep interest in every department of the lluspitat, and cspecially his anxicty to alvinace the new buildings for the Department for the Insade, continucel mualsated, and he must long be heds in grattefal remembrance by all combected with the institution.

He died at Philatelybial, Auguit 2r, I 855 , in his seventy-sixth year.

JuHx Farien, elected $18+6$, died in 1872

l]e was ing hirth, education, and con viction at member af the Society of Friends.

[eeply interested in every portion of the Pemasylumia llospitat, he was especially so in the levartment for the lnsime, where be was a frecuent aml ever-wefrome visitor.

Jle wats me among the six whe gave a hearty anprosal to the folin to ereet at new IJospital for the Female lnsane, and slowed his sincerity ly at mee making at first subseription of onte themanam dost. lars in aicl of the oblijert. Hesulserpuently iddeal liberally to his first subeription: he also offereet to give five thomsinul, whenever four other sums of a similat sum were subscribed, which in blue time were obtained.

In his last days and in the testamentary distribution of his property be showed a generous rememblance of the lemensylumiat llespital.

I] clied June II, $\mathbb{S}_{7} 2$, in the eightysecontel gear of his atge.

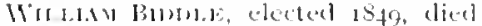
in ${ }^{2} 88$, was elected the filteenth presi dent of the Bourd of Mantige's in 1 s. and hetel the position until his detath. He Wass a member of the Committere of the Board of Mamagers to ereet at new huileling for the vale bepartment for the losime. II e also was the nimeteconth

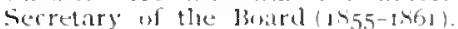

lle was the son of John and Elizabeth

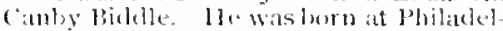

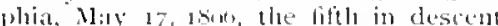
from William Bidelle. who sottled at liur lington in 1690 , allel who was a memlure of the Cruscomor's Council, wille Assembly ims of the comacil of proprietors of West Jersey of the litter body he was for a comsideralde time President. It is frem him that the litrge falmuly in this sity bearing his name is descedided.

Tle subje: of this sketch was the grandson of l wen bicklle, promintent in colonial times, and at one time it cum missary in the army.

II is education was obtained in the Friends' selowol, and thrimg his whole life he touk anl active interest in the edo

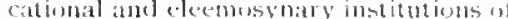
this city. He was at prenoment member of the Society of Frends.

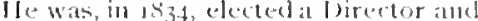
afterwarels a cuntrolier of the imblic sclwols, in which capalcity he serverd: ammber of years. In topo he became Nilliager of the Miagdalen Asylum, and in the sitno year wals elected a frirector of Cirard College. In the oreanization of that imstitution he ters an active part. he was commeded with it fourteen vears He was a memler of the "-hocicty" for

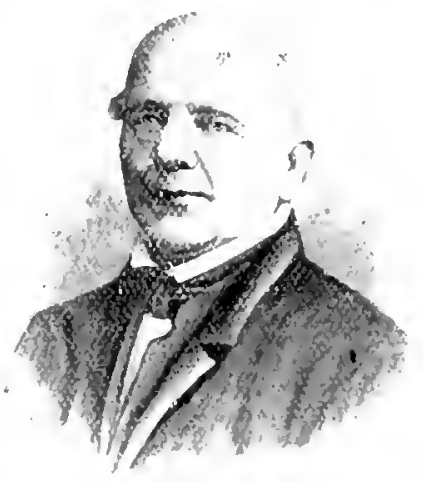

Alleviatme the Miseries of Puldic Pris ons." He was rlusen Presikent of the Mine llitl \& sehuylkill Havers Railroald Comprany in sisez.

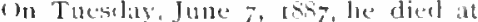
fermantown, philadelphia, aged eighty yetrs.

The Board of damagers of the Penusyl vamia Hospital, at a special mecting bed June o, 1 s.t. nniminously adopted the fillewing minute

"WhERlels, It having pleatsed hitine l'rovidence to terminate the sisthly difeol our friend and colleatsue, William Birblle. we deem it proper to place on onr recort some fitting tribute to bis momory and if our scose of the loss which we and the institution over which he so long amel finthfuly presided, have sustaned by his cleath.

"IIe was elected as a Mallager of this Ilnspital in rista, and to the presielency

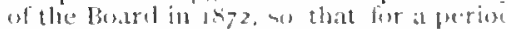




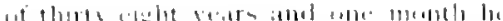

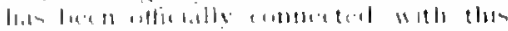

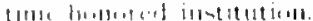

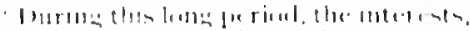

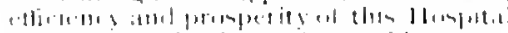

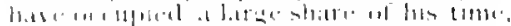

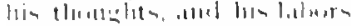

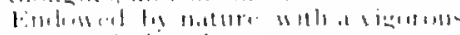

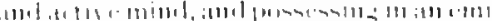

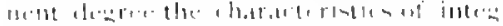

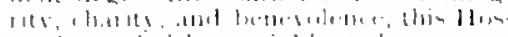

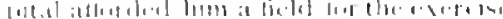
id all low

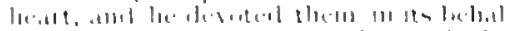

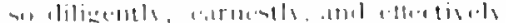

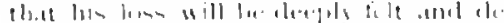

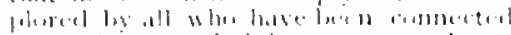

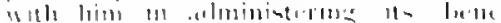

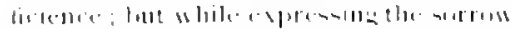

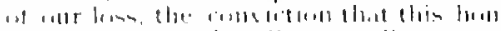

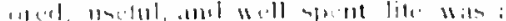

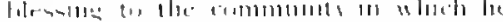

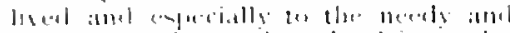

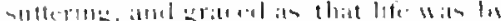

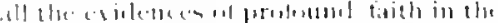

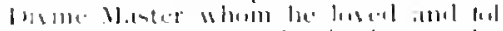

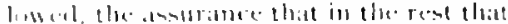

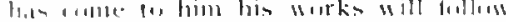

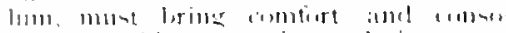

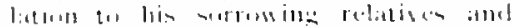
H11.1112

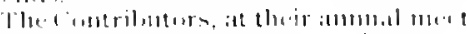

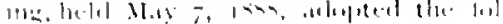
10.36111:-

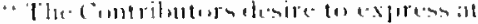

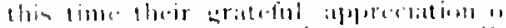

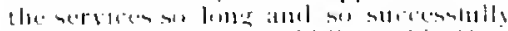

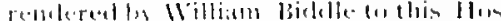

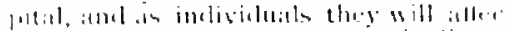

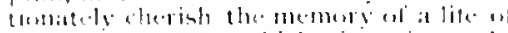

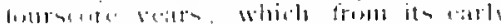

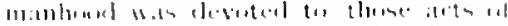

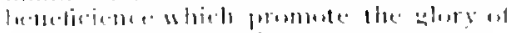

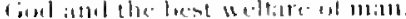

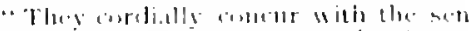

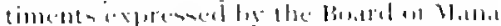

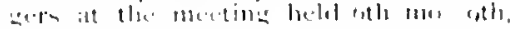
in-..."

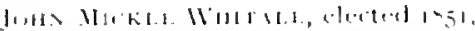

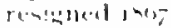

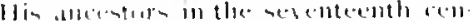

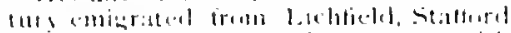

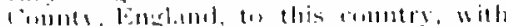

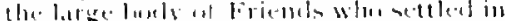

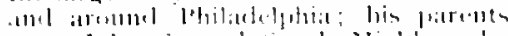

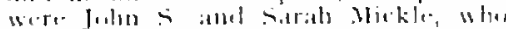

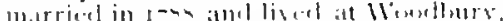

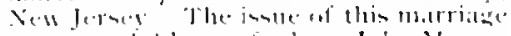

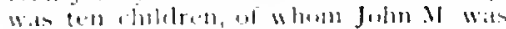

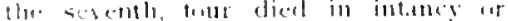
rlifhlunes

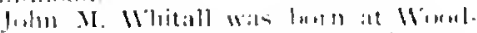

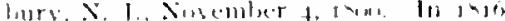

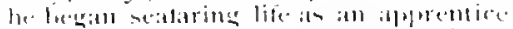

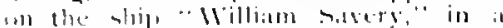

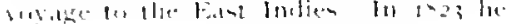

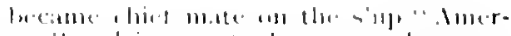

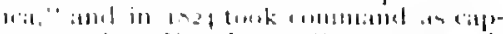

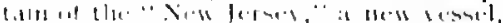

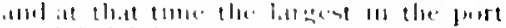

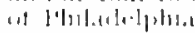

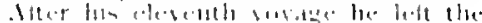

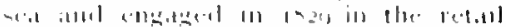

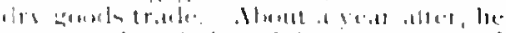

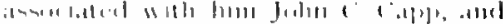

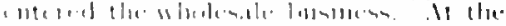

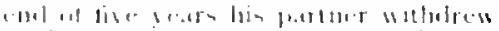

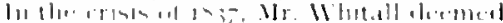

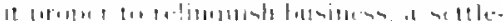

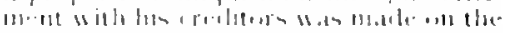

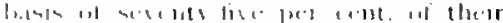

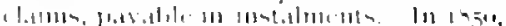

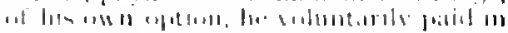

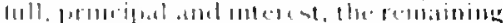

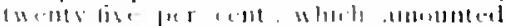

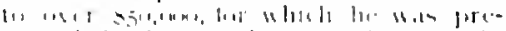
-

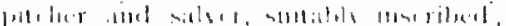

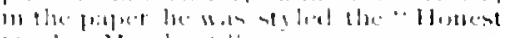
Btolker Herohitht.

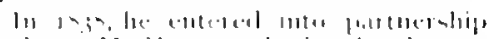

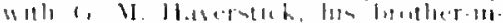

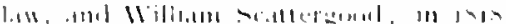

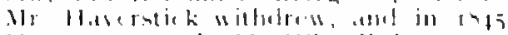

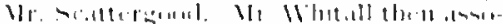

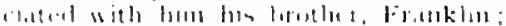

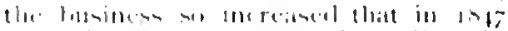

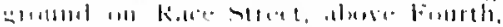

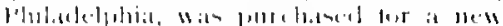

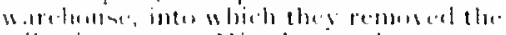

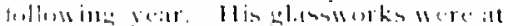

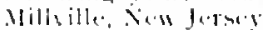

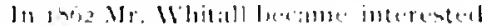

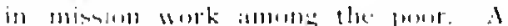

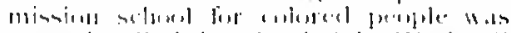

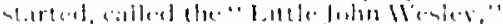

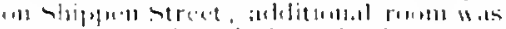

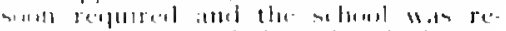

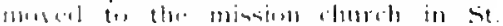
Jats street d Mother's Meting in

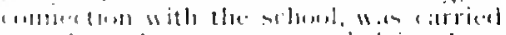

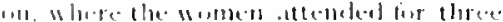

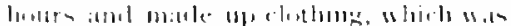

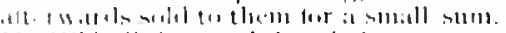

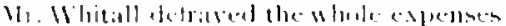
iil the on la,e,

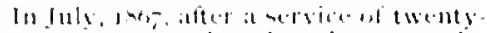

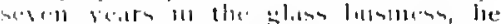

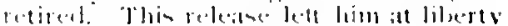
an enter more actisely inta ditferent fullila warke

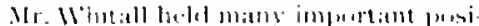

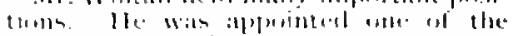

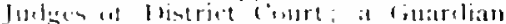

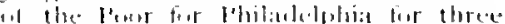

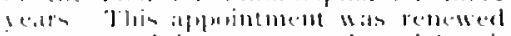

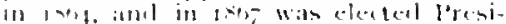

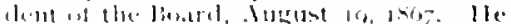

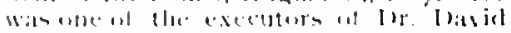

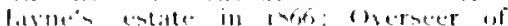

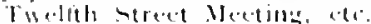

111 Xosemler 5. 13.3\%, in Frient's

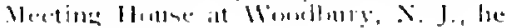


married Mary, sixtio liaghler of Juhn and l Iammah latlem

He w rotesequal religious tractsamong whell were thase on "The lane christial

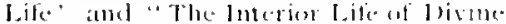
linicon."

Johll M. Whitall was almireal tou lits

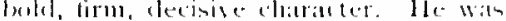
also losed fir his warme sympathetie natlure and, when any were in mast.

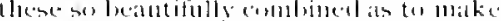
him a most valuable allul comforting friend and commellur

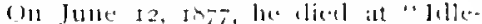

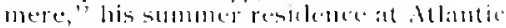
City, X. J., istel sovellty-six yeats

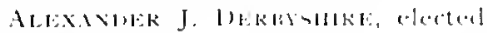

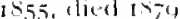

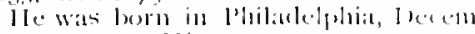

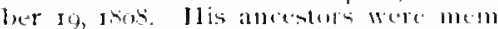

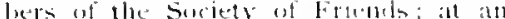
e:arly ang he recenterl instruetom at the

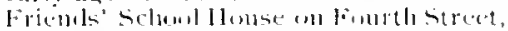

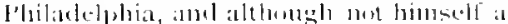
member of this religious buely, he wat al

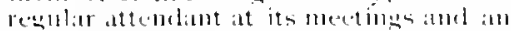

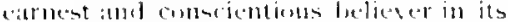

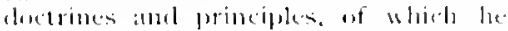

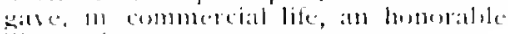
illuntrittium.

At the age of sixlecent he wals alphren

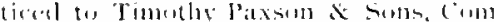
mission Mercluatsts, with whenn he pe

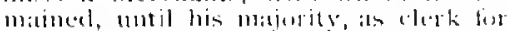

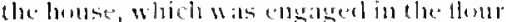

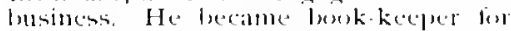
Hhe tirm, amel when Mr. Paxson, the head

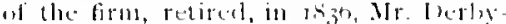
shire ratricaloul the business allul assie ailled Mr. Waltsem Jentes with him. The

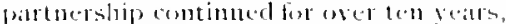

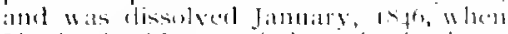

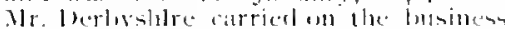

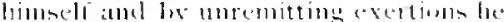
latil the fomblation for bis future suceses

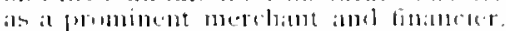

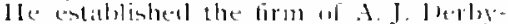

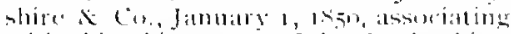
with him his cousin, John lerbethire.

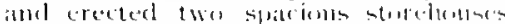

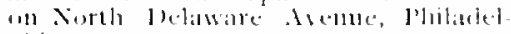
plisiat

Wr. Dethoshire alsut this time satse

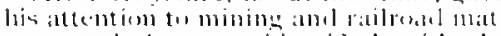

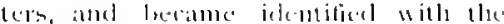

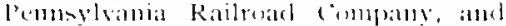
was ane of its lierecturs at the time

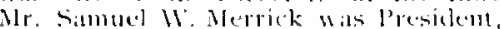
whan the terminus of the protel wats at

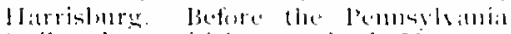

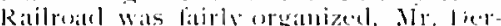

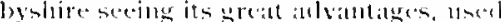
all his indlueduce in the beard of Trable to fivilitite the comstrontion of the

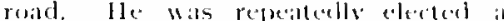
Ibirectis at the complang, and rematimed

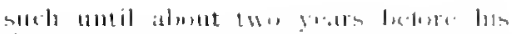

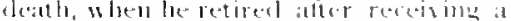
complimentary vere for l birecur

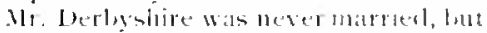

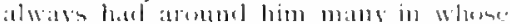
welfire be felt an interent.en bith whom

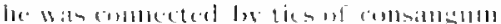
iff allel whem he felt a real pleasure in

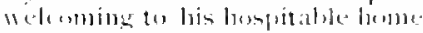

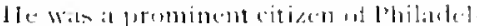

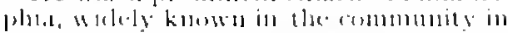

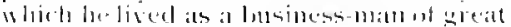

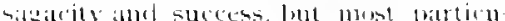
lably form the active, earmest inderest lie.

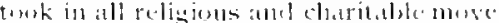

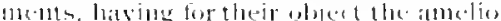

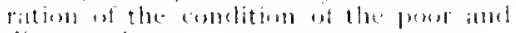
listresuntl.

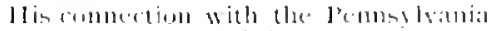
Homplital commenced in the reat thos.

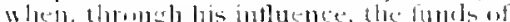

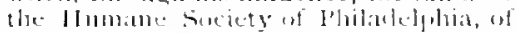

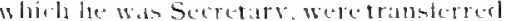

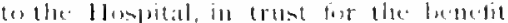
at thuse whis might combe umbles its aile.

He mandented an mowaremer interest

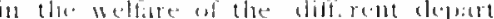

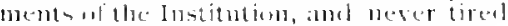

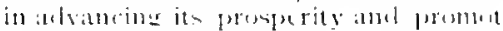

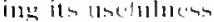

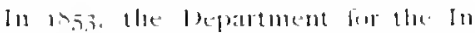

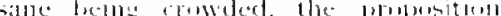

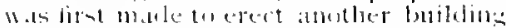

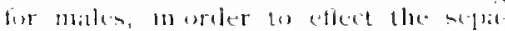

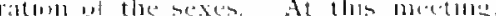

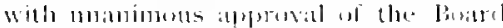

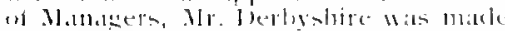

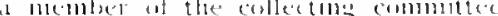

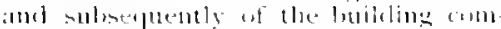

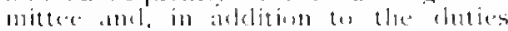

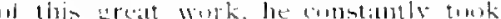
"Ipurtunitien to motke valuable present

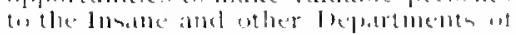
the lastitution.

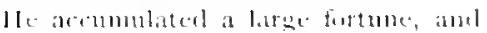

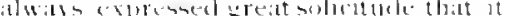

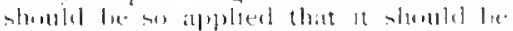

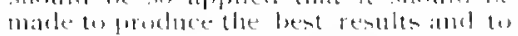

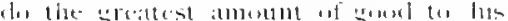

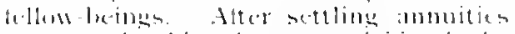

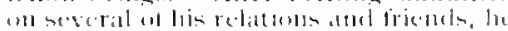

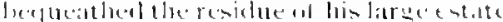

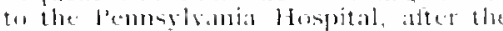

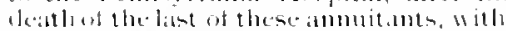

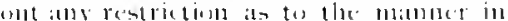
whell it should be ased.

llis name nill be rememlereal nith

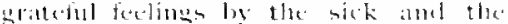

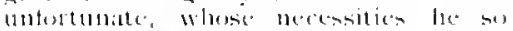

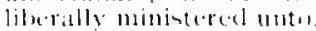

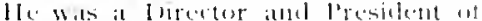
the thine-11ill and selnulkill Howell kithroble Ile was a member of selerel

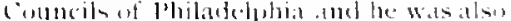

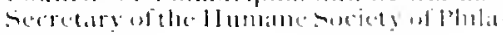




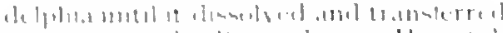

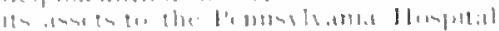

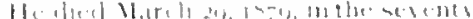

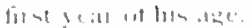

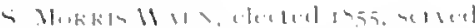

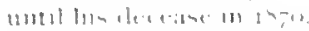

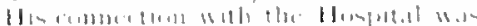

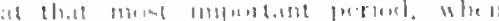

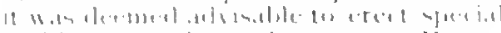

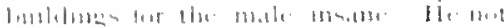

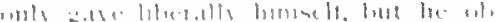

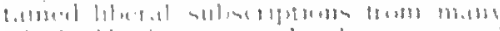

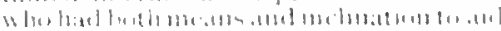

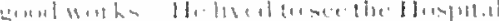

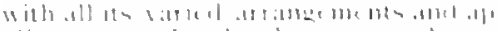

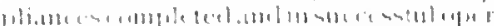

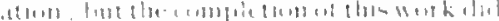

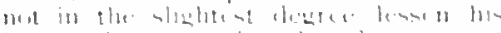

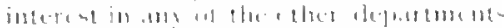

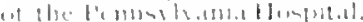

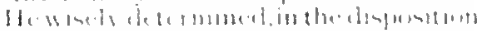

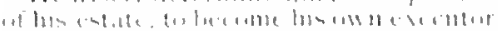

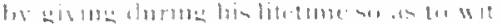

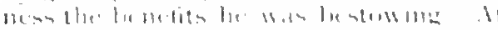

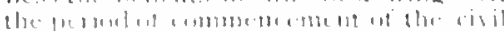

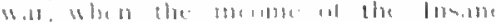

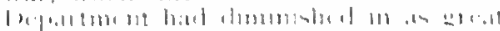

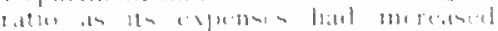

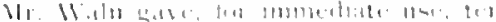

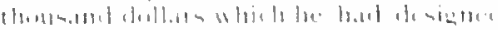

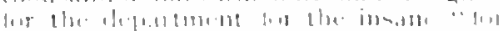

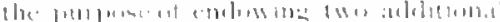

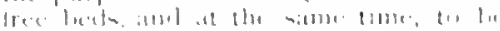

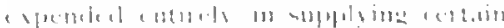

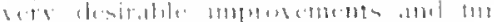

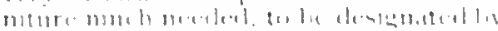

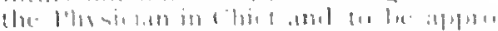

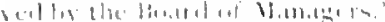

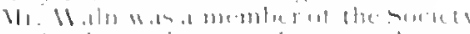

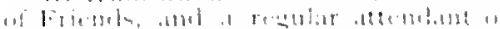

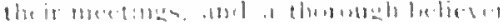

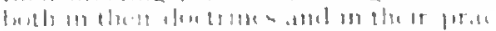

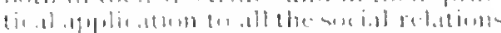

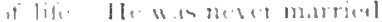

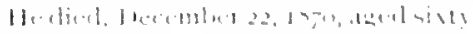
chrecterats

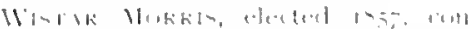

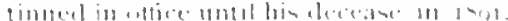

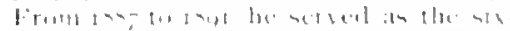

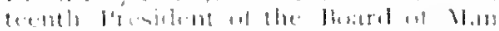
.19etas.

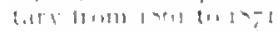

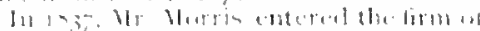

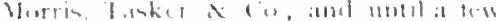

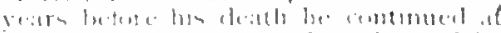

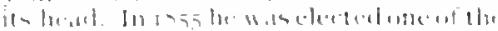

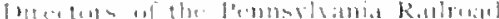

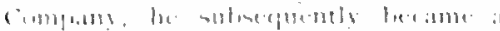

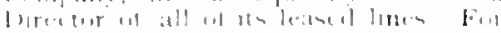

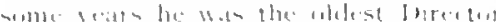

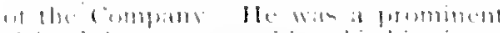

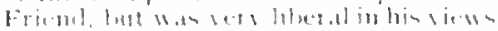

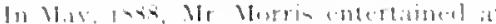

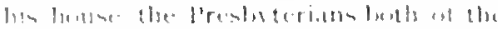

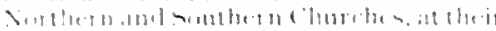

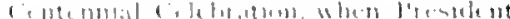

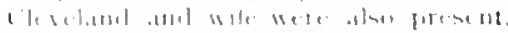

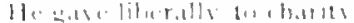

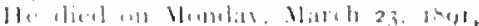

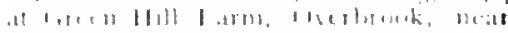

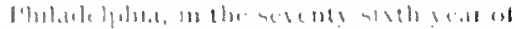
$\operatorname{lil} 1,121$.

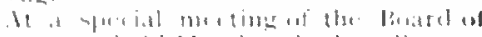

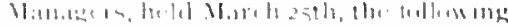

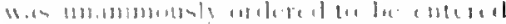
aif the pmintite

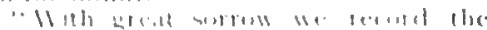

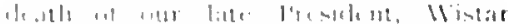

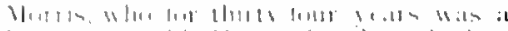

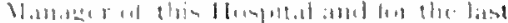

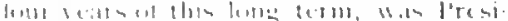

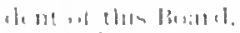

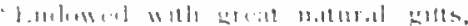

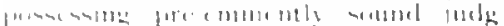

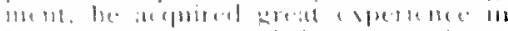

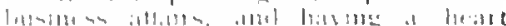

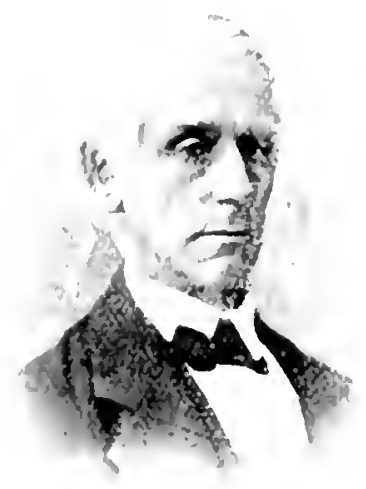

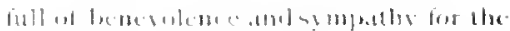

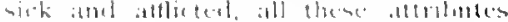

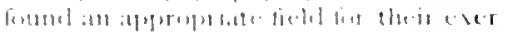

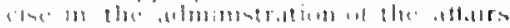

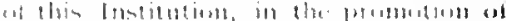

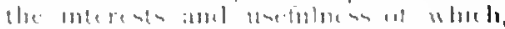

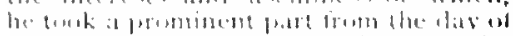

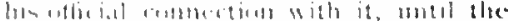
oleme at bis bie

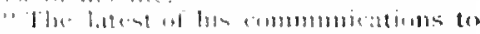

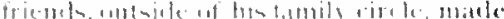

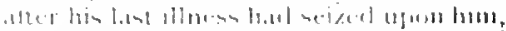

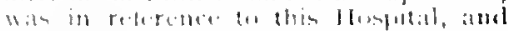

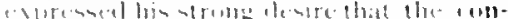

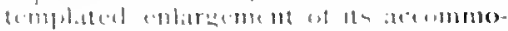

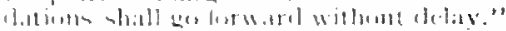

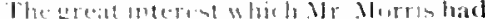
latken in the Huspital cluring has life,

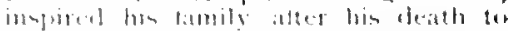

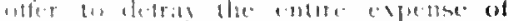

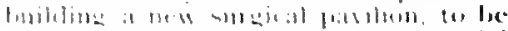

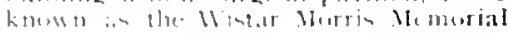


IVard The amount required wats \$15n,one, and the buikding was erected

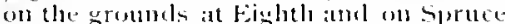
Strexts, as already deseribed and illustrated isee pitge 1 iol.

CAles Culfe, elected risor, resigne-rl I.66, was born at Gireenslurg, the county. seat of llestmoreland Cinmme. Pis. July in, 1797 . Je was descemded from an obl and distinguished fomily. Oliser cine. his fither, came to this comatry witl the earliest colonists and settled it Grectsburg, becoming prominest in Rewolutionary times. ] [is fatler havion died during his infancy, Caleh, at the age of eighteen, on Julle il, int5, le.t his lome, by stage, for Philateluhia, where he entered the conuting hosue of his uncles. Thomats P., Isracl, am Jasper Cope, whowereengigerl in a generial mer. chandise business atul did inl extensige susther and Western tracle. Ater four vears, he was indmitted intu the firm, and finally sulceteded to the entire husiness. Ar. Cope, referring to thim, satil: "From is fatherless bos in my uncler astablish. ment in sos 15.1 rose to be senior partne. in une of the largest mercantile lisuses. if not the very laresest, in the Liniteri Stitter."

His strint attention to busintess was rewarded with increalsed prosperity amol success, and the business of the firm clatme from a supply of general merchamblise to a growing and remuneritive East Indat and Liverpoul track in silks.

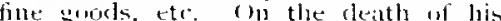
uncles, the firm became Caleb Cupe $\&$ (i)

H. later assuciated with him as part ners, Herry C. Howell and Buck Johnson, and opened one of the largest irygrouds houses in the conmers. Ja the panio of 1457 this house went idown, the accountints reporting that dishonest part. mers had caused the failure he defraud. ing Mr. (ope of npwarls of $s_{2}(x)$ or $x$ ) Having been granterl an extensinn by bis credieurs, at few yours alterwarde be paicl off the entire amonnt of the firm's inclebtedness, principal and interest, and suliseguently retired from commercial life with a hitmelseme competence.

He was married to his cousin. Abtic. Ann cope. in rosh, and went to hollsekeeping at the cormer of Quince and

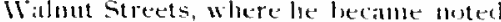
for las generous bospitality, including anumg his guests all the prominent visi. tors of the city. After the teath of his wife, in 14+5, he purchased "Spring loresk." (n) the flelitware River near Holmeslure. He distimgished himself here by the introductien inte this country of the beatutiful watter lily, the licturia Regia, the gift of his friend, Sir William

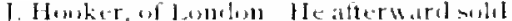

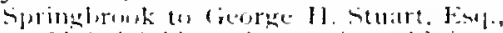
in Pluladedpliat, who again sold it to Folw in Finrest the trigedian, and it hats since lecome the " Forrest Henne."

lo the fhe was married a serend tinue

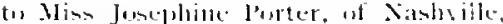
Temmessee, at stuclent in the Acarbemy at Fine Arts, Plilatlolpliat.

Mr. (ople was combecterl with many important assoriations: he was the last survisine member of the Penmelsani

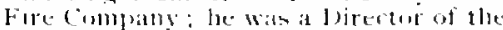
Acidemy of Fine Arts, and for twelle rears its l'resident. Historioal sorete ties

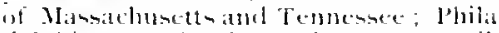
deiphiat Burar of Trade: Medeantile fibrars: Institution fire the lnstruction ol the Blind: Matediden sucjety ; Academy

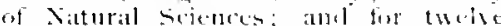

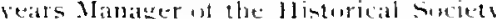

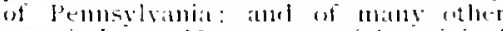

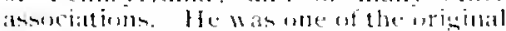

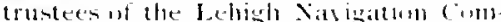

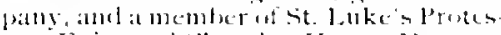

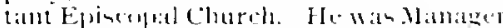

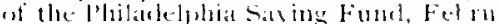
ars 14. 14 fl, and the l'resictent of solme from Jamuars th mest by. He wats. In

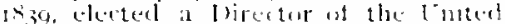
Stites Bank, lut withelrew presioms to the fature of that institution. In 195 , he wrote a privalte lijeting of the latuk. He was Treasurer of the f nitced states Sani tare (Commiosion allul ane of its muse wetive workers : at the chese of the situitary Fair, he drew his cheok tor the

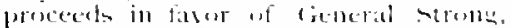

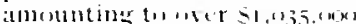

Hedied laty 12, inthe, iged ereer nincts rears.

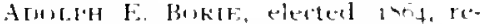
sirned uns wats a represelltative merclatht of Philadelphiat.

He wis a denceludiat on his muther"s side of a fimily of refureas from san

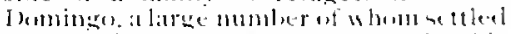
in Philatelghia. He was forn in this city. Nosember 25 . 19u celus itterl at the Eniversity, in clatse uf 1 s.5. was sent to France to culntilue his stuclies, and re turned lome in inge. He was intemuled hy lus father tor the lewall profension lut riving to his inl health this was relin guished, and he entered the conmtine

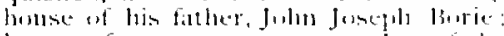
he was for many rears a menher of the

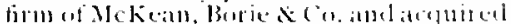
a large fortune in the foast India tratle.

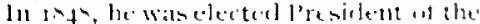
bank if commerese, which monition he

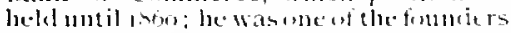

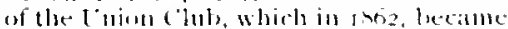
the Lnion lecague, of which he wats the firse vicepresielent. He gatre latge sums twated the enlistment and carte of 


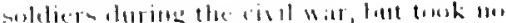

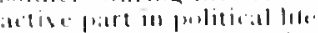

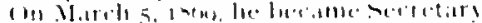

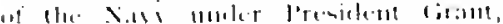

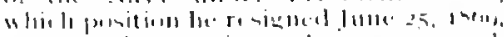

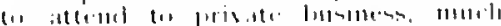

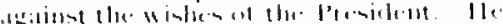

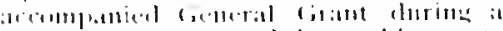

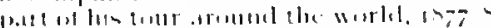

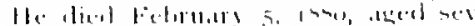
encisy ye.11

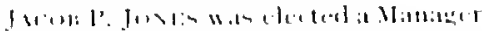

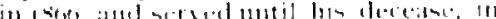
iखis.

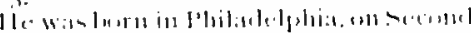

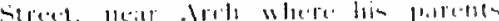

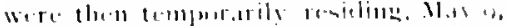

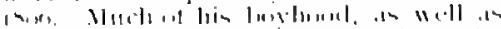

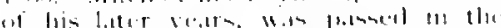

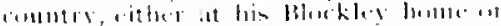

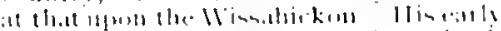

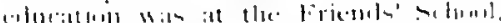

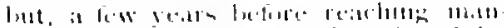

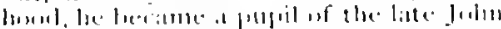

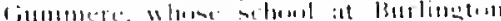

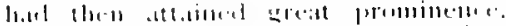

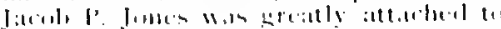

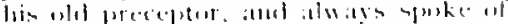
limin wh the repers

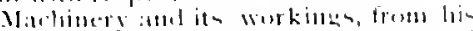

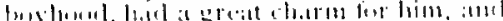

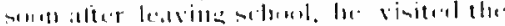

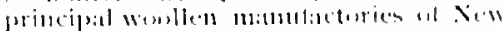

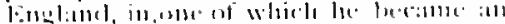

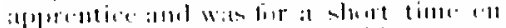

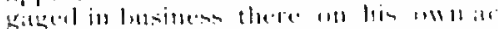

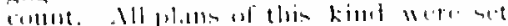

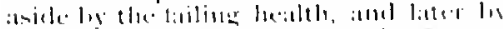

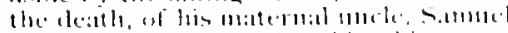

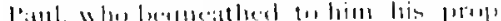

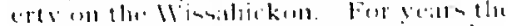

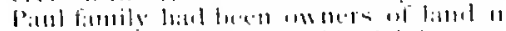

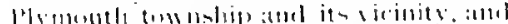
la:il lecen protitably interestad in the

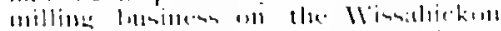

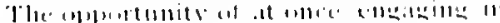

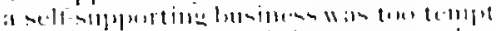

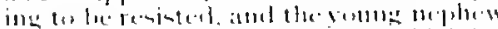

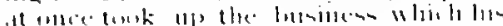

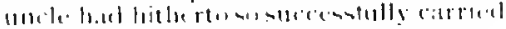
1112.

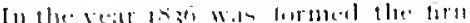

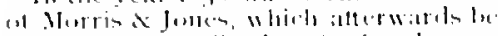

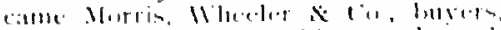

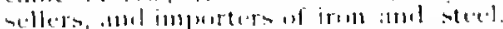

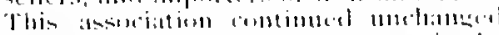

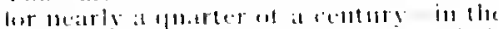
worde ni the stersising parteser, theis

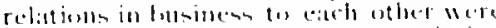
"perfect." while the eluse assediation

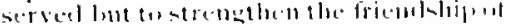

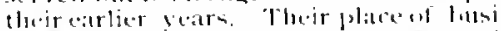

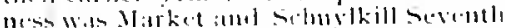
Sirecto the latter luw ealled sixtedeth),

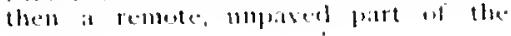
lainn.

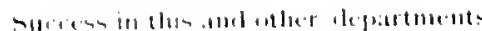

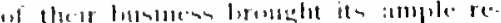

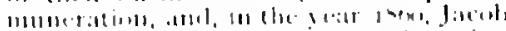

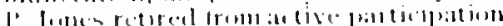

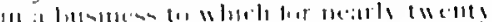
11. I

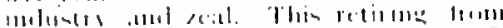

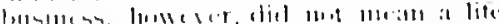

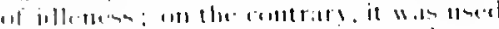

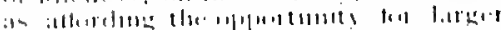

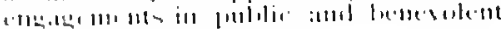
wort

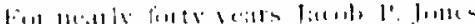

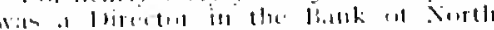

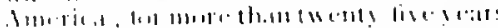

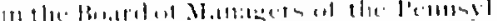

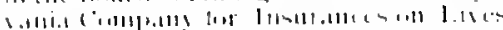

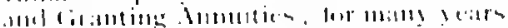

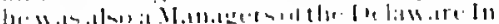

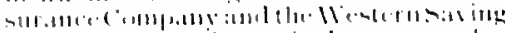

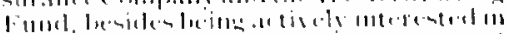

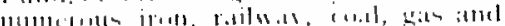

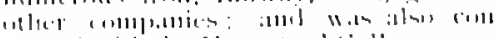

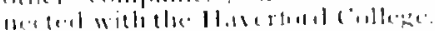

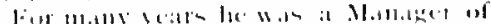

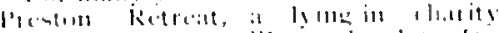

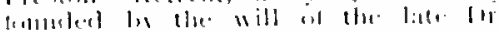

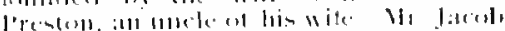

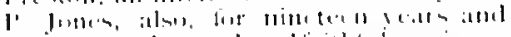

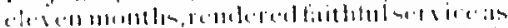
1)

H. Marrial, July is, I fu, Mars,

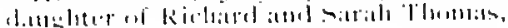

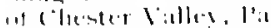

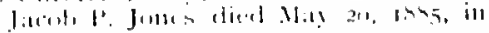
hime eithlieth $y: 010$

1 perttiat al him, a gilt from his

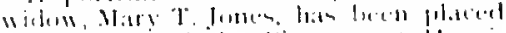

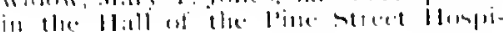
$1: 1$

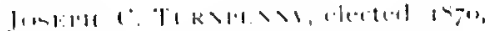

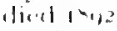

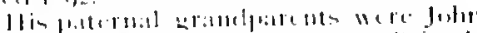

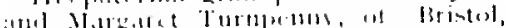

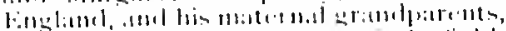

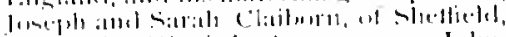

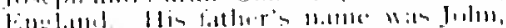

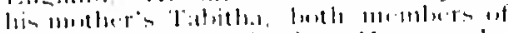

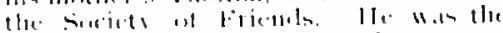

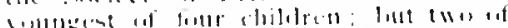

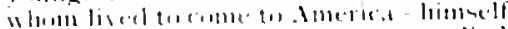

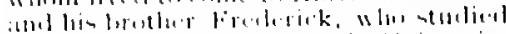

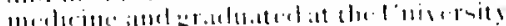

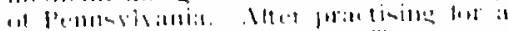

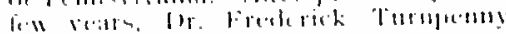

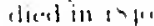

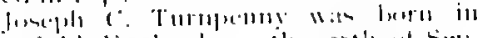

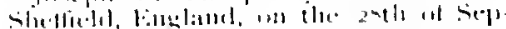

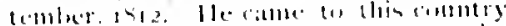

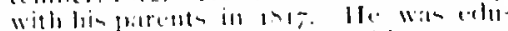

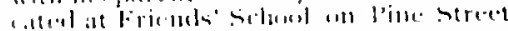
meits sicandm.

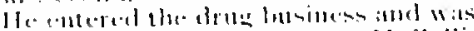

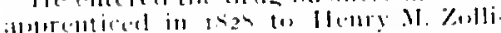

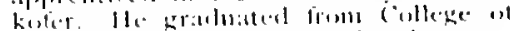

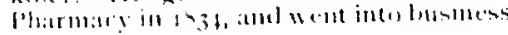


for limself in as 3 t, and retired from busi ness in listoy.

in November 9, 1953, he married Elizabetl Richardson, dinghter of foh and Matrgaret Richaritsan of Roctiwell, near Wilmington, letatware.

lurime many geass he wats an active manager of matly bentevelent institu tions. Ife was fir almolt forty year Manager of Beck's Schos, (atharine street: for many years Manager of the Grandom Institute: Preston Retreat Howard Hospital : W'ills' Huspital : for twenty-five years Treasurer of the crtariedic Hospital; and for more than twenty years Nitharer of the Pent sylvania Hospital.

He died July 15, I 922 , in Philatlelphia, aged seventy-nine years.

Joms J. Tumbess, elected [r; and continued in office until his decealse in $13-5$.

Although a Nanages of the lloppital lut a short time his dety interest, genuine sympathy for the atflicted, his kiml werds and liferal acts, joineet t' a very genial manner, made him must highly. estermed, and his lons sincerely dephored by erer one who hat the privilege of knowing him.

Mr. Thempon was the seniur pirtner of the firm of I. P'. Morris \& (is., ol l'ort Richmond Jron Viorks, J'hilatelphia. While taking an artive interest in numerwus benevolent enterprises, he was the beard of athe of the largest numutacturiner establishnents in the city, emplinying humblecls of workmen and turninge unt some of the finest and heavit at michinery

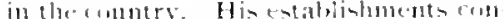
strusted the latre engime- for the l'nted stitce Mint: the engine tor the litke

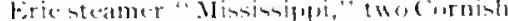
pumping engines at the choylkill llater

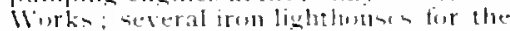
l'nited states gavermment, ind the (1) gines for exeretal of the moniture and irun-clats, beside ming other wolks of equal impertanet.

In $16-2$ Mr. Thompont wats elected at Manager of the l'enusylyanial Ifospitial, to fill a vacancy caused l, the leath of Mr. John Farmum: he ilways towh it deep interest in the success and uselul. ness of the Institutiton.

He died May $25,-5,5$, in the fity-ninth year of his age.

fors T LEwIs, elected Ihns, renizned [xiss, on account of impatireel lan:alth.

He hal previously served as the twelfth Treasurer being elected Fels ruary - infl, resigned in lase when be became Manager, miking at Holspitil nes vice of forty-seven yeats atmel ane month if which forty years and four moutlos he served as Treasurer of the lluspital of him an appreciative notice was gisen be lo. John F. Meigs, in his amiversiry acheress (sece parge fint).

The services of Mr. I.ewis's family in the treasuryship, of the Hospitit irm menced in 1 - 9 , comstituting a perion

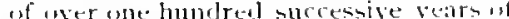
aratuitus services: a nephew of John $T$. Lewis perpetuates the fomily name in the Buard of Nallativers.

Ile dierl March 24. rogl, aseal eishty yetirs 


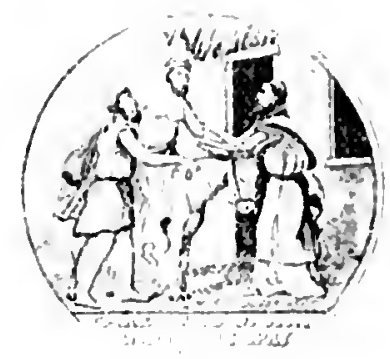

THE MEDICAL STAFF ANI) MELICAL TEACHING.

Compunting

ot the.

Mellic.ul

$\rightarrow$ t.til

The Medical staff of a hoppital consists of its corpe of fhe sicians. In its restricted sense, it comprises only the principals, or chief physicians and surgeons. Who are personatly charged with the duty of treating, or directing the treatment of, the patients within its walls. In a wider senee, it may le regareled as including every medical officer bohling an active, profensional position, in connection therewith: including hoth attending and resident physicians, as well an the combultants, specialists, and dispensary assistants. In this broad acceptation, the Staff is one arm of the hospital service; the other consinting of the Board of Managers, the Lxecutive Department. which is "harged with the general administration and economy of the household and the renponilility of directing its business interests.

The Managers of the l'ennsyliania Ilospital are members of the Corporation, who are elected ly the Contributors at the anmual meeting; the Medical Stafi, are appointed annually from the Contributors, by the Board of Managers. Inasmuch as the Board cannot well make appointment for a longer time than it has itself to serve, it follows that the physicians to the Hospital must be chosen each year by the newly elected lioard. It speaks volumes for the wise and conservative management of the Pennsylsania Hospital, that W. long custom the rule has been estallished of re-appointing the former Medical Staff, each year. In cane a vacancy should be created 
by death, or resignation, of a member of the Staff during the year, an election for his successor is held as soon as practicable. In consequence of the mutual respect and esteem which hav always existed between the professional and administrative authorities, the history of this Hospital is singularly free from misunderstandings and ill-feeling. The high regard, which the first Board of Managers entertained towards the Medical Staff, appears to have been handed down, from board to board and from father to son, until it has become a fixed tradition in this venerable institution, where the old-tinc considera-

The berard wi Managern and the Medicalstalf. tion and courtesy still mask the interconrse of the Boarl of Managers with the members of the Medical Staff, as indeed, with all who are connected with the Hospital.

As the Resident Physicians are to lee considered later, with the alprentices and students, the Nedical Staff proper will now engage attention.

Before taking up the individual liographies of the physicians, who have served upon the Nedical staff, however, a brief reference of a general character may be made to the standing in the community of the physicians who first actively moved in the estallishment of the Pennsylvania Hospital and who afterwards rendered distinguished services to the Institution. When Benjamin Franklin prenented a fetition signed by thirty-three citizens, asking for an appro!riation of funds by the Provincial Assembly to establish the Hosjutal, he was fully prepared to meet an oljection that he knew would be raised. .. That they could not afford to pay the physicians for their attendance "upon the sick," and he carred his point by announcing that the fhysicians had magnanimouly offered "to attend the patients for nothing and to supply all the medicines, for three years, at their own expense." Although the generous offer to supply medicines gratis was accejted at first, the Managers, becoming soon afterwards impressed with its injustice, ordered a supply of Irugs from london, but the physicians continued to give their personal attendance without charge. The unselfish example of the first Medical Staff has been generally followed, not only by their successors in this hospital, but atso by the physicians engaged in serving other public hospitali. subsequently established, in the large cities of this country.

The fact that Franklin could promise that the physicians would make personal acrifices in order to establish a hospital in the City of Brotherly Love, warrants the supposition that the physicians had leen selected in advance. This was doubtless the case with the individual members of the first Medical Staff. Doctor Thomas liond, who was the original proposer of the hospital, and whose friends were hargety 
enrolled mpun the lint of contributurs, womld naturally le one of the

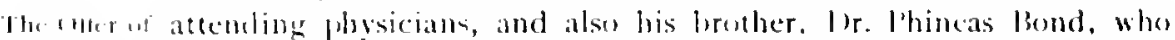

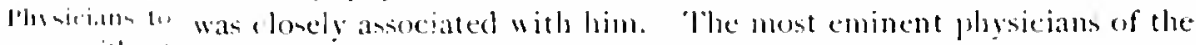
s.r.

(li,rise

alecepent with thanks

The tirs Malic al stanl "ity, at the time. Thomas (ireme. Thumats Caelwalader. John kedman, samuel l'reston Moore, and l.loyel \%arhary had also had their sympatby enlisted in tavor of the lospital by /r. Bomb and his friends. and blece were all eager to contribute to its success. huth financially and professionally. The first Medical staff was appointed Oetober 23. $175 \mathbf{I}$, by the Nanagers then passing a resolution thanking 1)rs. 1.logil Kalchary, and thomals and lluneas liond for their willingness "to attend gratis in taking care uf the sick as thysicians and surgeons for the first three years" and areepting their services.

The Board, furthemore, in orcler to grive greater dignity w the rising inslitution, or to keep alise the interest of as many inluential persons as possible, also appointed a staff of comsultants, ly repuenting " Irs. (irieme, Cadwalader, Moore, and Kedman to assist in consultation in extraordinary cares." (See page 28 ante.)

The first consulting staff had no immediate successors, as the attending physicians discovered that they did not repuire such assistance.

"The Ilanagers being very anxious to make no mistakes at the beginning and desiring to lay the fomblations of the new institution upon an enduring basis, apponted a committee, which drew up low following regulations with regard to the selection of plusicians and surgeons, which subseguently received the sinction of the contrilators and the legal representatives of the infant Commonwealth.

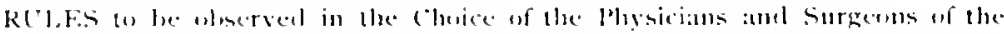

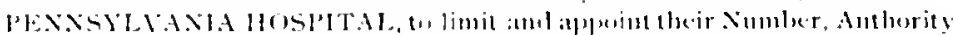

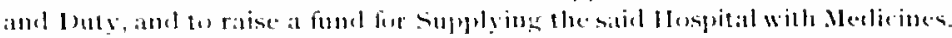

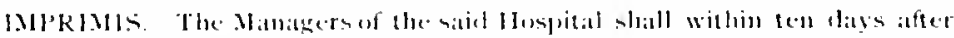

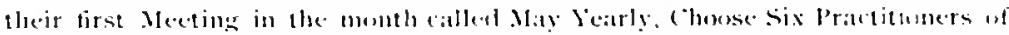

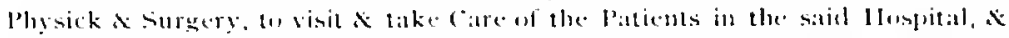

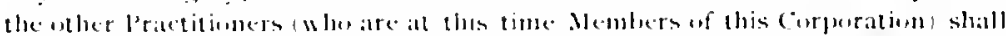

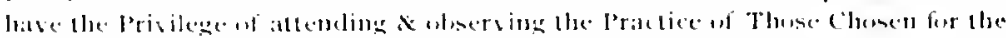
Service if the lear.

2d, the I'raetitiners choren slatl give the ir Attemelance alt such timses, and in

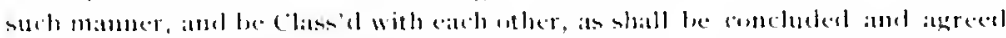

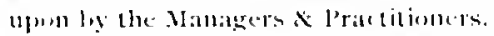

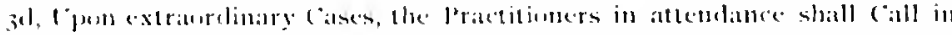

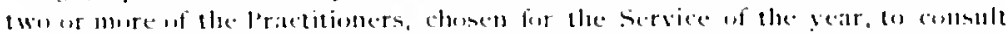
with.

fth, In all such cases, which will aslmil w time for delilerattion, all the six

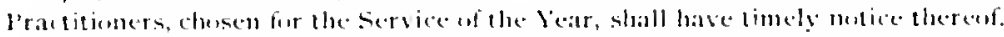

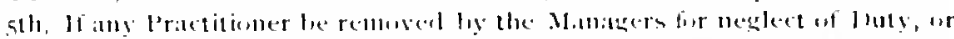

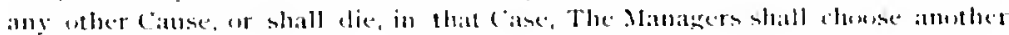

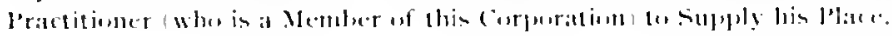


6th. Each Apprentice or other Setudent, the pratetioners shall introduce to

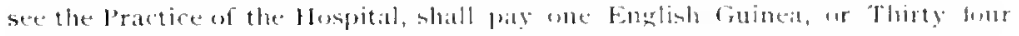

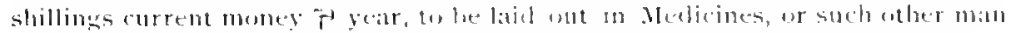
ner as the Nanagers think mome proper

the Xo Practitioner, cluring the Term for which he is chusen to hersed the Hespital shall Art ats at Mallater

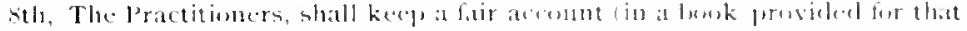

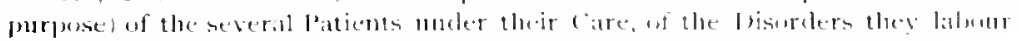

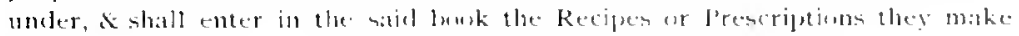
for each of them.

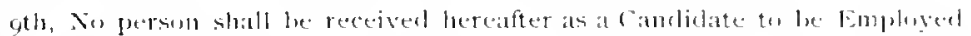

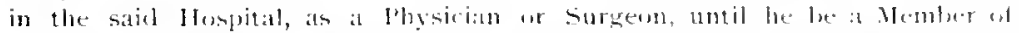
this corporation, \& of the Age of Twenty seven leatrs, hath serven at regulat

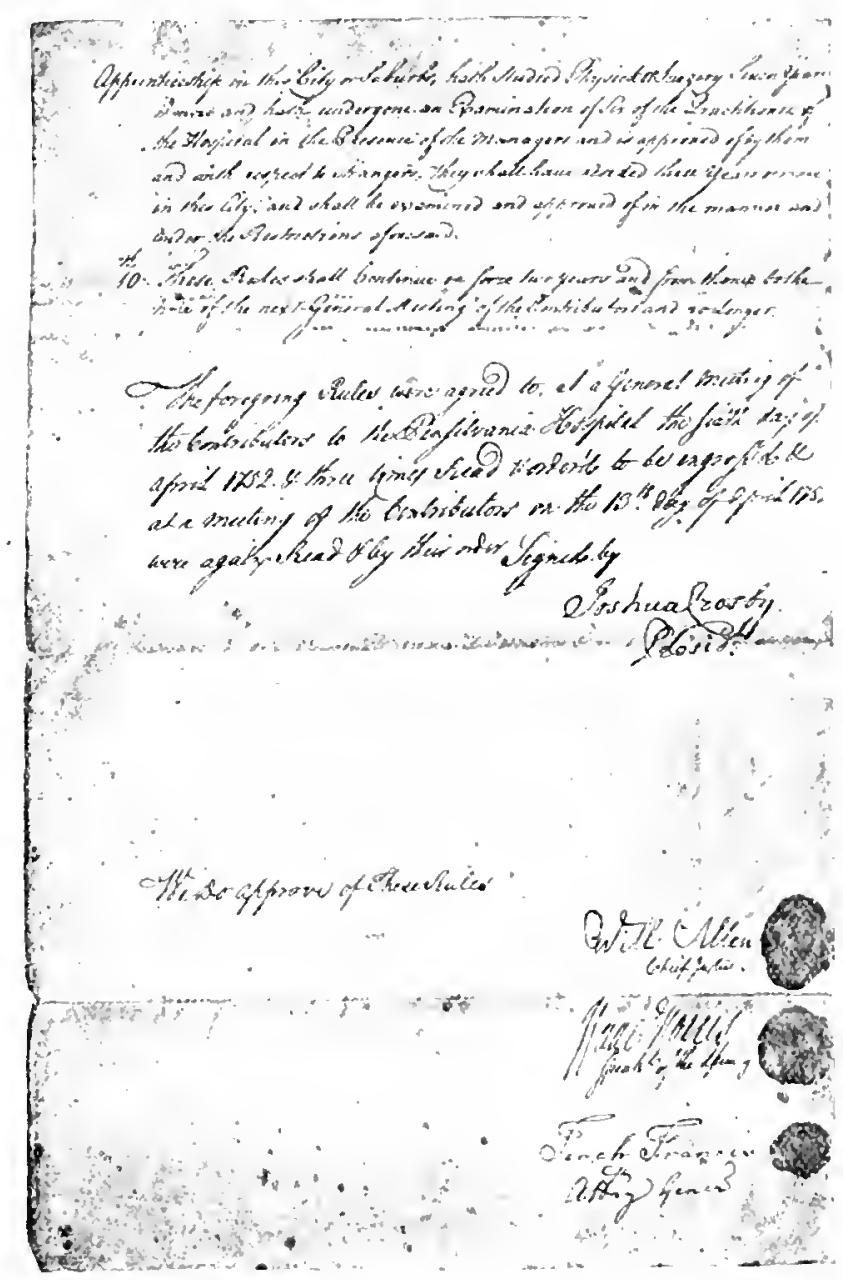

Reprovertion (n) 13rinal 1)r:ushth if Kuks, with Hignatures. 


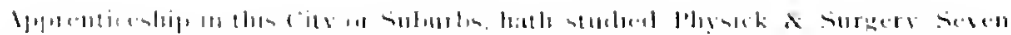

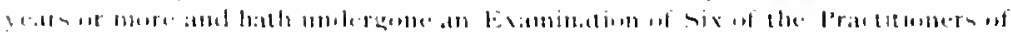

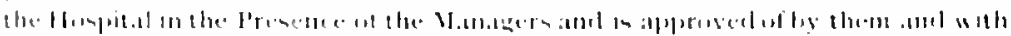

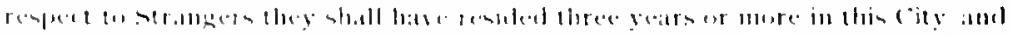

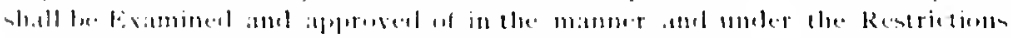
atimastir|

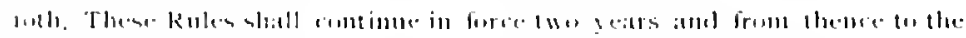

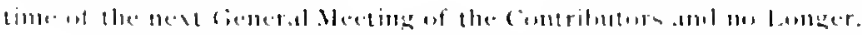

The foregoing rules received the approval of the Chief fustice of f'embylvania, the speaker of the imemlly and the Altorney General, as repuired ly the (harter of the Hoyptal (see page 10), and as shewn in the accompan!ing reproduction of the last page of the uriginal dranghe of the Rules taken from the Archives of the Henpial (see illustration on preceding page).

The The fhysicians, from the leginning, were encouraged on take a phurkun very active inlerest in the success of the Hospital and the extension "wively of its usefulness, and the Managers held frequent conferences with ilitera-sicel in lie wellite at the-11,inltidl. them with regart to propesed methods of improving and increasing the accommodations. An illustration of this is observed in the aceompanying extract from the minules of the Managers of January $7,17) 2$ :

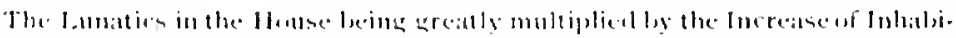

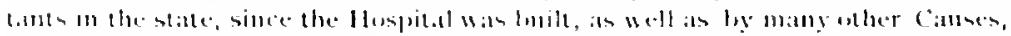

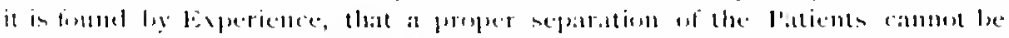

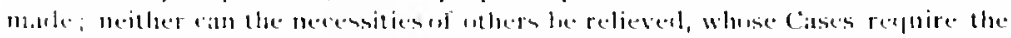

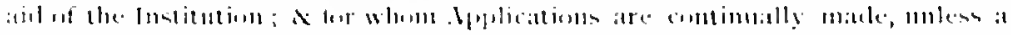

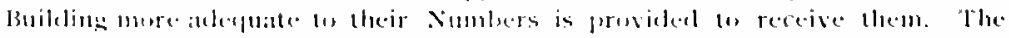

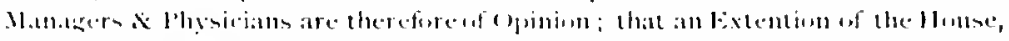

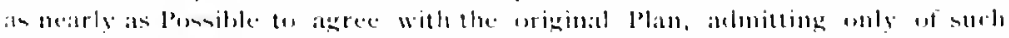

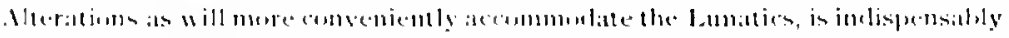

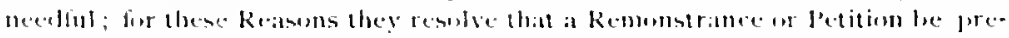

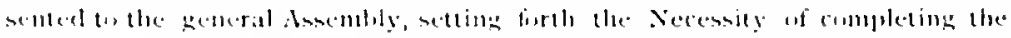

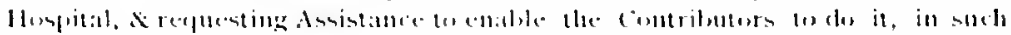

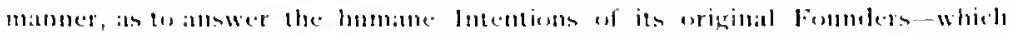

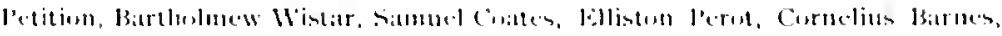

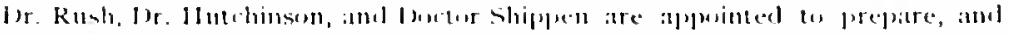

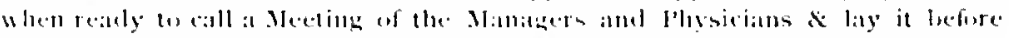

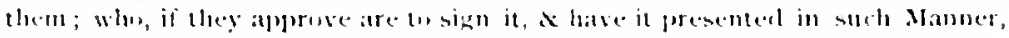
an they mity arrece to when assembleal logether.

The matter was kept actively under consideration and a special mecling of lecember 19,1792, contains the following record:

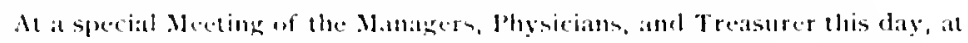
the heruse of simmel conates.

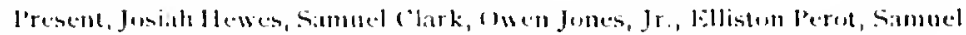

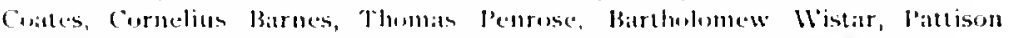
llarthluone, and Juseph lasschall, Mandgers: Mndecai lewis, Treasurer.

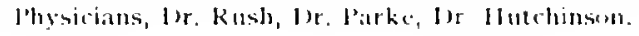




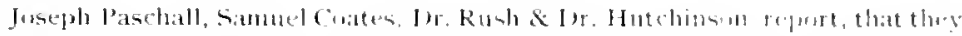

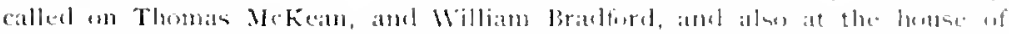
Elw'tl. Shippen, whe was mot at hume: to regutent that they, as Julges of the

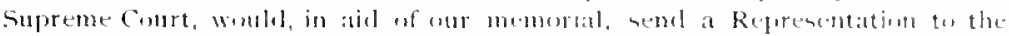

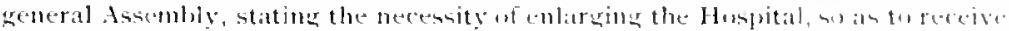
at greater number of foutients, and reguesting the frant, which the saicl Mlemorial solicited for that purpuse.

The Juches receised their lisit, in a friendly manner, expressing their gareat

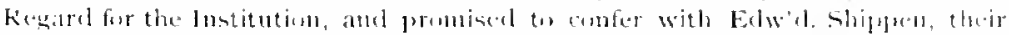

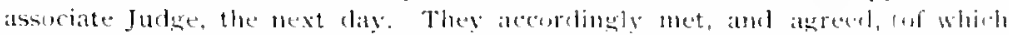
they informed Dr. IJutchimon, that they would deliver to the assembly, sul b at Representation \& letition, ats we requtested in their afficial Character, un this cimdition, That, if the money was granted, and the huibling extended, in sumequence of onr juint Applitations, a "latuse should be inserted to provide, that

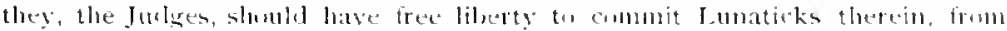

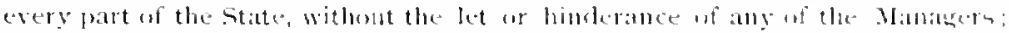
who nevertheless slumbl retain the right of fixing the rate uf laymant, ba the brated of Patients, when the funds were not suffeient to admit them an f'alupers:

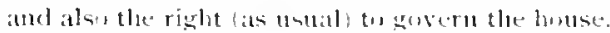

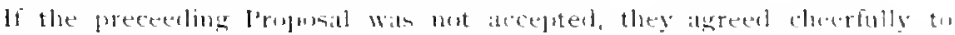
co-1perate with 11, or ally of their fellow citizens, in alplying for the promt, ats private Gentlemen, but wot as julges of the supreme Court; - whidh, heing cons-

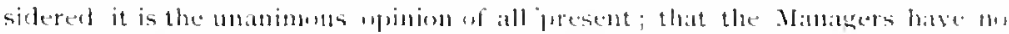

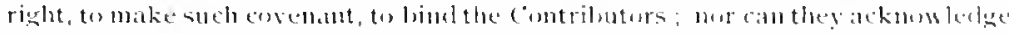
the propriety of any Anthorities being exetcised in the fompital, than and an are already kmuwn; and anree with the exintme Charter, and comstitution therewit.

The Managers e l'hysians, are nevertheless sensible of the kind llingmi

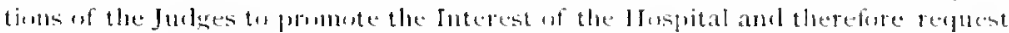
them to exert themselven ly personat Application, in shel mamner, as to them,

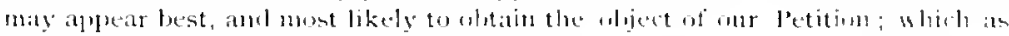
Citizens, they lave been pleased to approve.

In response to the above petition by the Managers and Phyicians a legislative committee visited the Hospital and made the following report, which was read at a meeting of the Nlanagers, held tst mo., 27 th, 1794 :

"The Committee apprinted lig the SENATE and ASSEMBI, of PENXSYL.

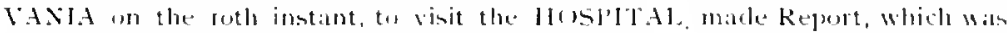
read as follows, viz. :

"That, accompanied by a cimmitee of the SEXATE, they hase visited the

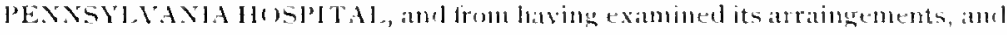
enquired into the State of its Funds, they have Reason to helieve that the lustitution is conducted with equal attention to sum oreler, and strict formony-

(iimmintecte repritrtis the I.ereisliture. Several very curious allatomical preparations, purchased from the Roper

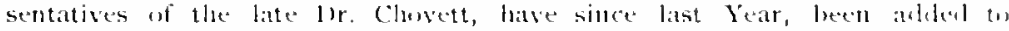
those previnusly collected, forming tongether an Exhibition which for its utility \& value we appreleend is unceguilled by any of a similan nature, in the United States: and notwithstanding the addition necessarily male we the atront

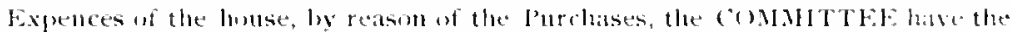

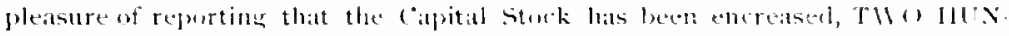

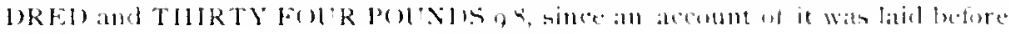

Repout of (immitter. 


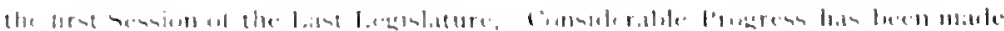

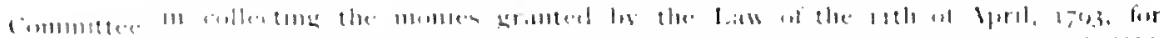

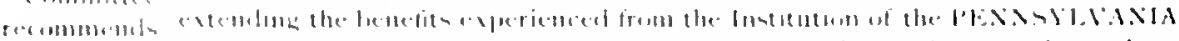

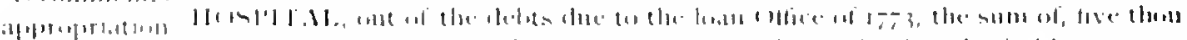

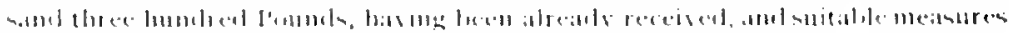

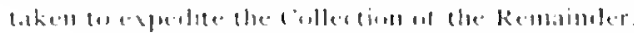

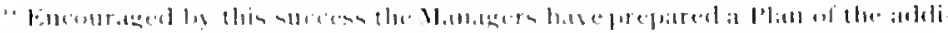

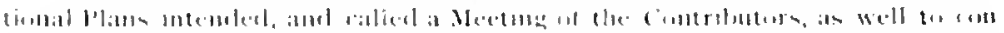

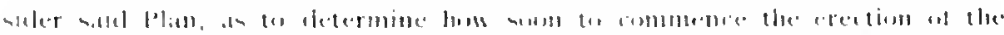

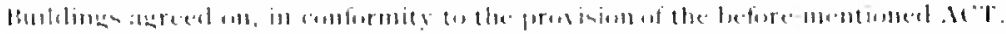

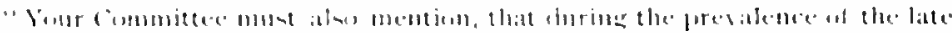

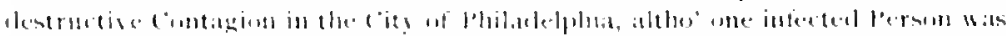

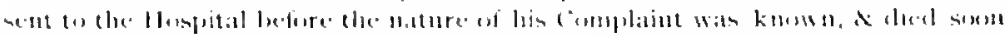

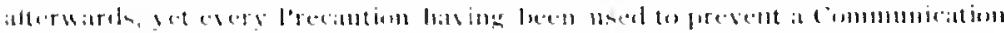

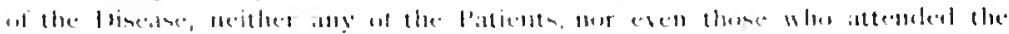

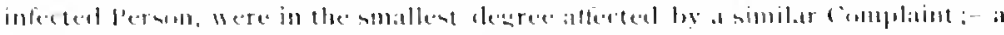

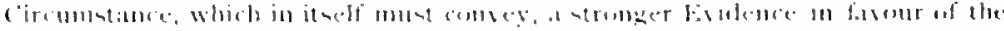

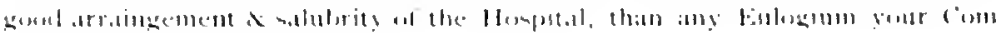

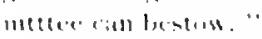

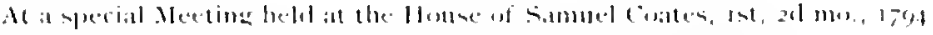

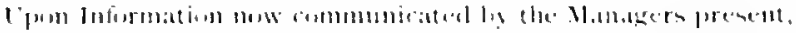

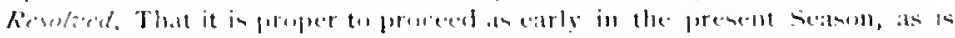

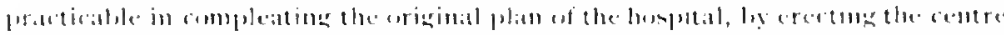

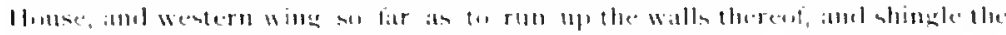

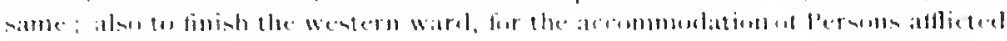

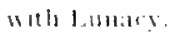

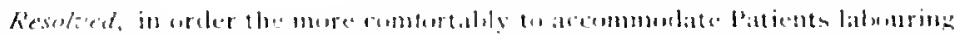

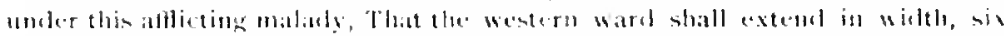

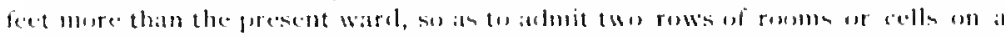
Hint fior this purquase.

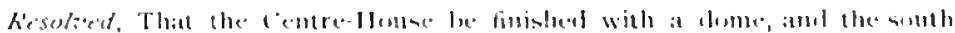

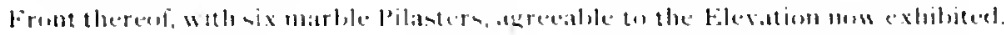

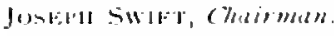

$$
\begin{aligned}
& \text { TunMas Minak, Cle's. }
\end{aligned}
$$

Anpreal tis Gincertum Villlin

Sovemlur 26, I 795, the Boarl considering the imporlance to the pulble of completing the new huilding, which could not be effected without further asistance from the I.egislature of the state, therefore, concluded to ask the fovernor to endorse lueir request, in his adeless to the (ieneral Assembly.

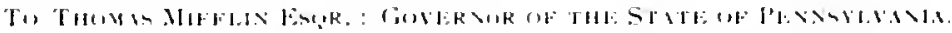

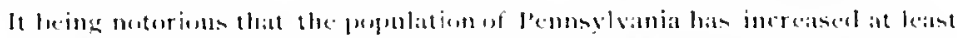

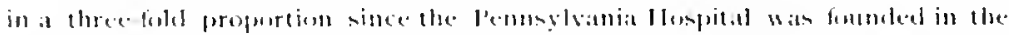

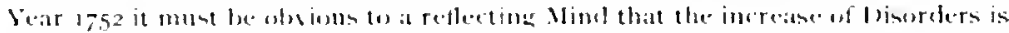
in some legree in at [ropertionate kathe the-rewith-Without aseribing it to any uncommen cause, as may thus accont for the mumber of lunatie l'atients whore

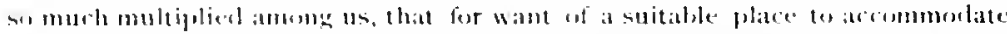

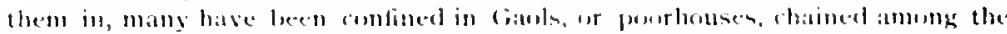

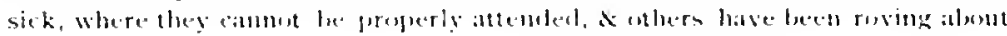


the City and Country, incapalse of matntaning themselves, and dangerous lo the

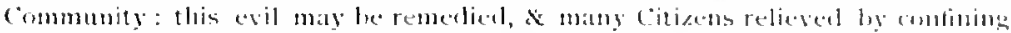

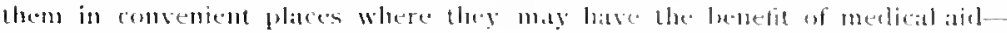

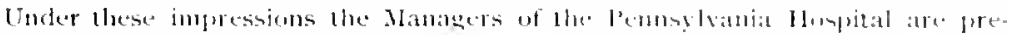

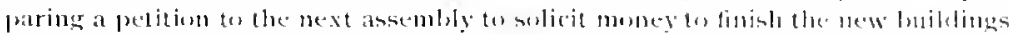

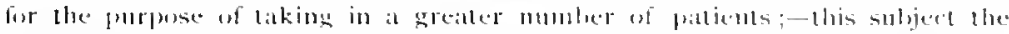

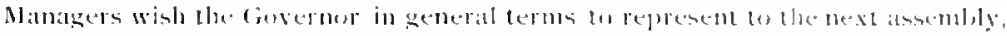

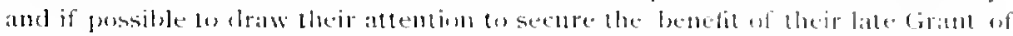

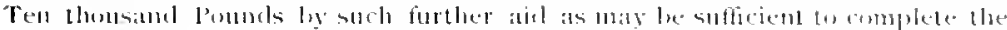

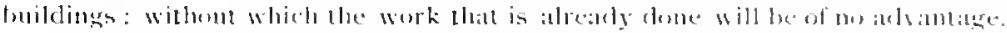

As already related (page 255) the Governor very favoratly mentioned the Hospital in his annual report, and the ultimate renult was a handsome appropriation for the purpose of completing the Hos. pital according to the original plan. In accomplishing this result the labors and influence of the Medical Staff were largely exercined and due credit should le given them for their disinterested devotion to the Hospital; the above is only a solitary illustration out of many which could be cited.

The personnel of the first Medical Stafi, as already observed, was of a high character. Its members were not only eminent in their own vocation, but they also had acyuirements and accomplishments which made them leaders in the community, and active and influential in it social affairs. 1)r. Lloyd Zachary is reputed to have been "one of the most gifted men that ever lived in Ihiladelphia. He rendered incalculable services to the Hospital, which was founded in his time, and of which he was made first physician. In the community, there probably was not one who was more respected and beloved. * * * * His derotion to the Hospital was never subdued, and, when he died, his will was found to contain a liberal donation in money and hooks to that institution."'

1)r. Thom us Bond was intimate with lienjamin Franklin and was actively interested in his schemes for general education and philanthropy. With Dr. Zachary, he was teacher of the medical students of the city, and inaugurated the present system of delivering clinical tectures at the Hospital. I Iis lirst lecture was deemed by the Nanagers of sufficient importance to warrant its insertion in full upon the minutes. 2 In fact, 1)r. Bond was himself a member of the first Board of Managers, this compliment being paid him in recognition of his agency in projecting the plan of the hospital and his energy in establishing it upon a working basis. When in November. 176 , the Iennsylvania Hospital was set apart for the use of the continental

\footnotetext{
1 Schatt \& Westcott.

"Ste page $\$ 02$ for lecture in full.
}

1112,11

(hitritcles if Farly Itomluers if the Ylinlical -1.11t. 


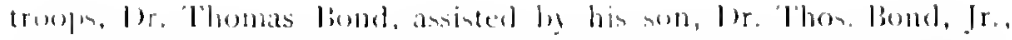
rendered efficient aid in organising the Continental . Irmy llopptal ustem now a proper hasis, and securing competent surgieal anel medical aid. It wan a trying time, for in ackltion to pentitieal troulles. smalbus loroke out among the soldiers, and, withont vaccinatun, it was impossible to perent the onntagion from-preading. Hewas selected an one of the representative citirens, by the Ansemlly in 1739 , we serve as one of the llanagers of the newly urganised lniversity of the state

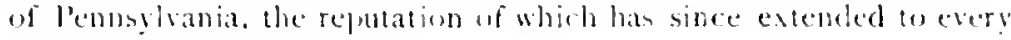
part of the civilised world.

Earl, ingicintment the prosince

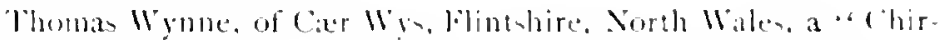
urgeon" cane orer in the ship " Welcome," which sailed fom

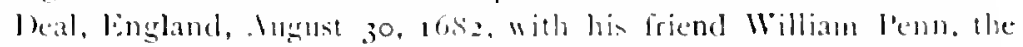
Proprietary. The servicen of this skilled plyssician were neceded by the company exen before rear hing their destination, for. it in recorded, that there was an outloreak of smallpes among the pasengers, during whic he thirgyene of them perished. A, an illuseration of the estecon in which physicians were held in those carly days and alow sorial infortance, it may be mentioned that lor. Wynne wan the

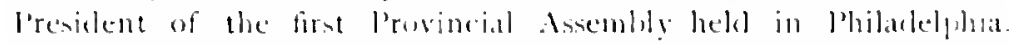
1)r. Winne's laughter married lr. Elwarel fones. Seventy yeats atter the founding of the rit! le lenn, the llospital was crganiecl and, on its consulting staff, we lind Dr. Thomas Cadwalader, "hove father had married Martha fone's. the gramb-danghter of lhoman Wyme. Ir. Thomas cadwalduer was therefore the sreat gramon

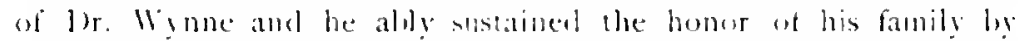

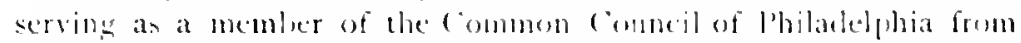
1751 to $172+$; he also wat a member of the l'rovincial conncil fiom 1755 to the period of the Revolution. When he letane a Vedual llirector in the army. In $155^{\circ}$. he hate the honor of preparing the

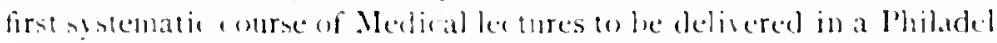
phiat follege. These fact are mentioned to illustrate the statement that the members of the Medical staff of the llospitat were nut enly eminems in their own profession but were men of affairs and patrots.

1 relative of 1)r. (adwalader's. 1)r. Cadwalader licans, a man of nose in his las. also served on the staff of the How,ital; being the sucessor of lir. Sammel l'restun Moore. It was to Dr. Cadwalader colden, who carly in the eighteenth century was a resident of thiladelphia, (but alter living here for ten years removed permanently (o) Xew lork), that lienjanin franklin was indelted for valual, le sngwestions, that eventually led to the formation of the scientific Asuriation. which developed inte the present American lhilosophial 
society. The brothers. Drs. 'Thomas and Phineas lind. were associated in the famous Iunto, and vere among the originaturs of Franklin's more ambitious organization for "Promotng I'seful Knowledge among the Iritish l'lantations in America." This Soriety, which went into full operation in $174 t$ had the following original members: Inr. Thomas liond as I'hysician; John Bartran, buanint; Thomas Godfrey, mathematician; Samuel Khoads, merhanician ; Willian I'arsons, geographer; 1)r. Thineas Bond, general Naturat Philosopher; Thomas Hopkinson, I'resident; William Colemin, Treasurer: Lenjamin liranklin, Secretary. In 1767 , this wis consolidated with the "American Society for Promoting and Propagating Useful Knowledge," among the members of which were the physicians above mentioned, and the American I'hilosolhical suciety "as organized with I)r. Thomas Bond as the representative of the okler organization, with I r. Benjamin franklin as its first l'resident. It is interesting to trace the intimate astociation of Franklin with the members of the first Medical Staff, since it led directly to the foundation of the Pennsylrania Hospital, in the growtl and development wi which he lecame so deeply interested.

Dr. John Redman, who was one of the fonnders and the firnt I'resident of the Cullege of Physicians of Philadelphia, was also the medical preceptor of the American Sydenham. Dr. Lienjamin Ruh, who became a member of the Inedical Staff of the Inpital. Dr. Thomas Graeme who was invited to attend the hospital as a consultant in extraordinary cases, was a graduate of the Univernity of leyden and a highly educated and accomplished fhysician. Ile

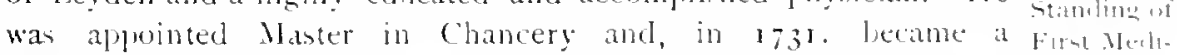
Justice of the supureme Court. He was the hirnt P'readent of the ral atatt St. Andrew's Society. Founded in 174\%. 'l'he services of 1 r. $11 \mathrm{~m}$. Shippen, Ir.. to medical education in this combry, are acknowledged upon another bage and alo referred to elewhere in this history. Enough has been recorded in this flace to show that the prenent members of the medical staff have good reason to think highl! of their predecessors in the service of the Institution, and may indeed be proud of having men of such eminent attainments in science. of such excellent achievements in civil and social affairs, and of such high moral worth, as members of the medical staff. exen in the early day's of the Ho:pital.

The leaders in the profesion in l'hiladelphia, in 1751, were Thomas and Thineas Bond. Thomas ('allwalacler, Lloyd \%arhary. Samuel Preston Moore, fohn Redman, and 'Thomas Ciratme, who, as already stated, formed the first medical and surgical atalf of the 


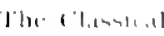
.111! - S1 1.-111111,

Att.1111110112 a) linth

f'in

Ilospital. The other moled physidians of the time were lor. Edward

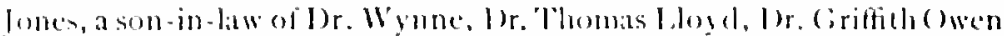
and bectors Goodson, Mitt. Colelen, and John hearley, Junior. It is most interesting to learn that "There is scarrely one named ferm old Dr. Daniel Wille (of liurlington, X. I.) down, who either dired ty ly his punerity. or imtireetly by nome atet of his life, has not

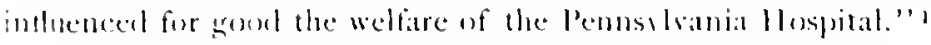

Is lescrileel in Thacher's American Medeal liography, we fincl that the grofessional men of the seventerents ame eighteenth centuries were generally mom better educated than most uf their succesors of the present time. Amost without exception they were losital scholars. Their graduating enays mut be wriben in latin. Travel wan essential. notwithstanding the encmonlered moles of motion to which they were subjected. Leyelen, l'aris, lidlinlurght, Iondon, (Mfirct, Upsal, lionn and to some estent Viema, lierlon, and the Italian, schools, received and homored them; they, as a rule by their subsequent career, equally homoring the places whith they visited and where they sojourned. They were also men of alfitirs. It is surprising what a part they took at home in politios (in its liroad semes and gerernment. 'lhey were gend soldiers, and ireely offered lhemedicts and their servicen 10 their comntry in timen of need.

I lomer roll of homor could le written to recorl their merits and cmlalm their memories: lout it may lex condensed in the single statement that with them education never militated against peronal good-

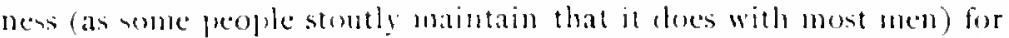
whether in pestilence and plighe, in poverty, or wealth, they rambed

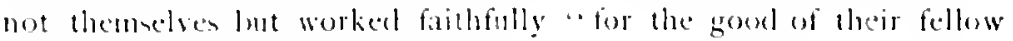
heings, and whe ghory of cod."

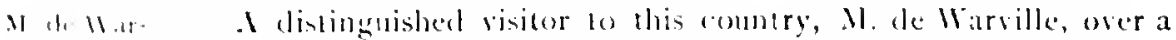
ville when entury ago, wrote at series of letters for pullication at his heme. in of a wit te finnce, which were afterward collected in book form, and a transla[110. Il, melt.11. toun wh wheh appested in Lingland. When in Philarlelphia, abut $1-5 s$, he paid a visit to the l'ennsyluania llospital, and his enthusiantic recital of his experience and impressions theresn are so graphic and at the same time so disingenums that no apology wilt be needed for intrulucing, a tew paragriphs here, especially as in them one of the fhisicians is mentioned, and a high compliment is paid to the entire management, both medical and administrative:

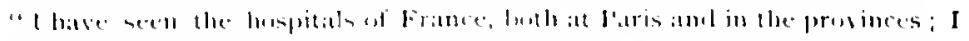

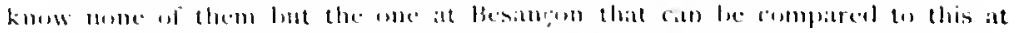

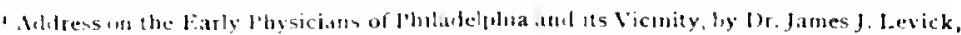

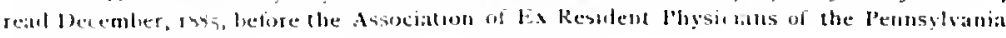
Hospit,il. 
Philatelphia. Exery sick and every pour prom has his bed well furnished, but

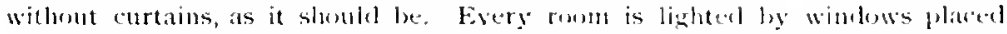
mplusite, which introcluce plenty of light.

"Blates are lece mingled with the whites and lodyed in the sume apartuments.

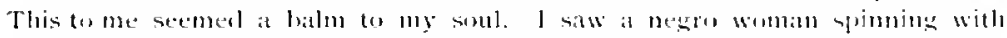
artivity ly the siele of her bed. She seemed to expert at ward in consolittion

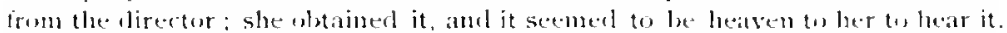

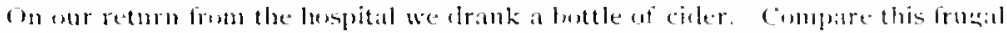

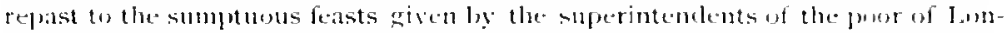

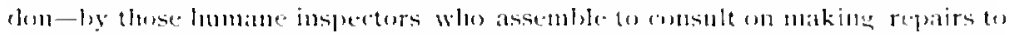
the anmont of six shillmgs and order a dinner for six guineas! Vou never find among the Quaters these bubleries upon indigence, these infamona treastoms against beneficence. Bless them, then, ye rieh and poor : ve rid, bocanse the ir

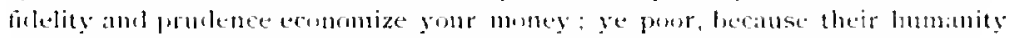
watches over goth without reasing.

"The huspital is fine, clegant and well bepte. I observed the bust w Franklin in the libary and was told this lomor was remlered to him asone of the principal founders of the institution. Fach one of the lunatics (albout fifterol hats a cell, with a bed, a table and a convenient window fitted with grates. Stoves are fixcd in the walls to warm the cells in winter. There were nomale persons among

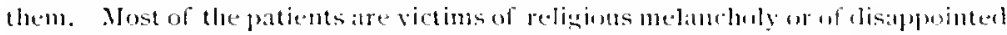
love. I)r. Rush has invented a kind of swing chair firt the.ir exereise. I askeel the humane and enligltened Dr. Rush why the cells were placed beneath the

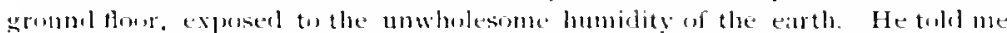
be hate endeavored for a long timse, but in vain, to introluce a change in this particular, and that this hospital wis foumled at a time when little attention wats thought necessary for the accommulation of fouls. I obaerved that wone of those

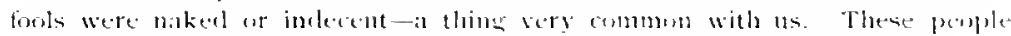
preserve, even in their folly, the ir primitive characteristic of decency."

In a paper contributed to the first volume of the Pennsylinia Hospital Reports (pullihed in 1867), Professor Charles D. Meigs gave some reminiscences of the Phyicians and surgeons who had served the Pennsylvania Hospital. The article is sufficiently interening and appropriate to warrant the insertion of a consideralse part of it here:

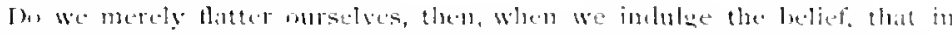

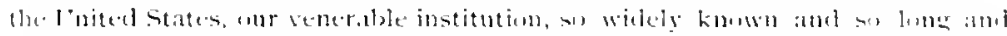

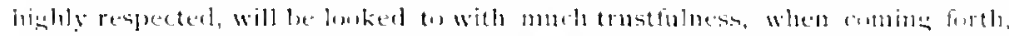

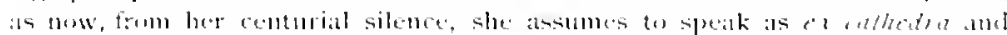

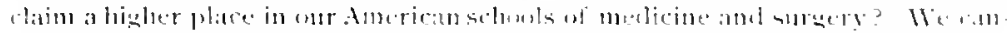

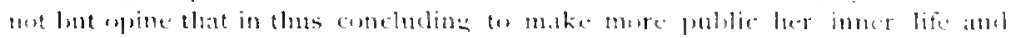

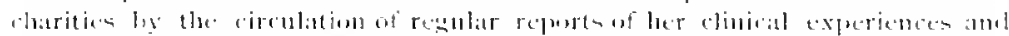

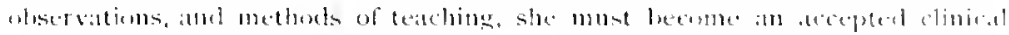

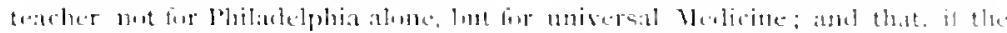

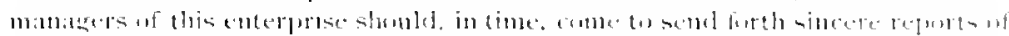

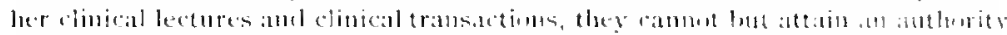

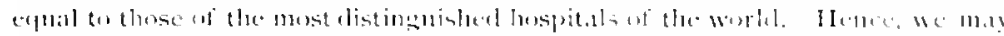

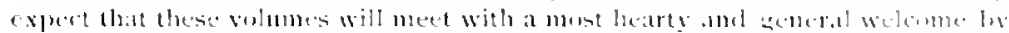

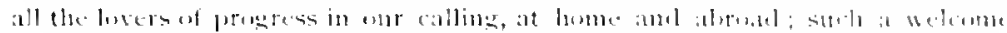

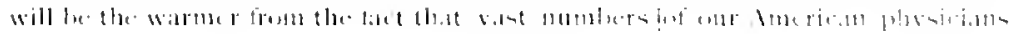




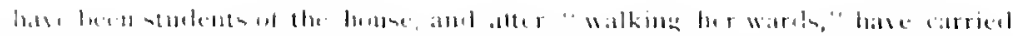

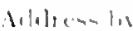

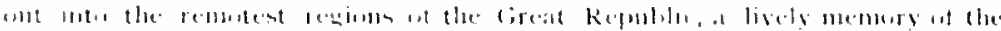

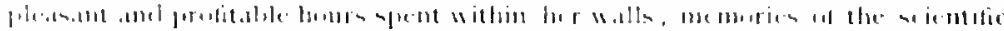

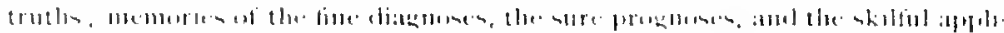

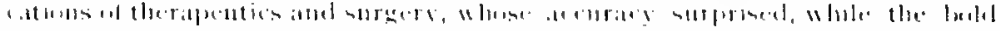

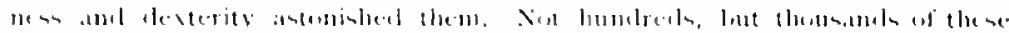

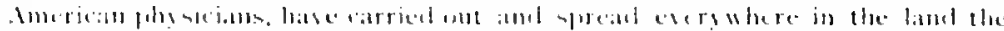

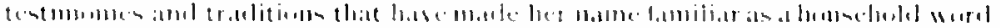

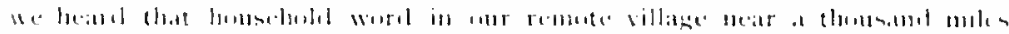

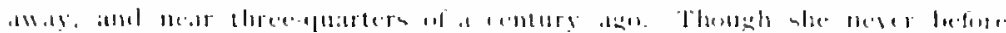

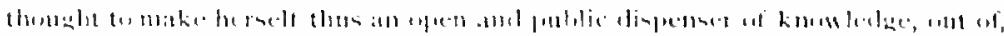

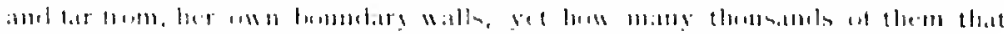

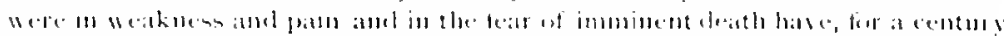

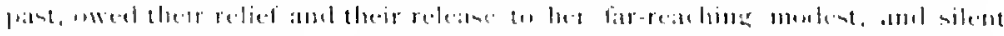
1h.1115.

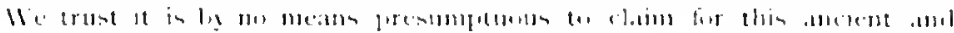

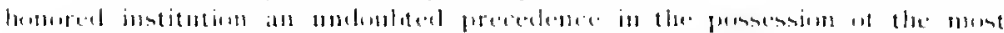

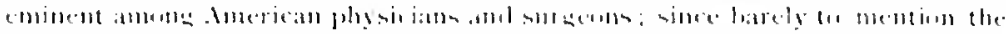

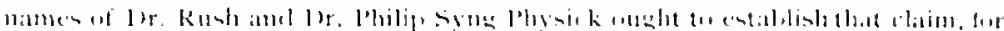

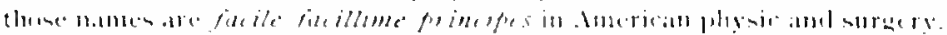

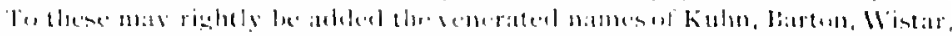

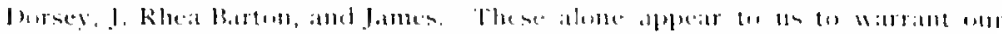

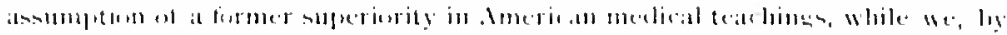

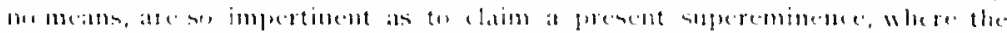

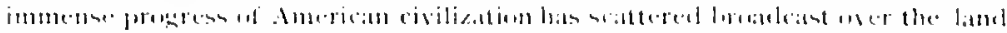

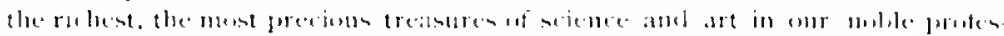

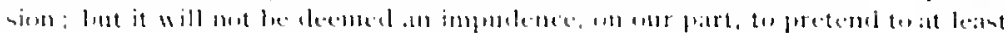
efual rank in the antual repuldie at melucal letters.

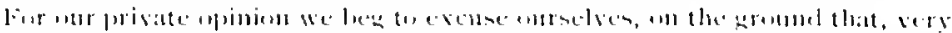

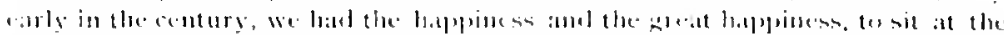

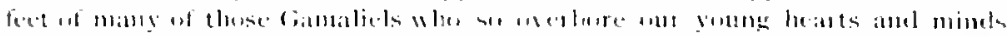

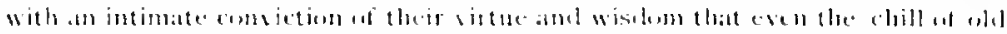

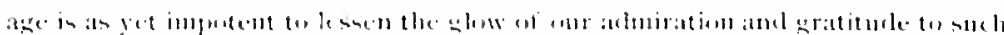

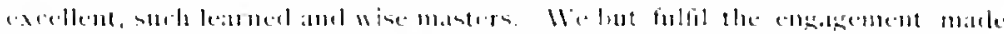

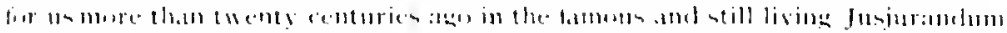

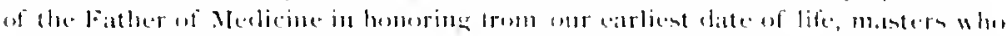

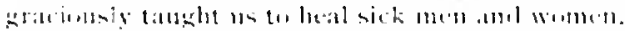

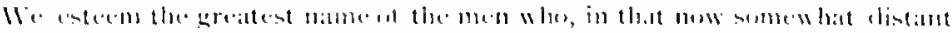

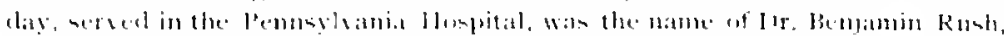

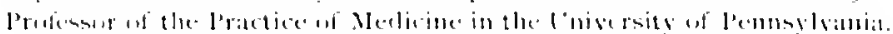

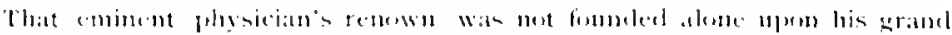

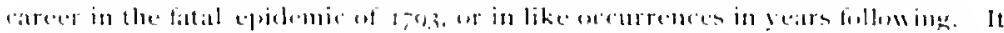

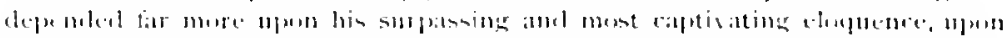

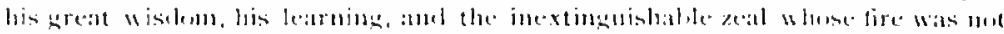

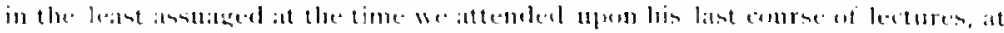

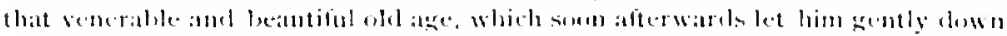

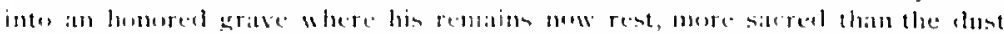

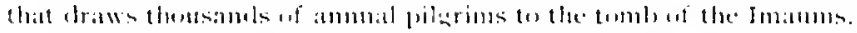

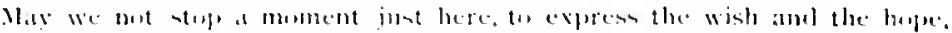

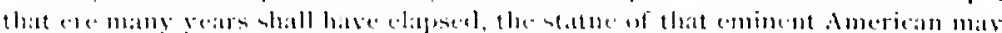

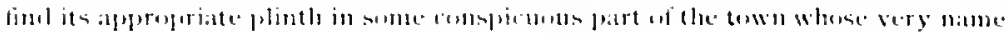

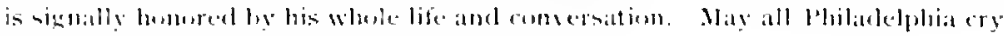

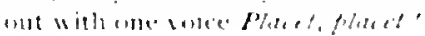




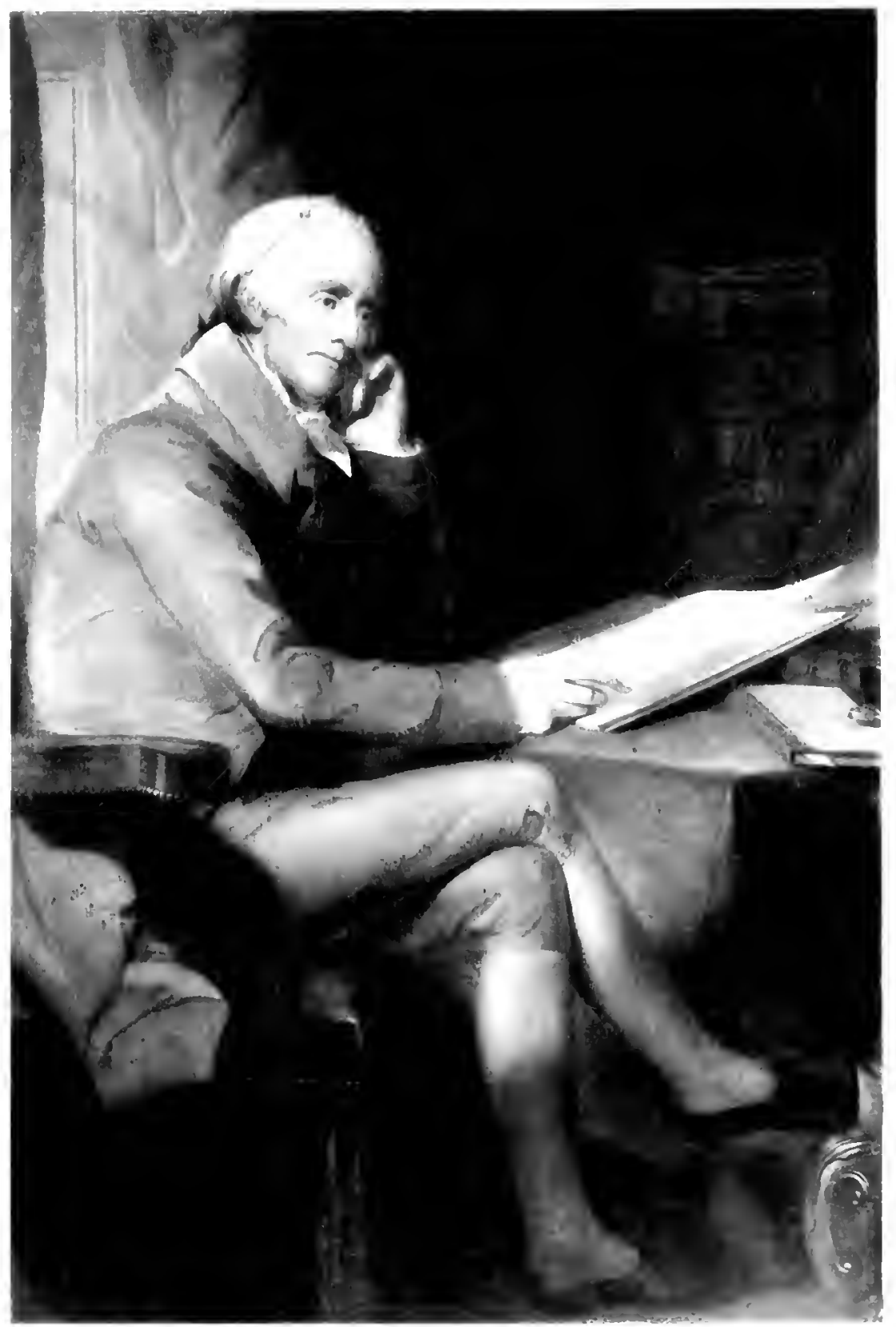





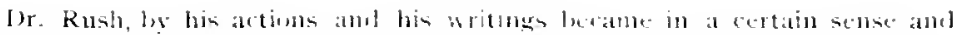
extent the American fialen, for we think it camme be denbted that he did transmit his idea, as a ewerning aml direding telement down thrumg mure than half at century of American Nedicine, controlling the practice of physic with an delembly H.. Me.izs. anthority during that time, as putent ats was the authority of the grealt Persame. nian in the far longer series of centuries, from the second until deep inte the seventeenth. Vet eren torlay the name of tialen is not bloted out; and like Rush's is only under the eclipse of this progressive age. They are luth marking

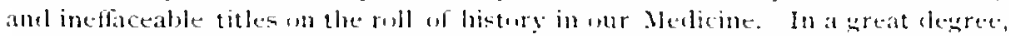

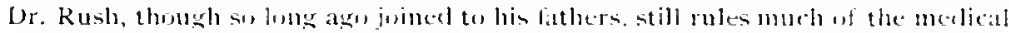
practice it maluy parts of the [nited states. His wits al great minsion and lie filled his statinil well.

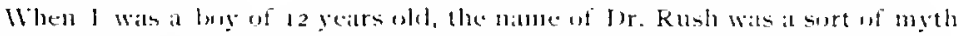
in my goung ears and was know by all the penple of yon stequentered village on the creet frontier: and when in the antumn of int 2 , pirst entered his lectureroom in the old coniversity hulding on Xinth Stret, I was enrelpt : his resice, sweeter than any flute, fell on my ears tike droppings from a sanctuary and the spectacle of his beantiful radiant countenance, with his earnest, most sincere. most persuasive ace ents. sunk so (lecep) into my heart that neither time nor ehatige could eradicate then from where they are at this heur freshly remembered. Wh! but le was a most charming gentlenan! a "grave and reseremel and putent signor" in the scholitr cliss of mankind!

Now this was one of the men who gracel this old Hospital in unr benng datys, with his teachings, his learning, his wischm and his molnmers, formed upun the arand obl style of Washingtm's court, of which, alas! but a few scattered and bused down specimens are here and there to be seen lingering in our conntry.

There it was, as well as in his lecture-rem. that he helped 20 mould amel hashion the manners and deportment of that house in a way to make it speciticcharacteristical. Vet not to him alene are our thanks due for the form of this schwol and its individual significuncy. He had hate coadjuturs whose ministrat tions there and teisewhere laid on the brows of Phibeletphia the Science-crown. that shone sy far and so bright in those palmy dags of his Schoul of . Werlicine.

Dr. Kuhn, a facorite pupil of Linnaus, whe learned to lowe him at Cpsilia, was a man distinguished for learning and probity ; an homor tow calling. Wr. bluilip Syng Physick, long a pupil and assistint and trusted friend of Mr. Hunter, and long a resident in the Hospital in .Ir. Hunter's service at Lonelen, was like lis master a nucled of exacthess am eertinty. I neser saw a man who knew so thorolghly well afl that he knew. It secmed at if his science amb at were ledgered in his brain, sis that he combl turn on the instint to patge and line. Dr. Physick's service in the house was cominued during more than twenty-two

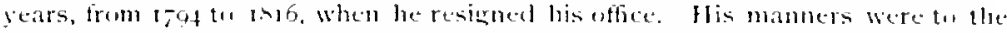
last legree dignified and elegrant. ant as he still wore his hair powedered and clubled, he bore about him a sort of tratitional lowk, which adeled to the respet which everywhert, in pulblic and private greeted imm, always reverently. In the midst of a crowd of students more than five hundreal in number assembled frim all quarters of the compass. impertuons, ingenums het heads from the carolinis, restless Georgians, bold suns of kentucky, and lackeges from the Nurthwest, on the graver students from the . North, the moment the l'rofessor entered the lecture. room, all was hush, with a general pleased expression murmured all eser the amphitheatre, "and ear and cye attentive lent " to the metlifums tomes of his boice, or the most admirable illustrations of sureical precesses that he so pro. fusely supplied. He was a man like a statue of marlike lut animated by at promethean light and warmth. Ir. l'hesitk was a very narking man in our 


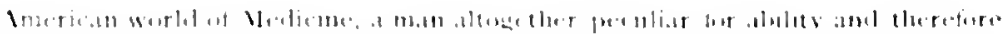

Allitem lis br Haiks

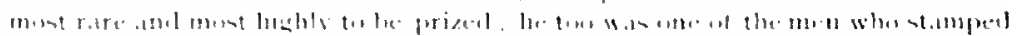

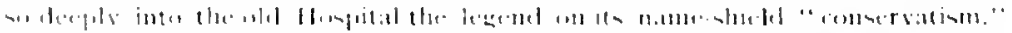

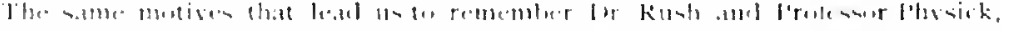

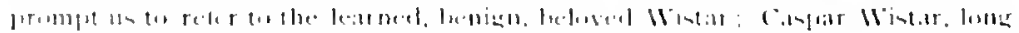

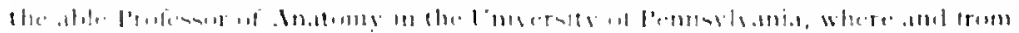

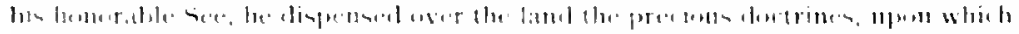

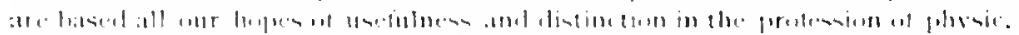

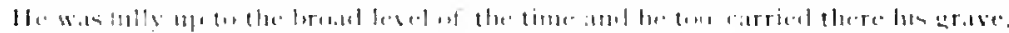

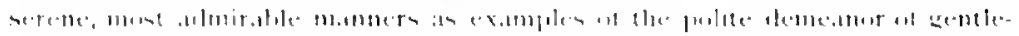

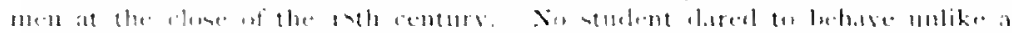

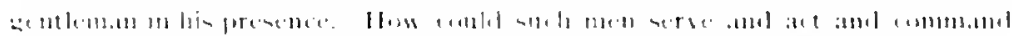

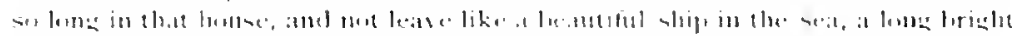

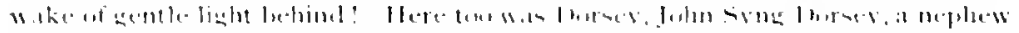

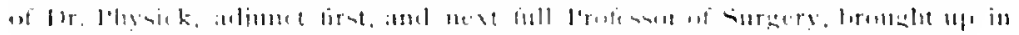

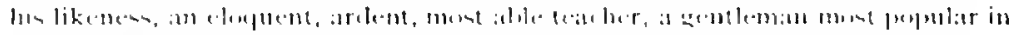

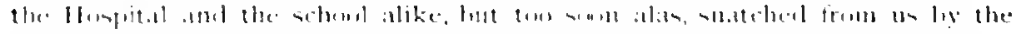

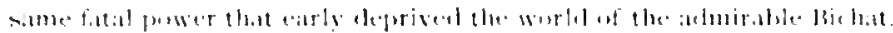

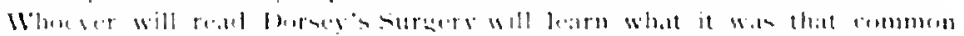

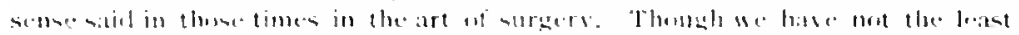

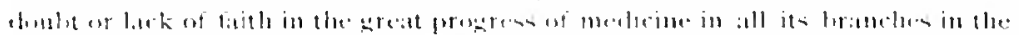

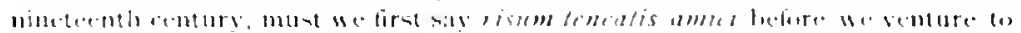

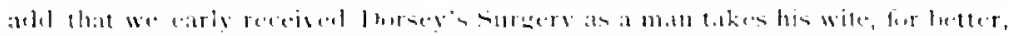

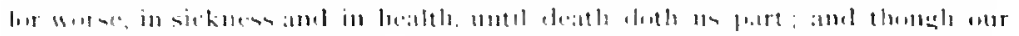

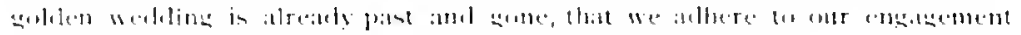
then and there.

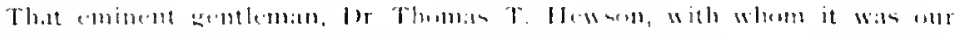

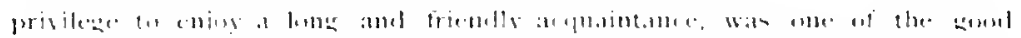

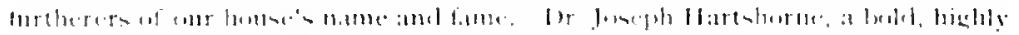

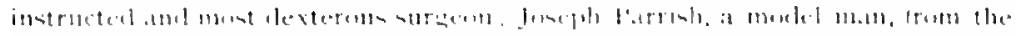

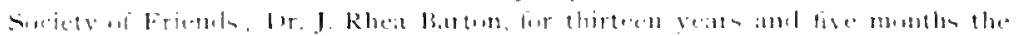

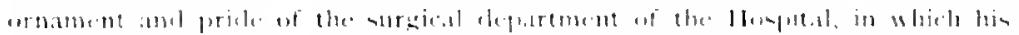

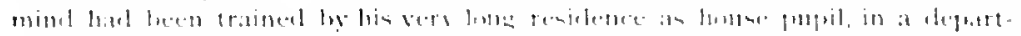

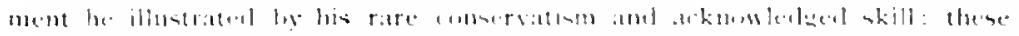

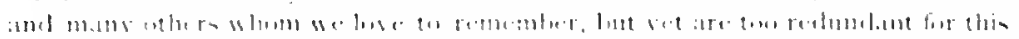

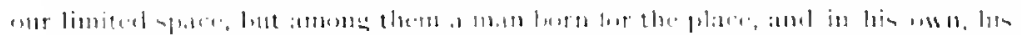
risht plate-

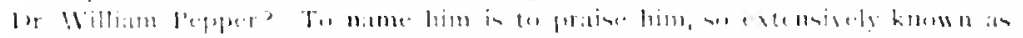

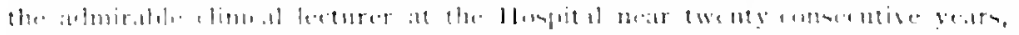

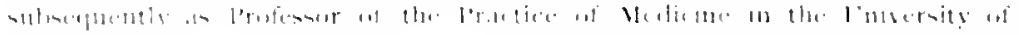
I' $1111,1,1,11,1$.

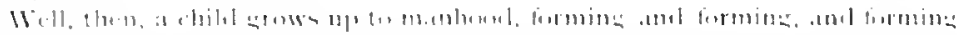

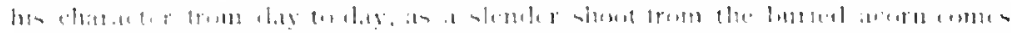

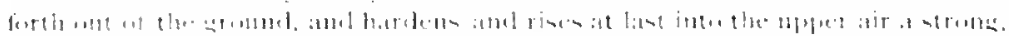

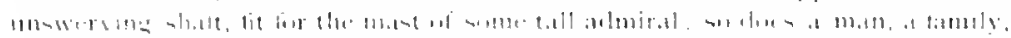

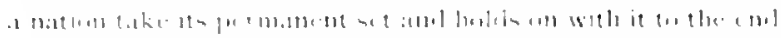

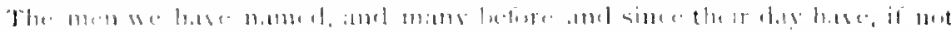

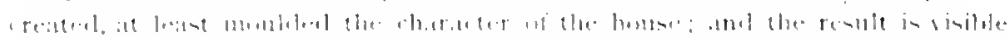

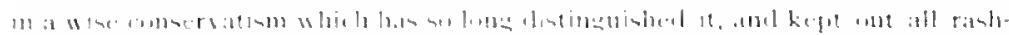

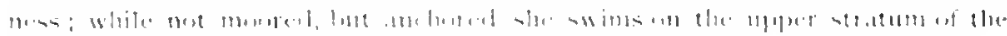

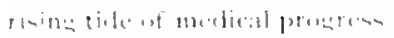

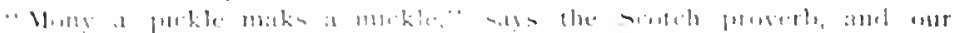

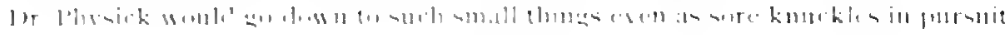


of useful truth, like a miser who womt jemure scales the' he likes mugerets better.

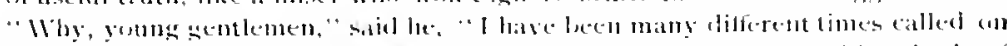

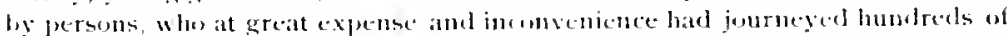
miles for the sole purpose of show ing me their sore knokles, which had anmoged them for vears and cost them litrge sllms in fees nithout the least abail. The sore

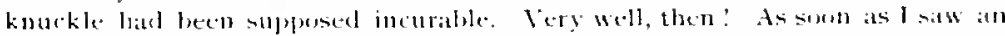

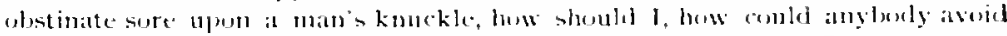
mating the reflection, that the sore must have lecen kejet up by the metion uf the

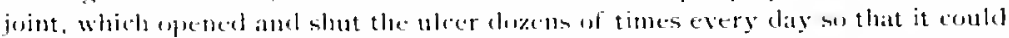
not heal; or that ather reflection, that a sure finger, like a broken bonce, requires for its treatnent mothine more than a splint." The l'rofessor then cut frum a catrel

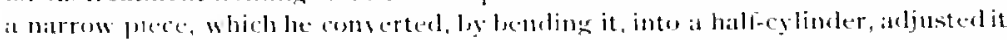
to the palmat surface of the sole fillger, dressed the sore with a create to prevent the banclage from stickines to the elges of the sure, and bound it with a narrow roller. "There! that's all! that will eure yeur fingrer "' And there never was

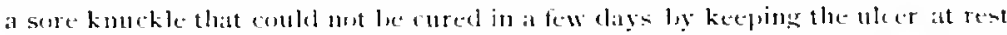

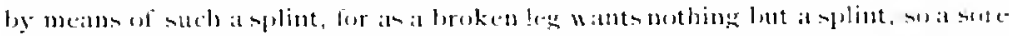
kunckle wants mothing lont a splint. lle said that his pationts were mute sur

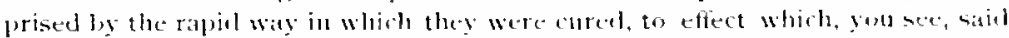

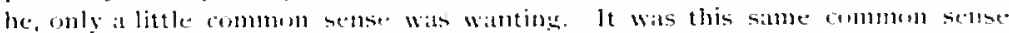
attribute by wheb he was alistinguished as at pratitioner and as ateater, that led

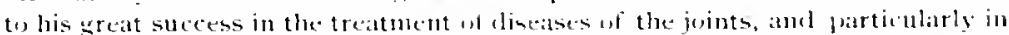
managenucht of morlus coxarius, which le alwast teated leg his carved splint

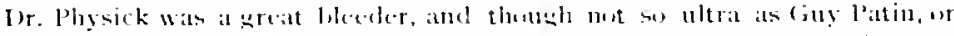

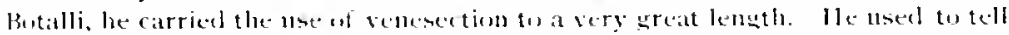
us that whike he was resident and ascistant in St. Georege's [lospital, at

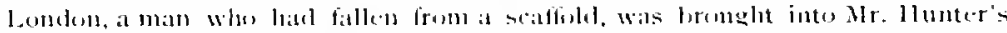
ward insensible from enemsion of the brain. "What shall t do for the man?"

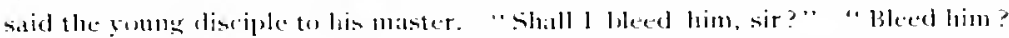
bleed him, sit? Xio, sit: you would kill him whtright. Wait, sir, until le reacts, and then bleed him-blecel him tudeath, sir : "

On this text 1). Physick fonmeled sery elaborate instructius for us whowere

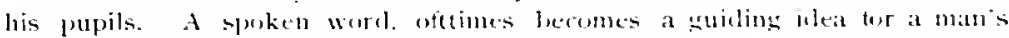
whole life, and the losplital pupil never fursut this anc.

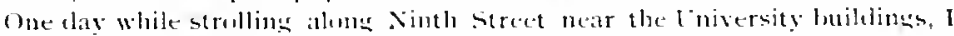

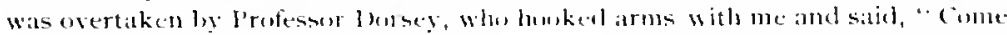
alones with me: 1 willshom yoll a case." We entered a house in Market sireet

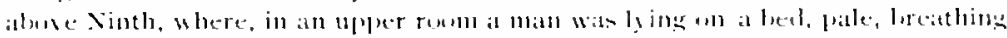

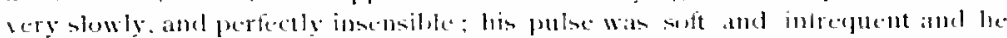

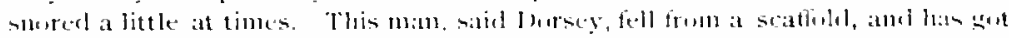

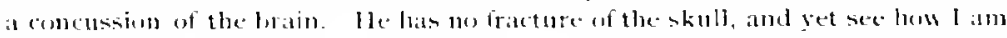

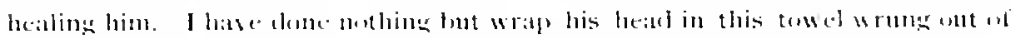
(an) water.

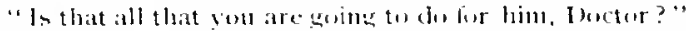

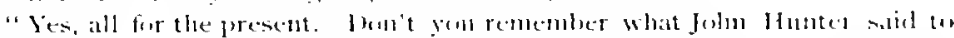

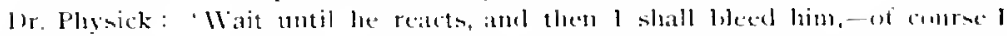
will $2+\cdots$

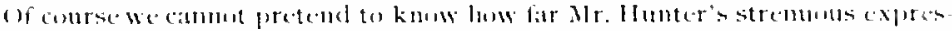

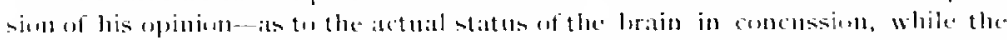

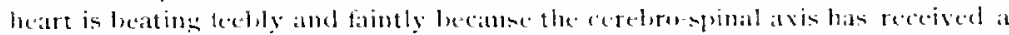

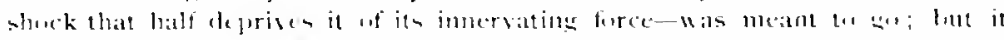

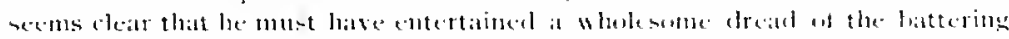

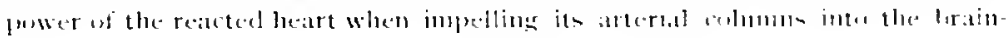




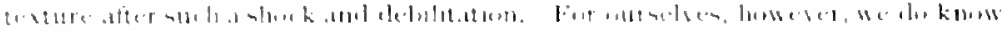

Allining 1) Vlitim

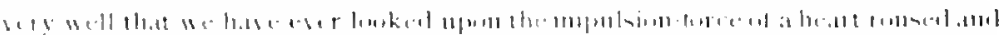

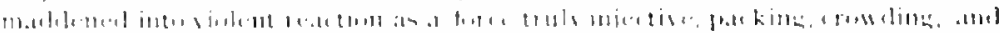

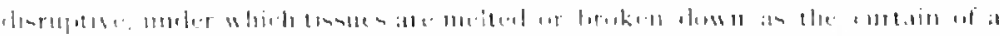

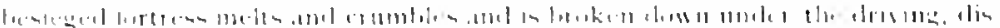

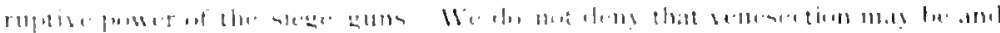

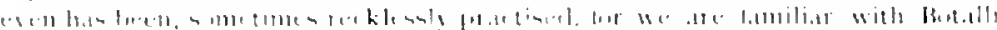

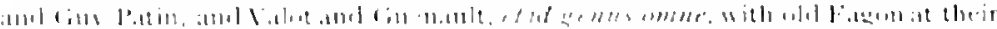

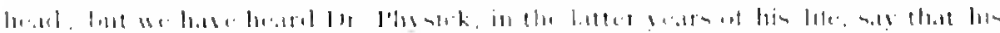

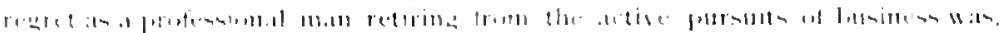

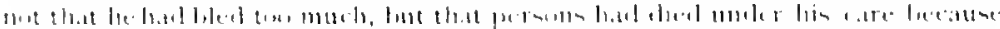

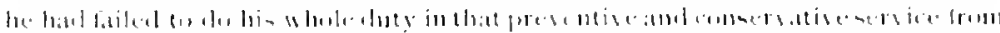

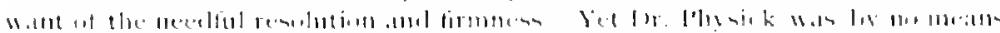

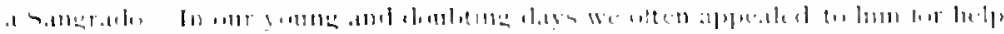

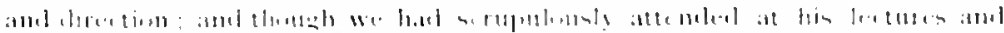

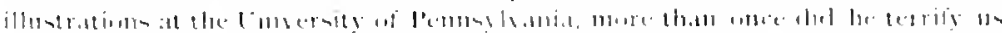

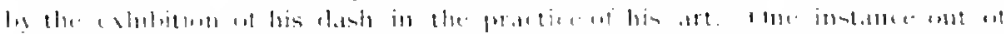

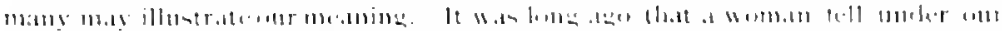

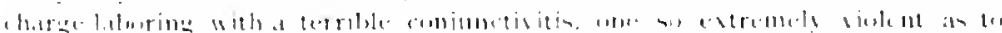

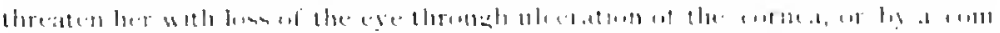

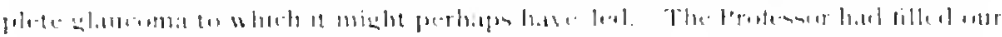

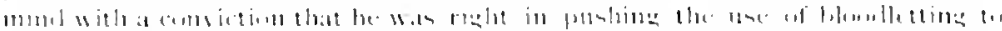

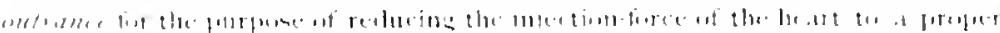

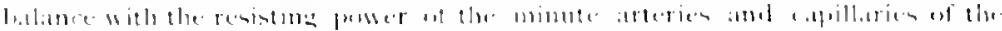

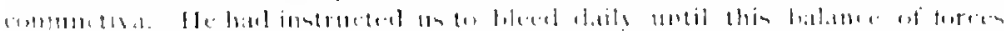

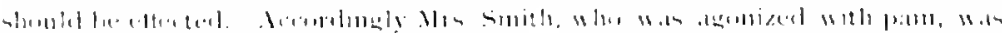

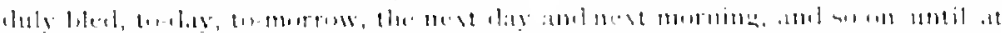

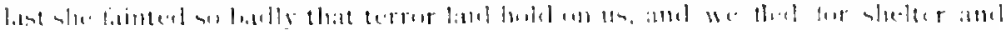

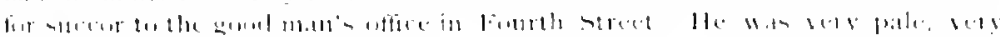

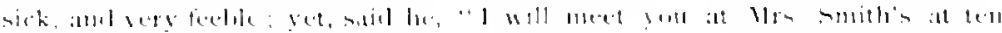

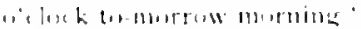

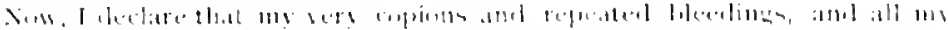

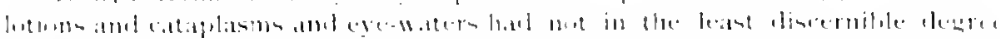

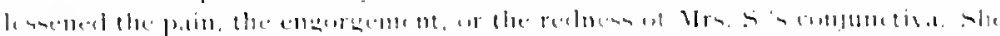

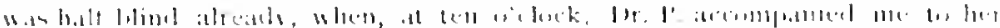

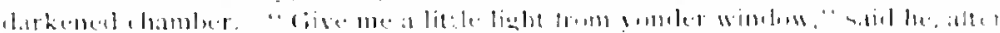

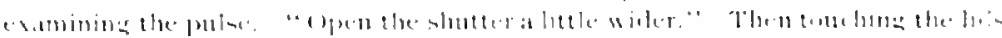

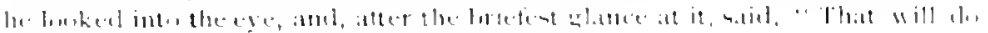

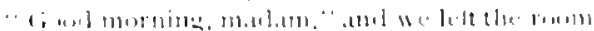

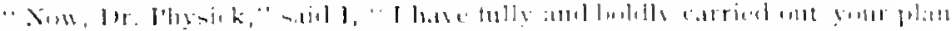

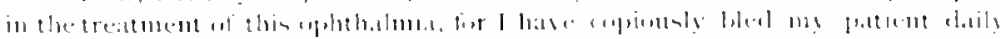

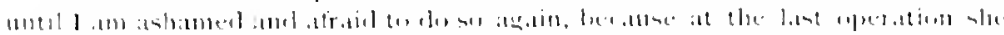

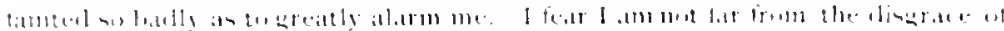

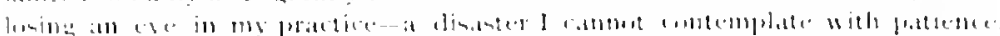

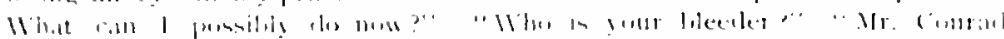

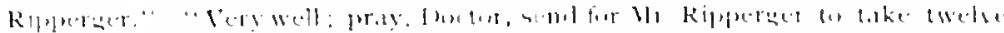

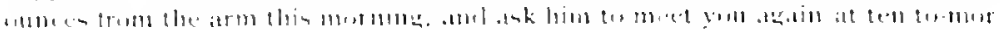

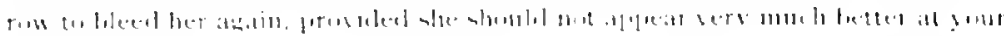
$11-1$ l init. "

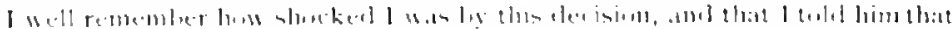

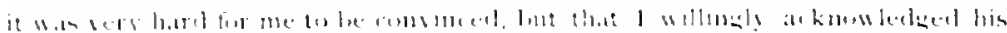

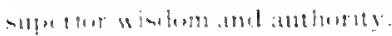




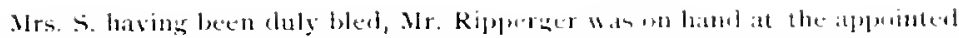
hour of the following day ; and truer words w. re never speken than these, that on lowking into the eye, I combl discover only fint trates w the bery violent and ohstinate inflammation, for virtually she was cured alreaty. Mr. R. elit wht repeat his operation, and Mrs. Smith"s eye wan howtly and perfectly restered to heilth.

Many and many were the instances of dangernus ophthalmiat that 1 treated suecessfully in that line alterwards-a line in which I hlumbl have continued to fislat it, were it wot that I many gears afterwards learmed that mutrate of silver

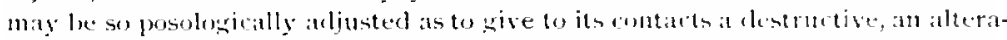
tive or curative, or an indilferent, force at my option. The impertan invention of the applicability of nitrate of silser to all acesesible sluperticial inllammations,

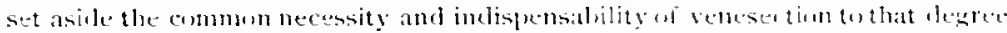
that might have ravished with joy and triumph the lest heeders of the font of

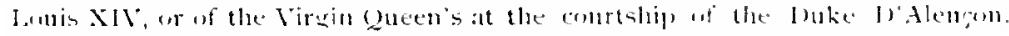
Anybuly may understand this who will read diug liatin's letters. ot Butallis lookt.

If the relation of this incident should happily serve to amuse or interest the

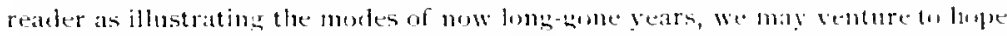

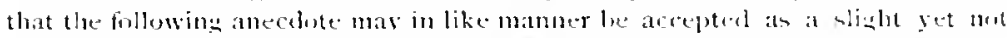

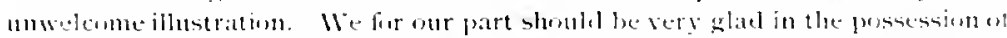
a diatry filled with the whole aspects and worth of the Bunde, the formes so the

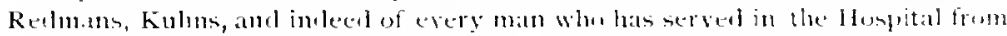
1,755 thitil $110 \%$

It Wils in the carly winter days of gire that, alung with a erowel of fellow

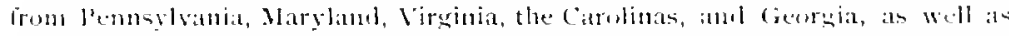

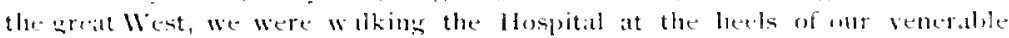

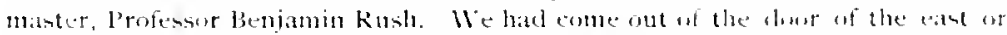
croms buthling in the second story and were passing now intu the men's medical ward Dr. Rusli pushed open the elowr and was stepping inte the ward when lat sullenly stopped, and lowking back upon us, the crowel, saiel, "stup a moment.

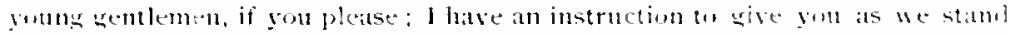
here at the dowe." Then, punting diagonally oser the wath to its morthwest

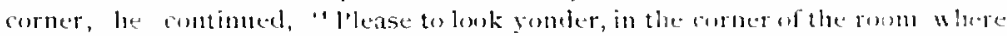

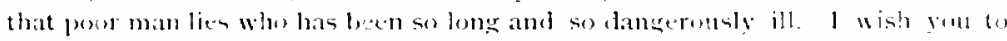
note that he is mow lyiner upun his side. That's all for the present. 1 call your

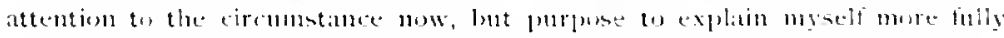
when we reach his leedsite in dace oreler."

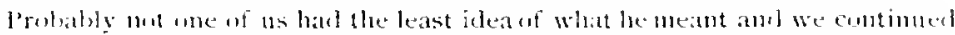

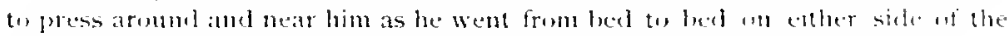

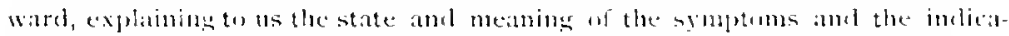
tions, mutil at length we came thether in the mothwest corner w the wart, at the couch of the supposed lopeless case of nervols fiect.

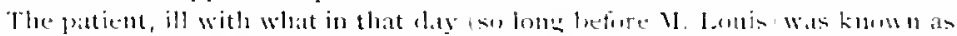

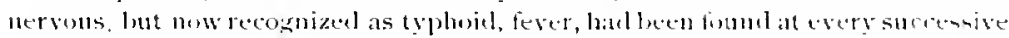

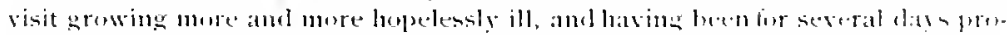

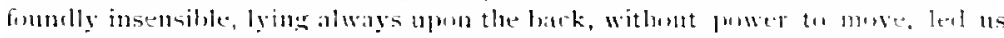

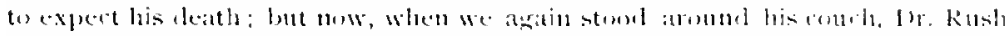
saticl, "You remember, young gentlemen, that when we entered the wetrol hy

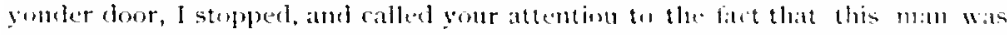

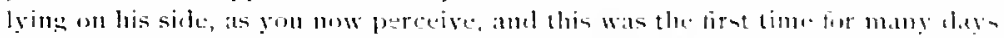

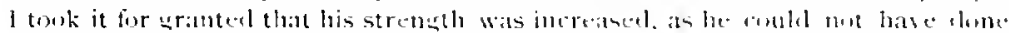

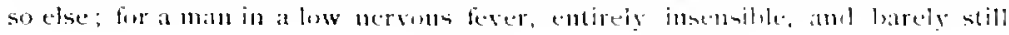


Alditionsin

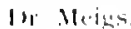

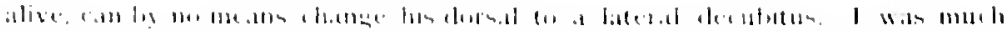

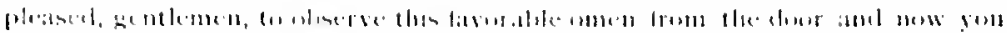

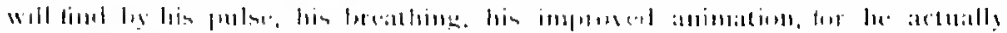

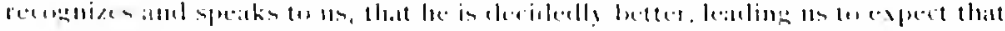

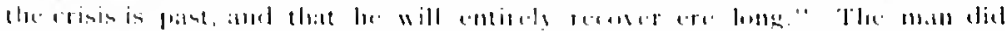

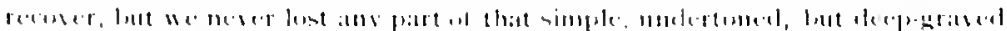

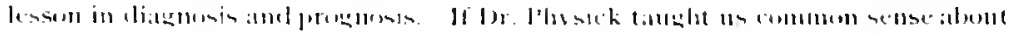

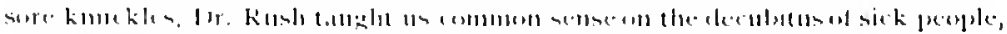

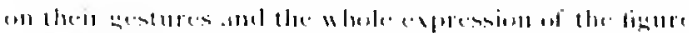

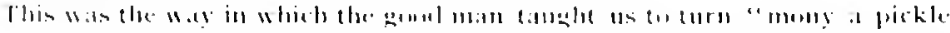

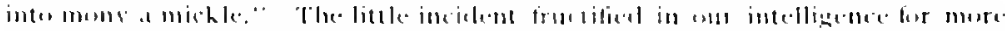

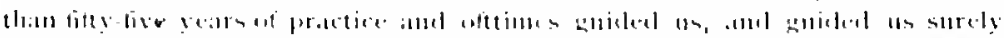

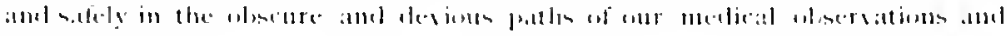
actiuitum

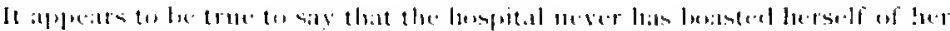

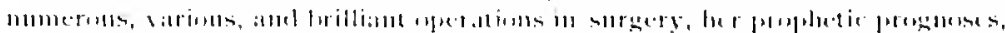

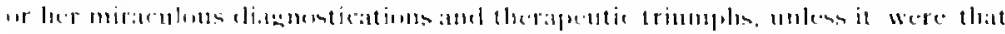

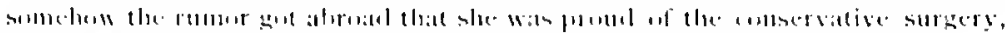
which if nut ere:ated and rarried ant, was at leatst het 11 und its plinth be br. J.

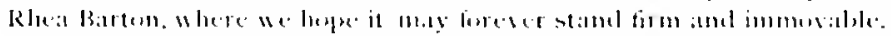

Brief sketches of the lives and services of the members of the Medical and surgical staff of the Pennsyluania llospital from its foundation to the present time are appented to this section. before taking up the biographies, it secms proper to consider loriefly the sistem of medical instruction ancl lectures at the llespital.

The Merlical

In the history of medical eduration in this country, the Mecheal statt and Staff of the l'ennsylvania Hospital has played a prominent and highly Malical honorable part. ${ }^{2}$ From the very inception of this benevolent enterTeaclintr. prise, the "practice of the house" has been always held in the highest esteem, and its value as a means of imparting instruction has been fully recosuized. The medical demonstrations, surgical operations and scientific lectures ocrurring within its walls, offered educational oppurtunities to medical students and even to phusicians of the infant commonwealth, which were caperly sought after, as, it being at that time, the only place in the cotntry where such facilities were offered. Its medical library and muemm, for many years, contained the only considerable collection of books and of pathological specimens, and uther suitable material for illustrating medical lectures, to be found on this side of the Atlantic ocean.

The future use of the Instilution in the serviec of medieal eduration, appears to have leen taken inte consideration, as carly as Aml 13. 1752, when the Nanagers adopted a series of "Rules to lee Ohserved in the Choice of Phnsicians." in which it is stipulated (in Arive Vl) that. "lach Apirentice, or other student the l'rac-

'Siec pages 134 et setqutur. 


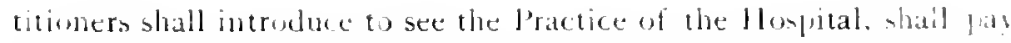
one English Guinea, or 'Thirty-four shilling current money, per year. to be laid out in Medicines." The degree of appreriation of the exe adrantages by the profession and the Managers, may le infernel from the fact that, in 1791, the loard, by formal resolution, tendered

The- Ilimpotal Encusarian. Buctical Fidue:ation. to the l'resident, of the College of Phyicians of l'hiladel phia. "the use of the books in the Nledical Library of the Hospital and the J'rivilege of attending the J'ractice of the Honse." Wherenpon it appears, ly the correspondence, that the offer was formally accepted by the College, with thanks.

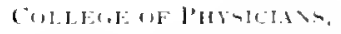

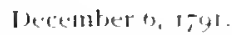

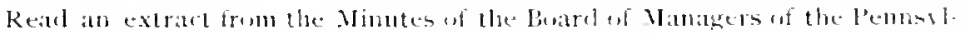

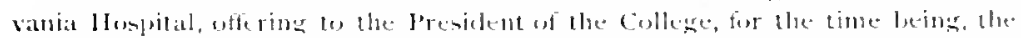

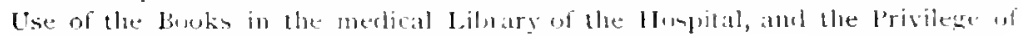
attending the Jratice of the Jluntse-

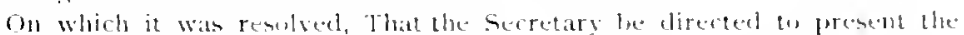

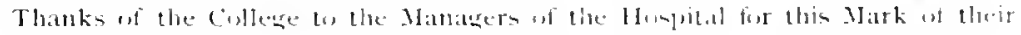

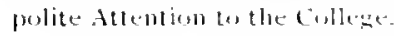

Extrated from the Minules.

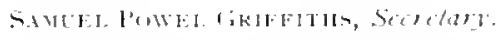

Again, in 1799 , the privilege of using the Jibrary is tendered wh the une in "the Presidents of the Lniversity, College of J'hysicians, Academ! of Melicine, Nedical society and the (hemical sociely of l'hiladel. thia," in compliance with the folsowing formal rerpues from the Medical Staff:

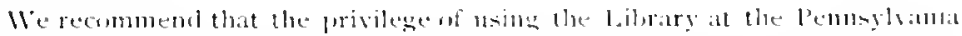

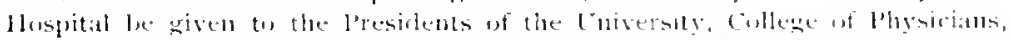

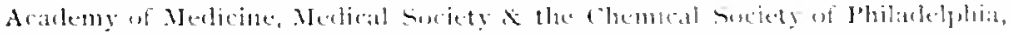

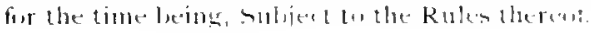

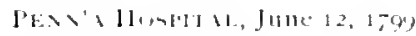

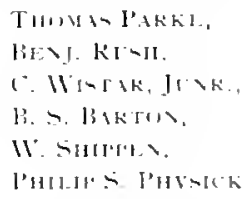

The library, it shonld be explained, had recelved nome donation and beguents of books by physicians, but was mainly entablished with the income derivel from the sale of tickets for leetures and the sum faid br students for attending the prartice of the house. The fich from each of these were according to custom in the European hoypitals. in reality the percuisites of the medical staff; lut the physicians not only offered their uratuitous services to attend patients. but also com* senter to lecturesostudents, without remuneration. onl! wipuluting that the Lihrary at valuatble privilenge.
The Meslicial libusars suplintert loy the bhyicians. 
the lees should le devested to the mantename of a Mcelical library.

A lores and l'nder the judit iom alminintation of the .Managers and fontering suluald care of the medical staft. the library in a slort time lecame the

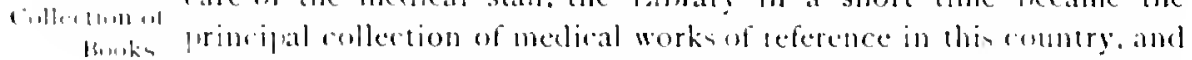

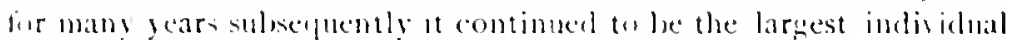
coller cion of medical hooks in the l'nitesl states. Even at present, It continues mingue in its pousssion of rate and valualple worke and of many complete files of medical journals. Which camot be now doplicated. The history of the library has been given on another fage: this mention is necessary in order to show its relation to medi-

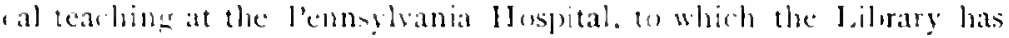
al ways leeen a valualile adjunct. In the other hand, no consicleration of the medical bibrary would be complete without reference to the lectures. which for a long tine were delivered in the same reom. and were illustrated ly the plates and molels ledonging to the library amil Museum.

The liint

Ai stated at the commencement of this section, medical couren colucation in this country received its lirst impulse and concourageLenturen ment from the menters of the medial staff of this institution.

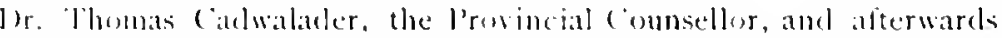
one of the physicians to the Hoypital. gave the lirst course of meelical lertures eledivered in the 1 eestern hemisplere. leefore a class of Philadephia fhysicians and students, as already stated (page +60$)$. One of his hearers. Mr. William Shippen. who received his medical training in the Province, conceived the idea of giving his own son uch superior ahantage as would qualify him to contimle this work of medical teathing under better auspices. After completing a course

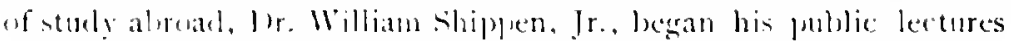
in l'hilulelphia in May, ig6z. The lectures have lecente historical, ince they were the lirst istematir anatomical course ever grien in thin country. It is probalble, owing to Dr. Shapents predilection for chatetoics, that he esperially talyht the partical application of anatomy to his farorite stuly, since l'rof. 'l. Gaillard Thomas, in a comtribution to ". I Century of American Medicine," in which he reviews the progresi of obstetrien and gynecology," states that " in

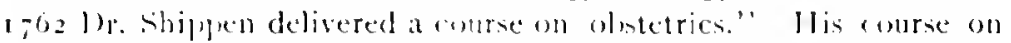
midwifery may have been supplementary to that on anatomy, lout the probability is that the same coure of lecture is refered to under these different titles. At all events. Dr. William Shiplen, Ir., las had the honor assigned him of inatgurating, upon this contunent, systematic lectures upon these two, important liranches of medical science.

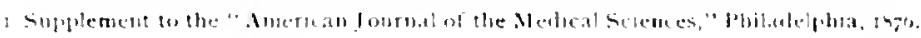


The lectures of 1)r. William Shippen, Jr., though not at first delivered at the Hospital, were shortly afterwards, for ly invitation of the Maragers, he attended the Mnsem, at stated times, "to explain the preparations and models." 1

In order to prove the intimate connection between the Hospital I). IVilitam silipuren, Jr., attends at the lasplital and 1)r. Shipuen's first course in anatomy, it is only necessary to lecture. recall the fact that Ir. John Fothergill, of London, (whose acpuaintance Dr. Shippen had made while abroad, not only donated (July 27 , 1762), the first book to the Hospital Library" "for the lenefit of the young students who may atiencl under the direction of the physicians." but also founded the musem by his generons wift of seven cases of anatomical drawings and casts (which were then valued at E.350). At the meeting of the Board of September inth, certain provisional rules were adopted "regulating admission to the Museum and attendance at Dr. William Shipen, Ir.'s Lectures, until Dr. Fothersill's desire on the sulject is ascertained." Dr. Futhergill soon after, in a letter to one of the Managers, Mr. James Pemlierton. Ir., exjressed his desire and suggested that "I)r. William Shippen, Jr., give a course of anatomical lectures at the Hospital, using the anatomical drawings and casts he presented the Hospital, in demonstration. ${ }^{2}$ It appears that it was at Dr. Shippen's suggestion that the Managers

In the hiograptical sketch of Dr. William Shipren, Ir., it is unted that in 1-trs. Ir Siup,

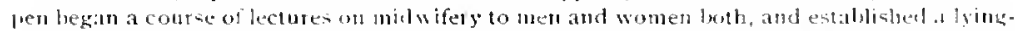

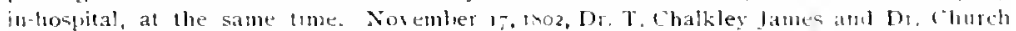
nave the fist regular course of lectures on Obstetrics in a Medical College in the l niterl states

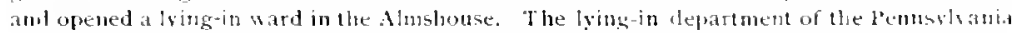
Hurpital was ovened a month later.

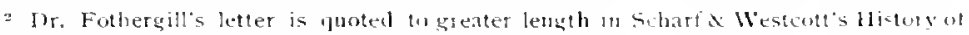
Jhiladelphiat, Kol. Jl, p. I = shi):

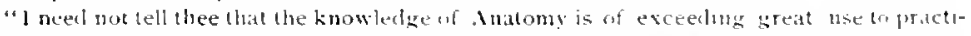
tioners in physic and surgery, and that the means of procuring humects with you are wot easy Sone prety accurate anatomical drawings, ahout half as hig as the bre, have fallen into my hants, which 1 propose to send to your hospital to he under the are of the phrsicians, and to be by them explained to the students and pupils who moly attend the bospital. In the want al

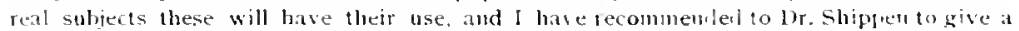
cumse of andomical lectures to such as may attemi. He is very well tualified for the subect, and will soon be followed by an able ascistaut, 1\%. Morgan, buth of whom 1 approhetel. will

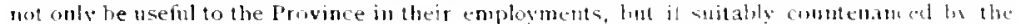

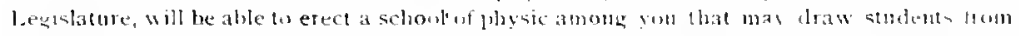

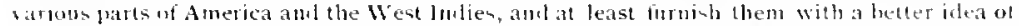

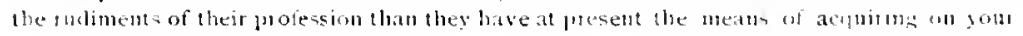
side of the water."

1). Morgan atrised two yeats after Dr. Shiplen began his lectules, and eventually br. Fothetgill's hypothetical possiblity hecame an accomplished hat, in the foumeling he the

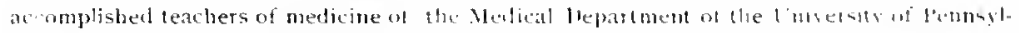

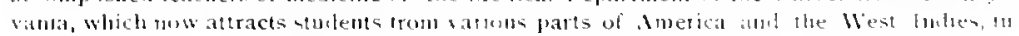

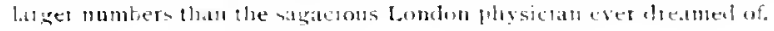


decided to treat linene lectures as a sourec of resenue. for it is

The. M.t1l.1

Litren. wirget

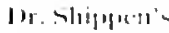

witier l.,

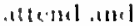

lertule in the

Mlunetlitl recorted on the minules of $11: 1917,1763$. that

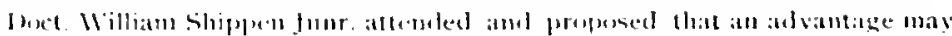

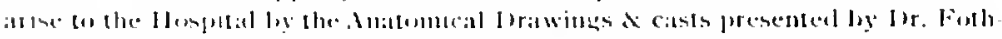

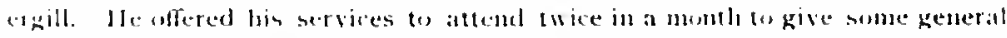

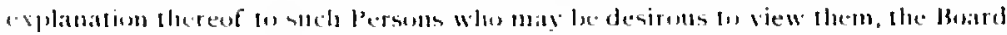

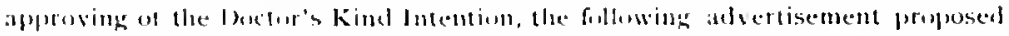
ty him was agreed to be puthlisbed in ble Next " (jakelle." viz.:

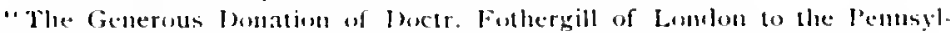
Vamia Ilonpital of a Sell of Anatomical l'aintings Castings in platister of latrs expestenting ditferem viewn of the several parts of the lomman buly, being now depensited in a convenient Chamber of the llespital, as there may les many l'ersons besifles stulents in l'lussek desimus to gatiu some general knowledge of lle sructure of the lomman lady.

"Dr. W'illiam Shippen Ir. proposes to attemel there on the seventh Ditg of the

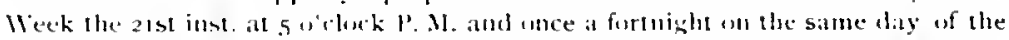

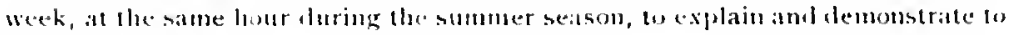
steb persons whe are willing to give a bablat each for the benefit at the lompital."

To show that this was nol inlended as an exchusive privilege, the Managers adopled the following general regulation :

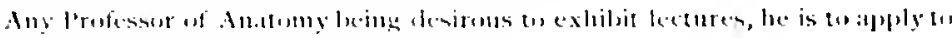

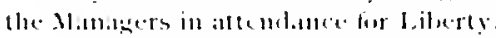

In order to limit the altendance upon the lectures and demonstrations to those who would be mos likely to profit by them, the following rule was aclopted at the sance nueting :

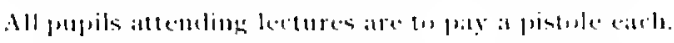

As a number of "sturlents in lhysic" were olserved to be attending the warks at the lime of the attending plusicians' isits "whlh a view 10 improve themelves in experience," the Manigers resulved (May 10, 176,3) that

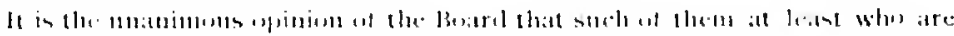

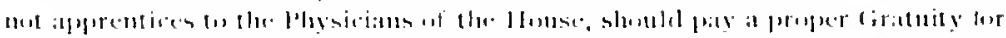

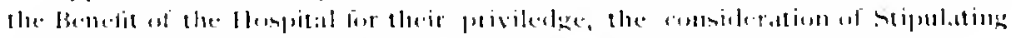

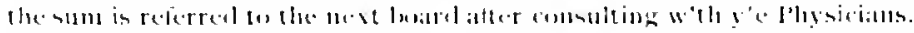

Sindents

The minutes of lhe following meeting (Aay $31,77_{3}$, ) comtain reguired to a letter from the altending l'hysicians, which exhibits their disinterpay tor estedness and liberality in a very honoralse light and al the same time frivilewers. proves that they were fully conscins of what was duc to their professimal standing and dignity. The meeting evidently wan the first one alter the Anmual libertion of Mantegers and l'hysicians:

Silin, 2ull, 170,3 .

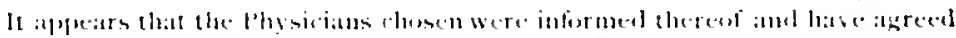

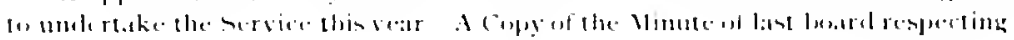




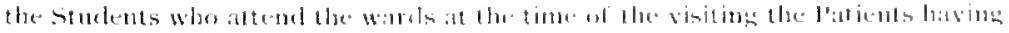

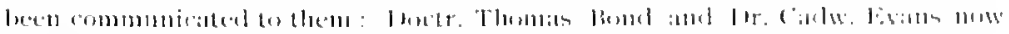

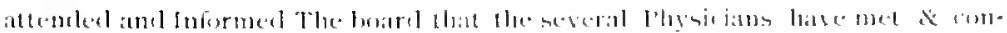

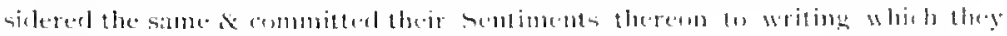

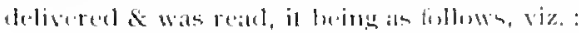

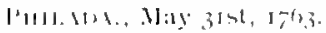

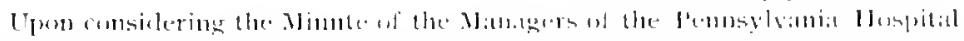

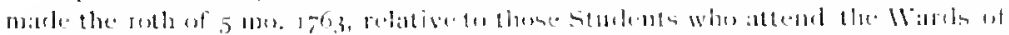

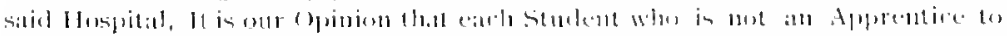

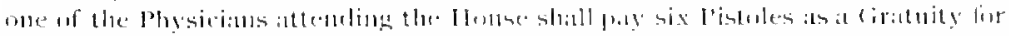

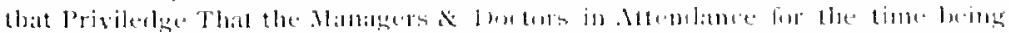

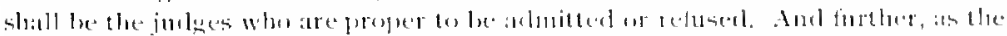

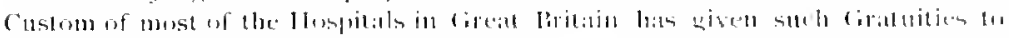

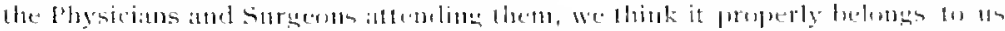

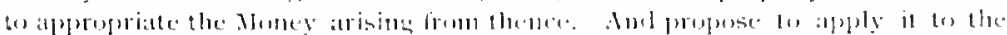

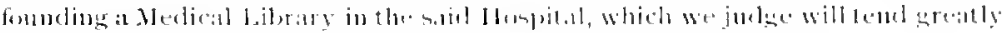

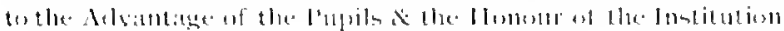

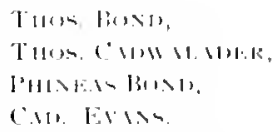

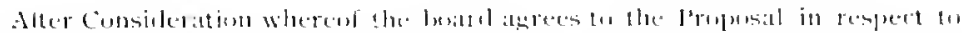

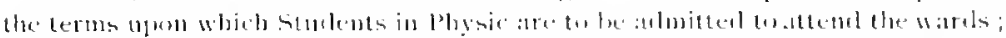

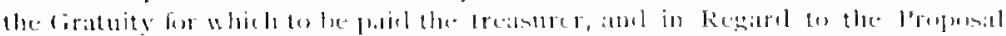

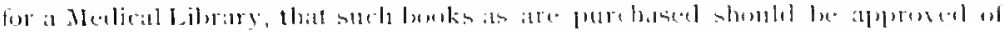

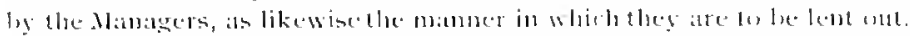

Although Dr. Shipden's anatomical lectures were given in accondance with Dr. Fothergill's suggestion, and the plates and casts nised to illustrate them, and the attending physicians annually delivered lectures in the wards to the students attending the frratice of the house, it was not until 1766 , that the suggestion was masle to the Managers by J)r. 'Thomals liond, that a regular conte uf clinical lectures at the Hospital should he instituted. In arder to secure hiv

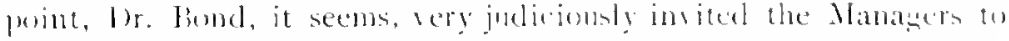

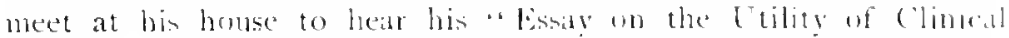
lectures." 'Their comsent alplears th have leen securel, since lor. bomel delivered his Inturluctory lecture 11 a course of elinical olmermations, a coly of which was sulpeptenty presented th the Nanagers and deposited in the limary. '

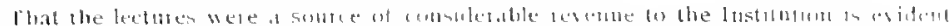

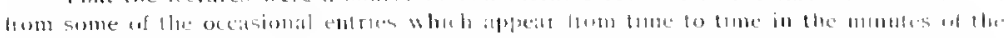

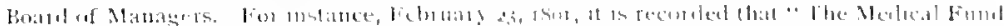

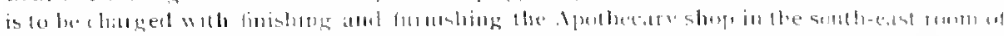

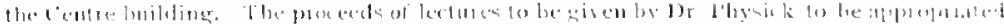

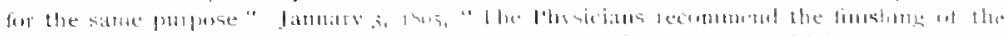

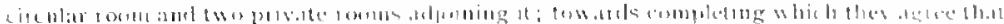

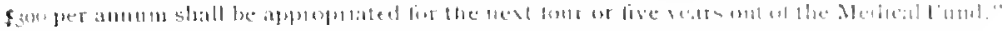

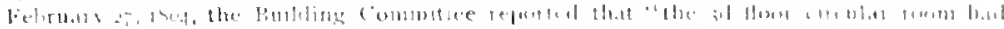




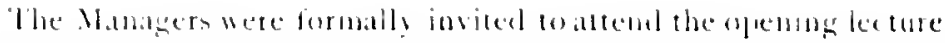

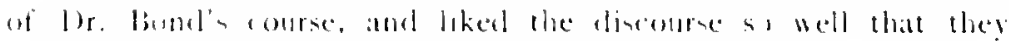

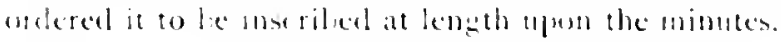

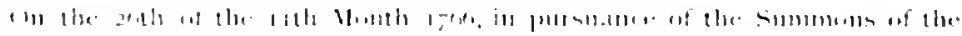

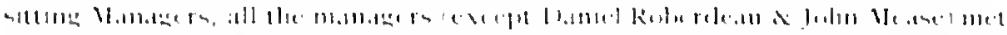

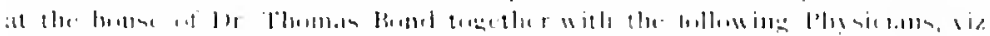

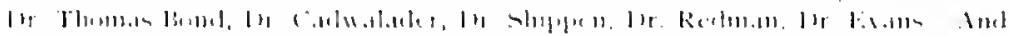

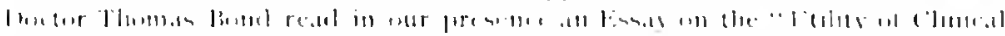

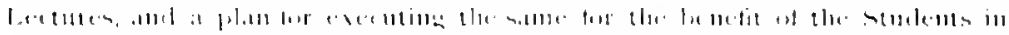

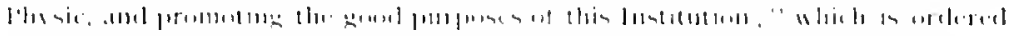

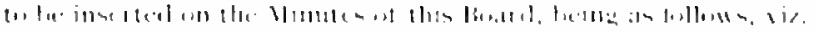

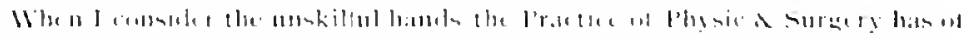

Ii) 1 11, . . $\mid+1)|+| 11$. trinitiatuin 1.1 .111$,

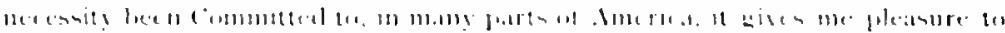

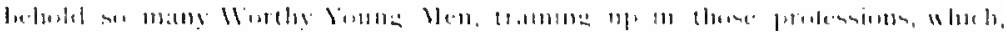

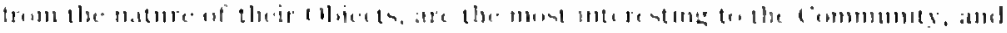

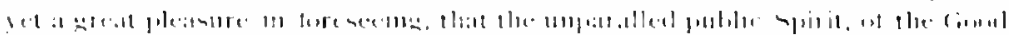

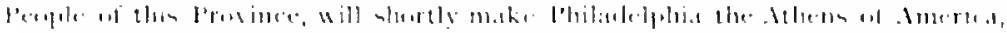

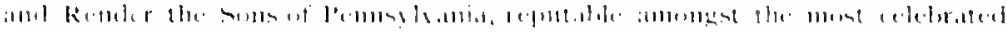

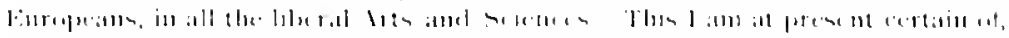

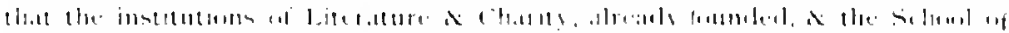

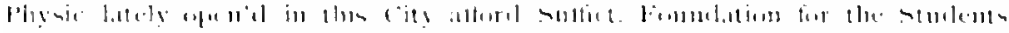

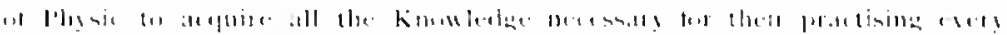

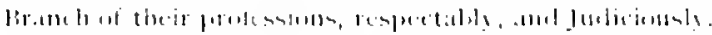

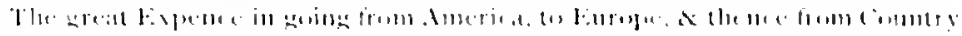

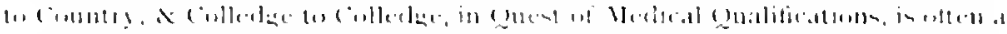

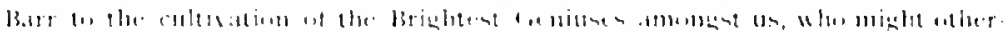

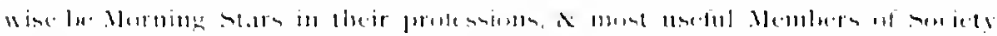

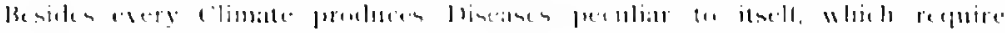

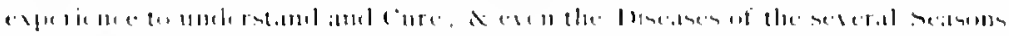

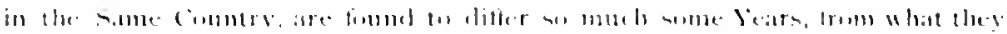

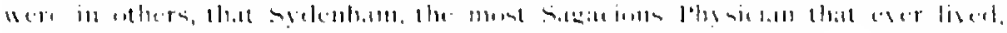

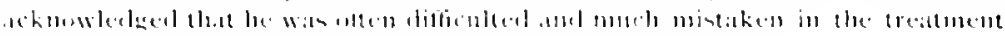

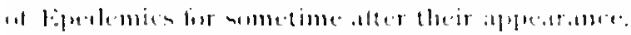

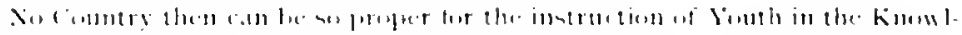

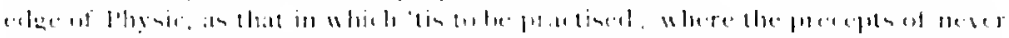

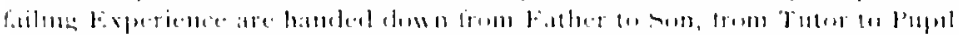

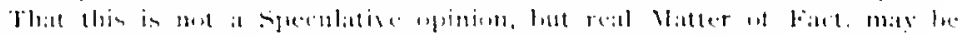

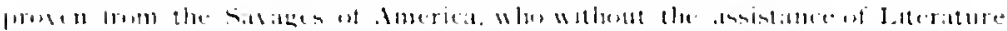

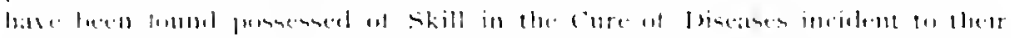

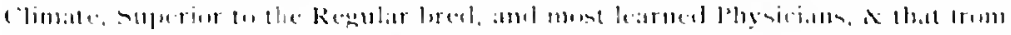

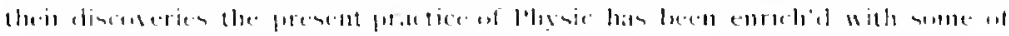

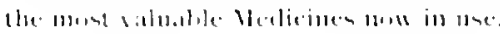

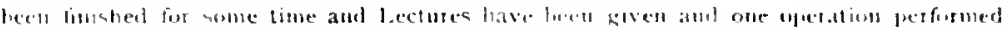

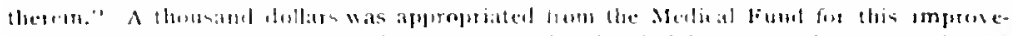

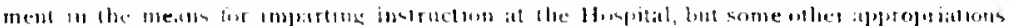

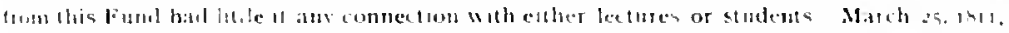

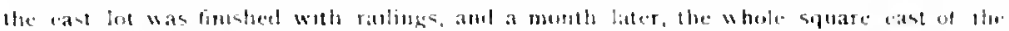

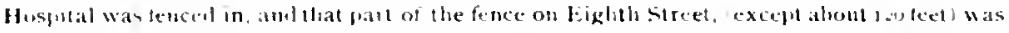

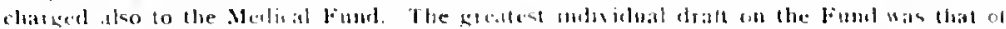

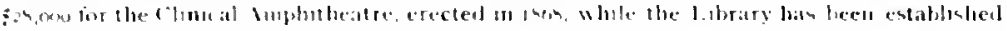

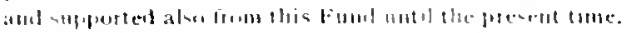


Therefore from l'rinciples of Patriotism and Humanity, the l'hymid sifhol here, should meet all the protedtin and Encouragentent, the frichis of their

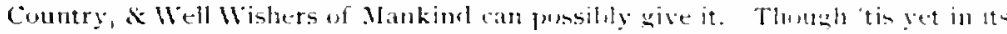
Infancy from the Jurlicious Treatment of it's ciuardians, it is alrealy become s

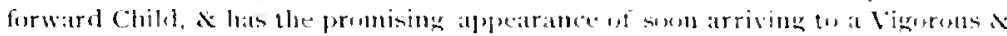
Healthful Maturity. The lerotessors in it at present are few ; but their depart 1.r. Thus.

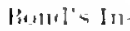
truluctury ments include the most Esstatial parts of Eolucation: Amother, whe dis

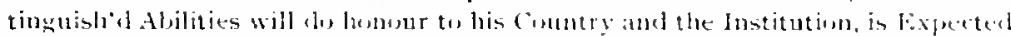
to join them in the Spring: And I think he hat litte Faith whe ran dould that

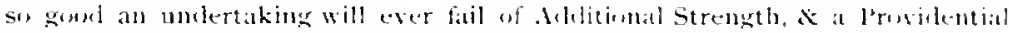
Blessing. And lan Certain mothing would give me so much pleasure as tu hase. it in my Power ha comtribute the least mite tmwarh it's perfect Estalibisment

The Professor of Anstomy and Physiology, is well Gualified for the Task his Dissections are Accurate and Elegant, $A$ his Lectures, Learned, Jadicious. \& clear.

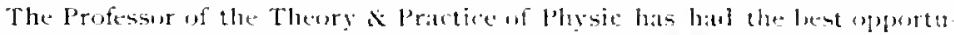

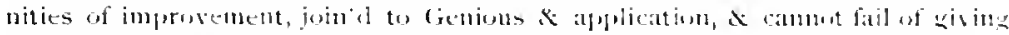
Necessary \& instructive Lessons to the lupils.

The Field this Genleman mulertakes is very Fxtensive. 0 has many difhent tites which may misteal the Fontuteges of an uneautioned Triveller, therefore Lectures, in which the elifterene Parts of the Therry \& Practice ef labse are Judieiunsly ciansed and systematically explaind, will prevent mally Perpitexitice

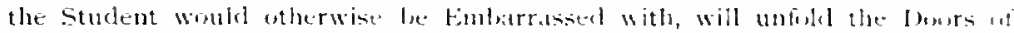

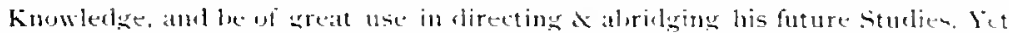
there is something further wanting. he must Juin Examples with Study, befire he

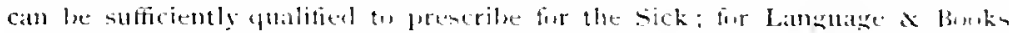

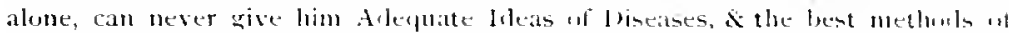
Treating them. Fot which reasons Intimaries are Justly reputed the Girmi Theatres of Medical kimwledge.

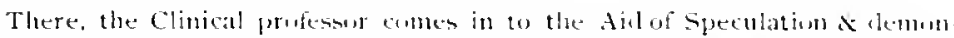
strates the Truth of Thenry he Forts: le meets his pupils at stater times in the

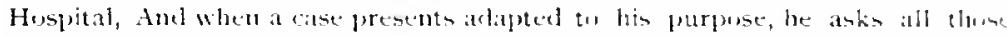

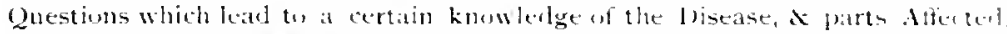
this be does in the muat exate and partientar manner, to consine the situdemo how many, \& what minute "iteumatances arewiten necessary tu furm a judgmeme of the Curative indications, an wheh, the safety $x$ life wh the Patient depeno!,

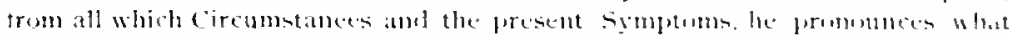

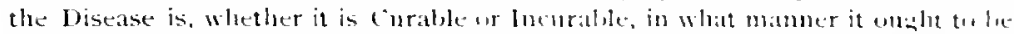
treated, and gives his reasons from Authority or Experience for all he soly at

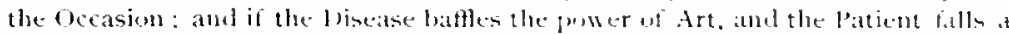
sacrifice to it, he then brings his knumbetge to the Test, a fixes llumbur in

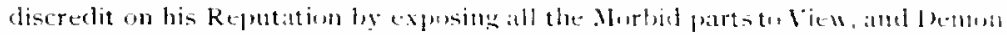

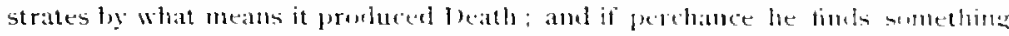

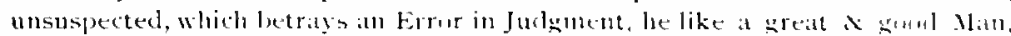

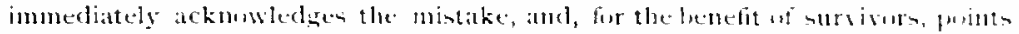
out wher methods by which it might latue men more hatpply Treated :-The latte part of this Field of Tuition is the surest methesl of obtatining fust leleam in I)iseases. The great Boxerhase was se attentive on it, that he wats mot only present at the oprening of Human Budies, hat frequenty attenderl the slatughter

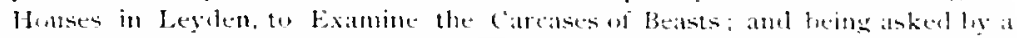

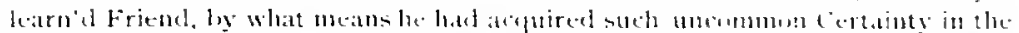

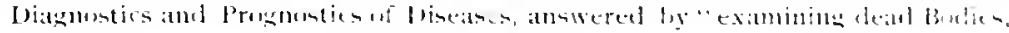


1). Tlum

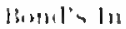

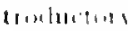
I.1.113:

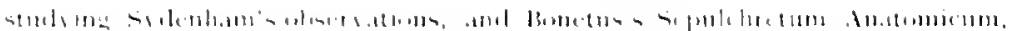

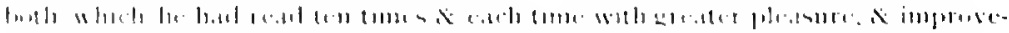
mint."

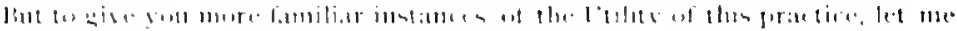

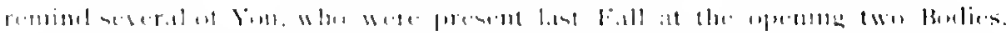

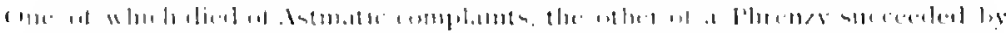

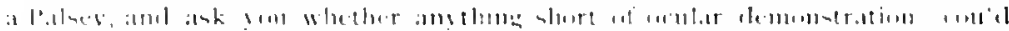

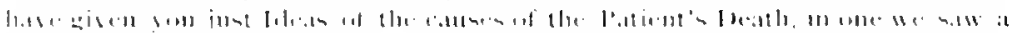

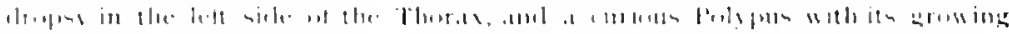

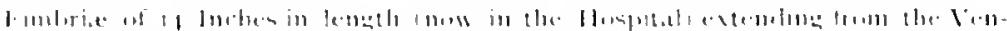

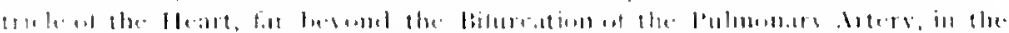

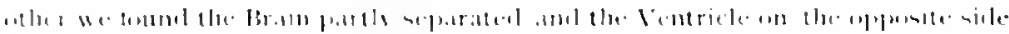

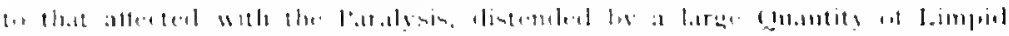

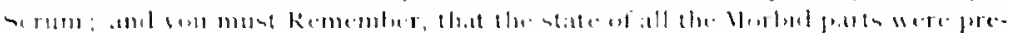

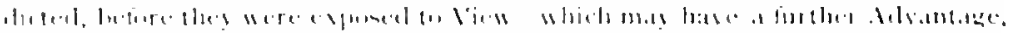

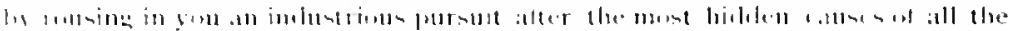

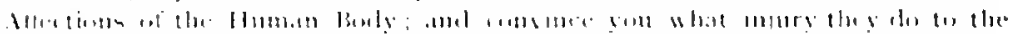

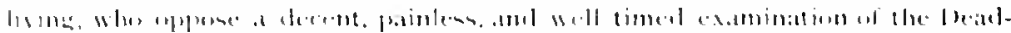

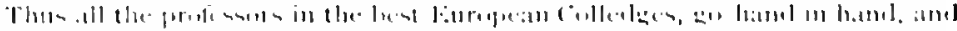

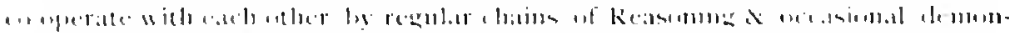

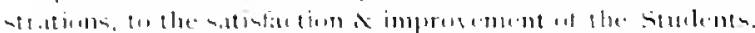

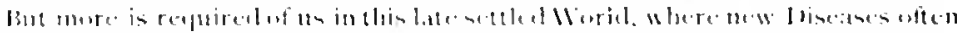

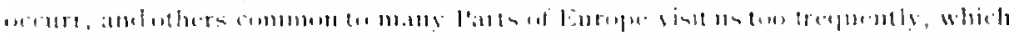

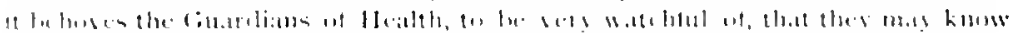

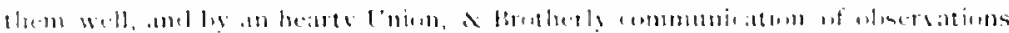

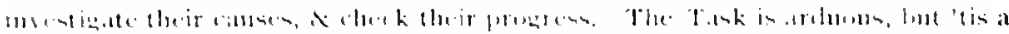

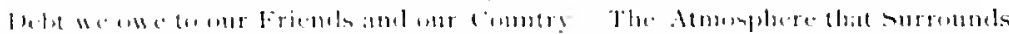

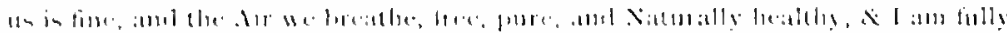

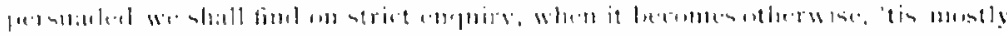

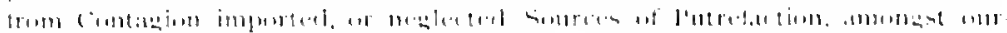

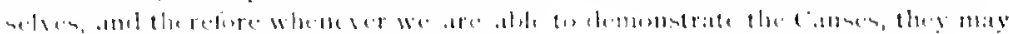

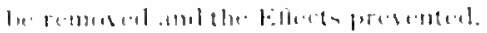

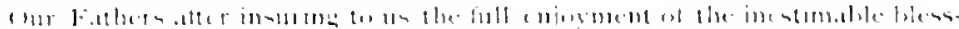

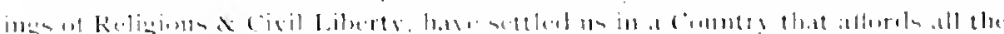

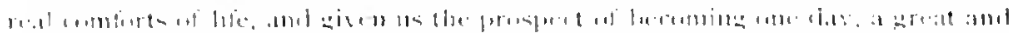

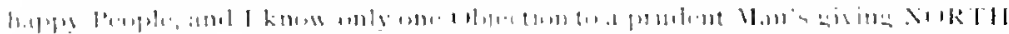

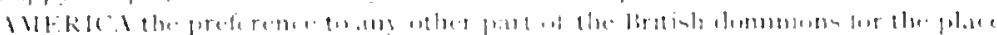

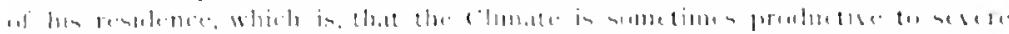

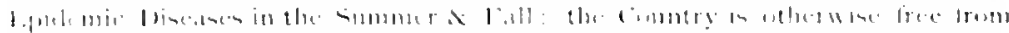

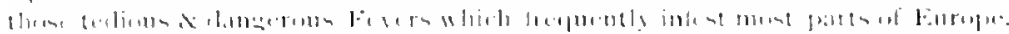

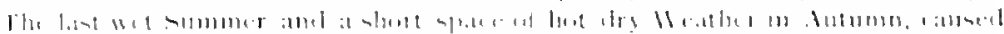

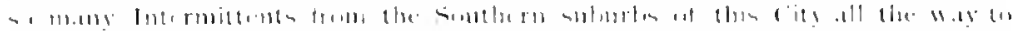

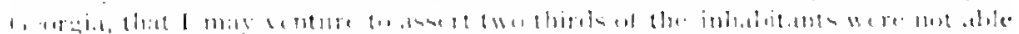

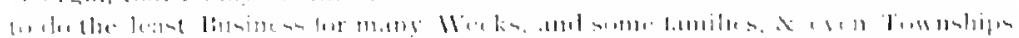

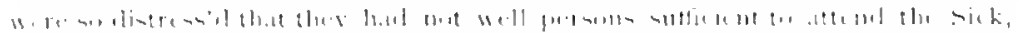

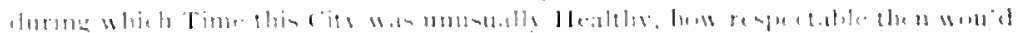

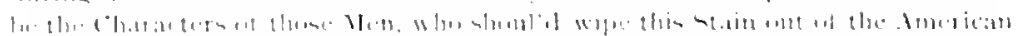

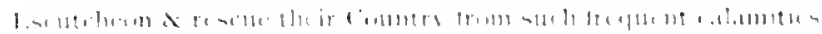

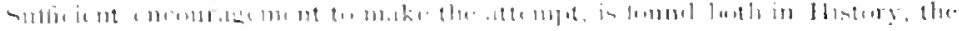

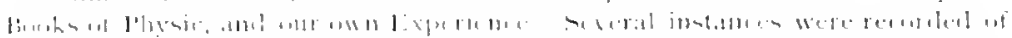

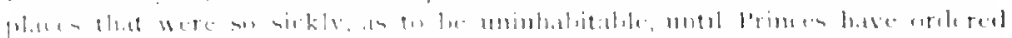

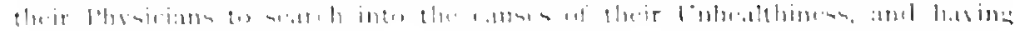

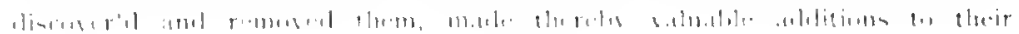


Kingdoms. Was not our Antient \& Great Master, Hipluserates, so hnowing in

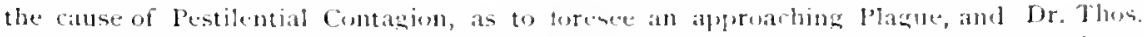

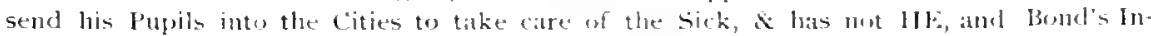
Sydenham the English Hippocrates, dene intinite service to the healing Art, and troductury

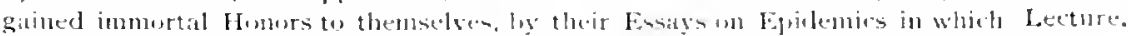
they not only accurately describe the biseane of their Resective Countries, luat show the depraved constitutim of the Air which proluced each of them. Our own Experience also aftords much Fncouragement: when 1 first came into this

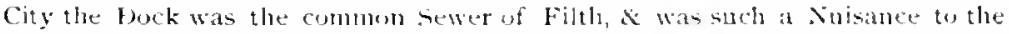
inhabitants about it, every Fall, that they were obliged to use nore pounds of Burk, than they have Ounces since it has been raised, and levelld. Ansther strikimg instance of the Alyantige of cleanliness for the preservation of lieath, atiords me an Opportunity of payine a Tribute, justly due, the the Wisdom of the

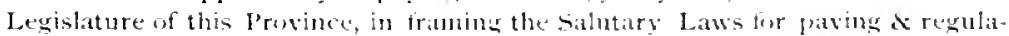
ting the stretes of this City, 8 to the indefitigalle industry \& skill of the Commissioners in executing them, whereby the have contributed so much to the If althiness of the Inhabitants, that 1 am confident the whole Expence will be requat'd in ten Years, br the lessening of Physic Bills alone. A Farm within a few miles of this city wats remarkably healty fir Fifty Years, whilst the Tide overflow'd the Low Lands, near the dwelling House, but after they were Bank'd by. Ditches so ill cuntrived that the often did not discharye the Water that fell into them for a considerable time, \& until it beame patrid, and thereby rendered the place as remarkably sickly, its it had before heen healthy, I was told loy a Gentleman of Veracity that he saw the Corps of one of Ninetentuts that had been carried from it in a lew lears.

The Vellow Fever, which ] take (1) be exatiy the same distemper as the Plague of Athens, described by Thucylides, has been fivedifferent times in this city since my residence in it; the cattses of three of them I was luckly able to Trace, \& am certain they were the same, which produced a raul Feser in uther places, \& an of opinion the difference letwixt the alplearance of these Fesers, arises from the climate, $\&$ the different state the Bodies are in when they Imbibe the Contagion: if so, the Sane methods which are taken to prevent a Gaol Fever, will equally prevent a Vellow Fever: 'Twas in the Year Forty One, 1 first saw that horrid Disease which was then imported by a Number uf Comviets from the Inthin Gaol. The second time it previlted it was indigenous from Evident ciluses, \& wasprincipally confined tw One Squared the City. The third time it wain generated on Board of Crowded ships in the l'urt, which brought in their Patsengers in Health, but soon after became very sickly. I here saw the appearance of Contagion like a Dim Spark which grarlually enereated to a Blaze, $\mathbb{E}$ smon alter lurst cut into a terrible Flame, carrying bevatat ins with it, and after continning two Nonths was extinguished ly the profuse Sweats of Tertiun Fevers, hut this is nut the ordinary course of the Contagion, "tis uslatly theck'd by the Com Evenings in Septem' $r$ and dies nn the Apreatrance of an Gecober Frost.

l lately risited an Irish Passenger lesseb, which brought the P'opple perfectly healthy untill they came in our River. I fomnd tive of them Hll, and others Unwell, \& saw that the Fomes of infection was sprealing among them. I therefore ordered the Ship to lay at Quarantine, to be well purified with the Gteams of Sulphur, \& with Vinegar, directed the Berdoling $\&$ Cloathing of the People to be well wash'd \& Air'd, hefore any person slouh be permitted to Land out an her, after which 1 advised separating the sick from the Healthy. This was dome by putting twelve in different Rows in one llouse, \& fourteen in another, out of the City, the conseniences of the two llouses were much the same, in one of them little care was taken of the sick, who were laid npon the sime foul beds, eley" 
11. Thers.

$13+1010112$ trulutulus

l.e.ture.

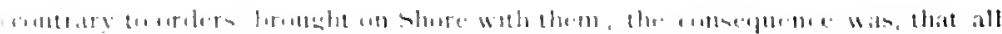

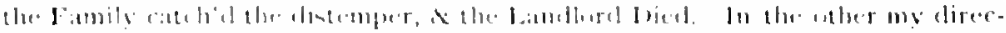

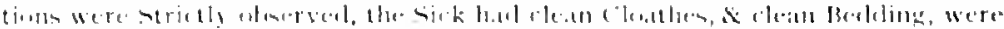

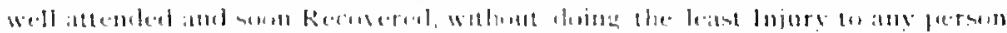

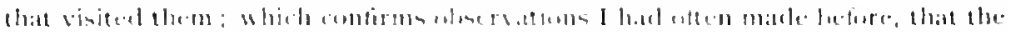

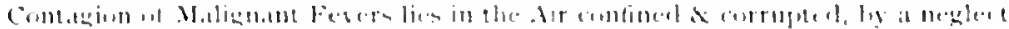

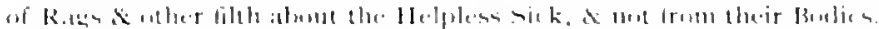

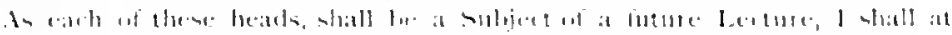

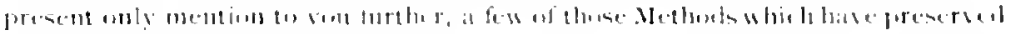

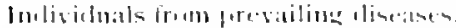

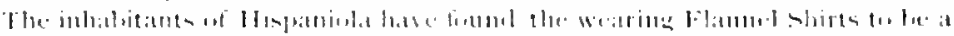

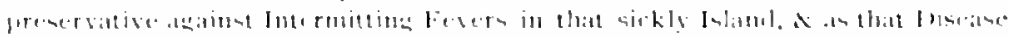

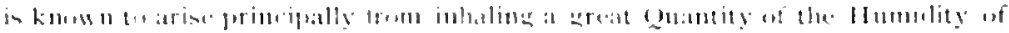

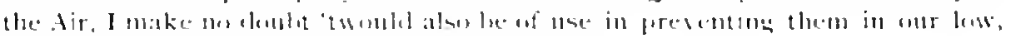
moing, level cinntrien.

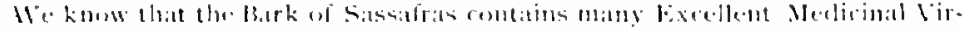

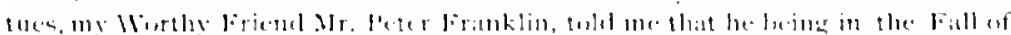

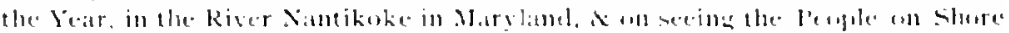

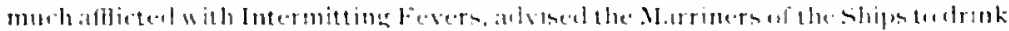

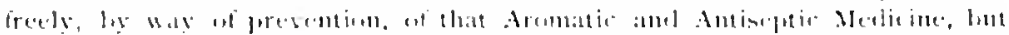

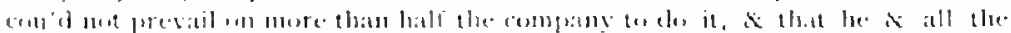

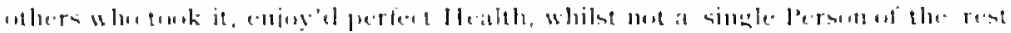

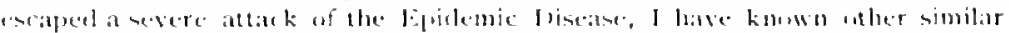

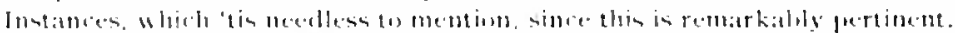

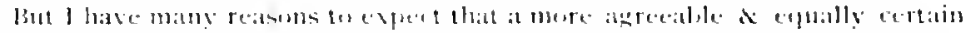

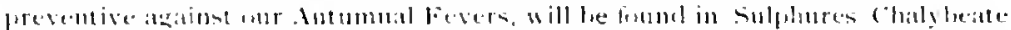
Waters, which mats reatlily he procored in mont parts of America, especially

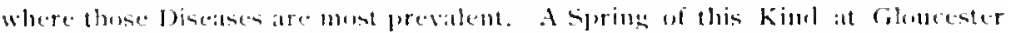

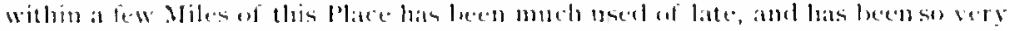

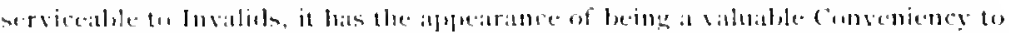

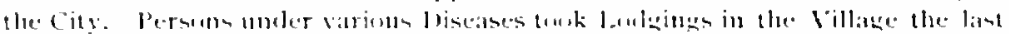

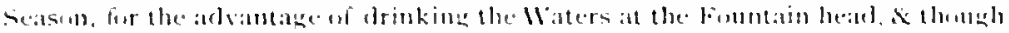

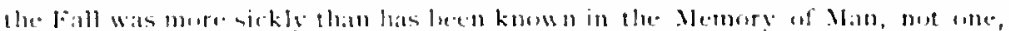

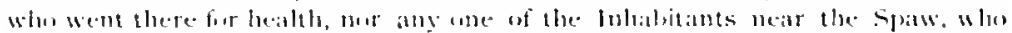

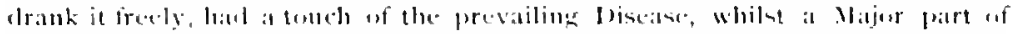

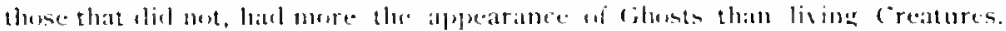

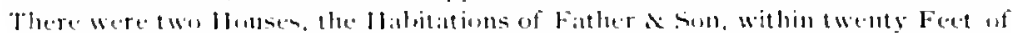

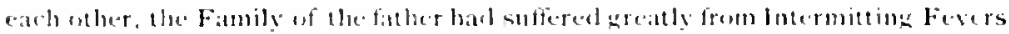

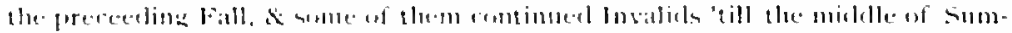

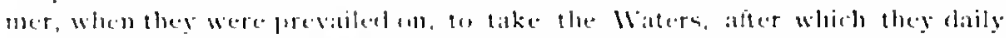

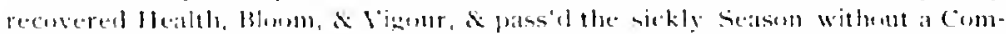

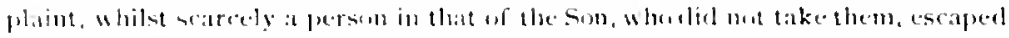

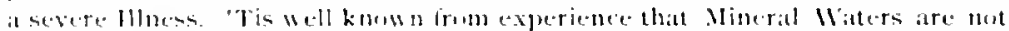

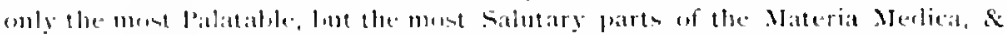

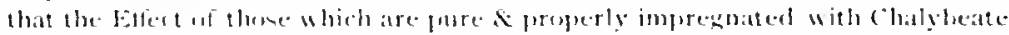

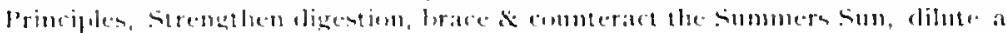

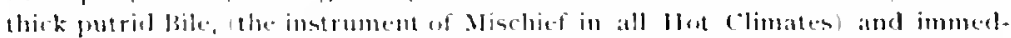
iately wash away putrefaction thromgl the Emumetories of the Busels, Skin, or Killners, and therefore appear lo be matural preservatives axamat the Effect of

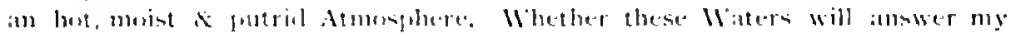
sanguine Expeequtions or mot, must be left $(1)$ the becision of Time. If they

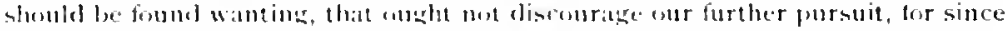
providence has furnishel every cinntry with defences for the lluman bodies, 


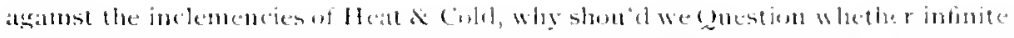

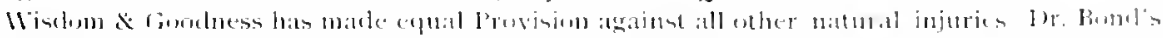

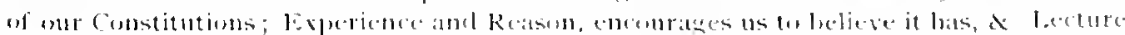

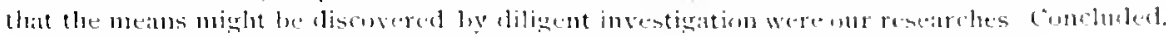

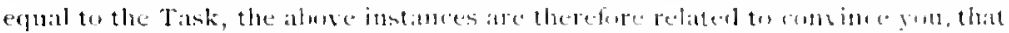

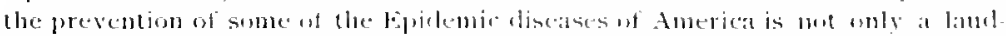

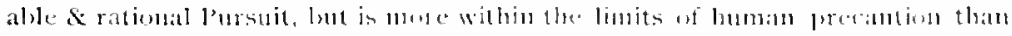

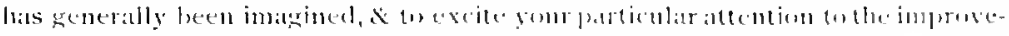

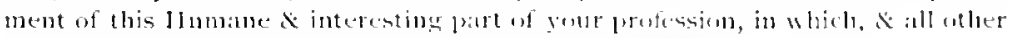

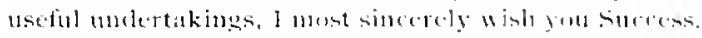

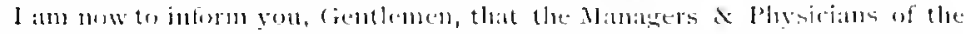

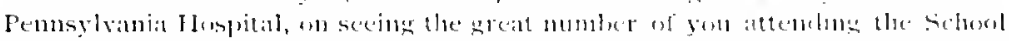

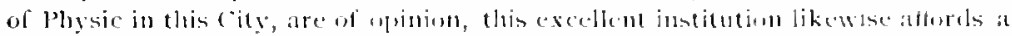

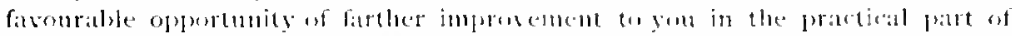

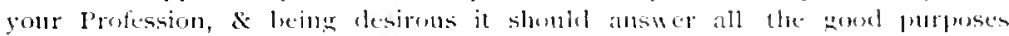

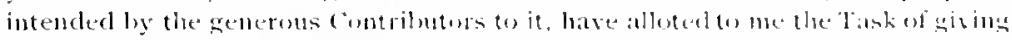

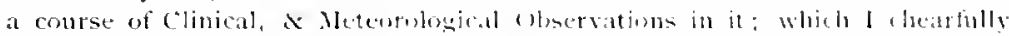

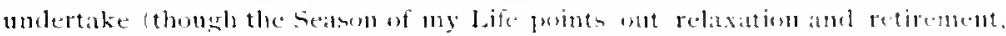

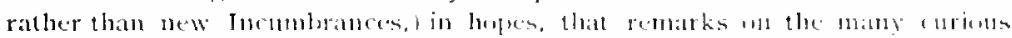

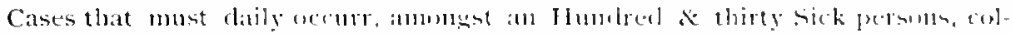

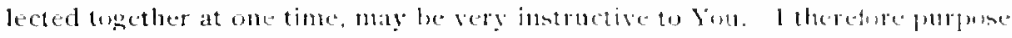

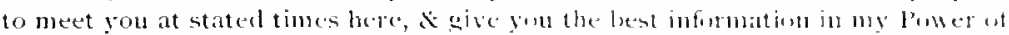

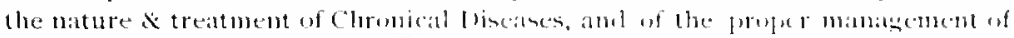

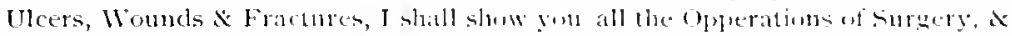

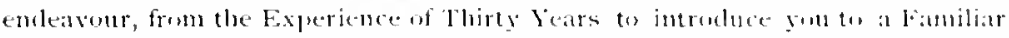

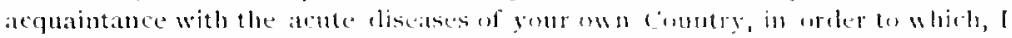

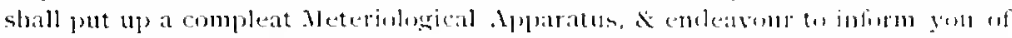

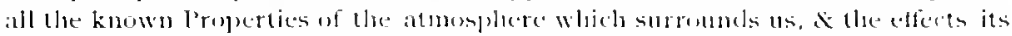

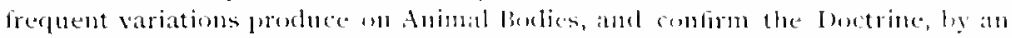

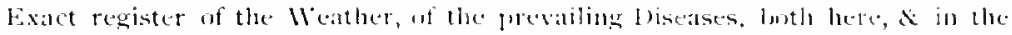
Neighbouring Provinces, to which l shatl adel, all the interesting obnervations which may occure in privale practice, es sincerely wish it may be in my prower to do them to your satisfaction.

Dr. 'Thomas Bond, seems tu have always been successful in luctures. attracting students to bis lectures. On December 29, i 766 , the sitting Managers informed the Board that l)r. Bond

Ilas resularly read his clinical Lectures, agrecalde to his Propusal, and that

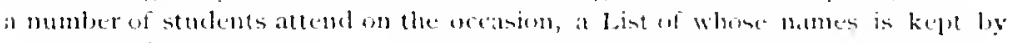
the Steward.

On April 2, 17;0, the minutes contain a reference to certain students who evidently were trying to evade the payment of the fee. A number of students having attended the lectures, who had not conformed with the regrulations, the physicians were desired of lay before the Board, at the next meeting, an exact list of the nanes of all the students who attend lectures given in this house and of the pupils who attend them on other occasions. This was to enforce the rules which required that each student should pay a fee hefore being permitted to attend the lectures. It was also ordered that no student, hereafter, be admitted without a certificate. 
In $177+$ the value of the elincal lectures having lecen fully established, the Managers decieled to raise the fee to $\mathrm{E}_{5}$, to be collected frum."all studenti atlending lectures, sce, not apprentices to physicians."

The April $2 S, 1-s_{3}$, the minntes state that the Wonthly (ommitte Matheren rejorted " that they confer'd with the attending l'hysicians, on the restitive t1tit

l'hisichlly

ili.13 $11,1 \mathrm{t}$

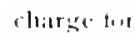

alte.111.111,

ummon pattiemt

it the dint

Iline. complaint made ly the Managers of the Houne of Employment agrinst the fee of three pommls ten shillings, charg'd in certain cases at the Alms-House by wo of the buctor-which being anain taken into Consideration, the Managers Resolve, that in such instance, the Ithysicians of this House are not entitled to, and therefore should not demand any fees, or reward for their services."

This resolution was the cause of the retirement of Dr. Morgan from the staff, as will be seen from the following letter:

$1+111 \ldots 1 ., 31: 1 y 21,1 ; 43$

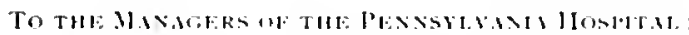

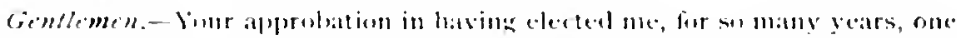

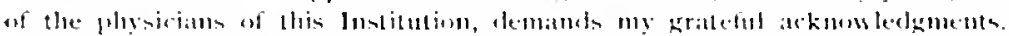

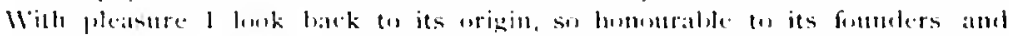

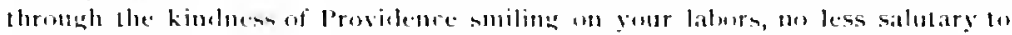
the sick, who have been reecived into it, than heneticial whe comments. The hessing of many who have been realy 10 prorish cantest fail to attend, and your

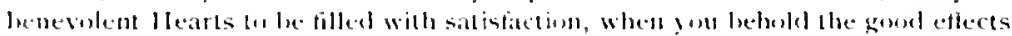
of such disinterested Ileated - horn chatrity.

My constant exertions to promele the landahbe designs of this generous

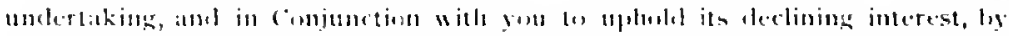
procuring is new irienels and enlarging the number of its subseribers in the worst

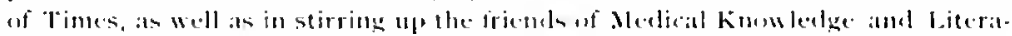

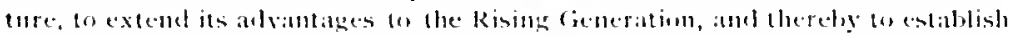

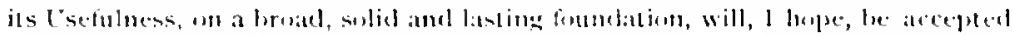
by you, as the utmol services in my puser to athorel.

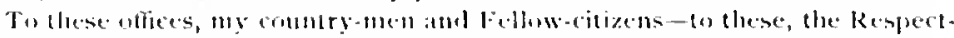
alle Mamagess of the Institution; to the se exery real obiect af Chatrity hat an

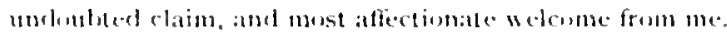

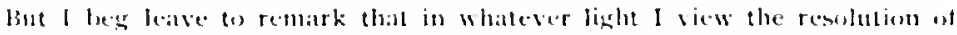

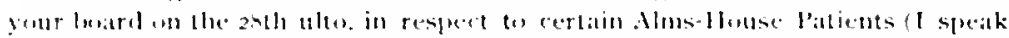
it with the utmos eleference to the Purity of Intentions and sugreme Wistom of

Resignition (i) I) John Norgin

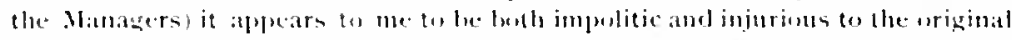
design of this excellent Charity, ats well as incongruous with the Sentiments of

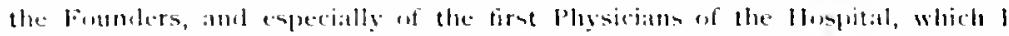
always supposed were to jerform Acts of Charily to Mberts and cases of Charity. I never imagine llueg meant an subject thenselsesur their Colleagues and Successers in etfice, th the Extra Juristiction of men, whether in public or privale stations, who hase me anthorily aver them; not that they eame under any obligation bo devole their time and attention to the Cure of Diseases broughe on ly Concupiscence, without tee or reward, which in my humble oproing lends rather to the growth than diminution of lmmorality. if 1 am not misinformed that reaslution took its rise fom persons not leelongmg to your Buard, who hase 


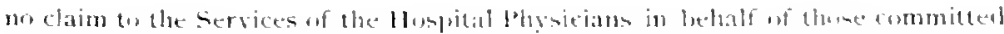
to their chatge: and who have and exereise the proser of nominating, and of

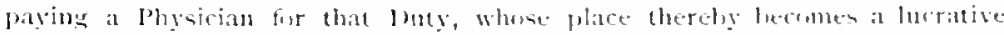

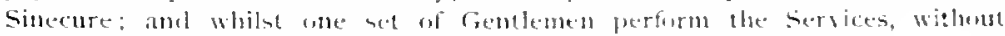
thanks, emolument on homor, another reaps the frot of their laburs.

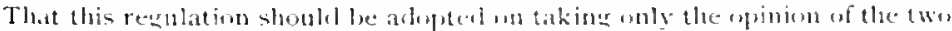
attending Physicians, without any regard pitid to the fudgment of the rest, on what regards the hemor and interest of each ohes, present of huture, aphally with

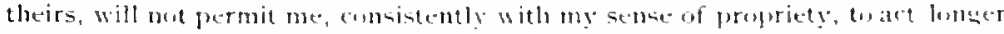

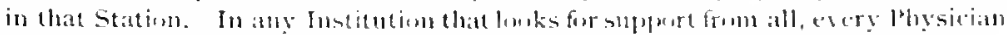
has an equal right whe comsuled in regateds the Faculty.

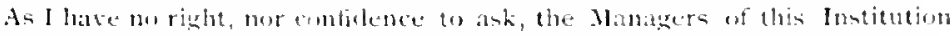

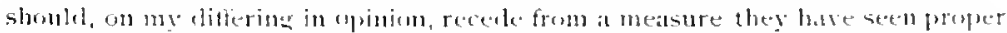

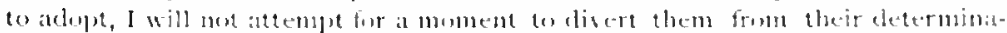

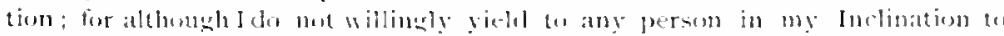
serve you and to promote the gomb of the Indertaking, I reabily resizn my place to oflhers whose views are mone comfirmalye w your sentiments.

I shall ever resere you as fientemen whe ate engaged in the greatent and moblest pursuits, that uf secking 10 relieve the calamities of uur fellow creatures. therefore deserving the applatuse of the prublic, and commanding my sincere

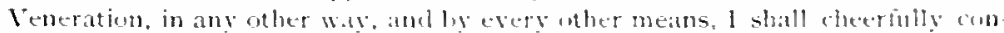
tribute lo promule your designo, an the utment of my fower, and I trust to the end of my life.

I remain Gentemen, ynt respectul Fritul and Fellow-("itizen,

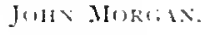

The Managers accepted this as Dr. Morgan's resignation from the Medical staff and proceeded to elect his successor.

Dr. Iohn Foulke applied (November $24,1_{7}, 8$ ) for the use of une of the upjer rooms of the Elaboratory to exhibit lectures on "Chirurgical and Phyical subjects during the season," which was granted.

The lectures of J octors Physick, Kush and Bond attracted large classes of students. April $27,7,67$, the Managers record on their minutes the following :

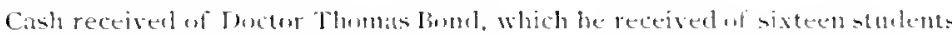

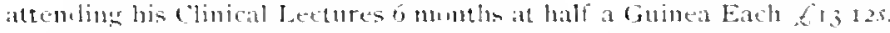

Dr. Fond also donated a set of meteorological apparatus "for (1) servation of the weather and keeping an exact account of epickmic Diseasts."

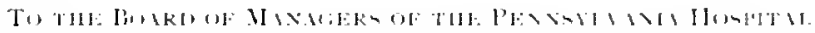

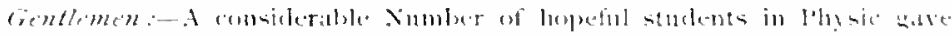

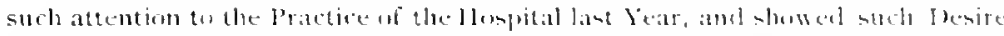

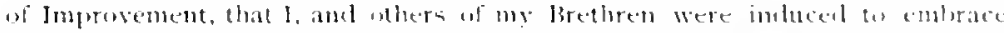

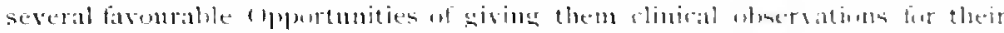

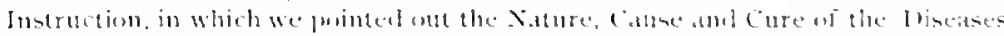

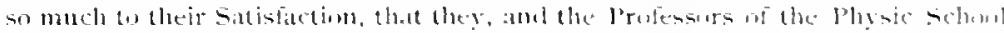
have requested the Lectures may be comtmued this llinter, whi-h atter combulting

1)r. Nlorguin l.teter to the Mlanigers.
Inireising Itendanet ilpontle the inicill Lectures.
Cimmunicatiins frum [?. Themas limite. 


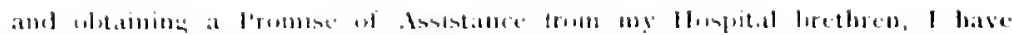

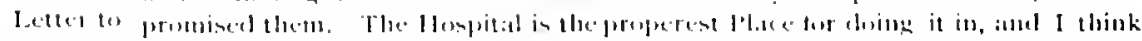

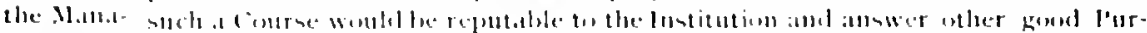

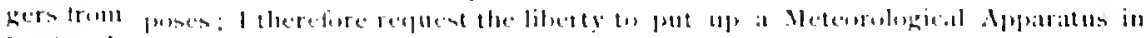

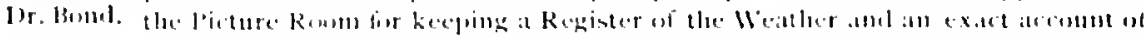

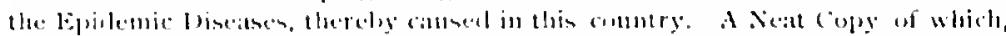
with all accome nill the curisus catsen which present in the Horpital, I will ammully depesit in the Library for the Permsal od busterity. I further redpuest

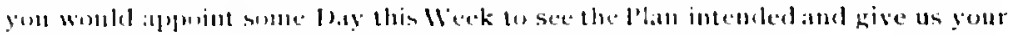
(ppisten of it in wbich you will ablige

Sinu respectiul llumble serst.

Niscomber 2.1, $1-66$.

Thos. Bovin.

The Minute of November 26,1766 , relerring to this is as follows:

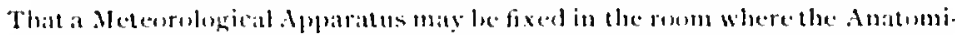

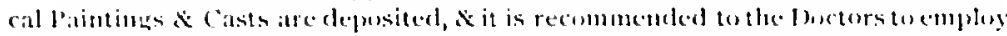
solme careful $\mathrm{e}$ skillful person to take down ohsersations on the state of the dir \& Weather and duly to register the same. 'And intsmuch as the exhibiting

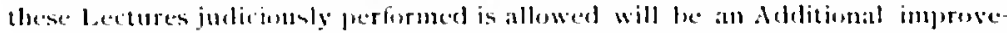
ment for the Benefit of the Stuclents in l'hysic, it is sgreed that cach student attenditug them (except steh who are subject to the payment of the six l'istoles

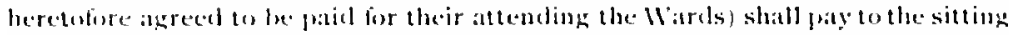
Managers or the Treasurer one Guines P'Anmum for the P'riviledge of attending

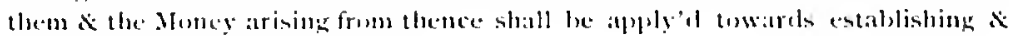
promoting the Medical Library."

Certificate of Students who Complettert their term, 1 attenulance in Hospitial.
The following is the form of a Certificate which was originally given the students in acknowledgment of their having completed the term of attendance upon the Hospital. It was drawn up by I)r. Thos. Rond :

Amongst the Advant:iges suring from a collection of many Sick Petsems into one Place that of atherding therely an Opportunity to the students in Plysic ex Surgery of heing actualited with the Nature and Symptums of llseases and

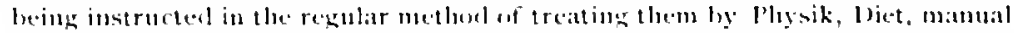
Operations, \&e, is of preat Impurtance to the Public, for which Reason we, the Managers \& physiatus in attendance of the l'enusylyaniat lluspital think it our

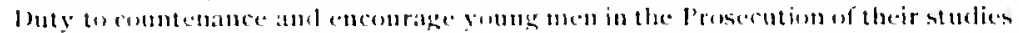
there, all in our liewer and to give them such credentials of conduct ats we think they instly merit: In remsedfuedure at our Resslution

This is to certify thit . . . . . . som of . . . . West Jersey entered regularly as pupil of the P'omsylsatuia lluspital . . . . . . 1,63 and

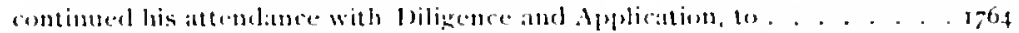
during which time we hope and have reason to he-lieve he has matle considerable

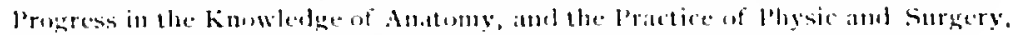
therefore wishing llappine and sucress we give form under our llands and the

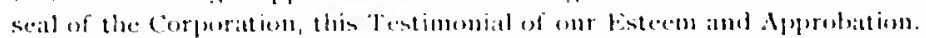

These obsetwation have becn kept ever sine and have often been called for in routs

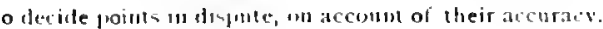




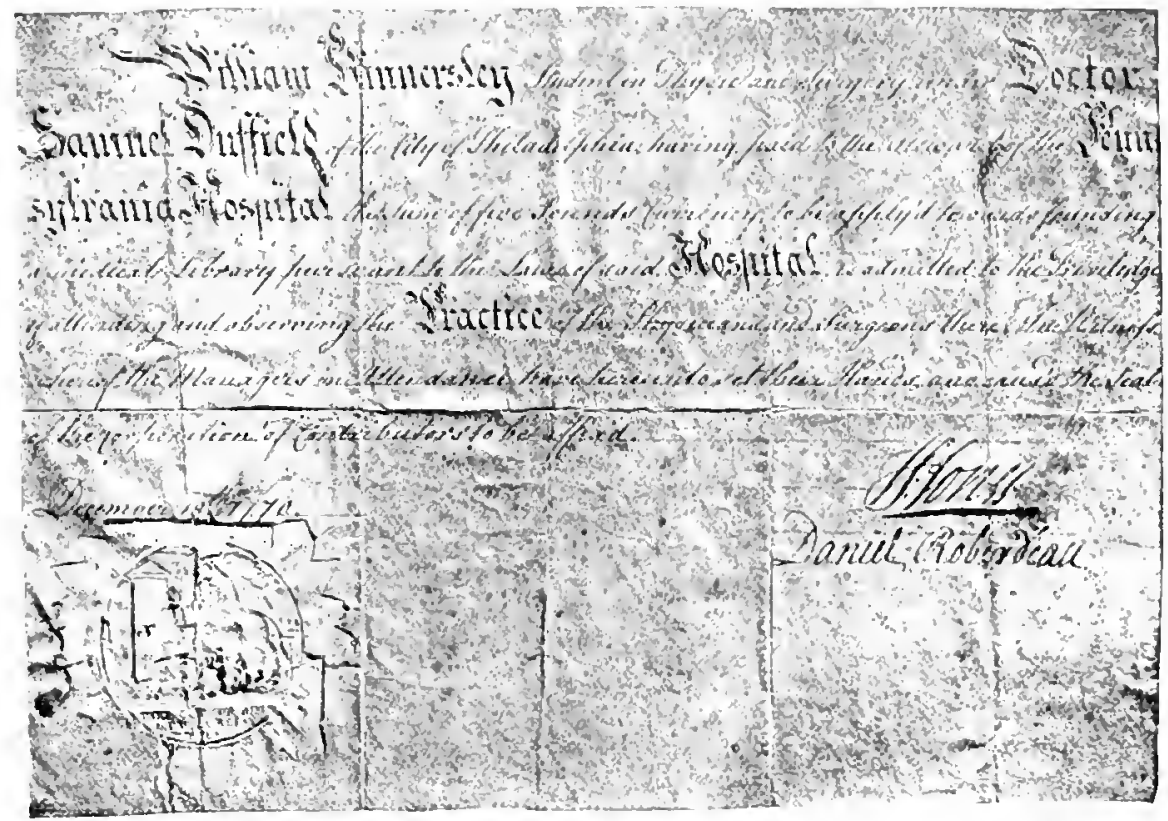

'The form of Students' Certificate, conferring the right to attend the Practice of the House, is shown in the illustration.

The following list of the members of one of the Early Clinical Classes of the Hospital is not without interest :

Dr. Thos. Bond's 1,ist, April 11, 1770. The clinical Pupls in 1760 are from

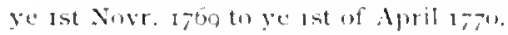

1. John Ireland of Maryiml, pol.

2. Thos, fiant of darylame, $\mathrm{m}$.

3. Ruhert Pottinger of Maryland, pal.

4. Juhn Julian of Virginiat, pul.

5. Thomas Crigory Johnson, Jamaical.

6. Robert Johuacm of thilatelplait.

7. Thes Park, Chester lonuty.

8. William Barlete of the Jersey

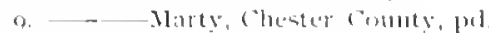

I1) Frealeric Khemon of Latheister, pul.

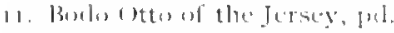

12. William Whaten of Marylani, pol.

1.;. Juseph ildll of Narytancl, pul.

14. Jolu Rowitu of lohilaslemphia.

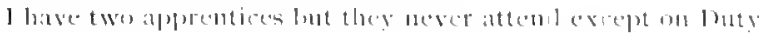

They are John Rowan, Tloses. Biclelle.

Both of the preceding letters to the Board of Managers ant the list of students are in Dr. Jond's handwriting. 
It occasionally happened that the Managers felt it expedient to

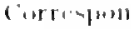

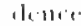

lecture.t1

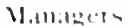
.mint the .Meali. 1.11 (1.194. enjoin ujon the students. the propriety of decorous conduct and lo repeat the admonitions whenever it was thought necessary to preserve grood order in the wards. (1) one occasion at beast, he students resenterl this and after laying their grievances before the visiling Managers, sent in a wrilten communication to the loard. The immediate cause of the remomstrance was the reating of the following letler to the class by direction of the Managers:

Feloruats $12,1806$.

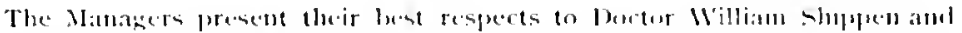

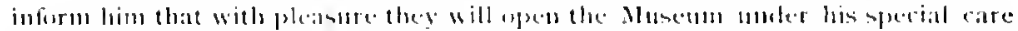

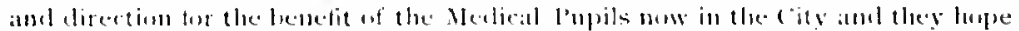

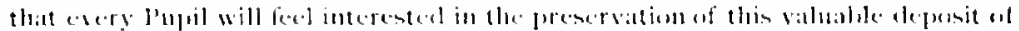

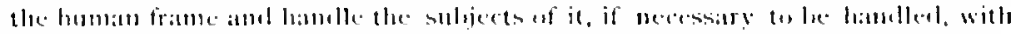

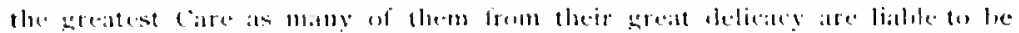
easily injureal and cammen ine replatecel:

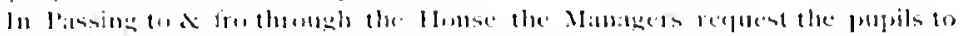

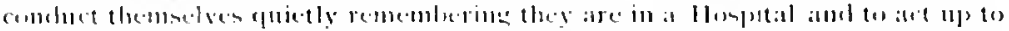

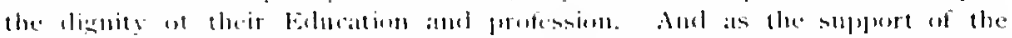

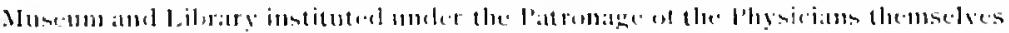

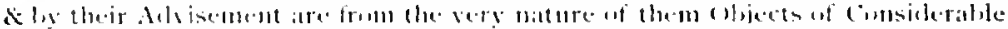

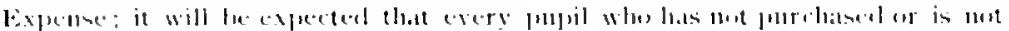

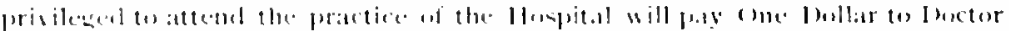

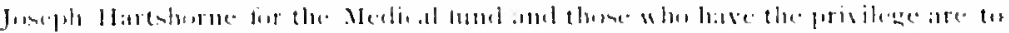

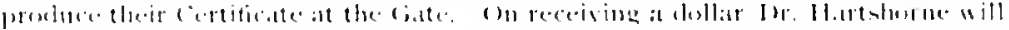

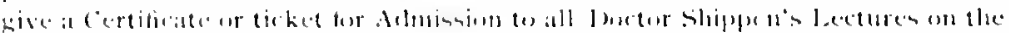

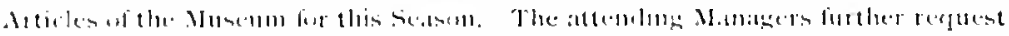

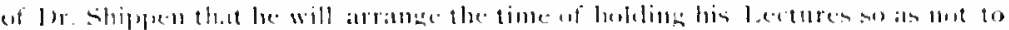

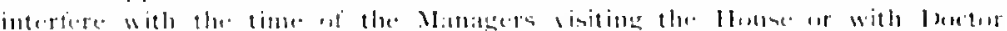

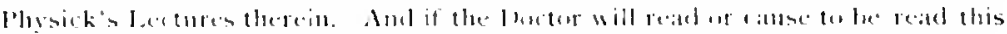

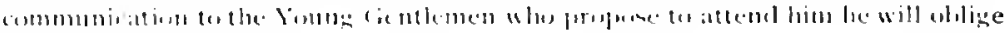
the sitting .H.t1.tgerer

Jus

I:I.1.1SIM l'1.RoT.

Lion receiving the preceding communication, the students sent the following reply:

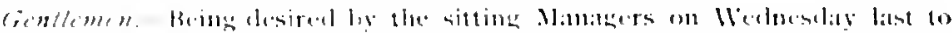

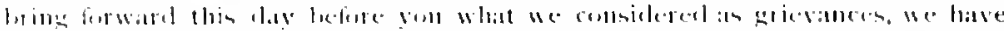

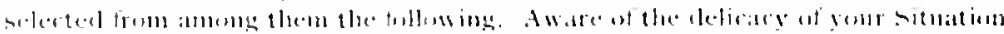

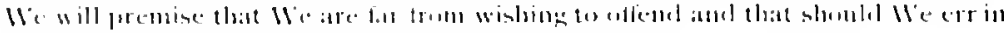
this it will nen be the entur al intertion.

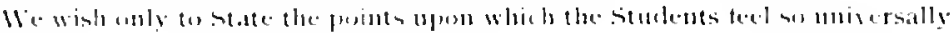
iniured

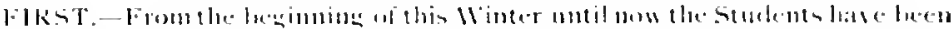

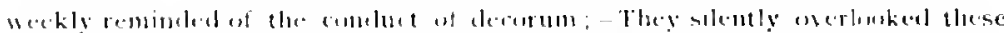

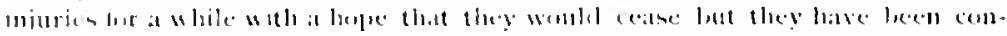

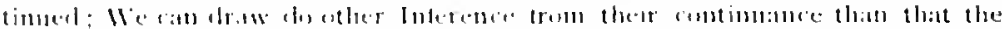

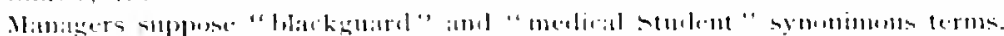

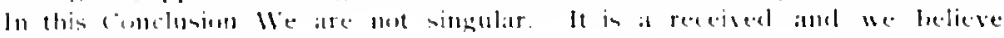




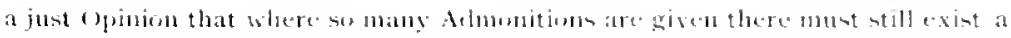

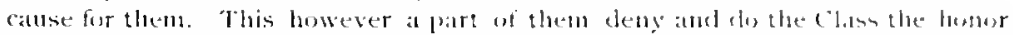
to sily they ean find no Catuse of Cimplatint aganst them. Have You Latws which

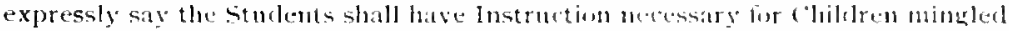

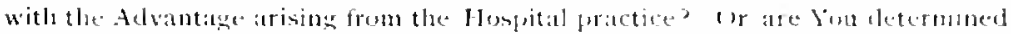
at stated periols to show the class that you view them as inferior beings and can make Use of the most improper Conduct withont incurring their kesentment?

SECONIH.Y.-The Students belonging to the class of lor. lingsick who bat

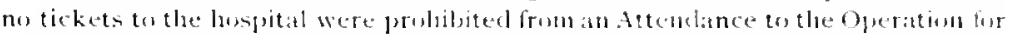

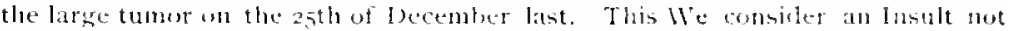
only offered the stuekents but Ductur Physick, as he informed the Students in his

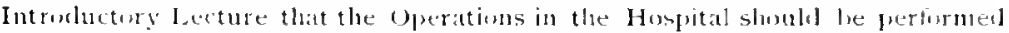

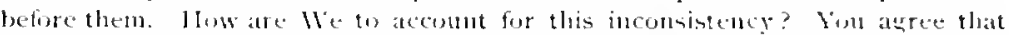
Dortor Physick has the privilege of intiting any Persan to see the Operations and yet yout requent him to infirm that part of lis class who hall wot tickets that they

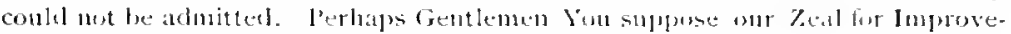

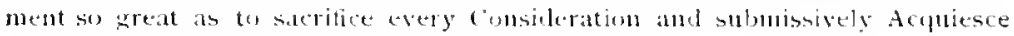
under any lmposition for its Acouirement.

TIIIRI)!: The Mamaners of the llospital have attempted to sell ns a

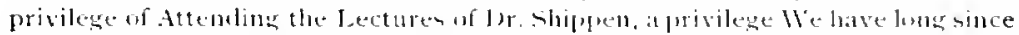

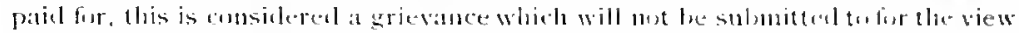

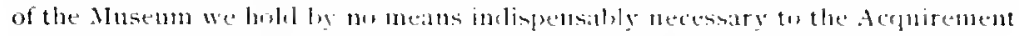

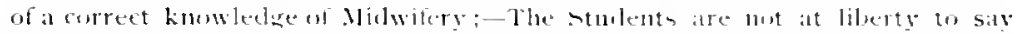

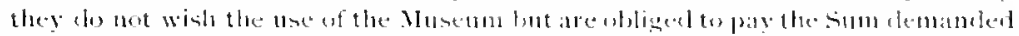

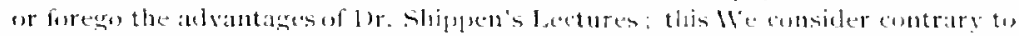
the principles of Justice and are resolved unamimumbly tor to pary the sum

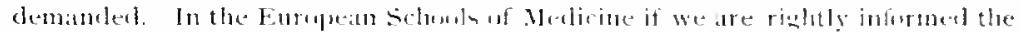

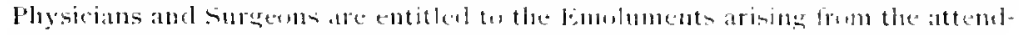

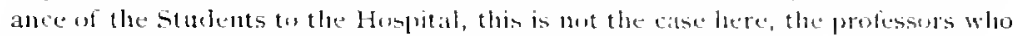

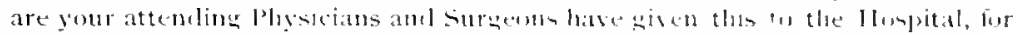

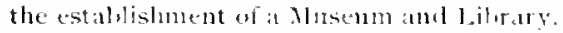

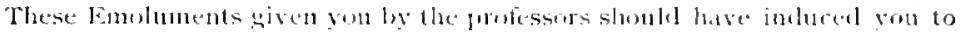

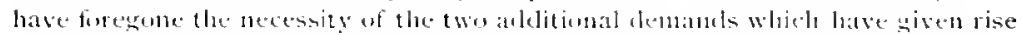

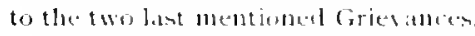

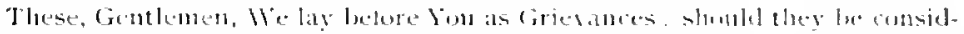

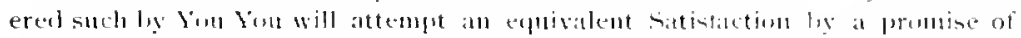

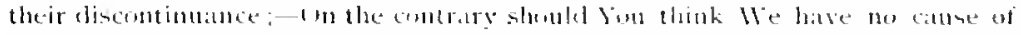

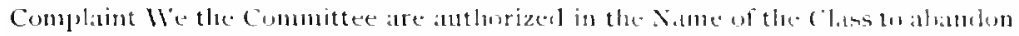

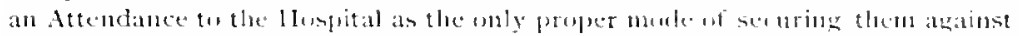

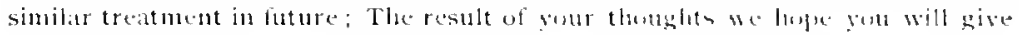
us in Mriting.

7. X11 $1111: 14$.

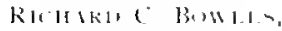

Runl:RT MUU,

IUII) II IKI.

TO IIL: MIASKEKS

On reading the foregoing, the following Minute was mate, of which a copy was ordered to be delivered to Doctors kush. Physick, and shippen, to be read to their pupils. 
Ariust then 1,11,

Minilgetsil silielents

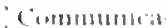
(H)

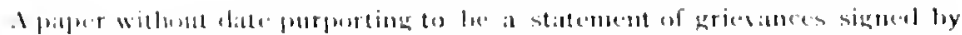

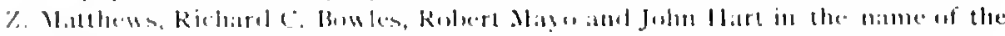

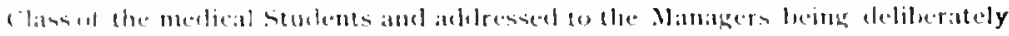
emallereat it in ingerent

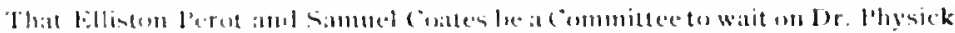

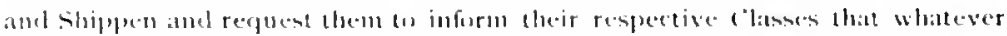

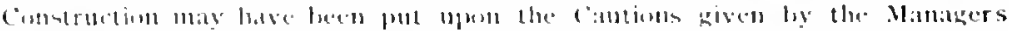

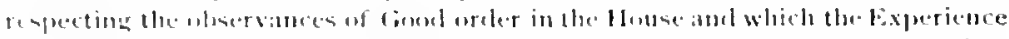

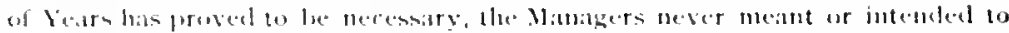

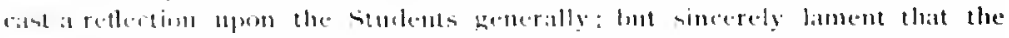

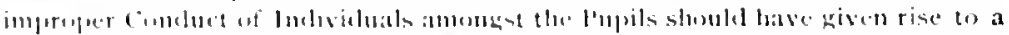

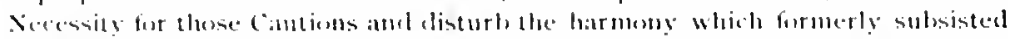

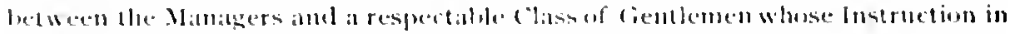

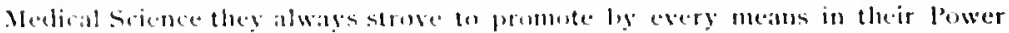

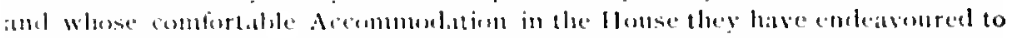

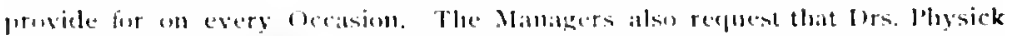
\& Slippen will inform the soung fentlement that comsistembly with the rules and regulitions of the llompital they ean to ne uther ways than keep up a clear elistimetion between those pupiis who acpuire ly purchase or other ways a right

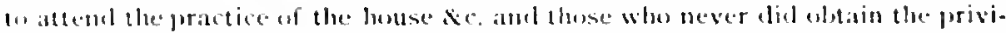

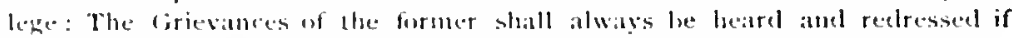

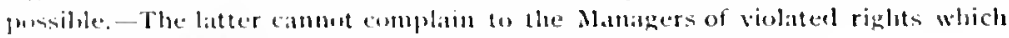
they mever jussessed.

\section{Signeed lig oreler of a liourd of Manigers.}

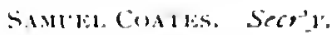

In this correspondence the advantage is with the Managers, but the gentemanly members of the Class were certainly cutitled to sympathy; the misconduct of a few having caused all to suffer.

The only subsequent difference between the Managers and the medical students arose many years later, when, by resolution of the loard, women students were armitted to the regular Ilospital Clinical lectures.

It should he remembered that for many years the clinical classes consisted entirely of men. In the course of time, after the establish. ment of the Woman's Medical College in Ihiladelphia and the legal recognition of women graduates as regular physicians, the question of the admission of women to the privileges of attemling the lectures was necessarily forced upon the atlention of the memiers of the Staff and the Managers.

The Managers, Octolser, 1869 , granted the repuest of the women students, with the result shown in the following extract from the

Disturlinuce eluring

Clinical i.e.turis. minutes:

A special meeting of the loard was hetd November 13, i.869, in comsequence of a serious disturlance which took place at the usual 
Clinical Lecture, held on the 6 th inst. After a free discussion the following was adopted:

WHEREAS, on Octuber 25, 1869 , the students from the Woman's Medical College were anthorized to attend the clinical lectures of the 11ospital. And

WHEREA, under this authority ahout thirty stuclents belonging to the sehool accompanied by one of their l'rofessors, attended the Clinic held on the 6th instant, at which time a number of the male students in attendance behaved in at very indecorous manner by hissing before the lecturer commenced the delivery of his lecture, and after it was over, by other conduct unbecoming in any well regulated Institution, and especially in one which has long maintained the stuncling of one of the leading charities of our City and as such has enjoyed the sympathy and respect of our fellow citizens, therefore

Resolved, That whilst a large majority of the students took no part in this disgraceful scene, the Managers deem it their dinty to censure such as did participate in it; and to adoph such measure as will secure gond order on future occasions.

Resolved, That the Managers would be unwilling to deprive any student of the important benefits to be derived from attending the clinical lectures at the Ilospital, but that this privilege can only be accorded to such as are disposed to couduct themselves with propriety.

These resolutions were directed to be published in the daily papers, signed by the President of the Board.

The incident referred to is concisely slated by Dr. John Forsyth Meigs, in his address entitled, "A History of the First Quarter of the Second Century of the Pennsylvania Hospital."

In the autumn of 1869 , the Dean of the Faculty of the Female Medical College applied to the Board of Managers for the admission of their students to the regular clinical courses. The Nanagers gave their permission on the ground that, by the rules of the lfospital then in use, all students of institutions recognized by the State laws, were to be received to the common benefits of the Ilospital clinical instruction.

The women came to one of the lectures very soon after this, taking their seats in the amphitheatre in the midst of the regular men's class. There was a scene of considerable jisorder both during and after the lecture.

The event caused a good real of agitation in the medical schouls of the city. and amongst the medital students, which extended in a slight degree to the general pulslic. It raised the great questions of women's rights, and of the com mon edncation of the sexes. And it showed, ton, most clearly, that women were willing, in urder to obtain their end, al general medical education and a status in the profession similar to that of men, to listen in mixed clasies to descriptions of all diseases, whether modical or surgical, and to wherve any chass of cases, which might be necessary in the contse of their medical education. It was a curvolu and an impressive lessm, to show how longestablished social habits and opjinions maty be clamged by the harel weight of necessity.

It was thought by many that the objection marde by the medical stmelents, and by the medical teachers of the old schools of the city, arose wholly from a jealum dislike to the increased competition that might ofeur in the professiom. shumbl wemen come to participate fully in the exereise of the medical art. I think mot. I believe the difficulty lies deeper than this. It is a psycholuginal unc, and,

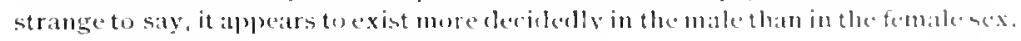

listriat from Aildiess cul 11r. Juhn For yth Meigs. 
In the followng chinal session, 1s;0-71, the whole mumber of

$111,01.01100$ 11) 111110 clinical 1.citises. students in attendance wats 206 , and of these 32 were women; whilst in the previons year, the number had leeen 500, of which number $4^{2}$ were wouncu.

The matler was arranged at the mecting of the Contributors, in May, 187 , on the flan of having separate elinics for the two sexes, and, arcordingly, the staff agreed to give, in addition to their regular semi-weekly lectures to the male students, one lecture a week to the wonen students.

This compromise was carriel ont for several sessions, when the excitement having died out, the former arrangement was restored, and since then separate clinical instruction to women students has been abandoned, and all the elinical lectures are now delivered before mixed classes.

The rlinical lectures instituted ly Dr. Thomas Bond in 1766 , have been continued up to the present day, with only the temporary interruption inseparable from the social disturlances accompanying the War of Inclependence and in the incidental occupation of the IJospital ly the Colonial and British tropes for their sick and wounded. Many thousands of American physicians aml successive generations of medical stuslents owe their medical training very largely to the practical instruction voluntarily given by the members of the Medical Staff of the I'onnsyluania Hospital. The literature of medical science has been enriched by numerous records of original methols of treatment, new instruments, linical olmervations upon the effects of novel remedies and the results of operations, with valualile medical and surgical statisties. 'lhese are contained in innumeralie published clinical lectures and contributions to journals ancl are referred to in text-bowki on medicine and surgery used in medical schools all over the workl.

A brief review of a few of the contributions which have been made to medicine and surery, and which probally, with few exceptions, were first cxhibited and explained to the students attending the lectures and practice of the house, may here be permitted, in spite of its acknowledged incompleteness.

Dr. Thomas liond devised a phine for fractures of the forearm, which is still in use ly surgeons.

1)r. Thysick first recommended and practised the method of manipmation, for the reduction of dislocations, in preference to pulleys and other mechanical methods of traction. He also devised a successful treament of coxalgia or hip-joint discase, by rest and immobilization of the joint. ly the use of his carved splint. He was 
the first in this country to practice capillary puncture of the head for hydrocephalus. A student of his, 1)r. Harry S. Lefert, while attending lectures in Philadelphia, originated the metallic suture. Dr. Physick is the inventor of the guillotine tonsillotome and of the needle-forceps, which, slightly modified in form, are still in use. Instruments and Appatrit. tun invented According to the late l'rofessor S. D. Gross, I r. I'hysick introduced the use of animal Jigatures in surgery, for tying arteries after amputa. tions, and also the practice of cutting ligatures short and permitting

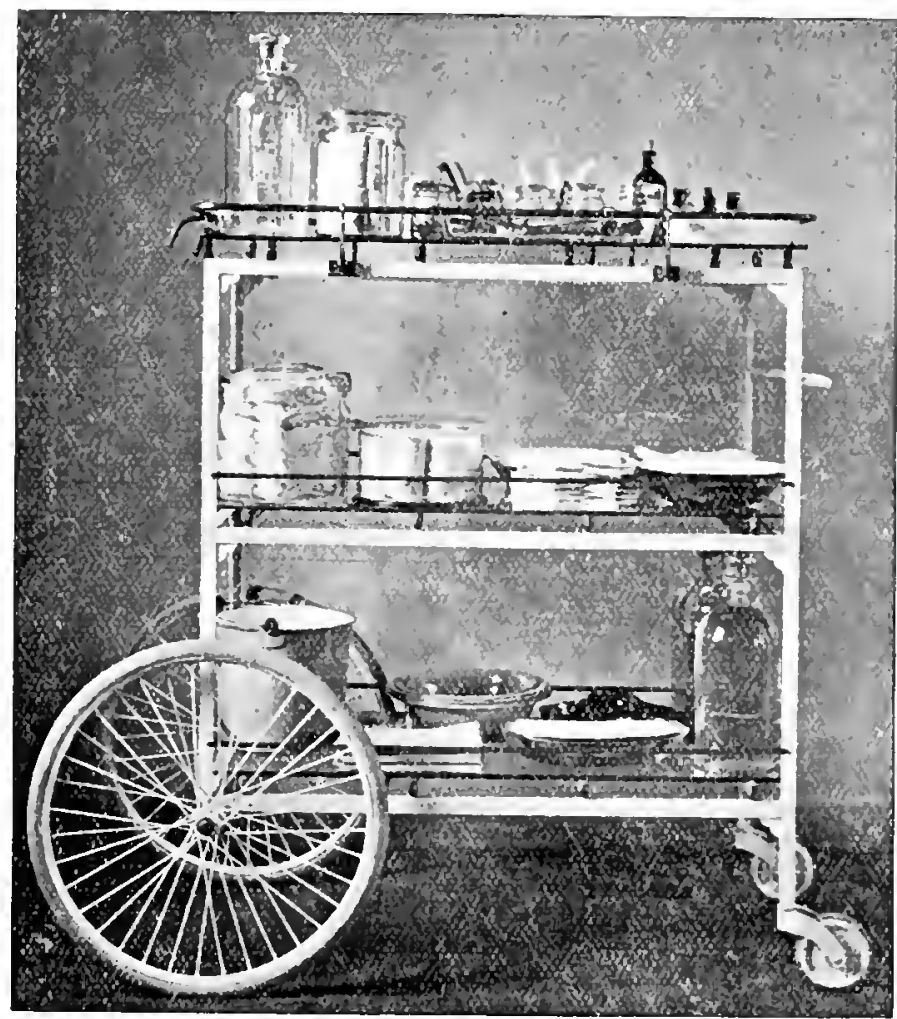

The Penusylvania Hospital Ward Dressing Carriage. (The Latest, Antiseptuc Nodel.)

them to become imbedded in the tissues and allowing them to be absorbed. He devised a novel form of treatment of cases of umunted fracture and successfully employed it in a patient, thus saving a limb that otherwise would have had to be amputated.

A ward dressing carriage, introduced in 1866 , was invented by Dr. Thomas G. Morton, and at the International Exhibition, leeld 


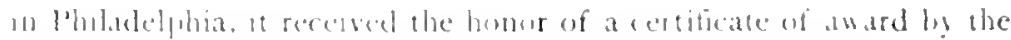

Itinl111111, 111

1,13.18.11114

.111111901 .1

$(1,0)=1, \mid 12,1)$

lis $11 \cdot 941,1$

1.1 the mi.tis

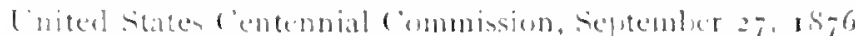

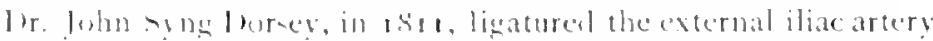
in a patient, in the sureical ward, with rerobers ent the case. 'This was the first time this operating hat been deme in this hemisphere.

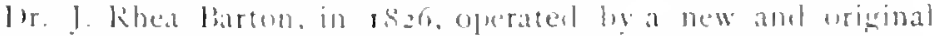

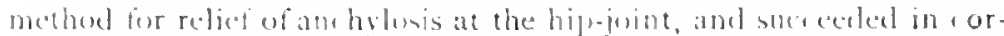
res ring deformity and in restoring the limb to dedialness. The widely

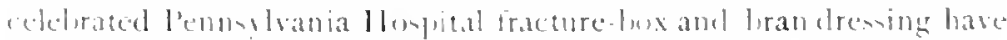

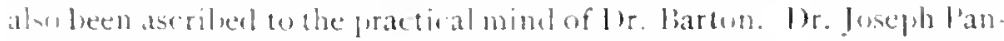
colst mate the biret surcessful hip - joint amputation at the llosprat. It was in a man thirty eight years of age, with a large tumor of the thigh; the fratient was discharged cured after forty-eight days treatment in the warkls.

The present method of usine straps of albesive plaster for exten. sion and comenterestension in treatment of fractures of the thigh home. with the use of sand hage in the place of splints. originated in the surrical wards of this llospital, and was first applied ly br. lillerslie Wallace, while he was a Resielent lhysician, In 1872 . I). Thomai (B. Morten devised a hed carriagc, consisting of a light truck on four whech, "yon whis heds can be casily moved, and patients earried to and from the Clinical Amphitheatre. 'This arcfial appliance is stall emplused thr this purpuse (sece cust).

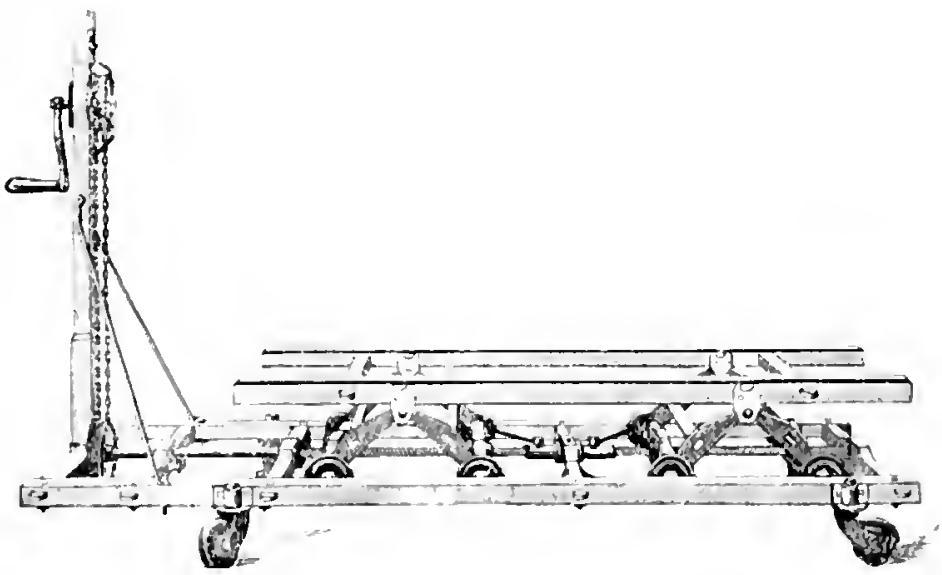

The mediral lee luses hase alwars illustraterd the best and most alproved methuds. Hr. Kush was the must prominent physician of his day and undoultedly influenced the practice of medicine in country more than any uther member of his profession, either"before 
or since his time. In his fectures and treatment "he paid very little attention to the name of a disease and founded his treatment on it nature and the conditions of the system. By this course." says Prof. Bigelow ", "he reduced his materia medica to a few active medicines and so prepared the way for the simplification of remedies that has been accomplished since his day." His observations on lellow Fever, Cholera, Breakbone Fever, Hydrophobia, and Diseases of Soldiers, which are still preserved, embody the views which he tanght in his lectures.

Dr. Gerhard, who, first established the essential identity of typhoid fever as a distinct disease, was an attending physician of the Hospital. Dr. J. K. Nitchell made many original observations. among which is that of the occurrence of joint affections in spinal disease, which Charcot has recently so greatly extended. The use of ice in treatment of sunstroke originated in the warks of the Pennsylvania Hospital, heing the successful treatment derised by the late I) James J. Levick. Anæsthetics for surgical operations by inhalation of ether. chloroform, or nitrous oxide gas, were very promptly introduced into the Hospital after their discurery hy Wells and Morton, and are still in daily use. In the same way, antiseptic treatment of wounds was generally adopted, several years ago, as the practice of the Hourc, which is fully abreast of the best modern practice in its appliances and treatment of the sick as well as the injured.

In the early days of the Hospital, patients were few and the Attending Plyysicians did not find it necessary to hase skilled medical assistants; in the intervals of their visits, the sick were left in the care of the matron or the nurses. Soon atterwards, the number of the sick and injured increased, as the public became acquainted with the facilities offered by the only building especially constructed for general hospital purposes in the province, and the Attending Physicians brought with them their office students, or apprentices, to follow the practice of the house, to aplly dressings, and render other ansintance. The Hospital then charged a fee for each student thus aclmitted to the lectures and demonstrations in order to purchase medicines and to form a Medical Fund for the Library. In 1773 , the Managers decided to take apprentices to live in the house, in order to learn the art of medicine, as there was no Medical College in the country at that time. To the former class of students, the Nanagers had been in the habit of giving a certificate at the termination of the term, signed by the Managers and Medical Staff, testifying to the faithful

\footnotetext{
${ }^{1}$ Century of American Medicine, Journal of the Medical Sciences, Mhila., Ian, : $9-h$.
} 
ferformance of dutiens and the completion of the enose of stullies.

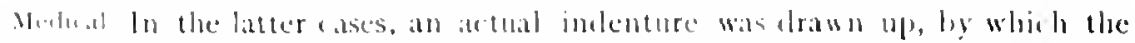

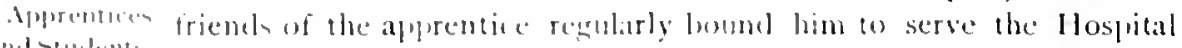
and sturbente for a persol of five vears, the Mamegers on their part agrecing to instruct him in the ort of medieine. ete. (siec indenture opposite.)

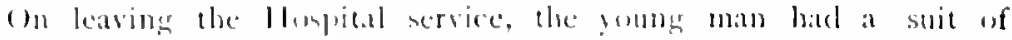
"rlothes" and ald congronsed certificate, if he completed his engagement satsfactorily. lienides the dpprentices, there were occasionally wher residene pupils, amble ats the work on the wards was not sufficient wentirely acopy them. the board atempted to utitie their time in preparing medicines for the house and onte-fatient department. 'This, hewerer, wasson foumd to te impracticable and it was decided to congage a skilled apothecory for this work.

As alreacly stated the Managers at lirst aceejted the services of medical students, who acted as asistants to the Alending l'bysicians aml surgeons. Subsequently these resident students were made regularly inflentured apprentices. After the establishment of the Mcelical Department of the Lniversity of l'ennsylania, the appentices attended lectures while serving the lluspital and usually graduated before their term as apprentices hat expired. Very many of these young men, after graduation. took a tour abroad and visited the hospitals of lingland and sicotland, or of lirance and Germany, and upon their return home were subseduently honored by election to the Attending Medical staff of the lennsylvania llospital. Since the year 1824 , the rule then aluped has been stretly enforced, reguiring Residents to be graduates in medirine previous to entering upon theor duties in the Hospital.

In adelition to their duties in the wards the early resident physicions were also liable to te called upon to visit cases wishing admis. sion inte the llospital, at their awn homes, in order to determine whether or not they could properly le sulmittel. They also assisted at the clinical lectures, and hat the bencfit of the teaching of the members of the staff, in their weekly, or semi-weckly, clinical lectures, an conviable privilege, as it must have leen regarded by the outside stulents, who hat by their registration and fee, only obtained the right to witness "the practice of the house" and to attend the clinical lectures.

The first apprentice, 'I'homas Boulter, simply learmed the "art and mystery of the apotherary" and did not study medicine. The first Ilouse l'hysician, or Nedical Aprentice, was Jacol, Ehrenzeller, who was approinted in 1773 and left at the expriation of his five years term. A period of eight yars then was allowed to pass without 


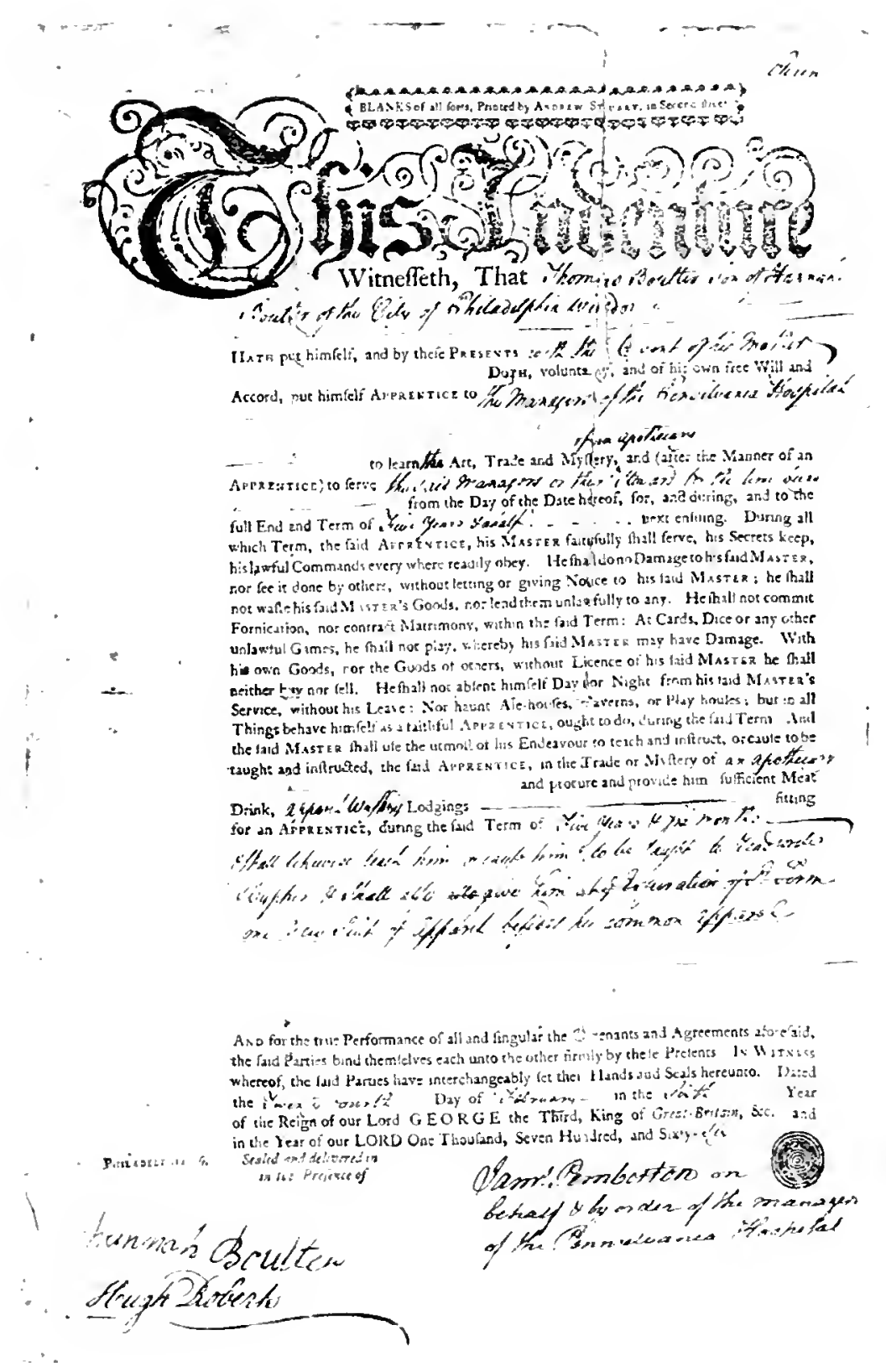



electing his successor, but, in 7 766, William (ardener was indentured, who also rerved for live years. Ldward Cutbush was the third in order of succession; he was elected in 1790 and served until 1794 . when he Re-MUlent Phycicians. was graduated by the Nedical Department of the University. Dr. lienjamin Rush was a pupil of J)r. Kedman and attended the lectures, lout was not an apprentice or resident within the I Iospital. I rs. samme! Betton, Wm. P. C. Barton, Stmuel Cuthom, and William l'rice were graduates in medicine before becoming aplrentices, as were l)rs. Robert I. Clarke, Southey S. Satchell and Charles B. Jaudon, who were appointed to fill the unexpired terms of other apprentices.

In 1824 , two Resiclent Physirians were elected, 1)r. Caspar W'istar fur two years, and Dr. Caspar Morris. to serve for three years. The number of Residents continued to be two until. at a meeting held May. is $\delta_{4} \delta$, it was resolved to increase the number to three, ear h to serve for two years. A few years later, the term was redued to eighteen months, and subserguently (in $18 s 8$ ) this was increaned to twenty months, the first four months to be spent in the Iepartment for the Insane and the remainder of the service divided between the Medical and the Surgical Wards in the Department for the sick and injured. A fourth Resident Physician was alded in responne to the following :

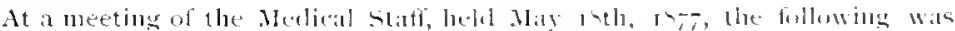
adopted :

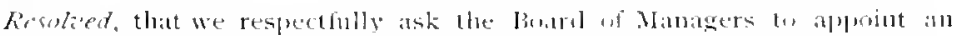

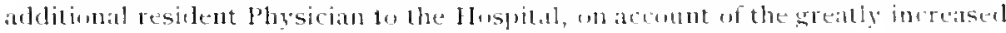
cluties rerpuired of the Residents.

Early in $189+$ the lyoard appointed a sixth Resident l'hysician and increased the term to twenty-four months.

(In leaving the Hospital at the termination of the period of service of each Resident Physician, it is customary for the Managers to pass a complimentary vote acknowledging faithful service and giving the Irivilege of the use of the library and the practice of the Houre.

The Association of the Lx-Resident lhysicians of the Pennsylvania Hospital was organized in the year 1885 , for the purpose of reviving old friendships, developing fraternal intercourie as Ansulitition of EX-Resielent Bhystions. Physicians, and to show the continued interest of its members in the welfare of an institution that had contributed largely to their jrofesional education.

Being the oldest, active Ex-Resident, l'rof. Henry H. Smith, of Phila., was chosen, at the first meeting, President of the Association and a Committee of Arrangements was appointed, to serve for eac hannmal

${ }^{2}$ Died, March, Isgo. 
meeting, the Charman of the Committe being the senior Resident

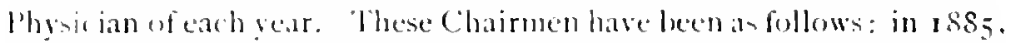

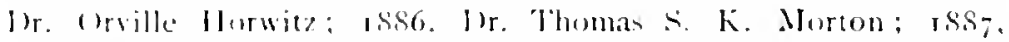

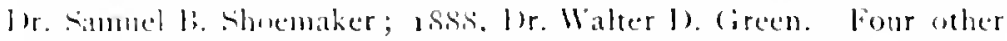
members of the lsociation. including one of the staff. constionted the ('ommintee for each year.

Anmu.1! M: 1 ind he $\mid 1\} \cdot 1$

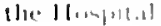

Sillus une int

C.196.

kंendelut

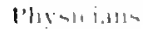

'The anmulat meetings of the Assiciation are hetel in the lif rars

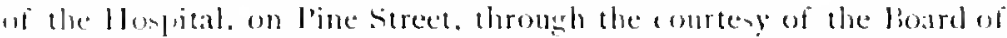
Managers, and a simple repast (poid for by the Ansm iation) enconrages strial intercurse. Occasionally. papers of general medical interest, ur conneeted with the history of the Intitution, or its " incelited

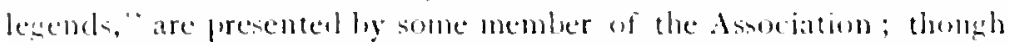
the main ohjeet of each meeting is the preservation of al lirotherhoud lecteen the Resilent Phyicians of the varinus periods of service. This Asociation has been previously referred to in these prage (jige 103).

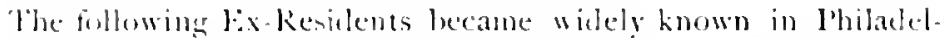
fhia and elsewhere for their professomal sill, much of their rejutation lecing the to the training and knowledge they acouired in serving the intitution: Simmel ('ooper, Thomat Ilorsefielel. Joseph Ilarts-

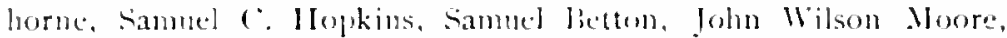
Jenjamin $\therefore$. Janney, Juhn Rheil barton, lienjamin 1l. Coates, Jastn

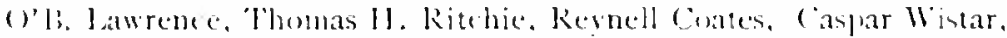
Caplar Morris. George fon. Thomas stewardsom, Jr., Gicorge W.

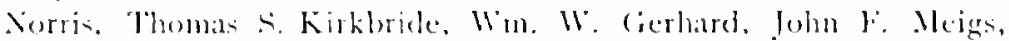
Elward llartshorse. Many others yet living alos illustrate the value of the clinical experience ohtained while serving as Residents in the lluspital.

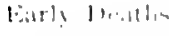
(111111:!

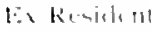

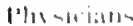

Some of the Resident lhysicians who grave promise of great usefuncss in their profession dieal som after entering apon the artive dutien of their profesion, shortly after leaving the llowpital. Imong these was sammel (ooper $(1792-1) 7$ ), who perisherl while acting as ansistant ghrsicion at the lellow Fever Hospital, doring the epidemit in Ihiladelphia of the year 1798. J)r. Eelward khouds (1864-65), died with the dropsy and liright's diease a few months after leaving the llespital. Herace linney llare $(1866-67)$, perished with pulmonary disease at the beginning of a most lorilliant career. Elliott Richardson (1968-70), lived os serve tie Institution for several sears as surgeon to the Out-latient lepartment, but died hefore he had reaped the reward of his industry and application. lidward W. Jameson $(1 \$ 73-75)$, began practice in a western city and was stricken with pnemmonia within a few years after leaving the 


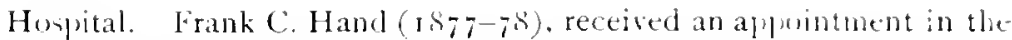
Out-Iatient Department and was preparing for active professional life when he was sudclenly called away. John (;. Lee (1,iso-8I), lived for a longer period. and was the l'hysician to the Coroner's Office for several years lefore his death. (jeorge T. Lewis $\left(188_{2}-83\right)$ ). Charles Meigs Wilon $\left(1 S_{3} 3-84\right)$, and Samuel b. Shomaker (IS86-87), also did not survive many years their service an Resident Physicians in the Hospital ; the latter, having leen elected to the OutPatient Department, died . Ypril 2, Isy3, shortly after his aplointment.

\section{MEMBERS OF MEDICAL AND SURGICAL STAFF}

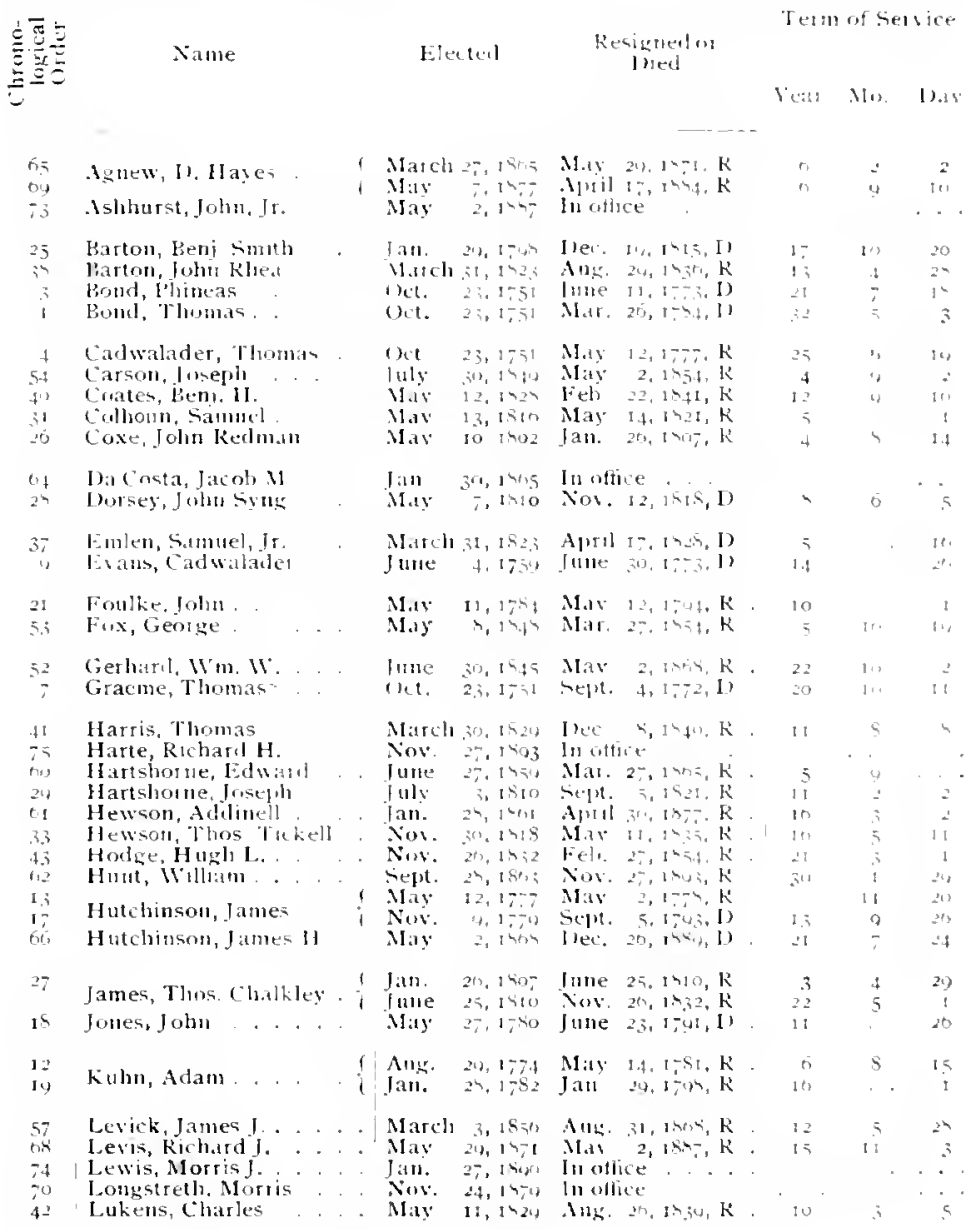




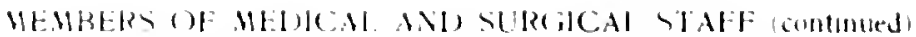

$>$.

I. $|\cdot| \cdot \mid+2)$

Kenigention

I eith ut Serble

Year $\quad 11, \quad 11,1, y$

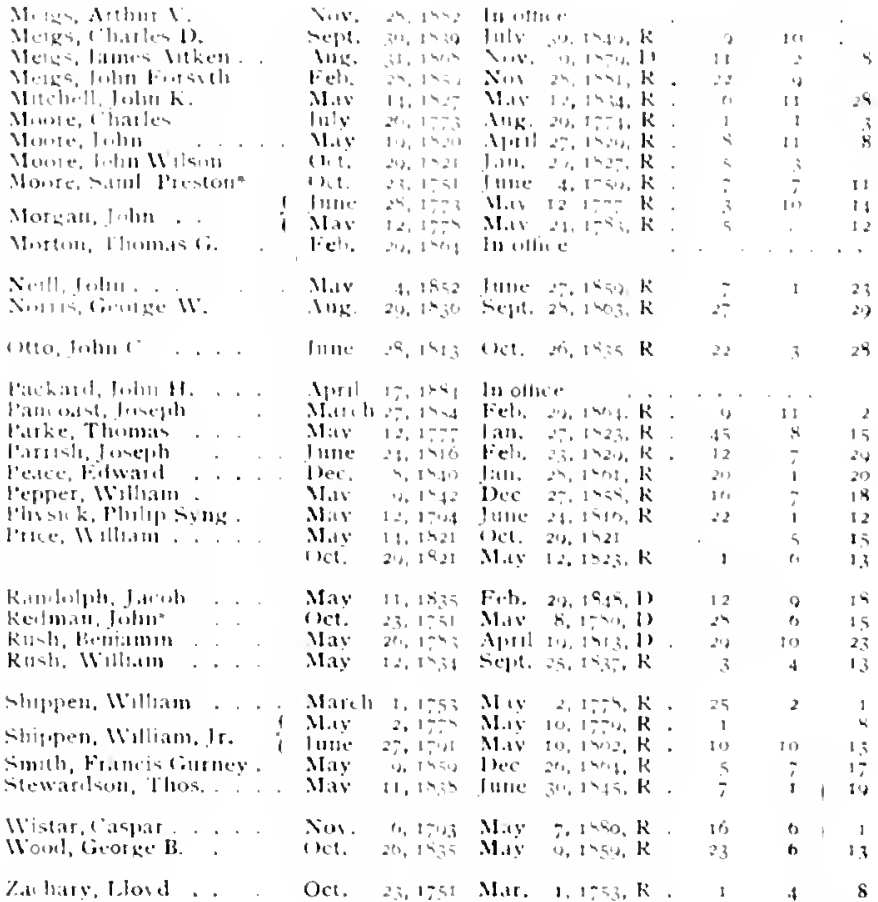

In alduton to the atove, two physi, tats were elected to the Medical Stath, but did not

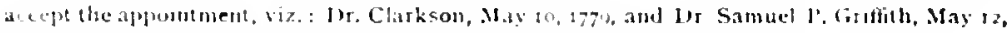
$17 ., 1$

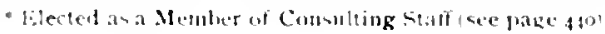




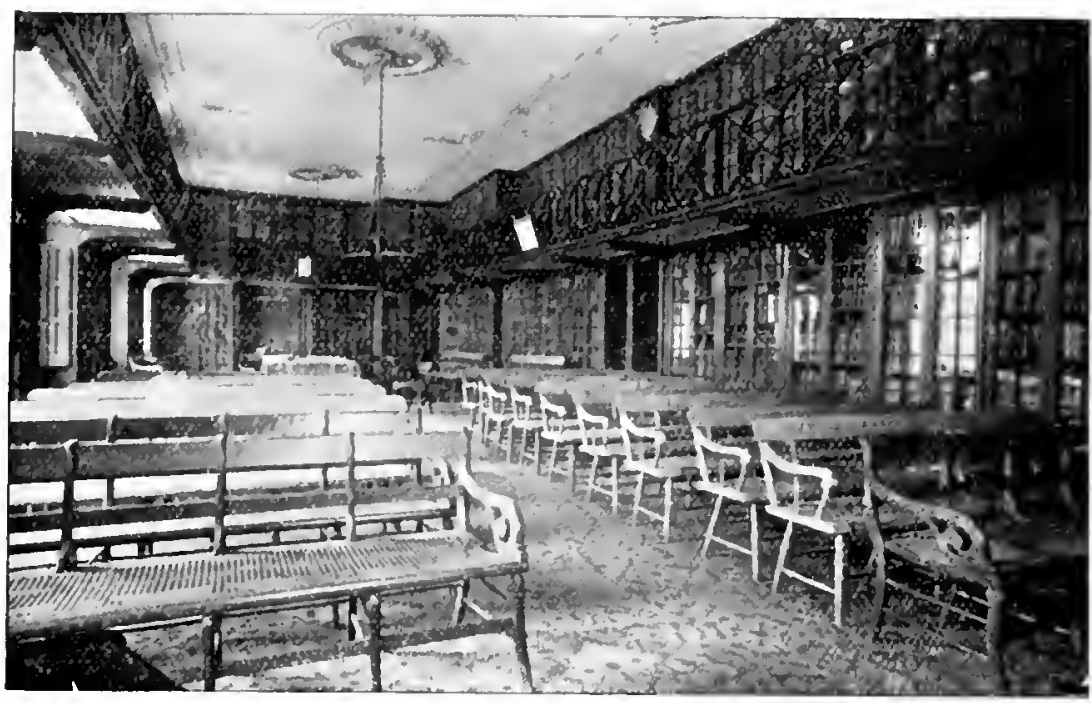

The Library.

BIOGRAPHICAL SKETCHES OF HOSPITAL PHYSICIANS

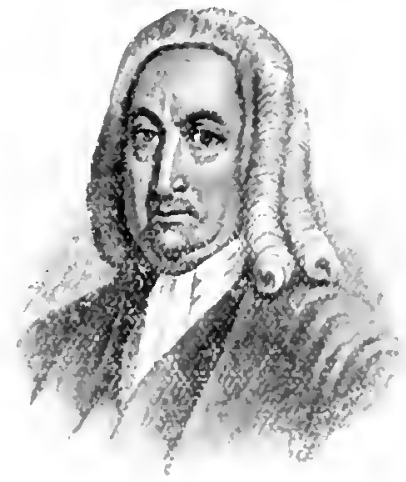

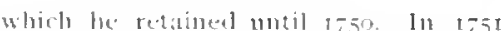
he is alpusintel consulting surgent in extraterdinary cases, wh the l'omsty trania Hospital. ILe for malme veots was Col.

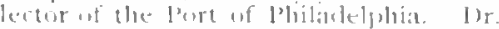
Gratome was the tirst l'pesident if the st.

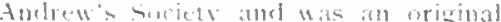
member if dhe American Philesenplical Suciery.

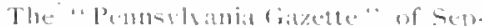

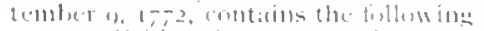

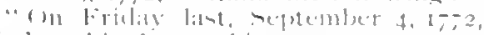

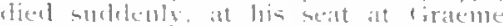

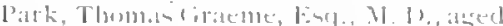

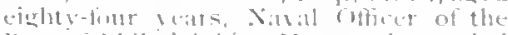

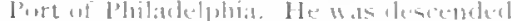

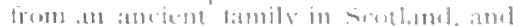

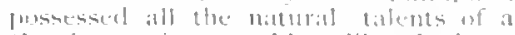

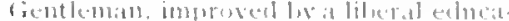

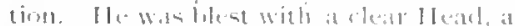

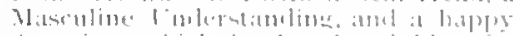

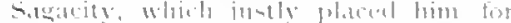

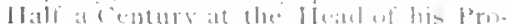

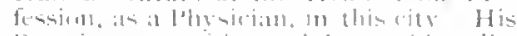
Practice was fisir and loumotable, dis tingumberl at well lo hin Medical Ahilities and commonicative Tomper, als ly a mitural Jhilanthropse that led him

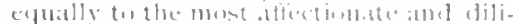

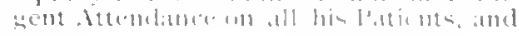




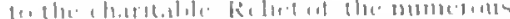

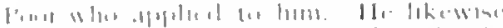

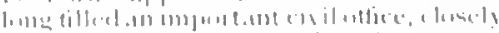

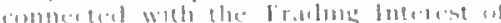

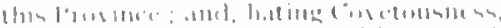

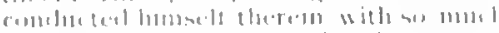

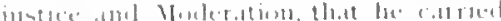

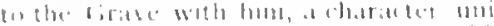

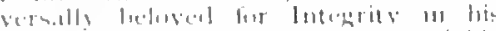

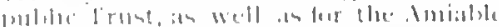

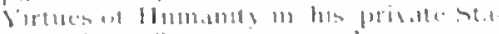

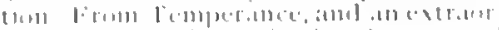

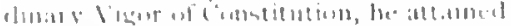
lullnew in bears

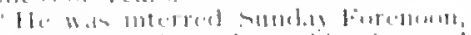

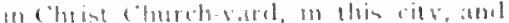

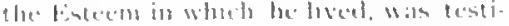

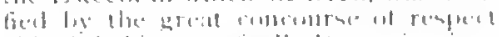

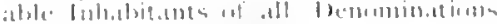

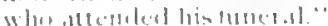

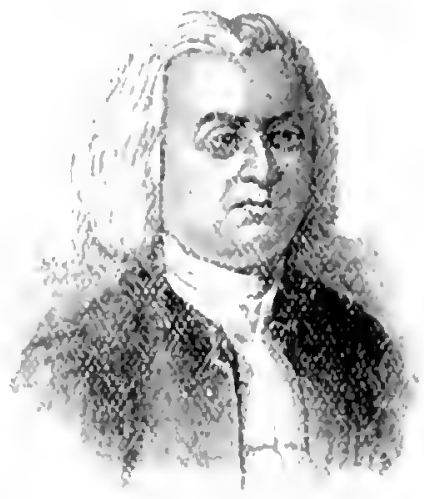

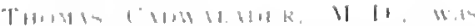

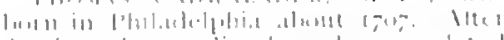

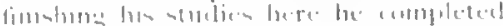

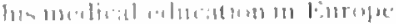

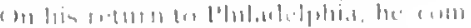

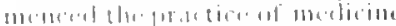

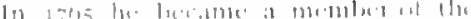

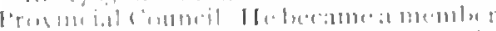

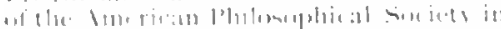

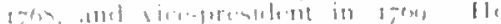

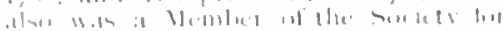

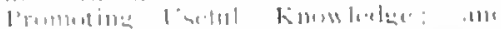

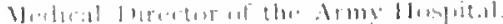

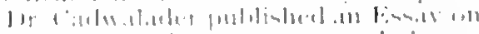

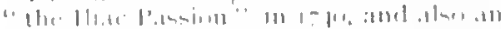

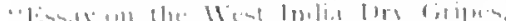

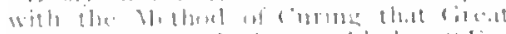

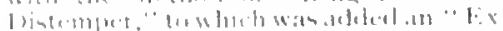

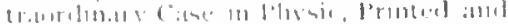

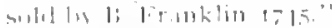

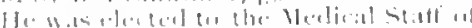

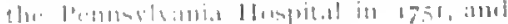
$r \cdot \rightarrow+i 1\}, 1, \ldots$

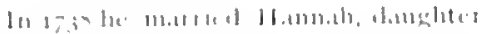

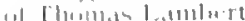

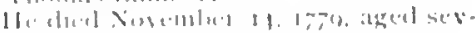

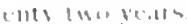

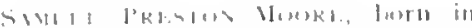

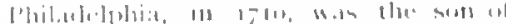

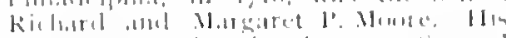

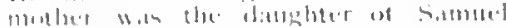

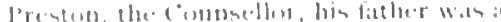

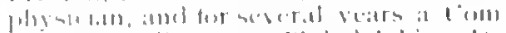

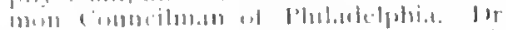

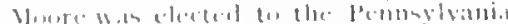

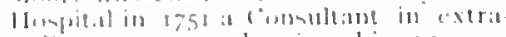

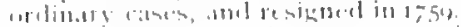

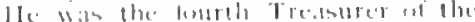

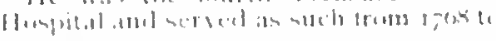
$1=111$

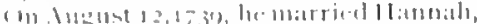

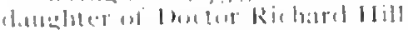

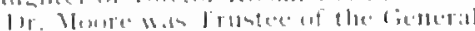

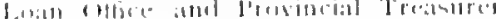

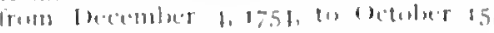
$1-\hat{3}$,

H1. elie.1 July is, t-5 in the nesenty

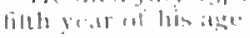

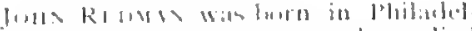

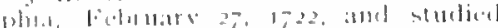

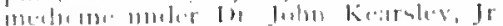

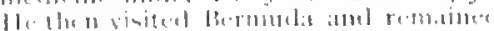

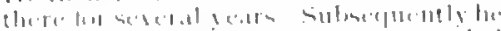

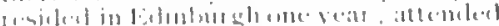

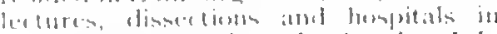

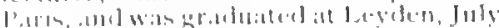

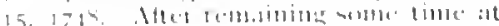

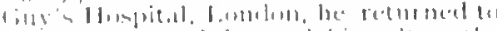

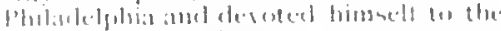
Heale?

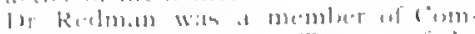

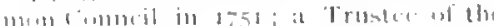

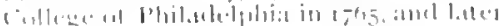

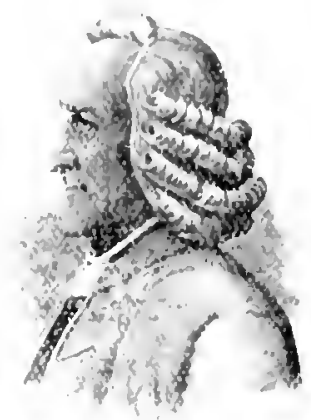

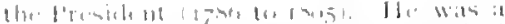

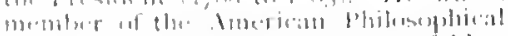

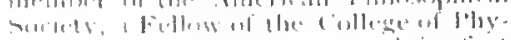

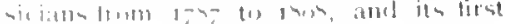


President ( I 7 - 6 to litos) He served for many vears as Trusted of the College of Now jerser. Me wats an elder of the Secomel presheterian Church, Ihiladel. phia, in rist.

Dr, Redman was elected nue of the Comsulting stafl of the pemmstramat

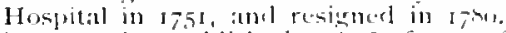
In 1759 he pulblisted "A Ilefence of Inoculation

He was highly resperted in the community on aleconnt of his henevolent charater and professional still : the fist lowing little gem preserved among the papers of Dr. Benlansin Rush, who was his pripil, shows his exalterl viens of the medical professirus:

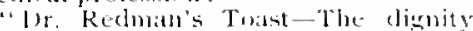
and success of the lueting art: and lonler health and competent wealth, and exquisite happiness to the indivithal prastitiemer who makes the health, atm com fort and happiness of his foline mertats one of the chief ends and delights of hio life, anel acts therein from motives that reveler him superior to all the difficult ies he maly have to encennter in the pursuit thereot."

1)r. Redman died March 19, 1508, aereal eichly-six years.

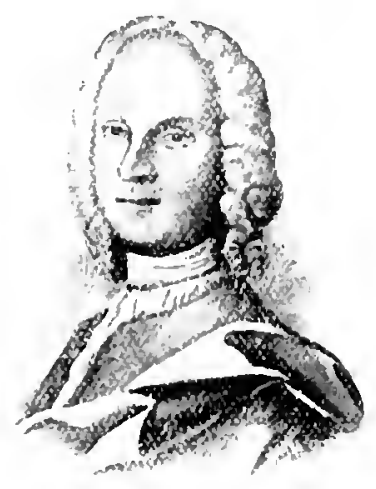

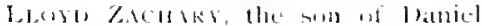
and blizaleth \%achaty (who wats the

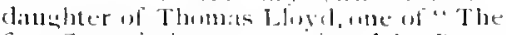

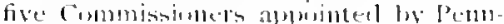

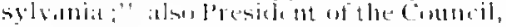
and subseguently beputy Governor of the provincel, was lumb in bustull. Nuremaler 15, 1731.

Beinger aphanel early in life. he remoned to phbibelelubiat to lise with als uncle, Mr. Hills

After finishing his aratemical aluas.

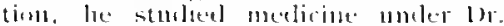
John Kearsley, atul in $1-23$ Welut tu Europe, where he rematined thee yours.

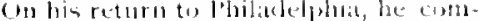
menceel the protetiec at melicine and stum lecame emonent in his protessiuns.

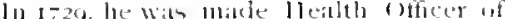
the Jort of Platalelelphia in ronjunetion

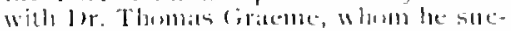

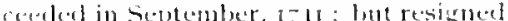
the sine mutull. Jle was me we the fimbelers of the (uillege of lohidelephia,

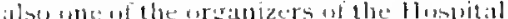
and at member of the dirst Werdical stati. Being stricken with patratisis in March, I5 53 , he resierned, leut his elevotion tor the Honpital only exatsed wath his life.

llis will colltidned the libetal bes guest of $C 350$ to the Institution. with furty three volumes and a numbler of pamphlets for the Lifirars.

II clierl septemler 20, 1756 , in the lilty-ifth yeat wi his age.

Thoness Buxl, was furn in (alvert

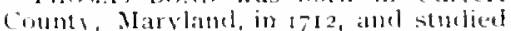
uncler Ior. IIatmilton, allsts of Citleert Combtr. Ife alsitravelled in Furupe and spent comsitcrable time in the l'aris Hospitals.

1)r. Bend lewean pratctice in Philateljoliti in 1732 . He first sugsesterl to Fromklin, alusut 1751 , the iolea of cotalllishing a small Irovincial ibuspital for the sick and injured, and lunatics, which

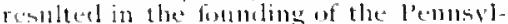
vallat llospitil. IIe wats a nemler of

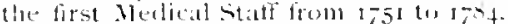

In $1-06$, he instituted the first course of chacil lectures in the Hosplate anel

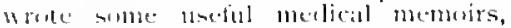
alterwards poldisled in lemelum. He onds ariginal menuler and an officer of the American l'hilosiphisal suciety from

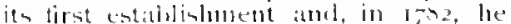
drelivered the andual adelress beting that

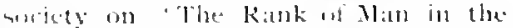
siale of being.

Ir. Bunt joined st. Juln's, the first

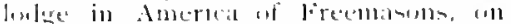

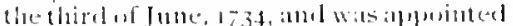
Qumin lisaluel llatelen of the (iramal

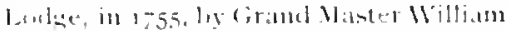
Nie'is.

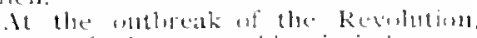
T). Puald, then past his sixtieth reatr,

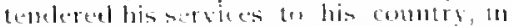

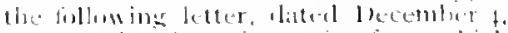

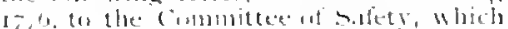

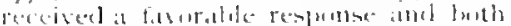

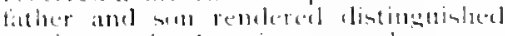

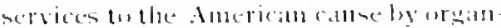

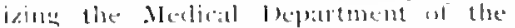
Arims

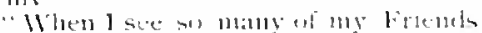

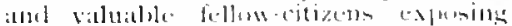

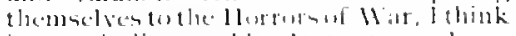
it my indispersable linty to make a

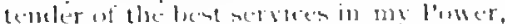

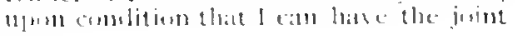




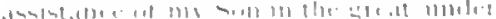

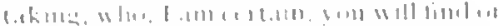

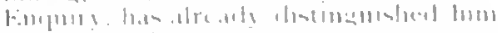

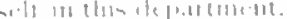

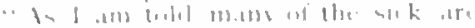

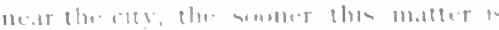

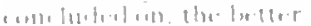

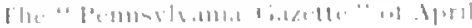

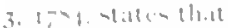

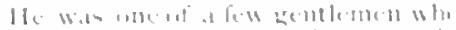

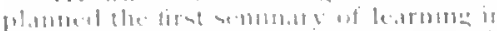

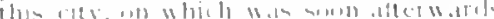

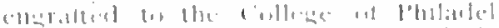

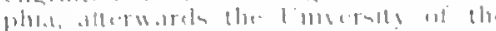

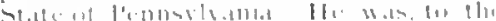

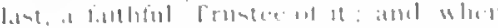

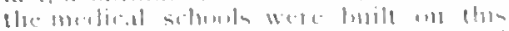

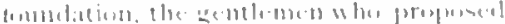

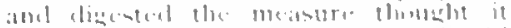

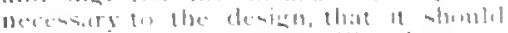

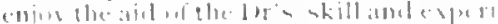

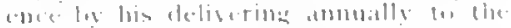

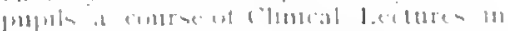

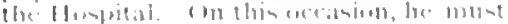

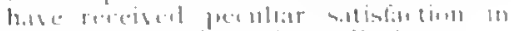

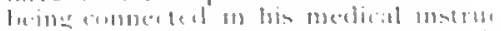
riven uth an institutien whieh at the s.tme lime that it retletes the hishent

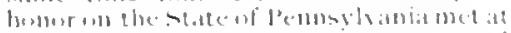

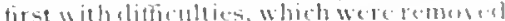

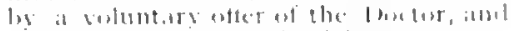

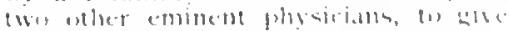

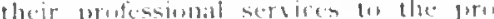

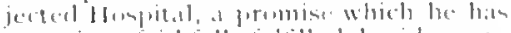
"ver since liathfully fulfilled, lesides and

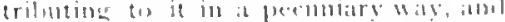

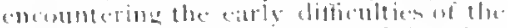

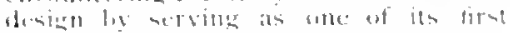
Miningers

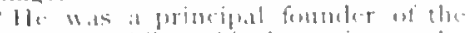

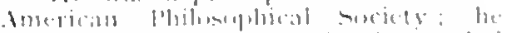

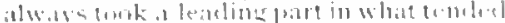

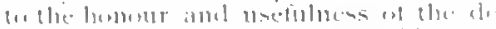

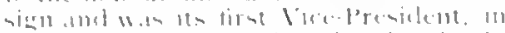

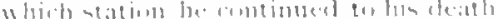

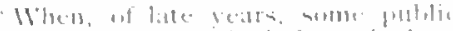

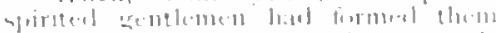

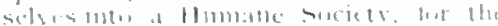

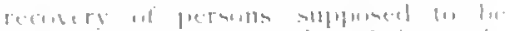

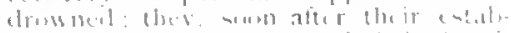

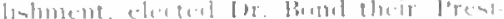

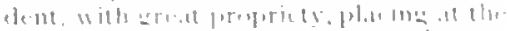

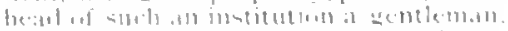

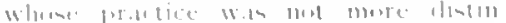

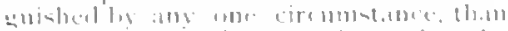

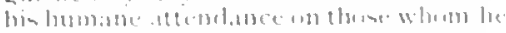

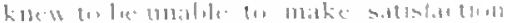

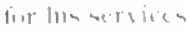

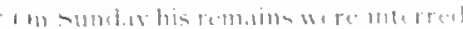

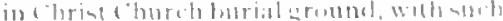

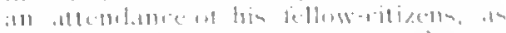

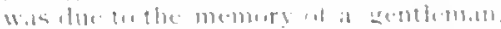

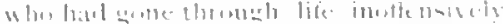

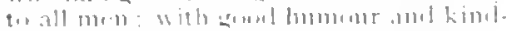

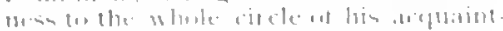

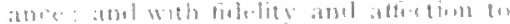
his irienile

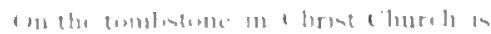

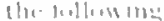

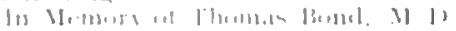

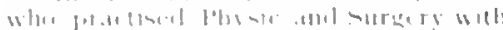

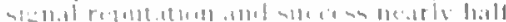

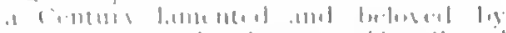

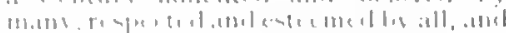

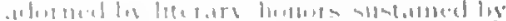

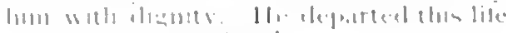

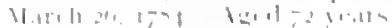

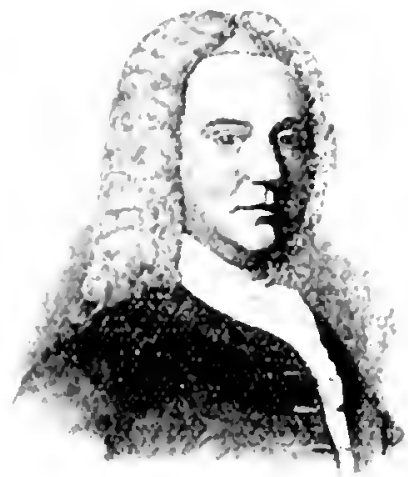

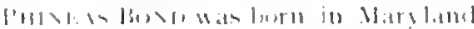

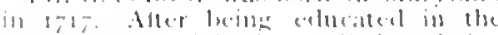

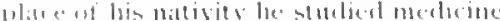

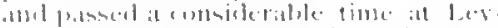

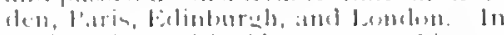

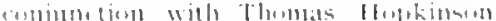

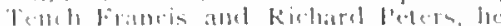

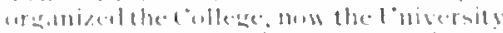

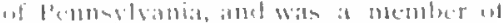

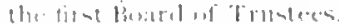

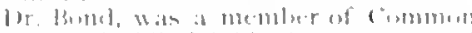

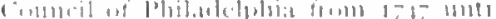

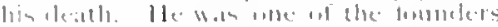

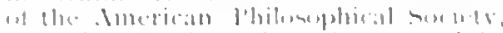

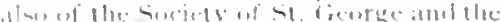

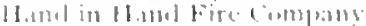

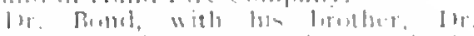

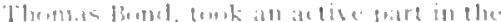

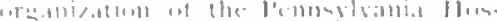
fold and w.

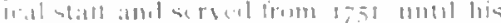
$1,1,4.140$

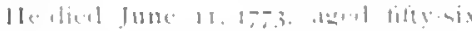
$3 \cdot 11$

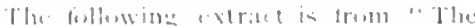

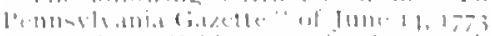

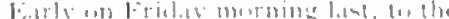

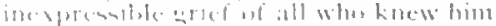

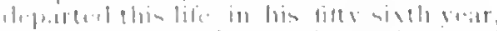

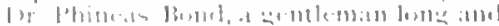

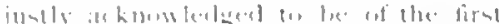

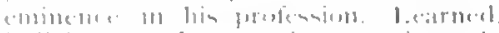

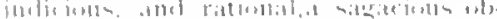

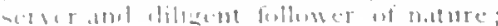


nobly rased alone erety low art ot vulgat prejulice; he som ancepured it

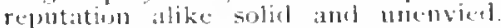
Honest, cambliel, checrful, and sincere; of manners gentle, and conversation in. structive manifestine the rery soul of bevesolence and humbanty in all his collduet; he was one of these happerempered men who could nost be know with out being loved, and therefore hatrlly ever had it patient is whom he had mot is frienel. As his practice Mats extensive, it is not to be wondered then, that we hiave, perlatps, never hatel amomg us at person in whese life more goned inen of ill ranks and denominations secemed to have interested themkelves, than in his. This was abmulantly evireldeed by his aflectionite fellow citizens, ats well dor ing his last illness, as at his intermuent."

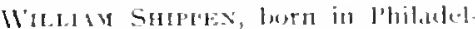

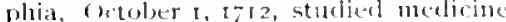
under I)r. John Kearsley, Jr.

He was is delegate from Ponnsylyania to the Continental cingress, Ninemler 20, 17.58 , and again November $1.3,1759$. IIe was a member of the Americall Philusophical society in $176-$ and life l'resident in $17 \% 9$. He was alsy a fonnder of the Sccond Preshyterian Clurel of which be was a member: Trustere of the (in) lege of Philadelplaia, and one of its founders, and during the greater part if his life he was a l'rustee of the cilletge of New Jersey.

Actuated by a patrintic desirew atid in supplyine the deficiency al means to obtain a medical education in the Cor onies, he gave his son the advintage of the best training in the profession and sent him to Europe. (In his return, in 1752. he encouraged him to deliver a course of lectures on Anatomy, amd thum prepared the wisy for the estahlishment of a Medical Schoul in America.

Ior. Shippen was elected to the Medical Staff of the Penmsyluania lfuppitall in I-53, and resigned in $x-2$,

ile died Nostmber fo shor, aged eighty nine vears

Ilis mucle of life wats simple and it was

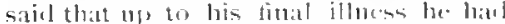
never tasted wine nor spirita. His temoner was never rubler and his besterulende wass withent stint.

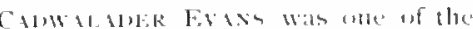

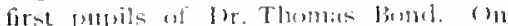
completime his stmelies bere, he silled to Englane with the view of fintshes he mediend extucition at Edinlourah. At this time wat existed between spritu, France and England, and be vessed in which be saibed wats captured les a spamish privalteer and carried on to Harti, where

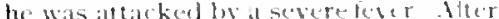

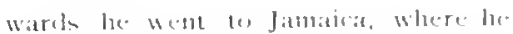

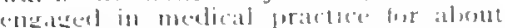

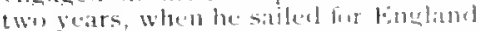

llature resided at bear at felmburgh. amel lometon, lise returned and com menced the fractice of medicine in ['hiladelpoli:

He wats elected to the Merlia:al statt on the lenosslumia Hospital in 17.59 , in which fusition be contimed until his de:ath, Jome 30, 1773 .

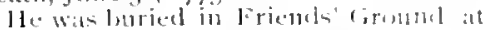
North Wales

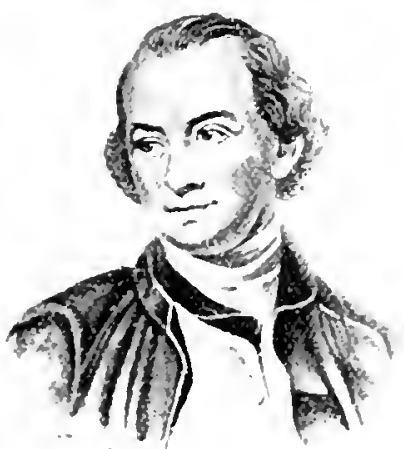

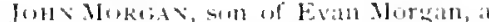
Ifedshman, whe harl long been a reside-nt of the Prosince, was hurn in philadely. whia in r 735 and received a classical edu. cation at forthengham Acarlemy, chester (i). Penma de was tramserted to the (olleare of philatelphial and on May i? 1757 , received the legree of $A$. B. at the firat commencement of the institutiinil.

He studied medirine uncler lir. John

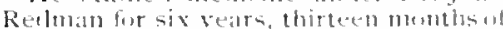
which he spent in the l'enm-romial Hospital an Remilent Aprotheciry and at the

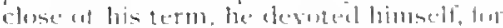

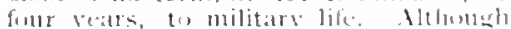
he held a Lieutenant a commiasion,

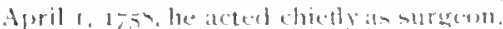

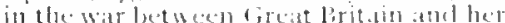
colenies and Fratres ; at the cluse of the

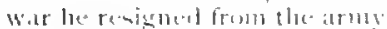

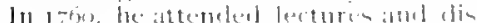

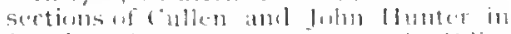

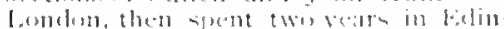

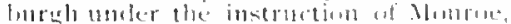

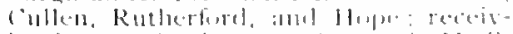

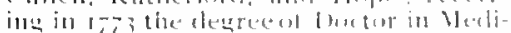

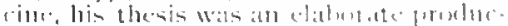
tion on "Suppuration ant the fintmation

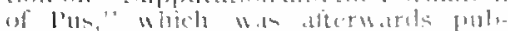
licland

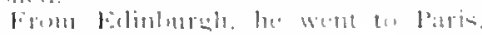

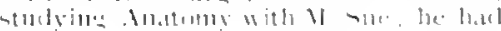




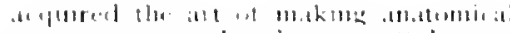

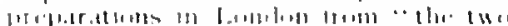

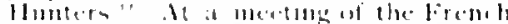

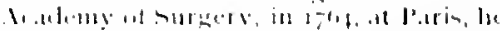

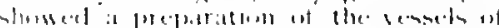

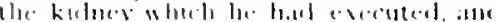

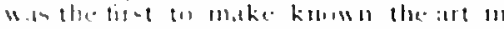

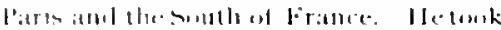

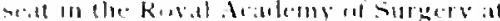

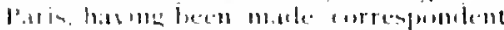

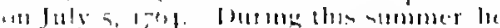

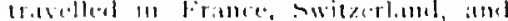

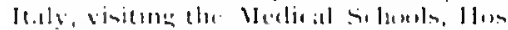

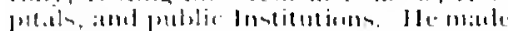

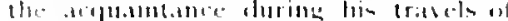

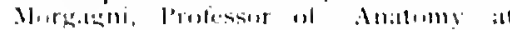

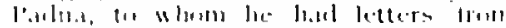

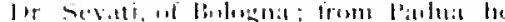

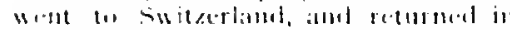

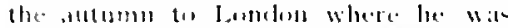

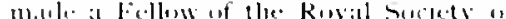

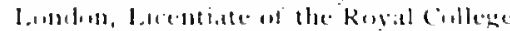

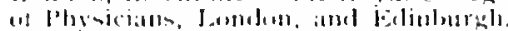

Ile rebured la liblatedphia early in 1,05. With lor. Shippers. Jr. he with the

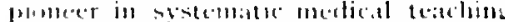

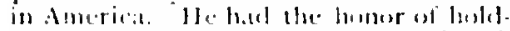
ing tle firat medical profesosership ia this

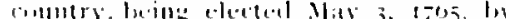
the frumterent the (inllege of fobilatel

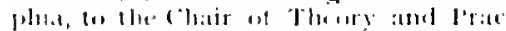

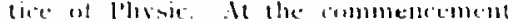

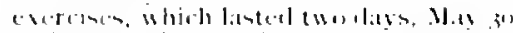

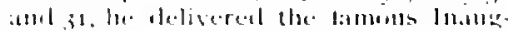

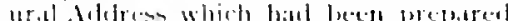

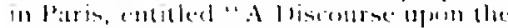
lostitution ut Medienal siliands is

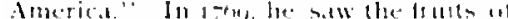

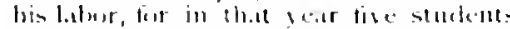

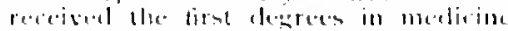

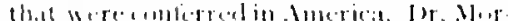

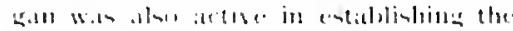

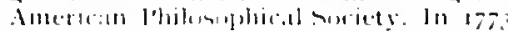

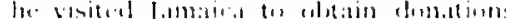
fin the alvaneement of general literatere

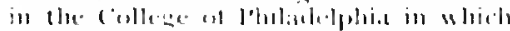

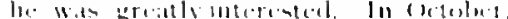

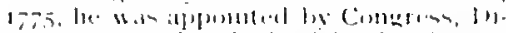

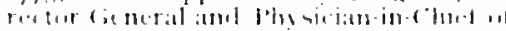

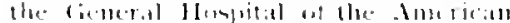

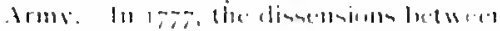

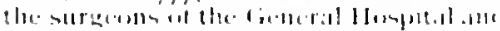

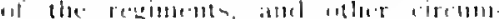

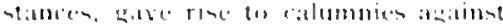

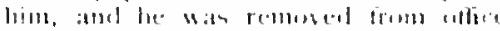
u ithont an +1), seli; he milmeduenty applied for :

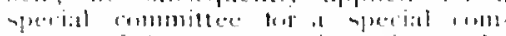

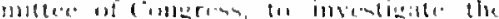

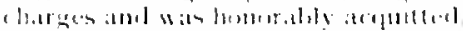

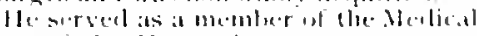

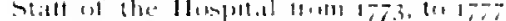

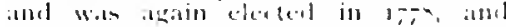
serial intil $1 ; x_{3}$

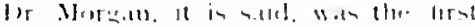

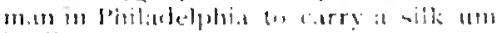
I.1 .11 .1

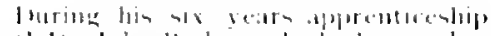

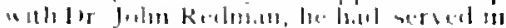

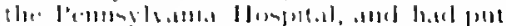

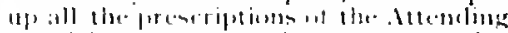

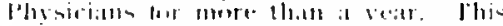

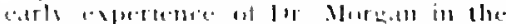

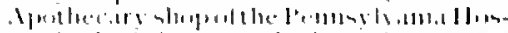

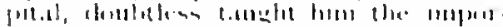

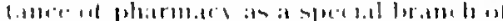

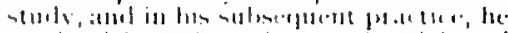

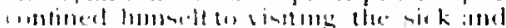

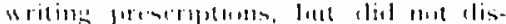

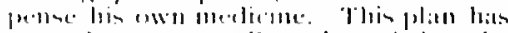

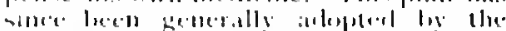

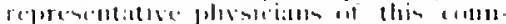
try, although It was a darimg momeateon

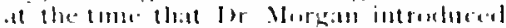
It.

11. puthinhed "Tentamen Melicum

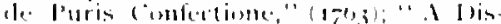

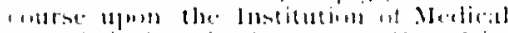

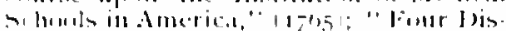

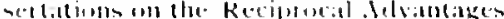
of a lengetual l mom betwent ireat Bri.

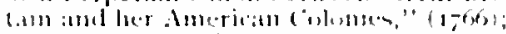

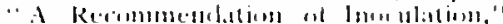

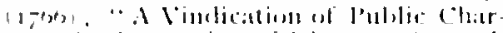
ater in the station of birector fieneral, ate.

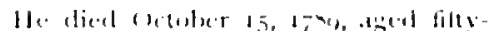
hiser yeats

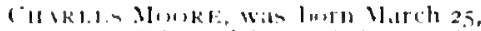

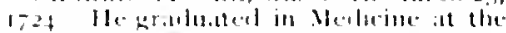

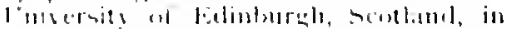
$1,7.5$

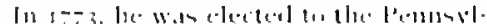

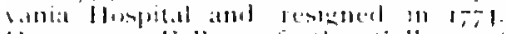

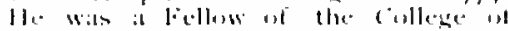
lihyojolims

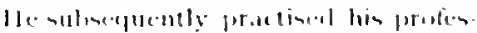

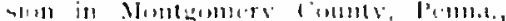

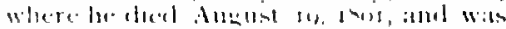

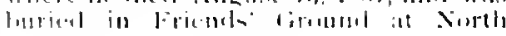
11.,1e:s

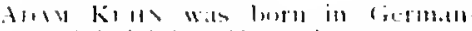

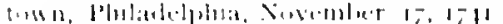

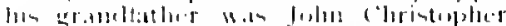

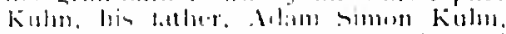

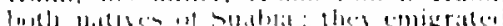

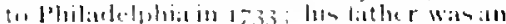

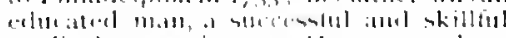

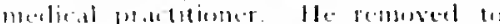

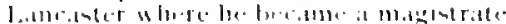

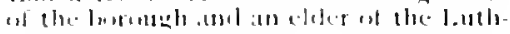
(.r.11 + "hatris.

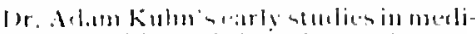

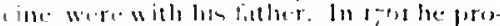

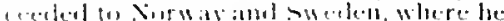

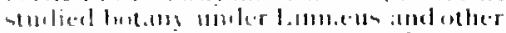

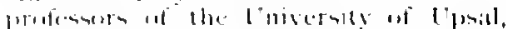

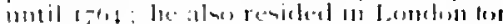
one year ; then went tu Folimbursh where

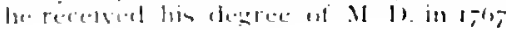


from the lunisersty his thesis being "De. Lavatione Frigicla."

Afler visiting France, IJollame and Germany, he returmed (1) Amerias in 1766 , and was at once alperinted l're fessor of Materiat Medion and lintamy in the college of Philatelyhia: he comsmenced his forst course of hertures in

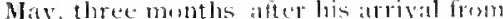
Enrope Ite continned in his pesition twenty-ome years, antil transfereded the chatir of l'ractice.

In Jamuary 1774, he was ons of the

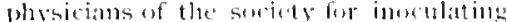
the poor. He was one of the fomelers of the college of Physicians and its president in 18 ses, and also a mentere of the American Phalusphlical Suriety.

He was Professer of Theory and l'rac tice of Meclicine in the liniversity of the State of Pemmsyluania $(1-8,0)$ amel was transferted to the same chait in the tui versity of Pennsylyanial in 1792 , from which he resigned in 170 .

He was twire dected 10 the Vlecticis Stalf of the Ilospital: he serverd from

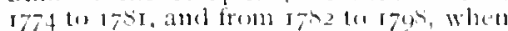
he resigned.

He married Elizabeth, dimghter of Isatic llartman, Esq, in lhe Jiatnd of St Crop, Maly, I-sos.

It is sach of him, "II was not rematrkable for the prower of imagination: but in soumd inderment he greatly excelled."

br. Kulun's talent for whervation wis

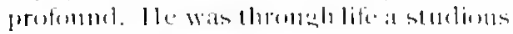

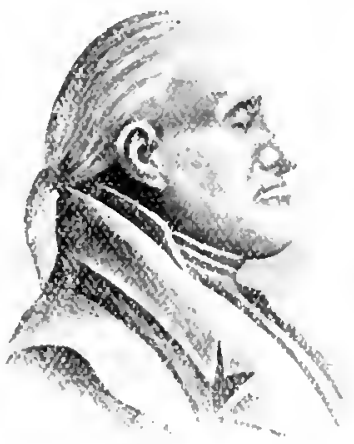

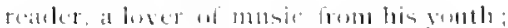
remarkatsly alosteminsus and regulats in

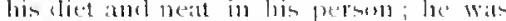

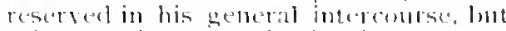
alfable and communicative its the com pally of his fricmels. Ilis mantures were soiti al ostentition a

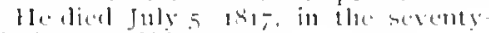
sixth rear whis alge.

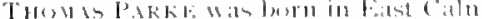

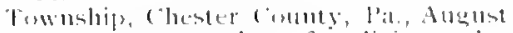
o, $1-10$; he was atulent of incolio-ine $111 \mathrm{~d}$ -

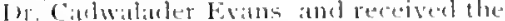

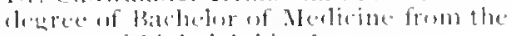

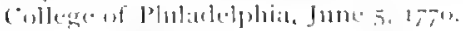

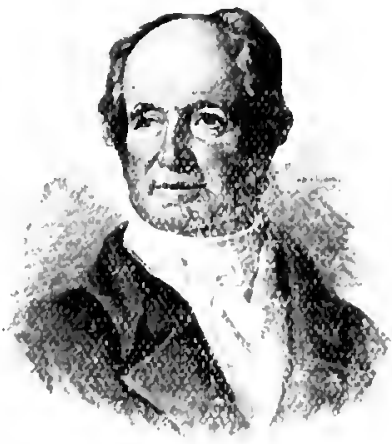

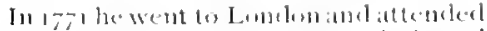
fily's atmel st. Thomas's I losprital alud

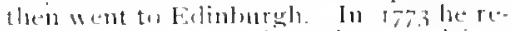
turned to philatelphis and colered intw partuership with hispreceptor, I r. IEaths. in the mactice of medicine.

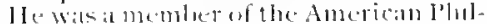

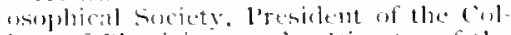
fore of Physicians and a loirectur of the Plibatelphial library

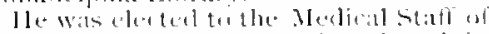
the. I Inspital in $1,-5$, and resignal in 1423

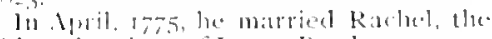

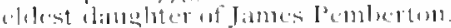

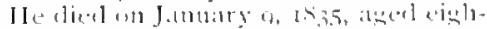
ly-lise yeatis.

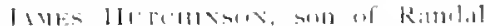

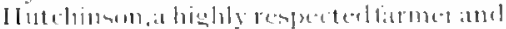

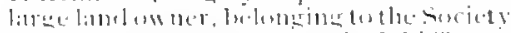

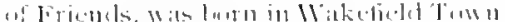

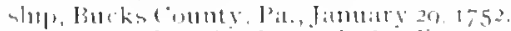

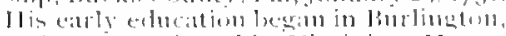

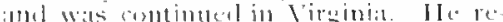

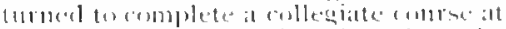
the collese of I'hilatelphiat. whele le

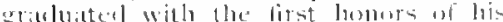

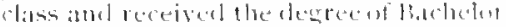
of Ais

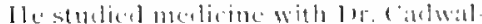

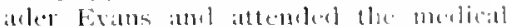

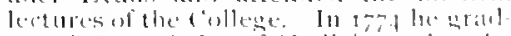

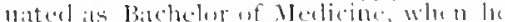

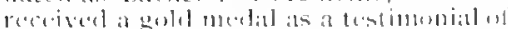
him ability athd attalinments, moste pattis

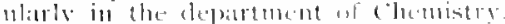

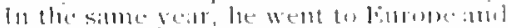

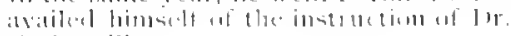
Fithorill. 


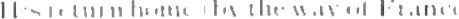

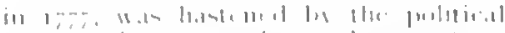

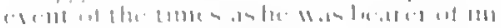

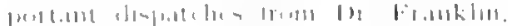

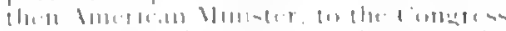

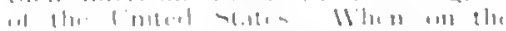

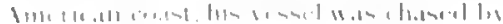

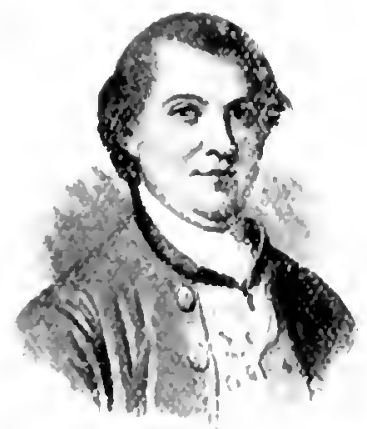

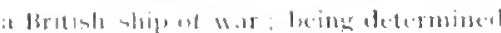

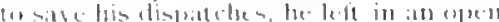

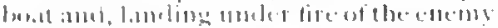

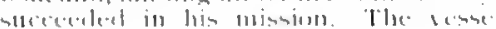

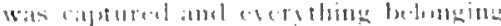

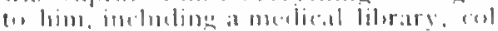

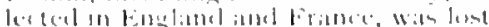

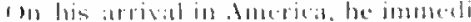

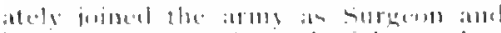

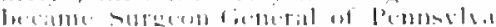

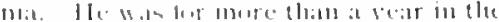

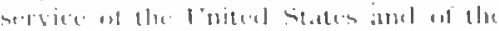

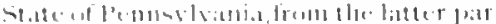

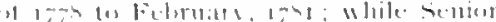

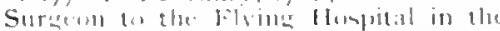

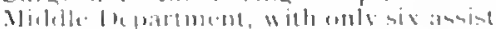

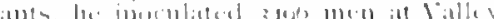

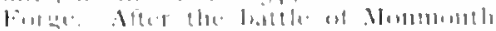

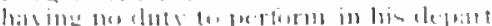

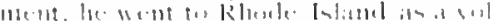

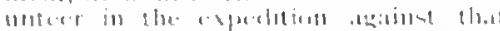

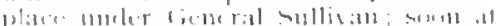

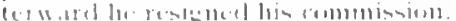

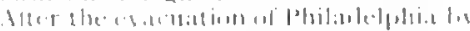

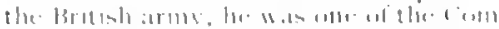

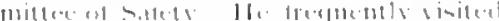

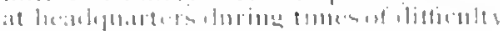

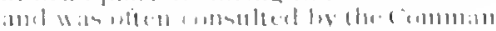

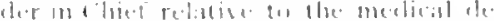
$1+11+1120.110$

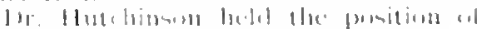

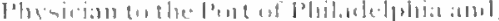

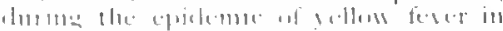

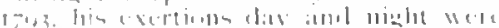

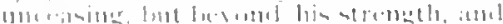

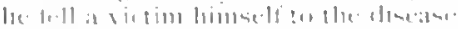

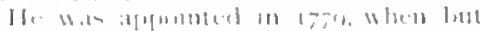

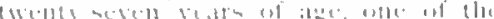

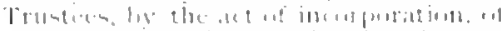

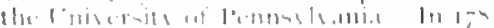

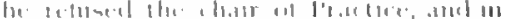

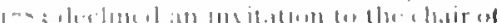

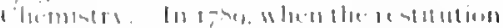

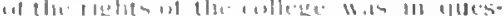

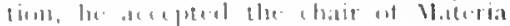

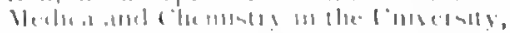

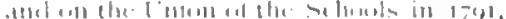

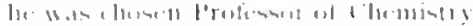

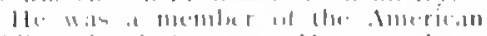

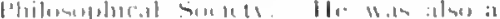

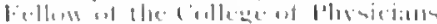

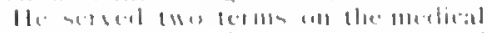

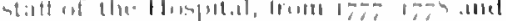

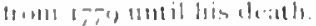

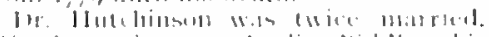

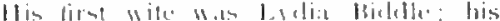

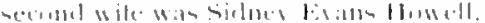

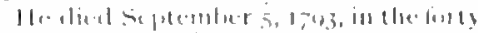

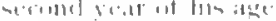

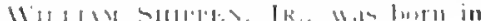

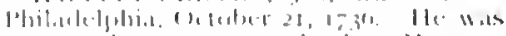

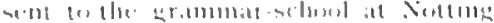

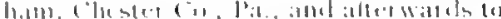

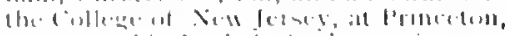

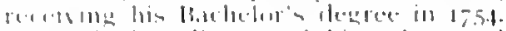

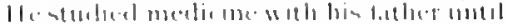

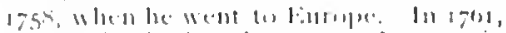

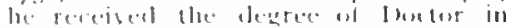

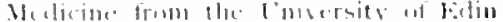

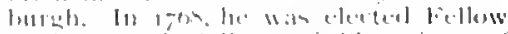

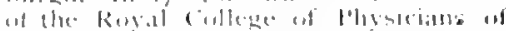

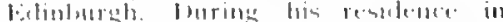

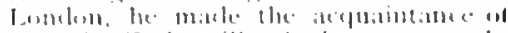

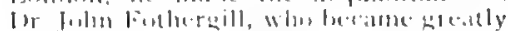

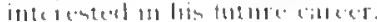

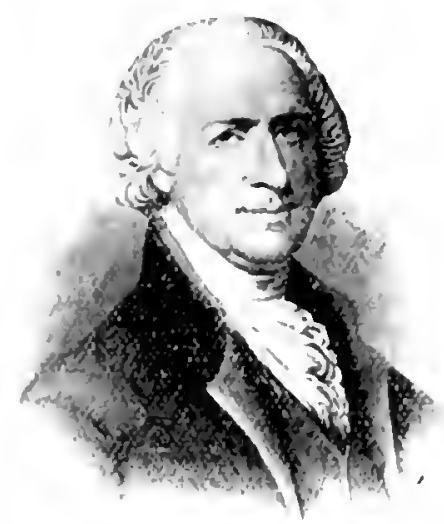

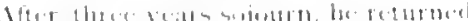

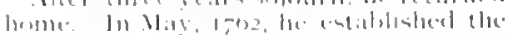

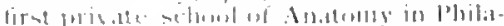

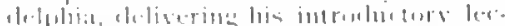
tirte al the stafe llouse on Xiscemler

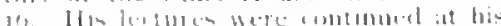

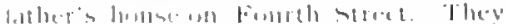

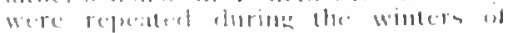


$1563-6+$ and $1704-6,5$. In $1,-65$, lue was elected lentessur of Anitomy and Surtery in the medical schoul of the College of Philadelphia, lecoming the assuctite of his friend and fellum-stuelent lor. John Murgitu.

When the cinlege of l'hilatelphia was

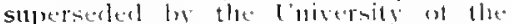
State of lenmsyluanial, the tristecs, 111

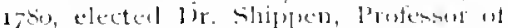
Andomb, Stroters, and Midwifery; alterward he was Professor of Anatumy

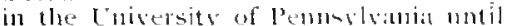
1sob. when lie resigned. At the ontherat of the Revolution, lat wats appunted

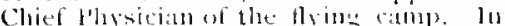
Natrch, I-7, he sulmatted a plan for the oreanization of the hospotatl depotrtunent, which, with some molifioation, was arlopted and Aprit $[1,17-2$, Constess elected him" Director-foneral al all tlic militars hospitals of the Armies of the United States." I1t resigned form the

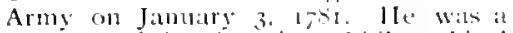
member of the American philesendical Society, Comsulting Physician at thilat delphia loimpenstry, a Fellow of the College of poysicians, Philatelphia, and wats its president, ( I sis $5-18 \mathrm{~s}$ )

He was clected twice to the Medicial Staff of the Penllsylvamia Huspital, atul served from 1775 in $17-9$. and from 1791 ti isuz, when he resigned

Dessection of humath bodites excited so much prejudice in Philadelphia. that in 1765 , Dr. Shippen felt whligted t" publicly anmounce thist for his dissections, he had never taken dean bodies from grateyarels. In 1770, the exertement led to what was called "the salitu"s mol,." in which Dr. Shippen's horuse wals attacked, and the widuss lroken.

in $1-65$. Dr. Shippen beratl at entrese on Midwitery (1) men amel women lretl. estallishing a lying in llompital at the silme time.

1)r. Wulliam Shipproll, Jr.'s antuste ar lectures in 1762 , on Aliatems "for llut advantage of young gentlemen, engiderent in the study of juysics, in this and neighboring provinces, whose riremmstances will not permit their goiner abroad for inmosement, to the Anatomi"al Schouls of Enrope," was the first eftort Lowarls establishing systenatte medical teaching on this contintent.

On December, 1762, the budy at a newro, who hat committed sticide, wats hambled over to lor. Shippen, after the verdict of the comoner's jury; and after that time his anatomical musemom got the bollies of all suicides and criminals

He died July I I, 1 ko8, at Germiantuma, aged nearly serenty-two.

Joms Joxes, son of 1)r. Evans Julles (and grandson of Edward Jones, whose wife, Mary, was, the eldest dambliter of

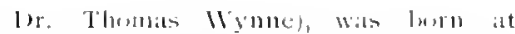

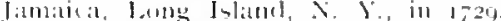
ile frestin the stady at medicinte at the

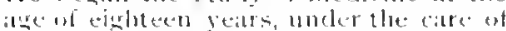

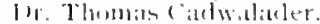

Aler completime las soluclies in this

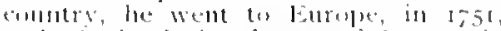

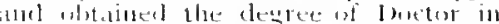

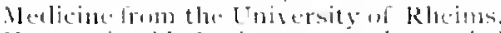

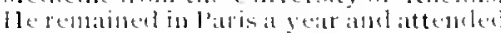

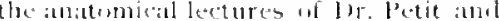
the fritediceof the llutel l)ien; and spent

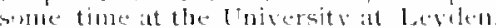
and buatly visited Edimburuls.

on his leturn, hesettled at Xew Jotk

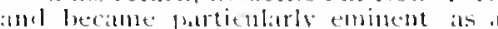
surges) In the wat of 1775 , he served in the colunial Army antinst the Fenel,

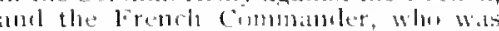
serety wombled, was attelleted ly him.

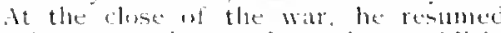
brivate prateter, and on the testillishinent of the lledical l)toartment of the

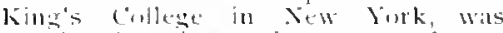

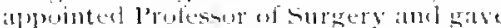

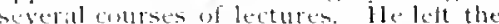
rity in 1-, wh, when it was arcupied by the enems, anct sected in l'hildeleplat, where he fecame the family physician of IV:ahington and latoklin

He was a nember of the American

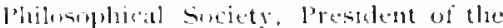
Humane suciets, and in $1,-60$, first Vietel'resident if the College of Physt. tiins

Het served on the Medical staff of the

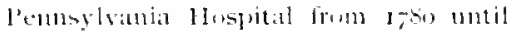
his de:illt.

In the atutumn of the year 1725 lie publisherl "l'lain remarks an Wounds iniul Fractures" for the use of Surgerens (if the flom and Nits

1)r. Jumes was specially distinguished as a sucessiul lithutmist atud acounch.

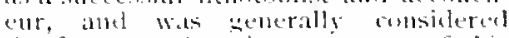
the foermest Ameriean simgeom of his disy.

He died Junc 23, 17u, ared sixty-twn yentis.

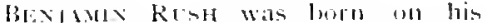
father'surm in Byberrs 'low nship, l'hilat delphia Cutunty, Decenber 24,$1745 ;$ luth his aramslfither, James Rush, who died in 1727. and his fittier, John Rusl, were

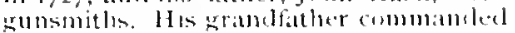
at trowp of lonse in the arms of (1)liser Cromuell. () a tate resturation of the menarche, his parents, being menbers of the Socitety of Frients, followed William Penn, in $168_{3}$, to this combly

Dr. Rush was the most eninent Amere iritl plysician and author of his day and lats lecen callet the American syelesilam. llis services to medical sevellet are so familiar to all that only tho lerietest bicblaphical note need be inserted lere. 


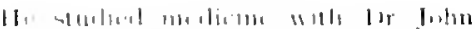

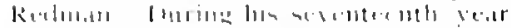

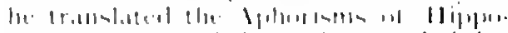

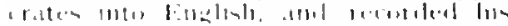

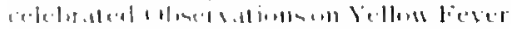
it $1,7+2$

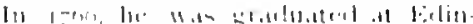

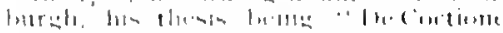

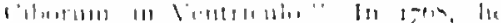

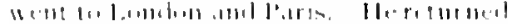

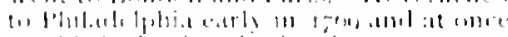

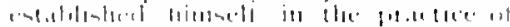
$m \cdot 1,111 \%$.

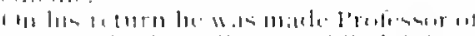

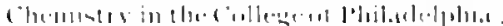

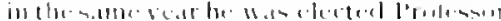

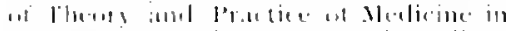

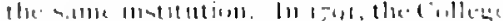

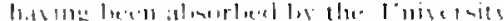

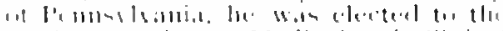

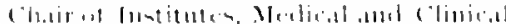

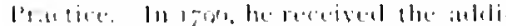

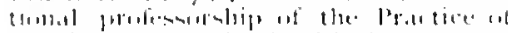

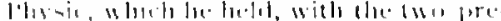

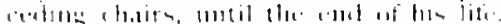

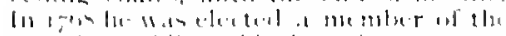

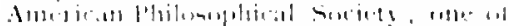

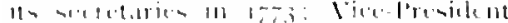

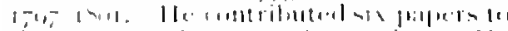

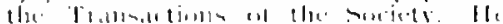

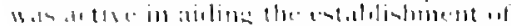

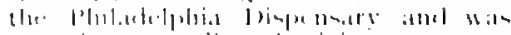

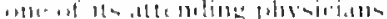

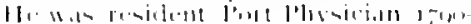

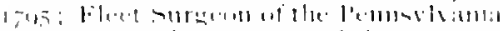

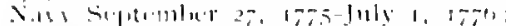

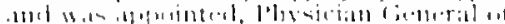

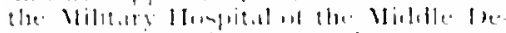

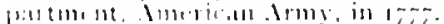

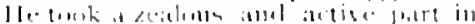

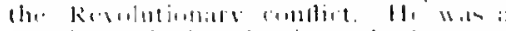

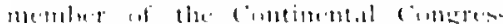

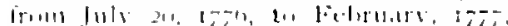

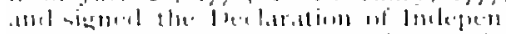

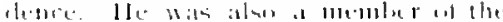

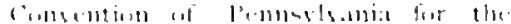

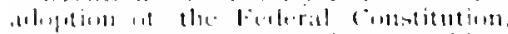

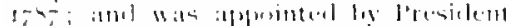

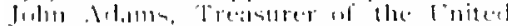

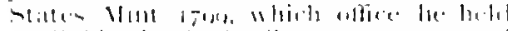

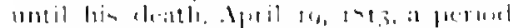

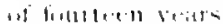

IVlen lor kinh lexenth his lectures in

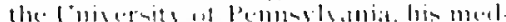

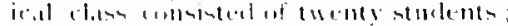

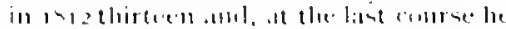

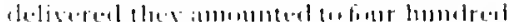

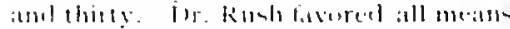

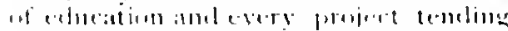

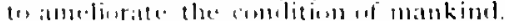

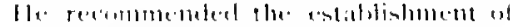

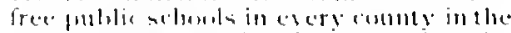

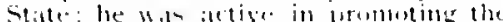

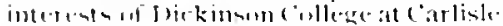

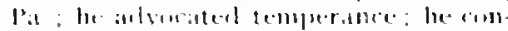

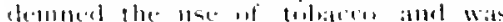

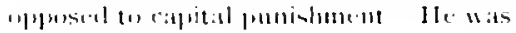

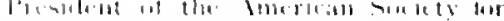

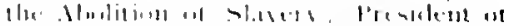

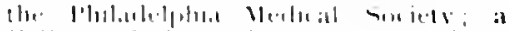

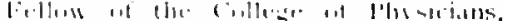

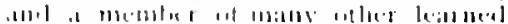

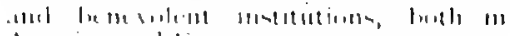

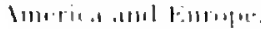

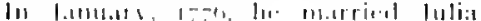

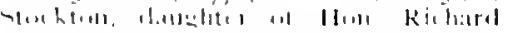
arukkinl >

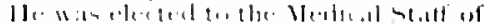

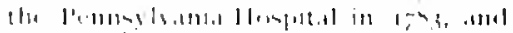

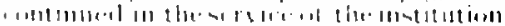

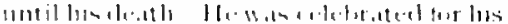

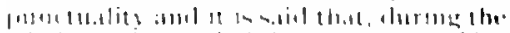

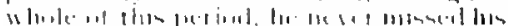

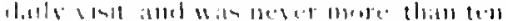

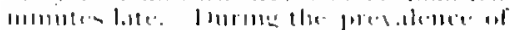

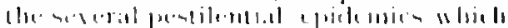

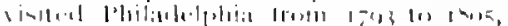

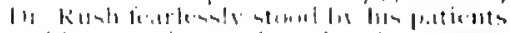

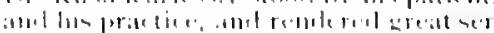

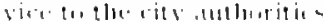

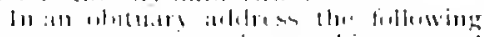

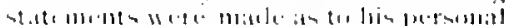

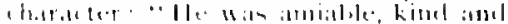

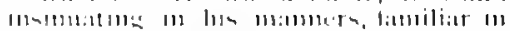

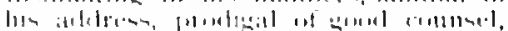

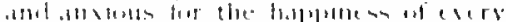

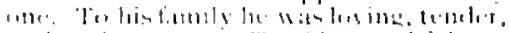

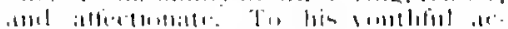

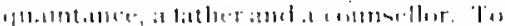

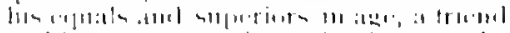

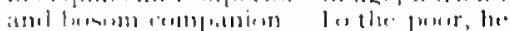

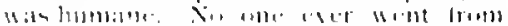

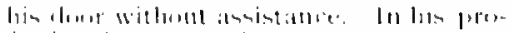

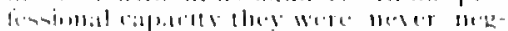

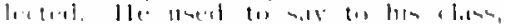

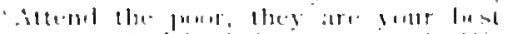

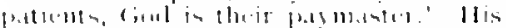

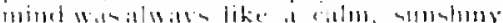

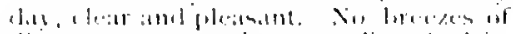

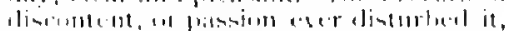

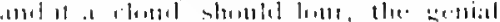

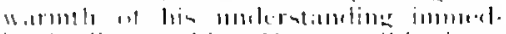

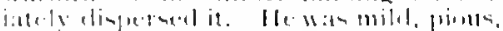

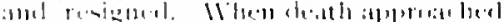

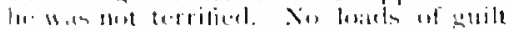

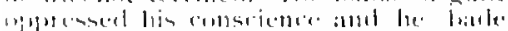

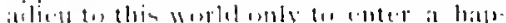

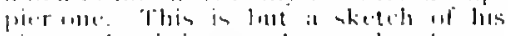

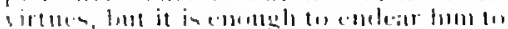

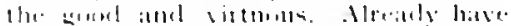

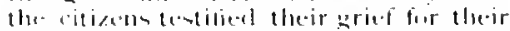

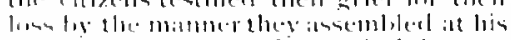

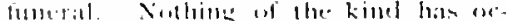

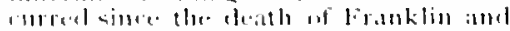

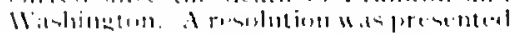

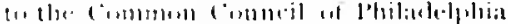

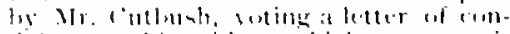

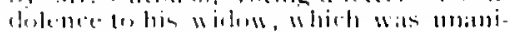
momaly indingledl."

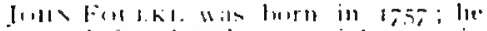
frepletel for the elegree ot lanctas in Nerelicine, in 1 - we, at line fillege of thilatelphitis 
The minutes of the college of l'bilat delphia show that Mr. Fonlke was ex:llm inerl for the Bitchelor's degree Jume t, 1779, lut after the mandamus was ismod the commencement wis interdicted by the President of the Fxecutive Conncilos

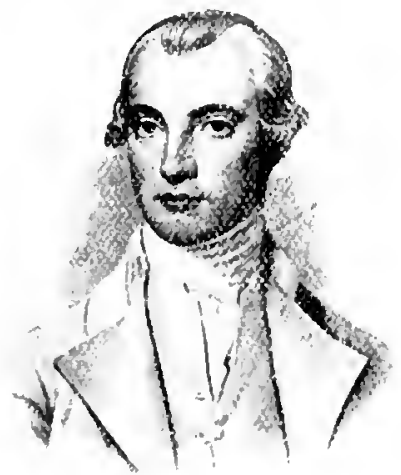

the state this ves the begiming of the difficuity which eventuated in the aretiom of the legistature by the passige al all ict, Xinember 2- $1--0$, by which the charter of the cinlente was abrugated. and its property" tramsicred to the I ni versity af the State or l'emssylyatia.

by. Fonlke was Jecture on Anatumy from 1-5t-1-06; a member al the Amer-

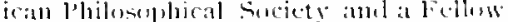
of the College of physicialus.

He was elected to the Nedical Stalî uf the Pennsylyatial lispitat in I-4. re signed s, 94 .

Ite died in 1 gof. ared 30 veras.

Cispak Wistak was hurn in l'hilitdelphia, september 13, rgis, ancl as his parcents and ancesturs. win lorth sielen, were at the Sociely of Friemls, he received his celucation in the l'ulliceschum fommled by Charter for the lonvel and cimnty of phidatejplita. When in the

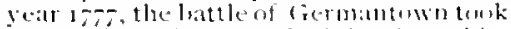
place, his reliesous principles kept him from contering military servete but his Immanits led him to seek the wrmmeled solder, and he was active aments thome who were administering relict. His bencovelent heart was solecply impressed with the happy effects of the medical art, that he detcrmisted to deveste his life to alleviating the miserics of mankind.

Firm in his purpose, Wistar applicel himself to the study of medicine for thres gears, muler [)t. John Redmatn.

Having gome llomely the uallal course of study, in $1-82$, he received the degree of Bachefor of Medicine from the Ini-

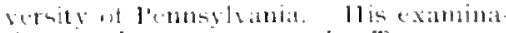

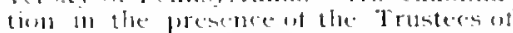

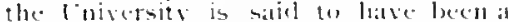

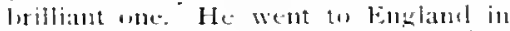
1. 3, where be remained a year, then attemeleal iectures in Folimburah.

for twe sucensige yeats he was elected ine of the l'resielents of the Ruyal Medical Society of Eulinhurgh amel he was also elected l'resident of the

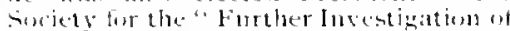
Sitturit Hinturs."

In $1-46$, he towk lis degree in Melieme at the lonersity of Erlinburgh, ater

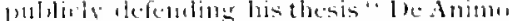
I)"minsir."

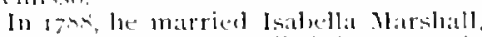
wi l'hilatephia, who died in izous in lecember, 1,gs, be married a seemel time, taking Elizaluth Nifilin, a niece

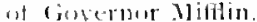

In the -11mater of 1795 , while treating cosen of Sellow Fefer lie had himete an attack ot this disuate.

lit 5os he was elected une of the blosians lo the lemosylvanda lompital

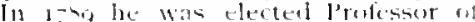

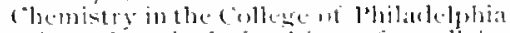
When the risial faculties wi medicine

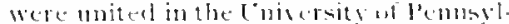
butu, Wiatar was elected Jamuary

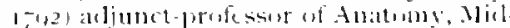
wifery and Suraery.

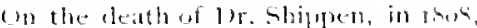

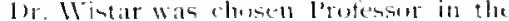

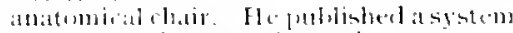
wi amatumy in two volumes in thits.

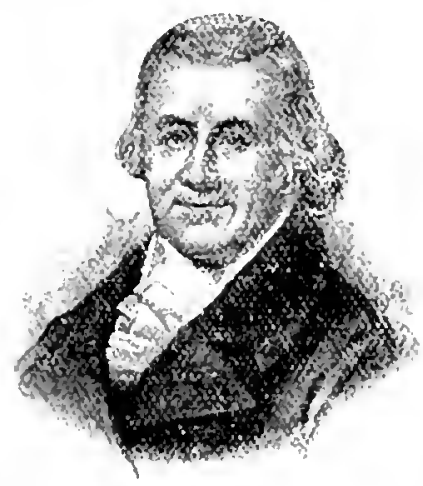

(1) May 7, salu, when ho resinged as physian to the lemmstramia llospital, the followionereseblation enterect an the. minutes was male: "The comelusion al 1)r. N"istat to witharate at the presemt time was mexpected and rey mul contetted lo the Managers whit wellel have glally embracel the apportunity of 


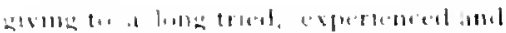

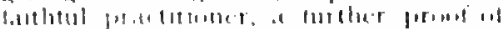

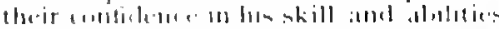

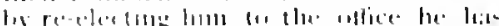

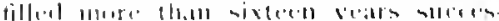

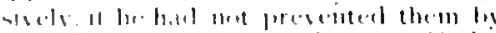

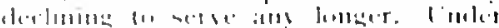

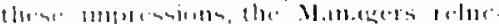

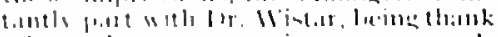

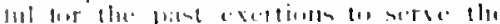

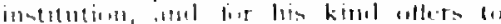

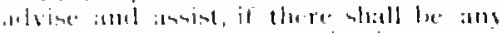

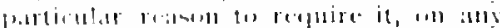

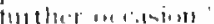

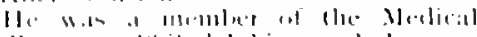

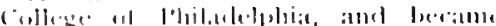

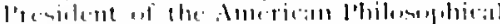

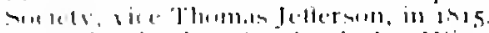

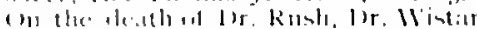

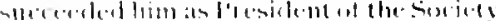

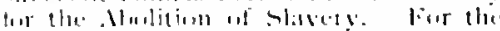

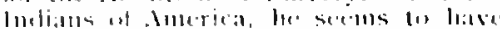

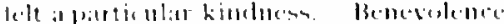

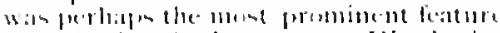

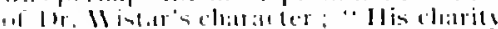

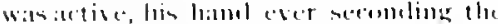

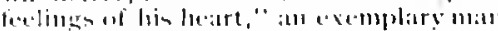

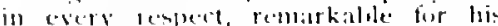

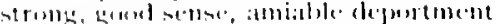

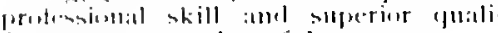

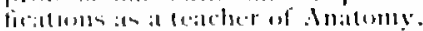

He was the fiemeler at the " Vistat partics." an attrative leature in the

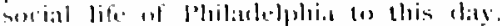
At first the meetings touk place all Sin

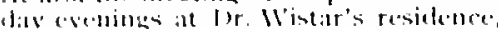

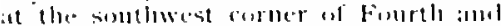

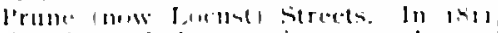
the time of the meneling was rhanexel drum Sumbla en siaturalay.

The arginal llistar ("hl, which arose frem these meetions, was compersed uf

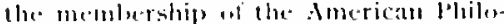
sisplisal sociely, of which 1)r. Mistits was omed jesident. chief Justiece rilg h:tu speatints at a rertain commiten meeting wi this sureiety, silys, "It wis the rustum atter the lussiness of llue evening was ronchuled, to enter mom

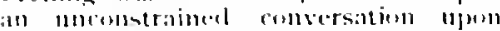
literary sulsiects. Flen, without intending it, onr lamented friend (J). Wistar) would insensibly take the leat ; and so inferenting were his ancerlotes, ancl so just his rematks, that, trawing tlase is the alying embers, we enfen forget the

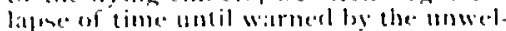
come rlect that we hasl entered upest another , lis.."

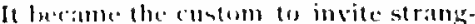
ers of alimetmetin whe might be in the fity, to the Saturalay evening parties. Thus, in thit, for bintar emfertaineel Baron wom llumbollt and his young friemel Bemplame. At first the entertiti. ments were lharacterized loy a frugil simplicity, hut afterwards they berame

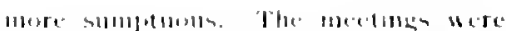

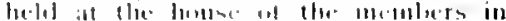

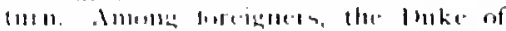

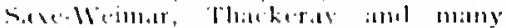

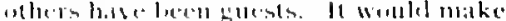

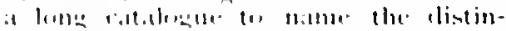

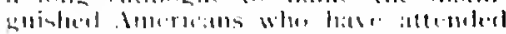

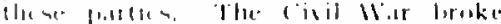

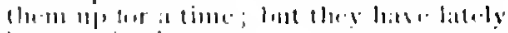
lexin revisidel

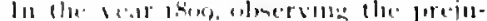

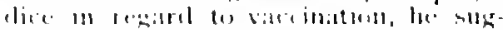

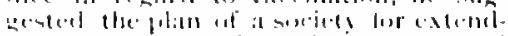

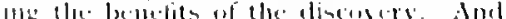

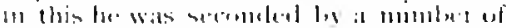

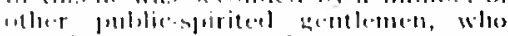

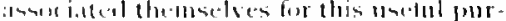

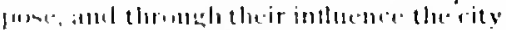

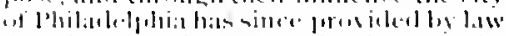

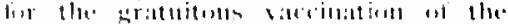
junt in the city

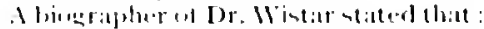

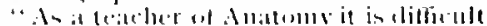

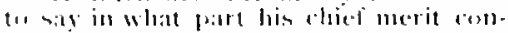

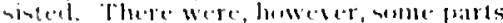

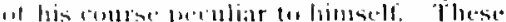
were the atelition of medels on a lery latere scale, la illustrale smill parts of the human strueture and the alisisens uf the feneral elass inte a number ol shall rlasses, each of which he suppolied "itlo a las of termes, in orsker that they

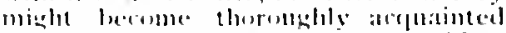
with the lumoun skeletorin-at subject which in acknowledereal by all (1) be at the very lommelation of Anatumical

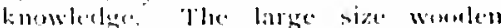
morle.ts of the sphenosid, pallate and eth.

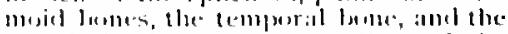
labyrinth wi lle cats as wedl as of the fratin in sertions, from whith the suceses

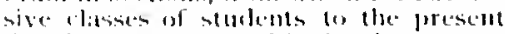
dav, in commection with the lemonstra-

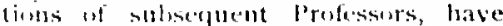

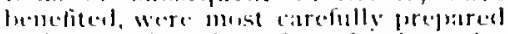
muler the direction of prof. ivistat, loy Wr. Rush, the most cefeluraterl carrer of his time in lhitalelphia. Ju his museom of murlels, he has befpentheal a rich lreatsure (1) his stlccessurs in the anaterninal chair.

"The discosery minle he him of the morte of alevelppoment at the cells of the

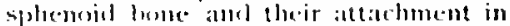
the eatls fueriml of life to the ethmoid, was one which comferred homer on him as an insestigatur amel lisinecret, and in

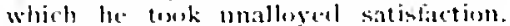
()n the subliect of that liseosety be received a lew datys before his death, al letert finm p'rofessent suemmering, of the Kingelem of Bavaria, me of the most releterated Analumists in Europe, of which the following is an extract The neat speecimen of the spluetorid and ethmo,irl folmes, is an invaluable addition (1) IIs anatemical collertion, having 
never seen then myself in such a pertiet stitte. I shall mow be very attentive tu examine these processe's of the ethmoir] leome in children of two yours of age,

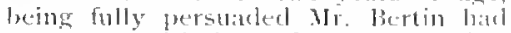
never met with them ut surh a comsider able size not of such pouliats atructure.

"During the vears of Wr. Mistal"s Professorshipu an Antomy in the Inited sity of Pennsylvania, he was indedatid able in the collection ol anatomial pre farations, maluy of which he oreleres and purchased from lecghorat, furod ring some from the celeluated l'polessu Milscitguc,"

At the time of his leath ill bist thin collection was presented to the fuiver. sity of Pennsylyant, Where it is pre. served with the Hormur collection in the Vistar and Fornor Muscum.

Dr. Nistar died on January 22, 1 bis in the fifty-seventh veat of his atece.

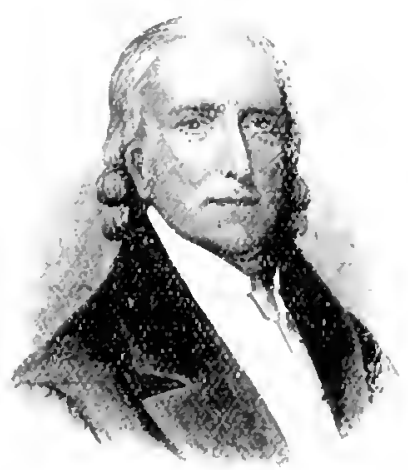

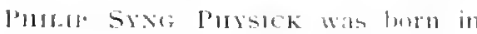
Pliladelphia, Juls 7 , $-6,5$. He enteres the Deportment of Arts of the Luiversity of Pentosylvania and wis graduated as Bachelor of Arts, Mav, 1-6is.

Ire commenced his medical sturlies under Dr Adam Kuhn and attended the lectures delivered in the [iniversity. ln Sovember 1788, after three and al half sears of sturly be went to lomelom. and was a pupil of lor. John llunter, who, in 1700, had him electerl llouse

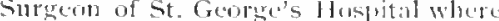
he hat access to the lectures al clarkt. Osbornc, Batlie, Ilome and the cruick' shanks. He received the diploma of the koyal College of Surgeoms of Lmodum the remained with and assisted Dr. IInter from January to Mar, when lu went to Edinfurgh and receistel from the Iniversity there, the degrete of loctur in Medicine (Mav, 1792); his

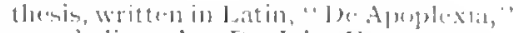
was dedicated to Jor. Juhn [lumter.

le returmed to Philatelphia in $1-0,2$ ancl combunesuced the practice al moli rille. He wis sonn callerl upon to coven.

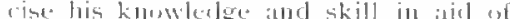
lok attlicteal and terror-stricken ritizens, in the eprelemic of yellem ferer in 1703

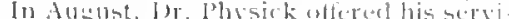
ab and was clected Resident [Hysidial in the fellow Fever Hospital at bush bill. Vellow ever abalin broke wat is

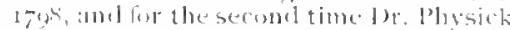

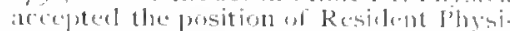

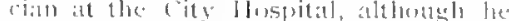

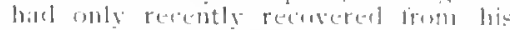

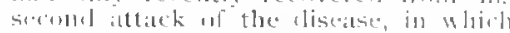

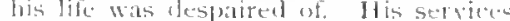
were af stols value to the city that the

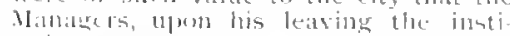
tution, fresented him with some vilnalsle nilver plate, in ackmomledemutut of "tlacis respectfol approsbitions of his valuntary and inestinuthle sersion."

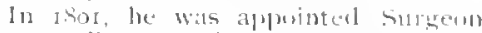

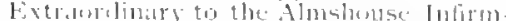

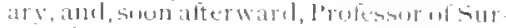

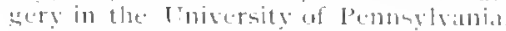

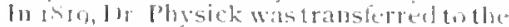
chatir of Anatomy, masle vacant lon the

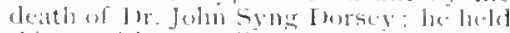

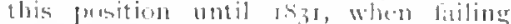
health uldiged hims torelinguislothe active dutice of it bublic teacler, amol the r in-

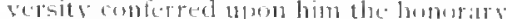
title of "Eneritus Professur al Surgely and Andtomy',

In Oetaler, 1s.3, he pelformed success fully the aperation of lithutomy upon ("hifet Justice Marsiall, then in his seventy-lith year, and the operatar sixty-three yeals ori atre.

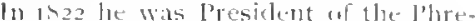

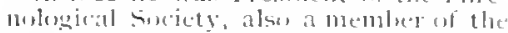

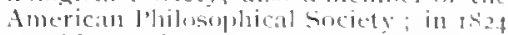
I'resickent of the I'hilatelphis Mtalical

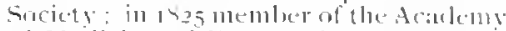

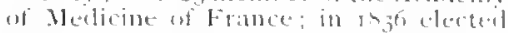
[Jomoraty Fedlu of the Koyal Modicil and Chirereical sinciety of limelom.

Dr. lhysick was electeel to the Methical Staft of the ]"enswrania l[ospital in 1794. whicle position lac retained unt Isi6. As aturactator, he is descrilued as havius a correct, slare and dist riminit.

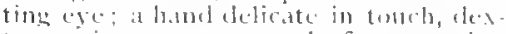
teroms in molement and of nuswelube

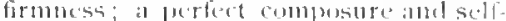
[ussessin which rose in lonc and deep encel in stealiness with the complication of the case in hanch.

1)r. Jither, in speaking of hr. Phosick, sald he is known als "the fathe ofl Amer" iran surgery." he wass a diseonerer, a thinker, a worker, but nost an anthor; he

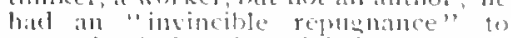
appering before the pulilic in that capat- 


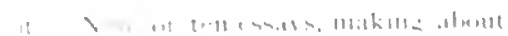

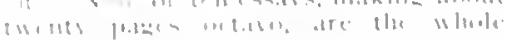

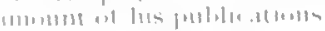

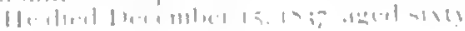
13:16, +1.110

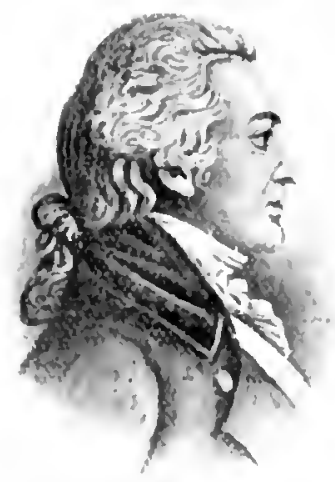

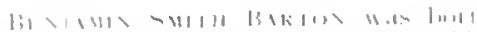

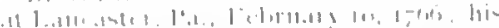

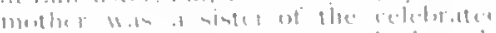

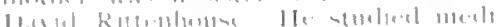

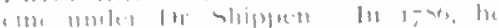

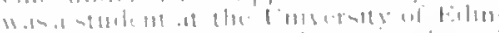

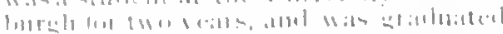

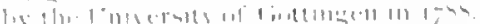

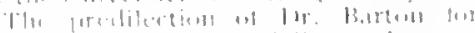

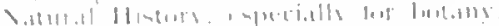

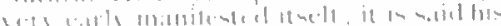

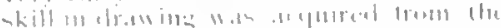

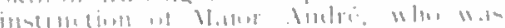

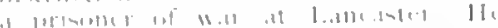

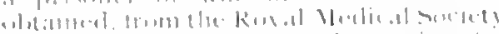

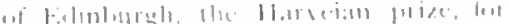

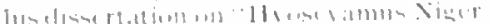

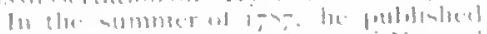

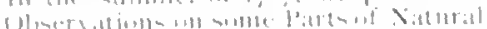

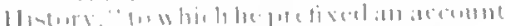

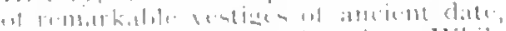

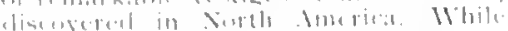

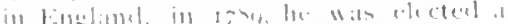

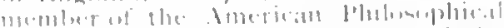

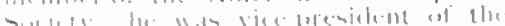

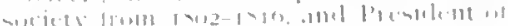

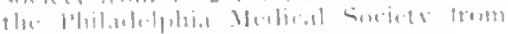

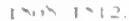

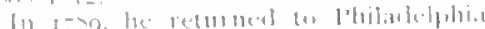

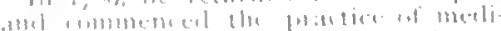

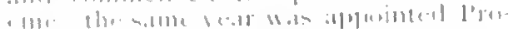

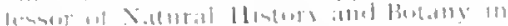

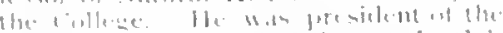

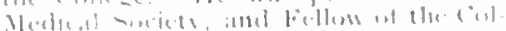

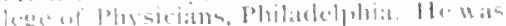

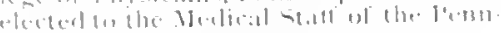

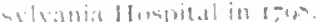

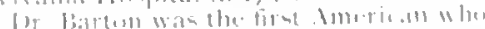

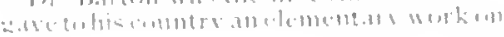

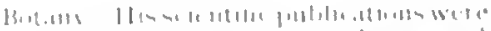

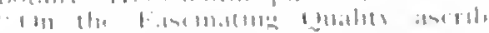

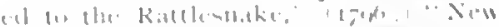

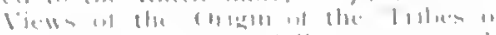

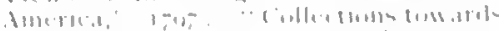

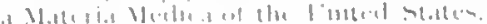

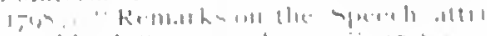

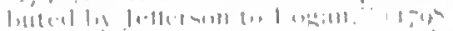

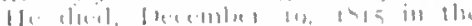

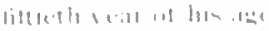

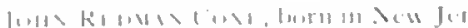

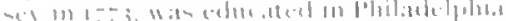

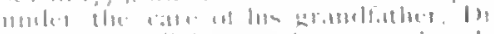

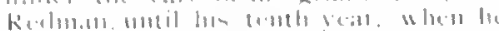

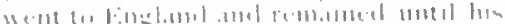

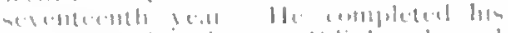

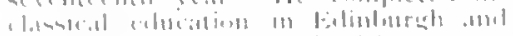

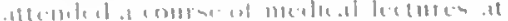

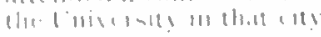

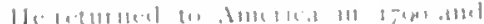

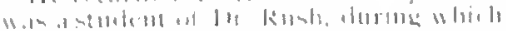

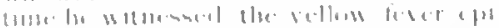

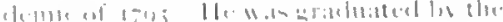

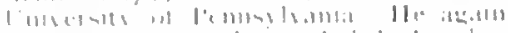

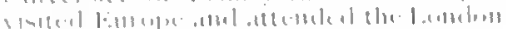

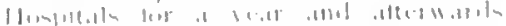

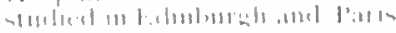

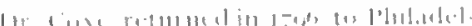

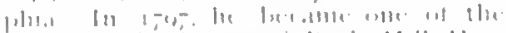

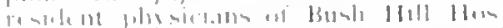

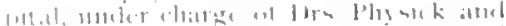

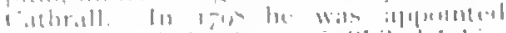

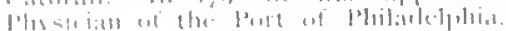

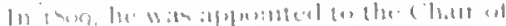

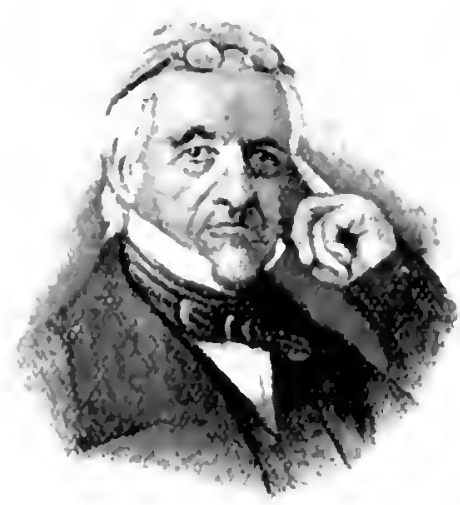

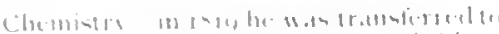

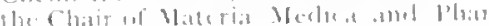

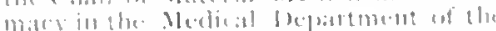

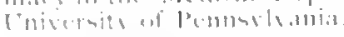

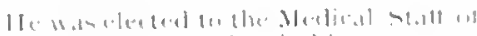

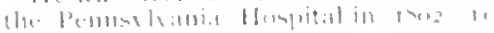

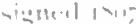


a 


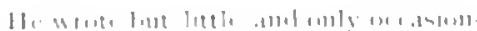
olls |

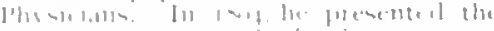

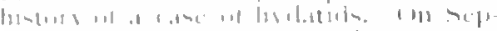

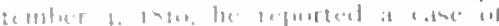

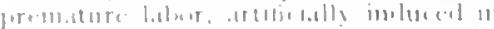

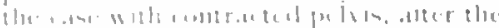

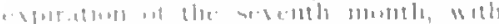

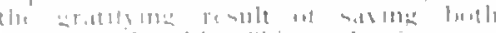

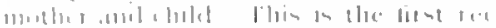

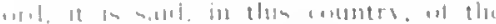

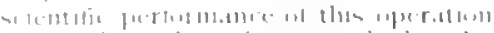

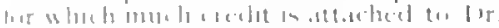

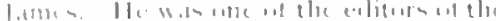

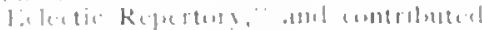

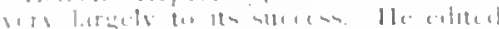

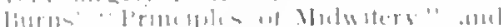

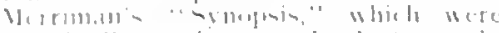

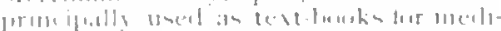
(.1) $\rightarrow$ thiol, int

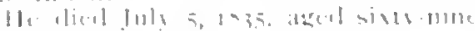
$11 ., 1 \mathrm{r}=$

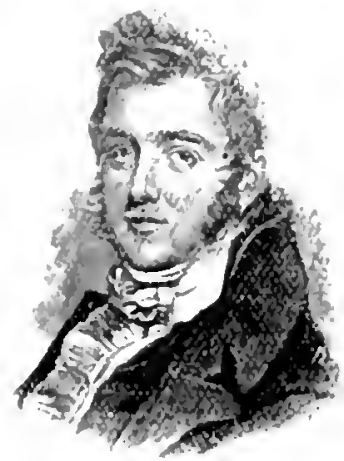

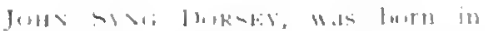

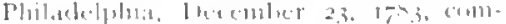
menced the stuets af medecine with hes

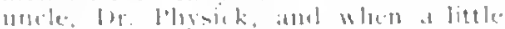

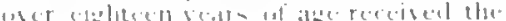

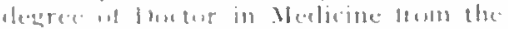

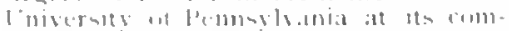

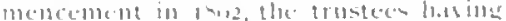
dispensel in lum idse with the rule

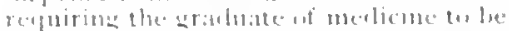

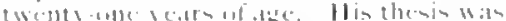

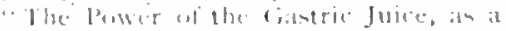

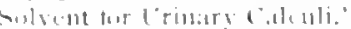

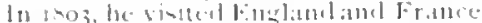

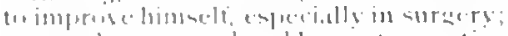

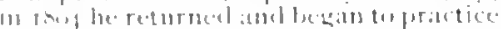

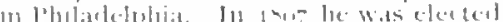

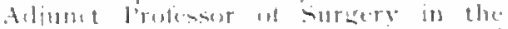

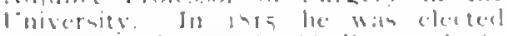

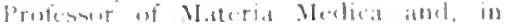

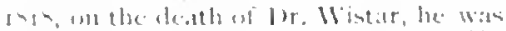

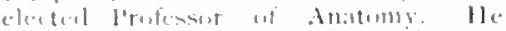

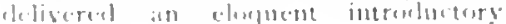

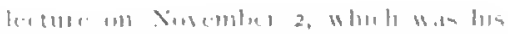

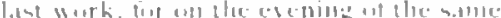

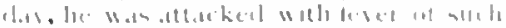

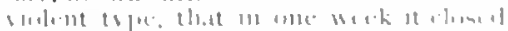

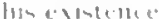

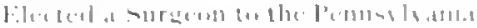

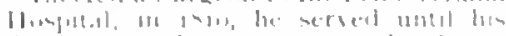

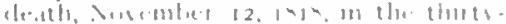

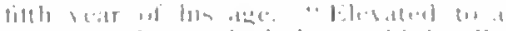

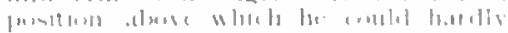

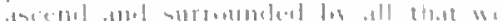

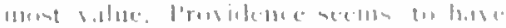

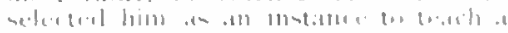

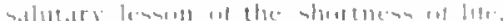

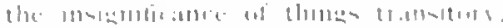

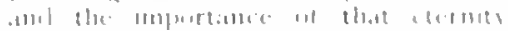

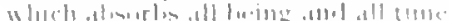

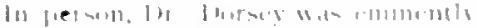

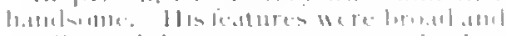

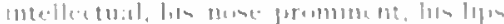

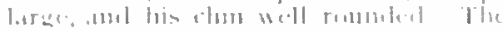

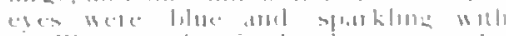

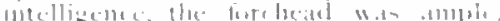
and the holt wheh wis rallier

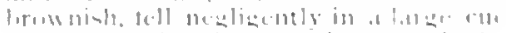

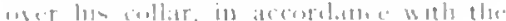

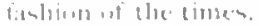

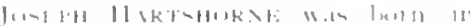

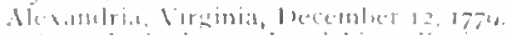

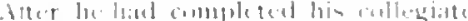

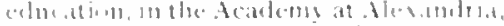

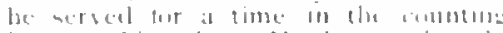

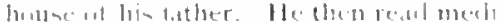

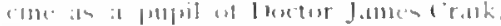

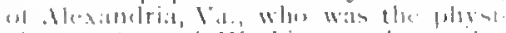

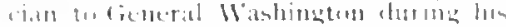
l.1me 111110.s.

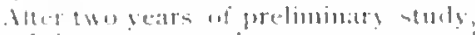

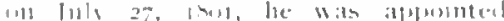

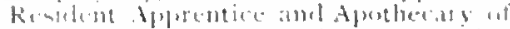

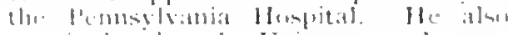

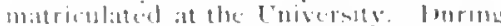
hin tive sears term of sersice the lilusts

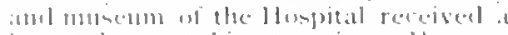

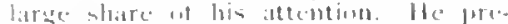

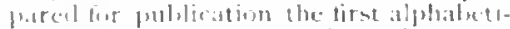

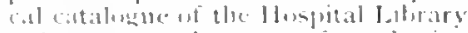

Alecr several years of study in the Hompital and attemlature an lecteres, ho

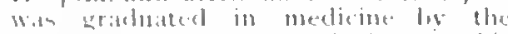

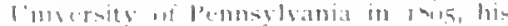

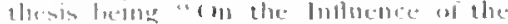
Almospliere in Respirition."

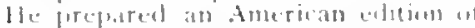

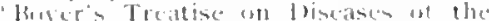

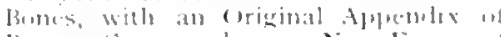

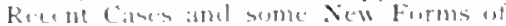
Alupar.tus"

In shas he matle a voyage to liatsuin as

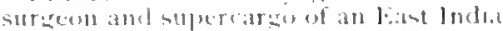
Ilerchatutman, which aceupied abuse ted months allel was feecuniarily sucecessul.

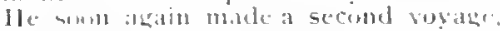

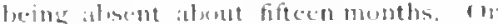
his retarn lo l'hilatelphia. he entered an the pratice of his proitession. 
In I-tis he married Anma, a diuxhtes of Inaar boumall, of philarlelphic.

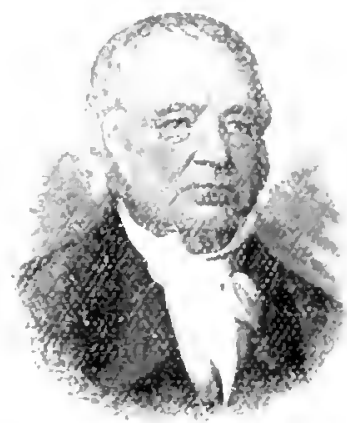

He sile teteted a member w the Phidit. delphir Medical society, w the American Philusmolical suciety, and in 1 and wan mithe a Fetlow of the college of Plom cians of Philadelphis

ln 1810, he was electerd th the Medical -taff of the Pennsolyanla Huplital, but resigned on account of the deminds on a larese private practice. Ausus $27,19=1$ he hat previonsly served in the out patsent Department from tamualy in

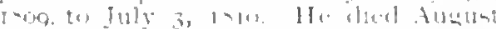

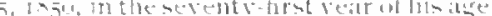

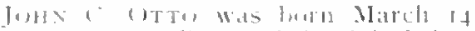

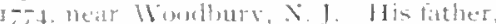

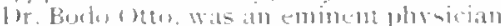
uf his sime amel an officer in the

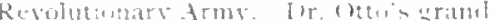
lather innd greategramdinthe were buth

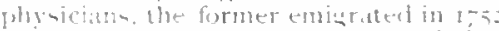
trom derminy io this country. hint then forgy-three veats of alae bie setthed ir) Philadelphia. Hatsing redeived

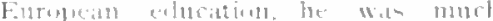

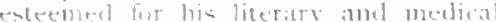
knowledec: his practic wals latedy

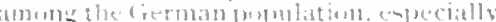

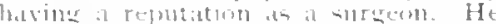

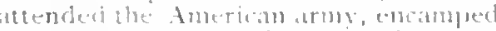

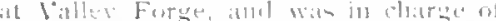
the Hompled there during tise winter of

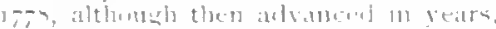

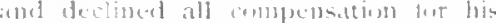
etrigen

Dr. Joluta of ate wats educitidel att the follen al Xelv lerser at P'rincedon, where he received the dearee of $A$. B in $1,-2$. He then came to plibalelphiat whete he commenced the sturly or medlicmp. and lecame at pupil of lor.

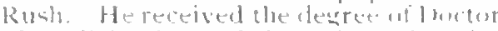

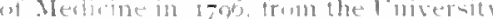
if Penustraniat and immetiately en-

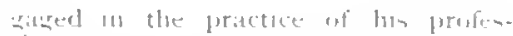
ainis

Je wath elected in the Mealical staft us

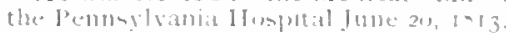

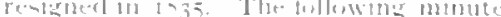

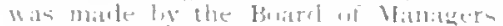

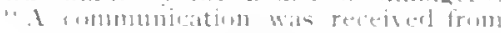

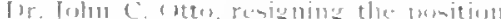

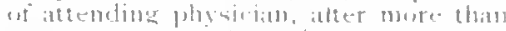
twenty-two yeitr bervide most atreeptathly rendered this Inatituteng The Monagers, on parting whotially trom the berctur. temder to hims their ar knowlerly.

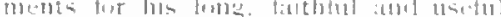
laburn: and ansure him of their cordial regard, and best whbes lor whatevers maly contribute to his fiuture habpiness?

the published an "Alcount of an

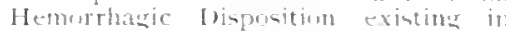
rertath Fimilien:" "A ("ine ul Em.

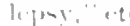

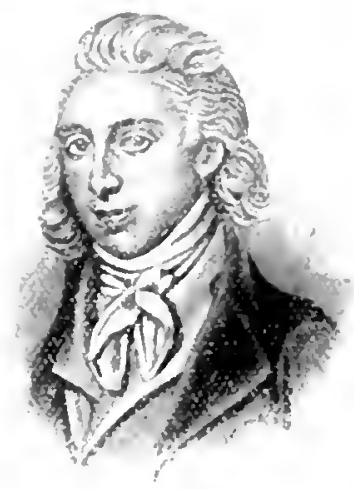

Ior cuen was a member of the Ameti.

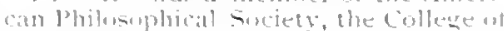

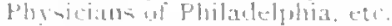

fir. Intu died June 20 , If, anel sevents vears

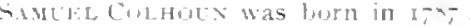
he was a medical apprentice and student of medicine of the Pennsyvania Hos pital from llay II, I footo isto. He way subsequentl a member of the philadelflina Medical sociery; and of the College of Phusicians. He was also profensor of Materia Medica in the Pennsylyana Medical College

He wris elected memper of the Hedinit Staff of the ['ennstrania llompital in IS16, resigned in 1821 .

He died tpril - 134 I, ared fity-four years.

JOSEPH PARKInI was horn in thiladel. plita, sepiember 2, 1,79

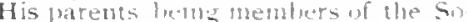
ciety of Frenda, be was tatught in theit 


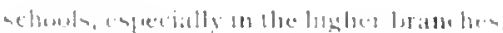
inctuling lattul

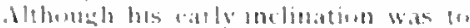

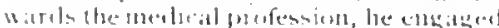

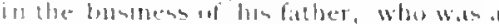

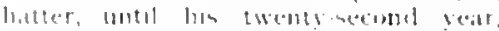

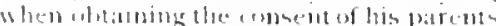

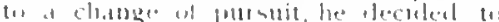

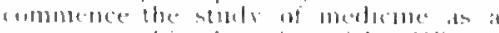
forsatte pulat in the antice al Bu. Mintat

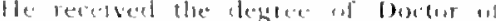

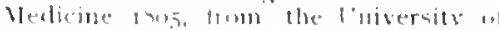

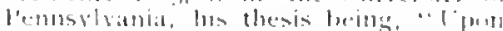

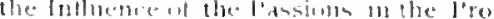

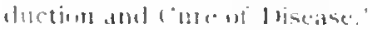

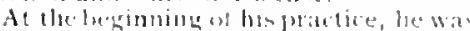

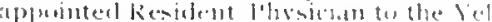

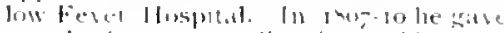

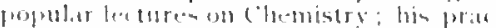

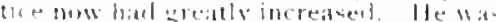

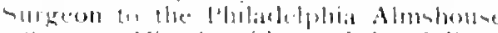

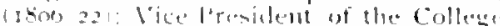

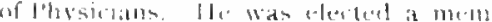

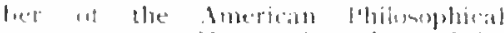

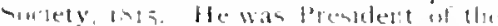

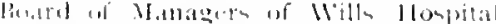

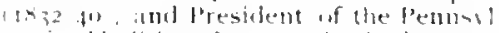

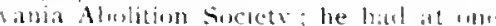

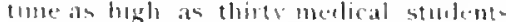

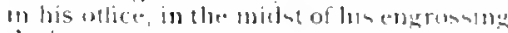
duties.

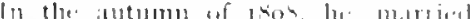

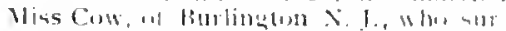
siral him.

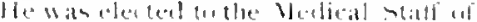

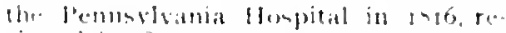
sizneal in 1820

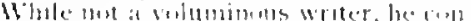
troluted a munber of palpers in meelie al

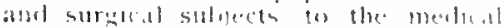
fingindisate

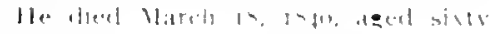
veats

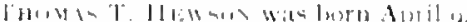

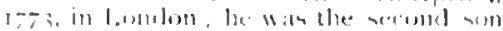

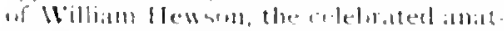

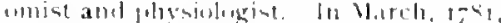
whes ereht reats ald he antereal the

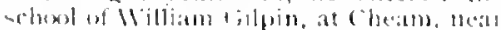

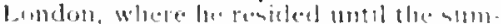
mer of t-we. With the exception of lise menths which he -quell at l'ansy, with

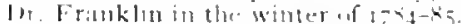

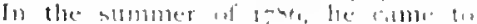

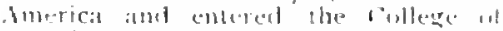

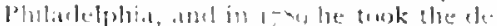
strece of $1 \mathrm{l}$ is

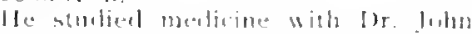

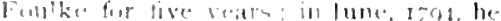

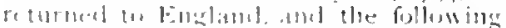

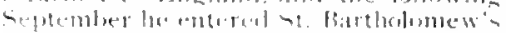

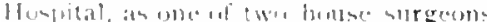

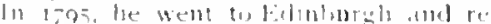

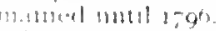

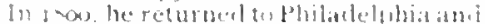

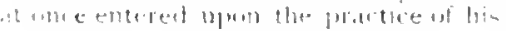

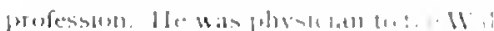

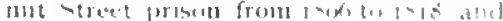

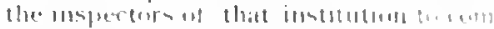

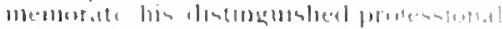

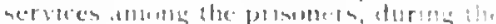

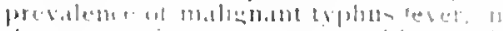

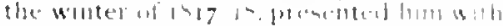

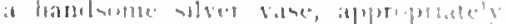
imaltitued

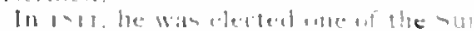

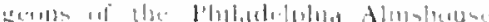

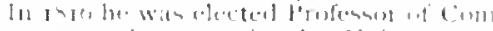

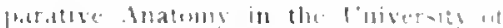

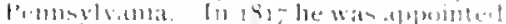

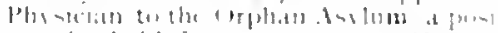

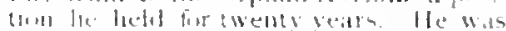

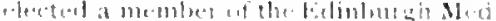

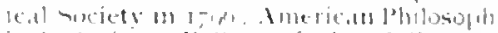

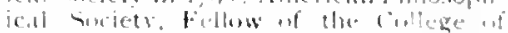

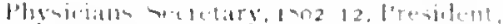

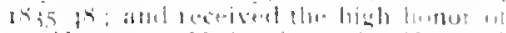

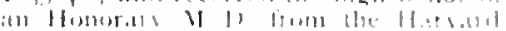
foibersits in ț2

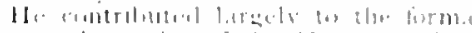

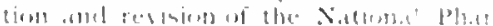
mone?

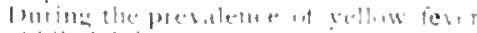

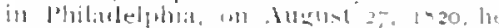

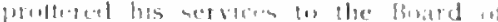

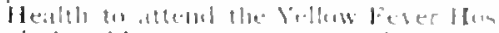

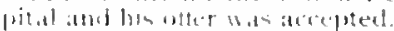

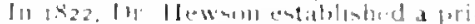

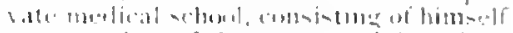

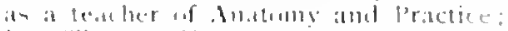

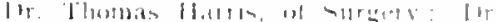

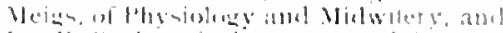

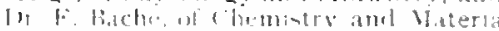

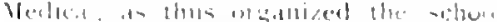

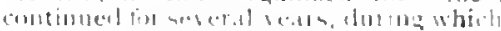

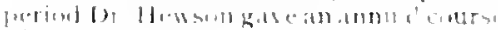

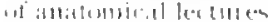

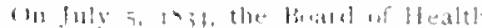

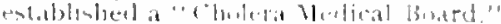

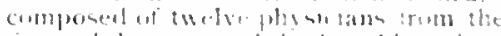

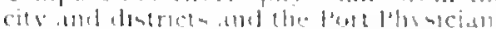

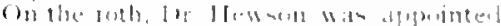

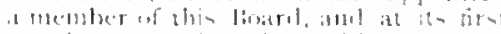

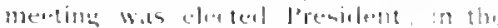

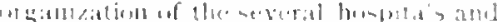

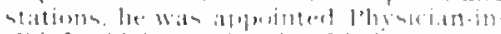

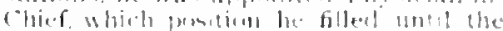

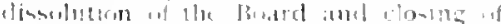

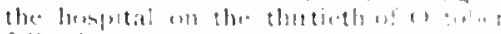
folluming

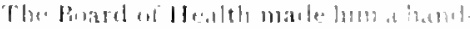

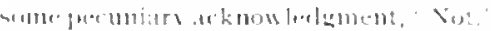

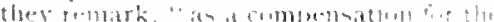

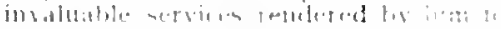

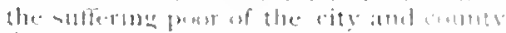

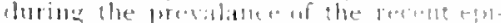

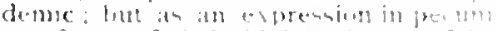

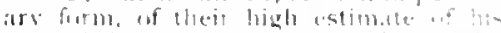
unremitting attontion to the ditte-..

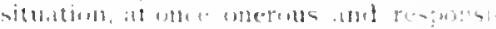

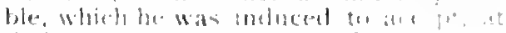

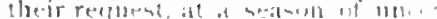

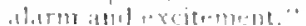


He was electect one of the turgeons of the Medical staff of the Pennsyliania IJuspital in 1918, ald continued in the prastion until 1835 .

He married on November 5,1912 , Emily Banks, of Washington, J1, C.

He died February r7, 1948 ageat netarly seventy-five years.

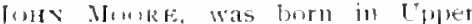
Werion Township. Wontgumesy County, l'a., April 1s, i-g. His parents were members of the society of Friende: him elementary edncation was reccived in a neighboring school, but mostly at home under bis eliter lorotber's tuition. who was a lawyer inm Judge in crawford County. Ai the atge of eighteen, John went to resile in the fimily of It IIil. sum, of Bucks Connty, who being a classi(it) scholar, taught him Latin, ind ho commenced the stucty of medicine, 1705

In the winter of 597 , he removerl philadelphia and became a private pupil w Dr. Caspar llistar, and during the following winter, becante a memler is the Nedical suciety. In 17an, he was atp puinted Apothecary to the Philadolphia Ambhouse, but owing to his health he coming impaired, he resighed his pusi tiun in r799. He shortly afterward re turned, remaining there until the spring b. 1900 , when he received the dearee of luctor of Hedicine from the Iniversity of Pennsyinania, his thesis being "Digi talis Purpurea."

He commenced the practice of his pro fession in the ricinity of Ionkintown, Iontgomery County, Pa, in lion, as a lartner to Dr. Samuel Glenm.

He was elected to the Medical Staff of the Pemselvania llospital in 1420, a ()bstetrician, and continued to serve in that capacity umtil he resigned in I 929.

lir lloore was a Fellow of Culleare of Plugicians. He was ilsu one of the ()yer. eecrs of Public Schorils

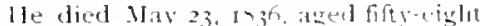
years.

WHIIAY Profe was born Semtenuler $17,2-88$. I1e was nne of the early West Town schelars, and he lett home hefore he was of axe unteach a schonl for culored children, under the care of Friends, in Philadelphia. He studied medicine with in Jomeph Parriah. He wis araduated in 1813 from the Iniversity of lemsyl. vania. and served as medical apprentice in the Pentiss lyania Hospital fromist is 14 lle spent some three vears in Patris, in assiduoms attendance upon lectures and hospritals of that great cente of merlical teaching. Returning, he commenced the practice if medicine jo philaclelphia.

In ingl, he hecame a mothler of olu

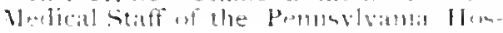

pital : he resigned Way 12, in23. In : 921

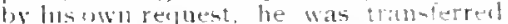
frum the Nedical to the surgical I reprant ment. He was diverted froms the regular pursult of his profesaion athd served fut

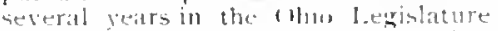
but resumed practice in cintounati, where

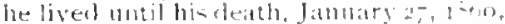
aged serentritwo yeats.

Ifis dimprestion wike must kind and sucial, imt his manters, alwatre gente and withut affectation. Welc mot pusishel anct attractise

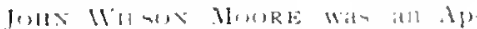
prentice from iom-1siz and "'llivef Apotherary" (in rorol at the l'eralsy-

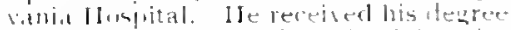
sof loctor in Bedicube from the I niversity

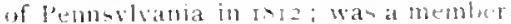
of the I'hiladelphia leclical sowiety: Fellow rif College of Plissicians and in the fmerisan Vledical Asomedattill

life was elected to the Medical stati its

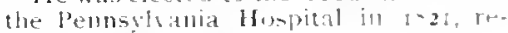
sianed t s $_{2}-$

He tienl lu11e 25, 1865.

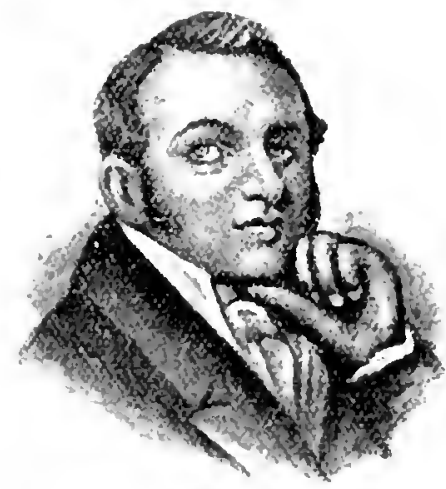

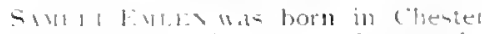

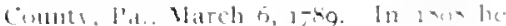
commenced the -tudy of medicine wit [or Joneph Parrisl and waspridhdted by the I"wisersity in 1812 .

The following Jume, he vinited Furrogu and the Hospitals of Jonetom and Harm Ifter the capitulation of fitris. Ine te

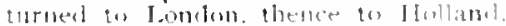
and came home, after a lind yeds al

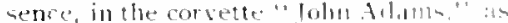

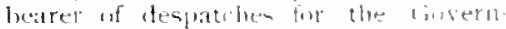

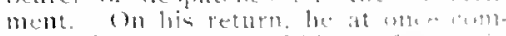
menced the practice of him profestem in Philatelphia. He was necretary the

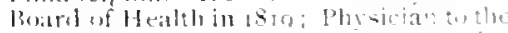

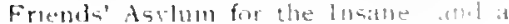

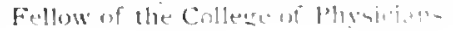




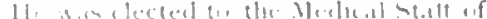

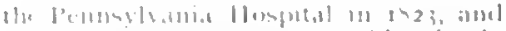

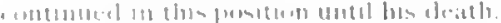

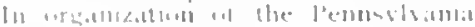

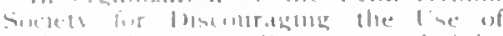

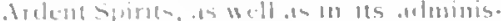

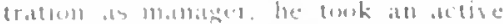
pillt

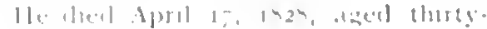
mille irats

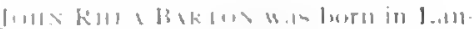

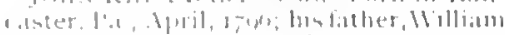

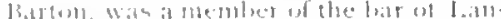

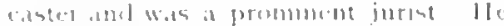
liecome the J'resiolent ludge of the mobutid distucts mimpusted of Lancaster

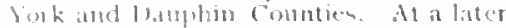

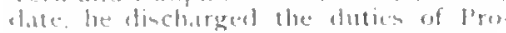

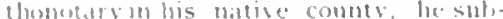
sedpently exmosed form l.ancaster in l'hlatelphlat, when he was appointed sedretars of the Ingerioan l'hilosophical sucicts, recelving shortly after, from the

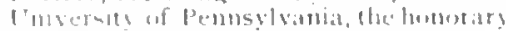

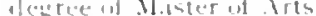

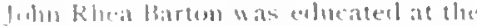

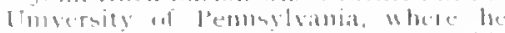

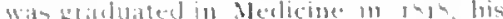
thesis lecing "certain Injurices of the

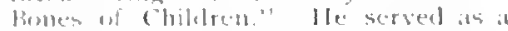

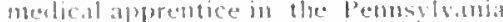

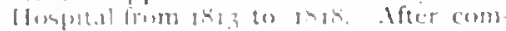
pletimg his medical sthelies he was alp

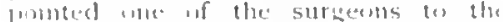
l'hiladelphia Alushouse.

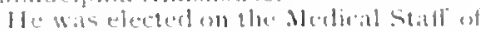

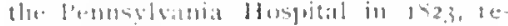
signted is $3^{\circ}$

Iir. Battun's ingenuity and meehanical

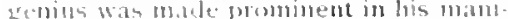

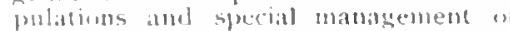

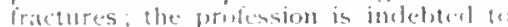

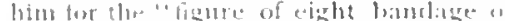

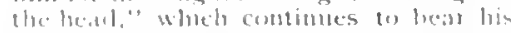

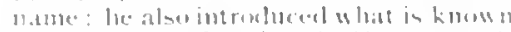

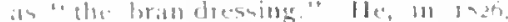
wis the liret stligeon to prome er the "say

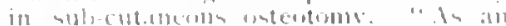

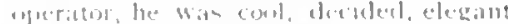

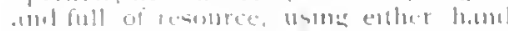

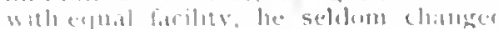

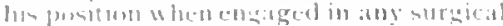
promediure.

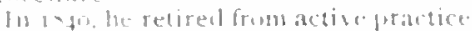

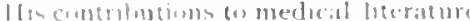

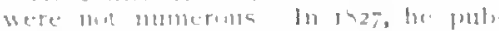
linteel in the "North Mmeriran Medicil

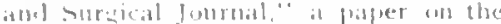

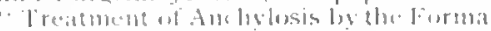

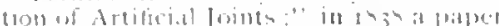

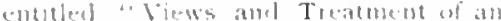
Improt.unt Inury tollie Hist."

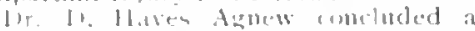
lerief sketell of his life, with the lreautufu

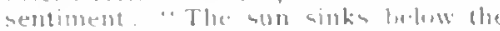

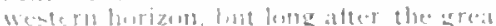

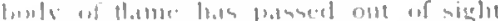

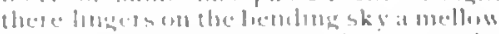

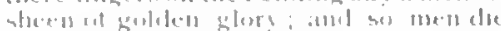

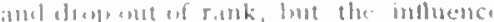

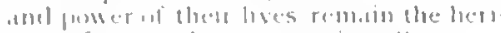

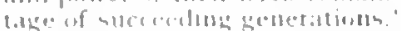

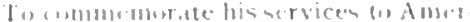

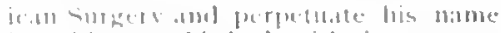

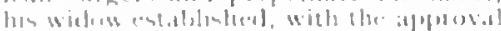

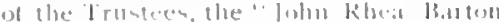

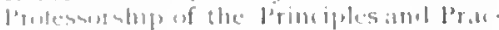

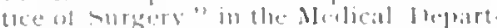

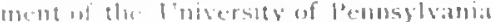

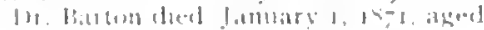
beventy live reats

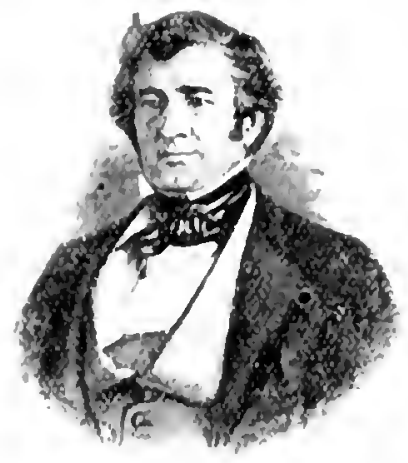

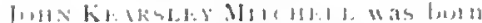

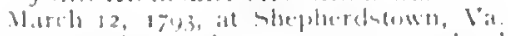
It an eatly age, he was sent to sed tand

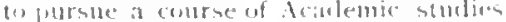

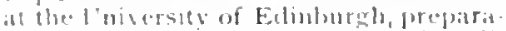

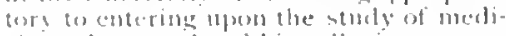

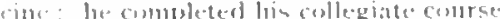

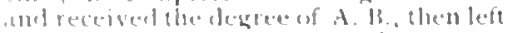

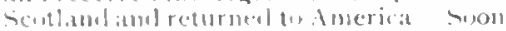

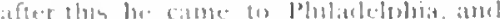

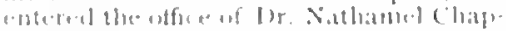
math 1516 and commenced his pro

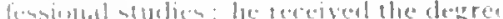

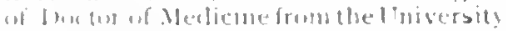

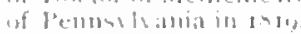

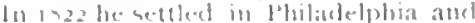

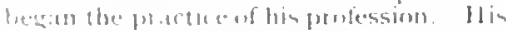

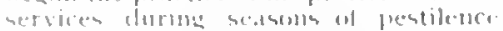

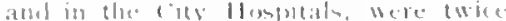

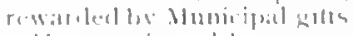

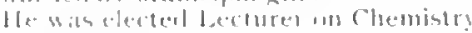
the is thet 10, he lectlllet in the

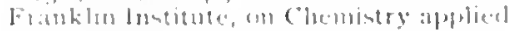
(1) the Irts

He. una a member of the deaclems

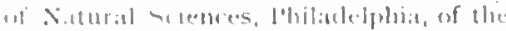

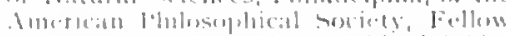

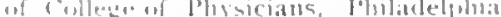

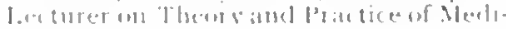

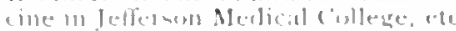


Dr. Witchell was electer to the Verlical -tafi of the Hospital, tirize, atud in 1834 he was succeeded by Dr. William Rush.

He cuntributed to the North Americals Medical and Surgical Journil, articles upon Chronic Dysentery, based upun his ciperience and treatment of thin disease an lie hard seen it in the East Indies (1 2.4. irloo "Un a New Practice in Acule and chronic Rheumatism" and two vear afterward, another article upon the same sublect. He edited Faradiy's chemical Vanifulations, with notes $(1830)$ wrote Chenical anel 'harmacentical History and Toxicological Effects of Arsenic (1s zh): Cryptogamous origia of Malarious and Endemic Fevers; witl his lyprothesis of the cause of these diseases and of Cholera Asiatscin, Plague, and Jellow Fever; and other valuable contributions. A collection of his essays, uncluding a valuable paper on Anima Jagnetism, was published in issi. 11 e wats author of "Indecision and otluer Poems " I I 39): also of Populat Lectures on Scientific Subjects which were trans Jated into several foreign languages.

He died April t 1958, aged sixty-five yeurs

BENTAUX H. Co.ten was born Nuyembel $14,1-97$. From his early veats be slowed a natural love for books, and for science, which was so characteristic of him throughunt life. Ile received an evellent literary and classical eduration at Friends' Grammar School.

He was a resident, medical student of the Penusylvania 1lospital, from t8sa to 1.s. inder the preceptorship of I)r. Philips. Physick. Ite was graduated from the Iniversity of Pennsylvania Doctor in Nedicine, in 1818 . Je was a member of the Academy of Natural sciences, the American Ploilosophical suciety Cullege of physicians, American Mtrlical Association, Presldent uf the Pliladelphia County Medical Society. wite of the founders and rice-President of the lTistorical suciety of lenusvilyania. Ife delivered the address at the laving of the corner stone of the Dopitrinent fur the Tusane, June 22, Is 36.

He was elected to the Miedical statit of

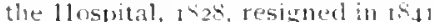

lle died october 16,1851 , aged netirly righlity-four vears.

THuMAn 11 akkta was bun in Chester

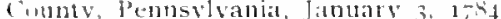
He was the eldest son of ieneril illilliam Hitris, who seried witi distinction dur. ing the war of the Revolution.

In the epring of 1 Sot, he commenced the study of medicine and olitained his deuree in thog, from the Univetsity of lemusyluniat. ln 19t2, during the war wh Great Britatin, he receiserl from
Mr. Madison a cummission as surgeon in the navy and joined the Wasp sloop of war, under the command of ("ommodore Jarob Jones Hardly hat lur. Harris entered the service, when be hitd the grood fortune to take part $i_{1}$ onc of the most brilliant actions of the war. A week after sailing from New Castle, the Masp encumutered the sloop of war Frolic, of a superior force, and after an action of little more than half an hour, cilptures lier. An hour subsequently, however, luth ships fell intu the hands of the l'oictiers, seventy-four, which curried them into Bermuda. Hert they remained at feil weeks, until they were exchanged.

I) r. Harris commenced the practice of his profession in Philadelphia in $18: 7$, $\mathrm{H}$ is success was brilliant and he was, for a number of years, a lecturer on surgery". His style was familiar, sometimes conversational and his matter bad the great attraction of appearing to emanate more from his own experience than the gleanings from books. Thutgh not a great writer, he cuntributed a number of articles to different medical periodicals and published a life of Commodrre liainbridge in 18.37. He was elected to the Nedical Staff of the Hospital in 1829 , and resigned in 1810 .

Lr. Harris died in 1861 .

CHARIFs LUKFNS was graduated in Hedicine from the University of Pennsyl. vania in 1816 .

He was a Fellow of College of Physicians.

He was elected to the Medical Staff of the Pennsylyania 1Hospital in 1829 , and resigned 1830

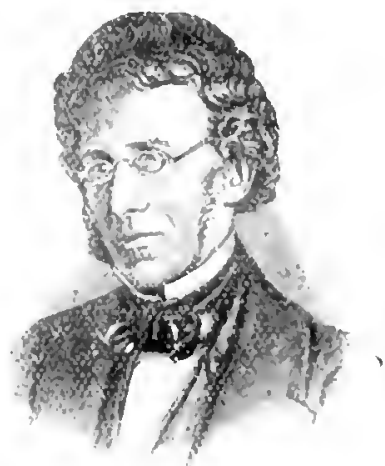

Hugh L. Horrie was hurn in Philudeiphia Jume $2-1-96$. He received the degree of A. B. in Ixit from the College of New Jersey, at l'rinceton, an graduated 

1ur best wishes for his future prosperity and happiness.

The published works of Dr. Hood are The I - Hispensatory edited in conjunc tion with Dr. Bache; also a Treatise un the practice of Medicine; and a Treatist on "Therapeutics and Pharmacology, eack "f which went through several editions.

He died March $30,5: 9$. in the eighty" third year of his age.

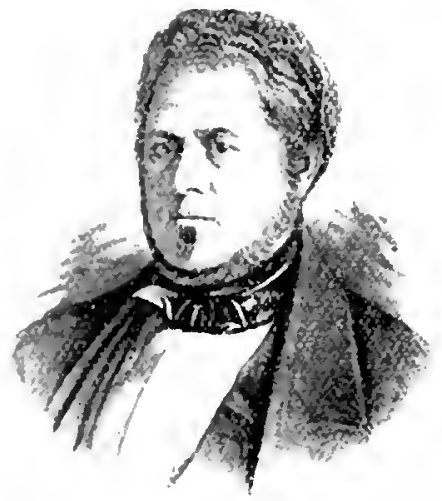

JAcol RANDull was born in l'lila delphia, November 25, 1-06. In 1914, lie commenced the study of medicine and. in $18 \%$, received the degree of Doctor in Iledicine from the lniversity of lenut sylrania. He was subsequently made surgeon to a vessel hound to China, but left the vessel on its arrival in England. in consequence of acsere and protracted suffering from seasickness. He passed -everal momblin in vising siotland and France. Onlis return to philadelphia. It cimmenced the practice of his profession

He married in 1222 , daughter of Ir. J'hilip sym l'lysich.

In 1 in 30 , he receited the apluintment of surgeon to the Almshouse Intirmary, or Plifadelphia Hospital; in the same year he wat ansociated with other prac titioners as a lecturey on surgers, in thi "Summer siphool of Medicine."

He was elect a nember of the Phila delplia Nedical suciety, in 55 ; Americam Hhilosophical suciety, I.733: College of Jhysicians of Pliladelphia, Is $34-4$; and Imerican Medical Astociation, Ma-

While abtoad, in If 40 , he was flected lerofessor of iperative surgers in the Jetterson .Iedical College of Philadeluhia which he declined, as it required an immediate return. After an absence of wo years, he returned to l'hiladelplaia and resumed the practice of his profesion, principally as consulting surgeon.

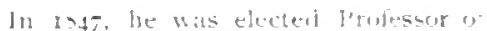
Clinical surgery in the lingersity rot lentusyrania.

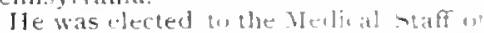
the Hespitil, in a 35 , and contmuted in it service until his leath, Felmuin! $20,154^{4}$ at the aye of tifty-one vearm.

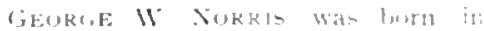
Philadelplia. Norember 5,1 aus. I1 entered the Acidemical betartment it the Inisersits of Pennulbania and $1 \mathrm{c}$.

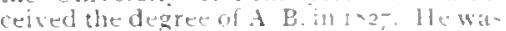
a mupisot Dr. Jonemh Parrish and fecelved

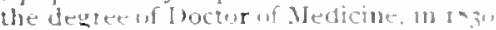
from the Intersity of Penusylumia

Immediately alter graduatim, he was elected resident physician if the Penn svivania llowpital and served until sas the silne seat he went (o) batts alt?

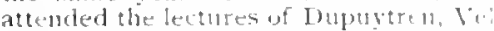
peau, Ronx and Magendie. Wlite 19 Paric le wits elected a memler of the societe bedicaled Observation. In ix 35 late returned a Philadelphit and legan the uractin of his profession.

In let he was teleted Protussor wi Clinical Surgery in the Univernity of Hennsvivania: he served until 195 when he resigned, having been electui Truster of the lniversity.

He was elected to the Statt of the Pemusylumia Hospital in 143, and a sigued in 1 - 6 ;

Dr. Norris - first publication. Which al peared in a 3 - in the "Americall Journ.

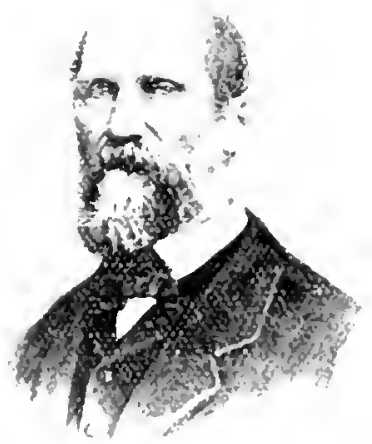

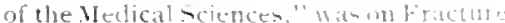

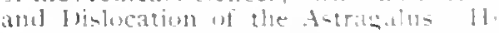
contributed durine a permin at thirt vears, at intervals, a number wi metides

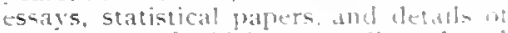
cases. most of which were collected all? publislied before his death, in .1 usk t.?

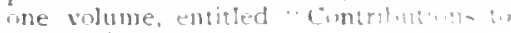
practical sirgerv" 
[0r. Nerris wat one of the Collollting

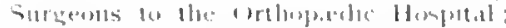

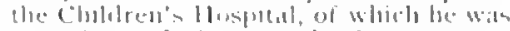

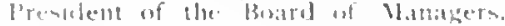

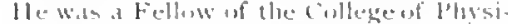

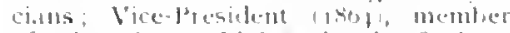

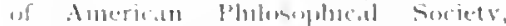

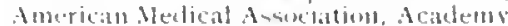
of Datural ficientes, etc. l'resiclent of the

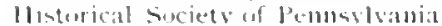

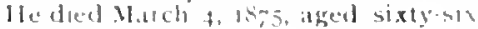
yeatis

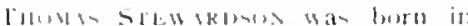
Plibidelphia july to. isop: he attended

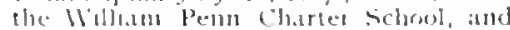

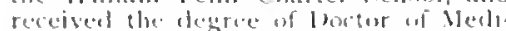

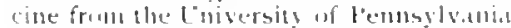
in 1 in

fle was suon after elected Resillem Plysician in the bennsyluatia Hompled

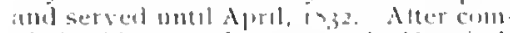
pleting his term uf serblce in the 11 ospital. fie sisited laris and passol the winter in walking the hospitals In M.tell $18,3,3$ lice visited ltitly and ofter a three mumb his absence be roburned to l'atis Inctober. Iti3. Je was elected a member of

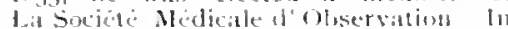
May, is it he left baris, and remsined several weeks in bugland and seotland,

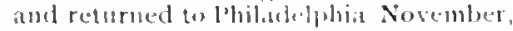
in: 34

He was elected on the lemusyluaniol Huspital in May it inge resigned in acoulut af ill-fuealth in iod5

[or. sewatson was a follow of the follege of lefseicians, and it member of

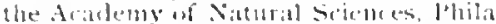

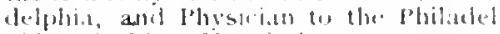
phis (bjocklev) Homplat

He wat sive of the Cullaboratols of the "Anurican Journal of the Medicisl sciences." and edlited the dirat Amertenth eclition of for. John Filienson's l'rinciple. allel l'ractice of Bedieine

Aboll 1s4t, he had a severe attald of

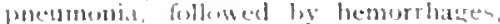

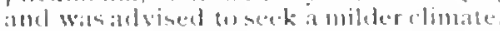
He selected sivilumah, Gat, as his luthre

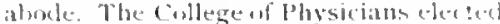
lian an associate Follow in 19.47.

br. Stewardson established hmonself in Sarannath in 18.45 and made a specialts of the ereatment ut Yellow Feser $d:$ the end of font vears, itfer oldetining a

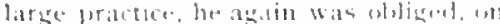

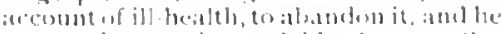

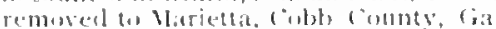

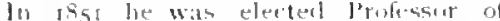
Nitural Scienee in the finorgia Military flltitute at barjelta, which lete resigned

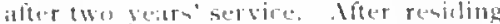
unelve verirs in Goorgia. he returned to philadeluhit in the antmmm of 1 thes although apvarents in goud health, he flid not resume the practive uf his probes sion Ile was atgundelucted to the ("iblege

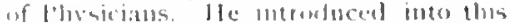

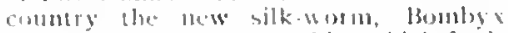

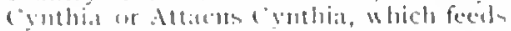
usi the leaves of the dilanthus tree.

Ior. stemardsian dical June 30, 18ja. atgent 110 aly seventy athe years.

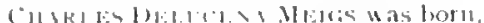

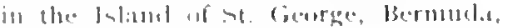

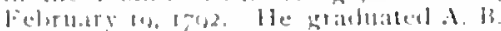

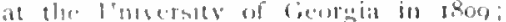

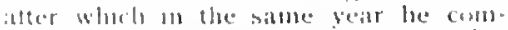
mented the sturly of medicine ander

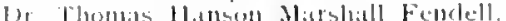

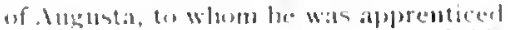
for llace veats, itt the exprisation of this inme he retutued, in Ist 2 , to his lome at Ithens.

lle remosed to l'hiladelphia and ma. ficulated at the tinjersity of l'enmert-

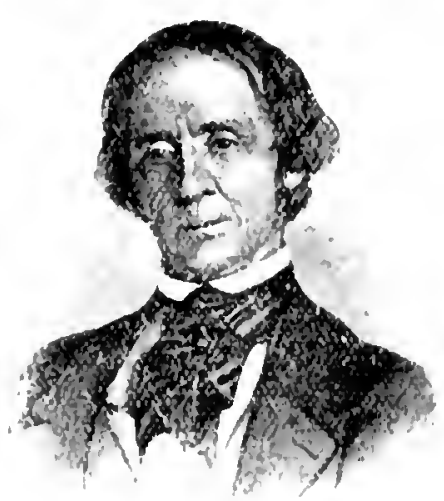

vantat in tif 2, and received the degree ot

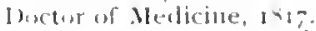

In 1 it 5 , he commonered the pratctice of his profession in feorgia.

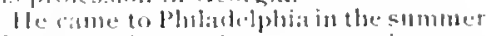

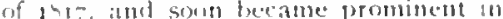
his profession. In nos he received the

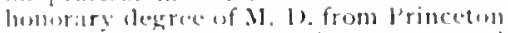

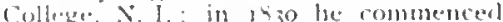

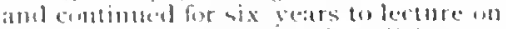
Mialwifery in the Sehors of Medieine; 11

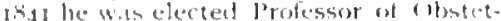
rics and loiscases of chibleen in the Jefo

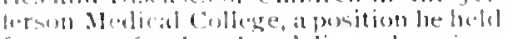

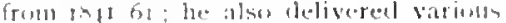
publir fecturem and addresnes.

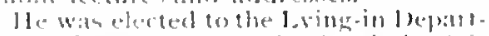

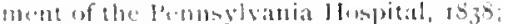
resismed, 78,10

l'rofessor Heigs"s literity work was vere vreat lle was ande of the orige indellews in is 20 , of the " North Amer= 
ican Medical and Surgical Journal" ; be translated and published Velpeau's Ele mentary Treatise on Midwifery, Translation of Colombat de L'Isére's Treatise on the Diseases and Special Hygiene of $\mathrm{Ft}$ males, (1845); anthor of Woman, her I iseases and Remedies, Observations on Certain I Iiseases of Children, (1.850) . Memoir of 1)r. Samuel G. Morton, President of the Academy of Natural sciences, (185I): of Dr. Danit Drake, (1853) Treatise on Acute and Chronic IDiseases of the Neck of the Uterus, on Certain Uiseases of Children, etc.

He was connected with at very large number of medical organizations; Acarl. emy of Natural Sciences, American Phitusophical Suciety, College of Physicians, American Medical Association, Suciety of Swedish Physicians, Iצs4.

On February 25, $186 \mathrm{I}$, he delivered his last lecture at the Jefferson Medical College and retired from further actue duties of his profession.

He died June 22, 1869, aged seventy seven years.

EDward Peace, was born in Philadelphia, February ro, rsı. He was graduated by the University of Pennsylvania in 1833, and was elected to the Merlical Staft of the Pennsylvania llospisal in is40; resigned 1561 .

Dr. Peace was a member of the lohila. delphia Medical Society, the Academy of Natural Sciences, and also a member of the Philadelphia County Medical Societ $y$

He died September 9, 1579 , aned sixtyeight years.

Willaty PEPPER, born in Philadel phia, January 21, 1810, received his col legiate education at Princeton, New Jersey, and was graduated with the first honors, receiving the degree of $\mathrm{A} . \mathrm{B}$. in 1825 . He studied medicine, under Dr. Thomas T. Hewson, and received the degree of M. D. in $18_{32}$, from the University of Pennsylvania. Juring this year the Astatic Cholera made its alpear ance in Philadelphia, and Dr. Pepper volunteered his services and resided in the Cholera Hospital during the epidemic. He subsequently spent two years in Paris, devoting himself with remarkable industry and ability to the investigation of disease. The friendships then formed with some of the ablest men of the Frencl School, and especially with the eminent Louis, were strong and lasting. On his return to Philadelphia, in the latter part of the year $18_{34}$, he immediately entered upon the practice of his profession and with such conspicuous success that he steadily and rapidly rose in the estimation of the profession and the public until, for a number of years before his death, he was recognized as the learling consultant in the community.

He was Physician to the Mills Hospital and to the Pennsylvania Hospital; with the latter lse was connected for twenty-six vears until the close of $185^{\circ}$, and during this long term of service took a leading share in the clinical teaching for which that institution has so long been celebrated. In 1860, he was elected Prifessor of the Theory and Practice of Medicine in the University of Pennsylvania. He had delivered onjy four annual conrses of lectures when he was furced by illhealth to resign this position in the spring of 185,4 .

Ilis clinical and didactic lectures were models of clear, forcible and practical teaching: and he was especially renowned for his diagrostic skill antl for his judicious and succesiful treatment of disease.

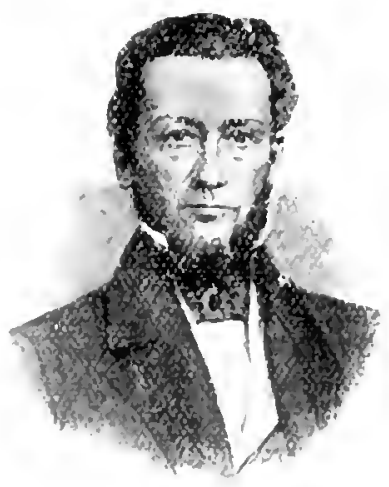

Ile was a nember of the American Philosophical society and of the Philadel. phia Academy of Natural Sciences, and a Fellow of the College of Physicians.

His familiarity with medical literature was extensive aud accurate; but although he had accumulated an enormous numher of recurds of important cases, the constant claims of his engrossing practice prevented him from contributing very largely to medical literature.

Jie married Sarah, a daughter of Wil liam Platt, Esq He was elected to the Merlical Staff of the Pennsylvania Hospltal, 1842 ; resigned, 1858 .

lie died October 15, 1564, aged fift four years.

It was remarked in his menoir by Dr. Thomas S Kirkbride that "The strong feature of Dr. Pepper's medical character was the pussession of andytical acumen and decided ideas of diagnosis 


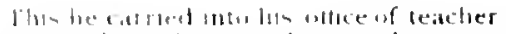

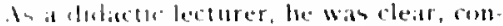
ine, amb complete. Thirty rears of

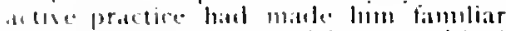

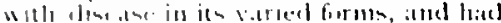

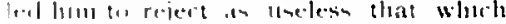
wan merely speculatosem meducine, while

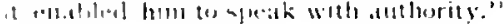

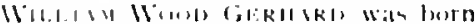

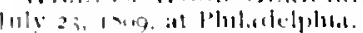

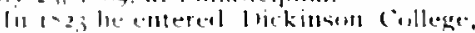

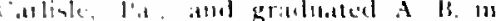

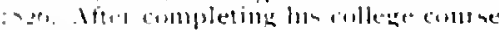
be icturned to Philulelphia and colts. menced the atudy at meslicine molet 11. Jomegh l'arriali. He was graduate

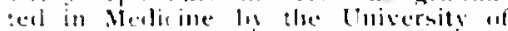

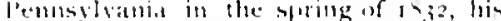

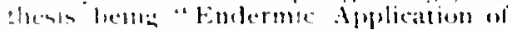
Hedutime Ite was attiched to the

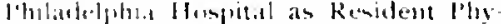

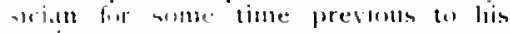
atulution

III in he visited Paris and andilen linmatif of the teachings of thomet, Inds,t, ancl of lomis lle mate investi.

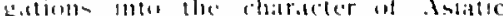

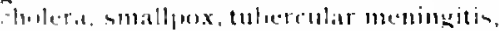

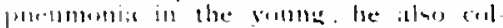
eected a pertant of the materiobs for his rriginal work an typhoid and eyplute ficers, which lae alterwirels completed

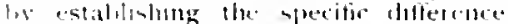
between thene two clisectses

fle feturned to l'hilarlelphia in the foll of 14 iz atud wis relected Resident Ply seidu at the lemmoliania Hosprital in

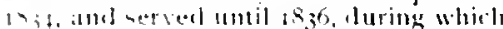

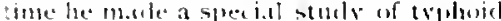

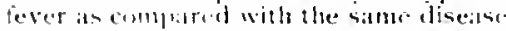

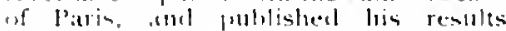
astoblishing the fact that they wete alentianis

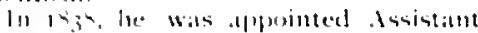
Profemon lostitutes of Merdicine in the

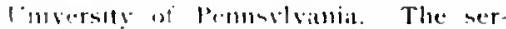

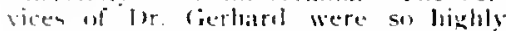
valuesl los the students at the clinic of

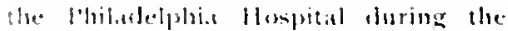
wuter of a fie, that a series of compli.

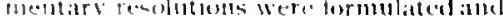
presented to him expresinge of their ilpprobition In tad, the swatem of llis.

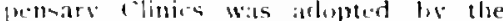
fondermits and entablisleel and conll.

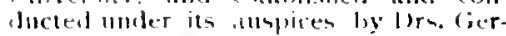
hated and lohmotom, in the building of the

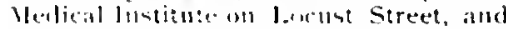
there comtinued nutil 1, is, when it was transierred so the lonivereity Buideling

lit the early part of Isiz, I)r. Gerhard humbelf suffered from in acnte attack of aphoirl fever. Inthe winter uf 18 \& 4.1. his health was further impairal liy anuther attack of illuess. It was deemuil mvicilice for him (1) make a trip l"
Furope 111 the - bmomer of is th Alier severil month-ilimence he retal need much impresied.

lle warelected to the Nerlical Stati uf the Pentrivanua IIspital in 14/5, and resigned 11 1.66s

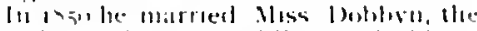

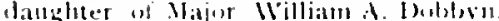
formerly of the Brotish arme.

He wasthe uthor of sariums papes ul the "American louratl uf Merficat siciencen," and Iutle "Medical Fxammer," "uf which he was one of the editors In $183^{4}$. Ils principal work was the biarnows, l'athologe and Treatment of the Dineanes of the (lie-t, 14t2, whicl lirst aflyeared an al sluort treatine on the biagnosis of "Thoracid Jisealses, 1835 bilt at the requeent of matly of his pupils he addeal genteral shuptoms atud treat

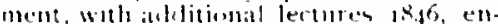

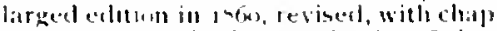
ters an Simoted Fever, ferebro spina

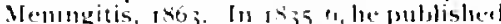
a tilmber af reports on calses with resulte of olsersatoms on varions diseases 11

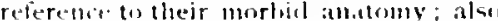
an essaty an the importance of clinical indructions: and on " Trphosid Fever Foplentic in fhilatelphia during the

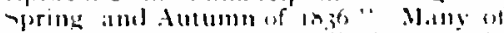
lis contributions ter Marifical Journits were in the form of repurts of clinical fertiures

He was it mellter of the Plitadelphi.t Medical Stroter. Cillegenf Plusicians. Academy of Nitural ficines, linysiriat Platadelphia Jlospital, President of the

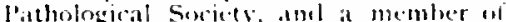
the Americull libuesphical suciets.

Ur. Cierliard died at Philadelphia April

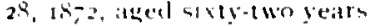

(iloskat: Ful the grandsum of Joscph Fix, spuater of the Colomial A usembly in $-1,5$ was born in Philatelphia May 1,8x, luthe atutumm of 1 in 22 he entered the liniersity of Penmsliania and irriuluiterl A B. in 1825

He received the dezrese of brector of Medicine from the I nuersity of l'emnst vania VIrcls lsak lle was heon after wards elected Residem llysician uf the

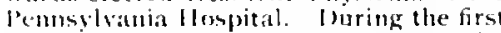
vear of his residence in the Ilospital be devised an app:iratus for the treatmen of fractures of the claviele. Fux's al' paratus has been employed during more thin late a century, is still used in and sut of the llospital, and is described in most text-hook an surgery

Ilis contrilutions to medical literature were few but interesting

He wis a member and Vice-f'resident uf the Phibalelphia Hedical Society, of

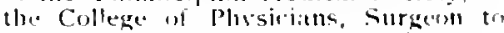
Vill Ifospital. Nember Acatemy o 
Natural sciences, Mcmber Anerican Mistical Associaton, Vicel'resident uf the Philarlelphia County . Medical Society. 1. Fox was the originator of the enter orise that secured to the College of Pho stcians the uround inr erection of the buldngs at the northeast curner of Thut teenth and locust streets, Philatelplia. While he had able coaljutors, it was his tact in affairs, financial sitgacity, uru dence and persintency that was essemilial it the accomplishment of the project.

in I a he was elected to the vledical -tari of the Pennsylunia Mospital, anel resisned in $1<54$

the retired frum a prosperuus profes. slonal career In 1554 , in perfect health and removel tu a larze farm at banli. chester County, Pa. where after a resi. dence of three sears, he removed to his place on the lelawite River, above Torresiale, where he passed the re mainder of his life, evcept an annual winter sesinum in the city.

He dien Decentrer $2^{-}$, ISs2, alyed sevents-six years.

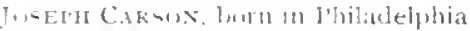
April 10, thos, was of ticottish ancestry

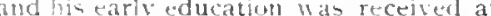
the Gernamtown Acatemy. At the Lnj bersity of l'ellustrania, he received in th 25 the degree of $A . B$. : he then elltered the wholesale drag store of l)r. Edward Lowher, but som withdrew; and after dewing a tew vears to lotans, he cum menced the -tudy of medicine, as a propil of Ior. Thomas T. Hewsom, ald was graduated from the l"niverstu" of Penmsyluatia in In.jo.

He was at once elected Resident Jlusician uf the Penmsilvama Hospital. Be fore entering upon private firactice he nuate a vorage to the Fast Indies as Surgeon of the slup Genrgiana. and vis ined Wadras and Calcuta. He returned to Plibladelphia in August, I832, and cmmmenced the practice of his profession.

I': the thirty-third year of his age he matried Mary Goddard, who died soom after: later he married Mary Hulings worth.

After the fitst ten vears his practice rupidly increancel, and he gained an en vied fusition is a practitionser of obstet. rice. As this pranch of his profession involved great bissical labor and "xpo -we he was compelled in the midnt of

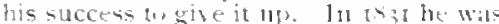
elected Professor of Materia Verlica, in the Philadelphia College of Pharmacy. and held the position tuntil s 50 ; in that vear he was elected probsus of Materia Nedica and Therapeutics III the "aviversity of Penusvlyania, which he held until ;nd when lie resirned and wat then ..'thise Eneritus Promessor
He wis elected to the Obstetrical staft if the Pennsylyania Hospital in I" +9 . The held this position until 1.854. When this department of the hospitil was closed

]r. Carson was a member of the phila. lelphia Dledical Society. Academy Natu. ral Sciences; Lecturerin Materia Medica and Pharmacy in Vedicat lnstitute: a member of the American Philosophical Society, American Wedical Association, Cational Convention for Revision of Pharmacopuciat, toto; member Quarantine comvention, Cincinnati, Vay, IS6I; Philadelphia Coumty Nedical society. President, istor

lle died lrecember $3^{\circ}, 18-5$, aged about sixty-eight years.

1)r. Carsun was a voluminums writer he was editor of the "Isumal of Phim macy," from October is $3^{\text {th }}$ until Jul ision, and contributed to it mot less thatn

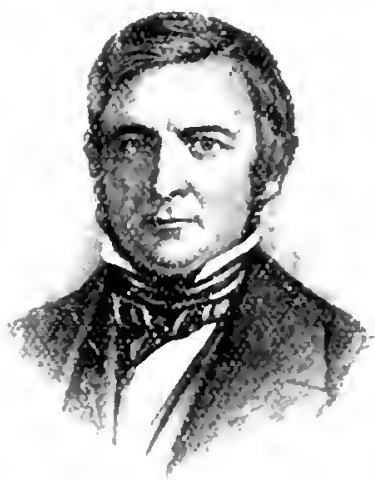

ieventy-six urigimal pajers; while cont nected with the sitme, he edited with llotes and alditions, wo editions w "Pereirs's Materia Medica": and in 194 published his "lilustrations of Medicai Butamy." in two quarto volumes. many of the illustrations having been drawn and culured by binself. Perhaps tlue most impurtiant of all his works is hin admirable History of the Medical Ite partment of the piversity of Pennsylunia, being a testimmial of his reward, love, and loyaltr to his Alma Blater

Tunx Dent was desconded on both sides from a distinguished medical ancestry : he was horn Philadelphia, July 1310.

At an early age he entered the lcade. mical Jepartment of the l miversity of P'onsylvana, and yraduated $A$. $B$, in 18, ; he then entered tho medical delnit: ment and was graduated in is 4 n 


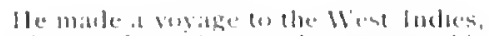
in ibarge of at priticat. and for reerust his

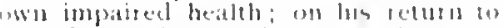
fhisdedphat in s 12 , he began the prite.

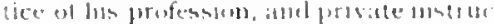
tholl of medical students.

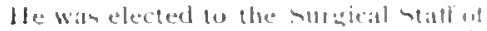

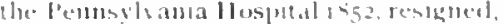
1 is

He was comblecterl professindully or

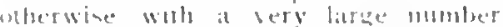

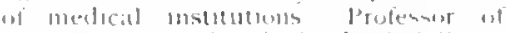

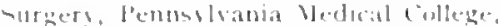

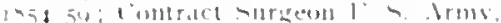

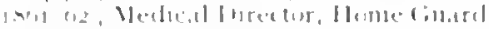

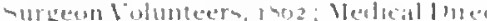

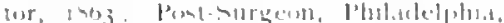

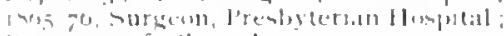

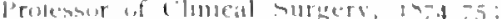

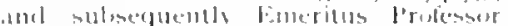

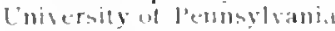

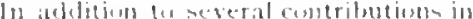

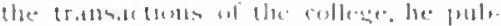

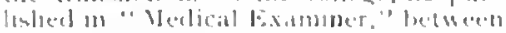

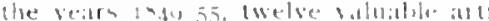

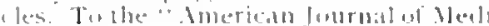
tal selentes." from andiz -5.5 lie comlin uled sesell belfers; early ill lis profers aisenal carcer he published threse fitte lowks m the Veims. Arteries, amol kerves He complent, with lir. Francis Gormes smoth, a compendium of tle Merlical aciences: and just befure his lidiol illuess he projected at work on lie l'rinciples of surgery, lout passed awity before his Jotes on the first chapter were completed

Ile died bantary 11,1850 , inged sixty vears.

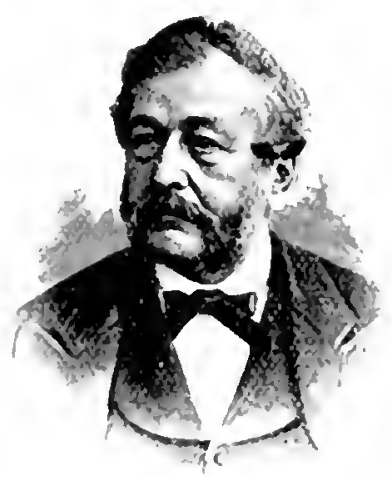

JosepH Pixcolst was born in Burlimeton Comnty, New Jersey. Nistem. bet 23,1 ho5. IJe was graduates in Nedicine in isos, by the Iniversity of pennsylvania, and inmediately begani lhe practice of his profession in Ihiladelphit.

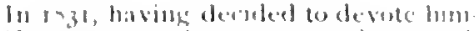

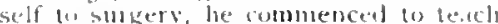

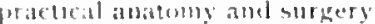

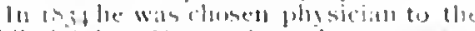

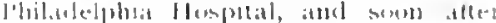

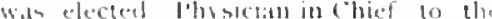
cholelrent : themplat in llee sithe Institu lome, ald frum the 45 was me of the

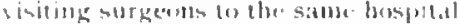

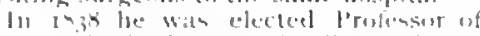
surgers in the Jeflersin Mledicinl fillege,

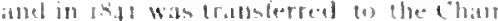

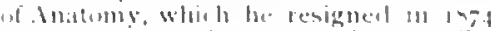

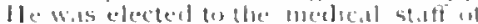
the l'ennolvania Hospital 111 isst.

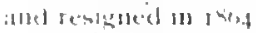

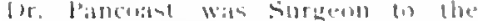
fohlatehohia Ilosputal: rollow of college

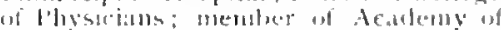
Nolluril Siclences Amerie"ill Vedien

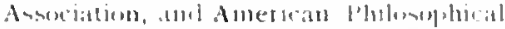
Sociely.

1) hes publeatione we noter, in 1331 , at t.umbation from the I. the structure, foundumb and lineases at the lluman simulatuetc derse los

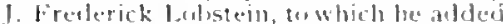
moles: in 1.94. a Treatise on ciferative

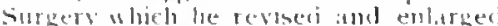
in 1t52, In git the remuntelled the work originally writen lof or tasmar

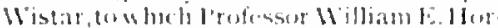
mor made vitlualule aclelitums, entited "A sistem of Alithomy for lize 1 'se of stu "lents." lle enlied at variolum times Jatentece on the rireat sympathetic Nerve; the cerebrespinal System in

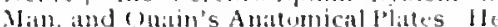
also contributed numerous articles itud elinical lectures to the American Journal of lhe Medical Sciencess Mmericall Meali-

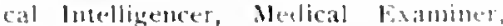
besides puldiahing monographen patho. logical and surgical sulpects.

Ife died March 6, 1482, aged seremb. six years

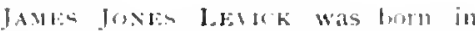
f'hiladelphia Juty 28, IS2\%, attended schom at llaverford, and studied medi.

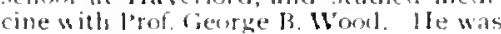

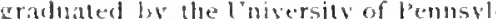
vamia in rists. He served the l'musil simia Jluspotal as a Rosident plusician and was elected to the Medical staff in 1456 , and resiguted in 1864 .

ile was a Fellow of the College of l'hiciolus, and for forly-une yeats physician to the Magdalen Asylum: Was a member of the IJistorical Societo. bo. the American Medical Association : the Academy of Natural Sciences of Philadelphia; the Historical Sociely of Jentsylsanis, and the Philadelphia Connty Medical society. In 188 f he received an I omorary loggree of $A$. M. from Haverford college. 
He was a frequent contributor to the journals and his able patpers on medica subjects comnanded attention in this cuuntry, as well as abroad. He wrote, in is61, a most valuable and important paper on "Epidemic Influenza and Its "Treatment." I)r. I,evick was an authority on historical suljects, especially on the early settiers of l'ennsylrania, and was the autior of a paper on the early physicians of l'biladelphia, prepared by request of the Assuciation of the FxResident Physicians of the Pennsylvamia llospital, and reat by him at the first meeting of that Association.

He was early identified with the Welsh society and became one of its most prominent members, as his grandfather had been. His last literary work, read beiore the Historical suciety, was on

"The Early Welsl ( wakers, and Their Emigration to l'ennsylvania."

As a teacher of medical students, in the amplitheatre, and at the bedside of the patient, he was unsurpassed. His delivery" was clear, concise, and thorough, in cunsequence of which he was a suc. cessful "Oniz" Master.

The Weish motwes which adom the Bryu Mawr Hotel, l'a., werc devised by 1)r. Levick, who spent part of two summers in Wales, going over the country, freshening old memories, and securing historical data. He was a most prudent. safe, and conservative physician, and was constantly sought in consultation by his fellow practioners He was a man of excellent literary attainment and considerable poetical taste. In disposition, he was social, was a good entertainer.

He was a member of the society of Friends, in which he bad a birthright

He died on Jume 25 , 1393 , aged sixtyeight vears.

JuHA Furstot Mrags was born in Puiladelphia, Octoler 3, 1818 . I tis early education was at the school of Dr. Crawford. At the age of sixtern, lue bugan the study of medicine and, after four years at the University of Pemmsylvania, he received the degree of Dnctor of Medi. cine, in 1838 , when not yet twenty years of ane.

He was at once elected a resident plusician of the Pennsylvania I Isspital and served a perjorl of two rears. After completing his hospital term, be in April, Is 4o, sailed for Eurupe, visiting ltaly. Sivitzerland, France, Belgium, England, going east as far as Varsaw and Vienna, and south to Naples. Whike in Paris, he attended the lectures of lelpeau, l.onis, and other eminent French plissicians.

In August, $18+1$, he returued to Philadelplia and commenced the practice of lis profession. In the spring of $18+3$, he gave is course of lectures an Olsstetrics in the l'hilateluhia Association for Medi. call Instruction. Sulsequently he lectured upon wther iopics during the time he was contueted whll this organization.

He was narred vetober 17,1544 , to Ann Wilcocks lngersoll.

In Is5s, lie published his book on Diseases of Children, which passed througl three editions. In Is6g lie associated with himself, Dr. William l'epper for the fourth edition, changing its title to "Mleigs and lejper on Discases of Children."

He contributed a number of articles to various medical jourmals and, ly invita tiinll of the Managers, compiled a history of the first quarter of the second century of the l'ennsyliania Hospital.

He was elected to the Werijoal Stafi of the lennsylvania Hospital in 1859 , resigned I85ir.

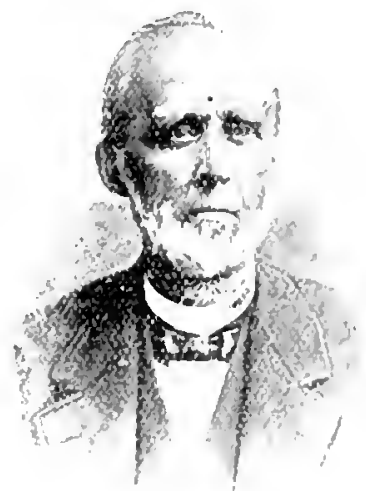

Besinles his course on Obstetrics, he lectured on Practice of Medicinte, and on Diseases of Children, in the lholadelphia Association for Medical Instruction. IJ was Fellow of the College of l'lusicians, philadclyluia: a member of the Acatemy of Natural Sciences; Anerican Philosophical Sirciety, Philadelphial county Nedical society, etc.

He died lecember 16, [582, ired sixty-fomr years.

Emblk1, IIRThande, the sceond soll of Wr. Joseph barthorne, was lorn in l'hiludelplia, May ht, isis. He received the degitee of $A$. B. an tha from l'rincetun, N. I., and of A. MI, in ston: he received the degree of lowet in Medicine from the l'ninersity of l'enu. sylsania, in s.s.o.

After graduatiog, he was First Issist. ant l'hysician in the Insane Departnent 


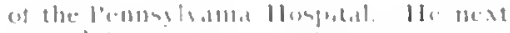

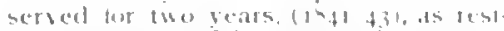

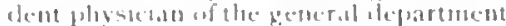

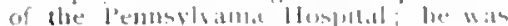

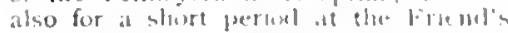

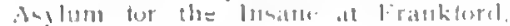

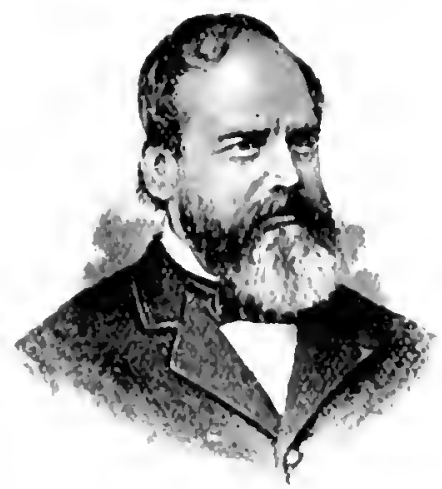

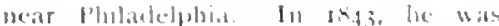
enecterl the first resident phesteiall of the

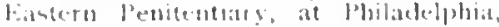
abl in his antual reports, gave speciat attention to the ellects uf separate cons. funement upon the mentit) as well as plosical onmelition of the combicts, clearis

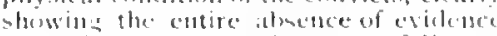
that this system was the cattse of discast or impilinuent of genesit lieallh. \& second edision at this revort, publisheat by the lnspectirs 111 ant5 was bitgely circulated in linglinul, and translites and pulslished in France, Cermany Belgium, atm] Hullasul

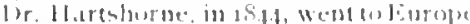
aud spent two vears 111 studices and

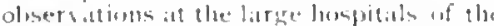

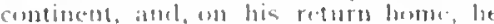
commenced the prowtice of his professins

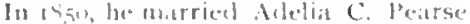
formerly of Bontum.

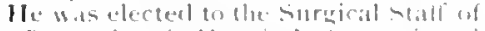

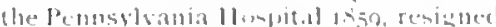

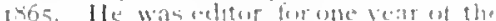

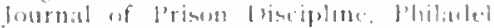

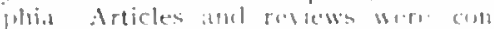

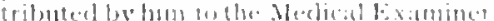

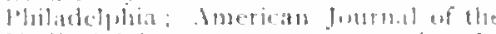

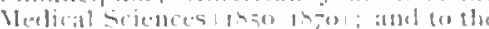
North Anericall Medicu eliorurgical Ro vien Ite also wrote ond extemated nowe

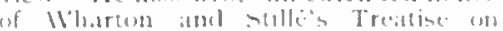

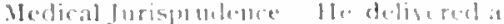
course of lectures on Medical luris.

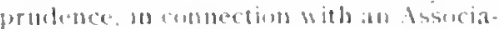

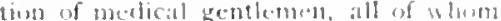
obtaned sobseguent dintintion as fouls.

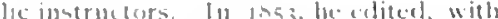
metes ated adelatums, the Americat lidenen of linglar's Madical Jurise portidellice

truring the coil war be was culluty

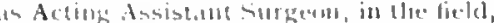

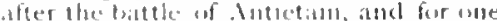
(1) two jeats, ats attertelung or combultion

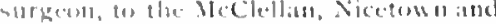

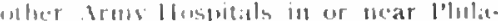
delplotit. He wian actibely engarged in the

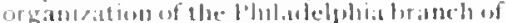
the ("ulted states solmitate (ommission, lutbig the bar, lecing teqretary ot its

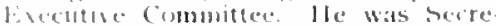

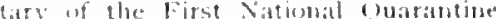
and sanitary Consention, which met in philadelphia a fell yous lefere the war

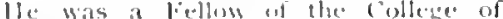

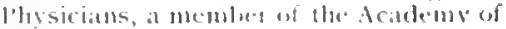

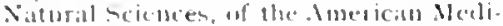

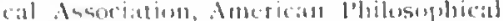

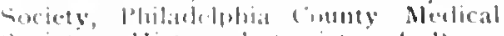

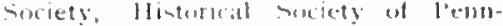
whintia and otlieis

He dicol fume 22,1485, aned sisty. seconterats

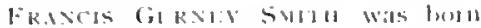

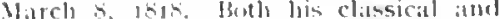
his melical education were recerivel at the University of lembylrania Ite graduated A B in in 35 and commented his medical stuclese umeler his forether,

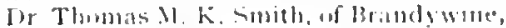
nciur llibmingtom, fol. In the spring of

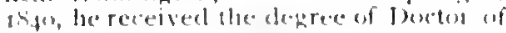
Medicine.

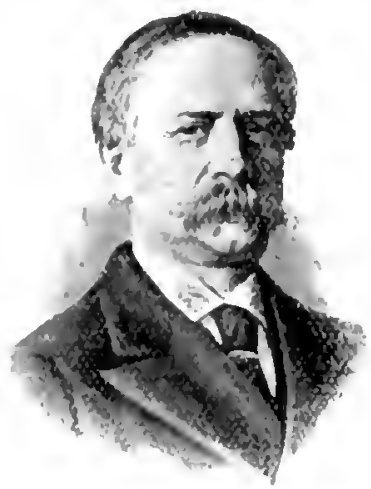

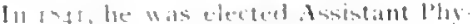

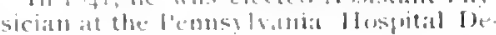
partment for lnsane : lout resiguted after

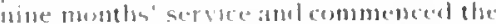
practice of jus profossiont as an assistatl

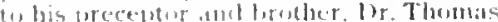
II. K. Sintili 
On his return tu lelibalelphia, 14 in 92, lo devoted himbelf principally" to the practice of whstetrics and diseases peculiar to womell. The same yoar be was chosen I.ecturer on lohsiology lus"

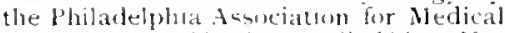
Instruction, amel he then abulied himself to locturing and quizzing. Has prisate class numbered over one hundred atudents.

In in the marred Catharine .1]. Wutilh, of Philadelphia

Fhe was elected lonfessor of Plyysinlogy in the Pennsylvania Nedical College $1>52$, this pristion, which greatly contributed to bus own reputition andilso to that of the instutution, he held until I 63 . While occupring this positin he, in 1253 . assisted ly prof. R. E. Rogers, made an clitborate series of experiments on the celebrated Canadian. Alexis St. Nartin. whicl was published under the title of "Tlie Physiology of l)igrestion," wherein he maintained that lictic acid wis the principal acid of the gastric juice in man. In April, 1-56, he delifered, by request, an address before the Linnean Assuclation of Gettysturg, which was the urigin of his celebrated lecture on "Life and Death." In 1563 , he was elected Professor of the Institutes of Nedicine, in the Cnversity of Pemusyrania, succeediug Dr. Samucl lackson

On December $16,1,6 r$, Dr. Smith was appointed Chairman of a sub-committet with Professor Frazier, judge Hare and br. J. H. 13. McClellan to visit the ses eral camps near the city of Philadelphia and the military hospitals in operatiun. He was an associate member of the I"nited States Sanitary Commission and Medical Jirector of Christian Street Enited Stites Ar'm Hospital.

Ior. Snith founded and established the first Physiological Laboratory in the luiversity of Pennsylymia, in $1 \times-5$ : he was also the first to introduce hypolermic medication into Philadelphia, while on service in the Flospital.

ITe contributed a number of articles and translations to medical literature

He was wected to the Uhedical staff of the Penmsylvanla lospital in 1450 , te igned 1559

t) $r$. Smith was a member of the Phila delphia Medical society, Collese of Pliy sicians, Acalemy of Satural siciences. state Vedical Sicuer of Pennsylsania. American Metical Assuciation, American Philosophical Society. Prolessor of Plysiolngy, Penusvlvania Medical college, 1.952-62; l'hysician to the Episcopal tho pital, rs5-05; Acting Assistant Surgeon Enited states Armo, 1.652-65: Physician to Plibadelphia Orphan Astum a 963 ; and also Plyysician $\rightarrow t$. Ioseph's Juspital

He died April 6, in, ancel sixty years.

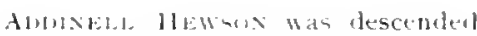
frum endinently modical ancestry, beint the fourth in desecont from a prominemt London surgenn. He wats the son of Professor Thomas T. Huwson, who served on the Wedical Stint ot the Pem sylvama llosfital from $1,14-35$ Addinel thewson was born in Plyiladelphia, Novem ber 22,1424 , and was educated at the Academtc Diepartment of the [nisersity of Pennsyliana, from which he rectived the degree of A B. in IA

He at unce commencel the study of nedicine as a pupil of Professor Juseph Pancoast He was graduaterl in ix ${ }^{\circ}$ o by the Jefterson Medicat College.

As surreon of a sailing ressel, he visited Europe and becalnt a student of sir Villiam Vilde, at St. Wark's Hospital: he also attended lectures at the Rotunda Hospital, Dublin.

He returned to Philadelphia in ins and served in the Pennsylvania Hospita as Resiclent Pinsician frum 1451 to 1452 He then commenced the practice of his profession.

On November 22, I854, he married Rachel Macomb, daughter of IVilliam Vetherill, M. I. of Philadelphia.

He was elected to the Nedical Staft of the P(nnsyluania Hospital in 1561 , te. signed I $>7 \%$.

I) r. Hewson was a Nember ut the Academy of Natural Solences, Fellow College of Physicians, surseon to the Episcunal Hropital, a memler of the Philadelphia Commty Medicil Society. American Medical Association, 1955 : Pathological Soctets. Philadelphia, 1,5, : Surgeon to St reurge s Society, Surseou to Wils Eve Ilospital

Healsulectured in 1855 , and for several successive years, on surgery, in the summer school of Jefferson hedical Cillege. At the organization of the Philadelphia Academi of surgery in the cofice of the late Prof. S. J, Ciross, on April $21,1,79$. I)r. Hew son acted as Chairm.ln nits first meeting.

He carly adupted the administration of electricity in the forms of primars and secondary current, with favorable results, in the employment of Hackley's chatin for vromular conlunctivitis in i\$5\%. He invented a torsing forceps, and in 1565 be amputated the thigh at the Pennsyl. vania Hospital, uning tolsion insteald of ligatures. In thing he begun the use of the antiscpticearth treatment for wounds, contusiona chronic and acute inflamma. tions, tumors, and rellerally for surgical dressimas. In asoo he adiled sulphuretted ludrogen gas to his eartl te eitnuent for tumors and intlammations

He wrote a large number of papers as contributions to the sitrinas medical jour. nals, etc. Heedited, in 1453 , alt rejuest 
of the

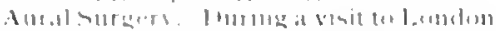

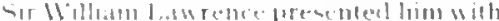

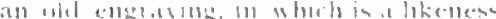

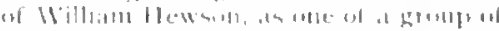

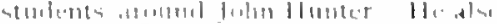

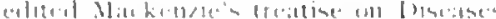
of the live, $111+145=$

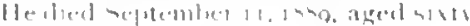
sin

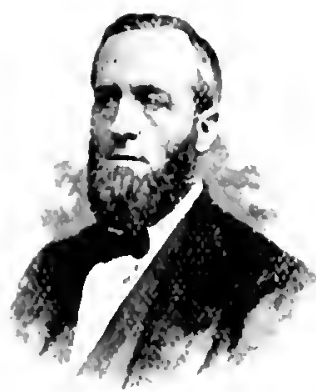

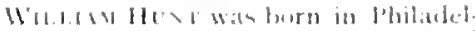
buta, Septeminer 26, 1 h25. Ile received hic educition at a Friends schoul do

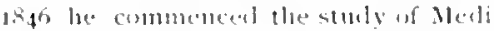

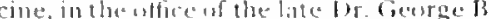

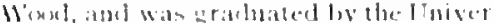

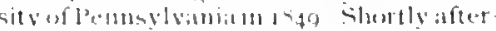

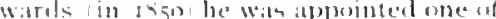

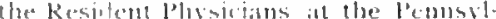
bomia Ifospital, which pusition he ecent

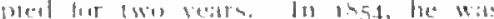

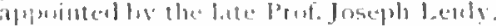

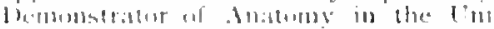

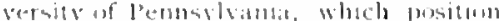
he heolet fin lese reatro

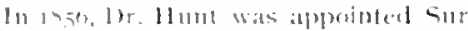

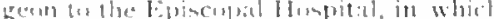

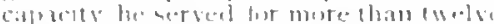

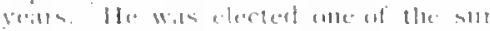

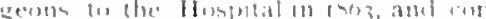

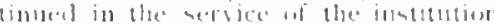

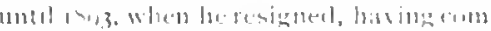

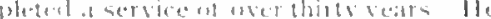

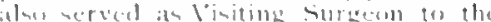

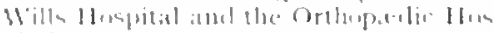
pit.l

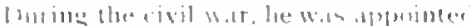

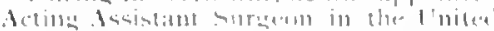

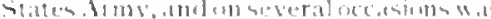

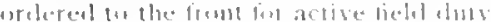

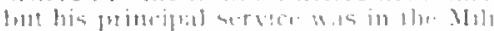

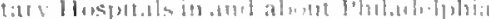

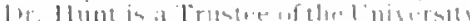

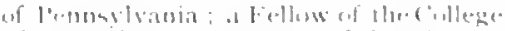

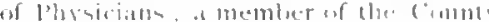

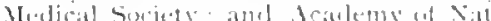

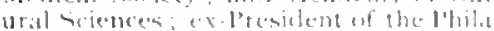

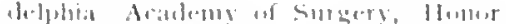

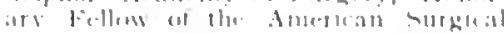

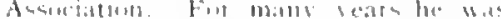

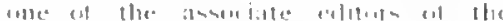

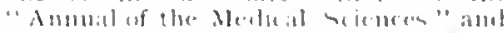

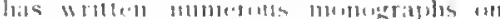

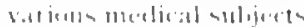

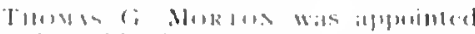

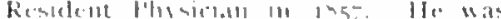

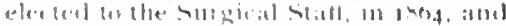
(antimus-in uflice.

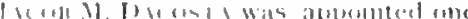

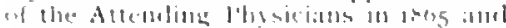
comlntules in ulfite

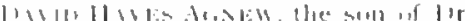

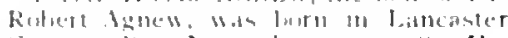

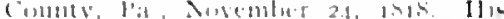

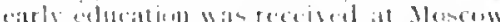

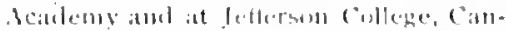

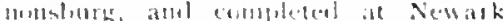
Ciallege, I relawate

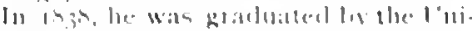

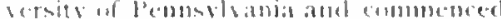

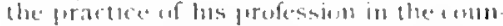

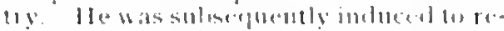

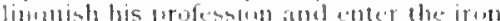

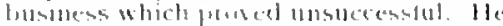

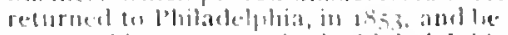

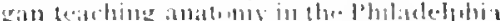

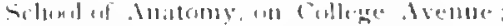

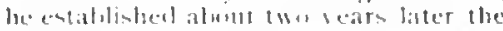
Phatalelphia schon! on Opurative sur $20+1$

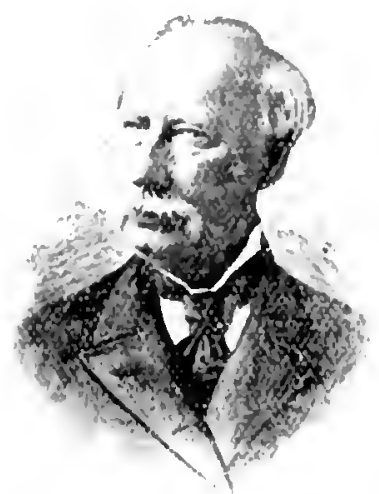

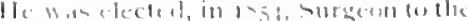

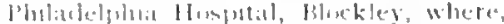

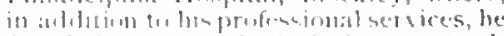

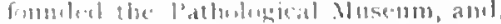

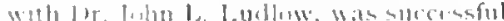

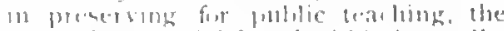
valualde material fomml willin its walls

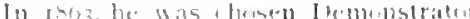
af Bnatuang and lusistant lecturer of 
Clinical surgery in the Lniversity of Penmsylvania. In the same year, he wat; appointed one of the wo Consulting sur geuns, $\mathrm{C}$. S. A to the Homer Hospmal, at Chestnut Hilt. In IS5. Was elected Surweon to Wills Hospital, and in 18-6, Surgeon to Orthopedic Hospital.

He was telecled to the Medical Staft of the Husprital in 1565 : tesigned, 18-1; and re-elected Niay 7 , wor, and resigned April $17,1884$.

In 18 ; 0 , he was elected l'rofessor of Operative Surgery in the Inisersity of Pennsylyania: in 18-1, was the John Rhea Barton, Professor of Principles and lractice of Surgery, which he heid until ixig. He then, on account of his health, resigned all public posttions and was elected Emeritus Professor to the lniver sity, and Honorary l'rofessor to the l'niversity IHospital. In 1874, he was elected P'rofessor of Clnical Surgery in the Ini versity Hospital; the dexree of I.L. I was conferred upon hm in $1,-6$ by the college of $\mathrm{New}$ Jerser.

In 1841 , he married Iargaret C. Irwin.

Dr. Agnew was a Fellow of the College of Physicians and its I'residen in togo memluer American Philosophical Sociely (18-2); President of the County . Hedical Society, l'resident Philadelphia Academy ot Surgery, and of American Surgical Association ( 1 ist) : Consulting surgeon. Orthryedic Hospital; and to the Ger mantown Hospital.

He was elected Honorary Surgeon to the Presbyterian Hospital, thilade phiat Isol, being the only one "il whom this title has been conferred.

thlough not a voluminous writer yet in the last decade. he published one hin. dred jowrmal articles. In 18,66 , he issued "lractical Anatomy for Dissertors" also his Classical Mlonographs on "Laceration of the Female Perineum," and on "Vesico-laginal Fistula." As an auther his fame rests principally upon latge systematic work in two volumes, the "Principles and Practice of Surgery."

He was a member of the Surgical Club, and other social organizations.

He died March 22,1592 , in his $74^{\text {th }}$ year.

Jantes H. Huteminson. was the grandson of lyr. James Hutchinson. He was born August 3.1834, at Cinta, near Jisbon, Portuxal, where his father at that time was engaged in business. His parents returned to Ploiladelphia white he was yet in early" childhood. Hic attended a private sctool in New Haven for four years, and then entered the lniversity of f'enmsvlvania where be re ceived the degree of A. B. in 1854 . Then he revisited Europe. He returned to lhiladehphia, in 1855 , and commenced his medical studies, receivme the degret of
Inector of lledicine from the lniversity

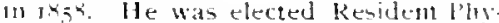
siciatl in $1 \times 5$ s

Ont the conpletion of his hospital service, he asain visited Europer remain ing twe years in the llosplitals of l'aris and lienos. on his return to philadel plita, in the attumn of inte he com menced the practse of medicine. In

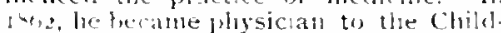
retis Hosplat which afprointment he held until his death. He was alsuat thin time 1862-65 acting Assintant aurgern of $1^{\circ} . \rightarrow$. A servon at the saltetlete General Hespital in llest lhiladelphis

In 1 \$62 he married Ama, daushter of Charles Jugersoll, Esq. of l'luladuluia.

He was elected to the Bledral staff of the Hospital in $185 x$, which pusitiun the helat until his decease, 1 geo.

1). Hutchinsin was President of the

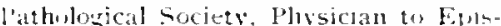
conal hospital, vice-l'resident of the (is) lege of Physicians, also member of the American Hedical Associaticn, Academb of Nitural sciences, and the therisan philusephical societr.

He edited lwo American editions on Bristone's "Practice of Medicine": and contributed elaborate articles, which are still rearaled as chasmical, on typhoid, typhus and simple comtinued fevers, to the "Syatem of Medicine." edited by Irrs. Peuper and starr Ile was a contributor ti) the Transactions of College of l'hysiciars, of the Asso. ciation of American Plysicians of the Philadelphia Pathological Siciety and to the Pennsylvina Hospital Reports, and the American Jourmal of the Medical sciences. He was for wo rears editur of the "lohiladelphia Medical Times."

fir. Hutchinson died Ilecember zó 1sto. aged fifty-five years.

IAMEs Althex MEus wat porn in Philadelphia, July $31,1 \times 20$, it Englinh and Scotel ancestry, on his father's, and of Scotch and ficrman ancestry umo his mother's, side, llis early education was obtained at public achowls and he teceived the degree if $A$. B. in 18 's, from the Central High Selowol of Philadelphiat.

li April, ofin be commenced his medi cal studies and in Oetoher matriculated at Jetfermon College, from which he was graduated in 1551

He llas ior many bars assistallt to Dr. Francis Gurne sinuth, whle l'ru fessor of l'lysplogy in the l'ellunylatini. College, and engaged in the preparation of students forgraduatum. In Scpitmier it5t, he was appunted l'rufesenot of c:lima tology and Phosologe in the l panklin Institule, and consinuted in lhis postinn eight beas. In 1955 . he wan elected one

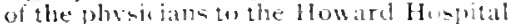




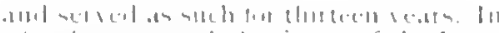

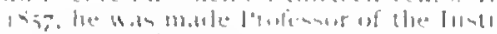

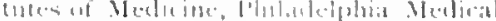

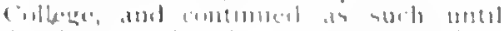
Aloril 1850 . whell he was transersed to

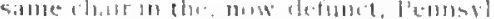

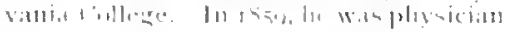

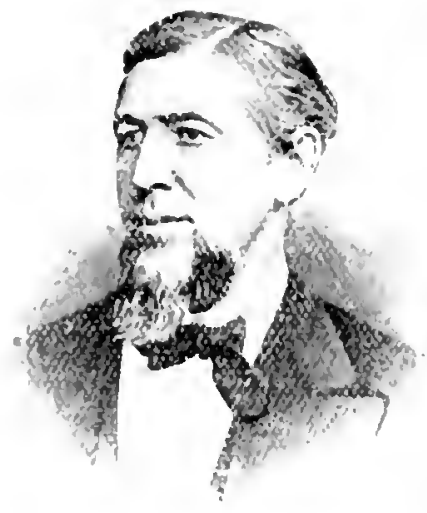

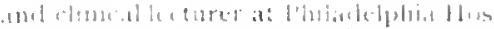

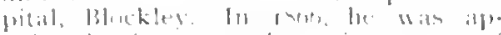

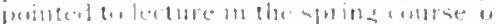

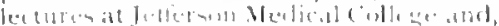

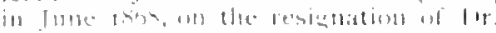

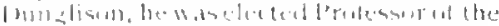

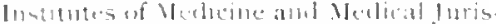

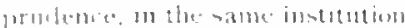

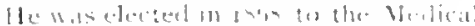

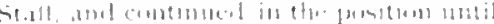
himilath, in in=n

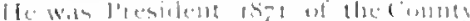

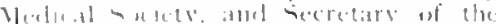

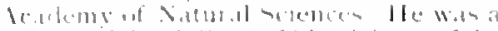

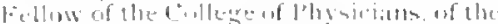

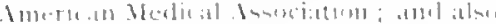

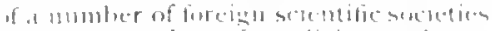

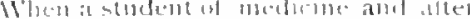

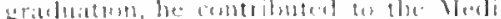

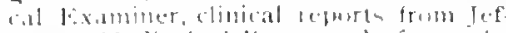

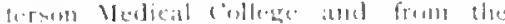

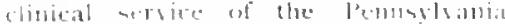

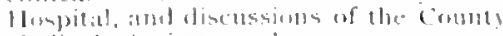

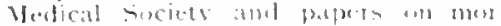

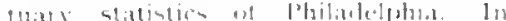
1.5.5, in lestroal of Franklin lu-itule, lo

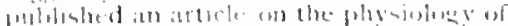

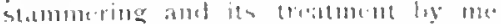

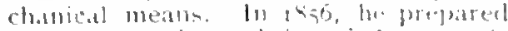

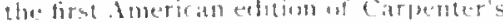

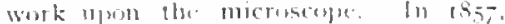

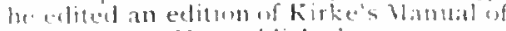

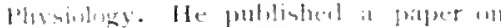

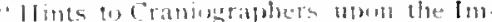

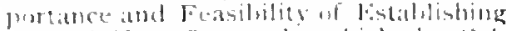
ande. leniform sintem low which the col.

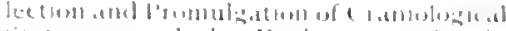

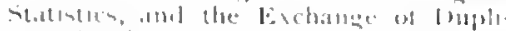

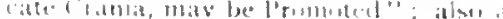

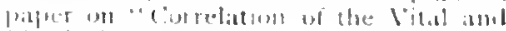

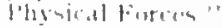

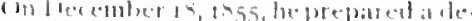

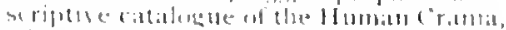

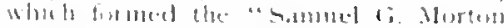

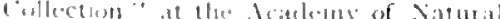

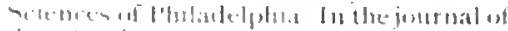

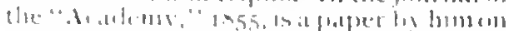

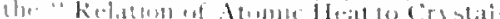

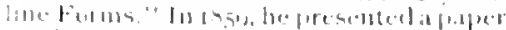

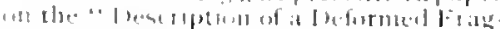

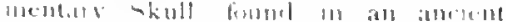

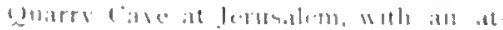

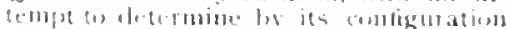

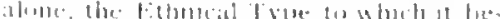

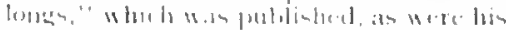

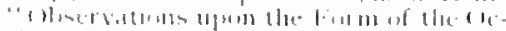

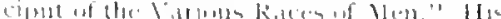

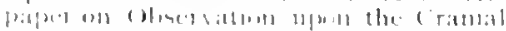

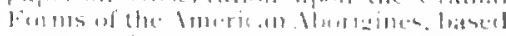

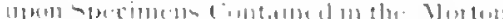

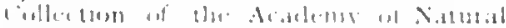

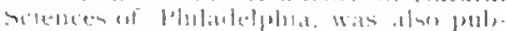

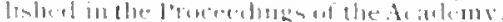

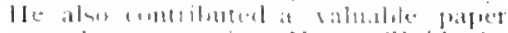

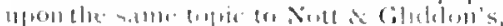

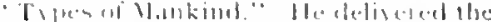

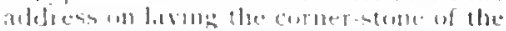

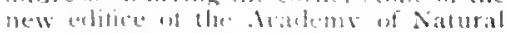

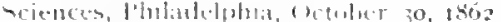

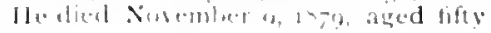
I.t.in

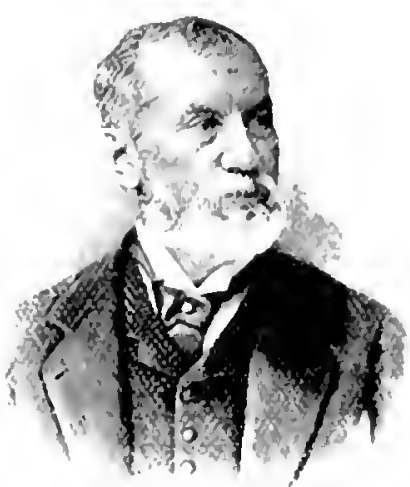

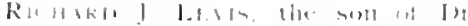

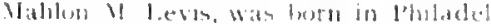
phial, flune 24, 1827\%

for. lovis recejved tis pretiminat

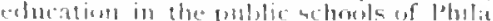

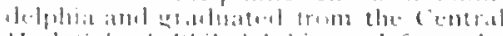

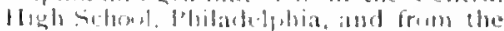

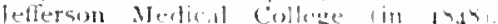
shortly alter thim ho serverl as surseent

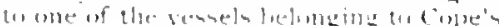


Packet Line. He then ertablished himself in practice in Philadelphia, and sogn became known for his proficiency in ophthalmic and general surgery.

In 1859 , he was elected surgeon to the Philadelphia Hospital, Blockley, which position he held until elected, in is; $t$, sur. geon to the Pennsulvania Hospital. in which he serverl until iss7. 11e was also Attending Surgeon to Willa llospital. atnd was elected Emeritus Surgeon on his resignation at the end of twelve years' active service in that institution. During the IVar of the Relsellion he was acting Assistant Surgeon to two United States Military Hospitals in Philadel. phia. He was Clinical Jecturer on Ophthalmic and Aural Surgery at the Jefferson Medical College for many yealrs.

When the Jefferson Hospitil was opened he was elected Atten linir surem and Lecturer on Clinical siruers. Fur many vears, and up to the time of his death, he was Cousulting Sigrem to the Jewish Hospitil of Pliladelphia. When the Philadelplua Polvelinic and Collert for Graduates in Medicine Witu trganizo.l. Dr. Levis was prominent in eutablishins it and was one of the original memlers in the Faculty being Profeswor of Clinic:al and Operative surgery. Ile was also first President of the Board of Trustee

In 1885 and 1846 , he was elected I'resi dent of the Philadelphia fomnty Merlical Society and in s'se President of the Medical Society of the State of lemmsyl. vania.

The librars of the Penusyluania Hospital contains a numler of lound rol umes of manuscript reports of his clinics. which were prepared $\mathrm{h}$ students whin were awarded the annual prize. which for many years Dr. Levis nifered for the best report of this branch of his hospital work.

His investigations of fracture of the patella and of a fracture at the luser end of the radiun nere mude dering his connection with this lospitial. II modification of iperative procedures and of surgical instruments, which always had the merit of simplicity, were ifuite numerous and showed much oriyillality and skill.

His presidential addresses before the State Medical sinciety in Ins on "Tra. ditimal Errors in Sirgery" showed his dialike for routine practice.

1)r. Levis retired from active pantice in 1846 and resided at "Cerliteroft." Kennet sipuare, Pennsvlvania, where he died, November r2, 18ino.

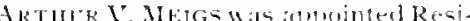
dent l'hsician in $18-2$ and we of the Attendinir Physicians, in anz, and continues in wfilice

Jorl 11 PACk $\backslash$ RI was appointed Resi. dent f'hesician in Iass and sne of the ittemling surgeons, In 1684. and ron. tinues in offece

Jom Aambros, Jke, was apminted Resident l'bsician in Int allel was cected one of the Attending Sureons, in 148, , and continues in office.

MORRIS IANG:TRETH was appointe! Resident lhrsician in ts-o and ofle of the Attending loysicians, in $15-0$, and $\mathrm{con}$ tinues in office

MORRIS J. L.RWIS was appointed Resident physician in rsta and one of the Attending Phaicians, 111 rao, and continnes in office.

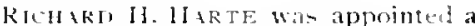
Resident Physician, in 1 -on, and one of the Attending Surgenns, in 1 so 3 . and comtinues in antice. 


\section{MEUICAL APlRENTICHS ANU RESIUIAN PHYSICIANS}

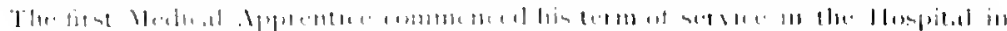

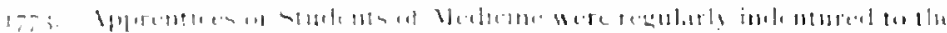

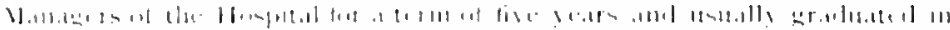

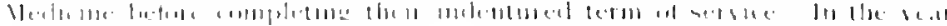

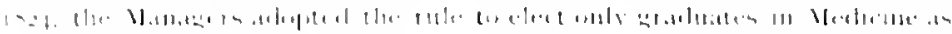
K. $-11,11110113-1,1,114$

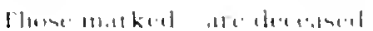

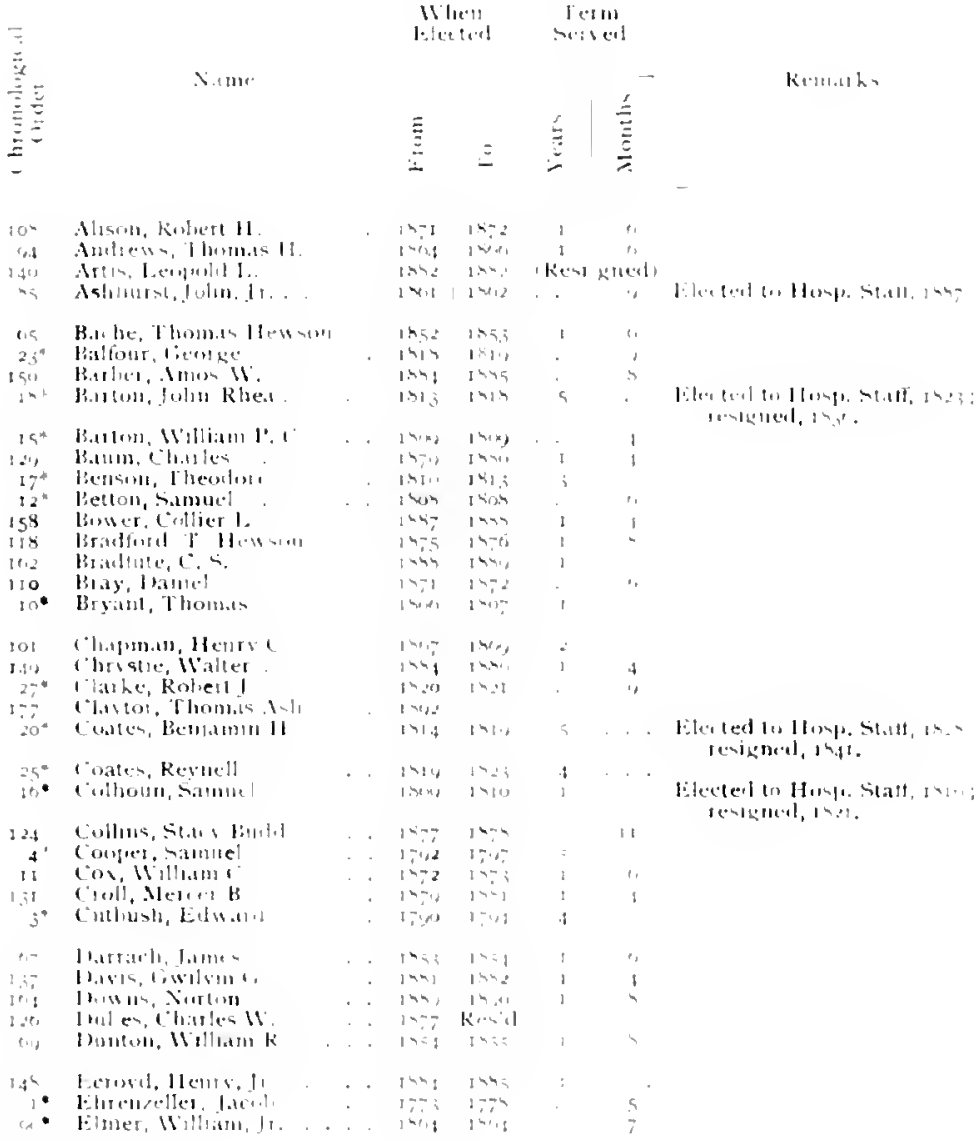


When Term
Elected Seried

Fisher, Henry ir

Flanuer, Thomas

Fileming. A1 drew

Forbes, IVilliam

Fin, Josepla. II.

rarulener, Nilliam

Giemaid Georges.

Gerhard, Wintian vi:

Gillespie, fohn.

Grliam, Villiam G.

Gobrecht, Milliam 11.

Graysin, Charles $\mathbf{M}$

Green. Walter D.

Gummey, Frank Bi:1

Hail, A. Douglass

Hanersley, Ralph

Hand, Frank

Hare, Horace Bimnes

Harlan, Geotge Cuv'r

Harris, Rohert $\mathrm{P}$.

Harte, Richard H.

Hartshome, Esward intl iss

$1,5-7 \quad 1=-$

15ic iदि

14.551859

i $483 \quad 1855$

Elected wHoll, Stait, y

$18-5 \quad 1590$

resigued, 1 hit.

$1501,50150$.

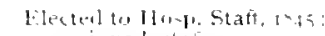
revicued, the

$1581 \quad 155$ :

touo lingl

$1850 \quad 1551$

1853 1 124

140,140,

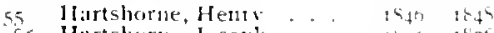

Hartshurbe, Jusepli + 1 - 1409

Herbert, Theordor

G. Hewson, Addinell

$79^{*}$ Hodge, IH. Lenox

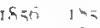

In 20 is 150

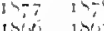

thit 1 ist

into the

In I I 45

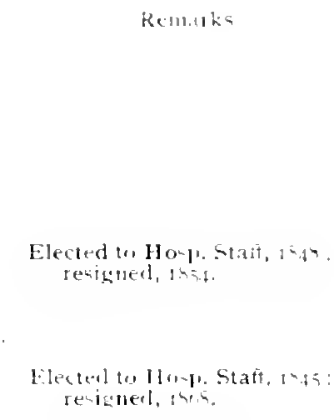

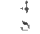

Elected to Ilosp. Stali, $360:$ Elected to Hosp. Staff, is 5y: rengued, 14 t...

Elected to Hrocy. Stafi, Inso resigned, 1 t21.

Elected to Horp. Staff, ISol resigned, this:

Elected to Hom stat, $14: 2$ resigned, ins:

$50^{*}$ Hollingsworth, samuel I.. Hopkins, Samuel C

Hopkins, ivillian Baton

Horrefie

Horsefield. Thomb

Horwith Orville
Howell, ivillidm

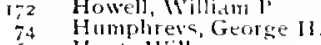

Hunt, Williaı.

14:

$19+2144$

$1.50 .9 \quad 130.5$

$-6,100$

पदिश 145

49. . .

in 5 in $18=8$

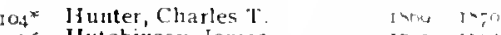

$\rightarrow$ Hutchinson James

Hutchinsun, Jannes II. . I450 ins3

$115^{4}$ Jameson, Felward 11 . . . 14,3 10,5

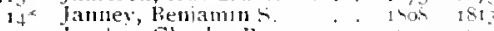

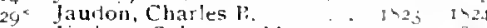

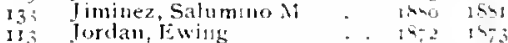

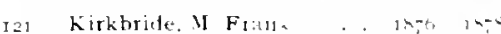

fic Kirkbride, Thomats 1933 an

2 * Lawrence, I amon U' 1

in? l.econte, kobert $\mathrm{f}$.

$i^{*}$ Lee, Charies Cario

to lee, Georst:

$54^{k}$ Lee, John dirigs

$5 g^{*}$ Ledidy Joseph!

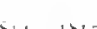

14it is isi.

1.4 1451

क) Lewis, Frum $=W$...

Iin in then

Elected to llusp. Stalt, tast:

Elected to Hocp. Stati, 150;. resig'ued, thes.

Elected to Hosp. Staft, 1 son: died, isso. 


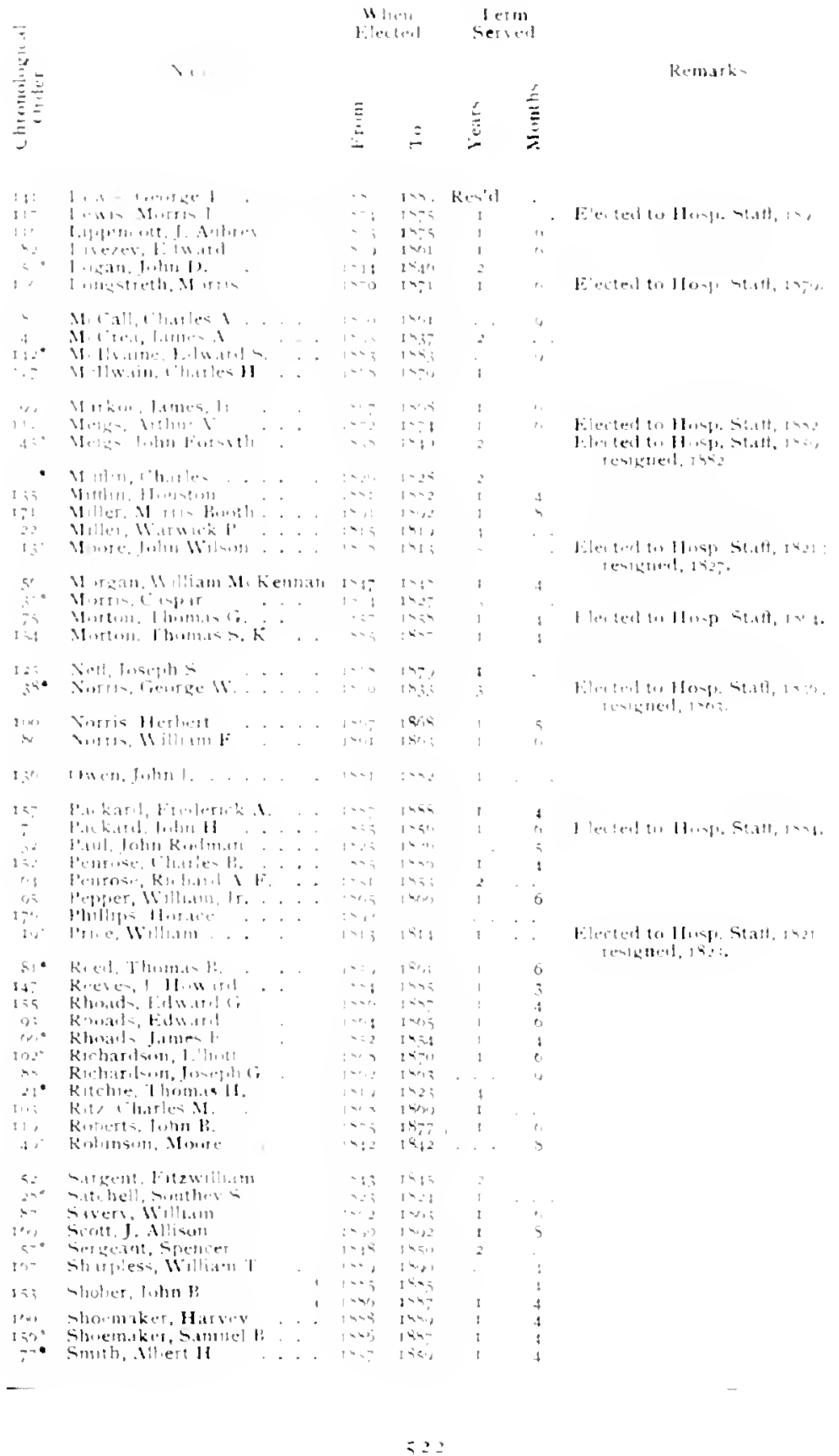




\begin{tabular}{|c|c|c|c|c|c|c|}
\hline \multirow{3}{*}{ 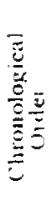 } & & \multicolumn{2}{|c|}{$\begin{array}{l}\text { When } \\
\text { Elected }\end{array}$} & \multicolumn{2}{|c|}{$\begin{array}{l}\text { Term } \\
\text { Served }\end{array}$} & \multirow{3}{*}{ kemasks } \\
\hline & Nitne & & & & & \\
\hline & & $\stackrel{\Xi}{\Xi}$ & $\therefore$ & $\frac{1}{\tilde{j}}$ & $\overline{\bar{\Xi}}$ & \\
\hline 1.44 & Smith, Henry It. & 1937 & 14.30 & 2 & 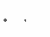 & \\
\hline $\begin{array}{l}173 \\
175\end{array}$ & Smith, Lawrence S. & inut & 1012 & Resd & - & \\
\hline $\begin{array}{l}75 \\
37\end{array}$ & $\begin{array}{l}\text { Spelliss, } \\
\text { Stewardson, Thomas, ir. }\end{array}$ & $\begin{array}{l}1092 \\
14+15\end{array}$ & 18,32 & 2 & & Eilected to Hoyp. Stath, is is \\
\hline$\frac{46}{58^{*}}$ & $\begin{array}{l}\text { Stille, Alfred } \\
\text { Sille, Moretong }\end{array}$ & 19.39 & 14: & $=$ & & \\
\hline 48 & $\begin{array}{l}\text { Stille, Moreton } \\
\text { Stocker, Anthony E }\end{array}$ & $\begin{array}{l}14,4 \\
19,0\end{array}$ & $\begin{array}{ll}24: 2 \\
14 \$ 2\end{array}$ & 2 & " & \\
\hline & Taylor, William Johnson & $m:$ & $1 \times 24$ & : & $\because$ & \\
\hline $11^{*}$ & Thornion, Philip & $1 \times k^{2}$ & $18 \sin ^{4}(2)$ & $i$ & ij & \\
\hline 145 & Trotler, spencer & $1.4 i$ & Insi & : & 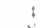 & \\
\hline 91 & Tyson, lames. & $1+t:$ & Inte & 1. & " & \\
\hline 105 & Van Harlingen, Arthus C. & 18, & $19-1$ & I & 6 & \\
\hline $5^{1^{x}}$ & Wallace. Ellerslie & $: 4+3$ & $1 \$_{1.1}$ & : & & \\
\hline $43^{*}$ & Wallace, Joshue ir. & 以施 & 1034 & $=$ & . & \\
\hline $34 *$ & Waathington, James A. & $\ln z$ & $12=9$ & $=$ & $\therefore$ & \\
\hline $\begin{array}{l}766^{6} \\
1661\end{array}$ & Wells, Wiliiam Lehmin & $I_{4}=2$ & is $=7$ & & $\div$ & \\
\hline 161 & Westcott, Thompsons. & 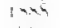 & ine & i & 3 & \\
\hline 13 & Wetherill, Henry $M, I r$. & 10,9 & $1=0$ & : & $i$ & \\
\hline 5 & Willians, Charles B. & 1 1ैंक & $16+2$ & i & ? & \\
\hline yo & Williams, Horace & $\ln 5$ & Wh & 1 & 0 & \\
\hline 132 & Wills, Joseph H. . & 134 & 154 & : & 4 & \\
\hline 50 & Wilson, durustus & Nit & 1456 & I & $=$ & \\
\hline $145^{*}$ & Wilson, Charle, Meiry & $1=3$ & 1544 & I & 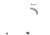 & \\
\hline 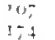 & $\begin{array}{l}\text { Wilson, †anes C. } \\
\text { Wilson, Kichard. }\end{array}$ & ino & 371 & I & $\therefore$ & \\
\hline $10 *$ & Wistar, Caspar & 142.4 & $1 \leqslant 26$ & $=$ & 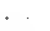 & \\
\hline $39^{\circ}$ & Wistar, Mifflin. & 14,32 & $1 \Omega_{34}$ & 2 & & \\
\hline 92 & Wistar, Thomas & $\sin 3$ & ISTi & I & is & \\
\hline Sa & Wood, Horatio $C$. & $1+0,3$ & $\mathrm{ISO}_{4}$ & . & n & \\
\hline 184 & Woodtury, Frank & 1473 & 1874 & 1 & . & 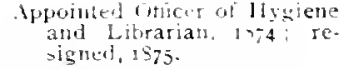 \\
\hline
\end{tabular}




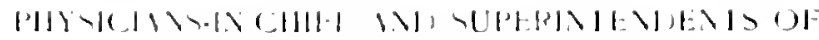

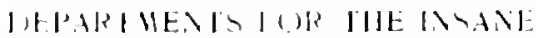

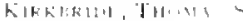

(") 11118,61101 :

leorn Montlin

(1)

Iit witiex.

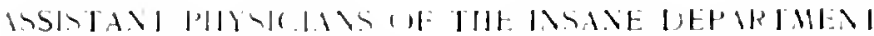

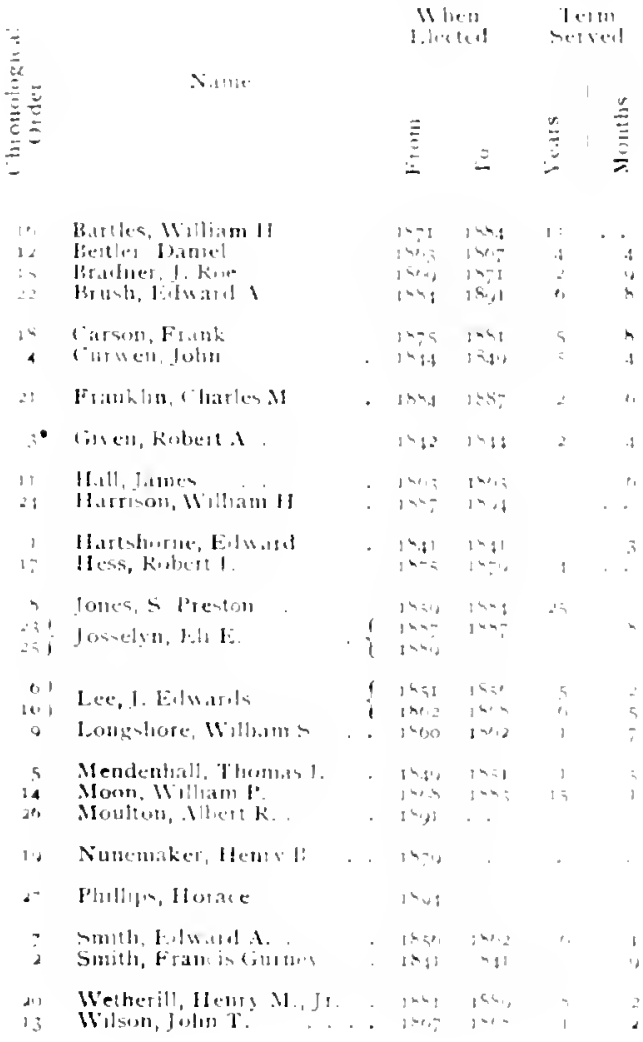

Kurnaths 


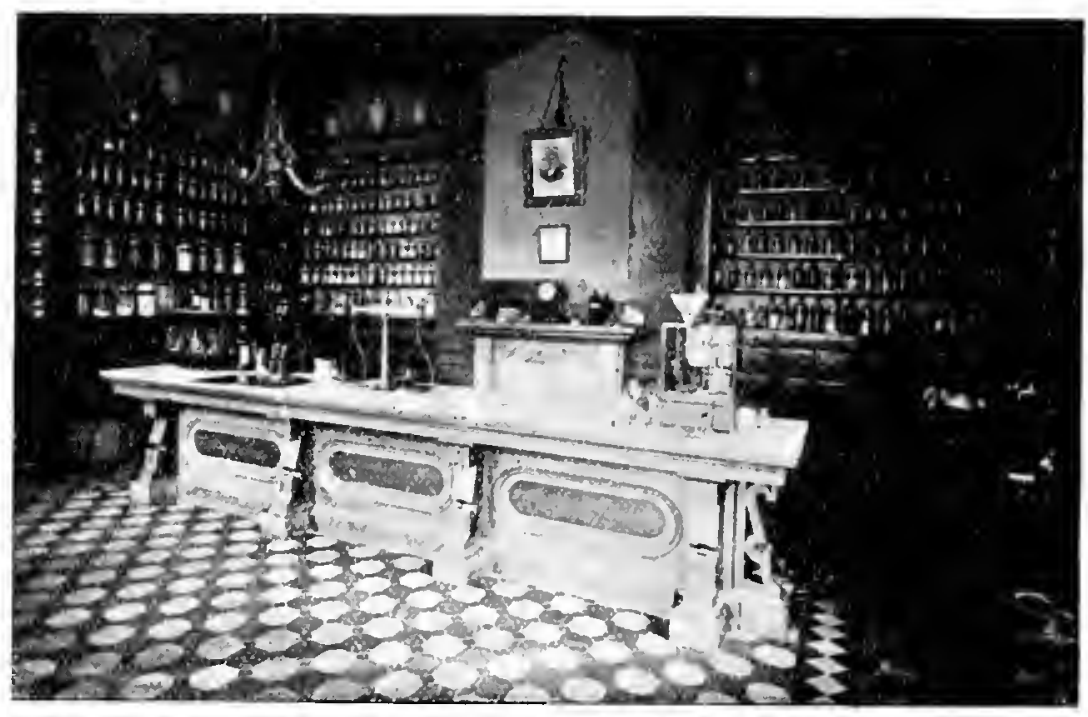

The Hospital Pharmacy.

APOTHECARIES, STEWARDS, AND MATRONS.

The first medicines and medical supplies for the patients in the wards of the Hospital were contributed by the members of the Medical Staff: Jut this arrangement was only temporary.

At a meeting of the l3oard of Managers, held December, 1752. in order to pay for a large order of clrugs shipped from London, it was

Agreed that the Managers, each of them in their Turns solicit Subscriptions from the rich widows and other single 1 ornen in Town, in order to raise a Fund to pay for the Drugs.

The appeal was not in rain (see page 267 ) but the resolution was adopted not to rely upon such expedients in future. but to restrict the purchase of medicines to the amounts actually in hand and available for the purpose.

A complete stock of drugs necessarily involved the idea of a place trun. Shop to keep them, accordingly it was ayreed ". to jut up a partition in Established. the East back-room of the IIospitat, with shelves, drawers, etr., for a shopr." It further involverl the idea of an apothecary, who should he emplosed to prepare and compoumd the medicines and administer them agreeably to the prescriptions of the physicians and surgeons. and who would be able to give security for the faithful performance of his duties. In 1752 , Jonathan Roberts was recommended ln! 


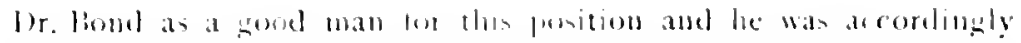
empenered to empley libu. Alter receiving hin apjosintment, lie served the llompital acceptally for two years alsd a puarter. II is

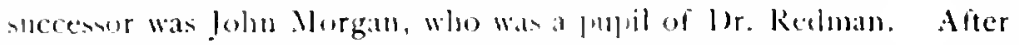

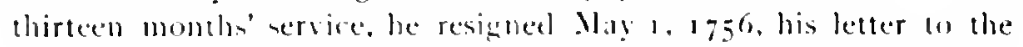
loard, stating in the formai phrascology of the elay " that hasing a prospect of business more atrantageous than his present employment. he desired to be disclariged."

Ifhn liond, a nepluew of Mr. Thomas Bond. was the thirt apotherary. He entered $11,0 \mathrm{~m}$ hi ruties and released his predecensor Way 6. $175^{6}$. After a servire of a little over two year, Dr. John Bond also "fombd a prospert of more Adrantageons linsiness. ete.," and accordingly resigned .llay $17,1,5$ s.

Dr. Catwalader recommeneled famen Ashtom thayard "as a sther foung man mitalle (o be : b employed," and joined in an olligation for the faitheil performance of his duty, anel be was accordingly dected to the vacancy.

Mr. Bayarel served for one year anel semt in his resignation, asking to le discharged. In this emergency, the flyysician were invited to consult alout choosing an alpotherary for the ensuing year

Medical Sturlents to serve as Apothecaries. as it was now believed that the work of the lywthecary shop could be satisfactorily performed ly medical students. as a part of their duty. Accordingly the following minute was adopted in 175 is:

And considering the advantage a grung student of lhyic and surgers may receive by being employed as the Aputhecary, it will not be copedient to cuntinte th. silary to the Apotheciry.

Apparently the experiment of having the medicines compromeled b! the resideat medical stutents. was not satinfactory and had we lee abandoned. the managers finding it necesary to bate some renponsi-

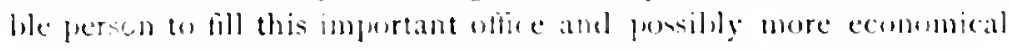
in the ent.

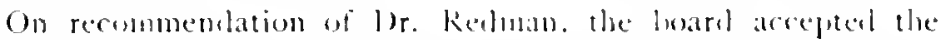

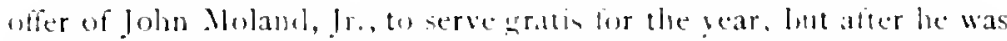
appointed. he found that hi health wombl not permit him to serve.

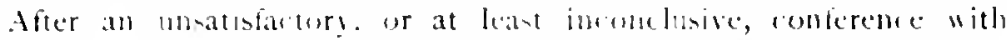
another comblidate. the lioard of Manigers decided wo advertise

Awertise mirnt for an Anithecary. in the "Gasten," "that an dpotherary is wanted in the service of the Ilospital." Amome the applirant wats llr. George Wecel, of

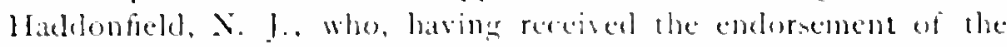
Nerlical staff, was waited noon at his house. The stewarel and matron had each given notire of their intention to leave, whic ls made it necessary that the vacancies shembl be filled immediately. 
'The Medical staff presented the following communication, containing a recommendation, which has since been adopted in other hospitals :

In order that the Business of the Hospital may be less burdensome to ourselves, and more thoroughly performed we propose that there may be a Surgeryman, as in English Hospitals, to prepare the Lressings as we dilect, w he ready on all Occasions whereby we could, or our Apprentices in our Absence, dress the Patients with more ease and adrantage than has been pomsible for as to do, without such preparation.

We also think it a matter of great Consequence not only to the Institution, and the Patients in the liospital, but to the Pupils who attend, that the Apothecary he a person of fidelity, and skill in the various branches of his business; is it is impossible for any who have not been conversant in matters of the kinci, to be competent Judges of the latter Qualification, we request no person may te chosen, wlthout hasing first obtained our recommendation.

Moreover, we crave leave to represent, that the Apothecary's Shop is very defective in furniture, necessary to preserve the Virtues of the Merlicines, and to keep them separate and also in sundry things, essential, for preparing, compounding and dispensing, what is prescribed, in the most accurate, efficacious manner.

And lastly, if your fund admitt of it, we think a small Laboratory wou'd be A Iharmaof singular use; as such an Apothecary wou'd have a considerable share of ceutical Jeisure, and might prepare most of the chemical, and the botanical Medicines, Laboratory avoiding any temptation to adulterate; and we should have many of them, suggested. cheaper, genuine, fresh, and possessed of their full virtues.

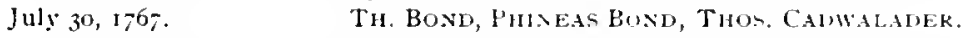

The necessity for obtaining a pualified apothecary was the suljeet of another communication to the Board of Managers from the Medical Staff, sent in a few months later:

Gentlemen:-According to rour desire we have had several Conferences about an Aputhecary for the Pennsylvania Hospital and think it absolutely necessary that a person properly Qualified for that Business should be procured as soon as you conveniently can; We are of Opinion that the best way will be to apply to some Person in England whose Judgment and good will to the Institution may be depended upon for a Recommendation of such a Person. This can be no Difficult matter as some of you have Connections with l'ople eminen in the Medical way in England. For our Parts we think no properer persons can be thought of than Dr. Fothergill and II. Bevan. The intended Apothecary may be informed that he is to do Duty in the House as is Customary in small Hospitals in England Ours containing one tume with Another from 150 to tho Sick. He should be so well stilled in the Affairs of Chymistry as to be able to Manane a small Laboratory if it should be found necessary.

In order to obviate any fears of his having toogreat Employment, he may be informed that the Business of Iressing Is to be done by us, or our l'upils under our strict inspection for their sreater Improvement, Sto the general Benetit of the sick.

We have thought of some few Regulations "w be made in the Ghop, but ats we have reason to believe an Apothecary will be had in the Spring we think it best "n, postpone the Execution of them until his Arrival.

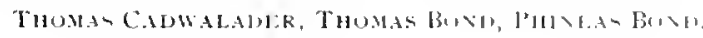

Octuber $5,1,-5$, 


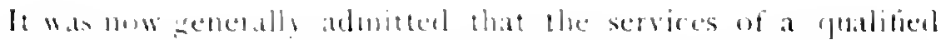

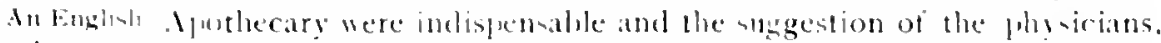
ipelleceriry to be ingursted to mport a druggist from lingliund. was an cordingly alopled.

In this emergeney, as in mans others, the Managers turned to their friemel. bocker forluergill in london:

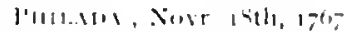

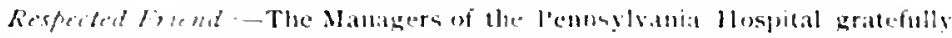

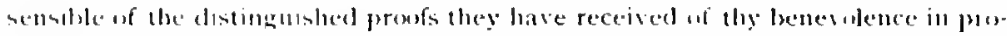
moting that useful Charity, \& thy Friendshin in assisting them, ate Encouraged to

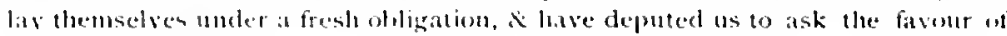
thy bind assistance in a motter which the present state uf the Institution requires

Letler to lit

Fothergill requesting

him 60

('ligine .111

Apothecurs:

for the:

Ilospital.

Our Matron who had been in the service several lears with ("redit to herself. \& satisfaction of the Mhnagers, died last winter much regretted, her llushand. the Apothecary not being so fully Qualified as we could wish, lett the service, hy consent, a few Montlis since.

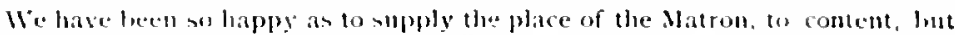
we atre in want of atn Aputhecary of abilitics superior to the last: and apprehending we can he served better from Great Britain than here, nome has ing utfered fully approvel has determined the Wanagers to seck one from your side: Thedr instructions to us thereon are so lully Expressed by their minutes of which we send Extracts antexed, we think it untecessary to abd moch on that heatd, than to desire if thou shouldst snceeed in obtaining ane on the terms therein mentioned, thon wouldst be pleased to fingige hion to come over in the first ship: Wm. Jogan jun'r who was lately here on a Visit to his l'arents, infurmed us of a fuung Man who served his Ipprenticeship ant lived with Joseph Fry at Bristol,

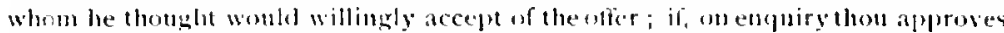
of him, the Character we have received of him gives us reason to think he may suit : Shublut he be otherwise engaged, we hoje some person in the Circle of thy knowledge, maty be met with to suit us, at the sime time we mas venture to ahl it will be no unfavourable prospect as a loung Man desiroms of promoting him. self; It is arreed he should be a single persom, \& must consent to live in the Honse.

We bave the pleasure to infum thee, that the lenusylvania Hompitil, con-

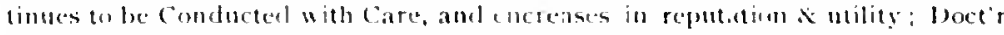

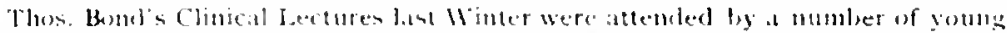

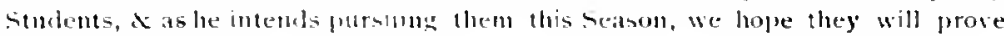
further Instructive:

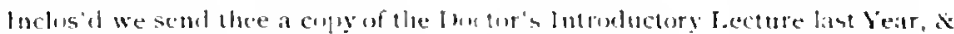
Ihat of the l'reseme

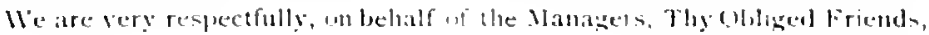
THos. IIIIKTOS.

TWDR, IOHS FOUHEKGII.L.

IUYE PENIERTAS

The Engli-1:

In the interval, fohn lovis was appointed (boloer 26.1767 .60

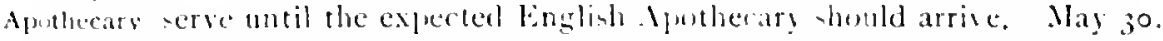
Arrives, $176 s$, Kobert slade entered ujen the dutien as steward and Ipothe. cary, hiv passage money f6. 6s., lrom lisistol. heing paid lig the Mamagers. On July 1 f. I $; 60$. the following minnte appear: 
Died Robert Slade, steward and Apothecary to the Hospital, and was huried Funeral the $55^{\text {th }}$ in St. Peter's Clurch Yard, his Funeral being attended by the Managers of the Doctors and a number of Reputable lnhabitants.

The following communication from the Medical Staff was sent to the Managers, early in May $17 \%$

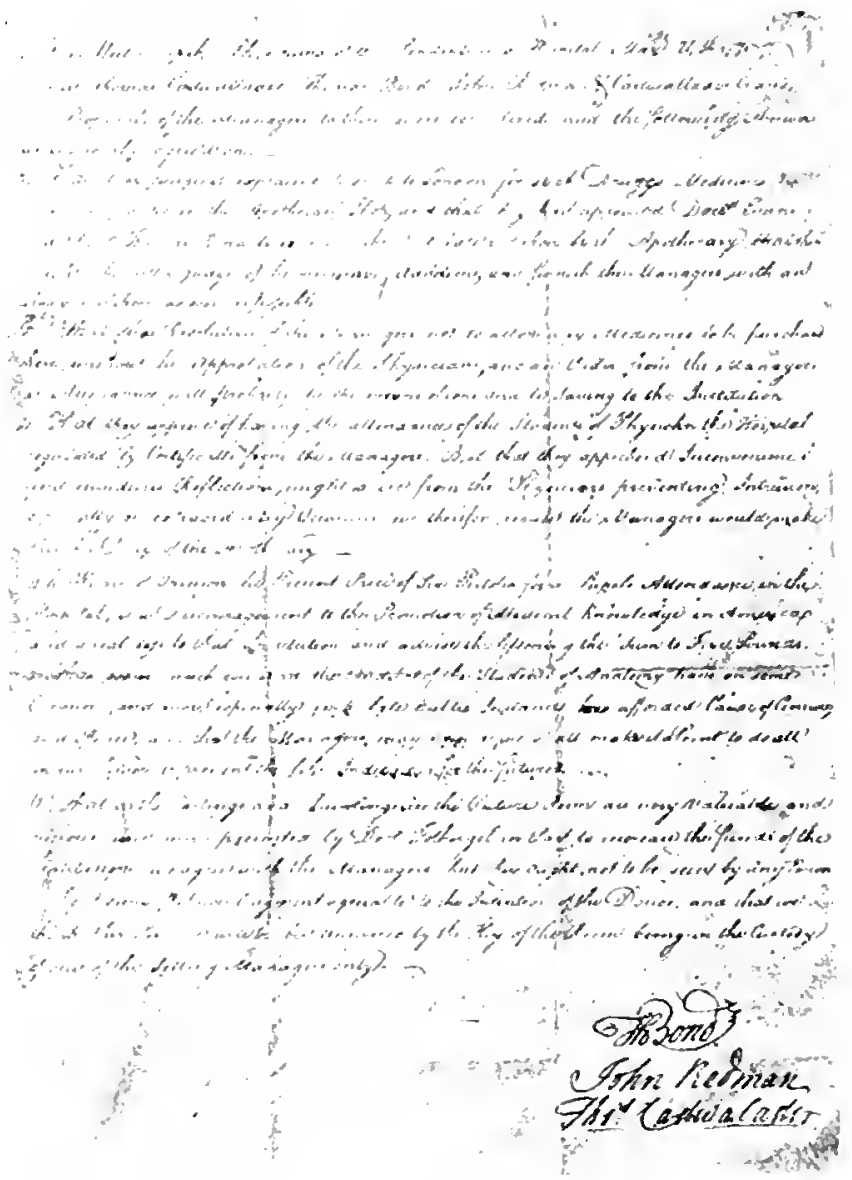

Reproduction if Autograph Communicas tion trum Vedical staff

After conferring with the Medical Staft, the Managers again aldressed an alplication to Dr. Fothergill, giving their views with much clearness as to the needs of the Hospital. In respronse to this another letter, from the Board, Dr. William Smith was sent from England. Aputhecary who delivered his credentials May 16,1770 , and the articles of from Engled agreement were drawn up and signed. 
The following entract from the minutes, shows the carcfulness of the managers, in requiring a formal contract with the new apothecary, so ats to avoicl any futue misunclerstanding:

Dectur William smitls just arrised from lonton, in the Mlipe, Penusylvania

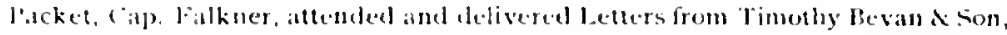

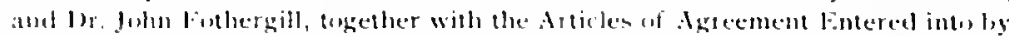

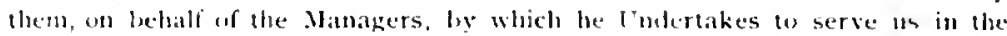
station of an spothecary on the lerms therein set forth, Viz:

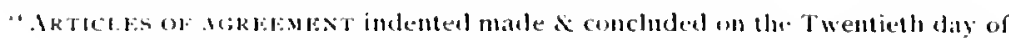

March in the year of our lood One Thushand sesen hundreal is seventy, .tut in the Fenth lear of the Reign of our Sovereign loml, George the l'hircl, by the Grace of cied of creat Britain, France allel lreland, King defender of the liaith $\&$ so forth. Between William smith at pesent of fondon Apothecary of the one part, \& Timothy hevan $\&$ Son of London liruggists, for and on the part and hehalf of lstael lemberton samuel Rhouds \& James pemberton and the ollee fosernurs of an llospital entahlshed in the city of lhilatelphia in Nurth Amerien, of the other part as follows:

Finmal "lirst the sain William smith doth covenant promise and agree, to $d$ with Contract the sadd Timothy Bevan and Son. Lheir Executors $\mathrm{N}$ Administrators, hy lleese mate with l'resents, That he the said William smith shall and will Embark on board such Apothes:ly. Ship cr Vessel in the River of Thames bourd for Pbiladelphia, as the saic

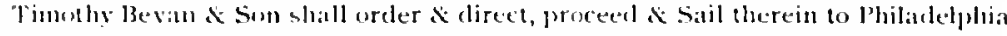

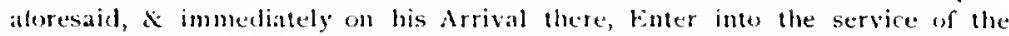
Governors of the 11-mpital established as aforesaid, in the Capacity or Station of an

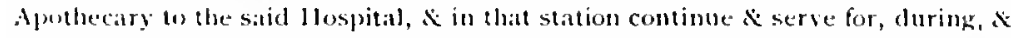
untu the fult End and Term of three Vears, to Commence \& be accounted, from the time of his Arrival at philudelpliat aforesaid, during which Term, the satd IVhliam Smith, shall and will achminister, do, perform \& execute, according to the best 2 utmost of his power, skill \& kmowledge, whatever shall te needful atod mecessary to be Administered, done, performed and Fxecuted, in, about, or conconing the l'atients of the said Jlospital, and shall and will behave himself in an orelerly, Civit $x$ ohliging manner to the Governors of the said Hospital, for the time being, and as one in his Capacity or Station ought to do. Ix ConsIn:kation

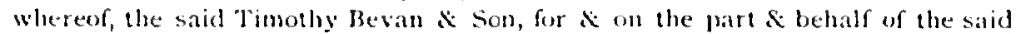
lsrael lemberton, Samuel Rhoads, $\&$ James P'emberton and the other Governors

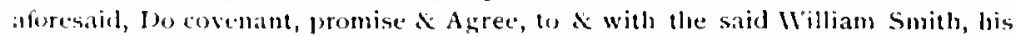
Fixccutors \& Adminintrators, hy these l'resents, That they the said Timotlyy levan \& Son, or the said lsraet l'emberton, Samuel Rhouds and Janes l'embertou, and the other fovernors, their, some or one of their Executors or Administraturs shall and will, not only pay for the Passage of the said William Smith to Philadelphia aforesaicl, and immediately on his Arrival there, take $\&$ receive him intw the service and station of an Apothecary to the lfospital before mentioned, and find 2 provide for the said William smith, good is sufficient Mcat, lrink, Wishing \& Lodging, during the Term of lluree leats to Connence as aforesaid, such as is necessary usual and custumary for one in his Station or Capacity there, 13. I ALso shall \& will well and truly pay, or Cause to be paid to the said Willam Stmith, his Exeruters, Aoministrators or Assigns, the full aud just sum of One hundred pounds Currency of Philadetphia, a Vear, for each \& Every of the saicl three lears, by Even $\mathbb{N}$ Equal half yearly l'ayments in each Vear, \& so in propurtion for a greater or lesser time than a vear, in full for such service to 
be done \& performed as aforesaid. Avin it is hereby mutually covenanted $\&$ agreed by $\&$ between the said William Smith, \& the said Timothy Bevan $\&$ Som on behalf of the Governors afortesaid, That in cast it shall happen that the satict William Smith shall be minded or desirous to quit the service \& empling. herein before agreed on, or that the Governors of the Hospital established as aforesaid, shall be minded to biseharese the said William smith frum such service \& employ, at any time before the end or expiration of the Term of three Years herein before mentioned, What then $\mathbb{S}$ in such Case, it shall be lawful for him or them so to do, upon giving Six Munths warning or Notice thereof in writing, under his or their hands, to the Party or l'arties therein concerned of such his or their denire or intention. Provided always and it is hereby agreed, that in Case such warning or nutice shall be given by the said William Smith within the first Year of his servitude, That then it shall be lawful for the Governors of the said Hospital to deduct and detain out of his Salary or Wages whatever Sum or Sums of Money the said Timothy Bevan \& Son, or the said Governors shail have atvanced \& paid to, of for the Passage of the said William Smith to Philadelphia aforesaid; and that in Case the said William Smith shall give such Yotice or warning after the first Vear, and before the Expiration of the second Year of his said servitude, that then it shall be lawful for the saicl Governors to detain $\mathbb{*}$ deduct out of his Wages, one half part of Whatever sum or Sums of Money, shall have been expeneled or paid as aforesaid for his l'assage to Philadelphia, anything herein hefore contained to the contrary notwithstanding AND to the performance here of the said William smith, and the said Tumotisy Bevan \& Son on behalf of the fovernor's afuresaid, DO severally hint and oblige themselves, their several \& respective Executors \& Administrators reciprocally, each unto the other in the Penal Sum of One hundred Pounds sterling, firmly by these Presents. In WITxess wherenf the said l'arties have hereunto set their hands \& Seals the day and Year first alove written.

$$
\begin{aligned}
& \text { Wilday Smitil "Seal." } \\
& \text { Truotur Bridx \& Sox "Seal." }
\end{aligned}
$$

SEALED \& DELIVERED, (being first dus

Stampt) in the PRESENCl of

\section{THOMAS GRAHAM. \\ WiLliaM TUMMAX.}

After reading the Above Articles the board Adjourned to meet again To Morrow Mlorning

William Smith Apothecary, attended, \& Agreed to Enter into the service, and to use his best Endeavours to perfurm the same for the General benefit of the Institution, concerning which some remarks were made for his Government therein.

Thos. Boulter's tern as alprentice having expired fugust 26,177 . a sult of apparel was provided for him, and he was engaged as A sistant Apothecary, and on the resignation of Dr. Smith, March 1 2, 1773 , he was directed to supply the place "until a more suituble perion can be provided."

The same year, the Managers decided to select an Apothecary after a competitive examination, accordingly this was duly conducted by the Medical Staff. which made the following report and recommendation :

The Eugfisli Apothecary (unters itpon his duties and unbserjucontly resigns. 


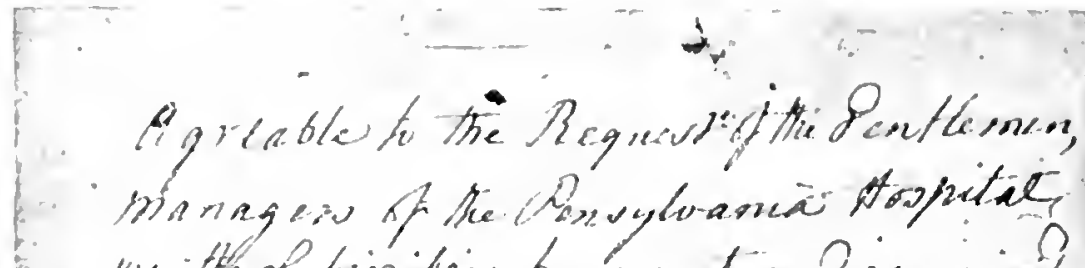

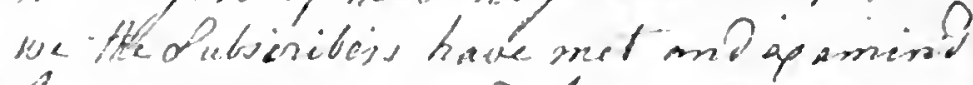

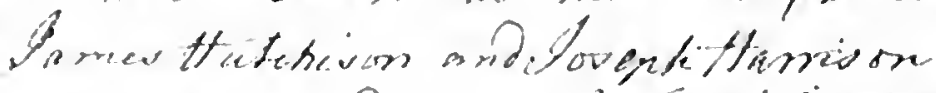

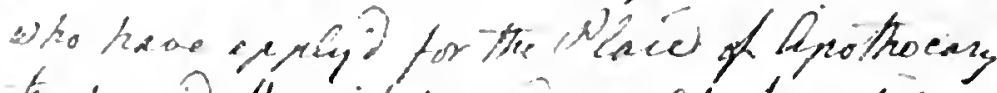

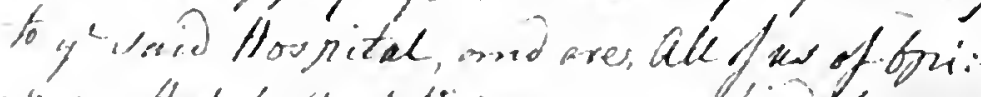
Hem that bots of thein are quateleci for

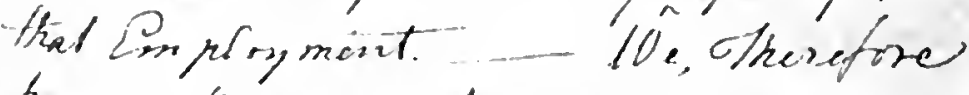
haces retherig wore to say we ise torig the Phace of lerition of the on han that itappen is us the Intozst of sine Noveritat weill be inomited fy the Choses of hem whose future

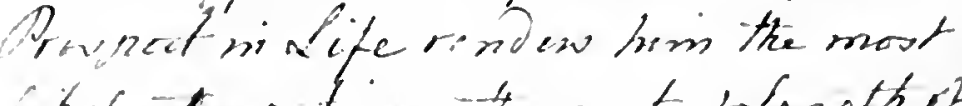

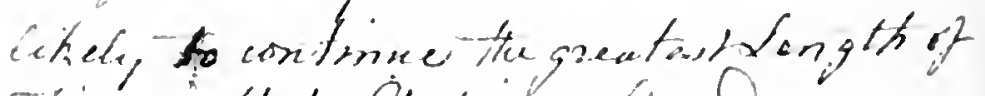
Time m that fotaten signed

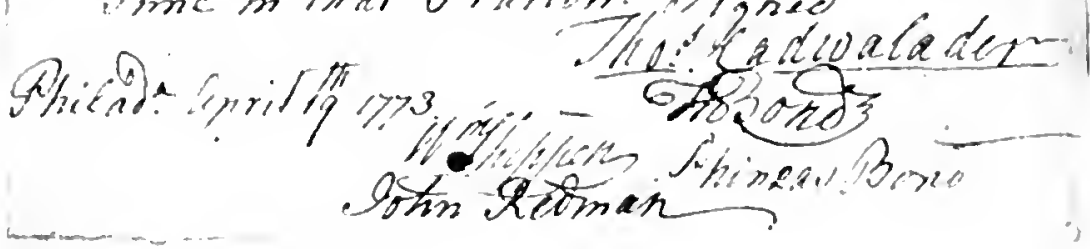

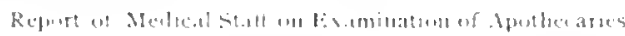

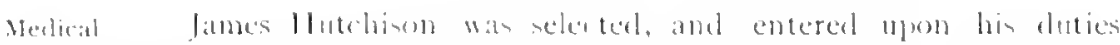

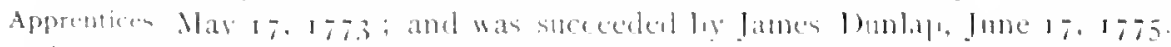

to act an In the meantione, a medical appentire had been taken, lalob Ehren-

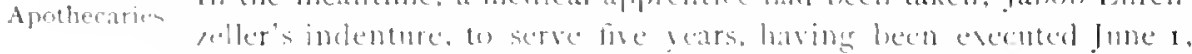

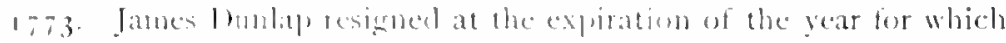

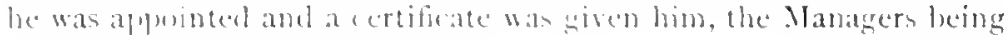
well satistice! with hivermoluet. 
Abont this time, there applears to have been some dissatisfaction with the management of this lepartment and the Steward, John Story, was directed to attend to the Apothecary's cluties. Mr. Story appears to have had no small amount of confidence in his alsility, for on lecem. ber $26,177^{8}$, he offered to combine in himelf. the functions of I'hysician. Librarian and Apothecary, in addition to those of the stewarel. It appears that Mr. Story must have actually exercised these several functions, or thought that he had, for on November 15,1779 , be sent to the Board an account for wages as Physician, Resident Apothecary. and Librarian, but as the Managers could find nothing upon the minutes anthorizing this expenditure, it does not appear that they allowed it.

February 29, 1780, Peter Yarnall. who applied to the boarl for the office of Apothecary, "for which he expects no wages, only to be provided with board and lodging," was chosen as Apothecary and Librarian. Three months later lir. Yarnall received permission to employ Thomas Hughes as an asintant.

Said Hughes to be allowed bis loard amb longing in the Hospital and the value of a Spanish Milled dollar in paper currency per month, Dr. Yarmall to furnish him with necessary clothing.

The following year, June, 1781, (iustavus Fred Kielman, an Apothecary, was recommended ly the physician, and it was agreed to employ him and that he "be found in meat, drink, washing, and lodging." He resigned at the end of sixtcen months.

Dr. Hartley succeeded 1)r. Kielman, and served for fifteen months.

May 11,1784 , Dr. Nathaniel B. Waters offered to serve for one year without salary and was accordingly aplointed at the end of the year. At the end of three years' service, he resigned and a certificate was given him, the Board conferring upon him the privilege uf attendance upon the practice of the house, and also the tree use of the library.

At this time, the Buard again decided to permit the duties of the Apothecary to be performed by the aplentices. Ir. Waters offering to assist withont pay, when at leisure. Wm. Gardner, who was aplointed Apprentice and ansistint fuly 30. 1797. succeeded to the office, and served nutil the end of his apprenticeship, March $2 S$. I79I, when he turned over the office to Edward Cutmish. another resident student, who had legun his alprenticeshif. September 27 . 1790. Wm. Gardner was duly presented "with the use of the library and the privilege of attending the practice of the house at pleasure."

Me.dical dpotentices fuserve as Apothecaries. 


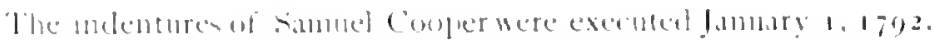
rerans on and, two bar later, he signed a receipt for imeruments, allatomical

Medical in prentices: am Apulberites

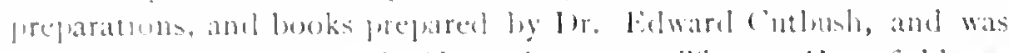

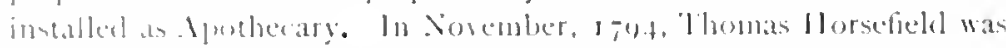
conplused an ansintant, and an agreeneme approved and executed.

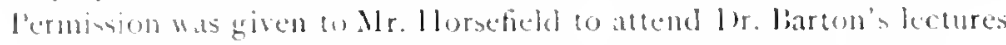
(1) lintan?.

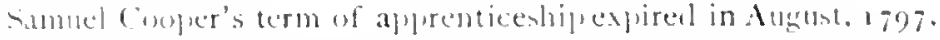
when 'lhomas llorefiedd took (harge of the pharmacy. A rote of

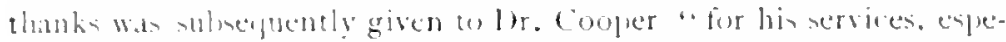
- bally for his great care of patiente during the yetlow fever." also the privilege tor life of the library and practice of the 1 lomede. In Nevem-

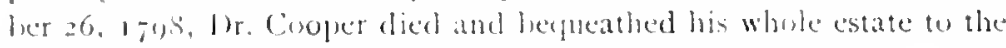
llopplat, alter making grovision for hinding out his young negrocs.

the following certificate of a medical apprencice was signed by lor. (raik, who had lecen Physician to Irevident Washingubn.

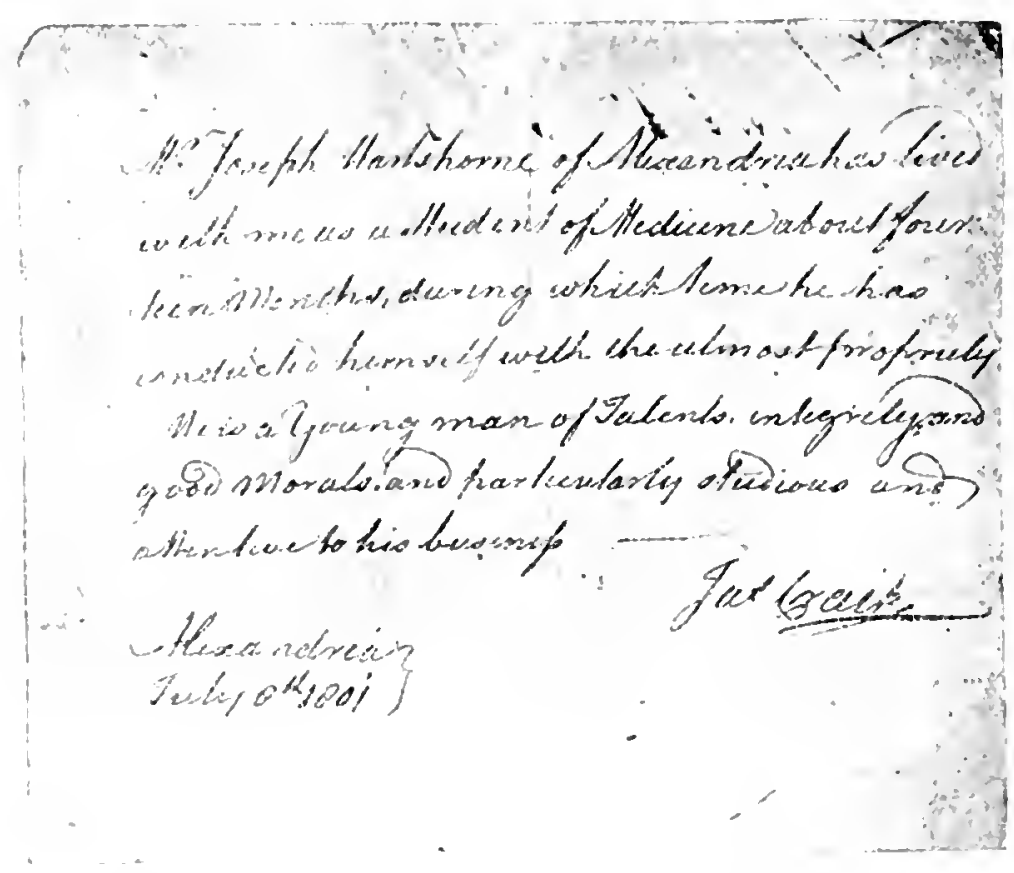

In 1800 , when the centre lublong was completed, the apothecary shop was transerred to the south rom oppusite the achinistration office, where it has since remitined. 
The apjrenticeship of 'Thomas llorsctield would have expired November 24,1799 , but on Octoler 28 th, he was released and permitted to leave, in order to accept a pusition as surgeon on the ship Medical Apprentices. "China," which was about to sail. A certificate was given to Dr. Horsefield. George 1.ee, a pupil of Dr. Samuel Duffield, was accepted as an apprentice October 30, 1797. At a meeting held July 28, I 800,1 r. Wm. Hartshorne made application to have his son Joseph admitted as apprentice when 1)r. lee's term should expire. Dr. Lee's health being poor, he was recommended a sea royage and a change of occupation. He was sulsequently released from his indentures, his faithful services commented, and he was given the usual privileges of house and library. Dr. Jas. Hutchinson. Jr., supplied the place of Dr. l.ee, from 1799 to $\mathbf{1} 804$.

At the expiration of five years service as resident puyil, Dr. James lfutchinson. Jr., delivered the books, etc., to Joseph Hartshorne, who served until the expiration of his term of five years, in I $\$ \circ 6$, when the usual certificates and the privileges were roted.

This method of combining the offices of medical apprentice and apothecary was continued nominally until $\mathbf{s} \$_{24}$, when the office of medical apprentice was discontinued, and it was decided to choose graduates in medicine only for resident physicians. As early as iszo, however, vacancies were filled by graduates in medicine by the election at this time of Rolvert J. Clark. M. N., to fill the unexpired term of 'Thomas Flanner.

The Board, in is 4 , at length adopted the plan of internal administration, which has leen in satisfactory operation for the last seventy years, by appointing an educated pharmacist and relieving the medical staff and the resident physicians from all responsibility in this department. Graham Hoskins, a qualified pharmacist, was elected in I $82 \mathrm{I}$. After two years service, he was succeeded by Rohert Harris. who served only ten months, and who in turn was followed by Samuel C. Sheppard, who remained fourteen months. The successor, Newberry Snitll, Jr.. aplointed in 1825. served four years, and Franklin R. Smith succeeded him in 1829 . He served for two years, when Dr. John Conrad was chosen to fill the position. From $1 S_{3}$ I to $\mathrm{x} 870$, Dr. Conrad faithfully performed the duties of the office, and won the affectionate regard of all who came in contact with him. The following resolutions were adolted ly the Board upon receiving his resignation:

Fesolited, lhat in accepting the resignation of Dr, John Conrad who for 30 years has held the situation of Apothecary to the Institution, the Buard desire to express their sense of the failhful and satisfaclory mantuer in which he has 


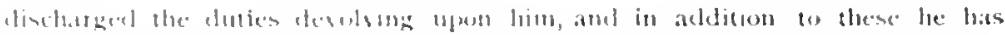
11, Jutan lesoted nuch time amb allention to the care of the garden and green honse.

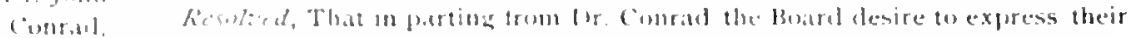

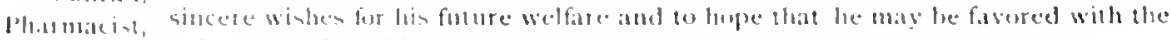

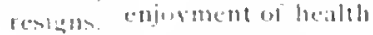

fesoberd. That the huspitilities of lhe llouse and the use of the Library and

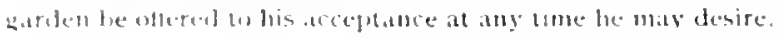

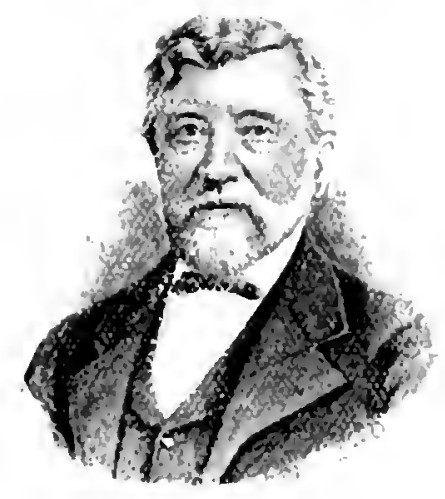

1)r. Conritel was lurn lunce 21 , sisro, wan a graduate of the leffer. sim Nedical College, 1850, and died ()etoluer 15,1 sist.

() his retirement from the Ilespital, a numler of the intimate merlical friendsol ibr. Conrad mate up a purse of st500. which they presented to him ats a tangible token of their regard.

On the twenti-first of lieleruary, 1 sisi, at a mecting of the Nedical staff. ex-kesiclent Physicians and friends in the library. a portrait of ior. Conrad was pre. sented to the Hospital be the committec, and the following minute was adopted:

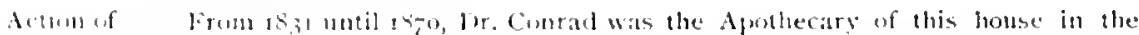
Sorely of department for the sick. The list uf Resident lhysicians cluring that time includes Hinevident fhysichens. mang have won more than a local reputation, but whether widedy known or not, or whether living or dead, is there one among them wheser forgot Juhn Conrad?

He was learned not only in his art, hut in scienc:" in literature, and in language lte nas a loser of poety, of llowers, and of chileten. Ilis dedights were with his gurcter, his bouks and his frients. Ilis cares were mostly sympathes for others. He never matriced, yet his lowe for man and woman never deet.

He Memory leng will live alone,

la all our hearts a menornfiul light.

That broods aloove the fillen siun

And dwells in Heaven half the nighte.

the interest shown lig I)r. conrad in the garden and esperially in his roses, was a matter of freepent comment, and recalls the hact that the physicians hat in presious ycars attempted to establish a lotanical garden which deserves a few words of recugnition.

A But.uniail

'lo carry ont the project of cetablishing a "Botanic Garden" Garden. suggested hy the fhysicions and surgeons, the Hoard of Managers resolved feebruary 26,$1 ; 69$ :

Thit a consenient part of the lot westwatr of this llouse mat be allotted towards planting a butiunc Garilen. 
This Garden was at first proposed as an adjunct to the "Elaboratory," which was built during the summer of 1769 . It is mentioned in a letter written by the managers to Dr. Fothergill about this time, in which they reported jrogress as follows:

A Botanicat

rarden

Propesed.

We have been at a considerable expense this sunmer in building a House and Purchasing the Apparatus for an Elaboratory, expecting a considerable saving in the Expense of Medicines.

The proposed garden was to furnish the necessary flants to be used in the preparation in the Elaboratory of various tinctures, etc., needed for the patients. Although a measure intended to promote economy, it is evident that such a garden could not be supplied with sufficient quantity and variety of plants to meet in any practical degree the requirements of the physicians' prescriptions, but it might have considerable value from a scientific and educational standpoint. The garden continued in this unformed condition for over five years, at least it is not again mentioned during that time, in the minutes. On May 9, 577 , the monthly committee was instrueted to inform the pliysicians.

Thit if they will meet and agree on a list of such medical books, as are necessary to be added to the Medical Library, the Board is willing, out of the funds allotted for that purpose, to apply such Sim as may be necessary for purchasing them, and they are likewise desired to communicate their Sentiments of the best Method of obtaining a compleat Collection of Plunts and Herls to furnishour Garden in such manner that the proposal long since made of having a good Bolanical Garden may be efiecled.

From which it may be inferred that the garden at this time was far from being complete, if any steps had really been taken towarcls its establishment.

The Conmittee reported:

That a conference had been held with the physicians in resard to the Gardess and that the latter decided "to give sheir opinion in writing."

This communication was read at a meeting held June $27.17 i t$ :

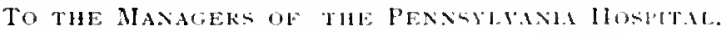

The Sugiges.

Genllemen-We are pleased with your proposal senernsly to execute a plan tion approved of a Botanical Garden formerly agreed upon for the benefit of the Pennsylvania by the Medi. Hospital, which we think may be made useful to that noble Instutution and it cal Staff. appears to us that the present Garden and bot of fromol Northward of the Hon. pital, within the Square, will be most fit for lise purpose.

We doubt not rou will join in opinion with us that the sooner a shillful Botanical Gardener is engaged the better.

We are Gentlemen, lour very ready Friends,

THus. Camwlame, THos. Bond

WII.IM SHIPPL, JOHN RETMA.

June the ;h, 1774. 


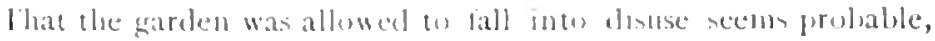

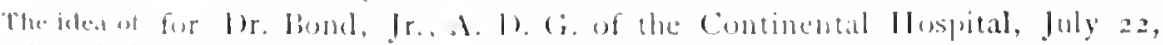

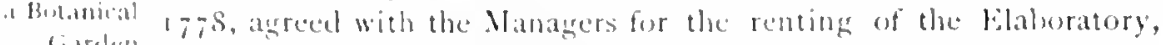

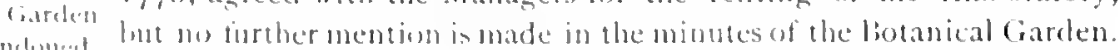
Abenthined. le in presumalile that expericmes showed that the preduction from this source would not justify the expense of providing a sardener exclusibety for the are of medir inat plants, the design was finally abandoncel and the plot latil ont in flower leds.

Ifl the engravings of the Hospital show the presence of latrge trees around the ludikings. In Mr. Malin's "Some Account of the llospital," pmlilished in 18,32 , it is said that it is surrounded on the borkers of the sifuare by majestic forest trees, which he stated were "Buttomwood, wr fecidental Plane, trees, the largest growth of the North American forent; they were planted in the 1 ear $1756 \mathrm{by}$ Hugh Roluerts, one of the first Nanagers of the institution." Within the grounds, attention has atso leeen directed to the setting out of trees, maler the shade of which the patients were permitted to rest, wr take exercive in the well lajil-out garelen. Among the trees most denerving (1) notice is an elon which has an interesting history.

- ind it ithe lin:m lism.
The minutes of the Honpital, derted dlay 26,1810 . state that "at seion from the roes of a wee ratled the direat Elum of Kensington. seinl to have heen the sime tree moler which William l'enn, the proprieter of lennsidanial hedel the first treaty with the lontians, was presented ly Matthen V.mblucen, atmel phanted by Peter lirown. lisel., near the centre of the westernmont lot leetonging to the llospital: for which lecter lirown is replacented to return to Natthew Vandnecn the thanks of the Momagers, and wo procure a box to defend it from injury. The farent tree was lown down in a late storm."

The "westermmont" lot cetended from Xinth to Tenth and from spruece to Pine strcets. When Clintum Street was opened, the curb-lise respired the remural of the historic clm; for sime time an elfore wals molle w

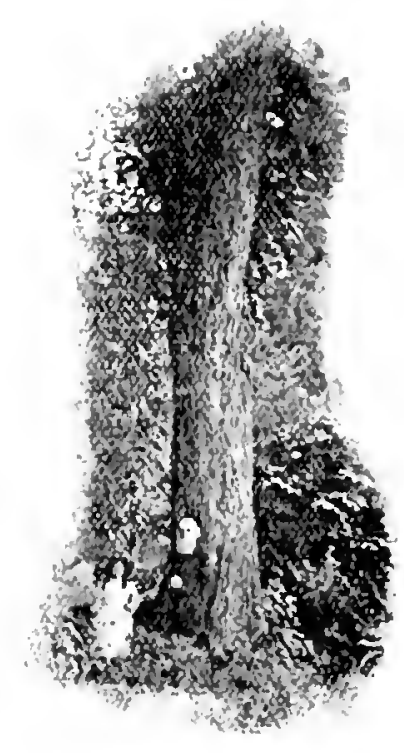


preserve the tree by paving aromnd it, lut finally, in 1841 , it was cut down. Then it was that Mr. Charles Rolserts, one of the Managers, The and the Steward, Mr. Malin, secured cuttings, several of which were planted within the grounds now included in the llospital inclosure. One developed in to the now magnificent tree, which stands only a few feet distant from the southeantern end of the new Menorial huildings. One brancli which at first grew well, was subseruently blown down. Another was planted in the grounds surrounding the Intane Department in West Philadelphia, where it now stanch a well grown tree. ${ }^{1}$

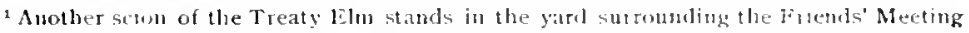
House in 1'welfth Street, hetween Market and Chestunt. The hramches of lhis heautiful tree spread themselves ont to the roof of the Meting House. In this bouse, und the hranches of this elm, a few years ago, a meeting was bold, in wheth representatues of the Sionx, Arapahoe, Comanche and other Western Indiuns, had a loving conncil with the Friends, the descenlants and brethren in faith of those who were with lewn, two humbed years ago, under the old elm at Shackamaxon.

When the Treaty. Fim was blown down, in 1810 , it was determined hy it 1 rings that it was at least wo humbled and eighty-three years old. Durms the Revolutionary War, when the bitish occupied the city anl firewond was extremely scarce, the l'reaty 'l"ree was several times in danger of the woodman's axt, hut was saved hy the british officers on account of its history. General Semcre, who had command of the troops at one time, ontered a squad of British soldiers to protect it day and night. When the tree was blown down, many persons sought, as relics pieces, of its wood, which were carverl intu chairs, whes, petholders, and varions other anticles. A pitcher was also marle oust of its wood, which war reyardecl at that period as a marvelous piece of carving. The Pliladelphia Association of coopers purchaseal it and presented the redic to General Jackson after the battle w New (1) leans. This picher is preserved, with other objects of interest, at the Hermituge Mustum in Temnesee.

Aftet the Treaty Elm was blown down, no efort was mate to mark the spot until is $S_{-}$, when an association of citizens, organized fur the commemoration of historical subjects, comnected with the history of Pennsylvana, and called the Penu society, was formed. I he first move this organization made was to oltain the right of placing a small mashle monnment on an colosure al ground on leach Street, Kensington, wear where the grcat n.lm stomol. This memorial was the first juhlic momment erectod in lohiatelphia, and is, there. fore, of lumble inlerest. It is a plain bluck of marble, upon a marlile base, ahout four fect high atul in the shage of a truncated pyamid, topung from the base. The lustiptions on the stone are as follows:

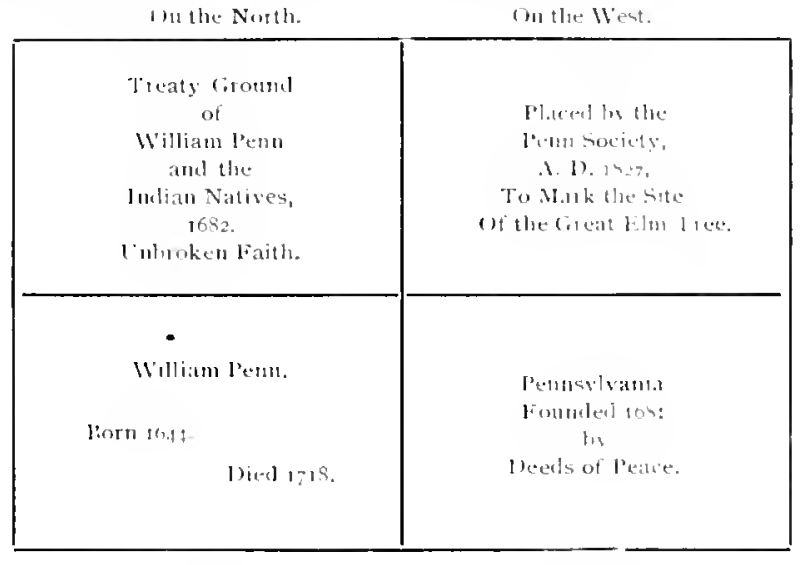

() I the south.

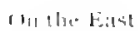




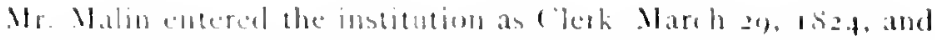

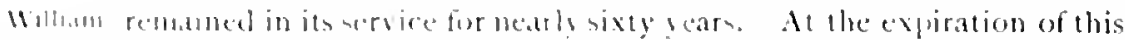

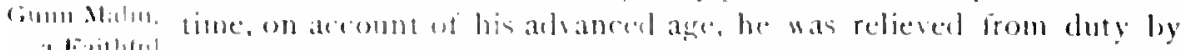
at Fithlutul the lioarel, which, in consideration of his faithful, desoted, and long service fensinned him, and offered him a home in the hosprital

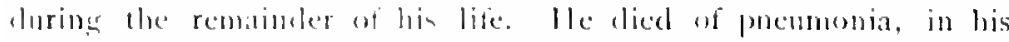

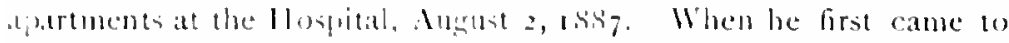
this combery as an immigrant from lingland, in risz, he was obliged (1) work as driver of a brewer's wagon, and ont of his savings he returned, lefure the end of a year, to his parente, his passage. money to America. The was fortunate in fombing more congenial

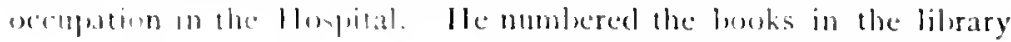

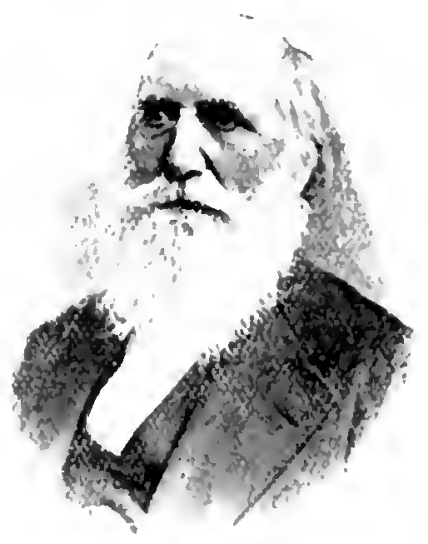
and make a catalogue, which he fircented to the board Jamuary 26 , 1529. and it was orelered published. In septemiser of the salle year, it was issued, together with an intro. buctory steteh, aho prepared hy him. of the history of the Medial bilurary. Two years later, ly direction of the Managers, Mr. Malin compiled a small work entilecl. "Some Account of the PennIVimia IIospital; its Origin, (Mjects, and Present State," which wils alse prublished ly the buard. in 1s.80, when the leprartment for the Insane was opened in West Philadel.

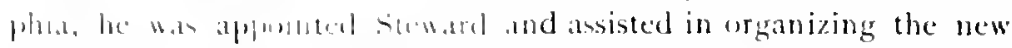
administrotion. Nine year bater, he was made Steward and practically Superintendent of the lepproment for the sick and Injured, which position be filled until 188,3 . when he was retired from active eluty. Mout this time. be wit complimented by having a dinner given in his homer by the Isocittion of Ex-Residems l'hysicians, many of whem hat leen ansoriated with him cluring his long service in the institution. The libary was used in which to beld the banquet, there were llowers and speer hes, and the faithful steward occupied the seat of henor. On this ocrasion, a life-size portrait of Mr. Malin in oil was unveiled and formally presented to the llospital by the Associa(i,n of Ex-Resialent l'hysicians. (See also page roz.)

On his retirement from his active dutien, the following minute was mate the fart and the action of the lioard thereon: 


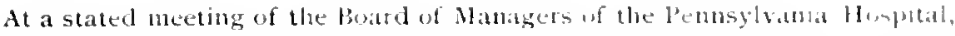
held $2 \mathrm{~d}$ month, $26 \mathrm{th}, 1583$, the following was unaminusly achoted.

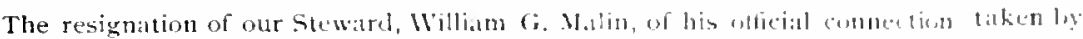
with our Institution, which was continted for fifty-nine fears, impeses tlu duty which we freely recognize, of placing on olu records some testimonial uf ont appreciation of his services to the lennsylvana lluspitil, during the long prod rod througl which those services were rendered. Thetefore,

Resolacd, That while we have aceepted the remignation of un friend Mbilliand

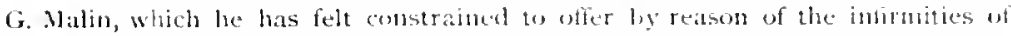
advancing alge, we accompany that acceptanec with the declariation that it is difficult to over-estinjate the value to this Iospitinl f fis intelligent, assicluous and faithful discharge of all the duties of the various offorial positins which he has held in this lnstitution for almost three-score years.

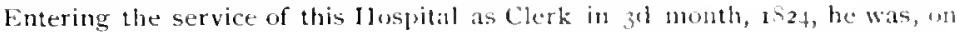

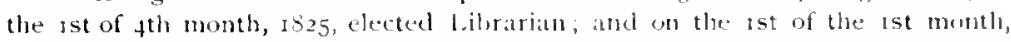
$18 \$ 1$, to the office of Steward, and from thenceforth has been continualy re-terted to the latter office. During all this periot, by the unanimous judgment of all the successive members of this Board, as alsu of the l'lysicians and surgents, who, from time to time, have composed our statt, and under whose ubservtions his labors in this lustitution bave been rendered, he has fulfilled the arduous and unremitting duties of lis position to their entire satisfaction, and has impressed upun every one concerned for the welfure of the llospital, the profunnd assurance that all his dealings have been characterized by the most scrupuluus integrity, and the most sedulous care for the interest of our lustitution and its inmates.

Resole'd, That we deem this Institution and the many thousands of patients who have occupied its wards while its Stewitrdhlip was tu the hands of our friend, William G. Malin, very fortunate in having had his larme experience and watchul attention, constantly exercised for their henefit; and we recognize and acknowledge it as a great blessing that a kind l'rovidence has protonged lis days, his health and his usefulness, througl so exceptionally long a term.

Resolied, That in severing the official relations which he has lun wo tong held, to this Hospital, our friend may be assured that he possesses the confidence and affectionate regards of cvery member of this board; and we express our sincere desire that in the home which we offer him, in the Hospital for whose prosperity and efficiency he so long and well labored, lie will find all the comfort and kind consideration, which he so eminently deserves.

Resolied, That a copy of the foregoing l'reamble and Resolutions be cugrosined, signed by the President, Treasurer, and all the Memters of this Boart, and presented to W'illiam G. Malin.

William Malin, the grandfather of Mr. Malin, was a revident of Preston Capes, Northamptonshire, Englancl, wherc his son, John Malin, was born, who removed to Woodforl llabe, and married Mary, the daughter of John Gunn, of Banlury : of this union William Biongaphical siketels of IVilli.tul Ginul Miliu. G. Natin sprang, a scion of good English stoek. Ifis parents were religious and of Moravian conncetion. l'he grandiather on the mother's side was a descendant of ()laf Rolfon, a noted Yiking and Vice Jarl under the Earl of Orkney and Caithness: the youngest son of the adventurous Norseman was named cimni and hence the 
surname (imn arose in the family that chamed through its founder Bungaphical relationshipl o the "lourds of the lsles" and "Kings of Man," sketch of famous in utury and song.

William Willium Comn Malin wa lern in Woodford, near Bifeld, North. Coun Nalin. amptombire, Enolaml, Vosember 7.1501 ; he had scant schooling at Eyolum, a his tather intended to erfilp him for no higher station than that of market carrier to lianlury and leventry. lieing impresied with the idea that he was destined for letter things, he took fasiage in a saling ship, the ". Massasoit," for Baltimore, lut a storm drose the vesed into the port of Boston, ly which means he providentially escaped the danger of yellow fever which was then epidemic in his crginal place of destination. IJe made his way to fermantown. now a part of the city of Plaladedphia, and found sccupation temporarily: A pear later, he considered himself most fortunate in receiving the alpointment as Clerk and subseguently was appointed Librarian.

Ilis handwriting was very legille and so regular that it was almost like eneraving. Mr. Malin was largely selfeducated and was a modest and diligent student. He lored books, enpecially old blackletter English solumes, preferably. Bibles and works relating to the history of the Moravian Church, of which he was a life-long and consistent member. Nuch of his leisure time was occupied in poring over his choice posscssions, which included works in latin, Janish, Dutch, French, German, Italian, with which he made so much progress as to be able to translate the portions in which he took the most interest. It his death, he leefueathed his library in trust for the Moravian Chureh, at Bethlehem, Jennsylvania, and it was regarded as a particularly valuable collection, since it pessessed unigue copies and rare works un the carly history of the Church, the fruit of many years' patient studying of catalogues and correspondence with dealers in all parts of the world and, the expenditure of money which cont much elf-denial to save. As a result of his wide reading. Mr. Malin was a well-informed man and, althongh he did not seck comversation, being rather renerved in his manner, yet he showed ly his remarks that he had good judgment and possessed a mind converant with a multitude of mbjects in art, literature, and popular sciences.

In his intercourse with . Ianagers and lhysicians he was always most courteons, cheerful, and cordial in his manner. llis long association with the physicians of the institution was unmarred by any unpleasantness, in tari, in conseguence of his uniform amiability of demeanor, many of the residents and members of the Medical Staff became his life-long, (herished friends. Mr. Malin, soon after his transfer to the Pine Strect llopital in I 8.49 , married a lady who had 
formerly been an inmate of the institution; but she died in a little over a year afterwards and without offspring; he did not marry a second time.

Although Mr. Malin's tastes did not incline towards medical studies, he showed great interest in the treatment of the insane. As the result of his nbservations, he presented to the Board of Managers, in $x 82 S$, an article on the necessity of providing a separate asylum for the insane; and again, in $18_{34}$, a paper on employment of the insane. Mr. Malin's views possessed so much originality and force as to lead the State Committee on Lunacy to publish these papers in its annual report for the year 1884 . Copious extracts have also been made from these papers on another page of this history. (See pagre I $_{4}$ ).

Mr. Malin was buried August 5,1887 , in the Woodlands Cemetery, Philadelyhia, and his collection of historical and bohemian books have a permanent resting place in the library of the Moravian Brethren's Church, at Bethlehem. His portrait is in the hall of the Hospital, just at the entrance of the office where he lived for so many years.

\section{APOTHECARIES.}

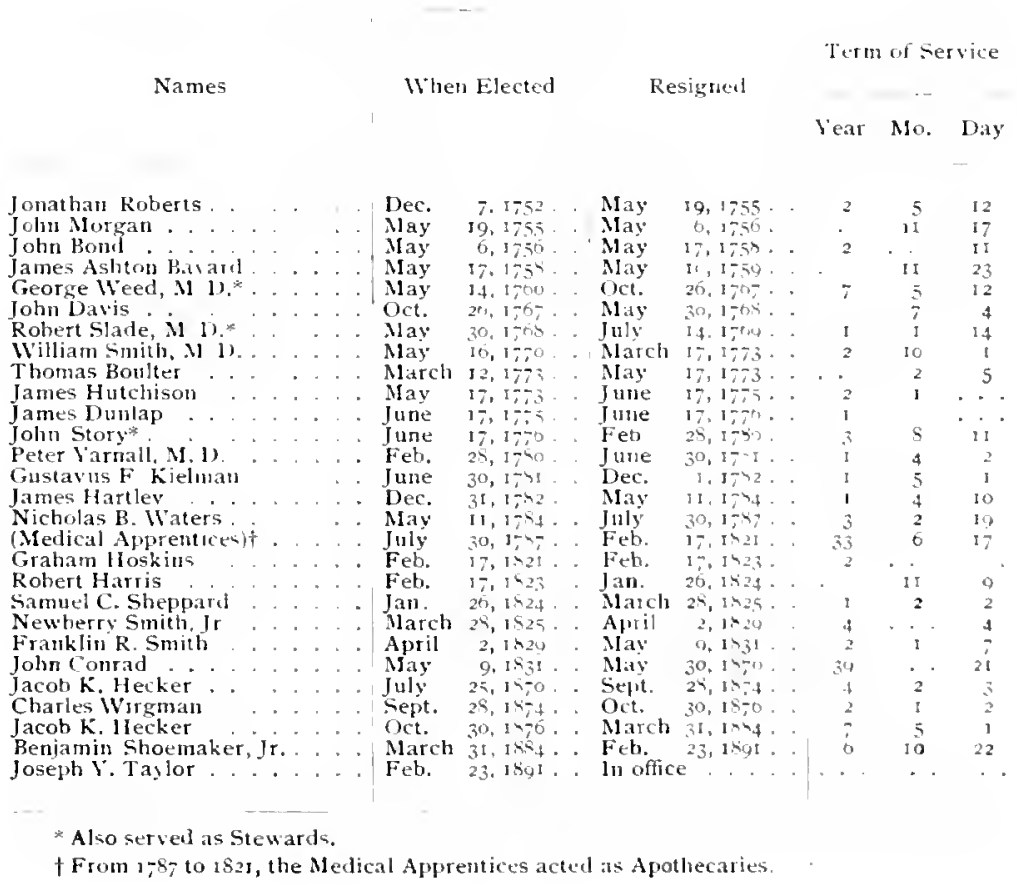


SIEWARIS.

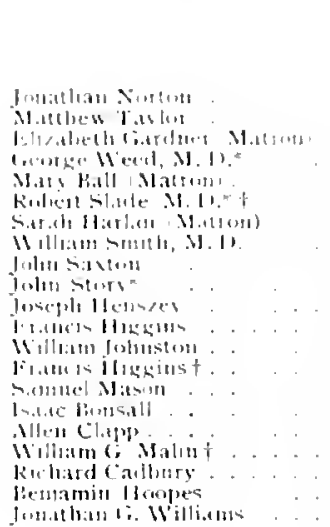

\begin{tabular}{|c|c|}
\hline tot. & $1 \therefore 17$ \\
\hline Dい。 & $\therefore, 1,1=\mathrm{m}$ \\
\hline Viw. & $\because 17=0$ \\
\hline VI. & $14.1 \%+0$ \\
\hline 13t. & $\therefore 1,1$. \\
\hline Mlis: & .19 \\
\hline Ints & $11.1 \%$ \\
\hline M.1y & $11.1=-13$ \\
\hline $1 .+1 i$ & $2: 1,1 \ldots i$ \\
\hline fich. & $\therefore 1 ; \%$ \\
\hline I.ch. & $20,1,-4,1$ \\
\hline T.11\}. & $\$ 0,1-1$, \\
\hline Nin. & $18,14,3$ \\
\hline AHg. & 11,19 \\
\hline Fel. & $1 ; .141,3$ \\
\hline Mirch & $13,14=0$ \\
\hline l Ict. & 11,14 . \\
\hline May & $s, 1<H_{2}$ \\
\hline Mpril & 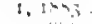 \\
\hline Nos. & $2 \pi, 18 x p$ \\
\hline & $51, I x_{1} 1$ \\
\hline
\end{tabular}

\begin{tabular}{|c|c|c|c|}
\hline$N_{1}$ & 2.1751 & 1 & 1 \\
\hline Nos. & $27,1-51$. & 1 & \\
\hline X.t. & $1 \mid 1,1 ; x)$ & & s \\
\hline 131. & $\therefore 1,1,0$. & 7 & 5 \\
\hline Miy & $30,1,-1,4$ & & T \\
\hline$|\mathbf{a}|$ & $14,1>(x)$ & 1 & i \\
\hline M.15 & $12,172,1$ & . & (1) \\
\hline Mut, h & $17,1 \div 3$ & $\therefore$ & I"1 \\
\hline $1 \cdot(\cdot)_{1}$ & $\therefore, 1=-1$ & $\therefore$ & \\
\hline Feth & $2(3,1,-4)$ & 1 & \\
\hline I:แ1. & io, $1: 1, \ldots$ & 1 & 11 \\
\hline Nont. & 11,$141 ;.$ & ; & $y$ \\
\hline Ans & 11,13 & 1 & $i$ \\
\hline$\because \mathrm{b}$ & 4 inlin. & 1 & 5 \\
\hline Natuch & $1 \therefore 1=2 x$ & 1.5 & \\
\hline 1161. & 11, in 0 . & 1 & $t$ \\
\hline Maluch & 27.148. & in & 5 \\
\hline M.treh & $20,1,3$. & $\therefore$ & 10 \\
\hline (let. & $23,1 \times 40$. & ; & is \\
\hline Aug. & $31,1 x_{131}=$ & 1 & 1) \\
\hline
\end{tabular}

- Mlan meted as Mpotheraries.

; I) Iéd.

\section{MATRONS.}

filizalieth Gandnea"

Either Weed t

Siaryh Ifarlan +

Siplua Saxton

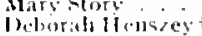

Mars folcourer

indi telenes

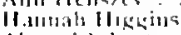

Mlikial Juliunlan

ll:mu,ril llegin

Mary .lasolit

Aling bomsallt.

Margarel Clappt
Mituratet Rohinson

Mitisatioth Romins

bizabeth Honton

il.trret P. Smiti

Mary D. Siliarpless

Amen M. Mores

Mdiales. Thomas . Dec.
Rebeca B. lirowa

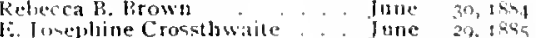

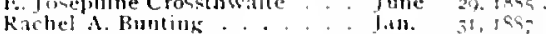

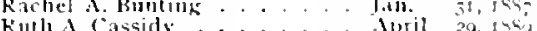

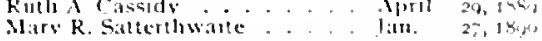

\begin{tabular}{|c|c|c|c|c|c|c|}
\hline Nox. & $0.175,1$ & M.ty & 1.4. 1,600 & 8 & " & \\
\hline M1ay" & 14.17008 & d.1II. & 7.1707 & " & ; & 2.3 \\
\hline March & 2.1707 & July & 25,178 & $!$ & 1 & $\because$ \\
\hline Jisy & $25,1,+156$ & l)ec. & 31,$1 ; \% 2$ & 1 & 5 & \\
\hline Fab. & $28,1: 3.3$. & $f \div \mathrm{cob}$ & $2 \div, 1720$ & 5 & & .3 \\
\hline l:b. & $27,1,20$ & Mav & 1,$1 ; \%$. & -1 & $\therefore$ & 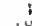 \\
\hline $11.3 y$ & 1,174 & MItTCl] & 19.170. & 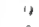 & 10 & 14 \\
\hline $1.16 \%$ & $\nabla 1, j>(x)$ & Ince & 14.175. & 5 & & 1) \\
\hline furse: & $30,191,5$ & . 1:atr. & $30,17 \%$ & & 7 & 11 \\
\hline I:11,. & $3 n, 1-1,1$. & $=0 t$. & $31,1403$. & ; & $"$ & 1 \\
\hline Nons. & $16,801,5$ & $\therefore 112$ & $11,1 \operatorname{son} x$ & 1 & "' & \\
\hline Allg & 11, thest. & $\because h$. & 13.1813 & 4 & 0 & 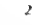 \\
\hline fubs. & $17,1013$. & Mach & $13,140$. & 1,3 & $\cdot$ & $\therefore$ \\
\hline litrcli & $1,3,142()$. & luly & $24,14,30$. & 4 & 1 & 1 \\
\hline oll, & $2 \pi, 15.50$ & X:arch & $\therefore 1935$. & 4 & 5 & I"1 \\
\hline March & $11,2=3.5$. & lı110 & 27.18 .35$. & & 3 & 14 \\
\hline Inuc & $\because 2.14$ is & $31.1 \%$ & $17.14,2$ & $\sigma_{3}$ & in & tin \\
\hline las & $1+1 \times 12$ & April & $24,154$. & 5 & I I & 15 \\
\hline Mlar & 8.14 .15 & $(1+1$ & $1,18 \div 3$. & .5 & 1 & $\therefore$ \\
\hline Seput. & 26,1453 & I:ceb. & $23.18-6$. & 22 & 1 & 27 \\
\hline inls & of $1,14, p$ & (). 1 . & $1,19-1)$ & $\therefore$ & 2 & \\
\hline Dec. & 27,1470 & linace & $30,18 \times 1$. & 1 & " & 1 \\
\hline finne & 30,1894 & Mis & .0 .1895$. & & ! & \\
\hline Junc & 29.1895 & ? & $31,1547$. & 1 & $=$ & 2 \\
\hline 411. & $34,189=$ & Antil & $21,1890$. & 2 & 2 & 24 \\
\hline & $20,144,8$ & I:atr. & $27, I \backslash(x)$ & & " & 24 \\
\hline :In. & $2 \approx 18, m$ & It aifl & & & & \\
\hline
\end{tabular}

- Aeted at times also ai Stewarls.

f piecel.

: In account of foithful service, the Managers voted ber a home for life 


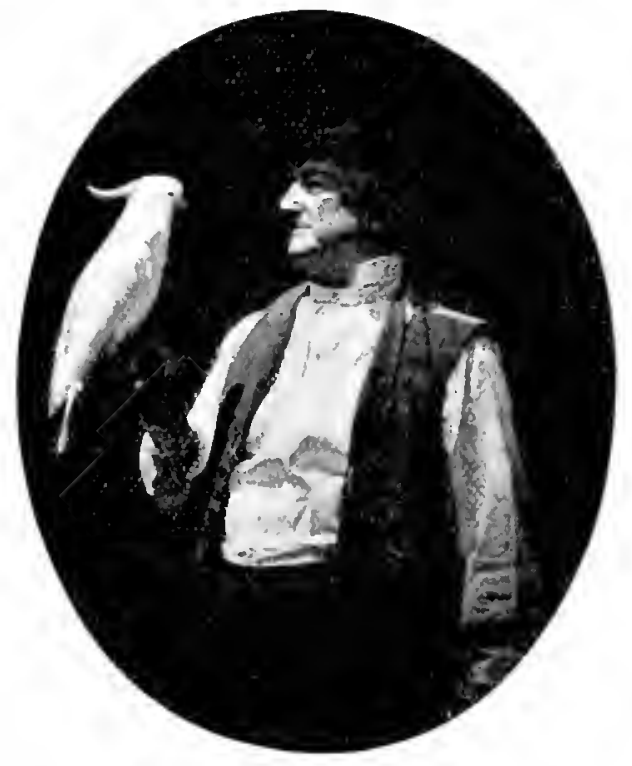

SOME REMINISCENCES.

For a number of years, while Captain George laylor was gate- The Gatekeeper, he kept a large white parrot, which greeted every visitor with keeper and a "How d'ye do?" or "Good-by." The students often stopped to speak to the parrot and taught it some phrases which it learned to use his bird "cruckit." very appropriately. One sentence, which referred to the janitor's habits of over-indulgence in spirits, nearly had serious consequences. because the Captain, overhearing the personal comment of the bird that " the old man's full again," chased the culprit around the garden until he caught it and then handled it so roughly that, in conserquence, it lost the sight of one of its eyes. The following short sketch will interest those who remember the old gatekeeter and his companion.

"Crockie" was a large, white, Australian cockatoo, with a sulphur yellow crest. It was brought to the Hospital by Captain Taylor in i $S_{49}$ and for over thirty years was a conspicuous feature at the gate-house. On the death of its owner, which occurred about is 79 . it was sold to a dealer, who, two years later, disposed of $\mathrm{it}$ to Mr. Cox, of Germantown, who purchased the parrot on account of its historical associations. Mr. Cox presented it to the Philadelphia Zoological Garden, where it died, in March. $1 \$_{92}$, at the estimated age of more than ninety 


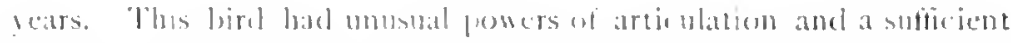
number of floranes at its command to make it a very amusing

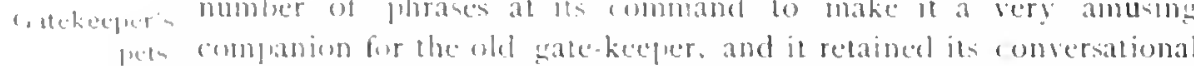

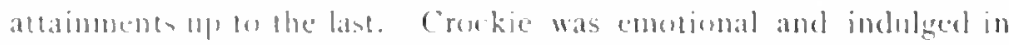
hearly fits af langluter. lut as soon as any one of his andience joined in the merrment, he would burst oul inte a torrent of aluse, with violent se reaniug and coaking and thajping of his wings.

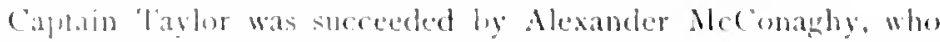
heph a mocking-lingl, a tame stuirrel and other pets at various times, which greatly interested visitors and espectally he thidren, of whom the old mon is still bery fond. Alexander was formerly a patient and had a leg amputated at this hosprial which prectuded him from more ative emplentent. He is now an invalid and a fermanent resident in the Ifosplital. Iy invitation of the lioard of Nanagers, in recognitum of he many years of hithtisl service.

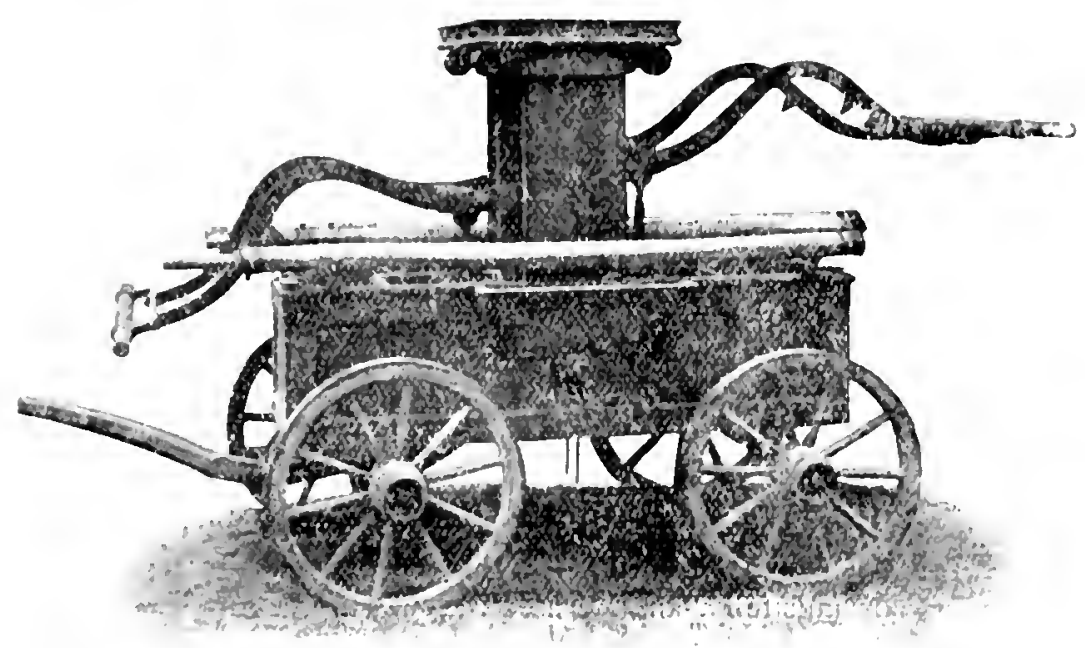

On cotober 25. 1,63. John kennell, line lieasurer, reported

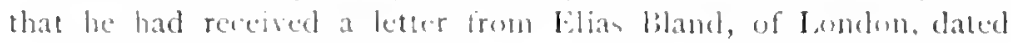
July s zth, in whirls he wrote:

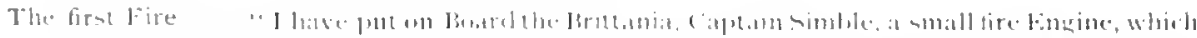

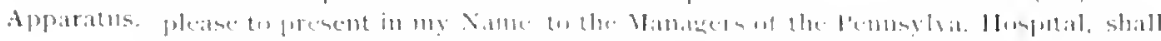

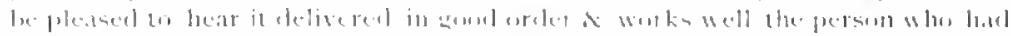

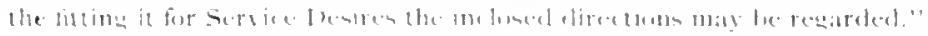

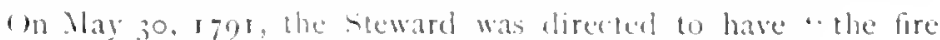
enginc plased csery month at the uncetings of the linard." 
After the Managers had purchased additional ground to the east, south and west, it was agreed, Scitember $27,{ }_{1} S_{3}$, to

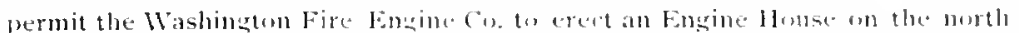

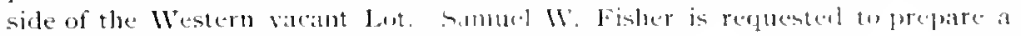
Lease for one Year stipulating the layment of a mall sum ats all Arknowlerigement of their tenancy.

It was thought that the proximity of the Fire Company would be Ground leased to the Washington Fire Company. an additional protection in case of fire in the Hospital, though every precaution was taken against accident, as the following minute shows:

As great dinger to the Buildings \& to the lives of the latients athers may precautions les apprehencled from the unseasonalile use of lights and fires within the hospital, against Fire.

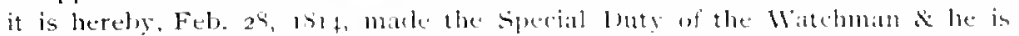
strictly enjoined to extinguish all the lights aml fires exery evening an com mencing his rounds. And to take sare that nome le permitted during the remaining part of the night exeegt suth at sall be Autherizerl for the Aceommo alition of the Sick, the Attendints on the deat or such as maty be necesary in the Apothecary's Shop for the Lise of the Resilent Physician and the Alprentices of the House.

The only fire, ${ }^{1}$ which ever hajpened and threatened to he serious, was on the night of January $9,1 S_{34}$; the record states:

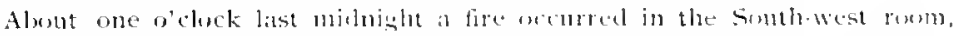
which was providentially axtinsuished without ingury of any of the pattents of much damage to the buildius.

The adjustments of the losses with the Hand-in-Hand and Green Tree Insurance Companies were satisfar torily completed in due time. The cause of this fire was not stated on the minutes, but it may have been caused by defects in the heating apluaratus.

I On October 2-, 1566, thete 1 as a chimmey-fure, which, however, did no damage, but which led to the adoption of precantion tu fuevent shch in atcident from again occurring. 



\title{
RULES AND REGULATIONS OF THE PENNSYLVANIA HOSPITAL.
}

\author{
DEPARTMENT FOR THE SICK AND INJUREU.
}

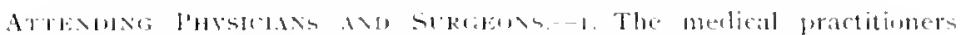
chusen to serve this Hospitat shall be classed with each other, and give their

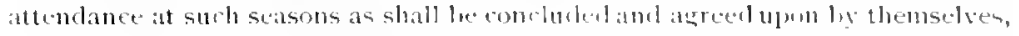
with the sanction of the Maniagers.

2. The l'hysicians and surgens on duty shall visit their respective wads

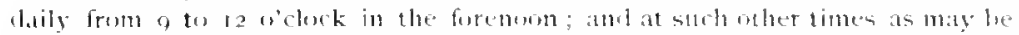
meressary for the faithful performance of their clutieg, and the two surecons

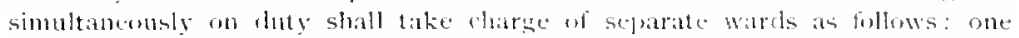
taking the lower Surgical Ward and the Women's surgiatl Ward, aldel the wher the Upper Surgical Wiat

They maly also on the Fourth and seventh day (Wodnestly and Saturday

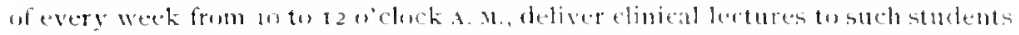
if medicine as may have actuired the right to attembl them.

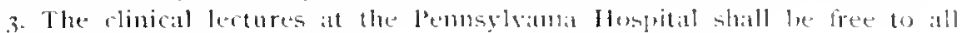
students uf medicine.

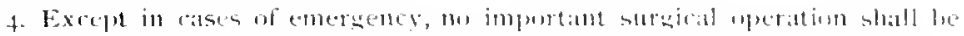

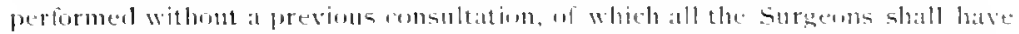
alue notice.

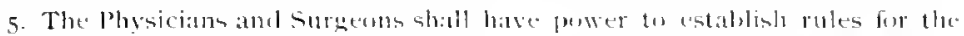

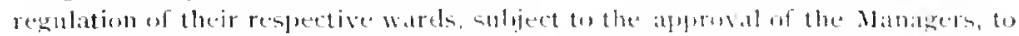
be tramed and home up the rein

6. No Surgern or Physician, without the onment of the Attending Mandgets.

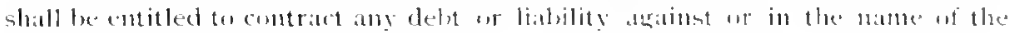
Ilespital, for any sursical, mediont, or meehantiol smples for the treatment or relief of amy patient.

7. Buring the temperary absence of either the Attonding bhysician on

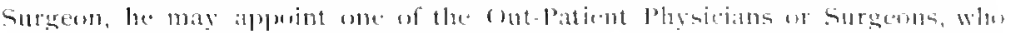
shall during his alsence have clarge of the warl and perform all the lutics per-

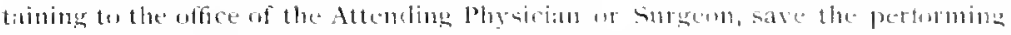

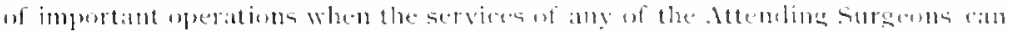

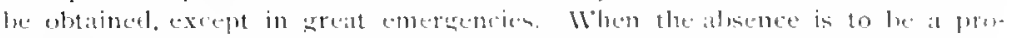

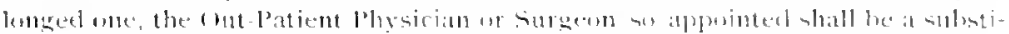

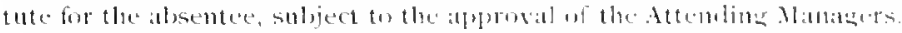

S. All professional services in the lloppital shall loe gratuituma amel any phy

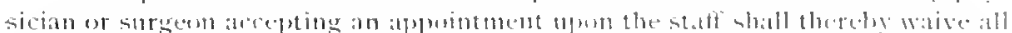

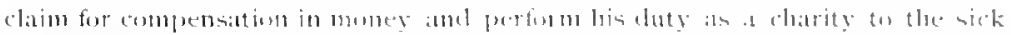

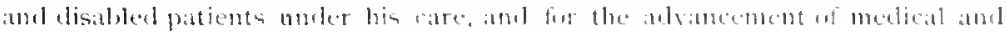
surerical science. 


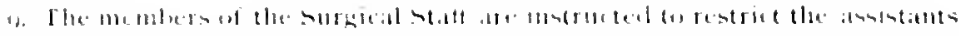

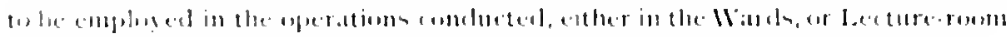

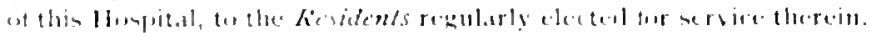

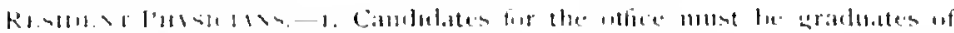

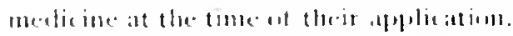

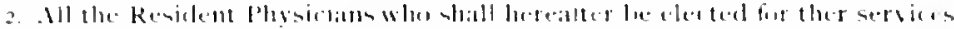

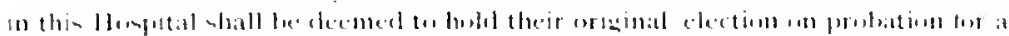

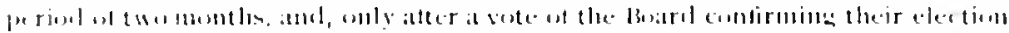

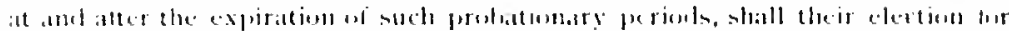

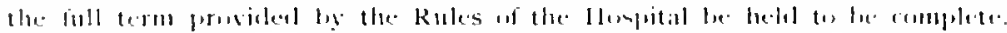

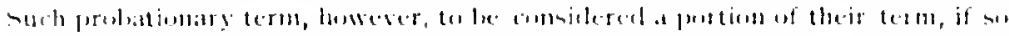
[infirmal.

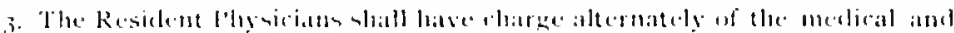

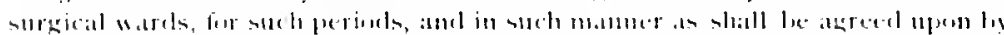

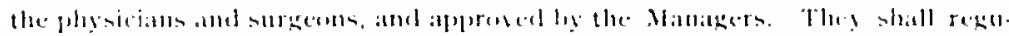

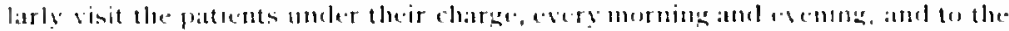

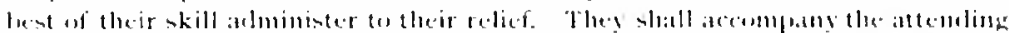

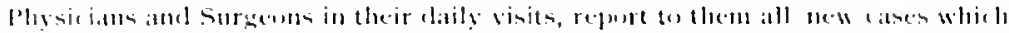

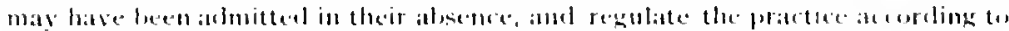

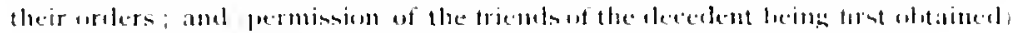

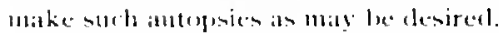

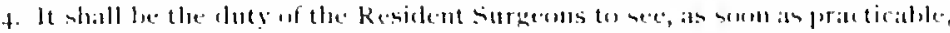

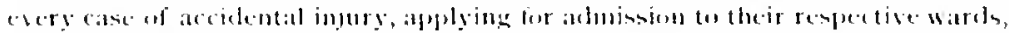

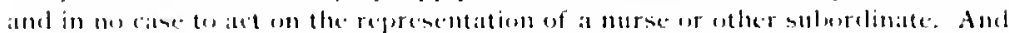

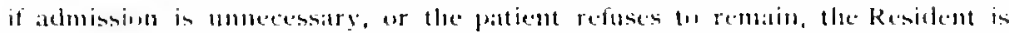

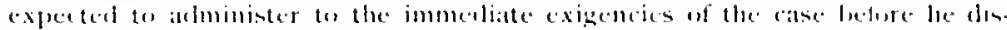
misses it, and shall kecp at reourd therent. And whels eases are sent foum the

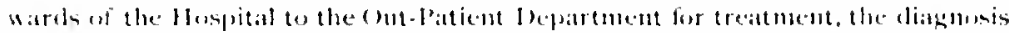

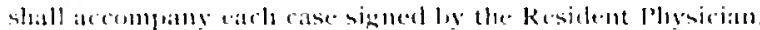

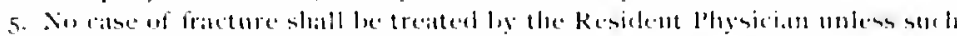

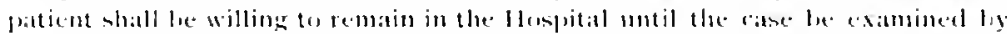

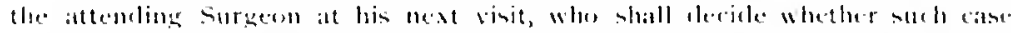

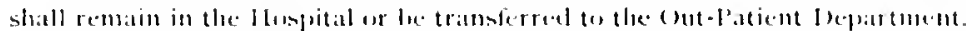

6. It shall he the duty of the kesident Plusicinn lecfore retiring for the night

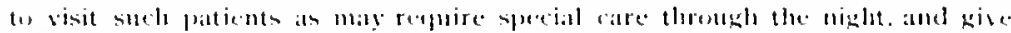

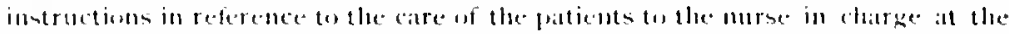

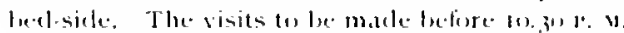

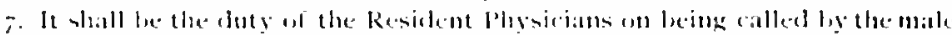

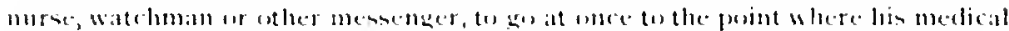

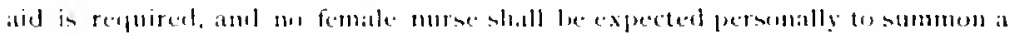

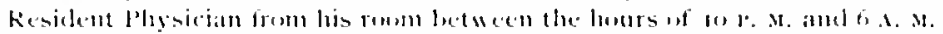

s. They shall alse make written recorts uf all siremustuces attenting the

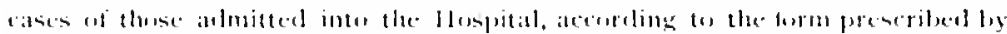

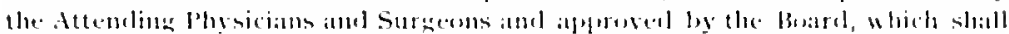

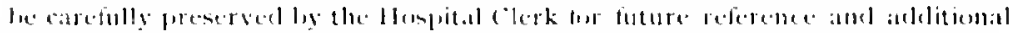

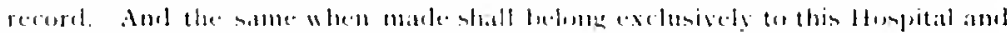

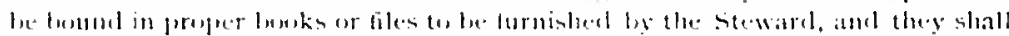

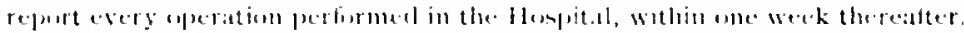

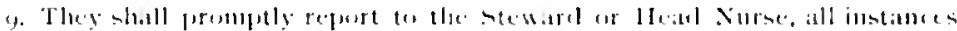
wi neulect if eluts.

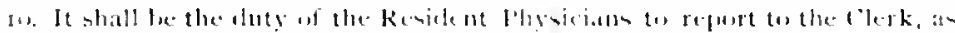

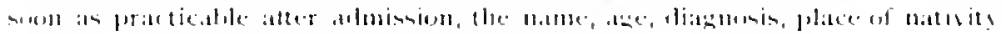




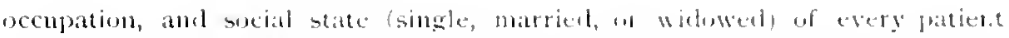
admitted into their respective warls.

I I. It shall also fre the duty at the Resichents to write, lewilly, the diagnosis of each catse on the andissien card shspended over the beel of the pitient, as soon after achission as practicable.

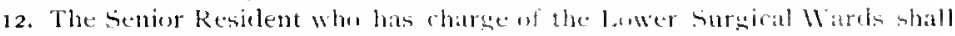

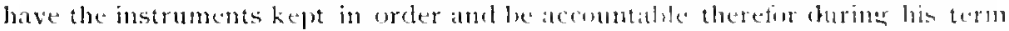
of service. He shall preserve an inventury of them, which, together with tho. instruments, he slall deliser to his successert. No instrument af any kind is ton be loaned to ang ane withent the writen urder of the Attending Surgenth an duty, and a record of such laans shall be preserved.

13. There shall at all times be, wn the premises of the Hospital, twe wi the Resident Physicians, me in the Medical and one in the Surgical IVards.

14. No Resident shall engage in the teathing or pratice of his profescinn, of in any other occupation out of the Hespital, nes shall be charge or receive at fee for attending patients therein, while at ing as kesident Plysician thereof.

15. It shall be the duty of each Resident l'lysician to motify the Curatur and pathologist of every post-mortem examinatin lite makes. Winten the exigencies of the case do mot allow of notice beins sent lueforehame, the Resiclent Physician must, in all cases, send such notice at the earliest practicatsle moment subsequently.

16. The Resident Physicians shall haud tw the clerk witlin nne week after the discharge of ach patient, the complete histury at the case.

77. It shall be the duty of each Resident to fuescric all desirable specintenc, taken post-morkm or otherwise, from the pittents uncter lis care, and hamet them, properly labeled, to the Curator.

15. It shall be the duty of the Resident Physicians to add to the notes ot their cases, the record of the post-whetem eximinations that hate leen macle by the l'athologist, which must be given tu the Resident Plysicians hy him in all such cases.

19. The Physician or Surgenn on duty shall have the pumer af alpuluting a substiute for a Resident who may be unalble to attend to his duties from sickness

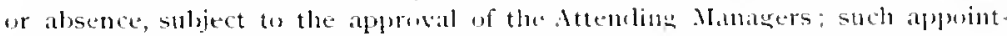
ment and its approval in all cases to be culered on the minutes of the latter.

20. Only those Resident Physicians who hase heen elected, and have setreel for the full term of twenty months, to the satislation of the Boatcl, shall he entitled to receive certificates.

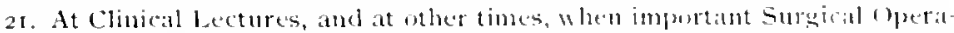

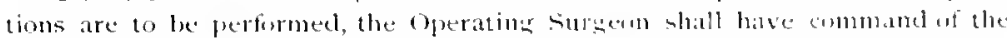
services of the Surgical Residents and alsu, if neecestry, wh those of the Meclical Residents, When their services are not redpured he the l'hysician an duty

The respective duties of the Residents at moli times are to be reablated lis the surgeon.

22. Tle two Seniut Residents mas deliver a combe uf lectures an medicaland surgical nursing before the female nurses, furins the winter manths.

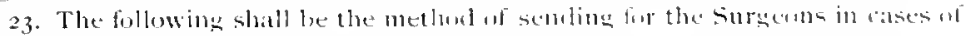
tmerency :

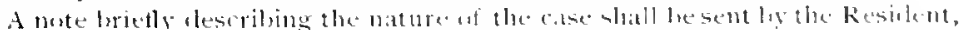

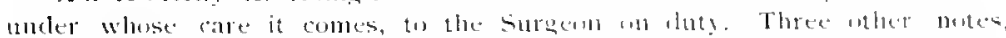

1 This rule was adopted in 1.837 . since that date the number w Recinlents has been mcreaseal. The tetm af service is now twenty-font months, the tirst lims nonth of which must be passed in the Male bepantment for the Insane. 


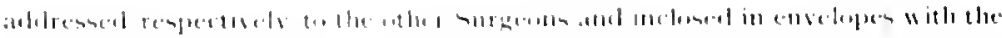

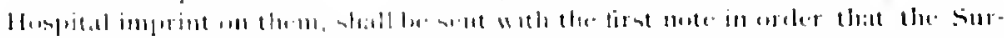

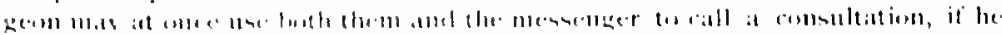

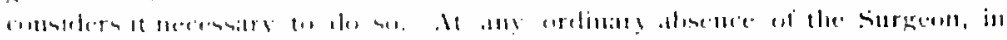

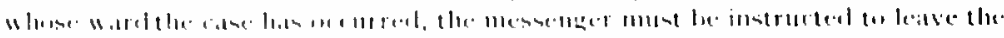

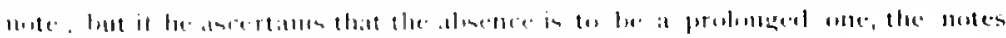

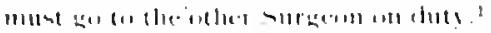

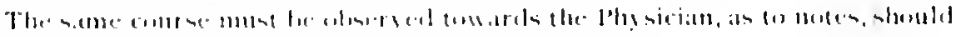

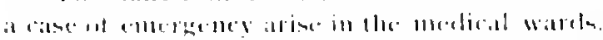

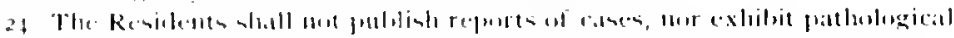

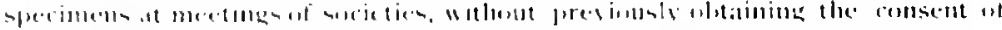

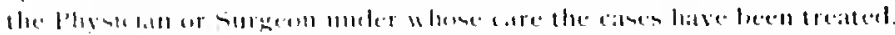

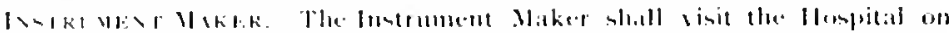

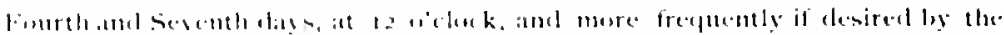

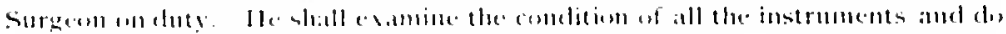

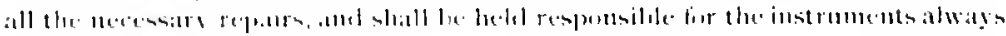

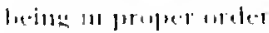

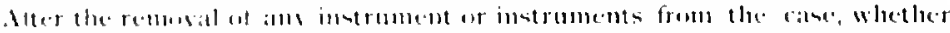

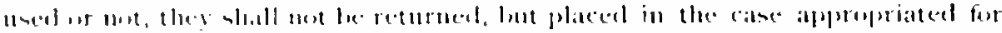

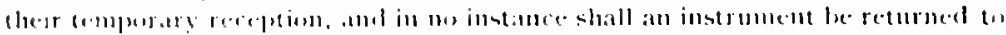

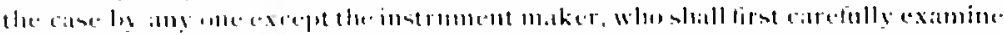

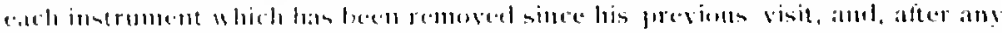

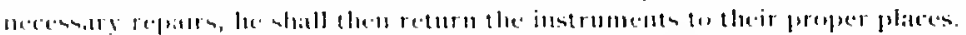

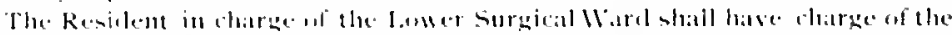

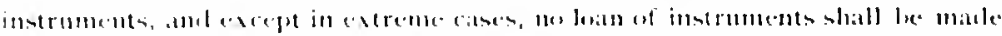

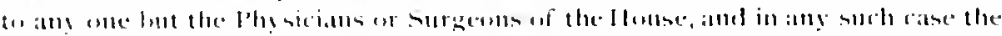

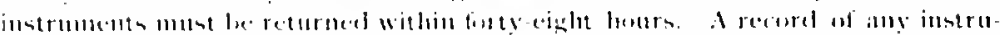

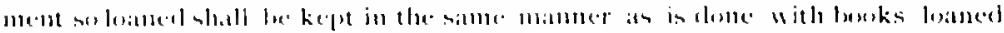

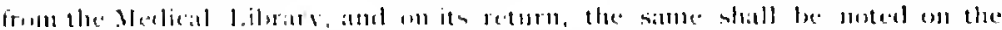
reenorel.

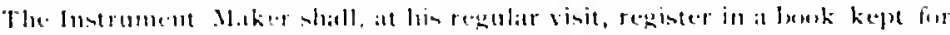

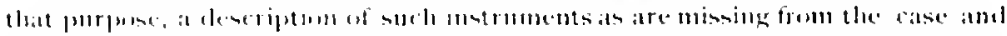

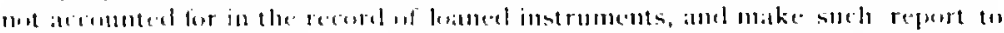

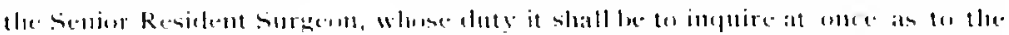

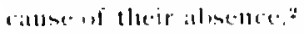

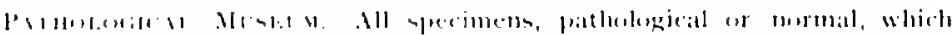

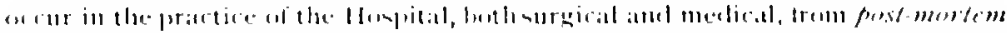

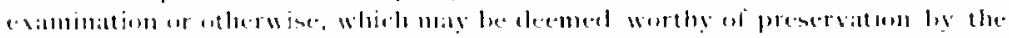

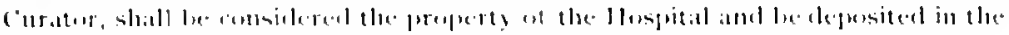
Nureari.

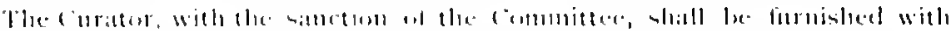

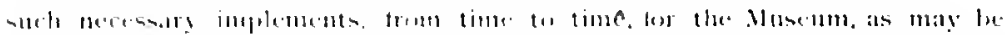

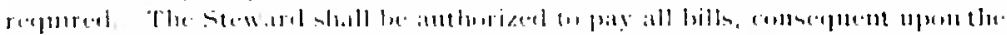

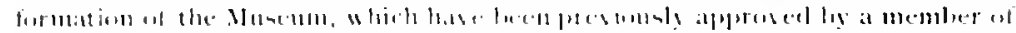

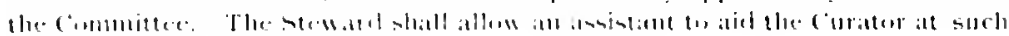

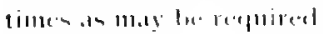

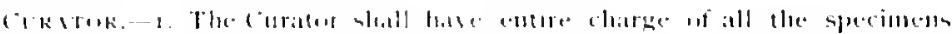

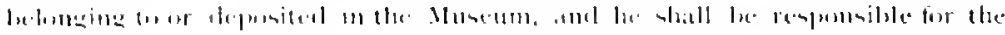
sitme

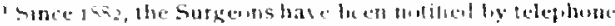

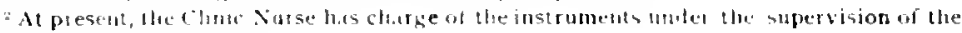
Sengor Resilent lltwin iath. 
2. He shatl keep a register in whill the histury of all the specimens shatl be recoreded, together with a cattilughe of the sande.

3. It shall be the daty of the Curater to have mosuted all the specimells, either as wet or as dried pueparations, as the canc mily redpirs.

4. The curator statl have motion given him hy the Resielent Phesicians ref

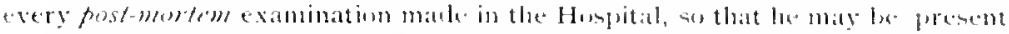
at such examinations and jurlere what sperimens maty be interesting for the

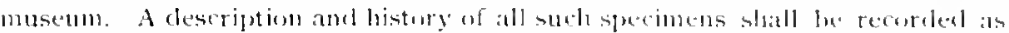
far as praticable and a regut of them be laticl anmually before the board of Mandgers by the curator, at well as any other information connected with this department.

5. The presence on the aceason of post-mostem examinations of ans others than those upun whom official duty is dewolved by the alles of the Fospital, and beresnary attendamt, will not be allwwed.

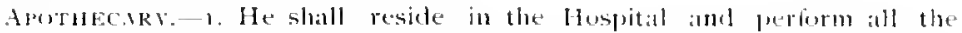
duties appertaining to his department. Ife shatl regularly preserte ererg pre-cription of the physician; and mo medicine or other articie shall be delivered by: him 21 iny person, unless furescribed in fue form.

2. He shall keep records of all medicines purchased ly direction of the Committete

3. Ile shall keep a Meteorologial recurd noting the meanturement of the themometer, bitrometer, anal other metemologinal instruments at stated times of each day.

f. He shail mot alssent himself from the Hospital without nutifying the Steward, and having his place supplied by ont of the Resident l'hysicians, or such other persons as shall be approved hy the Committee, mor shall he permit patients or whers (except officers of the [nstitution) touccupy the shop.

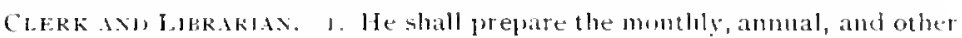
acenuts: and generally perform such duties as appertain to hisoffice, or may be" assigned to him by the Manatgers or Steward.

2. Ho shall have the eare of the Medical Libraty, subject to the rules for the management thereof.

3. He shall receive from the Resistent Plysician a history of eath case, and repurt to the Board at its monthly meeting the number of cases whe record is

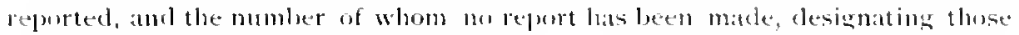
in whose charge the reperts are deficient.

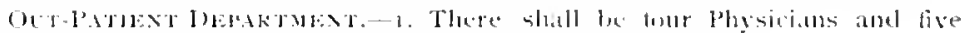

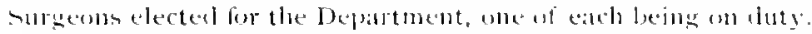

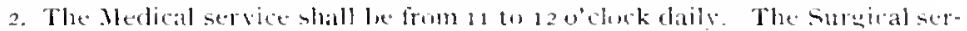

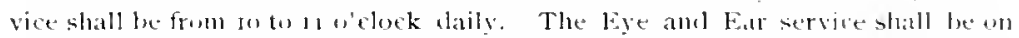

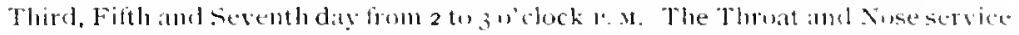

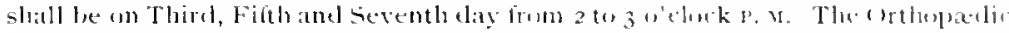

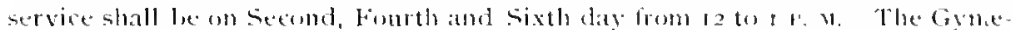

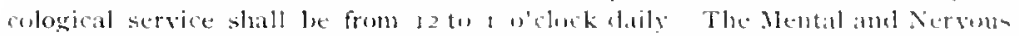

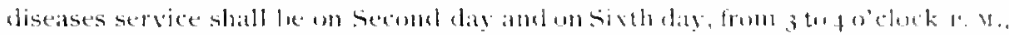

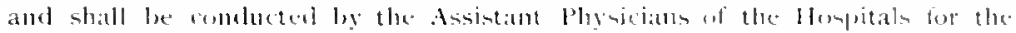
Insaine.

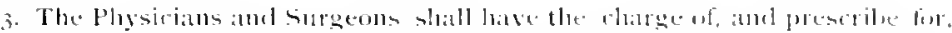

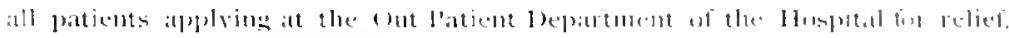

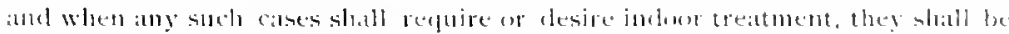

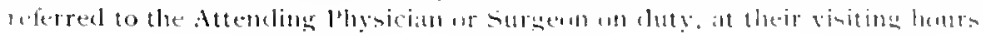




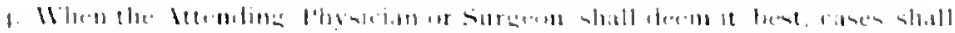

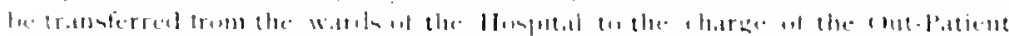

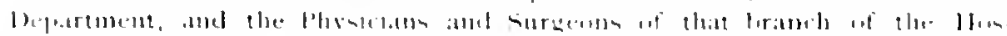

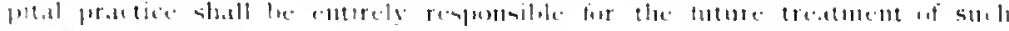
cistes.

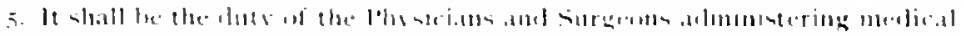

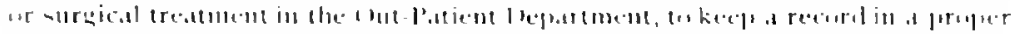

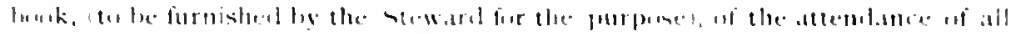

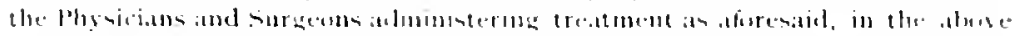
mamed depratument

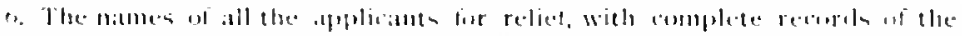

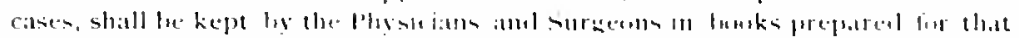

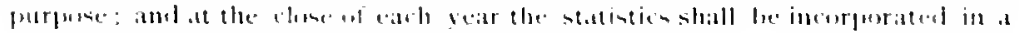

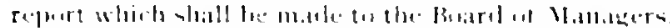

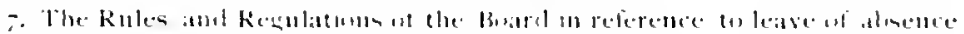

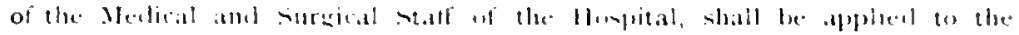

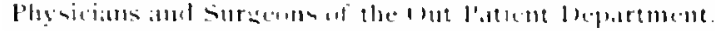

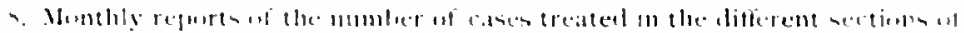

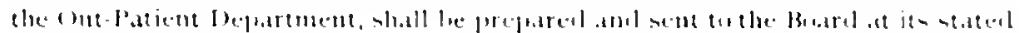
metetings.

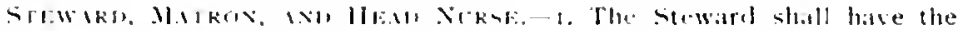

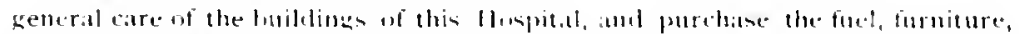

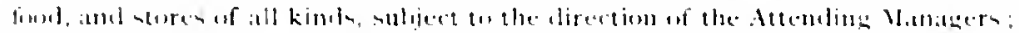

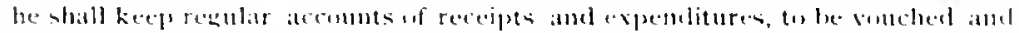

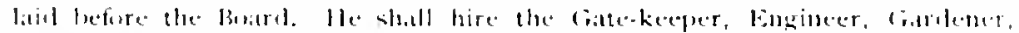

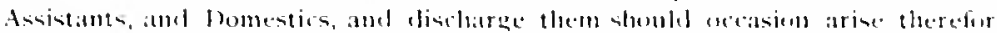

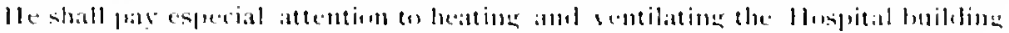
in winter and to its foreed ventilation in summer, to the proper ruming we the

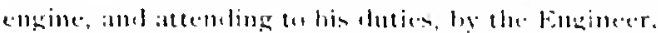

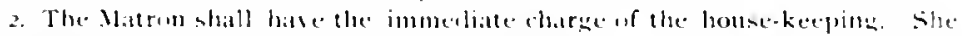

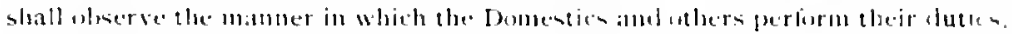

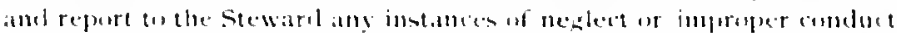

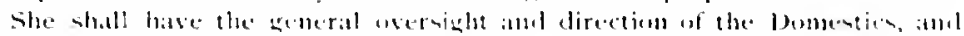

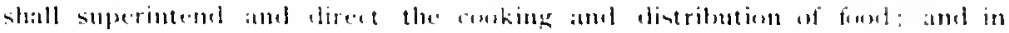

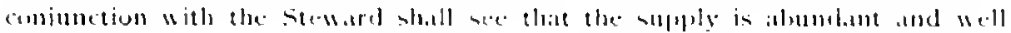
(r) ake.rl.

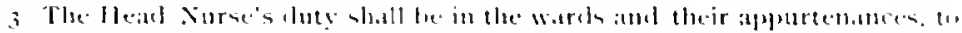

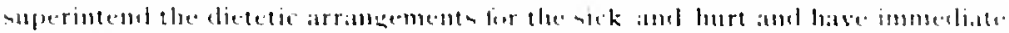

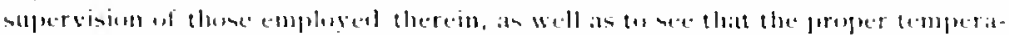

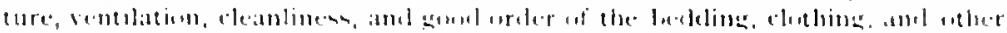

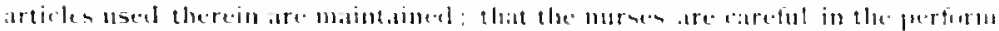

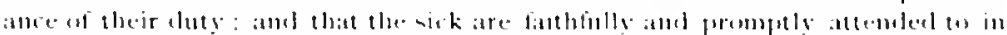

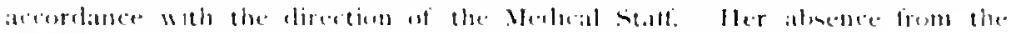

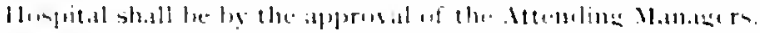

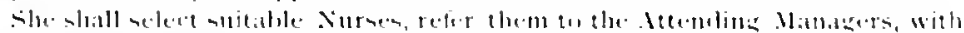

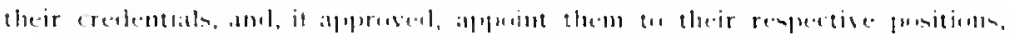

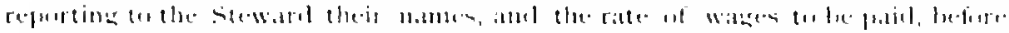

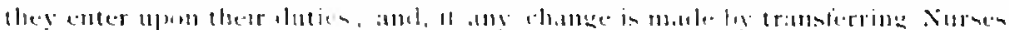

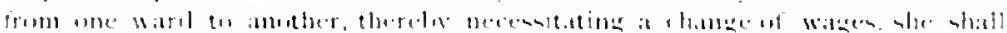

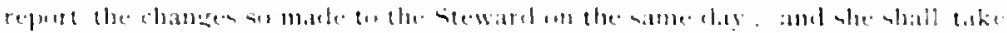

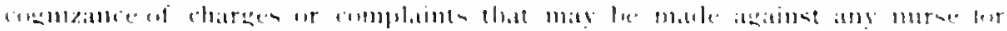

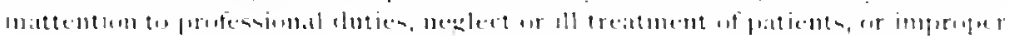


bebavior in the Hospital, investigatte the same, and if subtantiated, she shall with the approval of the steward or Attencling Nathagers discharge the wfender and report the discharge to the Steward without deday.

NiRSES-It is the duty of the murses faithrully 0 ittent the the patients

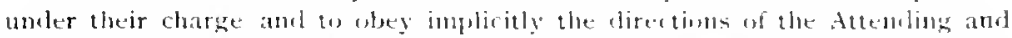
Resiclent Physicians and surgeons in regard to them, to sece that patients bellave with propriety, and oberve all the regulations of the llstitution, and to report any irregularity or breach of rule to the Steward, or Heind ciurse.

1. A graduate nurse is placed in charge of every department of the louspital, and her orders are to be strietly and respectuliy weyed by the pupil nurses uncler her charge. Tht nurses on bight duty are subject to the corders of the Night superintendent, 60 whon they are to alply in all cases of diffeulty.

2. All nurses are rerpuired to treat the pattients with the ntmust arentleness.

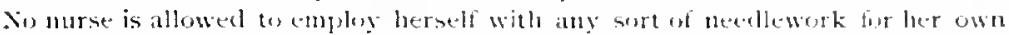
use, or to read any luxh, save one of al professional chatacter, when un duty. Nor are they allewed to empley a patient in any way, for their own personal service.

3. Nurses must not, under any circumstances, leave the llospitil without a pass, bearing the signature of the Heanl Nurse.

4. Nurses are not allewed to visit any department witlunt leave from the Heid Nurse, nor are they allowed to have friends to sisit them in the wards, or to take them round the Hospital witheut permission. They will not invite them to remain all night, or to partate of any neal without lease from the lfeat xurse.

5. Nurses are expected to conform strictly to the uniform worn in the IJospital. No jewelry to le worn. Alt wablang clothes to be plainly marked.

6. Nurses whe are unable 21 go on duty in the morning, must at once inform

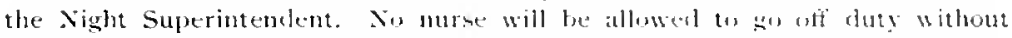
reporting herself to the Head Nurst.

7. Every nurse is expected to retire to her wn $n$ rom at $101 \mathrm{l}, \mathrm{M}$, and all lights to be turned out at to. $3^{0}$. After this time perfert silence is tu he whersed.

$\therefore$. The hours for meals, classes, and duty must le strictly whersed, and

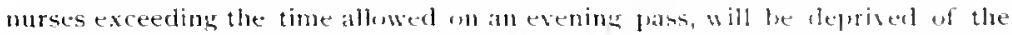
indulgence for a certatin time. Pupil nurnes rise at o .. u., breatiast, b.jo. on

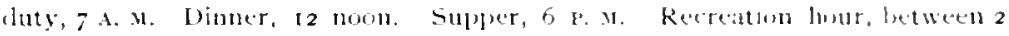

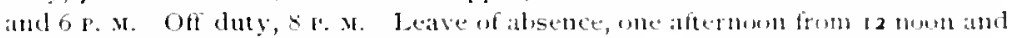
une evening from $+\mathrm{P}$. $\mathrm{u}$, in each weet, is given.

9. A nurse is not allowed to order ally article, or repatir, findm the Matron, Steward, or Carpenter, on her own responsibility. All moch orters must bear the signature of the Heild Nurse.

The term and course of instruction shall embrace a perionl of two geats, the first two months of whieh shall be probstiondry.

Candiedates for aclmision must be women between twenty-ume and thirty-five

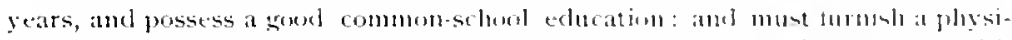

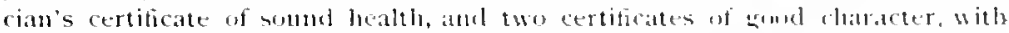

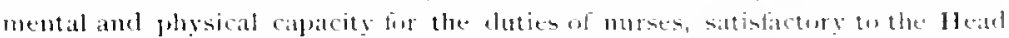

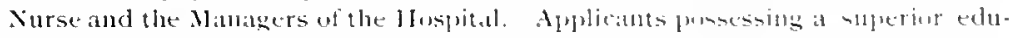
cation and refinement take precelener.

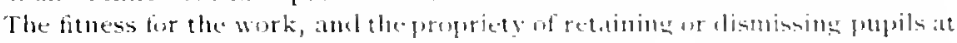

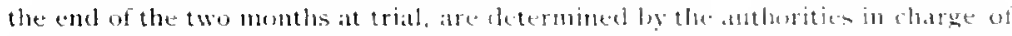

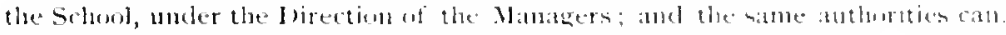

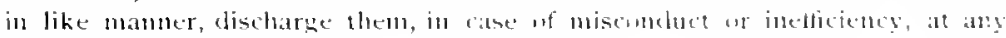
time. 


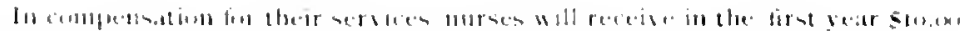

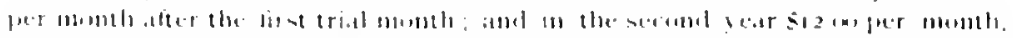

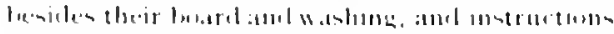

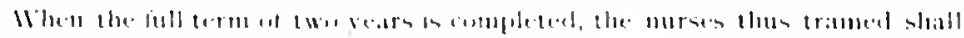

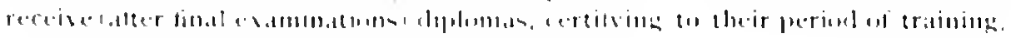

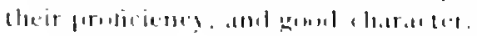

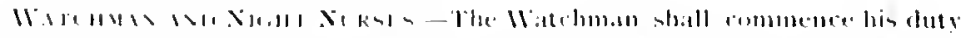

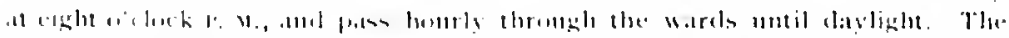

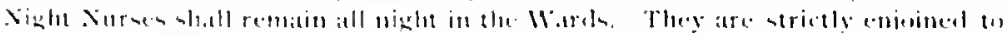

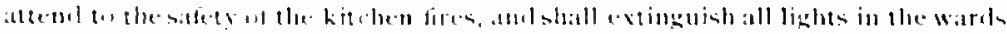

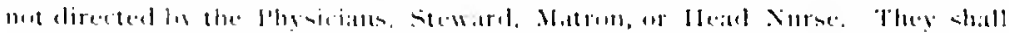

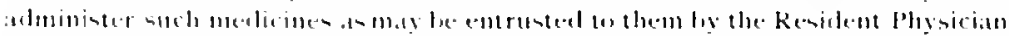

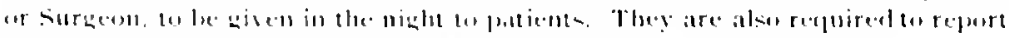

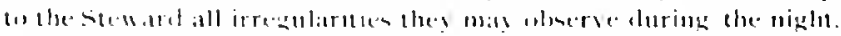

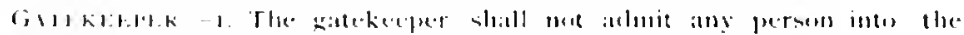

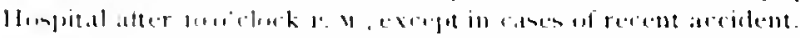

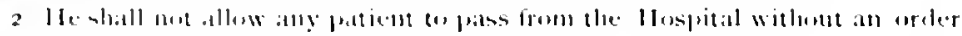

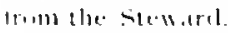

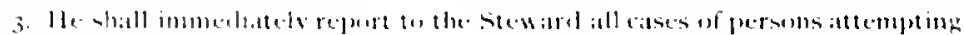

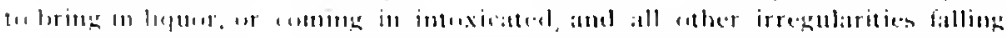

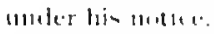

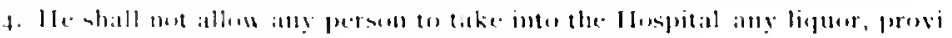

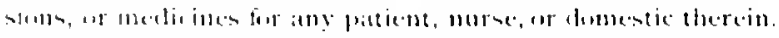

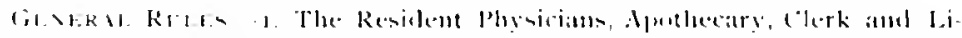

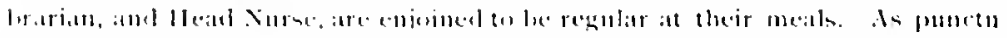

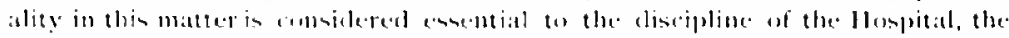

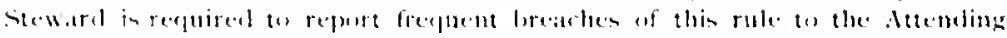
M.111:1200t?.

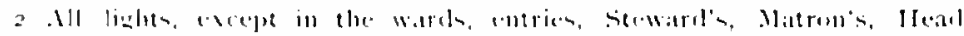

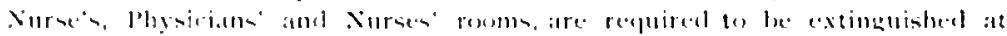

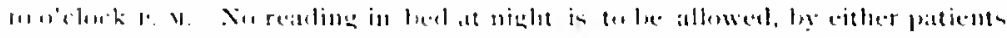

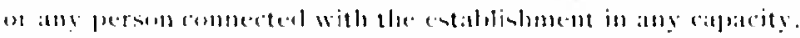

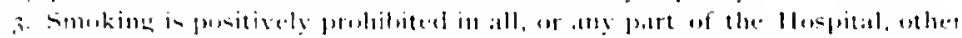

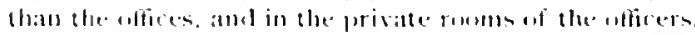

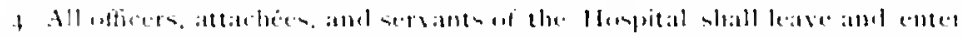

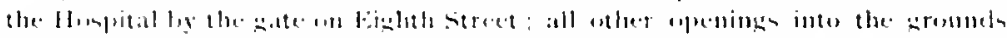

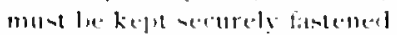

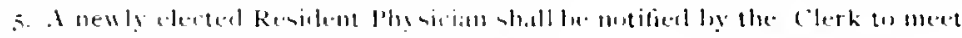

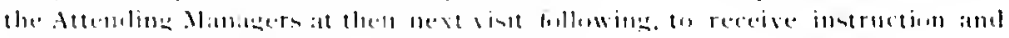

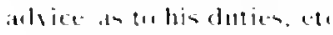

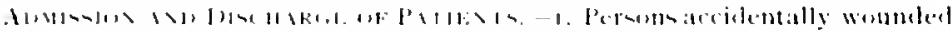

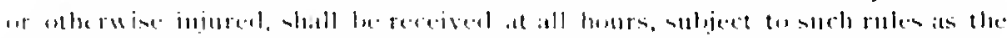

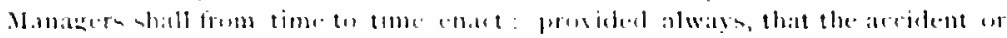

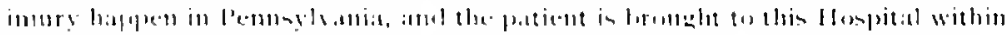

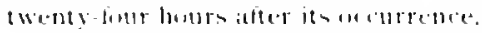

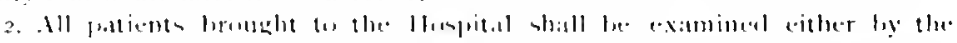

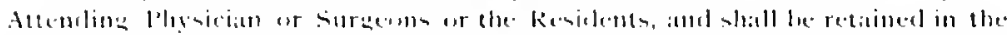

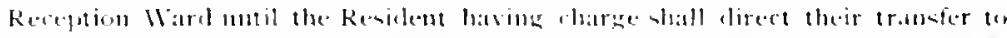

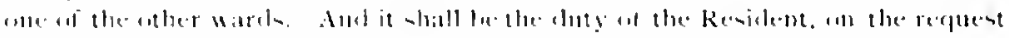

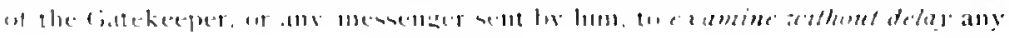


case which may he deemed of urgency, in order to determine the duention on armitting the pattient to the lospital.

3. The almission in all cases to be by printed rertificaten of name, itge. plate

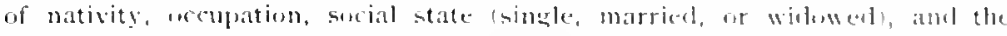
diagnosis under the signature of the doctor admitting; and the stewatsl shall also, whenever practicable, reguire security for the chothing of the fratient, and his or her renlonial whell discharged.

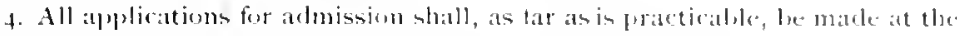
flospitil in the foremosu.

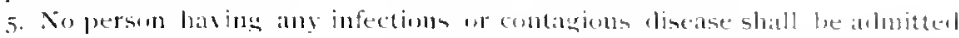
(1) this Hospital.

b. No incurable case of cancer, or any uther firm of incurable disease, sluall

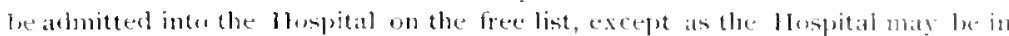
the receipt of funds, directed to be alpplied for soleb calses.

7 No person having a vonereal disease or mania-a putio hali le almitted at a frete patient.

S. Pay patients maty be admitted by the steward on the certuficate of a Hospital Physician at the rate of not less than one dollat per diyg except in cases of mania-ii-potu or alcoholism, the lowest charge for which shall le two dollar per day.

9. All patients shall give security for the payment of their bosid.

10. All patients shall be discharged as soon as they are cured; and all charity patients whose cases, after a reasmable time of trial, shall be julged incurable, thall be dischared.

11. All discharges, except for misconduct, which are hereinafter provided for, shall be made under the direction of the Attending ['lysician or Surgen.

12. All admissions and discharges shall be registered by the Clerk and reported to the Attending Managers, an their weekly visits, to be entered ly them on their minutes.

FreE BEDr. - A contrihution of s5ow to the permanent fund of the Hospital will endow a free bed in the l'ine Street Hospital, to be named, unless ot herwist directed, after the doner.

Avistaxce-The Ambulance shall alatal's le in readineso (1) answer a call and it shall be sent out whenever directed hy a menter of the surgicil or Methical Staft, or by any memler of the Board.

Partexts, - The patients are required to conduct themsetses witl decorm towards each other, the offeers of the lospital, nurses, and attendants. They shall not smoke tobacco or play at any games of chance in the llowpital.

2. No vencreal patient shall be placed in any other ward than those esped ally appointed for that class of patients, w which they shall he strictly comtined

3. No liquors, provisions, or medicines of any kind, shall le furnislued to any of the pationts be their friends; and no pattent wall be permited the lose of any diet prepared in the Thouse other than that which maly be ordered by the propet officers.

4. Xopatient shall be allowed to leave the bospital while under treatment. except by special permission of the physicians and steward.

5. Such free fratients, ats are ahle, shall give ansistance in mursing or utherwine when repuited o dosoly a Residene Physician, Steward or Heal Curse.

6. If any breach occur in any of the aluese rules, the aftender slatll be lidble to be discharged by the Attending Managers, or, in their atmenet, hy the stemarel, who shall report to them. 


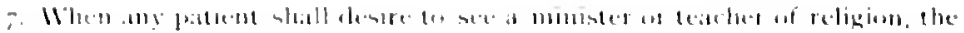

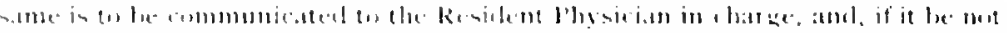

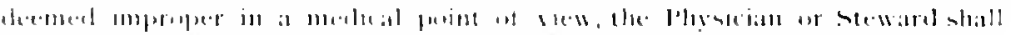

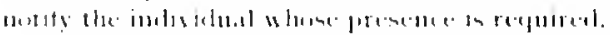

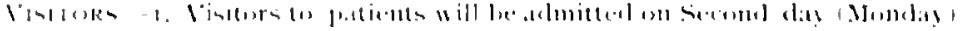

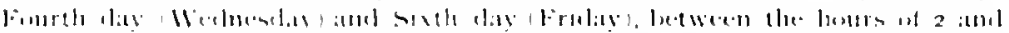

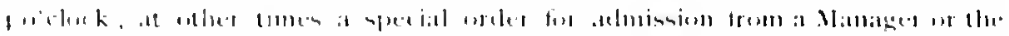

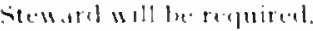

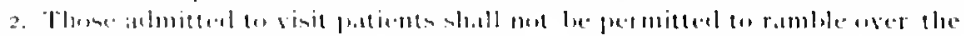

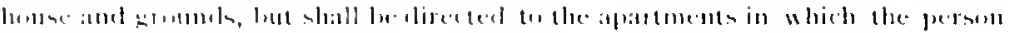

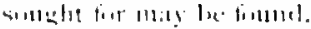

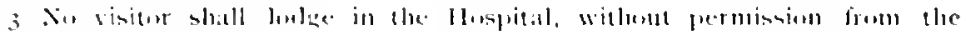
Stew.iril.

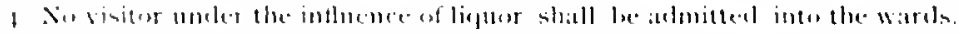

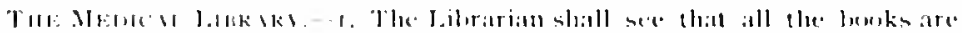

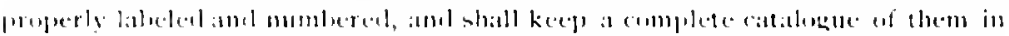

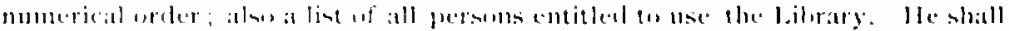

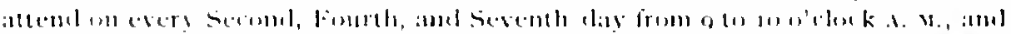

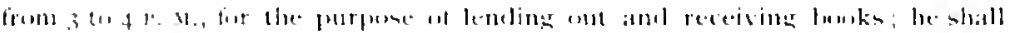

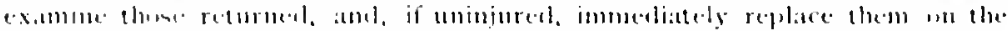

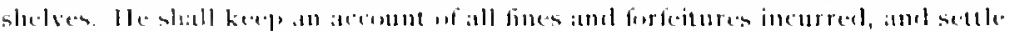

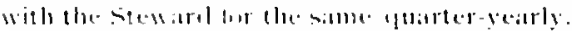

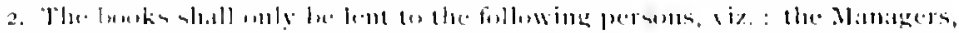

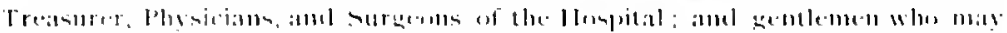

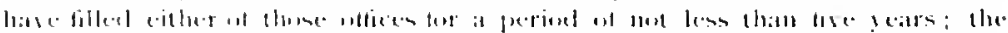

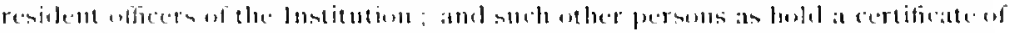

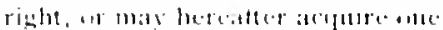

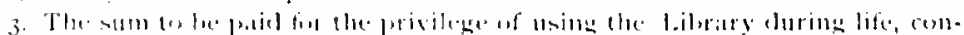

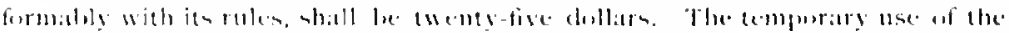

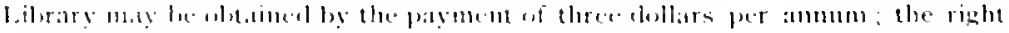

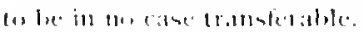

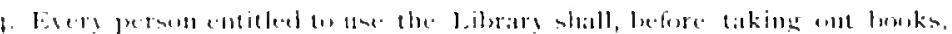

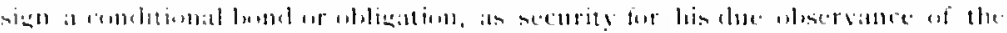

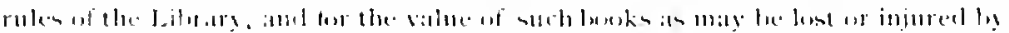

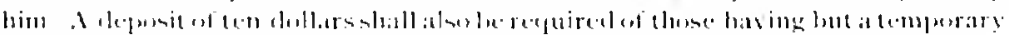
right to take ant leowhen

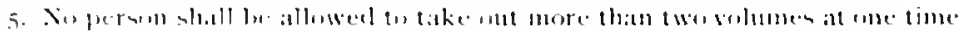

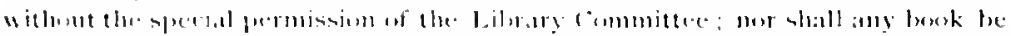

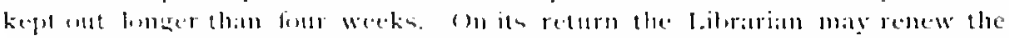

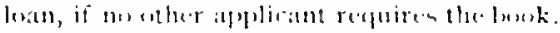

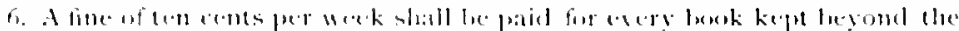

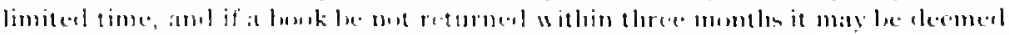

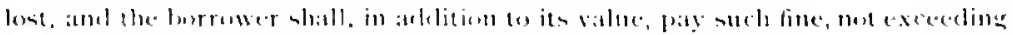

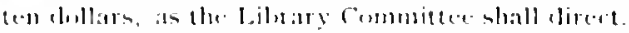

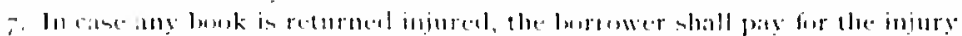

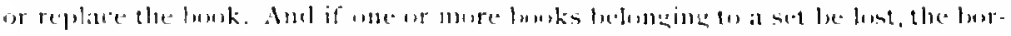

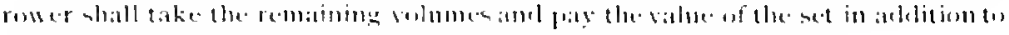

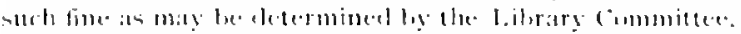

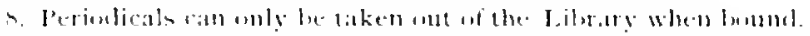

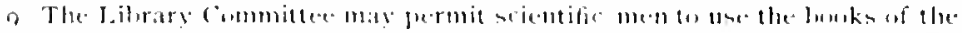

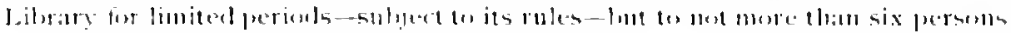
at ine time. 
10. Rare and contly foldo and quarte butes with engravinge are not to be lent

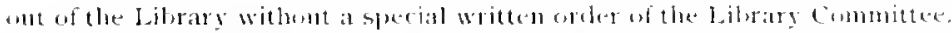

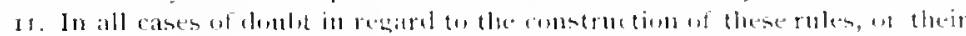

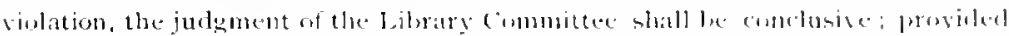

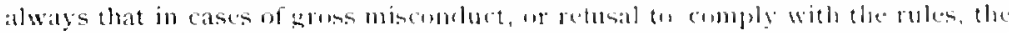

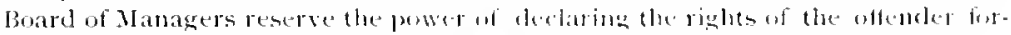
feited, and prohibiting his future access to the libtary.

12. The Steward shall be atuthorized to paty all bille which have been approved by the Libraty committer.

\section{DEPARTMENT FOR THE INSANE.}

The officers of the Pemsylvania lloppital Ineprorment for the Insane, shall

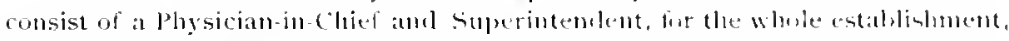
and one or more Assistant Plysicians, alse a consulting Gynceologist, amd a steward and a Matron for eash depattment.

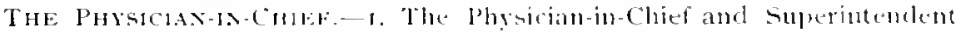

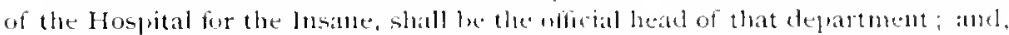
umber the instructions of the beatrd of Managers, shall have the general siperintendence and control thereof and of all persons employed on the premises.

2. He slatl reside upun the premises, and devote his whole tome to the prometion of the interests of the Institution and the wellare and romfint of the pitients.

3. He slall have the sole direction of the medical, moral, and dietetic treatment of the patients, and lis clirections fespecting them are to be implicitly olueverd by all persons about the extablishmont.

4. He shall have the puree to selent and dismiss al his pleasure all the

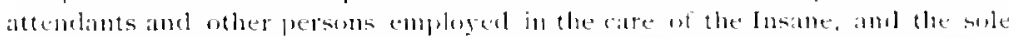

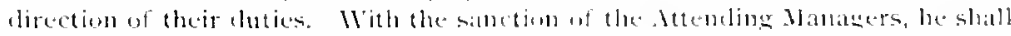

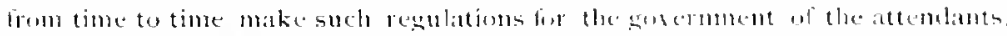
and all others engaget in any way alont the Institution, as he maly deem? salutary

5. The shath have the gencral direction of the firm, gatrelens, and grounde of the Honpital; and may make contracts with the farmer and athers emploged

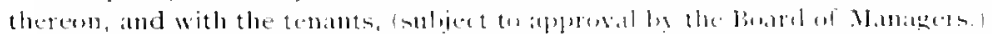

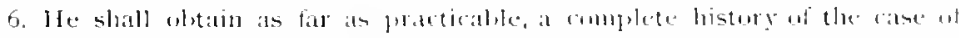

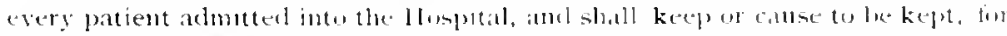

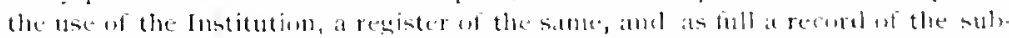
sefuent treatment and resules as he may decm likely to promete the interests at science, and tend to improve the theatment ut the insince.

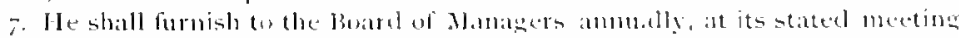

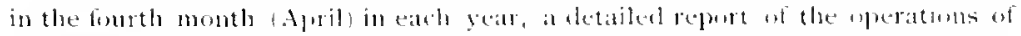
the Ifospital, with tabular statcments of the rases treated during the preceding

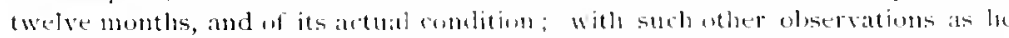
may deam narkil or interesting.

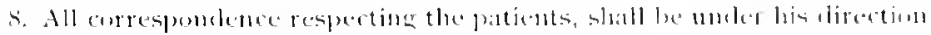

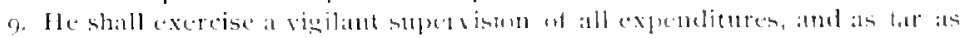

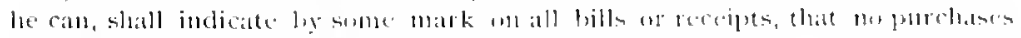

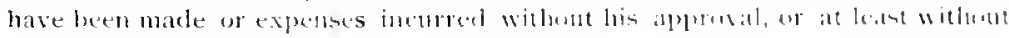
bis kmowicalge. 


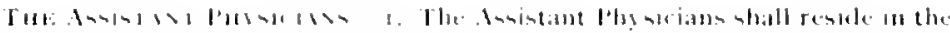

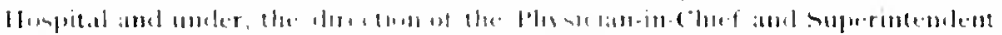

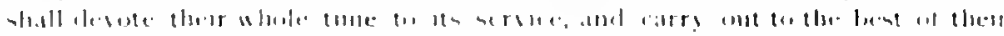

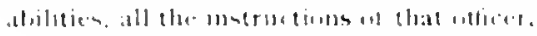

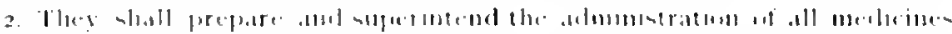

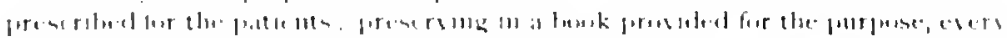

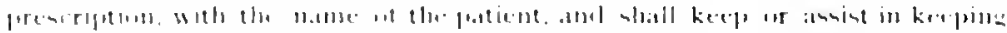

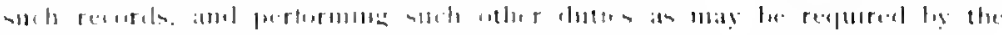

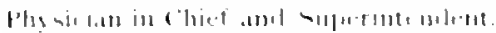

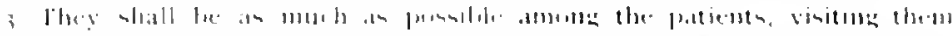

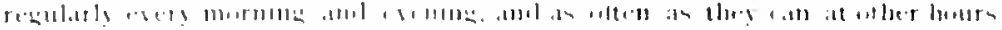

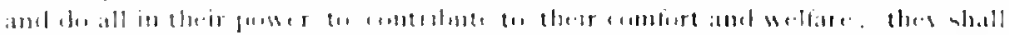

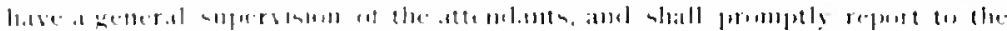

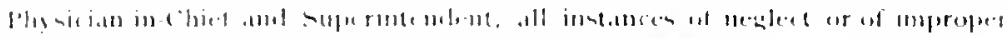

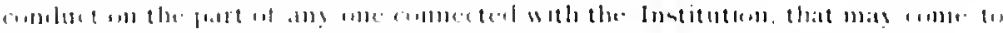

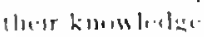

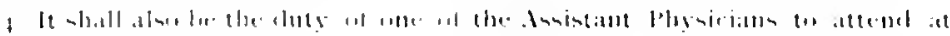

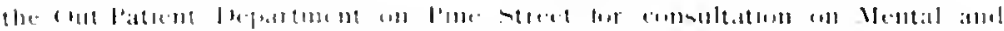

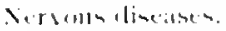

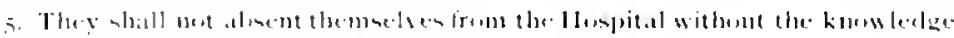

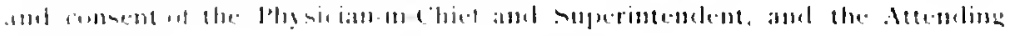
Vanagers.

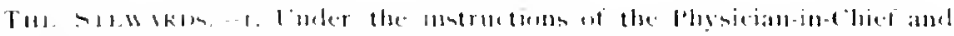

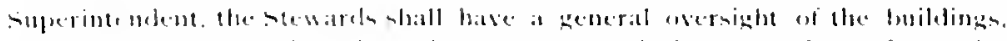

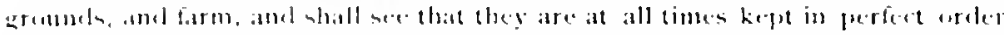

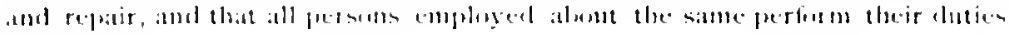
fishofully:

2. Finder the direction of the loysician-ju-chief and superintendent and

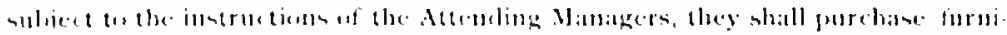

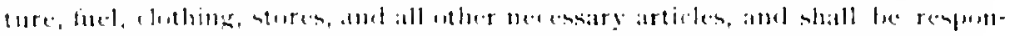

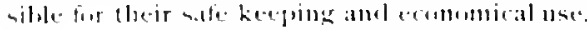

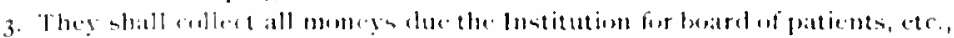

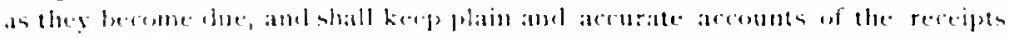

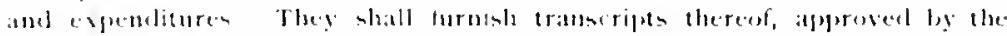

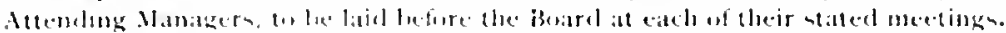

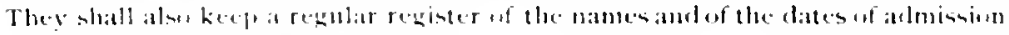
amel diacharge of esers pittient.

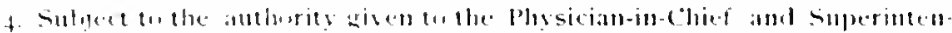

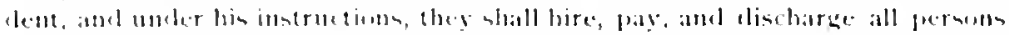

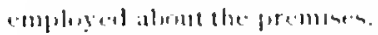

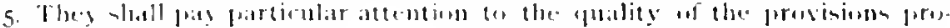

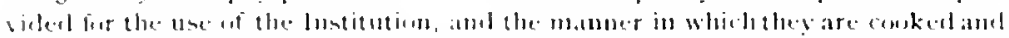

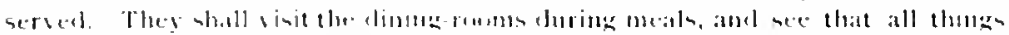

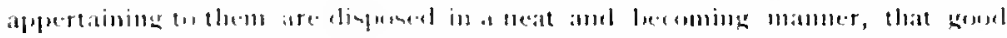

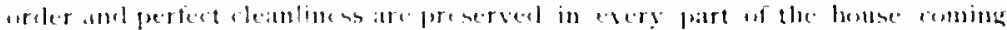

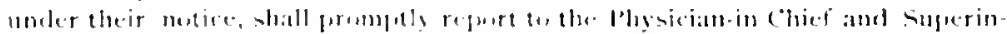

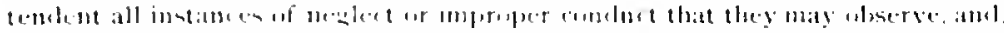

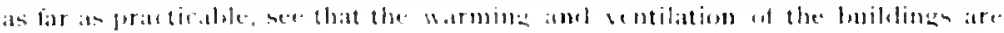
properly regulated.

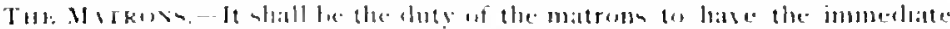

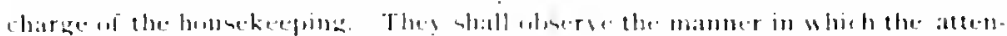

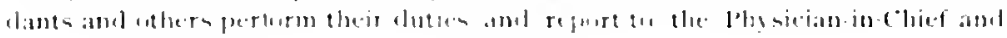


Supe rintendent any instame of nestect on improper eonchet aming umber their notice. They shall have the gentral wersight and direction of the chmestics, and shall superintend and direet the cooking and distribution of forml, and, in conjunction with the stewards, shall sece that the supply is ahomdant, varied, wellcooket, and neatly served, in all the dining-romm of the establishment, which they shall visit as often as possible at the luours for meak. They shall also see that the bedeling, clothing, etc., wh the patients are always kept clean and in gowd order. They are expected to devote the ir whole time to the service of the Institution, and under the instructions of the Physician-in-Chief and Superintendent, lo spare no efforts to promute its prosperity.

GENEKAL RCLES-All persons engaged, in any way, alwut the lnstitution. shall be careful to conform to the regulations made for the governulest of the Hospital, and at all times do what they coll to promete its prosperity. Xosmoking of tubacco by any thus emplesed, shall be alluwed within the enclustres, nor in the vicinity of the harns or wher outhildings; nor shall any persens be employed wher are addieted to the use of spirituous liquors.

All lights, except in the wards, entries, steward's, Itatron's, and l'hysicians" rums, are required to be extinguished at ten o'clock $r$. y. So realling in bed at night is to be allowed, either by paticnts or by any person commected with the establishment in any capacity.

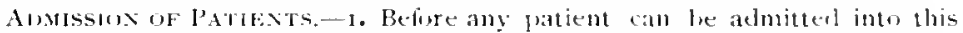
Ifospital, a request in writing to that effect from some near relative or fricold, and at certificate of said patient's insanity, signed by two respectable grathuates of medicine, shall in all cases be required, in the mode preseribed ly the laws of Peunstrania.

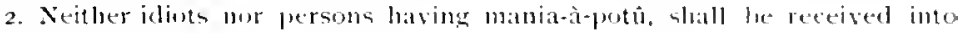
this Hosprital.

3. A limited number of insane persms in indigent circumstances, whose cases. are recent, and such as are believed to offer a filir chance rif cure, shall be admitted as patients by the Attending Managers, for a perinel und exceceling three months fur each calse, and shall be treated without any charge. ff promising favolably, and on the recommendation of the physician-in-Chief and superintendent, the period may be extended at the discretion of the Board. Socurity for the remowal of snch patients when discharged, and for their clothing whilst in the Hospital, shall be required of some responsilde. resthent of the city of philadelphia, or its vicinity. The number of these pratients sluall from time to time be regulated log the Buatrd of Managers, and is now fixed at fitty.

4. Patents paying leard may be admited by any member af the buard of Mantixers, under the following rules.

5. The rate of board slabll be regulated ly the pecumiary ahility of the pationt, or of the friends of the patient, ant the dism if ancommodations refuired. The lowest rate shall be nime dollats per week. They slath wot be admitted for a less periog than three monthe for which time the board shatl be

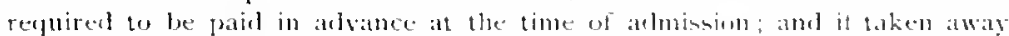
whote ed before the expiration of that periul, contrary tu the advice and consent of the Physician-in-chief and Superintentent of the Hompital, the anumbe as

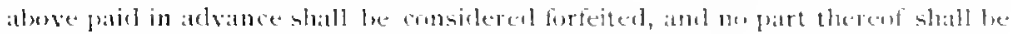

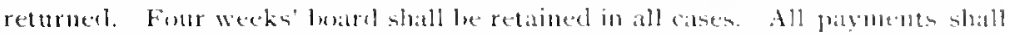

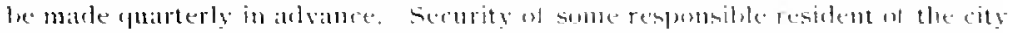

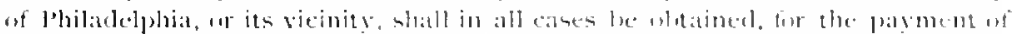

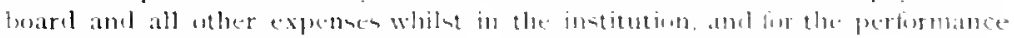
of the foregoing comblitions. 


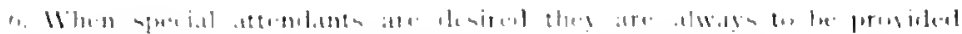

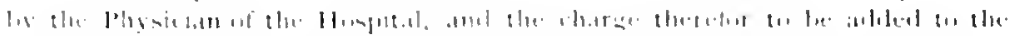
$|+1|+1 \mid$, .

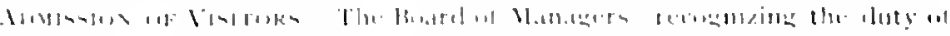

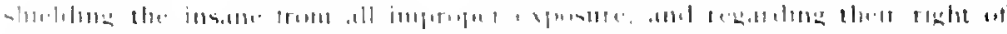

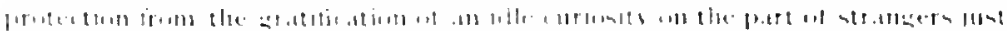

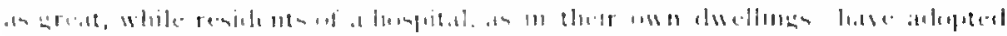

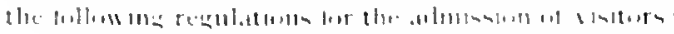

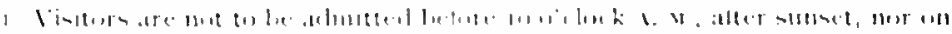

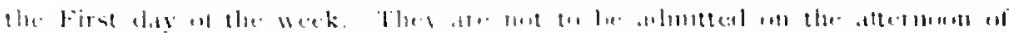

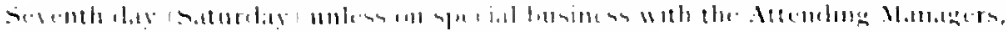

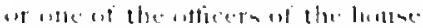

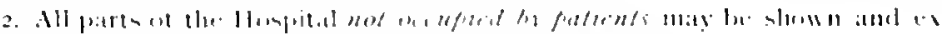

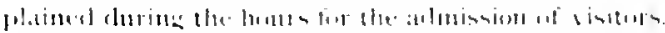

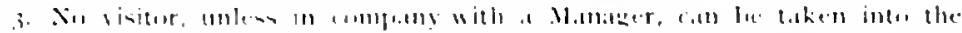

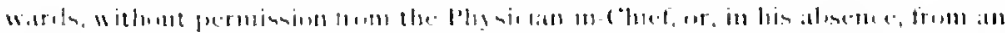

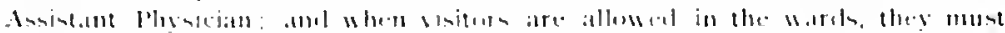

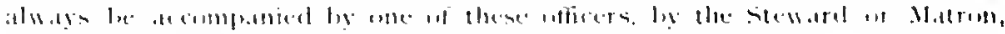

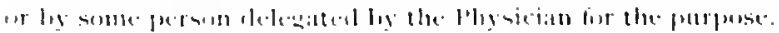

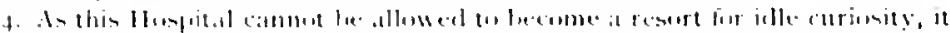

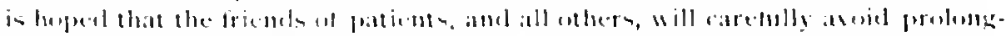

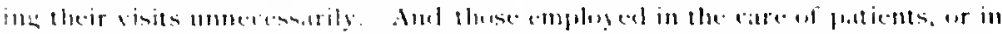

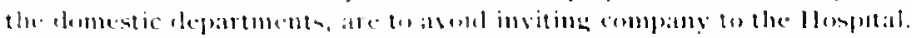

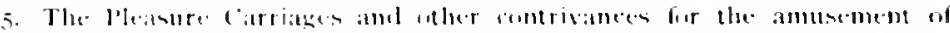

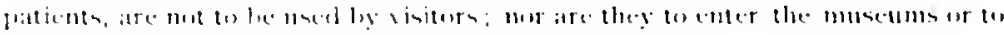

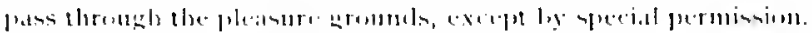

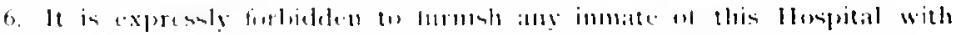

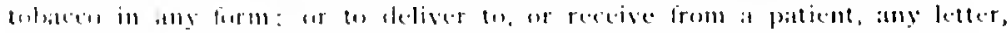

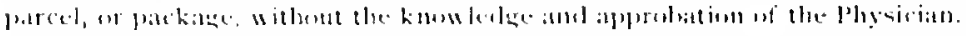

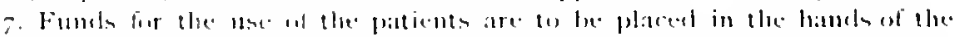

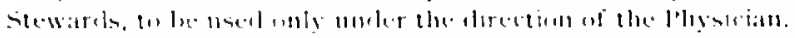

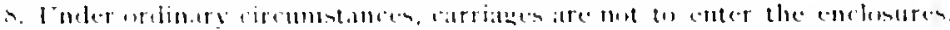

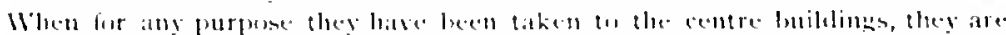

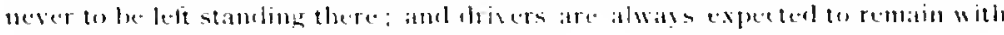

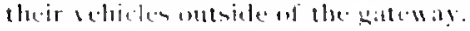




\section{OFFICERS OF THE PENNSTLYANIA HOSPITAL.}

At the $143^{d}$ Annual Meeting of the Corporation, held 5 th month 7 th. ISy, the following Contributors were elected to serve as Managers for the ensuing year:

LEXJAMIX II. SEIOEMAKER, JOIX B. GARRETT,

ALEXANIER BIDLIE, JIHN W. BIDLIE,

JOSEPIF I;. TOWNSEYI, JOHÃ T. LEWIS, JR.

T. WISTAR BROWX, JOHN S.JENKS,

CHARIES HARTSIORNE, JOSEPII E. GILIASGIIAN,

JAMES T.SHINN, EFFINGHAM B. MORRIS,

IIENRY HIANES, Treasuer

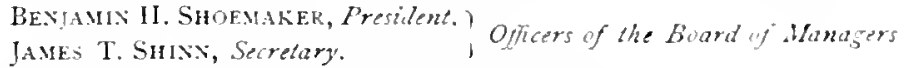
Arthek Biddi.e, Ess, Sulicitor.

Attending Physicians-J. M. LA ConT., M. D. ; Morris Longstreth, M. U.; Arthur I. MeIGs, M. D.; Morris J. I.EWIS, M. L.

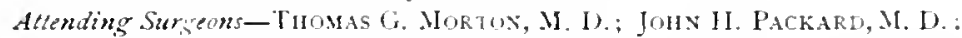

JohN Ashuukst, JR., M. D. : Richari, II IIARTE, M. I).

Resitent Physians-Thomas a Ciavtor, I. D.; Thomas F. Branas,

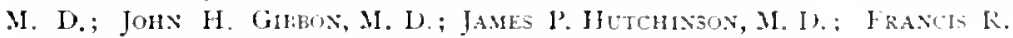

Packard, M. D. THOMAs S. KIRkBRIDE, ir., M. J).

Pathologist, Curator, and dhicroscopist-HENRY M, FIGHER, M. D.

Dispensary Phisicians-Hexky II. Fisher, M. D. ; Fredertck A. PACKAR [,

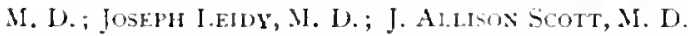

Dispensary Sugens-W. Barton Hofkss, M. D.; Water D. Grers.

M. D. ; ROBERT G. Le CONTE, M. D.; ThuMA S. K. MORTON, M. D.

Eye and Ear-GEukge C. HARLAS, M. D. : JETER N. K. SHWEXK, M. [?.

Throut and Vose-ALENASIER W. MACCrX, M. I'.

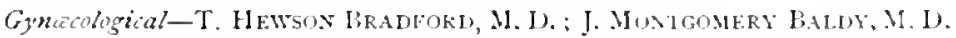

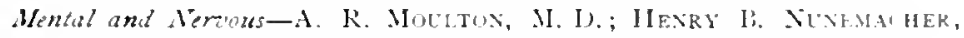

M. D.; Eli E. Josselyx, .I. D.; Horace Phillips, M. I).

Stezdard-Josathas G. WhLLMs.

Clerk and Librarian-UANiEL. D. TFsT.

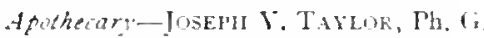

Watron-MIARY R. SATTERTHWAITE.

Heda dure-Elizabetu S. Colluer.

DEPARTWENT FOR THE INSANE.

Physicinin-Chief-Jonx B. Cuarr, M. I).

DEPARTMEXT FOR MEX.

lärt Assistant-A. K. Mol.tos, .I. L.

Second Assistan-IFur.ACF I'HH1.II', .I. I).

Steciard-GeurGe JONES.

Matron-IIANiAH l'. SAERER.

DEPARTAEXT FOK WOMEN

First Assistant-II. H. Nunematek, M. D.

Seconi"Assistant-E. E. JisseLYN, II. I).

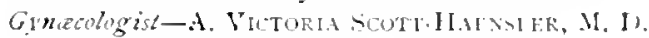

Sieward-GEURGE JONES. 


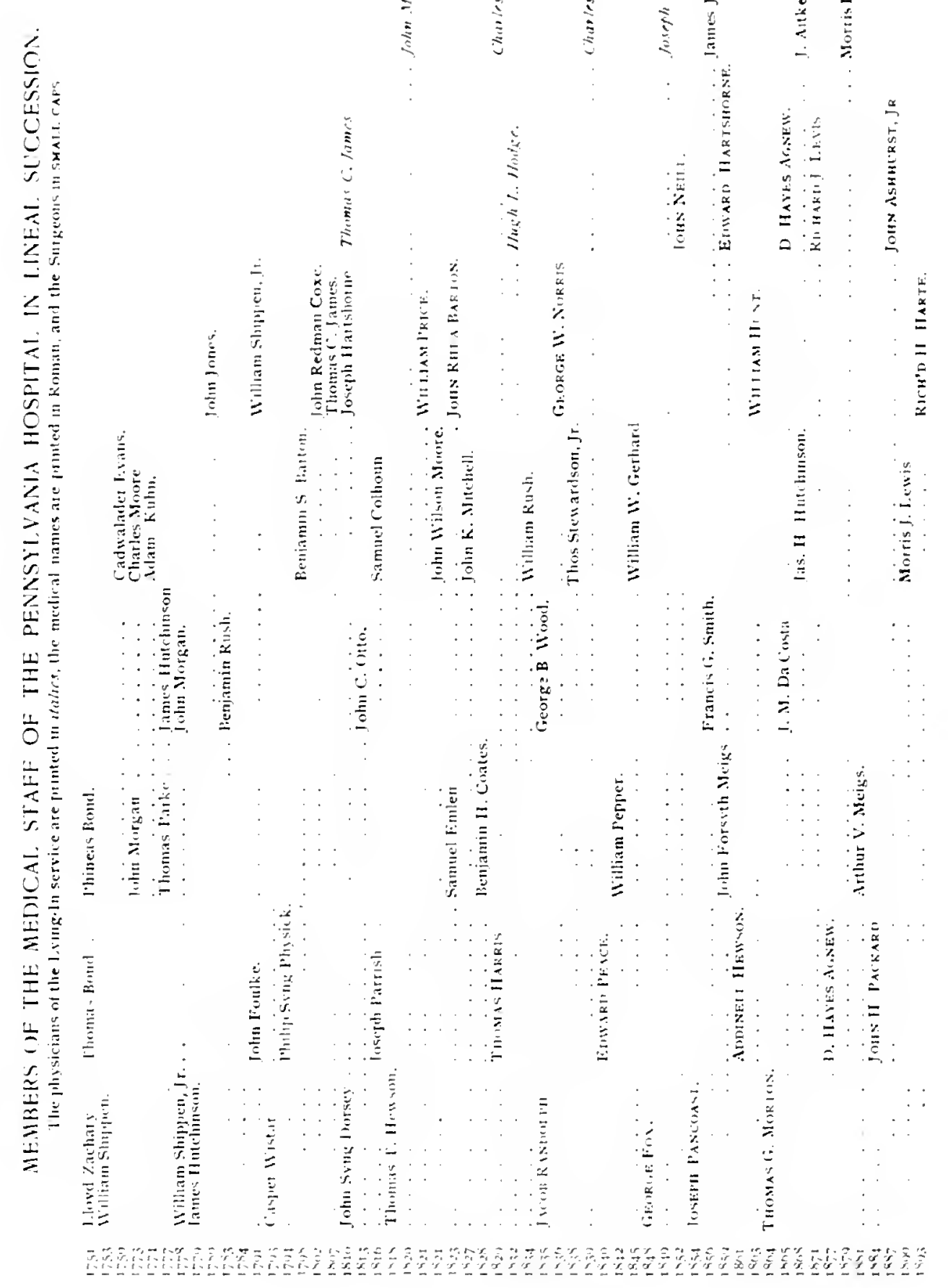




\section{INDEX}

Acadeny of Fine Arts

Acadians to issinbl

to he published anmually

Act Establishing Lying-in Department 233 of Incorporation . . . . . . . 24 Legislative . 241, 202 establishing the Hospital .... 11 Special . . . . S. g3. J $(x)$ to Encourage Establishing a Hos pital, ete. . . . . . 10 to remit duty on IVest's Painting 313 Allams, John Ouincy

Address by Dr. Charles I) Meigs $\begin{aligned} & 40 \\ & 40\end{aligned}$ by Dr. J. Forsyth Jeigs . . . . 403 hy Lr. Benjamin H. Coites. . . 121 by Gox. Jolm Penn h. Gov. Richard Penn to Proprietors

Administration, The Ifospital . . . 402

Admission Card, Form of . . . . 20 Fet to Hospital 153

Rules for . . . . . . . $55^{6}, 561,562$

Admissions, Decline of a. is

Agent in England, Franklin alpuointed t2

Agnew, Dr D. Hayes . . . 5í

Allen. Nath'l . .

Allen. Robert, seizes cows and hity, 290
Allen $10 m$. 9. $21,51,32$

Almshouse, The City. . . 52

Exchanging lots with. . $\quad 275$

Lying-in llard at . . $\quad 234$

Pitients from at a

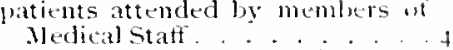

American Medico Psycholngical Assu-

$$
\text { ciation . }
$$

Amphitheatre, New Clinical . os, m

Amusement for the Insane, I60, 1-1, 173

Anesthetics .....

Ammal Report a 470

Anmuity yranted . . 13

Antiseptic treatment .

Apothecaries, English . . . 524,520

list of ......... 5.t.

Aputhecary . . . . . . .

Cimtract with . - 5, 50

Physicians desire a qualified . . .527

Shop, location of . . . . . 5.37
Aputherartes, Stewards and Matrum $52=$ students as . . . . 520,532 Apparatus designed ly Wedical stalf to

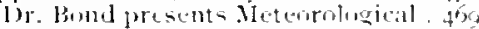
Fire

Appeal to the prublic Aprentices Mcdical a o to Appropriation ly Assembly $\quad z$ Areher, Elizateth. . . . Armitt, John . . . . Armitt Stephen . . . . o Arrison Estate recommemled $\$ 17$ Art llinks of, of Hospritil .315. it Articles in Corner-stone. 124, 170 Ashburst, Jr, [Mr. John _ . . . . 510 Assembly Act ai J alpuropriates Fines to Hospital of, 05 comes to Relicf. . 40.50. 5

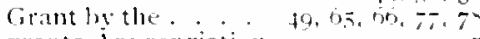
grants Aplopriatim. . . . . Orizinal putitiont t. ....... 3 Assistints. Female Board of . Assnciation of Ex-Resident Plysiciann

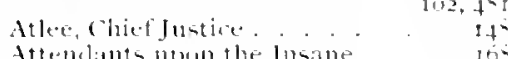

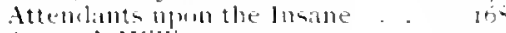
Alwur, Millian, .... thtopsies ....... 212

Bankrupts, Fstatesw Barnes Cornelins . . . $4+2$

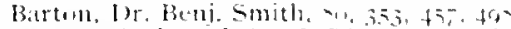

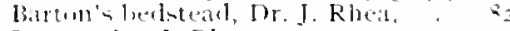

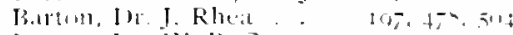

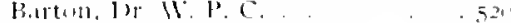

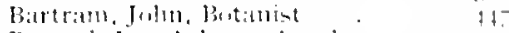

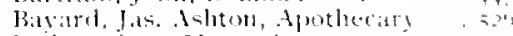
Becl-carriatese Murton's. Burlsteal invented by Dr. John Rheal Burton .

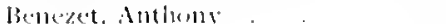

Bettle. Willian. o. on

Batton, i)r. Simmel tol to

Buran, Matthe I.

Burin, Silvamus . 1, 19, 17

Billilke clement c.

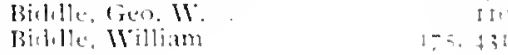




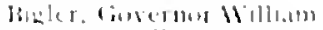

litilsule redit

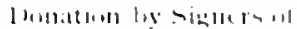

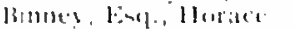

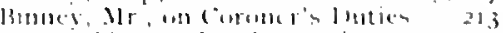

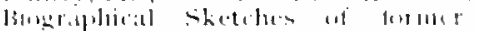

$$
\text { M.t1lugers }
$$

fin,

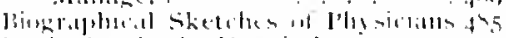

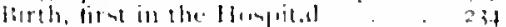

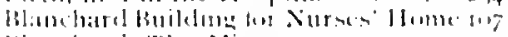

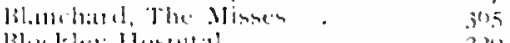

Blexkiey Hospltial . . 201

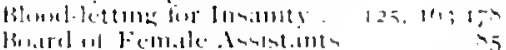

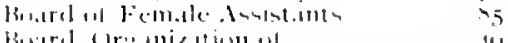

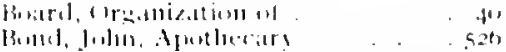

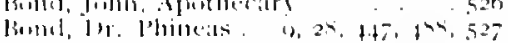

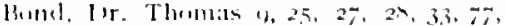

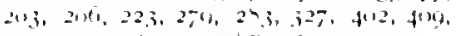
$43 \%+45,+14 \%+4,+4,529$

liond, for "llumian, |r. . $60,01,62$

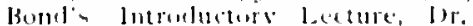
lines.

$4^{612}$

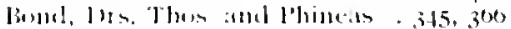

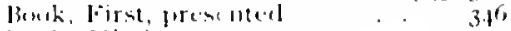

butkn Missilly

Horice dololph l:

bintimioal Garclen

Bunlter, lir. llum.

Aputhecars

Brablurd, Milliam

Brillsill, Mill.

\section{Frimklu, lextract trum}

Brief liew prestented to Assembly

Britisl, Army in Plitadelphial

British l'risioners an patients

Brown, M:ary 1).

Brisule leter

Brsatu, Chiet Justice . . . . . 14

"Bunch of (itapes" . . . . . . . . . .

Buntiug, Mliss Rachel A. . . . Mel

Busti, Nr. P.ul . . . II, 12t

cachalacler, Mrs. . . . . . . 83

cadwalater, 14. Thos, 28, 32, 46, 446

(inllumin, Dr. F. $45^{8}, 3311,527,529$

0.8 .4

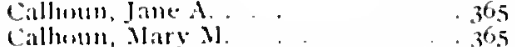

Candlestick prestnted . . . . $33^{6}$

Citpital soock not to be livpented it Decretse of . . . . . . . . . . . .

Citre uf Sick and] Insanc l'uers .

carriates

Catsill, Mr. Instili

('arter, it

Ciste, in sad

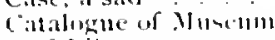

if Liturary.

Raisomné

Catlirall, Fiviral

("ilvilrs Fund

("ells.

centre Building

clinic Room in

I. ilirary remored

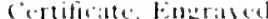
lor stirlente

$32.9,824,8213$ $47,4,1,470$

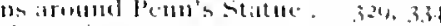
fus lumbtios . . . . . . 12ts

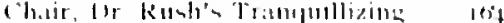

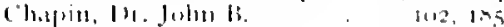
all lus:lnity . J Ch:1pmian, lir. Xathatulel. . 10, 234 character of Merlical stalt

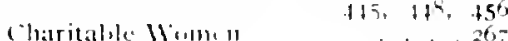

.$\cdot 267$

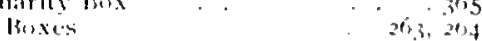
l'aticitle

Charter andel cirant of lamb of Ilue Ilompital. . . . o of l'rivileges. . . . . . . . . . . . of l'roprietarjes mot aceepted. 21

chauncery, (Thas, lisq. . . . . 26,

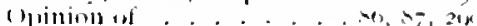

Chew, Benjamin . . . . . . . . .

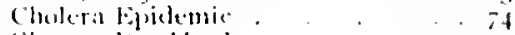

Chovet, Jir. Abrala:am o . 331,350

Clutist Healing ibe Sick . . . . 315

Clinrih, I)r, . . . . 234

Cits $\mathrm{Tr}(\mathrm{wp}), . .2,56,237$

(ivi) $11: \mathrm{ar}, \ldots 26$

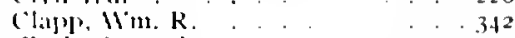

Clatk, Samuluel. . . . 4t2

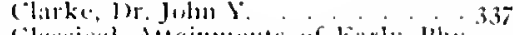

Clasical Attaimments of lasty l'hysiciams. . . . . . . .

(1assifieation at lusane . . . I15

Class af lor. Thomats Bond in 1720 .

clav, lletury. . . . . . . . . - 3t

Clergymen in the Ilospital . . . . " o6

Clinies at Almslouse. . . . . 220

Clinica! implitheatre- 112

Lectures. . . . 4t6

Cut-pattient Service. . . . 109

Teaching, Dr. lsond on. . . . . 462

Clock, Rittemhense . . . . . . . 3.37

Closing of lyejg-in IVard . . . . 238

Coal int rodured . . . . . . .

Contes, Amy. . . . \$4. 121,505

Coates, Ior. Beniamin H. . 121, 139

contes, John Reynell . . . . 331, 3.13

Contes, Simmel, Accommi of Jellow Fever. . . . . . . . 72

Coates, Samucl, $71,73,77,83,130,152$, $225,256,259,262,295,295,205,296$, $326,3.31,3.52,421,442,474$.

Coates, Prirtrait of Samuel , 139,342

Coffee IIouse . . . 50,75

Colden, Jor. Cachalader 50,75

Colemiu, Villiwm A.

College en pliblacleiphia .

college of lplysiciats. 92,325

Colhoun Dr Simulel

Collier, Miss Elizaluth s. . 106

Collins, lsatc . . . . . . . . . . 91

cillins, /atchens, 208, $236,269,295,342$

culd llater $\quad 343,362, \$ 24$

(i)lomb, 1)r.

colored l'atients $\quad 202,419$ 
Commitments for Insanity, 127, 133,145

Committer on Rules of (miler . 25

Report on Fratiolin Areounts o.

of siafety.

Compantuns for the Lendittics $14,1,5$

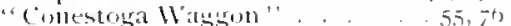

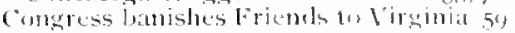

Memorial to

compad, Jor. Jolun, Aputherary 5.35

Comstitution al I'ennsyluatuia . 3nt

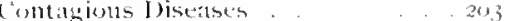

contincental Munte . . . . . 56, 244

cimtract with Aputhe ally - . 5, 30

cintract, a life. . 1 is

("intrilutions _. . - 3to

cuntributurs . . 3\%

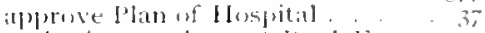

alaborize purchase at Keal listiate is -

authorize Sale of firoumel. . . . 29u

lecine Franklin's Conditional Be-

yuest . . . . . . . . 60

finermment of Hospital vesteel in

the

incorporalted. . . . . . ,

In folinte of suscossiom al . . I

List at . . . 37

metet in Haspital. . . . . fil

Powers and louties of . . . . 365

to blect Managers and Treanurers

dimually

to the Pennsyluania Hospotal 37

moe Removal of Insane to IVest

Philadelphist. .

conk, Wim. IV.

conlidge, R. H., Me+1, Inspertor U.S.A

Comper, Ior samulal, Apulliecary

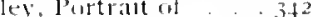

(in)e, Caleb ..... 435

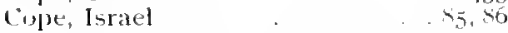

Cope, Mary . . . . . . . St

Cope, Thumbls Pym, $33,85,86,296,297$

Cinner-stume

$30,10,120,175$

coroner, office ut . . . . . . 213

Corporation of Contributors to the Penusyluania Iospital . . . .

correspondence alout site of l1ospi. tal

Conncils of Philartelphia Cits extmpt Vacant lents from Titxation. . 290

Court House. . . . . . . . 75 sipreme, decides that the llaspital is a Pulslic chatity . . . Is (ow's, Hay, ete, sold fur fraxes . . 290 Cixe, I)r. Julnn Rednuan . . Min 498

Coxe, Tench . . . . . . 410 craik, Certificately lir. Jas. 534

Cramond, Henry. . . . . . . 365

"Crockit," The Gateketper and . . 545 Croshe, Joshua, 0, 13, 22, 24, 25, 27, 32,

Cromber, Thus

curaturs af Patholugical Mnsemm. 305

cuthusls, I)r. Edward . . f t's, 53.3

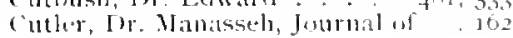

I) il instia, lor, J. MI

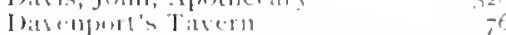

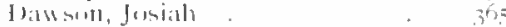

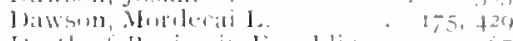

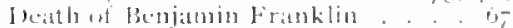

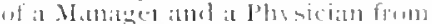
rellom finter

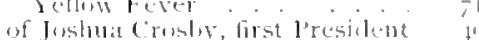

Dexiths of ex-Resilent linsicials the

I)eceisted Patients. 2I1, 212

Ilecol tor llostital I.oi . 27,273

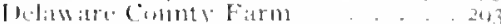

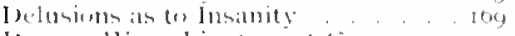

1)

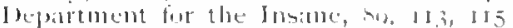
$116,122,243,5,50$

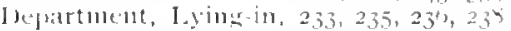

(1)11-l'ittient 215

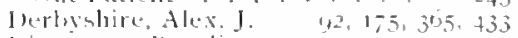

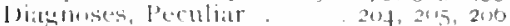

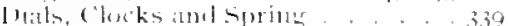

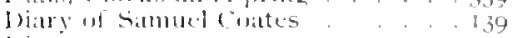

l biet.

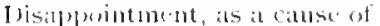
lusillity. . . . 142

I lischarge statement 2.12

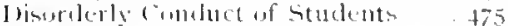

bisfensily service . . . . 10-

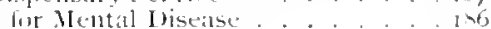

Dilliars . . . 205

lonilelsim, Jibun 236

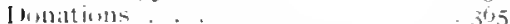

from city Trump. . . 236

of fromol from the penis . . .51.54

if Real Estate.

Inmations, lomusual . . . . 258

Dorscy, I r. John syng, 10\%, $24,3+1,3+2$

$47,5(m)$

Doz, Amblew 266, 121

Dreamy of Simmel Coates.

lotesing Carriatse, Morton's 4-5

lopessers, Appointment of . -

loruss . . . . . . . . 525

ordered from England . 43

1)

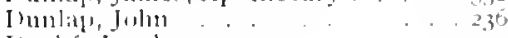

Inuche, Jacul,

I Juclling . . . . . 152

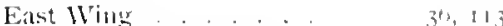

Melical Libraly in. 3.

Ecomomy, cimmonttee ili

Alulisher 45

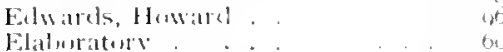

Elaturatery

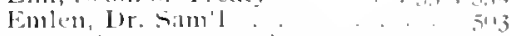

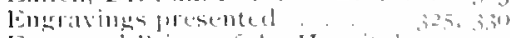

Enerabed l'rints of the laspital, ize in

Enteltanments

Entratne dianded tis Eiglith st.

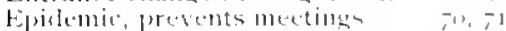

Estate, Limitation of. i1, 240

Eulugimm ontrablin .

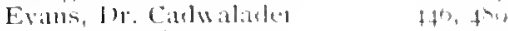

Evinls, funathan. 
linhtion in linte and liredtument in InndIte . . .

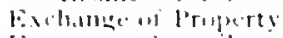

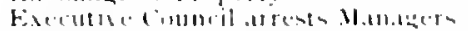

Evlum Jahur. Engraver

Exambitum at Iputhedarien

Fatomer, Xithaniel

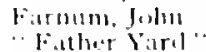

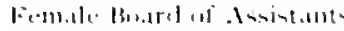

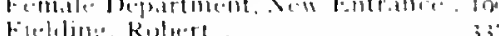

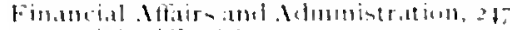

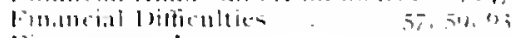

finter [ratuted

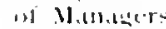

Fire in the llompititl

Engine.

lantrance

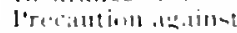

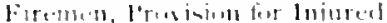

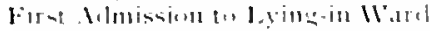

(Mild larm

Vectingen Momiger

Fingher, hr. Finil.

Fisber"- Intumel lurebaned

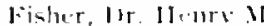

Finher, Juseph. Fin

Fisher. Samli it

Finler, Thimile

Fisher, Wilham 11

Fisher, Rechwoul

Fling, IVin. B

Flecsill, Phunkett

Furluse, lontin I

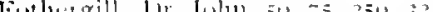

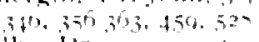

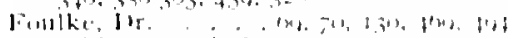

Fommllug Hopital. . 23.3.

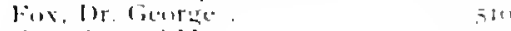

lins, s.mulal $1 \mathrm{I}$.

Frales, frecleriots

Francis, Tenth

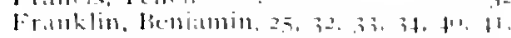

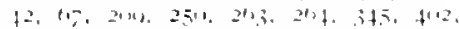
$400.43 .+15.14^{4}, 414$

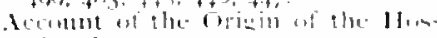
pital b.

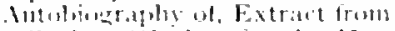

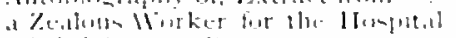
"Briel dicillut"

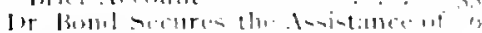

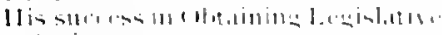
desistathin.

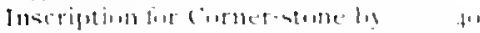

"Justu", "15

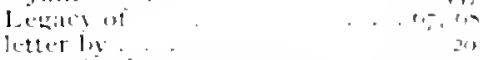

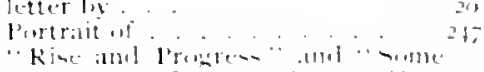

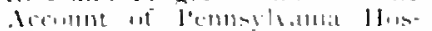
pit.1."

-

Stittle + , t

the Fir-t a \% r

write- the Petitiontl

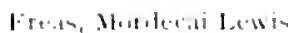

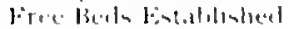

liendill llingutal.

$$
\text { Xentrials }
$$

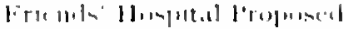

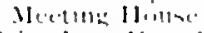

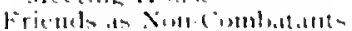

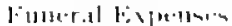

firmutere, Memurial

liall.t1in. Nithert

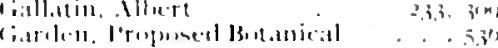

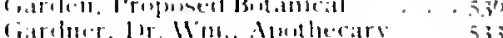

cintele. Juhn b.

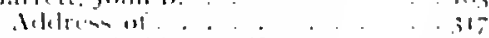

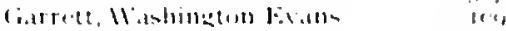

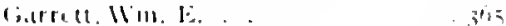

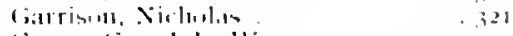

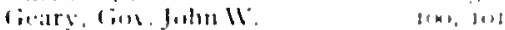

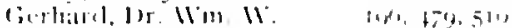

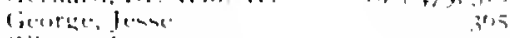

Citmen, junkes

Gilprin. Jimlun.t

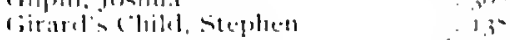
stephen 236. 35

llite al stephen.

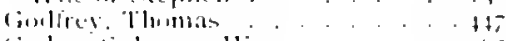

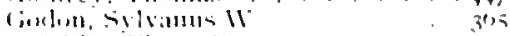

"rialdentilecere"

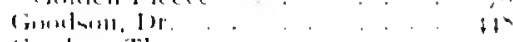

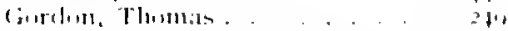

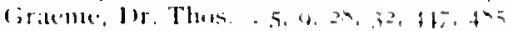

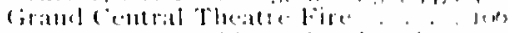

citant b. Asemble diamel to lan at Letilil ....... 10

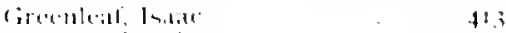

Giresed Jas K. . 175. 120

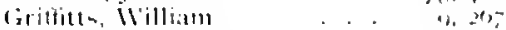

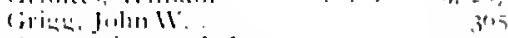

(irop)

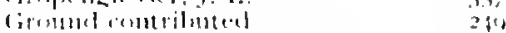

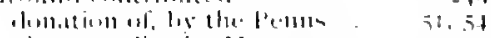

Given to r ity la Manters. 11,

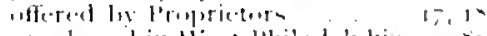

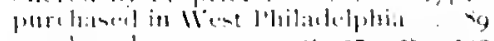

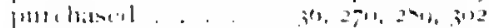

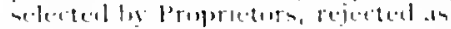

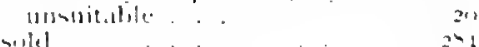

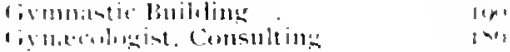

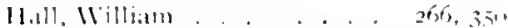

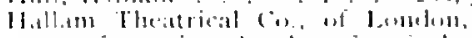

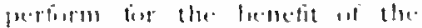
Ilumpital.

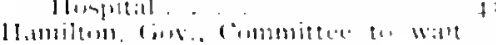
11ind

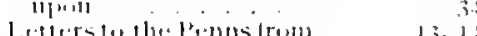

11.1ral vomey recpluired

H.tre. lot Horate Binner o. . in

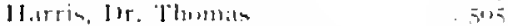

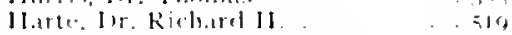

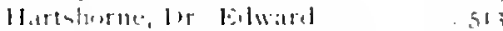

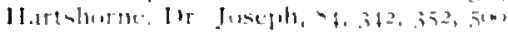

ke-iall 


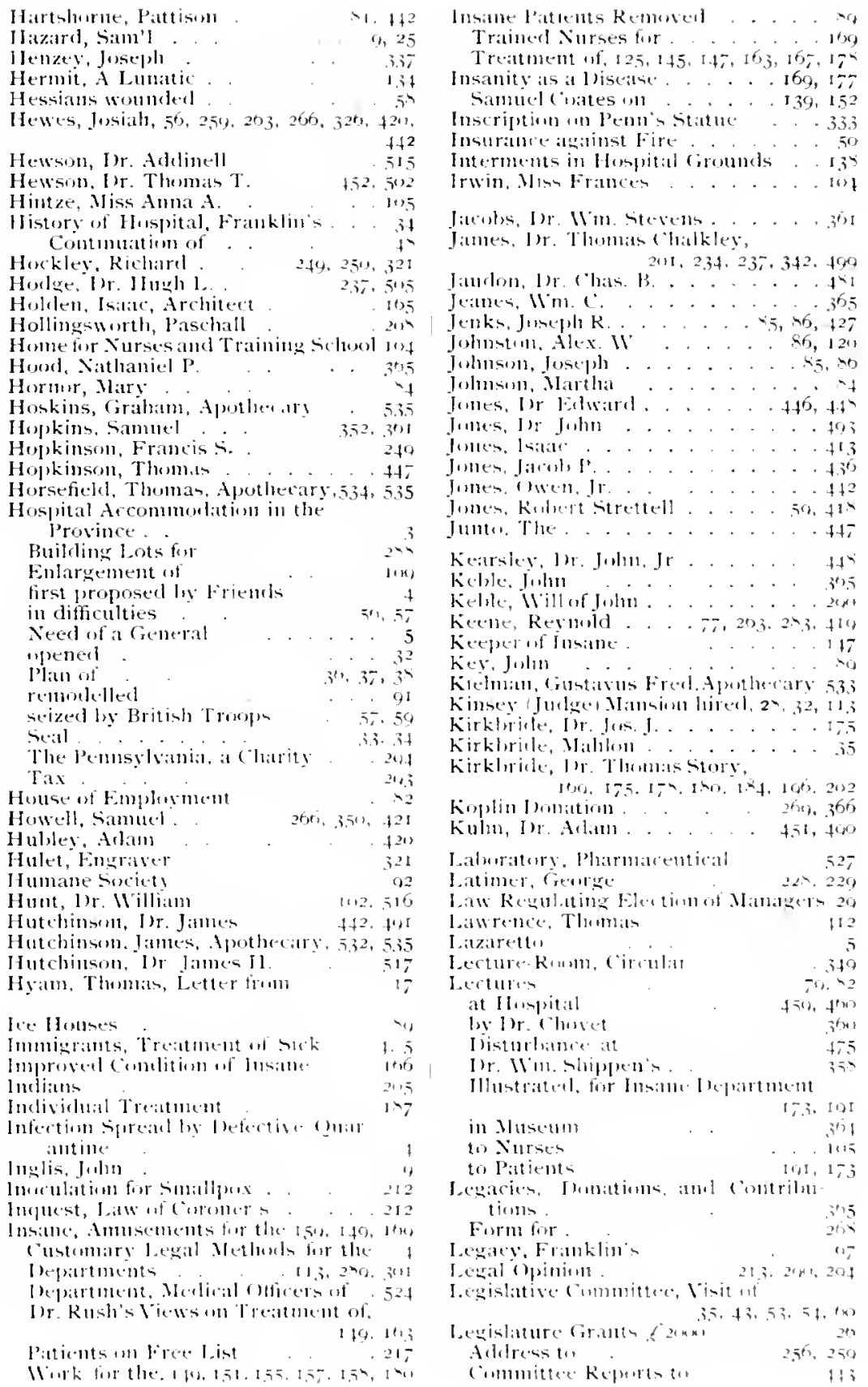




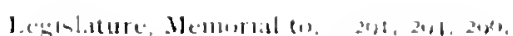

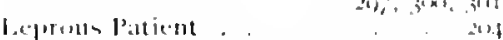

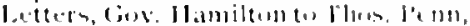

Jisl 13.11

1. Ilalker, Ir., lirituh Azent, ti.

the Vallitecrs . . . .225

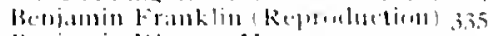

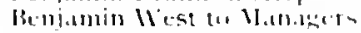

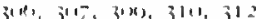

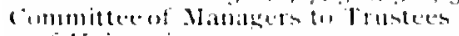
of lancersity

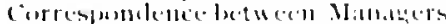

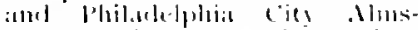
house and Jinuse uf Fimples.

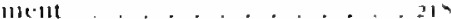

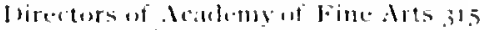

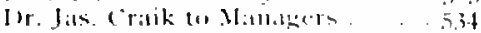

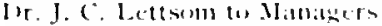

$322,324.3213$

1)r. John Futhergill a Jamics Pelli-

lertan) . . . . . . . $55^{\circ}$

10. John Fothergill to Manatgers 4.54

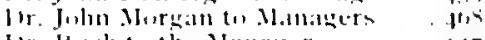

ir. Kuslotothe Minagers . . 14

Ior. Finnas lsmel to Managers fou

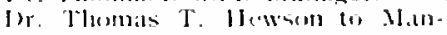
agers 0.05

Glias Bland tu Juhn Keyluell, Matu-

Father of Mary Flizalecth liser to the Manalgers . . . . . 3.31

(icorge Latimer, esilector of the

lort, lothe Matragers . . . 224

(iov Thumas Mckeall (1) M:ana-

gers . . . . . . . . . . . 325

Humane Suejety to the Mamageps. 92

lewry s. Drinker W Malligers 3.36

11 yam and Beyan to Maniagers 17.23

1. Melcher to Samuel Rhosals. 0

James "Traguatir to Mamagers. 311. 3.t I

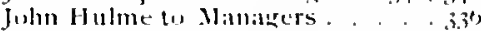

J. R. Ingersoll to Managers . 3its

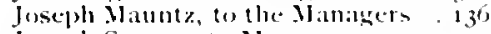

Joseph S:tnsw!n (1) Managers . \$3.32

Jos. Recel, Secretary of Trustees

lniversity of l'ennsylvamial, to

Mamagers . . . . . . . . . 352

Joshua fijpin to Managers. 306. 3100

Willagers to Benpamin West in 3124

Matmagers to I)r. Jobn Fothereill

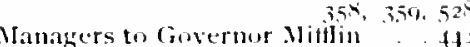

Innagers to llyam alud Bevan

$$
\text { It), } 21,21,23,24
$$

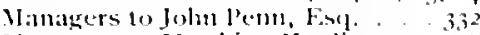

Managers to Matthias kinplin. . 2i

Managers to Meclical class 472,47

Managers lo Jeter Wynuc, Est. 3.51

Minngers of Proprictarices . 15, 52, 5.

Managers to 11 m. Stralian . . . 3t

Iatthias koplin to Christopler

Satret..... . . 2 . 2

Medical Statf to Managero

Wedical students tu Mamacers $5.32,5,3$

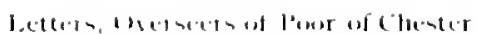

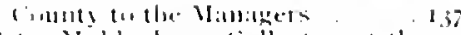

lecter Minlilemberes. Cinlectur as the

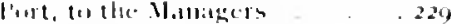

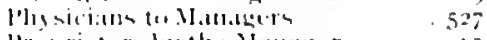

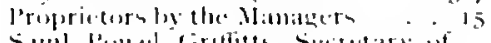

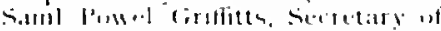
cillege of l'bysicians, lo Maniscers

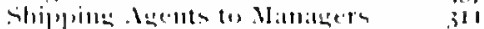

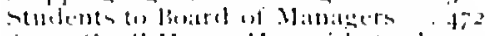

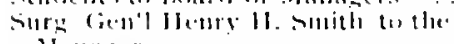

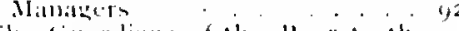

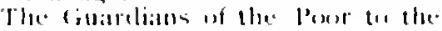

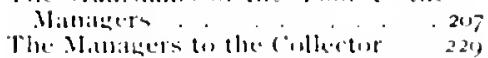

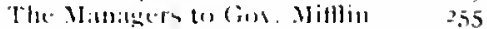

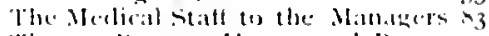

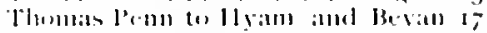

"lous. Wiugtalfe to Wamagers 3.39

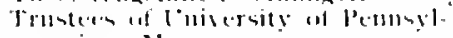

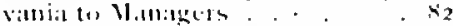

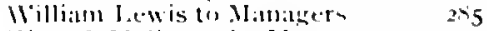

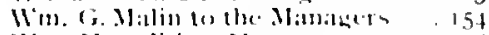

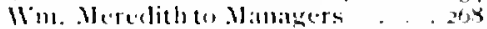

with cellectur of the l'urt . . 3,30

with Juhn sitrgeante. l'resiclent of

l'restem Retreatt . . . . . * 2,37

with llat offuce in regaral to Sul.

dier l'atients. - . . 224

Voman's lluspital tis lle Mama.

सetक . . . . . . . 1195

1, et1soll, 1)r. $322,323,325,316,351,352$

Levick, Wrs. Elizalietliv, 221

I.c.ick, Wr. Jamles J. $\quad 179,512$

J.cvis, inr. Richatel J. . . 51k

J.cois, Jlanmal . . . . s.

l.cwis, Joseph sinumlers os

l.cwis, Jacol, . 120,1,3, 274

l.wis, Jus. I. _. . . 200

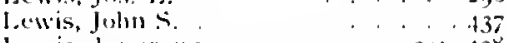

1.ewis, leatrence at, 423

Iewis, Murterai . $71,86,517,120,124$

Lewis, Mureleat, Jr. $426,44^{2}$

L.ewis, Jor. Morris] . . . . 519

l.ibratry and l'atholugical Wlusemum 34.5

Jighlis and fires. . . . . . . . . 547

J.logel, 1)r. Thos. . . . . . . . . . . . . .

1.nin Ohine Funcls. . . . . 254, 262

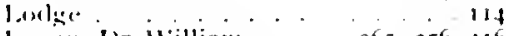

l.ugin, Ir. William * . 265, $\$ 56,116$

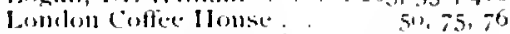

l.omgerity, Instance of . . 135

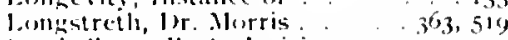

lomel Chancellor's decisions o 251

lowe, as a callse of aliseiste . . . 20.4

l.ownes, Joseph. . 250, 20, . 231, 124

l.ukens, i)r. (has. . . . . 237.545

l.motic lepartment remosed . . 115

l.minties $\cdot . \cdot 3,14,132,133$

J.unatics, Jirst provideel for by the Juspital! . . . . . . 3

Lunatic l'aticut, jirst . . . . . 32

lomatic l'atients. Free . . . . 217

withrut Puldie J'rosision

I. ing in l lepirtment . . 262, 2,32, 349 
Madd-shirt

Male Departnient rpened

Malin, Mr., on Truatment of Insane.

Malin, Wm, G., a Faithul steward. I02, 353, .7.54. 54,

Managers action on Theatricil Bene.

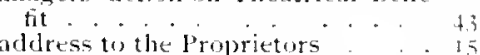
address to the Proprieturs . . . 1.5 appeal for Subseriptions o arrested by Executive council sonished to Virminia. chosen Annually by the Contritu tors. -

Economy of

Fines of

First Board of ..... . . 12

areeting to Gov. Denny . 4i

Law Regulatins, Election of 20

meet at Coffec House . . . . 50, 7.5

meet at "Conestoga 11 agegor" . 55

Pennsylrania IIospital . . fos

punctuality ... . . . . . 25

suspend ileetings on accuunt of

villum Ferver

visit Musem

Manclamus applied for and refusal

Mania, Treatment of

Marine Hospital Service

Martial Law, Hospital under 223

Matson, Samuel. . . . gi

Masters, llilliam . . 414

Maternity lWard. . . . . . . . 232

Matrons, List of . . . . . . . . 54t

McConaghy, Alexander, Gateketer, 545

Mckean, Chiet Justice

Mckean, Thumas . . .325, 13

Wedical and Surgical Reports . Iul

Medical Apprentices. . . . . . S2 as Apothecario's and Resident Phusicians.

$520 \cdot 5,32$

Medical Fund . . . . . . . 212

Medical Jibrary . . . . 90, 457

Medical Schooj first suggented by I)r. Fothergill. . . . . . . . . . . . .

Nedical Staft . . . . . . . . . 3, 201

Nedical staff and Medical Teaching, $43^{\circ}$ 4,56

Medicine, First Course of 1ectures on . . . . . . . . . 45

Weeting in Hospital, First . . . 40 of Contributors nust be held Annually in Philadelplia, in Ma!

Meigs, Dr. Arthur V. . . .

Meigs, Dr. Charles 1\%. . . . . 237.509

Meigs, Prof. Chas. D. Address by . 479

Meigs, [or. James Aitken . : . . 517

Meigs, Dr. John F., Adelecess by . . q

Meigs. Dr. Juhn Forsyth $\quad$ iti. 402,513 on 11 omen Stadents . . 475

Nemorial Fumiture . . . 305

Pavilines log, ili

Tablet, Dr. Kirkbride's . 2no

to Legislature. . . -

Wental and Nervous Department . . 14?

Mental Wiseases, Inispensary Service, is6
Merodith, 16

Nerenlitli, Reese

Merealith, Willians

Jletecorolues [1r Bull on 25

Nicruscopist Appoubler .

Vidwitery Xecletec]. 233

Mier. Thos. and ram'l

Mithin, Alpeal en cincenes 44

Miftim, remere.

Miftin, rimerturs . $\quad 25.5,256$

Mitllin. Julan : : :

Mitchell, Is Jolu $\mathrm{k} \quad 479.504$

Mittlin, Thenmas 55,233 . 4to

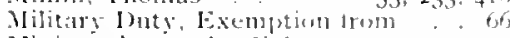

Ministration tothe sick . . . . 0,5

Muney, First Grant by I.enginiature. 2f

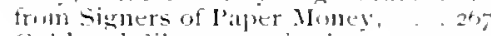

Gold and silver, required . . 5\%, 5\%

Hard 2 de

Second Grant lis Lenistanto

Moure, lor. chitrles. . . 4 . 4

Munte, Jor. John Vilson , 202, 2,- 503

Mone, 19r. Johis. 5

Monte, Jot Samuel Prestum.

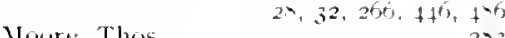

Moure, Thos. . . . 24.3

Marean, Dor. . . . . . $\$ 50$

Morgan, Dr. Jolu, as Aputhecary . 526

Bimeraphy of . . . . +

Resignation eif 450

Morgan, Evan , 249. +11

Morris. A., Jr. . (3)

Murris, Anth.

Morris, Jor, Benlamion . 347

Morris. lor casprar . . . . 41, 522

Morris, Catharine 11.

Murris, Delurah . . . .55

Moris, Jacob $G$. . $\quad+20$

Morris, Juseph . . 20 20. +11

Worris, Josegh Situnders _. . $\$ 26$

Morris, I.uke . . ... . . . 9

Morris, Robert, Esy. Financiter General. . . nj

Morris. Samuel . 236

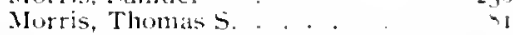

Morris, llistar. . . . . - 41, 30.4. 4.3.4

Mortgape on Hospital lenperty . 3 Palnent in Depreciated currency Refused

Norton, Charles M

Morton, Dr. Thomas $\mathrm{G}$.

102, I 13, 362, $30 \%, 47,4-2,516$

Morton's Ward liressina Citgriast 47

Mulienbers. Peter. . . . . 224, 2,30

Musical Instruments . . . . . . 337

Mustum and Litrary . . . . . . . .5,

Neill, [or. Jolnn . . . . . . . . . 51 I

Nicloles, Monument to chirles. . . 51

Nixum, Julun. . . . . . + . . . . .

Nurris, Charles
Surris, lor George 11

Surrio, lsate $\quad 11,32,211,211$

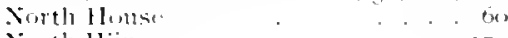

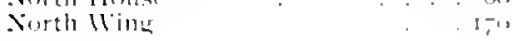




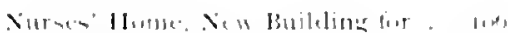

Nuraca, Rulem li,r

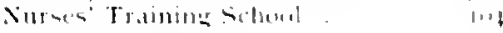

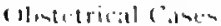

() 1 ag

$141,1,51,155,15$,

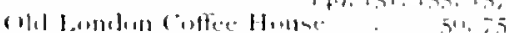

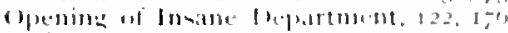

Cral. (ien, IS

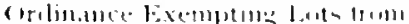

Taxition . . . . . 210

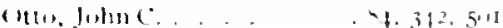

(11t littient Lepattment

Service a. . . . 115

(wen. I) ciritith

l'lekalul, I r Juln 11

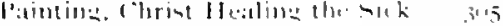

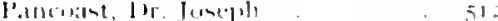

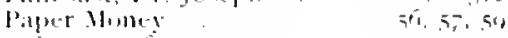
Sistretom of

Parke, lir. Thombur

Fisperienterent.

Pitrrisil, lis Jisedph

l'arams, Milla:m

Paschili, lomejols

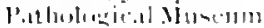

("lichlot

liticht, tirnt

lintients

Finplingment

Free insillu

(itatchi)!

Interesting

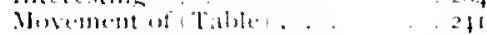

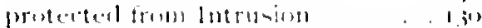

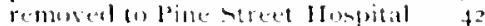

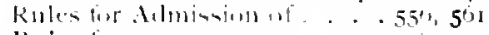

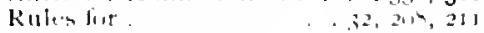

liall, Juln

l:mil, |l:tum:1

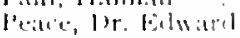

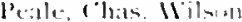

Peomberturu, I.Imies

lomished ti, Virteing,

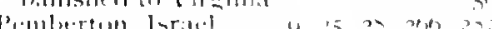

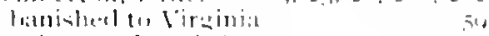

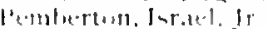

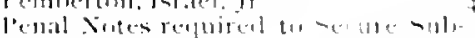

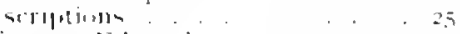

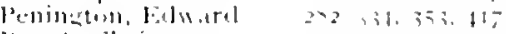

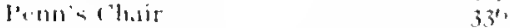

lenn F.mily

lemtr. Julin

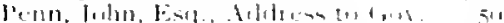

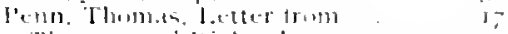

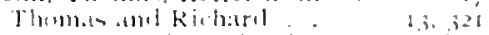

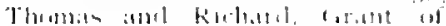
I.:Int)

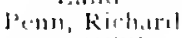

Ienn, Milli:mu

bilst is

pentrias. Thim

I. liuml,

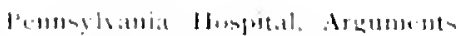
$131 .+11,1,18$

llimput.le elu.trter

limpitat and l, llluttich

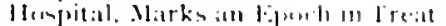
ment ut the lns:me. .

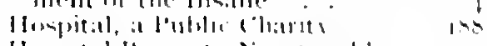

Homptal l'roperty Xint tesalde. jou

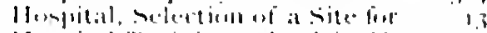

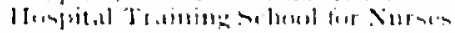

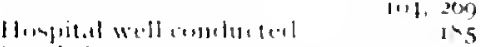

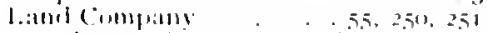

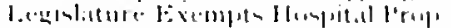

enty. . . . 301, 31!

lever, cientases.

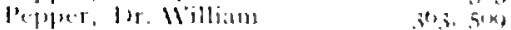

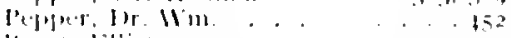

14-rut, fillistull . . . 12. 112

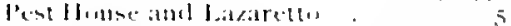

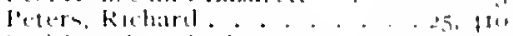

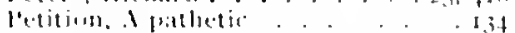

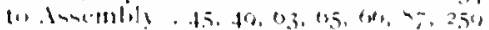

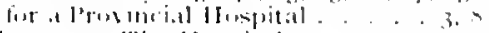

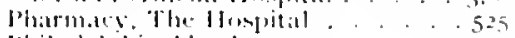

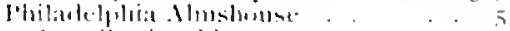

contributionahip). . . . 54 1\%

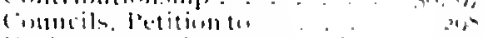

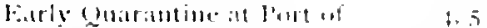

Ilumitial 2 230

Vollim Fever in .

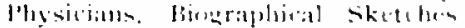

if . . . . . . . . . . . . .

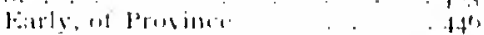

interested in Mellate uf Hompital ats

must lisit l'atinelts betore . lamisiniti

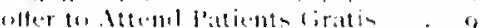

kentelent . . . . . fut

(1) rive f'rmit al skill . . . 26

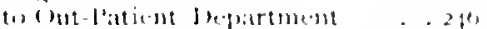

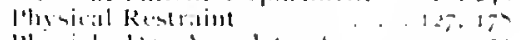

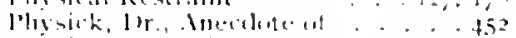

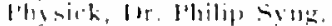

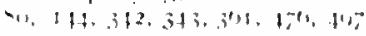

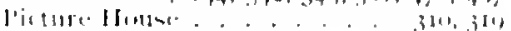

Hereal for Ninrses. Mes.

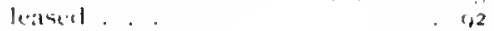

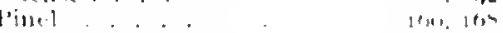

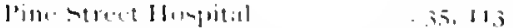

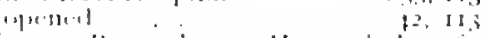

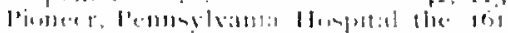

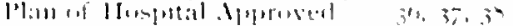

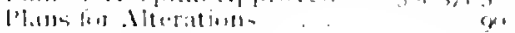

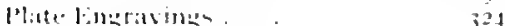

l'lataillth, Imratel

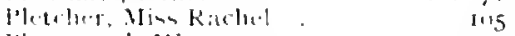

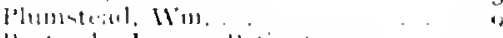

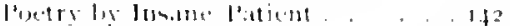

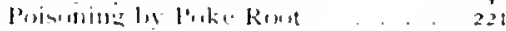

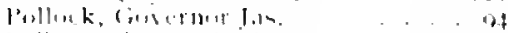

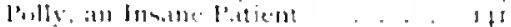

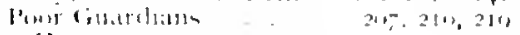

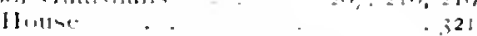

litingtis

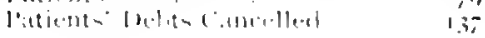


Puor sick and lusane, without Cire previous to Establishment il the Pennsyluantia llosintal

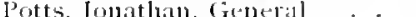

poulsol. Zachariah . . . . 3.5.3, 425

Puwell, Samucl.

Practice of the liouse . . . . . 45े

l'ritt's Royal staludird Tavern . 2,

Precautions aganst leliow Fever 60,7

President, Flanklin Elected . . . th

Prick, Jostepli . . . . . . . .6, 427

Price, 1or. llilliam. . . . 202,503

Prints, Engrations, and statuary . 32:

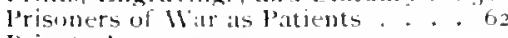

Privalte Apartments . . . . 39

Prize Mulley firnted, Cnclaimed 66, 249

Property of Insane Department . . 195

levied [7rom and sind for Taxes . 29.5

Proparietors, Aduress to. . . . . . 15

Province, Fally Plasicians of . . . 4t6

levincial Assembly lirant . . . 24

thospitill proposed . . . . . . 3

Public llumses, a (ause of bisease . 207

Puerperal Fever in Maternity lVard. 23

lupils of l'bysiciant . . . . . . . .

Quarantine, First in l'hiladelphial . +

Randulpli, Lr. Jacoly . . . . . . . . 50

Real Estate, 1,imit Extended, 9.3, 269.301

Redman, br. 2s. 32, $351,35 \%, 350,447.466$.

Redinan, Joseph

Redemption Setranty

Registrars Aplowinted

Remuval of Insine l'atients

Religious Mork in the llospital . . 95, 96

Report of Buildine Committee , $1,6,177$

Reports, Ansulail

of Cases.

Resignation of Dr. Comrid

Residence of Mr. Butati

Resident l'lusicialls

Early

list of .

Rulestor

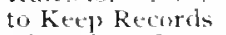

Resiguation of I) J. John Moraia

Retreat from ilcdical Teaching
Revenute from

of Hospital.

Kevolution, Hospital duriner the 526,520

Revolutionary IIar Period.

Rloads, satmule, 9, 3b, 37, 42, 50, I29, 1, is

Riclatulson, J12, $211,235,249,264,411,447$

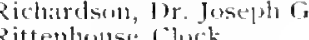

use (li)k

Ritz, Im. Clarles M

Roberdeall, llaniel

Roberts, charles.

Rolerts, IIn⿺l一

Rohñls, Jutnathitm

Rusal Stanclard "latrer

Rulea :Ir)d Revulitions

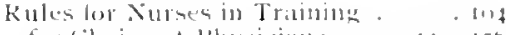

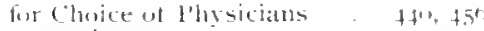

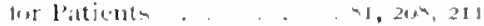

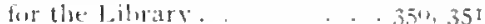

Rusi, li, Benjamin, -5, mo, 245, $+42,4+5$

$+51,401,49$

231,343

lowtritit of $3+34$ Servicus of $143,147,146,1+3,161$

in Treatument of losinte 149,102

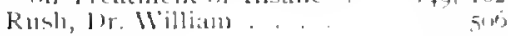

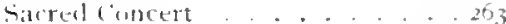
sililurs . . . . . 220, 227, 2,32

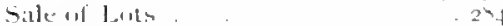

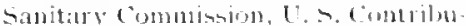
tionil from

Salmom, beukh

Silnsolnt, Sinns'l

Sitchell, Dr. Sonthey :

scotchumilu, hride ni a

seal of llospital . . . . . . . . 331 34

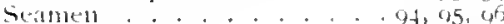

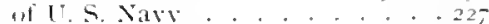

Serkel, liswrence . . . . . . n

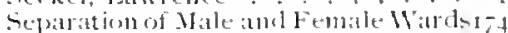

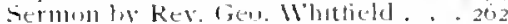

Servants, pomestio, l'usthined. . I

sesmlut, Engraver . . . . . . 328

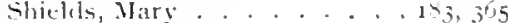

shipuen, Felivind - . . . . . 443

slipuen, Juseph . . . . . . . o

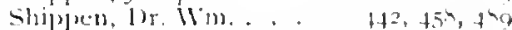

slifpren, 1)r. Nilliam, J1, 51, 75, 233, 345 $356,4+2,459,4$ tou $41,+42$

Shoenaker, Berij. H. . . . 110, iro

Slunsiaker, Junathan. . , . 4263

Sluemaker, s . . . . . . (3)

Shuemakte, I)r, Sammel H. . . . . 4

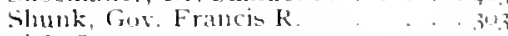

sick Straugets and Insane Poor, Early l'rugisian for Sims, Jus. . . . . . . . . . Site of 110 spitit, Selection of. . 13,16 siade, Robert, Apothecary . . 52 Slaves. . . . . . . . . 1 1 1, 203 Sonn, Sammed, Architect . . . 175

Smitl, 1)r. Francis Gurncy... .514

smith, Franklin R. Apotieciay" 53

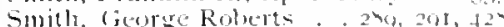

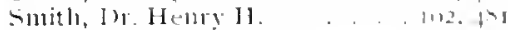

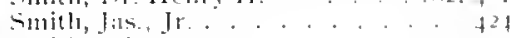

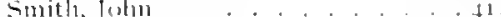

Sirrith, Jobu, J1. . . . . . 11\%, 121

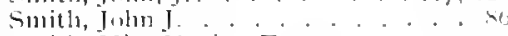

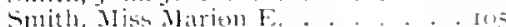

sustl, Xewherry, Ir. Apothecary . 5.35

smitl, kolvelt

Smith, simulel

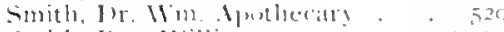

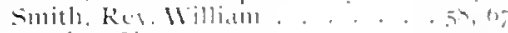

Sllyler, Siruoll. . . . . \$20

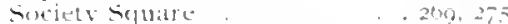

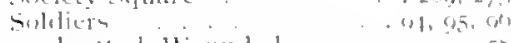

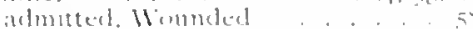

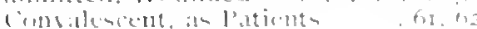




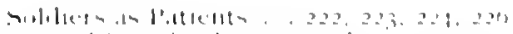

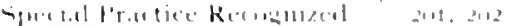

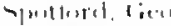

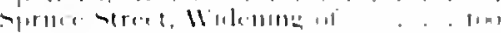

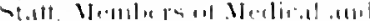

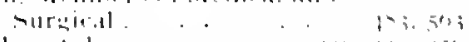

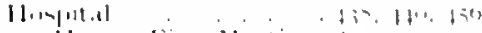

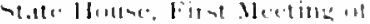

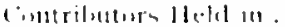

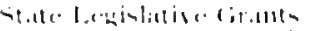

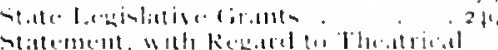
lienlle'tit

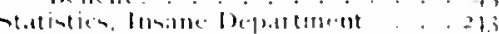

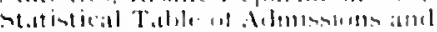

lobehorges

$2: \cdots$

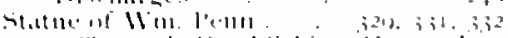

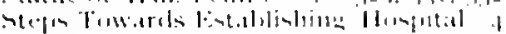

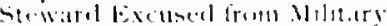

$$
\text { service }
$$

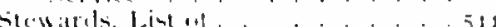

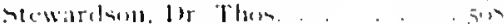

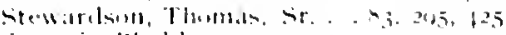

stome in Blinluler. 24

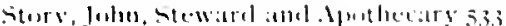

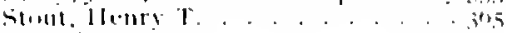

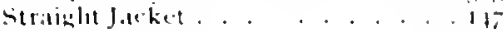

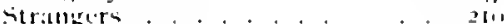

eveluseled . . . . . . . . . . . 5.3

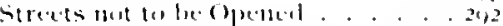

strutall, tmos. . . . . . . 0.115

firicklami, M11... . . . . . . \$2

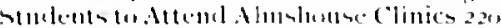

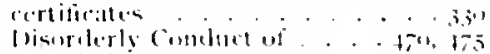
edfencleal . . . . . . . .

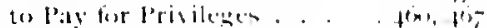

sulperiptiens . . . . . . . . . 85 Nintestior. suliciterl ...... . . . 25

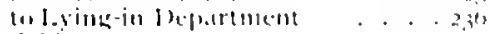

Silleviele. . . . . is

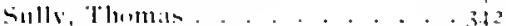

silnderlamel, John . . . . . . . . 1,5

Sillistruke.

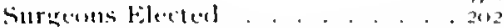

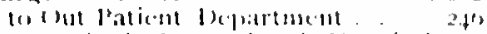

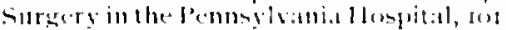

swilt, fosephll. . . . . . . .59. 4.4

Tituter, Thumbis. . . . . . (1)

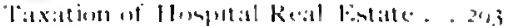

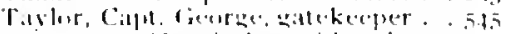

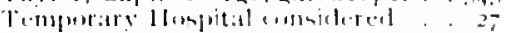

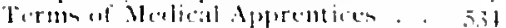

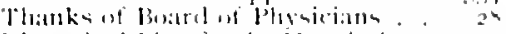

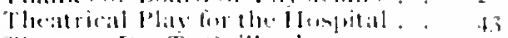

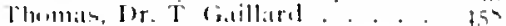

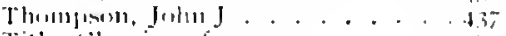

Teitle. clestrime of . . . . . . . 24!

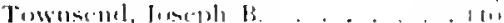

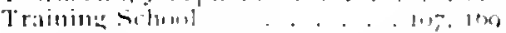

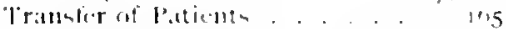

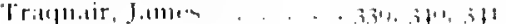

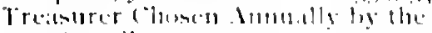
(int) riluluines.

to gise securtits

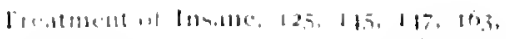
$117,1 \%$

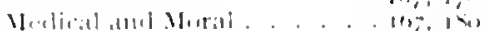

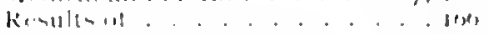

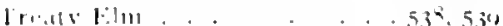

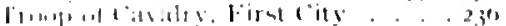

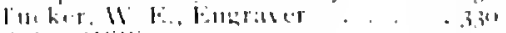

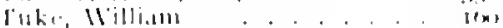

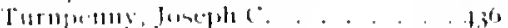

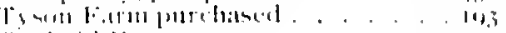

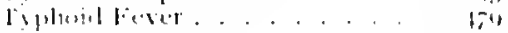

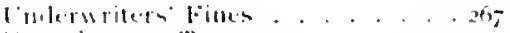

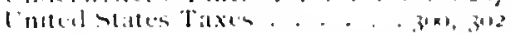

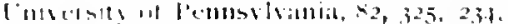

lenent Liluars. . . . . . . . . . 45

Vacrinatiun, firee. . . . . . . . 212

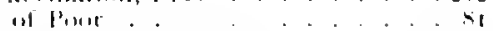

Vatus, Rirhitrd, Mabur . . . . 175

letis. Kaluelts. . . . . . . 12h

Vimilurs, delmiscionit. . . . . 502

Fincisul . . . . . . . . . l11;

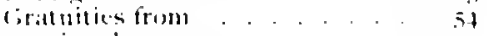

restricteel ....... . . . . . . . .

Molpstafte. Tlums. . . . . . . . . 3.30

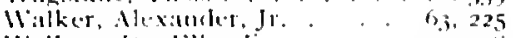

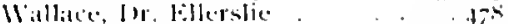

Maln, Roluett. . . . . . . . . . J1, \$2;

Walı, Roluert, j\%. . . . . . . . $26 \%$

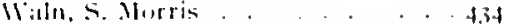

IV:almut Street l'risess, Sellow Fuer

ill. . . . . . . . . . . 73

Mircls delditional . . . . . . . 17

"The "Fisher" . . . . . 14, 1, 182

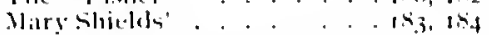

IVarming Apartments fort the Insatue, is.

llar ut the Rebellinm. . . . . . . 94

IVallatle, II. Ae, Inescription of

IJompitall by . . . . . . .

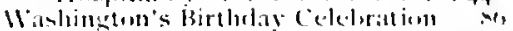

Nithlugtun, Bust ut . . . . it1

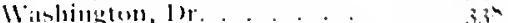

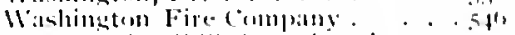

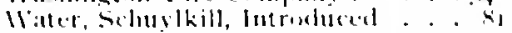

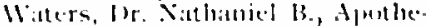
cary . . . . . . . . . . . . . . . . . .

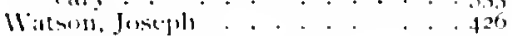

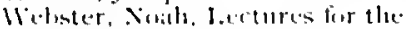
llospitial. . . . . . . . . . . 26.

Mecal, Itr. (iecolge _. . . 145

Aputheratrs . . . . 526

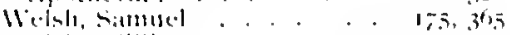

Nelsh. IVillian , . . . . . rit

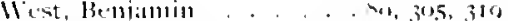

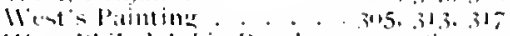

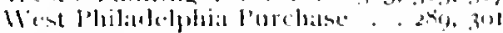

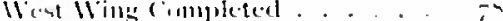

II'stern Wing. . . . . .114.114

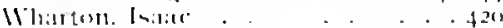

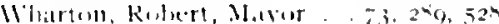

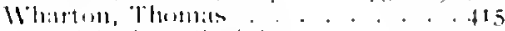

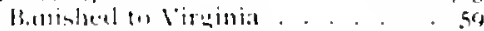

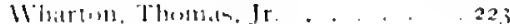


Whitall John W

White, Rev. William

Whitfielel, Rev. Georye

lViduws and single llismen

Wrilliamson, Isatiah ${ }^{\circ}$.

IVilliamson, The I I Building sol ty

llistar, Bartholotnew $86,117,121,+1^{2}$

llistar. Calspal . . 295, 234, 301, fin libut uf

IVistar, Caspar, Jr.

WVistat, Richard

Wistitr, Thomas

lVolf Gevernor Gicurere

lloman Visitors, Buarel of

Woman's Jlospital Nirstes

Medicial College Sturlents

IVimen, Charitable

students

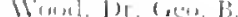

Ailutress if

Wims, Horation

Wiortion to! tot

$1,5,514 x$

1,2

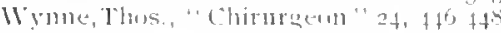

Yarrl, Erlmund J. ......

Sarmall Peter, Apotheras

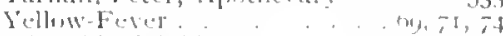

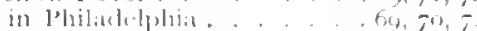

in the fluspitil ..... It

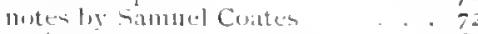

patients . . . . 64

lork Retriatt 1tx), 165

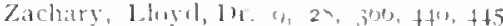
$4 \rightarrow-$

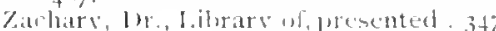

Zante, satrall $\quad 337,344^{2}$

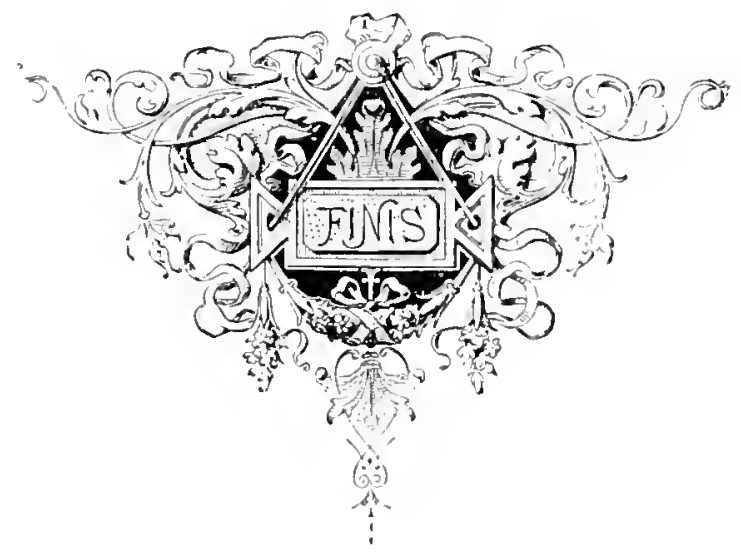




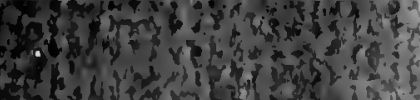

sty

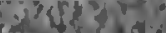

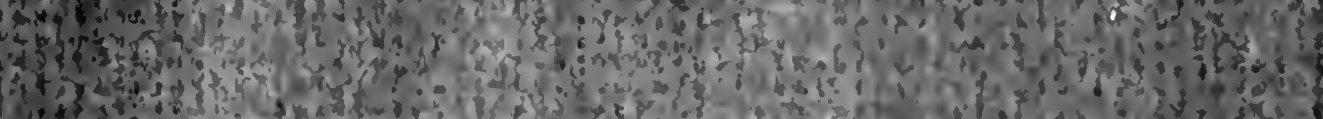

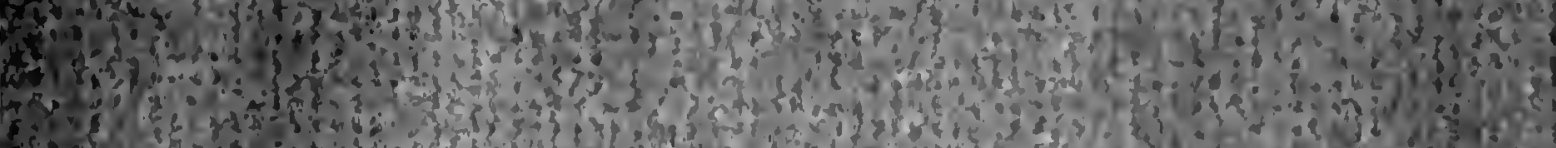

\section{Cis at}

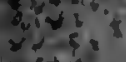

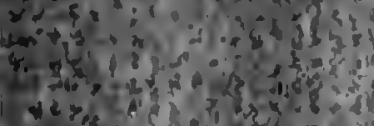

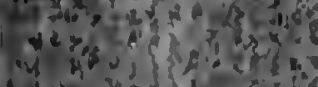

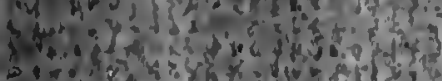

(c)

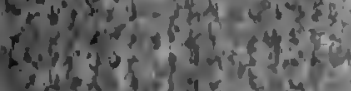

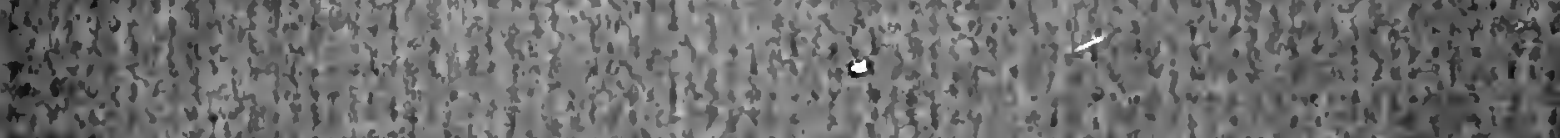

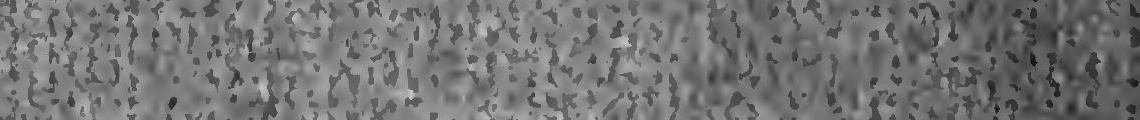

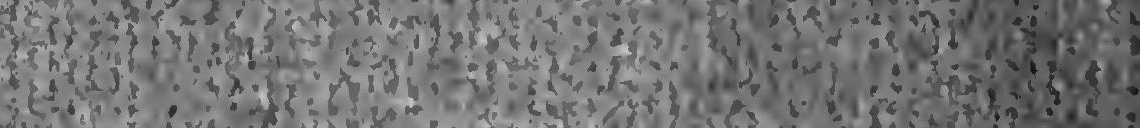

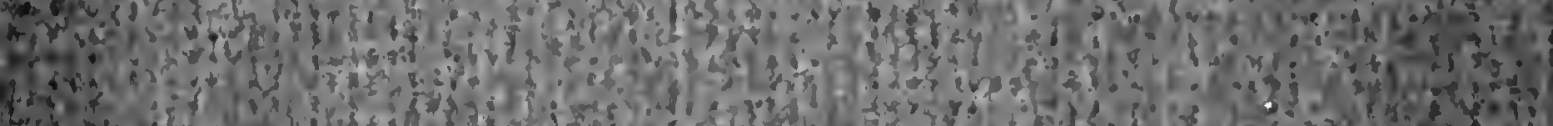

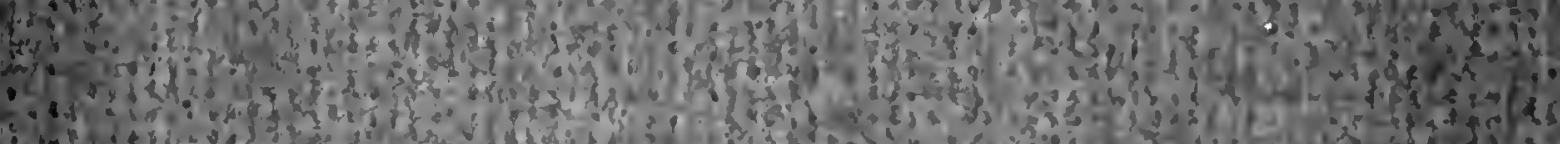

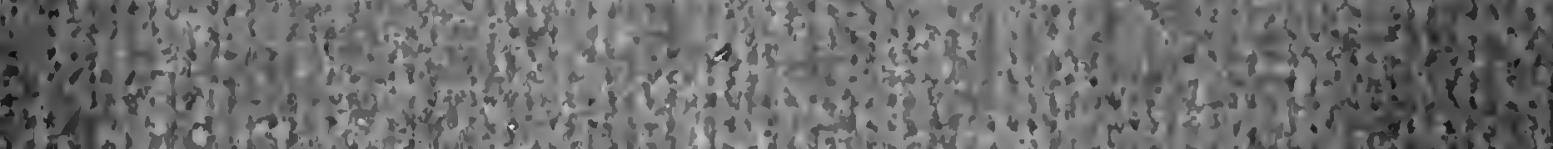
3. ins

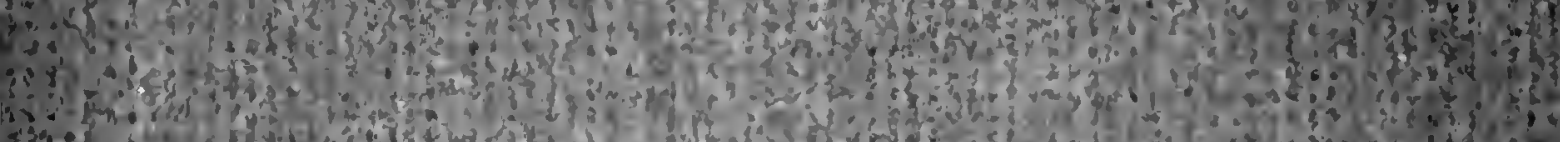

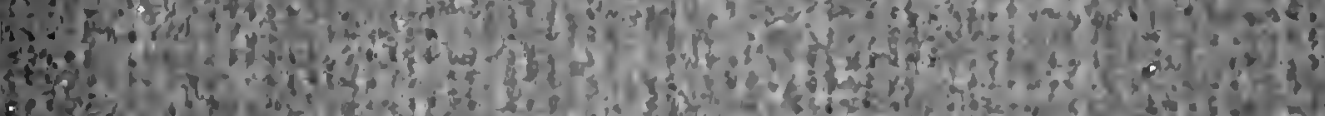

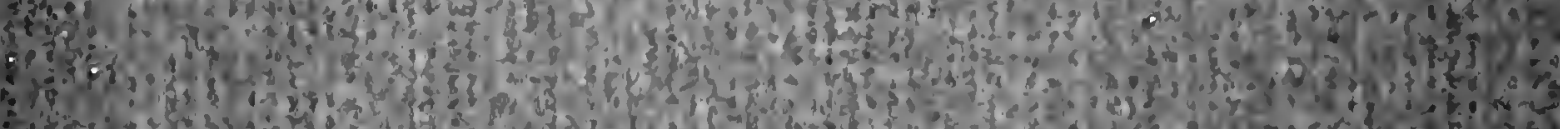

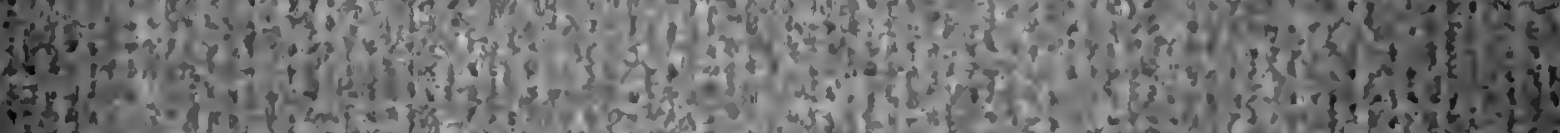

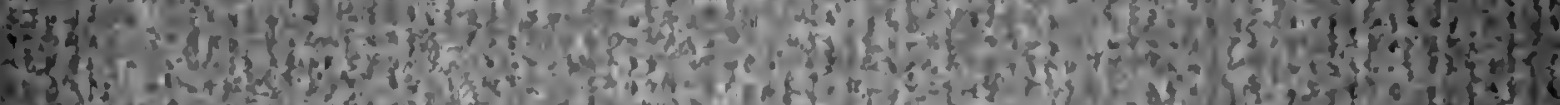

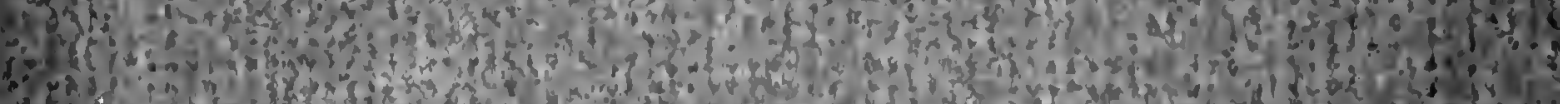

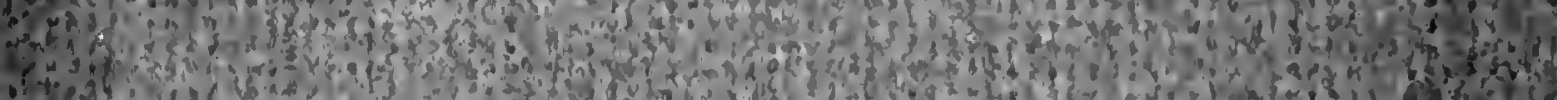
if

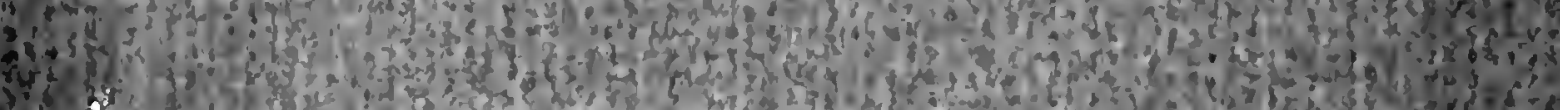

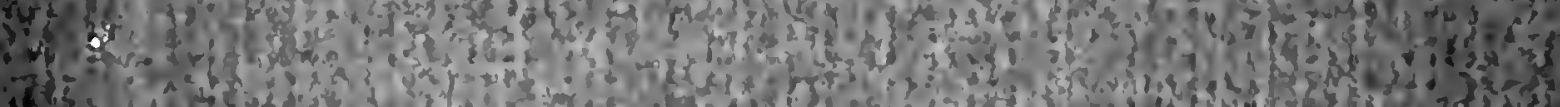
-

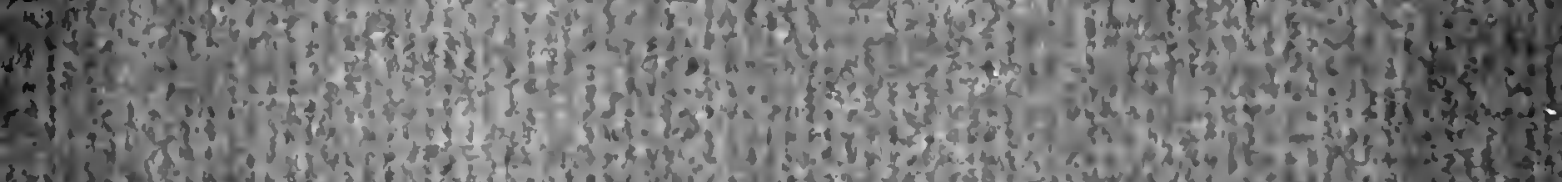

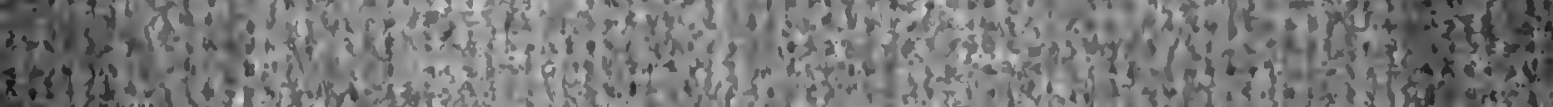
g. का 4h

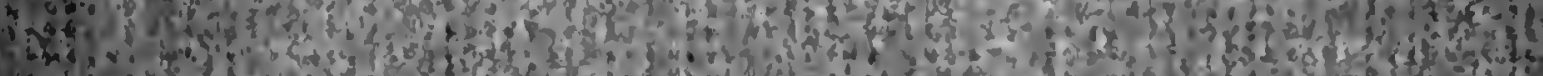

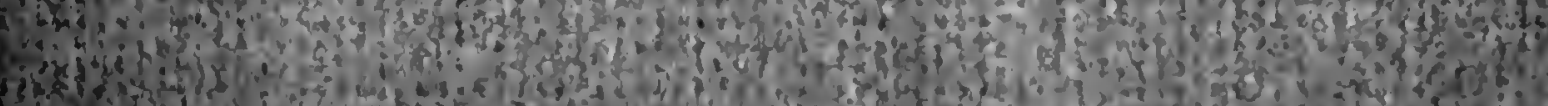

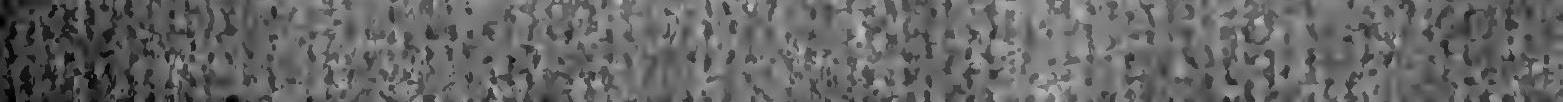




